\title{
Geology of the Buckingham Stockwork Molybdenum Deposit and Surrounding Area, Lander County, Nevada
}

U.S. GEOLOGICAL SURVEY PROFESSIONAL PAPER 798-D

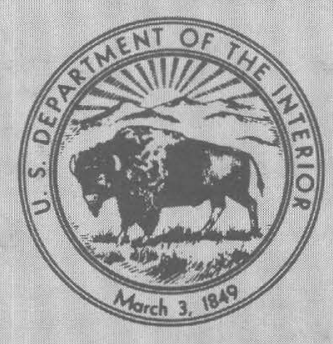



GEOLOGY OF THE BUCKINGHAM STOCKWORK MOLYBDENUM DEPOSIT AND SURROUNDING AREA, LANDER COUNTY, NEVADA 


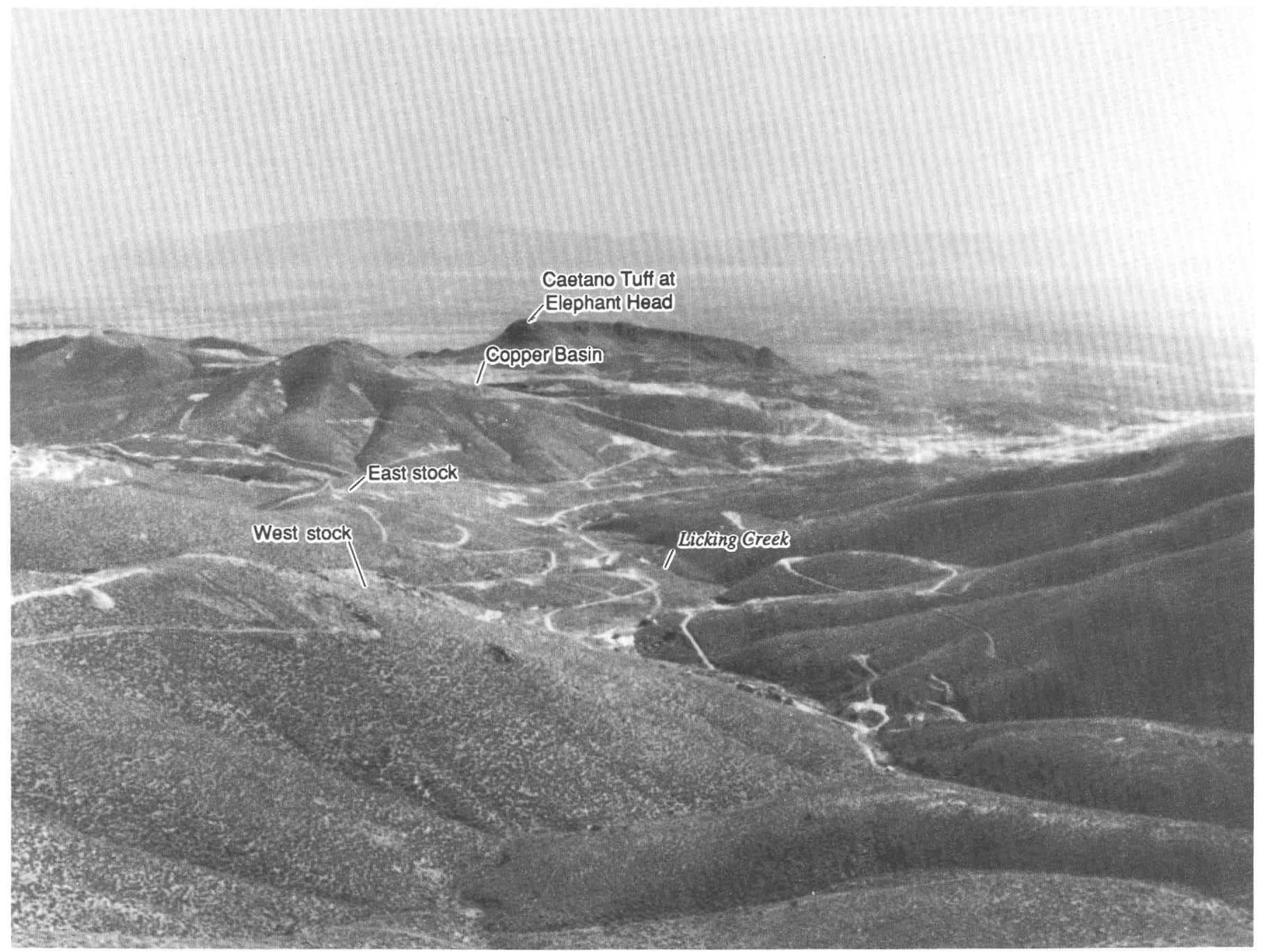

Frontispiece. Buckingham area. Group of buildings in foreground is Buckingham Camp. Reese River Valley and northern Shoshone Range make up background. View northwestward. 


\section{Geology of the Buckingham Stockwork Molybdenum Deposit and Surrounding Area, Lander County, Nevada}

By TED G. THEODORE, DAVID W. BLAKE, THOMAS A. LOUCKS, and

CRAIG A. JOHNSON

With a section on POTASSIUM-ARGON AND ${ }^{40} \mathrm{Ar} /{ }^{39} \mathrm{Ar}$ GEOCHRONOLOGY OF SELECTED PLUTONS IN THE BUCKINGHAM AREA

By EDWIN H. McKEE

and a section on ECONOMIC GEOLOGY

By THOMAS A. LOUCKS and CRAIG A. JOHNSON

and a section on SUPERGENE COPPER DEPOSITS AT COPPER BASIN

By DAVID W. BLAKE

and a section on MINERAL CHEMISTRY OF LATE CRETACEOUS

AND TERTIARY SKARNS

By JANE M. HAMMARSTROM

GEOCHEMISTRY OF THE PORPHYRY COPPER ENVIRONMENT IN THE BATTLE MOUNTAIN MINING DISTRICT, NEVADA

\section{U.S. GEOLOGICAL SURVEY PROFESSIONAL PAPER 798-D}

The Buckingham stockwork molybdenum deposit, a Late Cretaceous calc-alkaline system, is estimated to contain more that 1,000 million tons of mineralized rock averaging 0.10 weight percent Mo (as $\left.\mathrm{MoS}_{2}\right)$ and containing small amounts of silver, tungsten, copper, and gold

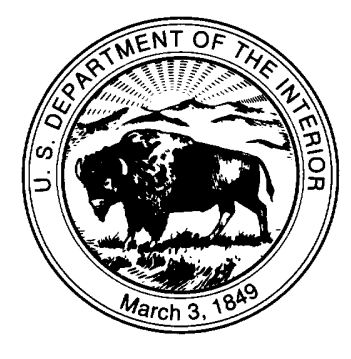

UNITED STATES GOVERNMENT PRINTING OFFICE，WASHINGTON：1992 


\section{U.S. DEPARTMENT OF THE INTERIOR}

MANUEL LUJAN, $\mathbf{J}_{\mathrm{R} .}$, Secretary

\section{U.S. GEOLOGICAL SURVEY}

Dallas L. Peck, Director

Any use of trade, product, or firm names in this publication

is for descriptive purposes only and does not imply endorsement

by the U.S. Government

\section{Library of Congress Cataloging-in-Publication Data}

Geology of the Buckingham stockwork molybdenum deposit and surrounding area, Lander County, Nevada / by Ted G.

Theodore . . . [et al.]. With a section on potassium-argon and ${ }^{40} \mathrm{Ar} /{ }^{39} \mathrm{Ar}$ geochronology of selected plutons in the Buckingham area / by Edwin H. McKee and a section on Economic geology / by Thomas A. Loucks and Craig A. Johnson, and a section on Supergene copper deposits at Copper Basin / by David W. Blake, and a section on Mineral chemistry of Late Cretaceous and Tertiary skarns / by Jane M. Hammarstrom.

p. $\quad \mathrm{cm}$. - (Geochemistry of the porphyry copper environment in the battle mountain mining district, Nevada) (U.S. Geological Survey professional paper ; 798-D

1. Geochemistry -Nevada-Lander Co. 2. Molybdenum ores-Nevada-Lander Co. 3. Geology-Nevada-Lander

Co. I. Theodore, Ted G. II. Series. III. Series: Geological Survey professional paper ; 798-D

For sale by Books and Open-File Report Sales, U.S. Geological Survey, Box 25286, Denver, CO 80225 


\section{CONTENTS}

Abstract

Introduction

Acknowledgments

Structural and stratigraphic features of the mining district

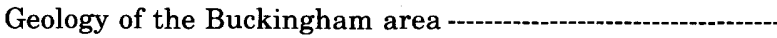

Cambrian System

Harmony Formation

Ordovician and (or) Devonian Systems Diabase

Devonian System

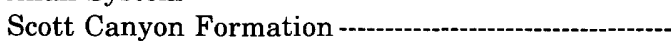

Pennsylvanian System -------.--

Battle Formation -

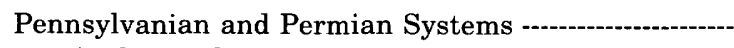

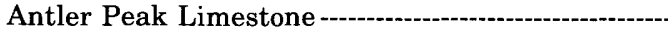

Quaternary System

Surficial deposits -

Intrusive rocks

Introduction

Potassium-argon and ${ }^{40} \mathrm{Ar} /{ }^{39} \mathrm{Ar}$ geochronology of selected plutons in the Buckingham area, by Edwin H. McKee

Cretaceous monzogranites of the Buckingham area

Tertiary granitic and rhyolitic intrusive rocks Late Cretaceous

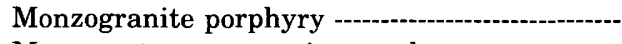

Megacryst monzogranite porphyry -----.-------

Aplite

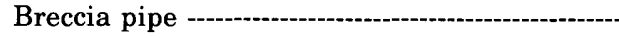

Late Eocene or early Oligocene

Biotite-hornblende monzogranite of Bluff area

Breccia pipe of Bluff area

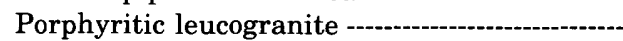

Petrography

Chemistry

Associated skarn alteration -...-.-.-.-.-.

Altered granodiorite of Hill 6010 area ------.--

Rhyolite

Miscellaneous intrusive rocks -..---.--.--

Early Oligocene -----

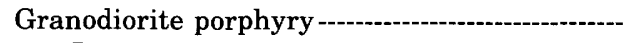

Petrography

Chemistry

Associated skarn

Intrusion breccia pipe

Altered hornblende porphyry --...-...--..--

Structural geology

Antler orogeny deformation

Sonoma orogeny deformation

Late Cretaceous deformation

Tertiary deformation -

Buckingham stockwork molydenum deposit -----.--------

Classification of the deposit -

Economic geology, by Thomas A. Loucks

and Craig A. Johnson
Page

2

8

13

13

13

21

21

22

22

27

27

33

33

35

35

35

35

36

\section{6}

40

40

42

45

47

48

48

49

55

59

62

67

71

78

79

84

86

86

87

87

92
Geology of the Buckingham area-Continued

Buckingham stockwork molydenum deposit-Continued Economic geology-Continued

\begin{tabular}{|c|c|}
\hline bstract & D101 \\
\hline atroduction & 102 \\
\hline Acknowledgments ----- & 103 \\
\hline General geology --.--..- & 103 \\
\hline Paleozoic rocks & 104 \\
\hline Premineral and synmineral intrusions -.- & 106 \\
\hline $\begin{array}{l}\text { Quartz monzonite porphyry -...--..-- } \\
\text { K-feldspar-quartz monzonite }\end{array}$ & 107 \\
\hline
\end{tabular}
porphyry ---.--.-- 107

Quartz-K-feldspar porphyry --.---.---- 107

Fine-grained quartz-feldspar porphyry -

Quartz-feldspar porphyries -.----.-- $\quad 110$

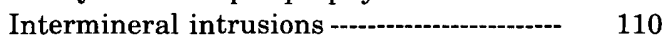

Large K-feldspar porphyry ---------- $\quad 113$

Intermineral dikes -..--.-- 116

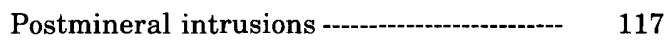

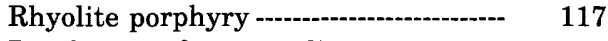

Porphyries of intermediate composition ---.--..-- 120

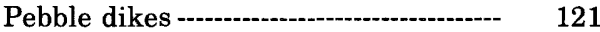

Basalt - - 121

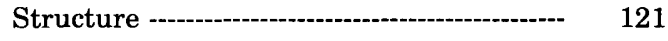

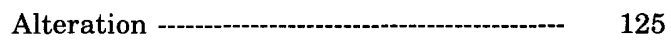

Contact metamorphism --.-.------.- $\quad 125$

Hypogene alteration --.-------------- 126

Fault-related and supergene alteration -.--- 127

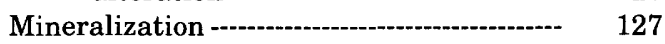

Molybdenum -.--.--.--.--.-- 129

Potential byproducts --.--on 133

Quartz and pyrite veining -........-.-- 134

Late vein and disseminated basemetal-silver mineralization -------.-. 137

Conclusions ------------ 138

Additional petrographic and chemical studies

near the East stock -.-.- 138

Petrography --.---on 138

Chemistry - - 144

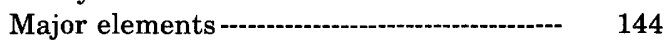

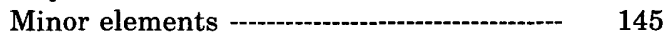

Associated skarn alteration - - 150

Supergene copper deposits at Copper Basin,

by David W. Blake --.-.-.- 154

Introduction -.-.-.-.-- 154

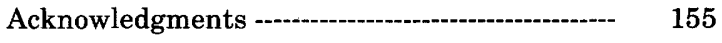

History - - 155

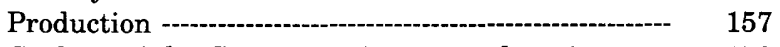

Geology of the Copper Basin copper deposits ------ $\quad 158$

Geology on the 5575-ft bench of the

Contention deposit -..--.--.-- 159

Hypogene mineralization --.-_- 162

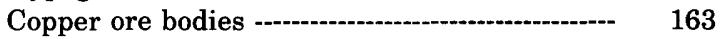

Supergene alteration -- 164 
Geology of the Buckingham area--Continued

Supergene copper deposits at Copper Basin-Con.

Geology of the Copper Basin copper deposits-Con.

Leached capping ----------- D165

Summary ----10

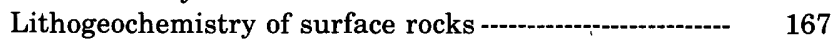

Variation of minor elements in and around the Buckingham system -

Variation of minor elements in the general area of Bluff

168

Comparison of the distributions of fluorine, molybdenum, and copper in the Bluff area with the Buckingham molybdenum system ..-

Multivariate statistics

Mineral chemistry of Late Cretaceous and Tertiary

skarns, by Jane M. Hammarstrom

Introduction

Acknowledgments

Description of samples

Skarn in the Harmony Formation

Skarn in the Battle Formation --

Skarn in the Antler Peak Limestone -.........-......

Analytical technique

Mineral chemistry

Garnet

Pyroxene

Epidote
Page

Mineral chemistry of Late Cretaceous and Tertiary skarns-Continued

Mineral chemistry-Continued

Amphibole --

Phyllosilicate minerals

Clay minerals

Apatite -

Scapolite

Opaque minerals ---

Discussion

Environment of skarn development ..............................

Fluid-inclusion studies

Buckingham molybdenum system --.-.-.--

Skarn -

Quartz-molybdenite stockworks

Vail Ridge block

East block

West block

Geobarometry

Stable isotopes

Discussion -

Little Giant Mine -

Quartz stockworks at Bluff

Porphyritic leucogranite and associated skarn--..---.-.-

Placer nugget from Paiute Gulch

Suggestions for exploratory programs

References
Page

224

224

226

228

228

229

232

236

238

240

240

247

247

261

267

276

278

281

287

287

288

290

292

294

\section{ILLUSTRATIONS}

[Plates are in pocket]

Frontispiece. View of the Buckingham area, looking southeast.

Plate 1. Geology of the Buckingham stockwork molybdenum deposit and surrounding area, Lander County, Nevada.

2. Geology of the Buckingham stockwork molybdenum deposit, Lander County, Nevada.

FIGURE 1. Index map of north-central Nevada

2. Geologic sketch map of Antler Peak quadrangle

3. Sketch map showing major deposits and prospects in the Battle Mountain Mining District

4. Geologic sketch map showing spatial relation of major sediment-hosted gold deposits

5. Photographs showing characteristics in sandstone beds of the Upper Cambrian Harmony Formation in the Battle Mountain Mining District -

6. Ternary diagram showing modes of detrital framework grains from the Upper Cambrian Harmony Formation ------

7. Photographs showing a conformable, healed contact between rare greenstone in the Upper Cambrian Harmony Formation and medium-grained, olive-gray subarkose

8. Diagram showing chemically analyzed sedimentary and contact-metamorphosed sedimentary rocks of the Harmony Formation

9. Contour diagram showing attitudes of $\mathbf{4 4}$ slickensides measured in chert of the Scott Canyon Formation ----:-a----

10. Photograph showing relations in selected outcrops of chert belonging to the Devonian Scott Canyon Formation ------

11. Photomicrographs of altered andesite from the Devonian Scott Canyon Formation -

12. Sketch map showing distribution of Late Paleozoic terranes in the western Great Basin of Nevada -...-..-.-.-.-..-

13. Photographs showing typical craggy exposures of the flat-lying Middle Pennsylvanian Battle Formation ------------.-

14. Photograph showing block of rocks belonging to the Middle Pennsylvanian Battle Formation -

15. Diagram showing chemically analyzed samples of pebbly sandstone from largely conglomeratic, lower member of the Middle Pennsylvanian Battle Formation and chemically analyzed samples of calcareous conglomerate of the lower member

16. Diagram showing chemically analyzed samples of essentially unaltered silty shale and shaly hornfels of middle member of the Middle Pennsylvanian Battle Formation from the Buckingham area with chemically analyzed samples of the middle member from the southern part of the mining district

D3

4

7

9

14

16

21

24

25

26

28

29

30 
17. Photomicrographs of rocks from the Upper Pennsylvanian and Lower Permian Antler Peak Limestone -...--.---.--.--

18. Map showing locations of major intrusive rocks, major structures, and localities of dated samples -

19. Graph showing ${ }^{40} \mathrm{Ar} /{ }^{39} \mathrm{Ar}$ age spectra for a biotite separate from monzogranite porphyry of the Buckingham stockwork molybdenum system -

20-23. Photographs showing:

20. Geologic relations of Late Cretaceous monzogranites of Buckingham Camp

21. General aspect of veining associated with megacryst porphyry phase of the Buckingham stockwork molybdenum system

22. Breccia pipe and pebble dike associated with the Late Cretaceous Buckingham stockwork molybdenum system

23. Relations in general area of topographic survey point informally named "Bluff"

D34

24-26. Plots of:

24. $\mathrm{K}_{2} \mathrm{O} / \mathrm{Na}_{2} \mathrm{O}$ ratio versus $\mathrm{SiO}_{2}$ content for samples of chemically analyzed intrusive rocks from general area near promontory at Bluff

25. Total alkalis $\left(\mathrm{K}_{2} \mathrm{O}+\mathrm{Na}_{2} \mathrm{O}\right)$ and $\mathrm{CaO}$ versus $\mathrm{SiO}_{2}$ contents for analyzed samples of Tertiary igneous rocks from the Buckingham area -

26. $\mathrm{Al}_{2} \mathrm{O}_{3}:\left(\mathrm{K}_{2} \mathrm{O}+\mathrm{Na}_{2} \mathrm{O}+\mathrm{CaO}\right)$ ratio versus $\mathrm{SiO}_{2}$ content for various samples of analyzed Tertiary intrusive rocks in the Buckingham area

27. Ternary chemical and normative diagrams of analyzed Tertiary igneous rocks from the Buckingham area

28. Photomicrographs of textural relations in the late Eocene or early Oligocene breccia pipe of Bluff area --

29. Photographs of late Eocene or early Oligocene porphyritic leucotonalite

30. Sketch map showing distribution of porphyritic monzogranite and porphyritic tonalite phases, and contents of clinopyroxene and amphibole in modally analyzed samples of thin-sectioned porphyritic leucogranite from the Buckingham area

31. Photomicrographs showing textural relations in porphyritic leucogranite of the Buckingham area ---

32. Photomicrographs showing textural relations at or near contact between late Eocene or early Oligocene porphyritic

leucotonalite and the Upper Cambrian Harmony Formation -

33-36. Photographs and photomicrographs showing:

33. Garnet skarn faulted against porphyritic leucogranite near northeastern corner of the Buckingham area-

34. Selected relations of skarn formed in the Upper Cambrian Harmony Formation ---

35. Transitions of the Upper Cambrian Harmony Formation in outcrop from biotite hornfels to garnet skarn -

36. Conversion of subarkose and biotite hornfels of the Upper Cambrian Harmony Formation to diopside skarn

37. Photomicrographs showing skarn formed in the Upper Cambrian Harmony Formation in northeastern part of the Buckingham area -

38. Photomicrographs showing textural relations in fault-controlled garnet skarn and in skarn breccia ---

39. Photographs showing field relations of late Eocene or early Oligocene rhyolite from the Buckingham area ---------

40. Photomicrographs of late Eocene or early Oligocene rhyolite from the Buckingham area -

41. Photograph showing early Oligocene granodiorite porphyry from the Buckingham area --

42. Photographs showing early Oligocene granodiorite porphyry and the Upper Cambrian Harmony Formation at the Copper Queen Mine in the Buckingham area

43. Comparison of selected metal ratios in Oligocene granodiorite porphyry at Buckingham with ratios in the Oligocene Caetano Tuff and Oligocene dikes and sills at sediment-hosted gold deposits --

44. Photographs showing relations in general area of skarn associated with Oligocene granodiorite porphyry -----------

45. Photomicrographs showing textural relations in garnet skarn formed in carbonate host --.--

46. Photographs showing geologic relations associated with the Late Cretaceous, low-angle Contention fault -----------

47. Map showing distribution of major stockwork molydenum systems in the Cordillera of western North America ------

48. Diagram showing inferred relations among porphyry copper deposits, fluorine-deficient porphyry molybdenum deposits, porphyry gold deposits, porphyry tungsten deposits, and Climax-type porphyry molybdenum deposits, and inferred relative proportions of fluorine, carbon dioxide, and chlorine in their genetically associated fluids --

49. Schematic map showing distribution of principal areas of molybdenum mineralization in Winnemucca $1^{\circ}$ by $2^{\circ}$ quadrangle

50. Diagrams showing proportion of deposits that exceed a given value for tonnage and grade of mineralized rock for fluorine-deficient- or quartz monzonite-type and Climax-type molybdenum stockwork systems

51. Cross section showing geologic relations among footwall, interfault, and hanging-wall tectonic blocks along section line 2,136,200 N. through the East and West stocks

52. Cross sections showing inferred evolution of magmatism, mineralization, and postmineral faults along section line 391,100 E. through the East stock

53. Plot showing quartz-alkali feldspar-plagioclase modal analyses of some Buckingham intrusive rocks --------------

54. Photographs showing typical specimens of premineral and synmineral intrusive rocks -...-

55. Cross section showing geologic relations among intrusive phases and crenulate quartz layers within the West stock 
56. Cross section showing geologic relations among magmatic phases, intrusion breccia, and postmineral faults in the East stock

57. Photographs showing typical specimens of intermineral intrusive rocks

58. Photographs showing typical specimens of postmineral intrusive rocks

59. Photographs showing some structural features at Buckingham

60-65. Diagrams showing:

60. Relation of conspicuous, white quartzite beds to the West stock and to projected trace of the Buckingham fault zone

61. Projection to surface of distribution of molybdenite concentrations in footwall, interfault, and hangingwall ore zones

62. Pattern of alteration within the West stock

63. Schematic projection to surface of distribution of silver concentrations in footwall and hanging-wall ore zones -

64. Schematic projection to surface of distribution of copper concentrations in footwall and hanging-wall ore zones

65. Schematic projection to surface of distribution of tungsten concentrations in footwall and hanging-wall ore zones

66. Photographs showing representative exposures of variously classified types of veining in the Upper Cambrian Harmony Formation

67. Map showing schematic distribution of stockwork quartz veins, quartz veins, quartz-pyrite veins, and pyrite veins in general area of the Buckingham deposit

68. Photomicrographs showing textural relations in the East stock and its immediately adjacent country rock --...-.-.-.-.

69. Columnar section showing lithology, alteration assemblage(s) in thin-sectioned rocks, and molybdenum and copper in drill hole 1465 collared in the East stock of the Buckingham stockwork molybdenum system --........

70. Columnar section showing lithology, alteration assemblage(s) in thin-sectioned rocks, and molybdenum and copper in drill hole 1463 collared in the East stock of the Buckingham stockwork molybdenum system -

71. Diagram showing chemically analyzed fresh monzogranite porphyry, altered monzogranite porphyry, altered megacryst porphyry, and altered aplite from the Buckingham stockwork molybdenum system -

72. Diagram comparing ranges and means for $\mathrm{F}, \mathrm{Rb}, \mathrm{Sr}, \mathrm{Ba}, \mathrm{Sn}, \mathrm{Nb}, \mathrm{U}, \mathrm{Th}, \mathrm{La}$, and $\mathrm{Y}$ contents in various igneous phases of the Buckingham stockwork molybdenum deposit

73. Photographs of the Widow and Sweet Marie Mines

74. Geologic sketch map of the 5575-ft bench in the Contention pit at the Copper Basin Mine

75. Schematic cross section through the Copper Basin deposits

76. Photograph of pale-blue turquoise from the Copper Basin area cutting iron oxide-filled fractures that replace pyrite in sample of bleached arkosic sandstone of the Upper Cambrian Harmony Formation -

77. Map showing sample localities of rocks analyzed in tables 27 through 31 and traces of geochemical profiles $A-A^{\prime}$, $B-B^{\prime}, C-C^{\prime}, D-D^{\prime}$, and $E-E^{\prime}$

78-85. Diagrams showing:

78. Variations in $\mathrm{Mo}, \mathrm{F}, \mathrm{W}, \mathrm{B}, \mathrm{Cu}$, and $\mathrm{Ba}$ contents along traverse $A-A^{\prime}$ and their relations to pyrite halo and quartz stockworks associated with the Buckingham system -

79. Variations in $\mathrm{U}, \mathrm{Th}, \mathrm{Mn}$, and $\mathrm{Zn}$ contents along traverse $A-A^{\prime}$ and their relations to pyrite halo and quartz stockworks associated with the Buckingham system

80. Variations in $\mathrm{Mo}, \mathrm{F} ; \mathrm{W}, \mathrm{B}, \mathrm{Cu}, \mathrm{Zn}, \mathrm{Ba}, \mathrm{Mn}, \mathrm{U}$, and $\mathrm{Th}$ contents along traverse $B-B^{\prime}$ and their relations to quartz stockworks associated with the Buckingham system --

81. Variations in $\mathrm{Mo}, \mathrm{F}, \mathrm{W}, \mathrm{B}, \mathrm{Cu}, \mathrm{Ba}, \mathrm{Mn}, \mathrm{Sn}, \mathrm{Sb}$, and $\mathrm{As}$ contents along traverse $C-C^{\prime}$ and their relation to quartz stockworks exposed on Vail Ridge

82. Frequency distributions of 12 elements in 26 rock samples from geochemical traverse $E-E$

83. F versus $\mathrm{Mo}, \mathrm{Ba}, \mathrm{Cu}$, and $\mathrm{Li}$ contents in 26 rocks analyzed along traverse $E-E^{\prime}$

84. F versus $\mathrm{Mo}$ and $\mathrm{Cu}$ contents in Tertiary granitic rocks along traverse $E-E^{\prime}$ in the Bluff area and in Late Cretaceous granitic rocks along traverses $A-A^{\prime}$ and $C-C^{\prime}$ of the Buckingham molybdenum system, and, similarly, in rocks of the Upper Cambrian Harmony Formation

85. Loading on Q-mode factors associated with molybdenum mineralization

86. Geologic sketch map of northeastern part of the Buckingham area, showing skarns --

87. Photomicrographs showing alteration textures in sulfide minerals in skarn D

88. Photomicrographs showing gold-copper skarn ore at the Surprise deposit

89. Ternary plots showing Copper Basin garnet compositions in terms of molecular proportions of pyrope+almandine + spessartine, grossular, and andradite

90. Photomicrograph and variation in andradite content of a selected garnet crystal

91. Diagram showing microprobe traverses across zoned garnets from skarn $D$ -

92. Histograms showing variation in garnet compositions along a traverse for skarn $D$ in the Upper Cambrian Harmony Formation

93. Photomicrographs and microprobe traverses of zoned anisotropic garnets in the Upper Pennsylvanian and Lower Permian Antler Peak Limestone 
94-105. Diagrams showing:

94. Frequency of normal compared with inverse zoning for garnet

95. Variation of $\mathrm{TiO}_{2}$ content in garnets as a function of andradite content -

96. Total iron as $\mathrm{FeO}$ compared with $\mathrm{Na}_{2} \mathrm{O}$ and $\mathrm{MnO}$ contents in pyroxenes

97. Composition of Copper Basin pyroxenes in terms of molecular proportions of johannsenite, diopside, and hedenbergite

98. Range of epidote compositions in Copper Basin skarns -

99. Coexisting epidote-garnet compositions from Copper Basin skarns in terms of partition coefficient $K^{\prime}$-...-

100. Calculated curves at temperatures from 25 to $600{ }^{\circ} \mathrm{C}$ for coexisting garnet-epidote pairs at $1 \mathrm{kbar}$, and fields for coexisting garnet-epidote pairs from Copper Basin skarns -

101. Range of compositions for amphiboles from Copper Basin skarns -

102. Copper Basin chlorite compositions in terms of cations $\mathrm{Al}, \mathrm{Mg}$, and $\mathrm{Fe}+\mathrm{Mn}$

103. Range of chromite compositions in skarn $D$ in terms of cation ratios -

104. Range of skarn mineral compositions at Copper Basin compared with skarn mineral compositions in other skarns

105. Graphs showing oxygen fugacity-temperature regime for skarn mineral assemblages, and experimental data showing effects of decreasing $X_{\mathrm{CO} 2}$ on minimum thermal stability of andradite --

106. Diagram showing types of fluid inclusions

107. Photomicrographs of type I fluid inclusions in andradite collected $150 \mathrm{~m}$ south of north end of skarn $\mathrm{D}$

108. Scanning electron micrographs of fluid-inclusion cavities and desiccation products

109. Energy-dispersive X-ray spectra of minute minerals that formed as desiccation products on andradite --..---..-

110. Scanning electron micrographs of frozen fluid-inclusion waters in second-generation andradite from skarn $D$, and energy-dispersive X-ray spectra

111. Histogram showing filling temperatures in second-generation andradite of skarn $\mathrm{D}$ related to the Buckingham molybdenum system

112. Sketch showing relations of fluid inclusions to growth bands in a second-generation andradite crystal from skarn D -

113. Photomicrographs showing pseudosecondary fluid inclusions and respective homogenization temperatures in a selected crystal of second-generation andradite

114. Photomicrograph showing apparently primary fluid inclusions in second-generation andradite and homogenization temperatures -

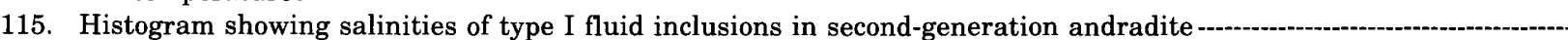

116. Plot of salinity versus homogenization temperature for fluid inclusions in second-generation andradite from skarn $D$ -

117. Map showing sample localities of quartz veins in the Buckingham system studied by heating and freezing tests -----

118. Histograms showing variation in fluid-inclusion homogenization temperatures with distance away from locus of magmatism and quartz stockwork development in the Vail Ridge block

119. Photomicrographs showing concentrations of secondary fluid inclusions in vein quartz from axial core of the Buckingham system in the Vail Ridge block ---

120. Photomicrographs showing types III and IV fluid inclusions in quartz stockworks from the Vail Ridge block -...-.-...

121. Plot of salinity versus homogenization temperature for 44 fluid inclusions in vein quartz -

122. Scanning electron micrographs of artificially opened fluid-inclusion cavities in quartz veins from the Vail Ridge block

123. Plot showing distribution of $\mathrm{CO}_{2}$ homogenization temperatures for fluid inclusions from the Vail Ridge block -------

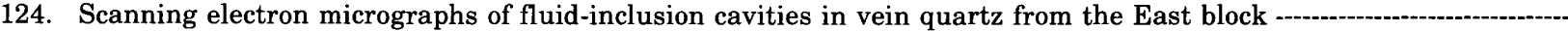

125. Diagram showing distribution of fluid-inclusion salinities in vein quartz from a drill hole in the East block ----------

126. Diagram showing distribution of fluid-inclusion homogenization temperatures in vein quartz from a drill hole in the East block

127. Plot of salinity versus homogenization temperature in vein quartz near the East stock

128. Diagram showing distribution of homogenization temperatures in 421 fluid inclusions from vein quartz in the West block -

129. Scanning electron micrographs showing type III fluid inclusions from the West block -

130. Scanning electron micrographs showing crystal-rich type III fluid inclusions from the West block -

131. Energy-dispersive X-ray spectra of sulfides in a selected fluid inclusion -

132. Phase diagram for vapor-saturated system $\mathrm{NaCl}-\mathrm{KCl}-\mathrm{H}_{2} \mathrm{O}$

133. Plot of salinity versus liquid-vapor homogenization temperature in fluid inclusions from the West block ---

134. Summary plot of liquid-vapor homogenization temperatures versus salinity for types I, II, III, and IV fluid inclusions from the West block of the Buckingham molybdenum system compared with similar data from skarn, Vail Ridge block, and East block

135. Plot of $\mathrm{dD}$ versus $\mathrm{d}^{18} \mathrm{O}$ values for water calculated to be in equilibrium with quartz

136. Diagram showing pressure-temperature projection of various curves

137. Secondary-electron micrograph and energy-dispersive X-ray spectra of placer gold -

138. Scanning electron micrographs of placer gold intergrown with probable sillenite

139. Scanning electron micrographs of placer gold intergrown with bismuth telluride 


\section{TABLES}

TABLE 1. Analytical data on the Upper Cambrian Harmony Formation of the Buckingham Camp-Copper Basin area, Lander County, Nevada -

2. Analytical data on the Middle Pennsylvanian Battle Formation of the Buckingham Camp-Copper Basin area, Lander County, Nevada

3. Analytical data on the Upper Pennsylvanian and Lower Permian Antler Peak Limestone of the Buckingham Camp-Copper Basin area, Lander County, Nevada

4. K-Ar analytical data on the Buckingham stockwork molybdenum system and nearby Tertiary intrusive rocks -------

5. Analytical data for six-step ${ }^{40} \mathrm{Ar} /{ }^{39} \mathrm{Ar}$ incremental-heating experiment on biotite from the monzogranitic body of Buckingham Camp

6. Chemical analyses of two very minimally altered, representative samples of the porphyritic phase of the biotitehornblende monzogranite of Bluff area

7. Modal data on late Eocene or early Oligocene porphyritic leucogranite of the Buckingham area -

8. Analytical data on late Eocene or early Oligocene porphyritic leucogranite of the Buckingham Camp-Copper Basin area, Lander County, Nevada

9. Analytical data on late Eocene or early Oligocene rhyolite of the Buckingham Camp-Copper Basin area, Lander County, Nevada -

10. Analytical data on altered porphyritic biotite monzogranite from a drill hole collared near the Little Giant Mine -----

11. Analytical data on early Oligocene granodiorite porphyry near the East stock of the Buckingham stockwork molybdenum system -

12. Analytical data on early Oligocene granodiorite porphyry emplaced in the middle member of the Middle Pennsylvanian Battle Formation and the Upper Pennsylvanian and Lower Permian Antler Peak Limestone --.-

13. Descriptions of igneous-rock units in the Buckingham stockwork molybenum system

14. Analytical data on fresh or weakly altered samples of premineral, synmineral, and intermineral intrusions in the Buckingham stockwork molybdenum system

15. Modal analyses of typical samples of postmineral rock units near the Buckingham stockwork molybdenum system ---

16. Analytical data on fresh or weakly altered samples of postmineral intrusive rocks of the Buckingham stockwork molybdenum system

17. Whole-rock chemical analyses comparing various alteration assemblages in quartz monzonite porphyry from the Buckingham stockwork molybdenum deposit

18. Hypogene molybdenum mineralization episodes in the Buckingham area

19. Ages and mineralization associated with several types of Tertiary intrusive rocks in the Buckingham area -...-...-...

20. Analytical data on Late Cretaceous monzogranite porphyry at different depths in the East stock associated with the Buckingham stockwork molybdenum deposit -

21. Analytical data on Late Cretaceous aplite in the East stock of the Buckingham porphyry molybdenum system, Lander County, Nevada

22. Analytical data on metamorphosed and hydrothermally altered samples of the Upper Cambrian Harmony Formation from the general area of the East stock in the Buckingham stockwork molybdenum deposit

23. Mean values and standard deviations for major-element cations in a standard cell of 160 oxygens calculated for 11 samples of altered monzogranite porphyry compared with fresh monzogranite porphyry from the Buckingham stockwork molybdenum system

24. Analytical data on garnet skarn formed in the Upper Cambrian Harmony Formation penecontemporaneously with Late Cretaceous molybdenum mineralization

25. Statistics of copper production by Duval Corp. at Copper Basin for 1965-81 -

26. Analytical data on turquoise from the Blue Gem deposit of the Copper Basin Mine compared with analytical data on turquoise from other areas

27. Analytical data obtained along traverse $A-A^{\prime}$ (fig. 77)

28. Analytical data obtained along traverse $B-B^{\prime}$ (fig. 77)

29. Analytical data obtained along traverse $C-C^{\prime}$ (fig. 77)

30. Analytical data on biotite hornfels and altered biotite hornfels of the Upper Cambrian Harmony Formation near the West stock, and on one sample of monzogranite porphyry of the West stock obtained along traverse $D-D^{\prime}$ (fig. 77)

31. Analytical data obtained along traverse $E-E^{\prime}$ (fig. 77 )

32. Supplementary analytical data for thorium and uranium obtained from samples collected along traverse $B-B^{\prime}$........

33. Replicate analytical data for thorium and uranium in samples of mineralized rocks of the Upper Cambrian Harmony Formation and in samples of Late Cretaceous granitic rocks and late Eocene or early Oligocene granodiorite porphyry analyzed in tables 11,20 , and 22

34. Unqualified minimum and maximum values for each of 30 selected elements analyzed in tables 27 through 31 , and the number and type of qualified determinations on rocks analyzed along traverses $A-A^{\prime}, B-B^{\prime}, C-C^{\prime}$, $D-D^{\prime}$, and $E-E^{\prime}$ (fig. 77 ) in the Buckingham area 
35. Array of correlation coefficients for 128 rocks (tables 27-31) from the Buckingham area

D190

36. Mineralogy of skarn, hornfels, and associated diabase from the Upper Cambrian Harmony Formation

37. Mineralogy of skarn from the Middle Pennsylvanian Battle Formation and the Upper Pennsylvanian and Lower Permian Antler Peak Limestone

38. Analytical data on skarn and garnet formed in the Upper Cambrian Harmony Formation, skarn formed in the middle member of the Middle Pennsylvanian Battle Formation, and associated clay layers at Copper Basin -.....

39. Representative analyses of feldspar in hornfels and skarn from the Upper Cambrian Harmony Formation

40. Representative analyses of garnet from Copper Basin skarns

41. Representative analyses of pyroxene from Copper Basin skarns

42. Representative analyses of epidote from Copper Basin skarns -

43. Representative analyses of amphibole from Copper Basin skarns

44. Representative analyses of biotite and chlorite from Copper Basin skarns -

45. Analytical data for clays associated with skarns at Copper Basin

46. Representative analyses of apatite from Copper Basin skarns

47. Representative analyses of scapolite in sample 85JH080, skarn C, Upper Cambrian Harmony Formation --...-.....

48. Representative analyses of opaque minerals in Copper Basin skarns

49. Temperature and salinity data from fluid inclusions hosted by vein quartz in the Vail Ridge block of the Buckingham stockwork molybdenum system

50. Isotopic composition of carbon dioxide in fluid inclusions hosted by vein quartz from the Buckingham stockwork molybdenum system

51. Temperature and salinity data from fluid inclusions hosted by vein quartz in the East block of the Buckingham stockwork molybdenum system

52. Temperature and salinity data from fluid inclusions hosted by vein quartz in the West block of the Buckingham stockwork molybdenum system

53. Temperature and salinity data from fluid inclusions hosted by vein quartz in the Little Giant Mine and in the quartz stockworks centered at Bluff

\section{CONVERSION FACTORS}

\begin{tabular}{rll}
\hline Metric & & Standard \\
\hline 1 micrometer $(\mathrm{mm})$ & $=$ & $1 \times 10^{-6}$ meter $(\mathrm{m})$ \\
1 meter $(\mathrm{m})$ & $=$ & 3.281 feet $(\mathrm{ft})$ \\
1 kilometer $(\mathrm{km})$ & $=$ & 0.6214 mile $(\mathrm{mi})$ \\
1 gram $(\mathrm{g})$ & & 0.0022 pound, avoirdupois $(\mathrm{lb}$ \\
& $=$ & avdp) \\
1 gram $(\mathrm{g})$ & & 0.035 ounce, avoirdupois $(\mathrm{oz}$ \\
& $=$ & avdp) \\
1 gram $(\mathrm{g})$ & $=$ & 0.032 troy ounce $($ troy oz $)$ \\
1 tonne $(\mathrm{t})$ & $=$ & 0.9842 long ton $(2,240 \mathrm{lb})$ \\
1 tonne $(\mathrm{t})$ & & \\
1 kilogram per square & $=$ & 0.98 bar $(0.9869$ atm $)$ \\
centimenter $\left(\mathrm{kg} / \mathrm{cm}^{2}\right)$ & $=$ & 10 bars \\
$1 \times 10^{6}$ pascals $(\mathrm{MPa})$ & $=$ & $1.8\left(\right.$ temp $\left.{ }^{\circ} \mathrm{C}\right)+32$ degrees \\
1 degree Celsius $\left({ }^{\circ} \mathrm{C}\right)$ & & Fahrenheit $\left({ }^{\circ} \mathrm{F}\right)$ \\
& &
\end{tabular}




\section{.}




\title{
GEOLOGY OF THE BUCKINGHAM STOCKWORK MOLYBDENUM DEPOSIT AND SURROUNDING AREA, LANDER COUNTY, NEVADA
}

\author{
By Ted G. Theodore, David W. Blake, ${ }^{1}$ Thomas A. Loucks, ${ }^{2}$ and Craig A. Johnson ${ }^{3}$
}

\section{ABSTRACT}

The Buckingham stockwork molybdenum deposit in northcentral Nevada, about $10 \mathrm{~km}$ southwest of the town of Battle Mountain, contains one of the largest identified resources of molybdenum in the United States. The Buckingham deposit is a calc-alkaline, stockwork molybdenum system located on the east flank of the Battle Mountain Mining District. The deposit is estimated to contain more than 1,000 million $t$ of mineralized rock averaging approximately 0.10 weight percent molybdenum (as $\mathrm{MoS}_{2}$ ) and containing small amounts of silver, tungsten, copper, and gold. Molybdenum mineralization is related to emplacement of a Late Cretaceous composite porphyry system that intruded and widely metamorphosed the surrounding Paleozoic rocks to hornfels in the upper plate of the Roberts Mountains thrust. The age of emplacement of the Buckingham system is based on evaluation of $10 \mathrm{~K}-\mathrm{Ar}$ and 1 incremental-heating ${ }^{40} \mathrm{Ar} /{ }^{39} \mathrm{Ar}$ age determinations. The ages range from $88.0 \pm 2.0$ to $61.3 \pm 1.5 \mathrm{Ma}$; four of these ages, including the major argon-release steps of the incremental-heating experiment, cluster around $86 \mathrm{Ma}$. This age is considered to represent the initial time of cooling of the porphyry system. The seven major intrusive phases that were identified in the Buckingham system were intruded sequentially from south to north in a narrow space; the present configuration of the intrusive center is an east-west alignment of two stocks, each a composite of several porphyries, and several outlying intrusive masses. All seven phases appear to have carried molybdenum. The two earliest intrusions, now forming border phases, and the latest, an outlying intrusion, were dike-forming pulses related to relatively weak molybdenum mineralization. The main Buckingham molybdenum deposit formed in association with five igneous phases located in the two stocks. All five phases developed umbrella-shaped shells of molybdenite mineralization that drape over the stocks and locally overlap to produce grades of approximately 0.10 to 0.20 weight percent $\mathrm{MoS}_{2}$. Silver, tungsten, and copper mineralization accompanied molybdenum in each succeeding magmatic/hydrothermal pulse. Approximately half of the Buckingham deposit is hosted by metamorphosed and intensely veined rocks belonging to the Upper Cambrian Harmony Formation. Gold skarn mineralization at the Surprise Mine and silver-gold mineralization associ-

${ }^{1}$ Battle Mountain Gold Co., Battle Mountain, NV 89820.

${ }^{2}$ Climax Molybdenum Co., Golden, CO 80401; current affiliation: Royal Gold, Inc., Denver, CO 80202

${ }^{3}$ Yale University, New Haven, CT 06520; current affiliation: American Museum of Natural History, New York, NY 10024.

Manuscript approved for publication, September 8, 1989. ated with silica-pyrite alteration at the Empire Mine and at the Northern Lights Mine apparently are associated genetically with the Buckingham system.

Deformation of the Buckingham system during the Tertiary includes significant, brittle-type tectonics that is manifested primarily along three major, low-angle faults. Such Tertiary extensional tectonism apparently progressed mostly from east to west somewhat irregularly during Oligocene and possibly even Miocene time. Imbricate, down-to-the-east, listric normal faulting along the Second and Buckingham faults probably merge together with the Long Canyon fault into a single master, flatlying dislocation somewhere to the east of the easternmost parts of the Buckingham system. In addition, major reverse dislocations in this area in the hanging wall of the Long Canyon fault probably reflect development of antithetic reverse faults in the toe region of a rigid-body glide block in compensation possibly for a buttressing by a decrease in the dip of the master dislocation surface.

Garnet skarns in the northern part of the Buckingham area formed locally in limey beds of the Harmony Formation intruded by late Eocene or early Oligocene porphyritic leucogranite, at the Surprise Mine and along a contact between the Harmony Formation and Middle Pennsylvanian Battle Formation cut by Late Cretaceous monzogranite porphyry related to the Buckingham system, and in the Battle Formation and the Pennsylvanian and Permian Antler Peak Limestone intruded by Oligocene granodiorite porphyry. The dominant prograde mineral assemblage in all skarns is andradite garnet $\left(\mathrm{Ad}_{40}-\mathrm{Ad}_{99}\right)$, which replaces diopsidic pyroxene $\left(\mathrm{Di}_{40}-\mathrm{Di}_{90}\right)$ and $\mathrm{K}$-feldspar. Late-stage, metasomatic and retrograde skarn assemblages are best formed along favorable structural channels, faults, or contacts, regardless of protolith. These assemblages include epidote, actinolite, chlorite, and smectite; wollastonite is absent. Despite wide-ranging differences in protolith and the ages of associated granitoids, calcsilicate compositions overlap, fall within previously established compositional fields for calc-silicates associated with copper and iron mineralization in calcic skarns, and overlap compositions of silicates in skarns associated with gold, copper, and silver mineralization elsewhere in the district. Gold skarn at the Labrador Mine apparently is associated with late Eocene or early Oligocene porphyritic leucogranite.

Hydrothermal fluids in the Buckingham system show complex histories that largely indicate their immediate chemical and physical parameters as the environment, possibly less than 2.5$\mathrm{km}$ depth, reacted to successive influxes of fluids mostly from newly injected magma into loci of earlier emplaced igneous phases. In distal parts of the system, where some andraditediopside skarn formed in carbonate beds of the Harmony Formation, associated fluids were moderately saline $\mathrm{CaCl}_{2}$ brines 
apparently circulating at relatively low temperatures of about $300{ }^{\circ} \mathrm{C}$, and presumably at extremely low mole fractions of $\mathrm{CO}_{2}$. However, in proximal parts of the system, where most of the quartz stockworks and molybdenite were deposited, fluids were relatively low density, boiling, low- to moderate-salinity $\mathrm{NaCl}$ brines that included highly variable amounts of $\mathrm{CQ}_{2}$. These early-stage fluids in the system probably established an ascending "plume" of fluid considerably less saline than fluids associated with most porphyry copper sytems in the Southwestern United States and with Climax-type systems. The magmas at Buckingham did not evolve large volumes of very dense, $\mathrm{NaCl}-$ rich fluids. High in the system, very sparse halite-bearing fluid inclusions probably formed largely through condensation from an earlier, higher temperature and moderately saline fluid. In the West block, the high-temperature and high-saline halite-bearing fluid inclusions, showing salinities as much as 65 weight percent $\mathrm{NaCl}$ equivalent and homogenization temperatures as high as $500{ }^{\circ} \mathrm{C}$, probably indicate ponded magmatic fluids from a deep source. Overall distribution of veins associated with such fluids appears to be quite restricted. Although a fluid-immiscibility model is probably applicable to some porphyry molybdenum systems where the exposed parts of the systems are well above a buried concentration of molybdenum, the geometry of the molybdenite-enriched shells and their proximity to the igneous source at Buckingham seem to argue against the prevalence of such a model here. These shells are tightly constrained to the flanks and apical parts of the two mineralized stocks, and the shells seem to show a genetic relation to a quartz-K-feldspar porphyry phase in the core of the stocks. Furthermore, an approximately $1-\mathrm{km}$-long, composite vertical section through the Buckingham system is available for study in the three tectonically offset blocks and nowhere is there a widespread presence of hypersaline fluids. Therefore, most of the moderately saline $\mathrm{H}_{2} \mathrm{O}-\mathrm{NaCl}$ $\mathrm{CO}_{2}$ mineralizing fluids associated with this deposit is related to quartz-K-feldspar porphyry and slightly deeper equivalent igneous phases.

The principal source of the supergene copper mineralization in the Copper Basin Mine, in the eastern part of the area, apparently is hypogene sulfides in skarn and calc-silicate hornfels in the Upper Cambrian Harmony Formation and possibly some from the Middle Pennsylvanian Battle Formation that overlay the area at one time. These originally calcareous beds were mineralized and altered by Late Cretaceous monzogranite porphyry associated with the Buckingham system that produced locally massive and widespread disseminated pyrite, pyrrhotite, and chalcopyrite in the copper-enriched outer halo of the system. Mineralization in the Copper Basin Mine occupies the eastdipping limb of a major anticline through the district and, upon oxidation of hypogene sulfides there, the supergene copperbearing solutions migrated downward along bedding planes and structures from mostly skarn and calc-silicate hornfels above. The high-grade zones of copper mineralization, both hypogene and supergene, are proximal to monzogranite porphyry. During the interval of time between the emplacement of the Late Cretaceous intrusions associated with the Buckingham system and subsequent deposition of the Oligocene Caetano Tuff, which crops out just east of the area studied, the area underwent a first-cycle oxidation and enrichment to form an intensive lowgrade chalcocite zone. Renewed oxidation and erosion occurred after the Oligocene Caetano Tuff was removed, exposing thereby the first cycle of supergene copper deposition. The second cycle of enrichment and oxidation, which continued to the present, removed additional oxide capping and enriched the first-cycle su- pergene copper zone at depth to yield the ore bodies in the Copper Basin Mine.

\section{INTRODUCTION}

Historically, the Battle Mountain Mining District, located west-southwest of the town of Battle Mountain in north-central Nevada, has been one of the largest producers of copper in the State of Nevada (fig. 1). However, recent discoveries have changed dramatically the economic outlook of the district to one of a center of gold and molybdenum endowment. Most of the copper in the district came from two centers of widespread metallization: Copper Canyon, in the southern part of the district, and Copper Basin, in the northeastern part (fig. 2). Copper showings in the Copper Canyon area were discovered before 1866 (Roberts and Arnold, 1965), however, large-scale mining did not begin in the district until 1967 (Sayers and others, 1968) when Duval Corp. established milling and leaching operations after about 17 million tons of milling ore were blocked out at Copper Canyon and Copper Basin. About this time, the stockwork porphyry molybdenite character of the extremely large Buckingham system, just west of Copper Basin, was recognized by Congdon and Carey geologists (see subsection below entitled "Economic Geology"), and joint-venture drilling of this deposit, primarily by the Rocky Mountain Energy Co. and the Climax Molybdenum Co., continued from about 1967 to 1982.

Concurrent with these exploration activities at the Buckingham system, milling of copper-goldsilver ores, mostly from two major replacement ore bodies at Copper Canyon (Theodore and Blake, 1975,1978 ), continued to 1977 , when minable copper-gold-silver ores at the East and West ore bodies were exhausted. Until 1974, combined milling and leaching operations of Duval Corp. from its two properties at Copper Canyon and Copper Basin yielded 102,083 tons of copper metal (Theodore and Blake, 1978). As such, copper-mining operations during 1967 to 1975 in the Battle Mountain Mining District ranked third in the State behind operations at Yerington and Ely; both operations were suspended in 1987. However, leaching operations in the Battle Mountain Mining District, centered mostly in the Copper Basin area, produced the largest amount of copper in the State of $\mathrm{Ne}$ vada in 1981 (Lockard and Schilling, 1983). The mining operation at Copper Canyon shifted to the 


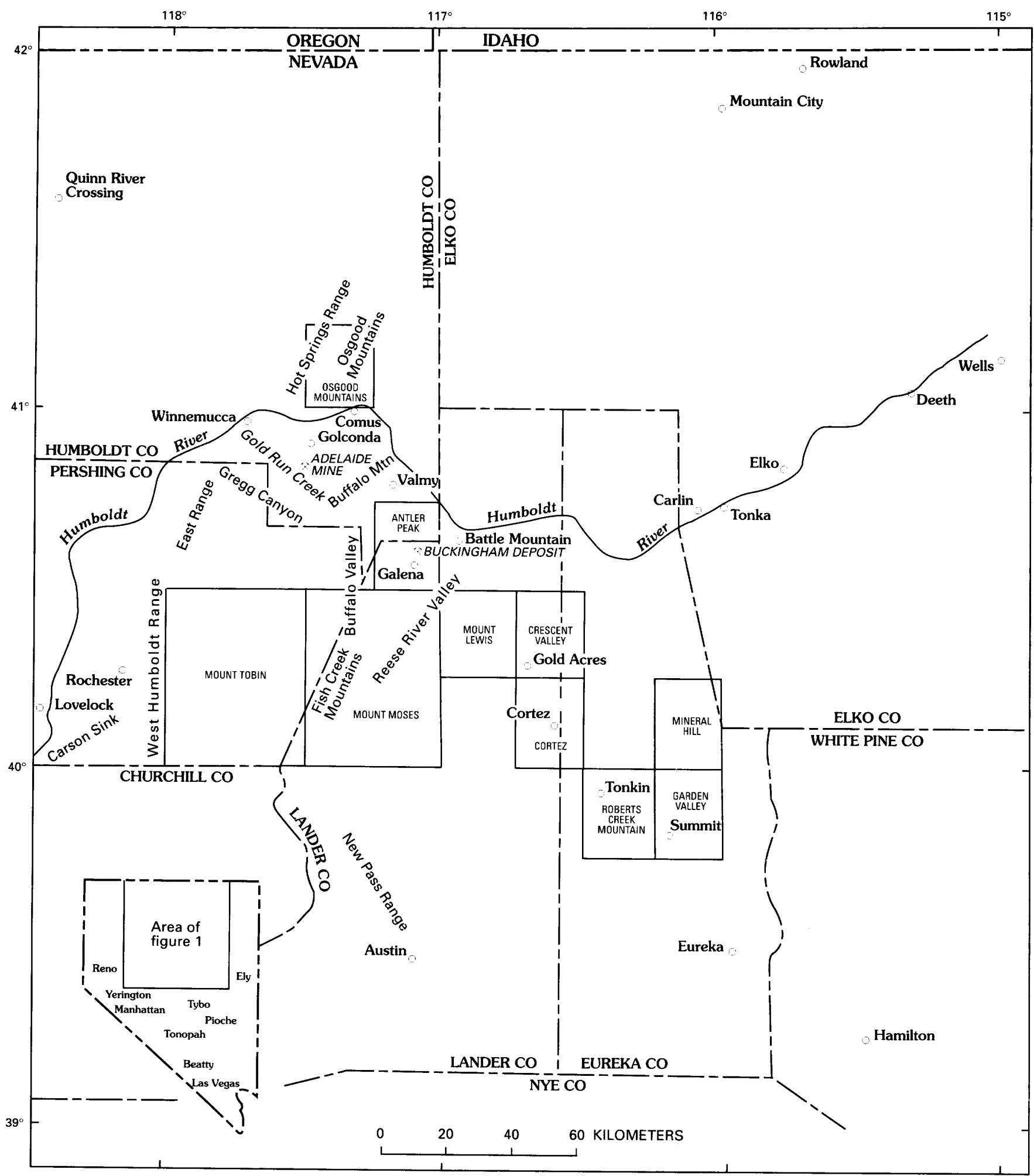

FIGURE 1.-Index map of north-central Nevada, showing location of Buckingham deposit and outlines and names of quadrangles mentioned in text. 


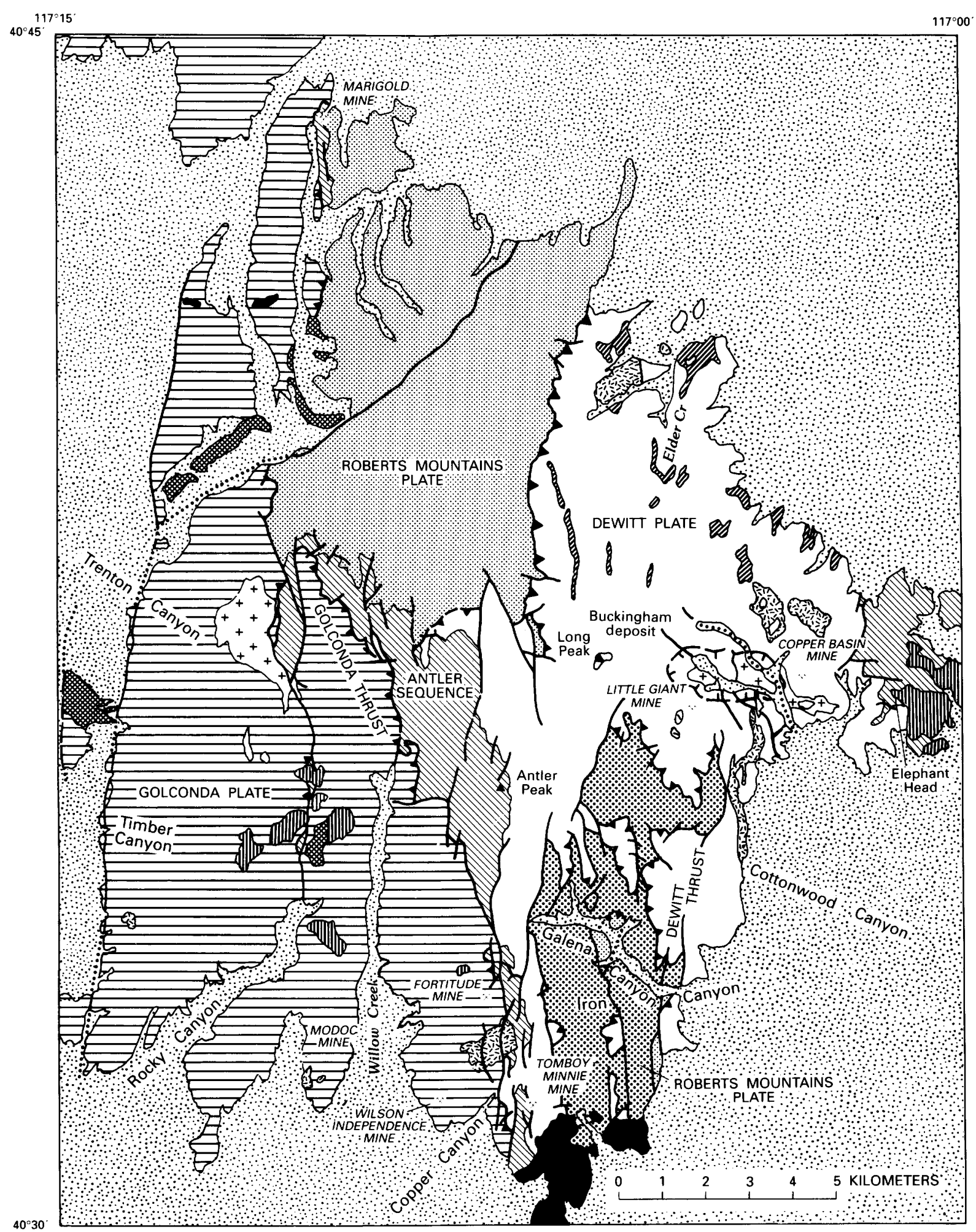

Figure 2.-Generalized geology of Antler Peak quadrangle (Battle Mountain Mining District), Nevada, showing location of Buckingham deposit. Geology modified from Roberts (1964, pl. 1). See figure 1 for location. 
processing of gold-silver ores in January 1979, initially in large part from highly sulfidized replacement ore bodies at the Tomboy-Minnie Mine (Blake and Kretschmer, 1983; Blake and others, 1984; Theodore and others, 1986). This production of gold-silver dore commenced from a plant facility modified to include cyanide leach and carbon-inpulp adsorption sections. The ore bodies, which are peripheral to central copper-gold-silver East and West ore bodies, are present in a gold-silver zone first outlined by Roberts and Arnold (1965). During 1980 and 1981, production of gold from ore bodies in the Copper Canyon area contributed significantly toward making Nevada the leading goldproducing State (Lockard and Schilling, 1983). Gold-silver production in 1980-84 from the Copper Canyon area included the following (prospectus issued by Battle Mountain Gold Co., July 12, 1985):

\section{EXPLANATION}

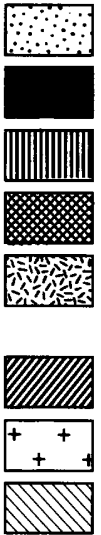

Alluvium (Quaternary)

Basalt (Tertiary)-Age is $\mathbf{3}$ Ma (this report)

Caetano Tuff (Oligocene)-Age is $34 \mathrm{Ma}$ (McKee and Silberman, 1970)

Welded tuff and pyroclastic rocks (Oligocene)

Granodiorite porphyry, monzogranite, tonalite, and rhyolite (Oligocene or Eocene)-Age dates range from 35 to $41 \mathrm{Ma}$ (Theodore and others, 1973; this report)

Monzogranite (Tertiary?)

Monzogranite and monzogranite porphyry (Late Cretaceous)-Age is 86-88 Ma (Theodore and others, 1973; this report)

Antler Sequence (Permian and Pennsylvanian)-Consists of Middle Pennsylvanian Battle Formation, Upper Pennsylvanian and Lower Permian Antler Peak Limestone, and Upper Permian Edna Permian Antler Peak
Mountain Formation

\section{GOLCONDA THRUST PLATE}

Havallah sequence of Silberling and Roberts (1962) and Roberts and Thomasson (1964) (Permian, Pennsylvanian, and Mississippian)

\section{ROBERTS MOUNTAINS THRUST PLATE}

Valmy Formation (Middle and Early Ordovician)

Scott Canyon Formation (Devonian)-In thrust fault contact with overlying Valmy Formation; base not exposed here

\section{DEWITT THRUST PLATE}

Harmony Formation (Late Cambrian)

\section{Contact}

High-angle fault-Dashed where approximately located; dotted where concealed or inferred

Thrust fault-Dashed where approximately located; dotted where concealed or inferred. Sawteeth on upper plate

Figure 2.-Continued

\begin{tabular}{|c|c|c|c|c|c|}
\hline \multirow{2}{*}{\multicolumn{6}{|c|}{$\begin{array}{ccc}1980 & 1981 & 1982 \\
\text { (Tons and ounces expressed in thousands) }\end{array}$}} \\
\hline & & & & & \\
\hline & 1,068 & 1,234 & 1,400 & 1,291 & 1,231 \\
\hline & $3.95: 1$ & 6.31:1 & $9.32: 1$ & $12.06: 1$ & 17.26: \\
\hline $\mathrm{Au} /$ ton $) \ldots$ & .073 & .064 & .059 & .072 & .071 \\
\hline $\mathrm{Au}$ (pct) ..... & 87 & 85 & 85 & 87 & 85 \\
\hline oz).. & 69 & 66 & 71 & 80 & 73 \\
\hline z). & 21 & 39 & 92 & 307 & 357 \\
\hline
\end{tabular}

In addition, through December 1984, recovery of precipitates of copper from leach dumps at both Copper Canyon and Copper Basin continued at a rate of approximately 2.4 million $\mathrm{lb} \mathrm{Cu} / \mathrm{yr}$ (see subsection below entitled "Supergene Copper Deposits at Copper Basin").

In 1981, Duval Corp. announced discovery of yet another large gold-silver ore body, the Fortitude, just north of the West ore body in the Copper Canyon area. The Tomboy-Minnie deposits were mined out during late 1982, and precious-metal mining operations shifted to the area immediately surrounding the Independence Mine, termed the "Northeast Extension," just north of the East ore body, while stripping of waste rock at the Fortitude proceeded. Full-scale production of the Fortitude, initially estimated to amount to about 150,000 troy oz Au/yr, was to be reached in 1985. The 16million-ton ore body was announced originally to contain 2.4 million troy oz $\mathrm{Au}$ and 9.2 million troy oz Ag (Anonymous, 1981). On January 1, 1985 estimates of ore reserves at the Fortitude and the Northeast Extension were revised to 1,874,000 troy oz $\mathrm{Au}$ in place and 9,954,000 troy oz $\mathrm{Ag}$ in place (prospectus issued by Battle Mountain Gold Co., July 12, 1985). The Fortitude deposit actually consists of two nearby ore bodies: The Upper Fortitude and the Lower Fortitude (Wotruba and others, 1986; Myers and Meinert, 1988). The better ores are in the Lower Fortitude which included, before startup, 5.1 million $t$ of minable ore at a grade of 0.305 troy oz Au/t, and 0.81 troy oz Ag/t (R.G. Benson and S.D. Johnson, written commun., 1988). On January 1, 1985 the board of directors of the Pennzoil Co., parent of Duval Corp., announced the formation of a wholly owned subsidiary, the Battle Mountain Gold Co., subsequent to an earlier announcement that all of Duval's metal-mining operations were up for sale (Epler, 1985). In 1986, the Battle Mountain Gold Co. confirmed the gold potential of rocks in the general area of the Surprise Mine north of Copper Basin (Argall, 1986; Schmidt and others, 1988). Estimated reserves there include approximately 160,000 troy oz $\mathrm{Au}$ in 1.75 million tons of ore (Anonymous, 1986) and production is expected during the first quarter of 
1988 (Anonymous, 1987a). Production in 1985 from the Fortitude Mine amounted to 220,000 troy oz $\mathrm{Au}$ and 647,000 troy oz Ag (Argall, 1986), and in 1986, 259,000 troy oz $\mathrm{Au}$ and 964,000 troy oz Ag (Anonymous, 1987b).

The Battle Mountain Mining District contains many other thoroughly evaluated prospects and some viable, still untested targets for base and (or) precious metals. Among the prospects are a stockwork porphyry molybdenum system that crops out near the southwest corner of the district, widespread quartz stockworks that crop out across about $1.5 \mathrm{~km}^{2}$ in the core of a Cretaceous granodiorite at Trenton Canyon, and extremely well developed Tertiary quartz stockworks that crop out in an area more than $3 \mathrm{~km}^{2}$ in the general area of Elder Creek. At Elder Creek, the geology suggests a weakly developed porphyry copper system (fig. 3). In addition, Horizon Gold Shares Inc. of Evergreen, Colo., began, in late 1985, preparing a site on the west flank of the range for the leaching of gold at the Buffalo Valley Gold Mine (see Roberts and Arnold, 1965). By 1988 the mine was reported to be producing about 9,200 troy oz Au/yr (Horizon Gold Shares Inc., 1988, annual report). Although the bulk of the gold in this deposit is present along steeply dipping fractures parallel to two narrow dikes, some of the highest concentrations of gold are present along narrow zones of highly sulfidized skarn that are oxidized to nontronite-bearing assemblages in the ore body. Finally another small gold skarn body, the Labrador, is present near one end of a 1.5-km-long skarn zone in the northeastern part of the Buckingham area (pl. 1; Battle Mountain Gold Co., 1987, annual report to stockholders, February 5, 1988; Schmidt and others, 1988).

The varied metal endowment of the Battle Mountain Mining District is a result of the location of the district in a shallow-seated geologic environment at the intersection of regional-scale metallotects of several ages, and the presence within the district of many metal-bearing plutons of highly diverse ages. In addition, several extremely important metallized trends within the district seem to characterize the known major ore bodies and their genetically related granitic rocks (Blake and others, 1979). The regional-scale metallotects include (1) a Late Cretaceous magmatic arc resulting from trench-related magmatism in a continental margin mobile belt (for example, Westra and Keith, 1981), (2) a highly metallized trend, the northwest-trending Eureka mineral belt of Shawe and Stewart (1976), previously termed the "Eureka-Battle Mountain mineral belt" by Roberts (1966), and (3) a north-south metallized trend, herein termed the "Rabbit Creek-Marigold mineral belt," that intersects the mining district in its northwestern part. Interpretation of regional gravity data in Nevada from which effects of shallow-seated responses have been removed by computer-aided, geologic-based algorithms suggests a major pre-Cenozoic crustal boundary correlates spatially with the Eureka-Battle Mountain mineral belt (Jachens and others, 1989). As pointed out by Barton and others (1988), Mesozoic copper mineralization shows a strong function with emplacement level in the Western United States, and it is viewed by them as having formed at depths less than $4 \mathrm{~km}$ in the general area of the Battle Mountain Mining District. The depth of emplacement of Cretaceous plutons in the Round Mountain and Manhattan Mining Districts, Nev., about $200 \mathrm{~km}$ south of the Battle Mountain Mining District, is inferred to be about 1.5 to $3.0 \mathrm{~km}$ (Shawe and others, 1986). In addition, Blake and others (1979) have outlined various northwesterly and northeasterly trends of fractures and mineralized intrusions within the district. The intradistrict metallotects at Battle Mountain include the caprock effect of impervious chert and argillite of the Mississippian, Pennsylvanian, and Permian Havallah sequence (Roberts and Thomasson, 1964; Stewart and others, 1986), which tectonically overlies favorable replacement horizons in the Middle Pennsylvanian to Upper Permian Antler sequence (Roberts and Arnold, 1965; Nash and Theodore, 1971; Theodore and Blake, 1975, 1978). The latter metallotect was genetically important in localizing ores in the Copper Canyon area, wherein a small, late Eocene to early Oligocene stock lies astride the major tectonic blocks in the district. These concentrations of deposits along northwesterly trending zones may have been localized along the shattered hingelines of broad anticlines formed during the Mesozoic (R.J. Madrid, oral commun., 1984).

This report is the latest in a series of relatively recent cooperative studies between the U.S. Geological Survey and private industry concerning the Battle Mountain Mining District. Theodore and others (1973) reported on the chemistry of many plutons in the district and the potassium-argon ages of their minerals. The section in the present report by E.H. McKee adds significantly to the data base of radiometrically dated samples from the district by describing the geochronologic implications of 14 new potassium-argon ages of minerals and of one whole-rock age, and a six-step incremental heating 


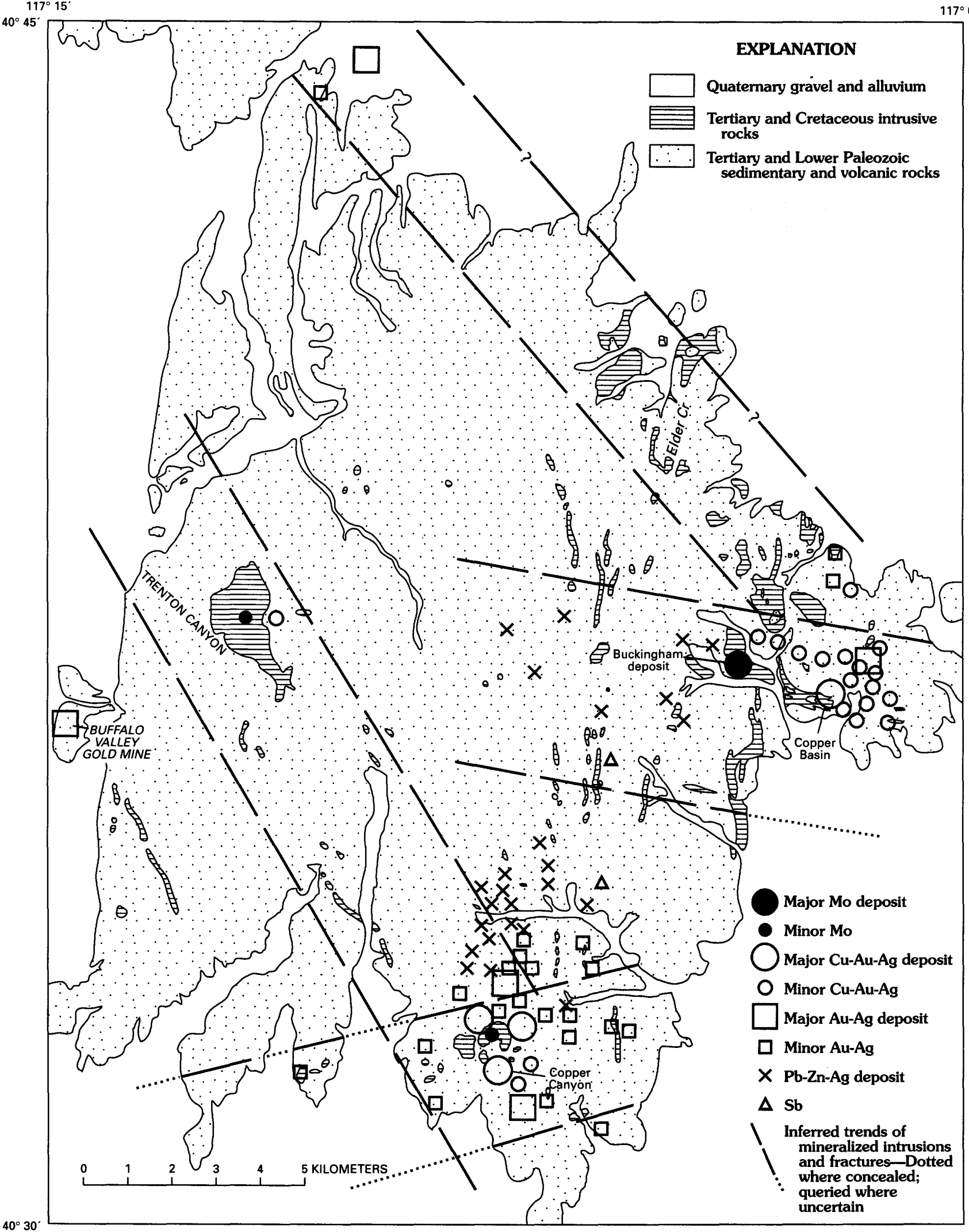

FIGURE 3.-Generalized geology of Antler Peak quadrangle, Lander County, Nevada, showing major deposits and prospects and inferred metal-concentrating trends in Battle Mountain Mining District. Geology modified from Roberts (1964, pl. 1). 
${ }^{40} \mathrm{Ar} /{ }^{39} \mathrm{Ar}$ of primary biotite from granitic rocks in the immediate area of the Buckingham deposit. In addition, the section by T.A. Loucks and C.A. Johnson includes one other potassium-argon age determination and one fission-track age determination. Theodore and Blake $(1975,1978)$ described the middle Tertiary copper-gold-silver East and West ore bodies at Copper Canyon. Several other reports (Nash and Theodore, 1971; Theodore and Nash, 1973; Batchelder and others, 1976; Batchelder, 1973, 1977) discussed the composition of fluids genetically associated with the deposits at Copper Canyon, and zonation of the fluids. Metal zonation of the deposits is described by Blake and others (1978), Blake and Kretschmer (1983), Blake and others (1984), and Theodore and others (1986), and a preliminary description of the Buckingham system is included in Blake and others (1979) and in Theodore (1982b). Mineral chemistry and fluid-inclusion relations of some of the barren Tertiary skarns in the northern part of the Buckingham area are characterized in detail by Theodore and Hammarstrom (1991). Roberts (1964) and Roberts and Arnold (1965) previously had described the geology of the district, regional setting of the district with respect to major allochthonous and autochthonous sequences of rock, and many of the ore deposits scattered throughout the district, including an extensive accumulation of geologic data from accessible underground workings. In this report, we provide an overview of middle Tertiary extensional tectonics superposed on the Late Cretaceous Buckingham system; a broad geochronologic sequence of magmatism across the area based on potassium-argon and ${ }^{40} \mathrm{Ar} /{ }^{39} \mathrm{Ar}$ studies; geologic details of the protracted series of magmatic pulses and their related ore shells in the system; relation of the copper ores at the Copper Basin deposit to the main mass of the molybdenum ores in the Buckingham system; comprehensive fluid-inclusion studies of several major deposit types in the area; mineral chemistry of Late Cretaceous and Tertiary skarn and finally, results of rock geochemistry from several sample traverses through the area.

\section{ACKNOWLEDGMENTS}

This study of the geology of the Buckingham deposit and its surrounding area could not have been assembled as completely as it has without the cooperation and encouragement of the managements of the Battle Mountain Gold Co., the Climax Molybdenum Co., Duval Corp., the Rocky Mountain Energy Co., and Union Pacific Mining Corp. A spe- cial gratitude must be accorded to the managements of these companies. The topographic base for plate 1 was provided by Duval Corp. The preceding investigations of Ralph J. Roberts provided the regional tectonostratigraphic framework for our studies. Fluid-inclusion studies were carried out in the laboratory of Wayne E. Hall (deceased), as were the fluid extractions for isotopic investigations. During the protracted fluid-inclusion studies, Theodore was ably assisted by Steven S. Spain (deceased), Timothy F. Lawton, R.A. LeVeque, and Robert P. Felder. For this study, determinations of $\mathrm{D} / \mathrm{H}$ ratio for fluid-inclusion waters and ${ }^{18} \mathrm{O}$ compositions of quartz were made, respectively, by S.S. Howe and L.M. Adami in the laboratory of J.R. O'Neil of the U.S. Geological Survey.

\section{STRUCTURAL AND STRATIGRAPHIC FEATURES OF THE MINING DISTRICT}

The locations of many ore deposits in northcentral Nevada are structurally controlled as are some of the major deposits in the Battle Mountain Mining District. This relation is exceptionally well documented by pronounced concentrations of metalproducing districts along the N. $45^{\circ}$ W.-trending Eureka mineral belt (Roberts, 1966), the concentration of gold deposits along the Carlin trend (Roberts, 1966; Bagby and Berger, 1985; Bloomstein, 1986; Evans and Peterson, 1986), and by occurrence of the Getchell, Pinson, and Preble gold deposits, possibly together with the tungsten-bearing Golconda hot springs area, all along a north-northeast-striking fault system on the east flank of the Osgood Mountains. Another structural control exerted on the distribution of many ore deposits in north-central Nevada is the thrust zone of regionally extensive tectonic plates. The Roberts Mountains thrust, which crops out mainly east of Battle Mountain, has the Carlin, Bullion Monarch, Blue Star, and several other disseminated, sediment-hosted gold deposits near its trace (fig. 4).

The Battle Mountain Mining District also is situated within widespread gold, lead-zinc, mercury, silver, and tungsten metal provinces as outlined by Noble (1970) and near the eastern fringes of a broad mercury belt (Joralemon, 1951). Within the Battle Mountain Mining District, the location of major copper-gold-silver and gold-silver deposits seems to have been controlled in large part by the presence of sedimentary rocks favorable for the development of 


\section{EXPLANATION}

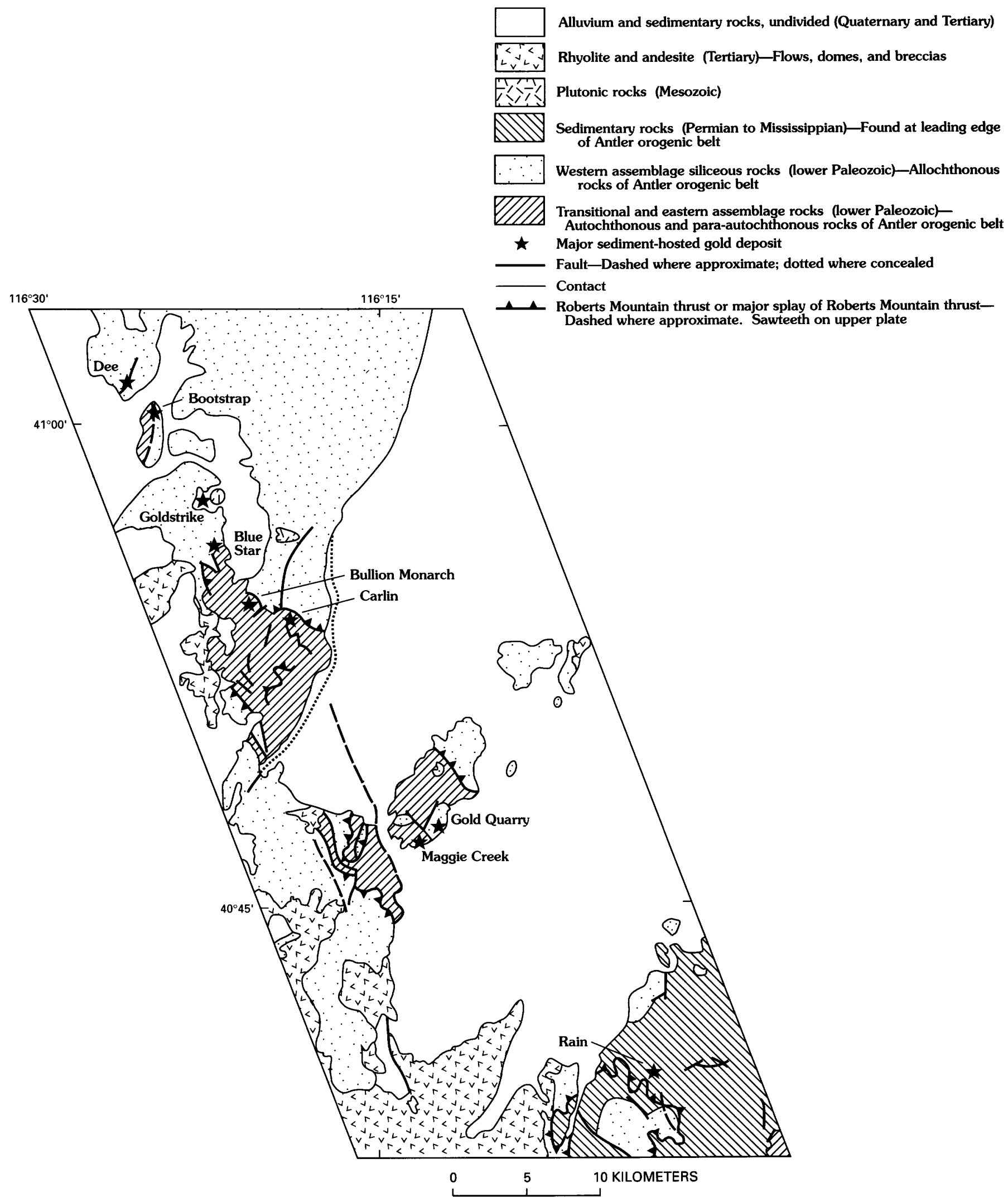

FIGURE 4.-Generalized geology of Roberts Mountain thrust zone, showing spatial relations of major sediment-hosted gold deposits along Carlin trend. Modified from Bagby and Berger (1985). 
replacement deposits below the Golconda thrust, and the caprock effect of impermeable rocks in the upper plate of the Golconda thrust (Nash and Theodore, 1971; Theodore and Blake, 1975).

Much of north-central Nevada is covered by siliceous and volcanic rocks in the upper plate of the Roberts Mountains thrust. At the latitude of the Battle Mountain Mining District, the width of allochthonous rocks from the apparent leading edge of the thrust on the east to the westernmost known window in the East Range (D.H. Whitebread, oral commun., 1983) is approximately $150 \mathrm{~km}$. The thrust carried oceanic volcanic rocks, chert, shale, and quartzite of early and middle Paleozoic age eastward over lower plate, continental shelf carbonate rocks of an equivalent age mostly during Mississippian thrusting in the Antler orogeny (Roberts and others, 1958; Roberts, 1966; Speed and Sleep, 1982). There is geologic evidence that some deformation within the Roberts Mountains allochthon may have occurred during Late Devonian time (Murphy and others, 1984). The Antler orogeny seems to have been the first major tectonism to affect sedimentary patterns in the Cordilleran miogeocline after rifting during the Proterozoic of the continental crystalline crust (Stewart, 1980). However, some rocks in the Cordilleran miogeocline also may have been affected by, and others owe their origins to, an early Paleozoic orogeny as proposed by Willden (1979). Many authors (Speed and Sleep, 1982; Nilsen and Stewart, 1980; Silberling, 1986) have pointed out that the allochthons of the Roberts Mountains thrust compose a number of internally deformed tectonic packets of rock which were emplaced owing to collision of east-facing island arcs with North America. As such, the allochthons represent forearc subductionaccretion wedges according to this model. A continental-scale extensional event along the Cordilleran margin during a 14-m.y. time interval in the Late Devonian may have immediately preceded displacements along the Roberts Mountains thrust (Turner, 1985). Although Ketner and Smith (1982) have questioned the middle Paleozoic timing of the Roberts Mountains thrust, Johnson (1983) presented a succinct summary of geologic relations supporting such a middle Paleozoic age. Furthermore, recent large-scale geologic mapping by R.J. Madrid (unpub. data, 1986) of the U.S. Geological Survey confirmed that the Dewitt thrust (Roberts, 1964), where it crops out several kilometers west of the Buckingham deposit, is a low-angle fault that juxtaposed tectonically rocks of the Upper Cambrian Harmony Formation and the Ordovician Valmy
Formation. Each of these formations shows a different attitude in its cleavage and the low-angle Dewitt fault is projected as having been overlapped unconformably by undeformed rocks of the Pennsylvanian and Permian Antler sequence. Thus, a pre-Pennsylvanian age of thrusting is indicated. The designation by Roberts (1964) of the Dewitt thrust as a major splay belonging to the Roberts Mountains allochthon apparently is correct.

The present complex array of crustal and supracrustal rocks in north-central Nevada is a culmination of geologic events protracted over an extremely long timespan. Before the Antler orogeny, distribution of siliceous, transitional, and carbonate assemblage rocks in the Cordilleran belt was arrayed in a somewhat uniform fashion with siliceous rocks on the west and carbonate slope rocks on the east (Stewart and Poole, 1974). Speed and Sleep (1982) maintained that a large accretionary prism was underthrust by the continental slope and outer shelf of the North American plate; the accretionary prism then became the Roberts Mountains allochthon. Alternately, Whiteford and others (1983) concluded from geologic relations in uppermost Devonian to Lower Permian rocks exposed in the Independence Mountains and elsewhere in northern Nevada, that emplacement of the Roberts Mountains thrust resulted from thrusting in a backarc basin offshore of western North America.

The composition of crust that underlay this part of Nevada has been inferred from isotopic study of plutons that have been emplaced into the sedimentary accretionary rocks. Recent ${ }^{87} \mathrm{Sr} /{ }^{86} \mathrm{Sr}$ isotopic studies of granitic plutons by Kistler (1983) indicate that the crust underlying the area depicted in figure 4 is characterized by initial isotopic signatures that range from 0.704 to 0.706 . These values are intermediate between the value of less than 0.704 generally assigned to oceanic crust and the value of more than 0.706 assigned to sialic crust. However, Farmer and DePaolo (1983) placed the 0.706 line in approximately the same position as located originally by Kistler and Peterman (1973). In addition, Farmer and DePaolo (1983) suggested from their neodymium and strontium isotopic data that the line marking those plutons showing initial ${ }^{87} \mathrm{Sr} /{ }^{86} \mathrm{Sr}$ ratios greater than 0.708 best indicates the western edge of continental crystalline crust. They then placed the 0.708 contour about $200 \mathrm{~km}$ east of the 0.706 contour, or approximately $75 \mathrm{~km}$ east of the Buckingham area (see Farmer and DePaolo, 1984). Furthermore, Farmer and DePaolo $(1983,1984)$ reported a systematic variation in the initial neodymium isotopic compositions of granite 
in the western Great Basin that they interpreted to reflect derivation of granite, including that in the Battle Mountain Mining District, primarily from crustal components. These results appear to be independent of the age of the granite that was emplaced long after major displacements along the Roberts Mountains allochthon had ceased.

The Roberts Mountains thrust does not crop out in the Battle Mountain Mining District (Roberts, 1964). Deep drill holes in the Roberts Mountains plate indicate that this thrust probably underlies the district at depths greater than $1,300 \mathrm{~m}$ (Theodore and Roberts, 1971). To the east of the mining district, about $150 \mathrm{~km}$, Coats and Riva (1983) have shown that the eastward deflection of lower Paleozoic oceanic terrane in the upper plate of the Roberts Mountains thrust from a generally northward trend in northern Elko County results from southward and eastward thrusting during the late Paleozoic, early Mesozoic, and post-Early Jurassic, although Thorman and Ketner (1979) argued that strike-slip displacements account for the present distribution of the rocks.

The region subsequently has been overridden by several structurally higher Paleozoic and Mesozoic thrusts. One of these thrusts, the post-late Early Permian to Early Triassic Golconda thrust, crops out prominently in the Battle Mountain Mining District (fig. 2). As noted by Speed (1977), the Golconda thrust marks a late Paleozoic (Pennsylvanian and Permian) boundary that juxtaposes rocks of two different terranes: an ocean basin terrane on the west and a continental borderland terrane on the east. Andesitic and rhyolitic flows and breccias of the McConnell Canyon area near Yerington, Nev., form part of the volcanic arc terrane of Speed (1977); they are intruded by quartz porphyry and metadiorite, dated at 232 and 233 $\mathrm{Ma}$, respectively, that are possibly cogenetic with arc accumulation (Dilles and Wright, 1988). This arc-type magmatism apparently postdates the Sonoma orogeny and the Golconda thrust (Dilles and Wright, 1988). Furthermore, the district apparently is entirely within a $350-$ by $150-\mathrm{km}$ enclave of sparse Mesozoic deformation in central Nevada (Speed and Sleep, 1982, fig. 1), just east of the Luning-Fencemaker fold and thrust belt of Oldow (1983), wherein there has been regional-scale shortening in a northwest-southeast direction during the Middle Jurassic to Late Cretaceous. Nevertheless, we will document evidence for substantial extensional tectonism in this part of the mining district that began sometime during the Late Cretaceous, and recent studies suggest a broad, open style of folding also may have affected the region during the early Mesozoic (Russell, 1984; R.J. Madrid, oral commun., 1983). However, the extensional tectonics that began apparently sometime during the Late Cretaceous in the Battle Mountain Mining District occurred at a much higher level in the crust than Late Cretaceous metamorphism and synchronous deformation in some parts of the eastcentral Basin and Range province (Miller and others, 1986).

Three major thrust plates of regional significance crop out in the Battle Mountain Mining District (fig. 2): the Golconda plate, the Roberts Mountains plate, and the Dewitt plate. The Roberts Mountains plate and the Dewitt plate are below an equally important autochthonous block (Roberts, 1964). The lowest plate exposed (the Roberts Mountains plate) is made up of chert, shale, argillite, and greenstone of the Devonian Scott Canyon Formation; it also includes quartzite and chert of the Ordovician Valmy Formation (fig. 2). Both formations, the Scott Canyon and the Valmy, make up the upper plate of the Roberts Mountains thrust (the Roberts Mountains plate). These two formations are in fault contact at Galena Canyon along steeply dipping normal faults and along a shallow-dipping thrust fault (fig. 2). The Scott Canyon and Valmy were both, in turn, overthrust by sandstone and feldspathic sandstone of the Upper Cambrian Harmony Formation along the Dewitt thrust (fig. 2), which is a late middle or early late Paleozoic thrust that is about the same age as the Roberts Mountains thrust of the Antler orogeny (Roberts, 1964). The Harmony Formation, which makes up the middle (the Dewitt plate) of the three thrust plates, crops out widely in the Buckingham area (pl. 1). These two plates are overlain unconformably by the Antler sequence.

The upper Paleozoic Antler sequence makes up an autochthonous structural block that rests along a major unconformity on the Harmony Formation and the Valmy Formation in the district (fig. 2). The rocks of the Antler sequence belong to the overlap assemblage of post-Antler orogenic time (Roberts, 1964). Three formations compose the Antler sequence in the district: (1) the Middle Pennsylvanian Battle Formation, (2) the Upper Pennsylvanian and Lower Permian Antler Peak Limestone, and (3) the Upper Permian Edna Mountain Formation. However, Erickson and Marsh (1974) cautioned that the term "sequence" no longer be applied to this package of rocks because at Edna Mountain, about $35 \mathrm{~km}$ northwest of the Battle Mountain Mining District, they found that the basal formations of the sequence 
are folded, then capped unconformably by the uppermost formation in the sequence. The Battle Formation and the Antler Peak Limestone crop out in the Buckingham area north of the open pit at Copper Basin (pl. 1).

The uppermost of the three thrust plates, the Golconda plate, in the district is made up of chert and argillite belonging to the Pennsylvanian, and Permian Pumpernickel Formation and sandstone, shale, quartzite, limestone, and chert belonging to the Middle Pennsylvanian and Lower Permian Havallah Formation as mapped by Roberts (1964). The Havallah Formation crops out west of Willow Creek (fig. 2). This plate is in fault contact with the Antler sequence on the Golconda thrust and along steeply dipping Tertiary normal faults. Stewart and others (1977) and Stewart and others (1986) questioned the validity of regional correlations involving the Pumpernickel and Havallah Formations because of lateral changes in lithology and tectonic imbrication of units within the formations. Recent studies of the Pumpernickel and Havallah Formations in the Battle Mountain Mining District show that the Golconda allochthon here consists of four to six tectonically interleaved, major rock sequences that may be grouped (Miller and others, 1982; Brueckner and Snyder, 1985; Stewart and others, 1986) upward from the sole of the Golconda thrust in age as (1) late Early to early Late Permian; (2) Pennsylvanian and Early Permian; (3) Mississippian; and (4) undated rocks of the Trenton Canyon Member of the Havallah Formation (Roberts, 1964). Subsequent studies by Brueckner and Snyder (1985) have divided the Golconda allochthon in the Battle Mountain Mining District into six lithotectonic packets. Their recognition of altered and mineralized basalts containing ridge-type hydrothermal systems suggests that ocean-basin spreading centers must have been active at some sites of deposition of the rocks of the Golconda allochthon during much of late Paleozoic time. Thus, the age of major eastward displacement along the Golconda thrust must postdate the age of the youngest deformed rocks (early Late Permian) known in the upper plate of the thrust. However, the age of major movement(s) along the Golconda thrust is still equivocal: if the thrust occurred as part of the Sonoma orogeny, then it must be of pre-late Early Triassic age; if undeformed rocks of the Koipato and Star Peak Groups that rest unconformably on deformed rocks of the allochthon were transported "piggyback" (Stewart and others, 1986) then it must be of Jurassic or Cretaceous age (Ketner, 1984).

These four tectonic blocks, made up of lower to upper Paleozoic rocks, have been intruded by at least 50 mappable gabbro to felsic granite stocks and dikes (Roberts, 1964). Most sections of this report use the plutonic-rock-classification scheme of Streckeisen (1973), unless otherwise noted. Some of these stocks may cover more than $2.5 \mathrm{~km}^{2}$ in the district. The largest body crops out at Trenton Canyon, in the west-central part of the district, about $10 \mathrm{~km}$ west of Buckingham. Although the intrusive rocks vary widely in composition, most were emplaced originally as granodiorite and monzogranite (Theodore and others, 1973). Some granodiorite has been altered by postmagmatic hydrothermal fluids to potassic, phyllic, and (or) intermediate argillic assemblages.

Plutonism in this part of Nevada occurred during four periods of time from the Jurassic to the middle Tertiary (McKee and Silberman, 1970; Silberman and McKee, 1971). The plutonic body at Trenton Canyon is Late Cretaceous (87 Ma) in age, whereas all other plutonic rocks dated by Theodore and others (1973) are late Eocene or early Oligocene (41-37 $\mathrm{Ma}$ ). Recalculation of the Late Cretaceous age using currently accepted K-Ar constants yields an age of $89 \mathrm{Ma}$. K-Ar and ${ }^{40} \mathrm{Ar} /{ }^{39} \mathrm{Ar}$ studies of various alteration and intrusive phases of the Buckingham system yield Late Cretaceous to early Tertiary ages in the range 88-61 Ma (pl. 1). Seven of the radiometrically dated Tertiary igneous bodies in the area are late Eocene or early Oligocene (35-39 Ma) (pl. 1; see subsection below entitled "Potassium-Argon and ${ }^{40} \mathrm{Ar} /{ }^{39} \mathrm{Ar}$ Geochronology of Selected Plutons in the Buckingham Area"). The middle Tertiary plutons at Battle Mountain are part of a regional alignment of middle Tertiary plutons that extends from Eureka to Battle Mountain (Silberman and McKee, 1971). Some plutonism of Cretaceous age has been documented from other significant metal deposits elsewhere along this alignment. Silberman and McKee (1971) dated biotite from a granitic rock at depth below the Gold Acres sediment-hosted gold deposit at $98.8 \pm 2.0 \mathrm{Ma}$, and sericite at $92.8 \pm 1.0 \mathrm{Ma}$ using the K-Ar method. Sericite from a quartz porphyry cropping out within the alteration zone associated with the Gold Acres deposit was dated by them at 94.3 $\pm 1.9 \mathrm{Ma}$ (see Wrucke and Armbrustmacher, 1975). Recent studies by Rytuba (1985), however, have determined that gold mineralization at Gold Acres and the nearby Horse Canyon and Cortez deposits is most likely related to rhyolite porphyry dikes comagmatic with the approximately 34-Ma Oligocene Caetano Tuff. In addition, hydrothermal sericite associated with an altered monzogranite porphyry near the north end of the Fish Creek Mountains, about $35 \mathrm{~km}$ southwest of the town of 
Battle Mountain (fig. 1), has an age of $89.5 \pm 2.7 \mathrm{Ma}$ (Miller and Silberman, 1977).

Two suites of volcanic rocks crop out in the Battle Mountain Mining District: (1) calc-alkaline rhyolite welded tuffs occur as erosional outflowfacies remnants of the previously much more extensive Oligocene Caetano Tuff (Gilluly and Masursky, 1965; Stewart and McKee, 1977), whose age is $34 \mathrm{Ma}$ (McKee and Silberman, 1970), and (2) much younger Tertiary or Quaternary basalt (fig. 2). A sample of basalt from the southern part of the district, near Copper Canyon, has an age of 3.2 $\mathrm{Ma}$ using the K-Ar method (see subsection below entitled "Potassium-Argon and ${ }^{40} \mathrm{Ar} /{ }^{39} \mathrm{Ar}$ Geochronology of Selected Plutons in the Buckingham Area"). The most conspicuous exposures of Tertiary or Quaternary basalt are near the south edge of the mining district.

\section{GEOLOGY OF THE BUCKINGHAM AREA}

The Buckingham area includes parts of the allochthonous Roberts Mountains and Dewitt tectonic blocks and the autochthonous Antler sequence (pl. 1 ); about 70 percent of this $24-\mathrm{km}^{2}$ area contains exposures of rocks belonging to the Upper Cambrian Harmony Formation in the upper plate of the Dewitt thrust. Many Late Cretaceous, late Eocene or early Oligocene, and Oligocene granitic stocks and dikes crop out throughout the area. Some of the largest granitic bodies exposed measure about $1.2 \mathrm{~km}$ in their largest dimension at the surface. Although exposures throughout much of the area are poor, primarily because of the slope-forming character of the Harmony Formation, our large-scale geologic mapping, nonetheless, has revealed structural configurations that must represent superposition of several major tectonic events. These tectonic events include (1) thrusting during the Mississippian associated with the emplacement of the Roberts Mountains allochthon, (2) possibly some shortening associated with early Mesozoic thrusting of the Golconda plate (the upper plate of which does not crop out in the area), (3) arching of Paleozoic country rock probably before Late Cretaceous magmatism, and (4) extensional phenomena that probably began temporally very close to the waning stages of the Buckingham molybdenum system but that culminated probably during the Miocene. In addition, there is some evidence for local reactivation of some Mississippian thrusts during the Miocene.

\section{CAMBRIAN SYSTEM}

\section{THE HARMONY FORMATION}

The Harmony Formation as described by Roberts (1964) is allochthonous in the Battle Mountain Mining District. The Harmony Formation is considered middle and late Late Cambrian in age on the basis of contained trilobites found in the Hot Springs Range, 5 to $10 \mathrm{~km}$ west-northwest of the Osgood Mountains (Roberts and others, 1958), and it has a possible conformable relation with the underlying Paradise Valley Chert that has yielded early Late Cambrian fossils from limestone layers (Rowell and others, 1979). A reexamination of the Harmony-Paradise Valley Chert contact by T.G. Theodore and R.J. Madrid in 1982 indicates that it may be a fault, and so the fossils in the Paradise Valley Chert may not be used to constrain the age of the Harmony Formation. Willden (1979) doubted the middle and late Late Cambrian age of the Harmony Formation because he felt that it lies unconformably above the Devonian Scott Canyon Formation, as did McCollom and others (1987). McCollom and others (1987), on the basis of very little evidence, suggested also that the Harmony Formation may be equivalent to the Silurian Elder Formation. As mapped by Willden, (1979, fig. 5), the contact between the Harmony and Scott Canyon Formations is marked by a narrow transition zone which in places includes some mafic volcanic rocks that contain lenses of limestone, chert, and feldspathic sandstone. However, reexamination of these relations by the senior author revealed that the actual contact between the two formations is everywhere obscured by colluvium, and, furthermore, the narrow transition zone between the two formations may, in fact, be a debris flow of mixed lithologies in the Scott Canyon Formation (Madrid, 1987). The rocks are not at all well exposed in this general area. Nonetheless, the highly discordant bedding attitudes in the formations recorded by Willden (1979) may just as well be interpreted as indicating tectonic juxtaposition during thrusting as originally postulated by Roberts (1964). To date (1989), however, only trace fossils have been identified definitely from the Harmony Formation in the Battle Mountain Mining District (Suczek, 1977, p. 37). These fossils occur on bedding planes of sandstone and are considered to be feeding tracks of Zoophycos and Asterosoma. Nonetheless, the distinctive lithologies of the Harmony Formation in the Battle Mountain Mining District are the same as those that crop out in the Osgood Mountains 
quadrangle (fig. 1), wherein trilobite fauna were collected from exposures in the Hot Springs Range (Hotz and Willden, 1964). Furthermore, the regionally distinctive lithology of the Harmony Formation was recognized in clasts hosted by the Upper Devonian Slaven Chert in the Shoshone Range, $20 \mathrm{~km}$ southeast of the Buckingham area (Madrid, 1987). This relation indicates that the Harmony Formation must be older than Upper Devonian in age.

Throughout the Antler Peak quadrangle, the Harmony Formation consists of interbedded quartz arenite, subarkose, arkose, granule and pebbly quartz arenite, shale, and limestone (Roberts, 1964, p. A23). Most of the formation probably is subarkose, although silt and shale commonly crop out widely in some parts of the Buckingham area. The thickness cannot be measured directly, because the rocks are for the most part poorly exposed, weathering to smooth, gently rounded slopes that typically have a few outcrops (frontispiece). Furthermore, as shown by the geology of the Buckingham area (pl. 1), the overall structure of the Harmony Formation is extremely complex; exposed marker horizons within the formation are difficult to trace let alone trace for any significant distance. Roberts (1964, p. A23) estimated the formation's total thickness in the Antler Peak quadrangle to be about $900 \mathrm{~m}$, or approximately near the middle of the estimate by Stewart and Suczek (1977) for regional variation in thickness $(600$ to $1,300 \mathrm{~m})$. The provenance of sandstone belonging to the Harmony Formation has been classified as belonging to a suite transitional between interior craton and uplifted basement suites (Dickinson and Suczek, 1979). Rowell and others (1979) further suggested derivation of the Harmony Formation as proximal turbidites in the middle part of a submarine fan derived from Proterozoic granitic rocks to the northeast in the central Idaho, Salmon River arch (see Armstrong, 1975). On the one hand, the overall compositional and textural immaturity of sand, grit, and conglomerate in the Harmony Formation suggested to Palmer (1971) that the Harmony Formation was derived from the northeast; on the other hand, this same compositional and textural immaturity suggested to Ketner (1977) that these enigmatic rocks were derived locally. Erickson and Marsh (1974), who also believed that the rocks were derived locally, thought that they came from an emergent highland somewhere between the Sonoma Range to the west and the Battle Mountain Mining District. The uplift of this highland may be also indicated by the presence of west-verging folds in the Cam- brian Preble Formation and Cambrian(?) Osgood Mountain Quartzite according to their regional reconstructions. However, in the Hot Springs Range, the Harmony Formation is itself deformed in places into tightly appressed west-verging folds (Hotz and Willden, 1964). The clastic sedimentary rocks of the Harmony Formation are interpreted by Willden (1979) as having been derived from a part of the emergent continental crust in present-day northwestern Nevada. As envisioned by Willden (1979), such crust became emergent as a result of early Paleozoic disruption of the Cordilleran belt.

Although the Harmony Formation crops out widely in the Buckingham area, only small parts of it near the northwest and southwest corners of the map area are unaffected visibly by widespread recrystallization and alteration associated with the Late Cretaceous Buckingham stockwork system, and numerous late Eocene or early Oligocene and Oligocene plutons ( $\mathrm{pl}$. 1). Where essentially unaltered, the Harmony Formation consists for the most part of olive-green to brown graded sandstone (fig. 5A) belonging to several different clans (see below) including quartz arenite, arkose, subarkose, and litharenite according to the classification scheme of McBride (1963). Minor amounts of shale, calcareous shale, and pebbly quartz arenite also are present in the Harmony Formation. Skarn that is widespread in the Harmony Formation north of the Copper Basin Mine will be discussed below in sections describing their genetically associated plutons. Along ridges in the large area of unaltered

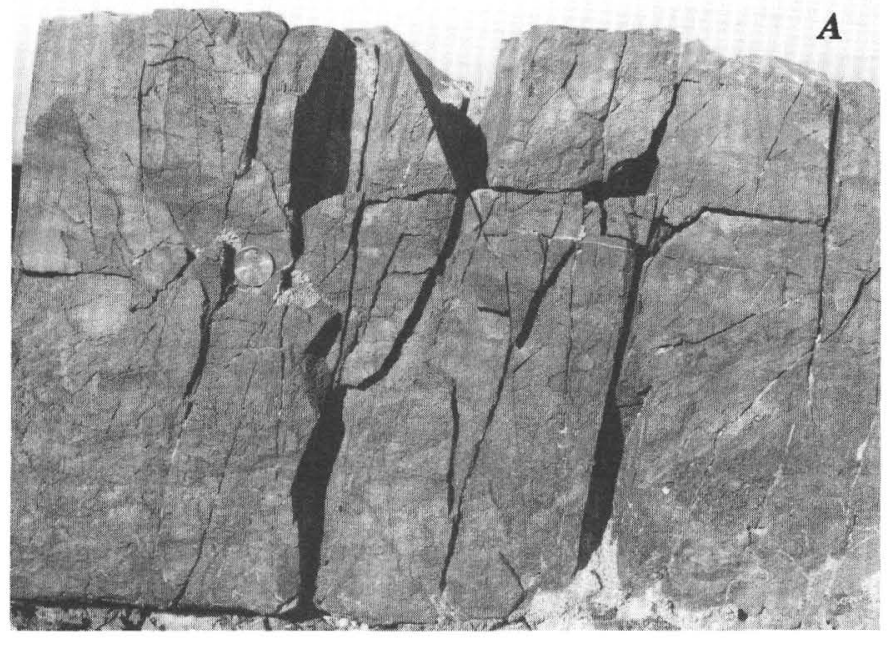

Figure 5.-Characteristics of sandstone beds of the Upper Cambrian Harmony Formation in Battle Mountain Mining District. A, Well-developed graded bedding. 
Harmony Formation in the northwestern part of the Buckingham area, the formation is fairly well exposed and consists of drab-olive-brown shale that is variably interbedded with olive-brown arkose and subarkose. Bedding in sandstone fractions averages probably about $0.3 \mathrm{~m}$ in thickness, although parting between beds ranges from $1 \mathrm{~cm}$ to about 1 $\mathrm{m}$. No secondary cleavage was noted in any rocks, including shale that, locally across some $20-\mathrm{m}$ thick sequences of rock, makes up about 50 percent of the section. Elsewhere, in this general area, shale makes up only about 10 percent of exposed sequences. Beds that grade sharply are common in the sandstones; they range from coarse-grained sandstone in the basal $0.2-\mathrm{m}$ sequences to siltstone near tops of $0.3-\mathrm{m}$-thick cycles. Some coarse sand-

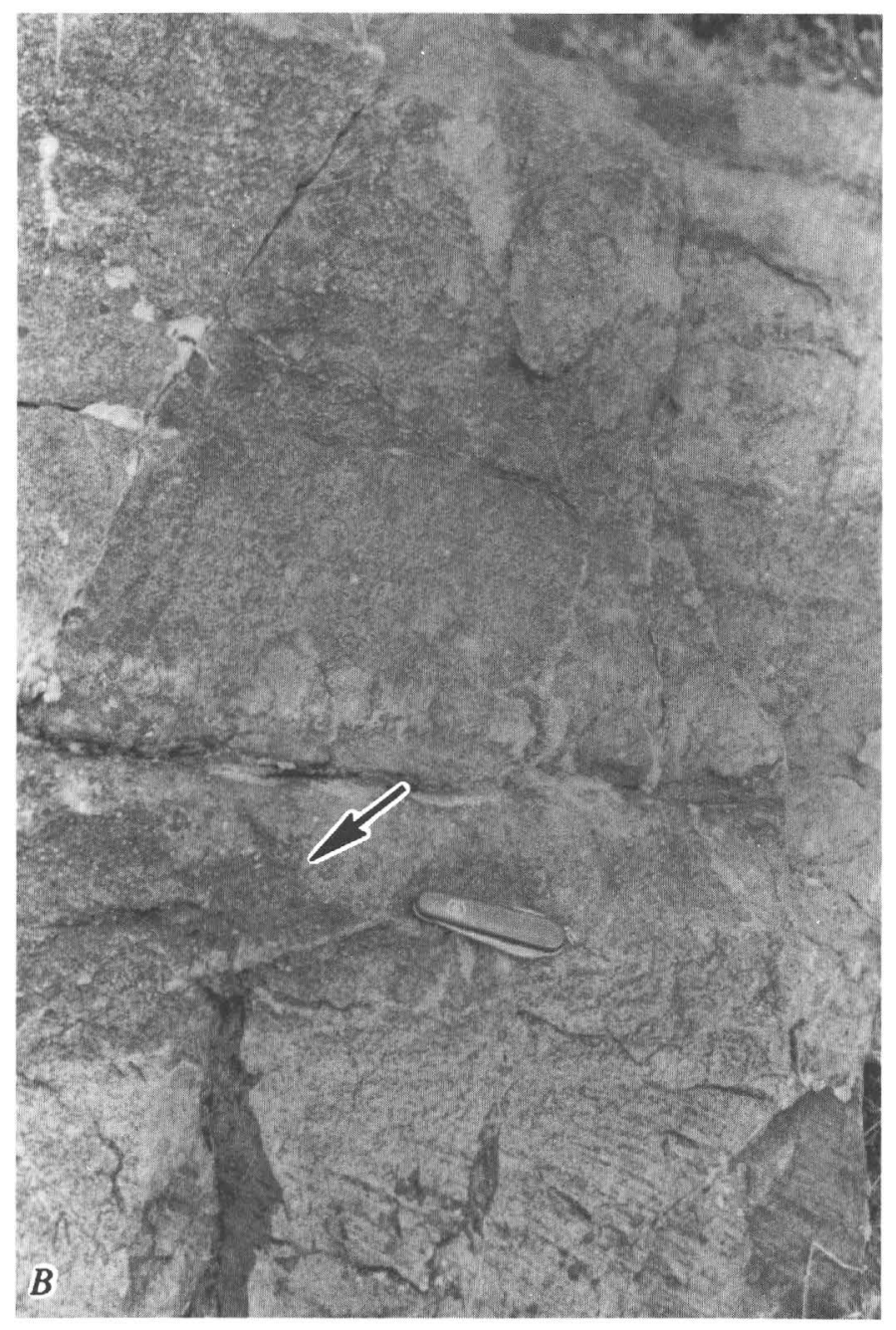

Figure 5.-Continued. B, Reversely graded bed capping scoured channel of coarse sand deposited across underlying crossbeds (arrow). stone deposits scoured channels across underlying crossbeds (fig. $5 B$ ); the entire sequence in such exposures is then capped by reversely graded sandstones. In fact, reversely graded beds locally are more common in some sequences of the Harmony Formation than normally graded ones, especially in the northwestern part of the Buckingham area. Several pods of limestone in the Harmony Formation crop out as mappable bodies that extend 150 to $300 \mathrm{~m}$ along the outcrop; these pods are present due south of the Little Giant Mine, at the south edge of the map area and south-southwest of the Empire Mine (pl. 1).

Two major transitions in overall lithology of the Harmony Formation apparently occur across the map area. From south to north, across approximately the western one-half of the area, there is a gradual increase in grain size of the sandstones. On Long Ridge, due west of the workings at the Copper Queen Mine, this south-to-north coarsening is indicated in part by outcrops of several 2- to 3m-thick beds of conspicuous pebbly quartzite that provide excellent, local marker horizons (pl. 1). The second apparent lithologic transition across the map area involves an increased abundance of shale and calcareous shale in the area north of the Copper Basin Mine. This relation may merely indicate a greater abundance of shale than sandstone in the upper part of the Harmony Formation that crops out mainly in this area.

Near the northeast corner of the map area, northwest of the Bailey Day Mine, relatively thin sequences of gray to light-gray, laminated silty shale and calcareous shale (possibly several tens of meters thick) contain apparent soft-sediment deformational structures. Bedding is convoluted in shale, and solution seams are confined locally to restricted, centimeter-wide zones between wellsorted, greenish-gray calcarenite. Some discoid pods of subarkose, about $5 \mathrm{~cm}$ thick in the shales, show a concentration of secondary minerals, mainly K-feldspar, in the matrix of the sub0arkose; these secondary minerals suggest a channeling of epigenetic fluids therein. In addition, lenticular microstreaks of dark carbonaceous material are common throughout much of the shale in the Harmony Formation in this general area. Furthermore, sandstones of the Harmony Formation here typically show well-developed crossbeds, all indicating tops to the east. Many fine sandstones of the Harmony Formation interbedded with these shales near the north edge of the area show relatively high modal percentages of framework feldspar; some are estimated to be about 50 volume 
percent feldspar. In addition, textural relations in some samples suggest that large grains of framework feldspar are most likely microcline, whereas plagioclase makes up most of fine-grained framework minerals.

Selected samples of sandstone from the Harmony Formation were examined petrographically to determine the modes of their detrital framework grains (see Dickinson, 1970; Dickinson and Suczek, 1979 , for the methods used). Our studies provide a supplement to more wide-ranging investigations of
Suczek (1977) involving petrotectonic evolution of sandstones of the Harmony Formation. In all, modes of 15 samples were determined (fig. 6). Sandstones of the Harmony Formation are texturally immature, or in places submature according to the classification of Folk (1974); clay matrix, now metamorphosed and (or) altered generally to micas, makes up typically more than 5 volume percent of the sandstones. Rounding is generally size specific, wherein large grains are commonly subrounded to rounded (using the scale of Powers, 1953) and

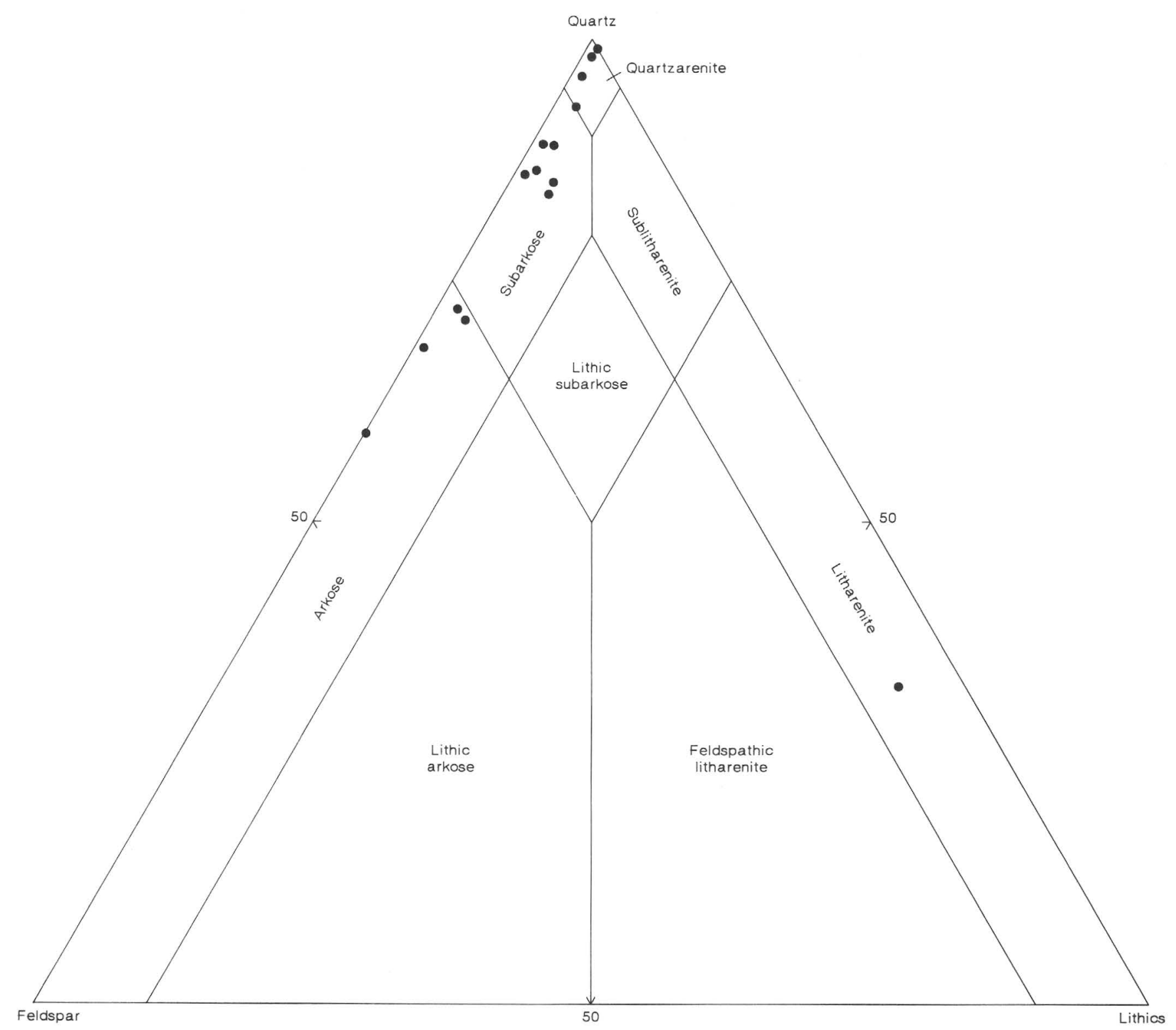

Figure 6.-Ternary diagram showing modes of detrital framework grains from the Upper Cambrian Harmony Formation. Classified according to McBride (1963). 
small grains in the size range $0.02-0.1 \mathrm{~mm}$ are angular. Rounding generally is concentrated in large detrital grains in sedimentary environments, and as such rounding in samples examined from the Harmony Formation suggests a period of reasonably prolonged abrasion before deposition of the sand grains. Although some samples show no obvious relation between mineralogy and rounding, thereby suggesting a common source for framework minerals, other samples contain a preponderance of rounded quartz grains and subangular to angular feldspar grains. Small subangular to angular feldspar grains are concentrated among relatively large, monocrystalline grains of quartz.

Sandstones of the Harmony Formation are well compacted and exhibit sutured and concavo-convex grain boundaries. Quartz grains in some samples show only local deformation lamellae radiating from adjoining framework grain contacts, whereas small domains in other samples include abundant deformation lamellae. Detrital micas are commonly bent, crimped, or broken where they contact framework grains. Furthermore, porosity of the Harmony Formation has been reduced to less than 1 percent by compaction, diagenetic clay growth, and cementation, and in the widespread areas affected by emplacement of the Cretaceous and Tertiary plutons, secondary recrystallization and mineralization. In these areas, detrital grains of biotite and white mica in the Harmony Formation merge into secondary micas as they are affected progressively by increasing degrees of contact metamorphism and metasomatism.

Monocrystalline quartz is the dominant framework mineral in all but one of the 15 samples studied modally (fig. 6). Feldspars are the second most abundant of the framework minerals, and they occupy about 40 percent of the framework sites. Two mature samples contain no detrital feldspar. The modal variability in sandstones counted from the Harmony Formation during this study (fig. 6) spans about the same range found previously by Suczek (1977, fig. 15). Lithic fragments are subordinant to detrital quartz and feldspars, and lithic fragments make up less than 5 volume percent in 14 of the 15 samples studied (fig. 6). Lithic fragments include chert, carbonate, recrystallized siltite, and volcanic fragments (typically altered heavily to various phyllosilicate-dominant assemblages). Heavy minerals observed optically include sphene, zircon, epidote, clinozoisite, garnet, apatite, and tourmaline, and they are compatible with derivation of most sandstones of the Harmony Formation from a plutonic source. In addition, some samples show textural relations in detrital micas suggesting derivation from at least two different plutonic source regions. In these samples, detrital grains of white mica show strongly rounded terminations, whereas detrital grains of biotite typically show ragged terminations, although grains of biotite are themselves bent and altered variably to chlorite. These relations suggest some white mica grains may have traveled to their deposition sites at Battle Mountain from a source more distant than the detrital grains of biotite.

The abundance of microcline, which composes at least half of the K-feldspar detrital component in many rocks studied modally, and the varied suite of heavy minerals suggests that the dominant source of the Harmony Formation was plutonic, as postulated by Suczek (1977) and Rowell and others (1979). A subordinate to important sedimentary source terrane is further indicated by the presence of chert and somewhat-common argillaceous lithic fragments and clastic carbonate grains, the latter suggesting carbonate detritus shed from a shelf setting. Nonetheless, the variability of all these lithic types and divergent feldspar (plagioclase-Kfeldspar) ratios indicate that the source terrain(s) may have changed or evolved during the course of deposition of the Harmony Formation. Petrofacies intervals, or petrologically distinct rock units, have been worked out for the Great Valley sequence of California (Dickinson and Rich, 1972), and these studies provide great insight into evolution of the adjacent Sierran arc terrain. In a complex structural setting such as the Battle Mountain Mining District, however, petrofacies intervals, once established, might clarify local geologic structure where gross lithofacies are insignificant. Difficulties in establishing such petrofacies intervals within the Harmony Formation, however, are the paucity of good outcrops and the absence of structurally intact thick sequences of sandstones of the Harmony Formation.

Two relatively large masses of limestone were mapped in the Harmony Formation; one crops out near the southwest corner of the map area, and the other south of the Empire Mine (pl. 1). Petrographic study of rocks from the first locality reveals that the rocks there are variably altered. Some of the least altered rocks studied show that they are, in fact, an aggregate of fine- to mediumgrained sand grains, measuring about 0.5 to 0.04 $\mathrm{mm}$ in diameter, set in a matrix of fine-grained micrite. Silicate sand grains, which make up about 40 volume percent of these rocks, include dominant monocrystalline quartz, together with much lesser 
abundances of microcline, perthite, plagioclase, biotite, and white mica; some detrital opaque minerals are present also. The bulk of these rocks, approximately 60 volume percent, is dark, cloudyappearing micrite matrix, consisting of densely packed, coarse-silt-size grains of calcite about 0.04 $\mathrm{mm}$ and less. Sparse radial sparry growth occurs in micrite matrix at some silicate grain boundaries. Locally, the rocks also include ovoid intraclasts that measure as much as $10 \mathrm{~mm}$ wide. In addition, some very thin, arcuate blades of hematite outline some semicircular, 0.1-mm-wide domains of micrite similar in size and appearance to micrite in the adjoining matrix. Some of the hematite-encrusted domains are collapsed and crushed inward; they probably were crushed during compaction. Elsewhere in this limestone body, samples show widespread incipient recrystallization of micrite matrix to pseudospar, accompanied by sparse calcite veins and pyrite. The implication of these hybrid rocks is that silicate material, identical in overall composition to widespread sands throughout the rest of the Harmony Formation, and carbonate material must have mixed elsewhere and subsequently been transported together. Mixing may have occurred during the transport of the silicate fraction in a turbidity current through a shelf environment, or conceivably even in an intratidal zone as suggested by the apparently detrital hematite crusts.

The dark- to buff-gray carbonate rocks in the Harmony Formation mapped near the Empire Mine are present almost entirely in one north-south-trending elongate body, broken medially by a fault also striking north (pl. 1). The carbonate rocks, which range from massive to thin bedded, are even laminated in places. Frosted granules of quartz sand are conspicuous on some weathered surfaces. The rocks are also locally crossbedded, and bedding surfaces mostly show a wavy, broadly open type of crenulation. However, locally some approximately 6 -m-thick sequences of carbonate rocks show steeply plunging and tightly appressed outcrop-scale folds whose limbs also dip steeply. Petrographic study of some samples from this carbonate body reveals that original micrite matrix is recrystallized to sparry calcite, including trace amounts of colorless amphibole, probably tremolite. Silicate sand grains, mostly monocrystalline quartz, are corroded by sparry matrix. Other samples are finely laminated, gray pseudospar containing approximately 0.5 to 1.0 volume percent pyrite and sparse silt-size fragments of monocrystalline quartz. The pseudospar is interbedded with buff to tan microspar that in places includes abundant angular to sub- rounded, silt-size fragments of monocrystalline quartz, feldspar, biotite, white mica, and tourmaline (trace). Elsewhere in the carbonate body, carbonaceous microspar is further recrystallized to flamelike zones of pseudospar. Detrital grains of white mica and biotite, mostly altered to chlorite and recrystallized to very fine grains of white mica, are present commonly in microspar, whereas neocrystallized clinochlore and tremolite are rare. Some outcrops have relatively abundant concentrations of randomly oriented veins of sparry calcite.

The Harmony Formation in at least two localities in the Buckingham area has some sequences of igneous rocks that are interpreted to be flows intercalated with more common metasandstone and metasiltite. One of these localities is a sequence of rocks penetrated at depth by a drill hole collared approximately $300 \mathrm{~m}$ southwest of Buckingham Camp. This drillsite is outside the surface projection of ore in the molybdenum system (see subsection below entitled "Economic Geology"). The other locality shows an approximately 1-m-thick sequence of greenstone that crops out about $300 \mathrm{~m}$ north of the main drainage of Long Canyon just outside the west edge of the map area of plate 1 . At the latter locality, greenstone of the Harmony Formation apparently shows a conformable, healed contact with slightly bleached, olive-gray subarkose that is medium grained (fig. 7). Furthermore, near the contact, some thin centimeter-thick beds of arkose are enveloped completely by greenstone. Under the microscope, a typical sample from greenstone shows a massive holocrystalline fabric consisting of a felted to pilotaxitic aggregate of microlites of plagioclase (approx $\mathrm{An}_{40}$ ), probably averaging about $0.04 \mathrm{~mm}$ in length. Interspaces among microlites of plagioclase are filled by slightly pleochroic (pale brown, optic Z-axis), cryptocrystalline aggregates of biotite (partially altered to chlorite, both verified by X-ray diffraction) and very minute granules of magnetite partially altered to hematite. Biotite in places is present as a reaction rim around some included euhedral crystals of quartz. Furthermore, somewhat coarser laths of biotite, about 0.03 to $0.04 \mathrm{~mm}$ in length, are extremely rare in the rocks. Primary, unaltered composition of the greenstone probably approached that of an andesite-a judgment based largely on the anorthite content $\left(\mathrm{An}_{40}\right)$ of microlites. In addition to secondary crystallization of extremely fine grained biotite, possibly replacing in part diagenetic phyllosilicates, the greenstone also includes late-stage, relatively dense concentrations of anas- 
tomosing veinlets of sparry calcite. Some of these veinlets are offset along stylolitic junctions.

Mafic volcanic rocks have only rarely been reported in the literature as constituting part of the Harmony Formation. Willden (1979) noted that mafic volcanic rocks, apparently submarine flows, are present in at least two localities in the Hot Springs Range. Furthermore, he surmised that these two localities of mafic volcanic rocks may, in
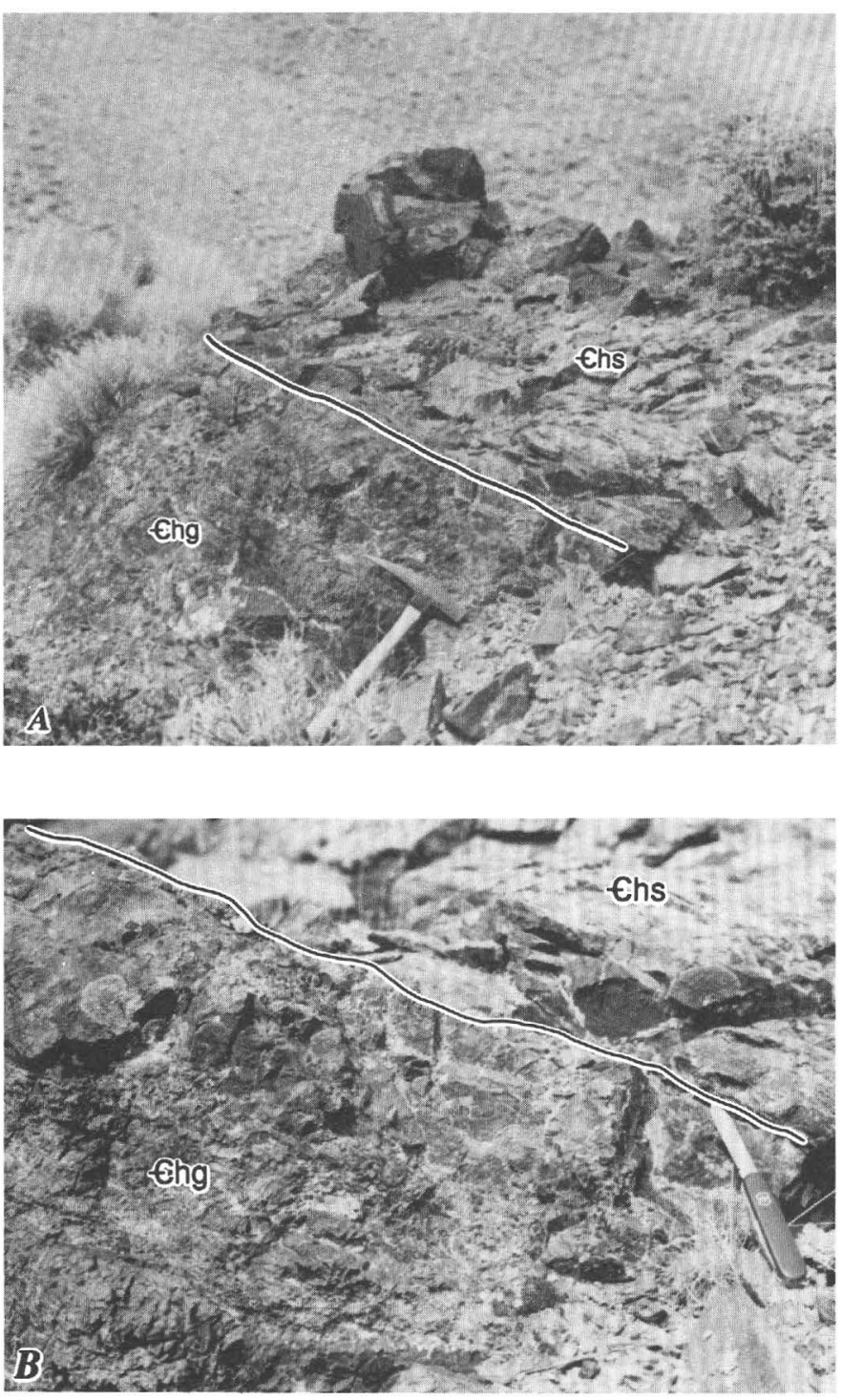

Figure 7.-Contact between greenstone and subarkose of the Upper Cambrian Harmony Formation. A, Conformable, healed contact between rare greenstone ( $€$ hg) and medium-grained, olive-gray subarkose ( $€$ hs) of the Harmony Formation. $B$, Closeup of figure 7A. Locality is $300 \mathrm{~m}$ north of main drainage through Long Canyon, just west of area in plate 1 . fact, be high in the section of the Harmony Formation because geographically they are rather far from exposures of the base of the formation.

Chemical analyses of six sandstones of the Harmony Formation (analyses 1-6, table 1) include samples that show both sparse and abundant evidence of recrystallization. Because rocks of the Harmony Formation can vary greatly in their premetamorphic mineralogy, the discussion to follow will not address any chemical changes that may or may not have attended metamorphism of these rocks. Nonetheless, chemical analyses of this limited number of samples from sandstones of the Harmony Formation document wide-ranging variations in major-oxide chemistry. Most of these variations probably are attributable directly to the irregular distribution of relatively $\mathrm{Al}_{2} \mathrm{O}_{3}$ rich phyllosilicate minerals in the matrix. However, one sample (analysis 3, table 1) also contains abundant calcite in its matrix, resulting in a data plot showing a strong deflection in total iron and $\mathrm{Al}_{2} \mathrm{O}_{3}$ contents from the apparent overall trend for these rocks from the Harmony Formation (fig. 8). The $\mathrm{Al}_{2} \mathrm{O}_{3}$ contents of these rocks, in addition, indicate their highly variable content of framework feldspar. However, from this plot of total alkalis $\left(\mathrm{Na}_{2} \mathrm{O}+\mathrm{K}_{2} \mathrm{O}\right)$ versus $\mathrm{SiO}_{2}$ contents and a comparison of chemical analyses with modal mineralogy, it appears likely that rocks analyzed from the Galena area have a slightly higher modal feldspar content at their respective $\mathrm{SiO}_{2}$ contents than for the established trend (fig. 8). Compared with chemical analyses of sandstones elsewhere, most of these major-element analyses of sedimentary and metasedimentary rocks (table 1) fall within the overall range of analyses of the arkoses of Pettijohn (1949, p. 56). Although slight differences in minor-element chemistry of these six analyzed sandstones indicate generally accepted abundances of elements in sandstones (see Parker, 1967), a striking difference appears in the reported barium contents. The barium content of these six analyzed samples ranges from 280 to $3,000 \mathrm{ppm}$, whereas sandstones are reported in the compilation by Parker to contain 10 to $90 \mathrm{ppm} \mathrm{Ba}$.

Table 1 also includes a single chemical analysis (7) of a greenstone-a highly altered flow that is interbedded with the sandstones of the Harmony Formation. This particular outcrop is situated west of the map area (see above). The $\mathrm{SiO}_{2}$ content of analyzed greenstone (50.6 weight percent) suggests, on the one hand, that the rock may have been a basalt before alteration; on the other hand, 
TABLE 1.-Analytical data on the Upper Cambrian Harmony Formation of the Buckingham CampCopper Basin area, Lander County, Nevada

[Chemical analyses in weight percent by X-ray spectroscopy supplemented by classical methods; analysts, A.J. Bartel, K. Stewart, J. Taggart, R. Moore, P. Aruscavage, and D. Kay. Optical-spectroscopic analyses in parts per million by inductively coupled plasma methods of Scott and Kokot (1975) and F.E. Lichte (unpub. data, 1983); analyst, M. Malcolm. Looked for, but not found, at parts per-million detection levels in parentheses: As (10), Bi (10), Cd (2), Eu (2), Ho (4), Mo (2), Sn (20), Ta (40), U (100). F determined by specific-ion-electrode methods, Au determined by atomic-absorption methods, and W determined colorimetrically; analysts, R. Moore, P. Aruscavage, and D. Kay. - , not detected]

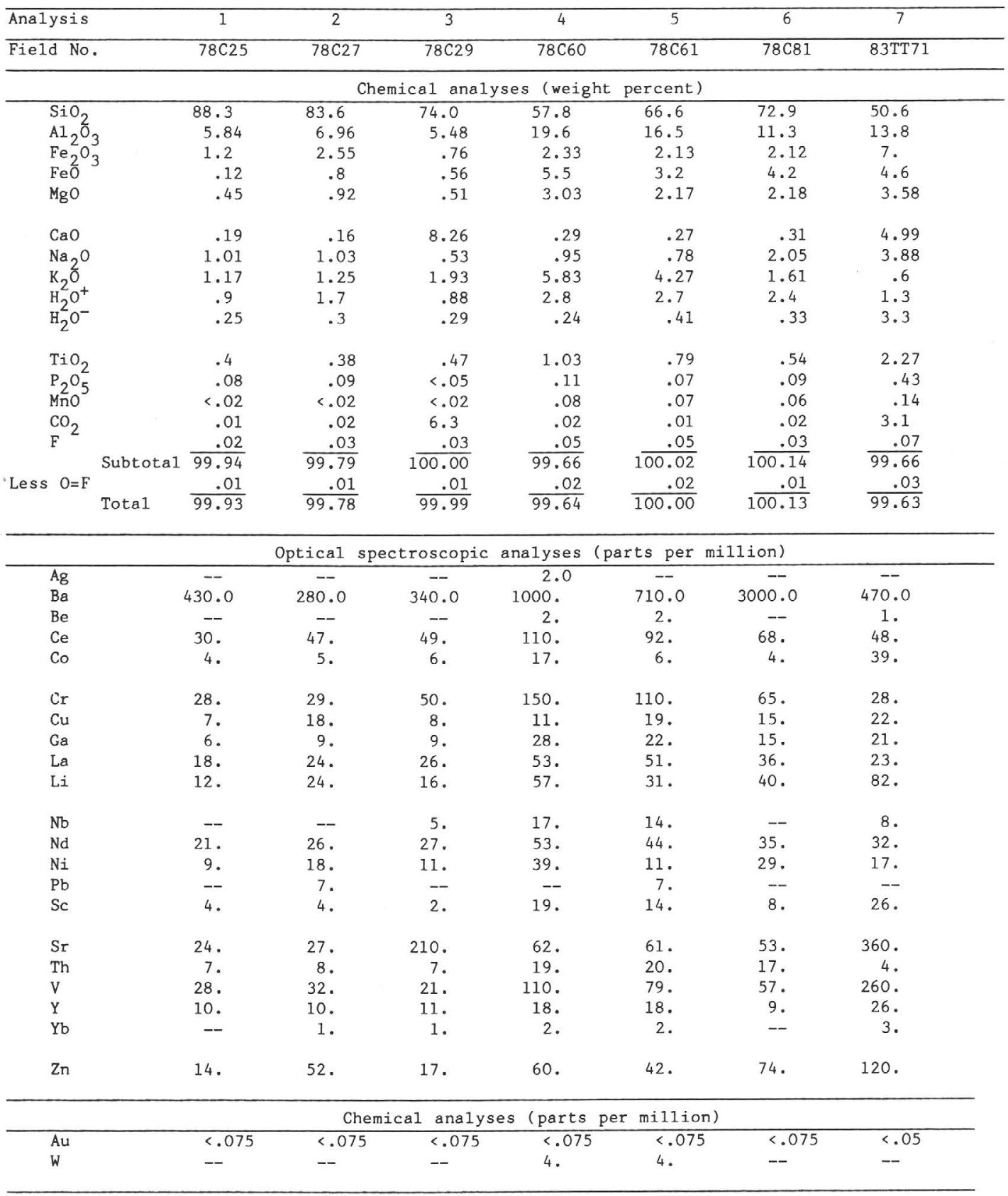

1. Quartzarenite, framework supported; sparse secondary biotite in matrix.

2. Subarkose, framework supported; sparse secondary biotite in matrix.

3. Calcareous subarkose; framework supported; relatively abundant calcite in matrix.

4. Interlayered hornfelsic subarkose and shale; matrix supported; abundant secondary biotite in matrix.

5. Hornfelsic subarkose; matrix supported; abundant secondary white mica and biotite in matrix.

6. Hornfelsic subarkose; framework supported; abundant secondary biotite in matrix.

7. Greenstone, highly altered; possibly an andesite in its unaltered state. 
its microlites are much more sodic $\left(\mathrm{An}_{40}\right)$ than those found typically in many basalts, a relation that suggests the greenstone may, in fact, have been closer to an andesite when originally laid down on the ocean floor. $\mathrm{CaO}$ and $\mathrm{Na}_{2} \mathrm{O}$ contents in the analyzed sample are 4.99 and 3.88 weight percent, respectively. Furthermore, overall chemical composition of this particular sample is remarkably similar to the analyses of several other lower Paleozoic lavas listed by Roberts (1964, table 5). Greenstone analyzed from the Harmony Formation (analysis 7 , table 1) contains 2.27 weight percent $\mathrm{TiO}_{2}$. Such a high $\mathrm{TiO}_{2}$ content relative to many other rocks in the Buckingham area provides us with some insight into the understanding of some highly metamorphosed rocks found at depth near the West stock. These rocks near the West stock also show high abundances of $\mathrm{TiO}_{2}$ and cobalt (T.A. Loucks and C.A. Johnson, oral commun., 1983). Thus, the rocks there probably include a signifi- cant proportion of volcanic flows interlayered with the sedimentary components of the Harmony Formation.

\section{ORDOVICIAN AND (OR) DEVONIAN SYSTEMS}

\section{DIABASE}

The most widespread exposures of presumably Ordovician and (or) Devonian age, drab-greenish-gray diabase in the Harmony Formation crop out in the west-central part of the map area (pl. 1). The age of the diabase cannot be established precisely. Roberts (1964) concluded that most of the diabase must be pre-Middle Pennsylvanian in age, that is, pre-Battle Formation (the basal formation in the overlap assemblage), because some diabase locally has been deformed into relatively tight folds along with

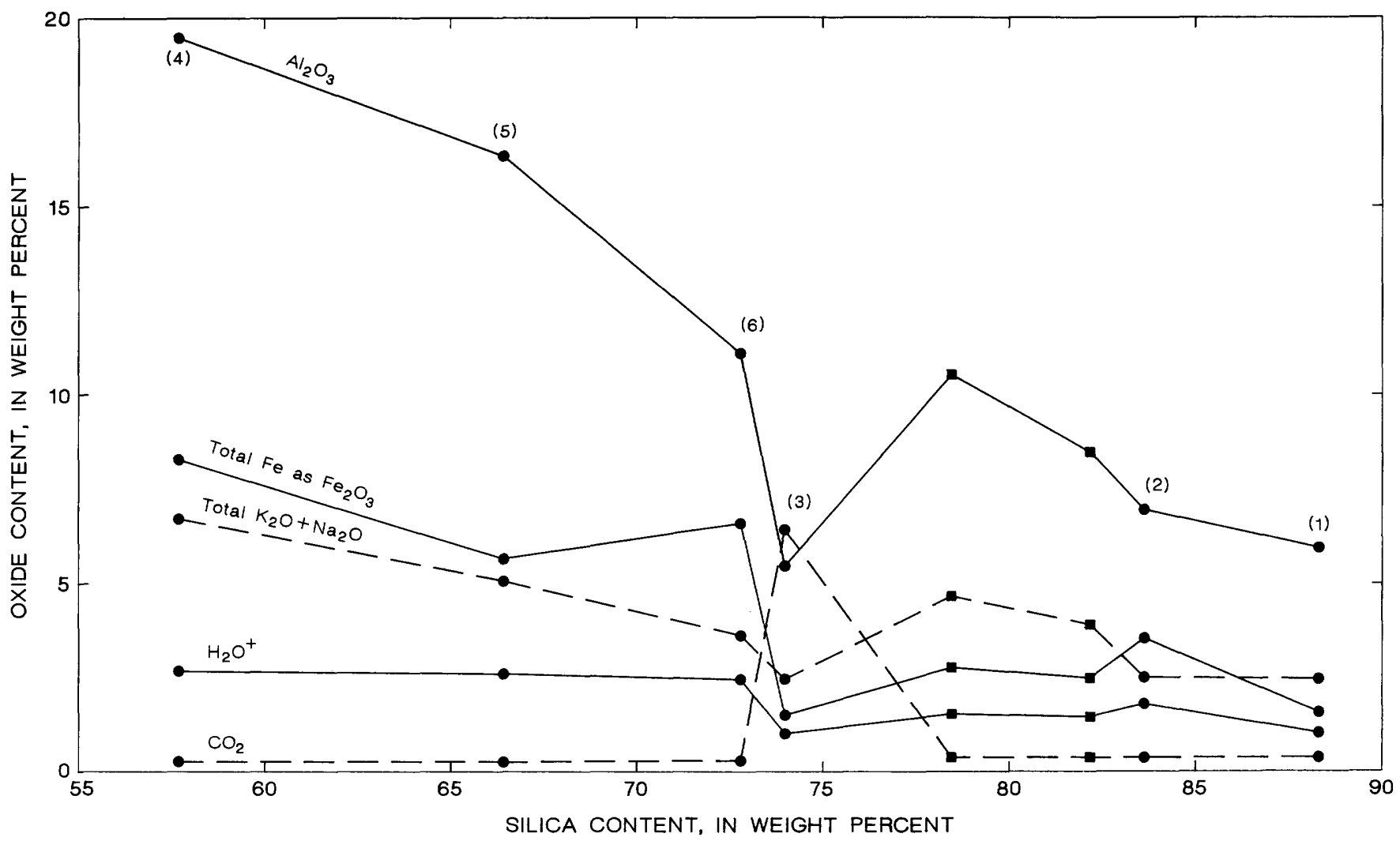

FIGURE 8.-Variation diagram comparing chemically analyzed sedimentary rocks and contact-metamorphosed sedimentary rocks of the Upper Cambrian Harmony Formation from Buckingham Camp-Copper Basin area with chemically analyzed sedimentary rocks of the Harmony Formation from
Galena area in southern part of Battle Mountain Mining District. Analysis numbers (in parentheses) refer to table 1. Dots, Buckingham Camp-Copper Basin area, this report (see table 1 for analytical data); squares, Galena area (from Theodore and Blake, 1975, table 9, Nos. 11, 14). 
enclosing subarkose and shaly arkose of the Harmony Formation, probably sometime during the middle Paleozoic Antler orogeny. The Battle Formation in the district is not deformed into outcrop-scale folds (Evans and Theodore, 1978). However, as will be discussed below, there is strong evidence that the Harmony Formation in the Buckingham area has been deformed, faulted, and folded into broad open folds, during the Mesozoic. Mafic igneous rocks make up significant parts of the Ordovician Valmy Formation, including some pillow lava and basaltic breccia (Roberts, 1964). The Devonian Slaven Chert (Gilluly and Gates, 1965); and the Devonian Scott Canyon Formation (Roberts, 1964; Theodore and Roberts, 1971), also include a significant proportion of mafic igneous rock. Thus, the relatively large masses of diabase in the Harmony Formation near Buckingham Camp may be Ordovician and (or) Devonian in age. Regardless, these large masses of diabase near Buckingham Camp are older than the Buckingham molybdenum system because they are. cut by quartz stockworks and millimeter-size pyrite veinlets related to this system. Molybdenite "paint" is present on fractures and joints that cut diabase in the Buckingham Camp area. As mapped, the largest body of diabase here measures about $200 \mathrm{~m}$ in its longest dimension at the surface. Roberts (1964), however, traced some diabase-rich zones for several kilometers elsewhere in the Harmony Formation. Generally, the diabase is very poorly exposed and its contacts obscured; it weathers to gently rounded slopes marked by small angular fragments. Elsewhere in the area, thin (2-3 m wide) sills of diabase show no apparent effects of contact metamorphism in the immediately adjacent sandstones of the Harmony Formation. In some of these sills, plagioclase phenocrysts are replaced by carbonate-bearing assemblages that weather out and thereby give a pitted appearance to the rocks. Textures in the diabase vary from subophitic to ophitic.

In all, 18 thin sections of diabase were studied petrographically. On the one hand, diabase, cropping out just inside the outer limit of secondary alteration effects visible in outcrop, shows a subophitic texture wherein all primary mafic minerals are replaced by a dense mat of a chlorite-dominant assemblage. Tabular, 0.3- to 0.4-mm-long crystals of calcic plagioclase $\left(A n_{60}\right)$ are altered to a carbonate-chloritetclay(s) assemblage. Indeed, some relict secondary biotite is itself in various degrees of replacement by chlorite. On the other hand, diabase near the core of the most intensely metamorphosed rocks near Buckingham Camp shows a well-developed metamorphic fabric dominated by secondary actinolite, and including lesser amounts of secondary biotite, pyrite, chalcopyrite (trace), apatite (trace), quartz (sparse), sphene, and relict, apparently stable plagioclase. The plagioclase is minimally clouded. An approximately $60-\mathrm{m}$-thick, fine-grained diabase sill also is present at a depth of about $600 \mathrm{~m}$ below ground surface in the general area of the East stock. This particular sill apparently shows an asymmetrically distributed metamorphic halo in adjoining metasedimentary rocks. Above the sill, an approximately $140-\mathrm{m}$-wide actinolite-bearing zone in mostly metamorphosed subarkose of the Harmony Formation is succeeded downward by an actinolite+diopside zone at least $65 \mathrm{~m}$ wide immediately adjacent to the sill. However, careful petrographic examination of 12 thin sections of samples across the zones suggests that most of the bulk of the actinolite, and possibly some of the diopside, is related not to the emplacement of the diabase, perhaps sometime during the Ordovician and (or) Devonian, but rather to the Late Cretaceous molybdenum system. Although tightly intergrown actinolite and biotite make up most of these rocks metamorphosed to hornfels, widespread potassic alteration is indicated by veins composed of K-feldspar-actinolite-biotite-quartz \pm sphene \pm pyrite \pm chalcopyrite \pm molybdenite \pm late-stage chlorite and carbonate assemblages. In places some veins show felted aggregates of actinolite in their selvages that unquestionably cut secondary biotite-dominant hornfels.

Samples of metamorphosed and subsequently metasomatized diabase show high abundances of cobalt, chromium, and titanium (table 1), relative to similarly altered arkose and subarkose of the Harmony Formation. Some chromium from the diabase probably has been remobilized from diabase during the emplacement of the Late Cretaceous molybdenum system and fixed as the chromium-mica fuchsite that is present rarely near the uppermost parts of the actinolite-bearing rocks. At its base, the diabase sill apparently is faulted against a sequence of steeply dipping, thinly bedded metasiltite that could belong either to the Harmony or the Scott Canyon Formation. The metasiltite shows no actinolite- or diopsidebearing assemblages; it does, however, include relatively significant concentrations of secondary $\mathrm{K}$ feldspar along permeable laminae and in veins.

\section{DEVONIAN SYSTEM}

\section{SCOTT CANYON FORMATION}

Rocks belonging to the Scott Canyon Formation are assigned to the Devonian on the basis of the fossil identifications of Jones and others (1978) 
from a locality near the townsite of Galena in the southern part of the mining district. Fossils collected from limestone blocks presumably enclosed within chert and argillite and originally identified in the study by Roberts (1964) suggest that the Scott Canyon Formation was Early and Middle Cambrian in age. However, radiolarians of Devonian age have since been found in chert collected from the Scott Canyon Formation (Jones and others, 1978; see below). Thus, the archaeocyathidbearing limestone collected from the Scott Canyon Formation may indicate slump deposits into a Devonian basin from Upper Proterozoic and Lower Cambrian siltstone, carbonate rocks, and quartzite to the south of the district (see Stewart and Suczek, 1977). Although radiolarians of probable Devonian age have now (1987) been obtained from at least two localities in chert of the Scott Canyon Formation south of the Buckingham area, repeated attempts by many workers to find additional radiolarians suitable for definitive age designation have failed. This failure indicates largely the highly recrystallized nature of almost all sequences of rocks within the formation. In addition, attempts to find conodonts suitable for dating in limestone of the Scott Canyon Formation have not been successful. The radiolarians mentioned above come from a suite of approximately eight composite chip samples collected from two localities, one in Galena Canyon and one in Cottonwood Canyon. All samples collected were found to contain very poorly preserved radiolarians because of the relatively intense recrystallization the rocks have undergone. One of the samples, SC-16 (USGS MR 2709) from the SEC sec. 14, T. 31 N., R. 43 E., contains a few Spumellariina with bladed primary spines, according to Benita L. Murchey of the U.S. Geological Survey (written commun., 1981). Murchey described the age of this particular sample as follows: "On the basis of very little evidence, SC-16 is probably no older than Late Devonian." The Spumellariina belong to the polyphyletic lineage of spheroidal radiolarians that have complex spines (see Jones and Murchey, 1986). However, additional faunal assemblages of Ordovician age have recently been discovered by McCollom and others (1987) in chert that previously had been mapped by Roberts (1964) and Theodore and Roberts (1971) as belonging to the Scott Canyon Formation. These faunal assemblages comprise identifiable conodonts obtained from chert (M.B. McCollom, oral commun., 1987). Therefore, until field relations of the Ordovician- and Devonian-bearing sequences are fully resolved by large-scale mapping and addi- tional sampling for fossils near Galena Canyon, two alternative hypotheses are tenable. First, the Scott Canyon Formation as orginally mapped by Roberts (1964) may include some tectonically imbricated sequences of the Valmy Formation. Second, the Ordovician fauna may, in fact, be hosted by rocks of Devonian age, as originally proposed by Jones and others (1978), but the Ordovician fauna may be in olistoliths thereby adding confidence to the Cambrian age for the rocks of the Harmony Formation that overlie tectonically the Scott Canyon Formation. As pointed out by Madrid (1987), archaeocyathid-bearing limestone clasts in the Scott Canyon Formation are present in volcanogenic debris flows.

The Scott Canyon Formation in the district consists predominantly of chert with interbedded carbonaceous shale partings, carbonaceous shale and argillite, and locally abundant greenstone (altered andesite and (or) basalt). In addition, relatively thin beds of quartzite and small, possibly exotic, blocks of limestone (including the archeocyathid-bearing limestone described above) crop out locally in many areas of the formation. Several pods of dark-gray limestone, laced with anastomosing veins of creamywhite calcite, crop out within individual map units of the Scott Canyon Formation in an imbricate fault block near the south edge of the map area (pl. 1). These pods are present at an elevation of $6250 \mathrm{ft}$. Relations with surrounding chert are equivocal because actual contacts of the pods of limestone are not exposed.

The thickness of the formation cannot be measured adequately because of a combination of: (1) incomplete sections of rocks, (2) postdiagenetic transposition of bedding, (3) many local repetitions of section by tight folds, and (4) the absence of suitable marker beds. These rocks. were extremely disrupted during the Mississippian emplacement of the Roberts Mountains allochthon (Evans and Theodore, 1978); chert phacoids, from tens of meters to several millimeters wide, are commonly surrounded by apparently more ductile shaly rocks of the same formation. Roberts (1964, p. A14) suggested that the total thickness of the Scott Canyon Formation may be more than $1,500 \mathrm{~m}$. A deep drill hole that was started in rocks of the Scott Canyon Formation at Iron Canyon about $6.5 \mathrm{~km}$ south of the Buckingham area bottomed in rock lithologically similar to the Scott Canyon Formation at a depth of about $1,300 \mathrm{~m}$ (Theodore and Roberts, 1971).

The Scott Canyon Formation as mapped crops out only in a small part of the Buckingham area southeast of the Little Giant Mine near the south edge of 
the map area and just northwest of the Little Giant Mine (pl. 1). Exposures generally are quite poor near the south edge of the area. Initially the assignment of very poorly exposed sequences of brown-black to black recrystallized chert or shale with contorted bedding, and including minor, well-sorted gray quartzite, was problematical. Recrystallized chert and (or) shale typically contains 2 to 3 volume percent monoclinic pyrrhotite near the underground Buckingham Mine. However, relatively abundant chips of bleached and clay-altered greenstone with subophitic texture that mantle slopes in this general area are assigned to the Scott Canyon Formation. Greenstone consisting of altered andesite and (or) basalt crops out prominently throughout much of the Scott Canyon Formation (Roberts, 1964). This relation is especially true in the Iron Canyon area, where probably as much as 40 volume percent of the exposed Scott Canyon Formation is greenstone (Theodore and Roberts, 1971). In the Buckingham area, the Scott Canyon Formation presumably is everywhere in fault contact with the Harmony Formation; the base of the Scott Canyon Formation is not exposed.

As mapped (pl. 1), the Scott Canyon Formation consists of three intergradational units: mostly greenstone, mostly chert and argillite, and an undivided unit consisting of greenstone, chert, argillite, limestone, and shale. All these rocks are confined largely to a north-northeast-trending area that measures approximately 1,200 by $400 \mathrm{~m}$ and is bounded for the most part by steeply east-dipping, Tertiary normal faults. These normal faults probably have relatively minor displacements that in places followed the trace(s) of the Mississippian Dewitt thrust that tectonically juxtaposed the Scott Canyon and Harmony Formations. The Dewitt thrust, dipping $15^{\circ}-40^{\circ} \mathrm{W}$., is mapped on the west side of an approximately $250-\mathrm{m}$-long tectonic sliver of the Scott Canyon Formation that crops out partly in a minor canyon approximately $300 \mathrm{~m}$ southeast of the main workings of the underground Buckingham Mine. There is excellent evidence for tectonic brecciation and slickenside development in the rocks of the Scott Canyon Formation along the trace of the Dewitt thrust. Several prospect pits that expose yellow- to ocher-brown fault breccia along a Tertiary normal fault, east side down, are present along the east margin of the north-south-trending sliver.

This sliver of dark-gray to black chert of the Scott Canyon Formation is characterized by abundant quartz veins that apparently predate the juxtaposition of chert with the Harmony Formation during thrusting in the Mississippian and by other mega- scopic structural features that developed probably during thrusting. Milky-white quartz veins, ranging from several millimeters to about $15 \mathrm{~cm}$ wide, are present throughout the body of chert. Overall abundance of veins increases to the south. Generally, these veins are lensoid and distributed quite irregularly; they locally flood into and fade out through a surrounding matrix of recrystallized chert. However, the rocks of the Harmony Formation immediately adjacent to the Scott Canyon Formation are not silicified. Some of the milky-white quartz veins in the sliver of the Scott Canyon Formation are polished tectonically and slickensided, thereby establishing the age of veins as predating at least the last penetrative deformation(s) to have affected the rocks. Brecciation along the Dewitt thrust obliterated most bedding in the chert such that only polished and striated fractures and joints remain. Such slickensides in places grade into a highly crenulated and ribboned surface. Measurement of the attitude of these axial features shows very strong, double-point maxima whose overall center of gravity plunges shallowly, about $25^{\circ}-30^{\circ}$, to about N. $60^{\circ}$ W. (fig. 9). Such attitudes probably are consistent with the local trend of final displacement as rocks of the Harmony Formation were thrust over those of the Scott Can-

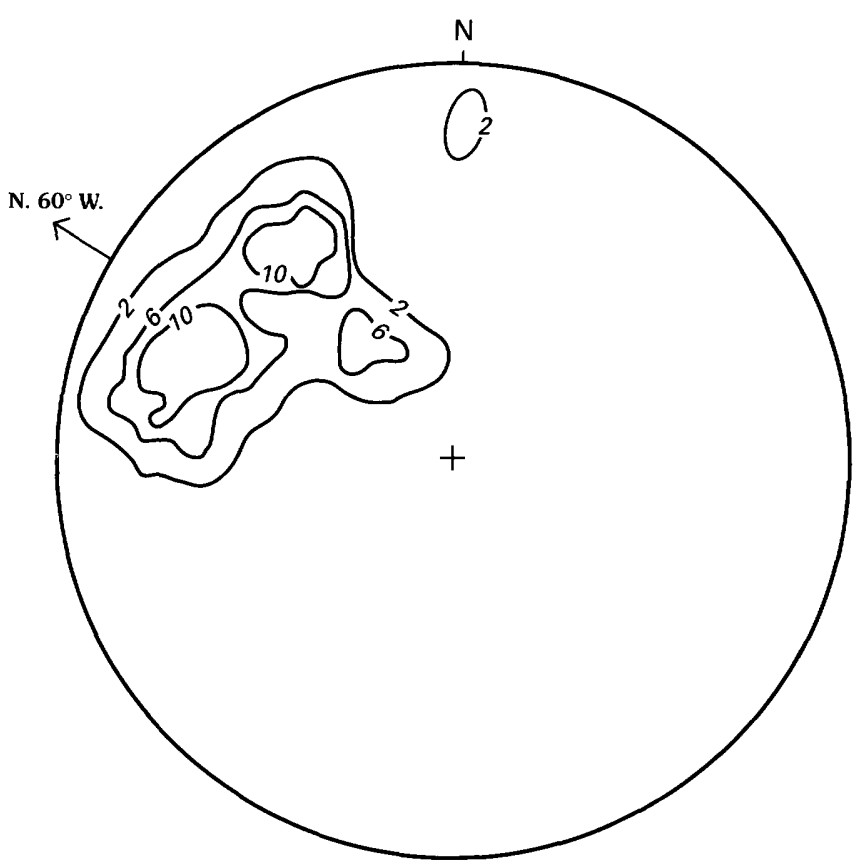

FIGURE 9.-Orientation of 44 slickenside measurements in chert of the Devonian Scott Canyon Formation near Dewitt thrust about $300 \mathrm{~m}$ southeast of Buckingham Mine. Lowerhemisphere, equal-area projection. Contours: 2,6 , and 10 percent per 1-percent area. 
yon Formation. Evans and Theodore (1978) found that megascopic fold axes in this general area of the Scott Canyon Formation plunge about $15^{\circ}, \mathrm{N}$. $15^{\circ}$ $20^{\circ} \mathrm{E}$., approximately at right angles to the trend of the slickensides. Careful examination of the attitudes of slickensides revealed that they seem to have a more or less uniform orientation within a given polished surface. However, the next adjacent polished surface may contain slickensides whose trend diverges as much as $30^{\circ}-40^{\circ}$ from the underlying polished surface. These relations suggest the rocks have yielded by brittle failure in a very complex manner during strains imposed by the overriding of the Harmony Formation.

Highly recrystallized, well-bedded chert crops out in a rectangular small area, measuring at most 300 $m$ at the surface, northwest of the Little Giant Mine; this mass of chert has been assigned tentatively to the Scott Canyon Formation (pl. 1). The recrystallized chert weathers to smooth slopes, and as mapped, it is apparently in tectonic contact with the surrounding Harmony Formation along a splay of the middle Paleozoic Dewitt thrust (fig. 10A) and also along three probable Tertiary normal faults that are steeply dipping. These normal faults have downfaulted the Harmony Formation relative to the chert. In addition, the chert here is intruded by a Tertiary rhyolite (unit Tr, pl. 1). Contacts of the chert with the surrounding Harmony Formation are obscured by colluvium derived mostly from the slope-forming rocks of the Harmony Formation.

Recrystallized chert near the Little Giant Mine is very distinctive compared with surrounding meta-arkose and metasubarkose of the Harmony Formation. Thin sequences of recrystallized chert are only locally well exposed within the outcrop area of this map unit. On fresh surfaces, the chert is milky white, but it weathers from creamy white to buff ocher brown. Where exposed, the chert is well bedded, showing somewhat-wavy undulations of its bedding planes that are about 2 to $5 \mathrm{~cm}$ thick. Some beds have a pronounced pinch and swell along strike (fig. $10 B$ ), others are highly contorted (fig. 10C). Nonetheless, bedding in the unit generally dips shallowly, about $20^{\circ} \mathrm{W}$., although some beds dip as much as $65^{\circ}$. When viewed at high magnifications under the microscope, recrystallization in chert ranges from moderate to intense. The moderately recrystallized chert shows complexly sutured quartz-quartz grain boundaries; individual crystals average about $0.04 \mathrm{~mm}$ wide, and very small domains of even finer grained crystals of relict sedimentary quartz are not uncommon. In these rocks, partings along bedding planes
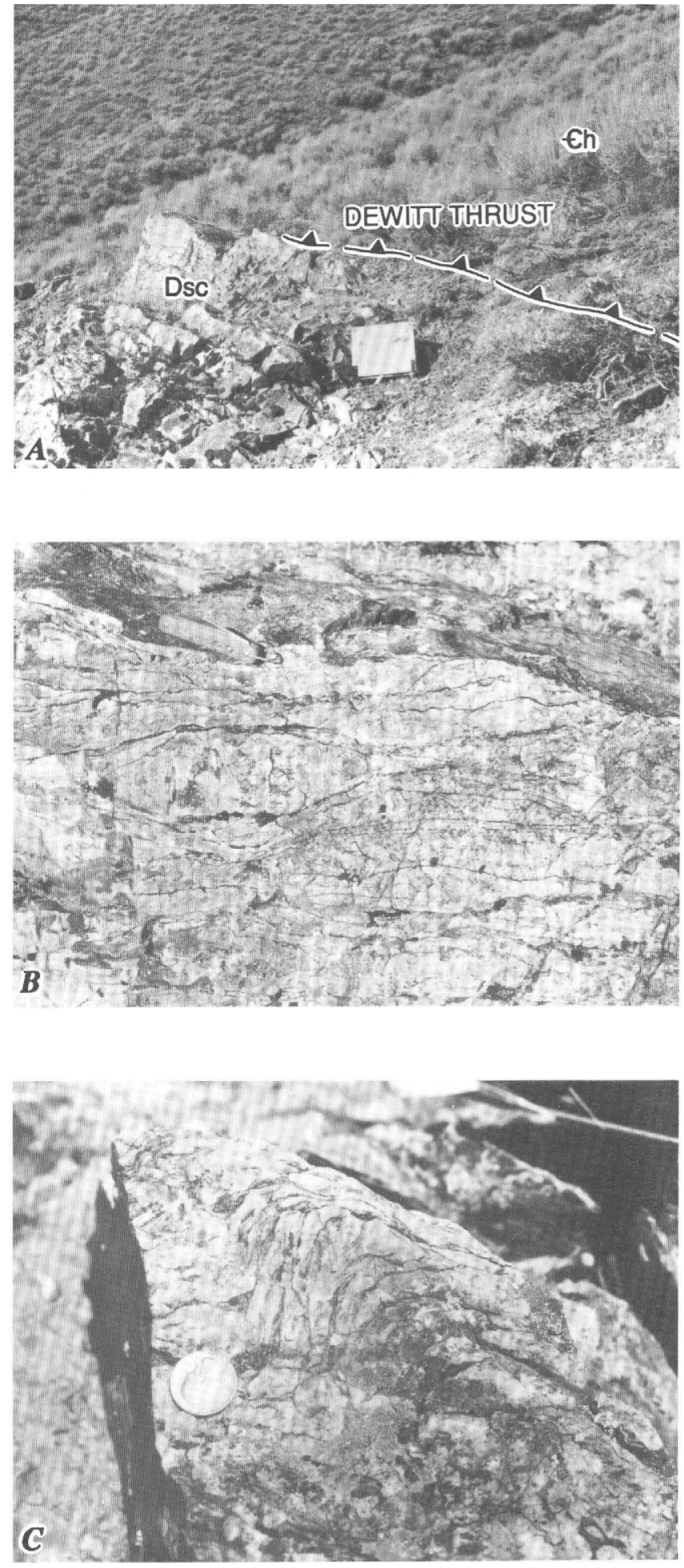

Figure 10.-Structural relations of chert of the Devonian Scott Canyon Formation (Dsc) at selected outcrops. A, Bedding in recrystallized chert dips conformably to west with Dewitt thrust surface. View to south along part of Dewitt thrust plane at base of Upper Cambrian Harmony Formation ( $€$ h). $B$, Pinching and swelling of individual chert beds along strike. $C$, Macroscopic, south-verging fold in thinly bedded sequence of chert. View N. $80^{\circ} \mathrm{W}$. 
are marked by abundant concentrations of white mica in zones about 1 to $2 \mathrm{~mm}$ wide. Intensely recrystallized chert includes abundant domains
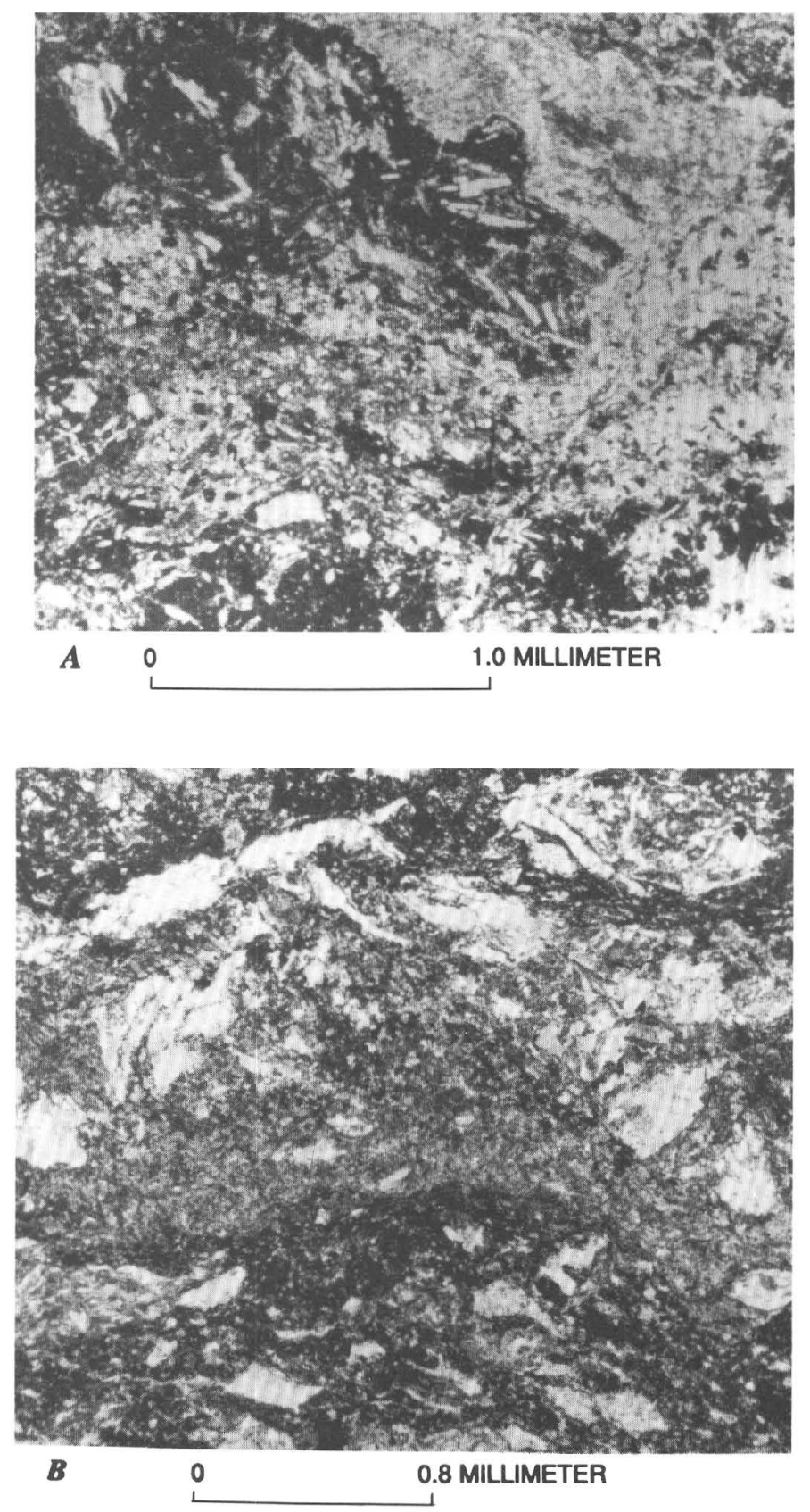

FIGURE 11.-Photomicrographs of altered andesite from the Devonian Scott Canyon Formation. Plane-polarized light. A, Fragments of clinopyroxene andesite set in intersertal groundmass including calcite, albitized andesine, serpentine, chlorite, minor clay(s), white mica, and sphene. Sample $78 \mathrm{C} 42 . B$, Highly disrupted flow fabric of intensely carbonate-altered greenstone. Sample 78C44. wherein individual crystals of quartz average about $0.1 \mathrm{~mm}$ in size, and quartz-quartz boundaries are mostly planar and typified by an abundance of $120^{\circ}$ dihedral angles.

Four additional thin-sectioned samples from the Scott Canyon Formation were examined petrographically. One of the thin sections includes clinopyroxene andesite clasts. The clasts are smooth, rounded and 1.5-cm-wide and are set in a highly altered aphanitic matrix (fig. 11A). Microlites of plagioclase within the clasts are altered to albite; they probably crystallized initially as andesine; this conclusion is based on the calcic contents of large, relict plagioclase. An analysis of basaltic lava from the Scott Canyon Formation collected from the east front of the range, near the south end of the mining district, showed 4.5 weight percent $\mathrm{Na}_{2} \mathrm{O}$ (Roberts, 1964). This value is high with respect to the 2.37 weight present $\mathrm{Na}_{2} \mathrm{O}$ in average tholeiite of LeMaitre (1976), and the 2.70 weight percent $\mathrm{Na}_{2} \mathrm{O}$ in average olivine basalt of the circum-Pacific (Poldervaart, 1955). Roberts (1964) suggested that the apparent increase in the abundance of $\mathrm{Na}_{2} \mathrm{O}$ in greenstone of the Scott Canyon Formation may have resulted from interaction with seawater as volcanic rocks were extruded in a submarine environment. Isolated, tabular laths of clinopyroxene, as much as $2.0 \mathrm{~mm}$ long, are sprinkled throughout the matrix enclosing the clasts in the clinopyroxene-andesite flow; the clinopyroxene is strongly altered to serpentine and chlorite, and then microveined by calcite. In addition, sparse occurrences of extremely fine grained chlorite outline the former presence of hornblende. The matrix includes abundant chlorite, microlites of albite, carbonate, and very minor white mica associated spatially with some of the carbonate. Some samples of greenstone show intensely disrupted fabrics, and include fragments of andesite that show, in places, a well-developed subophitic texture (fig. 11B). Secondary biotite in trace amounts has recrystallized in the matrix of some of the greenstone as much as $150 \mathrm{~m}$ or more beyond the approximate outer limit of epigenetic alteration visible in outcrop (pl. 1). Some greenstone includes excellently developed subophitic texture wherein laths of plagioclase, averaging about $0.5 \mathrm{~mm}$ in length, are complexly interbedded and set in a chlorite-tremolite-bearing matrix. Chert from the Scott Canyon Formation shows carbonaceous streaks and recrystallized, silt-size fragments of microcrystalline quartz aligned parallel to the bedding surfaces. The detrital, microcrystalline quartz 
fragments measure about $0.05 \mathrm{~mm}$ wide. Detrital flakes of mica show well-worn crystal ends. Poorly preserved radiolarian tests in the chert are recrystallized into complexly sutured, very fine grained crystals of quartz.

Veins are common in many of the chert sequences of the Scott Canyon Formation. The wispy, discontinuous veins of quartz common throughout much of the Scott Canyon Formation show no alteration halos in thin section, although they include trace amounts of white mica and some iron oxide, possibly replacing pyrite.

\section{PENNSYLVANIAN SYSTEM}

\section{BATTLE FORMATION}

The Middle Pennsylvanian Battle Formation is the basal formation of the autochthonous Antler sequence in the Battle Mountain Mining District, and its unconformable relation with the underlying Harmony Formation and Valmy Formation has widespread regional implications (Roberts and others, 1958; Roberts, 1964; Speed, 1977). Indeed, the prominent exposures of the Battle Formation in the district attracted the attention of early regional surveyors (see Hague and Emmons, 1877; Lawson, 1913). Coarse conglomerate of the Battle Formation was shed from highlands formed during the Antler orogeny (fig. 12) into the Continental Borderland terrane of Speed (1977). According to Speed, north of lat $39^{\circ} 30^{\prime}$ N., the Continental Borderland terrane also included the Pennsylvanian Wildcat Peak Formation (Kay and Crawford, 1964; McKee, 1976) and autochthonous, Permian neritic facies of the Diablo Formation (Ferguson and others, 1953). In the Edna Mountain area, northwest of the Battle Mountain Mining District, the Continental Borderland terrane consists of, in ascending order, the Battle Formation, the Middle and Upper Pennsylvanian Highway Limestone, the Upper Pennsylvanian and Lower Permian Antler Peak Limestone, and the Permian Edna Mountain Formation (Erickson and Marsh, 1974). Recently, Saller (1980) recognized in the Battle Formation a transgressive sequence of depositional facies ranging from proximal alluvial fans at the base, through distal fan sandstone and conglomerate intercalated with sandy dolomite of supratidal origins. In addition, he concluded from paleocurrent directions that rocks of the Battle Formation may have been deposited in a basin of internal drainage.
Roberts (1964) described three informally named members in the Battle Formation, but he was not able to show them individually on the geologic map of the quadrangle because of scale limitations. However, the three members are mapped separately in a large-scale geologic map of the Copper Canyon area, at the south end of the mining district (Theodore and Blake, 1975). Where unmetamorphosed, the three members as mapped there include a lower member composed of reddishbrown, calcareous conglomerate whose framework clasts include chert, quartzite, sandstone, limestone, and volcanic fragments; a variously colored middle member composed of calcareous shale; and an upper member composed of drab quartzite and chert-pebble conglomerate. Iron oxide-rich red beds of the lower member crop out conspicuously in sequences of the Battle Formation sparsely altered near the north edge of the Copper Canyon area (Theodore and Blake, 1975).

Roberts (1964, p. A29) measured an aggregate thickness of $222 \mathrm{~m}$ for the entire formation near Antler Peak, approximately $8 \mathrm{~km}$ southwest of the Buckingham area. From poorly exposed composite sections in the Copper Canyon area, Theodore and Blake (1975) estimated an aggregate thickness of approximately $175 \mathrm{~m}$ for the formation. Indeed, Roberts (1964) suggested that the locus of the deepest part of the basin for the Battle Formation probably is situated somewhere near the north edge of the Copper Canyon area, perhaps close to the townsite of Galena.

In the Buckingham area, the Battle Formation crops out as small erosional remnants primarily in a north-south-trending, narrow belt near the east edge (pl. 1). This distribution of the Battle Formation results probably from a combination of displacements along faults and also from probable regional-scale folding in the Mesozoic along a northnorthwest-trending hingeline through the district (see fig. 2). The Battle Formation and stratigraphically higher rocks of the Antler Peak Limestone and the Edna Mountain Formation dip gently to the west in the general area of Antler Peak, whereas the Battle Formation consistently dips east in the Buckingham area. Rocks of the Battle Formation in the Buckingham area are characterized by dips ranging from $25^{\circ}$ to $35^{\circ}$ near its south terminus, whereas rocks near its north limit commonly are typified by dips ranging from $55^{\circ}$ to $60^{\circ}$. In contrast to the bright brick-red hues of the Battle Formation where it is unmetamorphosed near Copper Canyon, the Battle Formation at Buckingham crops out entirely within 


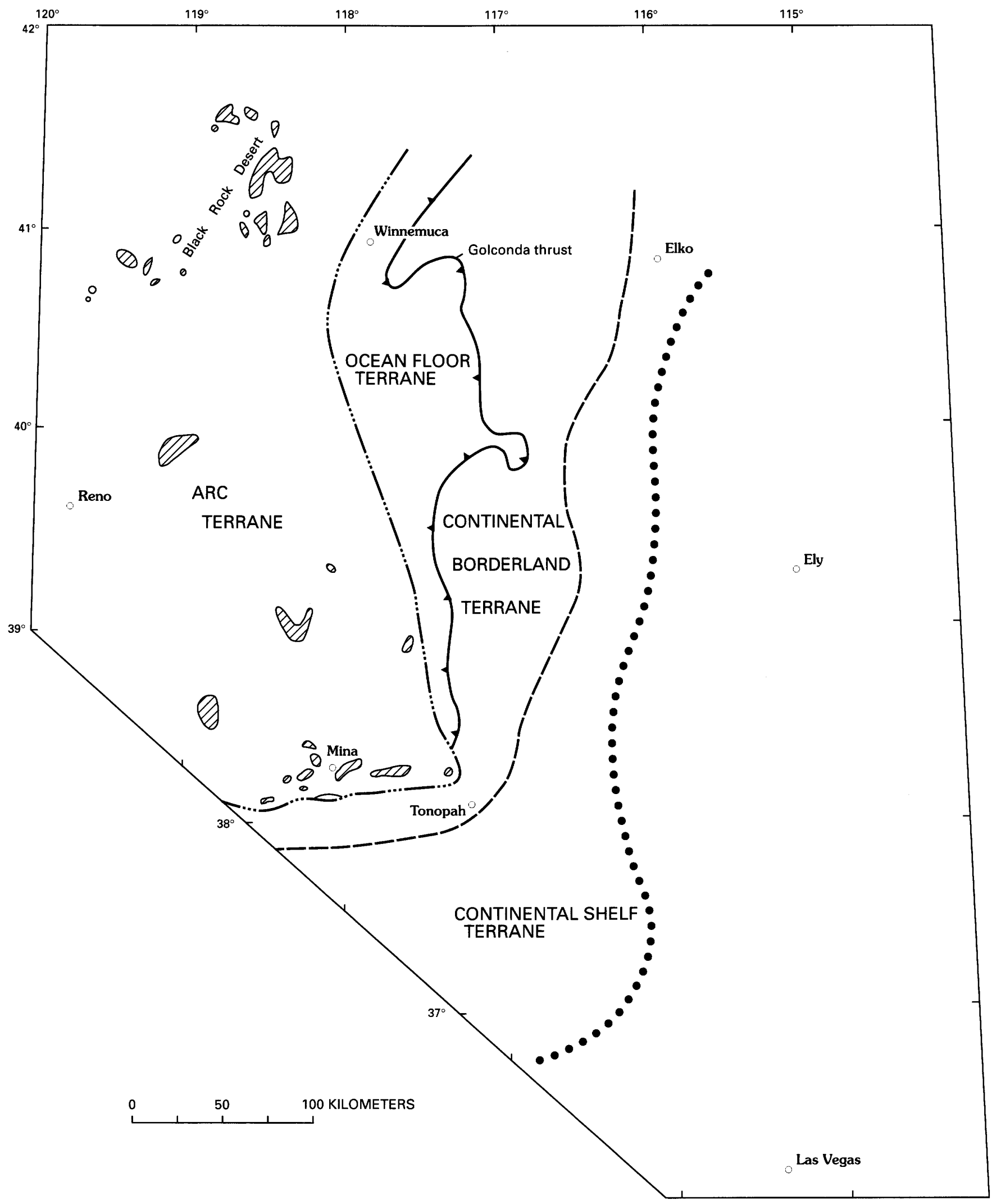

FIGURE 12.-Distribution of late Paleozoic terranes in western Great Basin of Nevada. Pattern, areas inferred to include arc-type volcanic rocks; dotted line, axis of maximum thickness of Mississippian rocks along depositional trough of con- tinental shelf. Coarse conglomerate of the Battle Formation formed during Antler orogeny in highlands was shed into Continental Borderland terrane. Modified from Speed (1977). Sawteeth on upper plate of Golconda thrust. 
superposed alteration zones associated with widespread Late Cretaceous and middle Tertiary magmatic pulses predominant in this part of the district. As such, the rocks of the Battle Formation here are recrystallized and partially silicified to various shades of light gray. Outcrops of the Battle Formation are highly resistant to weathering, and for the most part, wherever present, the Battle Formation is well exposed (fig. 13A). Nonetheless, nowhere in the Buckingham area is the unconformity with the underlying Harmony Formation displayed as spectacularly as in the Copper Canyon area, noted by Roberts (1964) and located on plate 1 of Theodore and Blake (1975). Rounded to angular, frameworksupported clasts of mostly quartzite and chert are common throughout the lower member in the Buckingham area (figs. 13B, 13C).

Two of the members of the Battle Formation (lower and middle members), as defined originally by Roberts (1964), apparently crop out in the area (pl. 1). Where the bulk of the sequence of the lower and middle members is exposed just north of the former location of workings at the Copper King Mine, the Battle Formation measures approximately $350 \mathrm{~m}$ in stratigraphic thickness, considerably thicker than that at the type section at Antler Peak measured by Roberts (1964). However, contacts are poorly exposed to the north of the Copper King Mine and the top of the middle member there is nowhere exposed; the uppermost sequences of the middle member have been cut out by a northnortheast-striking fault, filled now partly by Oligocene granodiorite porphyry (pl. 1).

Variably metamorphosed and altered conglomerate belonging to the lower member is the more widely exposed of the two; it crops out almost continuously along the entire north-south belt of the Battle Formation. Near the base of the lower member, drab, light-gray, well-indurated, well-bedded conglomerate has angular to subrounded, 1.5to $3.0-\mathrm{cm}$-wide clasts set in a medium-grained, granulose matrix. Clasts are relatively well sorted and have the following lithologies: light- and darkgray chert, red jasper, light-gray to creamy-white quartzite, and sparse brown shale. The clasts are dimensionally oriented with their long axes parallel to, and partly defining, bedding. Near the north end of this belt, the lower member of the Battle Formation as mapped consists of, high in its stratigraphic section, thinly bedded calcareous quartzarenite whose partings between beds ranges from 1 to $15 \mathrm{~cm}$. Here, quartzarenite, calcareous quartzarenite, and sparse calcareous shale weather gray to white, and include some drab, gray-green, highly disrupted interbeds of shale containing locally 2 - to
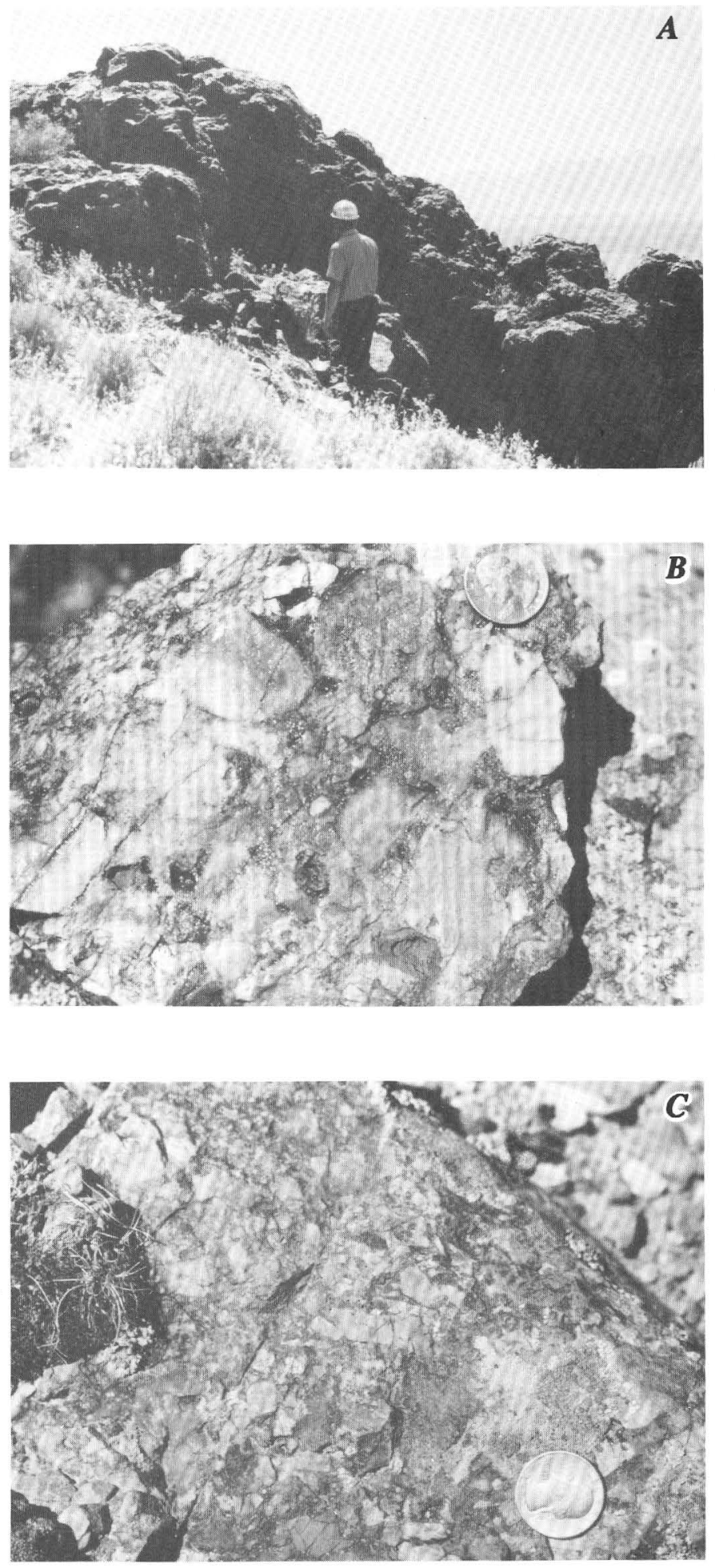

Figure 13.-Characteristics of outcrops of Middle Pennsylvanian Battle Formation at Buckingham. A, Typical craggy exposures of the flat-lying Battle Formation capping a ridge northeast of Empire Mine near east edge of map area. B, Closeup of rounded to subrounded fragments in lower member of the Battle Formation cropping out north of workings at Copper King Mine. $C$, Lower member of the Battle Formation, showing framework-supported angular fragments of chert set in hematitic matrix. Same locality as in figure $13 B$. 
5-cm-wide, ovoid fragments of medium-grained, gray quartz arenite. The thickest sequence of the basal member in the Buckingham area probably is present in a very poorly exposed, approximately 700 -m-long body mapped near the southeast corner of the area (pl. 1). For the most part, the basal contact of the lower member of the Battle Formation is the unconformity with the underlying Harmony Formation. However, in places the lower contact is a normal fault along which the Battle Formation has dropped down relative to the adjoining Harmony Formation. Just north of workings at the Copper King Mine, however, the lower member of the Battle Formation, as well as part of the middle member, has been repeated along a high-angle reverse fault, the Elvira fault, near the Surprise Mine (fig. 14). Separations along this structure determined by drilling are approximately $300^{\circ} \mathrm{m}$ (Kirk Schmidt, oral commun., 1985). The upper contact of the lower member of the Battle Formation is a fault for approximately half the strike length of the member exposed north of the Copper Basin Mine (pl. 1). Along this tectonic contact, the middle member of the Battle Formation has been cut out because the Antler Peak Limestone apparently has moved downward relative to the lower member of the Battle Formation.

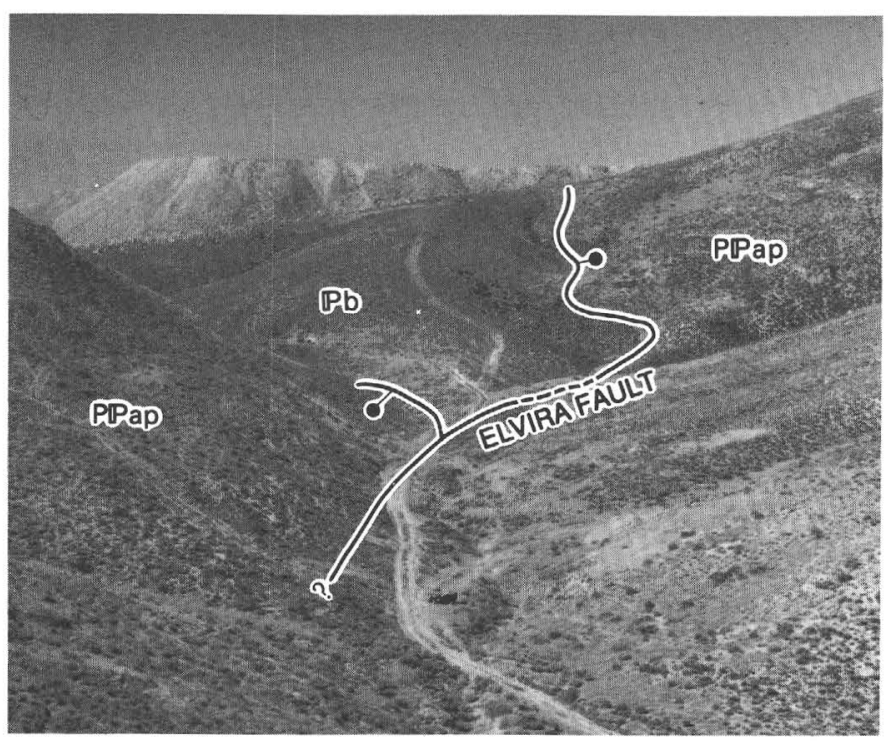

FiguRE 14.-Rocks belonging to lower and part of middle members of the Middle Pennsylvanian Battle Formation $(\mathbb{P b})$ tectonically juxtaposed against the Upper Pennsylvanian and Lower Permian Antler Peak Limestone (PPap) by reverse displacement(s) along Elvira fault. Fault dotted where concealed; queried where extent uncertain; bar and ball on downdropped side. View southeast, near Surprise Mine.
The middle member of the Battle Formation crops out only in a small area, approximately 300 $\mathrm{m}$ north of the Copper King Mine, near the east edge of the area (pl. 1). It is conformable with the lower member, but the entire section of the middle member is exposed nowhere in the Buckingham area. The strike of bedding in the middle member diverges on average by approximately $25^{\circ}$ from that in the Antler Peak Limestone: about N. $35^{\circ}$ E., compared with about N. $10^{\circ} \mathrm{E}$. in the Antler Peak Limestone. Lithologically, the middle member of the Battle Formation includes well-exposed and well-bedded sequences of light-buff-gray, calcareous silty shale, whose parting along bedding surfaces averages about 5 to $8 \mathrm{~cm}$. Grayish-green shaly partings are quite siliceous compared with intercalated calcareous silt and shale. Some shaly interbeds contain abundant granules of quartz. Furthermore, some isolated angular fragments of buff limestone, about $2 \mathrm{~cm}$ in their long dimension, are present within some shale. Parting along beds is quite pronounced in the uppermost sequences of the middle member such that individual beds may be traced for as much as $30 \mathrm{~m}$ along strike. Bedding surfaces within the middle member are somewhat undulating and contorted in places. Where locally recrystallized, such as near the north edge of the workings at the Copper Basin Mine, the middle member shows a welldeveloped granoblastic fabric that has various hues of green on fresh surfaces and greenish brown on weathered surfaces. Some samples within about $15 \mathrm{~m}$ of granodiorite porphyry show replacement of their sedimentary carbonate rocks by a dense mat of fine-grained diopside. Generally, the diopside mat is constrained tightly to outer margins of garnet-pyroxene skarn that occurs immediately adjacent to granodiorite porphyry. Furthermore, these metasomatic calc-silicates are mantled by a zone in the carbonate rocks, possibly as wide as $30 \mathrm{~m}$, wherein abundant, coarsely crystalline calcite is present in veins.

Up to this date (1989), most of the metal production from the district, including copper-gold-silver and gold-silver ores in the Copper Canyon area has been from favorable replacement zones within the Battle Formation (Theodore and others, 1986). Outcrops of the lower member of the Battle Formation, because of their highly siliceous nature in this part of the Buckingham area, apparently are not so heavily mineralized as those parts of the lower member cropping out in equivalent alteration zones in the Copper Canyon area. Locally, however, some 
parts of the Battle Formation contain significant concentrations of gold near the Surprise Mine (Roberts and Arnold, 1965; Anonymous, 1986). In addition, parts of the lower member of the Battle Formation, now removed by erosion, may also have been very heavily mineralized and metasomatized in areas more proximal to the locus of primary mineralization associated with the Copper Basin ore bodies (Tippett, 1967). In fact the relation of extensive garnet-pyroxene skarn in the Harmony Formation that is bounded by the basal contact of the Battle Formation (pl. 1) suggests local ponding of fluids by an impervious part of the lower member of the Battle Formation here, north of the Copper Basin Mine. Thus, permeability of the lower member of the Battle Formation apparently must have been highly variable throughout the mining district because at Copper Canyon some of the best ore formed in rocks of the Battle Formation (Theodore and Blake, 1975, 1978).

Petrographic examination of several samples of the lower member of the Battle Formation selected near its northernmost exposures, southeast of the Bailey Day Mine, shows abundant recrystallization in the matrix of the conglomerate. The coarse-sandy matrix, here averaging about $0.6 \mathrm{~mm}$ in grain size, has monocrystalline quartz as its dominant framework grain. These coarse sands are mostly framework supported, although close to some of the mapped bodies of Oligocene hornblende porphyry, the quartz sand matrix of the conglomerate is itself matrix supported apparently by secondary Kfeldspar. Generally, porosity is quite low. Monocrystalline grains of quartz show subrounded to rounded nucleii outlined by extremely small two-phase (liquid+vapor) fluid inclusions and mantled by quartz overgrowths containing abundant silicate inclusions and relatively sparse concentrations of somewhat larger two-phase fluid inclusions. The sandy matrix also includes lithic fragments of chert (some microveined heavily by quartz and K-feldspar), jasper, arkose, felsic K-feldspar-rich volcanic(?) rocks, metasiltite, altered mafic volcanic rocks, and limestone.

Chemical analyses of six representative samples of the Battle Formation, collected near the north edge of the map area (pl. 1), provide additional documentation of the districtwide variability in lithology of this important host for ore (table 2). As described above, the lower member of the Battle Formation in the Buckingham area is highly siliceous. This characteristic of the rocks here is highlighted in an oxide-variation plot that compares two representative samples (analyses 1,2 , table 2) of pebbly sandstone from the lower member with unmineralized calcareous conglomerate of the lower member that crops out near Galena (fig. 15). As such, both samples analyzed from the Buckingham area have a low abundance of calcite $(0.21$ and 0.11 weight percent $\mathrm{CO}_{2}$ ), whereas representative samples from the lower member of the Battle Formation near Galena have $\mathrm{CO}_{2}$ contents of at least 2 weight percent (fig. 15). Although these analyzed samples from the Buckingham area are unmineralized and contain some calcite-rich sandstone clasts, they nonetheless show secondary Kfeldspar and biotite locally in their matrix. Thus, some additional calcite in the matrix may have been replaced during crystallization of these secondary minerals. Analyses of four representative samples of the middle member (analyses 3-6, table 2 ), which are metamorphosed to grades as high as pyroxene hornfels showing a diopside-tremoliteepidote-K-feldspar assemblage, suggest that some of these rocks may have been metasomatized. Comparison of the analysis of unaltered, magnesian calcite- or dolomite-rich silty shale (analysis 3) with analyses of nearby metamorphosed rocks of the middle member (analyses 3-6) suggests that some $\mathrm{CaO}$ and $\mathrm{CO}_{2}$ were removed, and $\mathrm{K}_{2} \mathrm{O}$ and $\mathrm{Al}_{2} \mathrm{O}_{3}$ (as K-feldspar) were added during metamorphism of these rocks (fig. 16). These analytical data (table 2) suggest that significant amounts of $\mathrm{MgO}$ were neither added to nor depleted from these rocks during their metamorphism.

The middle member of the Battle Formation is commonly recrystallized with the development of felted mats of tremolite with or without diopside. Apparently, this widespread recrystallization is related to development of nearby skarn-some of which seems to have formed in conjunction with the emplacement of the Late Cretaceous molybdenum system, whereas the bulk of the skarn exposed in the area probably is related to late Eocene or early Oligocene porphyritic leucogranite, Oligocene granodiorite porphyry, and other minor intrusive rocks. Nonetheless, it is also possible that recrystallization of the middle member here may be related to the emplacement of one of the nonskarn-forming intrusions, late Eocene or early Oligocene rhyolite. This intrusive rock also crops out in the general area where the middle member of the Battle Formation is exposed (pl. 1). However, additive metasomatism of secondary $\mathrm{K}$ feldspar is an effect associated very strongly with the porphyritic leucogranite (see below). 
TABLE 2.-Analytical data on the Middle Pennsylvanian Battle Formation of the Buckingham Camp-Copper Basin area, Lander County, Nevada

[Chemical analyses in weight percent by X-ray spectroscopy supplemented by classic methods; analysts, A.J. Bartel, K. Stewart, J. Taggart, R. Moore, P. Aruscavage, and D. Kay. Optical-spectroscopic analyses in parts per million by inductively coupled plasma methods of Scott and Kokot (1975) and F.E. Lichte (unpub. data, 1983); analyst, M. Malcolm. Looked for, but not found, at parts-per-million detection levels in parentheses: Ag (2), Bi (10), Cd (2), Eu (2), Ho (4), Mo (2), Nb (4), Sn (20), Ta (40), U (100). F determined by specific-ion-electrode methods, Au determined by atomic-absorption methods, and $\mathrm{W}$ determined colorimetrically; analysts, R. Moore, P. Aruscavage, and D. Kay. - , not detected]

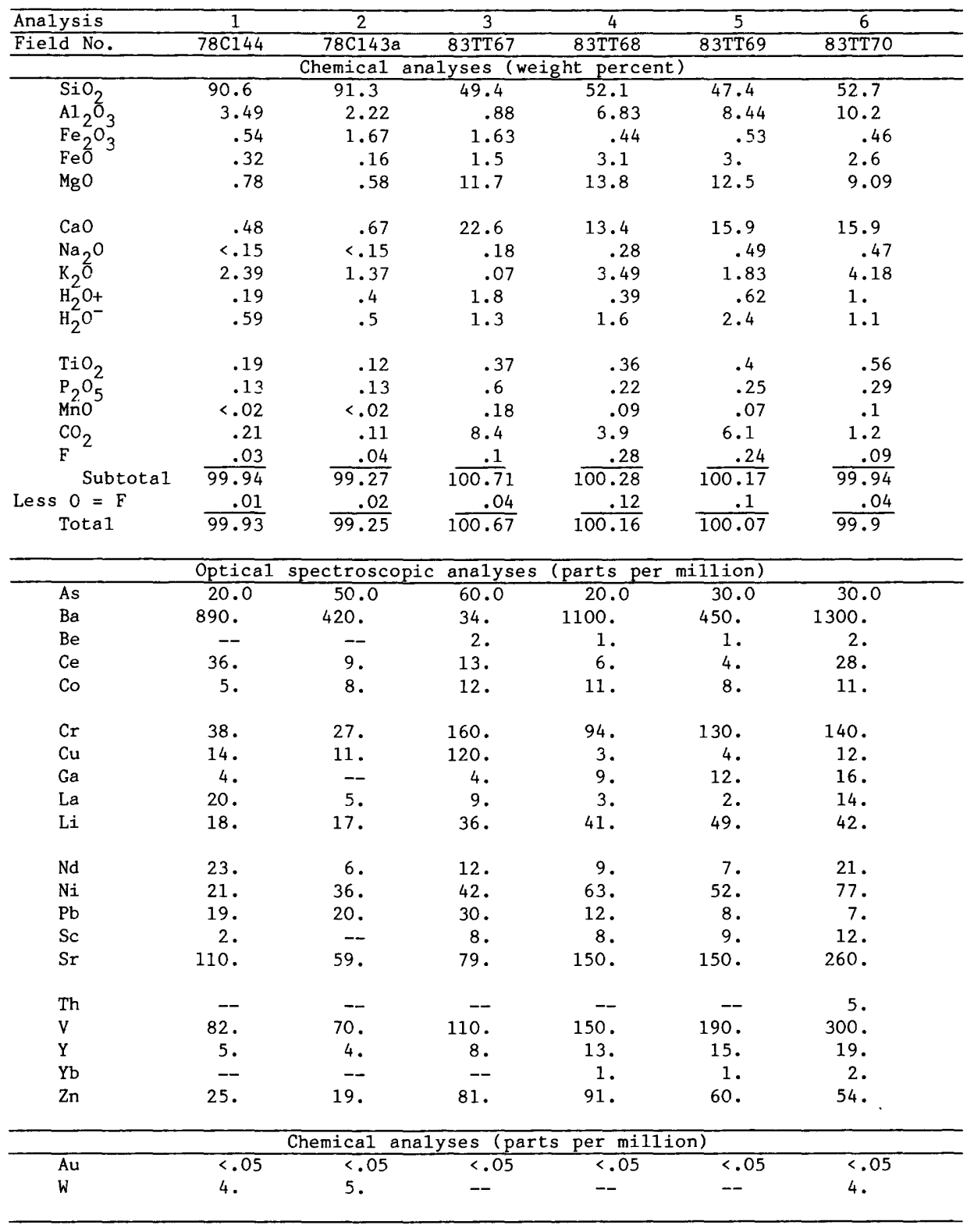

1. Pebbly sandstone from the largely conglomeratic lower member; matrix supported; includes locally abundant secondary potassium feldspar in matrix.

2. Pebbly sandstone from the largely conglomeratic lower member; framework supported; includes some secondary potassium feldspar and biotite in matrix.

3. Calcareous silty shale; middle member; essentially unaltered.

4. Calcareous shaly hornfels, middle member; abundant modal tremolite, some potassium feldspar.

5. Calcareous shaly hornfels, middle member; sparse to moderate concentrations of tremolite, secondary quartz, and potassium feldspar.

6. Calcareous shaly hornfels; middle member; moderate concentrations of diopside, tremolite, epidote, and potassium feldspar. 


\section{PENNSYLVANIAN AND PERMIAN SYSTEMS}

\section{ANTLER PEAK LIMESTONE}

The Antler Peak Limestone is the middle formation of the overlap assemblage in the mining district, and it is Late Pennsylvanian and Early Permian in age (Roberts, 1964, p. A34). The type locality of the Antler Peak Limestone is at Antler Peak, westsouthwest of the Buckingham area, where the formation is about $191 \mathrm{~m}$ thick.

In the Buckingham area (pl. 1), the Antler Peak Limestone consists of a relatively thick sequence of two major facies: a carbonate-dominant facies made up mostly of dark-gray micrite, and a silicadominant facies made up of buff-gray, well-bedded, carbonate-rich siltite. The Antler Peak Limestone crops out only in three regions in the Buckingham area. The largest mass underlies a region of about 1,500 by $300 \mathrm{~m}$ near the northeast corner of the area studied; two much smaller bodies of this unit crop out within narrow, lensoid fault slivers east of the Copper Basin Mine. Just beyond the northeast corner of the area mapped ( $p l$ 1.), the formation is overlain unconformably by the Oligocene Caetano Tuff (Gilluly and Masursky, 1965), which crops out prominently at Elephant Head (see fig. 2). The
Antler Peak Limestone in this general area of the mining district is equivalent stratigraphically to upper beds of the formation that crop out at Antler

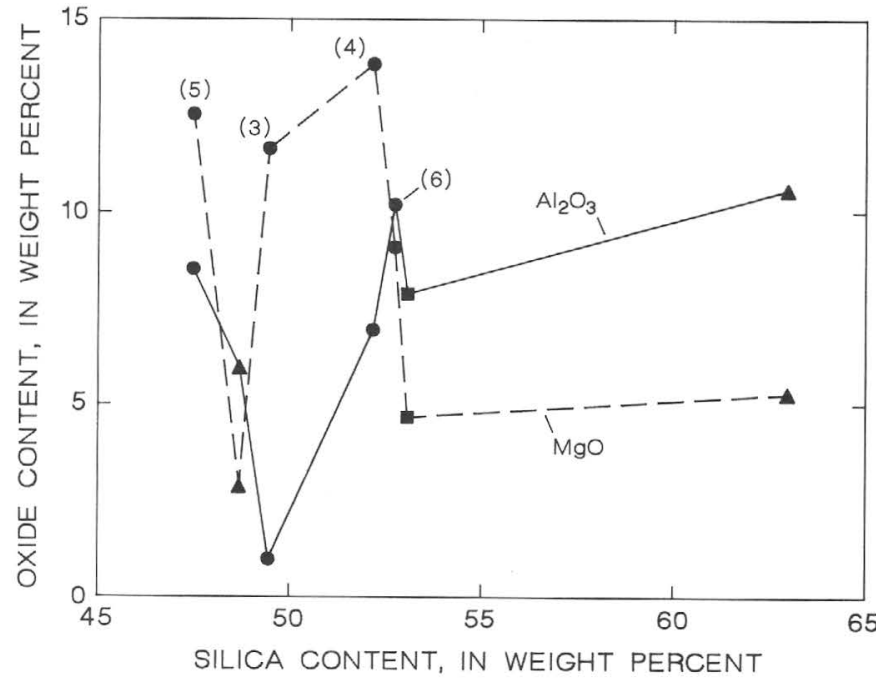

FIGURE 16.-Variation diagram comparing chemically analyzed samples (dots, analyses 3-6, table 2 ) of essentially unaltered silty shale and shaly hornfels of middle member of the Middle Pennsylvanian Battle Formation from Buckingham area with chemically analyzed samples of middle member from Galena area (southern part of mining district). Squares, from Roberts (1964, table 3); triangles, from Theodore and Blake (1975, table 9).

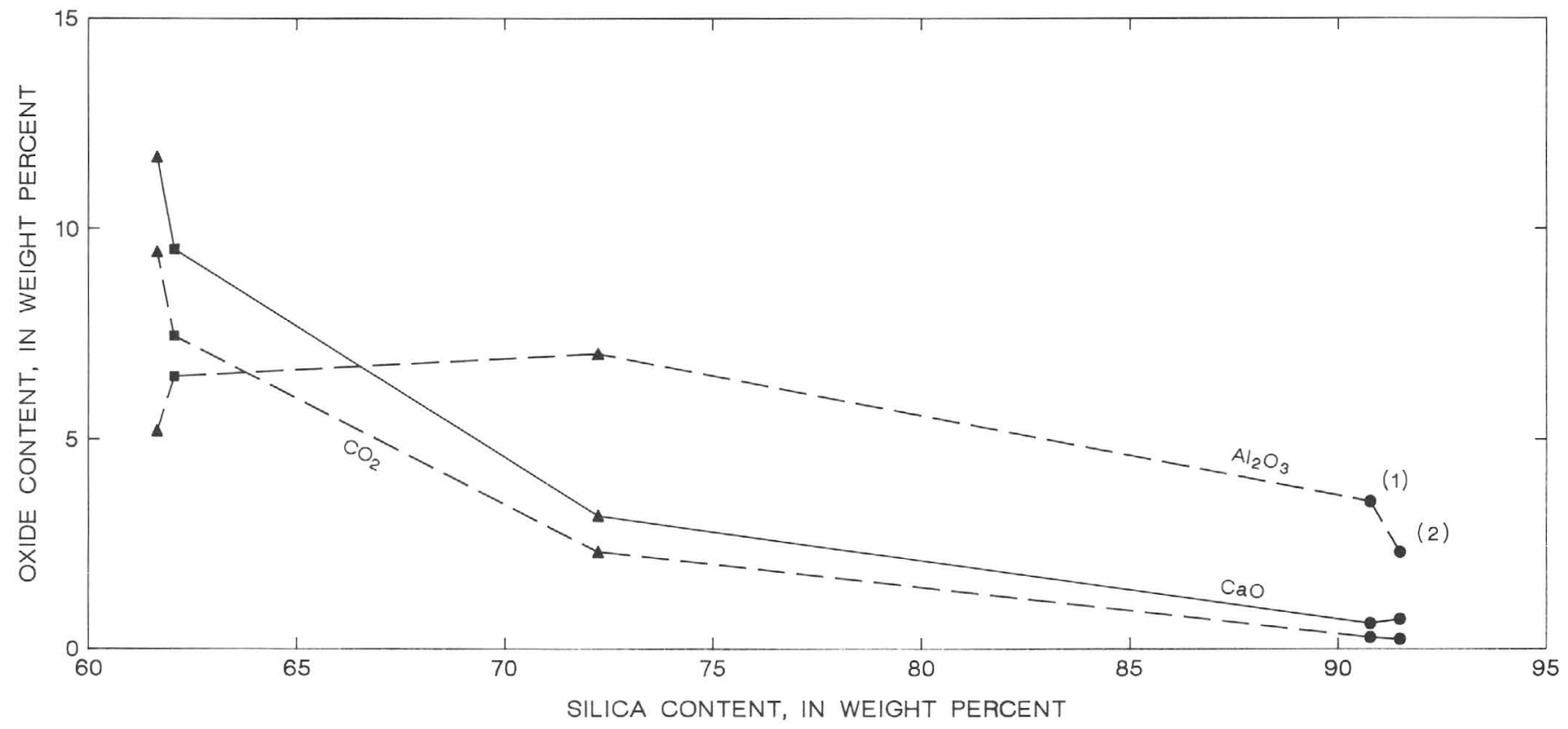

Figure 15.-Variation diagram comparing chemically analyzed samples (dots, analyses 1, 2, table 2) of pebbly sandstone from largely conglomeratic lower member of the Battle Formation with chemically analyzed samples of cal- careous conglomerate of lower member collected from Galena area (southern part of mining district). Squares, from Roberts (1964, table 3); triangles, from Theodore and Blake (1975, table 9). 
Peak (Roberts, 1964, p. A35). The lower beds of the Antler Peak Limestone apparently are missing in the Buckingham area. However, the overall stratigraphic thickness here is much greater than that measured at Antler Peak. H.G. Ferguson measured a section of about $600 \mathrm{~m}$ for the Antler Peak Limestone in the Buckingham-Elephant Head area. Some sequences of rocks of the Antler Peak Limestone, however, may have been repeated by faults (G.M. Jones, written commun., 1988; Kirk Schmidt, oral commun., 1985). In the Buckingham area (pl. 1), the base of the Antler Peak Limestone nowhere is exposed because it has been cut out tectonically together with some and (or) locally all of the stratigraphically underlying middle member of the Battle Formation. The top of the Antler Peak Limestone is not exposed in this area as well.

Petrographic examination of selected samples from the Antler Peak Limestone reveals that it consists of a wide variety of carbonate-bearing rocks. These include dark-gray, packed biomicrite, micrite, calclithite, intramicrite, and carbonate-rich sandy silt. A sample of packed biomicrite examined from an outcrop close to the east edge of the map area contains bryozoans, crinoids, brachiopod spines mostly from productids, fragments of brachiopods, and calcisphere algae (fig. 17A; A.K. Armstrong, written commun., 1983). The cores of many of the crinoids are filled with chert. In this general area, much of the Antler Peak Limestone is not stressed, nor does it show textural evidence of a thermal history. The lime-mud matrix shows no neocrystallization. However, some of the carbonate-rich sandy silts from other outcrops of the Antler Peak Limestone show abundant concentrations of neocrystallized, internally zoned rhombs of dolomite (fig. 17B). Many of the internal zones of these dolomite rhombs are outlined partly to completely by increased concentrations of iron oxide(s). Micrite probably is the most common lithology in the Antler Peak Limestone here, and some micrites show approximately $0.5-\mathrm{mm}$ thick zones of pseudospar with irregularly defined boundaries cutting their otherwise-detrital fabric. Saller $(1980,1982)$ has suggested that shallow marine carbonate rocks of the Antler Peak Limestone accumulated in part in open-marine waters and represent shoal, lagoonal, tidal-flat, tidal-channel, and tidal-delta environments.

Chemical analyses of four unmineralized samples (table 3) from the Antler Peak Limestone consist of two representative samples from each of the two major facies recognized within the formation: the dark-gray, carbonate-dominant facies (analyses 1,2 ), and the buff to orange, silica-dominant facies (analyses 3,4 ). The two analyzed samples of micrite, specifically a sparry micrite and a packed biomicrite, show a sparse amount of silica: 4.8 and 11.0 weight percent $\mathrm{SiO}_{2}$, respectively. The increased $\mathrm{SiO}_{2}$ content in the analyzed sample of
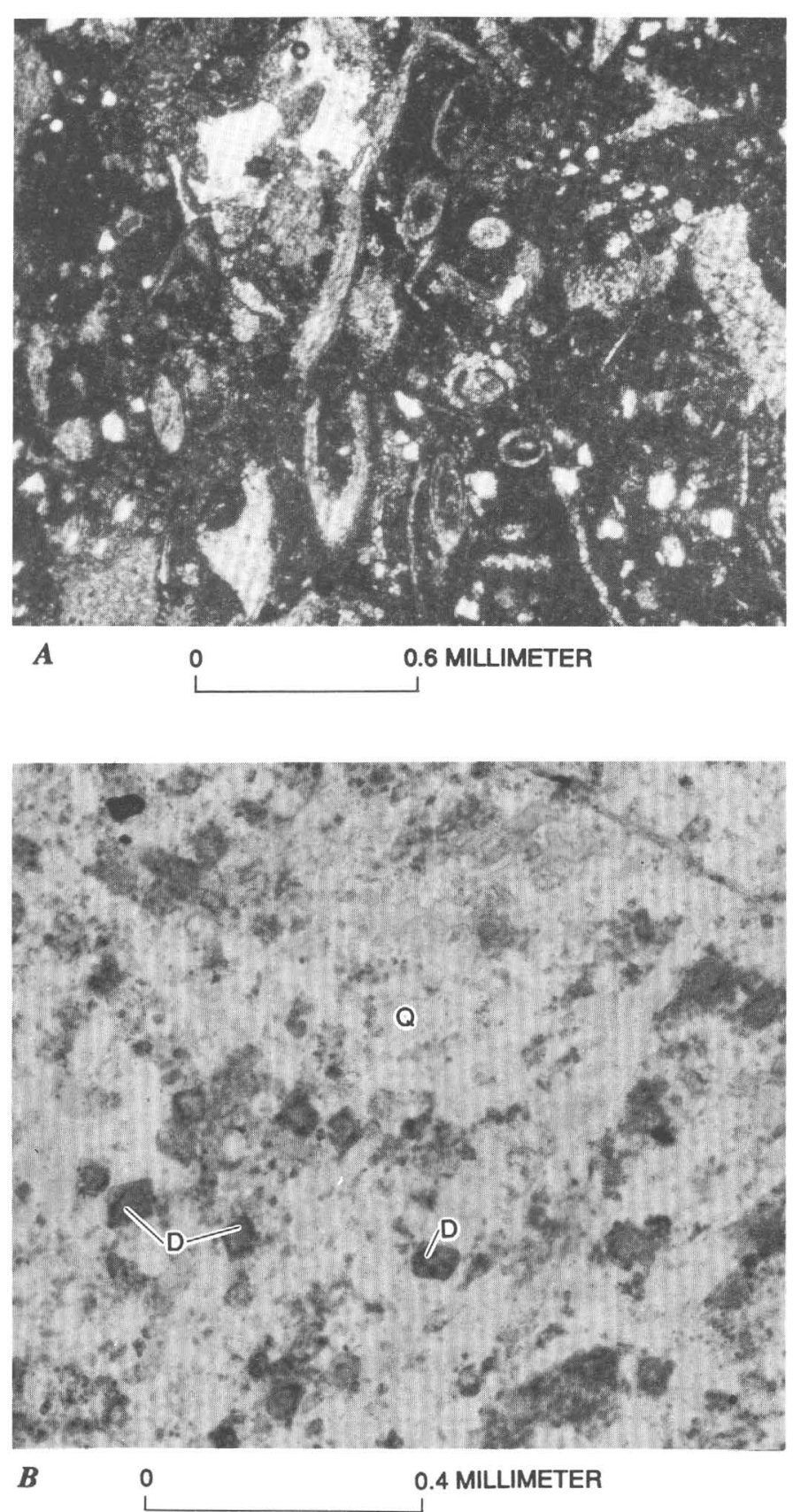

Figure 17.-Photomicrographs of rocks from the Upper Pennsylvanian and Lower Permian Antler Peak Limestone. A, Packed biomicrite. Sample 78C142, collected $50 \mathrm{~m}$ south-southwest of UTM coordinates N. 2,141,000, E. 401,000. B, Carbonate-rich sandy silt containing neocrystallized dolomite (D) and detrital quartz (Q). Sample 78C145. 
TABLE 3.-Analytical data on the Upper Pennsylvanian and Lower Permian Antler Peak Limestone of the Buckingham Camp-Copper Basin area, Lander County, Nevada

[Chemical analyses in weight percent by X-ray spectroscopy supplemented by classical methods; analysts, A.J. Bartel, K. Stewart, J. Taggart, R. Moore, P. Aruscavage, and D. Kay. Optical-spectroscopic analyses in parts per million by inductively coupled plasma methods of Scott and Kokot (1975) and F.E. Lichte (unpub. data, 1983); analyst, M. Malcolm. Looked for, but not found, at parts-per-million detection levels in parentheses: $\mathrm{Ag}$ (2), $\mathrm{As}(10), \mathrm{Be}(1), \mathrm{Bi}(10)$, Cd (2), Eu (2), Ho (4), Mo (2), Nb (4), Sn (20), Ta (40), Th (4), U (100). F determined by specific-ion-electrode methods, Au determined by atomic-absorption methods, and W determined colorimetrically; analysts, R. Moore, P. Aruscavage, and D. Kay. -, not detected]

\begin{tabular}{|c|c|c|c|c|}
\hline $\begin{array}{l}\text { Analysis } \\
\text { Field No. }\end{array}$ & $\frac{1}{78 \mathrm{C} 141}$ & $\frac{2}{78 \mathrm{C} 142}$ & $\frac{3}{78 \mathrm{C} 145}$ & $\begin{array}{c}4 \\
79 \mathrm{C} 147 \\
\end{array}$ \\
\hline \multicolumn{5}{|c|}{ Chemical analyses (weight percent) } \\
\hline $\begin{array}{l}\mathrm{SiO}_{2} \\
\mathrm{Al}_{2} \mathrm{O}_{3} \\
\mathrm{Fe}_{2} \mathrm{O}_{3} \\
\mathrm{FeO}_{3} \\
\mathrm{MgO}\end{array}$ & $\begin{array}{r}4.8 \\
<.1 \\
.04 \\
.12 \\
.77\end{array}$ & $\begin{array}{r}11.0 \\
.23 \\
<.04 \\
.08 \\
.96\end{array}$ & $\begin{array}{c}55.4 \\
.8 \\
.59 \\
.4 \\
8.2\end{array}$ & $\begin{array}{r}67.9 \\
4.58 \\
.53 \\
.44 \\
3.35\end{array}$ \\
\hline $\begin{array}{l}\mathrm{CaO} \\
\mathrm{Na}_{2} \mathrm{O} \\
\mathrm{K}_{2} \mathrm{O} \\
\mathrm{H}_{2} \mathrm{O}_{+} \\
\mathrm{H}_{2} \mathrm{O}^{-}\end{array}$ & $\begin{array}{l}53.3 \\
<.15 \\
.11 \\
.19 \\
.2\end{array}$ & $\begin{array}{c}49.3 \\
<.15 \\
.1 \\
.35 \\
.18\end{array}$ & $\begin{array}{c}14.5 \\
<\quad .15 \\
.27 \\
.4 \\
.22\end{array}$ & $\begin{array}{c}9.19 \\
.3 \\
1.98 \\
.36 \\
.43\end{array}$ \\
\hline 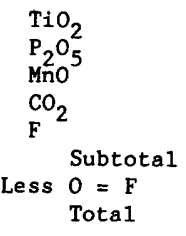 & $\begin{array}{c}<.02 \\
<.05 \\
<.02 \\
40.7 \\
.02 \\
100.25 \\
.01 \\
100.24\end{array}$ & $\begin{array}{r}<.02 \\
.06 \\
<.02 \\
37.6 \\
.02 \\
99.88 \\
.01 \\
99.87\end{array}$ & $\begin{array}{r}.08 \\
.07 \\
.02 \\
18.6 \\
.02 \\
99.57 \\
.01 \\
99.56\end{array}$ & $\begin{array}{r}.4 \\
.27 \\
<.02 \\
10 . \\
.07 \\
99.80 \\
.03 \\
99.77\end{array}$ \\
\hline \multicolumn{5}{|c|}{ Optical spectroscopic } \\
\hline $\begin{array}{l}\mathrm{Ba} \\
\mathrm{Ce} \\
\mathrm{Co} \\
\mathrm{Cr} \\
\mathrm{Cu}\end{array}$ & $\begin{array}{c}100.0 \\
-- \\
2 . \\
15 . \\
4 .\end{array}$ & $\begin{array}{c}490.0 \\
-- \\
3 . \\
49 . \\
4 .\end{array}$ & $\begin{array}{c}84.0 \\
7 . \\
4 . \\
51 . \\
6 .\end{array}$ & $\begin{array}{c}440.0 \\
32 . \\
4 . \\
150 \\
10 .\end{array}$ \\
\hline $\begin{array}{l}\mathrm{Ga} \\
\mathrm{La} \\
\mathrm{Li} \\
\mathrm{Nd} \\
\mathrm{Ni}\end{array}$ & $\begin{array}{l}-- \\
3 . \\
4 . \\
8 . \\
3 .\end{array}$ & $\begin{array}{l}- \\
\overline{7 .} \\
6 . \\
13 . \\
-\end{array}$ & $\begin{array}{r}-- \\
9 . \\
14 . \\
7 . \\
12 .\end{array}$ & $\begin{array}{l}6 . \\
21 . \\
16 . \\
26 . \\
24 .\end{array}$ \\
\hline $\begin{array}{l}\mathrm{Pb} \\
\mathrm{Sc} \\
\mathrm{Sr} \\
\mathrm{V} \\
\mathrm{Y}\end{array}$ & $\begin{array}{r}-- \\
600 . \\
10 . \\
3 .\end{array}$ & $\begin{array}{r}-- \\
-- \\
520 . \\
8 . \\
8 .\end{array}$ & $\begin{array}{c}4 . \\
-- \\
59 . \\
11 . \\
7 .\end{array}$ & $\begin{array}{r}11 . \\
4 . \\
85 \\
40 \\
15\end{array}$ \\
\hline $\begin{array}{l}\mathrm{Yb} \\
\mathrm{Zn}\end{array}$ & 15. & $\overrightarrow{12 .}$ & $\overline{35 .}$ & $\begin{array}{r}2 . \\
13 .\end{array}$ \\
\hline \multicolumn{5}{|c|}{ Chemical analyses (parts per million) } \\
\hline $\begin{array}{l}\mathrm{Au} \\
\mathrm{W}\end{array}$ & $\begin{array}{l}<.05 \\
<3 .\end{array}$ & $\begin{array}{l}<.05 \\
<3 .\end{array}$ & $\begin{array}{l}<.05 \\
<3 .\end{array}$ & $\begin{array}{l}<.05 \\
<3 .\end{array}$ \\
\hline
\end{tabular}

1. Dark-gray, sparry micrite.

2. Dark-gray, packed biomicrite; cores of crinoids filled with chert (see text).

3. Pale-orange to buff, chert- and sparse chalcedony-cemented silty micrite; includes relatively abundant authigenic dolomite.

4. Buff, calcareous siltstone. Includes authigenic dolomite, and detrital phyllosilicates and potassium feldspar. packed biomicrite indicates chert filling cores of crinoids. The MgO content of the micrites, from either magnesian calcite or authigenic dolomite, is less than 1 weight percent. Such an MgO content is much lower than that apparently common in the silica-dominant facies of this formation. The two analyzed samples of silica-dominant rock include 8.2 and 3.35 weight percent $\mathrm{MgO}-$ mostly as authigenic dolomite. The abundance of silica in this type of rock is highly variable, owing to wide-ranging ratios of silt-size detrital grains of quartz+chert cement to micrite. The $\mathrm{K}_{2} \mathrm{O}$ and $\mathrm{Al}_{2} \mathrm{O}_{3}$ contents in the chemical analysis of calcareous siltstone (analysis 4) indicate the relative abundance of detrital phyllosilicate(s) and detrital K-feldspar.

\section{QUATERNARY SYSTEM}

\section{SURFICIAL DEPOSITS}

Older alluvium, landslide, slopewash, talus, fanglomerate, and younger alluvium make up the surficial Quaternary deposits in the Buckingham area (pl. 1). The older alluvium in Vail Canyon, eastsoutheast of the workings at the Copper Queen Mine, is reported to have yielded about 1,104 ounces of gold from placers worked during 1915-42 (Roberts and Arnold, 1965, p. B88). Most of this gold was derived probably from a bedrock source centered on a Tertiary quartz stockwork system partly at the divide between the upper reaches of Vail Canyon on the south, known locally as Poorman's Gulch, and Paiute Gulch on the north. In late 1983, two small-scale dry-washing operations were exploiting gravels from older alluvium in Paiute Gulch, and concurrently a much larger test was being conducted on gravels of younger alluvium just to the north of the map area on Paiute Gulch. Evaluation of the gravels continued sporadically through 1985 .

\section{INTRUSIVE ROCKS}

\section{INTRODUCTION}

Felsic intrusive rocks of varying sizes and much less abundant diabase crop out throughout the Buckingham area (pl. 1). They are emplaced mostly into the Upper Cambrian Harmony Formation; several bodies of felsic intrusive rock, small in plan, also intrude the Middle Pennsylvanian Battle Formation and the Upper Pennsylvanian and Lower Permian 
Antler Peak Limestone. The diabase may be Ordovician and (or) Devonian in age (see above) or possibly Tertiary in age. The felsic intrusive rocks in the Buckingham area make up one of the four major loci of intrusive activity in the mining district (Roberts, 1964). The other three are centered at Copper Canyon, at Trenton Canyon (where the largest intrusive body in the district crops out), and in the Elder Creek area, which is about $8 \mathrm{~km}$ north-northwest of the Buckingham area (see fig. 2). The felsic intrusive rocks in the Buckingham area range in age from Late Cretaceous to middle Tertiary, and they include several varieties of both probable Late Cretaceous monzogranite and latest Eocene or earliest Oligocene monzogranite, late Eocene or early Oligocene rhyolite and porphyritic leucogranite (including a porphyritic monzogranite phase and a porphyritic tonalite phase), and early Oligocene granodiorite porphyry. In the sections to follow, we will show that Late Cretaceous monzogranites are associated genetically with significant molybdenum mineralization and minor gold skarn mineralization, whereas some late Eocene or early Oligocene monzogranite appears to be associated with gold mineralization, late Eocene or early Oligocene rhyolite mostly with silver mineralization, and Oligocene granodiorite porphyry with very minor gold mineralization and some minor leadzinc mineralization. Previous studies of intrusive activity in the mining district using the potassiumargon method established the emplacement age of the granodiorite of Trenton Canyon as Late Cretaceous, about $87.0 \mathrm{Ma}$ (Theodore and others, 1973). This study also showed that after the emplacement of the granodiorite of Trenton Canyon there was a gap in the intrusive activity in the district of about 46 m.y. Six samples from the Copper Canyon area, including two samples of metallized rock from the Battle Formation in the East ore body, yielded ages that range from 38.5 to $37.2 \mathrm{Ma}$ (Theodore and others, 1973).

\section{POTASSIUM-ARGON AND ${ }^{40} \mathrm{Ar} /{ }^{39} \mathrm{Ar}$ GEOCHRONOLOGY OF SELECTED PLUTONS IN THE BUCKINGHAM AREA}

By Edwin H. McKeE

The locations of dated intrusive rocks from the Buckingham area are shown in figure 18. A total of 11 age determinations were made on different parts of the Buckingham stockwork molybdenum system. These include eight muscovite, one biotite, one biotite-chlorite mix (approx 50/50), and one wholerock aplite. Seven ages were determined on intrusive rocks that are satellitic to the system or intrude it. These were on four hornblende and three biotite separates. The ages and analytical data are listed in tables 4 and 5 .

The age determinations were done in the laboratories of the U.S. Geological Survey, Menlo Park, Calif., using standard sample preparation and analytical procedures (Dalrymple and Lanphere, 1969). Bulk rock samples were prepared for mineral separation by crushing and sieving to retain the 1- to 0.1$\mathrm{mm}$-size fraction. Mineral phases were separated using magnetic and heavy liquid procedures. Purity of the separate was 99 percent or better, except for one biotite sample (sample Buck-1, table 4) that contained about 50 percent chlorite as an alteration mineral intergrown with biotite. Whole-rock samples were prepared by crushing and sieving from 1- to $0.1-\mathrm{mm}$ size, and treating for 30 minutes in $14 \mathrm{~mol}$ percent $\mathrm{HNO}_{3}$ and for 1 minute in $5 \mathrm{~mol}$ percent $\mathrm{HF}$ solutions. Samples dated by the K-Ar technique were analyzed for potassium by a lithium metaborate-flux fusion-flame-photometry technique (Ingamells, 1970), the argon was analyzed by standard isotope-dilution procedures, using a $60^{\circ}$-sector, 15.20 -cm-radius, Neir-type mass spectrometer, operated in the static mode for mass analyses. One sample of biotite was dated by the ${ }^{40} \mathrm{Ar} /{ }^{39} \mathrm{Ar}$ technique using selected data from a six-step incremental-heating experiment (table 5). Analyses for this sample were done by simultaneous measurements of argon isotope ratios in a five-collector mass spectrometer (Stacey and others, 1981).

Analytical precision of the reported ages is about 3 percent or less and is based on statistical analysis of a large number of replicate potassium analyses and duplicate argon analyses run during the course of earlier studies. The constants used for abundance and radioactive decay of ${ }^{40} \mathrm{~K}$ are those recommended by the International Union of Geological Sciences' Subcommission on Geochronology (Steiger and Jäger, 1977).

\section{CRETACEOUS MONZOGRANITES OF THE BUCKINGHAM AREA}

The age of the monzogranite porphyry of Buckingham is based on evaluation of $10 \mathrm{~K}-\mathrm{Ar}$ and 1 incremental-heating ${ }^{40} \mathrm{Ar} /{ }^{39} \mathrm{Ar}$ age determination (tables 4,5 ). The ages range from $88.0 \pm 2.0$ to $61.3 \pm 1.5 \mathrm{Ma}$. Four of the ages, including the major argon-release steps of the incremental heating experiment, cluster around $86 \mathrm{Ma}$. The younger seven age determinations are fairly evenly spaced in the time interval from about 77 to $61 \mathrm{Ma}(77.4,75.7$, 


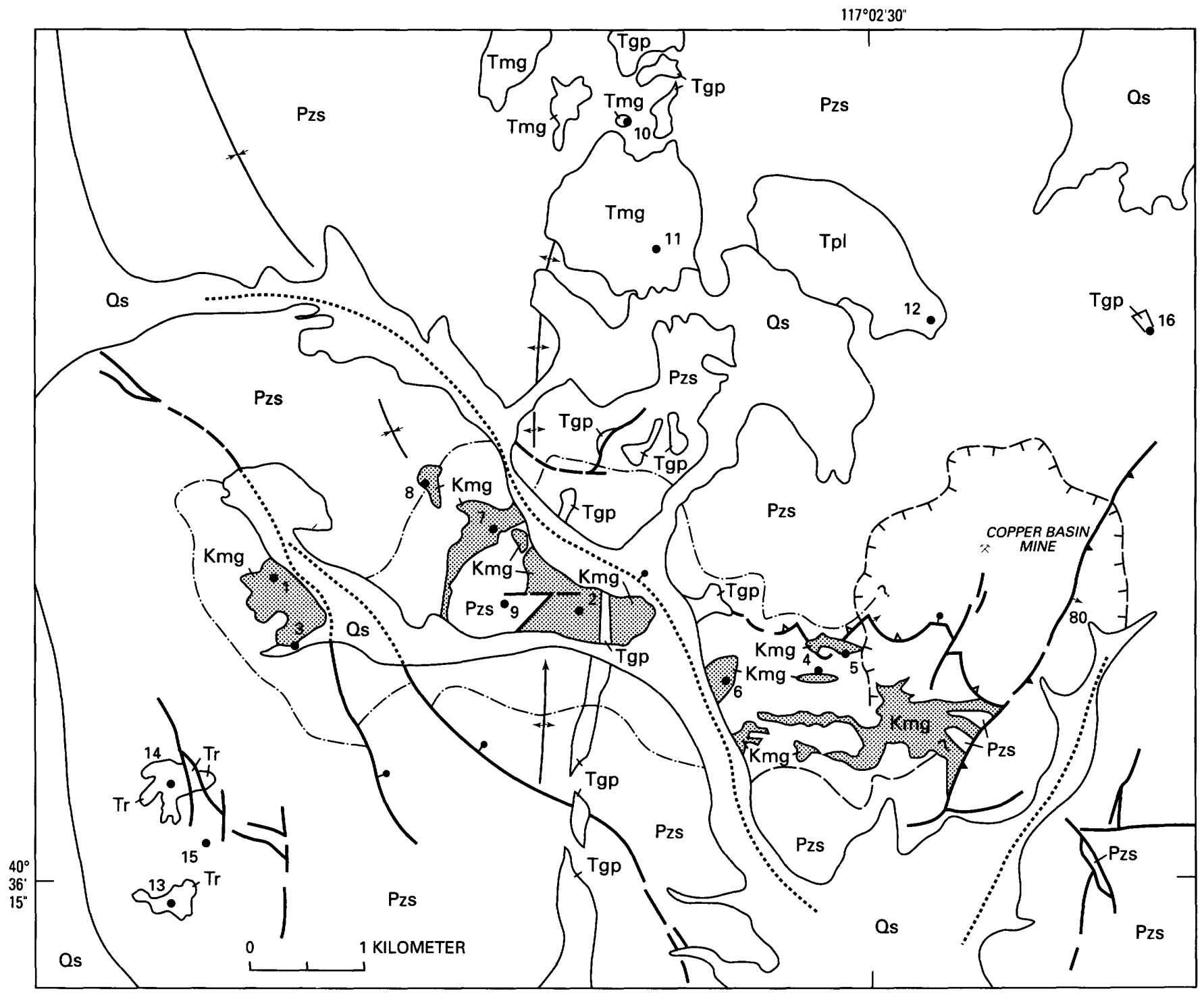

EXPLANATION

\begin{tabular}{cl} 
Tr & Rhyolite (Tertiary) Surficial \\
Qs & Superficial deposits (Quaternary) \\
Tgp & Granodiorite porphyry (Tertiary) \\
Tmg & Monzogranite (Teriary) \\
Tpl & Porphyritic leucogranite (Tertiary) \\
Kmg & Monzogranite porphyry (Cretaceous) \\
Pzs & Sedimentary rocks (Paleozoic) \\
\hline
\end{tabular}

Faults-Dashed where approximate; dotted where concealed. Bar and ball on downdropped side. May show dip

Normal
Low-angle gravity glide-Sawteeth on upper plate
Thrust-Sawteeth on upper plate

3 Sample site for age determination-See table 3 for more detailed information

\begin{tabular}{|c|c|}
\hline Sample No. & Age (Ma) \\
\hline \multicolumn{2}{|c|}{ From Buckingham deposit } \\
\hline $\begin{array}{l}1 \\
2 \\
3 \\
4 \\
5 \\
6 \\
7 \\
8 \\
9\end{array}$ & $\begin{array}{l}61.3 \pm 1.5 \\
68.6 \pm 1.7 \\
65.1 \pm 1.6 / 85.7+0.4 \\
88.0 \pm 2.0 / 86.1+2.0 \\
85.5 \pm 1.9 \\
77.4 \pm 1.6 \\
61.7 \pm 1.5 \\
75.7 \pm 1.6 \\
70.3 \pm 1.7\end{array}$ \\
\hline \multicolumn{2}{|c|}{ From Tertiary intrusive rocks } \\
\hline $\begin{array}{l}10 \\
11 \\
12 \\
13 \\
14 \\
15 \\
16\end{array}$ & $\begin{array}{l}39.9 \pm 1.1 \\
39.3 \pm 1.0 \\
37.7 \pm 1.4 \\
39.1 \pm 1.0 \\
37.3 \pm 1.1 \\
38.8 \pm 1.1 \\
35.4 \pm 1.1\end{array}$ \\
\hline
\end{tabular}

FIGURE 18.-Localities of samples collected for age determinations from Buckingham stockwork molybdenum system and nearby Tertiary intrusive rocks. Geology modified from plate 1. 
TABLE 4.-K-Ar analytical data on the Buckingham stockwork molybdenum system and nearby Tertiary intrusive rocks

$[-$, not determined $]$

\begin{tabular}{|c|c|c|c|c|c|c|c|c|}
\hline $\begin{array}{l}\text { Loc. } \\
\text { (See }\end{array}$ & $\begin{array}{l}\text { no. } \\
\text { fig. 18) }\end{array}$ & Field No. & Unit Name & Mineral dated & $\begin{array}{l}\mathrm{K}_{2} \mathrm{O} \\
\text { percent }\end{array}$ & $\begin{array}{l}{ }^{40} \mathrm{Ar} \text { rad } \\
\mathrm{mole} / \mathrm{g}\end{array}$ & $\begin{array}{l}{ }^{40} \mathrm{Ar} \\
\text { percent }\end{array}$ & $\begin{array}{l}\text { Apparent age } \\
(M a)\end{array}$ \\
\hline
\end{tabular}

Buckingham stockwork molybdenum system

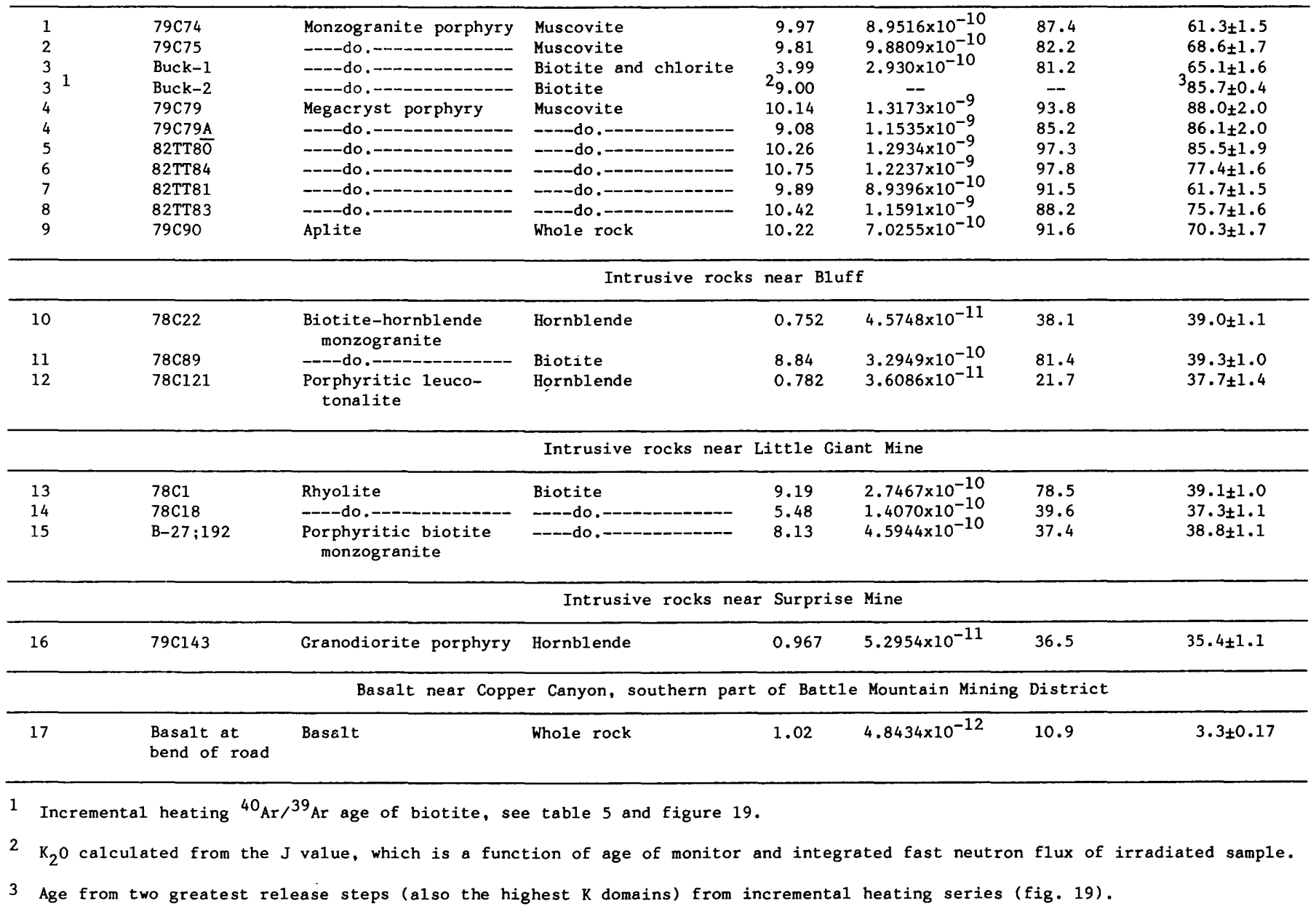

70.3, 68.6, 65.1, 61.7, and 61.3 Ma). The older ages, those about $86 \mathrm{Ma}$, are considered to represent the initial time of cooling of the porphyry system; the younger ages are judged to be the result of later heating and partial resetting of the K-Ar system.

Two periods of plutonism have been recognized in the Battle Mountain area (Theodore and others, 1973). The older is represented by the granodiorite of Trenton Canyon and is dated at $89 \mathrm{Ma}$. The younger includes six intrusive bodies ranging from 41.1 to $37.3 \mathrm{Ma}$ in age (Theodore and others, 1973). The 89-Ma Trenton Canyon pluton is about $9.5 \mathrm{~km}$ west of the Buckingham system, and the younger intrusive rocks are scattered throughout the region; some are as close as about $1.5 \mathrm{~km}$ from the Buckingham area. In light of the periods of plutonism recognized in the region, the 86-Ma cluster of $\mathrm{K}$-Ar ages from the Buckingham porphyry seems a likely age of emplacement and cooling for this body. The monzogranite porphyry of the Buckingham system and the granodiorite of Trenton Canyon are similar plutons ofthe same age (86 and $87 \mathrm{Ma}$, respectively). The anomalous and variable younger ages from the Buckingham system are difficult to interpret but clearly represent minimal values from a disturbed radioactive system. The six-step incremental-heating ${ }^{40} \mathrm{Ar} /{ }^{39} \mathrm{Ar}$ experiment bears these conclusions out. The cumulative 
TABLE 5.-Analytical data for six-step ${ }^{40} \mathrm{Ar} /{ }^{39} \mathrm{Ar}$ incremental-heating experiment on biotite from the monzogranitic body of Buckingham Camp

[Decay constants used: $\lambda_{\varepsilon}=0.581 \times 10^{-10} \mathrm{yr}^{-1} ; \lambda_{\beta}=4.96 \times 10^{-10} \mathrm{yr}^{-1} ;{ }^{40} \mathrm{~K} / \mathrm{K}_{\text {total }}=1.167 \times 10^{-4} \mathrm{~g} / \mathrm{g}$ ]

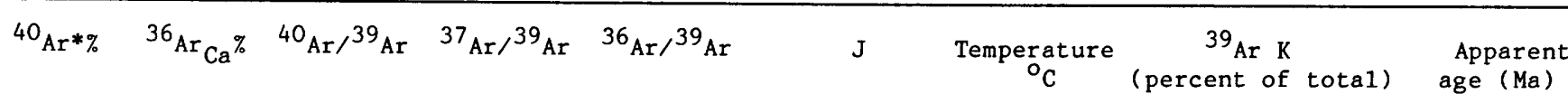

\begin{tabular}{|c|c|c|c|c|c|c|c|c|}
\hline 12.13 & 0.013 & 51.4 & 0.08 & 0.152 & 0.0040045 & 525 & 2.0 & $44.5 \pm 2.8$ \\
\hline 75.61 & 0.019 & 16.23 & 9.16 & 0.013 & ---do----- & 750 & 12.3 & $86.6 \pm 0.7$ \\
\hline 92.04 & 0.040 & 13.13 & 5.17 & 0.004 & ---do----- & 840 & 39.5 & $85.3 \pm 0.5$ \\
\hline 89.51 & 0.104 & 11.99 & 0.016 & 4.237 & ---do----- & 915 & 10.5 & $75.9 \pm 0.6$ \\
\hline 96.42 & 0.303 & 12.11 & 0.016 & 0.002 & ---do---- & 1015 & 35.0 & $82.5 \pm 0.5$ \\
\hline 52.49 & 0.076 & 22.58 & 0.101 & 0.036 & --do---- & Fusion & 0.7 & $83.7 \pm 7.1$ \\
\hline
\end{tabular}

${ }^{39} \mathrm{Ar}$-release diagram (fig. 19) shows a pattern that is similar to patterns from rocks with known disturbed histories (Lanphere and Dalrymple, 1971). In particular, the fourth step, or the $915^{\circ} \mathrm{C}$ release temperature, produced a calculated age of $75.9 \pm 0.6$ $\mathrm{Ma}$, which is about 10 percent younger than the other major argon-release steps. In evaluating the age from the ${ }^{39} \mathrm{Ar}$-release diagram, only the two main release steps, 750 and $840{ }^{\circ} \mathrm{C}$, which produced more than 50 percent of the total argon, were used. The 915 and $1,015{ }^{\circ} \mathrm{C}$ steps were excluded because they showed the effects of reheating. The age calculated using the two main release steps is $85.7 \pm 0.4 \mathrm{Ma}$ (fig. 19 ; table 5 ), in close

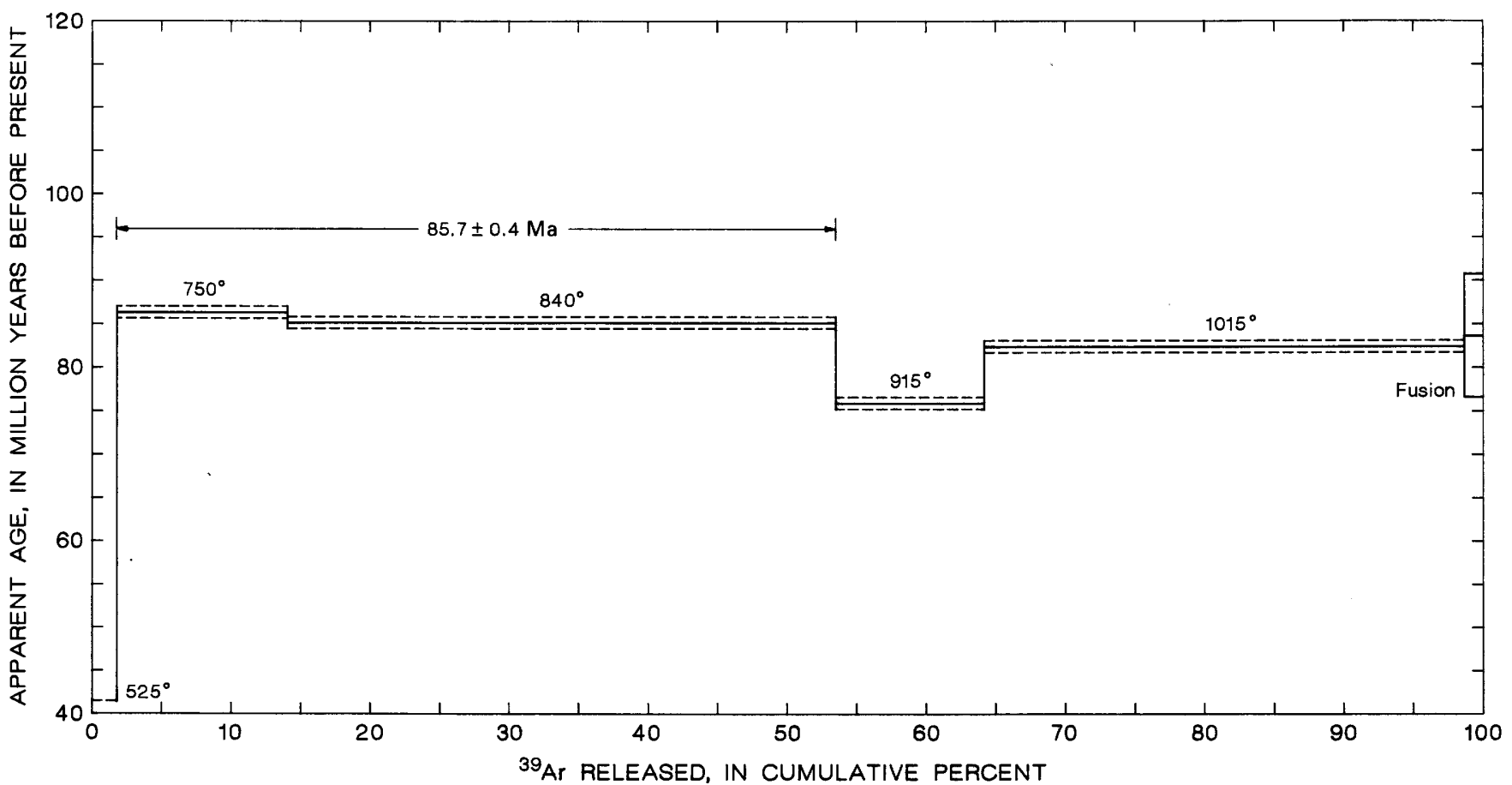

FIGURE 19.- ${ }^{40} \mathrm{Ar} /{ }^{\beta 9} \mathrm{Ar}$ age spectra for a biotite separate (sample Buck-2) from monzogranite porphyry of Buckingham stockwork molybdenum system. Horizontal lines, six heating steps and their temperature (in degrees Celsius); dashed horizontal lines indi- cate width of 1-standard-deviation confidence band. Release pattern is similar to patterns produced from minerals with disturbed thermal histories. Most likely age, calculated using two largest ${ }^{39} \mathrm{Ar}-$ release steps (750 and $840^{\circ} \mathrm{C}$ ), is $85.7 \pm 0.4 \mathrm{Ma}$ 
agreement with the three oldest ages determined by conventional K-Ar techniques. Thus, the Late Cretaceous age established herein for the Buckingham system coincides closely with ages obtained from the Thompson Creek, Idaho, stockwork molybdenum system, $86.6 \pm 3.1 \mathrm{Ma}$ (biotite $\mathrm{K}$-Ar age), $87.35 \pm 0.43 \mathrm{Ma}$, and $87.58 \pm 31 \mathrm{Ma}$ (sericite, ${ }^{40} \mathrm{Ar} /{ }^{39} \mathrm{Ar}$ age), and the stock associated with the White Cloud, Idaho, molybdenum system, 83.2 2 2.8 and 84.7 $\pm 1.9 \mathrm{Ma}$ (biotite, $\mathrm{K}-\mathrm{Ar}$ ages) (Lewis and others, 1987).

\section{TERTIARY GRANITIC AND RHYOLITIC INTRUSIVE ROCKS}

Small monzogranite, granodiorite porphyry, and rhyolite stocks and dikes near Buckingham yield $\mathrm{K}-\mathrm{Ar}$ ages on biotite and hornblende from $39.3 \pm 1.0$ to $35.4 \pm 1.1 \mathrm{Ma}$ (table 4). Most (six) of these bodies are satellitic to the main monzogranite porphyry of Buckingham and their ages are about $38 \mathrm{Ma}$. A system of granodiorite porphyry dikes that cut the Buckingham porphyry is slightly younger; it is dated at about $35 \mathrm{Ma}$. The approximately $38-\mathrm{Ma}$ age, which is latest Eocene or earliest Oligocene, is identical to that of the younger phase of plutonism recognized elsewhere in the Battle Mountain area by Theodore and others (1973). They dated six intrusive bodies, one about $1.5 \mathrm{~km}$ from Buckingham, that ranged in age from 41.1 to 37.3 Ma. Hydrothermal alteration and mineralization at Copper Canyon and probably at many other places in the Battle Mountain Mining District was determined to be related to the late phases of this pervasive period of igneous activity (Theodore and others, 1973). The effects of this late Eocene and early Oligocene intrusive event are seen on the Cretaceous Buckingham system as well. At a few places a distinctive granodiorite porphyry cuts the Buckingham system (fig. 18); hornblende from this granodiorite yields an age of $35.4 \pm 1.1 \mathrm{Ma}$. Secondary chlorite, which is pervasive throughout the Buckingham pluton, yields $\mathrm{K}$-Ar ages that are significantly younger (10-15 percent) than the $86-\mathrm{Ma}$ age considered to be the age of initial cooling of the pluton. The argon-release pattern of the incremental-heating ${ }^{40} \mathrm{Ar} /{ }^{39} \mathrm{Ar}$ experiment also indicates a complex thermal history of the biotite. The secondary thermal event was not great enough to completely reset the K-Ar clock, but it is clearly seen in the downstep plateau pattern of argon release (fig. 19). Heat and hydrothermal activity generated by the late Eocene and early Oligocene igneous event shows varying amounts of intensity at different places in the Buckingham system. Almost all sam- ples from the western part of the monzogranite body yield ages that are reset some amount. None of them, however, are completely reset to the approximately 38-Ma age of the younger plutons.

\section{LATE CRETACEOUS}

The Late Cretaceous monzogranites crop out mainly in three areas: (1) the West stock near Buckingham Camp, (2) the East stock near the intersection of Licking Creek and Long Canyon, and (3) east of Long Canyon as an east-westtrending complex of dikes and plugs that lie astride Vail Ridge. These dikes and plugs swell into somewhat larger masses of intrusive rock in the area now (1989) disturbed highly by mining operations associated with the copper ore bodies in the Copper Basin Mine. Distribution of these rocks at the surface before the startup of large-scale mining operations in 1966-67 may be inferred from the geologic map of Tippett (1967). Late Cretaceous monzogranites in the area are associated genetically with the Buckingham molybdenum system, and in this part of the report they are termed the "monzogranitic rocks of Buckingham Camp." These rocks intrude the Upper Cambrian Harmony Formation and are themselves intruded extensively by early Oligocene granodiorite porphyry. As pointed out by E.H. McKee in the immediately preceding section, a likely explanation for the wide-ranging and at times geologically conflicting ages (88$61 \mathrm{Ma}$ ) determined using potassium-argon and ${ }^{40} \mathrm{Ar} /{ }^{39} \mathrm{Ar}$ methods most probably includes a combination of (1) resetting by the extensive late Eocene or early Oligocene and early Oligocene intrusive rocks also common in the area; and (2) the highly complex and composite nature of emplacement in the Late Cretaceous (see subsection below entitled "Economic Geology"). As mapped (pl. 1), the monzogranitic rocks of Buckingham Camp make up four units: monzogranite porphyry (unit $\mathrm{Km}$ ) that includes conspicuous phenocrysts of quartz and, locally, very sparse phenocrysts of K-feldspar; megacryst monzogranite porphyry (unit $\mathrm{Kmp}$ ) that includes highly conspicuous, large K-feldspar phenocrysts together with some facies typified by a phenocrystic fabric including "crowded" plagioclase phenocrysts; a mostly aplitic phase (unit Kga); and a late-stage breccia-pipe phase (unit Kgbx). Comprehensive description and temporal resolution of the complex sequential emplacement of many additional intrusive phases recognized in the system are included by Loucks and Johnson below. Much 
of the monzogranites weather to smooth rounded slopes that, from a distance, might suggest a scarcity of outcrops (fig. 20A). However, these rocks lo-
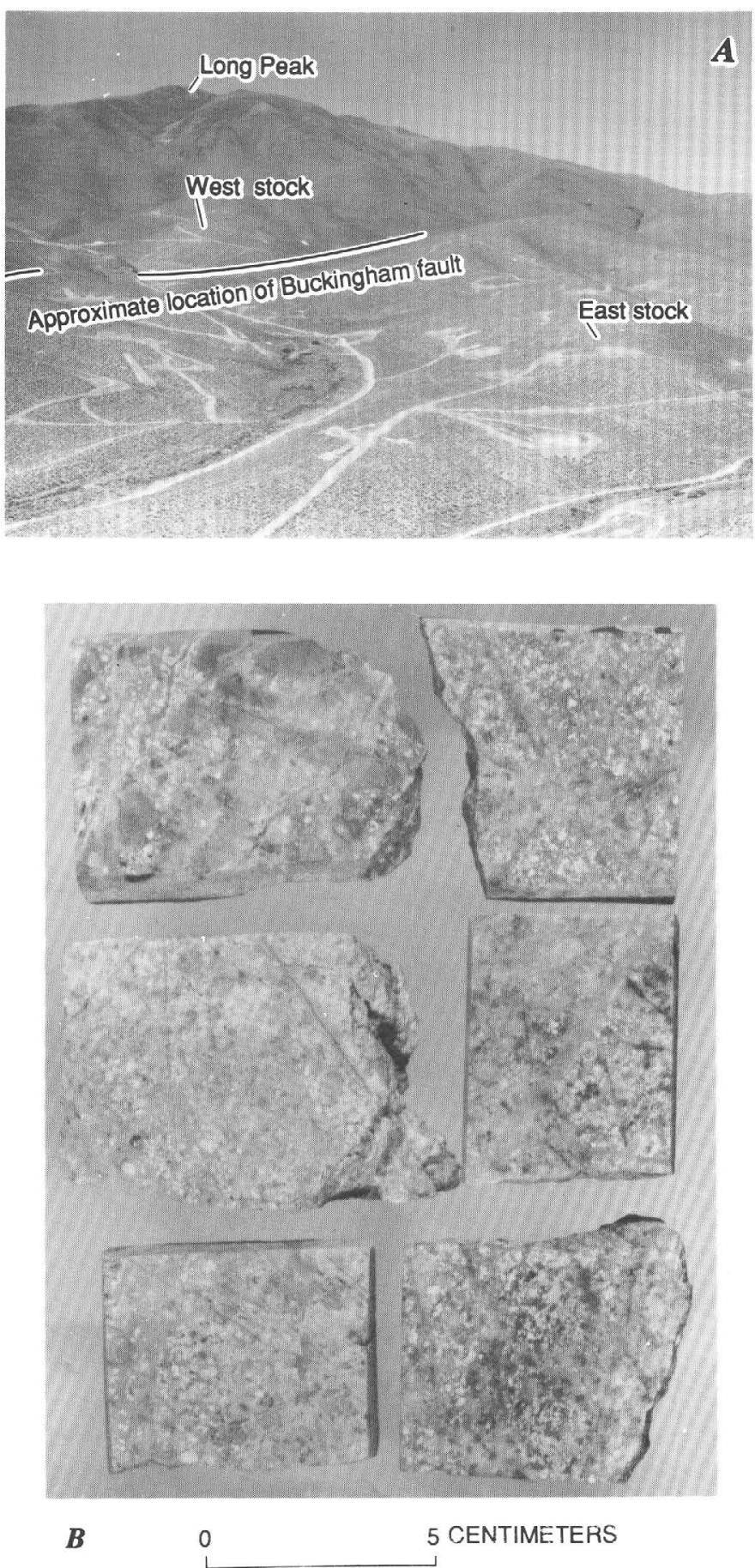

FIGURE 20.-Geologic relations of Late Cretaceous monzogranites of Buckingham Camp. A, View westward from ridgeline of Vail Ridge along main trend of outcrops of monzogranites, showing generally smooth, rounded slopes underlain by these rocks. Note roads for scale. $B$, Sawed surfaces of monzogranite, showing typical hypidiomorphic-granular fabric common to these cally are quite well exposed, and near the eastern distal parts of the system, they include phases that show typically a hypidiomorphic-granular fabric (fig. $20 B$ ) that at the surface mostly includes variously developed apparent phyllic- and (or) argillicalteration assemblages common to most porphyry systems. Petrographic study, however, has shown that potassic alteration is widespread in Late Cretaceous monzogranite, as are intermediate argillic assemblages (plagioclase destructive, K-feldspar stable; see below). The dark fragments (fig. 20B) are xenoliths of biotite hornfels that belong to the Harmony Formation; figured relation of these fragments to monzogranite porphyry illustrates the widespread stoping common in this system. Sparse
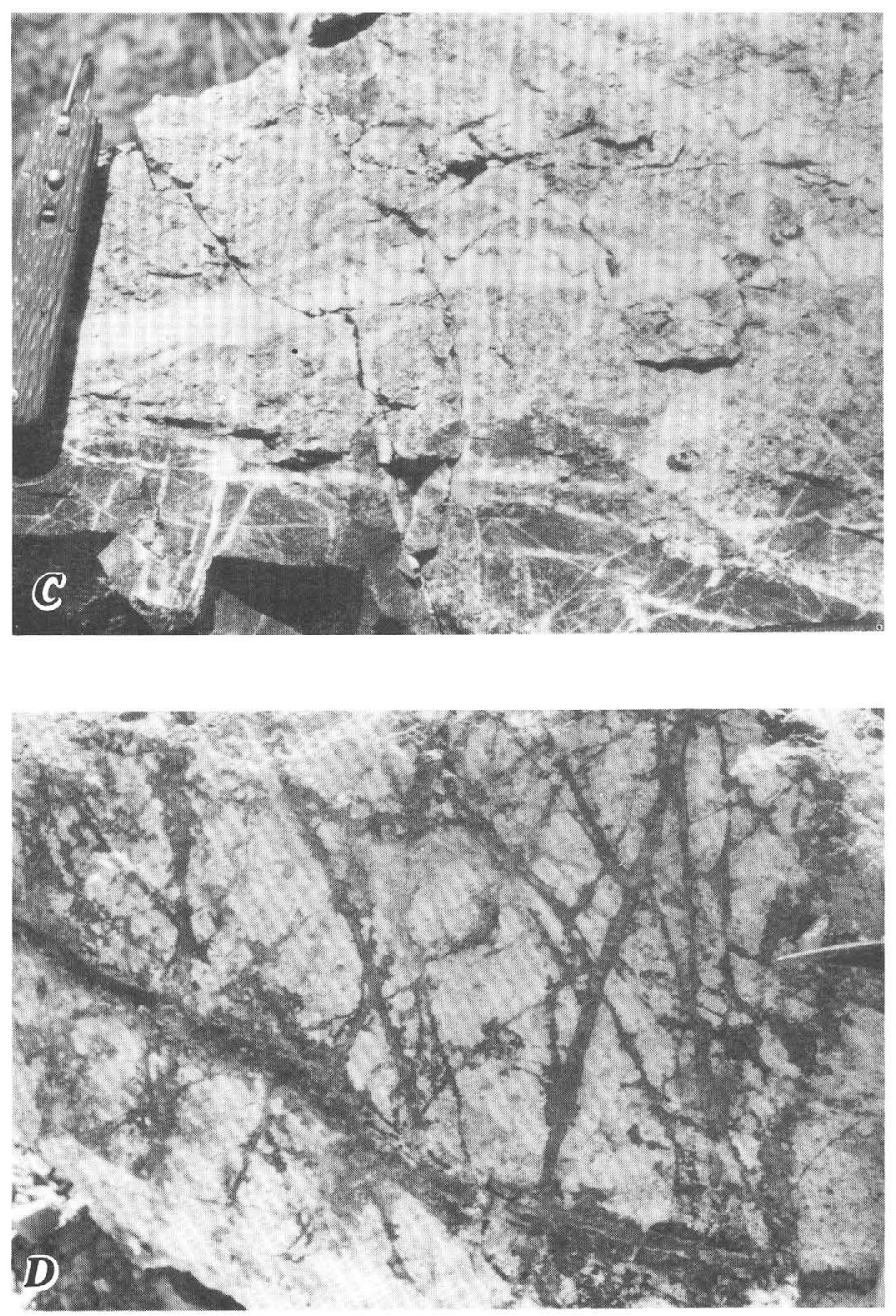

rocks. $C$, Relations at contact between highly veined monzogranite and black biotite hornfels of the Upper Cambrian Harmony Formation near Buckingham Camp. $D$, Typical density of quartz-pyrite stockworks near top of exposed Late Cretaceous system at Copper Basin. Note increased concentrations of iron oxide(s) replacing pyrite (compare figs. $20 C$ and $20 D$ ). 
occurrences of potassic alteration recognizable megascopically are preserved near the contacts of the monzogranite in the western part of the system. However, the most diagnostic characteristic of early igneous phases of the Late Cretaceous monzogranite in outcrop is the fact that they are veined intensely by widespread quartz-rich stockworks, a distinctive feature of fluorine-deficient (Theodore, 1982a; Theodore and Menzie, 1984) or quartz monzonite (White and others, 1981) molybdenum stockwork systems such as Buckingham, in contrast to most porphyry copper systems (fig. $20 C$ ). Such stockworks become progressively enriched outward in pyrite, particularly in the uppermost tectonic blocks of the system (compare figs. $20 C, 20 D$ ), but also laterally. Late Cretaceous monzogranite does not have any known cogenetic volcanic rocks in the surrounding region suggesting thereby that exposed levels of the Late Cretaceous. monzogranite may be relatively deep.

The Late Cretaceous monzogranites are altered hydrothermally, and they are present near the center of a broad zone of rocks affected by contact metamorphism and hydrothermal alteration. Contact metamorphism in the Harmony Formation is represented principally in conversion of various types of sandstone and shale to biotite hornfels. The outer limit of secondary biotite visible in outcrop near the south edge of the map area trends approximately east-west, approximately parallel to alignment of Late Cretaceous monzogranite (pl. 1). Somewhat interior to the outer limit of secondary biotite, rocks are bleached variably and show a widespread distribution of iron oxides that replace pyrite. The pyrite halo here locally follows approximately the outer limit of secondary biotite, and in places the pyrite halo extends about $2 \mathrm{~km}$ into the Harmony Formation from Late Cretaceous monzogranite. In all, metamorphosed and (or) altered rocks underlie about 90 percent of the Buckingham area, and they are part of a zone of altered rock that extends a minimum of about $2.5 \mathrm{~km}$ farther to the west beyond the Buckingham area (Roberts and Arnold, 1965, pl. 3; Krohn and others, 1978). This westward extension of alteration results mostly from the emplacement during the late Eocene and early Oligocene of a weakly mineralized monzogranite into the Harmony Formation at Long Peak (Theodore and others, 1973). Alteration associated with Late Cretaceous monzogranite also includes some relatively large bodies of skarn that crop out mostly in the Copper Basin Mine in the rocks of the Harmony Formation. One body of skarn crops out in discontinuous exposures as much as $0.7 \mathrm{~km}$ north of the mine (pl. 1).
One of the most important alteration boundaries shown on plate 1 is the outer limit of generally intensely developed quartz stockworks associated at the surface with Late Cretaceous monzogranite. This zone of intensely developed quartz stockworks is present about $1.5 \mathrm{~km}$ inside the outer limit of the pyrite halo along the south flank of the system, and about $1.1 \mathrm{~km}$ within the pyrite halo along the northwest flank on Long Ridge in the hanging wall of the Buckingham and Second faults. Furthermore, the mapped outer limit of the quartz stockworks, even though it is a diffuse gradational boundary across several tens of meters, apparently shows significant separations along some major postmineral and synmineral faults that cut the Buckingham system, including the Buckingham, Second, Long Canyon, and Contention faults. In addition, the zone of quartz stockworks, as mapped, represents quite well the projection to the surface of molybdenum-enriched rocks at depth (see subsection below entitled "Economic Geology").

\section{MONZOGRANITE PORPHYRY}

Late Cretaceous monzogranite porphyry is an undivided map unit that makes up most of the exposed parts of the West stock and the East stock (pl. 1). At the West stock, exposed monzogranite porphyry has been correlated by Loucks and Johnson (see subsection below entitled "Economic Geology") with their large K-feldspar porphyry unit. Monzogranite porphyry also crops out east of Long Canyon, where it is present as several approximately east-west-trending dikes and a smaller number of equant bodies on Vail Ridge. Monzogranite porphyry intrudes the Upper Cambrian Harmony Formation, and is itself apparently intruded by subsequent phases of the entire granitic complex of Buckingham Camp including megacryst monzogranite porphyry, aplite, and breccia. Furthermore, monzogranite porphyry is intruded by Oligocene granodiorite porphyry. As described above in the section by E.H. McKee, secondary white micas collected from two sample sites in monzogranite porphyry yielded ages of 61.3 and 68.6 Ma using the K-Ar method. These sample sites are located in the West and East stocks, respectively. Primary biotite from the West stock yielded an age of 65.1 Ma. All these ages probably indicate resetting by the late Eocene or early Oligocene and Oligocene dikes and plutons that are widespread in the Buckingham area. The calculated age using the two main ${ }^{39} \mathrm{Ar}$-release steps 
during a heating experiment on primary biotite is 85.7 $\pm 0.4 \mathrm{Ma}$ (fig. 19). Most likely the monzogranite porphyry was emplaced initially about $90 \mathrm{Ma}$; that age is based on the K-Ar ages of 88-86 Ma determined on the megacryst monzogranite porphyry phase of the Buckingham system.

Fabric of monzogranite porphyry in its outcrops represents a combination of protracted igneous processes superposed by multistage, subsolidus alteration phenomena, the type(s) and intensity of which result from, in part, the erosional levels currently exposed in the three major tectonic blocks of the molybdenum system. In the West stock, locally bold outcrops of yellow-ocher-brown to creamywhite, hydrothermally altered monzogranite porphyry show widely ranging proportions of quartz phenocrysts set in a fine-grained, hydrothermally altered groundmass that itself is very quartz rich. The quartz phenocrysts range from well-developed, square-sectioned bipyramids to rounded and subrounded outlines, in places making up as much as 20 to 25 volume percent of the monzogranite porphyry. Quartz phenocrysts probably average about $1 \mathrm{~cm}$ wide throughout much of the exposed parts of the West stock. In places, some facies include 1- to 1.5-cm-wide, pink K-feldspar phenocrysts, which seem overall to be subordinant to the amount of plagioclase. In outcrop, plagioclase phenocrysts are somewhat drab creamy white where altered mostly to clay(s), and the plagioclase phenocrysts have a lustrous, very pale greenish gray color where altered to white mica. Generally, the mediumgrained plagioclase phenocrysts lack clear crystal outlines; instead, they tend to merge into the enclosing groundmass. Stubby, 1.0- to 1.5-mm-long, tabular books of biotite are dispersed irregularly in the monzogranite porphyry, and they are altered intensely to varying proportions of white mica and chlorite. In fact, many exposures of monzogranite porphyry show relatively minor amounts of mafic minerals. The groundmass includes some iron oxide(s) that replace small, 0.25 - to $0.5-\mathrm{mm}$-wide cubes of pyrite that were disseminated throughout. However, the predominant hydrous silicate in the groundmass is white mica, most probably sericite. Very locally, this fine-grained white mica is intergrown with extremely small blades of bluishgray molybdenite, some of which also have halos of yellowish ferrimolybdite. In general, intense veining by quartz characterizes most exposures of the West stock (fig. $20 C$ ). In places, the veins coalesce to dense mats that make up about 40 to 50 volume percent of rocks across meter-size areas. Quartz is the dominant mineral in the veins, and quartz- white mica-pyrite the dominant assemblage visible in hand samples of the veins; some late-stage veins in the West stock show increased abundances of pyrite, now replaced by iron oxides, particularly along the medial parts of the veins.

Monzogranite porphyry in the East stock megascopically resembles that of the West stock; however, there are some differences. Overall abundance of quartz phenocrysts throughout that part of this unit that crops out in the East stock appears to be less than that in the West stock. Quartz phenocrysts in the East stock probably make up about 2 to 5 volume percent of the monzogranite porphyry. In addition, in the East stock, extremely fine grained molybdenite, as disseminated grains in matrix of the monzogranite porphyry, appears to be more common at the surface than in the West stock. Cursory examination of hand samples from the East stock would suggest that phyllic alteration-that is, plagioclase- and Kfeldspar-destructive replacement by a predominantly white mica bearing assemblage-is common throughout much of the East stock. However, extensive petrographic studies of surface samples and drill core suggest that the predominant, early-stage alteration assemblage associated with most of the quartz veining is potassic (see Creasey, 1966). In addition, these rocks also show a pervasive alteration of phenocrystic plagioclase to clay(s) and other minerals that suggests an intermediate argillic type of alteration such as that associated with main-stage veining at Butte, Mont. (see Meyer and Hemley, 1967), and elsewhere. This pervasive alteration of plagioclase in the East stock occurred largely without any visible alteration, even at extremely high magnifications, of K-feldspar both in groundmass and in phenocrysts. Plagioclase is argillized in the lowermost parts of the monzogranite porphyry penetrated by drilling into the East stock, and thus well below the zone of surfacerelated oxidation. K-feldspar-destructive alteration to white mica, which is actually quite spotty in this body of rock, is related principally to some wispy, white mica-rich veins that are typically quartz poor, and, in places, molybdenite rich. Nonetheless, locally, some of the easternmost monzogranite porphyry exposed at the East stock shows intense argillic alteration ( $\mathrm{pl}$. 1). In addition, some exposures of the monzogranite porphyry in the East stock on both the north and south sides of Licking Creek show a chlorite-dominant propylitic alteration. Such propylitic-alteration assemblages may be much younger than epigenetic, Late Cretaceous stages of the Buckingham molybdenite system 
because propylitic alteration apparently is associated genetically with nearby wide dikes of Oligocene granodiorite porphyry.

Exposures of monzogranite porphyry on Vail Ridge are confined to relatively narrow dikes and small, equant masses that in places have sharply defined planar contacts with the adjoining hornfels facies rocks of the Harmony Formation. Some dikes, however, have incorporated abundant fragments of this hornfels along their contacts. Many of these exposures show yellowish-tinged iron oxides on their weathered surfaces suggestive of ferrimolybdite. Quartz phenocrysts, some smoky in color, are typically 0.5 to $1.0 \mathrm{~cm}$ wide; they range in abundance from about 5 to 10 volume percent of the monzogranite porphyry and in shape from round to square. Monzogranite porphyry is here somewhat more argillically altered than either of the two previously described, much more widely exposed bodies of this unit at the West and East stocks. Locally near the mapped east ends of some of the major dikes of monzogranite porphyry, the alteration assemblages are predominantly phyllic and include relatively abundant molybdenite disseminated in groundmass. Plagioclase phenocrysts are altered heavily to milky-white clays(s); 1.0 - to 2.0-mm-wide former books of primary biotite now show complete replacement by iron oxide-stained white mica and (or) chlorite. In addition, the rocks are veined densely by quartz, and, in many exposures, the strike of the veins parallels closely the approximately east-westward trend of the dikes. The most strongly developed vein sets strike from about east-west to N. $60^{\circ}$ W. Generally, the overall density of veins in rocks of the Harmony Formation at distances greater than about $1 \mathrm{~m}$ from the monzogranite porphyry is much less than both that at distances less than $1 \mathrm{~m}$ and within monzogranite porphyry dikes. Molybdenite is dispersed irregularly throughout the groundmass of the monzogranite porphyry, and in some samples, very fine grained molybdenite appears to be best concentrated in small domains where white mica completely replaces primary biotite and any other mafic minerals. Some samples show relatively abundant, fine-grained molybdenite concentrated in granulose-textured groundmass, and clusters of molybdenite seem to be preferentially concentrated along the edges of quartz phenocrysts where molybdenite blades radiate out into the surrounding groundmass. Although most of the molybdenite in the monzogranite porphyry on Vail Ridge appears to be in groundmass, some veins also include molybdenite, as well as chrysocolla that probably has replaced chalcopyrite. There is a progressive decrease in overall abundance of quartz stockwork veins near the east end of many east-west-trending dikes of monzogranite porphyry in the area of Vail Ridge. Some joint surfaces in monzogranite porphyry also show stains of secondary copper minerals. These occurrences of secondary copper minerals indicate either the increased abundance of primary copper, as chalcopyrite, in the hypogene stages of the monzogranite porphyry on Vail Ridge as opposed to that in the West or East stocks. Or, they may simply result from supergene migration of copper from the nearby ore bodies in the Copper Basin Mine during any of the Oligocene and younger erosion cycles that affected the area.

In all, approximately 100 thin sections of monzogranite porphyry from the West and East stocks were examined petrographically. Although many samples were collected from outcrop, a significant number were obtained from drill core into the East stock near the junction of Long Canyon and Licking Creek. These petrographic studies confirm the wide distribution and, in places, pervasiveness of multiple late-stage, hydrolytic-alteration events (see Beane, 1982) that accompanied the emplacement of the Buckingham system. The predominant types of hydrothermal alteration in monzogranite porphyry are potassic, phyllic, and intermediate argillic, according to the classification schemes of Meyer and Hemley (1967) and Rose and Burt (1979); superposition of alteration types is common throughout the system (see subsection below entitled "Economic Geology"). At the surface of the West stock, quartz phenocrysts that range from ovoid to angular, square-outlined bipyramids, all typically about 2 to $10 \mathrm{~mm}$ wide, are relatively abundant in monzogranite porphyry; they are set in a fine-grained groundmass consisting of $\mathrm{K}$ feldspar, quartz, and minor amounts of white mica that replace plagioclase completely. Rounding of the quartz phenocrysts may indicate resorption of silica during episodic decreases in the prevailing pressure at the site of emplacement (Burnham, 1967; Whitney, 1975). Groundmass in the monzogranite porphyry probably averages about 0.1 to $0.2 \mathrm{~mm}$ in grain size, and its dominant mineral is K-feldspar, which makes up probably about twothirds of the groundmass. The predominant texture in the groundmass is not xenomorphic granular or a "droplike" intergrowth of $\mathrm{K}$-feldspar and mostly quartz, but rather a texture resulting from straight, planar crystal boundaries between these two minerals with an abundance of $120^{\circ}$ dihedral angles throughout the groundmass. These relations 
suggest continued subsolidus recrystallization of groundmass after initial quenching from a magma. A characteristic feature in the groundmass is the minimally clouded, yet otherwise relatively unaltered, state of the K-feldspar there, compared with the almost total replacement of plagioclase by dense mats of intergrown white mica and (or) clay(s). Complete alteration of plagioclase to white mica and clay(s) accompanied by only a minimal dusting of K-feldspar by phyllosilicates suggests that a late-stage, intermediate argillic (see Meyer and Hemley, 1967; Rose and Burt, 1979) type of alteration has affected the monzogranite porphyry even in its lowermost levels in the system penetrated by drilling into the West stock. In contrast, sericitization of both $\mathrm{K}$-feldspar and plagioclase is characteristic of the phyllic zone in porphyry systems (Lowell and Guilbert, 1970; Rose and Burt, 1979). In the West stock, primary, 1- to 2-mm-long books of biotite are also commonly replaced by white mica, vermiculite, and traces of chlorite and accessory blebs of rutile.

Common occurrence of low-sulfide quartz$\mathrm{K}$-feldspar veins and quartz-only veins, both of which show either a well-developed introduction of $\mathrm{K}$-feldspar or a stable recrystallization of $\mathrm{K}$ feldspar as selvages in the adjoining groundmass, all suggest that widespread potassic alteration affected the monzogranite porphyry in the West stock. The potassic alteration, accompanied by an intense flooding by silica in veins, must have occurred during the stock's early subsolidus stage(s) before superposition of the intermediate argillic assemblages. Petrographic examination of a limited number of samples from depths as great as $600 \mathrm{~m}$ in the West stock suggest the widespread nature of the early potassic event(s) that affected the monzogranite porphyry. The potassic alteration is preserved best at depth in the West stock (see subsection below entitled "Economic Geology" for an estimate of the distribution of well-developed potassic alteration at depth in the West stock). There in the West stock, clots of secondary biotite (very,pale red brown, optic Z-axis) are intergrown with pyrite and some apatite and sphene in groundmass of the monzogranite porphyry, and these clots are associated spatially with paragenetically late, minor calcite and, in places, epidote. In addition, there are some quartz-K-feldsparmolybdenite-rutile-bearing veins wherein earlystage molybdenite is intergrown with $\mathrm{K}$-feldspar, and late-stage molybdenite occurs along narrow, minute, wavy trains of recrystallized and deformed veins of quartz. Although much K-feldspar both in groundmass and in phenocrysts in the monzogranite porphyry at depth in the West stock appears to be more intensely clouded than that at the surface, all $\mathrm{K}$-feldspar is still remarkably fresh compared with plagioclase crystals, which are altered completely to a mat of white mica and clay(s).

Supplemental data concerning the petrography and chemistry of monzogranite porphyry and its associated alteration and mineralization are included below in the subsection entitled "Additional Petrographic and Chemical Studies near the East Stock."

\section{MEGACRYST MONZOGRANITE PORPHYRY}

Late Cretaceous megacryst monzogranite porphyry crops out predominantly in the East stock of the Buckingham system, east of the Buckingham and Second faults, and also in that part of the system on Vail Ridge, east of the Long Canyon fault (unit Kmp, pl. 1). This unit is the same as the large K-feldspar porphyry unit that Loucks and Johnson described on plate 2 in the subsection below entitled "Economic Geology." Megacryst monzogranite porphyry intrudes the Upper Cambrian Harmony Formation but can only be shown questionably to intrude the monzogranite porphyry phase of the Buckingham system, owing to poorly exposed contacts between the two rock types and nondiagnostic relations at contacts penetrated by drilling to date (1989). Nonetheless, the inference will be made below that most available geologic evidence suggests that the megacryst monzogranite porphyry is younger than the monzogranite porphyry. Relations in outcrop indicate that the megacryst monzogranite porphyry definitely has been intruded by the Oligocene granodiorite porphyry about $300 \mathrm{~m}$ north of the junction between Licking Creek and Long Canyon (pl. 1). As described by McKee above, six samples of secondary white mica obtained from five sites (fig. 18) in megacryst monzogranite porphyry yielded ages of $88.0,86.1,85.5$, $77.4,61.7$, and $75.7 \mathrm{Ma}$. The four oldest ages are from localities of megacryst monzogranite porphyry east of Long Canyon.

The most extensive exposures of the megacryst monzogranite porphyry are in the area of the East stock, where a cluster of variable-size bodies of megacryst monzogranite porphyry suggest a locus of emplacement slightly to the north-northwest of the main mass of monzogranite porphyry nearby in the East stock (pl. 1). In this area, the largest mass of megacryst monzogranite porphyry is an elongate, dikelike body that lies completely astride 
Long Ridge from Licking Creek on the south to Long Canyon on the north; this body has a maximum exposure length of about $500 \mathrm{~m}$ in a northeasterly direction. In outcrop, the distinguishing features of this highly altered unit are (1) the large, pink or white, euhedral K-feldspar phenocrysts distributed somewhat erratically through a groundmass that ranges from medium-grained, hypidiomorphic granular to microaplitic; (2) the marked decrease in the overall abundance of quartz veins compared with monzogranite porphyry; and (3) the apparent increased abundances of white mica and iron oxide(s) compared with that in monzogranite porphyry. Although some exposures of megacryst monzogranite porphyry show an intense development of quartz stockworks, such stockwork veining by quartz in megacryst monzogranite porphyry is typically quite restricted areally. More commonly, exposures of megacryst monzogranite porphyry show deeply weathered out, crosscutting sets of pyrite veins (altered to iron oxide) along throughgoing fractures (fig. 21A), whereas bleached rocks of the Harmony Formation immediately adjacent to megacryst monzogranite porphyry are very intensely veined by quartz and are highly fractured (fig. 21B). K-feldspar phenocrysts in megacryst monzogranite porphyry typically range in size from 0.5 to $2.0 \mathrm{~cm}$. Euhedral, square-outlined bipyramids of quartz also are conspicuous throughout this body of megacryst monzogranite porphyry; they range in size from 0.5 to 1.0 $\mathrm{cm}$. Microphenocrysts of plagioclase, generally about 2 to $10 \mathrm{~mm}$ in their largest dimension, are altered completely to intergrown mats of clay(s)+white mica. The overall abundance of altered plagioclase microphenocrysts varies widely in the megacryst monzogranite porphyry across extremely short distances. The fabric at one end of a hand sample of megacryst monzogranite porphyry may be microaplitic matrix supported and include about 10 to 15 volume percent altered plagioclase, whereas the other end may be altered plagioclase supported and include about 40 to 50 volume percent altered plagioclase. Such a "crowded plagioclase" fabric is quite common in some bodies of megacryst monzogranite porphyry, especially the one that straddles the contact showing the mapped outer limit of intensely developed quartz stockworks, near the northernmost extent of the East stock, and also in many of the very small dikes of megacryst monzogranite porphyry that crop out on Vail Ridge (pl. 1). Microphenocrysts of biotite in megacryst monzogranite porphyry that crops out in the East stock area are altered completely to white mica. In addition, several shallow prospect pits near the middle of megacryst monzogranite porphyry have followed occurrences of secondary copper, mostly chrysocolla and (or) malachite along fractures together with copper-manganese(?) oxides on weathered surfaces, in some of the small areas within the megacryst monzogranite porphyry that show well-developed quartz stockworks. However, there are also some visible occurrences of molybdenite associated with megacryst monzogranite porphyry just north of the projection to the surface of the major mineralized zones of the Buckingham system. This molybdenite is in a small body of megacryst monzogranite porphyry that crops out
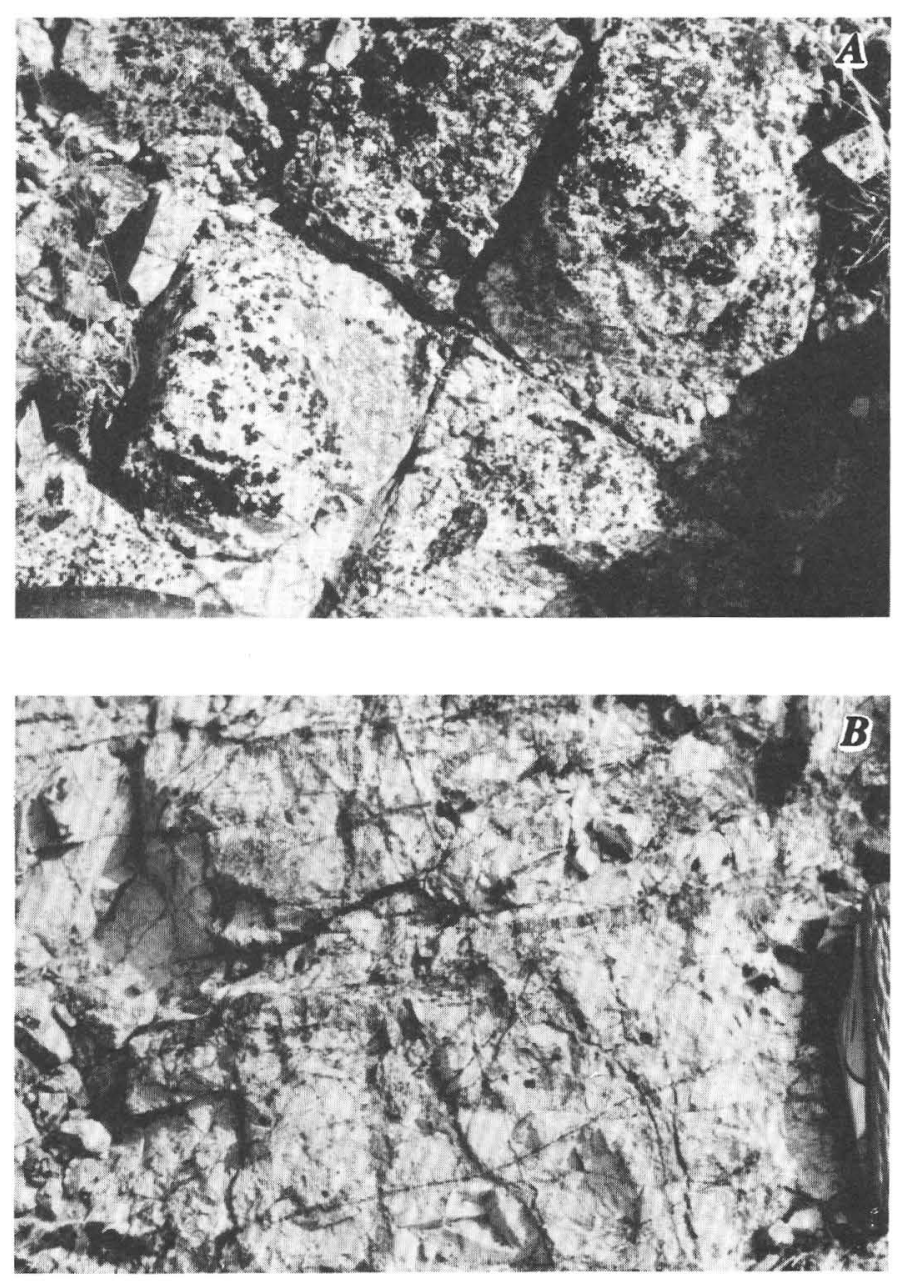

FIGURE 21.-Veining associated with megacryst porphyry phase of Buckingham stockwork molybdenum system. $A$, Exposure of megacryst monzogranite porphyry near Vail Ridge, showing deeply weathered, crosscutting sets of pyrite veins along throughgoing fractures. Pyrite is altered to iron oxide(s). $B$, Bleached rocks of the Upper Cambrian Harmony Formation immediately adjacent to megacryst monzogranite porphyry. 
along a northeast-striking fault that dips $25^{\circ}-40^{\circ}$ NW., approximately $300 \mathrm{~m}$ southwest of the workings at the Dipper Mine (pl. 1). Some megacryst monzogranite porphyry along this structure also shows well-developed quartz-K-feldspar crenulate structures or unidirectional solidification textures (see Shannon and others, 1982).

Megacryst monzogranite porphyry, in addition, is present quite conspicuously on Vail Ridge, either as narrow, short dikes or as small, nearly equant bodies, the largest of which crops out low on the west flank of Vail Ridge and measures about $150 \mathrm{~m}$ in longest dimension at the surface (pl. 1). On Vail Ridge, the intrusive center of these dikes and small bodies of megacryst monzogranite porphyry is inferred to lie north of the intrusive center of monzogranite porphyry. Such a difference in the spatial distribution between intrusive centers of megacryst monzogranite porphyry and monzogranite porphyry on Vail Ridge is the same as that noted in the general area of the East stock. Furthermore, one of the east-west-trending dikes of megacryst monzogranite porphyry crosscuts the trace of the Contention fault without any apparent offset of megacryst monzogranite porphyry by the fault. This is an extremely important geologic relation in that it fixes major movement(s) along the Contention fault as premegacryst monzogranite porphyry; white mica from this particular body of rock yielded a K-Ar age of 85.5 Ma (see subsection above entitled "PotassiumArgon and ${ }^{40} \mathrm{Ar} /{ }^{39} \mathrm{Ar}$ Geochronology of Selected Plutons in the Buckingham Area"). Furthermore, this dike that crosscuts the Contention fault does not show throughgoing, widespread shattering and related effects of an intensely concentrated, brittlestyle deformation, as is present along the trace of the Contention fault. Nonetheless, the megacryst monzogranite porphyry dike is fractured along some widely spaced joints, some of which show local development of slickensides along their surfaces that indicate at least some, probably minor post-megacryst monzogranite porphyry deformation. In addition, to the east just off the northwest-trending road that crosses the megacryst monzogranite porphyry dike, some poorly exposed, fault-gouged, and intensely clay altered megacryst monzogranite porphyry also suggests local, renewed movement(s) along a splay of the Contention fault that may have become active again after emplacement of the megacryst monzogranite porphyry dike. An overall comparison of densities of quartz veins in this megacryst monzogranite porphyry dike with densities of quartz veins in adjoining rocks of the Harmony Formation indicates that the dike unquestionably was intruded after most of the veining had ceased. On Vail Ridge, some east-west-trending dikes of megacryst monzogranite porphyry show K-feldspar megacrysts arranged in clusters of about four or five phenocrysts per 10- by $10-\mathrm{cm}$ area. In addition, most of the plagioclase microphenocrysts are altered intensely to clay(s), whereas K-feldspar megacrysts and groundmass crystals are relatively fresh; some of the plagioclase microphenocrysts are packed closely into a plagioclase microphenocryst-supported fabric. However, phyllic alteration of groundmass and feldspar phenocrysts is the predominant type of alteration of the largest body of megacryst monzogranite porphyry on Vail Ridge (pl. 1). Although a gradational boundary between phyllic-altered and argillically altered megacryst monzogranite porphyry has been mapped provisionally for an approximately 400 -m-long strike length along the west flank of Vail Ridge (pl. 1), implications of such an alteration boundary are difficult to interpret, owing to widespread, obviously supergene clay alteration of nearby Oligocene granodiorite porphyry. Molybdenite was noted in perhaps as many as 12 exposures of megacryst monzogranite porphyry on Vail Ridge; almost all these occurrences of molybdenite are within the mapped outer limits of intense development of quartz stockworks. Furthermore, most of these sparse to moderate concentrations of molybdenite are disseminated finely in matrix of megacryst monzogranite porphyry that also appears to show increased overall abundances of very finely dispersed white mica. Occurrences of secondary copper minerals, some associated spatially with paragenetically early-stage molybdenite, are fairly common in and near the megacryst monzogranite porphyry on Vail Ridge. Many of these occurrences have been explored by shallow prospect pits, as well as a few open cuts that measure about 30 to $40 \mathrm{~m}$ long. Although most of the secondary copper here is chrysocolla, some throughgoing, 0.5-mmthick, planar seams of poor-quality turquoise occur in megacryst monzogranite porphyry.

Additional details concerning petrography and chemistry of megacryst monzogranite porphyry are included below in the subsection entitled "Additional Petrographic and Chemical Studies near the East Stock."

APLITE

Outcrops of Late Cretaceous aplite (unit Kga, pl. 1) make up only a very small percentage of the igneous phases associated genetically with the Buckingham molybdenum system. Aplite was 
mapped at three localities in the general area of the East stock and some is present in the West stock (see subsection below entitled "Economic Geology"). At one of these localities in the general area of the East stock, approximately $300 \mathrm{~m}$ south of the Dipper Mine on the south side of the main drainage through Long Canyon, aplite as mapped apparently crosscuts a contact between megacryst monzogranite porphyry and the Harmony Formation. Although such an age relation (aplite younger than megacryst monzogranite porphyry) may, in fact, be true, actual contacts at this locality are obscured by colluvium. An age determination on a whole-rock sample of aplite from a depth of about $170 \mathrm{~m}$ below the surface in the East stock yielded an age of $70.3 \mathrm{Ma}$ using the K-Ar method (fig. 18). The best exposures of aplite probably are those that are present approximately $300 \mathrm{~m}$ southsouthwest of the main workings of the Copper Queen Mine and north of the main drainage through Long Canyon. At this locality, knobby exposures of leucocratic, seriate-textured aplite are stained pale pinkish gray and dark red brown on weathered surfaces and joints. Fresh surfaces are grayish white. Many planar fractures through aplite are filled by iron oxide(s) that most likely replace pyrite. However, aplite is not veined by quartz stockworks of the molybdenum system. The major characteristics of the unit are the granulose aspect of its groundmass, and the matrix-supported groundmass. The groundmass is typically milky white, medium grained, and K-feldspar rich; it generally makes up more than 50 volume percent of the overall rock. The relative amount of groundmass, however, varies highly throughout the exposed aplite. In places, aplite contains approximately 2 to 3 volume percent microphenocrysts of quartz that are either euhedral, square-sectioned bipyramids, or have highly resorbed round outlines; these quartz microphenocrysts are 3 to $5 \mathrm{~mm}$ wide. Much larger K-feldspar phenocrysts (as much as about $1 \mathrm{~cm}$ in longest dimension) are scattered rarely through aplite as are variable-size rock fragments of differing lithologies. Such fragments include microclasts of quartzite, sericitically altered angular microclasts of an unknown protolith that are metasomatically replaced marginally by $\mathrm{K}$ feldspar, and fragments of vein quartz. This latter relation places the relative time of emplacement of aplite into the molybdenum system after most of the mineralized quartz veins. The presence of xenolithic fragments in the aplite suggests that the aplite genetically is related possibly to the development of widespread breccia found in the system at depth (see subsection below entitled "Economic Geology"). Under the microscope, the groundmass of aplite is seen to include locally more than 50 volume percent clouded K-feldspar, about $0.2 \mathrm{~mm}$ in average grain size, and subordinate amounts of quartz, sericitically altered plagioclase, white mica, carbonate, and pyrite-listed in order of decreasing abundance. However, grain size of the groundmass itself is somewhat variable, and, in fact, tends to show a microseriate fabric. Some samples examined petrographically show complete overgrowths of white mica-altered plagioclase by K-feldspar.

\section{BRECCIA PIPE}

A very small (approx $20 \mathrm{~m}$ wide) circular area in the East stock is made up of a probable breccia pipe (unit $\mathrm{Kgbx}, \mathrm{pl}$. 1) related to the last stages of the Buckingham molybdenum system. The pipe partly contains variable-size fragments of differing lithologies from the sedimentary country rock of the Buckingham system; fragments range from 10 to $15 \mathrm{~cm}$ in width (fig. 22A). Most fragments are intensely argillized shaly hornfels derived from the Harmony Formation; some partially rounded fragments of vein quartz also occur in the breccia pipe. One subrounded dark-gray-black cherty argillite is a sample from the Devonian Scott Canyon Formation (fig. 22B); this essentially unaltered fragment of cherty argillite is set in a matrix of intensely argillized material. Development of the breccia pipe must be largely postmineral relative to molybdenum mineralization. However, some of the fragments in the breccia pipe include coatings by secondary copper minerals, chrysocolla and (or) malachite, on their weathered surfaces. A pebble dike that is exposed in the entrance to the Contention pit at the Copper Basin Mine cuts some of the heavily veined, Late Cretaceous monzogranite porphyry there (fig. 22C). This pebble dike includes some well-rounded, dark-gray pebbles and cobbles of chert, most likely derived also from the Scott Canyon Formation at depth. The development of this pebble dike probably is related temporally to the breccia pipe in the East stock.

\section{LATE EOCENE OR EARLY OLIGOCENE}

Following a significant gap in time after emplacement of the Buckingham molybdenum system during the Late Cretaceous, magmatic activity in the Buckingham areas was renewed in the late Eo- 

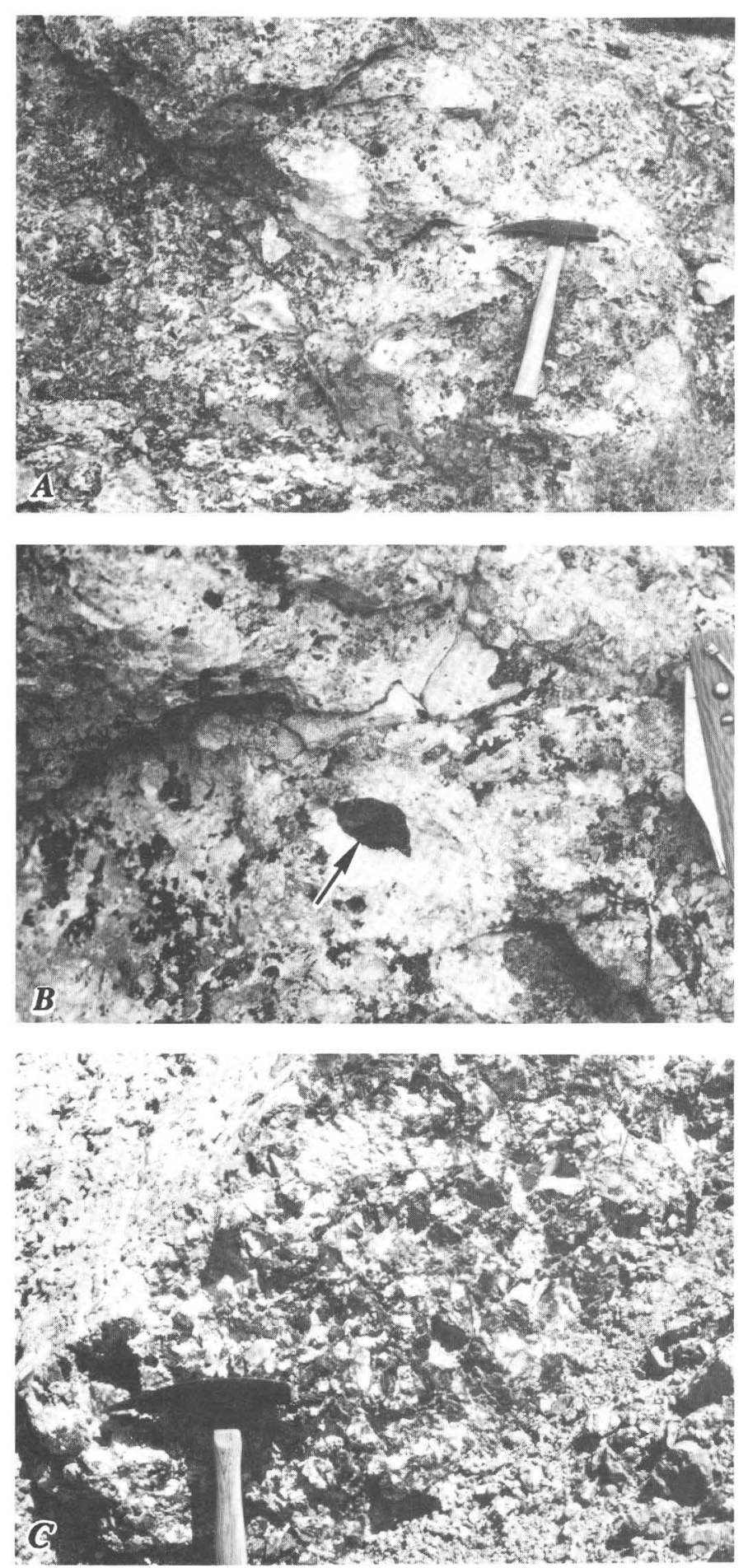

Figure 22.-Breccia pipe and pebble dike associated with Late Cretaceous Buckingham stockwork molybdenum system. A, Fragments of intensely argillized, mostly shaly hornfels from the Upper Cambrian Harmony Formation. B, Closeup of subrounded, dark-gray-black cherty argillite (at head of arrow) from the Devonian Scott Canyon Formation. C, Pebble dike exposed on bench face at entrance into main open pit at Copper Basin Mine. Pebble dike cuts heavily veined, Late Cretaceous monzogranite and includes some well-rounded cobbles and pebbles of chert derived from the Scott Canyon Formation. cene or early Oligocene. During a relatively short, 2 -m.y. timespan from approximately 39 to $37 \mathrm{Ma}$, numerous plutons and dikes, mostly granitic in composition and of highly variable sizes, intruded rocks of the Buckingham area (see subsection above entitled "Potassium-Argon and ${ }^{40} \mathrm{Ar} /{ }^{39} \mathrm{Ar} \mathrm{Geo}-$ chronology of Selected Plutons in the Buckingham Area"). The largest bodies of late Eocene or early Oligocene granitic rocks are centered just north of the workings at the Copper Queen Mine (pl. 1). Another locus of the late Eocene or early Oligocene plutonic magmatism is in the general area of the Little Giant Mine, near the southwest corner of the map area. Across the entire area, these late Eocene or early Oligocene plutons and dikes include biotite-hornblende monzogranite of Bluff area, breccia pipe of Bluff area, porphyritic leucogranite, rhyolite, altered granodiorite, and possibly very minor diabase.

\section{BIOTITE-HORNBLENDE MONZOGRANITE OF BLUFF AREA}

A distinctive biotite-hornblende monzogranite that is late Eocene or early Oligocene in age crops out prominently as a cluster of bodies near a craggy ridge named "Bluff" (fig. 23A) in the northcentral part of the Buckingham area, north of the workings at the Copper Queen Mine (unit Tmb, pl. 1 ). The largest body of the biotite-hornblende monzogranite in this cluster consists of a nearly circular mass that measures about $800 \mathrm{~m}$ in diameter. Several other much smaller equant and dikelike bodies of the biotite-hornblende monzogranite are satellitic to the largest body of this map unit. However, some small outcrops of the biotite-hornblende monzogranite must indicate much more extensive masses of intrusive rock at depth because of relatively widespread contactmetamorphic aureoles that surround them. In places, rocks of the Harmony Formation are converted to an intensely recrystallized, dense, black biotite hornfels for distances of as much as 50 to $60 \mathrm{~m}$ from contacts with the biotite-hornblende monzogranite. The biotite-hornblende monzogranite intrudes rocks of the Upper Cambrian Harmony Formation and is itself intruded by the late Eocene or early Oligocene porphyritic leucogranite and by the Oligocene granodiorite porphyry. Age determinations using the $\mathrm{K}$-Ar method on two mineral separates of primary biotite from the large body and from an isolated, small outcrop just to the north of the large body (fig. 18) yielded ages of 39.0 
and $39.3 \mathrm{Ma}$, respectively. In addition, the biotitehornblende monzogranite is associated genetically with a breccia pipe that is about $300 \mathrm{~m}$ wide (pl. 1 ). Abundant veins of quartz underlie about 50 percent of the area of outcrop of the biotite-hornblende monzogranite and some adjoining rocks of the Harmony Formation. These late Eocene or early Oligocene quartz veins locally form well-developed stockworks (fig. 23B), and in places they cut matrix and fragments of the breccia pipe. Furthermore, the breccia pipe also includes quartz-veined fragments of the biotite-hornblende monzogranite that must predate development of the breccia pipe.
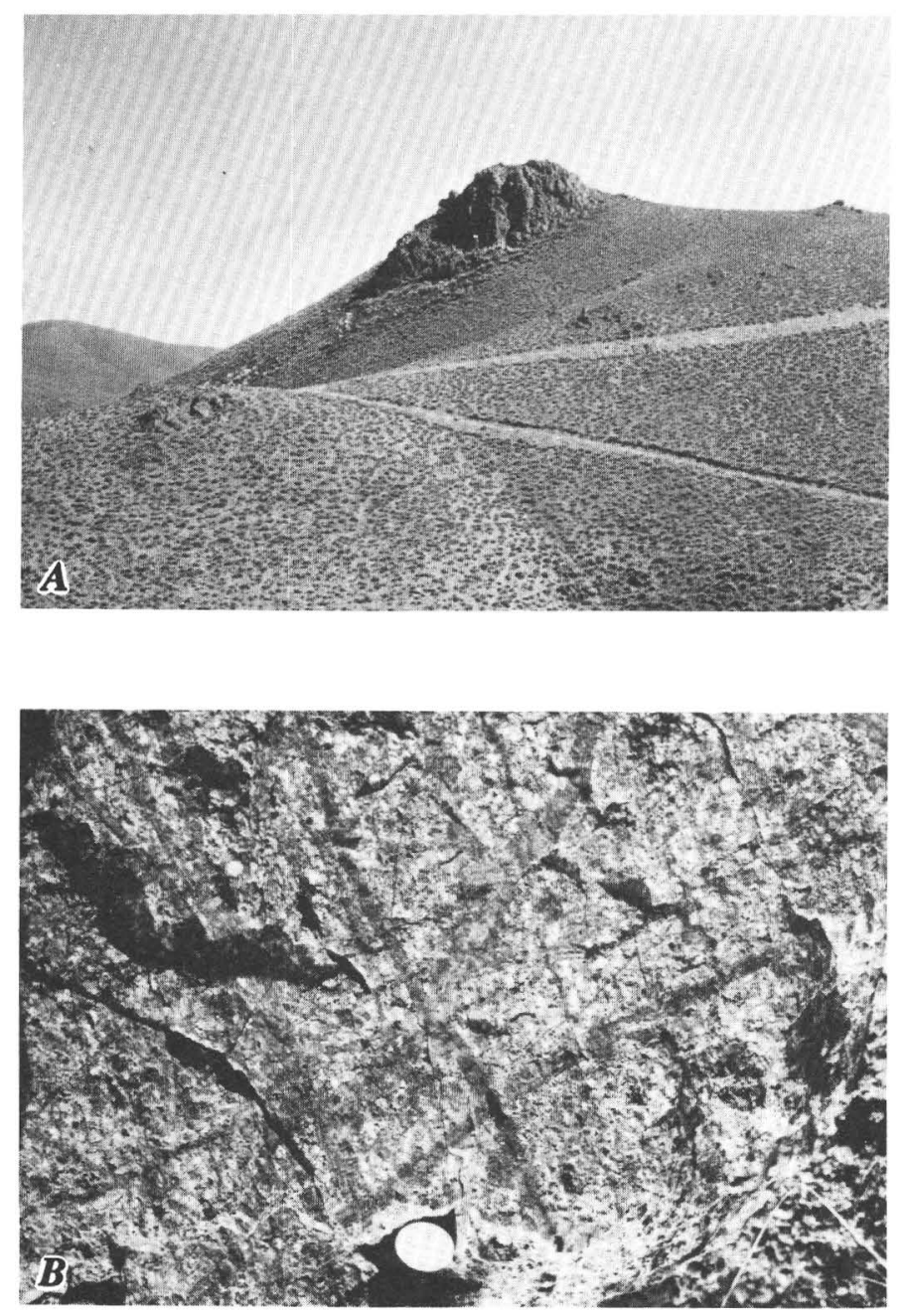

FIGURE 23.-Geologic relations in general area of topographic survey point informally named "Bluff." A, Promontory at Bluff consisting of intensely quartz veined, late Eocene or early Oligocene biotite-hornblende monzogranite. View northeastward. Note roads for scale. $B$, Closeup of biotite-hornblende monzogranite of Bluff area cut by veins including mostly quartz. Note coin at lower part of photograph. $C$, Angular frag-
Most likely, the entire magmatic-hydrothermal system associated with the biotite-hornblende monzogranite of Bluff area is the lode source of the placer gold mined in the now-abandoned (1989) workings of the Vail Placers along Vail Canyon and Poorman's Gulch (Roberts and Arnold, 1965). This system also must have yielded the placer gold evaluated during 1983-85 near the north edge of the map area in Paiute Gulch.

The outcrops of the late Eocene or early Oligocene biotite-hornblende monzogranite of Bluff area are quite distinctive from the Late Cretaceous igneous rocks associated with the Buckingham
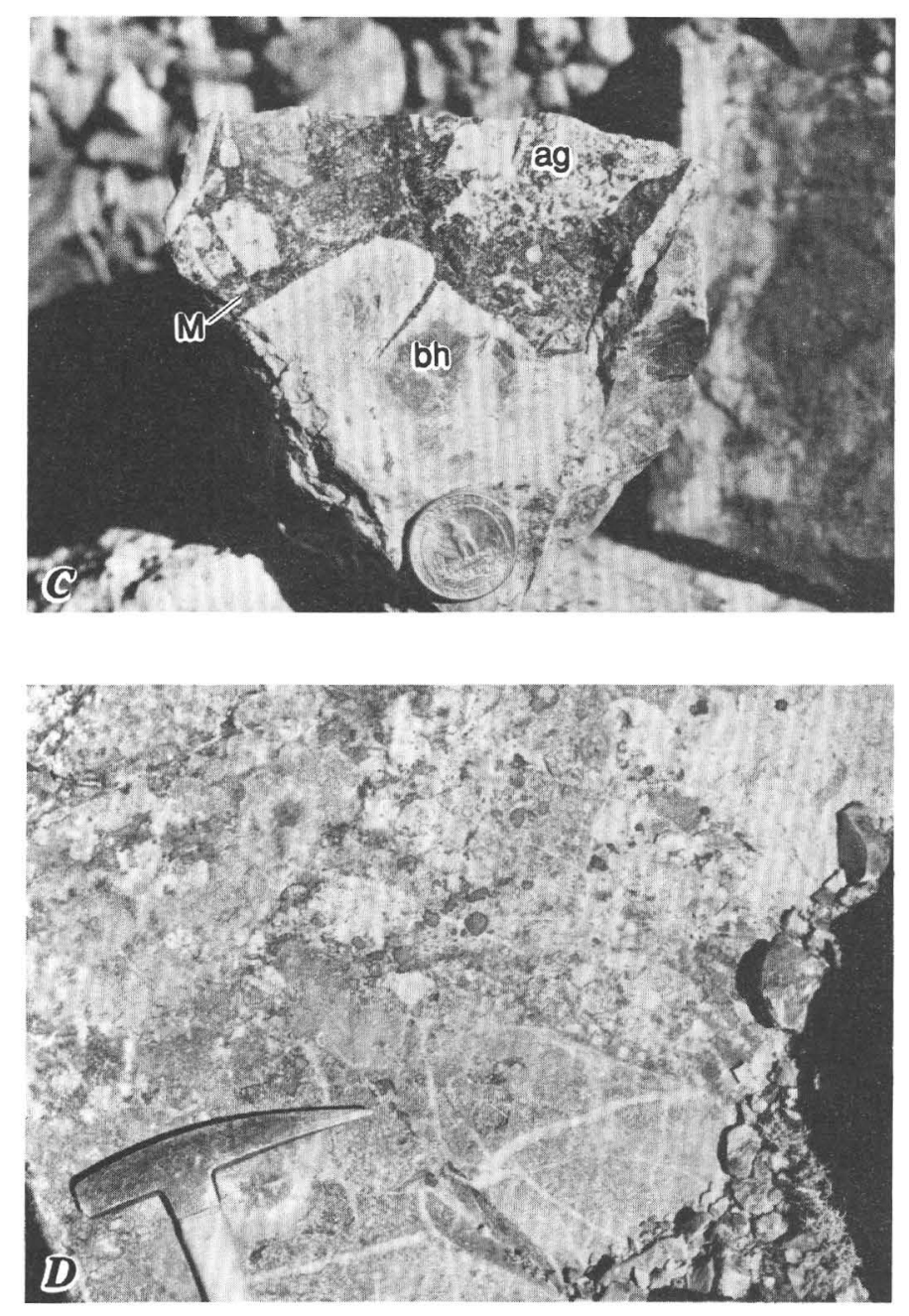

ments of biotite hornfels (bh), altered to K-feldspar along margins, of the Upper Cambrian Harmony Formation and clayaltered, medium-grained granite (ag) set in a matrix (M) including amphibole (mostly blue green, optic Z-axis), Kfeldspar, and generally trace amounts of quartz and sphene. $D$, Closeup of breccia pipe of Bluff area, showing at least two generations of quartz veins: pre- and post-breccia-pipe development. 
molybdenum system in that these Tertiary granitic rocks generally are deeply weathered, owing largely to their relatively high modal contents of primary hornblende and biotite. The color index of these rocks typically is about 20 to 25 , and where abundant, primary biotite phenocrysts commonly show stacking ratios (c to $a$ or $b$ ) of 1 or greater. Although hornblende (blue green, optic Z-axis) is commonly the most abundant mafic mineral in these rocks, one of the satellitic dikes includes diopsidic augite as phenocrysts modally somewhat more abundant than hornblende. Textures in the biotite-hornblende monzogranite range from hypidiomorphic granular to porphyritic. Phenocrysts are plagioclase $\left(\mathrm{An}_{25}-\mathrm{An}_{40}\right.$, showing both normal and oscillatory zoning), quartz (monocrystalline to partially recrystallized, polycrystalline aggregates), hornblende, and biotite. The microaplitic groundmass is most commonly in the size range 0.05-0.1 $\mathrm{mm}$ and ranges modally from about equal amounts of quartz and K-feldspar to K-feldspar/quartz ratios of about 2 to 1 . Accessory minerals include sphene, apatite, zircon, and traces of allanite.

The fabric of quartz veins associated with the biotite-hornblende monzogranite of Bluff area is also quite distinctive from that of veins associated with the Late Cretaceous Buckingham molybdenum system. Many quartz veins in the Bluff area are commonly highly planar and continuous for distances in the range $0.5-1.5 \mathrm{~m}$. Quartz veins in many outcrops also appear to have been emplaced in sets along closely spaced, parallel fractures or joints. Mapping of the attitudes of the most conspicuous set of quartz veins near the promontory at Bluff suggests that many of them are arrayed radially about a locus approximately $200 \mathrm{~m}$ due west of Bluff, and thus near the southeast end of the zone of well-developed quartz veins (pl. 1). In addition, many individual quartz veins in the biotite-hornblende monzogranite of Bluff area are banded, a texture that is not in quartz veins of the Buckingham system. This quartz-quartz banding that parallels walls of the veins indicates cessation of crystallization and opening of veins followed by an apparently immediate resumption of crystallization. Actual interfaces between bands are marked by an increased abundance of extremely small solid inclusions of pyrite and also by fluid inclusions, many of which host opaque, trapped minerals. In addition, the fluid-inclusion population indicates that highly saline, boiling fluids were associated with emplacement of the veins (see section below entitled "Fluid-Inclusion Studies"). It is extremely difficult to find well-exposed, unquestionable rela- tions among the different types of veins that are present in the zone. However, from the relations that have been recorded, the following generalization may be made. Early-stage, approximately 1$\mathrm{cm}$-wide veins with relatively high pyrite-to-quartz ratios were followed by apparently sulfide-free quartz veins, typically 4 to $5 \mathrm{~cm}$ wide. The rocks were then shattered, and sheeted composite veins were emplaced across both of the two earlier stages of veining. Finally, the rocks in places were broken again, and late-stage pyrite was emplaced along narrow fractures and hairline microveins that opened. Fluids associated with each of the quartzbearing stages were highly saline and boiling.

The biotite-hornblende monzogranite shows extremely varied alteration assemblages. Some quartz veins show well-developed, enhancement selvages of secondary $\mathrm{K}$-feldspar in groundmass and in various phenocrysts where they adjoin veins. K-feldspar-actinolite hairline microveins also cut many phenocrysts, and groundmass includes apparently compatible K-feldspar and actinolite. Although primary plagioclase phenocrysts are relatively fresh over all the biotite-hornblende monzogranite of Bluff area, in places plagioclase is clouded highly by clay and (or) white mica minerals. This is especially true where the biotitehornblende monzogranite is cut by dense swarms of vein quartz. However, this clay alteration is plagioclase destructive only and not K-feldspar destructive, suggesting an intermediate, argillic-type classification. Mineral assemblages also suggest that nonuniformly distributed and variably developed propylitic alteration is present in the biotite-hornblende monzogranite of Bluff area. Phenocrysts of hornblende are altered in part to chlorite, sphene, and actinolite. Some phenocrysts of biotite are replaced along their margins by an assemblage of actinolite, albite, and sphene.

Chemical analyses of two very minimally altered, representative samples of the porphyritic phase of the biotite-hornblende monzogranite of Bluff area suggest that this rock type is intermediate in overall composition between the "average" adamellite and "average" granodiorite of LeMaitre (1976) (table 6). In a plot of $\mathrm{K}_{2} \mathrm{O} / \mathrm{Na}_{2} \mathrm{O}$ ratio versus $\mathrm{SiO}_{2}$ content (fig. 24 ), the two samples analyzed chemically also plot in the monzogranite compositional field of Mason (1978). Furthermore, the apparent "degree of alkalinity" of the entire suite of late Eocene or early Oligocene intrusive rocks from the Buckingham area, as indicated using the alkali-lime index of Peacock (1931), is calcic (fig. 25), and all the analyzed Tertiary intrusive rocks from the area, except the 
TABLE 6.-Chemical analyses of two very minimally altered, rep resentative samples of porphyritic phase of the biotite hornblende monzogranite of Bluff area

[Chemical analyses in weight percent by X-ray spectroscopy supplemented by classical methods; analysts, A.J. Bartel, K. Stewart, J. Taggart, R. Moore, P. Aruscavage, and D. Kay. Optical-spectroscopic analyses in parts per million by inductively coupled plasma methods of Scott and Kokot (1975) and F.E. Lichte (unpub. data, 1983); analyst, M. Malcolm. Cross, Iddings, Pirsson, and Washington (CIPW) norms in weight percent. Looked for, but not found, at parts-per-million detection levels in parentheses: Ag (2), As (10), Bi (10), Cd (2), Eu (2), Ho (4), Mo (2), Sn (20), Ta (40), U (100). F determined by specific-ion-electrode methods, Au determined by atomic-absorption methods, and $\mathrm{W}$ determined colorimetrically; analysts, R. Moore, P. Aruscavage, and D. Kay. —, not detected; n.d., not determined]

\begin{tabular}{|c|c|c|c|c|c|c|c|}
\hline $\begin{array}{l}\text { Analy } \\
\text { Field }\end{array}$ & $\frac{\text { sis }}{\text { No. }}$ & $\frac{1}{78 \mathrm{C} 89}$ & $\frac{2}{78 \mathrm{C} 90}$ & 3 & 4 & 5 & 6 \\
\hline & & & Chemical & nalyses & ight perc & & \\
\hline SiO & & 67.7 & 66.0 & 68.65 & 66.09 & 70.25 & 66.43 \\
\hline $\mathrm{Al}_{2}$ & & 14.9 & 15.2 & 14.55 & 15.73 & 13.46 & 14.47 \\
\hline $\mathrm{Fe}_{2}$ & & .81 & .62 & 1.23 & 1.38 & 13.42 & 14.29 \\
\hline $\mathrm{FeO}$ & & 2. & 1.8 & 2.7 & 2.73 & N.d. & N.d. \\
\hline $\mathrm{MgO}$ & & 2.19 & 2.84 & 1.14 & 1.74 & 1.46 & 2.7 \\
\hline $\mathrm{CaO}$ & & 3.96 & 5.38 & 2.68 & 3.83 & 2.32 & 2.52 \\
\hline $\mathrm{Na}_{2}$ & & 2.87 & 3.14 & 3.47 & 3.75 & 2.02 & 2.52 \\
\hline $\mathrm{K}_{2} \mathrm{\delta}$ & & 3.51 & 3.12 & 4. & 2.73 & 4.88 & 4.22 \\
\hline $\mathrm{H}_{2}^{2} \mathrm{O}$ & & .68 & .5 & .59 & .85 & .45 & .3 \\
\hline $\mathrm{H}_{2}^{2} \mathrm{O}$ & & .31 & .35 & .14 & .19 & .9 & 1.12 \\
\hline TiO & & .33 & .41 & .54 & .54 & .36 & .42 \\
\hline $\mathrm{P}_{2} \mathrm{O}$ & & .12 & .14 & .19 & .18 & .15 & .13 \\
\hline Mño & & .02 & .04 & .08 & .08 & .02 & .03 \\
\hline $\mathrm{CO}_{2}$ & & .13 & .03 & .09 & .08 & .08 & .12 \\
\hline$F^{2}$ & & .09 & .09 & N.d. & N.d. & N.d. & N.d. \\
\hline $\mathrm{s}$ & & .21 & $<.01$ & N.d. & N.d. & $\frac{.51}{90}$ &. .81 \\
\hline & Subtotal & 99.81 & 99.66 & $\overline{100.05}$ & 99.9 & $\overline{100.28}$ & 100.03 \\
\hline Less & $\begin{array}{l}\text { O=F,S } \\
\text { Tota1 }\end{array}$ & $\frac{.13}{99.68}$ & $\frac{.04}{99.62}$ & $\overline{100.05}$ & 99.9 & $\frac{.21}{100.07}$ & $\frac{.34}{99.74}$ \\
\hline & & Optical & spectrosc & ic ana1y & (parts $p$ & million) & \\
\hline $\mathrm{Ba}$ & & 990.0 & 990.0 & N.d. & N.d. & N.d. & N.d. \\
\hline $\mathrm{Be}$ & & 2. & 2. & N.d. & N.d. & N.d. & N.d. \\
\hline $\mathrm{Ce}$ & & 31. & 28. & N.d. & N.d. & N.d. & N.d. \\
\hline Co & & 11. & 10. & N.d. & N.d. & N.d. & N.d. \\
\hline $\mathrm{Cr}$ & & 130. & 160. & N.d. & N.d. & N.d. & N.d. \\
\hline $\mathrm{Cu}$ & & 210. & 67. & N.d. & N.d. & N.d. & N.d. \\
\hline Ga & & 19. & 19. & N.d. & N.d. & N.d. & N.d. \\
\hline $\mathrm{La}$ & & 16. & 12. & N.d. & N.d. & N.d. & N.d. \\
\hline $\mathrm{Li}$ & & 13. & 7. & N.d. & N.d. & N.d. & N.d \\
\hline $\mathrm{Nb}$ & & -- & 7. & N.d. & N.d. & N.d. & N.d. \\
\hline $\mathrm{Nd}$ & & 16. & 21. & N.d. & N.d. & N.d. & N.d. \\
\hline $\mathrm{Ni}$ & & 21. & 30. & N.d. & N.d. & N.d. & N.d. \\
\hline $\mathrm{Pb}$ & & 15. & 14. & N.d. & N.d. & N.d. & N.d. \\
\hline $\mathrm{Sc}$ & & 7. & 9. & N.d. & N.d. & N.d. & N.d. \\
\hline $\mathrm{Sr}$ & & 530. & 600. & N.d. & N.d. & N.d. & N.d. \\
\hline Th & & - & 4. & N.d. & N.d. & N.d. & N.d. \\
\hline$v$ & & 56. & 70. & N.d. & N.d. & N.d. & N.d. \\
\hline $\mathbf{Y}$ & & 11. & 12. & N.d. & N.d. & N.d. & N.d. \\
\hline $\mathrm{Yb}$ & & 1. & 1. & N.d. & N.d. & N.d. & N.d. \\
\hline $\mathrm{Zn}$ & & 26. & 32. & N.d. & N.d. & N.d. & N.d. \\
\hline & & & hemical 8 & 1yses $(p$ & per mil & & \\
\hline $\mathrm{Au}$ & & $<0.05$ & $<0.05$ & N.d. & N.d. & N.d. & N.d. \\
\hline w & & $<3$ & $<3$. & N.d. & N.d. & N.d. & N.d. \\
\hline & & & C.I.P.W & norms ( $w$ & ht percen & & \\
\hline$q$ & & 25.99 & 21.39 & 25.06 & 22.4 & N.d. & N.d. \\
\hline c & & -- & -- & .3 & .26 & N.d. & N.d. \\
\hline or & & 20.85 & 18.57 & 23.66 & 16.18 & N.d. & N.d. \\
\hline$a b$ & & 24.41 & 26.75 & 29.39 & 31.8 & N.d. & N.d. \\
\hline an & & 17.5 & 18.29 & 11.49 & 17.37 & N.d. & N.d. \\
\hline wo & & .02 & 2.88 & -- & - & N.d. & N.d. \\
\hline en & & 5.48 & 7.12 & 2.84 & 4.35 & N.d. & N.d. \\
\hline fs & & 2.04 & 2.21 & 3.2 & 3.14 & N.d. & N.d. \\
\hline $\mathrm{mt}$ & & 1.18 & .91 & 1.79 & 2.01 & N.d. & N.d. \\
\hline il & & .63 & .78 & 1.03 & 1.03 & N.d. & N.d. \\
\hline ap & & .29 & .33 & .45 & .43 & N.d. & N.d. \\
\hline fr & & .16 & .16 & - & - & N.d. & N.d. \\
\hline $\mathrm{pr}$ & & .4 & -- & -- & -- & N.d. & N.d. \\
\hline cc & & .3 & .07 & .21 & .18 & N.d. & N.d. \\
\hline & Tota1 & $\overline{99.25}$ & $\overline{99.46}$ & $\overline{99.42}$ & $\overline{99.15}$ & & \\
\hline & Salic & 88.75 & 85. & 89.9 & 88.01 & & \\
\hline & Femic & 10.5 & 14.46 & 9.52 & 11.14 & & \\
\hline $\begin{array}{l}\text { Diffe } \\
\text { Index }\end{array}$ & rentiation & 71.25 & 66.71 & 78.11 & 70.38 & N.d. & N.d. \\
\hline
\end{tabular}

1 Total $\mathrm{Fe}$ as $\mathrm{Fe}_{2} \mathrm{O}_{3}$

Minimally altered biotite hornblende monzogranite collected approximately $600 \mathrm{~m}$ north-northwest of survey marker "Bluff".

"Average" adamelilite of LeMaitre (1976).

Guerago granodiorite or LeMatre (1976).

(able 6, analyis 1). rhyolites, are metaluminous (fig. 26). However, the biotite-hornblende monzogranite of Bluff area is not so alumina undersaturated as the analyzed samples from the porphyritic tonalite phase of the porphyritic leucogranite unit to be described below.

Various ternary plots of analytical data from the biotite-hornblende monzogranite of Bluff area reveal both a marked discordance and a moderate conformation with many of the other intrusive rocks of similar age in the area. For example, data from the biotite-hornblende monzogranite of Bluff area plot closer to the F corner in AlkFM and ACF ternary diagrams than the nearby porphyritic leucogranite (figs. $27 A, 27 B$ ). This relation largely indicates the somewhat $\mathrm{MgO}$ and $\mathrm{FeO}$ enriched composition of the biotite-hornblende monzogranite of Bluff area. However, in an AKF ternary diagram compositions of the two rock units show an apparent overlap (fig. $27 C$ ).

Comparison of the chemistry of the biotitehornblende monzogranite of Bluff area with the chemistry of other plutons related genetically to major gold-producing, magmato-hydrothermal systems in the district are especially pertinent because the biotite-hornblende monzogranite of Bluff area apparently is associated with the lode source of placer gold in the Vail and Paiute Gulch placers. Altered granodiorite of the Copper Canyon area (termed a "quartz monzonite" by Roberts (1964), using an alternative scheme for classification) is associated with economically significant ore bodies that currently (1989) are producing more than 240,000 troy oz $\mathrm{Au} / \mathrm{yr}$ from a mineralized system that contained at least 3.3 million troy oz $\mathrm{Au}$

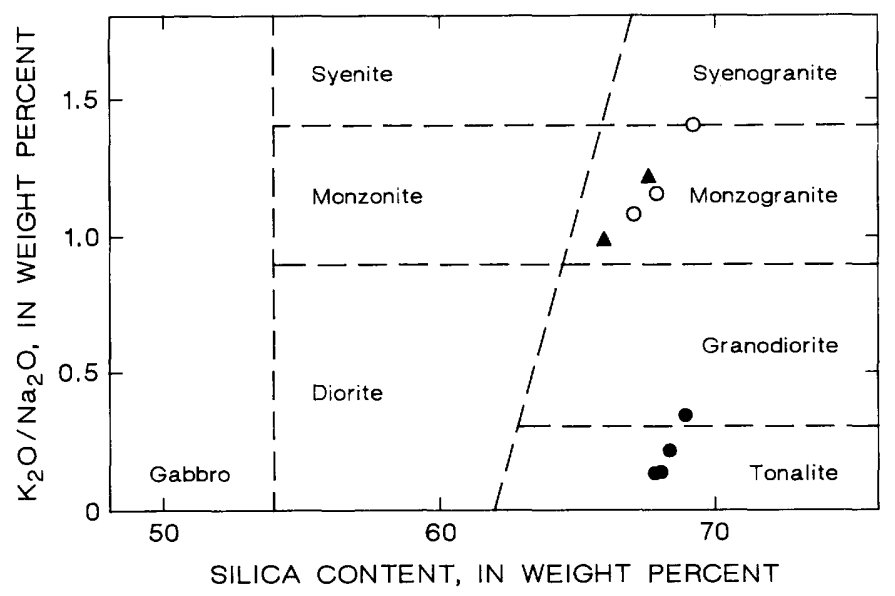

FIGURE 24.-Biotite-hornblende monzogranite of Bluff area (triangles) and porphyritic leucogranite, including porphyritic tonalite phase (dots) and porphyritic monzogranite phase (circles), plotted on compositional field diagram modified from Mason (1978). Data from tables 6 and 8. 
ALKALI-LIME INDEX OF PEACOCK (1931)

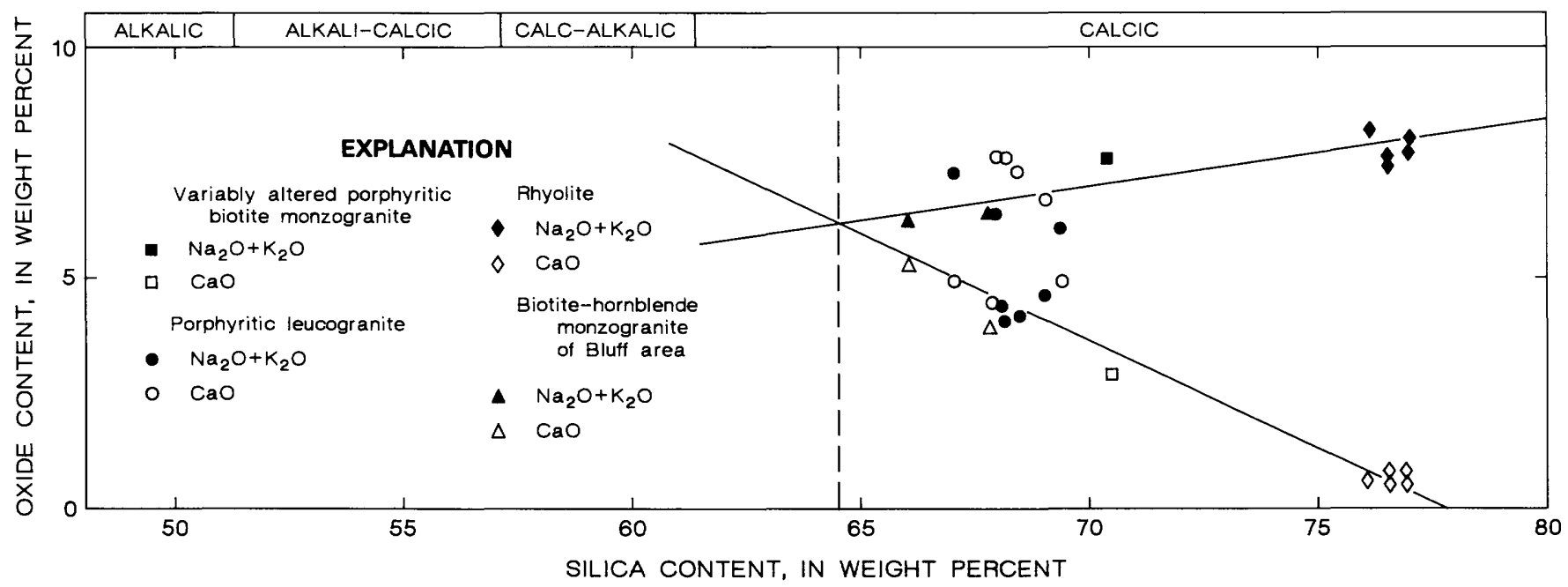

Figure 25.-Total alkalis $\left(\mathrm{K}_{2} \mathrm{O}+\mathrm{Na}_{2} \mathrm{O}\right)$ and $\mathrm{CaO}$ versus $\mathrm{SiO}_{2}$ contents in samples of Tertiary igneous rocks from Buckingham area. Trends of sum $\left(\mathrm{Na}_{2} \mathrm{O}+\mathrm{K}_{2} \mathrm{O}\right)$ and $\mathrm{CaO}$ (solid lines) for this series of igneous rocks were approximated using all data points except those from leucotonalite phase of porphyritic leucogranite (see text). Data from tables 6 and 8 through 10. Estimated $\mathrm{SiO}_{2}$ content at point where $\mathrm{Na}_{2} \mathrm{O}+\mathrm{K}_{2} \mathrm{O}$ equals $\mathrm{CaO}$ is 64.5 weight percent (dashed line): thus, the suite is calcic (after Peacock, 1931).

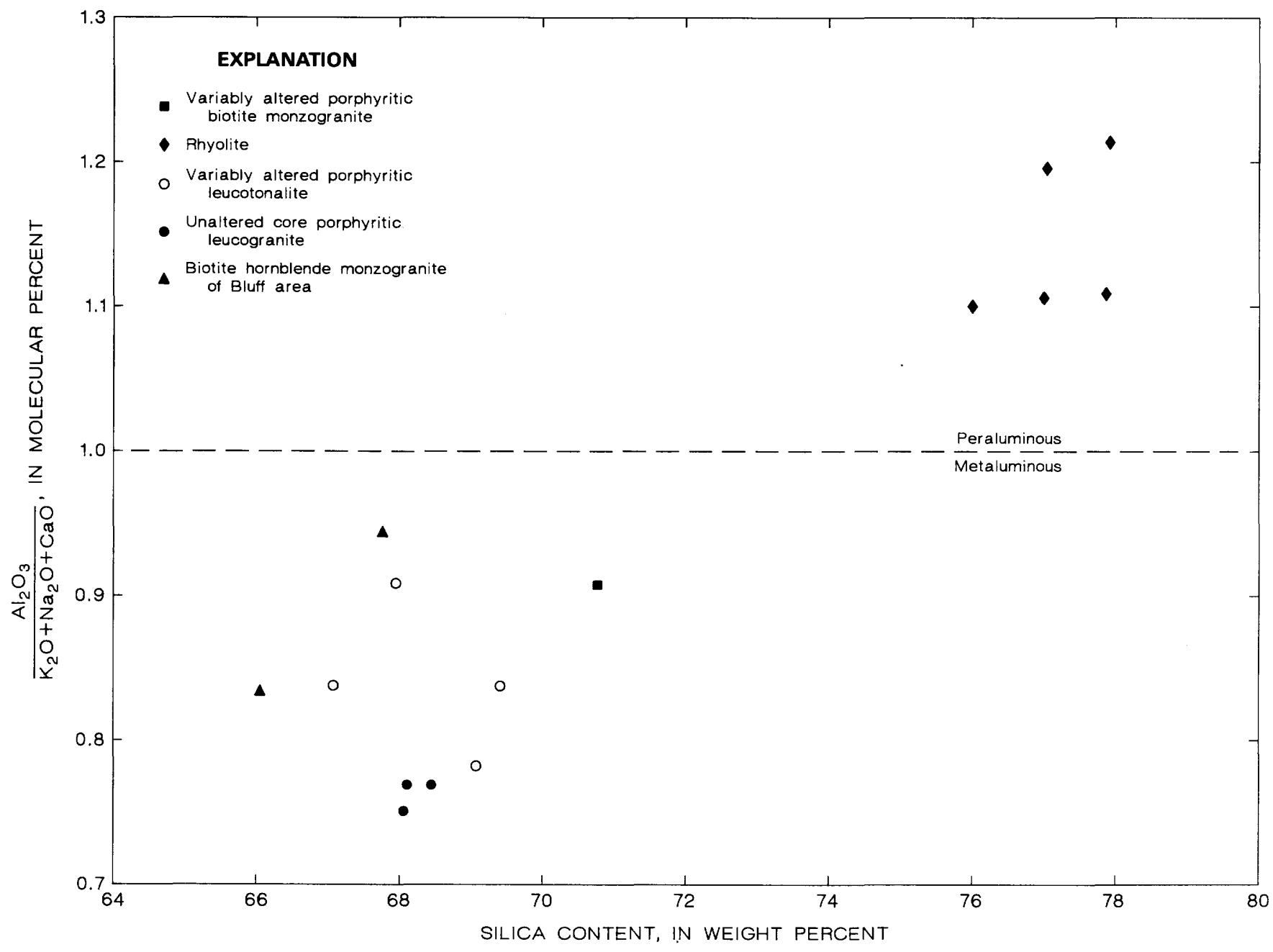

FIGURE 26.- $\mathrm{Al}_{2} \mathrm{O}_{3}:\left(\mathrm{K}_{2} \mathrm{O}+\mathrm{Na}_{2} \mathrm{O}+\mathrm{CaO}\right)$ ratio versus $\mathrm{SiO}_{2}$ content for samples of Tertiary intrusive rocks in Buckingham area. 
(Blake and others, 1984; Theodore and others, 1986). Two chemical analyses of samples from altered granodiorite of Copper Canyon (analyses 5, 6, table 6), are overall quite similar to analyzed samples of the biotite-hornblende monzogranite of Bluff area, however, there are some differences. The biotite-hornblende monzogranite of Bluff area apparently shows an increased abundance of $\mathrm{CaO}$ and $\mathrm{Na}_{2} \mathrm{O}$ and a decreased abundance of $\mathrm{K}_{2} \mathrm{O}$ rela- tive to altered granodiorite of the Copper Canyon area. Both of these relations probably are a reflection of widespread and intense potassic alteration that has affected the altered granodiorite of the Copper Canyon area (see Theodore and Blake,1975, 1978). The ferric:ferrous ratio of biotite-hornblende monzogranite of Bluff area (0.34-0.41; table 6) is compatible with the relatively reduced values for this ratio (less than 0.85 ) in plutons in the
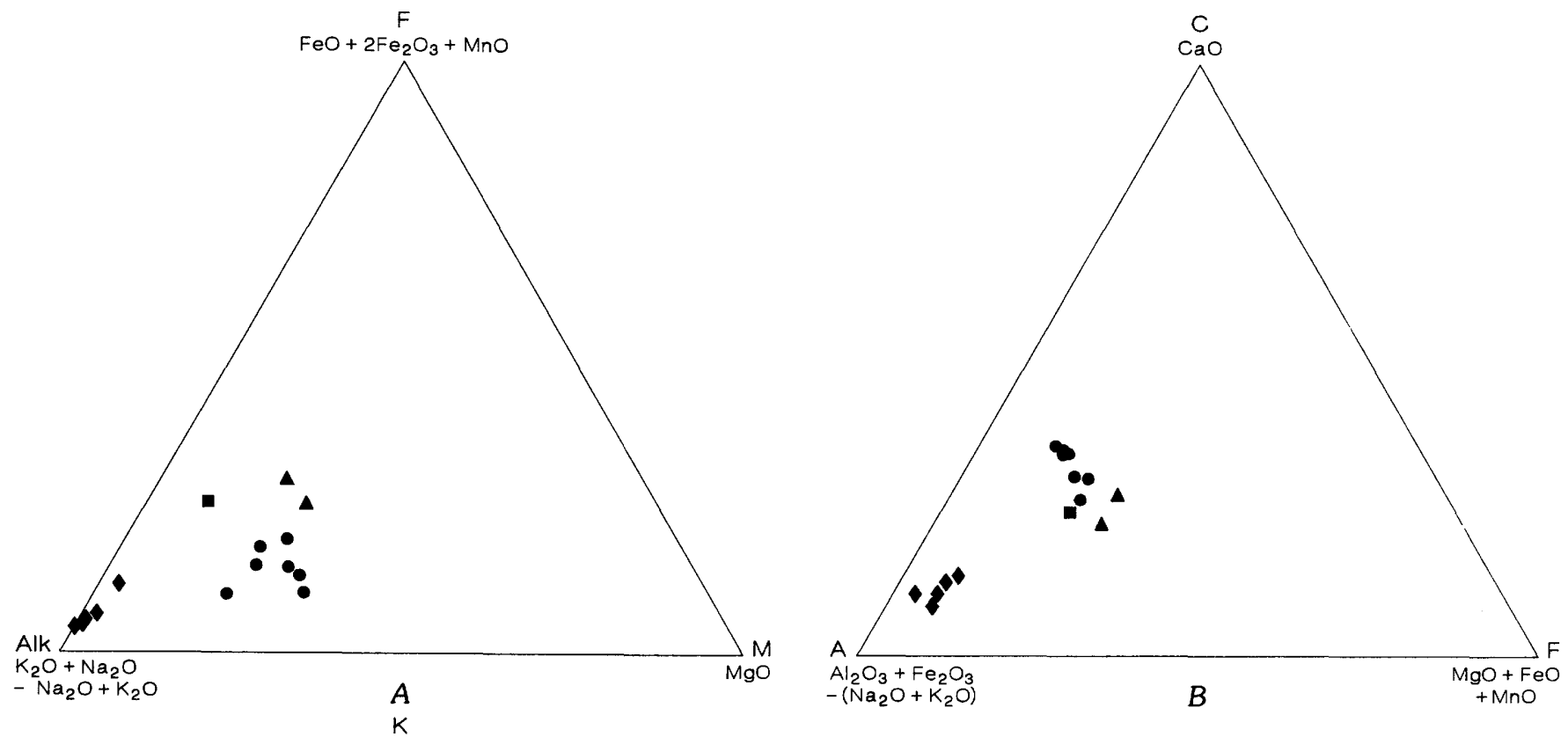

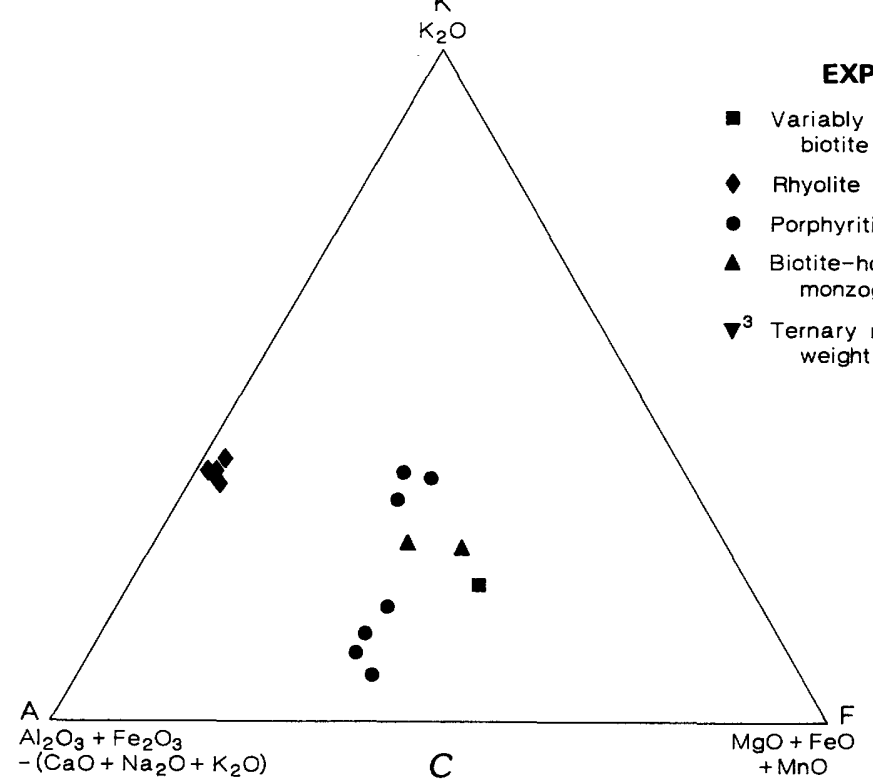

FIGURE 27.-Ternary chemical and normative diagrams of Tertiary igneous rocks from Buckingham area. A, AlkFM diagram. $B, A C F$ diagram. $C, A K F$ diagram. $D$, Normative proportions of albite, orthoclase, and quartz. Data from tables 6 and 8 through 10 . Triangles, ternary minimums

\section{EXPLANATION}

altered porphyritic

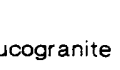
cogranite area nite of Bluff area inim at 3 rcent An

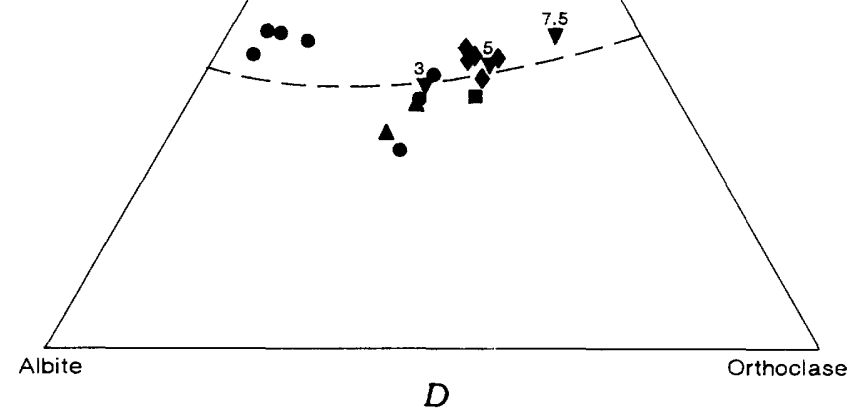

from James and Hamilton (1969) at designated anorthite content (in weight percent) for $P_{\text {total }}=P_{\mathrm{H}_{0}}=1 \mathrm{kbar}$. Dashed line, locus of ternary minimum temperatures projected onto anhydrous base of Ab-Or-Q- $\mathrm{H}_{2} \mathrm{O}$ tetrahedron for $\mathrm{P}_{\mathrm{H}_{2} \mathrm{O}}=\mathrm{P}_{\text {total }}=$ $500 \mathrm{~kg} / \mathrm{cm}^{2}$ from Tuttle and Bowen (1958). 
Golconda terrane of north-central Nevada (Keith and Swan, 1987). As many of these plutons in this part of Nevada are associated with gold mineralization, the regional nature of this correlation is intriguing. However, the ferric:ferrous ratios of the "average" granodiorite and the "average" adamellite of LeMaitre (1976) are 0.50 and 0.45 , respectively.

\section{BRECCIA PIPE OF BLUFF AREA}

An irregular breccia pipe crops out in an approximately 200 - by $500-\mathrm{m}$ section of the Bluff area. It is present mostly within biotite-hornblende monzogranite of Bluff area (unit Tbp, pl. 1). In addition, a narrow dike of breccia that crops out about $0.7 \mathrm{~km}$ west of the main body of breccia pipe probably is related genetically to the same processes associated with the genesis of the breccia pipe. As mapped, the breccia pipe is elongate in a N. $45^{\circ} \mathrm{W}$. direction, and its longest dimension in plan seemingly parallels the long axis of the zone of intensely developed quartz stockworks that borders, and locally impinges upon, the breccia pipe on the southwest. That this body of breccia must owe its genesis to development as a breccia pipe results from (1) the contrast of highly varied, mixed metasedimentary and igneous angular fragments within the unit to the largely homogeneous character of the surrounding biotite-hornblende monzogranite; (2) the fact that certain exotic rock fragments within the breccia must have had significant transport in a vertical direction before their inclusion in the exposed breccia; (3) the largely hydrothermal-metamorphic character of the matrix of the breccia; (4) the mapped geologic relations of the unit with its enclosing rocks; and (5) the presence of veined and unveined biotitehornblende monzogranite as fragments in breccia. Some outcrops of the breccia pipe, especially near the northwestern part of the unit, contain a matrix that is granitoid. However, this type of matrix is relatively sparse over all the unit. Outcrops of breccia pipe form fairly resistant, rugged exposures, particularly on the hillside west of the major drainage through the mapped breccia. Nonetheless, the breccia pipe also contains some extremely poor, slope-forming exposures where it is close to the trace of post-breccia-pipe, north-northeast-striking faults, and where it is weathered deeply, as along its easternmost exposures. In addition, the breccia pipe is marked further by a color anomaly resulting largely from iron oxides that replace either fine-grained cubes of pyrite dispersed sporadically in the matrix or very local dense concentrations of fine-grained magnetite in the matrix.

The distribution of breccia pipe with surrounding rocks suggests a probable complex configuration for geometry of the unit at depth. As mapped, the eastern contact of the breccia pipe suggests a more or less flat-lying attitude, whereas the west contact dips more steeply east (pl. 1). These relations, however, may be a consequence of a $12^{\circ}$ to $16^{\circ}$ tilting of the entire Buckingham-Copper Basin area, eastern parts down, after emplacement of breccia pipe and after deposition of the outflow facies, the Oligocene Caetano Tuff, at Elephant Head (see subsection below entitled "Structural Geology").

Metasedimentary and sedimentary rocks from several formations are present together with various types of igneous rock as fragments in the breccia pipe. Breccia pipe commonly includes angular fragments of biotite hornfels of the Harmony Formation that have been replaced partly along their margins by K-feldspar (fig. 23C). As also shown in this figure, fragments of granitic rocks are also fairly common in breccia pipe; some of these obviously were derived from biotite-hornblende monzogranite. In addition, angular to subrounded fragments of rhyolite porphyry, diabase, biotitic silty shale of the Harmony Formation, veined arkose and quartz arenite of the Harmony Formation, broken plagioclase crystals, and chert either of the Scott Canyon or Valmy Formation are present in the breccia pipe. As such, the breccia pipe most closely corresponds to the zone III classification of breccia pipes, "angular to rounded breccia *** exhibiting marked rotation and mixing of fragments," applied by Johnston and Lowell (1961) to the Copper Basin, Ariz., breccia pipes. Although fragments within the breccia pipe of Bluff area typically vary greatly in size, from individual blocks about $10 \mathrm{~m}$ wide to millimeter-size, slightly separated segments of vein quartz, many outcrops show a preponderance of fragments in the size range 10-15 $\mathrm{cm}$. The occurrence of chert belonging to either the Scott Canyon or Valmy Formation strongly suggests upward transport of these fragments from significant depths, because the Scott Canyon Formation or Valmy Formation must tectonically underlie the Harmony Formation in this general area (see pl. 1; Roberts, 1964). The Scott Canyon Formation is more likely than the Valmy Formation to be present at depth in this part of the district; this supposition is based on respective mapped overall distributions of the formations (fig. 
2). However, the possibility still remains that chert fragments in breccia may have been derived from either (1) previously overlying, chert-bearing conglomerate belonging to the Battle Formation that foundered into a collapsing column of sedimentary and igneous rocks that now make up breccia pipe, or (2) the entire map unit of breccia pipe simply represents some rocks of the Battle Formation that have been incorporated into biotite-hornblende monzogranite as a mega-xenolith. Neither of these alternative possibilities is viable. The angularity of the chert fragments in the breccia demonstrates that chert fragments could not have been derived individually from the Battle Formation which typically contains well-rounded clasts (see Roberts, 1964). Furthermore, the presence in the breccia pipe of veined and unveined fragments of late Eocene or early Oligocene biotite-hornblende monzogranite of Bluff area also indicates that the breccia unit as a whole could not be a large xenolith of the Battle Formation.

Development of breccia pipe overlaps temporally the widespread veining by quartz associated with the intrusive complex centered in the Bluff area. Many outcrops examined show generally at least two generations of vein quartz within the mapped outer limits of significant concentrations of quartz veins shown on the map (pl. 1). Some rocks of the breccia pipe include fragments showing termination of quartz veins at fragment-matrix interfaces, together with quartz veins that cut fragment-matrix interfaces (fig. 23D). Most postbreccia veins are steeply dipping. However, quartz-filled veins in the Bluff area do not form sheeted zones that parallel the boundaries of the breccia pipe analogous to the tourmaline-filled sheeted zones reported by Sillitoe and Sawkins (1971) for many of the copper-bearing, tourmaline breccia pipes in Chile. The one mapped dike of breccia correlated with the breccia pipe of Bluff area has a radial orientation with respect to the main mass of breccia pipe.

Generally unsorted and mixed lithologies of the fragments common megascopically in outcrops of the breccia pipe of Bluff area also persist down to thin-section scale (figs. 28A, 28B). However, the matrix in these rocks is completely recrystallized in contrast to unrecrystallized matrix consisting of highly comminuted grains or rock flour common in many breccia pipes elsewhere (see Bryner, 1961, 1968; Bryant, 1968; Sharp, 1978; Atkinson and others, 1982; Simmons and Sawkins, 1983). In all, paragenetic relations among mineral assemblages were examined in 10 thin-sectioned samples of the breccia pipe of Bluff area: Although the matrix of the breccia pipe includes, in places, a magnetitediopside-quartz-K-feldspar assemblage (fig. $28 \mathrm{C}$ ), the most common hydrothermal assemblage in the matrix over all the breccia pipe is amphibole (ranging in composition from tremolite to actinolite), $\mathrm{K}$ feldspar, sphene, quartz (generally in sparse to trace amounts), and with or without pyrite (fig. $28 B$ ). The presence of sparse copper oxides in some outcrops of the breccia pipe suggests that chalcopyrite is one of the early-stage hypogene minerals. All samples of the breccia pipe examined in detail under the microscope are dominated by hornfelsic textures that indicate physical-chemical conditions comparable with thorough recrystallization in a potassic-alteration zone. Fragments consisting of actinolite- or tremolite-dominant, or diopsidedominant, assemblages have not been found in the main body of the breccia pipe. They have been found, however, in the narrow breccia dike, $0.7 \mathrm{~km}$ west of the main body. Here, ovoid gray-green clots of diopside are set in a dark-gray, in places wispy matrix that is very magnetite rich and includes apparently compatible actinolite, green spinel (hercynite?), and low-birefringence phyllosilicate (kaolinite?). The diopside clots are mantled by narrow reaction rims of actinolite.

The exposed parts of the breccia pipe of Bluff area appear to indicate a relatively deep erosional level. Depths of emplacement probably are approximately compatible with qualitative and quantitative estimates for similarly altered breccia pipes elsewhere. In a schematic vertical column hypothesized for the copper-bearing tourmaline breccia pipes in Chile, Sillitoe and Sawkins (1971) show most heavily replaced parts to be near the base of the pipes they examined. Furthermore, Camus (1975) places widespread K-feldspar-stable alteration in the El Teniente, Chile, breccia pipe only in the deep parts of the system. Sharp (1978), in an elegant reconstruction of the Redwell Basin, Colo., molybdenum breccia pipe, infers the top of the potassium silicate zone there to have formed approximately $1,000 \mathrm{~m}$ below the surface. In addition, the breccia pipe of Bluff area does not contain any evidence of near-surface phenomena that have been reported by Gilluly and Gates (1965) and Gates (1959) for breccia pipes they examined approximately $25 \mathrm{~km}$ to the southeast in the Horse Canyon area of the Shoshone Range. Breccia pipes in the Horse Canyon area include some pyroxene- and amphibole-bearing assemblages, but they also show inward collapse and slumping of walls of the pipes, together with late-stage comminution attended by running surface waters. 
Geologic data from the breccia pipe and its immediately surrounding rocks do not provide compelling documentation for operation of a process of breccia development that favors strongly any one of many origins suggested previously (see Mitcham, 1974, for a review of different hypotheses proposed over a period of about 50 years for the origin of breccia pipes). Fault-related hypotheses, whether they be fault intersections (Kuhn, 1941) or local opening of fissure-related voids along normal faults (Mitcham, 1974), do not appear to offer viable alternatives in light of the absence of required structures (see pl. 1). The fact that most of the rocks presently incorporated as fragments in the breccia pipe are largely unreactive silicate lithologies (chert, quartz arenite, biotite hornfels, rhyolite porphyry, and monzogranite) seems to indicate that early dissolution followed by collapse (Locke, 1926) may not have been important, although Sawkins (1969) suggested that crackling of fine-grained siliceous rocks could result from the introduction of sodium- and potassium-rich fluids. Simons (1964) proposed a similar mechanism, his "hypogene exfoliation," wherein altered parts of fragments within breccia spall off to yield voids that were then filled by subsequently crystallized assemblages. Meinert

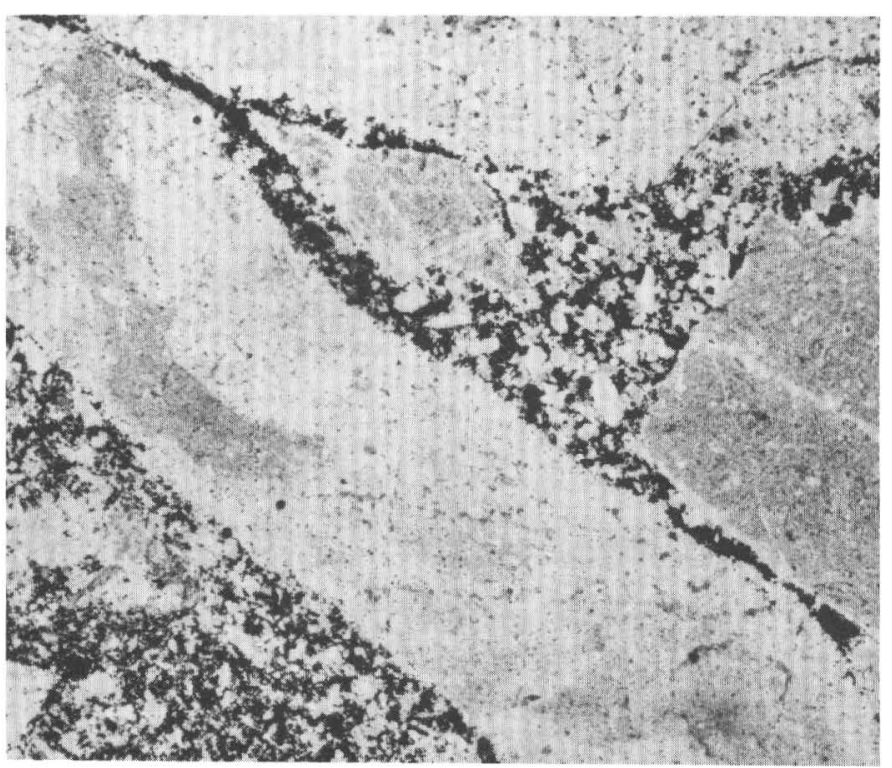

$\boldsymbol{A}$

5 MILLIMETERS

FIGURE 28.-Photomicrographs showing textural relations in late Eocene or early Oligocene breccia pipe of Bluff area. A, Fabric of sample of breccia pipe including abundant magnetite in matrix. Matrix also includes quartz, clinopyroxene, and actinolite. Sample 78C97. B, Matrix of breccia pipe including abundant
(1982) also called upon chemical dissolution and precipitation to produce some of the brecciation in base-metal-zoned breccia pipes at Cananea, Mexico. However, some of the striking characteristics of many of the breccia pipes leading to

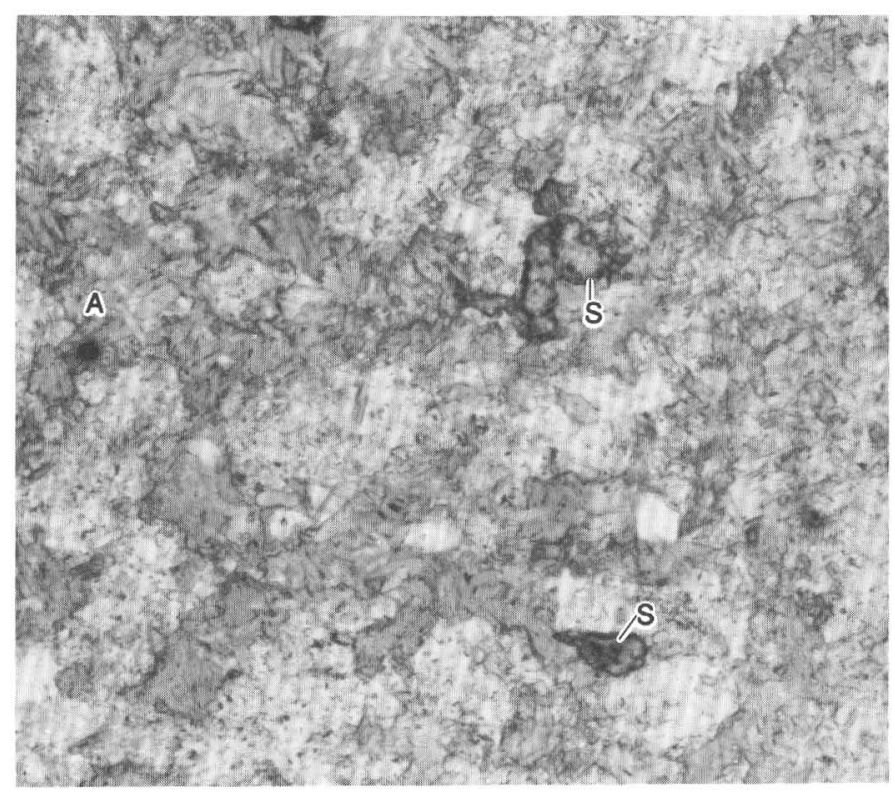

$\boldsymbol{B}$ 0 0.6 MILLIMETER

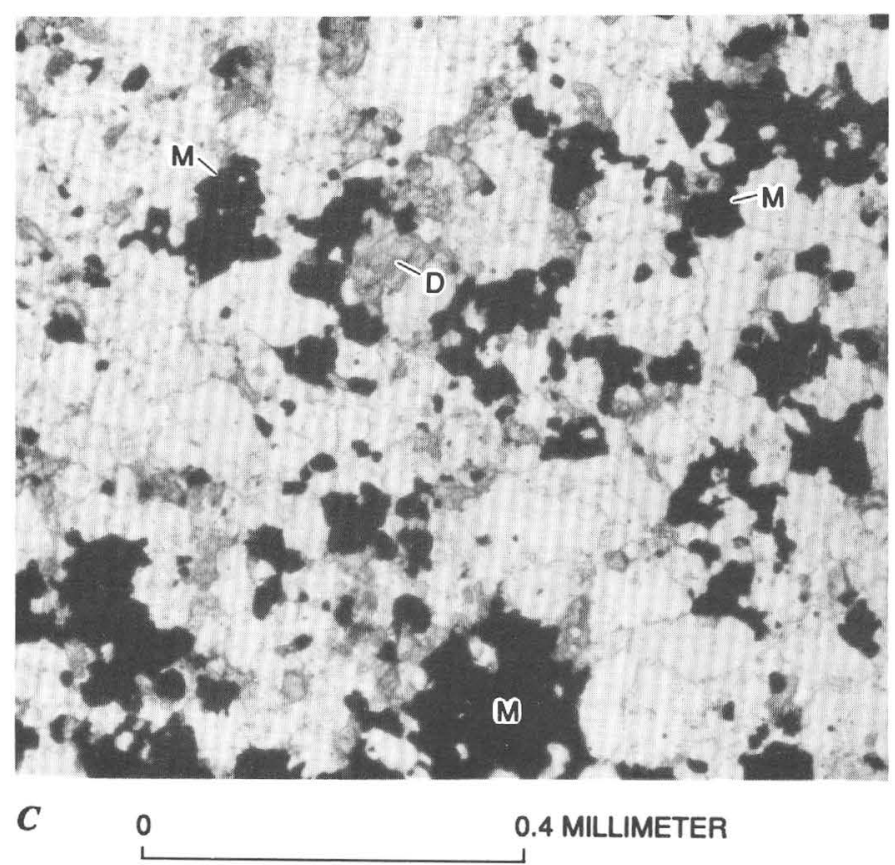

actinolite (A) and much lesser amounts of K-feldspar, quartz, and sphene (S). Sample 81TT208. C, Assemblage of magnetite (M), diopside (D), quartz, and $\mathrm{K}$-feldspar in matrix of selected samples from breccia pipe. Sample 78C97. 
dissolution-type origins include an apparent absence of significant movement between individual fragments, the uniformity of the lithology of the breccia fragments, and an "onionskin-like" peeling off of layers at margins of fragments without much dislocation between separated fragments. These criteria are not applicable to the breccia pipe of Bluff area. Furthermore, dissolution of rocks consisting almost entirely of quartz requires that magma associated with biotite-hornblende monzogranite exsolve an aqueous phase that would yield alteration assemblages wherein quartz is not stable. A possible type of such quartz-free alteration is $\mathrm{K}$ - or Na-feldspar-rich episyenite (see Evoy, 1961; Moreau and Ranchin, 1973; Leroy, 1978). Such an alteration type is not associated with the breccia pipe of Bluff area. Therefore, another hypothesis or combination of hypotheses that somehow involve magma of the biotite-hornblende monzogranite must be applicable here.

An attractive genetic hypothesis for the origin of the breccia pipe of Bluff area may involve trapping of an aqueous phase in a large bubble beneath an impervious rind and hydraulic fracturing (see Norton and Cathles, 1973; Phillips, 1973), followed by continued migration of fluids into a shattered zone of weakness. Presumably, the aqueous phase must have exsolved from a magma, a conclusion that is supported by the fact that fluids in the veins cogenetic with breccia pipe are high temperature, densely saline, mostly sodium chloride brines.

In the Bluff area, biotite-hornblende monzogranite must have made up the rind or cap that trapped highly saline fluids exsolved from subsequently crystallizing phase(s) of the intrusive body at depth. In support of such a hypothesis is the observation by Johnston and Lowell (1961) that most of the more than 25 breccia pipes in the Copper Basin, Ariz., area crop out along contacts between two or more types of igneous rock. Trapping of this bubble must have been followed by (1) collapse of the bubble due to the large negative $\delta P / \delta T$ ratios in the region where crystals, magma, and aqueous fluid are stable (Norton, 1982); and (2) rise of the collapsed, shattered rubble because its overall density is less than that of the enclosing rocks. Johnston and Lowell (1961) also suggested aqueous fluids from crystallizing magma would tend to accumulate in individual chambers before widespread inward collapse of rocks to form the pipe. Most likely the regional stress field in the Bluff area at the time the breccia pipe reached its currently exposed level was such that minimum compressive stress was oriented northeast-southwest; that is, at nearly right angles to the long axis, in plan, of the breccia pipe. However, the long axis in plan of the breccia pipe in the Copper Flat, N. Mex., porphyry copper system seems to have been parallel to the minimum compressive stress (Dunn, 1982). The proposed model for the origin of the breccia pipe of Bluff area as outlined above still has not accounted for the presence of fragments of chert. The bubble, as envisioned by Norton and Cathles (1973) and Norton (1982), must originally have been confined to the apex of a magma chamber, just below the outer impervious rind. Thus, the major rock type at depth in the general area below the original volume of the bubble must have been intrusive rock. Certainly, it is conceivable that some well-placed xenolithic block of chert belonging to the Scott Canyor Formation may have been incorporated into the breccia pipe as shattering expanded the original volume of the aqueous fluid to include other nearby rocks. But occurrence of such a set of circumstances would be highly fortuitous. It seems more likely that entrainment of chert fragments occurred in response to continued migration of additional fluids from another crystalizing magma into the structurally prepared conduit of breccia pipe previously established by collapse. In contrast to the beliefs of Perry (1961) that all brecciation in such pipes indicates collapse, it appears unequivocal in the Bluff area that chert fragments must have been injected into their present position from well below the present exposures. These chert fragments would thus be termed "hydrothermal intrusion breccias" in the terminology of Bryner (1968) because they would have been emplaced under the agency of hydrothermal fluids. In Chile, Sillitoe and Sawkins (1971) pointed out that upwarddirected emplacement of rock fragments is more closely associated with porphyry copper type of mineralization than with the copper-bearing tourmaline breccia pipes there.

Finally, the mineral potential of the breccia pipe of Bluff area needs to be considered. Quartz-Kfeldspar assemblages in breccia pipes elsewhere are known to include anomalous concentrations of metals. Quartz-K-feldspar assemblages characterize the Paleocene(?) intrusive breccias at Gold Bug Butte and in the Judith Peak-Red Mountain area, northcentral Montana (Lindsey and Fisher, 1985). These particular breccia localities are enriched in $\mathrm{Cu}, \mathrm{Mo}$, $\mathrm{Pb}, \mathrm{Co}, \mathrm{Cr}$, and $\mathrm{Ni}$. However, the $\mathrm{Mg}^{2+} /\left(2 \mathrm{H}^{+}\right)$ratio of the fluids associated with development of alteration assemblages in the Bluff area probably was significantly higher than that at Gold Bug Butte and in the Judith Peak-Red Mountain area, owing to the 
widespread occurrence of tremolite-actinolite and diopside in the assemblages of the Bluff area. Some actinolite-bearing quartz veins of Cretaceous age in the southern Toquima Range, Nev., are associated tetahedrite-tennantite, cinnabar, and stibnite (Shawe, 1986). At the time field work was being conducted, a systematic geochemical study of exposed parts of the breccia pipe seemed beyond the intended major emphasis of this report. Nonetheless, four samples from the zone of quartz stockworks that are adjacent to the breccia pipe were analyzed as part of a comparative study of the geochemistry of rocks close to the most intensely mineralized parts of the Buck-ingham molybdenum system (see subsection below entitled "Lithogeochemistry of Surface Rocks"). These four samples show increased abundances of a few metals: one of the samples includes $380 \mathrm{ppm}$ copper and $12 \mathrm{ppm}$ molybdenum and another $140 \mathrm{ppm}$ zinc. Tungsten contents range from 1.2 to $8.0 \mathrm{ppm}$ in the samples, and gold contents are less than $0.1 \mathrm{ppm}$, the detection limit for this particular group of samples. However, these metal contents may not be representative of the breccia pipe itself. Further geochemical studies of the breccia pipe seem warranted by the striking similarities of the alteration assemblages in the matrix with the assemblages at the copper-bismuth-silver skarn-breccia ore body at the Victoria Mine, Elko County, Nev. (Atkinson and others, 1982). At the Victoria Mine, the ore body is largely in the diopside zone, situated within a breccia pipe near its contact with country rock. Thus, it is conceivable that the diopside zone, which probably becomes the dominant silicate assemblage at depth in the breccia pipe of Bluff area, could contain similar concentrations of metals. Such a geochemical sampling program should focus particularly on the magnetite-rich facies of the breccia pipe, which locally includes magnetite as the supporting mineral to K-feldspar and quartz in the matrix. Similar textural relations are reported by Kerr and others (1950) for the breccia of Whim Hill, Santa Rita, N. Mex. Furthermore, the now-eroded parts of the breccia pipe may have contributed to the concentrations of placer gold in the area of Paiute Gulch, near the north edge of the study area and in the Vail placer (see pl. 1).

\section{PORPHYRITIC LEUCOGRANITE}

Porphyritic leucogranite crops out in variablesize masses of rock across a broad area in the northeast quadrant of the Buckingham area, mostly north-northwest of the Copper Basin Mine (unit Tpl, pl. 1). This porphyritic leucogranite (used in the broad sense) is somewhat unusual in that its dominant primary mafic minerals are clinopyroxene and hornblende, and not biotite and hornblende as is most common in the plutons elsewhere in the mining district (Roberts, 1964; Theodore and others, 1973). Most of the mapped porphyritic leucogranite at the present erosional level occurs in one very large, composite body (pl. 1). This body of rock includes a porphyritic monzogranite and a porphyritic tonalite phase that are not mapped separately on plate 1 but described below; the body measures approximately 500 by $1,200 \mathrm{~m}$ in plan and it is elongated in a N. $45^{\circ} \mathrm{W}$. direction. Typically, across the entire eastern parts of the large body of porphyritic leucogranite, exposures weather to smooth slopes marked by light-yellowish-white to locally grayish-white colors, owing to generally less than 15 color index for the unit (fig. 29A). On the other hand, somewhat coarser grained facies of porphyritic leucogranite weather to a characteristically knobby landscape of blocky, prominent exposures, in places quite angular in outcrop because of the effects of well-developed, widely spaced joints. In addition, porphyritic leucogranite is present at the Labrador Mine, where a small body was outlined at shallow depths below the surface (Schmidt and others, 1988). Porphyritic leucogranite intrudes the Upper Cambrian Harmony Formation, and it also includes as xenoliths fragments of late Eocene or early Oligocene biotite-hornblende monzogranite of Bluff area. Porphyritic leucogranite, as mapped near the east end of the large body, dips northeast and apparently crosscuts a small tabular body of biotite-hornblende monzogranite of Bluff area, which also dips northeast. However, actual contacts between these two units are obscured by colluvium in this general area. Furthermore, near its northwest end, the large body of porphyritic leucogranite is intruded by Oligocene granodiorite porphyry (pl. 1). This granodiorite porphyry includes fragments of the adjoining porphyritic leucogranite showing conclusively thereby that granodiorite porphyry is younger than porphyritic leucogranite. An age determination, shown above, using the K-Ar method on a mineral separate of primary hornblende obtained from the large body of porphyritic leucogranite near its southeast margin yielded an age of $37.9 \mathrm{Ma}$ (fig. 18). Roberts (1964) has described pyroxene-bearing granitic rocks from two other localities in the mining district. The southeastern parts of the Cretaceous granodiorite at Trenton Canyon contain an 

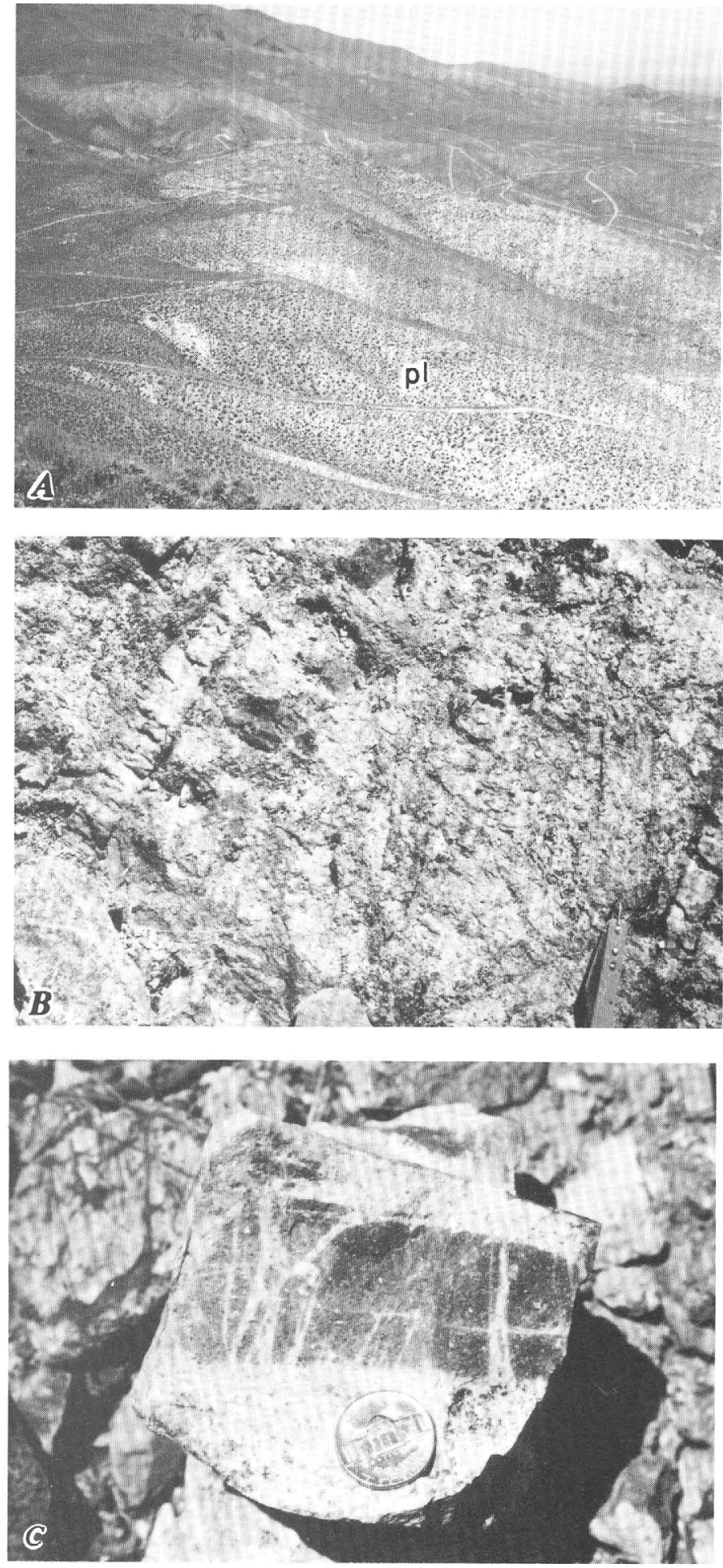

FIGURE 29.-Late Eocene or early Oligocene porphyritic leucogranite. A, Large body of porphyritic leucogranite (pl) that crops out due east of survey marker Bluff. View toward approximately N. $35^{\circ} \mathrm{W}$. from topographic high east of southeast end of body. Bright-white to splotchy-white, smooth, weathered slopes are due to low color index of unit. Note road in lower part of view for scale. $B$, Closeup of porphyritic leucogranite cut by planar, throughgoing veins of quartz. $C$, Closeup of porphyritic leucogranite, showing chilled margins against xenolithic fragments of silty biotite hornfels of the Upper Cambrian Harmony Formation. apparently diopside rich facies, and a small quartz diorite body just east of the Nevada Mine, in the northern part of the Copper Canyon area, also includes some primary pyroxene.

Porphyritic leucogranite, especially the porphyritic leucotonalite phase in the eastern parts of the large exposed body (fig. 30), apparently is associated spatially and possibly genetically with skarn and with well-developed quartz stockworks that formed extensively in rocks of the Harmony Formation north of the Copper Basin Mine (pl. 1). Descriptions of skarn are included in a separate subsection below. Igneous fabric of the large body of porphyritic leucogranite is cut by abundant concentrations of well-developed quartz stockworks near its northwest end, where resistant quartz stockworks give rise to the topographically highest point of the unit (fig. 29A). In addition, the large body of porphyritic leucogranite is cut by mappable quartz stockworks near its easternmost exposures, but the areal extent of the well-developed quartz stockworks is here concentrated mostly in the Harmony Formation. The Harmony Formation in this general area contains abundant quartz veins, which define an umbrellashaped zone, in plan, that is draped around the southeast end of the large body of porphyritic leucogranite. In places, near the southernmost parts of the body, moderate to heavy concentrations of quartz veins also crop out widely enough to be mapped as relatively small, isolated areas within porphyritic leucogranite itself. Here, quartz veins contain minor amounts of pyrite especially along their medial parts, and the veins have thicknesses generally in the size range $0.5-1.0 \mathrm{~cm}$; many individual veins are traceable in outcrop for distances of about 1 to $2 \mathrm{~m}$. The veins are sharp walled, show no selvages at all in outcrop, and are anastomosing; many pinch out in porphyritic leucogranite. However, overall extent of minimal amounts of quartz veins in this general area of the large body of porphyritic leucogranite is more areally extensive than shown on plate 1 . In many places along the contact between porphyritic leucogranite and dense biotite hornfels of the Harmony Formation, a zone of sparsely developed quartz veins, not shown on the map, extends for about 25 to $30 \mathrm{~cm}$ into porphyritic leucogranite. Some of these quartz veins locally include approximately 1 volume percent iron oxide(s) replacing pyrite, and the veins cut a markedly sucrose-textured groundmass that is tinged green by finely dispersed epidote. A few quartz-K-feldspar veins that cut porphyritic leucogranite near the center of the umbrella-shaped area veined by quartz (pl. 1) also include very small, irregular crystals of garnet that replace, in part, earlier-crystallized plagioclase. Nonetheless, porphyritic leucogranite that 
crops out northeast of the Bailey Day Mine is chilled against skarn. Therefore, skarn-forming fluids that apparently were associated with emplacement of porphyritic leucogranite circulated through these rocks both before and after porphyritic leucogranite was emplaced. At Copper Canyon, altered granodiorite apparently also reached associated skarn in the West ore body after andraditediopside-rich stages of the skarn had already crystallized (Theodore and Blake, 1978).

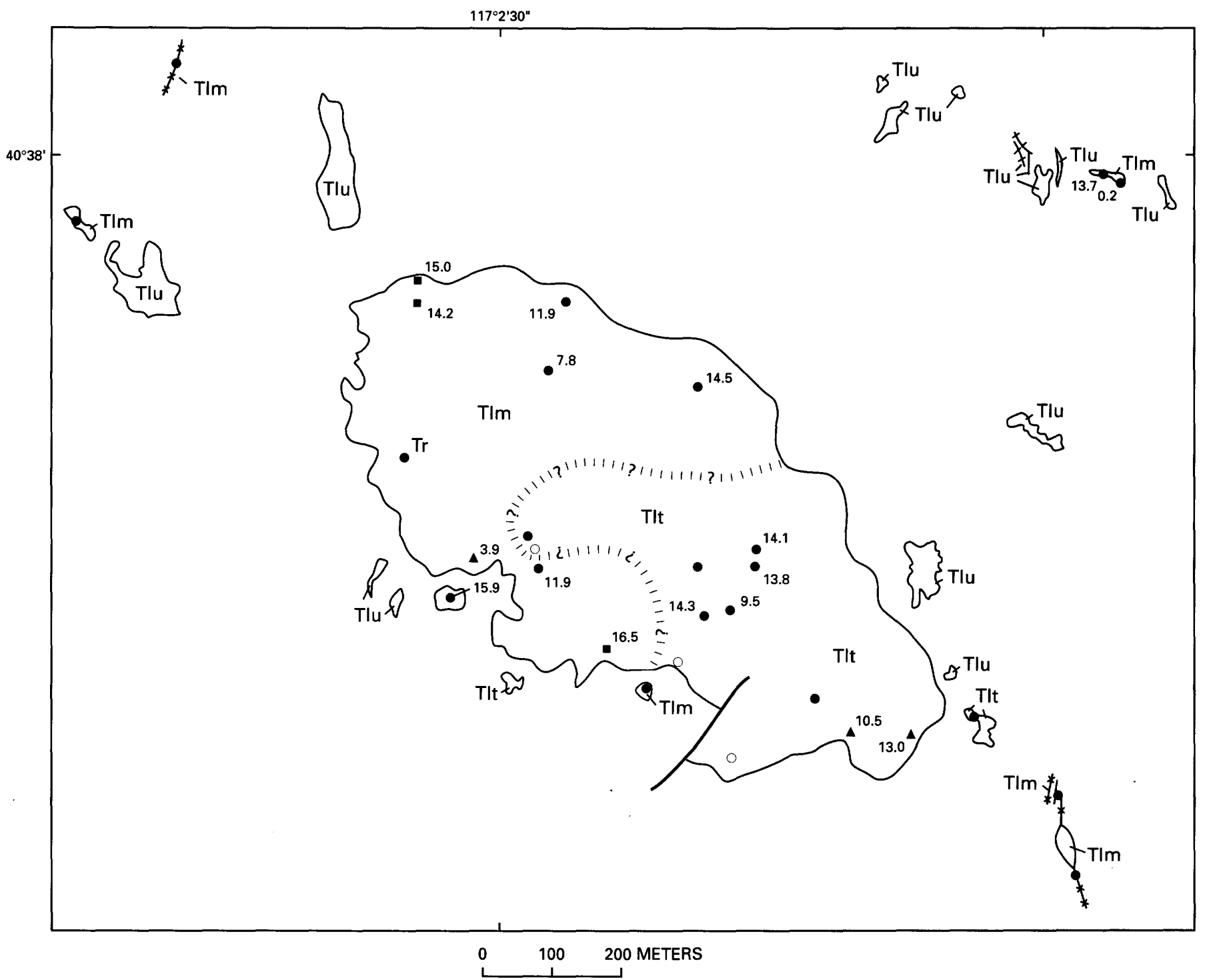

\section{EXPLANATION}

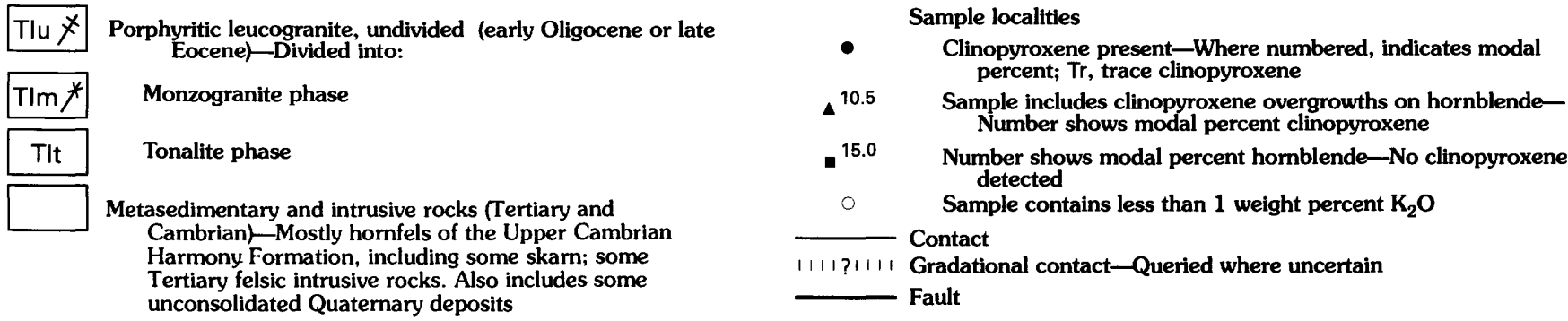

FIGURE 30.-Distribution of porphyritic monzogranite and porphyritic tonalite phases and of clinopyroxene contents in samples of thin-sectioned porphyritic leucogranite analyzed modally from Buckingham area. Geology modified from plate 1. 
TABLE 7.-Modal data on late Eocene or early Oligocene porphyritic leucogranite of the Buckingham area

[All values in volume percent. tr, trace; - , not detected; n.d., not determined]

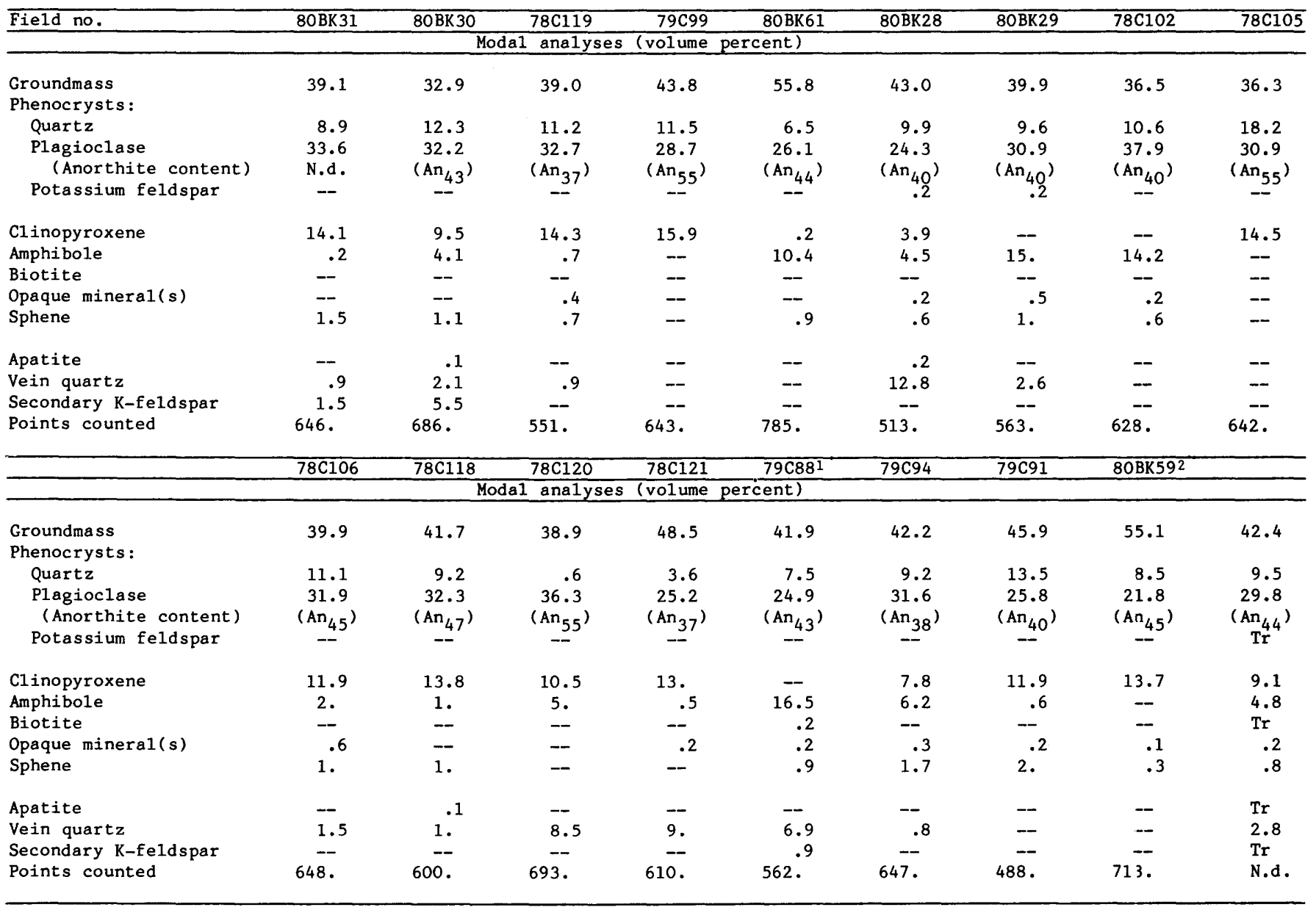

1 Includes 0.2 volume percent secondary calcite.

2 Includes 0.3 volume percent secondary calcite.

\section{PETROGRAPHY}

Porphyritic leucogranite of the Buckingham area appears in outcrop to be a rather homogeneous, grayish-white to light-gray, clinopyroxene- and (or) hornblende-bearing rock that contains minor modal variations in its overall phenocrystic composition. Although no contacts internal to the largest body of the map unit were found in the field, petrographic examination of approximately 25 thin sections and modal analyses of 17 samples of the porphyritic leucogranite revealed a composite aspect of the unit (fig. 30; table 7). A subtle, composite feature of the porphyritic leucogranite is reflected by its areally distinct, wide-ranging ratios of apparently primary K-feldspar to primary plagi- oclase, either oligoclase or albite, in its groundmass. Both facies of the porphyritic leucogranite, the porphyritic monzogranite and the porphyritic tonalite, show a quench-textured groundmass that is $\mathrm{K}$-feldspar and plagioclase rich, respectively. On the one hand, K-feldspar phenocrysts, in fact, make up only 0.2 volume percent of 2 of 17 samples of the porphyritic leucogranite analyzed modally (table 7). On the other hand, assignment of all $\mathrm{K}_{2} \mathrm{O}$ to modal $\mathrm{K}$-feldspar in representative samples of the chemically analyzed, K-feldspar-rich monzogranite phase from the western parts of the large body suggests that such rocks would include about 20 volume percent $\mathrm{K}$-feldspar. Reproducible point counts could not be obtained internally from the fine-grained, 0.03 - to $0.04-\mathrm{mm}$ groundmass of these 


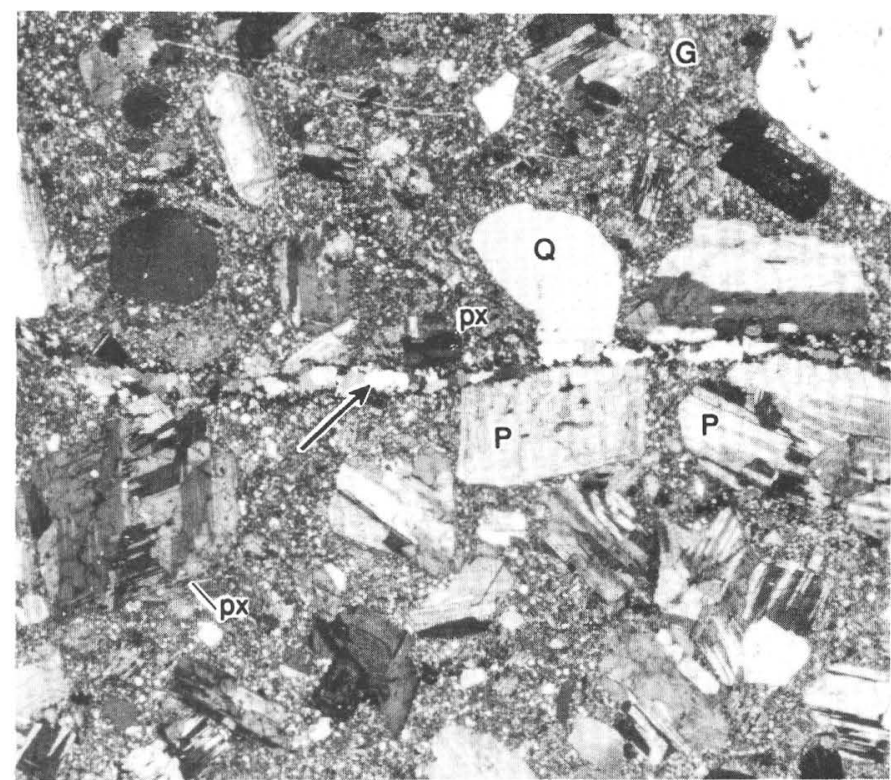

$\boldsymbol{A}$ 0 4 MILLIMETERS

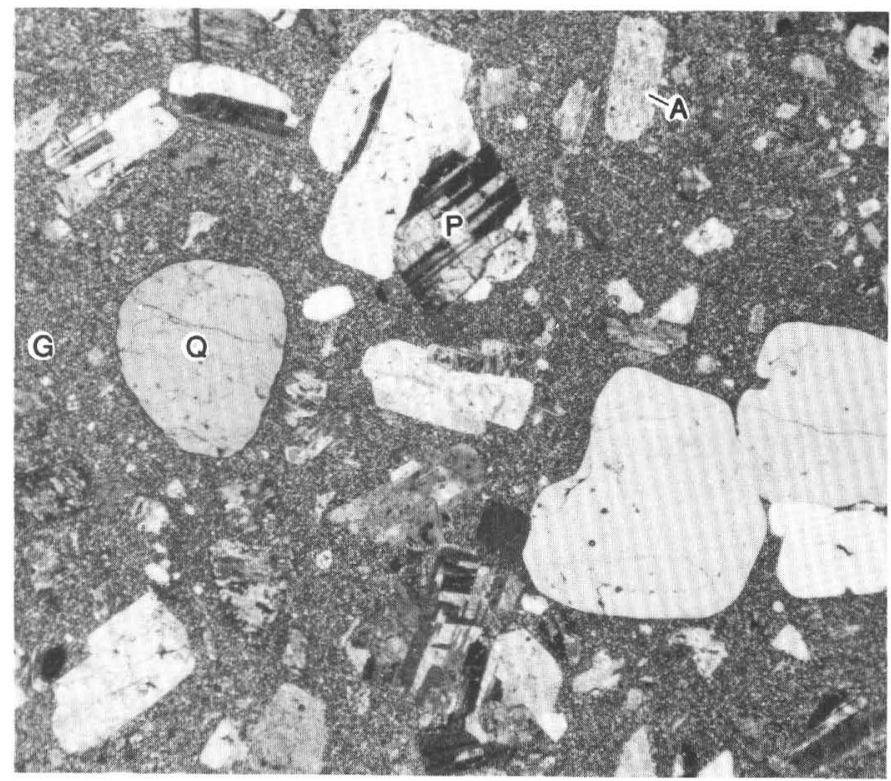

$\boldsymbol{B}$

4 MILLIMETERS

FIGURE 31.-Photomicrographs showing textural relations in porphyritic leucogranite of Buckingham area. A, Overall fabric of representative sample of leucotonalite phase including an albite-rich groundmass (G). P, plagioclase; $Q$, quartz; px, clinopyroxene. Quartz-K-feldspar veinlet at head of arrow. Crossed nicols. Sample 80BK31 (analysis 1, tables 7, 8). B, Fabric of representative sample of porphyritic monzogranite phase including primary $\mathrm{K}$-feldspar-rich groundmass (G). P, plagioclase; Q, quartz; A, primary amphibole. Crossed nicols. Sample

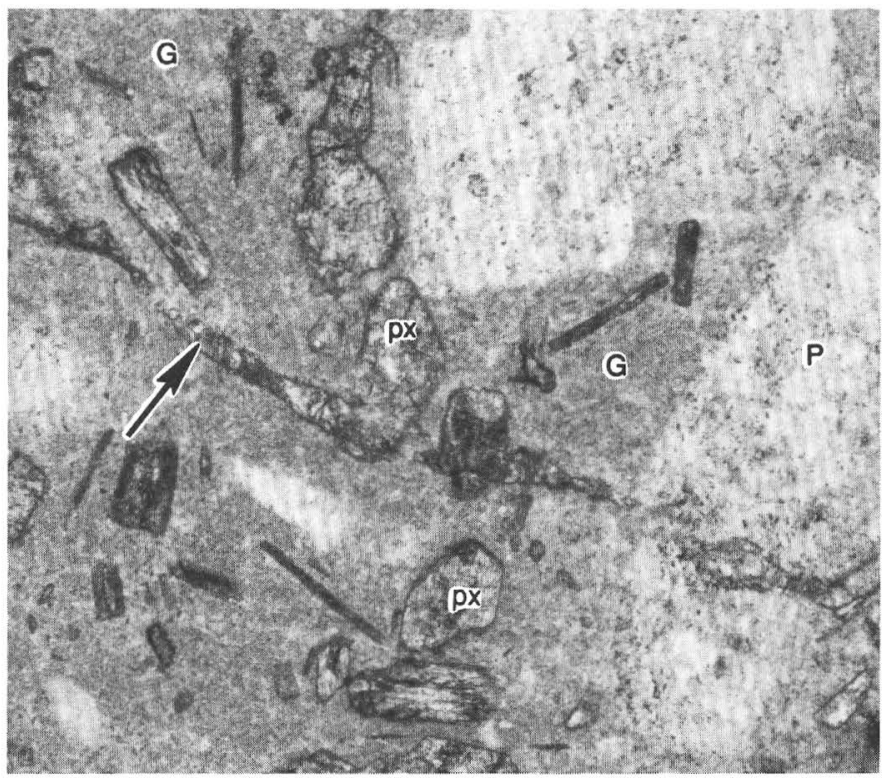

\section{C}

0

0.8 MILLIMETER

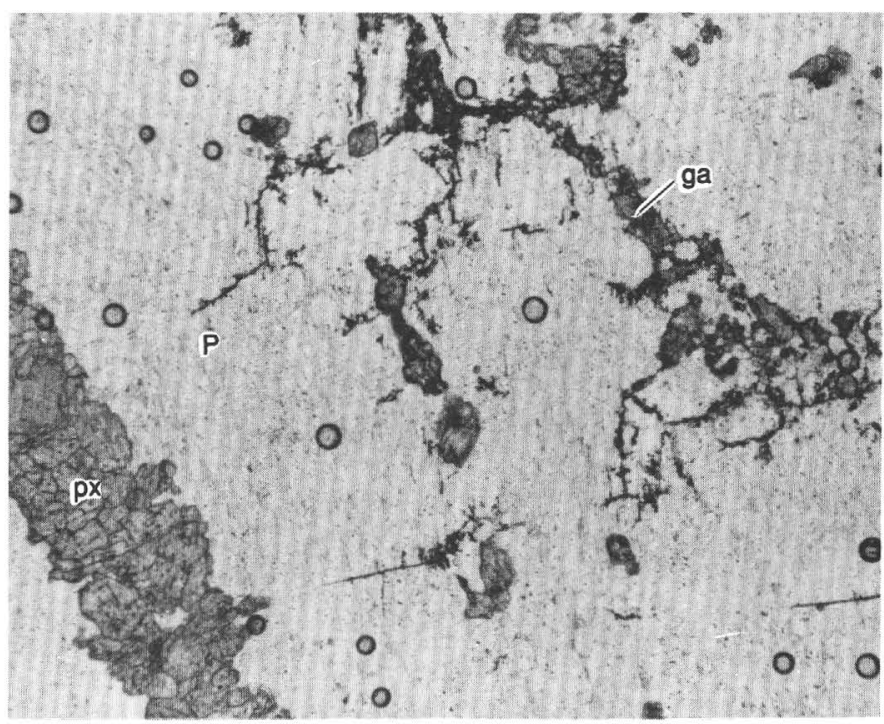

$\boldsymbol{D}$

0

0.6 MILLIMETER

80BK61 (analysis 5, tables 7, 8). C, Hairline microveinlet of clinopyroxene at head of arrow cutting phenocrysts of clinopyroxene (px), plagioclase (P), and K-feldspar-rich groundmass $(G)$ of sample of narrow dike of porphyritic leucogranite near southeast corner of its mapped extent (fig. 30). Plane-polarized light. Sample 80 BK59 (analysis 17, table 7). $D$, Microveinlet of clinopyroxene $(\mathrm{px})$ cutting large, strained phenocryst of plagioclase $(\mathrm{P})$, which is also cut by short, discontinuous microveinlets of garnet (ga). Sample 78C129. 
rocks because of inadequate staining. Thus, modal data of table 7 are not shown on a ternary quartzplagioclase-K-feldspar plot.

In thin section, the porphyritic leucogranite shows a rather uniform porphyritic fabric in its porphyritic tonalite phase (the eastern part of the large body; fig. $31 A$ ), and in its porphyritic monzogranite phase (fig. 31B). Typically in the eastern one-half of the large body of the map unit, euhedral laths of fresh, oscillatory-zoned plagioclase (as calcic as labradorite, $\mathrm{An}_{55}$, but more typically ande-
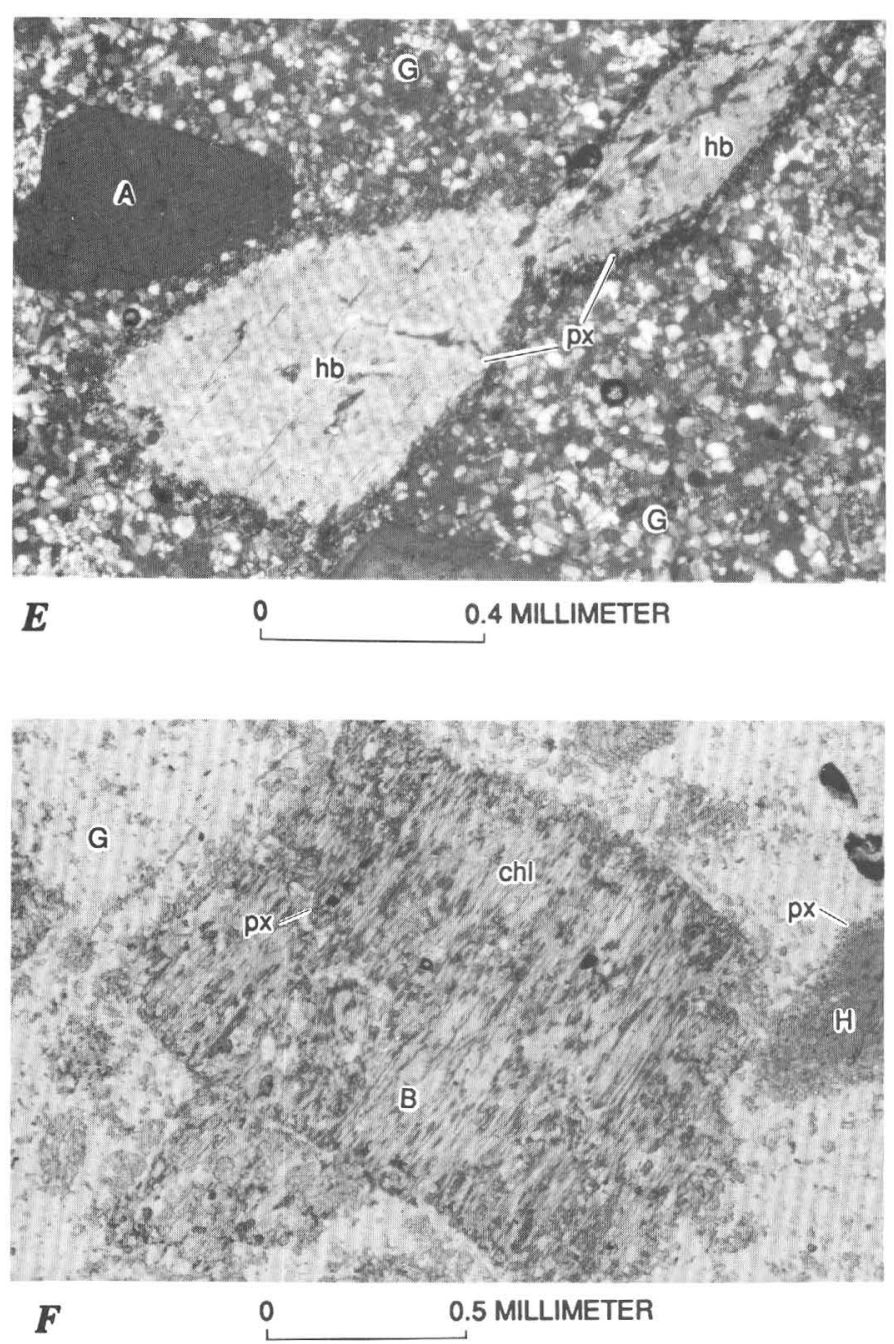

Figure 31.-Continued. E, Phenocryst of hornblende (hb) replaced along its margins by clinopyroxene (px), which also occurs as finely dispersed crystals in an oligoclase-dominant, microaplitic groundmass $(G)$ that also contains quartz, apatite (A), and minor alkali feldspar. Plane-polarized light. Sample 78C120. $F$, Relict phenocryst of probably biotite (B), showing almost complete replacement by clinopyroxene (px) and chlorite (chl), set in a microaplitic groundmass $(G)$ of mostly oligoclase. Some hornblende $(\mathrm{H})$ mantled by clinopyroxene is also in field of view. Plane-polarized light. Sample 78C120. sine, $\mathrm{An}_{45}-\mathrm{An}_{55}$ ) and square-sectioned bipyramids of phenocrystic quartz make up about 40 volume percent of the rocks and are set in a groundmass of mostly oligoclase or albite and quartz. The groundmass may form anywhere from about 30 to 40 volume percent of the rock as a whole (table 7). Clinopyroxene, most likely diopside rich, is the predominant mafic mineral in the porphyritic leucotonalite, where diopside is present in concentrations of about 14 volume percent. Mineralchemistry study of phenocrysts of clinopyroxene and clinopyroxene in the groundmass from a selected sample of the porphyritic leucotonalite indicates that clinopyroxene phenocrysts contain copious amounts of diopside $\left(\mathrm{Wo}_{51.1} \mathrm{En}_{48.1} \mathrm{Fs}_{0.79}\right.$; Theodore and Hammarstrom, 1991; see below). In contrast, clinopyroxene in the groundmass of the porphyritic leucotonalite is enriched in iron, sodium, and manganese and depleted in magnesium and calcium relative to the phenocrysts of clinopyroxene. Clinopyroxene also is present in the porphyritic monzogranite phase of the porphyritic leucogranite; it was found to make up about 16 volume percent of the rocks there. However, there is an especially wide-ranging variation in the ratio of augite to hornblende and (or) actinolite in the porphyritic monzogranite phase, wherein some rocks contain only hornblende and (or) secondary actinolite, also as much as about 16 volume percent (table 7 ), as the only mafic mineral.

It is important to emphasize that coarsely crystalline phenocrysts of diopside are distributed widely throughout the porphyritic leucogranite. The phenocrysts of diopside are either coherent and intact monocrystals, or they are skeletal with respect to either the plagioclase-rich or the $\mathrm{K}$-feldspar-rich groundmass, showing blebby intergrowths with the minerals of the groundmass. In addition, the hypersolidus crystallization of diopside in the porphyritic leucogranite of the Buckingham area is manifested by the presence of stoutly crystalline, euhedral inclusions of diopside in cores of some unaltered phenocrysts of plagioclase, and by occurrence of similar-shaped crystals of diopside within bipyramidal phenocrysts of quartz. Phenocrystic diopside must be one of the earlycrystallized minerals from the magma of the porphyritic leucogranite. Accessory sphene, apatite, and zircon, listed in order of overall decreasing abundances, also appear to be early-formed minerals. The fact that crystals of clinopyroxene apparently are not concentrated near margins of the large body (fig. 30) suggests thereby that assimilation of calcium from country rock at the present 
erosional level cannot have contributed significantly to the development of diopside in these rocks. Roberts (1964) concluded that a pyroxenebearing facies of the granodiorite of Trenton Canyon may have resulted from contamination of its magma by calcareous rocks in the adjoining Havallah sequence. Nor is the large composite body of porphyritic leucogranite zoned such that it shows margins more mafic than its core, owing to the presence of increased abundance of both diopside and hornblende. In fact, this body may be interpreted as being reversely zoned. Furthermore, where granodioritic rocks elsewhere immediately adjacent to calcareous rocks have been examined carefully for the effects of assimilation of calcium (pyroxene replacing hornblende and (or) biotite near the margins), such phenomena have been documented to extend only on the order of centimeters (Taylor, 1976). The development of grossularite- and clinopyroxene-bearing endoskarn in porphyry adjacent to skarn associated with porphyry copper systems also extends only on the order of centimeters, at most $1 \mathrm{~m}$, into the porphyry (Einaudi, 1982b). Another aspect of the study by Taylor (1976), using analysis of variance statistical methods to evaluate large-scale variations within a granite pluton in Peru, revealed that the effects of contamination by wallrocks there was subordinate to that resulting from differentiation.

The porphyritic leucogranite also contains clinopyroxene that is present in two other textural modes. The first, less common variety, which is an alteration phenomenon, consists of occurrences of fine-grained crystals of clinopyroxene in monomineralic, hairlike microveinlets that cut the igneous fabric of the porphyritic leucogranite (figs. 31C, $31 D$ ). Samples containing clinopyroxene of this type include either an albite-rich or a K-feldsparrich groundmass. Such vein-type clinopyroxene is present in dikes that crop out near the southeast corner of the large body of leucogranite, well within the umbrella-shaped area, in plan, that is underlain by well-developed quartz stockworks. This vein-type clinopyroxene must have crystallized in a nearly magmatic, subsolidus alteration environment wherein plagioclase and K-feldspar were stable and the porphyritic leucogranite could sustain brittle fracture. The areal extent of such an alteration has not been documented, but temporally it must closely correspond to development of extensive zones of garnet-clinopyroxene or skarn in nearby rocks of the Harmony Formation (pl. 1). Some microveinlets of clinopyroxene are also related to microveins of garnet, either as nearby, in thin section, monomineralic veins that cut phenocrysts of plagioclase or as selvages along mostly quartz bearing veins (fig. $31 D$ ). On the one hand, these relations establish conclusively the genetic and temporal relation between most of the widespread skarn in the rocks of the Harmony Formation here and the late Eocene or early Oligocene porphyritic tonalite phase of the porphyritic leucogranite. On the other hand, this rare fracturecontrolled alteration by clinopyroxene and garnet might be termed "endoskarn" by others and thus reflect substantial local migration of elements $(\mathrm{Ca}$, $\mathrm{Mg}, \mathrm{Fe}, \mathrm{Al}$ ) across a magmatic-metasedimentary interface. We do not have the textural and chemical data to substantiate such an interpretation. However, we prefer to restrict the term "endoskarn" to igneous rock that has had significant proportions of magmatic hornblende and (or) biotite replaced largely by a dense mat of fine-grained crystals of clinopyroxene. The fracture-controlled clinopyroxene and garnet alteration of the porphyritic leucogranite might correspond closely to an apparently deep-seated, centrally located pyroxene alteration, somewhat similar to that described at the Koloula igneous complex, Guadalcanal (Chivas, 1978), or to the pyroxene alteration associated with many nonporphyry related, copper skarns (Einaudi and others, 1981; Cox and Singer, 1986). Nonetheless, as will be described below, endoskarn is present near the margins of some small masses of diabase that crop out southeast of the large body of porphyritic leucogranite.

The final variety of clinopyroxene recognized in the porphyritic leucogranite involves several widespread occurrences wherein fine-grained crystals of clinopyroxene either partly replace phenocrysts of hornblende (blue green, optic Z-axis) or diopside along its margins, almost completely replace rare phenocrysts of biotite there, or occur as finely dispersed crystals in groundmass (figs. $31 E, 31 F$ ). Mineral-chemistry study of these fine-grained crystals of clinopyroxene that are present as reaction rims on large phenocrysts of hornblende indicates that the clinopyroxene has a salite composition (typical composition, $\mathrm{Wo}_{50.5} \mathrm{En}_{38.8} \mathrm{Fs}_{10.8}$; Theodore and Hammarstrom, 1991; see below). A thorough search under the microscope of all thin-sectioned samples of the porphyritic leucogranite revealed that the described transition to clinopyroxene stability from a primary hornblende and a primary biotite stability must have occurred probably very rapidly at the time "quenched" groundmass crystallized initially. Texturally, documentation of such a hydrous to anhydrous transition is preserved best 
in the porphyritic tonalite phase of the large body of porphyritic leucogranite (fig. 30). Euhedral crystals of hornblende (deep blue green, optic Z-axis), as long as $0.15 \mathrm{~mm}$, are trapped as inclusions within $0.2 \mathrm{~mm}$ of the edges of some unaltered laths of calcic andesine. However, the adjoining primary groundmass, which is in places very oligoclase rich, shows an apparently stable compatibility among the anhydrous minerals clinopyroxene, oligoclase, and quartz. Reaction rims of pyroxene around phenocrysts of thornblende in volcanic rocks elsewhere indicate the instability of the hornblende in either lower pressure or higher temperature environments(s) (Carmichael and others, 1974). The genetic implications of the crystallization of these late-stage, magmatic anhydrous assemblages relative to the generation of fluids associated with the development of garnet-pyroxene alteration in the country rock of the porphyritic leucogranite is discussed below. The textural relation wherein granules of clinopyroxene mantle much larger crystals of igneous amphibole in a granitoid also has been reported elsewhere in a geologic setting that includes development of extensive skarn. Lee (1951) described such relations in the Nickel Plate Mountain area of British Columbia that has some gold-skarn deposits (Orris and others, 1987; Theodore and others, 1991). Lee (1951) stated:

\footnotetext{
*** Reaction rims of fine granular augite on the hornblende show clearly that the amphibole had been dissolved and that corresponding amounts of the pyroxene had been precipitated from the magma....It is noteworthy that magmatic transformation of amphibole to pyroxene usually gives fuzzy reaction rims of randomly oriented granules of augite, whereas transformation of augite to amphibole more often results in rims that are optically continuous with the pyroxene core $* * *$.
}

In porphyritic leucogranite of the Buckingham area, some of the granules of clinopyroxene that mantle the hornblende crystals are optically continuous with one another, but not optically continuous with hornblende. Although Lee (1951) ascribed these relations to magmatic phenomena at Nickel Plate, their genesis in the Buckingham area seems to be related to late-stage magmatic processes (see section below entitled "Mineral Chemistry of Late Cretaceous and Tertiary Skarns") that occurred after crystallization of the porphyritic leucogranite to the point that it could sustain brittle fracture. This conclusion is based on the fact that some of these grains of clinopyroxene are confined to small microveinlets. Previously, Dol- mage and Brown (1945) had ascribed the replacement of primary hornblende, primary augite, and primary plagioclase by colorless augite to secondary, late-stage magmatic processes at Nickel Plate Mountain. Nonetheless, whatever their origin, whether owing to major changes in pressure or temperature, the hornblende-to-clinopyroxene transition in the magmas of the porphyritic leucogranite at Buckingham seems to correspond to circulation of fluids associated with skarn genesis in the adjoining rocks of the Harmony Formation.

The porphyritic leucogranite also contains some secondary amphibole. Most of the secondary amphibole is vein related and is present together with quartz, K-feldspar, and minor amounts of secondary sphene. However, some phenocrysts of quartz are mantled by thin rims of amphibole. In addition, some samples of the porphyritic leucogranite contain small domains of their groundmass, generally $\mathrm{K}$-feldspar rich, that include finely dispersed needles of amphibole. The generally minor amounts of secondary $\mathrm{K}$-feldspar, particularly in the porphyritic tonalite phase of the leucogranite, may be related to emplacement of the porphyritic monzogranite phase.

Several healed contacts between porphyritic leucogranite and metamorphosed rocks of the Harmony Formation were examined microscopically, as were a few rocks of the Harmony Formation in the immediate area of the porphyritic leucogranite. Although actual contacts in outcrop between the contrasting lithologies of the porphyritic leucogranite and the Harmony Formation apparently are quite sharp (fig. 29C), microscopic examination of these contacts reveals that on a scale of several millimeters or less the contacts are diffuse. The matrix of gritty subarkose of the Harmony Formation within a few millimeters of the contact is replaced by $\mathrm{K}$-feldspar that now includes sporadic, newly crystallized prisms of clinopyroxene, some of which are localized within framework grains of monocrystalline quartz (fig. 32A). The actual contact between metasedimentary rocks and porphyritic leucogranite is marked by a highly irregularly bounded, anastomosing mat of very finely crystalline clinopyroxene, together with some coarser crystals of plagioclase. Sparse garnet occurs in what appears to be an open-space-filling texture slightly "behind" the clinopyroxene-plagioclase front. Elsewhere along the contact between porphyritic leucogranite and pelitic, shaly parts of the Harmony Formation, the metasedimentary assemblage is biotite-andalusite-quartz (fig. 32B). 


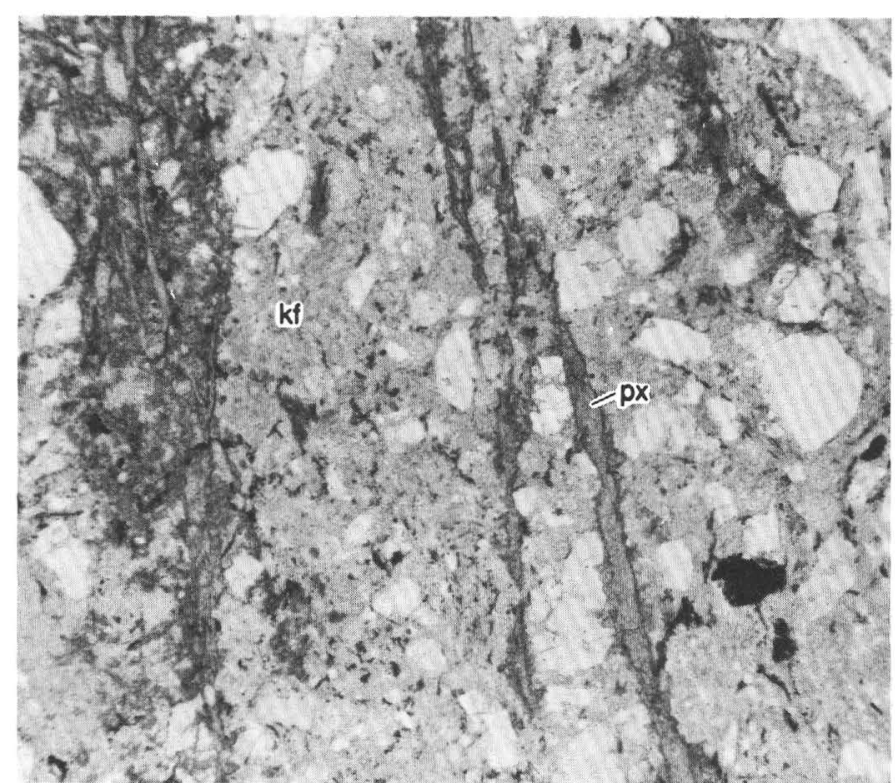

$\boldsymbol{A}$ 0 0.8 MILIMETER

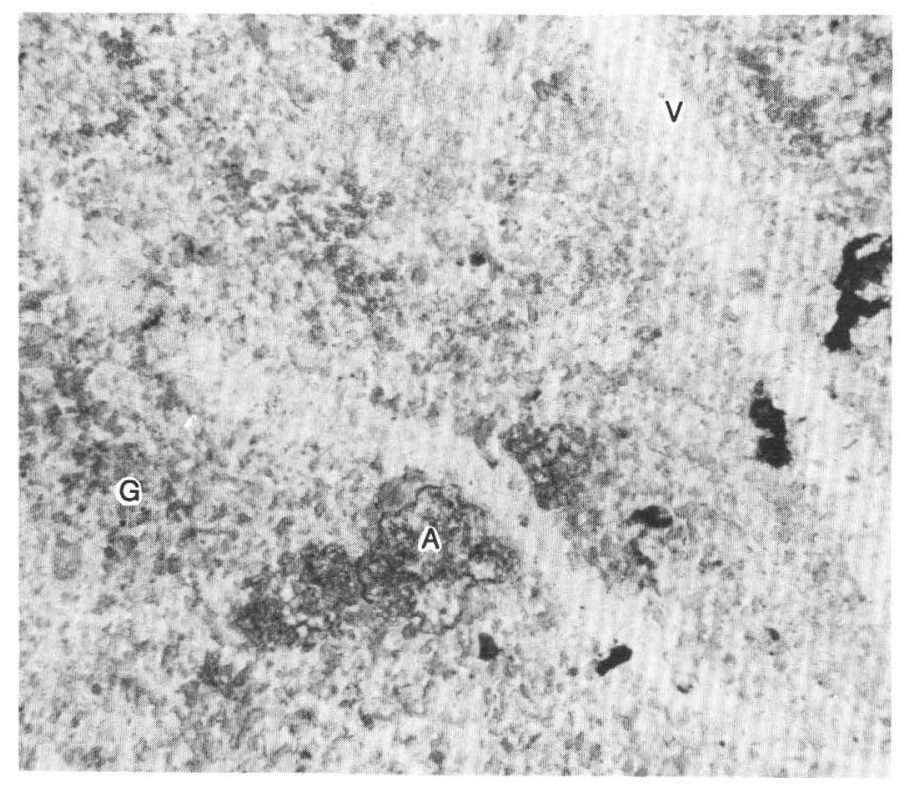
$\boldsymbol{B}$ 0.5 MILLIMETER

FIGURE 32.-Photomicrographs showing textural relations at or near contact between late Eocene or early Oligocene porphyritic leucogranite and the Upper Cambrian Harmony Formation. $A$, Matrix of subarkose of the Harmony flooded by K-feldspar (kf) and, in turn, microveined by clinopyroxene (px). Planepolarized light. Sample 80BK60. B, Microporphyroblasts of andalusite (A) set in a finely crystalline groundmass (G) of mostly biotite and quartz. Some quartz-K-feldspar biotite veins (V) also shown. Plane-polarized light. Sample 78C103.
CHEMISTRY

Chemically analyzed samples from porphyritic leucogranite include three samples from the porphyritic tonalite phase (analyses $1-3$, table 8 ), a sample showing a moderate degree of alteration by secondary K-feldspar (analysis 4), and three samples from the porphyritic monzogranite phase (analyses 5-7). As described above, modal $\mathrm{K}$-feldspar is almost totally non-existent as a phenocryst in the porphyritic tonalite phase. Major-element analyses of samples from the porphyritic tonalite phase are generally similar to that of the average tonalite of Nockolds (1954) but markedly different from that of the average tonalite of LeMaitre (1976) - both listed in table 8 for comparative purposes. The major differences include: (1) higher $\mathrm{SiO}_{2}$ content in porphyritic tonalite-68.2 weight percent, compared with 66.15 and 61.52 weight percent for the average tonalite of Nockolds (1954) and LeMaitre (1976), respectively; (2) lower $\mathrm{FeO}$ content-about 0.6 weight percent, compared with approximately 3.6 weight percent; (3) higher $\mathrm{CaO}$ content-about 7.5 weight percent, compared with about 5.0 weight percent; and (4) certainly much lower $\mathrm{K}_{2} \mathrm{O}$ content in the porphyritic tonalite phase-about 0.6 weight percent, compared with more than 1.4 weight percent. The higher $\mathrm{SiO}_{2}$ contents of these samples may indicate the inadvertent incorporation of some vein quartz in the materials submitted for analysis. Certainly, modal analyses of thin sections show the widespread presence of vein quartz in rocks from this map unit. However, the range in $\mathrm{SiO}_{2}$ content for the three samples of porphyritic tonalite phase is relatively restricted, from 68.0 to 68.4 weight percent (table 8), and thus free of the scatter in values that might be expected if secondarily introduced quartz were important.

Additional insight into the apparent effects of subsolidus alteration of the porphyritic leucogranite unit as a whole is evident in various relations of its alkali contents determined for these analyzed samples. Total alkalis $\left(\mathrm{K}_{2} \mathrm{O}+\mathrm{Na}_{2} \mathrm{O}\right)$ range from 4.01 to 4.46 weight percent for analyzed samples representative of the porphyritic tonalite phase (table 8). The marked bimodality of the essentially two phases of the porphyritic leucogranite unit is emphasized in a plot of $\mathrm{K}_{2} \mathrm{O} / \mathrm{Na}_{2} \mathrm{O}$ ratio versus $\mathrm{SiO}_{2}$ content for the available data (fig. 24). Although data from samples of the porphyritic tonalite phase cluster somewhat tightly in the tonalite field of Mason (1978), the increased 
[Chemical analyses in weight percent by X-ray spectroscopy supplemented by classical methods; analysts, A. Bartel, J.S. Wahlberg, J. Taggart, and J. Baker. Optical-spectroscopic analyses in parts per million by inductively coupled plasmas methods of Scott and Kokot (1975) and F.E. Lichte (unpub. data, 1983); analyst, P. Briggs. Cross, Iddings, Pirsson, and Washington (CIPW) norms in weight percent. Looked for, but not found, at partsdetermined colorimetrically; analysts, R. Moore and $\mathrm{Z}$. Hamlin. Nb and Rb determined by X-ray spectroscopy; analysts, R. Johnson, H.J. Rose, B. McCall, G. Sellers, and J. Lindsay. - - not detected; n.d., not determined

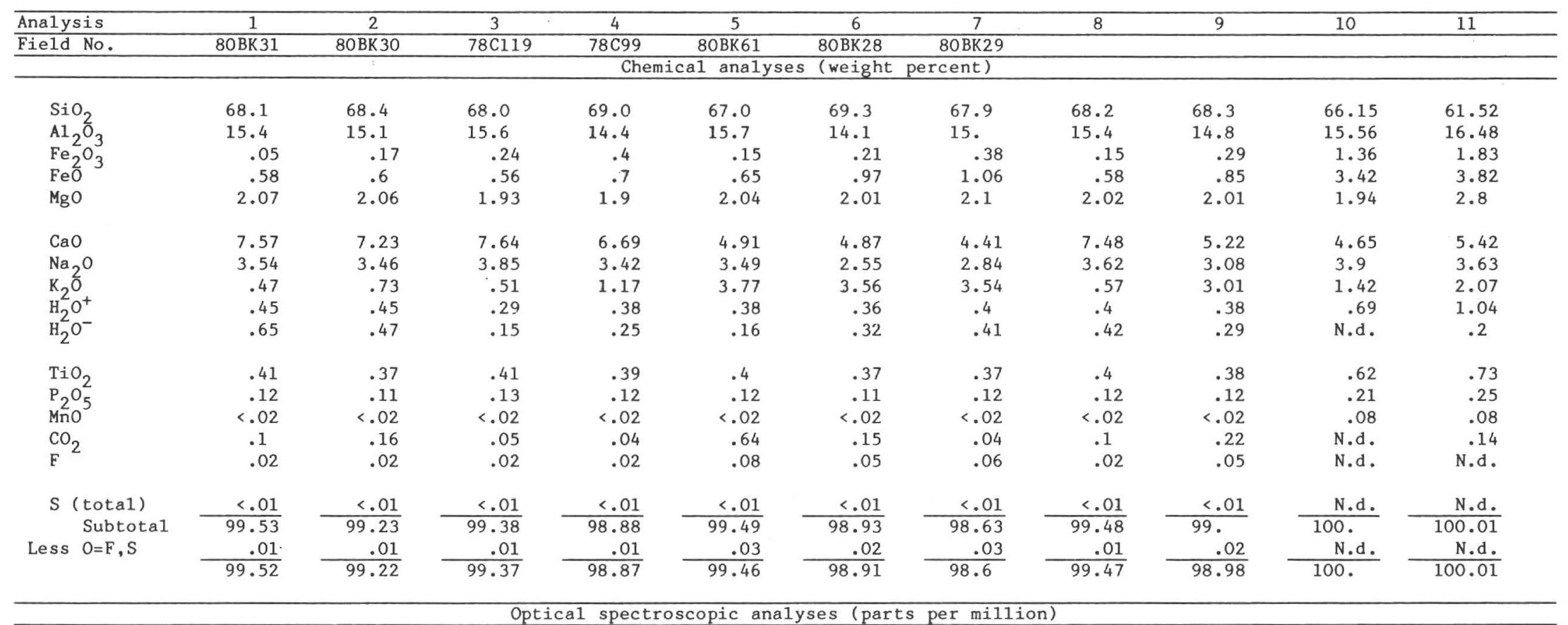

\begin{tabular}{|c|c|c|c|c|c|c|c|c|c|c|c|}
\hline \multicolumn{12}{|c|}{ Optica1 spectroscopic analyses (parts per million) } \\
\hline As & -- & -- & -- & 20.0 & -- & -- & -- & N.d. & N.d. & N.d. & N.d. \\
\hline $\mathrm{Ba}$ & 190.0 & 200.0 & 170.0 & 250. & 960.0 & 890.0 & 1000.0 & N.d. & N.d. & N.d. & N.d. \\
\hline $\mathrm{Be}$ & 2. & 2. & 2. & 2. & 2. & 2. & 2. & N.d. & N.d. & N.d. & N.d. \\
\hline $\mathrm{Ce}$ & 8. & 14. & 8. & 19. & 15. & 25. & 29. & N.d. & N.d. & N.d. & N.d. \\
\hline Co & - & - & -- & 2. & 2. & 2. & 3. & N.d. & N.d. & N.d. & N.d. \\
\hline $\mathrm{Cr}$ & 52. & 71. & 47. & 48. & 70. & 63. & 49. & N.d. & N.d. & N.d. & N.d. \\
\hline $\mathrm{Cu}$ & 52. & 62. & 37. & 48. & - & 90. & 83. & N.d. & N.d. & N.d. & N.d. \\
\hline $\mathrm{Ga}$ & 19. & 19. & 19. & 19. & 20. & 20. & 21. & N.d. & N.d. & N.d. & N.d. \\
\hline $\mathrm{La}$ & 7. & 7. & 6. & 9. & 9. & 13. & 17. & N.d. & N.d. & N.d. & N.d. \\
\hline $\mathrm{Li}$ & 11. & 7. & 5. & 8. & 7. & 5. & 7. & N.d. & N.d. & N.d. & N.d. \\
\hline Mn & 140. & 160. & 160. & 220 & 190. & 190. & 180. & N.d. & N.d. & N.d. & N.d. \\
\hline Mo & - & 20. & -- & -- & -- & 2. & -- & N.d. & N.d. & N.d. & N.d. \\
\hline $\mathrm{Nb}$ & 7. & 6. & 7. & 8. & 8. & 7. & 6. & N.d. & N.d. & N.d. & N.d. \\
\hline $\mathrm{Ni}$ & 10. & 6. & 5. & 12. & 15. & 16. & 15. & N.d. & N.d. & N.d. & N.d. \\
\hline $\mathrm{Pb}$ & 12. & 13. & 13. & 11. & 19. & 14. & 12. & N.d. & N.d. & N.d. & N.d. \\
\hline $\mathrm{Sc}$ & 8. & 9. & 9. & 9. & 10. & 10. & 10. & N.d. & N.d. & N.d. & N.d. \\
\hline $\mathrm{Sr}$ & 590. & 570. & 590. & 560. & 530. & 540. & 580. & N.d. & N.d. & N.d. & N.d. \\
\hline
\end{tabular}




\begin{tabular}{|c|c|c|c|c|c|c|c|c|c|c|c|}
\hline $\begin{array}{l}\text { Th } \\
\text { V } \\
\text { Y }\end{array}$ & $\begin{array}{c}7 . \\
51 \\
13 .\end{array}$ & $\begin{array}{l}7 . \\
51 . \\
12 .\end{array}$ & $\begin{array}{l}8 . \\
57 \\
12 .\end{array}$ & $\begin{array}{l}8 . \\
54 . \\
11 .\end{array}$ & $\begin{array}{c}7 . \\
54 . \\
13 .\end{array}$ & $\begin{array}{r}8 . \\
57 \\
13\end{array}$ & $\begin{array}{r}8 . \\
55 . \\
13 .\end{array}$ & $\begin{array}{l}\text { N.d. } \\
\text { N.d. } \\
\text { N.d. }\end{array}$ & $\begin{array}{l}\text { N.d. } \\
\text { N.d. } \\
\text { N.d. }\end{array}$ & $\begin{array}{l}\text { N.d. } \\
\text { N.d. } \\
\text { N.d, }\end{array}$ & $\begin{array}{l}\text { N.d. } \\
\text { N.d. } \\
\text { N.d. }\end{array}$ \\
\hline $\begin{array}{l}\mathrm{Zn} \\
\mathrm{Nd} \\
\mathrm{Yb}\end{array}$ & $\begin{array}{r}-- \\
10 . \\
1 .\end{array}$ & $\begin{array}{c}15 . \\
11 . \\
1 .\end{array}$ & $\begin{array}{c}16 \\
10 \\
1\end{array}$ & $\begin{array}{r}17 . \\
14 . \\
--\end{array}$ & $\begin{array}{r}61 . \\
11 . \\
1 .\end{array}$ & $\begin{array}{c}12 . \\
15 . \\
1 .\end{array}$ & $\begin{array}{r}26 \\
15 \\
1 .\end{array}$ & $\begin{array}{l}\text { N.d. } \\
\text { N.d. } \\
\text { N.d. }\end{array}$ & $\begin{array}{l}\text { N.d. } \\
\text { N.d. } \\
\text { N.d. }\end{array}$ & $\begin{array}{l}\text { N.d. } \\
\text { N.d. } \\
\text { N.d. }\end{array}$ & $\begin{array}{l}\text { N.d. } \\
\text { N.d. } \\
\text { N.d. }\end{array}$ \\
\hline \multicolumn{12}{|c|}{ Chemical analyses (parts per million) } \\
\hline $\begin{array}{l}\mathrm{Au} \\
\mathrm{Nb} \\
\mathrm{Rb} \\
\mathrm{W}\end{array}$ & $\begin{array}{c}<0.05 \\
11 . \\
20 . \\
.7\end{array}$ & $\begin{array}{c}<0.05 \\
9 . \\
19 . \\
3.6\end{array}$ & $\begin{array}{c}<0.05 \\
8 . \\
18 . \\
.74\end{array}$ & $\begin{array}{c}<0.05 \\
9 . \\
32 . \\
3.3\end{array}$ & $\begin{array}{l}<0.05 \\
10 . \\
89 . \\
5 .\end{array}$ & $\begin{array}{l}<0.05 \\
9 . \\
74 . \\
22 .\end{array}$ & $\begin{array}{l}<0.05 \\
8 . \\
80 . \\
6.1\end{array}$ & $\begin{array}{l}\text { N.d. } \\
\text { N.d. } \\
\text { N.d. } \\
\text { N.d. }\end{array}$ & $\begin{array}{l}\text { N.d. } \\
\text { N.d. } \\
\text { N.d. } \\
\text { N.d. }\end{array}$ & $\begin{array}{l}\text { N.d. } \\
\text { N.d. } \\
\text { N.d. } \\
\text { N.d. }\end{array}$ & $\begin{array}{l}\text { N.d. } \\
\text { N.d. } \\
\text { N.d. } \\
\text { N.d. }\end{array}$ \\
\hline \multicolumn{12}{|c|}{ C.I.P.W. norms (weight percent) } \\
\hline Q & 29.7 & 30.2 & 27.9 & 30.7 & 21.6 & 29.4 & 26.5 & 29.2 & 27.0 & 24.1 & 16.2 \\
\hline c & -- & -- & -- & -- & -- & -- & -- & -- & -- & -- & -- \\
\hline or & 2.8 & 4.4 & 3. & 7. & 22.4 & 21.3 & 21.3 & 3.4 & 18. & 8.3 & 12.3 \\
\hline$a b$ & 30.3 & 29.6 & 32.8 & 29.3 & 29.7 & 21.9 & 24.5 & 30.9 & 26.4 & 33. & 30.8 \\
\hline an & 25 . & 23.8 & 24. & 20.8 & 16.1 & 16.9 & 18. & 24.3 & 17.9 & 20.8 & 22.6 \\
\hline wo & 4.8 & 4.5 & 5.4 & 4.9 & 1.3 & 2.4 & 1.2 & 4.9 & 2.4 & .3 & .75 \\
\hline en & 5.2 & 5.2 & 4.8 & 4.8 & 5.1 & 5.1 & 5.3 & 5.1 & 5.1 & 4.9 & 7. \\
\hline fs & .4 & .4 & .15 & .32 & .41 & 1.01 & 1. & .28 & .7 & 4.1 & 4.5 \\
\hline $\mathrm{mt}$ & .1 & .25 & .35 & .59 & .22 & .31 & .56 & .22 & .43 & 2.1 & 2.7 \\
\hline $\mathrm{hm}$ & -- & $-\infty$ & -- & -- & -- & -- & -- & -- & -- & -- & -- \\
\hline i1 & .79 & .71 & .79 & .75 & .77 & .71 & .72 & .77 & .73 & 1.2 & 1.4 \\
\hline ap & .29 & .26 & .31 & .29 & .29 & .26 & .29 & .29 & .29 & .5 & .59 \\
\hline fr & .02 & .02 & .02 & .02 & .14 & .08 & .1 & .02 & .08 & -- & -- \\
\hline$c c$ & .23 & .37 & .12 & .09 & 1.5 & .35 & .09 & .23 & .51 & - & .32 \\
\hline Total & 99.63 & 99.71 & 99.64 & 99.56 & 99.53 & 99.52 & 99.56 & 99.61 & 99.54 & 99.3 & 99.16 \\
\hline Salic & 87.8 & 88 & 87.7 & 87.8 & 89.8 & 89.3 & 90.3 & 87.8 & 89.3 & 86.2 & 81.9 \\
\hline Femic & 11.83 & 11.71 & 11.84 & 11.76 & 9.73 & $10: 22$ & 9.26 & 11.81 & 10.24 & 13.1 & 17.26 \\
\hline D.I. 1 & 62.8 & 64.1 & 63.7 & 67. & 73.7 & 72.6 & 72.3 & 63.5 & 71.4 & 65.4 & 59.3 \\
\hline
\end{tabular}

1 Differentiation index of Thornton and Tuttle (1960) defined as the sum of normative quartz + normative albite + normative orthoclase.

1-4. Samples from porphyritic tonalite phase (see text). Same as model analyses 1-3, table 7.

5-7 Samples from porphyritic monzogranite phase. Same as modal analyses 4-7, table 7.

8. Average of analyses $1-3$ of this table.

9. Average of analyses 4-7 of this table.

10. "Average" tonalite of Nockolds (1954).

11. "Average" tonalite of LeMaitre (1976). 
abundance of apparently primary modal K-feldspar in the porphyritic monzogranite phase results in data points that plot well into the monzogranite field. Furthermore, a plot of $\mathrm{Na}_{2} \mathrm{O}+\mathrm{K}_{2} \mathrm{O}$ and $\mathrm{CaO}$ contents versus $\mathrm{SiO}_{2}$ content (fig. 25) does not show a decrease in $\mathrm{CaO}$ content concomitant with the increases in total alkali and total $\mathrm{SiO}_{2}$ contents for the samples analyzed. The broadly scattered data points in such a plot result from a combination of hypersolidus and subsolidus processes.

Chemical analyses of three samples of the porphyritic tonalite phase reveal the strong alumina undersaturation in these rocks. A plot of $\mathrm{Al}_{2} \mathrm{O}_{3}$ : $\left(\mathrm{K}_{2} \mathrm{O}+\mathrm{Na}_{2} \mathrm{O}+\mathrm{CaO}\right)$ ratio versus $\mathrm{SiO}_{2}$ content (fig. 26) shows that these samples are highly metaluminous. Such alumina undersaturation indicates the significant concentrations of modal diopside and salite (probably approx 10-14 volume percent; table 7) and the relatively low hornblende content (as much as approx 4 volume percent) in the rocks. Chemical analyses of these clinopyroxenes indicate that diopside phenocrysts contain about 1.2 to 2.5 weight percent $\mathrm{Al}_{2} \mathrm{O}_{3}$ and that salite in the groundmass contains about 0.6 to 2.6 weight percent $\mathrm{Al}_{2} \mathrm{O}_{3}$ (Theodore and Hammarstrom, 1991; see below). Many published analyses of clinopyroxenes show extremely low $\mathrm{Al}_{2} \mathrm{O}_{3}$ contents (Deer and others, 1978). Thus, the strongly metaluminous composition of bulk analyses of the rocks probably indicates a relatively high calcium content from clinopyroxene that has not been compensated for by a corresponding increase in $\mathrm{Al}_{2} \mathrm{O}_{3}$ content. Indeed, the fact that these rocks also are strongly wollastonite normative (table 8 ) must result from the presence of abundant modal diopside and (or) salite in them.

The very limited number of available analyses of the porphyritic tonalite phase precludes a proper documentation of major-element variation trends for the entire porphyritic leucogranite unit. The trend of major-element variations throughout the entire suite of Tertiary igneous rocks of the Buckingham area is discussed following descriptions of the units. Briefly, however, in the AlkFM and the ACF diagrams (figs. 27A, 27B), the analyzed samples from the porphyritic tonalite phase and the porphyritic monzogranite phase define rather tight clusters wherein the samples of the porphyritic monzogranite phase plot slightly away from the porphyritic tonalite phase. In the AKF diagram (fig. 27C) the samples from the porphyritic tonalite phase again cluster together, but the plotted data points of porphyritic tonalite samples, as expected, define a trend away from the porphyritic tonalite toward the $\mathrm{K}$ corner of the diagram. Last, figure $27 D$ shows normative proportions of $\mathrm{Q}$, Or, and $\mathrm{Ab}$ in the analyzed samples from the entire porphyritic leucogranite unit. All the samples contain more than 85 percent $A b+O r+A n+Q$. The samples from the porphyritic tonalite phase contain 62.8 to 64.1 percent $A b+O r+Q$, whereas the remaining four samples of porphyritic monzogranite show 67.0 to 73.7 percent $A b+O r+Q$. The An contents of the three samples of rock from the porphyritic tonalite phase, normalized to 100 percent $\mathrm{Q}+\mathrm{Or}+\mathrm{Ab}+\mathrm{An}$, range from 27.0 to 28.4 percent. This normative An content is significantly lower than the typical modal An content of plagioclase phenocrysts in the rocks, which is $\mathrm{An}_{35}$ to $\mathrm{An}_{45}$ (see above). However, the normative An content of the bulk rock indicates the increased abundance of albite and quartz in the groundmass of these rocks. The normative proportions of albite, orthoclase, and quartz in three samples from the porphyritic tonalite phase cluster in an area showing increased $\mathrm{SiO}_{2}$ content and strongly decreased $\mathrm{K}_{2} \mathrm{O}:\left(\mathrm{SiO}_{2}+\mathrm{Na}_{2} \mathrm{O}\right)$ ratio relative to a trendline connecting the ternary minima at $\mathrm{P}_{\mathrm{H}_{2} \mathrm{O}}=\mathrm{P}_{\text {total }}=0.5 \mathrm{kbar}$ for An contents ranging from 3 to 7.5 weight percent (fig. 27D). The cluster is near the quartz-albite sideline of the ternary diagram. Samples of the porphyritic monzogranite phase showing the most abundance of K-feldspar in their groundmass plot near the ternary minimum at an An content of 3 weight percent, and they are shown only for comparative purposes. In addition, the cluster of data points from the samples of the porphyritic tonalite phase is not coincident with the ternary minimum for $\mathrm{P}_{\mathrm{H}_{2} \mathrm{O}}=\mathrm{P}_{\text {total }}=500 \mathrm{~kg} / \mathrm{cm}^{2}$ projected onto the anhydrous base of the Ab-Or-Q- $\mathrm{H}_{2} \mathrm{O}$ tetrahedron determined by Tuttle and Bowen (1958). These data thus indicate that the porphyritic tonalite phase of the entire porphyritic leucogranite unit is not a highly differentiated rock. Moreover, these chemical analyses of the porphyritic tonalite phase suggest a reversal in the overall trend of differentiation here during the late Eocene or early Oligocene. Although the porphyritic leucogranite is younger than the biotite-hornblende monzogranite of Bluff area, the porphyritic leucogranite apparently is less differentiated than the biotite-hornblende monzogranite of the Bluff area.

Variation in most minor-element contents between the porphyritic tonalite phase and the porphyritic monzogranite phase is not particularly striking for most metals (table 8). Nonetheless, there appear to be some consistent differences between these two phases of the unit. Barium content seems to increase from about 190 to $900 \mathrm{ppm}$, 
cobalt content from below detection to $2 \mathrm{ppm}$, manganese content from 150 to approximately 190 ppm, ruthenium content from about 20 to more than $80 \mathrm{ppm}$, and tungsten content from $0.7-3.6$ ppm in the porphyritic tonalite phase to 5-22 ppm for the porphyritic monzogranite phase. The distribution of minor metals in the general area of both of these phases of the porphyritic leucogranite unit is discussed at somewhat greater length below in the subsection below entitled "Lithogeochemistry of Surface Rocks."

ASSOCIATED SKARN ALTERATION

Skarn alteration is widespread in the northeastern part of the Buckingham area (pl. 1). As described above, much skarn apparently is associated with the emplacement of the late Eocene or early Oligocene porphyritic leucogranite. The term "skarn" is used here in the non-genetic sense proposed by Einaudi and others (1981) to describe the occurrence of largely garnet-pyroxene rich calcsilicate rock. The numerous bodies of skarn mapped in the Buckingham area are composed of andradite-grossular garnet and clinopyroxene in variable proportions. Contacts are somewhat diffuse near the margins of the bodies. However, the contact was placed where significant decreases in andradite content occur. Many of the skarns shown on plate 1 are surrounded by very widely diffuse zones of buff to gray-green, pyroxene-rich rocks. Most of the skarn formed in the Harmony Formation seems to be related to the emplacement of the porphyritic leucogranite. A notable exception is the relatively large and continuous bodies of skarn that make up most of the skarns grouped under D (see section below entitled "Mineral Chemistry of Late Cretaceous and Tertiary Skarns"). Most of these skarn bodies seem to be related to emplacement of the Late Cretaceous Buckingham stockwork system as are the gold skarns at the Surprise Mine (Schmidt and others, 1988). However, gold skarn at the Overlook prospects and at the Labrador Mine seems to be associated with porphyritic leucogranite (Schmidt and others, 1988). A very small proportion of skarn replaced parts of the Battle Formation and the Antler Peak Limestone near the east edge of the map area and seems to be related to the emplacement of Tertiary granodiorite porphyry and possibly diabase. One of the most striking features of skarn hosted by the Harmony Formation is that some of it must have formed in rocks that were not carbonate rich before alter- ation. Textural relations near margins of most of the bodies of skarn related to emplacement of porphyritic leucogranite suggest a prograde, successive encroachment of a pyroxene assemblage and then a garnet assemblage upon biotite hornfels. The relict fabric of biotite hornfels suggests that some of the biotite hornfels must have been quite shaly in its unaltered, premetamorphic state. Moreover, we cannot conclusively exclude the possibility that these shales, which have since been converted to dense garnet-pyroxene rocks, did not contain some carbonate component(s) before their recrystallization. At the surface, much skarn apparently is confined largely to what were once shaly horizons within the Harmony Formation. The adjoining metasandstone sequences of the Harmony Formation typically do not show development of skarn. In addition, as shown on plate 1, only a few skarn bodies border on igneous rock bodies; most of them are, in fact, removed by quite a distance from any igneous rocks at the present erosional level. However, at a few localities where well-exposed skarn crops out adjacent to porphyritic leucogranite, porphyritic leucogranite is chilled against skarn as we described above. The contact is a fault at some well-exposed localities (fig. 33). Skarns as mapped range in plan from highly irregular shapes to rather uniform bodies that are elongate parallel to the general strike of bedding. Some measure as much as $150 \mathrm{~m}$ across their apparent stratigraphic thickness, and some individual bodies are mappable for strike lengths of as much as $500 \mathrm{~m}$. However, only a small part of the longest body of skarn could be shown on plate 1

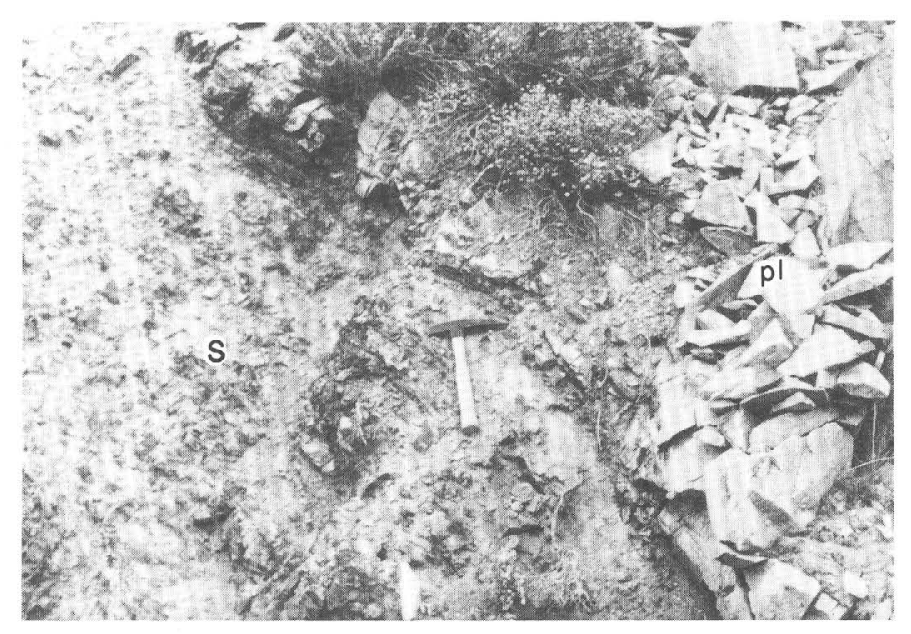

Frgure 33.-Garnet skarn (S) faulted against porphyritic leucogranite $(\mathrm{pl})$ near northeast corner of Buckingham area. 
because it has been obscured by dumps near the northern parts of the area affected by the open-pit operations at the Copper Basin Mine. An approximate strike length for this particular mass of skarn is $1.6 \mathrm{~km}$ (Blake and others, 1979). At one time, it could be traced more or less continuously along the contact between the Harmony and Battle Formations through the open pit at Copper Basin into Late Cretaceous monzogranite related to the Buckingham porphyry molybdenum system. In addition, it will be shown below that base-metal zonation in this especially extensive body of skarn is related to Late Cretaceous monzogranite. As such, this particular body of skarn (most of skarn D; see section below entitled "Mineral Chemistry of Late Cretaceous and Tertiary Skarns") may be Late Cretaceous in age, as opposed to the apparent late Eocene or early Oligocene age for many remaining bodies of skarn. The petrography and chemistry of the apparently Late Cretaceous skarn is reported separately below in conjunction with the detailed descriptions of alteration and mineralization associated with the Buckingham porphyry molybdenum system.

On the basis of its overall fabric and mineralogic composition, skarn mapped in the Harmony Formation is classed either as bedded (fig. 34A) or massive and calcic (see Einaudi and others 1981); both are extremely rich in garnet (pl. 1). Two other morphologic varieties of garnet skarn also are present in the area but are too small to show on the map: garnet skarn breccia and garnet skarn developed along faults near the north edge of the map area. Some outcrops that show a delicate lamination preserved through a prolonged succession of contact metamorphism and subsequent apparent metasomatism may be correlative with the sequences of largely unmetamorphosed calcareous shale in the Harmony Formation that crop out near the north edge of the map area (fig. 34B). Unfortunately, the complete transition from bedded skarn into calcareous shale is not exposed for study. However, there are excellent exposures in many localities that document a transition from noncalcareous biotite hornfels to massive garnet skarn. Such bodies of skarn are somewhat comparable to the skarn bodies hosted by andesite tuff at Ludwig, Nev. (Harris and Einaudi, 1982), or to some of the calcic iron skarn deposits (Einaudi and others, 1981); for example, the Dashkesan, U.S.S.R., magnetite-bearing calcic skarn (Sokolov and Grigor'ev, 1977). Initially, in biotite hornfels near the edges of these bodies of skarn in the Harmony Formation, relict patches of irregular biotite hornfels are preserved as "islands" within an anastomosing network of diopside veins and quartz
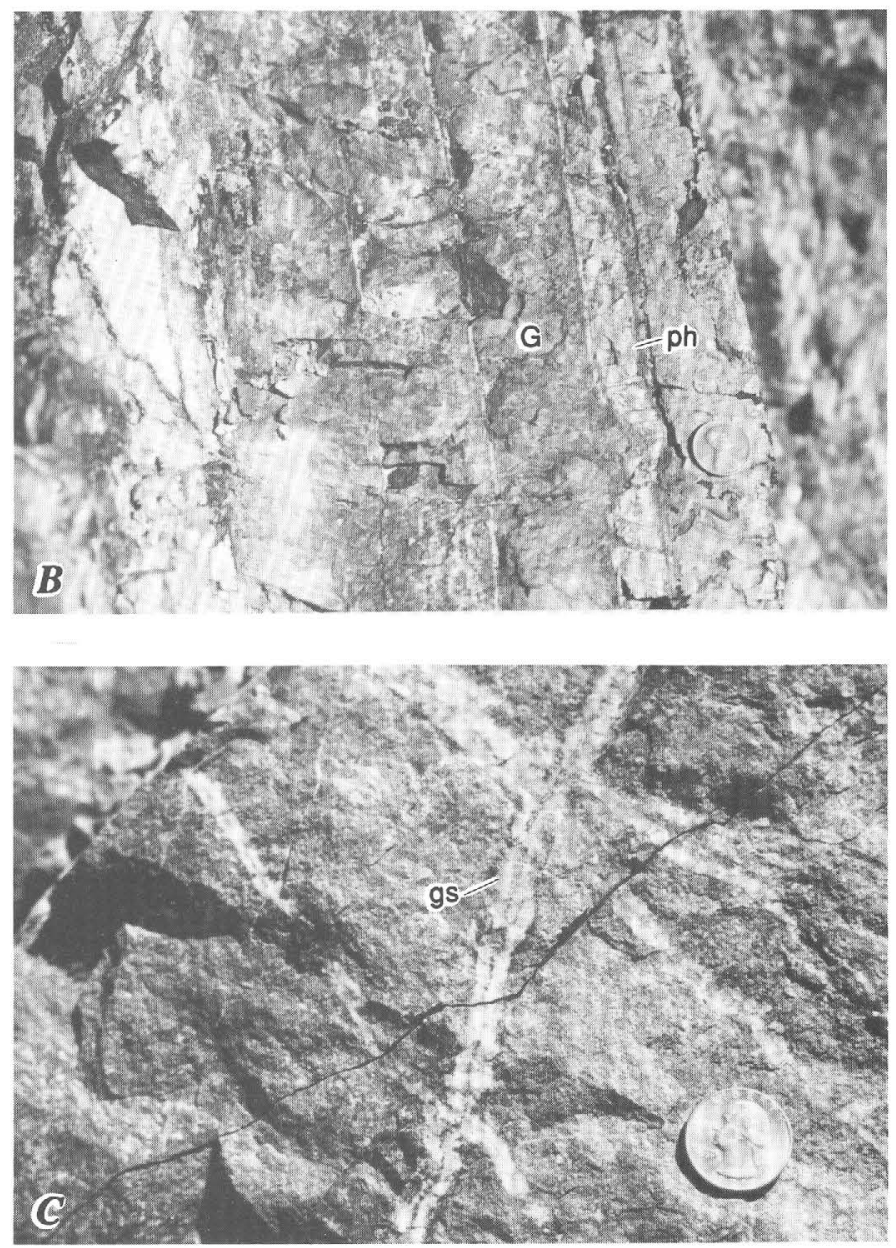

FIgURE 34.- Selected relations of skarn formed in the Upper Cambrian Harmony Formation. A, Well-bedded sequence of reddish-brown garnet skarn, striking approximately north and dipping $75^{\circ} \mathrm{E}$. Outcrop is approximately $300 \mathrm{~m}$ north of workings at Copper Basin and about $6 \mathrm{~m}$ from outcrop of potassicaltered Tertiary diabase. Scale shown by hammer. $B$, Sequence of banded reddish-brown garnet skarn $(\mathrm{G})$ and some bluish-gray pyroxene hornfels (ph), showing well-preserved lamination. Same locality as in figure 34A. C, Massive garnet skarn showing selvages of garnet (gs) along veins of quartz, some of which also include garnet along thin medial septa. Locality is approximately $300 \mathrm{~m}$ south of southeast contact of large body of porphyritic leucogranite. 
veins associated with coalescing selvages that include a clinopyroxene-bearing assemblage also (figs. $35 A, 35 B$ ). In outcrop, this transition from a hydrous to an anhydrous assemblage demonstrates a very pronounced leaching of iron to the point that the dark-brown to locally black biotite hornfels becomes a pale-gray-green diopside skarn. The lateral extent of such changes visible in outcrop is quite variable. Adjacent to some of the larger bodies of garnet skarn shown on plate 1, biotite hornfels of the Harmony Formation crops out in varying degrees of conversion to diopside skarn for distances of as much as 30 to $50 \mathrm{~m}$. In other places, the transition to diopside skarn adjacent to
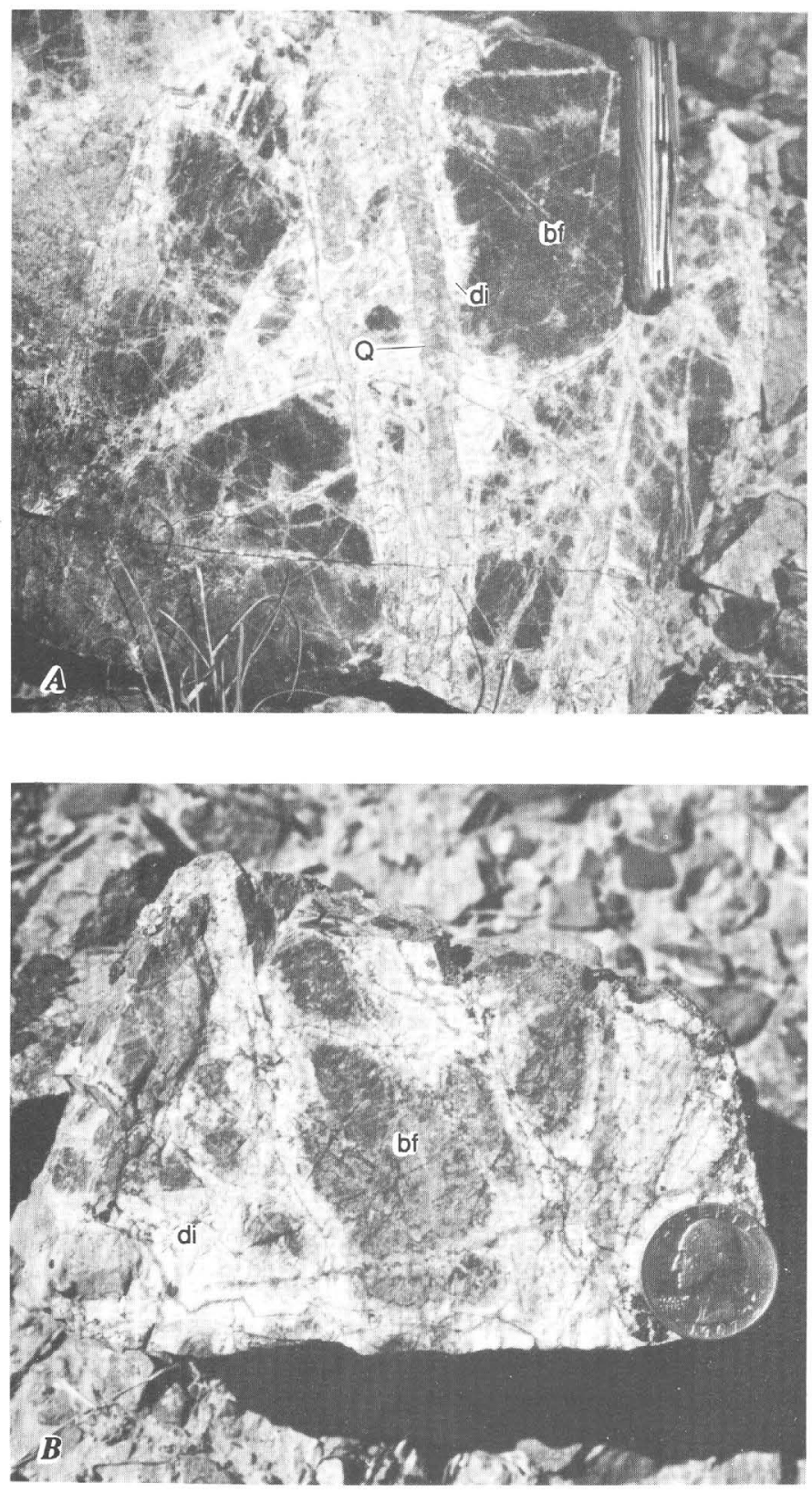

FIgURe 35.-Transitions of the Upper Cambrian Harmony Formation in outcrop from biotite hornfels to garnet skarn. A, Irregular, dark-brown biotite hornfels (bf) converted in part to pale-gray-green diopside skarn (di) associated with introduction of quartz veins $(\mathrm{Q})$. Locality near outer margin of recognizable diopside halo surrounding one of the larger bodies of garnet skarn, northeast of easternmost exposures of large body of porphyritic leucogranite. Note pocket knife in upper
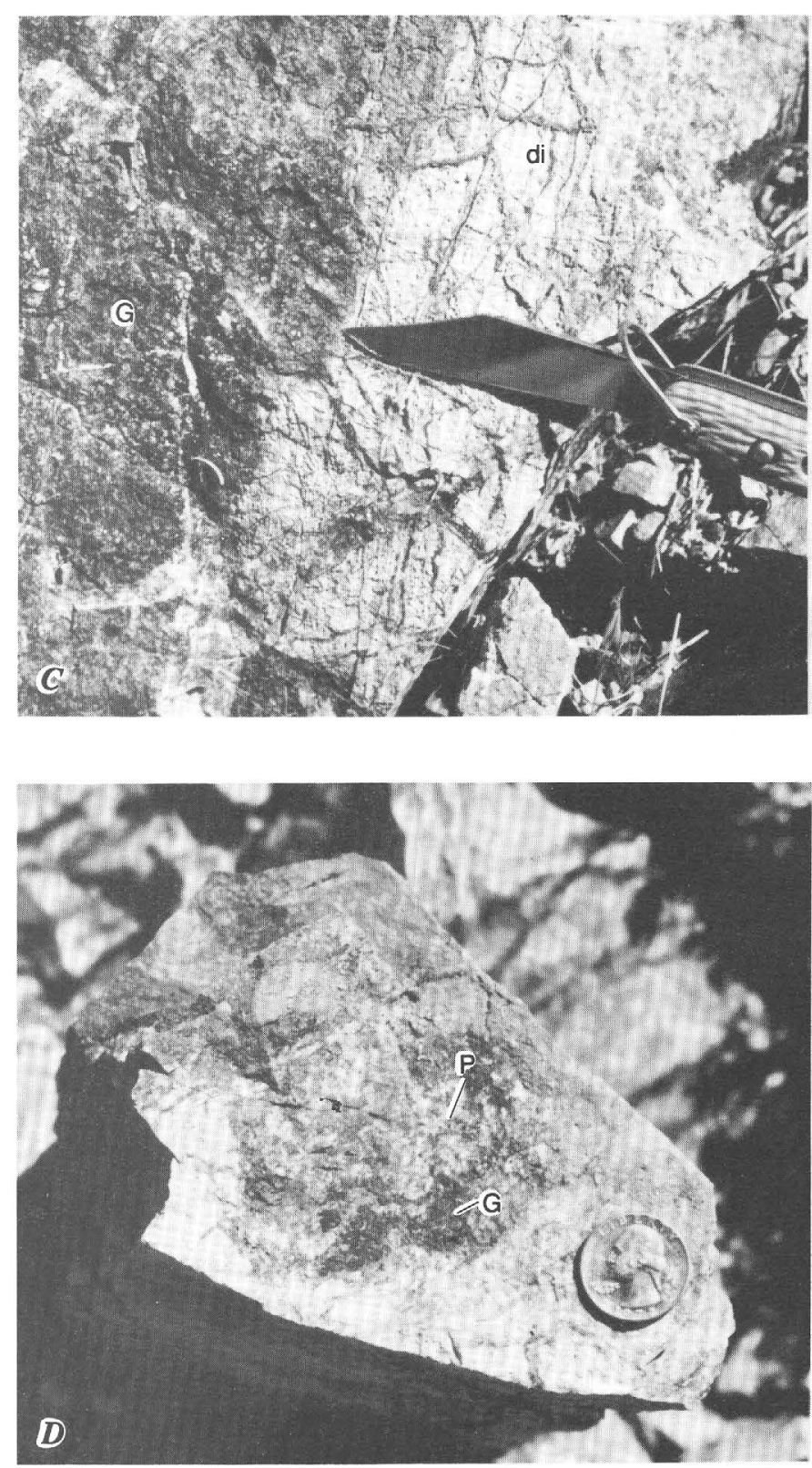

right for scale. $B$, Same as in figure $35 A$. Note coin in lower right for scale. $C$, Front of reddish-brown garnet skarn $(\mathrm{G})$, showing a knife-edge contact that is convex toward bluish-gray diopside skarn (di) which is being replaced. Locality approximately $300 \mathrm{~m}$ south of easternmost exposures of large body of porphyritic leucogranite. $D$, Relief crystals of pyroxene (P) in garnet skarn $(\mathrm{G})$ after conversion from pyroxene hornfels. Same locality as in figure $35 \mathrm{C}$. Note coin in lower right for scale. 
garnet skarn measures only a few centimeters. These diopside-bearing rocks are referred to as skarn rather than hornfels because some of them may owe their origin to largely metasomatic processes. In many porphyry copper environments, the simple monomineralic or bimineralic composition of such rocks suggests a metasomatic origin (Einaudi, $1982 b)$. Nonetheless, here at Buckingham, development of these diopside-bearing assemblages does not indicate either a strictly metamorphic or metasomatic phenomenon. However, crystallization of such paragenetically early, diopside-bearing assemblages is but one part of a process that in its entirety is metasomatic. Outward growth of the garnet skarn upon the diopside skarn is evidenced by knife-edge surfaces of reddish-brown garnet skarn that are scalloped with a convex margin toward the surrounding pale-gray-green to bluishgray diopside skarn (fig. $35 \mathrm{C}$ ) and show numerous narrow veinlets of garnet spreading from the massive garnet skarn and cutting the adjacent diopside skarn. The scalloped contact between garnet skarn and diopside skarn may be indicative of a local instability of fluid infiltration along the contact (Ortoleva and others, 1987); where permeability is higher, fluid flux is enhanced, and metasomatic reactions accelerate relative to elsewhere along the front. Furthermore, the conversion to garnet skarn is not everywhere complete. Relict crystals of diopside in places remain behind the garnet skarndiopside skarn "front." In their interiors, many of the large bodies of massive skarn also show an intense network of crosscutting quartz veins. Some of these veins include selvages of garnet developed along a wallrock of mostly garnet; some also show conspicuous medial septa of garnet (fig. $34 C$ ). The overall paragenetic relations of the assemblages noted above indicate development of calcic garnetpyroxene skarn in rock that apparently was quite devoid of any calcium carbonate. Significant amounts of calcium must have been added to the biotite hornfels during its conversion to garnet skarn. Elsewhere, Bookstrom (1977) showed that carbonate-free andesite porphyry at El Romeral Mine, Chile, received significant additions of calcium during its actinolization in a largely contact metasomatic environment. Furthermore, Seal and others (1987) documented a relative enrichment of calcium relative to ferrous iron, magnesium, and aluminum during calc-silicate alteration associated with tungsten-molybdenum mineralization at Lake George, southwestern New Brunswick, Canada. The subsolidus conversion of biotite hornfels to garnet skarn outlined above is documented fur- ther by textural relations observed under the microscope.

In all, approximately 70 rocks showing various degrees of skarn development during the late Eocene or early Oligocene were studied petrographically. In the Harmony Formation, the most common prograde zonation is biotite to diopside to andradite-grossular skarn (see section below entitled "Mineral Chemistry of Late Cretaceous and Tertiary Skarns"). Such conversion of biotite hornfels to diopside skarn was accomplished by chemical reactions dependent upon the permeability and chemistry of involved rocks. As we described above, most of these skarns may have developed in sequences of rocks that formerly were calcareous shale. In addition, some thin beds of subarkose in a sequence of silty shale, all contact metamophosed to biotite hornfels, subsequently acted as highly permeable channelways for fluids that deposited diopside among the relict grains of quartz in the subarkose (fig. 36A). Specifically, diopside certainly replaces feldspar and probably replaces contact-metamorphic biotite in the matrix of the metamorphosed subarkose (fig. 36B). In addition, contact-metamorphic biotite is no longer stable for distances of about 1 to $2 \mathrm{~cm}$ in the adjoining layers of metamorphosed silty shale, although deeper penetration of fluids than this was accomplished along some fractures. Elsewhere in diopside-zone rocks, permeability into metashale of the Harmony Formation apparently was almost entirely fracture related (figs. $36 C, 36 D$ ). Networks of narrow microveinlets of diopside-K-feldspar crosscut bleached metashale. The actual "front" between biotite stable and biotite unstable, or bleached rock, typically is enhanced by the spotty concentration of mats of extremely fine grained diopside for distances of as much as 1 to 2 $\mathrm{mm}$ on the bleached side of the "front." Other rocks show an intervening, 0.5 - to 1.0 -cm-wide, chalcedony-rich zone between diopside-rich rock and biotite hornfels (fig. 37A). The predominant metamorphic mineral in each of five mineral zones recognized across such a skarn contact is garnet, clinopyroxene, K-feldspar, chalcedony, and biotite. Chalcedony formed at the expense of biotized silty shale. In addition, some of the clinopyroxeneK-feldspar-altered silty shale includes subrounded, detrital tourmaline that includes extremely minute, prismatic crystals of neocrystallized tourmaline growing on detrital tourmaline (fig. 37B). However, such a regular zonation of minerals is not present everywhere at the outer edge of the bodies of skarn. Crystallization of garnet in some localities apparently lacks a strongly developed surrounding shell of mostly diopside and K-feldspar; some garnet occurs 
in contact either directly with detrital grains of quartz in some originally sandy facies of the Harmony Formation (fig. 37C) or as a straightforward replacement of hornfels (fig. 37D). Both isotropic and anisotropic varieties of amber garnet (presumably of compositions intermediate between grossular and andradite) occur in these two settings, together with somewhat paragenetically later hydrothermal biotite (greenish brown, optic Z-axis), K-feldspar, and iron sulfide. However, microscopic examination of the hornfels reveals that the introduction of garnet is largely at the expense of an extremely fine grained mat of previously crystallized diopside and quartz
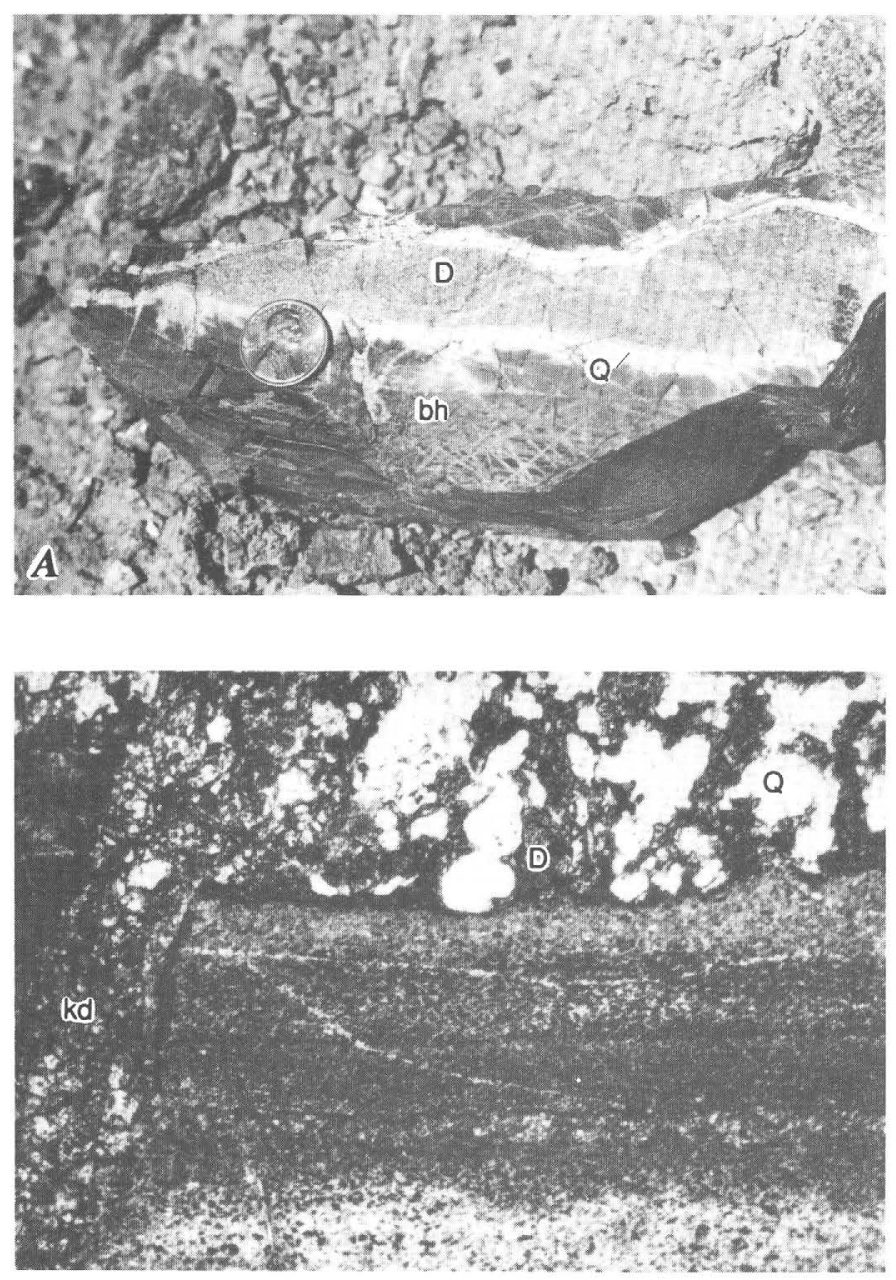

$\boldsymbol{B}$

0

0.8 MILLIMETER

FIGURE 36.-Photograph and photomicrographs showing conversion of subarkose and biotite hornfels of the Upper Cambrian Harmony Formation to diopside skarn. A, Diopside skarn (D) formed in thin bed of subarkose and mantled by chalcedonic quartz (Q) that replaced adjoining biotite hornfels (bh). Sample $80 \mathrm{BK} 80$. $B$, Photomicrograph showing preferential crystallization of diopside (D) replacing feldspar-rich matrix in quartz-rich (Q) subarkose. kd, K-feldspar and diopside veinlet. (fig. 37D). Evaluation of phase equilibria for experimentally determined relevant reactions suggest that prograde, garnet- and diopside-dominant skarn growth may have occurred at oxygen fugacities greater than that of the upper stability of clinopyroxene with a composition of 20 to 40 mol percent hedenbergite (see section below entitled "Mineral Chemistry of Late Cretaceous and Tertiary Skarns").

In addition to the skarn described above, there are a few other minor occurrences of faultcontrolled garnet skarn and skarn breccia that are not mapped separately on plate 1 but that merit mention. Typically, fault-controlled bodies of skarn
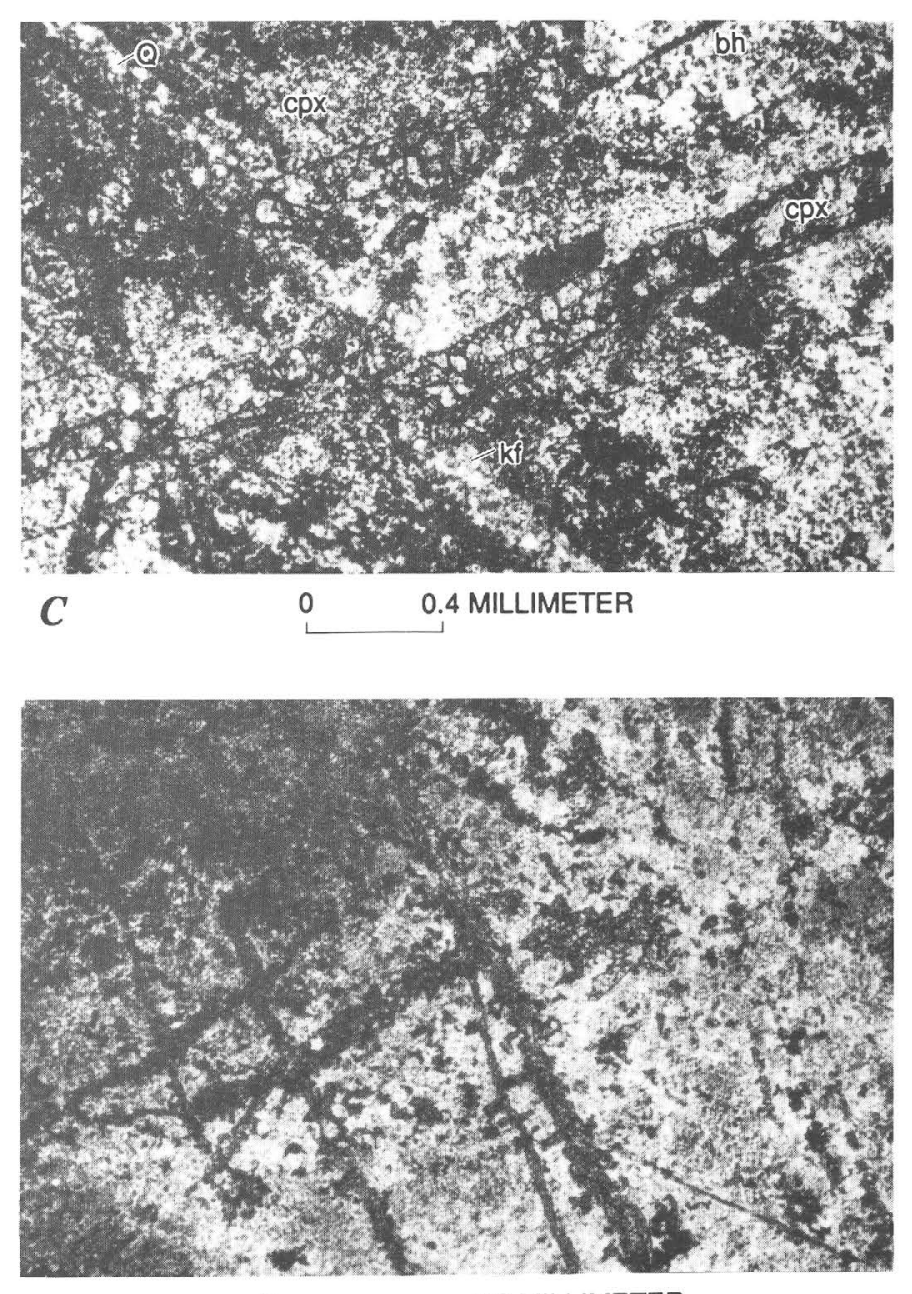

D

0.8 MILLIMETER

Same sample as in figure $36 A$. C, Photomicrograph of silty shale of the Harmony Formation metamorphosed to biotite hornfels (bh) and then subsequently converted to a mat mostly of extremely fine grained clinopyroxene (cpx) and cut by veins of Kfeldspar (kf), clinopyroxene, and sparse quartz (Q). Sample 80BK42. $D$, Photomicrograph of narrow diopside-K-feldspar veinlets cutting bleached metashale of the Harmony Formation. Same sample as in figure $36 C$. 
are 5 to $6 \mathrm{~m}$ wide and crop out near the north edge of the map area along generally north-striking faults. These skarns replace carbonate rocks in the Harmony Formation. Red-brown granulose garnet in hand sample, which probably averages about 0.5 to $0.6 \mathrm{~mm}$ wide, shows under the microscope isotropic cores in many of its larger crystals that are mantled by anisotropic rims; diopside is very rare. The garnets are replaced sparsely by epidote and by open-space fillings of minor pyrite. However,
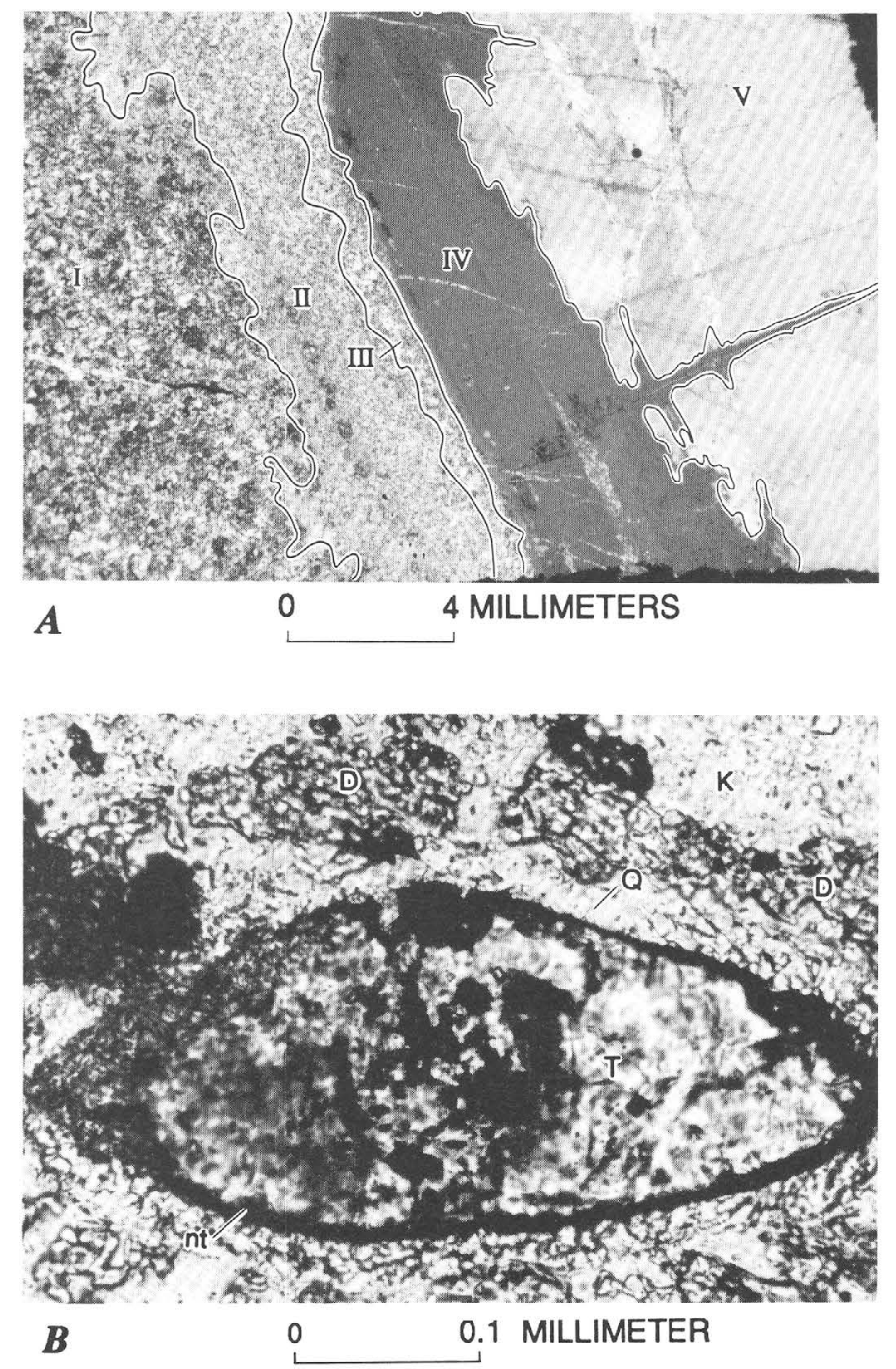

FIGURE 37.-Photomicrographs of skarn formed in the Upper Cambrian Harmony Formation in northeastern part of Buckingham area. A, Mineral zones adjacent to garnet skarn formed in biotite hornfels. Zone I: garnet (anisotropic and isotropic), clinopyroxene, biotite, quartz (trace), and K-feldspar; zone II: clinopyroxene, K-feldspar, very sparse garnet, and pyrite (trace); zone III: detrital quartz, neocrystallized K-feldspar, clinopyroxene (sparse), and opaque minerals; zone IV: mostly chalcedonic quartz but including silt-size detrital grains of quartz; zone V: silty shale metamorphosed to biotite rocks immediately adjacent to garnet skarn include some interesting relations wherein sedimentary carbonate minerals, replaced partly by dispersed needles of tremolite and some pyrite porphyroblasts, progressively give way to chlorite; this chlorite is followed by a chlorite-epidote-pyrite zone; and then finally by a quartz-K-feldspar-epidote zone-all at the thin-section scale. However, in many places K-feldspar, most likely adularia, apparently replaces calcite directly (fig. $38 \mathrm{~A}$ ). Some
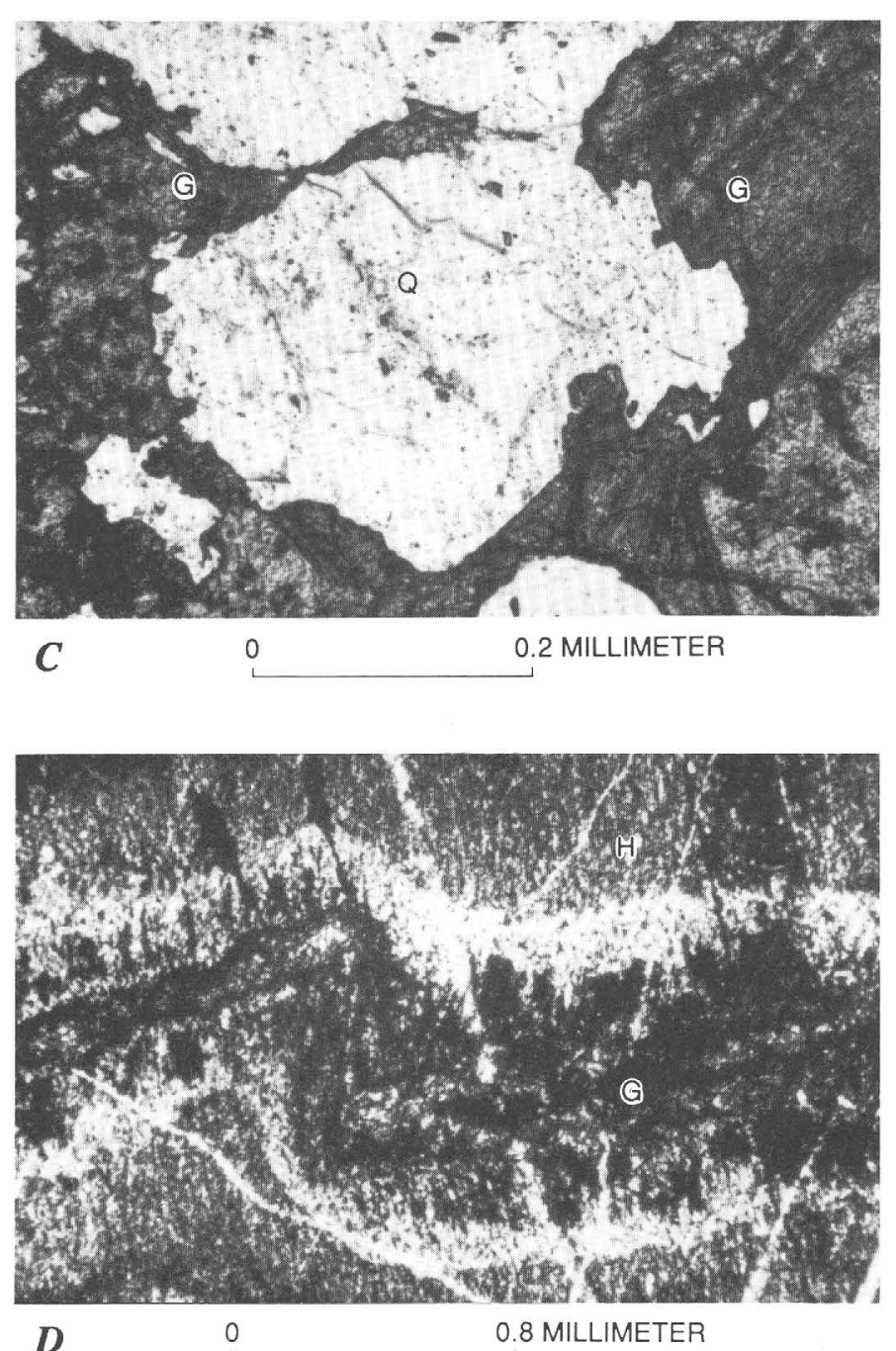

hornfels. Sample 78C137. B, Detrital grain of tourmaline (T), showing extremely small, prismatic crystals of newly crystallized tourmaline (nt) along its margins within a corona of probable quartz $(\mathrm{Q})$, all set in a $\mathrm{K}$-feldspar ( $\mathrm{K}$ )- and diopside (D)-altered silty shale. Sample 81TT122B. C, Vermiform encroachment of garnet $(\mathrm{G})$ along mineral boundaries between framework grains of quartz $(Q)$ in a quartz arenite. Sample 78C135. $D$, Garnet (G) replacing silty metashale previously recrystallized to a mostly diopside-quartz-hornfels $(\mathrm{H})$ assemblage. Sample 80BK90. 
$\mathrm{K}$-feldspar includes small granules of rutile. In addition, the replacement process includes neocrystallization of clinopyroxene, which also seems to replace calcite, and the introduction of quartz and

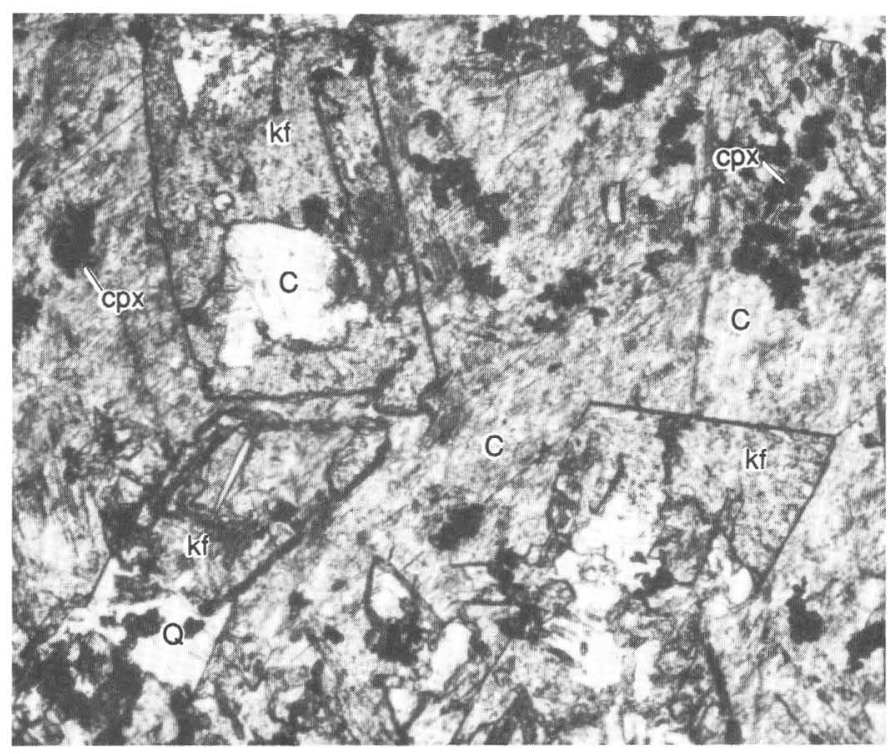

$\boldsymbol{A}$ 0 0.6 MILLIMETER

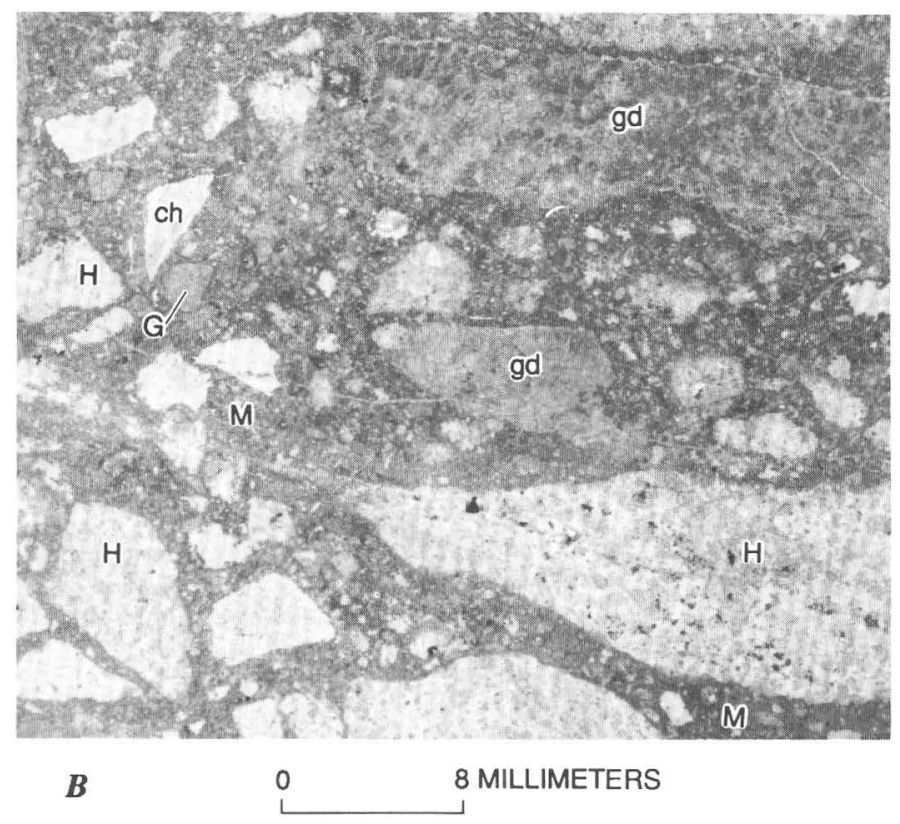

Figure 38.-Photomicrographs of textural relations in faultcontrolled garnet skarn and in skarn breccia. G, garnet; kf, K-feldspar; cpx, clinopyroxene, probably diopside. $A$, Upper Cambrian Harmony Formation, showing K-feldspar (shown in rhombic section) replacing carbonate (C) in rocks immediately adjacent to fault-controlled garnet skarn near north edge of map area. Q, quartz. Stained by sodium cobaltinitrate solution. Plane-polarized light. Sample 80BK68. B, Skarn breccia chlorite. Finally, the last minor type of skarn occurrence noted in the area is a 2-m-thick garnetdiopside skarn breccia (fig. 38B). This rock type was found near the contact of one of the mapped major masses of garnet skarn, about $300 \mathrm{~m}$ northeast of the east edge of the large body of porphyritic leucogranite. The skarn breccia is supported by an isotropic garnet-diopside matrix whose average grain size is about $0.1 \mathrm{~mm}$, and whose angular fragments are as much as about 5 to $7 \mathrm{~cm}$ wide. The fragments include: (1) two types of hornfels, (2) apparently unreactive chert, (3) garnet-diopside skarn, and (4) garnet skarn. The two types of hornfels are a diopside-K-feldspar-epidote-carbonate (trace) hornfels and an extremely fine grained metashale. Some angular fragments of garnetpyroxene skarn are mantled by a thin, outwardly serrated rim of euhedrally terminated crystals of garnet suggesting an open-space crystallization (fig. $38 C$ ). Skarn breccia is also cut by garnetdiopside veins with or without $\mathrm{K}$-feldspar, and narrow, monomineralic veins of $\mathrm{K}$-feldspar. Brecciation must have occurred after initial onset of conversion of the rocks of the Harmony Formation here to

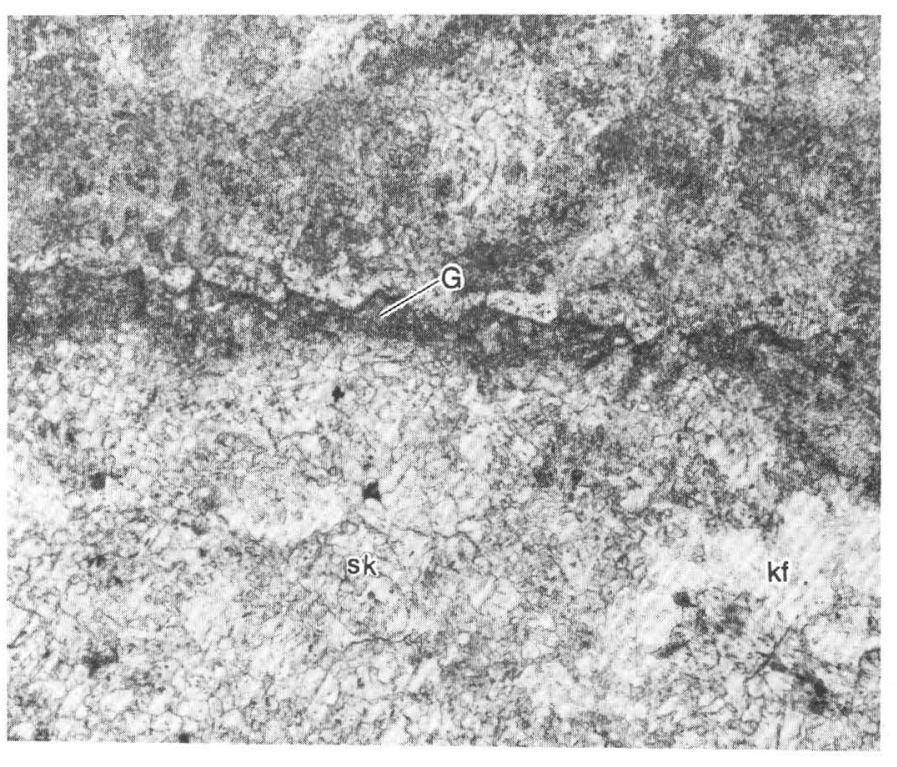

C

0

0.6 MILLIMETER

formed in the Harmony Formation near contact of one of large masses of garnet skarn shown on plate 1. Matrix (M) includes garnet and diopside; fragments consist of garnet-diopside skarn (gd), hornfels $(\mathrm{H})$, chert (ch), and garnet. Plane-polarized light. Sample 78C126. C, Closeup of figure $38 B$, showing serrated, thin mantle of garnet around angular fragment of garnetpyroxene-K-feldspar skarn (sk). Partially crossed nicols. 
skarn and may indicate synmineral faulting at margins of an evolving skarn.

\section{ALTERED GRANODIORITE OF HILL 6010 AREA}

A small body of fine- to medium-grained, altered granodiorite (unit Tgh, pl. 1), herein termed the "altered granodiorite of Hill 6010 area," crops out astride the north edge of the map area, about 0.5 $\mathrm{km}$ northwest of the largest mapped body of the biotite-hornblende monzogranite of Bluff area. The altered granodiorite of Hill 6010 area apparently is a sill-like mass that has been emplaced directly astride the N. $30^{\circ}$ E.- to N. $40^{\circ}$ E.-trending hingeline of a broad, open syncline formed in nearby rocks of the Harmony Formation. Geologic relations are not available to establish conclusively the age of the altered granodiorite of the Hill 6010 area with respect to other nearby Tertiary granitic rocks. However, actinolite-dominant secondary-alteration assemblages in the altered granodiorite of Hill 6010 area and marked similarity of a porphyritic phase in the unit with the porphyritic monzogranite phase of the porphyritic leucogranite described above both suggest very strongly that the altered granodiorite of Hill 6010 area is correlative temporally with the late Eocene or early Oligocene biotite-hornblende monzogranite of Bluff area and porphyritic leucogranite. Furthermore, altered granodiorite of Hill 6010 area locally includes abundant fragments of pale-brown biotite hornfels derived from the adjoining Harmony Formation. Some of these fragments show well-developed concentrations of actinolite along their margins. The overall abundance of such fragments and their distribution in altered granodiorite of Hill 6010 area suggests that this exposed igneous body must be relatively close to the original roof of its magma chamber.

Altered granodiorite of Hill 6010 area includes two phases: a conspicuously jointed, hypidiomorphicgranular or seriate phase and a porphyritic phase. The hypidiomorphic-granular or seriate variety includes primary biotite (red brown, optic Z-axis) and primary hornblende (blue green, optic Z-axis) in various stages of hydrothermal alteration to assemblage(s) of actinolite and sphene with or without sparse chlorite, sparse secondary quartz, traces of rutile, ilmenite, and local secondary K-feldspar. In addition, here and there in the rocks are some rare clots of fine-grained secondary biotite that are mantled by actinolite, a relation which suggests that at least some actinolite is paragenetically later than the secondary biotite. Nonetheless, the dominant secondary-alteration silicate is actinolite, and the alteration is feldspar stable. Primary plagioclase (andesine to labradorite) shows no visible effects of alteration under the microscope, even immediately adjacent to some very sparse veins of quartz+actinolite that cut the igneous fabric of the rocks. In addition, some outcrops of altered granodiorite of Hill 6010 area show increased abundances of pyrite to be concentrated especially along fractures that parallel the trace of quartz-actinolite veins. The orientation of most veins, which are not that densely concentrated in the unit overall, seemingly is controlled by joints that show a northwesterly strike.

The porphyritic variety of the altered granodiorite of Hill 6010 area is very similar to the porphyritic monzogranite phase of the porphyritic leucogranite. K-feldspar and secondary actinolite are reiatively abundant in microaplitic groundmass of the porphyritic variety of the altered granodiorite of Hill 6010 area. The groundmass makes up approximately 30 to 35 volume percent of these rocks. Phenocrysts of bipyramidal quartz, biotite, and hornblende show varying degrees of subsolidus alteration. Most primary hornblende phenocrysts are replaced by felted aggregates of fine-grained actinolite, with or without sphene, secondary plagioclase, and secondary $\mathrm{K}$-feldspar. The presence of primary crystals of biotite may be alluded to only by the characteristic crystal forms now shaped by mats of fine-grained actinolite. Some quartz phenocrysts, which incidentally make up a much greater percentage of the porphyritic phase than the nonporphyritic phase of the altered granodiorite of Hill 6010 area, are embayed and microveined by Kfeldspar. All of these secondary-alteration effects noted in the porphyritic phase of this map unit are feldspar stable. The labradorite phenocrysts are exceptionally fresh, even adjacent to some actinolite and actinolite-quartz microveinlets that cut them.

Rocks of the Harmony Formation in outcrop show visible contact effects up to about 20 to $30 \mathrm{~m}$ from the contact of the altered granodiorite of Hill 6010 area. The rocks of the Harmony Formation are intensely fractured, and a contact zone, intensely converted to biotite-hornfels, also includes some areas that are bleached highly, possibly as a result of the introduction of pyrite, and some small areas that are veined. Selective microscopic examination of representative samples of veined rocks from the Harmony Formation collected from the contact zone confirms that actinolite-dominant alteration assemblages in the intrusive rocks extend into the country rock. 


\section{RHYOLITE}

Rhyolite crops out mainly in three general localities in the Buckingham area: one is close to the Little Giant Mine, where the two most widely exposed masses of rhyolite crop out, and the other is south-southeast of the Bailey Day Mine, where several relatively small bodies of rhyolite were mapped (unit $\mathrm{Tr}$, pl. 1). The rhyolite of plate 1 is equivalent to the rhyolite porphyry described in the section "Economic Geology" below and on plate 2 . In addition, a narrow, east-west-trending, highly altered dike near the south-central edge of the map area also has been assigned provisionally to this map unit. The two bodies of rhyolite near the Little Giant Mine each have maximum dimensions at the surface of about $300 \mathrm{~m}$, and they intrude the Upper Cambrian Harmony Formation. South of the Bailey Day Mine, rhyolite intrudes the rocks of the Harmony Formation, the Middle Pennsylvanian Battle Formation, and the Upper Pennsylvanian and Lower Permian Antler Peak Limestone. Rhyolite is intruded by a narrow basalt dike, not shown on plate 1, emplaced along the Little Giant fault system. This basalt dike is well exposed in some workings at the Little Giant Mine. Age determinations on mineral separates of primary biotite from each of the two mapped bodies of rhyolite near the Little Giant Mine yield late Eocene to early Oligocene ages, ranging from 39.1 and $37.3 \mathrm{Ma}$, using the K-Ar method (fig. 18). The ages are thus approximately the same as those obtained from the biotite-hornblende monzogranite of Bluff area and porphyritic leucogranite. Also, they are approximately the same as those reported previously for age of emplacement of granodiorite at Copper Canyon and its associated copper-gold-silver mineralization (Theodore and others, 1973).

The two large bodies of rhyolite near the Little Giant Mine are generally well exposed (fig. 39A). Where it crops out best, rhyolite forms some bold, ridge-forming masses that are completely continuous for many tens of meters. In places near its contact with surrounding rocks of the Harmony Formation, rhyolite shows well-developed flow banding that dips steeply. This flow banding may be locally very contorted, and resulting outcrops intensely jointed. Rhyolite ranges from fine grained, very weakly porphyritic to medium grained, almost hypidiomorphic granular in some outcrops, strongly altered to white mica and clay near the trace of the Little Giant fault. As shown on plate 1, rhyolite is cut by the Little Giant fault. The presence of rhyolite on both sides of the main strands of the Little
Giant fault suggests that the last offsets along the fault were minor. Movements along this fault zone, however, probably initiated as thrust displacements during the middle Paleozoic Antler orogeny and then culminated as renewed shortening in the Oligocene after emplacement of rhyolite. Most rhyolite is quite fresh in outcrop in spite of the effects of secondary alteration associated with the structurally controlled, mostly silver mineralization along the Little Giant fault. Freshly broken surfaces of rhyolite are steel gray in color, whereas its weathered surfaces are white to pinkish-white; typically these freshly broken surfaces include sparkling, black phenocrysts of biotite (fig. 39B). Distribution of biotite is uneven throughout the rhyolite. However, where increased concentrations of biotite are present, there generally also is an increase in grain size of biotite to crystals about 1 to $2 \mathrm{~mm}$ wide. Moreover, bipyramidal phenocrysts of smoky quartz make up from 0 to $2-3$ volume percent of these rocks; small phenocrysts of sanidine are especially common in the fine-grained facies of the rhyolite. Hornblende is present in concentrations as high as about 1 to 2 volume percent in a few outcrops near the core of the largest body of rhyolite. In addition, the narrow dike of rhyolite in the south-central part of the map area shows what appears to be molds of completely weathered-out hornblende, possibly as much as about 5 volume percent, set in an intensely clay-altered and silicified rock type.

Rhyolite in the Buckingham area is associated with a wide variety of secondary alteration. Although the two large bodies of rhyolite near the Little Giant Mine are cut overall quite sparsely by veins of quartz containing minimal amounts of pyrite, the density of the veining and the overall concentration of sulfide(s) both along the veins themselves and disseminated in rhyolite increase significantly near the main strands of the Little Giant fault. Bleaching in rhyolite is rather highly restricted to the immediate area of the trace of the fault. Furthermore, some outcrops of rhyolite along the trace of the Little Giant fault contain welldeveloped quartz stockworks. Other outcrops of rhyolite along the fault are altered highly to clay(s), especially where the rhyolite is broken intensely by tightly spaced, steeply dipping fractures and joints. Where the Little Giant fault cuts the Harmony Formation, near the rhyolite, bleaching of the rocks of the Harmony Formation is limited generally to a distance of about 3 to $5 \mathrm{~m}$ away from the trace. However, near the uppermost elevation of the fault along the ridgeline showing elevation 
marker $6,744 \mathrm{ft}$ (pl. 1), bleaching and iron oxide staining of the rocks of the Harmony Formation extend outward for a distance of about 50 to $70 \mathrm{~m}$ from the trace of the fault. Also, alteration here is much more intense than that at lower elevations, and it is accompanied by widely spread occurrences of scorodite, a hydrated iron arsenate, that indicates the former presence of arsenopyrite. Some heavily pyritized, quartz-flooded fault breccias along the Little Giant fault show multiple generations of quartz. Where two conspicuous splays of the Little Giant fault converge, these fault breccias are approximately 7 to $8 \mathrm{~m}$ thick. Some early generations of vein quartz in fault breccia are as much as about $2 \mathrm{~cm}$ wide, and they contain 1-mm-wide
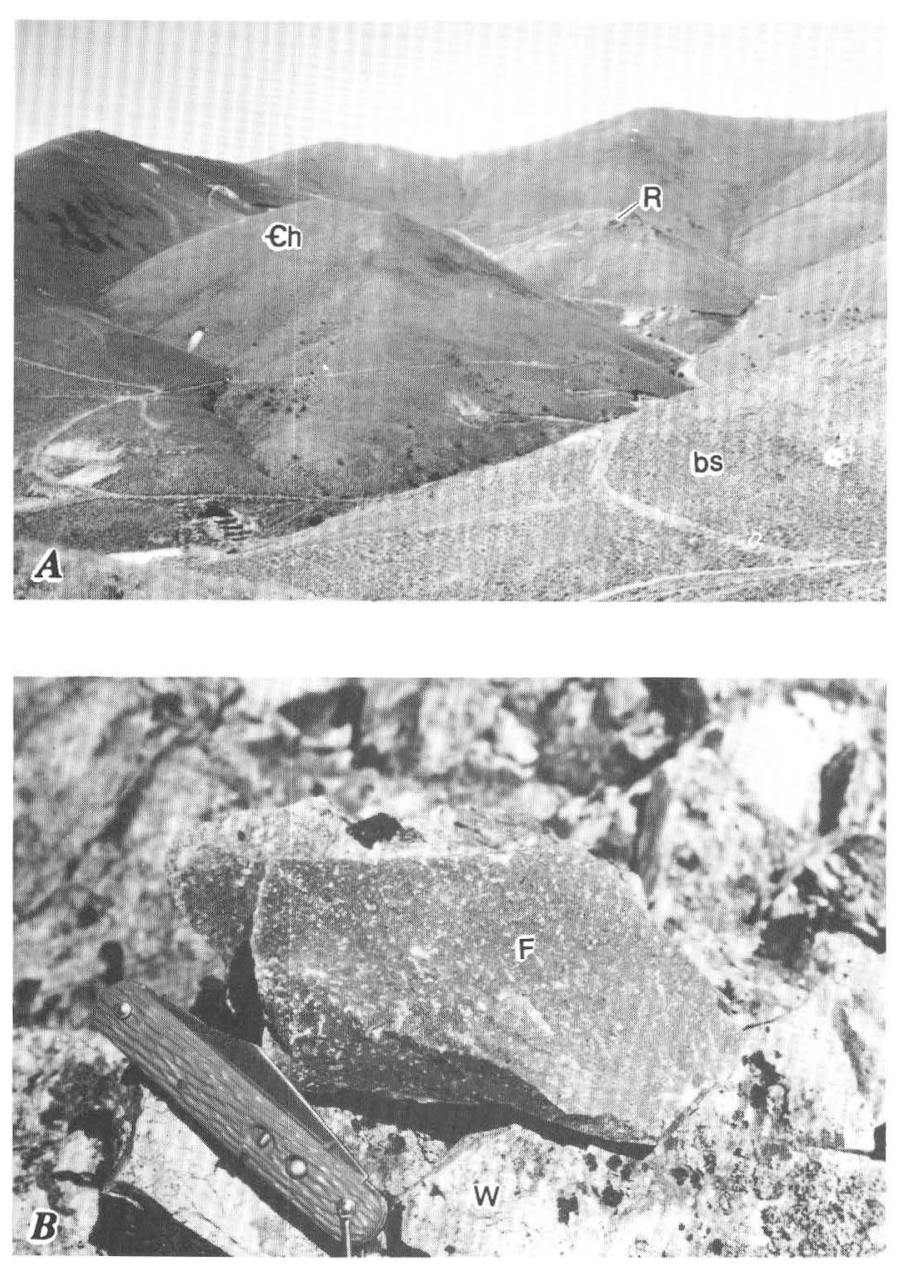

Figure 39.-Field relations of late Eocene or early Oligocene rhyolite from Buckingham area. A, View south-southwestward from survey point "Long" across east end of Buckingham molybdenum system in right foreground (bs), showing workings along Little Giant fault at left skyline and relatively bold outcrops of rhyolite (R). Smooth, rounded slopes are in the Upper Cambrian Harmony Formation (€h). B, Freshly broken surface crystals of molybdenite, remobilized possibly from the Late Cretaceous molybdenum system. Latestage, drusy quartz crystals line many of the vugs therein. However, when the two large bodies of rhyolite are considered in their entirety, they actually are cut quite sparsely by veins of sulfidebearing quartz. This relation is especially true when one considers the intensity and wide-ranging nature of quartz veins associated with the Late Cretaceous Buckingham molybdenum system. However, here and there through rhyolite, some outcrops are cut by abundant, closely spaced fractures (fig. $39 \mathrm{C}$ ). Some of these fractures were filled almost entirely by pyrite, now converted to ocher to buff iron oxide(s).

In addition to rhyolite mapped on plate 1 , there are a few other isolated outcrops of rhyolite that are not shown because of their extremely small size. Most of these small outcrops of rhyolite are present near the Little Giant Mine. Exposures of approximately $0.5-\mathrm{m}$-wide dikes of rhyolite along the road leading up to the topographically highest workings at the Little Giant Mine include very sparse veins of quartz. In addition, the immediately adjacent rocks of the Harmony Formation are typically flooded by abundant, disseminated pyrite-now altered to iron oxide(s).

Approximately 30 samples of rhyolite were studied petrographically. Most samples were collected from rhyolite near the Little Giant Mine. A large proportion of rhyolite includes both granophyric

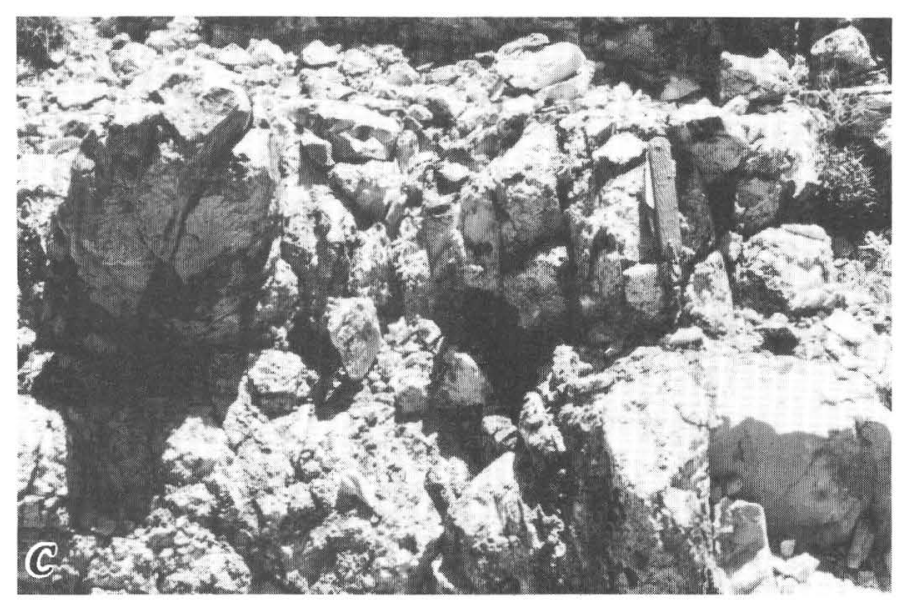

of rhyolite, showing contrast between steel-gray, fresh surface (F) and white, weathered surface (W). Crystals of primary biotite are barely discernible on fresh surface. Same locality same as in figure $39 A$. C, Outcrop of rhyolite cut by abundant closely spaced, iron oxide-stained fractures. Note pocket knife in upper right for scale. $80 \mathrm{BK} 2$. 
and micrographic intergrowths of alkali feldspar, mostly albite and quartz (fig. $40 \mathrm{~A}$ ). Phenocrysts, in order of decreasing abundance, in rhyolite include bipyramidal quartz, K-feldspar, plagioclase (mostly oligoclase, $\mathrm{An}_{15}-\mathrm{An}_{25}$ ), biotite (red brown, optic Zaxis), and very sparse hornblende. Primary accessory minerals noted under the microscope include sphene and very rare andalusite, the presence of the latter mineral suggesting alumina saturation during magmatic stages of the rhyolite (fig. 40B). Near the Little Giant fault, some samples of rhyolite show a phyllic- or feldspar-destructive alteration to white mica and some minor clay(s), whereas other samples show white-mica alteration

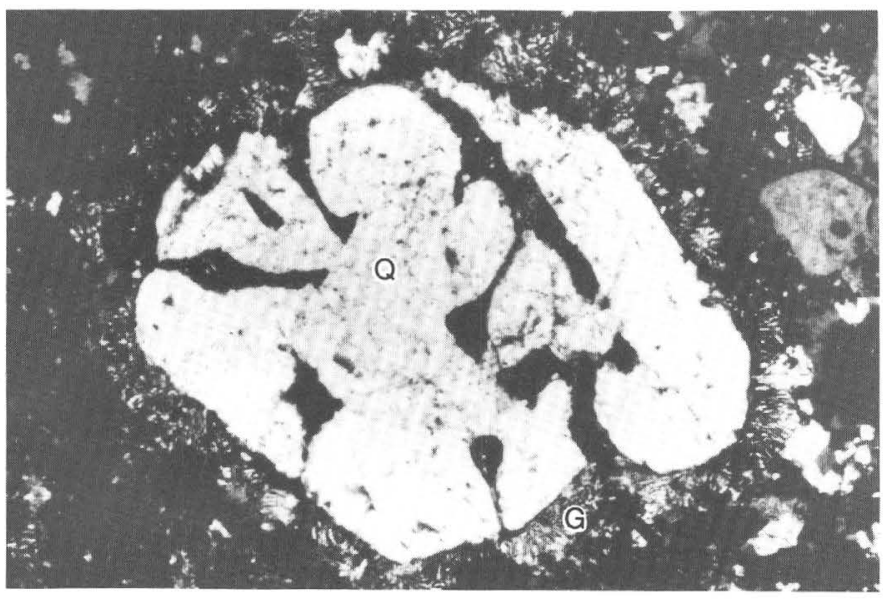
$\boldsymbol{A}$ 0 0.8 MILLIMETER

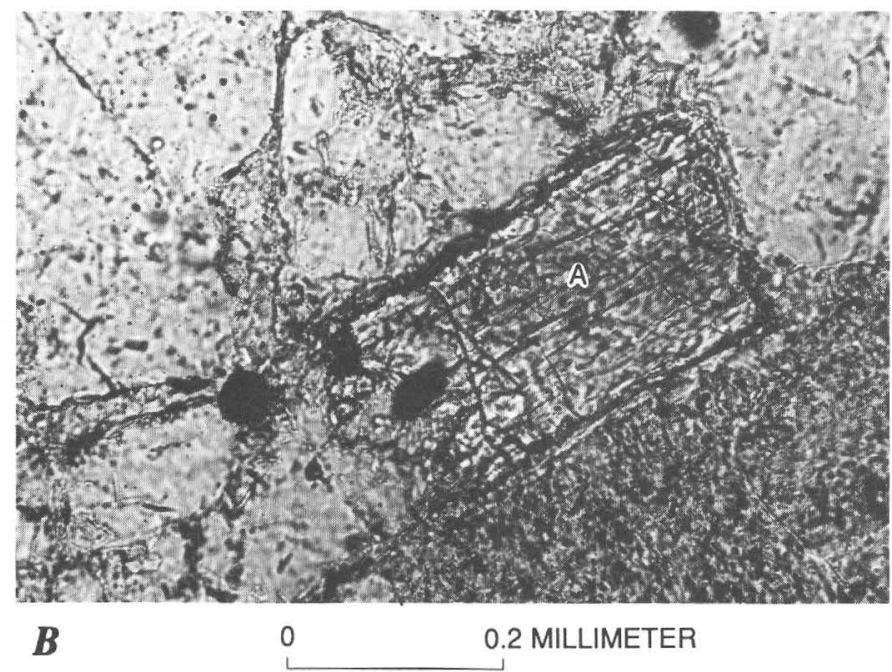

FIGURE 40.-Photomicrographs of late Eocene or early Oligocene rhyolite from Buckingham area. Q, quartz. A, Corona of granophyre (G) surrounding a quartz phenocryst. Sample 78C11. Crossed nicols. $B$, Primary accessory andalusite (A) in groundmass of narrow rhyolite dike that crops out near Little Giant of plagioclase and mafic minerals together with an apparent continued stability of K-feldspar.

Textural relations in some of the small bodies of rhyolite that crop out near the east edge of the map area, south-southeast of the Bailey Day Mine, suggest emplacement and hypersolidus crystallization of rhyolite occurred before cessation of circulation there of skarn-forming fluids. Such a relation is compatible with the assignment of the development of some of the skarn in this general area with the emplacement of Oligocene granodiorite porphyry. In places, the $\mathrm{K}$-feldspar-rich matrix of the rhyolite has been replaced by a mat of finegrained crystals of clinopyroxene (fig. $40 \mathrm{C}$ ). This clinopyroxene is related to microfractures. Open cavities that remained within these felted aggregates of secondary clinopyroxene apparently were first lined by quartz and then followed by further crystallization of clinopyroxene and pyrite. Finally, the clinopyroxene was cut by microveinlets of very fine grained actinolite.

Five samples of relatively unaltered rhyolite analyzed chemically from the large body that crops out near the Little Giant Mine reveal that these rocks are high-silica rhyolites that differ from the average rhyolite of LeMaitre (1976) (table 9). The $\mathrm{SiO}_{2}$ content of analyzed samples ranges from 76.0 to 76.9 weight percent, with an arithmetic mean of 76.6-quite a bit higher than LeMaitre's (1976) average of 72.82 weight percent. In addition, the total $\mathrm{Fe}, \mathrm{MgO}, \mathrm{CaO}$, and $\mathrm{Na}_{2} \mathrm{O}$ contents are all significantly lower than, and the $\mathrm{K}_{2} \mathrm{O}$ content higher

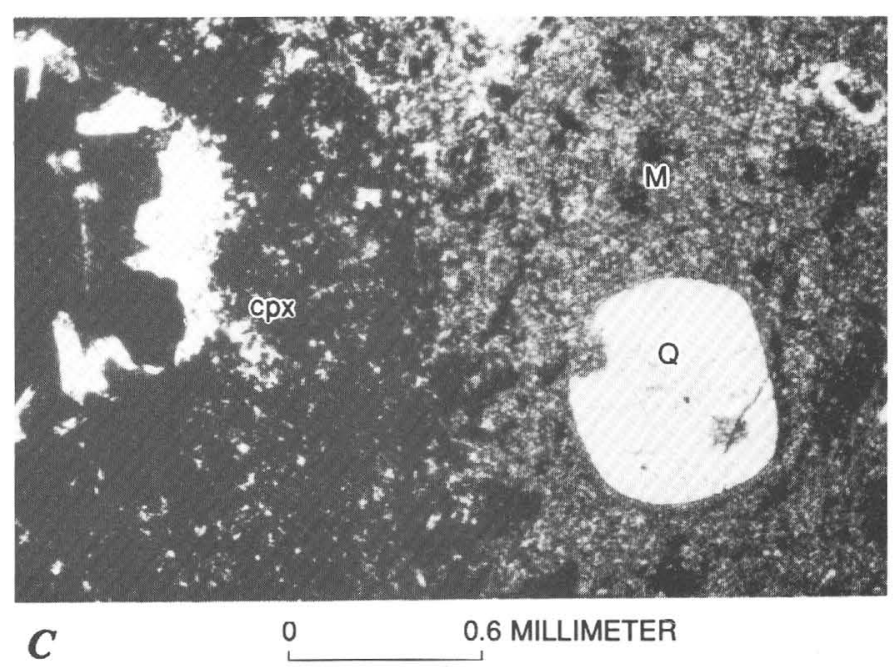

Mine. Sample 78C5. Plane-polarized light. C, Crystals of finegrained clinopyroxene (cpx) replacing K-feldspar-rich matrix (M) in rhyolite cropping out south-southeast of Bailey Day Mine. Sample 81TT217. Plane-polarized light. 
TABLE 9.-Analytical data on late Eocene or early Oligocene rhyolite of the Buckingham Camp-Copper Basin area, Lander County, Nevada

[Chemical analyses in weight percent by single-solution method of Shapiro (1975); analysts, D. Kobilis, A. Woodside, B. Scott, P. Hearn, and M. Pickering. Emissionspectrographic analyses in parts per million; analyst, J.L. Harris. Cross, Iddings, Pirsson, and Washington (CIPW) norms in weight percent. Relative standard deviation of any single reported concentration should be taken as plus 50 percent and minus 33 percent. Looked for, but not found, at parts-per-million detection levels in parentheses: As (100), Au (6.8), Bi (10), Cd (32), Dy (22), Er (4.6), Eu (2.2), Gd (15), Ge (4.6), Hf (15), Ho (6.8), In (6.8), Ir (15), Lu (15), Nd (32), Os (15), Pd (1), Pr (68), Pt (2.2), Re (10), Rh (2.2), Ru (2.2), Sb (68), Sm (10), Sn (4.6), Ta (320), Tb (32), Th (46), Tl (10), Tm (4.6), U (220), W (15), -, not detected; N.d., not determined]

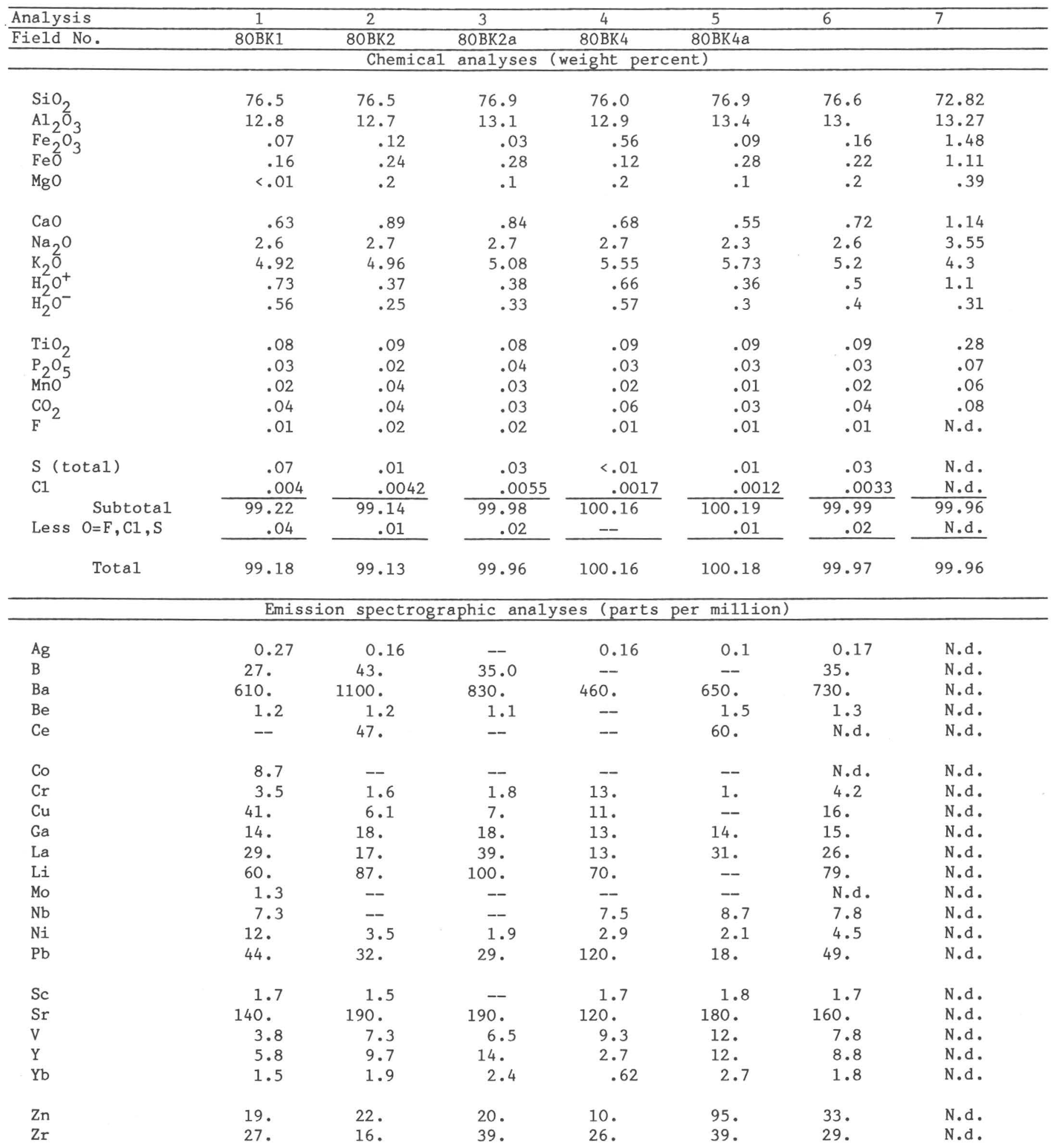


TABLE 9.-Analytical data on late Eocene or early Oligocene rhyolite of the Buckingham Camp-Copper Basin area, Lander County, Nevada-Continued

\begin{tabular}{|c|c|c|c|c|c|c|c|}
\hline Ana1ysis & 1 & 2 & 3 & 4 & 5 & 6 & 7 \\
\hline Field No. & $80 \mathrm{BK} 1$ & $80 \mathrm{BK} 2$ & $80 B K 2 a$ & $80 \mathrm{BK} 4$ & $80 \mathrm{BK} 4 \mathrm{a}$ & & \\
\hline \multicolumn{8}{|c|}{ C.I.P.W. norms (weight percent) } \\
\hline$q$ & 42.00 & 40.18 & 40.06 & 37.74 & 40.39 & 40.12 & 33.01 \\
\hline$c$ & 2.27 & 1.48 & 1.86 & 1.93 & 2.59 & 1.97 & 1.06 \\
\hline or & 29.47 & 29.63 & 30.13 & 32.93 & 33.9 & 30.86 & 25.5 \\
\hline$a b$ & 22.27 & 23.07 & 22.89 & 22.93 & 19.48 & 22.08 & 30.15 \\
\hline an & 2.66 & 3.94 & 3.61 & 2.76 & 2.27 & 3.08 & 4.71 \\
\hline h1 & .01 & .01 & .10 & -- & -- & .01 & -- \\
\hline en & - & .5 & .25 & .5 & .25 & .5 & .98 \\
\hline fs & - & .25 & .35 & -- & .29 & -- & .47 \\
\hline $\mathrm{mt}$ & .1 & .18 & .04 & .19 & .13 & .41 & 2.15 \\
\hline $\mathrm{hm}$ & - & - & -- & .43 & -- & .04 & -- \\
\hline i1 & .15 & .17 & .15 & .17 & .17 & .17 & .53 \\
\hline ap & .07 & .05 & .10 & .07 & .07 & .07 & .17 \\
\hline fr & .02 & .04 & .03 & .02 & .02 & .02 & -- \\
\hline pr & .13 & .02 & .06 & -- & .02 & .06 & - \\
\hline cc & .09 & .09 & .07 & .14 & .07 & .09 & .18 \\
\hline Total & 99.24 & 99.61 & 99.61 & 99.33 & 99.65 & 99.48 & 98.91 \\
\hline Salic & 98.67 & 98.30 & 98.55 & 97.81 & 98.63 & 98.11 & 94.43 \\
\hline Femic & 0.57 & 1.31 & 1.06 & 1.52 & 1.02 & 1.37 & 4.48 \\
\hline $\begin{array}{l}\text { Diffentiation } \\
\text { Index }\end{array}$ & 93.74 & 92.88 & 93.08 & 93.6 & 93.77 & 93.06 & 88.66 \\
\hline
\end{tabular}

1. Porphyritic rhyolite; altered somewhat to intermediate argillic assemblage.

2. Porphyritic rhyolite; very sparse alteration of feldspar to white mica.

3. Do.

4. Porphyritic rhyolite; micrographic.

5. Do.

6. Average of analyses Nos. 1-5, using only the fixed concentrations.

7. "Average" rhyolite from LeMaitre (1976).

than, their respective values in average rhyolite. However, total alkalis in analyzed samples of rhyolite from the Buckingham area are about the same as the average rhyolite. In addition, these samples of analyzed rhyolite are peraluminous (fig. 26) and corundum normative (table 9); both relations probably reflect a relatively depleted $\mathrm{CaO}$ content in these rocks. The major-element chemical data for this small number of analyzed samples of rhyolite yield relatively tight clusters of data points near the Alk corner and A corner of the AlkFM and ACF ternary diagrams, respectively (figs. $27 A, 27 B$ ), and near the midpoint of the AK sideline in the AKF diagram (fig. 27C). Normative proportions of Q, Or, and $\mathrm{Ab}$ in the analyzed samples of rhyolite cluster near the locus of ternary minimum temperatures that have been projected onto the anhydrous base of the Ab-Or-Q- $\mathrm{H}_{2} \mathrm{O}$ tetrahedron for $\mathrm{P}_{\mathrm{H}_{2} \mathrm{O}}=\mathrm{P}_{\text {total }}=500$ $\mathrm{kg} / \mathrm{cm}^{2}$ (fig. 27D). This cluster of data points in such a ternary plot is close to the ternary minimum at 5 weight percent An for $\mathrm{P}_{\mathrm{H}_{2} \mathrm{O}}=\mathrm{P}_{\text {total }}=1 \mathrm{kbar}$. However, the rhyolite contains only about 2.3 to 3.9 weight percent normative An (table 9).

The minor-element contents of analyzed samples of rhyolite from the general area of the Little Giant Mine differ considerably from what typically are considered to be geochemical signatures favorable for occurrence of Climax-type or granite molybdenite stockwork systems. The average fluorine content in these rocks from the Little Giant area is $100 \mathrm{ppm}$, as opposed to fluorine contents greater than $1,000 \mathrm{ppm}$ in a favorable geochemical signature for such systems (Ludington, 1981). The following other minor elements also differ from concentrations considered to be favorable for Climax-type stockwork molybdenite systems: 


$\begin{array}{ccc} & \begin{array}{c}\text { Rhyolite, Little Giant } \\ \text { area (ppm) }\end{array} & \begin{array}{c}\text { Favorable for } \\ \text { Climax-type molybdenite } \\ \text { systems }(p p m)\end{array} \\ \mathrm{Ba} \ldots \ldots \ldots \ldots . & 730.0 & \leq 300.0 \\ \mathrm{Sr} \ldots \ldots \ldots \ldots . . \ldots & 160 . & \leq 50 . \\ \mathrm{Sn} \ldots \ldots \ldots \ldots . & <4.6 & >5 . \\ \mathrm{La} \ldots \ldots \ldots \ldots . & 79 . & \leq 50 . \\ \mathrm{Y} \ldots \ldots \ldots \ldots . & 8.8 & \geq 50 .\end{array}$

Note, however, that four of the five samples analyzed contain detectable silver, in the range $0.1-0.27$ ppm (table 9). These silver contents are about 10 times greater than the generally accepted value for the abundance of silver in crustal igneous rocks, and about two to three times the silver abundance in undivided crust (Jones, 1969). As such, the low-level anomaly of silver in these essentially unaltered samples of rhyolite probably indicates genetic association here in the Buckingham area between rhyolite and silver mineralization, as exemplified by that exploited previously at the Little Giant Mine. In addition, silver ore from the Little Giant Mine is associated strongly with high concentrations of arsenic, lead, zinc, and tin. Arsenic, as scorodite derived secondarily from primary arsenopyrite, is especially widespread in rocks surrounding the Little Giant Mine. However, the relatively high detection levels for arsenic in samples of rhyolite analyzed (table 8) precluded our determination of a local background for arsenic in these rocks.

\section{MISCELLANEOUS INTRUSIVE ROCKS}

Miscellaneous intrusive rocks of late Eocene or early Oligocene age in the Buckingham area include (1) small outcrops of porphyritic rhyodacite in the northwestern part of the area (unit Trd, pl. 1); (2) small, irregular masses and narrow dikes of diabase mostly in a north-south-trending cluster just to the north of the workings at the Copper Basin part of the area and west of the Surprise Mine (unit Tdb); and (3) variably altered, porphyritic biotite monzogranite that does not crop out in the area but is present locally at depth as indicated by a drill hole collared near the Little Giant Mine. Although bodies of porphyritic rhyodacite are altered intensely (they include phenocrysts of clouded oligoclase, heavily chloritized and carbonate-altered hornblende, and chloritized biotite), most of the nearby surrounding rocks of the Harmony Formation are not affected visibly in outcrop to any significant degree by dispersed secondary alteration. In addition, the porphyritic rhyodacite shows, under the microscope, relatively abundant grains of secondary sphene and secondary apatite both concentrated at the sites of replaced primary hornblende. The small bodies of very fine grained diabase that cluster north of the Copper Basin open pit also show some effects of secondary alteration. These rocks typically include well-developed ophitic textures that are cut by microveins of garnet and show excellent fabrics suggestive of endoskarn. Thus, at least some of the diabase here, which apparently intrudes only the rocks of the Harmony Formation (Kirk Schmidt, oral commun., 1985), had been emplaced before the circulation of skarn-forming fluids. Well-exposed contacts between skarn and diabase north of the Copper Basin Mine show that skarn is brecciated and recrystallized immediately adjacent to diabase, whereas a short distance from the contact, skarn is very delicately laminated and apparently undisturbed. Moreover, some diabase includes fragments of apparently early-crystallized diabase. In addition, two small bodies of diabase crop out south of the Copper Basin Mine, near the southeast corner of the area (pl. 1). One of these diabases also shows a strongly developed calc-silicate type of subsolidus alteration of its primary igneous fabric. However, the predominant calc-silicate mineral here is actinolite. In as much as this alteration may be associated with the Late Cretaceous Buckingham molybdenum system, the possibility remains that some of the small masses of diabase assigned to the Tertiary south of the Copper Basin Mine may, in fact, be Ordovician and (or) Devonian in age. There are two other small outcrops of apparently Tertiary diabase mapped in the area. One outcrop, about $150 \mathrm{~m}$ west of the West stock of the Late Cretaceous Buckingham molybdenum system, is well within the outer limit of intensely developed quartz stockworks related to the molybdenum system. This diabase, as well as the diabase that cuts the late Eocene or early Oligocene rhyolite, is postmineral relative to the molybdenum mineralization, which is post-Late Cretaceous. Because variably altered porphyritic biotite monzogranite was penetrated at depth in an area of potential precious-metal mineralization, this rock type was studied in somewhat greater detail than the other miscellaneous intrusive rocks of the area.

Variably altered, porphyritic biotite monzogranite is present generally at depths greater than about $60 \mathrm{~m}$ along a significant length of a deep drill hole into the hanging wall of the Little Giant fault (sample site 15, fig. 18). These mediumgrained rocks probably are a less highly evolved 
phase of the late Eocene or early Oligocene rhyolite (see subsection below entitled "Economic Geology"). An age determination on a mineral separate of mostly primary biotite from this unexposed body yielded an age of $38.8 \mathrm{Ma}$. This particular mineral separate was composited from five approximately 15-cm-long intervals of drill core collected well below the oxide zone in this general area. Microscopic examination of five thin sections from the variably altered, porphyritic biotite monzogranite revealed that the rock has undergone widespread alteration to potassic-alteration assemblages, followed, in turn, by late-stage propylitic assemblages. Phenocrysts of primary biotite (red brown, optic Z-axis) are preserved generally, but some are altered to clusters of stubby fine-grained crystals of secondary biotite, in places obviously compatible with pyrite and some secondary sphene. Additional textural evidence in the rocks of a widespread potassic alteration is provided by quartz-K-feldsparrutile veins that here and there cut quartz phenocrysts, and by quartz-K-feldspar-pyrite veins that cut oscillatory-zoned phenocrysts of oligoclase. In places, some of the latter veins contain some very late stage carbonate along thin medial parts. The apparently late stage propylitic-alteration event in the rocks is indicated by partial replacement of potassic-alteration assemblages by chlorite, carbonate, and actinolite in various proportions, including additional amounts of pyrite and secondary sphene. On the whole, final subsolidus alteration of rocks here has been a plagioclase-destructive type alteration wherein plagioclase has been altered heavily to white mica, with or without carbonate and pyrite-the latter mineral typically filling microcracks in many phenocrysts of plagioclase.

One representative rock sample from this body of variably altered, biotite monzogranite has been analyzed chemically (table 10). This particular sample, from a depth of about $61 \mathrm{~m}$ below ground surface, was selected for chemical analysis primarily because it overall is the least altered of the samples. However, the high $\mathrm{K}_{2} \mathrm{O} / \mathrm{Na}_{2} \mathrm{O}$ ratio (approx 1.9) in the sample analyzed must indicate that late-stage, magmatic potassic alteration has affected the unit. Chemical data from the sample yield a plot in metaluminus field (fig. 26), and various ternary plots of the chemical data from this sample (fig. 27) exhibit a tendency to cluster more closely with similar data from the late Eocene or early Oligocene biotite-hornblende monzogranite of Bluff area and porphyritic leucotonalite than with data from the late Eocene or early Oligocene rhyolite.
TABLE 10.-Analytical data on altered porphyritic biotite monzogranite from a drill hole collared near Little Giant Mine

[Chemical analyses in weight percent by X-ray spectroscopy supplemented by classical methods; analysts, A.J. Bartel, K. Stewart, J. Taggart, R. Moore, P. Aruscavage, and D. Kay. Optical-spectroscopic analyses in parts per million by inductively coupled plasma methods of Scott and Kokot (1975) and F.E. Lichte (unpub. data, 1983); analyst, M. Malcolm. Cross, Iddings, Pirsson, and Washington (CIPW) norms in weight percent. Looked for, but not found, at parts-permillion detection levels in parentheses: $\mathrm{Ag}(2), \mathrm{As}(10), \mathrm{Au}$ (8), Bi (10), Cd (2), Eu (2), Ho (4), Mo (2), Nb (4), Sn (20), Ta (40), U (100). Au determined by atomicabsorption methods, F determined by specific-ion-electrode methods, and W determined colorimetrically; analysts, R. Moore, P. Aruscavage, and D. Kay. -, not detected]

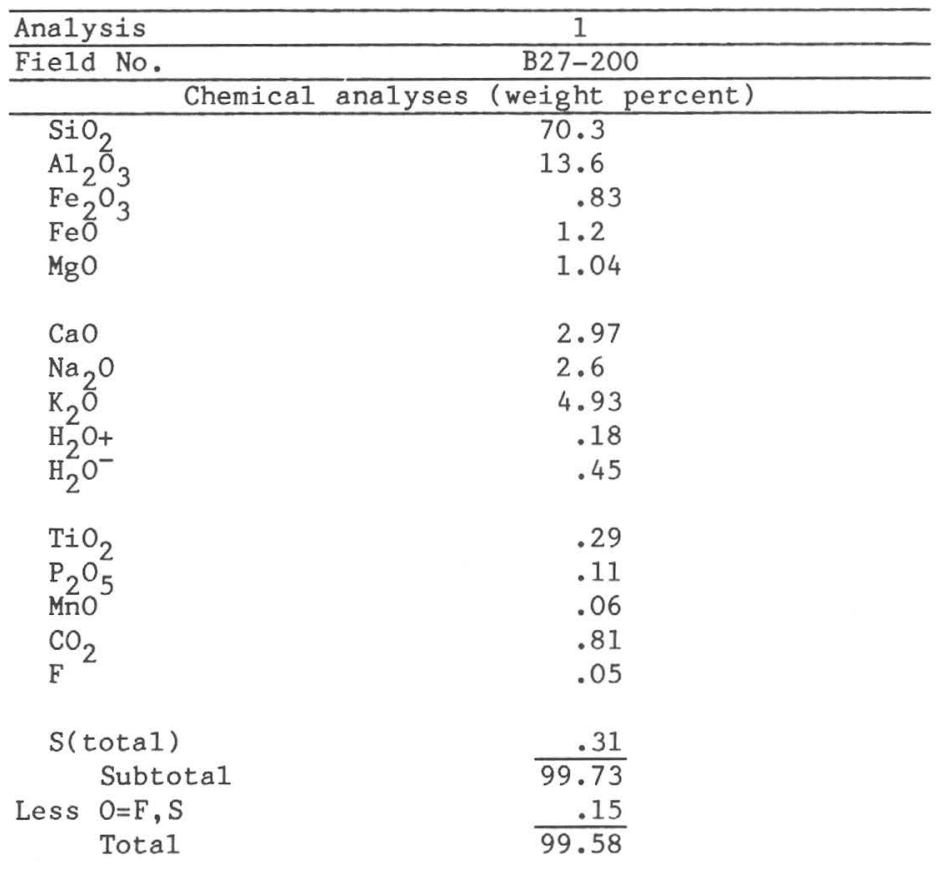

\section{Optical spectroscopic analyses (parts per million)}

$\begin{array}{lr}\mathrm{Ba} & 830.0 \\ \mathrm{Be} & 1 . \\ \mathrm{Ce} & 26 . \\ \mathrm{Co} & 5 . \\ \mathrm{Cr} & 17 . \\ \mathrm{Cu} & 25 . \\ \mathrm{Ga} & 16 . \\ \mathrm{La} & 13 . \\ \mathrm{Li} & 18 . \\ \mathrm{Nd} & 15 . \\ & \\ \mathrm{Ni} & 2 . \\ \mathrm{Pb} & 46 . \\ \mathrm{Sc} & 4 . \\ \mathrm{Sr} & 360 . \\ \mathrm{Th} & 6 . \\ & \\ \mathrm{V} & 40 . \\ \mathrm{Y} & 11 . \\ \mathrm{Yb} & 1 . \\ \mathrm{Zn} & 38 .\end{array}$


TABLE 10.-Analytical data on altered porphyritic biotite monzogranite from a drill hole collared near Little Giant MineContinued

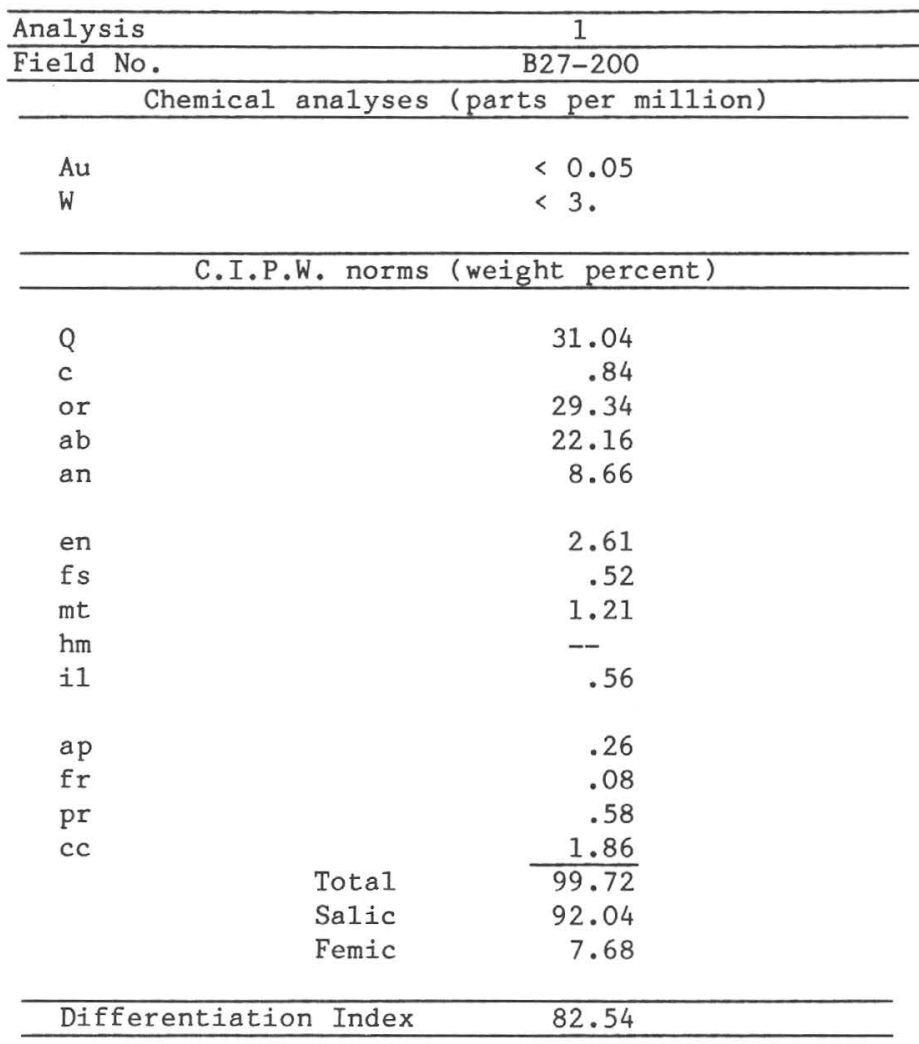

1. Variably potassic- and propylitic-altered porphyritic biotite monzogranite from depth of about 61 m near Little Giant Mine (see text).

\section{EARLY OUIGOCENE}

\section{GRANODIORITE PORPHYRY}

Irregular masses and dikes of early Oligocene granodiorite porphyry crop out discontinuously along a broad, north-south-trending belt, approximately $1.5 \mathrm{~km}$ wide, that extends from the south edge of the map area, through the vicinity of the East stock of the Buckingham stockwork molybdenite system, and finally to a cluster of bodies near the north-central edge of the map area (unit Tgp, pl. 1). Many outcrops of granodiorite porphyry form bold, resistant exposures (fig. $41 A$ ) that disintegrate to a granular soil cover. The characteristic aphanitic matrix of these rocks is grayish green, except where the rocks are altered intensely to argillic assemblages, and the grayish-green color represents either the presence of widely scattered, primary hornblende or the occurrence of secondary propylitic alteration. Large phenocrysts of pink to creamy-white K-feldspar are also common in these rocks (fig. $41 B$ ). Smoky-gray quartz bipyramids, slightly bluish gray in some of the most argillically altered outcrops, are ubiquitous in the unit, and they typically make up several volume percent of it. In addition, granodiorite porphyry (termed "quartz latite porphyry" by Blake and others, 1979, and in the subsection below entitled "Economic Geology") has been found extensively in many drill holes in the Buckingham stockwork system, in particular those drill holes collared near the East stock. As such, granodiorite porphyry in the Buckingham system makes up a swarm of west-dipping dikes. Granodiorite porphyry intrudes the rocks of the Upper Cambrian Harmony Formation, as well as all igneous rocks that belong to the Late Cretaceous Buckingham stockwork system. Moreover, the extensive quartz stockworks of the Buckingham sys-
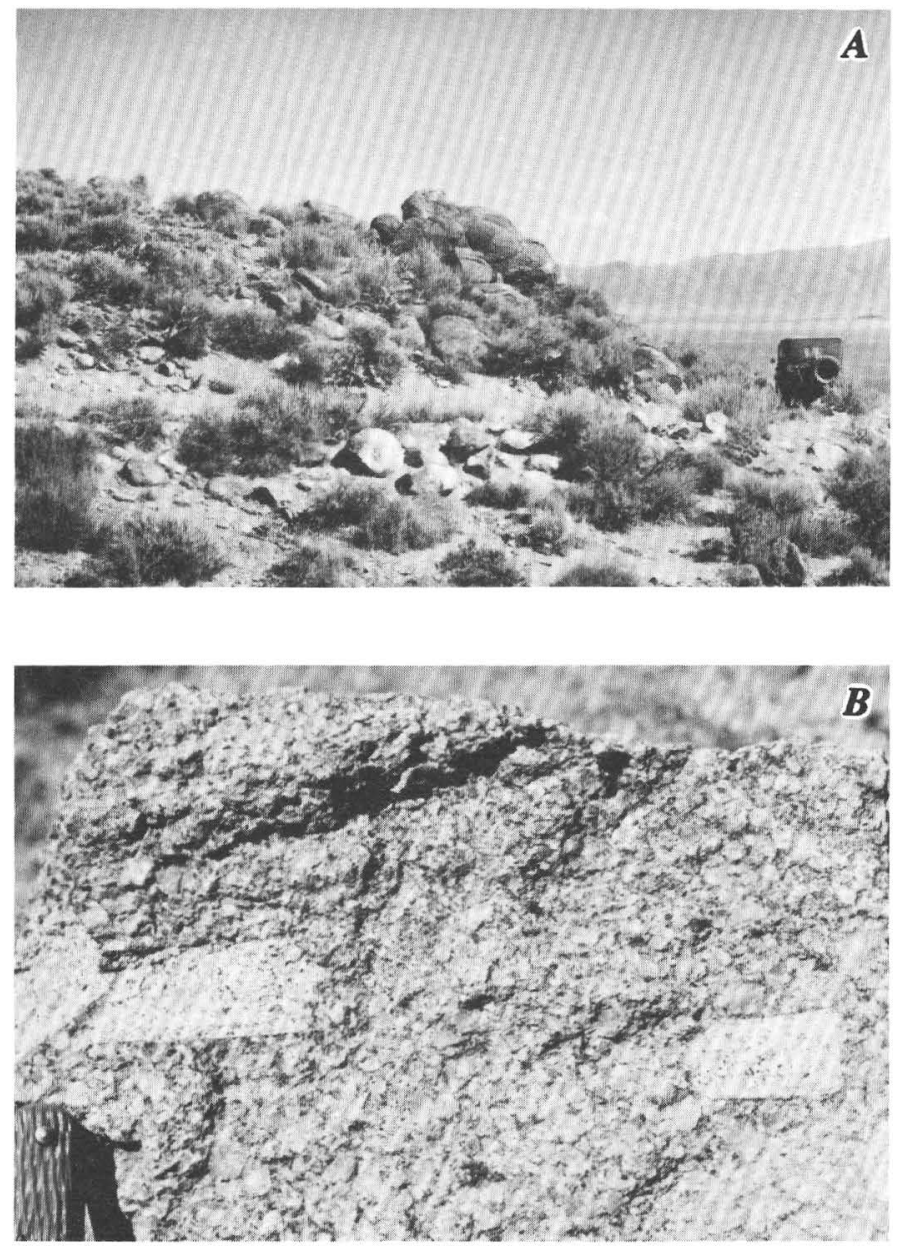

Figure 41.-Early Oligocene granodiorite porphyry from Buckingham area. A, Bold outcrop of granodiorite porphyry near southeast corner of area. Jeep on right side for scale. $B$, Large K-feldspar megacrysts in granodiorite porphyry. Such megacrysts are typically common in central parts of some wider bodies of granodiorite porphyry. Pocket knife in lower left corner for scale. 
tem, together with some conspicuous low-angle faults there, also are cut by granodiorite porphyry. Field relations indicate further that the granodiorite porphyry is younger than many other Tertiary igneous rocks in the area: the granodiorite porphyry intrudes the biotite-hornblende monzogranite of Bluff area, the breccia pipe of Bluff area, and the porphyritic leucogranite unit. A mineral separate of primary hornblende from a sample of exceptionally fresh granodiorite porphyry collected northnorthwest of the Surprise Mine (fig. 18) yielded an age of $35.4 \pm 1.1 \mathrm{Ma}$ using the K-Ar method (see subsection above entitled "Potassium-Argon and ${ }^{40} \mathrm{Ar} /{ }^{39} \mathrm{Ar}$ Geochronology of Selected Plutons in the Buckingham Area").

\section{PETROGRAPHY}

Granodiorite porphyry in the area shows both a wide variation in its primary mineralogy and a broad variability in the types and intensity of secondary alteration. The variation in primary mineralogy, which is not distinguished on the map, is indicated in the relative proportion of its mafic phenocrysts and in the relative proportion of $\mathrm{K}$ feldspar to plagioclase in the groundmass. Some granodiorite porphyry has only hornblende as its mafic phenocryst, some only biotite, whereas the most common variety has both, with hornblende generally predominant. Most of the hornblendebearing phases of the granodiorite porphyry show a strongly developed seriate texture wherein the size of phenocrystic hornblende extends down to that of the groundmass, typically 0.02 to $0.04 \mathrm{~mm}$. The second major variation in primary mineralogy involves the composition of the matrix. Apparently, most granodiorite porphyry near the southern part of the area has a very plagioclase rich groundmass, whereas most granodiorite porphyry elsewhere has $\mathrm{K}$-feldspar as the principal prealteration feldspar in the groundmass. The predominant types of secondary alteration to affect granodiorite porphyry in the area are propylitic and argillic; skarn alteration is associated with granodiorite porphyry in some areas where the country rock has abundant carbonate stata. Most granodiorite porphyry at depth in the general area of the East stock of the Buckingham stockwork system shows moderate to intense development of propylitic-alteration assemblages. These assemblages consist of chlorite, carbonate minerals, and minor white mica, with or without rutile, sphene, epidote-group minerals, actinolite, and iron sulfides-all as partial to complete replacements of primary hornblende and (or) biotite. Pyrrhotite is much more common than pyrite, and both are dispersed ubiquitously through granodiorite porphyry in variable proportions and at overall concentrations of as much as a few volume percent. Pyrrhotite and pyrite apparently both are present in stable association with various sitespecific propylitic assemblages. Some sparse concentrations of sphalerite and galena also have been reported in some of the dikes and sills penetrated at depth near the East stock (Blake and others, 1979). In addition, plagioclase phenocrysts in these rocks generally are converted partially to clay(s) and (or) white mica along their margins. Granodiorite porphyry affected most intensely by argillic assemblages is that in the general area of the Copper Queen Mine, some that crops out near Long Canyon, and some that is near the easternmost parts of the area disturbed by mining operations at the Copper Basin Mine. Some exposures of argillically altered granodiorite porphyry are pitted to a frothy-appearing surface because of the weathering out of the clay-altered plagioclase. At the Copper Queen Mine, much of the granodiorite porphyry is present in a zone of rocks that were fractured highly during development of the Late Cretaceous Buckingham molybdenum system. This zone of highly fractured rocks is quite diffuse but seemingly follows, as a fringe, the outermost limit of intensely developed quartz stockworks in the molybdenum system (pl. 1). In addition, the granodiorite porphyry itself, in this general area, is shattered by post-gránodiorite porphyry fractures and faults (fig. 42). In places here, granodiorite porphyry is cut by planar, largely iron oxide-filled seams and hairline fractures, and some sparse veins of quartz. The iron oxides replace pyrite and (or) pyrrhotite. However, throughout the granodiorite porphyry, both at the surface and at depth near the East stock, veins of quartz are very rare. Thus, the locally strong, argillic alteration of this unit must be partly a result of its emplacement into a zone of highly permeable, previously shattered rocks that already contained high concentrations of pyrite associated with the Buckingham molybdenum system. Further circulation of supergene fluids, possibly in the Tertiary, was enhanced by fractures and faults that are post-granodiorite porphyry in age.

\section{CHEMISTRY}

Chemical data on six representative samples of granodiorite porphyry from the Buckingham area are from drill core obtained between 101 and $281 \mathrm{~m}$ 
below ground surface near the East stock, and all the samples are altered propylitically (table 11). Some are altered intensely. $\mathrm{CO}_{2}$ contents range from about 1 to more than 3 weight percent, a result of secondary carbonate associated with propylitic assemblages in the rocks. As such, normative calculations from these analyses result in spurious values of normative corundum directly proportional to the amount of secondary carbonate (table 11). Thus, a rigorous comparison of the chemistry of the presumed prealteration state of these rocks with other igneous rocks in the area would be troublesome and would be fraught with inherent ambiguities. Nonetheless, most of these analyses, including both major and minor elements, show a minimal scatter of their
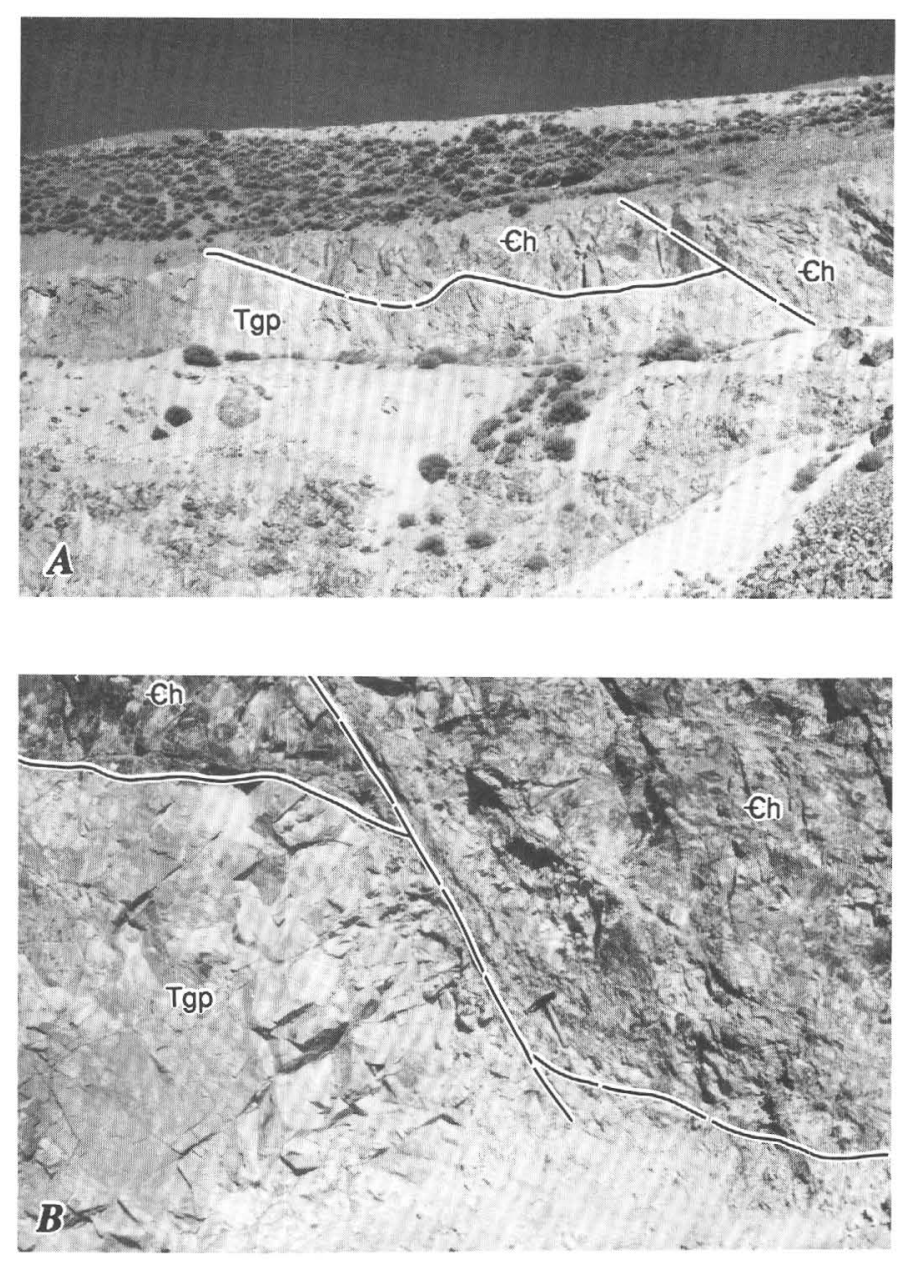

FiguRE 42.-Early Oligocene granodiorite porphyry (Tgp) and the Upper Cambrian Harmony Formation (€h) at Copper Queen Mine in Buckingham area. Faults dashed where approximate. $A$, View southwestward across open cut at Copper Queen Mine, showing intense bleaching of granodiorite porphyry resulting from argillic alteration. Field of view, $70 \mathrm{~m}$. B, Closeup of minor normal fault exposed in open cut of mine. Fault has values suggesting thereby that the analyses are at least generally representative of these rocks. Because of a close correspondence between the apparent age of emplacement of the granodiorite porphyry in the Buckingham area $(35.4 \pm 1.1 \mathrm{Ma})$ and the regionally extensive Oligocene Caetano Tuff (approx 34 $\mathrm{Ma}$ ), some of which crops out prominently at Elephant Head just $0.3 \mathrm{~km}$ to the east, a few general comparisons between the two units are in order. Furthermore, granodiorite porphyry near the east edge of the area ( $\mathrm{pl}$. 1) was emplaced to a level at most only $400 \mathrm{~m}$ below the projected erosional surface onto which the Caetano Tuff at Elephant Head was extruded. Large-scale geologic mapping at Elephant Head indicates that altered granodiorite porphyry apparently correlative with granodiorite porphyry in the Buckingham area, is unconformably overlain by unmineralized and unaltered Caetano Tuff (G.M. Jones, written commun., 1988).

In comparison with analyses of outflow facies of the Caetano Tuff in the district (Roberts, 1964; Stewart and McKee, 1977), these analyses (table 11) of granodiorite porphyry from the East stock of the Buckingham system are much lower in $\mathrm{SiO}_{2}$ content (66.8 compared with 70.7 weight percent), lower in $\mathrm{Na}_{2} \mathrm{O}$ content (2.6 compared with 3.2 weight percent), lower in $\mathrm{K}_{2} \mathrm{O}$ content (3.7 compared with 4.5 weight percent), higher in $\mathrm{CaO}$ content $(3.8 \mathrm{com}$ pared with 2.0 weight percent), and higher in $\mathrm{MgO}$ content (2.0 compared with 0.5 weight percent). Thus, there apparently are significant differences in

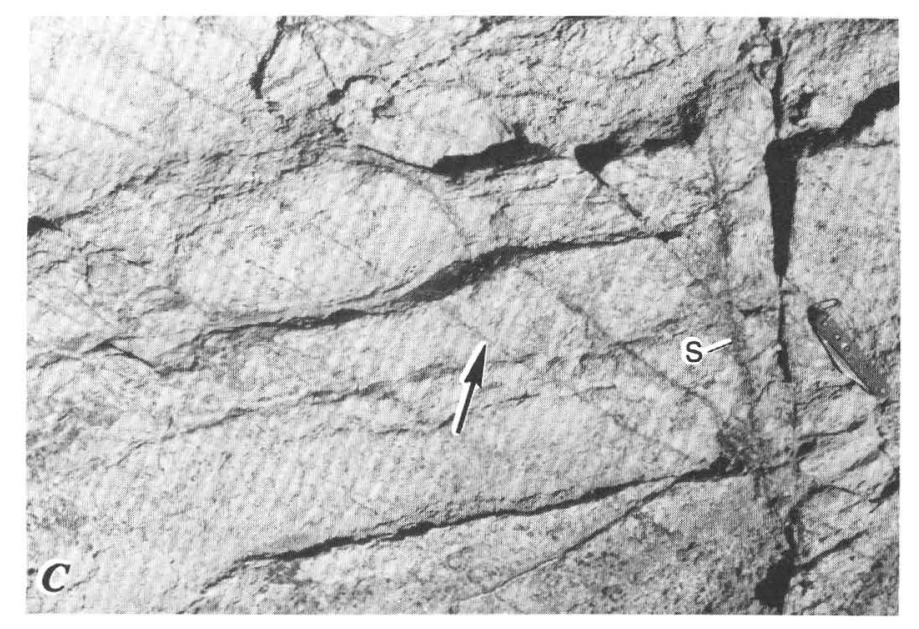

an approximately 3-m separation of upper contact of granodiorite porphyry. Hammer in lower center for scale. $C$, View near south end of open cut, showing argillically altered granodiorite porphyry cut by planar, largely iron oxide-filled seams (S) and hairline fractures (at head of arrow) that include some sparse veins of quartz. Pocket knife on right for scale. 
TABLE 11.-Analytical data on early Oligocene granodiorite porphyry near the East stock of the Buckingham stockwork molybdenum system

[Chemical analyses in weight percent by single-solution method of Shapiro (1975); analysts, K. Coates and H. Smith. Emission-spectrographic analyses in parts per million by J.L. Harris. Cross, Iddings, Pirsson, and Washington (CIPW) norms in weight percent. Relative standard deviation of any single reported concentration should be taken as plus 50 percent and minus 33 percent. Looked for, but not found, at parts-per-million detection levels in parentheses: $\mathrm{As} \mathrm{(150),} \mathrm{Au}(10), \mathrm{Cd}$ (32), Dy (22), Er (10), Gd (15), Ge (1.5), Hf (15), Ho (6.8), In (6.8), Ir (15), Lu (22), Nd (46), Os (22), Pd (1.5), Pr (68), Pt (6.8), Re (10), Rh (2.2), Ru (3.2), Sb (46), Sm (22), $\mathrm{Ta}(460), \mathrm{Tb}(32)$, Th (4.6), $\mathrm{W}(10) . \mathrm{Au}, \mathrm{Hg}$, and $\mathrm{Zn}$ determined by atomicabsorption spectroscopy; analysts, J. Budinsky and R. Moore. F determined by specific-ion-electrode methods; analysts, J. Budinsky and R. Moore. Cl determined spectrophotometrically; analysts, J. Budinsky and R. Moore. Th and U determined by instrumental delayed-neutron counting, using methods of Millard and Keaten (1982); analysts, H.T. Millard, Jr., F.M. Luman, and B.A. Keaten. Nb and Rb determined by X-ray spectroscopy; analysts, R. Johnson, H.J. Rose, B. McCall, G. Sellers, and J. Lindsay. —, not detected. cc, calcite; chl, chlorite; pg, plagioclase; po, pyrrhotite; py, pyrite; rut, rutile; sph, sphene; wm, white mica. - , not detected]

\begin{tabular}{|c|c|c|c|c|c|c|}
\hline Analysis & 1 & 2 & 3 & 4 & 5 & 6 \\
\hline Field No. & $1453-923$ & $1463-898$ & $1463-396$ & $1475-330$ & $1468-811$ & $1468-595$ \\
\hline \multicolumn{7}{|c|}{ Chemical analyses (weight percent) } \\
\hline $\mathrm{SiO}_{2}$ & 67.0 & 66.0 & 66.6 & 67.9 & 68.0 & 65.8 \\
\hline $\mathrm{Al}_{2} \mathrm{O}_{3}$ & 14.2 & 13.6 & 14.9 & 14.1 & 14.3 & 14.8 \\
\hline $\mathrm{Fe}_{2}^{2} \mathrm{O}_{3}$ & .47 & .81 & .43 & .43 & .88 & 1.2 \\
\hline $\mathrm{FeO}^{3}$ & 1.9 & 1.3 & 2.1 & 1.8 & 1.2 & 1.9 \\
\hline $\mathrm{MgO}$ & 1.9 & 2. & 1.8 & 2. & 1.7 & 2.8 \\
\hline $\mathrm{CaO}$ & 3.1 & 4. & 3.2 & 2.8 & 3.1 & 4. \\
\hline $\mathrm{Na}_{2} \mathrm{O}$ & 2.5 & 1.5 & 2.8 & 3.1 & 2.7 & 2.8 \\
\hline $\mathrm{x}_{2} \mathrm{O}$ & 4.2 & 4.2 & 3.3 & 3.5 & 3.7 & 3.3 \\
\hline $\mathrm{H}_{2}^{2} \mathrm{O}^{+}$ & 1.2 & 1.8 & 1.8 & 1.1 & 1.6 & 1.2 \\
\hline $\mathrm{H}_{2}^{2} \mathrm{O}^{-}$ & .41 & .44 & .48 & .55 & .44 & .38 \\
\hline $\mathrm{TiO}_{2}$ & .29 & .25 & .33 & .27 & .24 & .37 \\
\hline $\mathrm{P}_{2} \mathrm{O}_{5}^{2}$ & .09 & .08 & .09 & .08 & .07 & .09 \\
\hline $\mathrm{Mno}^{2}$ & .06 & .07 & .06 & .08 & .07 & .09 \\
\hline $\mathrm{CO}_{2}$ & 2.1 & 3.3 & 2. & 1.3 & 2.1 & .98 \\
\hline$F^{2}$ & .035 & .045 & .035 & .031 & .03 & .035 \\
\hline C1 & .025 & .023 & .026 & .026 & .017 & .018 \\
\hline$S($ tota 1$)$ & .36 & .44 & .27 & .01 & .38 & .42 \\
\hline Subtotal & $\overline{99.84}$ & $\overline{99.86}$ & $\overline{100.22}$ & $\overline{99.08}$ & $\overline{100.53}$ & $\overline{100.18}$ \\
\hline$S$ (sulfide) & .31 & .39 & .22 & -- & .33 & .34 \\
\hline Less $\mathrm{O}=\mathrm{F}, \underset{\text { Total }}{\mathrm{Cl}}, \mathrm{S}$ & S $\frac{.18}{99.66}$ & $\frac{.30}{99.56}$ & $\frac{.14}{100.08}$ & $\frac{.02}{99.06}$ & $\frac{.18}{100.35}$ & $\frac{.20}{99.98}$ \\
\hline
\end{tabular}

\begin{tabular}{|c|c|c|c|c|c|c|}
\hline \multicolumn{7}{|c|}{ Emission spectrographic analyses (parts per million) } \\
\hline $\mathrm{Ag}$ & 0.24 & 0.54 & -- & 2.4 & - & -- \\
\hline$B$ & 7.1 & 21 . & 8.2 & 7.8 & 26.0 & -- \\
\hline $\mathrm{Ba}$ & 1000 & 790. & 1400 & 1400 & 900 & 1300.0 \\
\hline $\mathrm{Be}$ & 2.1 & 2.2 & 2.8 & 3.7 & 2.1 & 1.9 \\
\hline $\mathrm{Bi}$ & -- & -- & -- & 15. & -- & -- \\
\hline $\mathrm{Ce}$ & 46. & 44. & -- & -- & 54. & -- \\
\hline Co & 5.7 & 5.3 & 6.2 & 8.2 & 5.3 & 12. \\
\hline $\mathrm{Cr}$ & 98. & 83. & 93. & 140. & 95. & 240 \\
\hline $\mathrm{Cu}$ & 33. & 31. & 2.5 & 1.7 & 2.7 & 9.7 \\
\hline $\mathrm{Ga}$ & 21 . & 21. & 29. & 29. & 22. & 29. \\
\hline La & 21. & 21. & 26 . & 34. & 27. & 15. \\
\hline $\mathrm{Li}$ & - & - & - & 89. & - & 95. \\
\hline Mo & -- & 25. & -- & -- & 3.1 & -- \\
\hline $\mathrm{Nb}$ & 2.4 & 4.4 & 5.6 & 5.1 & 5.1 & 7.3 \\
\hline $\mathrm{Ni}$ & 20. & 18. & 18. & 26. & 18. & 39. \\
\hline $\mathrm{Pb}$ & 180. & 170 & 54. & 56. & 49. & 62. \\
\hline Sc & 7.5 & 7.1 & 12. & 11. & 7.2 & 10. \\
\hline $\mathrm{Sn}$ & 2.7 & 3. & 3.2 & 14. & -- & 4.5 \\
\hline $\begin{array}{l}\text { Sr } \\
V\end{array}$ & $\begin{array}{r}680 . \\
50 .\end{array}$ & $\begin{array}{r}430 . \\
49 .\end{array}$ & $\begin{array}{r}770 . \\
58 .\end{array}$ & $\begin{array}{r}630 . \\
60 .\end{array}$ & $\begin{array}{r}510 . \\
47 .\end{array}$ & $\begin{array}{r}660 . \\
75 .\end{array}$ \\
\hline Y & 11. & 11. & 15. & 13. & 11. & 8.2 \\
\hline $\mathrm{Yb}$ & 1.9 & 2.1 & 2. & 2.1 & 2.3 & 1.9 \\
\hline $\mathrm{Zr}$ & 51. & 64. & 78. & 76. & 39. & 69. \\
\hline
\end{tabular}

the major-element compositions of these two units. However, granodiorite porphyry is altered, whereas the Caetano Tuff is not. Although the Caetano Tuff
TABLE 11.-Analytical data on early Oligocene granodiorite porphyry near the East stock of the Buckingham stockwork molybdenum system-Continued

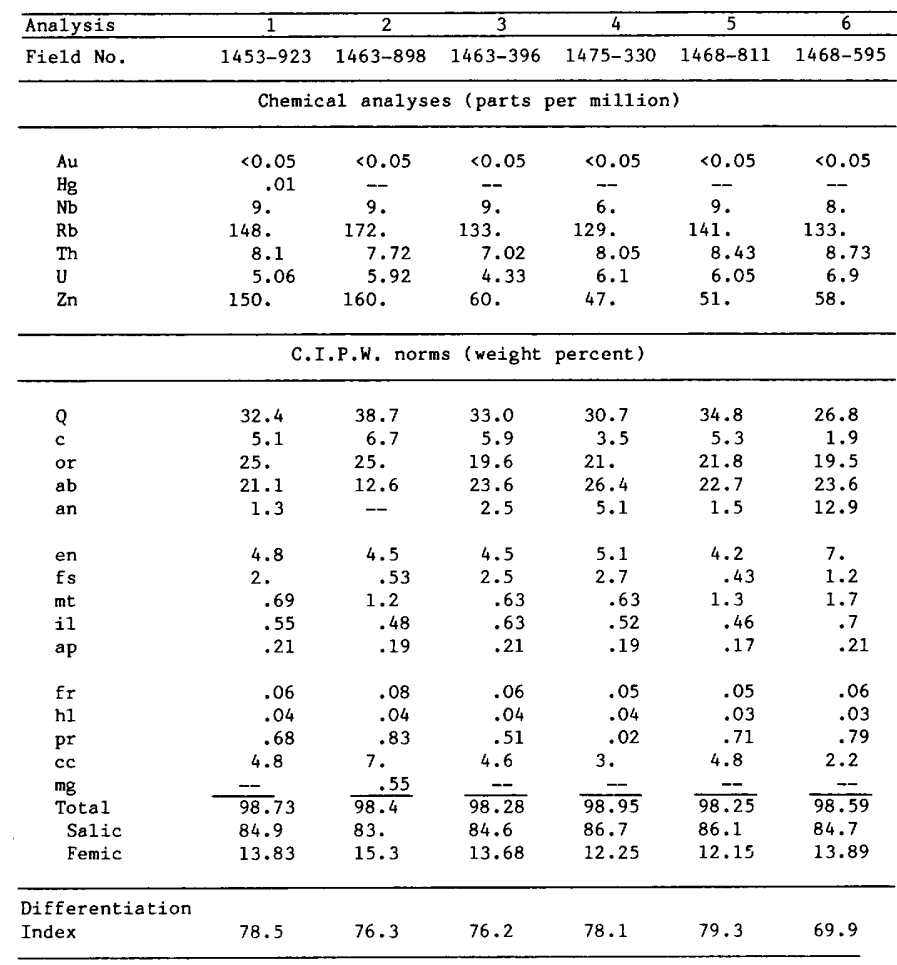

1. Depth $281 \mathrm{~m}$. Propylitically altered. Abundant potassium feldspar in groundmass; timely dispersed pyrrhotite and pyrite in the ratio $2: 1$ (po:py) associated with chl, cc, and wm.

2. Depth $274 \mathrm{~m}$. Intense propylitic alteration. Pg replaced completely. Groundmass kfs apparently stable. Approximately 1 volume percent po in groundmass.

3. Depth $121 \mathrm{~m}$. Propylitic alteration. Primary mafics replaced completely by $\mathrm{chl}, \mathrm{sph}$, and epidote group mineral( $\mathrm{s})$.

4. Depth $101 \mathrm{~m}$. Intense propylitic alteration. Mafics replaced completely by ch1, sph, and epidote group mineral(s).

5. Depth $247 \mathrm{~m}$. Intense propylitic alteration. Mafics altered to ch1, $\mathrm{cc}$, wm, \pm rut, and $\mathrm{pg}$, altered to clay(s), wm, and $\mathrm{cc}$. Ratio py:po is
greater than 1 ; sulfides compatible apparently with secondary minerals.

6. Depth $181 \mathrm{~m}$. Variably intense propylitic alteration. Most pg grain clouded slightly; others replaced in part by cc. Primary biotite alteration along margins to chl. Po:py ratio is slightly greater than one.

was termed a "quartz latite" in many early studies in the region, the Caetano Tuff is a low-silica or calcalkaline rhyolite (Stewart and McKee, 1977; Rytuba, 1985).

Analyses of granodiorite porphyry emplaced in a predominantly carbonate rich country rock show some major-element and, possibly, some minorelement contents markedly different from those in granodiorite porphyry emplaced in a siliceous country rock (compare tables 11,12). Granodiorite porphyry emplaced in the carbonate-rich middle member of the Battle Formation and the Antler Peak Limestone apparently is depleted in $\mathrm{SiO}_{2}$ but it has an increased $\mathrm{CaO}$ content compared 
TABLE 12.-Analytical data on early Oligocene granodiorite por phyry emplaced in the middle member of the Middle Pennsylvanian Battle Formation and the Upper Pennsylvanian and Lower Permian Antler Peak Limestone

[Chemical analyses in weight percent by single-solution method of Shapiro (1975); analysts, N. Elsheimer and T. Frost. Optical-spectroscopic analyses in parts per million; analyst, P.H. Briggs. Cross, Iddings, Pirsson, and Washington (CIPW) norms in weight percent. Looked for, but not found, at parts-per-million detection levels in parentheses: $\mathrm{Au}(8), \mathrm{Bi}(10), \mathrm{Eu}(2), \mathrm{Ho}(4), \mathrm{Mo}(2), \mathrm{Sn}(20)$, Ta (40), U (100). $\mathrm{Ag}, \mathrm{Sb}, \mathrm{As}$, and $\mathrm{Tl}$ determined by atomic-absorption spectroscopy; analysts, M. Doughten, K. Kennedy, and J.G. Crock. F determined by specific-ion-electrode methods; analysts, N. Elsheimer and T. Frost. Cl determined spectrophotometrically; analysts, N. Elsheimer and T. Frost. - , not detected]

\begin{tabular}{lcc}
\hline Analysis & 1 & 2 \\
\hline Fie1d No. & 85TT125 & 85TT126 \\
\hline
\end{tabular}

Chemical analyses (weight percent)

\begin{tabular}{|c|c|c|}
\hline $\mathrm{SiO}_{2}$ & 63.5 & 64.0 \\
\hline $\mathrm{Al}_{2} \mathrm{O}_{3}$ & 15.4 & 15.3 \\
\hline $\mathrm{Fe}_{2} \mathrm{O}_{3}$ & 1.21 & .86 \\
\hline $\mathrm{FeO}$ & 1.47 & 1.6 \\
\hline $\mathrm{MgO}$ & 2.9 & 2.6 \\
\hline $\mathrm{CaO}$ & 5.31 & 5.11 \\
\hline $\mathrm{Na}_{2} \mathrm{O}$ & 2.7 & 2.6 \\
\hline $\mathrm{K}_{2} \mathrm{O}$ & 4.1 & 4.27 \\
\hline $\mathrm{H}_{2}^{2} \mathrm{O}^{+}$ & .9 & .99 \\
\hline $\mathrm{H}_{2} \mathrm{O}^{-}$ & .64 & .68 \\
\hline $\mathrm{TiO}_{2}$ & .52 & .47 \\
\hline $\mathrm{P}_{2} \mathrm{O}_{5}$ & .18 & .16 \\
\hline $\mathrm{MnO}^{2}$ & .08 & .06 \\
\hline $\mathrm{CO}_{2}$ & .59 & .59 \\
\hline F & .06 & .06 \\
\hline $\mathrm{Cl}$ & .015 & 0.15 \\
\hline$S($ total) & $<.01$ & $<.01$ \\
\hline Subtotal & $\overline{98.58}$ & 98.50 \\
\hline S(sulfide) & -- & -- \\
\hline 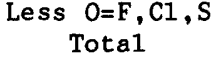 & $\frac{.03}{98.55}$ & $\frac{.03}{98.47}$ \\
\hline
\end{tabular}

Optical spectroscopic analyses (parts per million)

\begin{tabular}{|c|c|c|}
\hline As & 10. & 10. \\
\hline $\mathrm{Ba}$ & 1200 & 1300 \\
\hline $\mathrm{Be}$ & .2 & .2 \\
\hline $\mathrm{Cd}$ & 130. & 110. \\
\hline $\mathrm{Ce}$ & 33. & 47. \\
\hline Co & 13. & 12. \\
\hline $\mathrm{Cr}$ & 110 & 110. \\
\hline $\mathrm{Cu}$ & 5. & 3. \\
\hline $\mathrm{Ga}$ & 16. & 16. \\
\hline $\mathrm{La}$ & 15. & 22 . \\
\hline $\mathrm{Li}$ & 17. & 17. \\
\hline Nd & 19. & 24 . \\
\hline $\mathrm{Ni}$ & 23. & 22. \\
\hline $\mathrm{Pb}$ & 18. & 18. \\
\hline $\mathrm{Sc}$ & 12. & 12. \\
\hline $\mathrm{Sr}$ & 560. & 560. \\
\hline Th & 7. & 6. \\
\hline V & 82. & 81. \\
\hline $\mathbf{Y}$ & 14. & 14. \\
\hline $\mathrm{Yb}$ & 2. & 2. \\
\hline $\mathrm{Zn}$ & 2900 & 2200 \\
\hline
\end{tabular}

TABLE 12.-Analytical data on early Oligocene granodiorite porphyry emplaced in the middle member of the Middle Pennsylvanian Battle Formation and the Upper Pennsylvanian and Lower Permian Antler Peak Limestone-Continued

\begin{tabular}{lcc}
\hline Analysis & 1 & 2 \\
\hline Field No. & $85 T T 125$ & 85 TT126 \\
\hline
\end{tabular}

Chemical analyses (parts per million)

\begin{tabular}{lrc}
\hline & & \\
$\mathrm{Ag}$ & $<3$. & $<3$. \\
$\mathrm{As}$ & 18. & 33. \\
$\mathrm{Sb}$ & 4.4 & 6.7 \\
$\mathrm{~T} 1$ & 1.1 & 1.1 \\
\hline
\end{tabular}

C.I.P.W. norms (weight percent)

\begin{tabular}{lcc}
\hline Q & 19.2 & 20.1 \\
c & -- & -7.6 \\
or & 24.5 & 25.6 \\
ab & 23. & 22.2 \\
an & 18. & 17.8 \\
wo & 1.4 & 1.2 \\
en & 7.3 & 6.6 \\
fs & 1.01 .6 \\
mt & 1.8 & 1.3 \\
i1 & 1. & .9 \\
ap & .43 & .38 \\
fr & .09 & .03 \\
h1 & .03 & 1.4 \\
cc & 1.4 & 99.21 \\
Total & 99.15 & 85.7 \\
Salic & 84.7 & 13.51 \\
Femic & 14.45 & 67.9 \\
\hline Differentiation & 66.7 & \\
Index & & \\
\hline
\end{tabular}

1, 2. Fresh hornblende granoiorite porphyry showing only minor amounts of chlorite, calcite, and epidote. collected about $250 \mathrm{~m}$ west-northwest of Surprise Mine.

with granodiorite porphyry emplaced in arkose, feldspathic sandstone, and shale of the Harmony Formation. In addition, granodiorite porphyry emplaced in the Battle Formation and Antler Peak Limestone shows a high abundance of zinc. However, indentification of the zinc-bearing phases in these rocks proved somewhat problematical. The two analyzed samples of granodiorite porphyry are reported to contain 2,900 and $2,200 \mathrm{ppm}$ zinc; the total sulfur content of each rock is less than 100 ppm (table 12). In an attempt to identify the zincbearing mineral, two polished thin sections of a split from the rocks analyzed were studied in reflected light and with the scanning electron microprobe (SEM). No sphalerite was found in the polished sections. A 4- to 5- $\mu \mathrm{m}$-wide bleb of chalcopyrite also showed no detectable zinc during 100 second counts. However, some iron-bearing chromite grains, about $40 \mu \mathrm{m}$ wide, which are included 
within hornblende, showed traces of zinc. Nonetheless, the overall chromium content of these two analyzed samples is $100 \mathrm{ppm}$ (table 12). Therefore, traces of zinc in chromite cannot be the primary mode of occurrences to account for most of the zinc in granodiorite porphyry. In addition, the samples from which the polished sections were prepared were stained chemically to test for zinc. Again, no zinc was detected. Therefore, zinc (possibly as a secondary zinc oxide, carbonate, or silicate) must have been concentrated along a fracture included within the split of rock chemically analyzed. During the SEM study, the following minerals also were identified: zircon, magnetite, pyrite, apatite, allanite, sphene, barite, and an unknown nickel oxide or possibly nickel silicate. The mode of occurrence of the barite is as 4 - to 5 - $\mu \mathrm{m}$-wide grains in plagioclase.

Some granodiorite porphyry in the Buckingham area appears to be associated with variable amounts of base- and precious-metal mineralization. As described above, galena- and sphaleritebearing veins locally cut granodiorite porphyry that contains disseminated pyrrhotite and pyrite in the general area of the East stock. But more importantly, many dikes of granodiorite porphyry that cut the Late Cretaceous East stock and Upper Cambrian Harmony Formation show low-level, increased abundances of silver and traces of gold in the Harmony Formation generally as much as 10 $\mathrm{m}$ from granodiorite porphyry. Assays of channelsampled drill core show local background silver concentrations in propylitically altered granodiorite porphyry of about $0.3 \mathrm{ppm}$; background gold concentrations in granodiorite porphyry have not been established adequately. The increased silver contents in rocks of the Harmony Formation near granodiorite porphyry are generally 4 to 20 times local background, and these increased silver contents seem to be most pronounced at the lower contact of granodiorite porphyry, suggesting thereby the possible ponding of fluids by granodiorite porphyry after its emplacement in the Oligocene. Such increased silver contents do not correlate positively with any corresponding increases in the contents of molybdenum and, at much lower levels, copper in the Late Cretaceous Buckingham system. However, the spatial relation of precious-metal mineralization to associated dikes is very similar to that recognized recently at the Horse Canyon, Cortez, and Gold Acres sediment-hosted gold deposits, all approximately $50 \mathrm{~km}$ southeast (Rytuba, 1985). As reported by Rytuba (1985; J.J. Rytuba, unpub. data, 1989), gold mineralization at these deposits apparently is related to calc-alkaline rhyolite porphyry dikes that are comagmatic with the Caetano Tuff, on the basis of their similar $\mathrm{Rb} / \mathrm{Sr}, \mathrm{Nb} / \mathrm{Zr}$, and $\mathrm{Ba} / \mathrm{Sr}$ ratios. $\mathrm{Ba} / \mathrm{Sr}$ and $\mathrm{Nb} / \mathrm{Zr}$ ratios in propylitically altered granodiorite porphyry at Buckingham (tables 11, 12) are compared with those in the Caetano Tuff and calc-alkaline rhyolite porphyry dikes at the Horse Canyon, Cortez, and Gold Acres gold deposits (fig. 43). The failure of $\mathrm{Ba} / \mathrm{Zr}$ and $\mathrm{Nb} / \mathrm{Zr}$ enrichment trends for the granodiorite porphyry at Buckingham to coincide with such trends established by Rytuba (1985; J.J. Rytuba, unpub. data, 1987) for the Caetano Tuff and its comagmatic, calc-alkaline rhyolite dikes and sills suggests that granodiorite porphyry at Buckingham, and probably throughout the Battle Mountain Mining District, is not comagmatic with the Caetano Tuff (see Hildreth, 1981). Nonetheless, ferric to ferrous ratios of granodiorite porphyry from the Buckingham area (tables 11,12 ) range from 0.20 to 0.82 , with a mean of 0.50 . These data are thus compatible with anomalously reduced values in plutons (ferric:ferrous ratio< 0.85 ) shown by Keith and Swan (1987) to be regionally coextensive
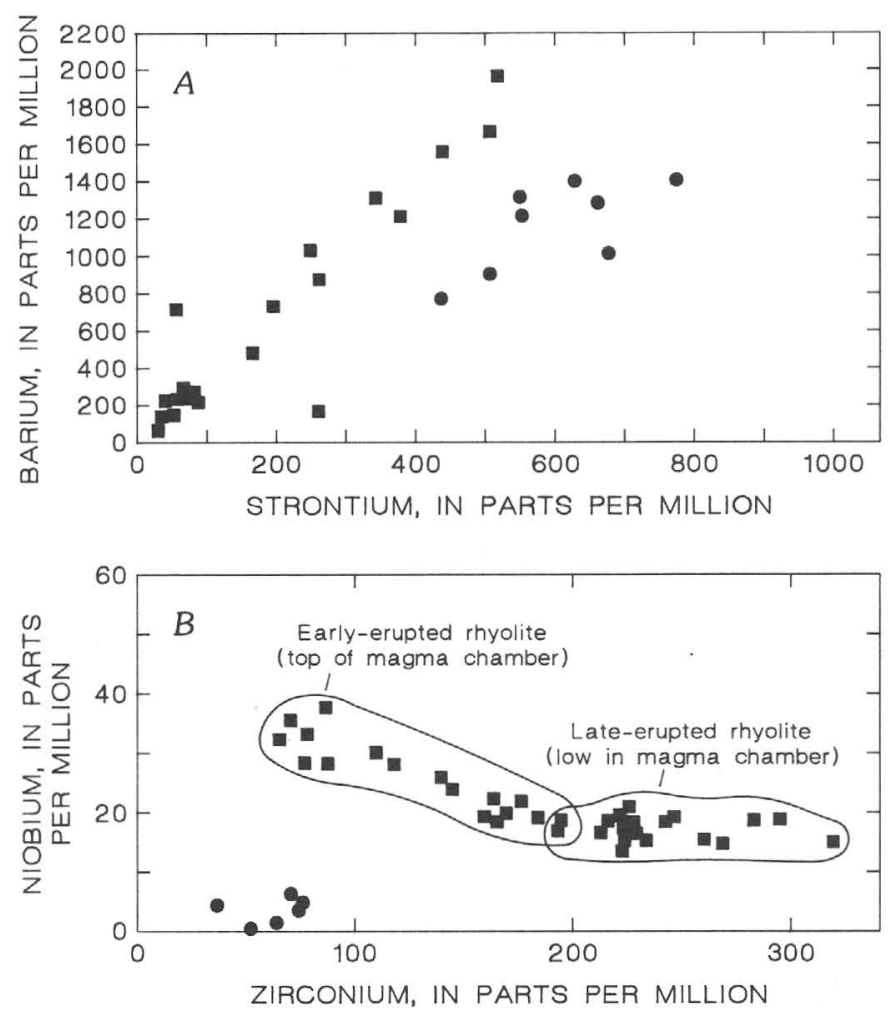

Figure 43.-Comparison of selected metal ratios in Oligocene granodiorite porphyry at Buckingham with ratios in Oligocene Caetano Tuff and Oligocene dikes and sills at sedimenthosted gold deposits. $\mathrm{A}, \mathrm{Ba} / \mathrm{Sr}$ ratios in granodiorite porphyry (dots, tables 11, 12) and in the intracaldera Oligocene Caetano Tuff or Oligocene calc-alkaline rhyolite dikes and sills at Cortez sediment-hosted gold deposit (squares); $B$, $\mathrm{Nb} / \mathrm{Zr}$ ratios in Oligocene granodiorite porphyry (dots, table 11) and in the Caetano Tuff and Oligocene calc-alkaline rhyolite dikes and sills at Cortez, Horse Canyon, and Gold Acres sediment-hosted gold deposits (squares). Modified from Rytuba (1985; J.J. Rytuba, unpub. data, 1989). 
in Nevada with the Golconda terrane of Silberling and others (1984) and with the distribution of sediment-hosted Au and Au-Ag skarn deposits. Keith and Swan attribute these values of ferric:ferrous ratio to minor assimilation of reduced crust into the parent magmas of the plutons.

\section{ASSOCIATED SKARN}

Garnet skarn and several other contactmetasomatic assemblages formed in rocks of the Antler Peak Limestone and in the Battle Formation probably in association with the emplacement of a number of north-south-trending dikes of Oligocene granodiorite porphyry north of the Surprise Mine (pl. 1). Although the map pattern of skarn compared with granodiorite porphyry suggests a marked asymmetry to development of the skarn here, very narrow zones of skarn also are present along the eastern contacts of the granodiorite porphyry dikes. Indeed, exposures along roads cut in this area since the area was first mapped indicate prograde contact-metasomatic effects in the middle member of the Battle Formation and in the Antler Peak Limestone that must be related to emplacement of granodiorite porphyry. Coarsely crystalline calcite in veins is present as a relatively broad front between essentially unaltered shaly carbonate rocks and the calc-silicate skarn that is restricted narrowly to general areas of granodiorite porphyry (figs. $44 A, 44 B$ ). In contrast to tightly interlocking, fine-grained crystals of reddish-brown garnet developed during replacement of metasilicate rocks of the Harmony Formation, garnet skarn in the Antler Peak Limestone shows abundant, amber to greenish garnets set in relict carbonate minerals (fig. 45A). Many individual garnet crystals contain complex growth zones of both anisotropic and isotropic garnet, probably indicative of periodic fluctuations of fluid chemistry at the time of growth. However, the overall paragenetic sequence of mineral assemblages in carbonate-hosted garnet skarn seems to be the same as that in silicate-hosted ones described above. In skarn hosted by the Antler Peak Limestone, fine-grained, prismatic crystals of diopside are sprinkled throughout the carbonate rocks, and their growth there apparently preceded somewhat the porphyroblasts of garnet. $\mathrm{K}$-feldspar also is relatively abundant locally and seems to be compatible with and temporally the same age as diopside. Diopside remained stable during crystallization of garnet. In some localities, especially near the outer mapped edges of the garnet skarn shown in the Ant- ler Peak Limestone (pl. 1), amber garnets are set in a matrix of bluish-gray tremolite (fig. $45 B$ ). In thin section, this tremolite (grayish green, optic Z-axis) has crystallized during a retrograde event mostly at the expense of carbonate and diopside. Most diopside crystals hosted previously by garnet have been replaced by tremolite. Also, some garnet has been corroded and embayed during this hydrosilicate stage (fig. $45 C$ ), which may be related to very late stages of early Oligocene granodiorite porphyry. The tremolite assemblage also includes some quartz and minor amounts of pyrite and (or) pyrrhotite. Some garnet skarn developed in the Battle Forma-
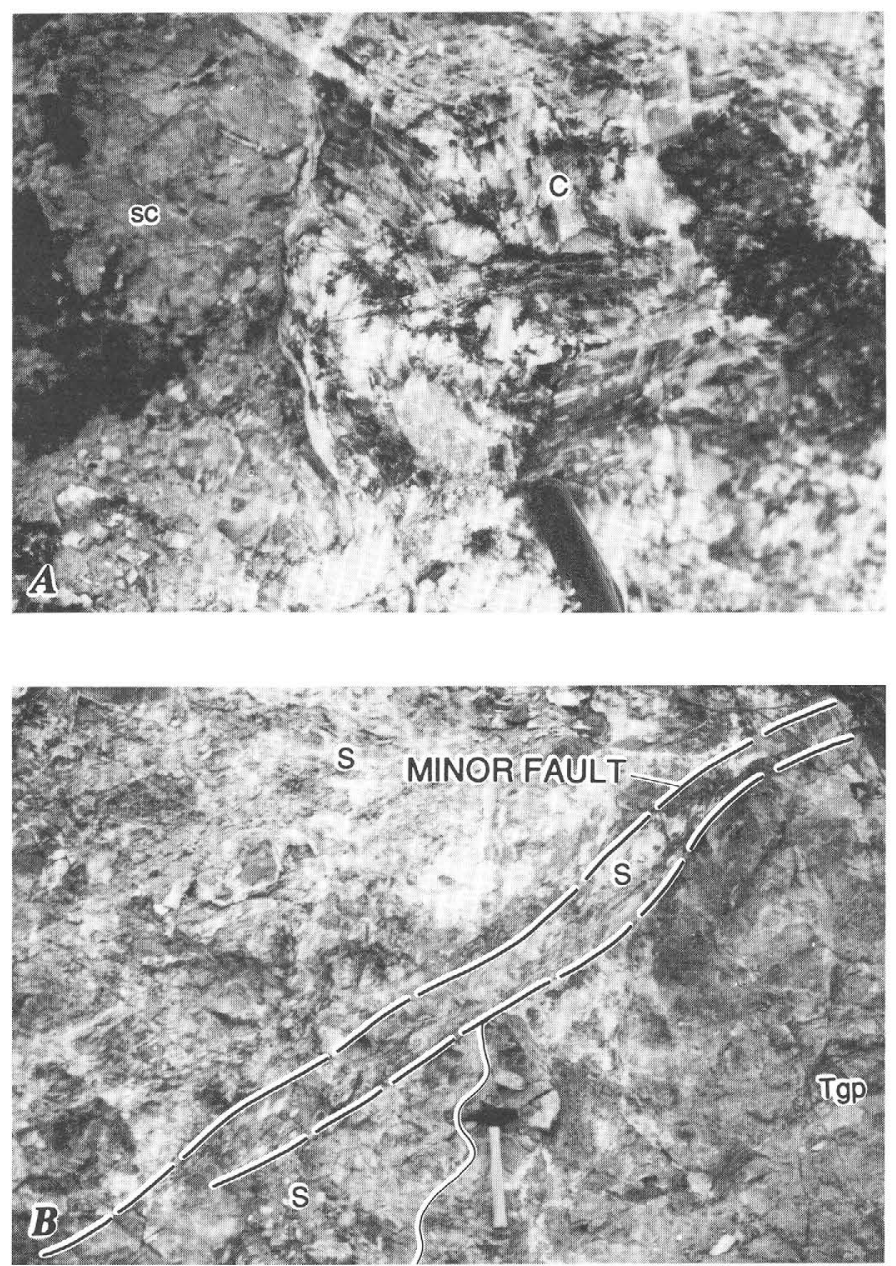

FiguRE 44.-Relations in general area of skarn associated with Oligocene granodiorite porphyry, north of Surprise Mine. A, Coarsely crystalline calcite $(\mathrm{C})$ in veins that form a broad front between essentially unaltered shaly carbonate rocks (sc) of middle member of the Middle Pennsylvanian Battle Formation and calc-silicate rocks of associated skarn. Pocket knife in lower center for scale. B, Contact between skarn (S) and Oligocene granodiorite porphyry (Tgp). Hammer in lower center for scale. 
tion, just to the north of the area affected by the workings surrounding the Copper Basin Mine (pl. 1 ), shows prograde garnet that partly replaces a calcareous sandy facies of the formation and subsequently is replaced, in part, by chlorite (fig. $45 D$ ).

\section{INTRUSION BRECCIA PIPE}

A small outcrop of extremely clay altered, white to iron oxide-stained intrusion breccia crops out on the east flank of Vail Ridge, about $0.6 \mathrm{~km}$ north of the

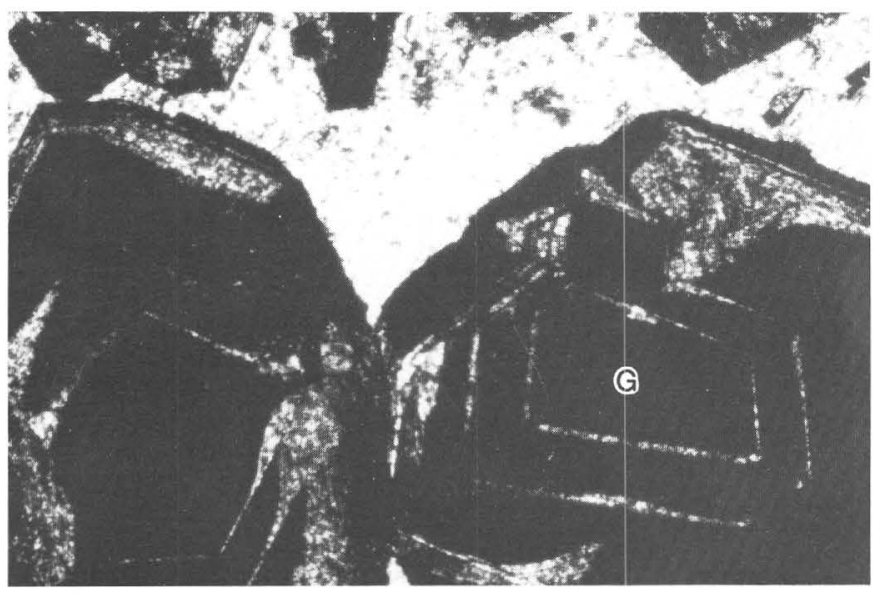

$\boldsymbol{A}$ 1 MILLIMETER

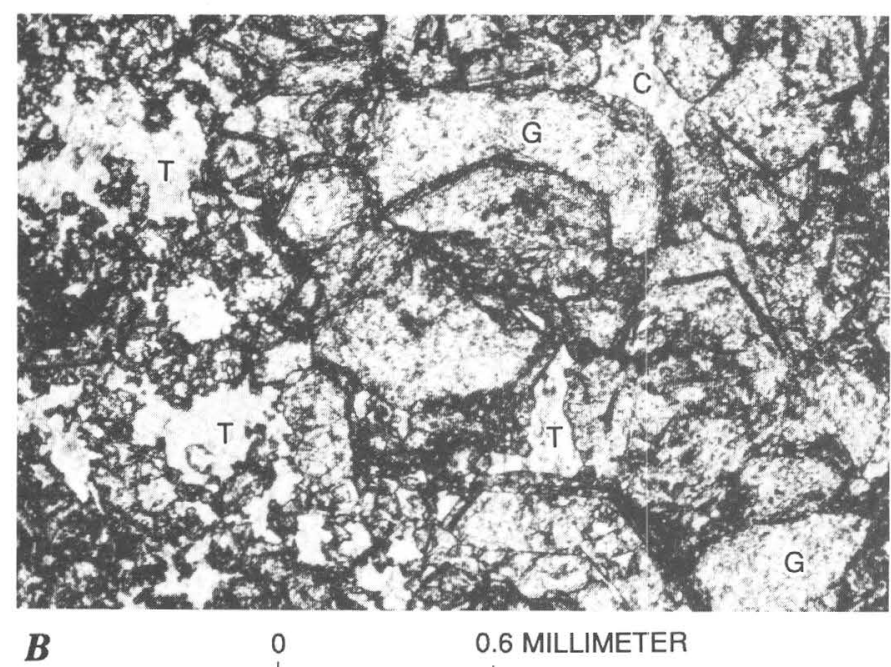

Figure 45.-Photomicrographs showing textural relations in garnet skarn formed in carbonate host. C, carbonate; G, garnet; $\mathrm{Q}$, quartz; T, tremolite. A, Upper Pennsylvanian and Lower Permian Antler Peak Limestone, showing complexly zoned, isotropic and anisotropic garnet crystallized in a diopside-containing carbonate host. Crossed nicols. Sample 80BK96. B, Antler Peak Limestone, showing prograde amber garnet partially replaced by fine-grained, retrograde tremolite that has crystallized entry to Long Canyon (unit Tib, pl. 1). This outcrop includes fragments of the Harmony Formation, some with veins and others without, and fragments of granodiorite porphyry. The intrusion breccia, as mapped, is adjacent to a much larger body of granodiorite porphyry, which also is very heavily altered to argillic assemblages, but which shows in many places a knife-edge contact with adjoining fractured and veined rocks of the Harmony Formation. The breccia is assumed to have originated as a breccia pipe, emplaced here approximately during the final stage(s) of intrusion of the granodiorite porphyry.

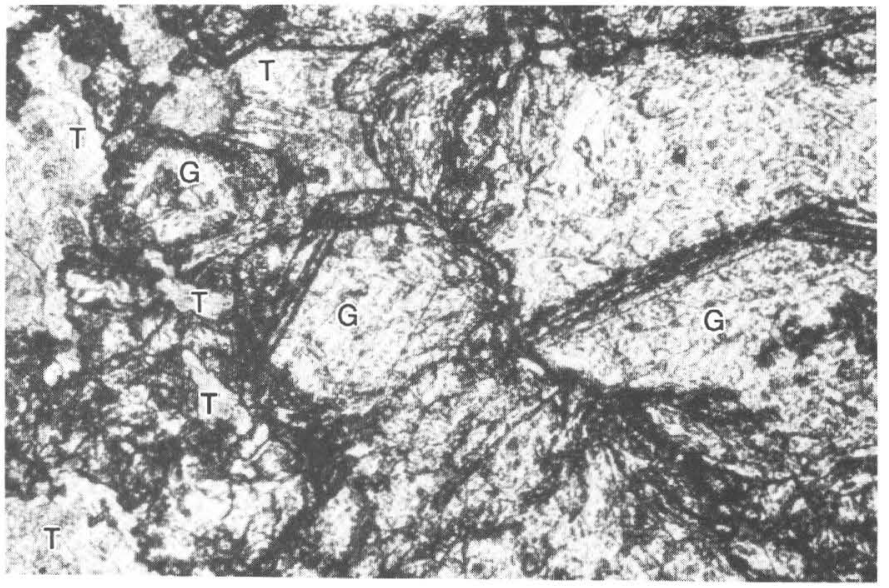

C

0 0.4 MILLIMETER

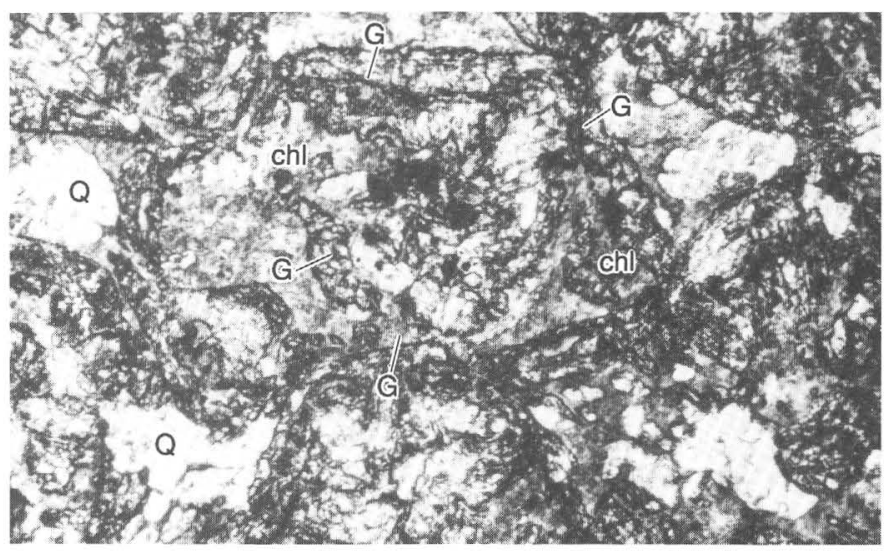

D

0

0.3 MILLIMETER

largely at sites of relict sedimentary carbonate. Plane-polarized light. Sample 80BK97. C, Closeup of figure $45 B$, showing corrosion of garnet during replacement of carbonate by tremolite. Plane-polarized light. $D$, Middle Pennsylvanian Battle Formation, showing prograde garnet replacing a calcareous sandstone facies, in turn partially replaced by chlorite (chl). Planepolarized light. Sample 80BK103. 


\section{ALTERED HORNBLENDE PORPHYRY}

Propylitically altered hornblende porphyry dikes crop out in a few localities that are scattered widely across the Buckingham area (unit Thp, pl. 1). A few these narrow dikes are present west of the West stock, near the west edge of the area; a lone exposure of the dikes also crops out in the main drainage through Long Canyon due north of the West stock; and some altered hornblende porphyry dikes, both mapped and unmapped, are present at the Gold Top and Bentley Mines, as well as at depth near the East stock. These dikes intrude rocks of the Harmony Formation and mineralized parts of the Late Cretaceous Buckingham stockwork molybdenum system. Altered hornblende porphyry dikes are quite distinctive in that they apparently lack quartz phenocrysts and they include propylitically altered, tabular to acicular, hornblende phenocrysts and clouded plagioclase phenocrysts, all set in a gray to grayish-brown cryptocrystalline matrix that probably averages $0.1 \mathrm{~mm}$ in size. The matrix is largely sodic oligoclase or albite. Typically, altered phenocrysts of hornblende make up 25 to 30 volume percent of the dikes, whereas plagioclase phenocrysts range in abundance from about 2 to 20 volume percent. Microscopic examination of a few representive samples reveals that hornblende phenocrysts have been replaced by tightly intergrown mats of actinolite, chlorite, K-feldspar, carbonate, sphene, epidote-group mineral(s), and pyrrhotite with or without pyrite. Generally, pyrrhotite is much more abundant than pyrite. Some samples also include pyrrhotite and pyrite as finely disseminated crystals in their groundmass. Chemical analyses for precious metals are not available from these sulfide-bearing, propylitically altered dikes. Some narrow quartz veins that contained pyrite as the predominant sulfide in pockets at the Gold Top Mine yielded minor amounts of gold and silver, apparently in a $1: 1$ ratio (Roberts and Arnold, 1965). Thus, propylitically altered, hornblende porphyry dikes that also crop out at the Gold Top Mine may be related to some of the preciousmetal mineralization there. However, no quartz veins were found to cut the altered hornblende porphyry dikes during this study.

\section{STRUCTURAL GEOLOGY}

\section{ANTLER OROGENY DEFORMATION}

Structures in the Buckingham area that developed during the thrusting phase of the Antler orog- eny include major faults related to the Roberts Mountains allochthon and also some probably minor thrusts. Well-exposed slickensides that are present locally near the exposed soles of some of the Antler orogeny-related thrusts in the area were produced by thrusting during this orogenic event. The major interformational thrust to crop out in the area is the Dewitt thrust, (Roberts, 1964). The Dewitt thrust bounds two major tectonic blocks in the upper plate of the Roberts Mountains thrust. The lower, Scott Canyon block is made up of the Devonian Scott Canyon Formation and the Ordovician Valmy Formation; and the upper, Dewitt block is made up of the Upper Cambrian Harmony Formation. The Dewitt thrust is fairly well exposed at several localities in the Buckingham area, especially in the general area of the Buckingham Mine, near the southwestern corner of the area (pl. 1). In addition, the Little Giant fault, a northwest-striking structure near the west edge of the map area, originated probably as a thrust showing relatively minor overall displacement(s), in a regional context at least, during the thrusting phase of the Antler orogeny. As mapped, the Little Giant fault is inferred to include an uplifted part of the Scott Canyon Formation in its hanging wall. This small patch of rocks belonging to the Scott Canyon Formation crops out approximately $250 \mathrm{~m}$ topographically higher in elevation than the rocks of the Scott Canyon Formation that crop out near the Buckingham Mine. Some additional very minor displacements along the Little Giant fault occurred after emplacement of late Eocene or early Oligocene rhyolite partly astride the trace of the Little Giant fault.

As described above, rocks of the Scott Canyon Formation show strongly developed slickensides on fractures and joints locally near some of the best exposures of the Dewitt thrust. The center of gravity of a stereographic projection of these slickensides plunges approximately $25^{\circ}-30^{\circ}$ and trends N. $60^{\circ} \mathrm{W}$. (see fig. 9). As such, the trend of these slickensides is approximately at right angles to the trend of minor, outcrop-scale folds in the rocks of the Scott Canyon Formation measured by Evans and Theodore (1978, pl. 1, area 1) in Cottonwood Canyon, about $1.5 \mathrm{~km}$ southwest of the Buckingham Mine. These minor folds show that approximately north to slightly northeasterly trends of their fold axes most likely developed during the Antler orogeny (Evans and Theodore, 1978; Raul Madrid, unpub. data, 1985). Thus, slickensides measured in the rocks of the Scott Canyon Formation in the Buckingham area apparently record the trend of the final stages of the tectonic transport of these rocks as they were overridden by the Harmony Formation. 


\section{SONOMA OROGENY DEFORMATION}

Deformation of rocks during the Late Permian and Early Triassic Sonoma orogeny (Silberling and Roberts, 1962) culminated in the emplacement of the Golconda allochthon in the mining district (Roberts, 1964) and probably included some crustal shortening in the Buckingham area as implied by the development of broad open folds that have affected rocks of the Dewitt and overlap assemblage blocks. The oceanic sequence of rocks in the upper plate of the Golconda allochthon was deposited in a rifted ocean basin that developed during the late Paleozoic (Speed, 1977), and the emplacement of the allochthon marked the end of major marine depositional patterns that had been fairly continuous along the margin of the Cordillera (Dickinson, 1981). Timing of tectonic emplacement of the Golconda allochthon is still not fully resolved. It may be entirely an Early Triassic event (Silberling and others, 1984) or an event that spans latest Paleozoic and earliest Mesozoic time (Brueckner and Snyder, 1985). However, emplacement may have occurred somewhat later in the Mesozoic (see above; Dickinson, 1979). In the southern Toiyabe Range, Nev., Mississippian, Pennsylvanian, and Late Permian rocks in the Golconda allochthon were deformed at various times during their emplacement to the east onto the continental margin of western North America (Babaie, 1987).

As shown by Roberts and Arnold (1965, pl. 2), the hingeline of a broad anticlinal arch through the Battle Mountain Mining District, termed the "Antler anticline" by them, shows a north-southward trend in the southern part of the district, but then swings gently into a northwesterly trend that parallels the mapped trace of the Golconda thrust in the northern part of the district. The rocks of the Harmony Formation in the northwestern part of the Buckingham area are deformed into a broad, open fold whose hingeline also trends northwesterly (fig. 18). Thus, the trace of this hingeline approximately parallels the trace of the Golconda fault as mapped to the southwest in the district, and thus, the emplacement of the Golconda allochthon and the development of the Antler anticline may have occurred penecontemporaneously. This deformation must have occurred sometime after deposition of the Upper Permian Edna Mountain Formation, which is the youngest formation of the overlap assemblage present in the southern part of the district (Roberts, 1964).

The rocks of the Harmony Formation and the rocks of the overlap assemblage in the Buckingham area have been folded into a broad anticlinal arch. The overlap assemblage rocks of the Battle Formation and the Antler Peak Limestone, along the east edge of the map (pl. 1), dip to the east and make up part of the east limb of the broad anticlinal arch. Near the unconformity between the rocks of the Harmony and the Battle Formations, west of the Surprise Mine, attitudes of bedding in the Battle Formation show dips of approximately $50^{\circ}-60^{\circ}$ E. (pl. 1). The dips, however, are somewhat less in the Antler Peak Limestone near the east edge of the map area, about $25^{\circ}-30^{\circ}$. Still farther east, in the area north and northeast of Elephant Head, attitudes of bedding in the Antler Peak Limestone are approximately $15^{\circ}-25^{\circ}$, and the beds still dip east (Gail M. Jones, unpub. data, 1987).

Restoration to horizontal of present-day bedding attitudes of the Caetano Tuff constrains development of the districtwide arch to sometime before deposition of the Caetano Tuff, or before Oligocene time. If the approximately $12^{\circ}-14^{\circ} \mathrm{E}$. dip in the Caetano Tuff that unconformably overlies the Antler Peak Limestone in the Elephant Head area were rotated to horizontal, then the sheet dips in the overlap assemblage here would assume sheet dips of about $45^{\circ}$ at the unconformity, and about $10^{\circ}$ approximately $2 \mathrm{~km}$ east of the unconformity. In other words, these rocks apparently must have made up an east-dipping limb of the districtwide arch before the emplacement of the outflow facies of the Caetano Tuff at Elephant Head. Nonetheless, it is impossible from geologic relations in the district to establish conclusively the age of the onset of the development of the arch more precisely than post-Late Permian, or the age of the Edna Mountain Formation. Indeed, the rocks of the Harmony Formation also are folded into a broad, open, north-plunging anticline, whose hingeline trends north-south across almost the entire Buckingham area. This fold probably is younger than the northwest-trending syncline that parallels the trace of the Golconda thrust, because the anticline, as mapped (pl. 1; fig. 18), apparently cuts the hingeline of the northwest-trending syncline.

\section{LATE CRETACEOUS DEFORMATION}

Deformation during the Late Cretaceous includes some relatively low angle normal faults whose displacement(s) probably were initiated by intruding magmas associated with the Late Cretaceous Buck-ingham stockwork molybdenum system. An excellent example of one of these Late Cretaceous structures is the Contention fault (pl. 1). The Contention fault crops out for a strike length of about $1.3 \mathrm{~km}$, in a west-northwesterly direction, across Vail Ridge and through the open pit at the 
Copper Basin Mine (fig. 46A). The Contention fault dips approximately $25^{\circ} \mathrm{N}$. West of the open pit, the trace of the Contention fault coincides approximately with the outer limit of intensely developed quartz stockworks associated with the Buckingham system. In addition, the overall strike of the fault here is just slightly more northerly than the general trend of Late Cretaceous dikes that crop out on Vail Ridge. The age of displacements along the Contention fault has been established by geologic relations within the fault zone itself, supplemented by $\mathrm{K}-\mathrm{Ar}$ dating of a sample of megacryst monzo-
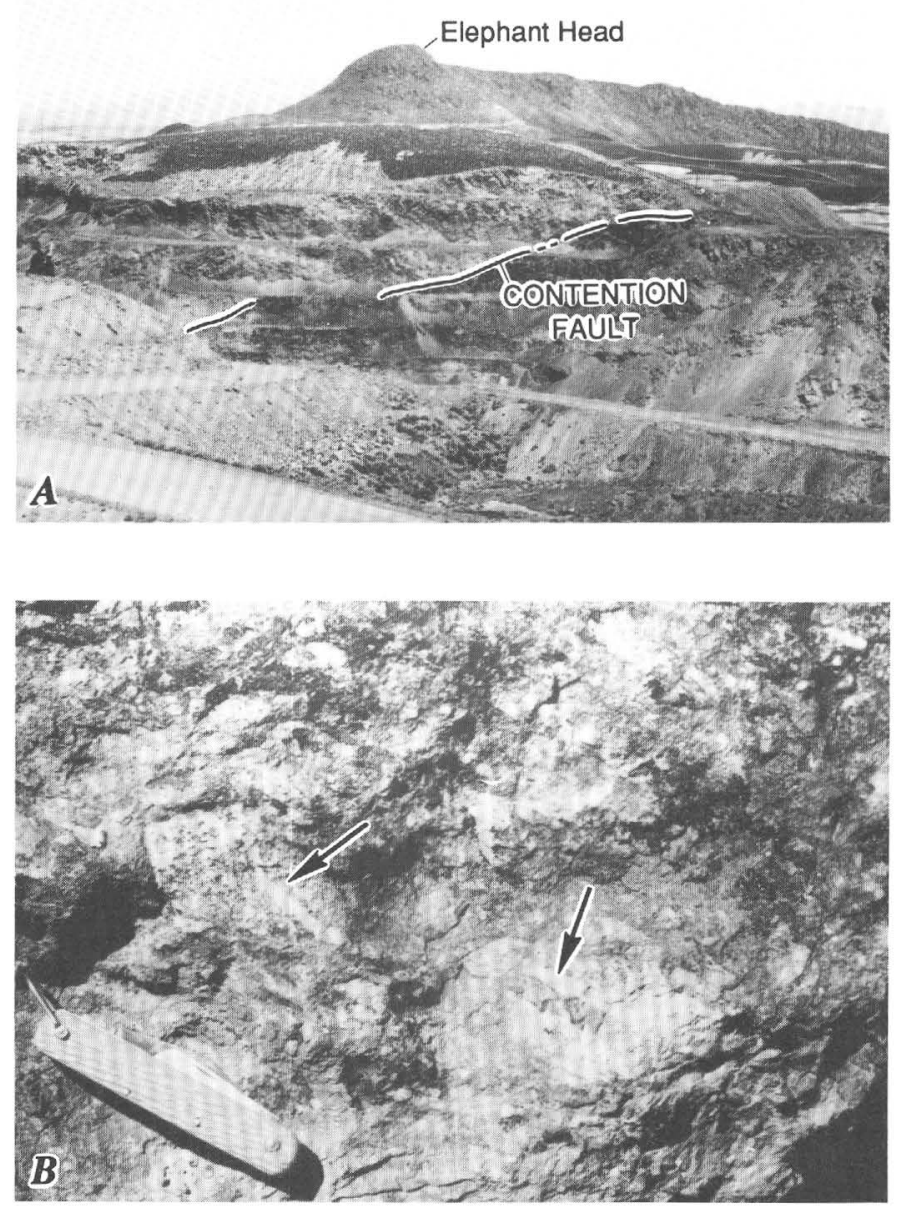

FIGURE 46.-Geologic relations associated with Late Cretaceous, low-angle Contention fault. A, View eastward across open pit at Copper Basin, showing trace of Contention fault along east wall of pit. Fault dotted where concealed. The Oligocene Caetano Tuff at Elephant Head is on skyline. Note haul road on left for scale. $B$, Closeup of quartz stockwork-veined cobbles (at heads of arrows) of the Upper Cambrian Harmony Formation caught up along silicified fault breccia where Contention fault crosses top of Vail Ridge. granite porphyry (85.5 Ma; see subsection above entitled "Potassium-Argon and ${ }^{40} \mathrm{Ar} /{ }^{39} \mathrm{Ar}$ Geochronology of Selected Plutons in the Buckingham Area") that cuts silicified fault breccia along the fault. The Contention fault, particularly along the top of Vail Ridge, but also elsewhere along its trace, includes quartz stockwork-veined cobbles of rocks of the Harmony Formation (fig. 46B). Most of such veins terminate at the cobble-silicified fault breccia interface. However, there are some quartz veins in the fault breccia of the Contention fault that also cut the tectonic fabric of the breccia. Thus, displacements along the Contention fault must have initiated after the onset of the development of the quartz stockworks of the Buckingham system, but also before such veining by quartz ceased. Moreover, the Contention fault apparently is cut by a dike of megacryst monzogranite porphyry dated as $85.5 \mathrm{Ma}$ as described above (pl. 1). There seemingly have been no major displacements along the Contention fault since the megacryst monzogranite porphyry was emplaced. Nonetheless, this dike of megacryst monzogranite porphyry includes some minor fractures that parallel the projected trace of the Contention fault. The fractures may have formed in response to local jostling along the Contention fault that resulted from any one of the subsequent Late Cretaceous or Tertiary tectonic events that affected the rocks in the Buckingham area.

The Contention fault apparently is cut off on the east by a northeast-striking system of faults that make up the Elvira fault zone (pl. 1; fig. 18). Individual fault strands that make up the Elvira fault zone strike nearly N. $35^{\circ}$ E., and they make up the westernmost part of a group of affiliated reverse faults-all showing the same overall strike and all having the same general separations-that is, west block down (Kirk Schmidt, oral commun., 1985). These reverse separations along the Elvira system of faults most likely are an antithetic accommodation to listric normal faulting that occurred along the Buckingham-Second fault systems probably during late Oligocene and (or) early Miocene time.

Some faults generally in two other parts of the Buckingham area may be mostly Late Cretaceous in age also. Near the southeast corner of the map area, rocks of the Harmony Formation are cut by numerous northeast-striking normal faults, east block down. Some of these faults are mineralized by relatively wide, structurally controlled concentrations of gold-bearing jasperoid at the Empire Mine and at the Northern Lights deposit (pl. 1). Both of these occurrences of gold-mineralized 
jasperiod probably should be classed as distaldisseminated silver-gold deposits according to the classification scheme of Dennis P. Cox (written commun., 1989). In addition, northeast-striking faults crop out prominently in the general area of the Buckingham Mine (pl. 1). Most of these faults apparently are older than the Second fault, a major low-angle, listric normal detachment that cuts the Late Cretaceous Buckingham molybdenum system (see subsection below entitled "Economic Geology") and is itself cut by Oligocene granodiorite porphyry (pl. 1). Thus, many of these northeast-striking faults near the Buckingham Mine conceivably may be related to some of the extensional tectonism that affected the rocks in the area and that began here probably sometime during the Late Cretaceous. However, extensional tectonism of a regional nature probably did not begin in this part of the Great Basin until about $18 \mathrm{Ma}$ ago (McKee and Noble, 1986). Extension that predates the breakup of rock sequences in the Great Basin into the morphologic configuration of the present-day Basin and Range mountain ranges has been documented well in several other areas in Nevada. Onset of preBasin and Range extension at the Hall stockwork molybdenum system near Tonopah, Nev., apparently occurred about 18-17 Ma (Shaver and McWilliams, 1987). In a $120-\mathrm{km}$-wide area in eastcentral Nevada, profound extension, apparently more than 100 percent, began before $36 \mathrm{Ma}$ and coincided there with emplacement of a suite of volcanic rocks that range from relatively potassium rich andesite to high-silica rhyolite (Gans, 1981; Gans and Miller, 1983).

Finally, in addition to these faults apparently associated with the Buckingham system, deformation during the Late Cretaceous probably also may include some folding. The hingeline of the major northsouth-trending anticline in the area seemingly passes from the north through the general area of the East stock, and then south into the rocks of the Harmony Formation in the hanging wall of the Second fault (pl. 1). Emplacement of magma associated with the Buckingham system during the Late Cretaceous thus may have contributed to an unknown, but overall probably minor, part of the arching of nearby bedding exposed in surrounding country rock.

\section{TERTIARY DEFORMATION}

Deformation during the Tertiary in the Buckingham area includes significant extensional, brittle-type tectonics that is manifested primar- ily along three major low-angle faults. These northeast-dipping faults all strike northwest, and, from east to west across the area, are the Long Canyon, Second, and Buckingham faults (pl. 1). On the one hand, the Long Canyon fault is not well known to us at depth, because no deep drill holes have been collared in its hanging wall near Vail Ridge. However, at the surface, the Long Canyon fault shows right-lateral separations of both (1) the outer limit of intensely developed quartz stockworks associated with the Buckingham system, and (2) the East stock from the projected locus of Late Cretaceous monzogranite porphyry and megacryst monzogranite porphyry on Vail Ridge (pl. 1). On the other hand, geometries and displacements of the Second fault and the Buckingham fault are exceptionally well documented at depth in the Buckingham stockwork molybdenum system (see subsection below entitled "Economic Geology"). Initial displacements along the Buckingham, Second, and Long Canyon faults may have started, however, sometime during the Late Cretaceous, owing to the discrepancy in separations between mapped intrusive bodies and ore shells as noted by Loucks and Johnson (see subsection below entitled "Economic Geology"). As mapped in outcrop, however, the main strand of the Second fault, south of Licking Creek, apparently is intruded by some Oligocene granodiorite porphyry (pl. 1). Yet at depth near the East stock, the Second fault cuts a large dike of granodiorite porphyry without any significant separation (see subsection below entitled "Economic Geology"). Thus, displacements along the Second fault apparently were somewhat protracted from older to probably just slightly younger than Oligocene granodiorite porphyry. However, displacements along the Buckingham fault seemingly are mostly post-granodiorite porphyry in age and make up some of the youngest detachment-type faulting in the area. Accordingly, Tertiary extensional tectonism in the Buckingham area apparently progressed from east to west somewhat irregularly during the Oligocene and possibly even during the Miocene. Imbricate, down-to-the-east, listric normal faulting along the Second and Buckingham faults probably merges together with the Long Canyon fault into a single master, flat-lying dislocation surface somewhere to the east of the East stock. This hypothesis is presented with the understanding that the geometry and structural evolution of these faults follow those of similar such faults documented elsewhere in the Basin and Range (see Crittenden and others, 1980; Gans and others, 1985). 
One of the intriguing structural relations recorded by the map pattern of, and by the separations along faults in the area, is that of the apparent repetition of the rocks of the Battle Formation by reverse separations along the Elvira fault system (pl. 1; fig. 14). Such major separations along the Elvira fault system, in fact reaching separations as much as $300 \mathrm{~m}$ (Kirk Schmidt, oral commun., 1985), may have occurred as an accommodation to gravity gliding and (or) gravitational collapse and spreading (see Ramberg, 1981) along the Long Canyon-Buckingham listric normal faults during late Oligocene and early Miocene time. However, the dip-slip component of displacement along the Elvira fault may be much less than $300 \mathrm{~m}$ because of the acuteness of the angle between the steeply dipping beds and the slightly more steeply dipping fault plane. As pointed out by Mandl and Crans (1981), rigid-body gravityslide blocks have a tendency to develop antithetic reverse faults in the toe region of glide blocks to compensate possibly for a buttressing there by a decrease in slope angle. Such a regional decrease in the basal slope angle of the glide block would in effect increase the potential for shortening, that is, reverse faults, in the toe region of the glide block. Furthermore, Price (1977) pointed out that the likelihood of faults developing first in the toe region of a glide block is enhanced by the presence in the glide block of relatively few, thick, massive units, such as in the Buckingham area.

Tertiary deformation in the Buckingham area thus both contrasts and compares favorably with the style of deformation in several other nearby areas of major mineralization. First of all, low-angle faults are not part of the Tertiary tectonic history of the Copper Canyon area of the mining district (Roberts and Arnold, 1965; Theodore and Blake, $1975,1978)$. However, near the Hilltop Mining District of the Shoshone Range, approximately $30 \mathrm{~km}$ southeast of the Buckingham area, recently completed studies by Desrochers (1984; G.J. Desrochers, unpub. data, 1985) apparently have documented dip-slip, normal displacements along low-angle faults. These displacements occurred along two parallel, north-striking faults that presumably are younger than some nearby late Eocene or early Oligocene intrusive rocks. Gold mineralization is structurally controlled and related possibly to the final stages of a weakly developed porphyry copper-molybdenum system (G.J. Desrochers, unpub. data, 1985). Somewhat farther to the south in the Horse Canyon area of the Shoshone Range, Madrid (1987) documented the occurrence there of major dip-slip dislocation(s), down on the west, along a major north-striking fault zone. This fault zone is postmineral in age relative to molybdenum mineralization in the breccia pipe of Horse Canyon.

\section{BUCKINGHAM STOCKWORK MOLYBDENUM DEPOSIT}

\section{CLASSIFICATION OF THE DEPOSIT}

The Buckingham system is the type example of a number of relatively recently reclassified molybdenum deposits and molybdenum-enriched systems that are associated with Jurassic to Pliocene calcalkaline magmatic arcs in the western North America Cordillera (fig. 47). In addition, several significant molybdenum-enriched porphyry systems of Paleozoic age (Schmidt, 1978), and presumed Paleozoic age (Ayuso and Shank, 1983), crop out in eastern North America and bear many similarities to the ones in western North America. Such stockwork molybdenum systems generally have low fluorine contents relative to deposits of the better known Climax type (Theodore and Menzie, 1984). The fluorine-deficient porphyry molybdenum systems previously have been included in different ways in the several classifications of porphyry molybdenum deposits that have been proposed in the past. Such systems have been referred to as zoned porphyry molybdenum deposits by Woodcock and Hollister (1978), as subduction-related deposits by Sillitoe (1980), as granodiorite-related by Mutschler and others (1981), as quartz monozoniterelated by White and others (1981), and as porphyry molybdenum, low fluorine by Cox and Singer (1986). Guilbert and Park (1986) considered the low-fluorine stockwork molybdenite deposits as a subset of porphyry base-metal systems. The one striking characteristic of all these systems is their minor-element signature, especially compared with the better known stockwork molybdenum systems exemplified by the one at Climax, Colo. (see Westra and Keith, 1981; White and others, 1981). Thompson (1982), in a further modification of the classification scheme for stockwork molybdenum deposits, suggested that alkali-calcic deposits and the alkali molybdenum stockwork deposits of Westra and Keith (1981) be subdivided into a monzonite-syenite subtype and a leucogranite subtype. The Climax-type systems are characterized by well-differentiated, high-silica rhyolitic magmas that are fluorine enriched (locally as much as 2-3 weight percent), niobium, rubidium, molyb- 


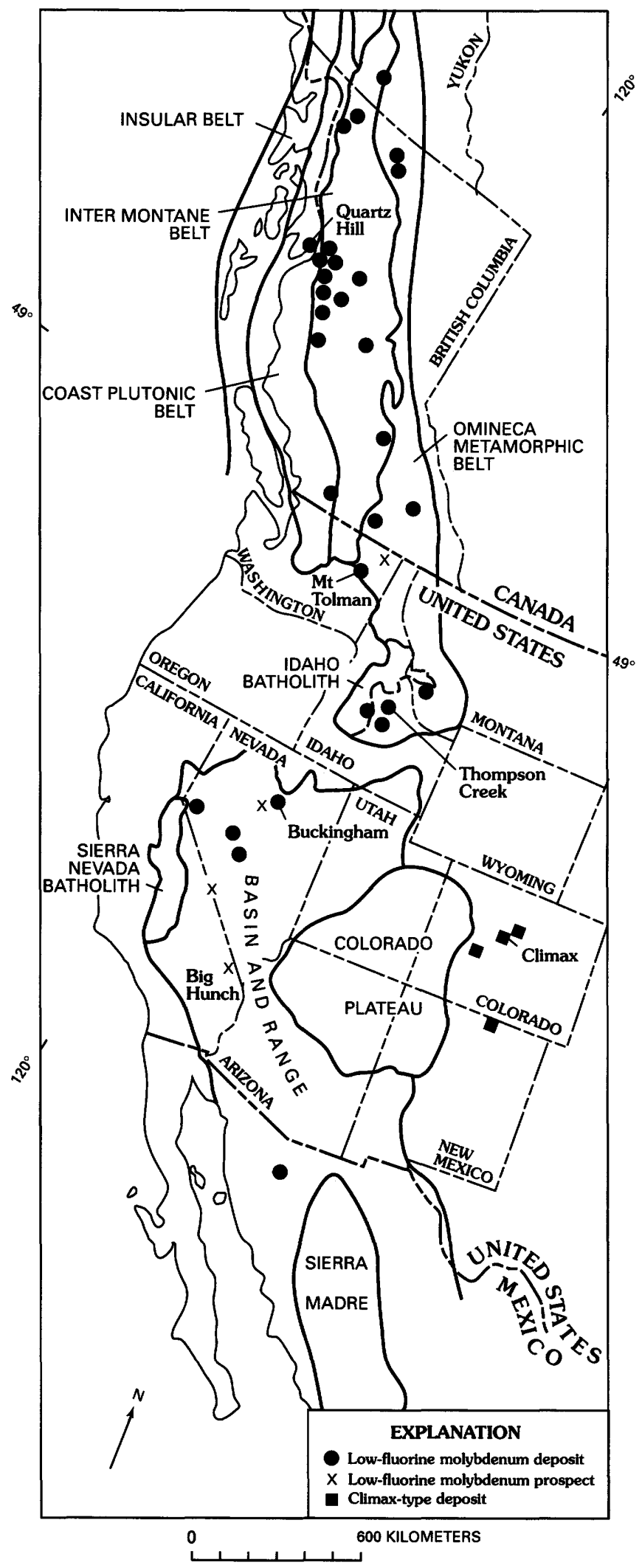

FIGURE 47.-Distribution of major stockwork molybdenum systems in Cordillera of western North America. See text for sources of geologic provinces. denum, tin, and tungsten and are nearly depleted in copper and strontium (Ludington, 1981). The Climax-type systems are present in rifted cratons, whereas the relatively low fluorine or quartz monzonite-type systems are related to continental margins. Fluorine-deficient porphyry molybdenum systems generally show an overall fluorine content of less than 0.1 weight percent, and many of these systems also include significant concentrations of copper and silver (Czehura, 1983); some include significant concentrations of tungsten and gold (Theodore, 1982a; Theodore and Menzie, 1984). At Buckingham, gold skarns at the Surprise Mine and at the Carissa Mine probably are temporally and genetically related to the Buckingham stockwork molybdenum system (Schmidt and others, 1988). Westra and Keith (1981, fig. 9) showed a continuity of hypogene copper and molybdenum grades between porphyry copper deposits and fluorinedeficient porphyry molybdenum deposits. However, both these deposit types, together with apparently fluorine-depleted porphyry tungsten deposits (Yan and others, 1980), and possibly even porphyry gold deposits, may be viewed as gradational end members of porphyry systems in general (fig. 48). As shown in figure 48 , the anion content of fluids

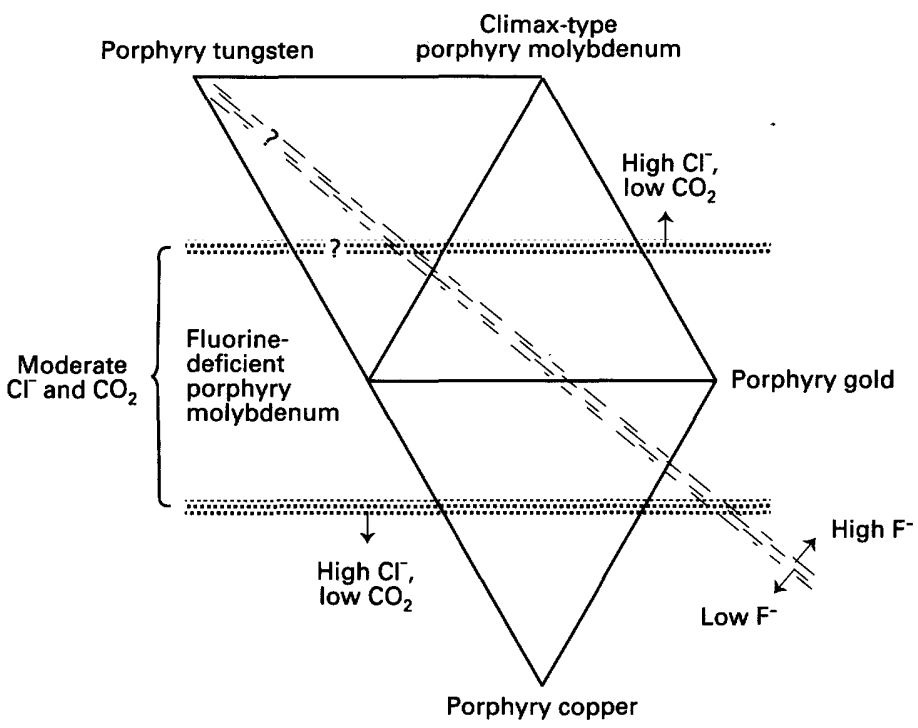

FIGURE 48.-Schematic diagram showing inferred relations among porphyry copper deposits, fluorine-deficient porphyry molybdenum deposits, porphyry gold deposits, porphyry tungsten deposits, and Climax-type porphyry molybdenum deposits and inferred relative proportions of fluorine, carbon dioxide, and chlorine in their genetically associated fluids. Modified from Theodore and Menzie (1984). Relations queried where uncertain. 
associated with these end members apparently ranges from high chlorine and low carbon dioxide bearing (almost all porphyry copper systems and the Climax-type systems), through high fluorine bearing (Climax-type systems and, possibly, porphyry gold systems), to moderate chlorine and carbon dioxide bearing in the fluorine-deficient stockwork molybdenum systems (Theodore and Menzie, 1984). The fluids associated with genesis of the Buckingham stockwork molybdenum system will be discussed at length below. In the Russian literature, the two types of stockwork molybdenum deposits commonly are referred to as the rare metal-tungsten-molybdenum type and the molybdenum type (Ignatovich, 1969), corresponding to the Climax type and the low-fluorine type, respectively. In addition, Pokalov (1977) referred to the two major types of molybdenum stockwork deposits as the greisen type and the hydrothermal type. In his classification, the Climax type would correspond to the greisen type.

Fluorine-deficient porphyry molybdenum systems, which are widespread throughout the geologic provinces of the Cordillera, are present in magmatic arcs that generally parallel the Mesozoic batholiths (fig. 47). In Canada and southeastern Alaska, from west to east, they may be localized in (1) isolated, transform-fault-related(?) or possibly regional extension-fault-related (Hudson and others, 1981) alkali granite masses (Quartz Hill) that were emplaced into the Mesozoic and Tertiary Coast plutonicmetamorphic complex of Brew and Ford (1984); (2) early Tertiary granitic stocks and plugs associated with this plutonic-metamorphic complex, but occurring mostly in the adjoining Mesozoic Intermontane Belt to the east; and (3) accretion-boundary-related Early Cretaceous intrusions (Endako, Boss Mountain) in the Intermontane Belt (Monger and others, 1972; Monger and Berg, 1984), which hosts most of the economically significant deposits of British Columbia. In the United States, rocks of the Idaho and Pioneer batholiths intrude the Omineca crystalline belt, and several molybdenum deposits in Idaho (at Cumo, Thompson Creek, White Cloud), as well as numerous prospects, are present near the eastern margins of these batholiths. In the Basin and Range province, several Late Cretaceous deposits in Nevada (Buckingham, Hall, Pine Nut) and many other prospects are related to small granitic bodies peripheral to the Sierra Nevada batholith. These prospects include the Magruder Mountain (Sylvania), Nev., and Big Hunch, Calif., systems, both of which may have been emplaced sometime in the Jurassic and Cretaceous, respectively. Well within the craton in Colora- do, many other mineralized systems similar to the low-fluorine stockwork type indicate there the easternmost position of a subduction-related arc before major rifting of the craton (Bookstrom, 1981); the Tertiary quartz monzonite of the Montezuma Mining District, central Colorado, may be an example of one of these molybdenum-mineralized systems (Botinelly, 1979).

In the general region of the Buckingham molybdenum system, significant molybdenum prospects include those at Gregg Canyon, Trenton Canyon, Buffalo Valley, Horse Canyon, French Boy Creek, and in the Railroad Mining District (fig. 49). In addition, drill holes in the Gold Acres gold deposit have revealed the presence of molybenite-enriched skarn at depth (Wrucke, 1974; Wrucke and Armbrustmacher, 1975). All of these molybdenum systems in the general region of the Buckingham system are in a broad region of the northern Great Basin wherein Mesozoic granitic bodies make up from 10 to 50 percent of the total number of exposed granitic bodies (Barton and others, 1988).

Grade and tonnage distribution plots for 33 fluorine-deficient and 9 Climax-type stockwork molybdenum systems reveal some significant differences between these two types of deposits (fig. 50). The curve in these plots is an inverse cumulative distribution fitted to data points that plot the proportion in the sample, and presumably thereby in the population, that exceed a given value. As such, the curve in these plots is a rescaled survival function that is defined by Hastings and Peacock (1974) as the probability that a variable takes a value greater than $X$ and is equal to $1-F(x)$, where $F(x)$ is the distribution function. For example, from the available data used to generate figure 50 , it might be inferred that 90 percent of all fluorine-deficient stockwork molybdenum systems will have tonnages greater than 19 million $t$ and that 90 percent of the Climax-type systems will have tonnages greater than 66 million t. However, data are available for only nine Climax-type systems (see Singer and others (1986) for a tabulation of the deposits used in the construction of these data points). The most pronounced difference between fluorine-deficient and Climax-type stockwork molybdenum deposits is their grades; median grade for the fluorine-deficient type is 0.084 weight percent Mo, and for the Climax-type 0.19 weight percent Mo (fig. $50 B$ ). The median tonnages for fluorine-deficient and Climax-type systems apparently are 93 million and 230 million $t$, respectively (fig. 50A).

Furthermore, this plot of the proportion of deposits versus tonnage for each of the two types of 
deposits includes a convergence of the fitted inverse cumulative-distribution curves in the region of the figure wherein the proportion of deposits is less than 0.1 . In fact, the data point used for the tonnage of the Buckingham deposit, approximately 907 million $t$, plots close to the fitted inverse cumulative distribution curve for the Climax-type systems (fig. 50A). Viewed somewhat differently, from these data plots for the fluorine-deficient molybdenum stockwork system, it might be estimated that about 10 percent (0.1) of such undiscovered systems in the Cordillera of western North America would include tonnages greater than 630 million t. Last, tonnage and grade for the fluorine-deficient molybdenum stockwork deposits are independent statistically (Theodore and Menzie, 1984).

\section{ECONOMIC GEOLOGY}

By Thomas A. Loucks and Craig A. Johnson

\section{ABSTRACT}

The Buckingham deposit is a calc-alkaline, stockwork molybdenum system located on the east flank of the Battle Mountain Mining District in the Basin and Range province of north-central Nevada. The deposit is estimated to contain more than 1,000 million tons of mineralized material averaging approximately 0.10 weight percent Mo (as $\mathrm{MoS}_{2}$ ) and containing small amounts of silver, tungsten, copper, and gold.

Molybdenum mineralization is related to emplacement of a Late Cretaceous composite quartz monzonite porphyry system that intruded and widely metamorphosed the surrounding Paleozoic rocks to hornfels. Seven major phases of molybdenum-related magmatism have been identified; the rocks were intruded sequentially from south to north. The present configuration of the intrusive center is two distinct stocks, each a composite of several porphyries, and several outlying intrusive masses. All seven phases appear to have carried molybdenum. The two earliest intrusions, now forming border phases, and the latest, an outlying intrusion, were dike-forming pulses related to relatively weak molybdenum mineralization. The main Buckingham molybdenum deposit formed in association with five igneous phases located in the two stocks. All five phases developed shells of molybdenite mineralization, and the shells locally

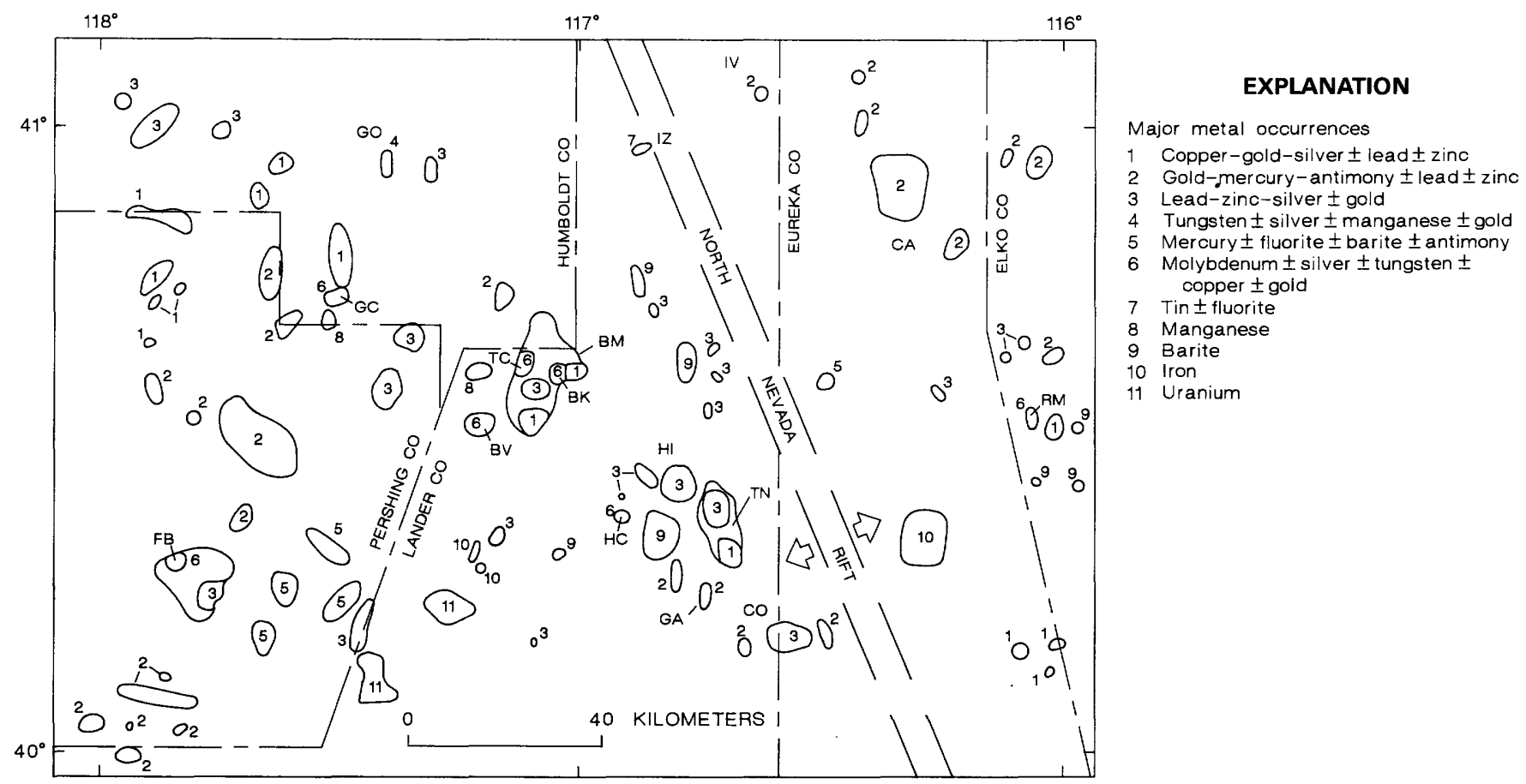

FIGURE 49.-Schematic map showing distribution of principal areas of molybdenum and other types of mineralization in Winnemucca $1^{\circ}$ by $2^{\circ}$ quadrangle and adjacent areas. BK, Buckingham; BM, Battle Mountain; BV, Buffalo Valley; CA, Carlin; CO, Cortez; FB, French Boy Creek; GA, Gold Acres;
GC, Gregg Canyon; GO, Golconda; HC, Horse Canyon; HI, Hilltop; IV, Ivanhoe; IZ, Izenhood; RM, Railroad Mining District; TC, Trenton Canyon; TN, Tanabo. Major metal occurrences modified from Wong (1983); northern Nevada rift modified from Maybey (1966) and Maybey and others (1978). 
overlap to produce grades of about 0.10 to 0.20 weight percent $\mathrm{MoS}_{2}$. We believe that silver, tungsten, and copper mineralization accompanied molybdenum in each succeeding magmatic/hydrothermal pulse.

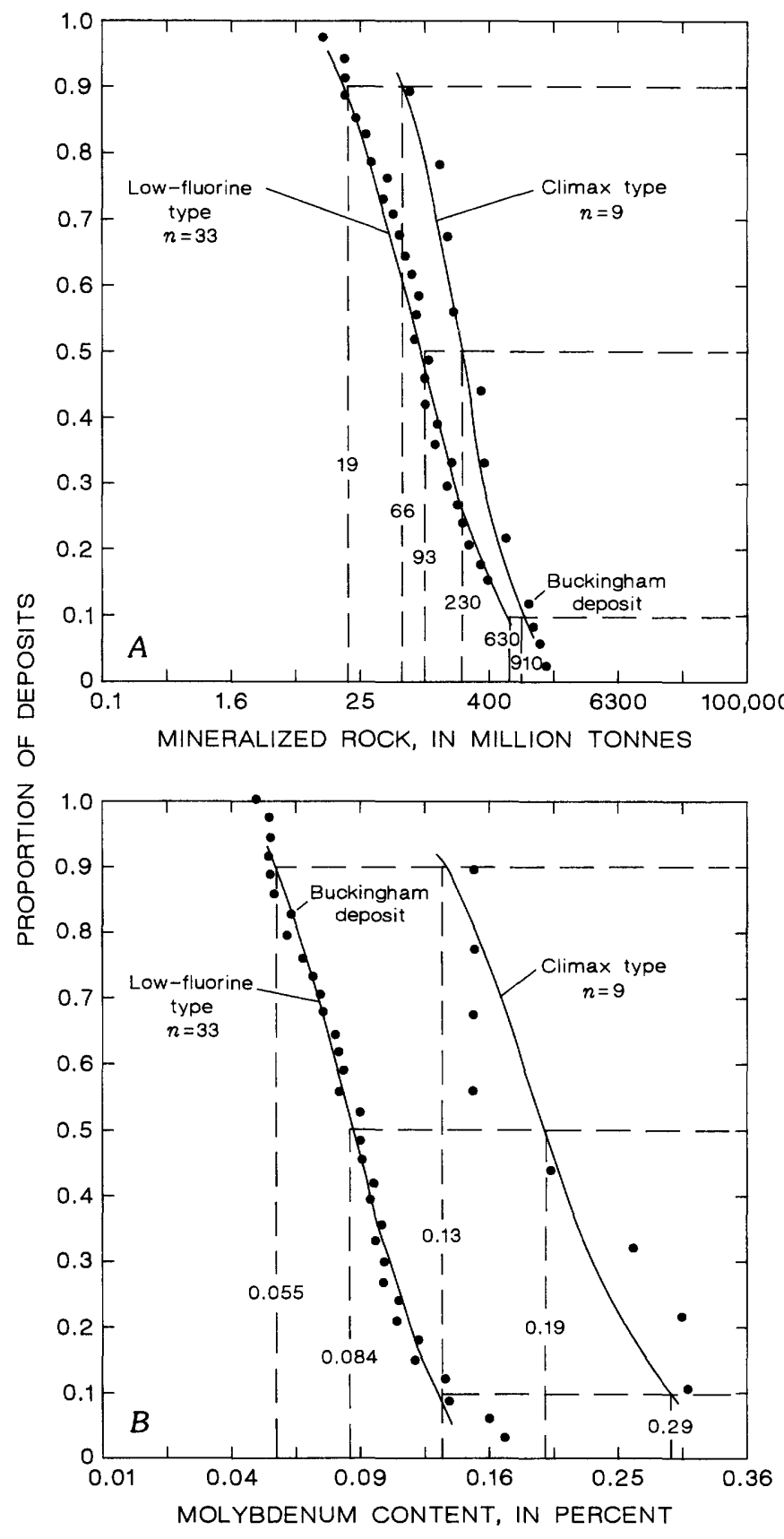

FiguRE 50.-Comparative plots for fluorine-deficient (quartz monzonite)-type and Climax-type molybdenum stockwork systems. Modified from Singer and others (1986) and Theodore and Menzie (1984). $n$, number of deposits. $A$, Proportion of deposits that exceed a given value for tonnage of mineralized rock. $B$, Proportion of deposits that exceed a given value for grade.
Alteration can be categorized into four events, in order of sequence: (1) contact metamorphism of host sedimentary rocks during emplacement of the porphyries, (2) hydrothermal alteration associated with metallization, (3) clay and sericite related to faulting, and (4) supergene alteration. The metamorphic aureole is characterized by recrystallized rock fabrics and pervasive development of biotite, tremolite-actinolite, epidote, and, locally, diopside. Hydrothermal alteration, which is vein and fracture controlled, is characterized by potassic, intermediate argillic, and propylitic assemblages; retrograde propylitic assemblages are present as well. Potassic, intermediate argillic, and propylitic-alteration assemblages may be associated with several, if not each, of the individual porphyry units. Sericite, kaolinite, and montmorillonite were associated with postmineral faulting and more recent weathering. Within the limits of pyritization, supergene.clay-sericite is widespread, and surface weathering has strongly oxidized and leached molybdenite along ridge crests. A series of middle Tertiary porphyry rocks ranging in composition from rhyolite to basalt were emplaced after molybdenum mineralization. Intermediate composition dikes of this suite are spatially and probably genetically related to high-grade, polymetallic base- and precious-metal vein systems that cut the molybdenum deposit. Whereas late-stage porphyries themselves are waste rock, the associated precious-metal veins will contribute to byproduct metal values.

Major deformation of the Paleozoic rocks during the Mississippian Antler and Late Permian to Early Triassic Sonoma orogenies took place before intrusion and mineralization. The porphyries of the system intruded a doubly plunging anticline that probably had formed before magmatic activity in the Late Cretaceous. Extensional faulting commenced before the end of Late Cretaceous molybdenum mineralization and was accompanied by minor rightlateral strike-slip displacement. Movement along these structures dissected the molybdenum deposit into three major and numerous small parts, some of which have been deeply eroded.

\section{INTRODUCTION}

The Buckingham molybdenum deposit is in a stockwork-veined, calc-alkaline intrusive system and contains more than 1,000 million tons of mineralized material grading approximately 0.10 weight percent $\mathrm{MoS}_{2}$. Potential byproducts within the limits of the molybdenum deposit include silver, tungsten, copper, and, possibly, gold. Although strongly oxidized out- 
crops of the Buckingham deposit are exposed along ridge crests, most of the deposit is covered by extensive Quaternary slopewash.

The potential for stockwork molybdenum mineralization at Buckingham was originally recognized in 1962 by Congdon and Carey, a small Denver-based mining and exploration firm. Congdon and Carey's first drill hole was centered on the barren igneous core of the West stock, and subsequent drill holes encountered the outermost fringes of the upper hornfels-hosted West stock molybdenite shell.

In 1967, Union Pacific Mining Corp. (subsequently named Rocky Mountain Energy Co.) optioned claims covering the center of the recognized molybdenum target and explored the eastward extension of mineralization by diamond drilling. With each succeeding eastward stepout, Union Pacific geologists found that mineralization was intersected at greater and greater depths in the footwall of a major, northeast-dipping structure that they termed the "Buckingham fault." The deposit they delineated was deep and of insufficient grade to be economic.

The Climax Molybdenum Co. signed a joint venture agreement with Union Pacific in 1972 and, during the years 1973-80, Climax explored the property by implementing several drilling programs designed to test many geologic concepts. The part of Union Pacific's deep mineralization offset by the Buckingham fault was of primary interest, and near-surface stockwork molybdenum mineralization in the East stock was tested as well. Subsequently, rhyolite porphyry plugs showing unidirectional solidification textures and quartz veining were identified southwest of Buckingham; these were tested for molybdenum before exploration of the East stock area was reemphasized in 1978.

Duval Corp. maintained a persistent exploration effort on its easternmost segment of the Buckingham deposit from 1975-82. Exploration drilling was concentrated on defining a shallow mineral reserve in what is now recognized as a part of the uppermost East stock molybdenite shell.

As part of a prefeasibility study during the period 1980-82, the Climax Molybdenum Co. launched an intensive geologic study of the Buckingham deposit. Climax recognized that earlier exploration programs had tested various fault blocks of the same deposit and that potential existed for numerous porphyry phases with multiple associated mineralizing episodes (a concept first proposed by Wallace and others, 1968). A geologic program was therefore implemented to remap the surface geology and to relog much of the drill core. During this course of the study, seven major phases of the intrusive center were identified, and the sequence of intrusion and mineralization that caused the Buckingham molybdenum deposit was unraveled.

The following part of this report presents a detailed description of the Buckingham molybdenum deposit and sets the stage for future exploration and research efforts. The end result of these geologic studies has been to outline a complex magmatic-hydrothermal history involving multiple intrusions of quartz monzonite porphyry with associated overlapping alteration zones and molybdenite and byproduct-metal shells.

\section{ACKNOWLEDGMENTS}

With pleasure we acknowledge the help of the Climax Molybdenum Co., which over the past two decades has strongly supported the geologic study of molybdenum deposits. In particular, we thank $R$. Kendrick, J. Ludwig, D. Ranta, and W. White for their guidance, and D. Baker, J. Delong, L. Malinconico Jr., S. Olmore, D. Ranta, and D. Stewart for collecting data and contributing to the geologic interpretation that follows.

The Rocky Mountain Energy Co., in particular E.T. Bond, E. Davis, and P.A. Meyer, was responsible for the project before 1973. Their work and work done under their supervision provided the starting point for Climax's geologic studies. Their continuing advice and criticism were invaluable and much appreciated.

As with most mineral deposits, the geologic study of the Buckingham deposit has been a team effort. We therefore extend our thanks to all those not herein mentioned by name who have been involved in the exploration and evaluation studies.

\section{GENERAL GEOLOGY}

A brief overview of the geology will provide a framework for the detailed descriptions that follow. Host rocks to the Buckingham intrusive center and mineral deposit are sedimentary rocks of the Upper Cambrian Harmony Formation and the Devonian Scott Canyon Formation (pl. 1). The intrusive center itself is composed of rocks formed by at least seven major phases that collectively form two stocks, known as the East and West stocks, and other outlying intrusive masses (pl. 2). A sequence 
of younger postmineral porphyries, mostly dikelike in character, cuts and dilutes molybdenum mineralization. Although the late-stage porphyries represent waste rock, vein mineralization associated with them may contribute heavily to byproduct precious metals. Postmineral displacement on the Buckingham and Second fault zones separated the deposit west of the Long Canyon fault into three tectonic segments known as the footwall, interfault, and hanging-wall blocks (pl. 2; fig. 51). Recent oxidation has affected the tenor of nearsurface mineralization.

\section{PALEOZOIC ROCKS}

Detailed descriptions of the Paleozoic rocks in the Buckingham area are given in other parts of this report. Therefore, only brief descriptions of these rocks as they are present near the deposit are given here.

The Harmony Formation is the dominant sedimentary unit surrounding the deposit and contains much of the low-grade molybdenite mineralization. Beds generally dip outward from the intrusive rocks near the deposit; it is not known whether the intrusions domed the sedimentary rocks or whether they intruded the hingeline of a doubly plunging anticline. Correlation from drill hole to drill hole of a distinctive, fine-grained, white quartzite and several green hornfels (diopside-tremolite) units shows that sedimentary rocks dip shallowly to the west in the footwall of the Buckingham fault. Surface exposures generally indicate a northerly to northwesterly dip on Long Ridge and an easterly dip in the area of Vail Peak. Drill core from the Buckingham system contains textures and structures that previously have not been reported in rocks from the Harmony Formation. Core from several drill holes indicates that, in the footwall of the Buckingham fault, bedding typically is very irregular and convoluted on a scale of centimeters. Occasionally, angular rip-up clasts were incorporated during deposition. These textures commonly are present in fine-grained, equigranular hornfels containing abundant tremolite (as much as 34 volume percent) or diopside (as much as 85 volume percent). Although rocks of this type also are present in the hanging-wall block, they are much less common. These rock textures and mineralogies are difficult to interpret because the rocks have been contact metamorphosed to assemblages of albite-epidote hornfels near the deposit. However, magnesiumrich mineralogies at depth may imply that lower parts of the Harmony Formation were derived from more mafic source rocks than those of the upper part of the Harmony Formation. Alternatively, the magnesium-rich facies may be relicts of calcareous and dolomitic units that reacted with hydrothermal fluids to form skarn.

The Harmony Formation is cut by sills and dikes of diabase and may contain some interbedded basaltic flows. Medium-grained, dark-green diabase sills range in width from several centimeters to about $10 \mathrm{~m}$ and are generally in zones that are traceable for several kilometers on a regional scale. In the core of the Buckingham system, most diabase is altered and mineralized and is truncated by the West stock (pl. 2), clearly demonstrating that emplacement of this diabase predated the stock and related metallization. Elsewhere in the Battle Mountain Mining District, some diabase is folded along with the Harmony Formation, establishing its age as pre-early Middle Pennsylvanian (Roberts, 1964). Diabase intercepts in drill holes in the western part of the system are nearly conformable to conspicuous white quartzite beds, implying that diabase bodies at Buckingham are predominantly sill-like in character or may even be remnant basaltic flows interbedded with sedimentary rocks. Diabasic texture is apparent in moderately altered samples. The felted, plagioclase-rich groundmass is weakly sericitized in these samples, but the plagioclase phenocrysts are completely replaced by sericite. Other relict phenocrysts are present and may have been pyroxene. Where diabase was strongly contact metamorphosed, ironrich pargasite porphyroblasts are present in a fine-grained chlorite-epidote-sericite rock. Strongly altered samples can be difficult to identify and to trace in outcrop or drill core.

Argillite, greenstone, and chert of the Scott Canyon Formation, which are present in uplifted fault blocks around the southern and western margins of the Buckingham deposit, are not exposed at the surface in the immediate vicinity of the deposit. However, black chert and argillite fragments are incorporated in pebble dikes in the East stock and, rarely, in intrusion breccias. Thus, the Scott Canyon Formation is inferred to be present at depth.

The upper Paleozoic Antler sequence, which unconformably overlies the Harmony Formation both east and west of the deposit, is inferred to have overlain the Buckingham area at the time of intrusion and mineralization. The Antler sequence has been eroded from the immediate vicinity of the Buckingham deposit (see subsection above entitled "Structural Geology"). 


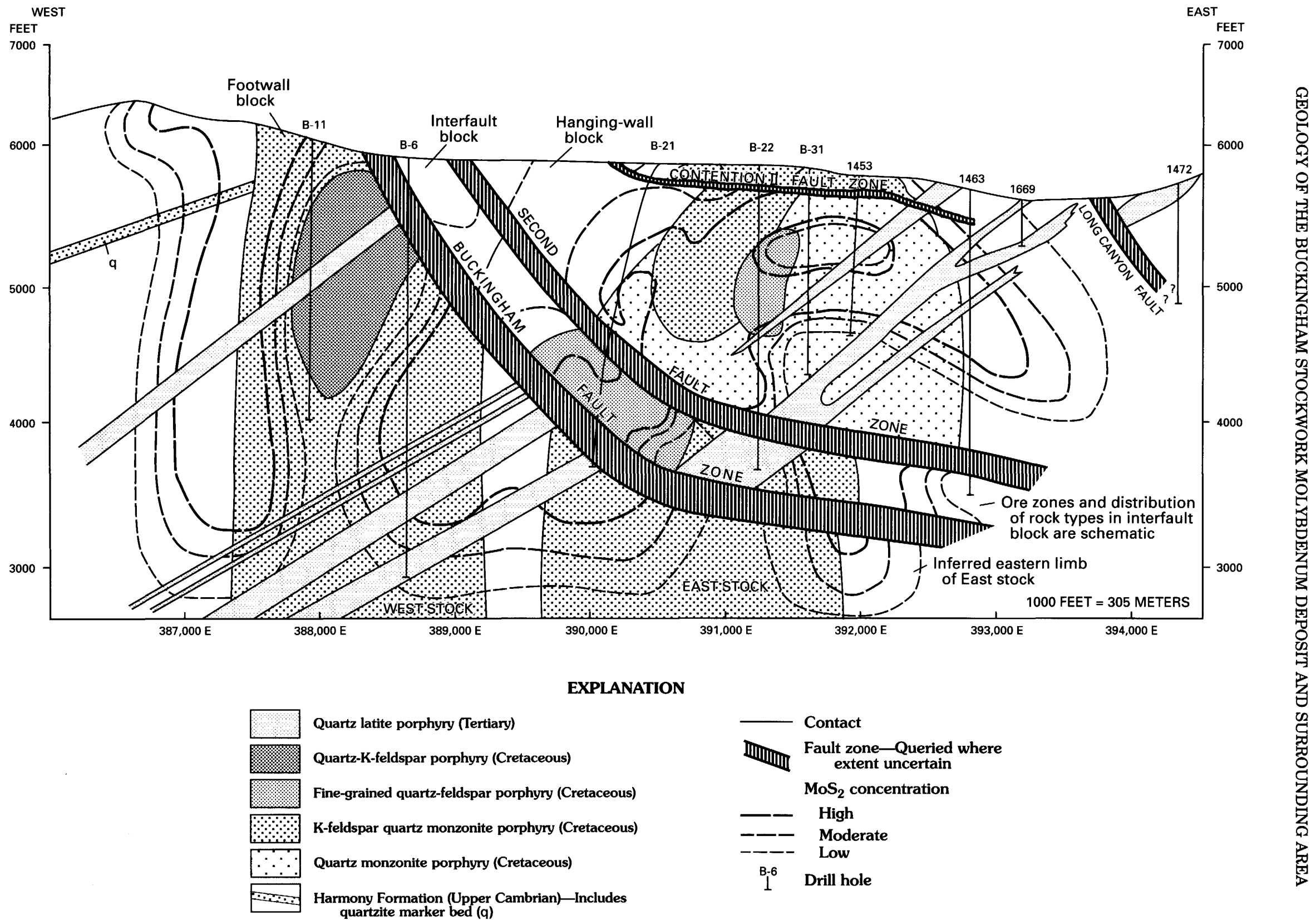

FIGURE 51.-Schematic east-west cross section through East and West stocks of Buckingham molybdenum system, showing geologic relations among footwall, interfault, and hanging-wall tectonic blocks along section line 2,136,200 N. 
PREMINERAL AND SYNMINERAL INTRUSIONS

The terms "premineral and synmineral intrusions" refer to the earliest quartz monzonites that host, or that are inferred to have produced, most of the molybdenum mineralization in the Buckingham system. Slight but significant textural differences and limited data on the location of contact zones as defined by unidirectional solidification textures (Shannon and others, 1982) have been used to distinguish these intrusive units. Much remains to be learned, however, about their geometries, timing, and relations to mineralizing events. As a result, the description of rock units and the intrusive history that follows will probably prove to be oversimplified after further, more detailed studies are conducted. However, this geologic model satisfactorily explains the present distribution of mineralization and has, in fact, been used successfully as a predictive tool in exploration drilling at the Buckingham deposit.

Molybdenum mineralization in the Buckingham deposit was associated with intrusion of several texturally similar porphyry units in two stocks (pl. 2 ; fig. 51). The general sequence of intrusion in the two stocks was similar, and rock textures characterizing correlative intrusive phases are essentially identical. Within the limits of present drilling, the stocks do not merge with depth. In fact, several of the intrusive units are pluglike in form with nearvertical walls, suggesting that, although the two stocks were undoubtedly derived essentially contemporaneously from the same source magma, they are separate and distinct intrusive bodies at the present erosional level. Therefore, correlative rock units in the two stocks, although they may be texturally indistinguishable, are considered to have been separate intrusions that may or may not have been emplaced at precisely the same time. In the following lithologic descriptions, some intrusive units are described with their counterpart from the other stock because, in these cases, the correlative units are texturally, mineralogically, and chemically indistinguishable. Correlative phases in the two stocks are distinguished below by reference to the stock in which the unit is present.

In both the East and West stocks, the most volumetrically significant premineral and synmineral igneous phases appear to have been intruded sequentially from south to north as follows: quartz monzonite porphyry, K-feldspar-quartz monzonite porphyry, and two varieties of quartz-K-feldspar porphyry. Quartz monzonite porphyry and Kfeldspar-quartz monzonite porphyry crop out in ap- proximately equal-size areas at the East stock (units Kqm and Kkqmp, respectively, pl. 2), whereas fine-grained quartz-K-feldspar porphyry and quartz-K-feldspar porphyry are present only at depth in central parts of the East and West stocks (fig. 51). Fine-grained quartz-K-feldspar porphyry is present in the core of the most intensely mineralized rock of the East stock, and quartz K-feldspar porphyry is present in the core of the most intensely mineralized rock of the West stock. Both stocks formed from the initial emplacement of quartz monzonite porphyry with associated lowgrade (approx 0.03 weight percent $\mathrm{MoS}_{2}$ ) mineralization. Subsequently, K-feldspar-quartz monzonite porphyry and quartz-K-feldspar porphyry were emplaced in each stock and produced moderate grade mineralization (approx 0.075 weight percent $\mathrm{MoS}_{2}$ ) and higher grade mineralization (approx 0.1 weight percent $\mathrm{MoS}_{2}$ ), respectively. Quartz-feldspar porphyry and fine-grained quartz-feldspar porphyry are volumetrically less significant and are somewhat poorly defined by the present drill-hole spacing.

The mode of emplacement for all major phases at Buckingham was consumptive, as indicated by enormous blocks, roof pendants and xenoliths of hornfels of the Harmony Formation in quartz monzonite porphyry and by xenoliths of both hornfels and older porphyries floating in a matrix of younger porphyry material. Minor intrusions were probably emplaced in a similar fashion, as in the case of fine-grained quartz-feldspar porphyry. Many of the intrusions appear to flare outward at their uppermost contacts (fine-grained quartzfeldspar porphyry, quartz-K-feldspar porphyry, and the subsequently emplaced large K-feldspar porphyry). Schematic north-south cross sections depicting the inferred evolution of the East stock are shown in figure 52.

The major units, quartz monzonite porphyry, Kfeldspar-quartz monzonite porphyry, quartz-Kfeldspar porphyry and the minor unit fine-grained quartz-feldspar porphyry are all very similar mineralogically. They have ratios of K-feldspar to plagioclase (in volume percent) ranging from 1.1:1 to 1.5:1 (fig. 53), with plagioclase phenocrysts typically showing normal zoning from about $\mathrm{An}_{45}$ cores to $\mathrm{An}_{35}$ rims. Plagioclase shows oscillatory zoning locally. On the basis of their ratios of $\mathrm{K}$-feldspar to plagioclase, the rocks were classified in the field as quartz monzonite, consistent with the terminology traditionally used by English-speaking geologists (for example, Moorhouse, 1959; Bateman, 1961; Bateman and others, 1963; Hietanen, 1963; 
O'Connor, 1965). In terms of Streckeisen's (1973) classification, the rocks are granite $B$ or monzogranite. Although the latter rock names are probably most appropriate, the term "quartz monzonite" has been retained in two of the following rock descriptions to be consistent with existing published and unpublished reports. The descriptions and chemical analyses of typical unaltered or weakly altered samples of several of the units are listed in tables 13 and 14, respectively.

\section{Quartz Monzonite Porphyry}

Megascopically, the quartz monzonite porphyry (unit Kqmp, pl. 2) is distinguished by its aplitic groundmass, small, distinct biotite phenocrysts, and, with rare exception, the absence of $\mathrm{K}$-feldspar phenocrysts (fig. 54A). Quartz eyes, which are evident in sawn or stained slabs, generally are not obvious in hand specimen. Quartz monzonite porphyry is present in both the East and West stocks, and in both places it forms the southern margin. Quartz monzonite porphyry in the East stock occurs as a roof pendant on Long Ridge and in three dikelike masses that dip steeply north and strike N. $70^{\circ}-85^{\circ} \mathrm{W}$. across Vail Ridge immediately east of Long Canyon. That quartz monzonite porphyry was the earliest of the major mineralizationrelated intrusions in both stocks is suggested by four lines of evidence: (1) the unit is on the margins of the stocks; (2) it does not cut other quartz monzonite-type rocks; (3) it has never been observed cutting quartz molybdenite veins in hornfels or in other porphyries; and (4) the quartz monzonite porphyry hosts the highest grade $\mathrm{MoS}_{2}$ mineralization found in the deposit. Quartz monzonite porphyry in the East stock was itself at least a weak mineralizer; dikes in the eastern area of the deposit extending beyond the limits of the ore zone consistently exhibit anomalous molybdenum concentrations that extend outward a few meters into the Harmony Formation.

\section{K-Feldspar-Quartz Monzonite Porphyry}

The K-feldspar-quartz monzonite porphyry (unit Kkqmp, pl. 2) is virtually identical to the quartz monzonite porphyry in texture and mineralogy but with the addition of K-feldspar phenocrysts (fig. $54 B$ ); correlative units in the East and West stocks appear to differ slightly in overall abundance of $\mathrm{K}$ feldspar phenocrysts. K-feldspar-quartz monzonite porphyry of the East stock averages 6 to $10 \mathrm{~K}$ feldspar phenocrysts per meter of drill core; Kfeldspar-quartz monzonite porphyry of the West stock averages about $30 \mathrm{~K}$-feldspar phenocrysts per meter. Where strongly altered or strongly weathered, these units can be indistinguishable from the quartz-K-feldspar porphyry described below; thus, their distributions are not precisely known. Kfeldspar-quartz monzonite porphyry forms much of the East stock where it crops out on the north and south flanks of Long Ridge. Deep drill-hole intercepts indicate that the apex of the intrusion probably occurred midway between Long Ridge and Licking Creek before the emplacement of subsequent intrusive phases. K-feldspar-quartz monzonite porphyry appears to form the western margin of the West stock and may be present locally in the subsurface just north and northeast of Buckingham Camp. Because exposures at the West stock cannot be identified reliably, they may be either Kfeldspar-quartz monzonite porphyry or quartz-Kfeldspar porphyry.

K-feldspar-quartz monzonite porphyry probably postdates quartz monzonite porphyry because it makes up the central mass of the East stock near the surface. We infer that $\mathrm{K}$-feldspar-quartz monzonite porphyry predates the main mineralizing phase in both stocks, quartz-K-feldspar porphyry, because it generally is strongly mineralized and occupies a peripheral position in the system. The emplacement of the younger phase destroyed the original geometry of K-feldspar-quartz monzonite porphyry in both stocks.

\section{Quartz-K-Feldspar Porphyry}

This unit is distinguished by the common occurrence of $\mathrm{K}$-feldspar phenocrysts and by generally larger and more rounded quartz phenocrysts than in previously described units (fig. 54C). Quartz-Kfeldspar porphyry is inferred to have been the major source of molybdenite in the system and apparently is present only at depth. On the basis of the present distribution of drill holes, most of the high-grade $\mathrm{MoS}_{2}$ appears to be shells zoned symmetrically around this intrusion. In addition, both quartz-K-feldspar porphyry bodies in both the East and West stocks have well-developed, high-silica and crenulate quartz band zones at their upper contacts suggesting that, by analogy with relations in the Climax and Henderson, Colo., molybdenum deposits, these units were associated with the greatest concentrations of hydrothermal fluids and 


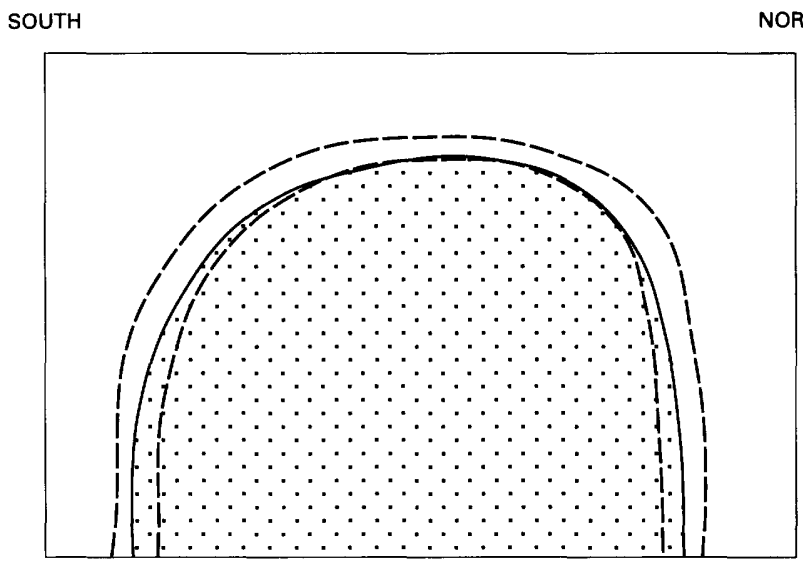

Consumptive placement of quartz monzonite porphyry: stoping and assimilation of wallrock of the Harmony Formation. percent $\mathrm{MoS}_{2}$ and may have formed a shell over and within intrusion (outlying dikes contain 0.03 percent $\mathrm{MoS}_{2}$ ).

SOUTH

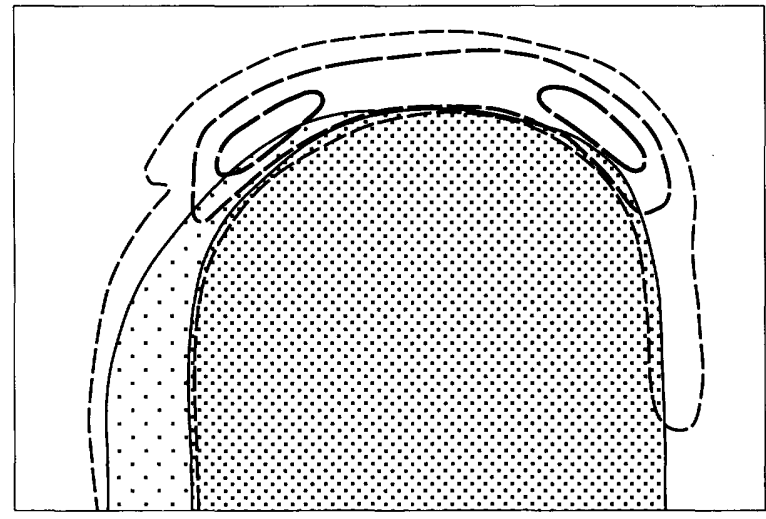

NORTH

EVENT 2

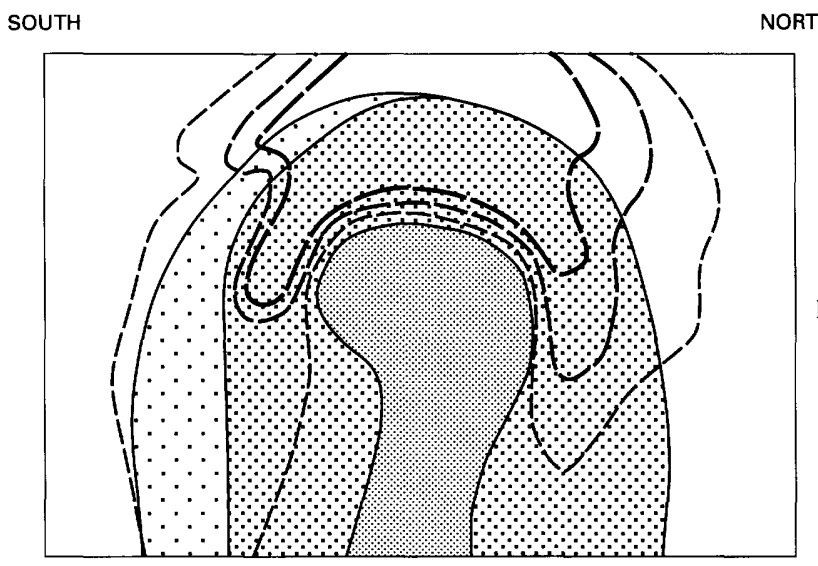

EVENT 3

\section{EXPLANATION}

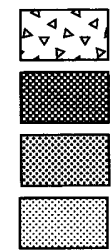

Aplite-intrusion breccia (Cretaceous)

Large K-feldspar porphyry (Cretaceous)

Quartz-K-feldspar porphyry (Cretaceous)

Fine-grained quartz-feldspar porphyry (Cretaceous)
K-feldspar quartz monzonite porphyry (Cretaceous)

Quartz monzonite porphyry (Cretaceous)

Harmony formation (Cambrian)

Contact

FIGURE 52.-Schematic north-south cross sections through East stock of Buckingham molybdenum system, showing inferred evolution breccia, roof pendants and partially assimilated xenoliths stoped 
SOUTH

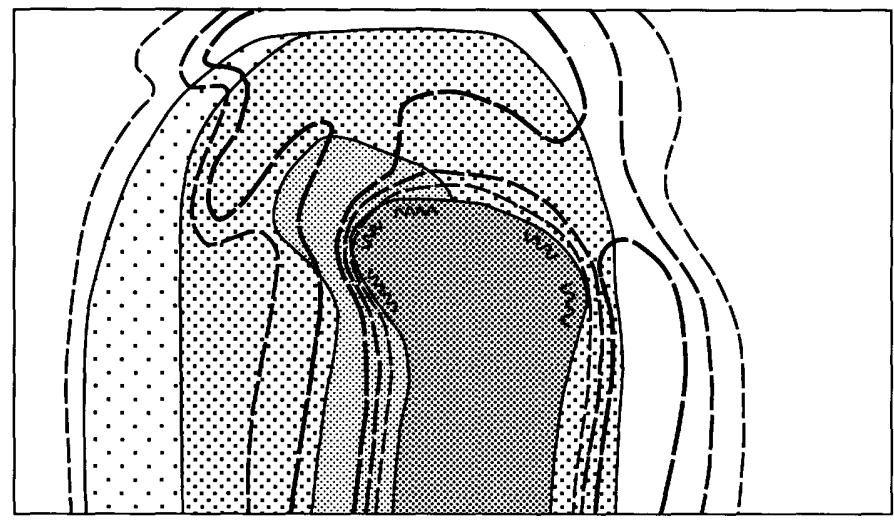

SOUTH

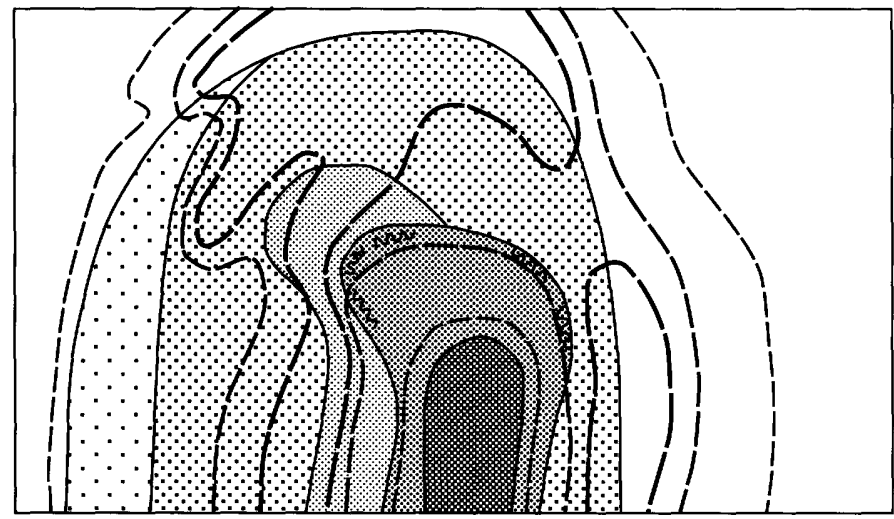

SOUTH

NORTH

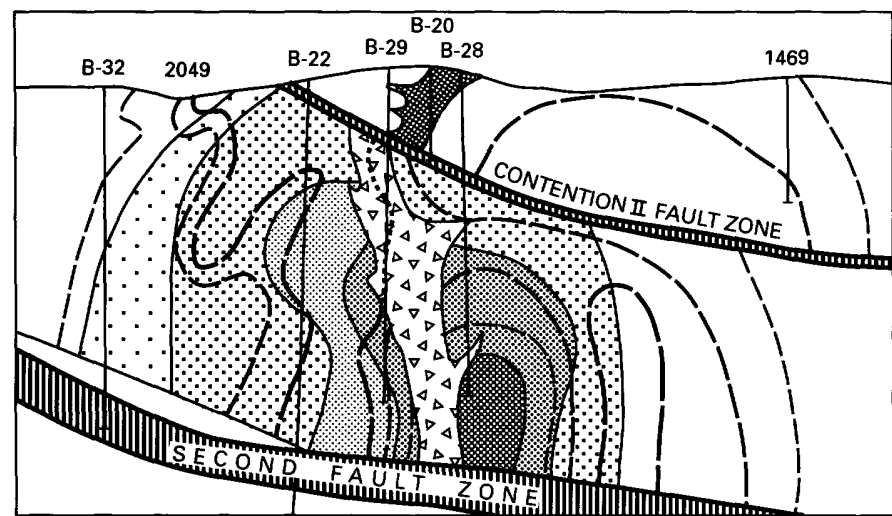

EVENT 5 EVENT 6 followed by weak quartz-molybdenite veining. Stoped blocks of higher grade material carry the breccia matrix at a grade of greater than 0.05 percent.

EVENT $7 \quad\{$ Intrusion of post-molybdenum age, Tertiary quartz latite porphyry (not shown on figure).

Major dislocation and dissection of East stock

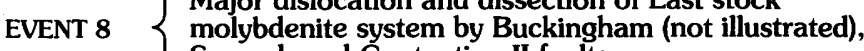
Second, and Contention II faults.

\section{EXPLANATION-Continued}
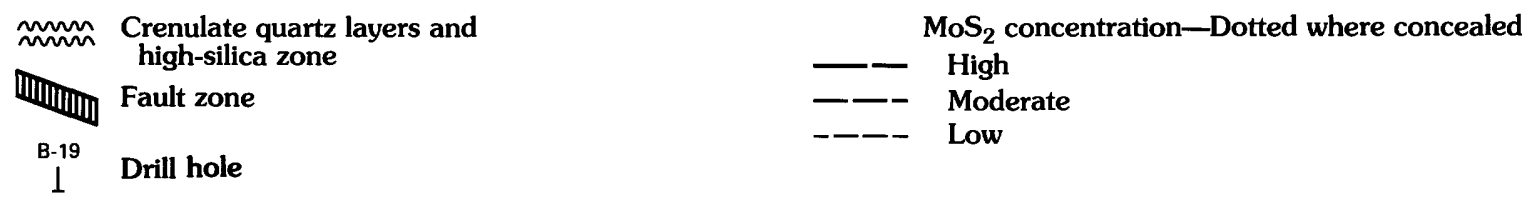

0

0.5 KILOMETER

APPROXIMATE SCALE

of magmatism, mineralization, and postmineral faults along section line 391,100 E. Except for earlier rocks stoped by aplite-intrusion during emplacement of Buckingham intrusions are omitted for simplicity. 
were probably the major molybdenum carriers in the system.

Quartz-K-feldspar porphyry makes up the core of the West stock. Its southern contact flares upward and outward (fig. 55), and it is characterized by high-silica alteration and crenulate quartz layers. The associated ore zone forms limbs that lay peripheral to the intrusion, and the central part of the unit is barren.

Quartz-K-feldspar porphyry of the East Stock is present beneath the crest of Long Ridge and mostly below an elevation of $5,000 \mathrm{ft}$. The unit also is present as xenoliths in an intrusion breccia of younger aplite, where it is characterized by highsilica alteration and crenulate quartz layers (fig. 56). Thus, aplite probably truncated a southern contact zone of quartz-K-feldspar porphyry where quartz-K-feldspar porphyry had intruded and mineralized K-feldspar-quartz monzonite porphyry and quartz monzonite porphyry in the East stock. The highest grade mineralization in the East stock lies just south of this aplite intrusion breccia in an ore shell that is inferred to have been deposited mostly by quartz-K-feldspar porphyry. Some mineralization may also be attributed to another igneous phase, the fine-grained quartz-feldspar porphyry, described below. In plan view, the width of the southern part of the East stock ore zone is nearly

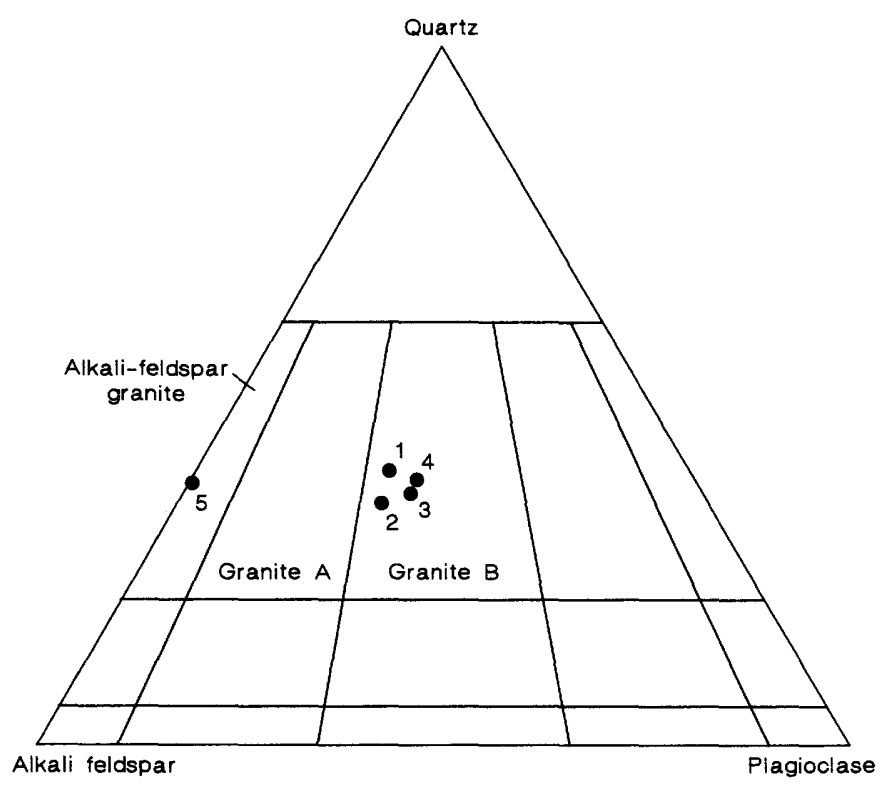

Figure 53.-Quartz-alkali feldspar-plagioclase ternary plot, showing modal analyses of some Buckingham intrusive rocks. Samples unaltered or weakly altered. Compositional fields from Streckeisen and others (1973). Samples: 1, 2, from quartz monzonite porphyry; 3, 4, from large K-feldspar porphyry; 5, aplite. comparable to that in the West stock, $430 \mathrm{~m}$ compared with $490 \mathrm{~m}$, respectively.

\section{Fine-Grained Quartz-Feldspar Porphyry}

This unit is distinguished by its bimodal groundmass with a population of quartz grains slightly coarser than the groundmass (fig. 54D). Quartz, plagioclase, biotite, and rare $\mathrm{K}$-feldspar compose the phenocryst assemblage. Fine-grained quartzfeldspar porphyry has been recognized only at depth in the East stock, where the rock is present in interfault and hanging-wall parts of the deposit. Because of its position relative to other intrusions and ore shells in the East stock, it is postulated that the rock postdates K-feldspar-quartz monzonite porphyry (see figs. 52, 56). Fine-grained quartz-feldspar porphyry was probably emplaced near-surface, and mineralization is greater than 0.1 weight percent $\mathrm{MoS}_{2}$; fine-grained quartzfeldspar porphyry was mineralized itself by quartzK-feldspar porphyry.

\section{Quartz-Feldspar Porphyries}

Fine-grained porphyries with stretched quartz eyes and plagioclase phenocrysts (fig. 54D) have been identified at depth in both the East stock and the West stock; they do not crop out in the immediate areas of the East and West stocks (pl. 2). Quartz-feldspar porphyry bears a strong textural resemblance to intermineral aplite, but the porphyry is characterized by a high density of quartz veining with accompanying molybdenite. Similar to aplite, stretched quartz "eyes" may actually be rounded vein fragments, and the rocks may be hybridized products of the aplite intrusion breccia.

\section{INTERMINERAL INTRUSIONS}

The intermineral intrusions include three rocks that clearly postdate rocks associated with most molybdenum deposition. Nevertheless, intermineral rocks are associated with low-grade $\mathrm{MoS}_{2}$ mineralization. In general, the rocks are weakly altered and clearly crosscut quartz-molybdenite veins in hornfels and earlier stage porphyries. Detailed descriptions of typical unaltered samples are provided in table 13 , and chemical analyses are listed in table 14 . 
TABLE 13.-Descriptions of igneous-rock units in the Buckingham stockwork molybdenum system

\begin{tabular}{|c|c|c|c|c|c|c|c|c|c|c|c|}
\hline \multirow{2}{*}{$\begin{array}{l}\overline{\text { MAP- }} \\
\text { UNIT } \\
\text { SYMBOL }\end{array}$} & \multicolumn{5}{|c|}{ Phenocrysts } & \multicolumn{4}{|c|}{ Groundmass } & \multicolumn{2}{|c|}{ Accessories } \\
\hline & Type & Morphology & $\begin{array}{c}\text { Vo1. } \\
z\end{array}$ & $\begin{array}{l}\text { Size } \\
(\mathrm{mm})\end{array}$ & Comments & Mineralogy & Texture & $\begin{array}{c}\text { Vo1. } \\
\%\end{array}$ & $\begin{array}{l}\text { Size } \\
(\mathrm{mm})\end{array}$ & Mineralogy & Comments \\
\hline $\mathrm{Kqmp}^{2}$ & $\begin{array}{l}\text { qz } \\
\text { plag } \\
\text { bio } \\
\text { hbd }\end{array}$ & $\begin{array}{l}\text { Sub-euhedral } \\
\text { Euhedral } \\
\text { Euhedral } \\
\text { Euhedra1 }\end{array}$ & $\begin{array}{c}5-8 \\
23-24 \\
\\
4-7 \\
t r-1\end{array}$ & $\begin{array}{c}1.0-5 \\
0.05-11 \\
.3-3 \\
.5-2\end{array}$ & $\begin{array}{l}\text { Seriate, normal } \\
\text { zoning } \mathrm{An}_{44}-\mathrm{An}_{33} \\
\text { Pale olive green } \\
\text { replaced by bio, } \\
\text { chlorite, pyrite }\end{array}$ & $\begin{array}{l}\text { qz } \\
\text { K-feld- } \\
\text { spar }\end{array}$ & $\begin{array}{l}\text { Equigranular, } \\
\text { allotriomorphic }\end{array}$ & $59-66$ & $\begin{array}{c}0.05-.5 \\
(.1-.3 \text { ave })\end{array}$ & $\begin{array}{l}\text { Apatite } \\
\text { Sphene } \\
\text { Zircon }\end{array}$ & $\begin{array}{l}\text { Intergrown with } \\
\text { occasional pyrite-- } \\
\text { hydrotherma1? }\end{array}$ \\
\hline Kkqmp ${ }^{2}$ & $\begin{array}{l}\text { qz } \\
\text { plag } \\
\text { K-feld- } \\
\text { spar } \\
\text { bio }\end{array}$ & $\begin{array}{l}\text { Subhedral } \\
\text { Euhedral } \\
\text { Euhedral } \\
\text { Euhedral }\end{array}$ & $\begin{array}{c}5-10 \\
20-25 \\
\operatorname{tr}-3 \\
3-5\end{array}$ & $\begin{array}{l}1-6 \\
.5-3 \\
4-15 \\
.5-3\end{array}$ & $\begin{array}{l}\text { Seriate, normal } \\
\text { zoning } \mathrm{An}_{46}-\mathrm{An}_{30} \\
\text { Epidote replaced }\end{array}$ & $\begin{array}{c}\text { qz } \\
\text { K-feld- } \\
\text { spar }\end{array}$ & $\begin{array}{l}\text { Equigranular, } \\
\text { allotriomorphic }\end{array}$ & & $\begin{array}{c}.08-.5 \\
(.1-.3 \text { ave })\end{array}$ & $\begin{array}{l}\text { Apatite } \\
\text { Sphene } \\
\text { Zircon }\end{array}$ & $\begin{array}{l}\text { Hydrotherma1? } \\
\text { color1ess }\end{array}$ \\
\hline$K f q f p^{2}$ & $\begin{array}{l}\text { qz } \\
\text { plag } \\
\text { bio }\end{array}$ & $\begin{array}{l}\text { Subhedra1 } \\
\text { Euhedra1 } \\
\text { Euhedra1 }\end{array}$ & $\begin{array}{l}5-9 \\
20-25 \\
\operatorname{tr}-3\end{array}$ & $\begin{array}{l}.5-7 \\
.5-4 \\
.5-3\end{array}$ & & $\begin{array}{c}q z \\
\text { K-feld- } \\
\text { spar }\end{array}$ & $\begin{array}{l}\text { Allotriomorphic, } \\
\text { equigranular }\end{array}$ & $65-75$ & $.04-.4$ & & \\
\hline $\mathrm{Kqkp}^{2}$ & $\begin{array}{l}\text { qz } \\
\text { plag } \\
\text { K-feld- } \\
\text { spar } \\
\text { bio }\end{array}$ & $\begin{array}{l}\text { Subhedral } \\
\text { Euhedral } \\
\text { Euhedral } \\
\text { Euhedral }\end{array}$ & $\begin{array}{c}8-12 \\
20-25 \\
1-10 \\
3-5\end{array}$ & $\begin{array}{l}1-8 \\
.5-3 \\
4-25 \\
.3-3\end{array}$ & $\begin{array}{l}\text { Seriate, normal } \\
\text { zoning } \mathrm{An}_{50}-\mathrm{An}_{34}\end{array}$ & $\begin{array}{l}\text { qz } \\
\text { K-feld- } \\
\text { spar }\end{array}$ & $\begin{array}{l}\text { Equigranular, } \\
\text { allotriomorphic }\end{array}$ & & $.08-.4$ & & \\
\hline $\mathrm{k} 1 \mathrm{kp}^{2}$ & $\begin{array}{l}\text { qz } \\
\text { plag } \\
\text { K-fe1d- } \\
\text { spar } \\
\text { bio }\end{array}$ & $\begin{array}{l}\text { Subhedral } \\
\text { Euhedral } \\
\text { Euhedra1 } \\
\text { Euhedral }\end{array}$ & $\begin{array}{c}6-8 \\
26-28 \\
3-7 \\
4-7\end{array}$ & $\begin{array}{r}.5-9 \\
.5-4 \\
5 .-30 \\
0.5-3\end{array}$ & $\begin{array}{l}\text { Norma1 zoning } \\
\mathrm{An}_{44}-\mathrm{An}_{34}\end{array}$ & $\underset{\substack{\mathrm{qz} \\
\text { spar }}}{\text { spar- }}$ & $\begin{array}{l}\text { Equigranular, } \\
\text { allotriomorphic }\end{array}$ & $50-55$ & $\begin{array}{l}.05-.3 \\
(.1 \text { ave })\end{array}$ & $\begin{array}{l}\text { Apatite } \\
\text { Sphene } \\
\text { Zircon }\end{array}$ & $\begin{array}{l}\text { Probably } \\
\text { hydothermal } \\
\text { Very small }\end{array}$ \\
\hline $\mathrm{Kap}^{2}$ & $\begin{array}{l}\text { qz } \\
\text { plag } \\
\text { bio }\end{array}$ & $\begin{array}{l}\text { Anhedral } \\
\text { Subhedral } \\
\text { Euhedral }\end{array}$ & $\begin{array}{l}2-5 \\
t r-1 \\
t r-1\end{array}$ & $\begin{array}{l}1-9 \\
1-3 \\
1-3\end{array}$ & & $\begin{array}{c}\text { qz } \\
\text { K-feld- } \\
\text { spar }\end{array}$ & $\begin{array}{l}\text { Equigranular, } \\
\text { allotriomorphic }\end{array}$ & $90-98$ & $.1-.4$ & Apatite & \\
\hline
\end{tabular}

See plate 2 and figures $51-56$.

2 Kqmp, quartz monzonite porphyry; Kqkp, quartz-K-feldspar porphyry; Kkqmp, K-feldspar quartz monzonite porphyry; K1kp, large K-feldspar porphyry; Kfqfp, fine-grained quartz-feldspar porphyry; Kap, aplite. 
TABLE 14.-Analytical data on fresh or weakly altered samples of premineral, synmineral, and intermineral intrusions in the Buckingham stockwork molybdenum system

[Chemical analyses and Cross, Iddings, Pirsson, and Washington (CIPW) norms in weight percent; analyst, Skyline Labs, Denver, Colo. n.d., not determined; - , not detected]

\begin{tabular}{|c|c|c|c|c|c|}
\hline Ana1ysis & 1 & 2 & 3 & 4 & 5 \\
\hline Field No. & $\mathrm{B} 27-171.5$ & B25-1630 & $\mathrm{B} 28-1620-30$ & B29-505 & B29-619 \\
\hline \multicolumn{6}{|c|}{ Chemical analyses (weight percent) } \\
\hline $\mathrm{SiO}_{2}$ & 68.3 & 69.4 & 67.2 & 66.86 & 68.72 \\
\hline $\mathrm{TiO}_{2}^{2}$ & .33 & N.d. & .38 & .47 & .44 \\
\hline $\mathrm{A}_{2} \mathrm{O}_{3}$ & 14.7 & 14.2 & 14.6 & 12.68 & 12.84 \\
\hline $\mathrm{Fe}_{2} \mathrm{O}_{3}$ & .92 & 2.2 & 1.1 & 1.42 & 1.02 \\
\hline $\mathrm{FeO}^{3}$ & 1.9 & 1.8 & .95 & .16 & .10 \\
\hline MnO & .067 & N.d. & .038 & .05 & .05 \\
\hline $\mathrm{MgO}$ & 1.3 & 1.1 & .86 & 1.80 & 1.50 \\
\hline $\mathrm{CaO}$ & 3.0 & 3.4 & 2.60 & 2.94 & 2.02 \\
\hline $\mathrm{Na}_{2} \mathrm{O}$ & 3.0 & 2.0 & 1.6 & 2.94 & 2.02 \\
\hline $\mathrm{K}_{2} \mathrm{O}$ & 4.4 & 5.5 & 6.5 & 9.19 & 10.07 \\
\hline $\left.\mathrm{Rb}_{2}{ }_{(\mathrm{Rb}}^{\mathrm{O}} \mathrm{ppm}\right)$ & $\begin{array}{r}.037 \\
(170)\end{array}$ & $\begin{array}{r}.046 \\
(210)\end{array}$ & N.d. & N.d. & N.d \\
\hline $\mathrm{P}_{2} \mathrm{O}_{5}$ & .05 & N.d. & .07 & .20 & .19 \\
\hline $\mathrm{H}_{2}^{2} \mathrm{O}+$ & 1.6 & N.d. & N.d. & 1.05 & .55 \\
\hline $\mathrm{H}_{2} \mathrm{O}_{-}$ & .1 & N.d. & N.d. & .10 & .11 \\
\hline $\mathrm{CO}_{2}$ & .8 & N.d. & 1.2 & 2.31 & 1.61 \\
\hline $\mathrm{F}$ & .062 & N.d. & .065 & .06 & .08 \\
\hline $\mathrm{C} 1$ & N.d. & N.d. & N.d. & --- & --- \\
\hline $\mathrm{S}$ & N.d. & .33 & N.d. & N.d. & N.d. \\
\hline$-\mathrm{O}=\mathrm{F}, \mathrm{C} 1, \mathrm{~S}$ & .026 & .082 & .027 & .02 & .03 \\
\hline Tota1 & 100.54 & 99.89 & 97.14 & 100.33 & 100.23 \\
\hline \multicolumn{6}{|c|}{ C.I.P.W. norms (weight percent) } \\
\hline$q$ & 27.05 & 28.07 & 29.71 & 22.82 & 22.35 \\
\hline c & 1.67 & --- & 3.31 & .99 & .36 \\
\hline or & 26.11 & 32.62 & 38.41 & 54.33 & 59.51 \\
\hline$a b$ & 25.38 & 16.94 & 13.53 & 8.97 & 8.13 \\
\hline an & 9.04 & 13.46 & 4.42 & -- & -- \\
\hline $\mathrm{d} i$ & -- & 2.16 & --- & -- & -- \\
\hline hd & --- & .54 & --- & --- & --- \\
\hline en & 3.23 & 1.74 & 2.14 & 4.49 & 3.73 \\
\hline fs & 2.3 & .5 & .26 & -- & -- \\
\hline $\mathrm{mt}$ & 1.34 & 3.2 & 1.60 & -- & --- \\
\hline i1 & .62 & -- & .73 & .44 & .32 \\
\hline $\mathrm{hm}$ & --- & --- & -- & 1.42 & 1.02 \\
\hline ru & -- & -- & -- & .24 & .27 \\
\hline ap & .13 & --- & .17 & .47 & .44 \\
\hline$c c$ & 1.82 & --- & 2.73 & 4.66 & 3. \\
\hline $\mathrm{fr}$ & .12 & -- & .12 & .09 & .13 \\
\hline $\mathrm{pr}$ & -- & 0.62 & -- & -- & -- \\
\hline${ }_{2}^{\mathrm{H}_{2} \mathrm{O}}\left(\mathrm{CO}_{2}\right)$ & 1.7 & -- & --- & $\begin{array}{l}1.15 \\
(.26) \\
\end{array}$ & $\begin{array}{c}.66 \\
(.29) \\
\end{array}$ \\
\hline Total & 100.51 & 99.85 & 97.13 & 100.32 & 100.21 \\
\hline
\end{tabular}

${ }^{1}$ Pulp from 1-m drill-core interval.

1. Quartz monzonite porphyry.

2. Do.

3. Large K-feldspar porphyry.

4. Ap1ite dike.

5. Do. 
Large K-Feldspar Porphyry

Large K-feldspar porphyry (unit KIkp, pl. 2) is distinguished from earlier igneous phases by abundant conspicuous, large K-feldspar phenocrysts, moderately large quartz phenocrysts, and a fine- to medium-grained groundmass (fig. 57A). Overall, although the rock bears strong textural similarities to earlier intrusions, it has a somewhat more

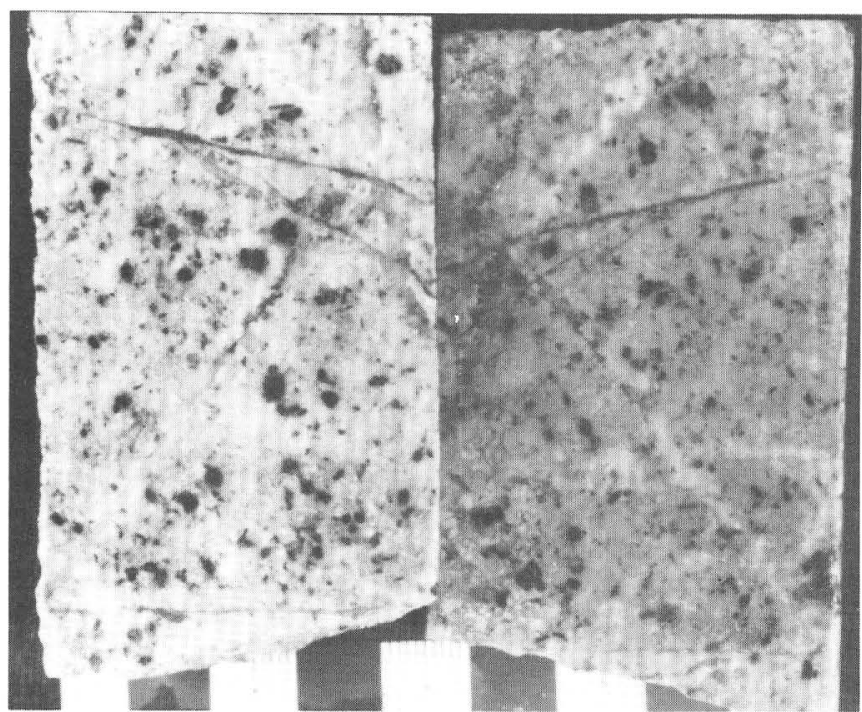

$\boldsymbol{A}$

0

2 CENTIMETERS

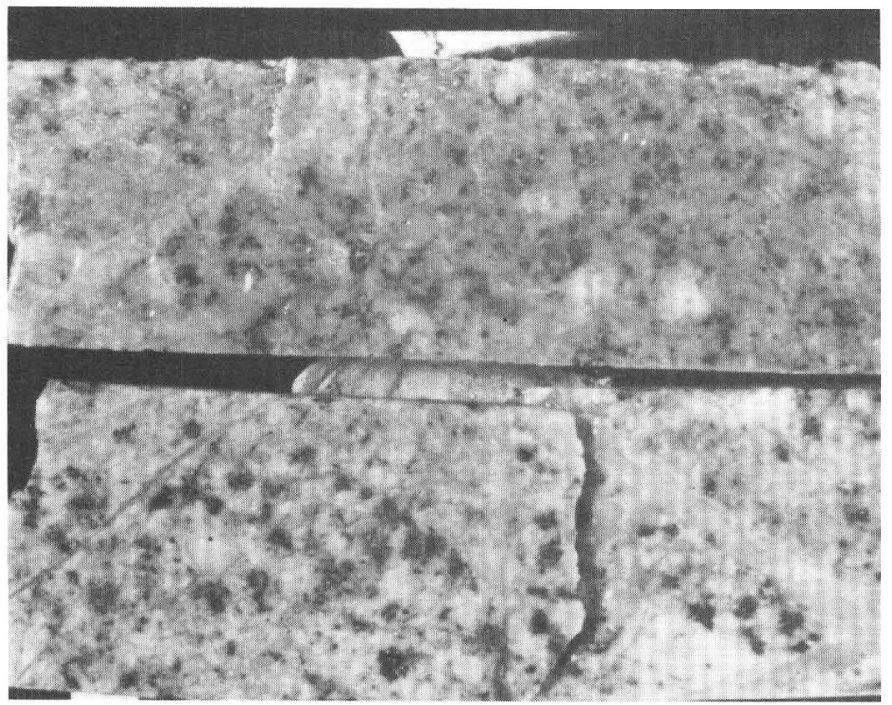

$\boldsymbol{B}$

2 CENTIMETERS

FIGURE 54.-Typical specimens of premineral and synmineral Cretaceous intrusive rocks. Except for specimen in figure $54 E$, one half of each sawn specimen has been stained to enhance alkali and plagioclase feldspar. Rocks shown in figures $54 \mathrm{C}$ through $54 E$ are present only at depth in Buckingham stock-
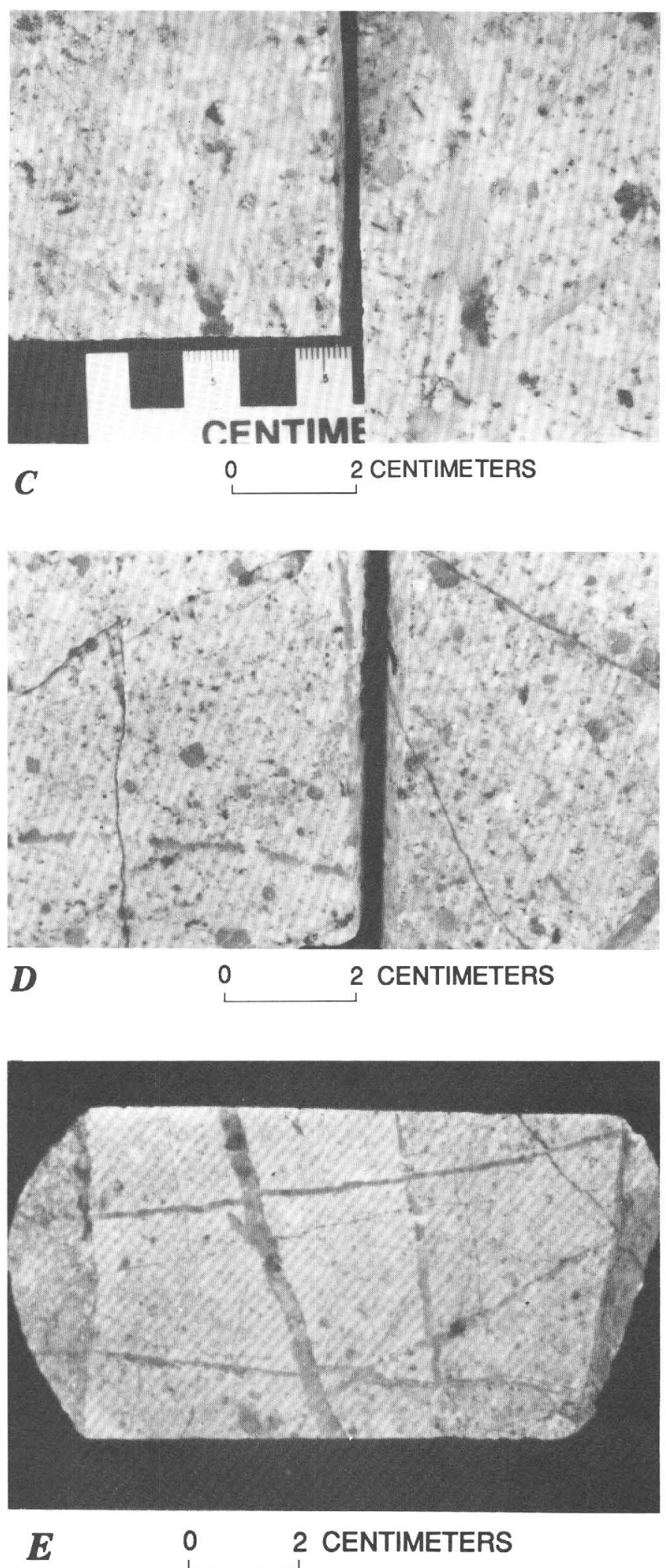

work molybdenum system. A, Quartz monzonite porphyry (Kqmp). $B$, K-feldspar-quartz monzonite porphyry (Kkqmp). $C$, Quartz-K-feldspar porphyry (fig. 51). D, Fine-grained quartzfeldspar porphyry (fig. 51). E, Quartz-feldspar porphyry (fig. 51). See plate 2 for unit symbols and names. 


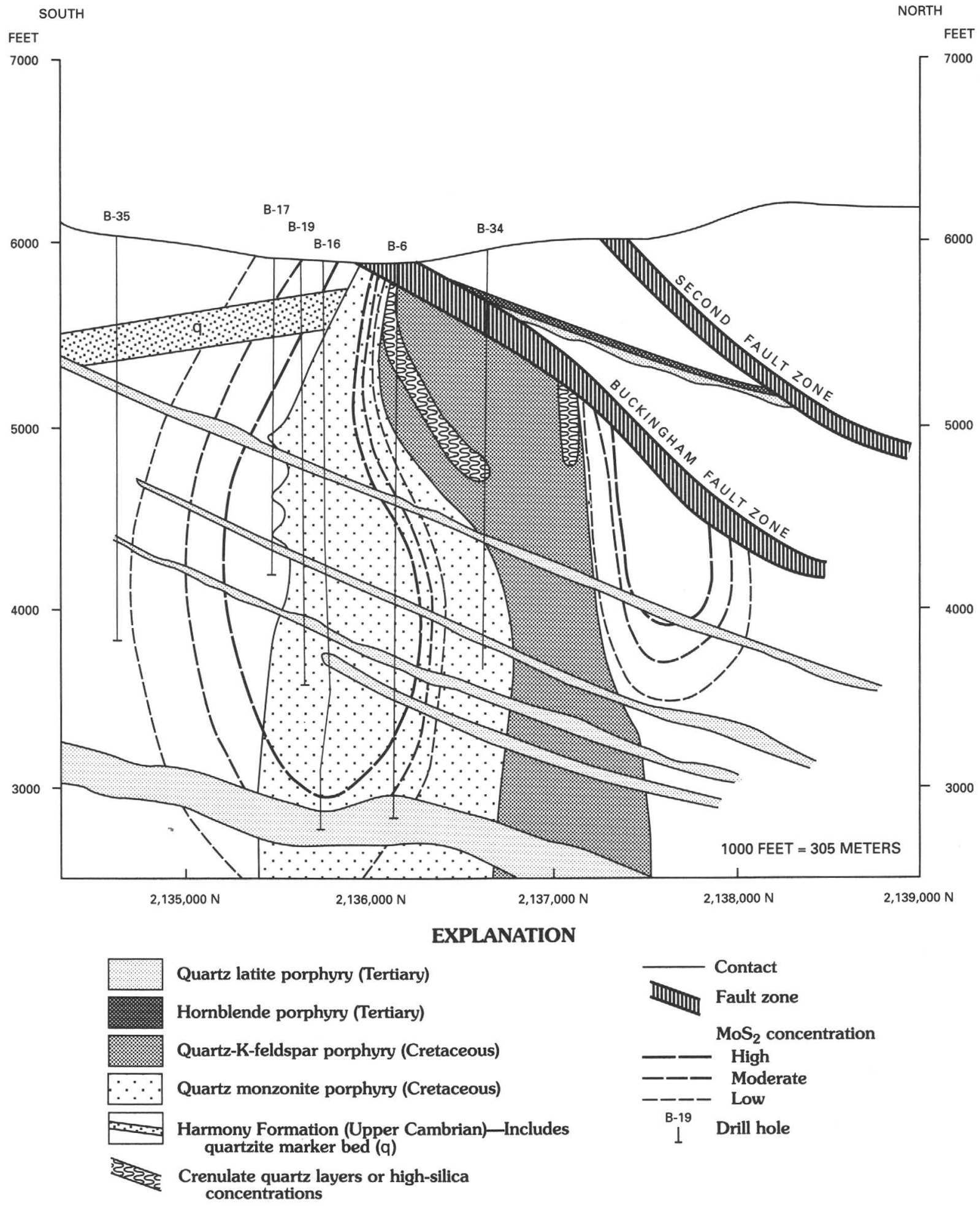

FIGURE 55.-Schematic north-south cross section through West stock of Buckingham molybdenum stockwork system, showing geologic relations among intrusive phases and crenulate quartz layers within stock and relations of stock to Buckingham and Second fault zones. 
uniform appearance; modally and chemically, it is indistinguishable from premineral and synmineral intrusions (tables 13, 14). Large K-feldspar porphyry crops out on the north flank of Long Ridge near the East stock. As mapped, the unit includes large roof pendants and numerous xenoliths of hornfels; these suggest that the present exposures are very close to the original roof of the intrusion. For that reason, the flat western contact of the body is interpreted not to imply sill-like emplacement but rather to be a manifestation of the flat upper surface of a pluglike mass exposed by erosion (pl. 2). Limited drill intercepts suggest the presence of a significant volume of large $\mathrm{K}$-feldspar porphyry midway between the Gold Top Mine and the Bentley Mine. We can only speculate how much

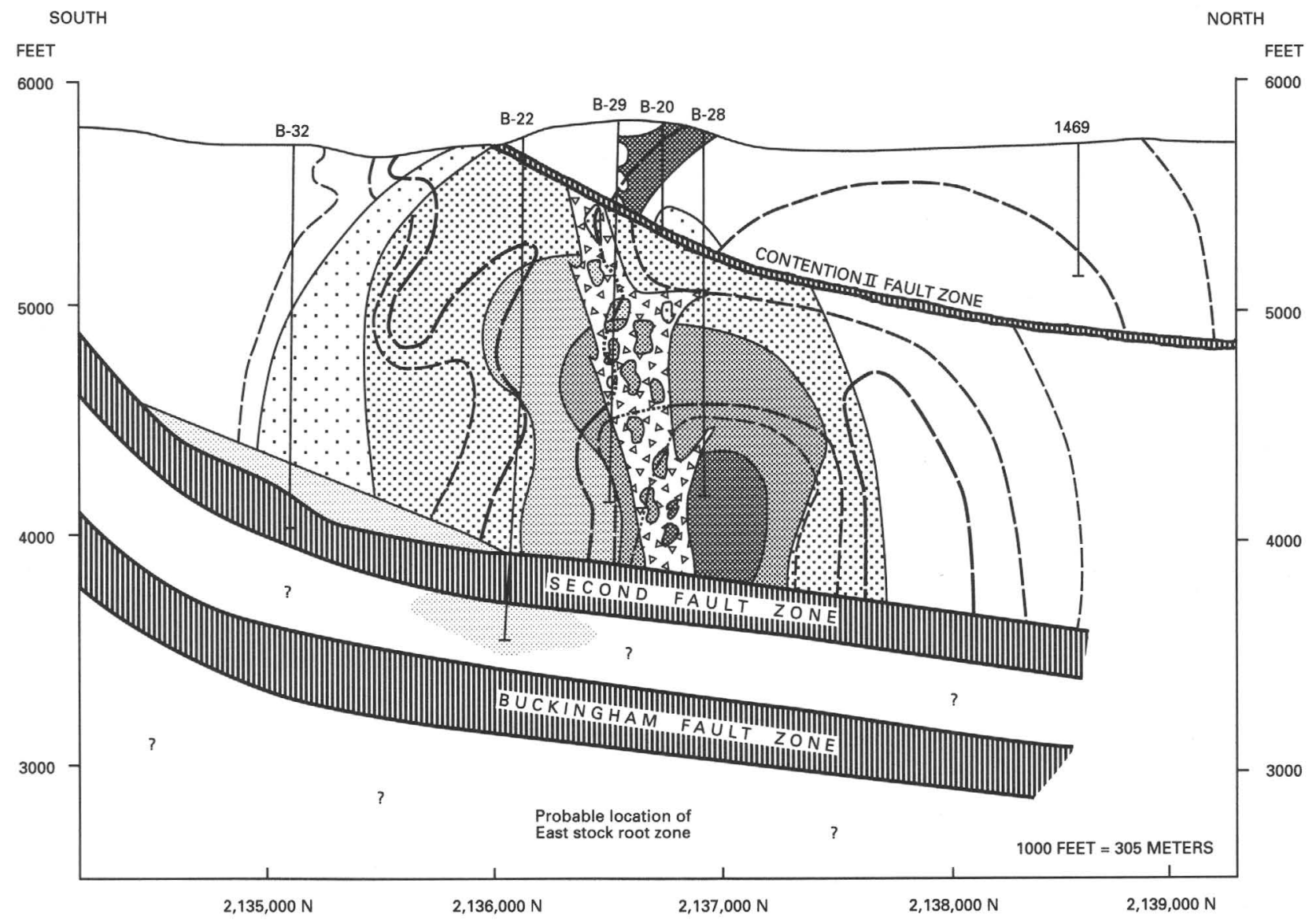

EXPLANATION

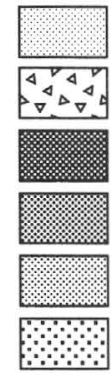

Quartz latite porphyry (Tertiary)

Aplite and intrusion breccia, undivided (Cretaceous)

Large K-feldspar porphyry (Cretaceous)

Quartz-K-feldspar porphyry (Cretaceous)

Fine-grained quartz-feldspar porphyry (Cretaceous)

K-feldspar quartz monzonite porphyry (Cretaceous)

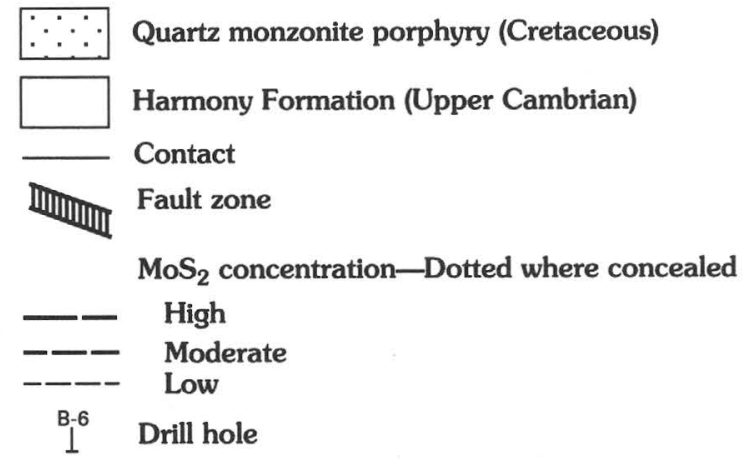

FIGURE 56.-Schematic north-south cross section through the East stock of Buckingham stockwork molybdenum system, showing geologic relations among magmatic phases, intrusion breccia, and postmineral faults along section line $391,100 \mathrm{E}$. 

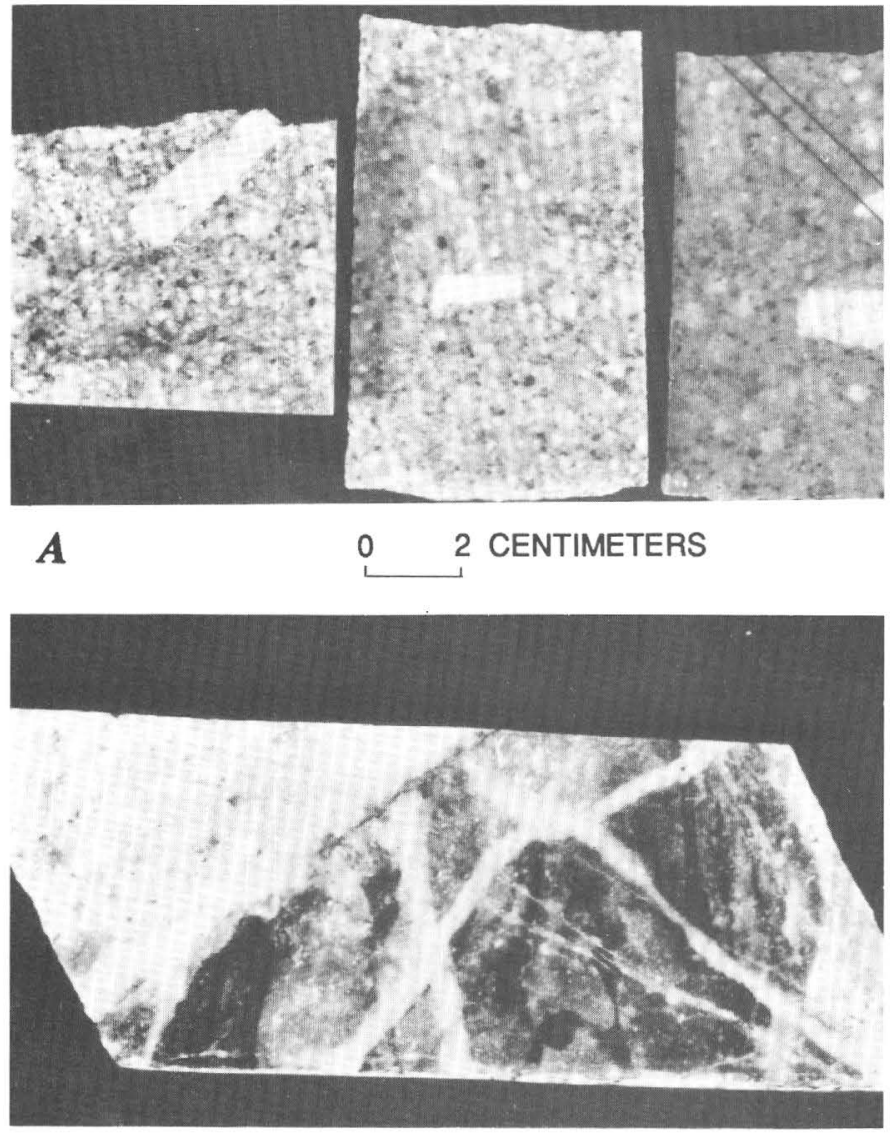

$\boldsymbol{B}$ O 2 CENTIMETERS

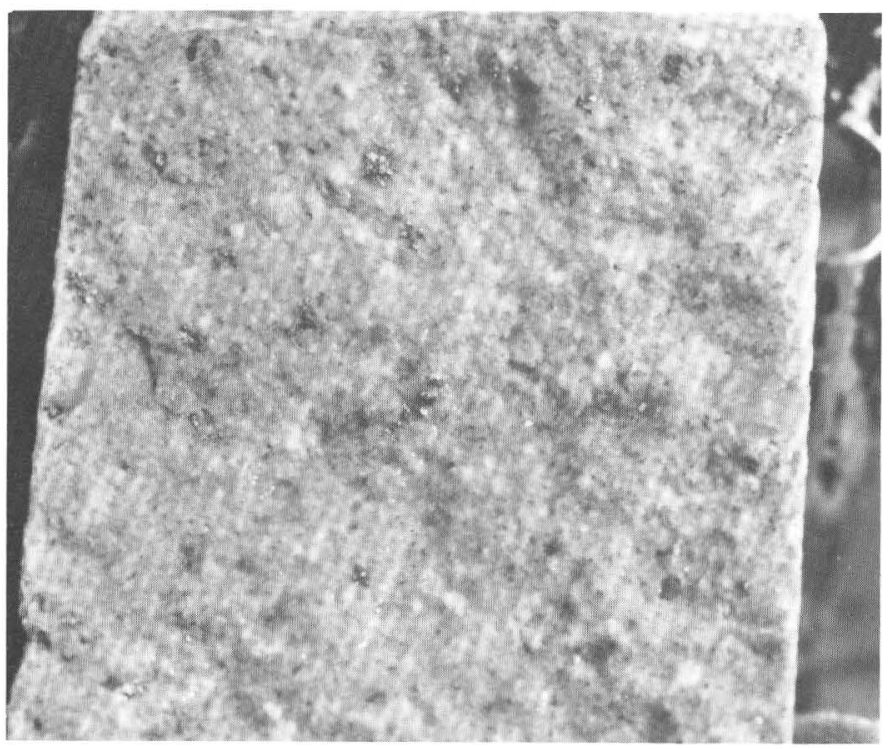

$\boldsymbol{C}$ 0 2 CENTIMETERS

FiguRE 57.-Typical specimens of intermineral Cretaceous intrusive rocks. A, Large $\mathrm{K}$-feldspar porphyry (KIkp). B, Large Kfeldspar porphyry cutting quartz veins in the Upper Cambrian Harmony Formation; C, Aplite (Kap). See plate 2 for unit symbols and names. large K-feldspar porphyry lies at depth; however, we infer from these intercepts that the intrusion is carrot shaped in section, expanding in width near the surface. This shape is consistent with the geometry of some other intrusions (that is, quartz-Kfeldspar porphyry and fine-grained quartz-feldspar porphyry; figs. 55 and 56 , respectively).

Molybdenite, which is present in large K-feldspar porphyry, is found in quartz molybdenite-pyrite veins. The fact that quartz veining and grades higher than 0.05 weight percent $\mathrm{MoS}_{2}$ can only locally be attributed to large $\mathrm{K}$-feldspar porphyry suggests that the hydrothermal system accompanying emplacement of this intrusive phase was weak and restricted. In general, the unit is waste rock and dilutes northern, near-surface parts of the East stock ore zones. Dikes of large K-feldspar porphyry clearly truncate quartz-molybdenite veins in hornfels and earlier intrusions (fig. 57B). Emplacement of large $\mathrm{K}$-feldspar porphyry appears to mark a transition in magmatic activity at Buckingham from large, well-mineralized quartz monzonite plugs to small intermineral dikes.

INTERmineral Dikes

Two varieties of intermineral dikes, aplite and intermineral porphyry, both of which are leucocratic, crop out in the general area of the East stock (unit Kap, pl. 2). Where aplite is mapped approximately $300 \mathrm{~m}$ west of the Dipper shaft, the unit includes some intermineral porphyry dikes that are a medium-grained, leucocratic porphyry that may be a coarser grained equivalent of aplite. At this locality, intermineral porphyry dikes are cut by few quartz veins, and the intermineral porphyry dikes strike parallel to aplite dikes in surface exposures of the East stock (pl. 2). Both aplite and intermineral porphyry are conspicuous, owing to their fine to medium grain size and weak to absent quartz veining in contrast to their more strongly quartz veined, porphyritic host rocks. Truncated veins are common in both drill core and outcrop. Aplite dikes strike northwesterly across the East stock and northerly across the West stock (pl. 2). The aplite is composed of rare quartz eyes and evenly disseminated patches of sericite (fig. $57 C$ ) replacing biotite in a fine-grained, sucrosic quartz-feldspar groundmass (tables 13, 14). The actual contents of quartz and K-feldspar phenocrysts are variable and misleading, for many of these crystals are brecciated fragments floating in an aplite matrix. Most, if not all, of the dissemi- 
TABLE 15.-Modal data on typical samples of postmineral rock units near the Buckingham stockwork molybdenum system

[All values in volume percent. Data obtained by point-counting stained rock slabs. tr, trace; -, not detected]

\begin{tabular}{|c|c|c|c|c|c|c|}
\hline Analysis & 1 & 2 & 3 & 4 & 5 & 6 \\
\hline Drill hole & B-27 & B-39 & B-28 & B-25 & $\mathrm{B}-13$ & B-24 \\
\hline Depth & $506^{\prime}$ & $545.5^{\prime}$ & $1322^{\prime}$ & $454^{\prime}$ & $2301^{\prime}$ & $1418^{\prime}$ \\
\hline Quartz (pheno) & 12.0 & -- & 1.0 & 4.0 & 10.0 & 9.0 \\
\hline K-spar (pheno) & 11. & -- & -- & --- & 6 . & --- \\
\hline Plagioclase & 15. & 1.0 & 4. & 6. & 32 . & 32 . \\
\hline Biotite & 1. & -- & $\operatorname{tr}$ & 2. & 6. & 10. \\
\hline Hornblende & --- & 18. & 11. & 12. & --- & --- \\
\hline Pyrite & 1. & 3. & 2. & --- & 1. & 1. \\
\hline Groundmass & 60. & 79. & 82. & 77. & 45. & 49. \\
\hline Tota1 & $\overline{100}$. & 101. & $\overline{100}$. & $\overline{101 .}$ & 100 . & 101. \\
\hline Points counted & 1024 & 1033 & 1011 & 1012 & 1030 & 1015 \\
\hline
\end{tabular}

1. Rhyolite porphyry.

2. Hornblende porphyry.

3. Biotite-feldspar porphyry.

4. Granodiorite porphyry.

5. Quartz 1atite porphyry.

6. Do.

nated molybdenite is derived from wallrock assimilation. Rare quartz-molybdenite veins, however, suggest that the rock is, indeed, intermineral. Aplite stoped and consumed relatively large volumes of hornfels and earlier, mineralized porphyries during emplacement. Although most intercepts of aplite are actually composed of intrusion breccia, locally the rock is free of xenoliths and homogeneous. Although intermineral aplite and aplite intrusion breccia affect the continuity of earlier formed ore shells, not all of this unit represents waste rock; significant amounts of the breccia carry oregrade material because of molybdenite contained in xenoliths.

\section{POSTMINERAL INTRUSIONS}

A series of calc-alkaline intrusions were emplaced near the deposit during late Eocene or early Oligocene time. These rocks, which cut and dilute the Buckingham deposit, produced the base- and precious-metal vein systems that contribute byproduct metal values to the Buckingham mineral inventory. Locally, the margins of these late Eocene or early Oligocene intrusions assimilated small amounts of wallrock and, as a result, contain anomalous molybdenum. The late intrusions generally take the form of dikes dipping moderately west. Rhyolite porphyry, granodiorite porphyry, pebble dikes, and basalt, however, are exceptions. Rhyolite porphyry forms two pluglike masses; the latter three intrusion types form dikes of apparently different or unknown orientation. Field evidence suggests that rhyolite porphyry may be the oldest postmolybdenum unit; basalt appears to be the youngest. Modes obtained by point counting stained slabs of typical postmineral rock samples are listed in table 15; chemical analyses and mineral norms are listed in table 16.

\section{RHYOLITE PORPHYRY}

Rhyolite porphyry forms two pluglike masses which are about $430 \mathrm{~m}$ southwest of the Buckingham deposit boundary (unit Trp, pl. 2). On the surface, the unit contains relatively small quartz, $\mathrm{K}$-feldspar, and plagioclase phenocrysts in an aphanitic quartz and K-feldspar groundmass. With depth, however, the rock becomes coarser grained, consisting of 10 to 14 volume percent quartz phenocrysts $(0.5-3 \mathrm{~mm}), 9$ to 12 volume percent $\mathrm{K}$ feldspar phenocrysts $(1-5 \mathrm{~mm}), 13$ to 15 volume percent plagioclase $(0.5-2 \mathrm{~mm})$, and 1 to 2 volume percent biotite $(0.5-1 \mathrm{~mm})$ in an aphanitic groundmass (fig. 58A). At a depth of about $360 \mathrm{~m}$, the rock might be more appropriately termed a "granite." Crenulate quartz layers appear at the margins of the intrusion against metasedimentary host rocks of the Harmony Formation. On the east edge of one plug, crenulate layers are cut by quartz veins that are probably related to the Little Giant vein system. Additional occurrences of quartz porphyries found in drill core from the Buckingham molybdenum deposit resemble the post-molybdenummineralization rhyolite porphyry of the Little Giant Mine area. These quartz por-phyries typically contain feldspar phenocrysts, are volumetrically insignificant in the molybdenum system, and are always postmineral. 
TABLE 16.-Analytical data on fresh or weakly altered samples of postmineral intrusive rocks of the Buckingham stockwork molybdenum system

[Chemical analyses and Cross, Iddings, Pirsson, and Washington (CIPW) norms in weight percent. n.d., not determined; -, not detected]

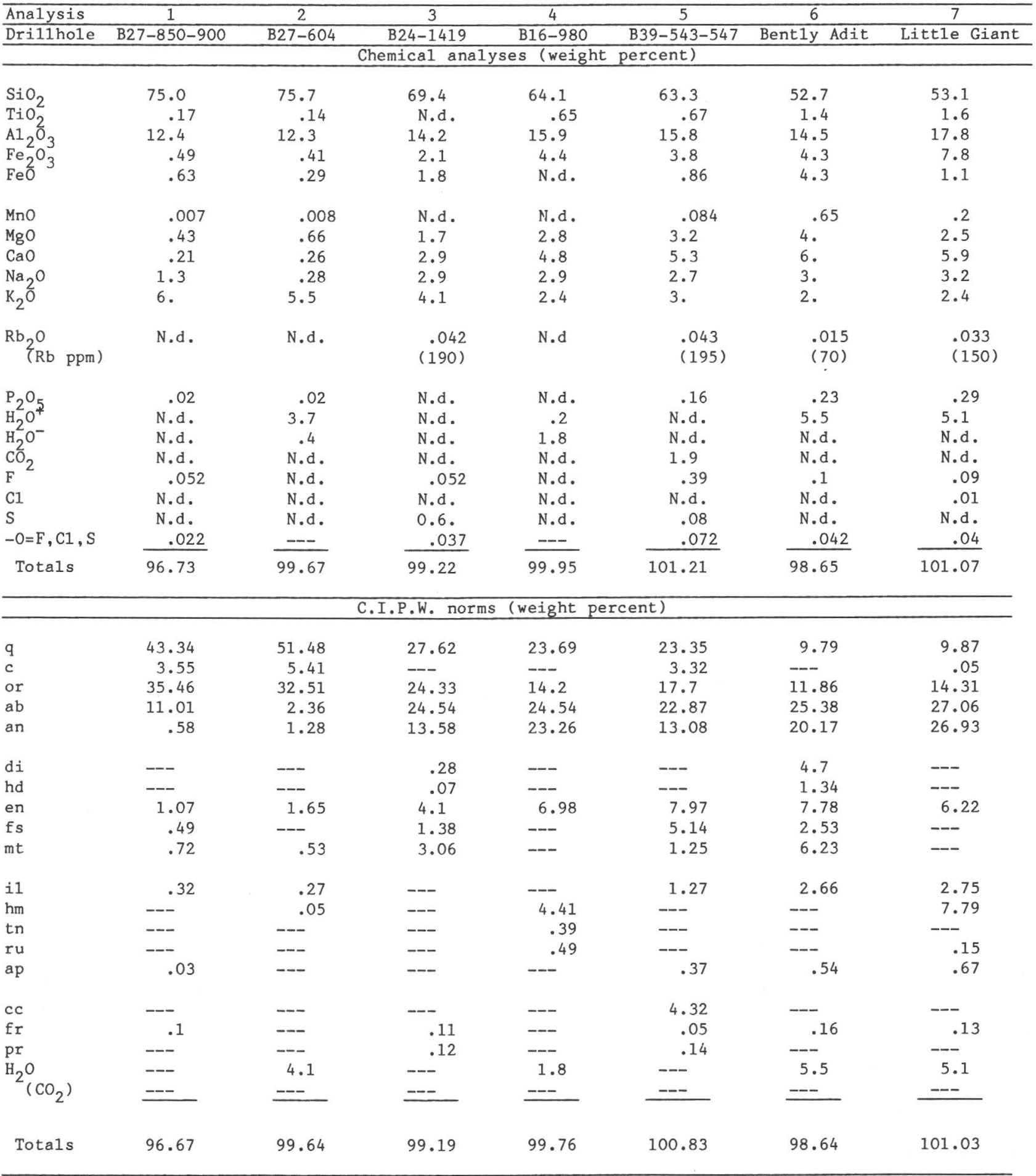

1. Rhyolite porphyry. Composite of $15.24-\mathrm{m}$ dri11-core interval.

2. Do.

3. Quartz latite porphyry.

4. Quartz-biotite-feldspar porphyry.

5. Hornblende porphyry.

6. Basalt.

7. Do. 


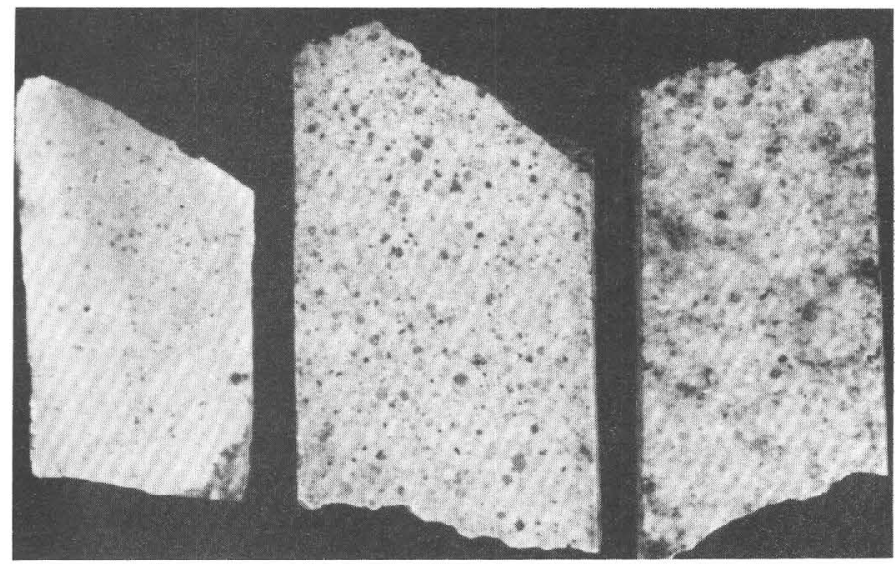

$\boldsymbol{A}$

2 CENTIMETERS

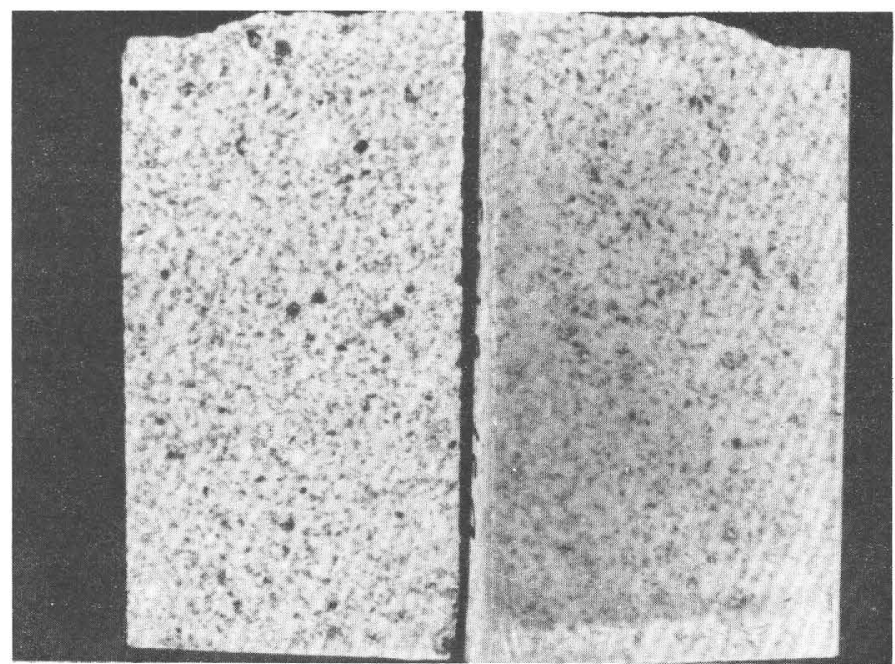

$B$

2 CENTIMETERS

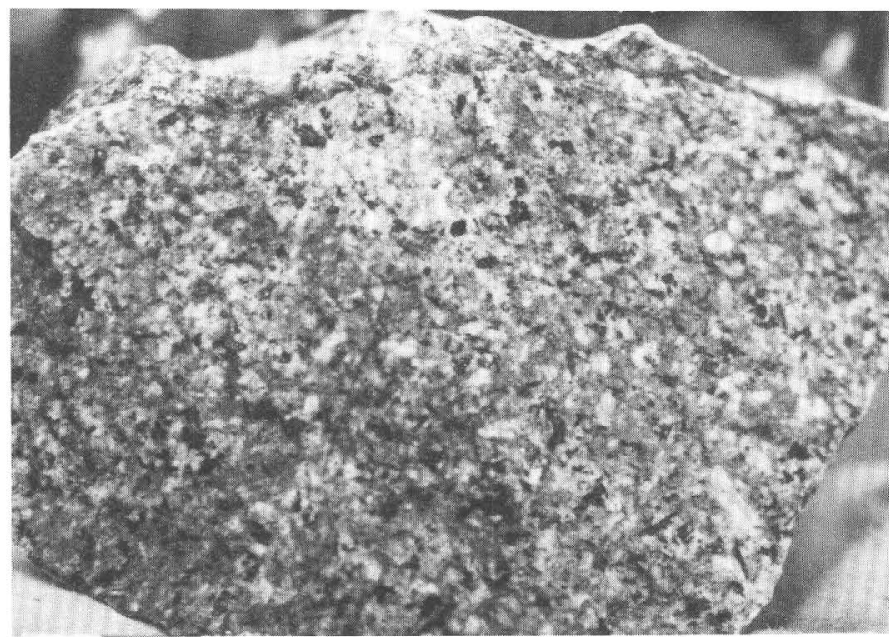

C

0

2 CENTIMETERS

Figure 58.-Typical specimens of postmineral Tertiary intrusive rocks. $A$, Rhyolite porphyry (Trp). Note variation in grain size. $B$, Hornblende porphyry (Thp). $C$, Biotite-feldspar porphyry (Tbfp). $D$, Quartz-biotite-feldspar porphyry (Tqbfp). $E$, Quartz latite porphyry (Tqlp), both stained (above) and unstained

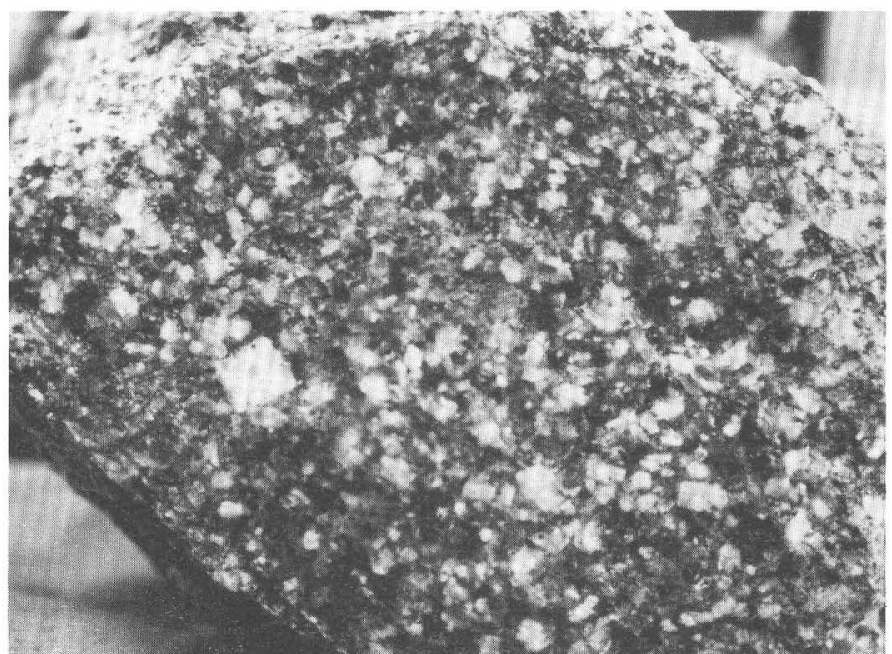

D

0

2 CENTIMETERS

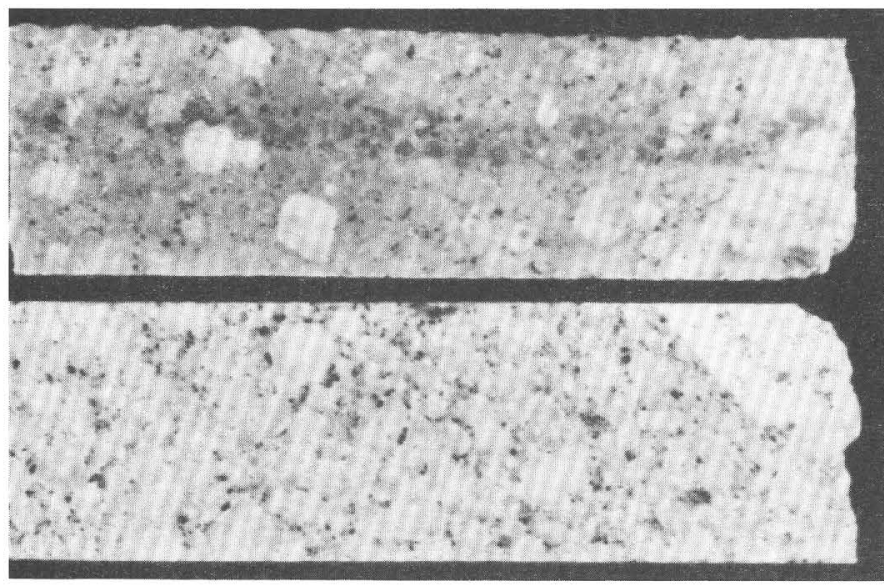

$\boldsymbol{E}$

0

2 CENTIMETERS

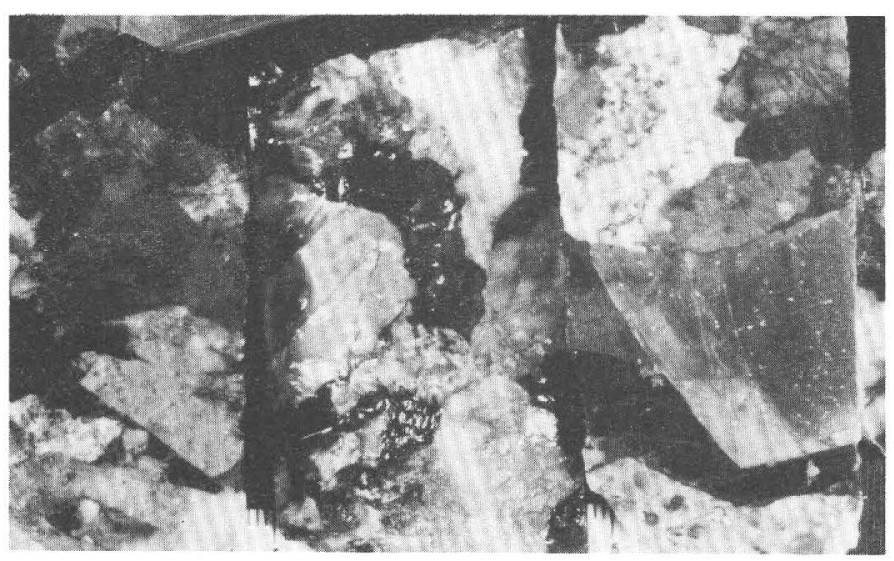

$\boldsymbol{F}$

2 CENTIMETERS

(below). $F$, Pebble dike (Tpb) containing rounded fragments of porphyry, hornfels of the Upper Cambrian Harmony Formation, and chert of the Devonian Scott Canyon Formation. See plate 2 for unit symbols and names. 
Porphyries of INTERMEdiate CoMposition

Porphyries of intermediate composition are dikelike in form and apparently make up a continuum grading from older, more mafic rocks to younger, felsic varieties. Few crosscutting relations have been observed, and the hypothesis that such a continuum exists is based on an assumption that all were derived from the same differentiating magma. Their similar attitudes imply emplacement under the same stress regime, further suggesting that they intruded over a relatively short timespan. Commonly, these late-stage porphyries contain weakly disseminated basemetal sulfides. Although these dikes clearly cut and dilute molybdenum and associated coppertungsten-silver mineralization (except for assimilated material at dike margins), they do contain some silver and are cut by rare quartz veins. Furthermore, base- and precious-metal vein systems, the sites of historical mining operations at Buckingham Camp, occupy major postmolybdenum age structures with attitudes similar to those of nearby late-stage dikes. The series of intermediate porphyries, and quartz latite porphyry in particular, may have caused some of the late vein mineralization superimposed upon the molybdenum system. The porphyries of intermediate composition include hornblende porphyry, biotite-feldspar porphyry, quartz-biotite-feldspar porphyry, granodiorite porphyry, and quartz latite porphyry.

Dikes of hornblende porphyry (unit Thp, pl. 2), generally 1 to $3 \mathrm{~m}$ thick, crop out near the Bentley and Gold Top Mines and west of the West stock. This rock is fairly distinctive, consisting of about 20 volume percent hornblende phenocrysts (1-6 $\mathrm{mm}$ ) and less than 1 volume percent plagioclase phenocrysts (1-3 mm) in a greenish-gray aphanitic groundmass (fig. 58B). Hornblende porphyry dikes can be correlated between drill holes and the surface in both areas.

Biotite-feldspar porphyry (unit Tbfp, pl. 2) and quartz-biotite-feldspar porphyry (Tqbfp) were originally distinguished on the basis of surface outcrops. Biotite-feldspar porphyry and quartzbiotite-feldspar porphyry dikes and a composite dike with biotite-feldspar porphyry lying immediately above quartz-biotite-feldspar porphyry crop out west of the West stock (pl. 2). Both units are distinguished from hornblende porphyry by the presence of quartz phenocrysts (figs. $58 C, 58 D$ ). Both have a grayish-green to brown aphanitic groundmass. Small, texturally similar hornblende (9-12 volume percent, 1-5 $\mathrm{mm}$ )-plagioclase (4-6 volume percent, 1-4 mm)-quartz (1-2 volume percent, 1-7 mm)-biotite (trace, 0.5-1 $\mathrm{mm}$ )-bearing dikes, which are fairly common at depth in the deposit, may, in fact, be quartz-biotite-feldspar porphyry. If so, then quartz-biotite-feldspar porphyry is the dominant variety of the two.

Short intercepts of granodiorite porphyry are present in several drill holes. At present, because we are unable to reliably correlate these intercepts, we do not know the orientation of granodiorite porphyry dikes and (or) sills. The unit is composed of 3 to 5 percent quartz phenocrysts $(2-13 \mathrm{~mm}), 5$ to 8 percent plagioclase phenocrysts $(0.5-3 \mathrm{~mm}), 10$ to 12 percent hornblende (1-3 $\mathrm{mm})$, and 1 to 2 percent biotite $(0.5-4 \mathrm{~mm})$ in a black aphanitic groundmass.

Quartz latite porphyry is by far the most volumetrically significant dike rock that is postmolybdenum mineralization in age (unit Tqlp, pl. 2). Present in west-dipping swarms, individual dikes or sheets range from 1 to $100 \mathrm{~m}$ in thickness. Quartz latite porphyry dikes are present mainly in the East stock part of the deposit, where they significantly dilute molybdenum mineralization. In the West stock, the dikes are volumetrically much less important; several dikes appear beneath Buckingham Camp at depths greater than $650 \mathrm{~m}$, and a single dike is present at relatively shallow depths. Quartz latite porphyry is composed of approximately 31 to 33 volume percent plagioclase (1-12 $\mathrm{mm}), 8$ to 11 volume percent quartz $(2-13 \mathrm{~mm}), 5$ to 10 volume percent biotite $(0.5-3 \mathrm{~mm})$, and generally large $\mathrm{K}$-feldspar phenocrysts (from $1 \mathrm{~cm}$ to several centimeters in diameter), set in an aphanitic graygreen groundmass (fig. $58 E$ ). Rock texture can be somewhat variable within a given dike. Quartz and plagioclase phenocrysts tend to decrease in size, and $\mathrm{K}$-feldspar phenocrysts tend to decrease in abundance, toward the margins of dikes. Quartz latite porphyry dikes can be irregular in strike and dip; however, the dike swarm appears to strike about $\mathrm{N}$. $10^{\circ} \mathrm{E}$. and $\operatorname{dip} 30^{\circ}-50^{\circ} \mathrm{W}$. Local changes in dip are fairly common, and some dikes branch into several smaller dikes near the surface. Quartz latite porphyry in places appears to have intruded preexisting fault zones. Both upper and lower dike contacts commonly are faulted as well; the faulting suggests reactivation of the older structures. Quartz latite porphyry locally remobilized molybdenite during emplacement; in these zones, characteristically on the margins of dikes, molybdenite is present in included fragments. Rarely, molybdenite is found in thick quartz veins that commonly show open cavities; this fact suggests that some molybdenum ac- 
companied quartz latite porphyry. Typically, however, the unit is barren of molybdenum. Quartz latite porphyry is closely associated with lead-zincsilver mineralization in the Little Giant and Gold Top Mines; dike margins and nearby host rocks are commonly anomalous in these elements; this fact suggests that there may be a genetic link between quartz latite porphyry and base- and precious-metal vein systems.

\section{Pebble Dikes}

Intrusive breccia dikes represent the youngest stage of igneous activity associated with late-stage intermediate porphyries. In surface exposures (unit $\mathrm{Tpb}, \mathrm{pl}$. 2), pebble dikes predominantly are present at the east end of Long Ridge and in the area immediate to the Copper Queen Mine. Little is known about overall distribution of pebble dikes, but the two longest outcrops near the East stock are spatially associated with the western exposed limit of large quartz latite porphyry dikes (Tqlp, pl. 2). At both places, pebble dikes dip more steeply than quartz latite porphyry. Crystallization of the porphyry dikes may have caused volatile pressure to build. Subsequent fracturing of the wallrock and the explosive release of fluids may have caused the formation of the pebble dikes. Although pebble dikes commonly contain fragments of quartz latite porphyry, as well as mineralized and quartz-veined fragments of stock and hornfels, they also characteristically contain fragments of black chert that appear to be from the Scott Canyon Formation (fig. $58 F$ ). Thus, the source of the pebble dikes and, possibly, of the quartz latite porphyry probably underlies the Dewitt thrust.

\section{BASALT}

Basalt dikes are present in and above the adit at the Bentley Mine and in the area of the Little Giant Mine (unit Tb, pl. 2). In addition, basalt appears as float along a road about $250 \mathrm{~m}$ west of the Miss Nevada Mine. The unit, which is black and aphanitic, locally contains vesicles, some of which contain euhedral diopside. At the Bentley adit the basalt dike is pyritized. A chemical analysis of a sample collected from the Little Giant Mine is listed in table 16. Calculation of the mineral norms from these data indicates that the rock is a tholeiite, according to the classification of Yoder and Tilley (1962).

\section{STRUCTURE}

Structural relations affecting the geometry of ore zones at Buckingham are dominated by (1) younger, N. $25^{\circ}$ W.-striking, northeast-dipping, listric fault systems, and (2) older, moderately west dipping vein-fault systems with a possible reverse movement. Structural features of lesser significance relative to the distribution of molybdenum include "shatter zones" of intense fracturing, normal faults with minor displacement, and sedimentary bedding.

The most significant structures at Buckingham are listric normal faults that strike northnorthwesterly, dip easterly, and are characterized by significant gouge and breccia zones separated by more competent rock (fig. 59A). The two major structures of this type are the Buckingham and Second fault zones (pl. 2) that divide the intrusive center and mineral deposit into three major sectors to the west of Long Canyon (fig. 51). Another structure of similar attitude is inferred to underlie Long Canyon; displacement on this fault zone has left the molybdenum deposit largely unaffected. A fourth structure called the Contention II fault may also belong to this generation of postmineral faulting; its projected trace intersects the crest of Long Ridge at shallow depth and may crop out on its south flank. The amount of rotation on listric faults is unknown at present.

The Buckingham fault zone is 100 to $225 \mathrm{~m}$ thick and is estimated to have had $520 \mathrm{~m}$ of dipslip movement and $175 \mathrm{~m}$ of right-lateral, strikeslip displacement. The dip-slip movement was estimated by measuring the fault displacement of a white quartzite marker horizon that was encountered in drill holes (fig. 60). The strike-slip component was determined by restoration of ore zones in plan view. Displacements of this magnitude can be appreciated in the field by noting the present-day relation of the Klondyke vein to the Little Giant vein (fig. 59B); the Buckingham fault displaced the Klondyke vein from its downdip extension on the Little Giant vein.

The Second fault is a separate structure in the hanging wall of the Buckingham fault zone, although brecciated zones related to the Buckingham and Second faults appear to merge in places. Offset on the Second fault is estimated at $295 \mathrm{~m}$ downdip and 110 $\mathrm{m}$ along strike in a right-lateral sense. These estimates are based on combined restorations of ore zones and distinctive porphyry units.

The Contention II fault underlies Long Ridge at shallow depth and apparently dips gently 
northward; its attitude is similar to and, possibly, on strike with that of the Contention fault, which extends eastward from Vail Ridge into the Copper Basin open pit (pl. 2). Movement on the Contention II fault is postmineral; this inference explains near-surface drill-hole intercepts of large $\mathrm{K}$ feldspar porphyry and low-grade hornfels directly over ore (fig. 56). Movement is interpreted to have been easterly, although more data are needed to document fully the amount of displacement. If the structure does connect with the Contention fault mapped on Vail Ridge (pl. 1), the timing of initial movement of the Contention II fault may be nearly equivalent to the age of emplacement of large $\mathrm{K}$ feldspar porphyry. This deduction is based on relations in the area of the Copper Basin Mine (see subsection above entitled "Structural Geology").

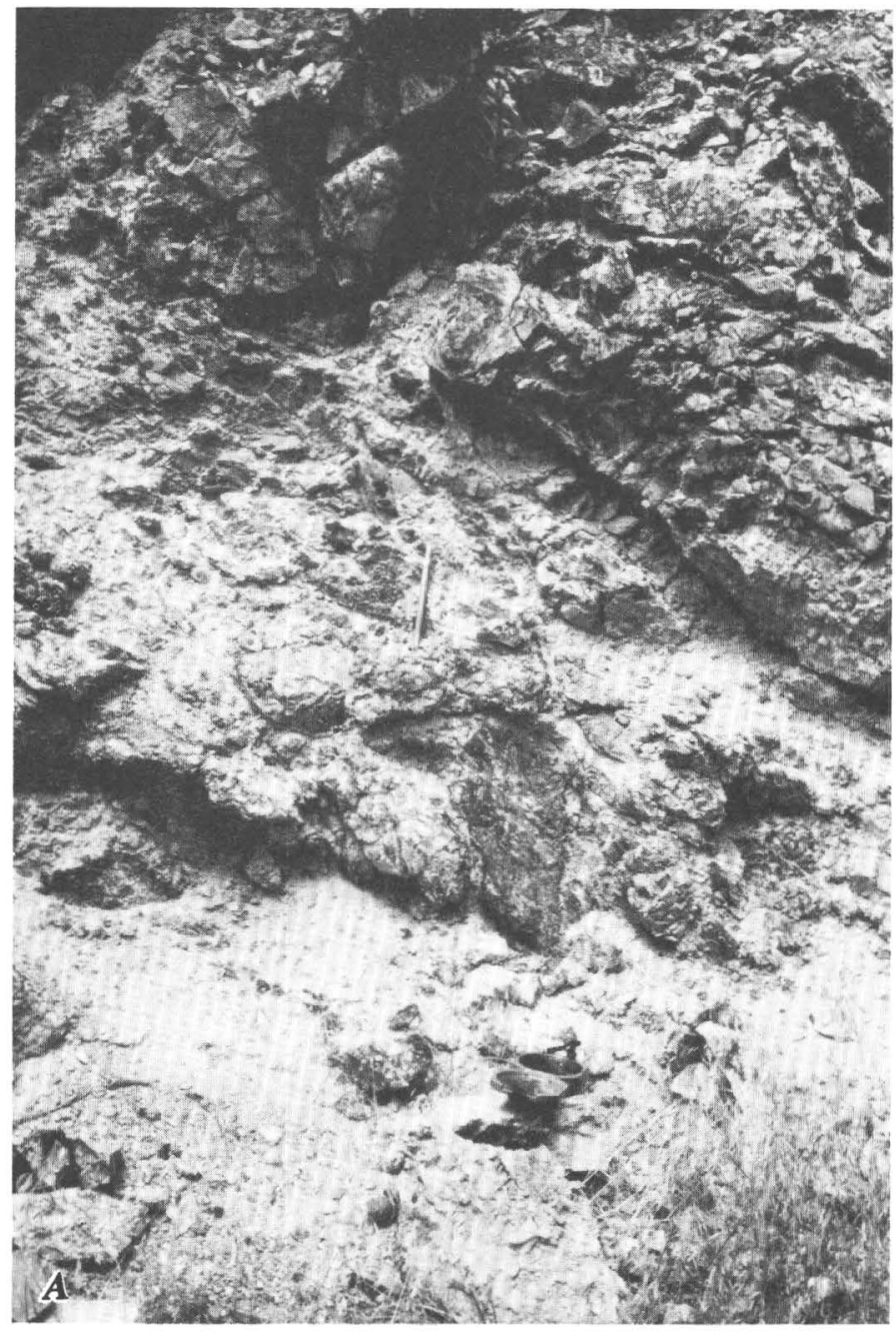

Figure 59.- Some structural features at Buckingham. $A$, Significant gangue and breccia zone separated by competent rock that characterizes listric normal faults, most significant postmineral structures at Buckingham. Pocket compass for scale in lower center. $B$, Inferred displacement of Little Giant vein along
Other relations also suggest that some movement on major postmineral structures commenced near the time of emplacement of large K-feldspar porphyry or at least before the intrusion of late-stage dikes during Oligocene time (approx $35 \mathrm{Ma}$; see above). Inferred displacement of large K-feldspar porphyry by the Buckingham and Second fault zones is less than displacement of ore zones (fig. 61); similarly, the amount of displacement of late-stage dikes is less than the offset on ore zones (fig. 51). These discrepancies suggest that movement on the Buckingham and Second fault zones and, possibly, on the Contention II fault occurred in several stages; earlier movements may have occurred after main-stage molybdenite mineralization, and later displacements occurred after the emplacement of large K-feldspar porphyry and late-stage dikes.
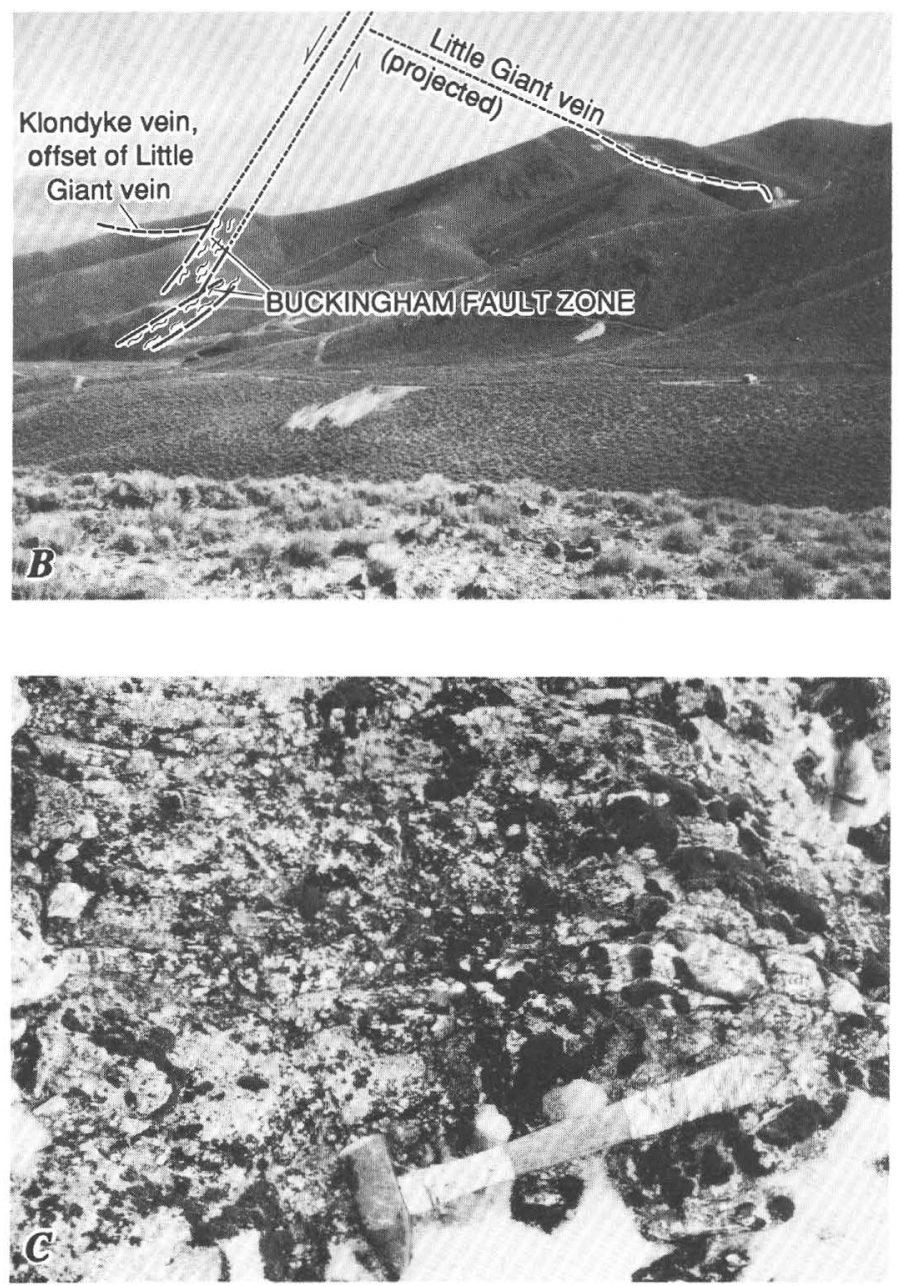

Buckingham fault. Faults dashed where approimately located; dotted where projected; arrows show relative direction of movement. Note car in right-central part of view for scale. $C$, Zones of "shattering" in West stock. 
West-dipping echelon fault zones host vein mineralization throughout the Buckingham area, and the fault zones are the sites of many of the old mine workings in the western, footwall part of the deposit. There, workings were developed on veinfault systems at the Irish Rose, Little Giant, Midland-Hardy, Northland, Fairview, and Miss Nevada Mines; all these veins dip generally
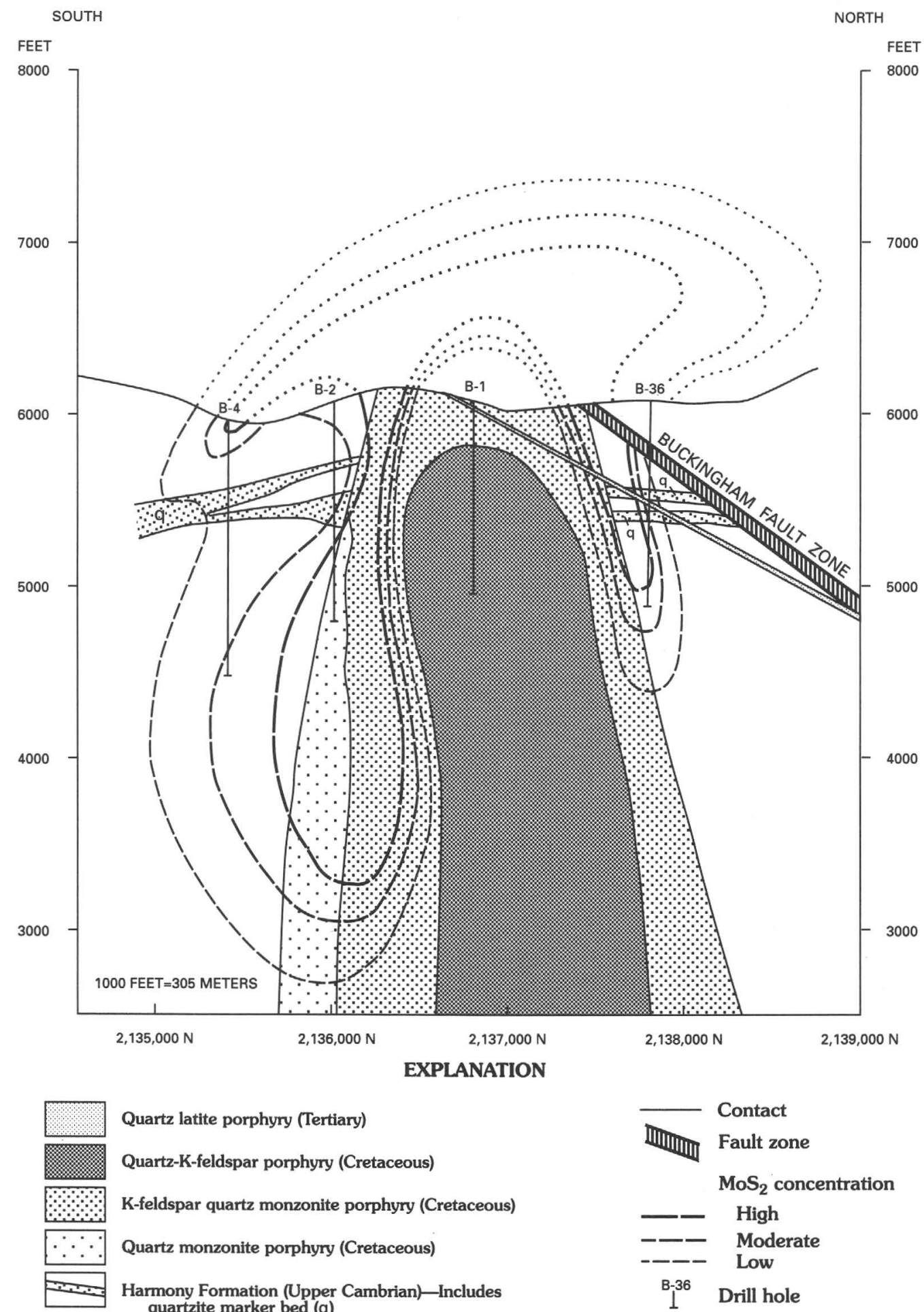

Quartz latite porphyry (Tertiary)

Quartz-K-feldspar porphyry (Cretaceous)

K-feldspar quartz monzonite porphyry (Cretaceous)

Quartz monzonite porphyry (Cretaceous)

Harmony Formation (Upper Cambrian)-Includes quartzite marker bed $(q)$

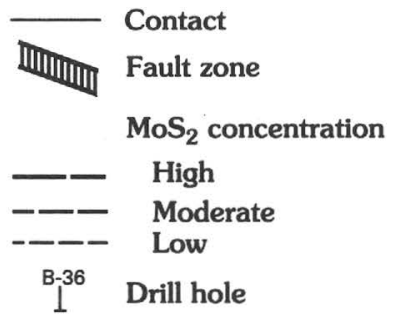

FIGURE 60.-Schematic north-south cross section through West stock, showing relations of conspicuous, white quartzite marker beds to stock and to projected trace of Buckingham fault zone. Cross section'along section line 387,600 E. 
$117^{\circ} 3^{\prime} 45^{\prime \prime}$

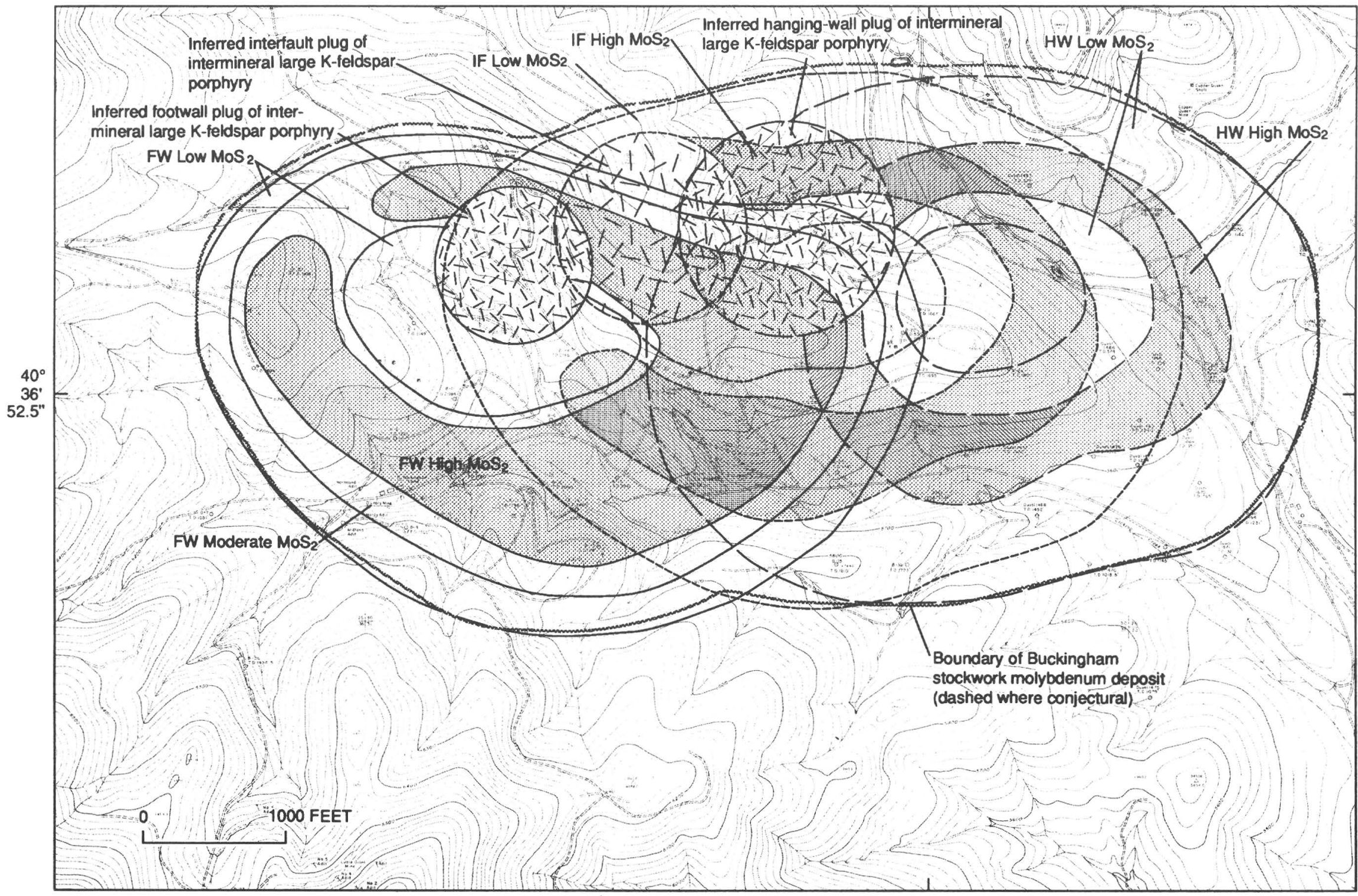

FIGURE 61.-Schematic projection to surface of distribution of molybdenite concentrations in footwall (FW), interfault (IF), and hanging-wall (HW) ore zones, and inferred locus of intermineral large K-feldspar porphyry. Base from Aerial Mapping Co., Boise, Idaho, for Climax Molybdenum Co., 1973. Contour interval, $20 \mathrm{ft}$. 
westward. In the interfault and hanging-wall parts of the deposit, similar veins are found at the Bentley and Gold Top Mines and at the Clyde 2 fault; all have a westerly dip, although there appears to be a systematic change in dip direction from southwesterly at the Little Giant to northwesterly at the Bentley Mine (pl. 2). It has not been determined whether this progressive change in dip direction represents a fracture pattern concentric to the West stock or whether the vein-fault systems were rotated by the younger listric faults.

Movement on these west-dipping zones is poorly defined, although evidence for local reverse movement has been noted at three localities. One strand of the Little Giant fault zone cuts postmineral rhyolite porphyry; the resulting outcrop pattern suggests that the main plug of rhyolite may have been shifted slightly eastward over its root (pl. 2). A low-angle, west-dipping structure on Long Ridge appears to have displaced the East stock and adjacent rocks eastward to overlie a late-stage dike, although some of this displacement could also have occurred along the Contention II fault. Finally, large $\mathrm{K}$-feldspar porphyry dikes on the ridge east of Long Canyon appear to have been offset with reverse movement on two structures. Repetition of rock types adjacent to some fault zones intersected in drill core also implies local reverse movement along structures.

Several semicontinuous zones of "shattering" were mapped across the West stock on the west side of the Buckingham fault zone (pl. 2). These zones are characterized by subparallel planes of intense fracturing spaced at millimeter-scale intervals over zones several meters wide (fig. 59C); quartz veins are broken but not offset along these planes. One explanation is that the feature is extensional, a physical response of the rock to pressure release after the hanging-wall block of the Buckingham fault was downdropped to the east (Stanley Miller and Daniel Stewart, oral communs., 1980).

Normal faults with minor displacement are recognized by offsets on late-stage dikes, changes in the intensity of quartz and pyrite veining, and by juxtaposition of different stratigraphic units (pl. 2). Although such structures are inferred to exist on the basis of unequivocal geologic evidence, and although the lithologic offsets commonly have a topographic expression, extensive alluvial cover at Buckingham precludes a systematic study of these faults and the timing of movement along them.

Attitudes on bedding in the Harmony Formation indicate either that the deposit was emplaced in a doubly plunging anticline or that host rocks to the system were domed during emplacement of the stock (pl. 2). Regional evidence apparently supports the former hypothesis, as the anticline extends north and south of the Buckingham area for several kilometers (Roberts, 1964; Theodore and Roberts, 1971).

\section{ALTERATION}

Alteration can be separated generally into four sequential types. In order of occurrence, they are (1) contact metamorphism of host sedimentary rocks by emplacement of intrusions associated with the Buckingham system, (2) hypogene alteration associated with metallization, (3) fault-related clay and sericite, and (4) supergene alteration.

\section{Contact Metamorphism}

Development of a metamorphic aureole, though not strictly a hydrothermal effect, was the initial mineralogic and textural response of the country rocks to emplacement of the intrusions. The outermost extent of recrystallized sedimentary rocks surrounding the igneous center is presently ill defined because textures in surface rocks are generally masked by strong weathering of biotite, muscovite, and matrix material and because drilling on the periphery of the aureole is sparse. There is a progressive inward change in sedimentary grain-boundary character. Approximately $520 \mathrm{~m}$ west of the West stock, recrystallization is weak. Somewhat rounded quartz grains with sharply defined edges and ragged biotite probably represent primary, detrital textures. The original poor sorting of the sedimentary rocks is apparent as large grains are cemented by a fine-grained, clasticappearing matrix. Close to the intrusive center, however, the rocks are equigranular. Quartz and biotite show no evidence of physical weathering; rather, they form an interlocking mosaic suggestive of recrystallization. Sedimentary units that were slightly more magnesian than the typical Harmony Formation and possibly slightly calcareous show fine-grained, finely dispersed tremolite-actinolite, epidote, and locally diopside. That these are metamorphic rather than hydrothermal effects is demonstrated by the fact that these textures and mineralogic assemblages are pervasively distributed rather than fracture or vein controlled. Furthermore, the changes are isochemical or nearly isochemical. By contrast, hydrothermal assemblages overprint metamorphic assemblages, are clearly fracture controlled, and generally involve 
significant addition or subtraction of components. Metamorphic grade can be difficult to determine in quartzofeldspathic sedimentary rocks. However, the presence of tremolite-actinolite and epidote in magnesium-bearing units suggests that metamorphism reached albite-epidote hornfels facies. The occasional occurrence of diopside may indicate that hornblende-hornfels facies temperatures were reached locally.

\section{Hypogene Alteration}

Hydrothermal alteration, which accompanied molybdenum mineralization, is characterized by crosscutting generations of vein- and fracture-controlled silicic, potassic, propylitic, and intermediate argillic assemblages. Local pervasive alteration is probably a result of coalescing vein envelopes. Classical, porphyry-type alteration zoning is obscured both by multiple igneous and associated hydrothermal events and by variable response of different original sedimentary lithologies to hydrothermal fluids changing in chemistry with time. Alteration effects in igneous and sedimentary rocks are therefore described separately.

In sedimentary rocks, vein and vein-envelope mineralogies are somewhat variable, and there is good evidence that they, like the contactmetamorphic mineralogies, are influenced by the original bulk chemistry of the rock. Although there are changes in alteration style and intensity with distance from intrusive rocks, discrete zones (that is, propylitic, intermediate argillic, potassic) are not apparent. Two assemblages termed "green and brown hornfels" dominate.

Altered, metamorphic, tremolite-bearing "green" hornfels commonly shows hydrothermal tremoliteactinolite and epidote and trace amounts of apatite, fluorite, and sphene (D. Kamilli, unpub. data, 1977); this assemblage is present in or is associated with quartz veins. K-feldspar and biotite appear in or as veins only close to igneous rocks; distinct brown biotite vein envelopes are common as much as a few hundred meters from the stock contact. Typically there is evidence of retrogression of hydrothermal minerals; chlorite-calcite assemblages replace tremolite-actinolite-epidote assemblages, and vein biotite commonly shows bleaching. Sulfides are generally abundant in these rocks; typically, 4 to 8 weight percent $\mathrm{FeS}_{2}$ equivalent is present as disseminated and less common vein pyrrhotite. In addition, veins are generally sulfide rich and quartz poor.
Altered, metamorphic biotite-bearing "brown" hornfels typically shows greenish-colored quartzsericite envelopes on veins; envelopes locally coalesce adjacent to igneous rocks but are narrow at distance from the contact. Brown biotite halos are rarely present, and they may imply that a biotitestable hydrothermal regime predated intermediate argillic and minor phyllic alteration. As in green hornfels, K-feldspar and biotite appear in veins proximal to the intrusive center, where pervasive $\mathrm{K}$-feldspar flooding is also apparent (R.J. Kamilli, unpub. data, 1977). The iron sulfide is generally present as pyrite, in contents of 1 to 3 volume percent. Veins are generally quartz rich and sulfide poor.

In addition to original bulk chemistry, grain size seems to have influenced the response of rocks to hydrothermal fluids. Both macroscopic and microscopic evidence indicates that coarse-grained units were more susceptible to alteration than fine-grained equivalents, probably because of enhanced permeability (R.J. Kamilli, unpub. data, 1977; T.A. Loucks, unpub. data, 1981).

In premineral/synmineral granitic rocks, potassic and intermediate argillic hydrothermalalteration assemblages are dominant. Petrographic studies of alteration assemblages in the West stock indicate several consistent patterns. A potassic zone is present at the core of the quartz monzonite porphyry border phase below about $4,900 \mathrm{ft}$ elevation (fig. 62). The potassic zone is characterized by $\mathrm{K}$-feldspar flooding in the groundmass, secondary biotite, and, where alteration is most intense, Kfeldspar replacing plagioclase phenocrysts. The potassic zone gives way laterally and upward to a zone of strong intermediate argillic alteration. Plagioclase is completely replaced by fine-grained white mica and clay(s) that give phenocrysts a green color in hand specimen. Both groundmass $\mathrm{K}$ feldspar and phenocryst K-feldspar are relatively unaltered; they have only a light dusting of sericite. Quartz flooding is nowhere apparent in the rocks; silica has probably been removed and mobilized into quartz veins. Point counts of altered rock among quartz veins indicate that it is now quartz deficient relative to fresh quartz monzonite porphyry. Intermediate argillic alteration decreases in intensity outward and upward in the intrusion, where remnants of fresh plagioclase remain.

The presence or absence of secondary biotite and retrograde epidote after plagioclase earmark zones of potassic, strong intermediate argillic, and weak intermediate argillic alteration fairly well. Secondary biotite is present in the potassic zone and locally where 
large volumes of the Harmony Formation have been stoped and partially assimilated. Epidote replaces plagioclase in the potassic zone and in the peripheral weaker parts of the intermediate argillic zone. Between these two zones, plagioclase is completely replaced by white micas and clay(s), and retrograde epidote is conspicuously absent.

High-silica alteration, in the form of coalescing silicified vein envelopes, is present locally and is best developed where associated with unidirectional solidification textures at the cupolas of various intrusive phases. Where most intense, quartz makes up more than $9 \theta$ volume percent of the rock. Drill-hole density is insufficient to define the geom-

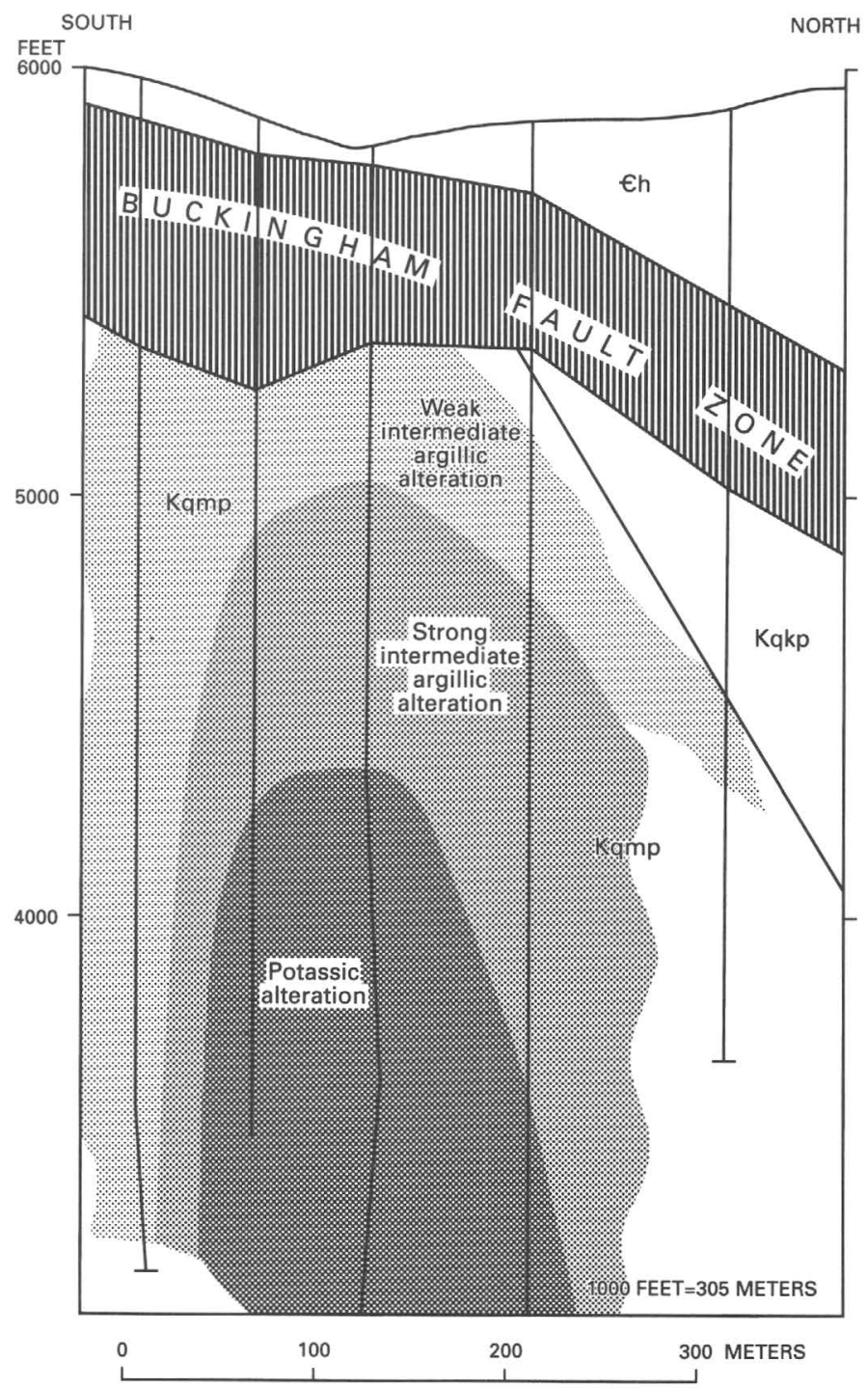

FIgURE 62.-Distribution of alteration within West stock. Kqmp, Cretaceous quartz monzonite porphyry; Kqkp, Cretaceous quartz-K-feldspar porphyry; €h, Upper Cambrian Harmony Formation. Vertical lines are drill holes. etry or thickness of high-silica zones; however, intercepts available to 1987 suggest that a zone of +90 weight percent $\mathrm{SiO}_{2}$ may be 10 to $25 \mathrm{~m}$ thick in footwall parts of the deposit. Molybdenum mineralization is generally weak in these areas.

Limited petrographic data from other major phases in the Buckingham intrusive complex suggest that potassic- and intermediate argillicalteration patterns repeat with each succeeding phase. In the West stock (fig. 62), alteration patterns related to quartz-K-feldspar porphyry are similar to those of quartz monzonite porphyry and are superimposed upon the border phase. Alteration in intermineral units is propylitic (chloriteepidote-calcite) or, less commonly, intermediate argillic or weak potassic. Postmineral units are fresh or propylitically altered.

Chemical analyses of altered intrusive rocks show that, in general, increasing alteration is accompanied by addition of $\mathrm{SiO}_{2}$ and $\mathrm{K}_{2} \mathrm{O}$ and by depletion of $\mathrm{Al}_{2} \mathrm{O}_{3}, \mathrm{Fe}_{2} \mathrm{O}_{3}, \mathrm{MgO}, \mathrm{CaO}$, and $\mathrm{Na}_{2} \mathrm{O}$ (table 17).

\section{Fault-Related and Supergene Alteration}

Postmineral argillic alteration accompanied late-stage faulting and more recent weathering, respectively. Locally strong white micamontmorillonite-kaolinite assemblages were developed along structures. Near-surface overprinting of all rocks and alteration types by supergene claywhite mica is widespread within the limit of pyritization. The intensity and depth of supergene alteration are related to original pyrite content and topography, respectively. Oxidation penetrated more deeply along ridge crests, leading to thicker zones of supergene alteration; supergene effects permeate more deeply in and adjacent to structures.

\section{MINERALIZATION}

Seven hypogene molybdenum mineralization events have been recognized at Buckingham, each related to a particular phase of the composite intrusive center, whereas two subsequent base- and precious-metal mineralization episodes were associated with the emplacement of younger dikes (table 18). Three intrusive phases in the East stock and two in the West stock were responsible for five high-grade molybdenum ore shells that compose most of the Buckingham deposit (fig. 61). Overlap zones between these shells contain even higher molybdenum grades. It is noteworthy that the earliest 
TABLE 17.-Whole-rock chemical analyses comparing various alteration assemblages in quartz monzonite porphyry from the Buckingham stockwork molybdenum deposit

[All values in weight percent. - , not detected]

\begin{tabular}{|c|c|c|c|c|c|}
\hline & $\begin{array}{c}\text { Fresh } \\
\text { B27-171.5 } \\
\end{array}$ & $\begin{array}{c}\text { Weak potassic } \\
\text { Weak sericitic } \\
\text { B25-1630 } \\
\end{array}$ & $\begin{array}{c}\text { Moderate1y } \\
\text { potassic } \\
\text { B32-780-790 } \\
\end{array}$ & $\begin{array}{c}\text { Strong } \\
\text { potassic } \\
\text { B6-2710-2720 }\end{array}$ & $\begin{array}{c}\text { Strong potassic- } \\
\text { Moderate late argillic } \\
\text { B16-1900-1910 }\end{array}$ \\
\hline $\mathrm{SiO}_{2}$ & 68.3 & 69.4 & 68.4 & 77.7 & 78.1 \\
\hline $\mathrm{TiO}_{2}^{2}$ & .33 & -- & .55 & .24 & .27 \\
\hline $\mathrm{Al}_{2} \mathrm{O}_{3}$ & 14.7 & 14.2 & 12.5 & 8.3 & 8.5 \\
\hline $\mathrm{Fe}_{2}^{2} \mathrm{O}_{3}$ & .92 & 2.2 & .71 & 1.4 & 1.3 \\
\hline $\mathrm{FeO}$ & 1.9 & 1.8 & 1.70 & .67 & .7 \\
\hline $\mathrm{MnO}$ & .067 & --- & .065 & .031 & .019 \\
\hline $\mathrm{MgO}$ & 1.3 & 1.1 & 1.6 & .62 & .18 \\
\hline $\mathrm{CaO}$ & 3. & 3.4 & 2.2 & 1.4 & .23 \\
\hline SrO & --- & --- & .043 & .027 & .021 \\
\hline $\mathrm{Na}_{2} \mathrm{O}$ & 3. & 2. & 1.5 & .48 & .24 \\
\hline $\mathrm{K}_{2} \mathrm{O}$ & 4.4 & 5.5 & 7. & 6.3 & 6.5 \\
\hline $\mathrm{Rb}_{2} \mathrm{O}$ & .037 & .046 & .034 & .03 & .029 \\
\hline $\mathrm{P}_{2} \mathrm{O}_{5}$ & .05 & --- & .17 & .1 & .12 \\
\hline & .062 & .066 & .094 & .052 & .046 \\
\hline $\mathrm{CO}_{2}$ & .8 & --- & .7 & 1. & $<0.1$ \\
\hline$-\mathrm{O}=\mathrm{F}$ & .05 & .06 & .08 & .04 & .04 \\
\hline Tota1 & 98.82 & 99.65 & 97.19 & 98.31 & 96.22 \\
\hline
\end{tabular}

and the latest pulses of molybdenum mineralization were low grade and were related to dikeforming phases of the intrusive center. The five main ore shells formed over discrete cupolas of that did not produce dikes or major apophyses.

Accompanying molybdenum during mineralization were silver, copper, and tungsten; the metals are present in tetrahedrite, chalcopyrite, and scheelite. It is not yet known whether these metals were deposited with each succeeding magmatic pulse, as was molybdenum, or whether silver, copper, and tungsten were related to a different phase of the composite intrusive center. Zoning patterns of silver, copper, and tungsten (figs. 63-65), however, support the former hypothesis. Chalcopyrite and scheelite are zoned peripherally with respect to high-grade molybdenite mineralization, whereas tetrahedrite is located centrally.

Quartz-pyrite-molybdenite veins at Buckingham may show preferred orientations. Data from oriented drill core in the West stock indicate that sets of open-space-filling veins tend to form cone sheets that move upward and outward from the stock (C.A. Johnson, unpub. data, 1982). Finer, relatively thin replacement veins may have a radial distribution.
Orientations of both vein types become more random with distance from the stock. Surrounding the entire deposit is the classical pyrite halo. At Buckingham, primary sedimentary lithology controlled the hydrothermal assemblages developed in hornfels. Thus, the iron sulfide halo consists of pyrite in brown biotite hornfels and of pyrrhotite in green magnesian hornfels.

After the cessation of Buckingham molybdenumsilver-copper-tungsten mineralization and, probably, after an initial period of post-molybdenum-age faulting, some disseminated base-metal-silver mineralization occurred that was related to emplacement of the intermediate late-stage dikes. These late-stage dikes also probably are the source of the high-grade, polymetallic base- and precious-metal vein systems that cut the deposit and that represent the last hypogene mineralizing event. Although some of the veins crop out beyond the molybdenum deposit limits (that is, at the Irish Rose, Little Giant and Bentley Mines), many are present within the deposit and locally enhance the equivalent grade of the molybdenum resource.

Local supergene copper and possibly minor supergene silver mineralization overprinted the hypo- 
TABLE 18.-Hypogene molybdenum mineralization episodes in the Buckingham area

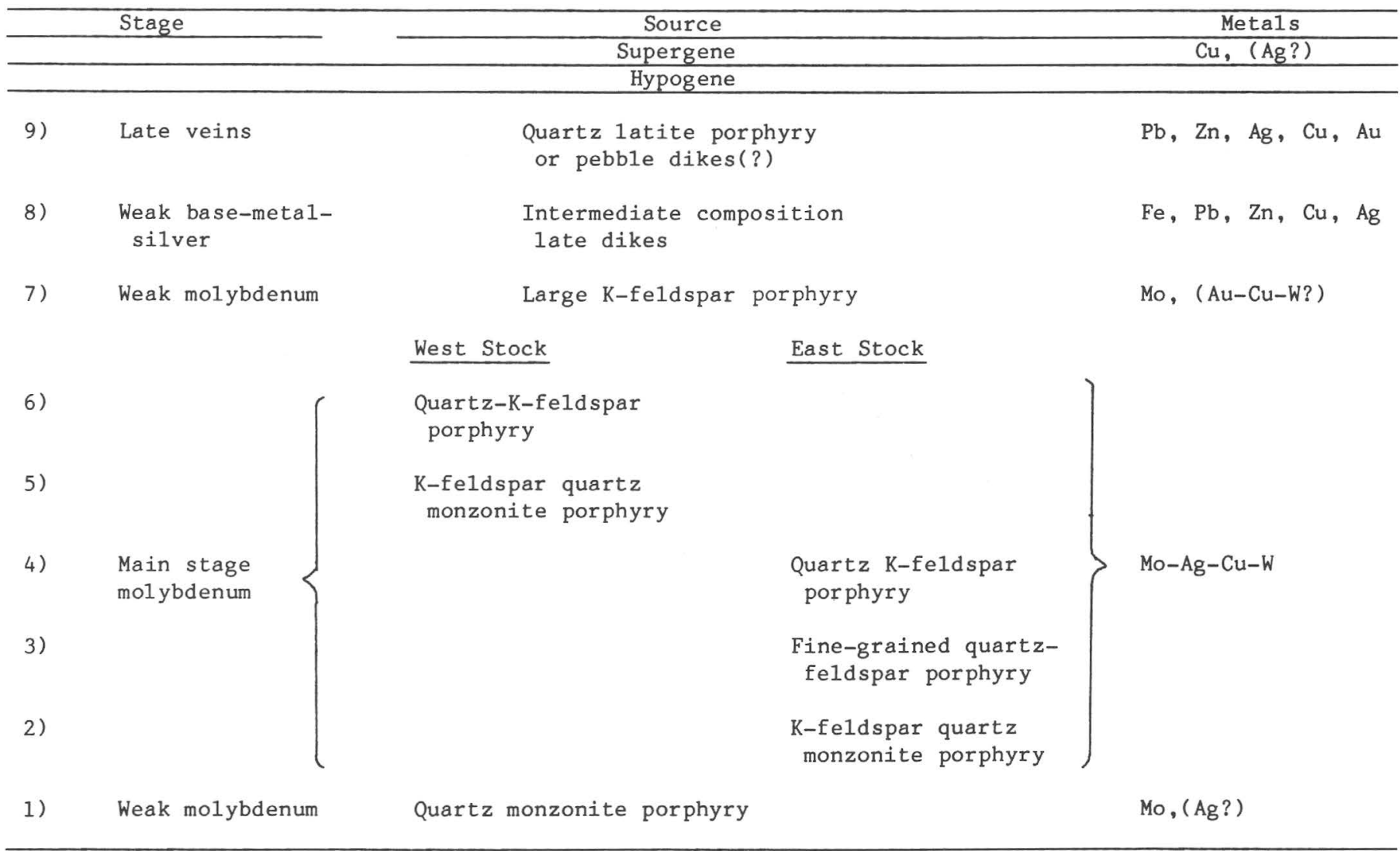

gene sulfide system as a result of near-surface oxidation, leaching, and reprecipitation. Where molybdenum mineralization occurs close to the present-day erosional surface, molybdenum has been oxidized and leached; in the valleys, however, little oxidation has taken place, and molybdenum as sulfide may be present at depths as shallow as 3 to $6 \mathrm{~m}$.

\section{MOLyBdenUm}

As mentioned above, seven periods of molybdenum mineralization have been identified and are related genetically to individual phases of the composite intrusive center. The earliest molybdenum mineralization was low grade, widely dispersed, and related to quartz monzonite porphyry, which now forms border phases of the East and West stocks near the present southern boundary of the deposit (pl. 2). Whether or not quartz monzonite porphyry formed discrete shells of lower grade molybdenite in the two stocks is unknown; however, dikes of quartz monzonite porphyry may contain anomalous $\mathrm{MoS}_{2}$ contents far beyond the limits of the known deposit.

After emplacement of the quartz monzonite porphyry, magmatism and attendant molybdenum mineralization shifted northward, where discrete high-grade shells were deposited over the tops of porphyries in two cupolas of the intrusive center. Restoration of offsets along the Buckingham and Second faults places the East stock at a higher elevation than the West stock; we infer from these relations that the East stock predated the West stock. Presently it is unknown, however, whether all molybdenum mineralization in the West stock followed deposition of that in the East stock, or whether texturally similar phases of two cupolas crystallized and deposited molybdenum concurrently.

Magmatic evolution of the East stock is more complex than that of the West stock; as a result, associated molybdenum mineralization is more difficult to unravel. The grade of molybdenum in ore shells of the East stock appears slightly lower than that to the west, but we do not know if this represents original lower grade mineralizing events or a 


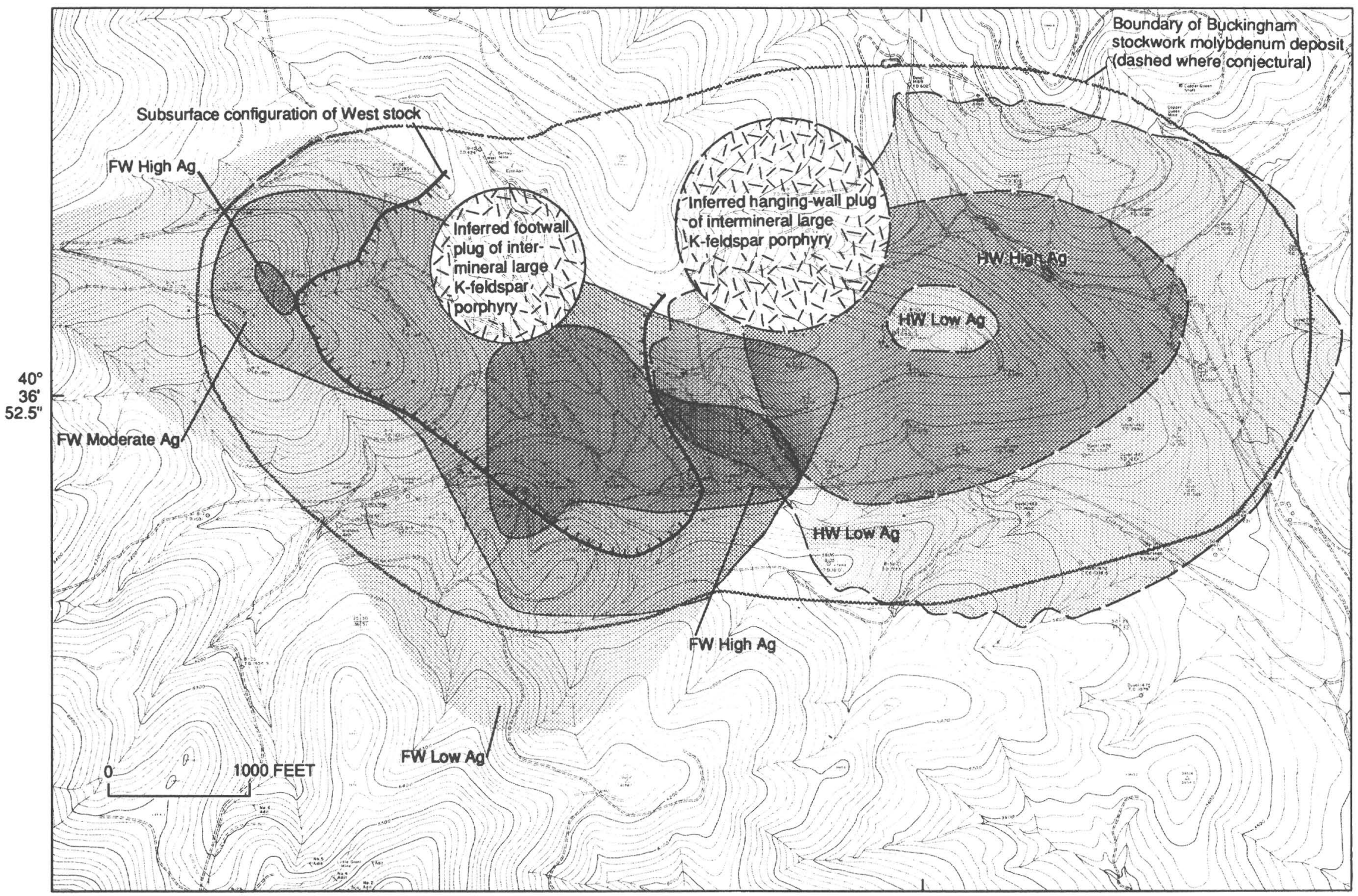

FIGURE 63.-Schematic projection to surface of distribution of silver concentrations in footwall (FW) and hanging-wall (HW) ore zones, subsurface configuration of West stock, and inferred plugs of intermineral large K-feldspar porphyry. Silver zones determined by averaging silver assays of all rocks except postmineral dikes over length of each drill hole (not shown). Base from Aerial Mapping Co., Boise, Idaho, for Climax Molybdenum Co., 1973. Contour interval, $20 \mathrm{ft}$. 
$117^{\circ} 3^{\prime} 45^{\prime \prime}$

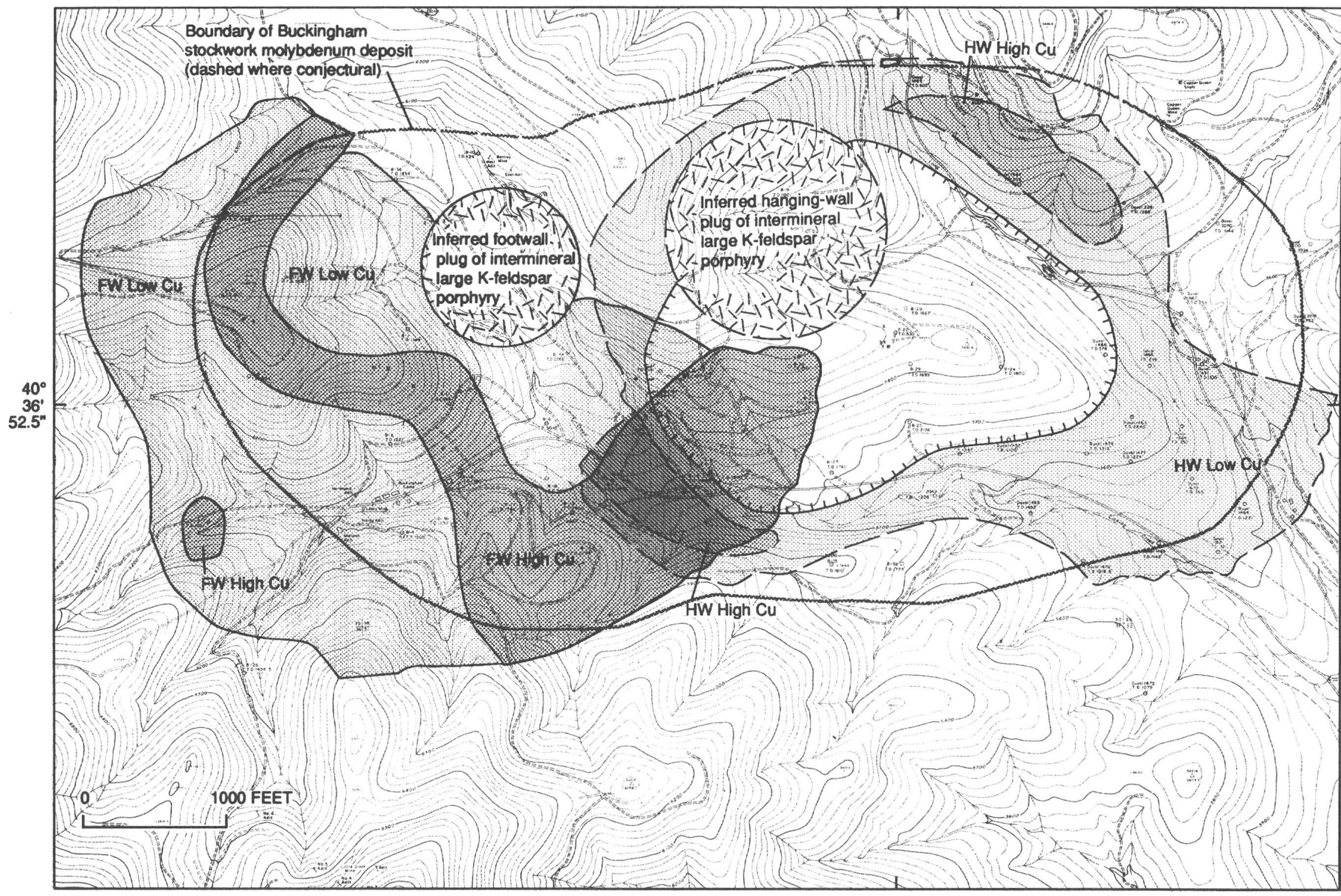

FIGURE 64.-Schematic.projection to surface of distribution of copper concentrations in footwall (FW) and hanging-wall (HW) ore zones and inferred plug of intermineral large K-feldspar porphyry. Copper zones determined by averaging copper assays of all rocks except postmineral dikes over length of each drill hole (not shown). Area inside hachured line contains minimal copper. Base from Aerial Mapping Co., Boise, Idaho, for Climax Molybdenum Co., 1973. Contour interval, $20 \mathrm{ft}$. 


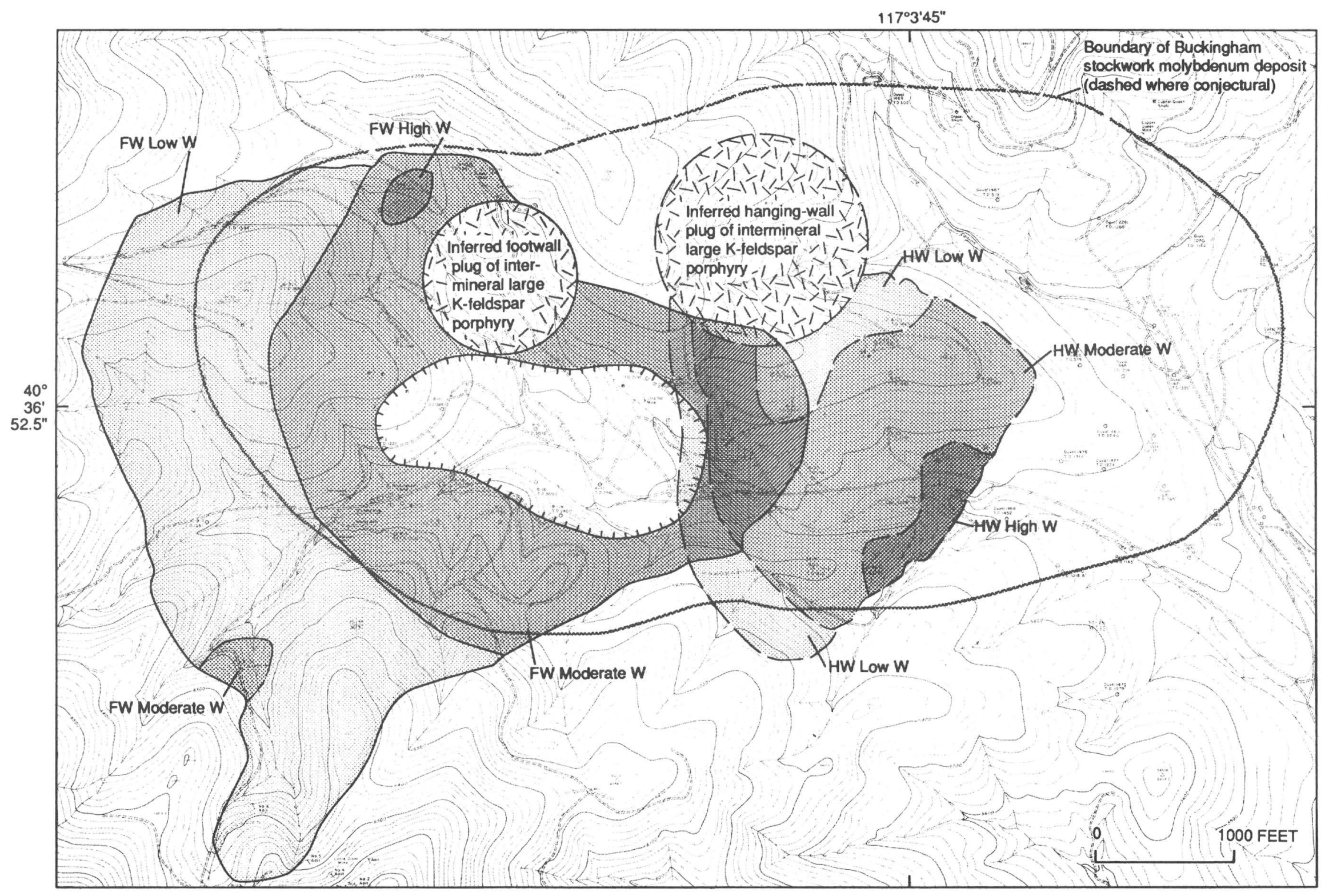

FigURE 65.-Schematic projection to surface of distribution of tungsten concentration in footwall (FW) and hanging-wall (HW) ore zones and inferred locus of intermineral large K-feldspar porphyry. Tungsten zones were determined by av-

each drill hole (not shown). Area inside hachured line contains minimal tungsten. Base from Aerial Mapping Co., Boise, Idaho, for Climax Molybdenum Co., 1973. intermineral large $\mathrm{K}$-feldspar porphyry. Tungsten zones were determined by av-
eraging tungsten assays of all rocks except postmineral dikes over length of 
lack of the extensive ore-shell overlap observed in the West stock. The first discrete molybdenum ore shell directly attributable to the East stock was associated with $\mathrm{K}$-feldspar-quartz monzonite porphyry. Much of this shell has been removed by erosion or faulting, although remnants are found on the south flank of the stock (fig. 56). The second episode of molybdenum mineralization in the East stock was produced by fine-grained quartz-feldspar porphyry (fig. 56). Superposition of molybdenum mineralization from this shell upon that related to $\mathrm{K}$-feldspar-quartz monzonite porphyry produced a significant overlap zone of high-grade material in the upper parts of the East stock. With emplacement of quartz-K-feldspar porphyry, magmatism and the third episode of East stock molybdenum mineralization moved northward once more. As described in the subsection above entitled "Premineral and Synmineral Intrusions," the geometry of this phase of the East stock was partially obliterated by intermineral intrusion breccia (fig. 56); nevertheless, deep zones of high-grade molybdenite within the East stock are related to this phase. With each succeeding northward shift in igneous activity and associated molybdenum mineralization, the southern limb of the deposit thickened (fig. 52). As new ore shells developed, overlap zones sometimes occurred, but the southern limb grew ever wider. To the north, however, the deposit geometry was different. The northward displacement of magmatism and consumptive mode of emplacement of each succeeding igneous phase meant that the northern limb was continually assimilated and regenerated. Thus, mineralization present on the north flank of the East stock, and probably on the north flank of the West stock as well, represents only the last stage of mineralization rather than the cumulative total of several mineralization events.

In the West stock, two molybdenite shells are clearly evident (figs. 55, 60). As mentioned in the subsection above entitled "Premineral and Synmineral Intrusions," weathering, oxidation, and structural complications have made it difficult to decipher which K-feldspar-bearing quartz monzonite phase crops out (for example, fig. 54C). By analogy with grades and ore-zone thicknesses in the East stock, we feel that the weak upper shell of the West stock, largely now removed by erosion, is related to K-feldspar-quartz monzonite porphyry, whereas the deep, high-grade $\mathrm{MoS}_{2}$ shells with steep limbs were deposited by quartz-K-feldspar porphyry (fig. 60). The highest grade mineralization found to date at Buckingham represents the overlap zone of shells related to similarly textured quartz-K-feldspar porphyries of the East and West stocks.

After the deposition of molybdenite in shells related to premineral and synmineral East and West stock phases, the locus of mineralization again shifted northward. Large K-feldspar porphyry, the last of the major quartz monzonite phases, clearly truncates earlier molybdenum mineralization (figs. 57,61 ), but it caused only a weak molybdenum mineralization event. Whether or not its associated molybdenum mineralization forms a discrete shell is unknown.

After the seven stages of molybdenum mineralization, the deposit west of the Long Canyon fault was segmented into three major parts by the Buckingham and Second faults. Plan views of footwall and hanging-wall $\mathrm{MoS}_{2}$ ore zones projected to the surface are shown in figure 61 ; interfault ore zones, still schematic and in need of better definition, are shown in the same figure. Minor remobilization of molybdenite during the emplacement of late-stage dikes does not affect the geometry of ore zones.

Potential Byproducts

Silver at Buckingham is present in tetrahedrite, according to the laboratories of AMAX Extractive R\&D, Golden, Colo. Because the tetrahedrite contains 3 to 30 weight percent $\mathrm{Ag}$, the appropriate varietal name for the mineral is freibergite. Tetrahedrite has been recognized megascopically in only a few, relatively wide veins and rare, disseminated grains. The low-grade tetrahedrite mineralization therefore is present predominantly on a microscopic scale. The distribution of silver in the footwall (fig. 63) indicates a strong correlation with the northwest-elongate West stock itself. Relatively high-grade zones of silver were probably produced by overlap zones related to different intrusive phases in a manner analogous to the overlapping shells of molybdenum mineralization. In addition, a few relatively high grade silver veins (for example, 2.6 troy oz Ag/ton) cut the footwall part of the deposit. The distribution of silver in the hanging wall (fig. 63) indicates a poor correlation between silver and quartz monzonite porphyry; the implication is that most silver mineralization related to the East stock is associated with deep, more northerly located porphyry units such as fine-grained quartz feldspar porphyry and quartz-K-feldspar porphyry. 
Hypogene copper at Buckingham is present in chalcopyrite and tetrahedrite (freibergite). The occurrence of tetrahedrite is described above; chalcopyrite is present in quartz-molybdenite veins, in quartz veins that cut quartz-molybdenite veins, and rarely on fractures. Footwall and hanging-wall copper distributions are similar, the footwall being slightly higher grade, and both distributions probably represent two populations. A subtle but important break in the cumulative frequency distribution of copper assays at 0.04 weight percent $\mathrm{Cu}$ may relate to a spatial overlap of tetrahedrite and chalcopyrite zones (W. Cassun, unpub. data, 1981). Not only does the outer boundary of the high-grade copper zone in the footwall block mimic that of the high-grade silver zone, but the pattern is also bilobate, suggesting two sources (fig. 64). Furthermore, the same bilobate pattern is barely perceptible in the plan view of silver distribution (compare figs. 63 and 64), and the zone of highgrade copper broadens to the southeast as the silver grade increases. The overlap and partial symmetry of high copper and silver grades correlates with the distribution of tetrahedrite. However, the fact that the distribution of copper in the footwall shows a low-grade core, unlike silver, is evidence of concentration of chalcopyrite predominantly as a mineral in the halo of the Buckingham system. Most copper mineralization falls on the outer edge of the molybdenum deposit (see below). The peripheral occurrence of copper relative to molybdenum and silver is more apparent in the hanging-wall block of the deposit, where copper surrounds the center of molybdenum-related igneous rocks on the north flank of Long Ridge (fig. $64)$.

The relation of secondary copper mineralization at the Copper Queen Mine (pl. 2) to hypogene copper and molybdenum mineralization at Buckingham has long been pondered. As stated above, copper as chalcopyrite is concentrated in quartz veins and in quartz-molybdenite veins as an outer halo to molybdenum mineralization in both the East and West stocks; the mostly peripheral distribution of copper concentrations at both stocks shows an important genetic relation to igneous rocks. The question then becomes one of defining relations between the Buckingham molybdenum system and supergene copper concentrated at the Copper Queen Mine. The source of supergene copper in the area of the Copper Queen Mine may have been hypogene replacement mineralization in conglomerate of the Battle Formation that at one time overlay the area (a hypothesis originally pro- posed by Tippett, 1967; D.W. Blake, oral commun., 1980). At present, rocks of the Battle Formation are exposed in east-dipping beds in the Copper Basin Mine (pl. 1); projection of the formation to the west shows that it would have laid above the concentrations of supergene copper. Because the East stock was originally emplaced to a level higher than the West stock as we described above, the copper halo of the East stock could have mineralized reactive, calcareous conglomerate at or near the base of the Battle Formation while the deeper West stock would have deposited copper only in the underlying Harmony Formation. Subsequently, but before deposition of the Caetano Tuff, the first cycle of oxidation and secondary enrichment would have taken place. As was the case at many porphyry copper deposits throughout the southwest (for example, Livingston and others, 1968), the earliest cycle of secondary enrichment would have preceded Basin and Range extension. Movements on the Buckingham and Second fault zones and possibly on the Contention II fault may have subsequently displaced the enriched copper sulfide ore to the northeast, where recent oxidation formed the copper oxide mineralization found today in the Copper Queen Mine.

Tungsten, as scheelite, is present at Buckingham in pyrite veins and along fractures that cut molybdenum mineralization; some scheelite is also present in quartz veins. The zone of relatively high grade tungsten in the footwall part of the deposit falls primarily outside the molybdenum deposit but within the area of well-developed copper mineralization (fig. 65). The distribution of tungsten in the hanging wall (fig. 65) is poorly known, owing to nsufficient analytical data. High tungsten grades again fall within the peripheral, relatively high grade copper zone and appear as a halo to molybdenite.

Quartz and Pyrite Veining

Because the combined effects of surface weathering and variations in primary lithology hindered mapping of alteration assemblages, the density of quartz and pyrite veining was used to outline the geometry of the Buckingham deposit in outcrop. A semiquantitative breakdown of mineralization style and intensity was established by classifying rocks as stockwork quartz veined (in sandstone), stockwork quartz veined (in siltstone), quartz-pyrite veined, or pyrite veined (without quartz). Representative exposures of this classification are shown 
in figure 66. The effects of original lithology were not totally eliminated; for example, vein widths are generally narrower in siltstone than in sandstone (compare figs. 66A and 66B). However, veining patterns mapped overall are rock-type transgressive. The distribution of vein quartz and pyrite is shown in figure 67.

Three patterns significant to the interpretation of the geology of the Buckingham system are evident in figure 67. First, the system has two apparent cores characterized by zones of stockwork quartz veining. The western core is truncated at its east edge by the Buckingham fault and is constrained tightly to exposed parts of the West stock. The larger eastern core of stockwork quartz veining exhibits a bilobate pattern interpreted to indicate superposition of quartz veining from the western system upon that of the eastern system.
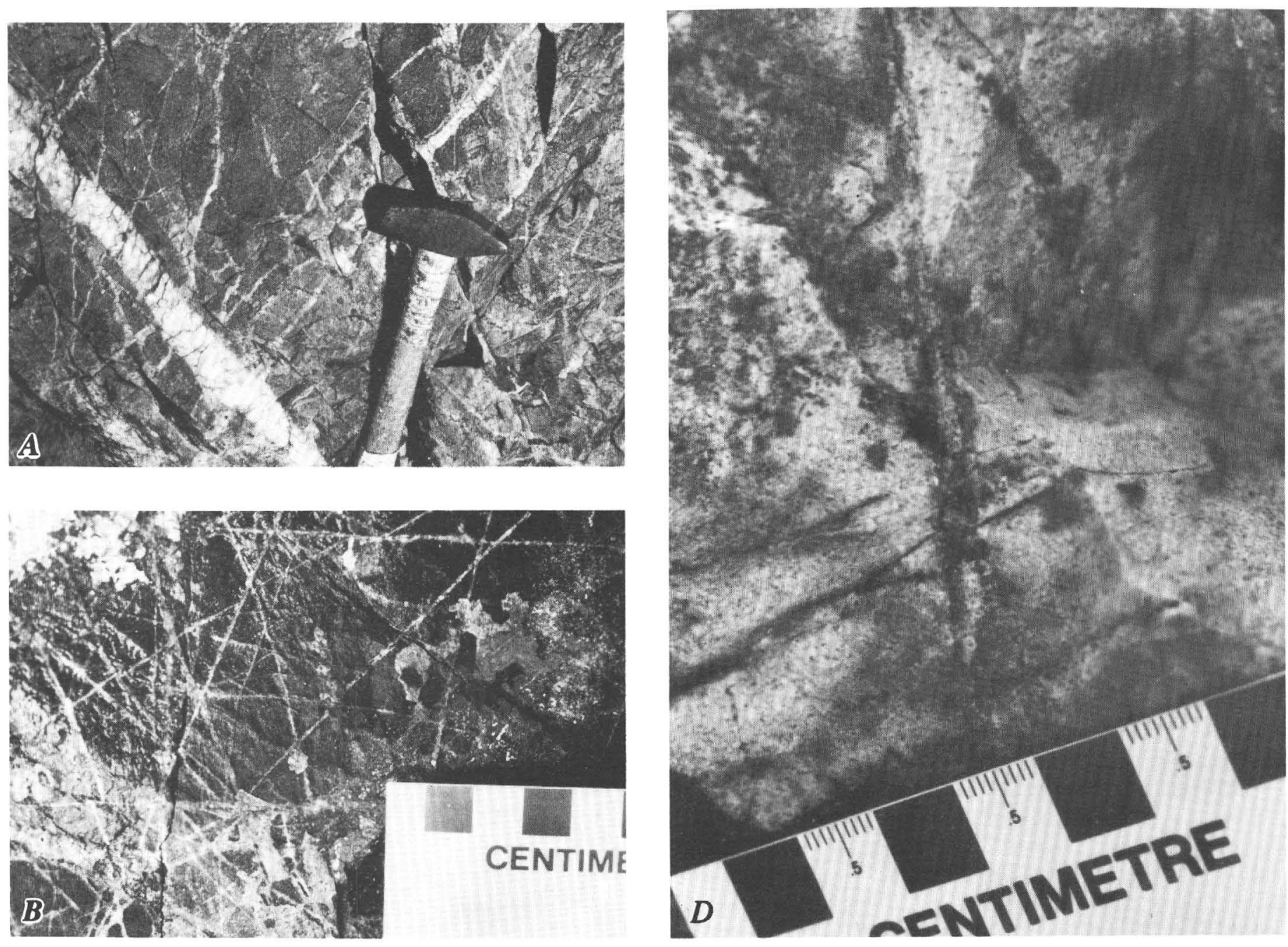

Figure 66.-Representative exposures of variously classified types of veining in the Upper Cambrian Harmony Formation. A, Stockworks of quartz veins (in sandstone). $B$, Stockworks of quartz veins (in siltstone). $C$, Quartz and pyrite veining. $D$, Pyrite veins. 
Second, numerous subtle shifts in quartz-vein distribution patterns across linear topographic features support the interpretation of these features as faults. Where lithologies on either side of the inferred structures are identical (for example, the Long Canyon fault), it is only the change in vein density that suggests an offset. Moreover, offsets of vein patterns are greater, in many cases, than offsets on late-stage dikes. This evidence supports the interpretation that a period of faulting postdated molybdenum mineralization but preceded the emplacement of late-stage dikes. Subsequent structural adjustments followed and disrupted both the deposit and the late-stage dikes. Third, the distri- bution of quartz and pyrite veining is asymmetrical with respect to the presently defined deposit. The effects of topography, structure, and lithology notwithstanding, the pyrite halo extends over $1,000 \mathrm{~m}$ south of the southern ore zone boundary, whereas a much narrower pyrite halo is present on the north. One interpretation is that minor rotation on major N. $25^{\circ}$ W.-striking structures has displaced the top of the system southward. An alternative interpretation may be that the broad vein pattern to the south emulates the same asymmetry observed in the width of the ore zones. As intrusive activity and mineralization migrated northward with time, southern limbs of ore shells and associ-
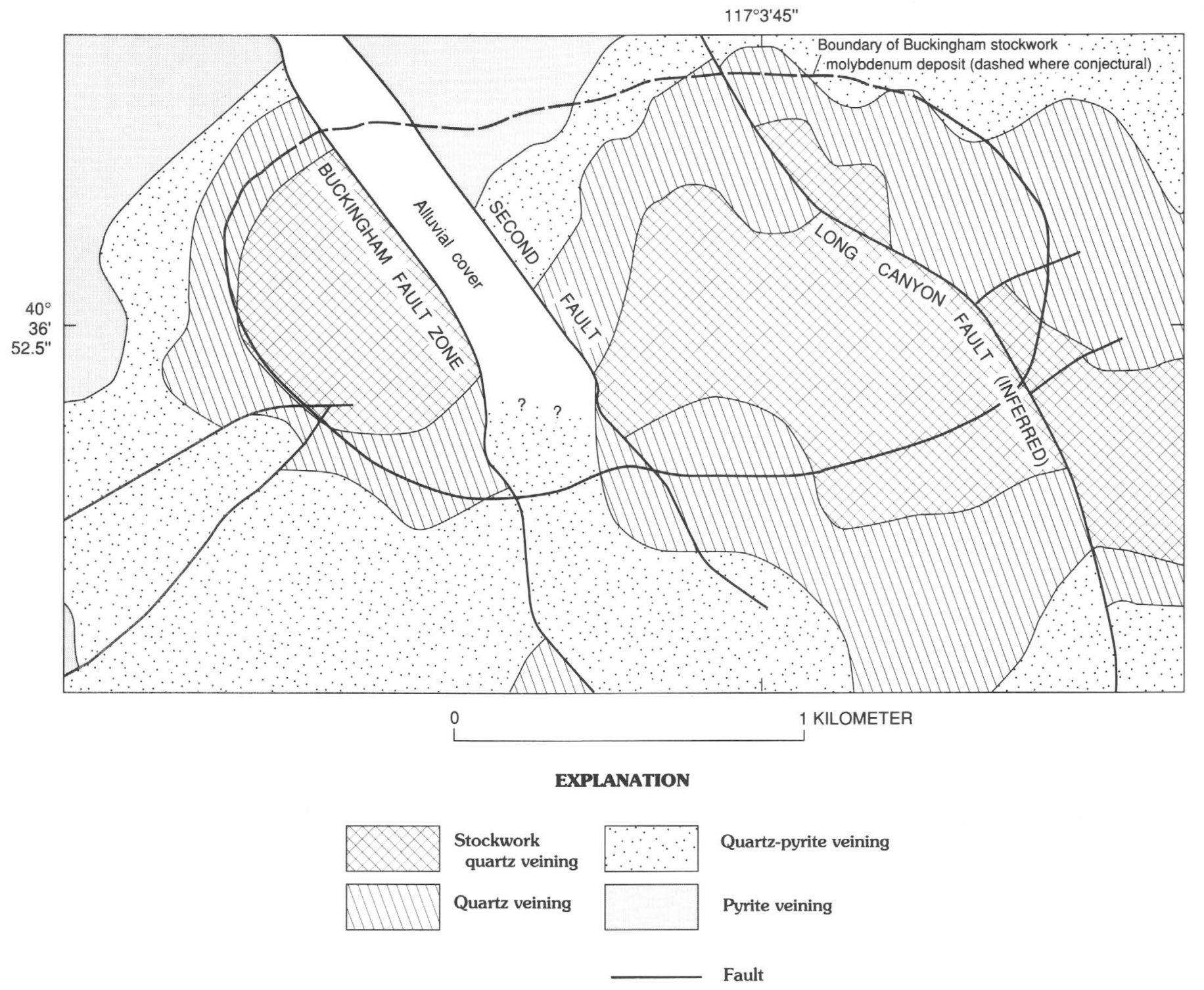

FIGURE 67.-Schematic distribution of stockwork quartz veins, quartz veins, quartz-pyrite veins, and pyrite veins in and around Buckingham deposit. Alluvial cover queried where extent uncertain. 
TABLE 19.-Ages and mineralization associated with several types of Tertiary intrusive rocks in the Buckingham area

\begin{tabular}{|c|c|c|c|c|}
\hline $\begin{array}{c}\text { Late porphyry } \\
\text { group }\end{array}$ & Rock type & $\begin{array}{r}\text { Age } \\
(\mathrm{Ma}) \\
\end{array}$ & Method & $\begin{array}{c}\text { Associated } \\
\text { mineralization }\end{array}$ \\
\hline Mafic (youngest) & Basa1t & 35.7 & $\mathrm{w}, \mathrm{K}-\mathrm{Ar}$ & Pyrite \\
\hline $\int$ quartz-rich & $\begin{array}{l}\text { Pebble dikes } \\
\text { Quartz latite porphyry } \\
\text { Granodiorite porphry } \\
\text { Quartz-biotite-feldspar } \\
\text { porphyry } \\
\text { Biotite-feldspar porphyry } \\
\text { Hornblende porphyry }\end{array}$ & y & $\begin{array}{c}z, \text { f.t. } \\
(\text { see text) }\end{array}$ & $\begin{array}{l}\text { Synmineralization } \\
\text { with weak chalco- } \\
\text { pyrite, pyrite, } \\
\text { pyrrhotite, galena, } \\
\text { sphalerite, silver(?) }\end{array}$ \\
\hline Fe1sic (oldest) & Rhyolite porphyry & 37.3 & $\begin{array}{c}\text { K-Ar (see } \\
\text { section by } \\
\text { McKee this } \\
\text { vol.) }\end{array}$ & $\begin{array}{l}\text { Crenulate quartz } \\
\text { layers }\end{array}$ \\
\hline
\end{tabular}

ated zones of quartz and pyrite veining were left intact and widened as new mineralization was added to the north. On the north flank of the intrusive center, consumptive emplacement continually removed or modified the existing ore shell as a new limb formed slightly farther north. The resulting pyrite halo on the north flank of the deposit is correspondingly narrow compared with that to the south.

\section{Late Vein and Disseminated}

Base-Metal-Silver Mineralization

Low-grade, disseminated chalcopyrite, pyrrhotite, tetrahedrite, and pyrite have been observed in latestage dikes of intermediate composition that truncate molybdenum mineralization. This low-grade mineralization event indicates a renewal of the introduction of sulfides significantly younger than molybdenum mineralization, as well as providing evidence for continued silver deposition. Silver contents in the late-stage dikes are not appreciably different from those in the molybdenum-mineralized rocks.

The last period of hypogene mineralization formed relatively high grade, polymetallic baseand precious-metal veins that crosscut molybdenum mineralization. These veins were the first ore deposits to be mined in the Buckingham area (Roberts and Arnold, 1965). The mineralogy of the veins varies locally but includes galena, sphalerite, chalcopyrite, pyrrhotite, pyrite, arsenopyrite, tetrahedrite, stibnite, gold, and minor bismuthinite and molybdenite. Veins fill large structures of several orientations, but predominantly those of moderate dip, dip west. Mineralization along the Little Giant vein cuts rhyolite porphyry, establishing a maximum relative age for this last hypogene mineralization event of about $39-37 \mathrm{Ma}$ (table 19). Throughout the eastern part of the Battle Mountain Mining District, base- and precious-metal veins such as these are spatially associated with quartz latite porphyry. This relation supports the interpretation that the veins postdate the Buckingham molybdenum system by possibly as much as $50 \mathrm{~m} . \mathrm{y}$. (see above). Another source for the vein mineralization may be the pebble dikes. Pebble dikes show a close spatial association with quartz latite porphyry at several localities and thus, it is inferred, with the polymetallic base- and preciousmetal vein systems. Some pebble dikes are sulfide bearing, and they are also enriched in silver to as much as $7 \mathrm{ppm}$.

Recent weathering has oxidized molybdenite where ore zones originally reached the surface, particularly at ridge crests. The total molybdenum content of the uppermost, oxidized parts of drill holes within the $\mathrm{MoS}_{2}$ deposit boundary is generally 50 weight percent less than that of nearby, unoxidized drill-hole intervals. Thus, leaching of molybdenum took place during oxidation. In valleys, the water table is surprisingly shallow, and sulfide molybdenum is commonly present at depths of 3 to $6 \mathrm{~m}$. 


\section{CONCLUSIONS}

The Buckingham stockwork molybdenum deposit was formed by mineralization related to at least seven distinct phases of a Late Cretaceous composite quartz monzonite porphyry. Individual phases were emplaced sequentially from south to north, forming two cupolas, outlying dikes, and a weakly mineralized plug lying farther north. Restoration of the structurally dissected deposit indicates that the eastern cupola, or East stock, was emplaced first; its earliest phase, now the southern border phase, and dikelike apophyses caused the early, weak molybdenum mineralization. Most of the molybdenite was deposited in three shells related to younger phases emplaced at depth. No major dikes appear to be related to the three main mineralizing porphyries.

Molybdenite deposition near the West stock had a similar history. The southernmost, dike-forming border phase was related to low-grade molybdenite mineralization, whereas most molybdenite was deposited in shells over the cupolas of two younger porphyry phases.

In both stocks, the locus of magmatic activity moved northward with time, and crystallization and mineralization occurred at progressively greater depths. Tremendous volumes of country rock and earlier porphyry phases were stoped. As overlap zones between molybdenite shells developed, the width of the southern ore-zone limbs increased. To the north, however, migration and consumptive mode of emplacment of succeeding intrusions caused the northern ore-zone limbs to be continually assimilated and regenerated. The northern part of the ore zones now represents only the last stage of mineralization rather than the cumulative total of several events.

After the emplacement of the East and West stocks and their corresponding molybdenite shells, a younger intrusive mass with associated dikes was emplaced north of and between the two stocks. Formed during the last of the major quartz monzonite phases, this plug and its apophyses clearly truncate earlier molybdenum mineralization but did develop a late-stage, weak molybdenite mineralizing event.

The distribution of silver, copper, and tungsten concentrations suggests that tetrahedrite, chalcopyrite, and scheelite accompanied molybdenite during metallization and that the individual byproducts may have been deposited in multiple shells in a manner analagous to that of the molybdenite shells. Chalcopyrite and scheelite are peripheral, as both are present in quartz and quartz-pyrite veins that crosscut quartz-molybdenite veins on the fringe of the Buckingham deposit. Tetrahedrite is present on the inner ore-zone boundary at the barren core of the deposit.

Hydrothermal-alteration patterns indicate that each succeeding major phase of the intrusive center developed potassic, propylitic, and intermediate argillic assemblages. This pattern of multiple, distinct hydrothermal-alteration events is compatible both with the separation of distinct molybdenite and byproduct shells and with the development of highsilica zones associated with magmatic, unidirectional solidification textures found in the cupolas of at least three phases of the stock.

Evidence supporting a protracted intrusive and mineralization history is provided by the consumptive emplacement mode of successive phases of the Buckingham igneous center. Exemplified by relations in the East stock, the enormous central roof pendant of quartz monzonite porphyry (pl. 2), itself containing blocks of Harmony Formation, had crystallized before the intrusion of $\mathrm{K}$-feldspar-quartz monzonite porphyry. K-feldspar-quartz monzonite porphyry, in turn, had solidified before being intruded by quartz-K-feldspar porphyry, a unit that was brecciated and partially consumed by the intermineral aplite dike series. The consistent variations in igneous textures and grade thicknesses in ore zones testify to the complexity of magmatic and hydrothermal processes that took place during the formation of the Buckingham molybdenum deposit in Late Cretaceous time.

The configuration of the molybdenum deposit has been affected by three postmineral events. In middle Tertiary time, a series of molybdenumbarren porphyry dikes intruded and diluted the deposit. Subsequently, late Tertiary normal faulting dissected and displaced the deposit into three major and numerous smaller parts. More recently, erosion is believed to have removed significant parts of the upper levels of the deposit, and strong weathering has oxidized and leached the deposit along ridge crests.

\section{ADDITIONAL PETROGRAPHIC AND CHEMICAL STUDIES NEAR THE EAST STOCK}

\section{PETROGRAPHY}

Monzogranite porphyry in the East stock shows under the microscope a rather uniformly distributed, porphyritic fabric wherein phenocrysts of 
quartz, altered plagioclase, sparse K-feldspar, and variably altered primary biotite and rare hornblende are set in a generally well ordered, microaplitic groundmass of mostly $\mathrm{K}$-feldspar and quartz (fig. 68A). It should be noted that the overwhelming bulk of the $\mathrm{K}$-feldspar is in the matrix. Although some facies of the monzogranite porphyry include some crystals of K-feldspar, perhaps as much as four or five times the approximately 0.1$\mathrm{mm}$-average grain size of the matrix, these large crystals of $\mathrm{K}$-feldspar merge into surrounding groundmass by very complexly sutured boundaries; these relations suggest that they were recrystallized. Similar to the West stock described above, by far the predominant characteristic of monzogranite porphyry is intense development of quartz stockworks, including either secondary K-feldspar or showing K-feldspar-stable selvages that are associated spatially with monzogranite porphyry. In areas of somewhat less intense veining by quartz, the monzogranite porphyry shows a hypidiomorphicgranular texture within about $1 \mathrm{~m}$ of its contact with rocks of the Harmony Formation. Such contacts with adjoining hornfels of the Harmony Formation generally are extremely sharp (fig. 68B), and in places the rocks of the Harmony Formation show a dense mat of small crystals of apatite that are as much as 1 to $2 \mathrm{~mm}$ away from the contact with the monzogranite porphyry (fig. $68 \mathrm{C}$ ). This relation is especially evident where a shaly facies of the Harmony Formation is in contact with monzogranite porphyry. Furthermore, this type of rock also shows a spotted texture resulting from envelopes of white mica that surround extremely small, ragged crystals of corundum (fig. $68 D$ ) that undoubtedly are a part of the contact-metamorphic assemblage that predates the metasomatism associated with mineralization. Corundum does not appear texturally to have replaced a previously crystallized andalusite as found by Gustafson and Hunt (1975) at the El Salvador, Chile, porphyry copper deposit. In addition, extremely close to some of the contacts with the Harmony Formation, monzogranite porphyry shows in places microlitic cavities lined by euhedrally terminated quartz, and filled by carbonate, pyrite, biotite (partially replaced by chlorite), and sparse white mica. Also, in monzogranite porphyry, there are sporadic clots of fine-grained, shreddy biotite, pyrite, and carbonate in the K-feldspar and quartz groundmass. This biotite is apparently compatible with K-feldspar and carbonate. Thus, these relations attest to relatively high activities of carbon dioxide that at times must have prevailed while the Buckingham system evolved during some of its early paragenetic hydrothermal stages.

Probably, the matrix of the monzogranite porphyry overall consists of equal amounts of remarkably fresh K-feldspar and quartz. However, some facies of monzogranite porphyry show, across limited intercepts, almost a 10:1 ratio of $\mathrm{K}$-feldspar to quartz in their matrix.

Phenocrysts of biotite (red brown, optic Z-axis) are only locally well preserved. Typically, the biotite is present in stubby books that show approximately equal dimensions both perpendicular to $c$ and parallel to $c$ in the size range 1-2 $\mathrm{mm}$. Some are recrystallized marginally to somewhat paler secondary biotite, whereas others are recrystallized completely to shreddy aggregates of secondary biotite intergrown with carbonate that shows no alteration phenomena with the secondary biotite (fig. $68 E$ ). However, primary, phenocrystic biotite in monzogranite porphyry typically has been replaced either completely or marginally by lamellar intergrowths of white mica and chlorite in variable proportions together with locally much less abundant carbonate. Accessory minerals common to many of these crystals of irregularly replaced primary biotite include ilmenite, sphene, pyrite, and rutile.

Phenocrysts of normally zoned, tabular plagioclase (most commonly about $\mathrm{An}_{40}-\mathrm{An}_{45}$ where unaltered) generally are intensely altered in the East stock to a dense mat of clay(s) and much less abundant white mica (fig. $68 F^{\prime}$ ). Such plagioclasedestructive alteration, and apparent continued stability of most of the $\mathrm{K}$-feldspar during postmagmatic hydrothermal event(s), is quite common throughout monzogranite porphyry in the East stock. Some of these altered phenocrysts show overgrowths of $\mathrm{K}$ feldspar as narrow rims that most likely predate development of clay(s) and that apparently remained relatively unaltered during subsequent hydrolysis of plagioclase. Relict. microveins of fresh $\mathrm{K}$-feldspar are common in many of the mats of intergrown clay(s) and white mica. Study of these clay(s) by X-ray-diffraction techniques in a number of samples collected from a drill hole through a relatively long intercept of monzogranite porphyry in the East stock indicates that they include various proportions of montmorillonite, kaolinite, and white mica, apparently both $1-$ and $2-\mathrm{m}$ polymorphs. There is no systematic increase in any one of the phyllosilicates either with increasing depth or toward the surface. For example, samples examined near the present-day erosional surface show large proportions of montmorillonite, whereas other samples from deep within the East stock also show that 
montmorillonite is the predominant phyllosilicate as the secondary-alteration product of primary plagioclase. Kaolinite apparently does not increase in abundance toward the present-day erosional surface. In fact, some of the most intense replacement of plagioclase by kaolinite-bearing argillic assemblages is

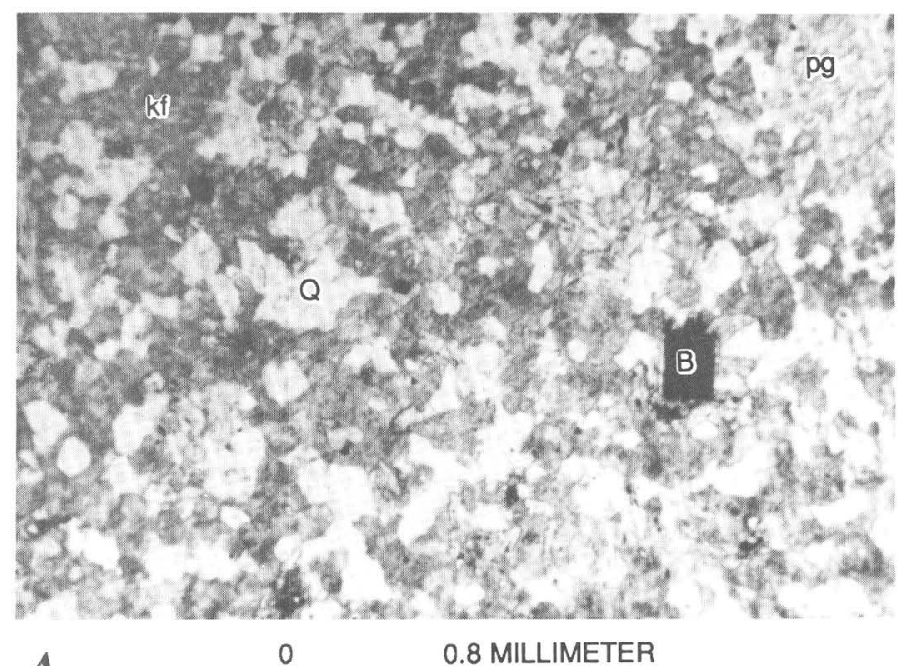

$\boldsymbol{A}$

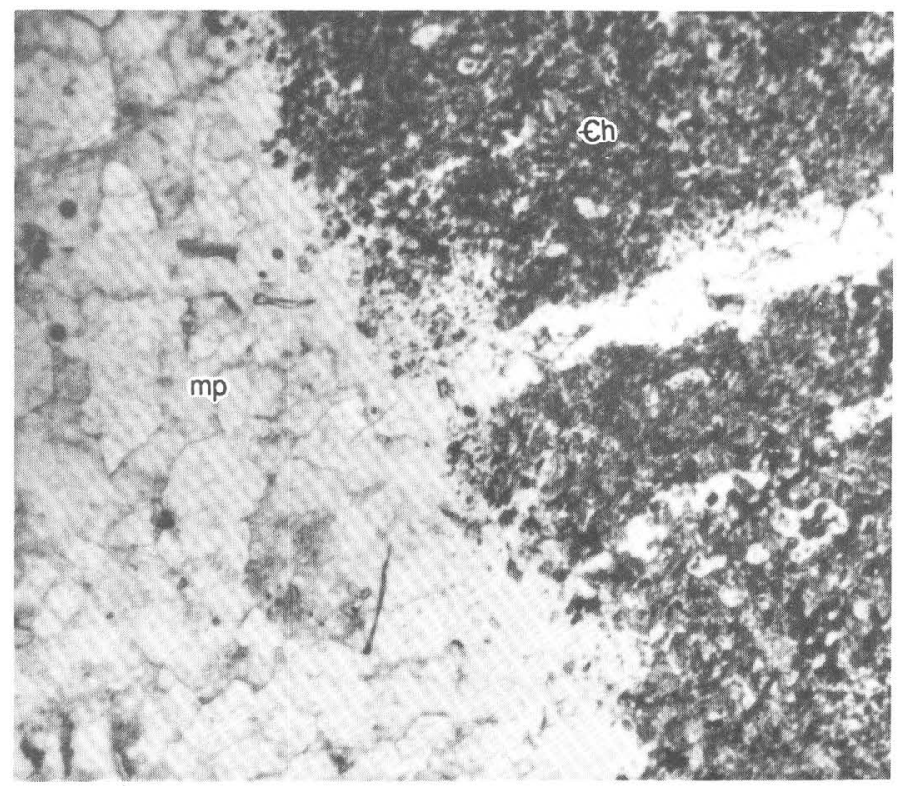

$B$

0.8 MILLIMETER

FIGURE 68.--Photomicrographs showing textural relations in East stock and immediately adjacent country rock. $€$ h, Upper Cambrian Harmony Formation; kf, K-feldspar; mp, monzogranite porphyry; $\mathrm{Q}$, quartz; wm, white mica. $A$, Well-ordered, microaplitic groundmass of mostly quartz and K-feldspar in monzogranite porphyry. Primary biotite (B) partially altered to white mica and plagioclase phenocryst (pg), also partially altered to white mica and clay(s). Sample stained by sodium cobalitinitrate solution. Plane-polarized light. Sample 1463-78. $B$, Knife-edge contact between monzogranite porphyry and hornfels of the Harmony Formation, microveined by $\mathrm{K}$ feldspar. Plane-polarized light. Sample 1463-165. C, Dense mat of small crystals of apatite (at head of arrow) concen-

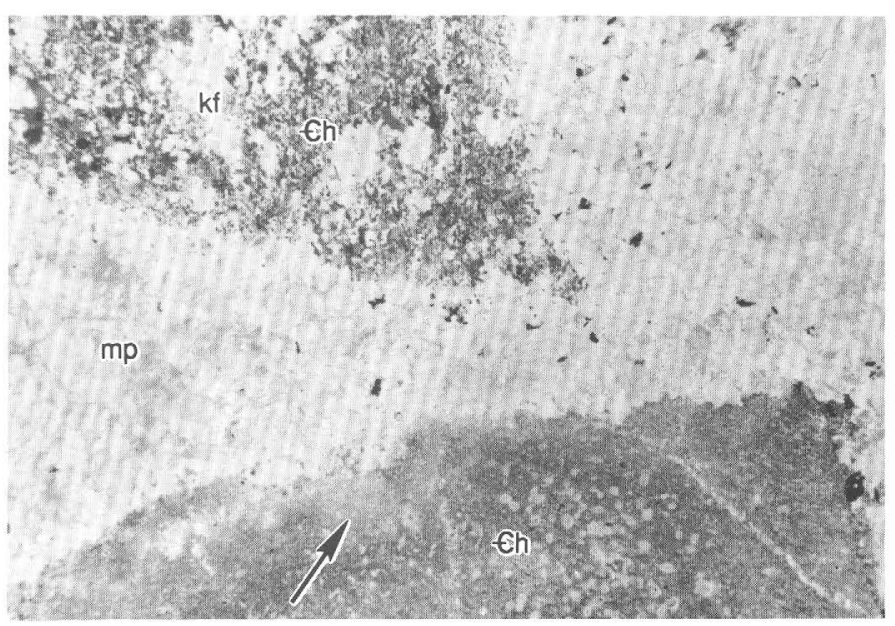

C

0 2 MILLIMETERS

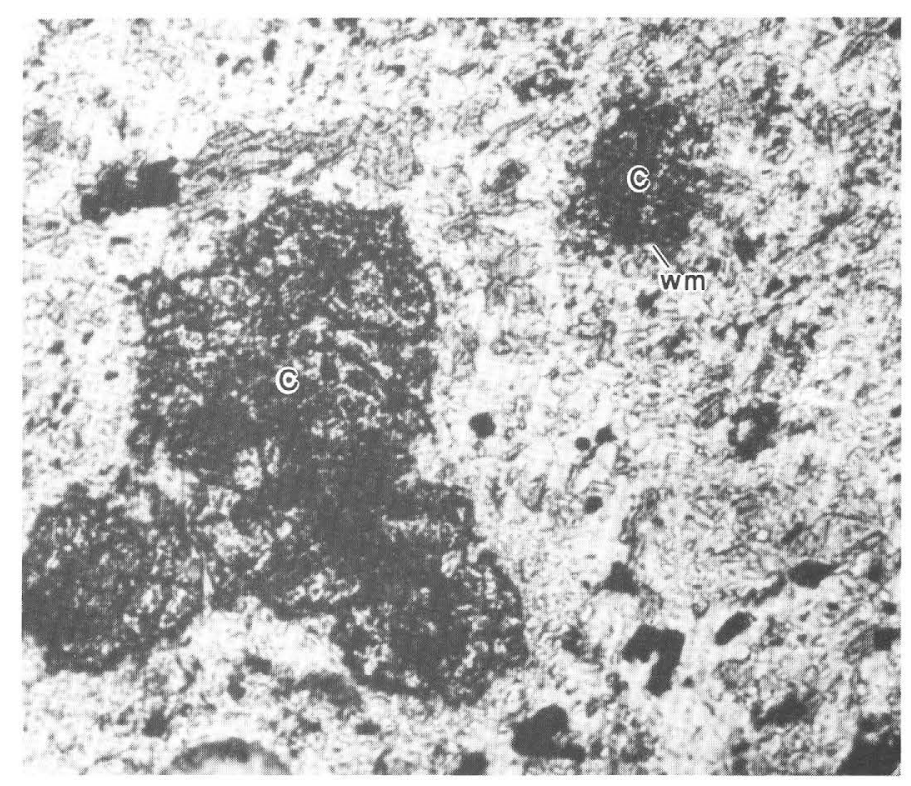

D

0

0.4 MILLIMETER

trated in the Harmony Formation about $2 \mathrm{~mm}$ from contact with monzogranite porphyry. Plane-polarized light. Sample 1463-165. $D$, Small ragged crystals of corundum (C) in K-feldspar-rich biotite hornfels of the Harmony Formation close to some dikes of monzogranite porphyry. Halos of white mica completely envelop some corundum. Plane-polarized light. Sample 1463-998. E, Clot of intergrown secondary biotite (B), carbonate (cc), and pyrite (py) in matrix of monzogranite porphyry. Secondary biotite and carbonate are apparently compatible with K-feldspar in matrix. Plane-polarized light. Sample 1463-165. F, Phenocrysts of plagioclase $(\mathrm{P})$ altered intensely to dense mat of white mica clay(s) and set in a matrix that includes apparently unaltered Kfeldspar. Plane-polarized light. Sample 1463-78. 
present very deep in the East stock. The univariant equilibrium curve for the reaction

$$
\text { kaolinite }+2 \text { quartz } \rightarrow \text { pyrophyllite }+\mathrm{H}_{2} \mathrm{O} \text {, }
$$

for $\mathrm{P}_{\mathrm{H}_{2} \mathrm{O}}=\mathrm{P}_{\text {total }}$, seems to be largely independent of pressure from 0.5 to $7.0 \mathrm{kbars}$, at a temperature of approximately $300{ }^{\circ} \mathrm{C}$ (Helgeson and others, 1978). Thus, one of the alteration phenomena common to igneous rocks throughout the Buckingham system is argillization of plagioclase and continued stability of
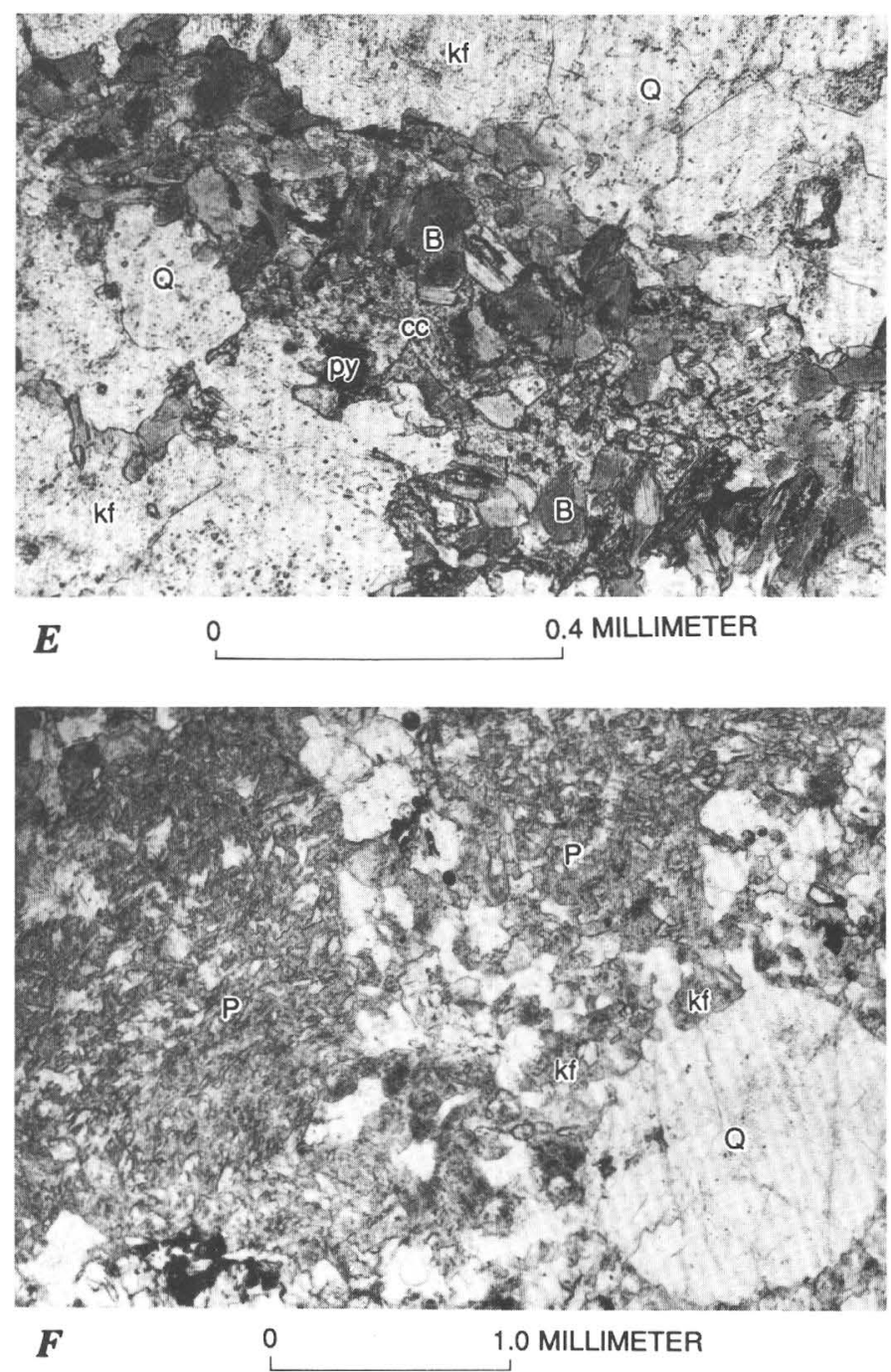

Figure 68.-Continued. $E$, Clot of intergrown secondary biotite (B), carbonate (cc), and pyrite (py) in matrix of monzogranite porphyry. Secondary biotite and carbonate are apparently compatible with K-feldspar in matrix. Plane-polarized light. Sample 1463-165. F, Phenocrysts of plagioclase (P) altered intensely to dense mat of white mica clay(s) and set in a matrix that includes apparently unaltered K-feldspar. Planepolarized light. Sample 1463-78. primary and secondary K-feldspar. More will be discussed below concerning the hypogene compared with the supergene timing of this alteration, and the implications thereby for the cation ratios in fluids associated with alteration. However, it is critical to emphasize that argillization of plagioclase under conditions such that K-feldspar apparently remained stable is not confined to apical parts of the multicentered loci of intrusive activity in the Buckingham system. Such alteration is pervasive throughout intrusive-hosted parts of the system, although some crystals of plagioclase seemingly are not so thoroughly altered at dep.th. Nonetheless, even in the deepest parts of the system penetrated by drilling to depths of about $700 \mathrm{~m}$ into the West stock, there are widespread, coextensive plagioclasedestructive and $\mathrm{K}$-feldspar-stable alteration relations. Such relations are similar to those described by Shaver (1984a, b) at the.Hall, Nev., molybdenum stockwork system. At Hall, Shaver attributed such argillic alteration to an upwelling of late-stage hypogene fluids that were reacting with progressively, as the depth decreased, less abundant biotite, relict from a preceding conversion to white mica. These relations at Buckingham may indicate an initial, lowtemperature $\left(300{ }^{\circ} \mathrm{C}\right.$ or below) decomposition of plagioclase to montmorillonite to kaolinite, as the $\mathrm{pH}$ of the fluids increased during the many hypogene stages of the Buckingham system (Fournier, 1967). Both of these reactions release silica, such that the activity of dissolved aqueous silica may have been greater than quartz saturation through either the sluggish onset of the crystallization of quartz or the development of silica gel. As calculated by Fournier, eventually kaolinite and K-feldspar may be in stable equilibrium in such an environment. However, the absence of a significant, widespread enrichment in the proportion of kaolinite in altered plagioclase near the surface suggests that supergene processes alone did not cause the development of these intermediate argillic assemblages.

The intermediate argillic assemblages in the Buckingham deposit are similar also to those described at the Santa Rita, N. Mex., porphyry copper deposit. At the Santa Rita deposit, alteration of feldspars in the pluton is zoned outward from fresh feldspar, to montmorillonite and kaolinite replacing plagioclase (K-feldspar unaltered), to kaolinite replacing plagioclase (K-feldspar unaltered), and, finally, to quartz-white mica replacing both plagioclase and K-feldspar (Nielsen, 1968). In two somewhat earlier studies of this same deposit, Jones and others (1967) suggested that the hydrolitic breakdown of plagioclase to clay(s) released silica, 
possibly fixed as vein quartz, and Rose and Baltosser (1966) noted the unusually large vertical extent of argillization of plagioclase there also. After these studies, Jacobs and Parry (1979) confirmed that superposition of argillic alteration of plagioclase on paragenetically early potassic alteration (mainly secondary orthoclase and biotite), in turn, was followed by feldspar-destructive introduction of white mica and pyrite.
Potassic alteration, however, is the predominant type of alteration associated with the early, hypogene introduction of molybdenum into the system at Buckingham. In the East stock, most samples show mineral assemblages diagnostic of more than one type of alteration; they are generally potassic, followed by intermediate argillic in monzogranite porphyry (fig. 69). Argillic alteration of metamorphosed and metasomatized rocks of the Harmony Formation

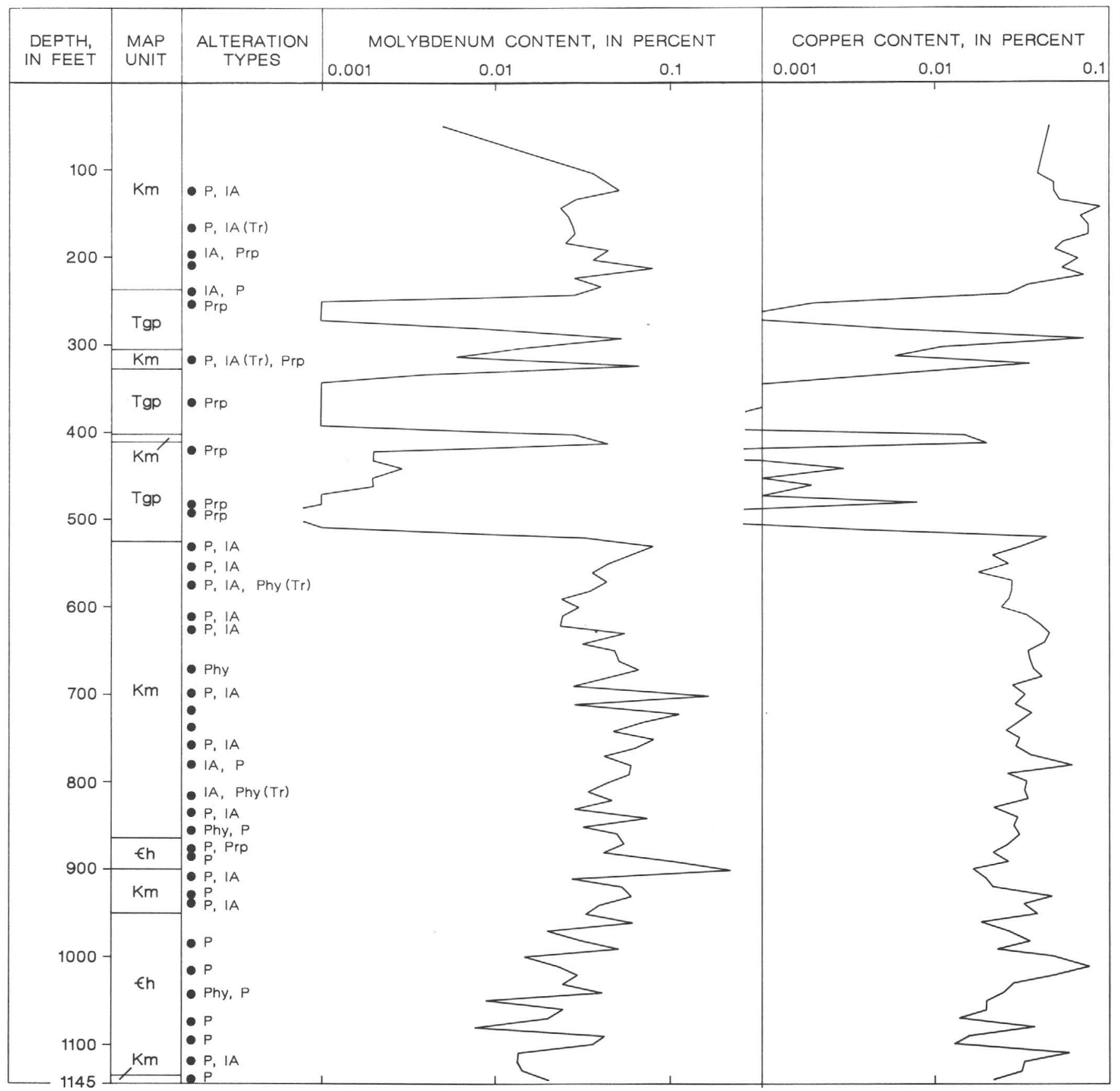

FIGURE 69.-Columnar section showing lithology, alteration assemblage(s) in thin sections, and molybdenum and copper contents from drill hole 1465 collared in East stock of Buckingham stockwork molybdenum system. Alteration types: IA, intermediate argillic; $\mathrm{P}$, potassic; Phy, phyllic; Prp, propylitic. $€ \mathrm{~h}$, Upper Cambrian Harmony Formation; Km, Late Cretaceous monzogranite porphyry; Tgp, Oligocene granodiorite porphyry. Dot, thin section; Tr, trace. 


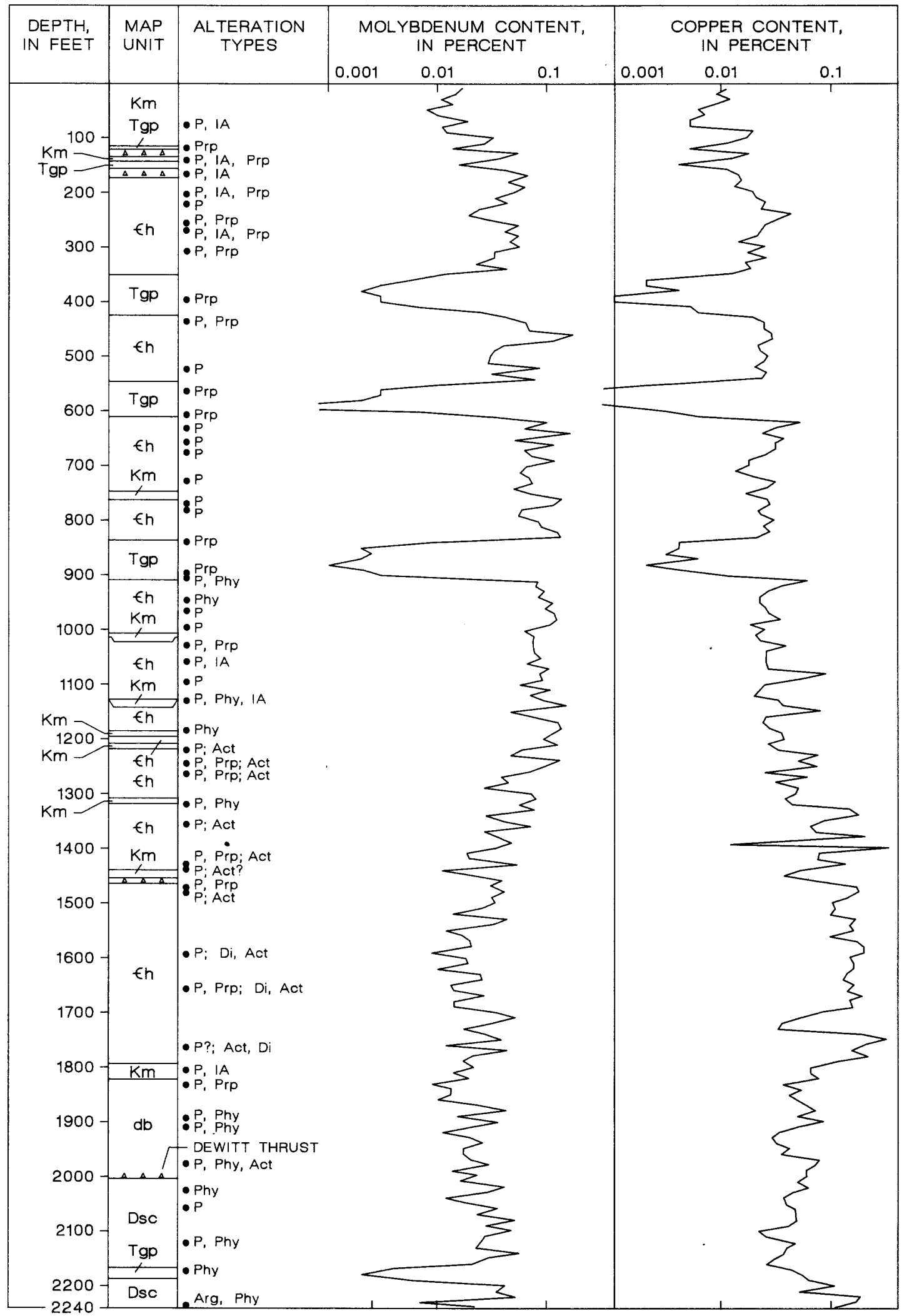

FIGURE 70.-Columnar section showing lithology, alteration assemblage(s) in thin sections, and molybdenum and copper from drill hole 1463 collared in East stock of Buckingham stockwork molybdenum system, including a significant proportion of Paleozoic country rock. Alteration types: IA, intermediate argillic; P, potassic; Phy, phyllic; Prp, propylitic; Arg, argillic; Act, actinolite, queried where uncertain; Ch, Upper Cambrian Harmony Formation; db, Devonian and (or) Ordovician diabase; Di, diopside; Dsc, Devonian Scott Canyon Formation; Km, Late Cretaceous monzogranite porphyry; Tgp, Oligocene granodiorite porphyry. Dot, thin section; triangles, brecciated rock. 
is quite minimal (fig. 70). Some of the K-feldsparbearing veins that cut metasedimentary rocks of the Harmony Formation near a relatively thick intercept of diabase just above the Dewitt thrust show selvages of diopside. Such diopside is much coarser grained at the wall of the vein than elsewhere in these rocks; this coarseness suggests thereby a genetic association with $\mathrm{K}$-feldspar-bearing veins. Actinolite-bearing veins, also containing $\mathrm{K}$-feldspar, are paragenetically younger than the diopside-Kfeldspar compatibility.

\section{CHEMISTRY}

\section{MAJOR ELEMENTS}

Nine additional representative samples of altered monzogranite porphyry from the East stock (table 20), two samples of aplite from the East stock (table 21), and two samples of highly mineralized rock from the Upper Cambrian Harmony Formation very close to the East stock (table 22) were analyzed chemically to characterize further these magmatic rocks and their immediately adjacent country rock. Samples analyzed were selected specifically from drill core below the base of the oxide zone; they were chosen to exclude as much vein quartz as physically possible. Unfortunately, however, most igneous rocks associated genetically with the Late Cretaceous stockwork molybdenum system are altered hydrothermally-commonly by an early potassic event, followed closely by either an intermediate argillic and (or) local-fracture-controlled phyllic stage and superposed propylitic assemblages. The latter assemblages probably are related to the emplacement into the molybdenum system of Oligocene granodiorite porphyry dikes. Therefore, because of the multiplicity of widespread hydrothermal events and the accompanying, largely incomplete chemical reactions here, chemical changes of various magmatic pulses as the Buckingham system evolved could not be documented well. Furthermore, only a few generalizations will be attempted.

Chemical analysis of a sample of fresh monzogranite porphyry provides a geochemical base to which all the other chemically analyzed samples of altered monzogranite porphyry will be compared. The normal variation in major-element composition of monzogranite porphyry before its hydrothermal alteration could not be determined because of widespread alteration.

Major-oxide composition of fresh monzogranite porphyry from the Buckingham system (table 14, analysis 1) apparently is remarkably similar to that of the average adamellite of LeMaitre (1976):

\begin{tabular}{|c|c|c|c|c|}
\hline & $\mathrm{SiO}_{2}$ & $\mathrm{~K}_{2} \mathrm{O}$ & $\mathrm{Na}_{2} \mathrm{O}$ & $\mathrm{CaO}$ \\
\hline Buckinghar & 68.3 & 4.4 & 3.0 & 3.0 \\
\hline$\ldots$ & 68.65 & 4.0 & 3.47 & 2.68 \\
\hline .................... & 69.15 & 4.58 & 3.35 & 2.45 \\
\hline
\end{tabular}

Nockolds' (1954) average of 121 chemical analyses of quartz monzonite (his terminology) is also listed above for comparison. Although the $\mathrm{K}_{2} \mathrm{O} / \mathrm{Na}_{2} \mathrm{O}$ ratio for fresh monzogranite porphyry from Buckingham (1.47) is elevated somewhat relative to most monzogranites and would plot in the syenogranite field using the classification of Mason (1978), the $\mathrm{Na}_{2} \mathrm{O}$ content of this sample nonetheless is greater apparently than that of the other analyzed samples of altered monzogranite porphyry. Furthermore, the $\mathrm{K}_{2} \mathrm{O} / \mathrm{Na}_{2} \mathrm{O}$ ratio in every sample of altered monzogranite porphyry is greater than 1.47 (see tables 17 and 20). In these variably altered samples, $\mathrm{K}_{2} \mathrm{O} / \mathrm{Na}_{2} \mathrm{O}$ ratios range from 1.58 to more than 40 . The extremely high $\mathrm{K}_{2} \mathrm{O} / \mathrm{Na}_{2} \mathrm{O}$ ratios are primarily the result of a depletion of $\mathrm{Na}_{2} \mathrm{O}$ concomitant with alteration to clay(s) of the plagioclase phenocrysts (table 20). However, potassic alteration before intermediate argillic alteration of the rocks apparently resulted in an overall increase in potassium content during the early hypogene stage(s) of the Buckingham system. Such a geochemical trend is not readily apparent in a ternary AlkFM diagram (fig. $71 A$ ), whereas an ACF plot of the data (fig. $71 B$ ) suggests that aluminum may have remained relatively immobile during the hydrothermal alteration of many of the samples of monzogranite porphyry. A comparison of the $\mathrm{K}_{2} \mathrm{O} / \mathrm{Al}_{2} \mathrm{O}_{3}$ ratios in fresh monzogranite porphyry and altered monzogranite porphyry, however, reveals that two of these samples of altered monzogranite porphyry (analyses 5 and 7, table 20) have $\mathrm{K}_{2} \mathrm{O} / \mathrm{Al}_{2} \mathrm{O}_{3}$ ratios less than that of the sample of fresh monzogranite porphyry. Both samples are from the same drill hole, approximately $4 \mathrm{~m}$ apart, and both samples show well-developed potassicalteration assemblages (dominated by secondary $\mathrm{K}$ feldspar as selvages along veins), with less pronounced retrograde intermediate argillic assemblages. In addition, the samples show high $\mathrm{FeO} / \mathrm{Fe}_{2} \mathrm{O}_{3}$ ratios, together with a relatively low overall sulfide sulfur content, indicating that most iron is probably in the relatively unaltered primary biotite. Some of the other samples of altered monzogranite porphyry show more than a twofold increase in their $\mathrm{K}_{2} \mathrm{O} / \mathrm{Al}_{2} \mathrm{O}_{3}$ ratios relative to the fresh sample (see tables 17, 20). These data thus suggest either a normal magmatic variation in the $\mathrm{Al}_{2} \mathrm{O}_{3}$ content of the rocks, or some mobility of aluminum may have occurred during alteration (see 
below). Nonetheless, the progressive enrichment of potassium during hypogene alteration of igneous rocks of the Buckingham system is readily apparent in an $\mathrm{AKF}$ plot of its data (fig. $71 C$ ), compared with a similar plot for the Tertiary igneous rocks in the area (see fig. $27 C$ ). In fact, the most potassium enriched Tertiary igneous rocks here show abundances of potassium nearly comparable with the least potassium enriched igneous rocks associated with the Buckingham system.

Mineralized rocks of the Harmony Formation in the general area of the East stock, represented by samples containing 530 and $220 \mathrm{ppm}$ Mo (table 22), apparently also show comparable levels of potassium enrichment to that suggested above for igneous rocks of the Buckingham system. These chemically analyzed samples of the Harmony Formation generally show twofold to threefold increases in their $\mathrm{K}_{2} \mathrm{O} / \mathrm{Al}_{2} \mathrm{O}_{3}$ ratios compared with the ratios in relatively unaltered and calcareous subarkose (see analyses 1-3, table 1).

To evaluate further the possibility that major differences in the density of these rocks may be contributing to apparent cation increases or decreases between fresh and altered monzogranite porphyry, similarities and differences between these two phases also were compared using Barth's $(1948,1962)$ cations. In his technique, Barth calculated the number of cations for a standard cell of 160 oxygens, thereby allowing comparison between chemical analyses on an equal-volume basis (see Creasey, 1984, for an indepth application of this technique through the use of small-number statistics). However, there is only one chemical analysis available for fresh monzogranite porphyry. The mean and standard deviation of Barth's cations were calculated for 11 samples of altered monzogranite porphyry and Barth's cations for the fresh monzogranite porphyry (table 23). A test for the significance of the difference between values for each cation is hampered by the fact that the variance for fresh monzogranite porphyry is unknown. Only potassium, sodium, and phosphorus cations in the altered monzogranite porphyry, however, show differences of their means more than one standard deviation from their respective values in the standard cell of fresh monzogranite porphyry. Thus, chemical analyses of these rocks substantiate quantitatively, through the apparent cationic increase in potassium and decrease in sodium, that such chemical changes are compatible with the petrographic observations. Much of the calcium released during the early hypogene potassium silicate alteration may have been fixed in the rock as carbonate that was stable during some of the sub- sequent intermediate argillic, phyllic, and propylitic stages.

\section{MINOR ELEMENTS}

Minor elements in analyzed intrusive rocks associated with the Buckingham system are listed in tables 17, 20, and 22. Evidently, the molybdenum and copper contents of these rocks are highly anomalous when compared with the molybdenum contents of low-calcium granite $(1.3 \mathrm{ppm})$ and highcalcium granite $(1.0 \mathrm{ppm})$, and with the copper contents of each of these two types of granite (10 and $30 \mathrm{ppm}$, respectively) (Parker, 1967). However, many other minor-element contents in these igneous rocks also contrast significantly with the minor-element signatures associated with Climaxtype stockwork molybdenum systems. As pointed out by Mutschler and others (1981), fluorinedeficient systems (termed "granodiorite systems" in their classification) include significantly higher abundances of copper, barium, and strontium, and lower abundances of fluorine, rubidium, and uranium than the Climax-type systems. In addition, Ludington (1981) noted that niobium, tin, lanthanum, and yttrium all show characteristic concentrations in the source granitic rocks thought to be favorable for occurrence of Climax-type systems (see Steigerwald and others, 1983, for the data bank on which these conclusions are based). A comparative plot of most of these minor elements considered to be diagnostic for discriminating the two types of molybdenum stockwork systems is shown in figure 72. Fluorine, rubidium, strontium, barium, tin, niobium, uranium, thorium, lanthanum, and yttrium contents in the Buckingham system apparently all differ to varying degrees from the respective contents ascribed to Climax-type systems. As shown in figure 72 , the overall range of fluorine contents in altered monzogranite porphyry from the Buckingham system is 400 to 1,200 ppm; the mean fluorine content is about $700 \mathrm{ppm}$. Analysis of one sample of fresh monzogranite porphyry shows a fluorine content of $600 \mathrm{ppm}$. Such fluorine contents, 600 and $700 \mathrm{ppm}$, are somewhat elevated with respect to the mean fluorine content of $410 \mathrm{ppm}$ in granitic rocks of the northwestern Great Basin province of Christiansen and Lee (1986), which includes the Battle Mountain Mining District. These authors ascribe the relatively depleted fluorine contents of the granitic rocks in this province to the absence of a comparatively fluorine enriched reservoir in the crust that underlies the province. Some of the relations observed for some 


\section{D146 GEOCHEMISTRY OF THE PORPHYRY COPPER ENVIRONMENT, BATTLE MOUNTAIN MINING DISTRICT, NEVADA}

TABLE 20.-Analytical data on Late Cretaceous monzogranite porphyry at different depths in the East stock associated with the Buckingham stockwork molybdenum deposit

[Chemical analyses in weight percent by single-solution method of Shapiro (1975); analysts, K. Coates and H. Smith. Emission-spectrographic analyses in parts per million; analyst, J.L. Harris. Cross, Iddings, Pirsson, and Washington (CIPW) norms in weight percent. Relative standard deviation of any single reported concentration should be taken as plus 50 percent and minus 33 percent. Looked for, but not found, at parts-per-million detection levels in parentheses: As (150), Au (10), Bi (15), Cd (32), Dy (22), Er (10), Gd (15), Ge (1.5), Hf (15), Ho (6.8), In (6.8), Ir (15), Li (68), Lu (22), Nd (46), Os (22), Pd (1.5), Pr (68), Pt (6.8), Re (10), Rh (2.2), Ru (3.2), Sb (46), Sm (22), Ta (460), Tb (32), Tn (4.6), W (10). Au, $\mathrm{Hg}$, and $\mathrm{Zn}$ determined by atomic-absorption spectroscopy; analysts, J. Budinsky and R. Moore. F determined by specific-ion-electrode methods; analysts, J. Budinsky and R. Moore. Cl determined spectrophometrically; analysts, J. Budinsky and R. Moore. Th and U determined by intrumental delayedneutron counting, using the methods of Millard and Keaten (1982); analysts, H.T. Millard, Jr., F.M. Luman, and B.A. Keaten. Nb and Rb determined by X-ray spectroscopy; analysts, R. Johnson, H.J. Rose, B. McCall, G. Sellers, and J. Lindsay. IA, intermediate argillic; P, potassic; Phy, phyllic; Prp, propylitic. - , not detected]

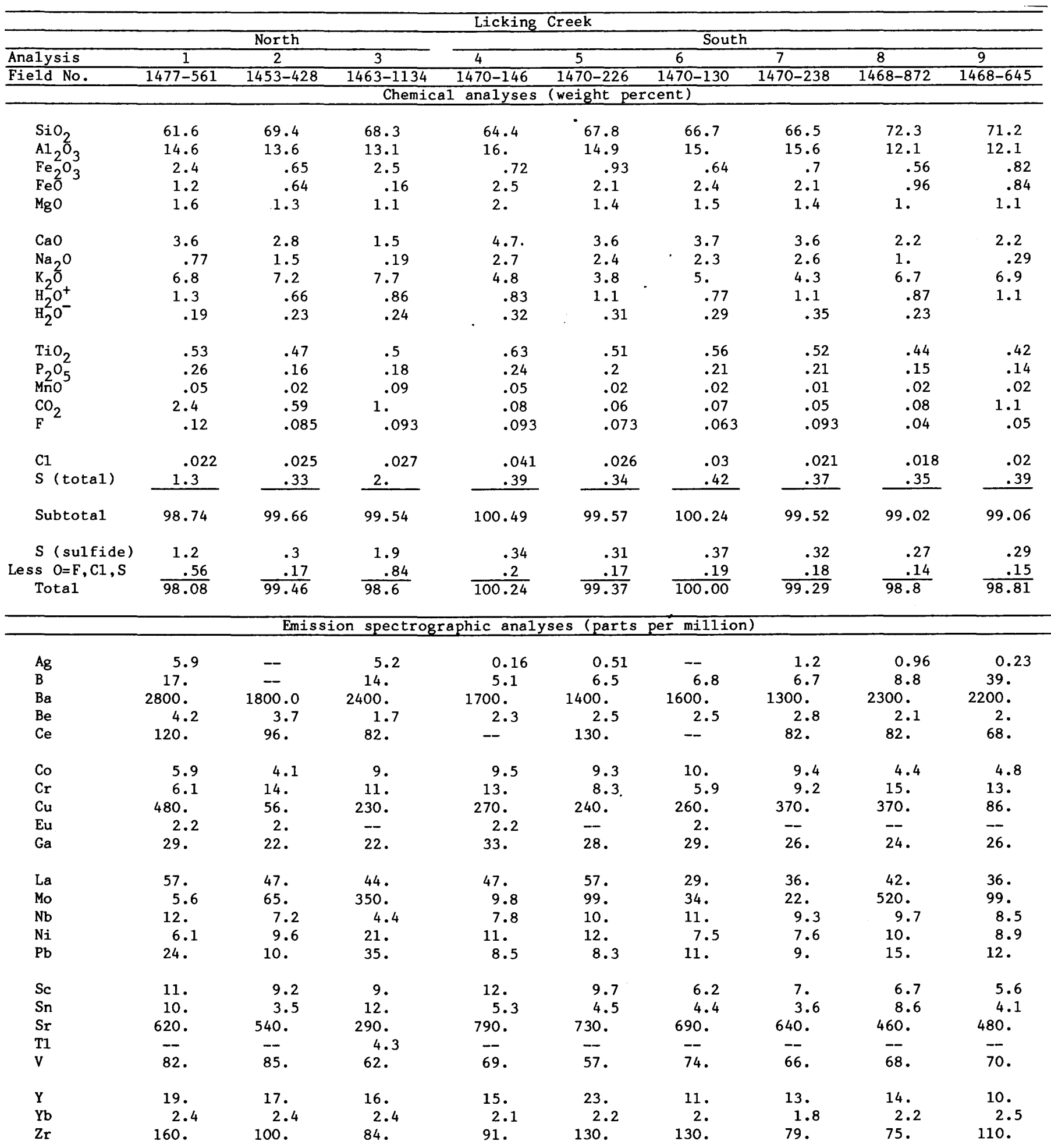


TABLE 20.-Analytical data on Late Cretaceous monzogranite porphyry at different depths in the East stock associated with the Buckingham stockwork molybdenum deposit-Continued

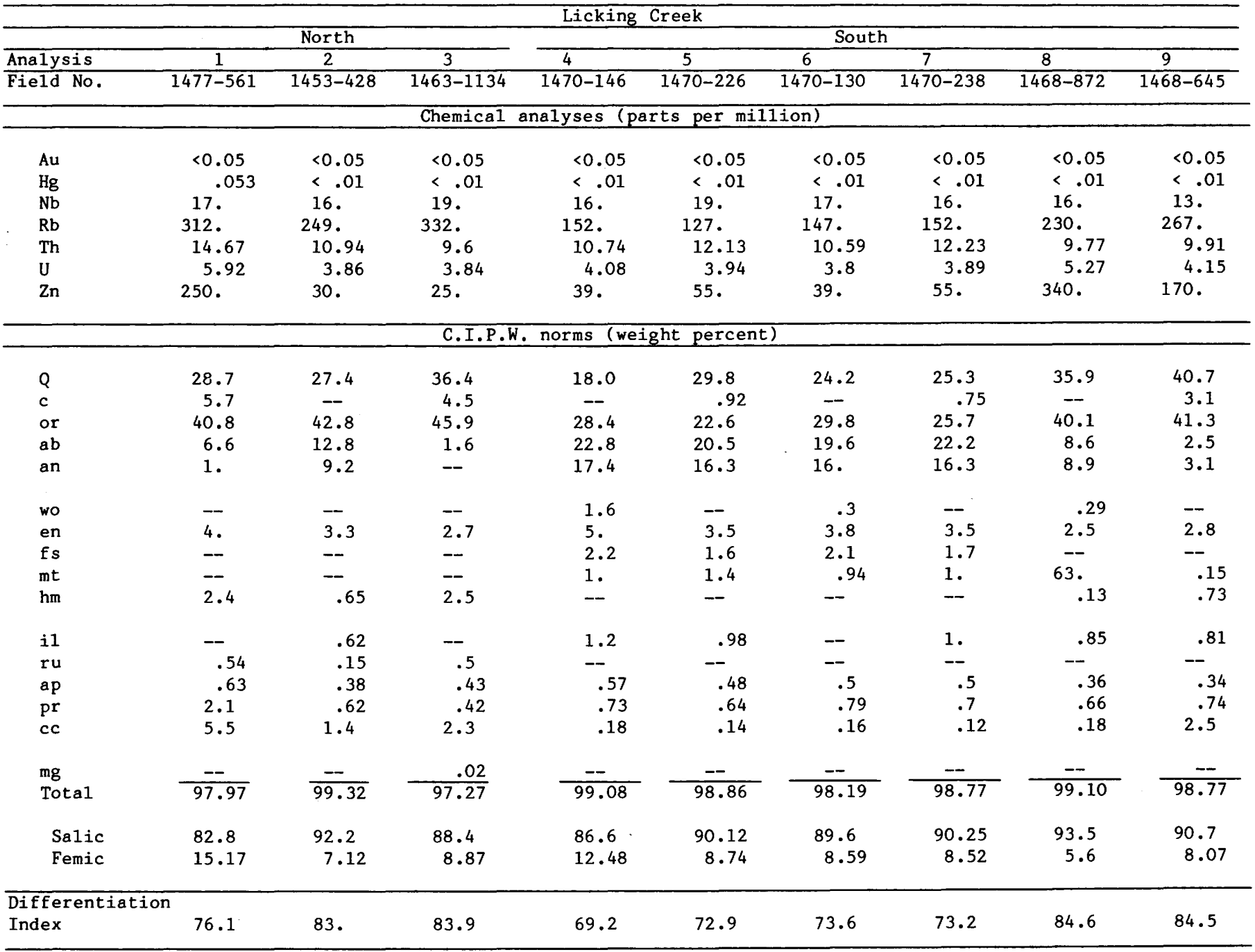

1. Drill hole no. 1477; Depth, $171.0 \mathrm{~m} ; \mathrm{P}, \mathrm{IA}$.

2. Drill hole no. 1453; Depth, 130.5 m; P, Prp, IA.

3. Dri1l hole no. 1463; Depth, $345.6 \mathrm{~m} ; \mathrm{P}$, Phy (trace).

4. Dril1 hole no. 1470; Depth, $44.5 \mathrm{~m}$; P, Prp, IA (trace).

5. Drill hole no. 1470; Depth, $68.9 \mathrm{~m} ; \mathrm{P}, \operatorname{Prp}$, IA.

6. Drill hole no. 1470; Depth, $39.6 \mathrm{~m}$; P, IA, Prp.

7. Drill hole no. 1470; Depth, $72.5 \mathrm{~m}$; P, Prp, IA (trace).

8. Drill hole no. 1468; Depth, $265.8 \mathrm{~m}$; P, IA.

9. Drill hole no. 1468; Depth, $196.6 \mathrm{~m} ; \mathrm{P}$, IA (trace).

of the minor elements in the Buckingham system require additional comment.

The range in the rubidium contents of igneous rocks of the Buckingham system shows both some similarities to and some differences from those typical of Climax-type systems. Unaltered monzogranite porphyry and altered aplite at Buckingham apparently contain abundances of rubidium characteristic of the Climax-type systems (fig. 72). In addition, the mean rubidium content in altered monzogranite porphyry (approx $210 \mathrm{ppm}$ ) is somewhat less than the minimum rubidium content thought to be favorable for Climax-type deposits $(250 \mathrm{ppm})$. The upper limit of rubidium content in these samples is more than $300 \mathrm{ppm}$. The high rubidium contents in these rocks are considered primarily to indicate the intense potassium metasomatism that the rocks have undergone. The $\mathrm{Rb} / \mathrm{Sr}$ ratio, however, is still significantly lower in these rocks than in Climax-type systems because of 
TABLE 21.-Analytical data of Late Cretaceous aplite in the East stock of the Buckingham porphyry molybdenum system, Lander County, Nevada

[Both aplites underwent sparse phyllic alteration associated with secondary carbonate. Chemical analyses in weight percent by X-ray spectroscopy supplemented by classical methods; analysts, S. Ramage and J. Riviello. Emission-spectroscopic analyses in parts per million; analyst, J. Kent. Cross, Iddings, Pirsson, and Washington (CIPW) norms in weight percent. Relative standard deviation of any single reported concentration should be taken as plus 50 percent and minus 33 percent. Looked for, but not found, at parts-per-million detection levels in parentheses: $\mathrm{Ag}(0.5), \mathrm{As}(300), \mathrm{Au}(14), \mathrm{Be}(2), \mathrm{Bi}(14), \mathrm{Cd}(14)$, Co (2), $\mathrm{Nb}(20), \mathrm{Pb}$ (14), Sb (40), W (20), Y (14), Ce (100), Ge (14), In (3), Re (14), Tl (6), Yb (2). Au, $\mathrm{Hg}$, and $\mathrm{Zn}$ determined by atomic-absorption spectroscopy; analysts, W. D'Angelo, J. Kane, and R. Moore. W determined colorimetrically; analysts, W. D'Angelo, J Kane, and R. Moore. F determined by specific-ion-electrode methods; analyst, $J$ Riviello. Cl determined spectrophotometrically; analyst, V. McDaniel. Th and U determined by instrumental delayed-neutron counting, using methods of Millard and Keaten (1982); analysts, B. Vaughn, M. Coughlin, S. Danahey, and J. Story. $\mathrm{Nb}$ and $\mathrm{Rb}$ determined by $\mathrm{X}$-ray spectroscopy; analyst, Harry Rose. - , not detected]

\begin{tabular}{lcc}
\hline Depth (m) & 153.9 & 188.4 \\
\hline Field no. & $79 \mathrm{C} 89$ & $79 \mathrm{C} 90$ \\
\hline Chemical analyses (weight & percent) \\
\hline
\end{tabular}

\begin{tabular}{|c|c|c|}
\hline $\mathrm{SiO}_{2}$ & 66.86 & 68.72 \\
\hline $\mathrm{Al}_{2} \mathrm{O}_{3}$ & 12.68 & 12.84 \\
\hline $\mathrm{Fe}_{2}^{2} \mathrm{O}_{3}$ & 1.42 & 1.02 \\
\hline $\mathrm{FeO}$ & .16 & .1 \\
\hline $\mathrm{MgO}$ & 1.8 & 1.5 \\
\hline $\mathrm{CaO}$ & 2.94 & 2.02 \\
\hline $\mathrm{Na}_{2} \mathrm{O}$ & 1.06 & .96 \\
\hline $\mathrm{K}_{2}$ & 9.19 & 10.07 \\
\hline $\mathrm{H}_{2}^{2} \mathrm{O}+$ & 1.05 & .55 \\
\hline $\mathrm{H}_{2}^{2} \mathrm{O}^{-}$ & .1 & .11 \\
\hline $\mathrm{TiO}_{2}$ & .47 & .44 \\
\hline $\mathrm{P}_{2} \mathrm{O}_{5}^{2}$ & .2 & .19 \\
\hline $\mathrm{MnO}^{\circ}$ & .05 & .05 \\
\hline $\mathrm{CO}_{2}$ & 2.31 & 1.61 \\
\hline$F^{2}$ & .07 & .08 \\
\hline $\mathrm{Cl}$ & .004 & .006 \\
\hline Subtotal & 100.36 & 100.26 \\
\hline Less $\mathrm{O}=\mathrm{F}$ & .03 & .03 \\
\hline Total & 100.33 & 100.23 \\
\hline
\end{tabular}

Emission spectroscopic analyses (parts per million)

$\begin{array}{lrr}\mathrm{B} & 5.0 & -- \\ \mathrm{Ba} & 2000 . & 2000.0 \\ \mathrm{Cr} & 12 . & 8 . \\ \mathrm{Cu} & 33 . & 4 . \\ \mathrm{La} & 31 . & 40 . \\ \mathrm{Mo} & 18 . & 57 . \\ \mathrm{Ni} & 5 . & 6 . \\ \mathrm{Sc} & 6 . & 6 . \\ \mathrm{Sn} & 10 . & -- \\ \mathrm{Sr} & 350 . & 300 . \\ \mathrm{V} & & 60 . \\ \mathrm{Zr} & 65 . & 100 . \\ \mathrm{Ga} & 130 . & 14 .\end{array}$

TABLE 21.-Analytical data of Late Cretaceous aplite in the East stock of the Buckingham porphyry molybdenum system, Lander County, Nevada-Continued

\begin{tabular}{|c|c|c|}
\hline Depth (m) & 153.9 & 188.4 \\
\hline Field no. & $79 C 89$ & 79090 \\
\hline & analyses (parts & per mil1i \\
\hline $\mathrm{Au}$ & $<0.05$ & $<0.05$ \\
\hline $\mathrm{Hg}$ & .27 & .12 \\
\hline $\mathrm{Nb}$ & 19. & 17. \\
\hline $\mathrm{Rb}$ & 323. & 351 . \\
\hline Th & 10.8 & 12. \\
\hline $\mathrm{U}$ & 5.36 & 8.73 \\
\hline W & 19. & 17. \\
\hline $\mathrm{Zn}$ & 30 . & 20 . \\
\hline
\end{tabular}

\begin{tabular}{|c|c|c|c|c|c|}
\hline & C.I & W. norms & (weight & percent) & • \\
\hline$Q$ & & 23.17 & & 22.76 & \\
\hline c & & .99 & & .37 & \\
\hline or & & 54.16 & & 59.41 & \\
\hline$a b$ & & 8.92 & & 8.07 & \\
\hline an & & -- & & -- & \\
\hline h1 & & .01 & & .01 & \\
\hline en & & 3.86 & & 3.06 & \\
\hline $\mathrm{hm}$ & & 1.42 & & 1.02 & \\
\hline il & & .44 & & .32 & \\
\hline $\mathbf{r u}$ & & .24 & & .27 & \\
\hline ap & & .47 & & .45 & \\
\hline $\mathrm{fr}$ & & .11 & & .13 & \\
\hline$c c$ & & 4.63 & & 2.99 & \\
\hline $\mathrm{mg}$ & & .52 & & .56 & \\
\hline & Total & 98.94 & & 99.42 & \\
\hline & Sa1ic & 87.24 & & 90.61 & \\
\hline & Femic & 11.7 & & 8.81 & \\
\hline \multicolumn{6}{|c|}{ Differentiation } \\
\hline Index & & 86.25 & & 90.24 & \\
\hline
\end{tabular}

the extremely low strontium contents in the latter, generally less than $50 \mathrm{ppm}$ (Ludington, 1981). A plot of rubidium versus $\mathrm{SiO}_{2}$ contents in igneous rocks of the Buckingham system would show them to fall in the "within plate" magma type of Pearce and Gale (1977). However, the applicability of such a plot as a discriminant for the tectonic settings of magmas is diminished for these samples because of the widespread secondary potassic alteration here.

The extremely high barium contents in analyzed samples (approx. mean, 2,000 ppm for altered monzogranite porphyry and altered aplite; fig. 72) may be because the mining district is part of a high-barium province. Barium in analyzed samples 
TABLE 22.-Analytical data on metamorphosed and hydrothermally altered samples of the Upper Cambrian Harmony Formation from the general area of the East stock in the Buckingham stockwork molybdenum deposit

[Chemical analyses in weight percent by single-solution method of Shapiro (1975); analysts, K. Coates and H. Smith. Emission-spectrographic analyses in parts per million; analyst, J.L. Harris. Relative standard deviation of any single reported concentration should be taken as plus 50 percent and minus 33 percent. Looked for, but not found, at parts-per-million detection levels in parentheses: As (150), $\mathrm{Au}(10)$, Bi (15), Cd (32), Dy (22), Er (10), Gd (15), Ge (1.5), Hf (15), Ho (6.8), In (6.8), Ir (15), Li (68), Lu (22), Nd (46), Os (22), Pd (1.5), Pr (68), Pt (6.8) Re (10), Rh (2.2), Ru (3.2), Sb (46), Sm (22), Ta (460), Tb (32), Th (4.6), W (10). Au, Hg, and $\mathrm{Zn}$ determined by atomic-absorption spectroscopy; analysts, J. Budinsky and R. Moore. F determined by specific-ion electrode methods; analysts, J. Budinsky and R. Moore. Cl determined spectrophotometrically; analysts, J. Budinsky and R. Moore. Th and $\mathrm{U}$ determined by instrumental delayed-neutron counting, using method of Millard and Keaten (1982); analysts, H.T. Millard, Jr., F.M. Luman, and B.A. Keaten. $\mathrm{Nb}$ and $\mathrm{Rb}$ determined by $\mathrm{X}$-ray spectroscopy; analysts, R. Johnson, H.J. Rose, B. McCall, G. Sellers, and J. Lindsay. —, not detected]

\begin{tabular}{lcc}
\hline Analysis & 1 & 2 \\
\hline Field No. & $1464-185$ & $1471-760$ \\
\hline & & \\
\hline
\end{tabular}

\begin{tabular}{|c|c|c|}
\hline $\mathrm{SiO}_{2}$ & 82.5 & 84.2 \\
\hline $\mathrm{Al}_{2} \mathrm{O}_{3}$ & 7.8 & 6.3 \\
\hline $\mathrm{Fe}_{2} \mathrm{O}_{3}^{3}$ & .98 & 1.7 \\
\hline $\mathrm{FeO}^{3}$ & .44 & .12 \\
\hline $\mathrm{MgO}$ & .91 & .22 \\
\hline $\mathrm{CaO}$ & .13 & .03 \\
\hline $\mathrm{Na}_{2} \mathrm{O}$ & .3 & .09 \\
\hline $\mathrm{K}_{2} \mathrm{O}$ & 5.2 & 4.3 \\
\hline $\mathrm{H}_{2}^{2} \mathrm{O}+$ & .48 & .4 \\
\hline $\mathrm{H}_{2} \mathrm{O}-$ & .26 & .12 \\
\hline $\mathrm{TiO}_{2}$ & .36 & .28 \\
\hline $\mathrm{P}_{2} \mathrm{O}_{5}^{2}$ & .04 & .03 \\
\hline $\mathrm{MnO}^{\circ}$ & -- & -- \\
\hline $\mathrm{CO}_{2}$ & .01 & .01 \\
\hline$F^{2}$ & .092 & .033 \\
\hline $\mathrm{Cl}$ & .02 & .017 \\
\hline$S($ tota 1$)$ & .8 & 1.4 \\
\hline Subtotal & $\overline{100.32}$ & 99.25 \\
\hline S(sulfide) & - .7 & 1.3 \\
\hline Less $\mathrm{O}=\mathrm{F}, \mathrm{Cl}, \mathrm{S}$ & $\frac{.34}{99.88}$ & $\frac{.57}{98.68}$ \\
\hline
\end{tabular}

of igneous rocks from the Buckingham system probably is present mostly in K-feldspar, both primary and secondary, and in primary biotite. Devonian rocks in the region are one of the premier bedded-barite-producing metallotects in the world (Papke, 1984). Highly elevated local background levels for barium have been documented for the Devonian Scott Canyon Formation in the southern part of the mining district (Theodore and Roberts, 1971) and for much of the Tertiary mineralization in the southern part of the mining district (Theodore and Blake, 1975, 1978).
TABLE 22.-Analytical data on metamorphosed and hydrothermally altered samples of the Upper Cambrian Harmony Formation from the general area of the East stock in the Buckingham stockwork molybdenum deposit-Continued

\begin{tabular}{lcc}
\hline Analysis & 1 & 2 \\
\hline Field No. & $1464-185$ & $1471-760$ \\
\hline Emission spectrographic analyses (parts per million)
\end{tabular}

\begin{tabular}{|c|c|c|}
\hline $\mathrm{Ag}$ & 0.37 & 1.7 \\
\hline B & 7.4 & 18 \\
\hline $\mathrm{Ba}$ & 930. & 870 \\
\hline $\mathrm{Be}$ & 1.4 & - \\
\hline $\mathrm{Ce}$ & 64. & -- \\
\hline Co & 4.2 & 4.8 \\
\hline $\mathrm{Cr}$ & 53. & 29. \\
\hline $\mathrm{Cu}$ & 88. & 73. \\
\hline $\mathrm{Ga}$ & 13. & 18.4 \\
\hline $\mathrm{La}$ & 35. & 21 \\
\hline Mn & 160 & 49. \\
\hline Mo & 530 & 220 . \\
\hline $\mathrm{Nb}$ & 2.8 & -- \\
\hline $\mathrm{Ni}$ & 21 & 17. \\
\hline $\mathrm{Pb}$ & 8.1 & 7.2 \\
\hline $\mathrm{Sc}$ & 8.2 & 4.7 \\
\hline $\mathrm{Sn}$ & 5.1 & 2.8 \\
\hline $\mathrm{Sr}$ & 220 & 75 \\
\hline V & 57. & 34. \\
\hline$Y$ & 12. & 9.6 \\
\hline $\mathrm{Yb}$ & 1.9 & 1.6 \\
\hline $\mathrm{Zr}$ & 74 . & 120 \\
\hline \multicolumn{3}{|c|}{ Chemical analyses (parts per million) } \\
\hline $\mathrm{Au}$ & $<0.05$ & $<0.05$ \\
\hline $\mathrm{Hg}$ & -- & .016 \\
\hline $\mathrm{Nb}$ & 11. & 12. \\
\hline $\mathrm{Rb}$ & 187. & 166. \\
\hline Th & 10.63 & 7.77 \\
\hline $\mathrm{U}$ & 2.53 & 1.9 \\
\hline $\mathrm{Zn}$ & 85. & 21 \\
\hline
\end{tabular}

1. Potassic altered and veined subarkose; largely matrix supported; superposed weak phyllic alteration; and weak intermediate argillic alteration of framework feldspar.

2. Potassic altered and veined subarkose or quartz arenite; matrix-supported; sparse phyllic alteration. 


\section{ASSOCIATED SKARN ALTERATION}

Some rocks of the Upper Cambrian Harmony Formation have been altered to calcic skarn apparently more or less penecontemporaneously with the emplacement of the Buckingham molybdenum system during the Late Cretaceous. Specifically, most of the garnet-pyroxene skarn exposed somewhat continuously for about $1.5 \mathrm{~km}$ from a point westnorthwest of the Surprise Mine through the Contention pit of the Copper Basin Mine (pl. 1) appears to be related to the molybdenum system.
This particular body of skarn near its north end is bounded on the east by siliceous conglomerate of the Battle Formation; it is termed "skarn D" in the section below entitled "Mineral Chemistry of Late Cretaceous and Tertiary Skarns." In the Contention pit, the skarn is cut unequivocally by Late Cretaceous monzogranite porphyry (see subsection below entitled "Supergene Copper Deposits at Copper Basin"). Thus, the prograde assemblages of skarn D cannot be associated with emplacement of nearby Tertiary igneous bodies, some of which also are associated with skarn as described above. At
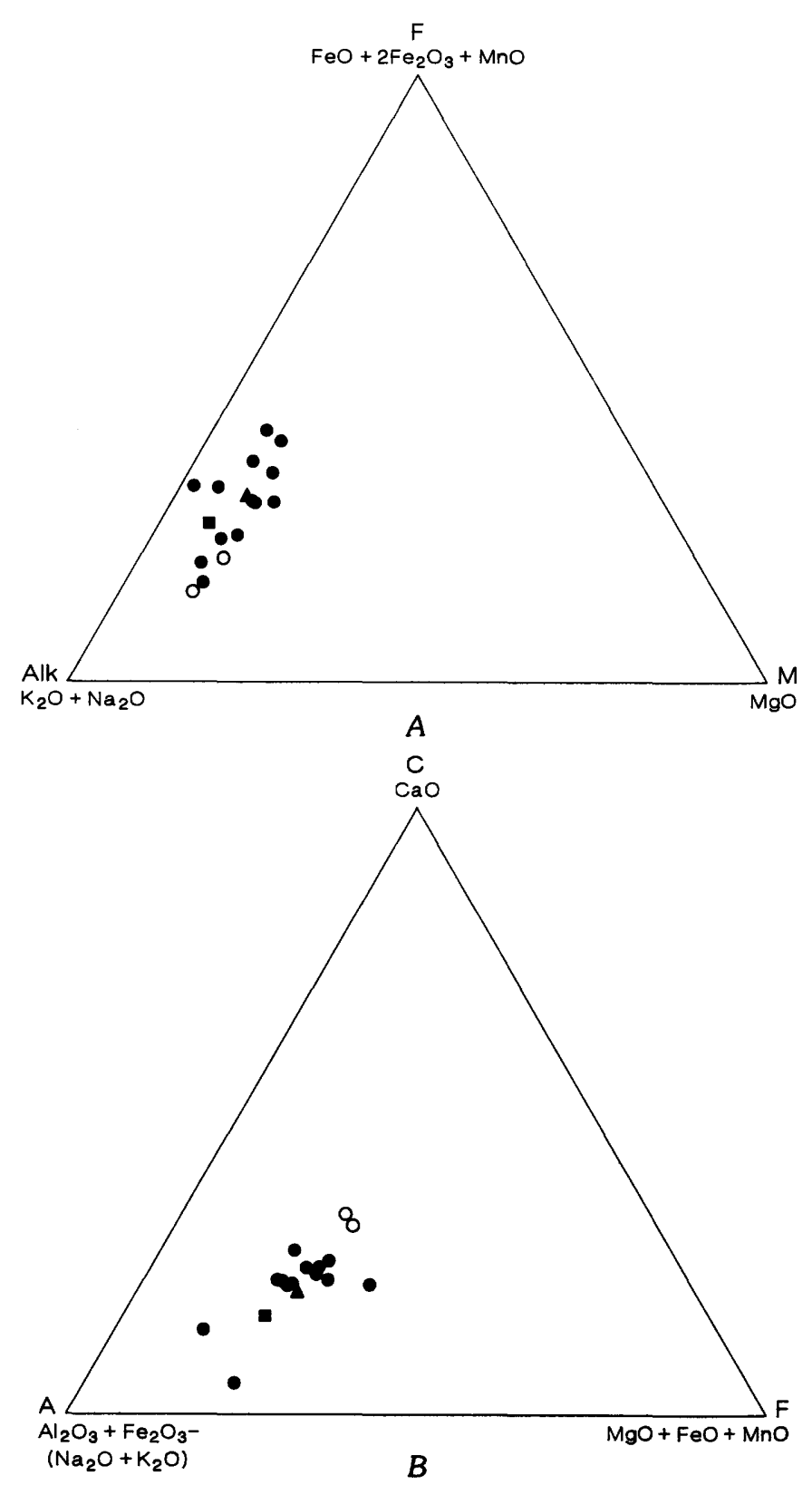

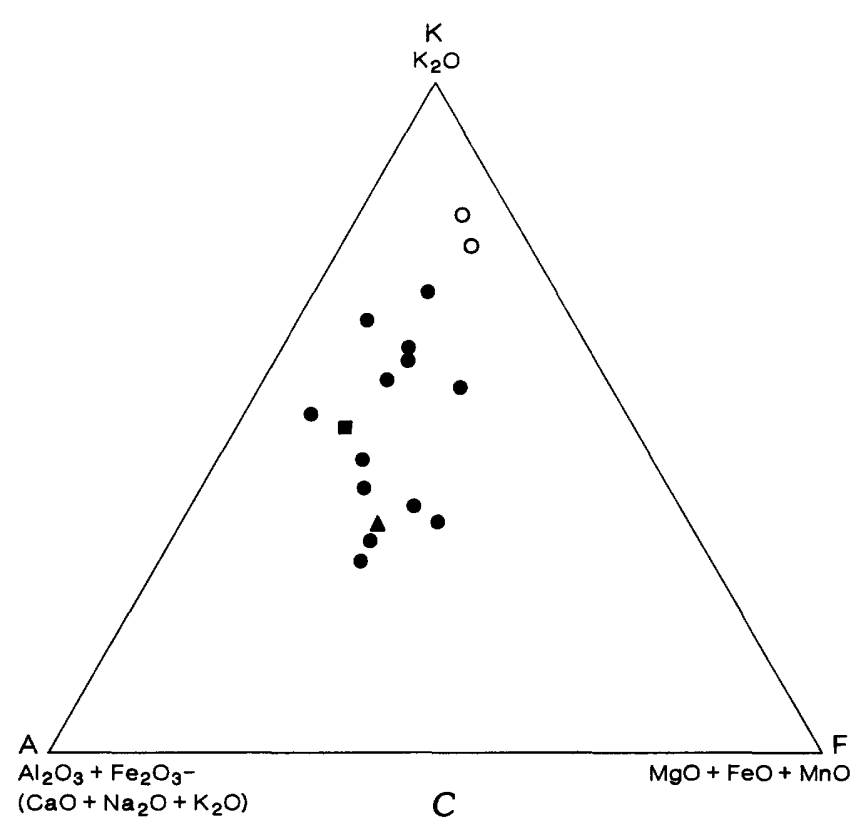

EXPLANATION

- Altered monzogranite porphyry

- Fresh monzogranite porphyry

- Altered megacryst porphyry

- Altered aplite

FIGURE 71.-Ternary chemical diagrams of analyzed fresh monzogranite porphyry, altered monzogranite porphyry, altered megacryst porphyry, and altered aplite from Buckingham stockwork molybdenum system. $A$, AlkFM diagram. $B$, ACF diagram. $C$, AKF diagram. See tables 14, 17, 20, and 21 for analytical data. 
TABLE 23.-Mean values and standard deviations for major-element cations in a standard cell of 160 oxygens calculated for 11 samples of altered monzogranite porphyry compared with fresh monzogranite porphyry from the Buckingham stockwork molybdenum system

\begin{tabular}{lcc}
\hline Analysis & 1 & 2 \\
\hline $\mathrm{Si}$ & $67.87 \pm 5.44$ & 64.48 \\
$\mathrm{Al}$ & $14.73 \pm 3.27$ & 16.36 \\
$\mathrm{Fe}^{3+}$ & $.7 \pm .35$ & .65 \\
$\mathrm{Fe}^{2+}$ & $1.2 \pm .58$ & 1.5 \\
$\mathrm{Mg}$ & $1.72 \pm .69$ & 1.83 \\
$\mathrm{Ca}$ & $2.81 \pm 1.26$ & 3.03 \\
$\mathrm{na}$ & $2.82 \pm 1.71$ & 5.49 \\
$\mathrm{k}$ & $7.18 \pm 1.5$ & 5.3 \\
$\mathrm{p}$ & $.14 \pm .03$ & .04 \\
$\mathrm{ti}$ & $.33 \pm .09$ & .23 \\
& & \\
\hline
\end{tabular}

1. Altered monzogranite porphyry; from tables 17 and 20.

2. Fresh monzogranite porphyry; from analysis 1 , table 14 .

the Labrador Mine (pl. 1), Late Cretaceous skarn D has been intruded by late Eocene or Early Oligocene porphyritic leucogranite that contains phenocrysts of abundant diopside and sparse hornblende (blue green, optic Z-axis). The introduction of gold at this deposit appears to be related to the porphyritic leucogranite (Schmidt and others, 1988). In the Copper Canyon area, copper-gold-silver-bearing skarn of the West ore body also is cut by the genetically associated altered granodiorite at the currently exposed levels of the system there (Theodore and Blake, 1978). However, because of the following relations associated with the $1.5-\mathrm{km}$-long body of skarn D in the Copper Basin area, we conclude that most of its prograde paragenesis is probably related to magmatism during the Late Cretaceous associated with the Buckingham molybdenum system: (1) overall metal zoning in the skarn body (including an increase in copper and silver contents from north to south toward the monzogranite porphyry), (2) a significant increase toward the south in the retrograde replacement of magnetite and anhydrous calc-silicates by various sulfide-hydrous silicate assemblages, and (3) the mapped relation of the skarn to Late Cretaceous monzogranite porphyry.

Several significant areal and paragenetic changes occur in the mineralogy and fabric of the skarn. Near its northern distal end, the skarn includes essentially a garnet prograde assemblage. Here, the skarn is generally massive, and it contains sparse localities wherein a weakly developed layered fabric is suggestive of original bedding. For the most part, drab-pale-amber to slightly olive green, very early stage or first-generation garnet imparts a tightly packed, granulose texture to the rocks; garnet at this stage may be, on average, about 1 to $2 \mathrm{~mm}$ in grain size. This garnet is followed paragenetically by a well-developed, second-generation, red-brown (in hand sample) garnet that cuts the first-generation garnet along discontinuous, very poorly bounded veins. Individual crystals among these late-stage garnet veins commonly measure as much as $1 \mathrm{~cm}$ wide. Alteration selvages are lacking on the borders of the veins. Microscopic examination of vein-wallrock boundaries suggests that the second-generation garnet veins apparently crystallized largely in an openspace environment temporally without probably much of an intervening time gap from the previously crystallized garnet. First-generation garnet is largely anisotropic, although single and multiple isotropic growth zones characterize some crystals. These garnets are mostly andraditic in composition and range from $\mathrm{Ad}_{72}$ to $\mathrm{Ad}_{74}$ in overall composition (see section below entitled "Mineral Chemistry of Late Cretaceous and Tertiary Skarns"). As pointed out in the aforementioned section by Hammarstrom, second-generation garnets include a significant proportion as an isotropic, yellow-green (in thin section) core $\left(\mathrm{Ad}_{99}\right)$ that is mantled by thin, anisotropic growth zones $\left(\mathrm{Ad}_{56}-\mathrm{Ad}_{82}\right)$. In addition, the remaining open spaces in skarn are filled by K-feldspar and quartz during the final, anhydrous stages of the skarn. However, late-stage potassium metasomatism present in some rocks of skarn $D$ may be a distal effect of the late Eocene or early Oligocene emplacement of porphyritic leucogranite at the Labrador Mine. As described above, some metasomatic facies associated with this intrusive event show significant introduction of K-feldspar. Such rocks also include traces of definitely retrograde secondary biotite, altered partially to chlorite, and epidote. This unsulfidized garnet skarn shows extremely high $\mathrm{Fe}_{2} \mathrm{O}_{3} / \mathrm{FeO}$ ratios (analysis 1 , table 24) and other major-oxide ratios $\left(\mathrm{CaO} / \mathrm{Al}_{2} \mathrm{O}_{3}, \mathrm{Fe}_{2} \mathrm{O}_{3} / \mathrm{Al}_{2} \mathrm{O}_{3}\right)$ that are controlled largely by the strong andraditic composition of the garnets. Most of the fluorine in the rock (0.22 weight percent; analysis 1 , table 24 ) probably is present in the small amounts of retrograde hydrous silicates there.

The localization of this extensive body of skarn in rocks of the Harmony Formation along the contact between the Harmony and Battle Formations emphasizes thereby the dual importance that permeable channelways and chemically reactive hosts have in the development of such rocks. Although all the chemically reactive rocks at the stratigraphic position of the skarn have been altered 

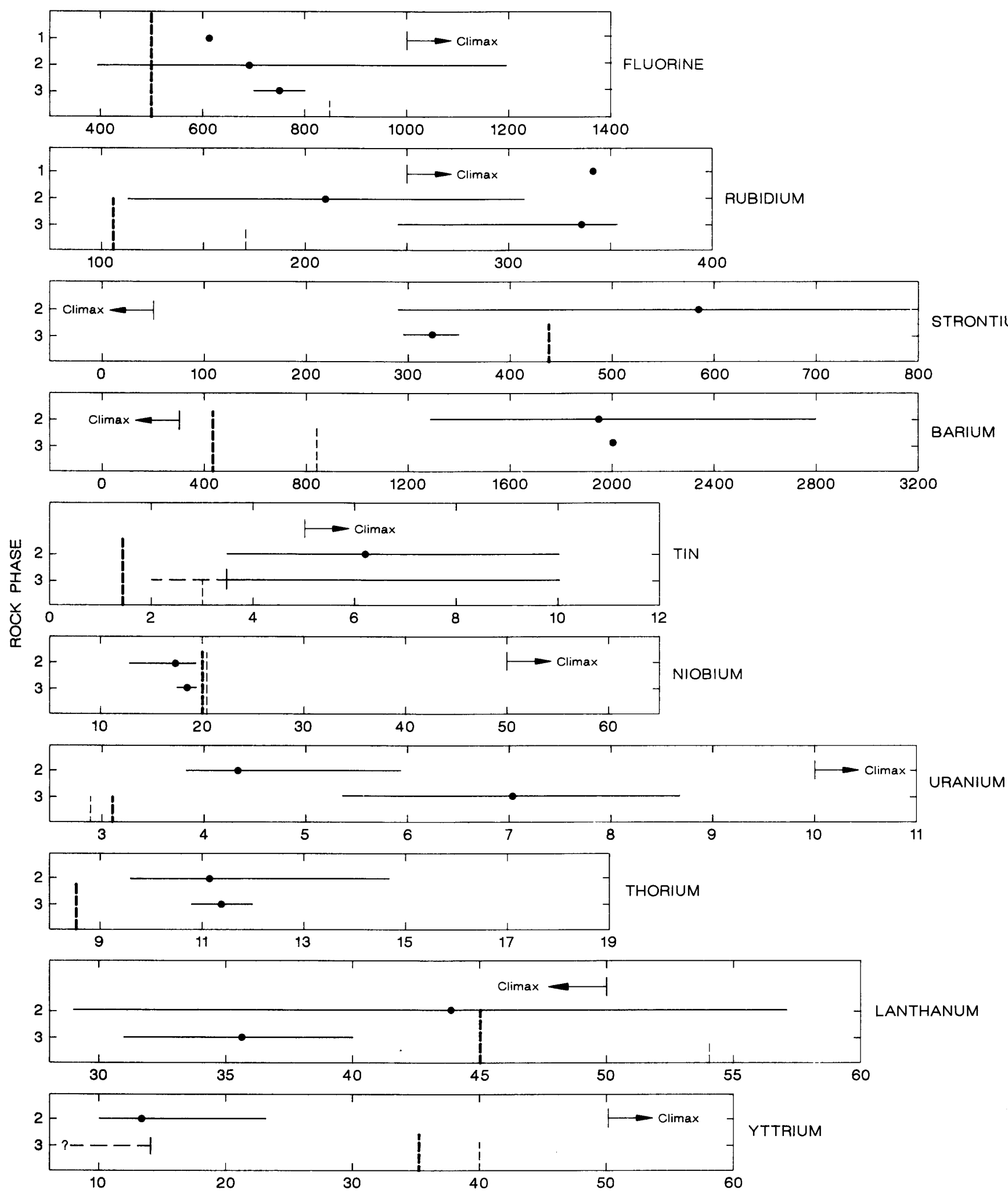

RANGE IN VALUES

Figure 72.-Comparison of range in values and mean for fluorine, rubidium, strontium, barium, tin, niobium, uranium, thorium, lanthanum, and yttrium in various igneous phases of Buckingham stockwork molybdenum deposit. All values in parts per million. Data from tables 17, 20, and 21. Rock phases: 1, fresh quartz monzonite porphyry; 2, altered monzogranite porphyry; 3 , altered aplite. Abundances in av- erage granite and average granodiorite from Parker (1967). Values for Climax-type stockwork molybdenum systems (arrows) in their source igneous rocks from Ludington (1981). Dot, mean value; bar, range of detected values, dashed where below detection level, queried where uncertain; heavy vertical dashed line, average granodiorite; light vertical dashed line, average granite. 
TABLE 24.-Analytical data on garnet skarn formed in the Upper Cambrian Harmony Formation penecontemporaneously with Late Cretaceous molybdenum mineralization

[Chemical analyses in weight percent by rapid rock methods of Shapiro (1975); analysts, K. Coates and H. Smith. Emission-spectrographic analyses in parts per million; analyst, Leung Mei. F determined by specific-ion-electrode methods, $\mathrm{Au}$ and $\mathrm{Hg}$ determined by atomic-absorption spectroscopy, and $\mathrm{Cl}$ and $\mathrm{W}$ determined spectrophotometrically; analyst, $R$. Moore. Relative standard deviation of any single reported concentration should be taken as plus 50 percent and minus 33 percent. Looked for, but not found: B, Bi, Cd, Dy, Er, Hf, Ho, In, Ir, Li, Lu, Nd, Os, Pd, Pr, $\mathrm{Pt}, \mathrm{Re}, \mathrm{Rh}, \mathrm{Ru}, \mathrm{Sb}, \mathrm{Sm}, \mathrm{Ta}, \mathrm{Tb}, \mathrm{Th}, \mathrm{Tl}, \mathrm{Tm}, \mathrm{U}, \mathrm{W} .-$, not detected; n.d., not determined]

\begin{tabular}{|c|c|c|c|c|c|c|}
\hline$\frac{\text { Analysis }}{\text { Field No. }}$ & $\frac{1}{76 \mathrm{CB} 2}$ & $\frac{2}{76 \mathrm{CB} 4}$ & $\frac{3}{76 \mathrm{CB} 5}$ & $\frac{4}{76 \mathrm{CB} 7}$ & $\frac{5}{76 \mathrm{CB} 9}$ & $\frac{6}{76 \mathrm{CB} 10}$ \\
\hline & Chemical & analyses & (weight & percent) & & \\
\hline $\mathrm{SiO}_{2}$ & 38.0 & 40.9 & 36.7 & 38.8 & 37.4 & 31.7 \\
\hline $\mathrm{A} 1, \mathrm{O}_{3}$ & 6.4 & 7.3 & 4.4 & 10.8 & 5.4 & 8.5 \\
\hline $\mathrm{Fe}_{2}^{2} \mathrm{O}_{3}$ & 22.1 & 16.2 & 25. & 12.8 & 22.8 & 13.5 \\
\hline FeO & .52 & .72 & .92 & 1.1 & .8 & 16.2 \\
\hline $\mathrm{MgO}$ & .17 & 2.7 & .17 & .66 & .15 & .78 \\
\hline $\mathrm{CaO}$ & 32.2 & 29. & 32. & 28.6 & 31. & 21.5 \\
\hline $\mathrm{Na}_{2} \mathrm{O}$ & -- & .01 & -- & .01 & -- & .12 \\
\hline $\mathrm{K}_{2} \mathrm{O}$ & .06 & .13 & .06 & .56 & .1 & .3 \\
\hline $\mathrm{H}_{2}^{2} \mathrm{O}^{+}$ & .25 & .73 & .46 & .54 & .52 & .99 \\
\hline $\mathrm{H}_{2}^{2} \mathrm{O}^{-}$ & .1 & 1.1 & .2 & .27 & .22 & .59 \\
\hline $\mathrm{TiO}_{2}$ & .28 & .77 & .93 & .71 & .14 & .43 \\
\hline $\mathrm{P}_{2} \mathrm{O}_{5}^{2}$ & .06 & .07 & .15 & .2 & .07 & .06 \\
\hline $\mathrm{MnO}^{2}$ & .2 & .24 & .13 & .16 & .15 & .38 \\
\hline $\mathrm{CO}_{2}$ & .01 & .01 & .01 & 4.2 & .08 & .06 \\
\hline $\mathrm{F}$ & .22 & .25 & .23 & .27 & .27 & .19 \\
\hline
\end{tabular}

\begin{tabular}{|c|c|c|c|c|c|c|}
\hline $\begin{array}{c}\text { Ignition loss, } \\
\text { less } \mathrm{CO}_{2}+\mathrm{H}_{2} \mathrm{O} \\
\text { Subtotal } \\
\text { Less } \mathrm{O}=\mathrm{F} \\
\text { Total }\end{array}$ & $\begin{array}{r}\text { N.D. } \\
100.57 \\
.09 \\
100.48\end{array}$ & $\begin{array}{r}\text { N.D. } \\
100.13 \\
100.02\end{array}$ & $\begin{array}{c}\frac{\text { N.D. }}{101.36} \\
\frac{.1}{101.26}\end{array}$ & $\begin{array}{r}\text { N.D. } \\
99.68 \\
.11 \\
99.57\end{array}$ & $\begin{array}{r}\text { N.D. } \\
99.10 \\
.11 \\
98.99\end{array}$ & $\begin{array}{r}4.7 \\
95.3 \\
.08 \\
95.22\end{array}$ \\
\hline Emissi & pectrogr & phic ans & lyses (p & arts per & million & \\
\hline $\mathrm{Ag}$ & - & 0.21 & 0.67 & - & 1.5 & 4.1 \\
\hline As & 210.0 & -- & 210. & - & 340. & -- \\
\hline $\mathrm{Ba}$ & 16. & 23. & 29. & 32. & 24. & 5.8 \\
\hline $\mathrm{Be}$ & -- & .81 & - & .8 & -- & 1.2 \\
\hline $\mathrm{Ce}$ & 84. & -- & -- & 150. & -- & -- \\
\hline Co & -- & 9.1 & 16. & 4.1 & 12. & 36. \\
\hline $\mathrm{Cr}$ & 24. & 870 & 130. & 81. & 17. & 22 . \\
\hline $\mathrm{Cu}$ & 11. & 330 & 170. & 14. & 480. & $>3200$. \\
\hline $\mathrm{Eu}$ & 2. & - & 2.7 & 2.3 & -- & 5.5 \\
\hline $\mathrm{Ga}$ & & & & & & \\
\hline Gd & 15. & 16. & 22 . & 29. & 29. & 38. \\
\hline $\mathrm{Ge}$ & - & - & - & 6.9 & - & 7. \\
\hline $\mathrm{La}$ & 25. & -- & 16. & 77. & -- & 43. \\
\hline Mo & -- & 15. & 20. & 9.2 & 13. & 22. \\
\hline $\mathrm{Nb}$ & 10. & 19. & 21 . & 17. & -- & 26. \\
\hline $\mathrm{Ni}$ & 7. & 61. & 10. & 15. & 26 . & 31. \\
\hline $\mathrm{Pb}$ & 15. & 70. & 35. & 16. & - & 23. \\
\hline Sc & 6.7 & 20. & 11. & 12. & 4.9 & 9. \\
\hline Sn & 14. & 34 . & 28. & 33. & 77. & 62. \\
\hline $\mathrm{Sr}$ & 6.5 & 17. & 8.7 & 240. & 11. & 6.6 \\
\hline $\mathrm{V}$ & 44. & 130. & 58. & 60. & 33. & 63. \\
\hline $\begin{array}{l}\mathrm{Y} \\
\mathrm{Yb}\end{array}$ & $\begin{array}{r}18 . \\
3.9\end{array}$ & $\begin{array}{l}32 . \\
4.3\end{array}$ & $\begin{array}{r}21 . \\
4.3\end{array}$ & $\begin{array}{c}18 . \\
2.6\end{array}$ & $\begin{array}{l}20 . \\
4.2\end{array}$ & $\begin{array}{l}22 . \\
3.5\end{array}$ \\
\hline $\mathrm{Zn}$ & 110. & 210 & 130. & 81. & 160. & 120. \\
\hline $\mathrm{Zr}$ & 160. & 86. & 280 & 97. & 38. & 220 . \\
\hline
\end{tabular}

entirely to some variant of skarn, including either prograde and (or) retrograde facies, these rocks probably contained a significant component of carbonate before their alteration. However, the presence of some relict clots of detrital carbonate in the largely siliceous conglomerate of the Battle Formation that abuts the skarn suggests that penetration of skarn-forming fluids was not pervasive. The
TABLE 24.-Analytical data on garnet skarn formed in the Upper Cambrian Harmony Formation penecontemporaneously with Late Cretaceous molybdenum mineralization-Continued

\begin{tabular}{|c|c|c|c|c|c|c|}
\hline $\begin{array}{l}\text { Analysis } \\
\text { Field No. }\end{array}$ & $\frac{1}{76 \mathrm{CB} 2}$ & $\frac{2}{76 \mathrm{CB} 4}$ & $\frac{3}{76 \mathrm{CB} 5}$ & $\frac{4}{76 \mathrm{CB} 7}$ & $\frac{5}{76 \mathrm{CB} 9}$ & $\frac{6}{76 \text { CB10 }}$ \\
\hline \multicolumn{7}{|c|}{ Chemical analyses (parts per million) } \\
\hline $\mathrm{Cl}$ & 150.0 & 330.0 & 160.0 & 120.0 & 93.0 & 240.0 \\
\hline $\mathrm{Hg}$ & .24 & .37 & .4 & .26 & .17 & .19 \\
\hline $\mathrm{Au}$ & $<.05$ & $<.05$ & $<.05$ & $<.05$ & $<.05$ & $<.05$ \\
\hline W & 96. & 12. & 96. & 18. & 130 . & 83. \\
\hline \multicolumn{7}{|c|}{ Density $\left(\mathrm{g} / \mathrm{cm}^{3}\right)$} \\
\hline Bulk & 3.56 & 3.22 & 3.57 & 3.42 & 3.53 & 3.61 \\
\hline Powder & 3.59 & 3.32 & 3.56 & 3.29 & 3.68 & 3.66 \\
\hline
\end{tabular}

1. Garnet-magnetite (trace) skarn; mostly amber, anisotropic garnets; sparse late, red-brown isotropic garnets.

2. Garnet-pyroxene-magnetite skarn; partly replaced by irregularly shaped mats of very fine grained biotite.

3. Garnet-pyroxene (trace)-magnetite skarn; mostly amber garnets showing isotropic cores and anisotropic rims.

4. Garnet-magnetite skarn; open spaces filled by quartz, potassium feldspar, and actinolite; sparse epidote replacing garnet; carbonate relatively abundant.

5. Garnet-pyroxene (trace)-magnetite (trace) skarn; mostly red-brown anisotropic garnets; actinolite after pyroxene; some secondary biotite and $\mathrm{K}$-feldspar; trace late-stage carbonate.

6. Garnet-magnetite-pyroxene (trace) skarn partly replaced by pyrite, chalcopyrite, secondary biotite and quartz; mostly drabgray-green, anisotropic garnets.

highly siliceous, impermeable rocks near the unconformity between the Harmony and Battle Formations may have confined fluid flow.

Skarn that crops out at the Labrador Mine at an elevation of approximately $5,980 \mathrm{ft}$ on the ridge northwest of the Surprise Mine, about $300 \mathrm{~m}$ south from the north end of the 1.5-km-long body, continues to show well-developed early-stage garnet (-diopside) assemblages. For the most part, skarn in this general area includes somewhat subdued, massive, drab-olive-green exposures consisting largely of amber to somewhat reddish-tinged garnet, together with locally high abundances of diopside-all tightly packed into a granulose fabric. Compared with skarn at the north end of the body, the skarn here includes a much higher mole percentage of isotropic andradite (see section below entitled "Mineral Chemistry of Late Cretaceous and Tertiary Skarns"). However, the granulose matrix of these rocks, when observed at high magnifications, actually includes abundant microveins of garnet that are mostly devoid of diopside. Alternatively, the matrix immediately adjacent to some veins of garnet includes about 10 to 15 volume percent diopside finely dispersed as extremely fine grained, tabular crystals. All of the above relations attest to a very complex paragenetic history, and, in turn, petrochemical evolution for these rocks that appears to be the result of multiple ages of skarn formation. The skarn did not evolve during its prograde stages simply as a result of a single passage of fluid that produced fluid-rock chemical 
reactions primarily at a migrating front or interface between carbonate and calc-silicate rocks. Since the geology of plate 1 was mapped, many closely spaced drill holes and open cuts have revealed the presence of a small body of late Eocene or early Oligocene porphyritic leucogranite just below the surface at the site of the Labrador Mine (Schmidt and others, 1988). Many andradite veins that make up the fabric of skarns here are probably due to emplacement of porphyritic leucogranite (see above). In addition, sparse biotite, in part converted to chlorite, and trace amounts of secondary quartz and K-feldspar fill most of the remaining open space in these rocks. Representative grab samples from this general area (analyses $2-4$, table 24) show somewhat increased overall abundances of $\mathrm{FeO}$ and $\mathrm{MgO}$ relative to the samples analyzed from the north end of the skarn body (analysis 1); but they also show widely fluctuating $\mathrm{Fe}_{2} \mathrm{O}_{3} / \mathrm{FeO}$ ratios-probably indicative mostly of varying proportions of clinopyroxene in the samples analyzed. The contents of copper, molybdenum, and tin also show increases here, whereas two of the three samples analyzed (analyses 2, 4) contain tungsten (scheelite?), 12 and $18 \mathrm{ppm}$, respectively, although the tungsten content here is apparently much lower than that detected in the remaining samples analyzed from elsewhere along the body. The bulk of the sulfide mineralization, mostly chalcopyrite, in this general area is confined tightly to the faults that cut skarn. The overall amount of copper introduced into the rocks at the Labrador Mine in conjunction with emplacement of the late Eocene or early Oligocene porphyritic leucogranite is much less than the amount of copper associated with gold skarn mineralization at the Surprise Mine. Schmidt and others (1988) noted that copper mineralization and retrograde hematite-specularite are notably absent from the Labrador Mine, whereas minable ore at the Surprise Mine has an average grade of 0.85 weight percent $\mathrm{Cu}$. However, some samples at the Labrador Mine show slightly increased abundances of iron sulfide (pyrite and (or) pyrrhotite), now somewhat oxidized, as part of a late-stage, openspace-filling, quartz-K-feldspar-hydrous-silicate assemblage; actinolite progressively replaces biotite as the dominant hydrous silicate in this assemblage toward the south. Furthermore, garnet that lines the cavities hosting the late-stage, sulfidehydrous silicate assemblage typically is not altered visibly under the microscope. In fact, many samples of skarn remain quite porous because their cavities are not filled completely-a porosity that undoubtedly played a major role in the metallization of this skarn unit by the introduction of porphyritic leucogranite at the Labrador Mine and by Late Cretaceous monzogranite porphyry farther to the south in the area of the Copper Basin Mine.

Generally to the south of these occurrences at the Labrador Mine, skarn D becomes increasingly sulfidized as it approaches the Late Cretaceous monzogranite porphyry where monzogranite porphyry crops out near the Contention pit in the Copper Basin Mine. Pyrite is present in several textural associations: either as the major phase of the open-space-filling assemblage, or as largely monomineralic veins that cut the granulose fabric of garnet-pyroxene (trace) skarn, or finally as very fine grained, dispersed crystals that selectively replace garnet and (or) magnetite (see section below entitled "Mineral Chemistry of Late Cretaceous and Tertiary Skarns" for additional description of sulfide-silicate relations in skarn $\mathrm{D}$ ). Chalcopyrite may be a significant phase in any of the above textural associations. Comparison of a chemical analysis of a representative grab sample (analysis 6, table 24) from such highly sulfidized rocks with some of the essentially unsulfidized or very weakly sulfidized rocks of skarn farther to the north seems to reveal adequately the changes observed in the rocks. Furthermore, in the immediate area of skarn and monzogranite porphyry in the Contention pit, quartz stockworks are constrained tightly to the contact, especially on the monzogranite porphyry side of the contact.

\section{SUPERGENE COPPER DEPOSITS AT COPPER BASIN}

\author{
By DaVid W. BLAKE
}

\section{INTRODUCTION}

This section of the report presents a summary of the recent mining activity in the Copper Basin area. In the early 1960's, Duval Corp. conducted an intense exploration program that culminated in a discovery of sufficient copper reserves that would support a heap-leach operation. From 1965 to 1981,34 million tons of leach-grade copper ore were mined from four open pits; most of the production came from the Contention and Carissa open pits. Approximately three million tons of millable-grade copper ore was trucked to Duval's flotation recovery facilities at Copper Canyon located 
approximately $16 \mathrm{~km}$ south of the Copper Basin deposits.

All of the copper-bearing material mined at Copper Basin came from secondary copper deposits that had formed in fine-grained clastic rocks of the Harmony Formation. These sedimentary beds dip steeply to the east within an east limb of a major north-south-trending anticline through the district. Locally, the Harmony Formation has been intruded by Late Cretaceous and middle Tertiary igneous rocks that form dikes, sills, and irregular bodies. The postore, approximately 34-Ma Caetano Tuff aided in preserving most of the secondary copper mineralization. Secondary copper mineralization in Copper Basin is the result of a combination of receptive host rocks and cycles of enrichment and oxidation, locally influenced by low- and high-angle structures.

In this section, I discuss the geology and hypogene and secondary copper mineralization as it is related to the various sedimentary and igneous rocks exposed mostly in the Contention and Carissa deposits of the Copper Basin area. Information has been gathered from detailed geologic pit mapping and limited petrographic studies. Some aspects of hydrothermal and supergene alteration also are presented because of their impact on the mineralizing events that formed the primary and secondary metal occurrences.

\section{ACKNOWLEDGMENTS}

The initial pit mapping was done by E.D. Fields in 1966-67. R.L. Ames and E.L. Kretschmer mapped the individual deposits at various periods of time and assisted in other related geologic studies. R.A. Sumin, vice president of operations for the Battle Mountain Gold Co., graciously gave me permission to publish production data and the details of the geology of the Copper Basin deposits. This section was reviewed critically by R.G. Benson and P.R. Wotruba of the Geology Department of the Battle Mountain Gold Co.

\section{HISTORY}

The earliest recorded copper production from Copper Basin was by the Glasgow and Western Exploration Co., Ltd., in the late 1890's (Roberts and Arnold, 1965, p. B64). The following history of early mining activities in this part of the Battle Mountain Mining District is taken largely from an unpublished report by Robert R. Raring in 1951 for the Copper Canyon Mining Co. First discoveries of copper at Copper Basin were probably made in the middle or late 1860 's, because old newspapers dating back to 1866 have been found in some of the workings. Such dates correspond to general prospecting in this region of Nevada, following the impetus of the silver bonanza at the Comstock Lode, Nev., discovery in 1869.

Early work was sporadic in the Copper Basin area; it was not until 1897, when the Glasgow Western Exploration Co., Ltd., undertook to consolidate the ground, that exploration and development were formalized. At that time, Glasgow Western owned a small copper smelter at Golconda, Nev., and operated the Copper Canyon Mine, $19 \mathrm{~km}$ southwest of Battle Mountain, and the Adelaide Mine, $19 \mathrm{~km}$ south of Golconda, in addition to Copper Basin. These three properties were used as sources of ore for the smelter at Golconda.

Copper Canyon Co. records indicate that Glasgow Western first drilled eight surface churn-drill holes at Copper Basin with discouraging results. Then in 1914, W.P. Hammond of California gold-dredging fame, drilled three additional holes also without notable success. Frank Paul subsequently secured a lease and option on the property in 1916 and shipped 5,000 tons of ore averaging 6.2 weight percent $\mathrm{Cu}$ realizing $\$ 95,000$ as a net smelter return. He failed to exercise his option, however, and the Copper Basin Group was acquired by the Copper Canyon Mining Co. in August 1917.

The Copper Canyon Mining Co. had meanwhile been operating the Copper Canyon Mine. In November 1918, a fire destroyed the small powerplant at Copper Canyon, and rather than repair the damage, the management decided to suspend operations at Copper Canyon and concentrate all work at Copper Basin. A camp was built at Copper Basin, and a general exploration and development program undertaken.

Activities initially focused exploration workings near productive areas, deepening old shafts or sinking new shafts from which lateral underground workings were driven to explore and develop the mineralized areas. This program led to the discovery of the Sweet Marie, Widow, Chase, Contention, and Happy Mines. Development ore was shipped either to the American Smelting and Refining Co. smelter at Garfield, Utah, or to the U.S. Smelting Co. at Kennett, Calif. Later, surface churn drills were brought in to supplement the underground work and, in time, all effort was concentrated on drilling 
and underground work was suspended. Until January 1, 1924, 5,079 $\mathrm{m}$ of underground work had been completed, and about 75 churn-drill holes had been put down for a total footage of $5,061 \mathrm{~m}$. The average hole was thus about $70.4 \mathrm{~m}$ deep.

The period from 1918 to 1924 was also marked by intensive geologic studies. J.C. Jones of the University of Nevada had been retained as consulting geologist and, at different times, Augustus Locke, Guy Bjorge, Edson Bastin, Carl O. Linberg, and Walter Harvey Weed supplemented the work by Jones. Metallurgic tests were conducted at laboratories of the Nevada Consolidated Copper Co. at McGill, Nev., and by A. Schwarz, a consulting metallurgist of Joplin, Mo. Schermuly-Polaritizator Corp. of New York City sent Felix Vogel to the Copper Basin area during the latter part of 1922 , and he conducted geophysical surveys of the various mineralized workings. However, the results and interpretations of his surveys were the subject of heated debate. This could be expected in light of the experimental nature of the instrument used, but it is interesting that Copper Basin was the site of one of the earliest applications of geophysics to mineral deposits. Mr. Vogel did outline a pyritic deposit, herein named the Consolance, which had a distinct possibility as a source for sulfuric acid. By late 1922, copper was in abundant supply as a result of the post-World War I economic recession. There was little incentive to continue development and to equip the workings at Copper Basin for further production, although planning in this direction had been well advanced, even to the point where a millsite had been acquired and surveys completed for extending a railroad spur line from Battle Mountain to the mill. On May 1, 1924, the decision was made to suspend all operations and to put the property at Copper Basin on standby. For all effective purposes, the Copper Canyon Mining Co. went into a deep hibernation.

Within a few years, however, the copper markets improved and leases were granted to different local miners. Steady shipments were soon being made from the Sweet Marie, Widow, Contention, and Chase Mines, and although tonnages were small, grades were high. Between 1927 and until 1936, there are records of 27,425 dry tons being shipped with an average grade of 11.4 weight percent $\mathrm{Cu}$. All of this ore was shipped in a rather crude state either to the American Smelting and Refining Co. smelter at Garfield or, for a time, to the Mason Valley smelter near Yerington, Nev.

These lessee operations were more or less continuous until 1951. Activity varied with metal prices and marketing costs. During 1937, leasing flourished, and during World War II, relatively large shipments were made under the stimulus of the Premium Price Plan; however, copper production came to a virtual standstill in July 1947 when the Plan was terminated.

In late 1935, two prospectors, Ernest Johnson and $\mathrm{Al}$ Dolezal, undertook work on a gold showing on the Carissa No. 1 Claim. Their efforts were fruitful, and within two years they shipped 7,000 tons of gossan material that averaged 0.55 troy oz $\mathrm{Au} / \mathrm{ton}, 2.4$ troy oz $\mathrm{Ag} / \mathrm{ton}$, and 3 weight percent $\mathrm{Cu}$. This discovery stimulated the search for gold with the result that moderate tonnages $(5,000$ tons) were shipped from the Copper King. Through 1946 there had been shipped slightly more than 13,000 dry tons of gold-bearing ore, grade of which averaged 0.44 troy oz Au/ton, 2.65 troy oz Ag/ton, and 2.91 weight percent $\mathrm{Cu}$. This was all gossan material; the greatest depth to which such mineralization had been mined was $17 \mathrm{~m}$ below the surface.

The International Smelting and Refining Co., an Anaconda subsidiary, secured a lease on all properties of the Copper Canyon Mining Co., including Copper Basin, in the spring of 1941. Most efforts, however, were concentrated at Copper Canyon, where a modern plant was built, complete with a 350-ton-per-day flotation mill, shops, and support facilities. Copper Basin was remapped, and 26 surface diamond-drill holes were put down. These holes were planned either to supplement the old churn-drill holes or to explore certain gossanenriched areas. The program was too ambitious for the footage allocated, but some moderate success was realized. The lease to the International Smelting and Refining Co. terminated December 1, 1945, and all holdings reverted to the Copper Canyon Mining Co. as of that date. The large alluvial fan south and southeast of Copper Basin camp received some attention in the Summer of 1946 when the Natomas Co. drilled a string of test holes across it. The testing was preliminary and not conclusive other than to indicate that the gold content of the gravels was well below commercial values for the price of gold at that time. Indications were that, overall, it would average about 5 cents per cubic yard, based on $\$ 35$ per troy ounce of gold; yardage is very great, probably about 100 million $\mathrm{yd}^{3}$. Certain channels contain concentrations of placer gold far above this figure. American Smelting and Refining Co. purchased the Copper Basin and Copper Canyon properties in 1959 and conducted an exploration program at both mining properties. In 1962, 
Duval Corp. acquired the properties from American Smelting and Refining Co.

Duval Corp. continued with an intense geologic and drilling development program in the early 1960's at both Copper Basin and Copper Canyon to determine the feasibility of mining the small copper-gold-silver and copper ore deposits. This exploration resulted in the definition of leachableand millable-grade copper reserves at Copper Basin. Millable and leach-grade copper ore eventually was mined from four open pits, the Sweet Marie, Contention, Carissa, and Widow, which were the sites of former underground-mining operations (pl. 1; fig. 73).

Mining of the Sweet Marie open-pit deposit began in 1965 and was completed during September 1966 (Tippett, 1967). Mining of the Contention deposit for

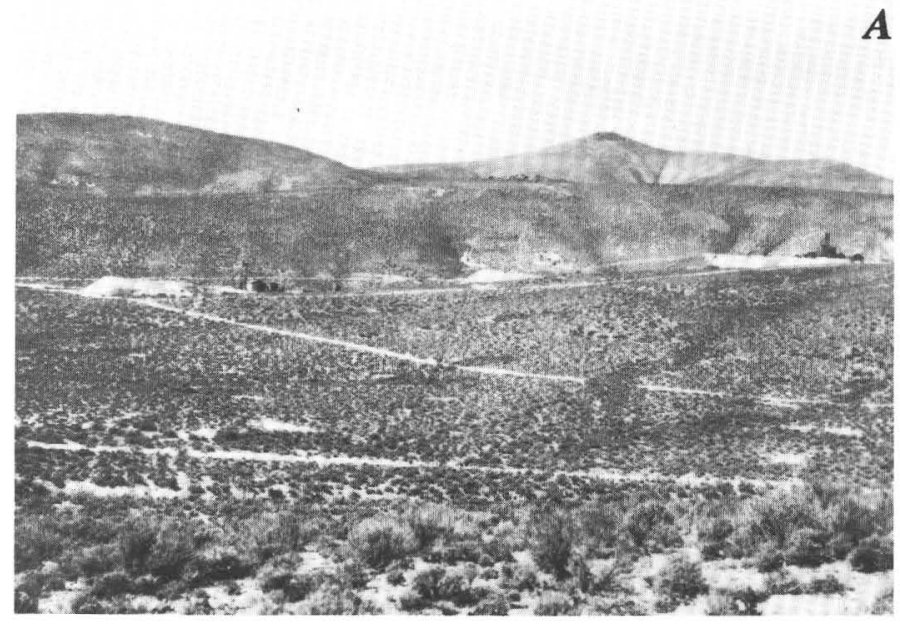

$\boldsymbol{B}$

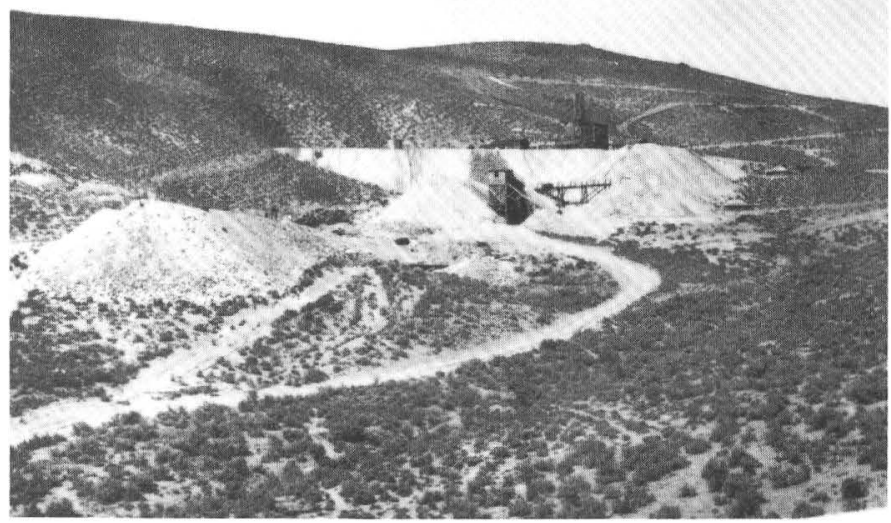

Figure 73.-Widow and Sweet Marie Mines. Photographs by F.C. Schrader, taken September 1930. A, Widow Mine (left) and Sweet Marie Mine at an elevation of 5,400 ft. View westward. $B$, Closeup of Sweet Marie Mine. View northeastward. mill-grade and leach-grade copper ores was begun in 1967. The mill-grade copper ore was transported to the Copper Canyon mill for processing by flotation methods. In January 1975, mining of leach-grade copper ore was started in the Carissa open-pit deposit, and the stripping of the Widow open-pit deposit began in March 1981. All copper mining was suspended in the Copper Basin area in June 1981. Recovery of leach copper from the dumps was curtailed during December 1984.

Several additional ore bodies subsequently were discovered north and east of the supergene copper deposits at Copper Basin. As noted by Schmidt and others (1988), Duval Corp. began exploring the Copper Basin area primarily for gold in 1981. However, it was not until 1984 when the first significant discovery of gold was made at the Surprise Mine (pl. 1). Production from the Surprise Mine by the newly created Battle Mountain Gold Co. (see above) began in June 1987 at a rate of about $450 \mathrm{t}$ per day. This ore was hauled to the mill at Copper Canyon and was processed with ore from the Fortitude Mine. In the Copper Basin area, a total of five small gold and gold-copper ore bodies have been discovered to date (1989) with a minable aggregate tonnage of 3.6 million $\mathrm{t}$ containing 254,000 troy oz $\mathrm{Au}, 1.9$ million troy oz $\mathrm{Ag}$, and approximately 29 million $\mathrm{lb} \mathrm{Cu}$ (Schmidt and others, 1988). These ore bodies include the apparently Late Cretaceous gold-copper skarn at the Surprise Mine, the Late Cretaceous silica-pyrite, or distal-disseminated silver-gold (Dennis P. Cox, written commun., 1989), deposits at the Northern Lights and Empire Mines, and the apparently late Eocene or early Oligocene gold skarn at the Labrador Mine (pl. 1). Most gold ore at the Northern Lights and Empire Mines is hosted by structurally controlled jasperoid related to emplacement of the Buckingham stockwork molybdenum system.

\section{PRODUCTION}

Past production from 1916 to 1953 for the entire Copper Basin area, including some mines just outside the main Copper Basin copper deposits themselves, includes 67,354 tons of ore containing 8,914.81 troy oz $\mathrm{Au}, 66,758$ troy oz $\mathrm{Ag}$, and $10,851,939 \mathrm{lb} \mathrm{Cu}$ (Roberts and Arnold, 1965, table 7, p. B64). Because this report discusses the geology and mineralization in and adjacent to four former underground mines at which additional open-pit reserves were subsequently developed, their underground production and metal grades are 
shown individually below from Roberts and Arnold (1965, p. B65, B67-B68):

\begin{tabular}{|c|c|c|c|c|c|}
\hline & $\begin{array}{l}\text { Ore } \\
\text { (tons) }\end{array}$ & $\begin{array}{c}\text { Gold } \\
\text { (oz/ton) }\end{array}$ & $\begin{array}{l}\text { Silver } \\
\text { (oz/ton) }\end{array}$ & $\begin{array}{l}\text { Copper } \\
\text { (wt pct) }\end{array}$ & Value \\
\hline $\begin{array}{l}\text { Sweet Marie Mine, } \\
1929 \text { and prior } \\
\text { years-1954 ........... }\end{array}$ & $23,038.1$ & 0.006 & 0.27 & 9222 & $\$ 468193$ \\
\hline Carissa Mine & & & & & \\
\hline 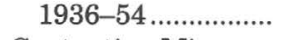 & $9,104.3$ & .499 & 2.15 & 2.96 & 194,059 \\
\hline $\begin{array}{l}\text { Contention Mine, } \\
1927-54 \ldots \ldots \ldots \ldots \ldots . .\end{array}$ & $8,078.3$ & .011 & .36 & 7.38 & 130,332 \\
\hline $\begin{array}{l}\text { Widow Mine, } \\
1927-45 \ldots \ldots . .\end{array}$ & $2,741.8$ & .005 & .23 & 8.48 & 43,411 \\
\hline
\end{tabular}

The initial reserves announced by Duval Corp. for the Copper Basin deposits were 22,657,000 tons of leach-grade material with an average grade of 0.41 weight percent $\mathrm{Cu}$, and the ore-grade reserves for milling operations were $3,066,000$ tons with an average grade of 1.75 weight percent $\mathrm{Cu}$ (Sayers and others, 1968).

Duval's production for the period 1966-81 from the Copper Basin deposits is listed in table 25. It is significant to note that until 1981, the open-pit deposits at Copper Basin yielded as much as 11 million tons of ore more than the announced initial reserves. However, the amount of copper metal mined is less than the initial amount anticipated because of lower grades. Nonetheless, the overall amount of copper in the deposits was more than that announced initially because several tens of millions tons leachable material still (1989) remains in place. The mill-grade copper ore was transported to the milling facilities at Copper Canyon and the leach-grade material was placed on dumps in the Copper Basin area. Leach copper initially was recovered by a precipitation cement plant located downdrainage from the producing dumps. In 1979, a solvent extraction plant was placed in operation to process the copper-bearing solutions from the leach dumps. This method of recovery was installed to reduce costs and to increase production of copper from the dumps. Pre-Duval Corp. production records show the presence of recoverable precious metals in the underground mines near Copper Basin. Precious metals from Copper Basin added to the byproducts recoverable in the flotation circuits at Copper Canyon during processing of the copper ores there.

\section{GEOLOGY OF THE COPPER BASIN COPPER DEPOSITS}

The supergene copper deposits at Copper Basin have been described previously by Roberts and
TABLE 25.-Statistics of copper production by Duval Corp. at Copper Basin for 1965-81

\begin{tabular}{|c|c|c|c|c|c|}
\hline \multirow[b]{2}{*}{ Year } & \multicolumn{2}{|c|}{ Milling operations } & \multicolumn{2}{|c|}{ Leaching operations } & \multirow[b]{2}{*}{$\begin{array}{l}\text { Waste } \\
\text { (tons) }\end{array}$} \\
\hline & $\begin{array}{l}\text { Ore } \\
\text { (tons) }\end{array}$ & $\begin{array}{l}\text { Copper } \\
\text { content } \\
\text { (percent) }\end{array}$ & $\begin{array}{c}\text { Ore } \\
\text { (tons) }\end{array}$ & $\begin{array}{l}\text { Copper } \\
\text { content } \\
\text { (percent) }\end{array}$ & \\
\hline 1965 & - & -- & -- & -- & 499,075 \\
\hline 1966------ & -- & -- & $2,776,360$ & 0.55 & $8,235,534$ \\
\hline 1967-_--_- & 201,313 & 1.42 & $3,081,347$ & .25 & $3,543,283$ \\
\hline 1968-_-_-- & 460,267 & 1.16 & $2,082,208$ & .30 & $2,118,918$ \\
\hline 1969 & 373,105 & 1.13 & $2,114,734$ & .26 & $3,422,770$ \\
\hline 1970------ & 284,684 & 1.08 & $2,940,033$ & .31 & $2,115,762$ \\
\hline 1971-_-_-- & 264,439 & 1.09 & $2,312,904$ & .32 & $1,071,508$ \\
\hline 1972 & 204,417 & 1.35 & $2,313,175$ & .28 & 228,939 \\
\hline 1973------- & 183,513 & 1.12 & $1,211,561$ & .30 & 114,838 \\
\hline $1974 \ldots$ & 434,763 & 1.06 & $2,310,294$ & .32 & 666,516 \\
\hline 1975-_-_-- & 254,265 & .92 & $1,835,197$ & .30 & $1,750,777$ \\
\hline 1976------ & 250,982 & 1.01 & $1,450,684$ & .29 & 992,337 \\
\hline 977 & 239,726 & 1.01 & $2,072,243$ & .27 & 659,548 \\
\hline 1978-_---- & 25,259 & 1.75 & $2,967,363$ & .31 & 437,711 \\
\hline 1979_-_--- & - & - & 278,787 & .45 & $1,170,892$ \\
\hline 1980-_-_-- & - & - & $2,148,690$ & .34 & $1,646,860$ \\
\hline 981------ & -- & - & $2,493,137$ & .39 & 806,546 \\
\hline Totals---- & $\overline{3,176,733}$ & $\overline{1.11}$ & $\overline{34,388,717}$ & $\overline{0.33}$ & $\overline{29,481,814}$ \\
\hline
\end{tabular}

Arnold (1965), Sayers and others (1968), and Tippett (1967). Their studies were based on examination of the surface, underground, and drill-hole geology and mineralized rocks. These earlier geologic studies provided the framework for the follow-through investigations of the open-pit deposits.

Within the four open-pit mines that compose the Copper Basin deposit (pl. 1), copper mineralization is present in an interbedded sequence of quartzite, quartzitic sandstone, arkosic and feldspathic sandstone, siltstone, shale, and various calcareous lithologies of the Harmony Formation. Clastic material decreases stratigraphically upward in the Harmony Formation as the formation is here exposed in the east-dipping limb of the districtwide Antler anticline. Commonly, individual mappable units in the Harmony Formation also show gradation along strike from siliceous sandstone to a thin-bedded, calcareous, shaly sandstone. The calcareous beds also increase in abundance stratigraphically higher in the parts of the Harmony Formation east of the main deposits at Copper Basin.

The beds of the Harmony Formation in and adjacent to the four open pits have been metamorphosed mostly by Late Cretaceous plutonism and, much less so, by minor Paleozoic dikes and sills. Intense effects of this metamorphism are present in the southern part of the Contention pit adjacent to the east-west-trending monzogranite porphyry. On the one hand, recrystallization of micaceous sandstone, siltstone, and shale to biotite hornfels is the main textural change observed in hand samples. On the other hand, calcareous beds, mostly shale and minor limestone(?), have been metamor- 
phosed and metasomatized to skarn and calcsilicate hornfels. Probably Paleozoic diabasic and gabbroic dikes and sills also intrude the clastic sedimentary rocks of the Harmony Formation in the Contention and Carissa pits. The various textural stages of skarn in transition from a predominantly sulfide mineralogy to an oxide mineralogy are shown below in the section entitled "Mineral Chemistry of Late Cretaceous and Tertiary Skarns." However, any metamorphic effects possibly related to the generally narrow diabasic dikes and gabbroic dikes and sills were not recognized in the deposits, inasmuch as the metamorphic effects may have been destroyed by subsequent hypogene and supergene alteration and mineralization.

Hydrothermal alteration and mineralization took place after the peak of the thermal metamorphic event during the Late Cretaceous. This hydrothermal stage produced sulfide-bearing quartz veins and veinlets, sulfide-bearing fracture fillings and disseminations in the clastic beds, and replacement and dissemination of sulfides in skarn and calc-silicate hornfels. The overall distribution of hypogene sulfides in the Copper Basin deposits is related spatially to the Late Cretaceous monzogranite porphyry. Total sulfide content decreases toward the north, away from monzogranite porphyry. Minor dikes of probably Paleozoic gabbro, correlative with either gabbro in the Ordovician Valmy Formation (Roberts, 1964) or mafic volcaniclastic rock in the Devonian Scott Canyon Formation, cut beds of the Harmony Formation in these pits. The probably Paleozoic gabbro dikes (not mapped separately in fig. 74) contain exceptionally coarse grained primary plagioclase and clinopyroxene that have been altered intensely by mineralization associated with the Late Cretaceous Buckingham system. In addition, distribution of hypogene sulfides is increasingly controlled by fractures toward the north.

Alteration associated with hypogene mineralization is indicated predominantly by phyllic and argillic assemblages in the clastic lithologies. In skarn and calc-silicate hornfels, epidote associated with varying quantities of tremolite and actinolite is present as replacements of prograde garnet and clinopyroxene and occupies fractures. Quartz veins and veinlets are present throughout the deposits. Locally, K-feldspar is present as a partial replacement of detrital feldspar grains, and clay minerals and white mica replace the matrix and some of the detrital feldspar grains.

The distribution of copper-enriched rock is controlled primarily by structures. The economically most significant faults commonly have dips less than $50^{\circ}$ in the Copper Basin deposits and are ex- emplified by two low-angle faults that dip north in the Sweet Marie and Contention deposits. These faults controlled much of the eventual distribution of secondary copper mineralization there. Near the faults, highly dispersed, low-grade, secondary copper mineralization is present in fine- to mediumgrained sandstone beds. Here the pyrite-bearing altered matrix and some of the iron-bearing detrital minerals have been replaced by chalcocite. Such replacement of pyrite formed the chalcocite ore bodies mined in the Contention and Carissa deposits. Most of the supergene copper apparently originated from the oxidation of primary chalcopyrite that formerly was predominantly in skarn and calc-silicate hornfels of the Harmony Formation and possibly even some of the Battle Formation that has since been removed by erosion (Tippett, 1967). Very minor chalcopyrite, mainly in quartz veins, is found in the clastic rock types. Oxide copper minerals are restricted to the leached capping and within and adjacent to the partially oxidized skarn and calc-silicate hornfels. The leached capping that overlay the Copper Basin copper deposits closely corresponded to the copper-enriched blanket there. It is typical of the leached capping associated with many of the Southwestern United States porphyry copper deposits described by Titley and Hicks (1966) and Titley (1982).

\section{GEOLOGY ON THE 5575-FT BENCH OF THE CONTENTION DEPOSIT}

The 5575-ft bench was selected to illustrate many of the salient features of the geology in the Contention deposit (fig. 74) because this bench depicts many of the geologic controls of mineralization, as well as rock types important in forming the primary and supergene copper deposits found in the Copper Basin Mine as a whole. The Harmony Formation on this bench consists of mixed clastic and metasomatic sequences, including calcsilicate hornfels, skarn, and weakly metamorphosed calcareous shale and siltstone with some local concentrations of skarn and calc-silicate hornfels (fig. 74). These strata belong to the upper part of the Harmony Formation in the Copper Basin area. The clastic strata on the bench consist of an interbedded sequence of quartzitic, arkosic, and feldspathic sandstone (fig. 74). Generally, these sandstones contain thinly interbedded shale and siltstone that are locally intergradational with each other. Along the east part of the bench, a relatively thick sequence of interbedded garnetpyroxene skarn and calc-silicate hornfels crops out. 


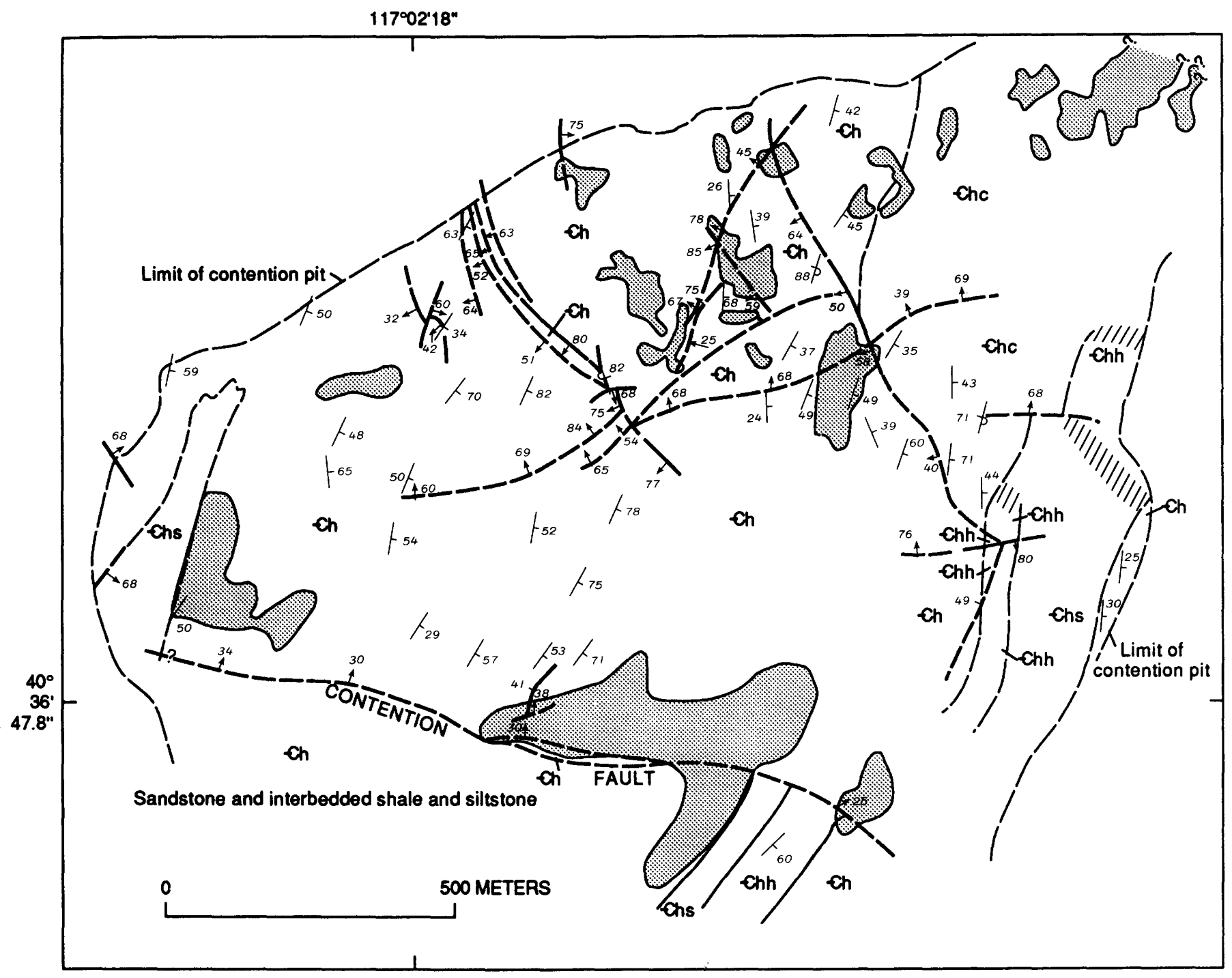

EXPLANATION

Ch Harmony Formation (Upper Cambrian)-Sandstone and interbedded shale and siltstone. Locally divided into:

Chh Calc-silicate hornfels-Generally includes diopside and (or) tremolite

Chs

Che

Skarn-Includes abundant andradite and diopside

Calcareous shale and siltstone-Locally includes skarn and calc-silicate homfels

FIGURE 74.-Geologic sketch map of the 5575-ft bench in Contention pit at Copper Basin Mine, showing areas of more than 1 weight percent $\mathrm{Cu}$. Other parts of bench contain more than 0.3 weight percent $\mathrm{Cu}$. Copper is mostly chalcocite but
Area of $\geq 1$ weight percent copper-Approximately located. Queried where extent uncertain

Contact-Dashed where approximately located
$/ / / / /$ Gradational contact

130 - Fault-Showing dip. Long dashed where approximately located; short dashed where inferred; queried where uncertain

\section{$\stackrel{54}{1} \quad$ Strike and dip of beds}

$p^{71}$ Strike and dip of overturned beds

includes some copper oxides(s). Copper contents from blasthole assays on 5575-ft bench modified by projection of data from underlying bench. Geology by D.W. Blake, E.D. Fields, R.L. Ames, and E.L. Kretschmer, 1967-75. 
To the north, this sequence of calc-silicate rocks grades into weakly metamorphosed, thin- to medium-bedded calcareous shale and siltstone. This fine clastic sequence also contains some beds of brown to reddish-brown biotite hornfels and a few interbedded sandstone beds. In addition, an isolated garnet-pyroxene skarn bed is exposed along the west side of the 5575 -ft bench. Here, the skarn is on the hanging wall of the Contention fault (fig. 74). Offset of the skarn by the Contention fault could not be determined because of the absence of exposures beyond the limits of the open pit. Another sequence of garnet-pyroxene skarn and calc-silicates is exposed in the footwall of the Contention fault. Its projected continuation northward across the Contention fault shows a slight separation from the garnet-pyroxene skarn and calc-silicate hornfels that crop out along the east edge of the $5575-\mathrm{ft}$ bench. This separation would be reduced if bedding in the garnet-pyroxene skarn and calc-silicate hornfels sequence in the hanging wall of the Contention fault were to bend westward and conform thereby to the attitudes of bedding measured in the nearby other rocks of the Harmony Formation.

Bedding on the 5575-ft bench generally strikes north-northeast and dips moderately east-southeast. Locally, some beds have been overturned. Within the central part of the Contention deposit and elsewhere, small folds with north-south-trending fold axes are present.

Three conspicuous fault trends were found on the 5575-ft bench (fig. 74). One fault set, high angle, strikes northwest and dips south. A second highangle fault system strikes northeast to east and dips northwest. The main ore-controlling fault, the Contention, however, strikes nearly east-west and dips slightly less than $30^{\circ} \mathrm{N}$. (fig. 74). Many minor faults, fractures, and quartz veins, not shown on the map of the 5575-ft bench, follow the attitudes of all these three structural patterns. Most of the faults are marked by clay gouge along their traces and contain pyrite and (or) secondary copper minerals. Some show fault breccias and contain similar sulfide minerals.

Pebble dikes, as much as $1 \mathrm{~m}$ wide, crop out locally within the Contention deposit and the other satellite deposits. Fragments, as much as $0.3 \mathrm{~m}$ long, are rounded and have undergone hypogene alteration and mineralization. Most of the fragments are rock types common throughout the rest of the Harmony Formation and Late Cretaceous monzogranite porphyry; all fragments are set in a black flourlike matrix that contains finely disseminated pyrite. At the south downramp to the Contention pit, a highangle pebble dike that cuts monzogranite porphyry contains rounded black shale fragments apparently derived from the Scott Canyon Formation, as well as other fragments derived from the Harmony Formation, and some granitic rocks (see fig. 22C).

Typically, the bleached grayish-white to white sandstone of the Harmony Formation within the Contention deposit is fine to medium grained with a few coarse-grained beds. Where supergene alteration is less intense, however, the sandstone retains its brownish-gray color, owing to the presence of metamorphic biotite that primarily replaces the detrital mica and clay mineral premetamorphic constituents. The arkosic and feldspathic sandstone facies contains feldspar, mainly microcline, and lesser quartz in various proportions. Locally these feldspar-bearing sandstones exhibit a pinkish-gray tint, owing to the presence of K-feldspar. Quartzitic sandstone is essentially free of feldspar and micaceous minerals. Where metamorphosed, the quartzitic sandstone is recrystallized into a very dense quartzite. The original micaceous material, including both biotite and muscovite, of the sandstones shows the most conspicuous effects of recrystallization.

Siltstone ranges in composition from calcareous to micaceous. Where metamorphosed, calcareous siltstone has been recrystallized to calc-silicate assemblage(s) and micaceous siltstone to a dense biotite hornfels. Beds essentially unaffected by supergene alteration retain their characteristic greenish-gray and reddish-brown colors. The other main constituent of siltstone is quartz; feldspar is quite sparse overall. Siltstone composes most of the fine-grained, thin to moderately bedded sequences exposed along the northern part of the $5575-\mathrm{ft}$ bench (fig. 74). As a comparison, the northern parts of the Carissa pit locally show concentrations of calc-silicate minerals in what were previously calcareous siltstone. These rocks are poorly consolidated, owing to the removal of carbonate and subsequent development of clay minerals. Locally these beds also have been selectively replaced by silica and various sulfides.

Shale exposed within the Contention deposit is typically bleached grayish white and generally exhibits intense argillic alteration. Sericite is present in moderate amounts as a replacement of detrital micas and detrital clay minerals. Thermal metamorphism has converted these micaceous and calcareous shales to biotite and calc-silicate hornfels. Some thin shale beds also have undergone extensive replacement by silica. 
Skarn and calc-silicate hornfels exposed in the Contention deposit, as well as the Sweet Marie and Carissa deposits, are present as interfingering lenticular bodies for the most part. As mapped in figure 74, skarn and calc-silicate hornfels are differentiated on the basis of the percentage of garnet. Skarn contains more than 50 volume percent garnet and the calc-silicate hornfels consists of predominantly various calc-silicate minerals, mostly diopside, with less than 50 volume percent garnet. Variation in original mineral composition of sedimentary rocks of the Harmony Formation and some unresolved structural relations due to the absence of exposure also influenced the final distribution of metamorphic assemblages mapped on this bench.

Skarn and calc-silicate hornfels are highly varied in the Contention deposit. Most skarn is dark green to dark blackish green and locally olive green and reddish brown in outcrop. It is apparently composed mainly of medium- to coarsegrained andradite and lesser amounts of grossularite. Intermixed with garnet are epidote, tremolite, actinolite, diopside, quartz, and sulfides. Calcite is only locally present. The sulfide content of skarn ranges from 5 to more than 50 volume percent. Petrographic examination of a few thin sections of skarn from the Contention deposit shows that the zoned garnets have been partially to almost completely replaced by epidote. Associated with the epidote is quartz. Both epidote and quartz also occupy some veinlets. The abundance of sulfides is related directly to the overall intensity of silicification that has been superposed on the skarn. Calcsilicate hornfels is olive green to black green and composed of quartz, diopside, tremolite, epidote, and actinolite containing varying amounts of garnet, mainly grandite intermediate in composition between andradite and grossularite. Calc-silicate hornfels is finer grained than most skarn, except where tremolite and actinolite are dominant. In addition, the sulfide content in calc-silicate hornfels is generally less than in skarn.

The Harmony Formation in the Contention and Carissa pits has been intruded by probably Paleozoic diabase and gabbro dikes and sills, Late Cretaceous monzogranite porphyry, and middle Tertiary granodiorite porphyry. Most intrusive rocks that cut the Harmony Formation in the pits have been altered and mineralized, except some of the middle Tertiary granodiorite porphyry dikes. Quartz stockworks and argillic alteration are conspicuous in the east-west-trending, Late Cretaceous monzogranite porphyry exposed near the south edge of the Contention deposit. Many of the quartz veins and veinlets in the monzogranite porphyry have white mica selvages here. White mica and clay minerals also have altered the primary minerals of the monzogranite porphyry. Pyroxenes and feldspars of the diabase and gabbro dikes and sills have been argillized, pyritized, and weakly propylitized.

\section{HYPOGENE MINERALIZATION}

Hypogene mineralization, which is present as fracture fillings, disseminations, and quartz veins, is confined mostly to clastic rocks of the Harmony Formation. The hypogene sulfides in the Copper Basin copper deposits are pyrite, pyrrhotite, chalcopyrite, galena, sphalerite, molybdenite, marcasite, and rare arsenopyrite. Especially high abundances of pyrite, chalcopyrite, galena, and sphalerite also are present along some of the major faults. Calc-silicate hornfels and skarn are dominated by sulfides showing replacement and disseminated modes of occurrence. Some selective beds that seem to show less well developed calcsilicate assemblages are associated primarily with pyrite.

The lithology of the host rock seems to have some control on the type and abundance of hypogene assemblages developed in the rocks. Quartzonly veins and quartz veinlets with pyrite and minor chalcopyrite are common in sandstone and less so in siltstone. Some pyrite in these rocks also is found along fractures and along bedding planes, wherein veinlets of pyrite cut an earlier stage vein assemblage consisting of quartz+K-feldspar+ sulfide. Other veinlets consist of pyrite+quartz+ calcite with white mica selvages. The white mica has altered earlier stage metamorphic biotite. In some metamorphosed fine-grained clastic beds, there are veinlets of epidote+tremolite+sulfide. Total sulfide content in the clastic rocks averages about 2 volume percent. The greatest concentration of pyrite, however, is found in those more porous sandstone beds that also have been altered subsequently by intense clay and white mica alteration. Sulfide content in these beds ranges from 5 to 10 volume percent.

Hypogene sulfide assemblages in the monzogranite porphyry could not be determined directly because all the monzogranite porphyry available for study is from the oxide zone or the chalcociteenrichment blanket and the attendant intense bleaching and oxidation therein. The types of limo- 
nite noted and the yellow ferrimolybdite indicate that the quartz veins and veinlets must have contained pyrite \pm chalcopyrite \pm molybdenite, similar to the veins that are associated with the core of the Buckingham molybdenum system to the west. In the near-surface, Late Cretaceous monzogranite porphyry at Copper Basin, the chalcopyrite: molybdenite ratio apparently is higher than that in the igneous rocks closely associated with the Buckingham deposit in the East and West stocks of the system.

Skarn and calc-silicate hornfels contain the highest concentration of sulfides at Copper Basin. They also contain important quantities of chalcopyrite, which upon oxidation, formed the supergene copper deposits. The dominant sulfide is pyrrhotite generally with slightly less abundant pyrite and much lesser quantities of sphalerite, galena, and chalcopyrite. Within skarn and calc-silicate hornfels, the total sulfide content decreases toward the north, and pyrite gradually becomes the predominant sulfide as replacements and disseminations in skarn and calc-silicate hornfels (see section below entitled "Mineral Chemistry of Late Cretaceous and Tertiary Skarns").

Galena and sphalerite are confined to skarn and a few faults and veins where they form small lenticular replacement bodies. Intermixed with the galena and sphalerite are pyrite, pyrrhotite, and chalcopyrite. On the 5575-ft bench, the termination of a major northwest-striking fault in calc-silicate hornfels near coordinate E. 397,750; N. 2,135,250, contained a small ore shoot of massive galena (fig.
74). Selected samples of galena assayed 45 to 100 troy oz $\mathrm{Ag} /$ ton and averaged 0.1 troy oz $\mathrm{Au} /$ ton. This fissure vein was localized where the fault intersected a calc-silicate bed. Along the trace of the fault to the northwest, where it intersected sandstone, galena was not found.

By comparison, elsewhere in the other open-pit deposits at Copper Basin, a single skarn body in the Sweet Marie deposit contained as much as 80 volume percent sulfides. This conspicuous sulfide occurrence there included mainly pyrrhotite, pyrite, and moderate amounts of chalcopyrite. Marcasite, where found, is present as a secondary-alteration product of pyrrhotite. Veins of vuggy quartz in the skarn also contained pyrite and galena. In addition, calc-silicate hornfels throughout the Sweet Marie deposit contained disseminated sulfides, numerous pyrite veinlets, massive pyrite veins, and quartz+ chalcopyrite+pyrite veins containing minor molybdenite that cut the early-stage disseminated mineralization. A few quartz+galena+molybdenite veins are also present in the skarn and calc-silicate hornfels.

\section{COPPER ORE BODIES}

The dominant mineral in the enrichment zone is chalcocite, which forms a blanket that averages approximately $24 \mathrm{~m}$ in thickness (fig. 75). Thickness of the chalcocite-rich zone of mineralized rock increases where structures and favorable beds controlled and localized the migration of copperbearing solutions in the supergene environment. In

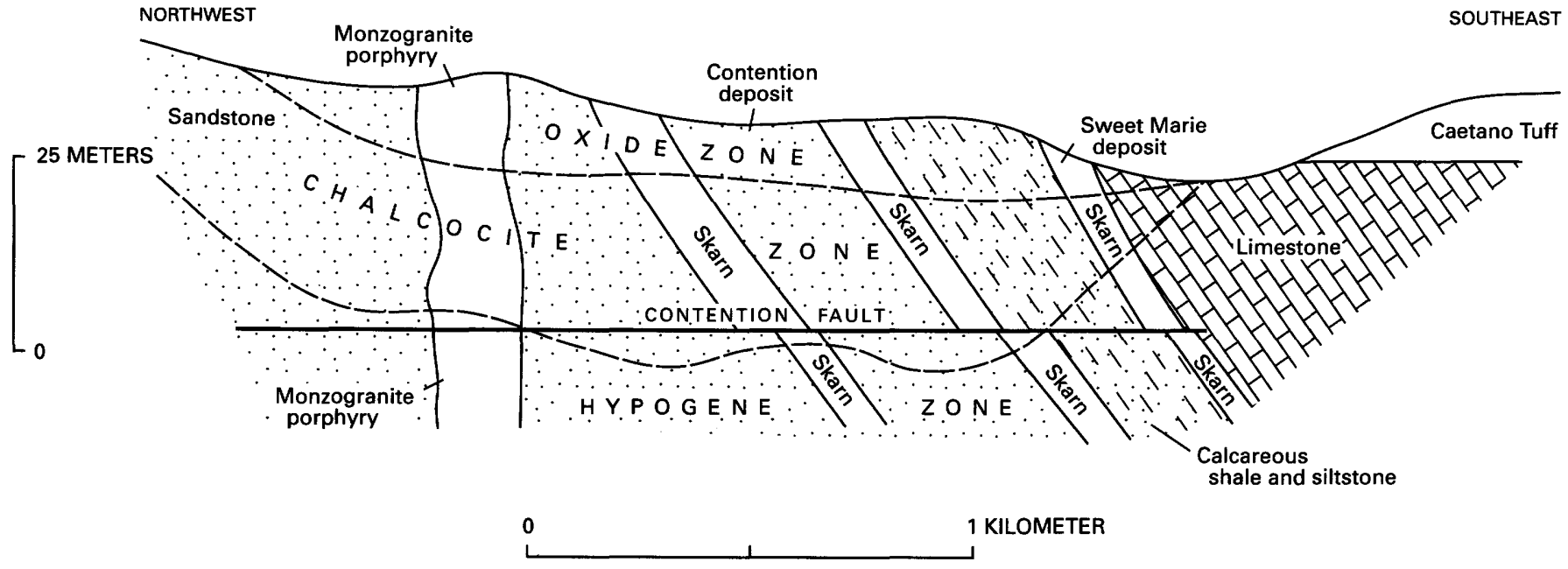

FIgURE 75.-Schematic cross section of Copper Basin deposits showing copper mineralization zones. Sandstone, skarn, and calcareous shale and siltstone are subunits of the Upper Cambrian Harmony Formation. Limestone is Early Permian and Late Pennsylvanian Antler Peak Limestone. Geology modified from Sayers and others (1968). View northeastward. Approximate vertical exaggeration, $\times 18$. 
many areas within the Contention deposit, the chalcocite-enrichment zone is more than $30 \mathrm{~m}$ thick. Near the base of the enrichment zone, both chalcocite and covellite are present. At the upper boundary, along oxidized structures, and in the oxide capping, oxidized copper minerals are more abundant. Within the chalcocite zone, massive vein-filling steely chalcocite is present as a replacement of pyrite- and chalcopyrite-bearing fissure veins. Sooty chalcocite is the prevalent variant where pyrite has been nearly or completely replaced. This type of replacement apparently is more abundant in the upper and middle parts of the enriched zone. In the lower parts of the enriched zone, pyrite is partially replaced and typically shows a film of covellite along its margins. This suite of secondary copper minerals may have been deposited in association with some other secondary copper minerals not recognized during the mapping of the pit but that are common in other secondary copper-enrichment zones elsewhere.

The thickness of the chalcocite zone also varies depending on rock type, intensity of hydrothermal alteration, and structures present. These relations with the leached capping and hypogene mineralization in the Contention ore body show that the chalcocite zone generally conforms to the present topography there, especially the upper interface of the chalcocite zone with the leached capping (fig. 75). The nearly flat-lying Contention fault intersects the plane of the schematic cross section near the lower limit of the chalcocite blanket. Mining on the 5450 -ft bench, approximately $38 \mathrm{~m}$ lower in elevation than the level of figure 74 , showed a Tshaped ore zone in plan that assayed more than 4 weight percent $\mathrm{Cu}$ and that had formed at the intersection of the Contention fault and an underlying receptive porous sandstone bed of the Harmony Formation. Primary pyrite content in both the Contention fault and the sandstone was high, thereby confirming that the Contention fault is either a premineral or synmineral structure.

Secondary copper mineralization in the Sweet Marie ore body was present to a depth of $91 \mathrm{~m}$ below the premining surface. Oxidized copper minerals were localized at the intersection of some favorable beds and the Sweet Marie fault, which strikes north-northeast and dips $25^{\circ} \mathrm{W}$. (Sayers and others, 1968, p. 61-62). Here, the copper minerals include chrysocolla, melaconite-tenorite, malachite, azurite, cuprite, and brochantite, and, at depth, residual chalcocite (Sayers and others, 1968 , p. 62). These oxidized copper minerals formed at the expense of an irregular chalcocite zone that developed at an earlier evolutionary stage of the system.

The copper ore body in the Carissa pit contains a mixture of oxide copper minerals and chalcocite mineralization. Variations in rock types and in their porosity and permeability influenced the development of hypogene and supergene sulfides, as well as the oxidized copper minerals. Most of the chalcocite mineralization is erratic; it is confined commonly to beds of sandstone and siltstone that were partially altered by supergene solutions. Oxide copper minerals recognized in the Carissa ore body include azurite, malachite, tenorite(?), turquoise, and chrysocolla. The copper carbonates show an enhanced affinity for calcareous-bearing strata and interbedded skarn and calc-silicate hornfels. Here, the upper boundary of the chalcocite-enrichment zone closely parallels the present surface. Much of the supergene copper mineralization is localized by numerous fractures and faults that show small displacements. Fracturing is more apparent in shaly beds and in siltstone. Bedding planes contain mixed supergene copper sulfide(s) and oxidized copper minerals along their surfaces. Thus, the distribution of supergene and oxidized copper minerals in the Carissa ore body is very similar to that of the Sweet Marie ore body.

\section{SUPERGENE ALTERATION}

Alteration of silicates associated with the supergene copper deposits at Copper Basin consists mainly of the development of clay minerals and white mica. The separation of processes associated with supergene and hypogene hydrothermalalteration events is difficult to determine, but in most cases, the widespread and pervasive nature of moderate to intense clay development is quite closely associated spatially with the secondary copper-enrichment zone. Overall intensity of clay development shows a twofold increase over hydrothermal intermediate argillic alteration described above. Renewed supergene white-mica alteration is also noteworthy. In exposures dominated by primary mineralization, the intensity of clay and white-mica development is greatly diminished. Most of the clay minerals appear to be kaolinite in shale, siltstone, and the monzogranite porphyry and lesser amounts of montmorillonite associated with diabase, calc-silicate hornfels, and skarn. Throughout the deposits, there are numerous faults and fractures that contain halloysite in their gouge and breccia. 


\section{LEACHED CAPPING}

Studies by Sayers and others (1968) and Tippett (1967) in the Copper Basin area provide descriptions of the leached capping that was present before mining operations began. Their studies show that the chalcocite enrichment developed in two cycles. The initial cycle was the oxidation of hypogene sulfidebearing skarn and calc-silicate hornfels. The first cycle of oxidation and enrichment was interrupted by the approximately 34-Ma Caetano Tuff that at one time covered the Copper Basin copper deposits. The subsequent removal by erosion of the Caetano Tuff initiated the second cycle of oxidation and enrichment in the deposits. This second cycle locally has been reactivated by Basin and Range extension tectonics. Erosion and oxidation of the upper parts of the chalcocite zone has generally kept pace with post-Caetano tectonic adjustments. Along major drainages, the copper-enriched zone is being eroded at a faster rate, producing oxidized copper minerals.

Limonite mineralogy and textural features of limonite in leached cappings offer some clues as to the extent of the underlying hypogene and supergene mineralization. Sayers and others (1968) suggested that favorable limonite was present over the deposits at Copper Basin, but that its mere presence did not lend itself to identifying the extent of the enrichment zone and ore-grade copper on the basis of only a cursory examination. The leached capping over the Contention deposit, which was composed mainly of goethite and hematite, was approximately $60 \mathrm{~m}$ thick (fig. 75). The typical capping contains 15 volume percent hematite, 20 volume percent jarosite, and 65 volume percent goethite. Other types of limonite recognized in the capping include pitch and transport limonite. The pitch limonite varies from red to black. A variation in the color of hematite limonite was recognized and was useful in discriminating between former pyrite and chalcocite+pyrite-bearing capping. The pyrite capping the deposit is brick red, whereas the chalcocite+pyrite limonite here is distinctly maroon.

The hematite content in the capping decreases toward the chalcocite zone. As hematite decreases, jarosite increases slightly. Goethite content remains fairly constant throughout the leached capping but is higher in oxidized skarn and calcsilicate assemblages. Oxidation of pyrrhotite in skarn produces a distinct limonite that is goethitic but has a diagnostic deep-brownish-red color. Within the capping, boxworks of relief, fringing, and indigeneous limonite are present in the more receptive sandstones and quartz veins. Transport limonite, which is common along fractures and faults, commonly masks hematitic limonite in the adjacent wallrocks.

Turquoise is common in the leached capping and near the upper boundary of the enriched zone (fig. 76). Before the onset of large-scale mining at Copper Basin, approximately $\$ 1$ million in rough turquoise was mined from the Blue Gem deposit, also known as the Pedro lode claim, which is situated near the south limit of the Contention pit (see pl. 1; Morrissey, 1968, p. 13). The turquoise here commonly is present with other oxidized copper minerals, and where it is of good gem quality, it has a deep-blue color and excellent hardness. Available major- and minor-element chemical analyses of several samples of turquoise collected by R.J. Roberts from the Blue Gem deposit show some relation between chemical composition and color (table 26). Samples of turquoise that are a hue of green apparently contain more iron than those that are light blue to dark blue. In addition, the $\mathrm{Al}_{2} \mathrm{O}_{3}$ content of these samples seems to vary inversely with the total iron content, here reported as $\mathrm{Fe}_{2} \mathrm{O}_{3}$. This relation suggests that at least some of the reported iron content of these samples may be in the $\mathrm{Fe}^{3+}$ form and that this iron may, in fact, be substituting for $\mathrm{Al}^{3+}$ in the lattice of the turquoise (Zhang and others, 1984). However, the purity of these mineral separates is highly variable as indicated by the reported 1.0 to 8.6 weight percent $\mathrm{SiO}_{2}$. Ideally, turquoise should not contain any $\mathrm{SiO}_{2}$ (Dana and Ford, 1949). Furthermore, there are no

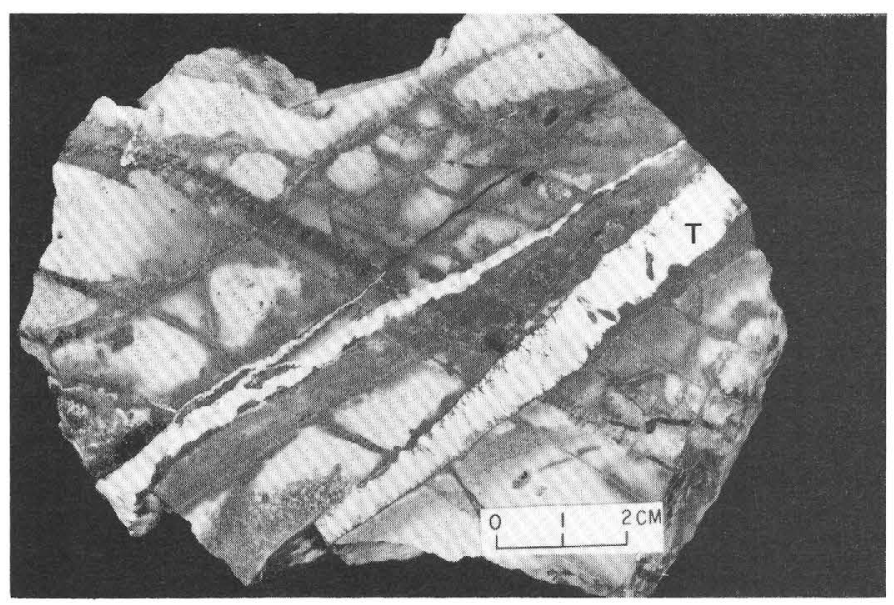

Figure 76.-Pale-blue turquoise ( $\mathrm{T}$ ) from Copper Basin area cutting iron oxide-filled fractures that replace pyrite in sample of bleached arkosic sandstone of the Upper Cambrian Harmony Formation. 
TABLE 26.-Analytical data on turquoise from the Blue Gem deposit of the Copper Basin Mine compared with analytical data on turquoise from other areas [Chemical analyses in weight percent by classical gravimetric methods; analyst, W.W. Brannock.
Quantitative spectrographic analyses in parts per million; analyst, Marcelyn Cremer. -, not detected]

\begin{tabular}{|c|c|c|c|c|c|c|}
\hline Analysis & 1 & 2 & 3 & 4 & 5 & 6 \\
\hline Lab number & $62 \mathrm{M}-15$ & $62 M-16$ & $62 \mathrm{M}-17$ & $62 \mathrm{M}-18$ & $62-\mathrm{M} 19 a$ & $62 \mathrm{M}-14$ \\
\hline \multicolumn{7}{|c|}{ Chemical analyses (weight percent) } \\
\hline $\mathrm{SiO}_{2}^{-----}$ & 6.2 & 6.3 & 8.6 & 3.0 & 1.0 & 2.1 \\
\hline $\mathrm{Al}_{2} \mathrm{O}_{3}---$ & 32.3 & 30.7 & 28.3 & 31.3 & 35.5 & 32.4 \\
\hline${ }^{1} \mathrm{Fe}_{2} \mathrm{O}_{3} \mathrm{O}^{-\cdots--}$ & 2.8 & 4.8 & 6.8 & 6.4 & 2.1 & 3.9 \\
\hline${ }^{2} \mathrm{MgO}_{-}{ }^{3}---$ & - & -- & .32 & - & - & - \\
\hline $\mathrm{CaO}------$ & .56 & .88 & 1.9 & .63 & .28 & .44 \\
\hline $\mathrm{Na}_{2} \mathrm{O}-----$ & .33 & .32 & .28 & .22 & .21 & .21 \\
\hline $\mathrm{K}_{2} \mathrm{O}-\ldots-\cdots$ & .11 & .11 & .08 & .11 & .1 & .04 \\
\hline $\mathrm{H}_{2}^{2} \mathrm{O}^{+}-----$ & 17.9 & 17.5 & 16.5 & 17.9 & 18.3 & 18.1 \\
\hline $\mathrm{H}_{2}^{2} \mathrm{O}^{-}---$ & .85 & 1.5 & 2.2 & 1.2 & .75 & .46 \\
\hline $\mathrm{P}_{2}^{2} \mathrm{O}_{5^{-----}}$ & 31. & 29.6 & 27.8 & 31.7 & 33.4 & 33.4 \\
\hline $\mathrm{CuO}------$ & 7.7 & 7.6 & 7. & 7. & 8.7 & 7.4 \\
\hline $\mathrm{ZnO}------$ & .06 & .05 & .01 & .35 & .07 & .76 \\
\hline $\mathrm{As}_{2} \mathrm{O}_{3}---$ & .24 & .34 & .3 & .36 & .06 & .36 \\
\hline${ }^{\mathrm{BaO}}-----$ & - & - & -- & - & -- & .12 \\
\hline Total---- & 100.0 & 99.7 & $\overline{100.1}$ & 100.2 & 100.5 & 99.7 \\
\hline \multicolumn{7}{|c|}{ Quantitative spectrographic analysis (parts per million) } \\
\hline Ti------ & 50.0 & 74.0 & 67.0 & 230.0 & 370.0 & 65.0 \\
\hline Ag------- & $<2$. & 24. & 22. & 18. & 7. & $<2$. \\
\hline As-------- & 3000 . & 4000 & 3000 . & 4000 . & 1000 . & 5000 . \\
\hline B--------- & 40. & 30 . & 20. & 20. & 20. & $<20$. \\
\hline Ba------- & 290. & 46. & 30. & 88 . & 68. & 1100 . \\
\hline Be------- & 10. & 9. & 8. & 7. & 10. & $<2$. \\
\hline Co------- & $<4$. & $<4$. & $<4$. & 7. & 4. & 9. \\
\hline $\mathrm{Cr}-\cdots$ & 230 . & 120. & 110. & 110. & 84. & 190. \\
\hline Ga--.--- & $<8$. & 8. & 12. & 16. & 13. & $<8$. \\
\hline Li------- & 300 . & 200 . & 200. & 300. & $<200$. & 200 . \\
\hline $\mathrm{Pb}-------$ & $<20$. & $<20$. & $<20$. & 70. & $<20$. & $<20$. \\
\hline Sc-n-.- & 160. & 64. & 64. & 84. & 80 . & 20 . \\
\hline Sr-- - - - & 190. & 32 . & 360. & 330. & 210 . & 100. \\
\hline V-c--c- & 20. & 10. & 10. & 30 . & 30 . & 40 . \\
\hline W-------- & 100 . & $<100$. & $<100$. & $<100$. & 100 . & $<100$. \\
\hline Zn------- & $<200$. & $<200$. & $<200$. & 2500 . & $<200$. & 570. \\
\hline
\end{tabular}

2 Total iron calculated as $\mathrm{Fe}_{2} \mathrm{O}_{3}$.

2 Quantitative spectrographic analyses.

1. Blue turquoise, Blue Gem deposit, Copper Basin Mine.

2. Light-green turquoise, Blue Gem deposit, Copper Basin Mine.

3. Medium-green turquoise, Blue Gem deposit, Copper Basin Mine.

4. Green turquoise, Blue Gem deposit, Copper Basin Mine.

5. Dark-b1ue turquoise, Blue Gem deposit, Copper Basin Mine.

6. Light-blue turquoise, No. 8 Mine, Eureka Co., Nev.

analyses for sulfur available for these analyzed samples to suggest thereby the amount of sulfide(s), if any, that may have been included inadvertently during the separation procedures. Nonetheless, these analyses of varicolored turquoise are compatible with the findings of Zhang and others (1984) who concluded

$* * *$ that the main reason for the color change of turquoise is the enhancement of the $\mathrm{O}^{2-} \mathrm{Fe}^{3+}$ charge-transfer band when the iron content increases, which enables its low energy tail to shift further toward long wavelength and absorb the blue light partially or completely. This may account for the color change of turquoise from blue to yellow and the tint change from light to dark with increasing iron content. Relatively pure turquoise with low iron content shows a blue color. Naturally, the basic blue color of the relatively pure turquoise has been essentially determined by the octahedrally coordinated $\mathrm{Cu}^{2+*} * *$.

\section{SUMMARY}

The principal source of the supergene copper mineralization apparently is hypogene sulfides in skarn and calc-silicate hornfels in the Harmony Formation and possibly some from the Battle Formation that 
overlay the area at one time. These originally calcareous-bearing beds probably were mineralized and altered by Late Cretaceous monzogranite porphyry that produced locally massive and widespread disseminated pyrite, pyrrhotite, and chalcopyrite in the copper-enriched outer halo of the Buckingham molybdenum system. Some hypogene copper may also have been introduced during the Tertiary emplacement of magmas associated with gold and copper skarn bodies in the mining district.

Underlying the metamorphosed calcareous beds are shale, siltstone, and various types of sandstone that contain pyrite and minor chalcopyrite as disseminations, fracture fillings, and quartz veins. Mineralization in the Copper Basin Mine occupies the east-dipping limb of a major anticline and, upon oxidation of the hypogene sulfides there, the supergene copper-bearing solutions migrated downward along bedding planes and structures from mostly skarn and calc-silicate hornfels above. The high-grade zones of copper mineralization, both hypogene and supergene generally are proximal to monzogranite porphyry. During the interval of time between the emplacement of the Late Cretaceous intrusions associated with the Buckingham system, the late Eocene or early Oligocene porphyritic leucogranite and the early Oligocene granodiorite porphyry, and subsequent deposition of the Oligocene Caetano Tuff, the Copper Basin area underwent a first-cycle oxidation and enrichment to form an intensive low-grade chalcocite zone. Renewed oxidation and erosion occurred after the Caetano Tuff was removed, exposing thereby the first cycle of supergene copper deposition. The second cycle of enrichment and oxidation, which continues to the present, removed additional oxide capping and enriched the first-cycle supergene copper zone at depth to yield the ore bodies in the Copper Basin Mine.

\section{LITHOGEOCHEMISTRY OF SURFACE ROCKS}

Comprehensive lithogeochemical studies that describe areal and vertical distribution of minor metals in fluorine-deficient, stockwork molybdenum deposits are generally not available. A notable exception to this is the geochemical investigation by Shaver $(1984 b, 1986)$ at the Hall (Nevada Moly), Nev., molybdenum stockwork deposit. However, the Hall deposit probably should be considered a transitional deposit (Theodore, 1982a) between strictly end-member fluorine-deficient types, such as the
Buckingham system, and other quartz monzonite stockwork molybdenite systems relatively enriched in fluorine. In his study, Shaver (1986) showed that molybdenum anomalies at the Hall molybdenum deposit are encompassed for 30 to $60 \mathrm{~m}$ by a zone dominated by high fluorine, and the fluorine zone, in turn, is ringed by a lead-zinc-silvermanganese zone that is 40 to $80 \mathrm{~m}$ beyond the molybdenum anomalies. In this part of the report, we attempt to provide some additional geochemical data from the Buckingham system by means of a selected bedrock sampling of the system partly along four traverse lines $\left(A-A^{\prime}, B-B^{\prime}, C-C^{\prime}, D-D^{\prime}\right.$, fig. 77). In all, 102 samples were collected along these traverses. Spacing between sampling localities is fairly widespread along the first three of the traverses. For example, traverse $A-A^{\prime}$ spans almost the entire Buckingham area in a north-south direction, and 45 samples were taken. Along the last traverse $\left(D-D^{\prime}\right)$, however, 13 samples were collected along a $300-\mathrm{m}$ traverse relatively close to the West stock. In addition, 26 other sites were sampled for comparative purposes along traverse $E-E^{\prime}$, just to the north of the Buckingham stockwork molybdenum system (fig. 77). This particular traverse has some veined rocks related to the late Eocene or early Oligocene biotite-hornblende monzogranite of Bluff area and to the porphyritic leucogranite there of approximately the same age.

Chemical, spectrographic, and opticalspectroscopic analyses were made in the permanent laboratory facilities of the U.S. Geological Survey in Menlo Park, Calif., Denver, Colo., and Reston, Va. The types of analyses performed are not consistently uniform for the entire data set, primarily because of the protracted duration of the study and intervening shift in priorities of laboratory resources to other programs. Furthermore, the relatively high lower limits of determination for some elements (silver, arsenic, gold, niobium, lead, antimony, and tin, in particular) resulted in a large number of qualified analyses for these elements, and thereby precluded our making adequate judgements concerning much of their areal distributions and elemental associations. The material analyzed consisted of approximately 1-kg composite rock-chip samples that commonly were collected over an outcrop area of about $10 \mathrm{~m}^{2}$. Some of the samples include vein, gossan, and mineralized fault-gouge material, particularly along traverse $A-A^{\prime}$ where it crosses mineralized structures at the Little Giant Mine. Commonly, at such sites, more than one sample was collected (fig. 77). The various analytical techniques used to determine the concentrations of the elements 
TABLE 27.-Analytical data obtained along traverse A-A' (fig. 77)

\begin{abstract}
[Quantitative emission-spectrographic analyses in parts per million; analyst, R.E. Mays. Relative standard deviation of any single reported concentration should be taken as plus or minus 15 percent. Looked for, but not found, at parts-per-million detection levels in parentheses: $\mathrm{Bi}$ (14), Cd (14), $\mathrm{Nb}(20)$, Sb (40), Ce (50), Ge (14), In (3), Re (14), Tl (6). Au determined by fire assay followed by flameless atomic-absorption spectroscopy, W determined colorimetrically, Hg determined by cold-vapor atomic-absorption spectroscopy, and Zn determined by flame atomic-absorption spectroscopy; analysts, A. Neuville, A. Childress, J. Kane, and R. Moore. F determined by specific-ion-electrode methods; analysts, S. Neil. Th and U determined by instrumental delayed-neutron counting, using methods of Millard and Keaten (1982); analysts, H.T. Millard, Jr., B.A. Keaten, and F.M. Luman. -, not detected; n.d., not determined]
\end{abstract}

\begin{tabular}{|c|c|c|c|c|c|c|c|c|c|c|c|c|}
\hline Field No. & $79 \mathrm{C} 1$ & $79 \mathrm{C} 2$ & $79 \mathrm{C} 3$ & $79 \mathrm{C} 4$ & $79 C 5$ & $79 \mathrm{C} 6$ & $79 C 7$ & $79 \mathrm{C8}$ & $79 C 9$ & $79 \mathrm{C} 10$ & $79 \mathrm{CI1}$ & $79 \mathrm{C} 12$ \\
\hline \multicolumn{13}{|c|}{ Quantitative emission } \\
\hline $\mathrm{Ag}$ & - & - & - & - & - & - & - & - & -- & - & 1.0 & - \\
\hline As & -- & -- & -- & -- & - & - & - & -- & -- & - & -- & - \\
\hline B & 36.0 & 26.0 & 38.0 & 42.0 & 54.0 & 40.0 & 11.0 & 30.0 & 34.0 & - & 40. & 38.0 \\
\hline $\mathrm{Ba}$ & 400 & 260 . & 260 . & 320. & 330. & 760. & 220 . & 1100. & 300. & 700.0 & 800 & 1300 \\
\hline Be & - & -- & - & - & - & - & - & - & - & - & - & 5. \\
\hline Co & 5. & 4. & 4. & -- & -- & 4. & -- & 4. & -- & -- & -- & 4. \\
\hline $\mathrm{Cr}$ & 20. & 20. & 13. & 20. & 180 & 24 . & 13. & 64. & 12. & 16. & 17. & 80. \\
\hline $\mathrm{Cu}$ & 20. & 6. & 7. & 14. & 4. & 10. & 16. & 320. & 44. & 40. & 74. & 84. \\
\hline $\mathrm{Ga}$ & 9. & 10. & 8. & 8. & 7. & 10. & 7. & 17. & 8. & 8. & 11. & 20. \\
\hline $\mathrm{La}$ & - & - & - & -- & -- & - & - & 30. & -- & -- & -- & 30. \\
\hline Mn & 260. & 210 & 300. & 150. & 26. & 62. & 96. & 240. & 32. & 40. & 80. & 240 \\
\hline Mo & -- & -- & - & - & - & - & - & - & - & - & - & -- \\
\hline $\mathrm{Ni}$ & 18. & 8. & 6. & 7. & - & 6. & 4. & 22 . & - & - & 8. & 16. \\
\hline $\mathrm{Pb}$ & - & - & - & - & -- & - & -- & - & -- & - & - & -- \\
\hline $\mathrm{Sb}$ & -- & -- & -- & -- & -- & - & -- & -- & -- & -- & - & -- \\
\hline $\mathrm{Sc}$ & 11. & 10. & 9. & 10. & 10. & 11. & 10. & 19. & 8. & 10. & 10. & 19. \\
\hline Sn & -- & - & - & - & - & - & - & - & - & - & - & - \\
\hline Sr & 18. & 20. & 26. & 40. & 24. & 19. & 16. & 40. & 20. & 22. & 50 & 96. \\
\hline $\begin{array}{l}\mathrm{Ti} \\
\mathrm{V}\end{array}$ & $\begin{array}{r}3000 . \\
16 .\end{array}$ & $\begin{array}{r}3000 . \\
22 .\end{array}$ & $\begin{array}{r}2800 . \\
18 .\end{array}$ & $\begin{array}{r}3200 . \\
16 .\end{array}$ & $\begin{array}{r}3600 . \\
28 .\end{array}$ & $\begin{array}{r}3200 . \\
32 .\end{array}$ & $\begin{array}{r}1900 . \\
17 .\end{array}$ & $\begin{array}{r}4000 . \\
96 .\end{array}$ & $\begin{array}{r}1800 . \\
20 .\end{array}$ & $\begin{array}{r}2000 . \\
26 .\end{array}$ & $\begin{array}{r}2300 . \\
32 \text {. }\end{array}$ & $\begin{array}{r}>4000 \\
120\end{array}$ \\
\hline$Y$ & 20 & 24. & 18. & 20. & 16. & 18. & -- & 34. & 12. & 14. & - & 34. \\
\hline $\mathrm{Yb}$ & 2. & 2. & 2. & 2. & 2. & 2. & 1. & 5. & 1. & 2. & 2. & 6. \\
\hline $\mathrm{Zr}$ & 300 & 500. & 260 & 260 & 330. & 240 & 240 & 560. & 120 & 240. & 130 & 260 \\
\hline \multicolumn{13}{|c|}{ Chemical analyses (parts per million) } \\
\hline $\mathrm{Au}$ & $<0.05$ & $<0.05$ & $<0.05$ & $<0.05$ & $<0.05$ & $<0.05$ & $<0.05$ & $<0.05$ & $<0.05$ & $<0.05$ & $<0.05$ & $<0.05$ \\
\hline $\mathrm{F}$ & 200 . & 200 . & 100 . & 200 . & 200 . & 200 . & 100 . & 600 . & 300 . & 200 & 200 & 400 \\
\hline $\mathrm{Hg}$ & .092 & .033 & .022 & .02 & .021 & .028 & .025 & .023 & .032 & .024 & .032 & .034 \\
\hline Th & 7.04 & 7.33 & 7.06 & 6.98 & 7.98 & 7.57 & 4.54 & 15.27 & 5.9 & 5.75 & 6.42 & 16.45 \\
\hline $\mathrm{U}$ & 2.05 & 2. & 1.85 & 2.32 & 2.33 & 2.07 & 1.65 & 4.99 & 1.52 & 1.85 & 1.8 & 4.99 \\
\hline W & .9 & .97 & 1. & 1.3 & .88 & 2.9 & 1.8 & 2.3 & 1.9 & 1.5 & 2.6 & 2.9 \\
\hline $\mathrm{Zn}$ & 48. & 36. & 22 . & 16. & 8. & 16. & 16. & 36. & 8. & 10 & 18. & 49. \\
\hline
\end{tabular}

are indicated on the tables of the geochemical data (see tables 27-31). A representative distribution of uranium and thorium in rocks at the surface of the Buckingham system was determined along two of the geochemical traverses, $A-A^{\prime}$ and $B-B^{\prime}$. The coefficient of variation of the uranium and thorium analyses reported for this system may be estimated by referring to tables 32 and 33 . Table 33 includes two sets of six replicate delayed-neutron determinations of uranium and thorium for each of 17 samples whose complete analyses are presented elsewhere in this report (tables 11, 20, 22). The unqualified minimum and maximum values for each of 30 selected elements analyzed in tables 27 through 31 , together with the number and type of qualified determinations for the 128 samples analyzed, are listed in table 34 .

\section{VARIATION OF MINOR ELEMENTS IN AND AROUND THE BUCKINGHAM SYSTEM}

From our data, we infer that concentrations of many elements in rock show fairly specific relations to the surface projection of the boundary of the Buckingham molybdenum deposit and to the outer limit of quartz stockworks at the surface. The surface projection of the deposit known as of 1989 , and the mapped outer limit of the quartz stockworks coincide closely for much of the deposit (fig. 77). This relation holds especially for the western parts of the deposit. All samples that contain at least $50 \mathrm{ppm}$ Mo are accentuated in figure 77; the highest molydenum contents in these analyzed samples is $780 \mathrm{ppm}$. Thus, from the distribution of samples containing 50 or more ppm molybdenum, 
TABLE 27.-Analytical data obtained along traverse A-A' (fig. 77)—Continued

\begin{tabular}{|c|c|c|c|c|c|c|c|c|c|c|c|c|}
\hline Field No. & $79 \mathrm{C13}$ & $79 \mathrm{Cl}$ & $79 \mathrm{C} 15$ & $79 \mathrm{C} 16$ & $79 C 17$ & $79 \mathrm{C} 18$ & $79 C 19$ & $79 \mathrm{C20}$ & $79 \mathrm{C21}$ & $79 \mathrm{C} 22$ & $79 \mathrm{C} 23$ & $79 \mathrm{C} 24$ \\
\hline \multicolumn{13}{|c|}{ per million) } \\
\hline $\mathrm{Ag}$ & 190.0 & 1300.0 & 160.0 & 3.0 & 1.0 & 11.0 & 7.0 & 2.0 & -- & 130. & -- & - \\
\hline As & $>20000$ & $>20000$ & $>20000$ & - & - & - & -- & - & - & $>20000$ & - & - \\
\hline B & 28 & 28 & 20 . & 70. & 60. & 32. & 110 & -- & -- & 96. & -- & -- \\
\hline $\mathrm{Ba}$ & 220. & 480. & 60. & 1100 . & 600 & 900. & 2800 . & 960. & 960.0 & 40. & 760.0 & 840.0 \\
\hline $\mathrm{Be}$ & - & - & - & 5. & -- & - & - & 4. & 4. & -- & -- & -- \\
\hline Co & -- & - & - & 5. & - & - & - & 12. & 30. & 12. & 16. & - \\
\hline $\mathrm{Cr}$ & 92. & 46. & 110. & 80 . & 110. & 60. & 120. & 120. & 120. & 32 . & 110. & 100 \\
\hline $\mathrm{Cu}$ & 96. & 500. & 350 . & 110. & 60 & 84. & 74. & 74. & 84. & 190. & 58. & 58. \\
\hline $\mathrm{Ga}$ & 9. & 13. & 8. & 26. & 26. & 17. & 24. & 28 . & 24. & 14. & 20. & 20. \\
\hline $\mathrm{La}$ & - & - & - & 54. & 52. & 44. & 54. & 30. & 30. & -- & 30. & - \\
\hline Mn & 64. & 100 & 60. & 280 & 170 . & 64. & 110. & 700 . & 800 . & 330. & 800 . & 520. \\
\hline Mo & 66. & 13. & 15. & 22. & 72 . & 15. & 260 . & 130. & 76 . & 260 . & 100. & 700 \\
\hline $\mathrm{Ni}$ & - & - & - & 12. & 8. & - & 5. & 44. & 64. & 50. & 58. & 46. \\
\hline $\mathrm{Pb}$ & 10000 & 10000 & 10000 & - & - & 90. & 60. & - & -- & 10000 & 50. & -- \\
\hline $\mathrm{Sb}$ & 720 . & 2600 . & 780 & -- & -- & - & $\cdots$ & -- & -- & 10000 & 50. & -- \\
\hline Sc & 9. & 16. & 10. & 22 . & 24. & 19. & 22. & 26. & 22 . & -- & 22. & 19. \\
\hline $\mathrm{Sn}$ & 160 & 260. & 120 & - & $=$ & - & - & - & - & 260 & - & -- \\
\hline $\mathrm{Sr}$ & 24 . & 22 . & 13. & 50. & 110. & 28. & 74. & 300. & 180. & - & 160 & 220 \\
\hline $\mathrm{Ti}$ & 1600. & 2300. & 1200 . & 4000. & 4000 . & 3400 . & $>4000$ & $>4000$. & $>4000$. & 300 . & $>4000$. & $>4000$. \\
\hline $\mathrm{V}$ & 19. & 34. & 19. & 120 & 190 & 96. & 110 & 52 & 150 & - & 120 & 100 \\
\hline$Y$ & - & - & $\ldots$ & 34. & 46. & 26. & 22. & 36. & 32. & - & 26 . & 22 . \\
\hline $\mathrm{Yb}$ & 1 . & 2. & 2. & 9. & 8. & 3. & 4. & 7. & 9. & 7. & 4. & 4. \\
\hline $\mathrm{Zr}$ & 160. & 180. & 160. & 240 . & 280 & 200. & 240 . & 160. & 200 & - & 180. & 140. \\
\hline \multicolumn{13}{|c|}{ Chemical analyses (parts per million) } \\
\hline $\mathrm{Au}$ & $<0.05$ & 12.0 & 6.3 & $<0.05$ & $<0.05$ & $<0.05$ & $<0.05$ & $<0.05$ & $<0.05$ & 2.5 & $<0.05$ & $<0.05$ \\
\hline $\mathbf{F}$ & 300 . & 300 . & 200 & 500. & 600 & 400 & 600 & 700. & 500 . & 100 & 600 & 900. \\
\hline $\mathrm{Hg}$ & 91. & 1.1 & .73 & .45 & .044 & .024 & .026 & .025 & .072 & .15 & .071 & .032 \\
\hline Th & 4.07 & 8.75 & 3.17 & 17.82 & 20.33 & 12.68 & 17.95 & 16.72 & 15.4 & .29 & 13.37 & 13.05 \\
\hline U & 1.52 & 12.82 & 1.13 & 4.91 & 5.06 & 2.75 & 3.7 & 4.42 & 3.21 & .09 & 2.59 & 3.57 \\
\hline W & 6.5 & 4.9 & 2.4 & 10. & 9.3 & 11. & 15. & 6.6 & 6. & 23. & 5.1 & 8.5 \\
\hline $\mathrm{Zn}$ & 63. & 190. & 280 & 27 . & 15. & 13. & 16. & 350 . & 83. & 5800 . & 300 & 290 \\
\hline
\end{tabular}

there appear to be three loci of widely extensive, high concentrations of molybdenum at the surface: at and near the West stock, at the East stock, and on Vail Ridge, where well-developed quartz stockworks crop out (fig. 77). High concentrations of molybdenum in rocks provide the best geochemical signature of the widespread extent of the Buckingham molybdenum system. Geochemical background for molybdenum apparently is less than 5 ppm along geochemical profile $A-A^{\prime}$ in contactmetamorphosed and altered rocks of the Harmony Formation that are beyond the outer limit of quartz stockworks associated with the system (fig. 78). The lower determination limit of molybdenum for the samples analyzed along this particular traverse is $5 \mathrm{ppm}$. Along traverse $E-E^{\prime}$ (fig. 77), however, many of the samples have molybdenum contents in the range $2-8 \mathrm{ppm}$ (see table 31 ).

Several other elements show increased abundances along geochemical profile $A-A^{\prime}$ near the West stock and its surrounding halo of quartz stockworks. Fluorine shows an increase from about 200-250 ppm to about 500-600 ppm (but with a 900-ppm maximum), largely within the area underlain by quartz stockworks (fig. 78). The fluorine anomaly here coincides strongly with the elevated molybdenum content. However, these data suggest that local, increased concentrations of fluorine and molybdenum may extend farther to the south of the West stock than to the north. These fluorinemolybdenum relations seemingly differ somewhat from those found at the Hall (Nevada Moly), Nev., molybdenum deposit by Shaver (1984b, 1986). At Hall, fluorine contents apparently reach their maximum values just peripheral to areas showing the highest molybdenum contents. Tungsten contents at Buckingham increase near the West stock from a background of about $1 \mathrm{ppm}$ to values that fluctuate widely between adjacent samples in the range $6-30 \mathrm{ppm}$ in the area underlain by the quartz stockworks (fig. 78). Boron contents, on the one hand, south of the West stock, seem to increase gradually from 30 to about $100 \mathrm{ppm}$ at the outer edge of the quartz stockworks (fig. 78). On the other hand, in the area immediately underlain by the Buckingham deposit, boron seems to be 
TABLE 27.-Analytical data obtained along traverse A-A' (fig. 77)—Continued

\begin{tabular}{|c|c|c|c|c|c|c|c|c|c|c|c|c|c|}
\hline Field No. & $79 \mathrm{C} 25$ & $79 \mathrm{C} 26$ & $79 \mathrm{C} 27$ & $79 \mathrm{C} 28$ & $79 \mathrm{C} 29$ & $79 \mathrm{C} 30$ & $79 \mathrm{C} 31$ & $79 \mathrm{C} 32$ & $79 \mathrm{C} 33$ & $79 \mathrm{C} 34$ & $79 \mathrm{C} 35$ & $79 \mathrm{C} 36$ & $79 \mathrm{C} 37$ \\
\hline \multicolumn{14}{|c|}{ Quantitative emission spectrographic analyses (parts } \\
\hline $\mathrm{Ag}$ & 2.0 & 3.0 & 8.0 & 2.0 & - & - & 6.0 & 3.0 & 2.0 & - & -- & - & -- \\
\hline As & -- & 2800 & - & - & - & - & -- & - & - & -- & - & - & -- \\
\hline B & - & -- & -- & - & -- & -- & - & -- & 28 . & 20.0 & 30.0 & 40.0 & -- \\
\hline $\mathrm{Ba}$ & 1800 & 2000 & 2000 & 180 & 260.0 & 260.0 & 220 & 300 & 400 & 360 & 360 & 380 & 230.0 \\
\hline $\mathrm{Be}$ & - & -- & -- & - & - & - & -- & -- & - & - & -- & -- & -- \\
\hline Co & -- & - & -- & - & 4. & - & - & - & -- & 5. & 9. & 8. & 6. \\
\hline $\mathrm{Cr}$ & 4. & 6. & 3. & 11. & 22. & 16. & 9. & 7. & 18. & 17. & 34. & 44. & 46. \\
\hline $\mathrm{Cu}$ & 16. & 50. & 92. & 42. & 60. & 10. & 9. & 10. & 15. & 18. & 11. & 10. & 8. \\
\hline $\mathrm{Ga}$ & 14. & 14. & 17. & 8. & 11. & 8. & 8. & 8. & 10. & 8. & 13. & 15. & 9. \\
\hline La & -- & 30. & -- & - & 44. & - & - & -- & -- & 40. & 30. & 42. & -- \\
\hline Mn & 42. & 60. & 42. & 32. & 74. & 30. & 56. & 32. & 80. & 320. & 380 & 440 & 300 \\
\hline Mo & 78. & 78. & 260 & - & - & - & - & - & - & -- & -- & - & - \\
\hline $\mathrm{Ni}$ & - & -- & 5. & 4. & 6. & - & -- & -- & 5. & 9. & 18. & 24. & 16. \\
\hline $\mathrm{Pb}$ & 160. & 50. & 120 & - & - & -- & 520. & -- & - & - & - & - & - \\
\hline $\mathrm{Sb}$ & -- & -- & -- & -- & - & - & -- & -- & -- & -- & -- & -- & -- \\
\hline $\mathrm{Sc}$ & 9. & 9. & 9. & 8. & 10. & 9. & 8. & - & 12. & 12. & 12. & 15. & 12. \\
\hline $\mathrm{Sn}$ & -- & -- & - & -- & - & -- & - & -- & -- & -- & - & - & -- \\
\hline SI & 140. & 180 & 220 . & 15. & 34. & 30. & 8. & 15. & 26. & 32. & 40. & 68. & 48. \\
\hline $\mathrm{Ti}$ & 1300 . & 1800 . & 1400 & 1200 & 1900. & $16000^{\circ}$ & 900. & 800 & 1600 & 1500 . & 2300 & 2500 & 2100 \\
\hline $\mathrm{V}$ & 32. & 42. & 34. & 24. & 34. & 18 & - & -- & 24 & 24 . & 38. & 50. & 38. \\
\hline$Y$ & -- & - & -- & 14. & 18. & 16. & - & -- & 18. & 16. & 16. & 20. & 13. \\
\hline $\mathrm{Yb}$ & - & - & - & 1. & 3. & 2. & - & -- & 2. & 2. & 2. & 3. & 2. \\
\hline $\mathrm{Zr}$ & 76. & 52. & 52. & 140. & 440. & 240 & 100 & 66. & 230. & 150. & 130. & 150. & 130. \\
\hline \multicolumn{14}{|c|}{ Chemical analyses (parts per million) } \\
\hline $\mathrm{Au}$ & $<0.05$ & $<0.05$ & $<0.05$ & $<0.05$ & $<0.05$ & $<0.05$ & $<0.05$ & $<0.05$ & $<0.05$ & $<0.05$ & $<0.05$ & $<0.05$ & $<0.05$ \\
\hline$F$ & N.d. & 600 & 400 & 200 & 300. & 200 . & 200 & 100 & 200 & 300 & 300 & 400 & 200 \\
\hline $\mathrm{Hg}$ & .035 & .037 & .044 & .045 & .042 & .048 & .052 & .068 & .046 & .043 & .041 & .04 & .044 \\
\hline Th & 8.24 & 11.24 & 9.55 & 10.71 & 22.2 & 15.98 & 7.68 & 7.45 & 10.62 & 14.9 & 17.22 & 18.18 & 12.62 \\
\hline $\mathrm{U}$ & 2.02 & 3.69 & 2.92 & 2.24 & 3.75 & 3.14 & 1.53 & 1.5 & 2.54 & 3.32 & 3.13 & 3.83 & 2. \\
\hline W & 9.2 & 8.4 & 30. & 5.3 & 15. & 4.1 & 4.1 & 4. & 2.9 & 6.5 & .93 & 1.5 & .94 \\
\hline $\mathrm{Zn}$ & 19. & 59. & 30. & 33. & 13. & 19. & 17. & 11. & 87 & 89. & 140 & 66 & 31. \\
\hline
\end{tabular}

depleted to contents of less than $10 \mathrm{ppm}$, the lower determination limit. Such a depletion also seems to extend as far as $250 \mathrm{~m}$ north of the north limit of the surface projection of the deposit along profile $A-A^{\prime}$. Copper contents increase from a local background of about $10 \mathrm{ppm}$ to values generally in the range 50-190 ppm in the area of the quartz stockworks surrounding the West stock (fig. 78). The $\mathrm{Cu} / \mathrm{Mo}$ ratio in these samples within the surface projection of the Buckingham deposit (profile $A-A^{\prime}$, fig. 77) is generally less than 1 . However, as pointed out in the subsection above entitled "Economic Geology," hypogene copper typically is present as chalcopyrite-here mostly in a relatively narrow halo that surrounds the molybdenumenriched, steeply plunging shells that make up much of the deposit (fig. 64). However, south of the West stock, in the general area of the Little Giant Mine, mineralized rocks along the Little Giant fault show high copper contents, possibly from tetrahedrite, in the range $350-500 \mathrm{ppm}$. In addition, one other sample along profile $A-A^{\prime}$ south of the Little Giant Mine has a copper content of 320 ppm. This particular rock sample is a biotite hornfels that contains some iron oxide(s) that replace sulfides; it probably also contains some chalcopyrite. There is no apparent increase in the concentration of copper along the geochemical profile at the outer limit of the pyrite halo that surrounds the Buckingham system (fig. 78). Barium also seems to show an increased abundance in most of the rocks sampled within the surface projection of the deposit at the West stock (fig. 78). Background for barium in unmineralized rocks of the Harmony Formation outside the pyritic halo seems to be about 280 to $300 \mathrm{ppm}$ (fig. 78). However, local background within the pyritic halo also seems to be at these same levels across a broad area to the north of the West stock. Locally high barium contents, to about 800 to $1,200 \mathrm{ppm}$, in unaltered rocks of the Harmony Formation near the north terminus of geochemical profile $A-A^{\prime}$ probably indicate the presence there of minor amounts of syngenetic barite associated with carbonate rocks.

Several other elements apparently show no relation along geochemical profile $A-A^{\prime}$ to underlying 
TABLE 27.-Analytical data obtained along traverse A-A' (fig. 77)—Continued

\begin{tabular}{|c|c|c|c|c|c|c|c|c|}
\hline Field No. & $79 C 38$ & 79039 & $79 C 40$ & $79 \mathrm{C} 41$ & $79 C 42$ & $79 \mathrm{C} 43$ & 79044 & $79 \mathrm{C}_{45}$ \\
\hline & Quantitative & emission & spectrogr & raphic a & analyses ( & parts per & mi11ion) & \\
\hline $\mathrm{Ag}$ & - & - & - & - & - & -- & -- & - \\
\hline As & - & - & - & - & -- & - & - & - \\
\hline B & 20.0 & - & - & 50.0 & 46.0 & 64.0 & 68.0 & 58.0 \\
\hline $\mathrm{Ba}$ & 260. & 1100.0 & 800.0 & 1160. & 290. & 440. & 280 . & 350. \\
\hline $\mathrm{Be}$ & - & - & - & -- & - & - & - & -- \\
\hline Co & 6. & 6. & 6. & - & 6. & 6. & 4. & 6. \\
\hline $\mathrm{Cr}$ & 34. & 30. & 26. & 5. & 40. & 40. & 28 . & 35. \\
\hline $\mathrm{Cu}$ & 7. & 34. & 11. & -- & 9. & 13. & 5. & 12. \\
\hline $\mathrm{Ga}$ & 9. & 12. & 12. & 20. & 10. & 15. & 10. & 10. \\
\hline $\mathrm{La}$ & - & 60. & -- & 72 . & 46. & 51. & - & -- \\
\hline Mn & 440. & 330. & 360. & 580. & 360 . & 420. & 580. & 1400. \\
\hline Mo & - & - & - & -- & - & - & - & -- \\
\hline $\mathrm{Ni}$ & 16. & 13. & 10. & - & 12. & 14. & 4. & 9. \\
\hline $\mathrm{Pb}$ & - & 20. & - & - & - & 33. & - & - \\
\hline $\mathrm{Sb}$ & - & - & -- & -- & -- & - & -- & - \\
\hline Sc & 11. & 12. & 12. & 9. & 8. & 9. & 7. & 14. \\
\hline Sn & - & -- & -- & - & -- & - & - & -- \\
\hline $\mathrm{Sr}$ & 22 . & 130. & 100. & 550. & 12. & 160. & 160 . & 410. \\
\hline $\mathrm{Ti}$ & 1900. & 2500 . & 1900. & 4600 & 4800 . & 5000 & 2700 & 4000 . \\
\hline V & 30. & 34. & 30 & 38. & 38. & 43. & 26 & 37. \\
\hline $\mathbf{Y}$ & 12. & 20. & 14. & 20. & 20. & 24. & 19. & 26 . \\
\hline $\mathrm{Yb}$ & 2. & 3. & 2. & - & 2. & 2. & - & 2. \\
\hline $\mathrm{Zr}$ & 130. & 240 . & 140. & 150. & 200 . & 280 . & 170 . & 150. \\
\hline \multicolumn{9}{|c|}{ Chemical } \\
\hline $\mathrm{Au}$ & $<0.05$ & $<0.05$ & $<0.05$ & $<0.05$ & $<0.05$ & $<0.05$ & $<0.05$ & $<0.05$ \\
\hline F & 200. & 300 . & 300 . & 400. & 300 . & 200 . & 200. & 500 . \\
\hline $\mathrm{Hg}$ & .048 & .049 & .043 & .35 & .13 & .078 & .085 & .36 \\
\hline Th & 10.2 & N.d. & 12.1 & 11.6 & 16.4 & 16.6 & 12.4 & 7.33 \\
\hline $\mathbf{U}$ & 1.59 & N.d. & 2.54 & 3.56 & 2.8 & 2.93 & 1.99 & 3.05 \\
\hline W & .89 & .84 & .79 & 1. & 1. & 2.1 & 1.9 & 2.3 \\
\hline $\mathrm{Zn}$ & 73. & 25. & 28. & 35 . & 48. & 65. & 32. & 33. \\
\hline
\end{tabular}

metallization in the Buckingham deposit. These include uranium and thorium (fig. 79). However, background concentrations of uranium and thorium beyond the outer limit of the pyrite halo that surrounds the deposit seem to have a much lower variance near the south terminus of the profile than elsewhere. Distribution of manganese along the profile (fig. 79) might be interpreted to represent local irregular increases from a nearby local background of about $150 \mathrm{ppm}$ to values in the range 600-800 ppm throughout the underlying Buckingham deposit. However, some of these samples throughout the Buckingham deposit are from structures that include abundant sulfides related most likely to vein-type mineralization during the Tertiary. The widespread increase in manganese contents in the general area of the north end of geochemical profile $A-A^{\prime}$ indicates the presence there of manganiferous carbonates in some unaltered sands of the Harmony Formation. The increased zinc contents of a few samples within the quartz stockworks along geochemical profile $A-A^{\prime}$ (fig. 79) probably also indicate the superposition of metallized Tertiary structures on the Late Cretaceous molybdenum system. Samples collected from mineralized strands of the Little Giant fault where they cross the geochemical profile also show high zinc contents: 190 to $280 \mathrm{ppm}$, compared with an approximate local background of 15 to $20 \mathrm{ppm}$ in the surrounding rocks within the pyritic halo of the Buckingham system.

Concentrations of tin detected or, more appropriately, not detected along geochemical profile $A-A^{\prime}$ also merit some discussion because tin is an important byproduct associated with some molybdenum deposits such as the Climax, Colo., system. Of the 45 samples collected along profile $A-A^{\prime}$, tin was detected in only four of the samples. The lower limit of determination for tin by the method used on these samples is $4 \mathrm{ppm}$ (table 27). Three of the four samples that contain detectable tin are mineralized rocks from the Little Giant Mine area, a locus of Tertiary silver-base-metal mineralization (samples 13-15, table 27); the tin contents of these samples are 160,260 , and $120 \mathrm{ppm}$, respectively. The samples also contain more than $20,000 \mathrm{ppm} \mathrm{As}$ and more than $10,000 \mathrm{ppm} \mathrm{Pb}$; much of the arsenic 
TABLE 28.-Analytical data obtained along traverse B-B' (fig. 77)

[Quantitative emission-spectrographic analyses by R.E. Mays. Relative standard deviation of any single reported concentration should be taken as plus or minus 15 percent. Looked for, but not found, at parts-per-million detection levels in parentheses: As (300), Be (2), Bi (14), Cd (14), Nb (20), Sb (40), Sn (4), Ce (50), Ge (14), In (3), Re (14), $\mathrm{Tl}$ (6). Au determined by fire assay followed by flameless atomic-absorption spectroscopy, $\mathrm{Hg}$ determined by cold-vapor atomic-absorption spectroscopy, Zn determined by flame atomic-absorption spectroscopy, and W determined colorimetrically; analysts, A. Neville, A. Childress, J. Kane, and R. Moore. F determined by specific-ionelectrode methods; analyst, S. Neil. Th and U determined by instrumental delayed-neutron counting, using the methods of Millard and Keaten (1982); analysts, H.T. Millard, Jr., B.A. Keaten, and F.M. Luman. -, not detected]

\begin{tabular}{|c|c|c|c|c|c|c|c|c|c|c|c|c|c|c|}
\hline Analysis & 1 & 2 & 3 & 4 & 5 & 6 & 7 & 8 & 9 & 10 & 11 & 12 & 13 & 14 \\
\hline Field No. & $79 \mathrm{C} 46$ & $79 \mathrm{C47}$ & $78 \mathrm{C} 48$ & $79 \mathrm{C} 49$ & $79 \mathrm{C50}$ & $79 \mathrm{C51}$ & $79 \mathrm{C52}$ & $79 \mathrm{C} 53$ & $79 \mathrm{C55}$ & $79 \mathrm{C} 54$ & $79 \mathrm{C} 65$ & $79 \mathrm{C} 64$ & $79 \mathrm{C} 63$ & $79 \mathrm{C} 62$ \\
\hline \multicolumn{15}{|c|}{ Quantitative emission spectrographic analyses (parts per miliion) } \\
\hline $\mathrm{Ag}$ & - & - & -- & - & - & - & 2.0 & - & - & -- & - & - & - & -- \\
\hline$B$ & 96.0 & 80.0 & 52.0 & 58.0 & 34.0 & - & 110. & 52.0 & 72.0 & 62.0 & 40.0 & 52.0 & 58.0 & 90.0 \\
\hline $\mathrm{Ba}$ & 630. & $>2000$ & $>2000$ & 970. & 1300. & 1300. & 970. & $>2000$ & $>2000$ & $>2000$ & 900. & 630. & 1300 & 310. \\
\hline Co & 5. & 3. & 3. & 9. & 7. & 8. & - & - & - & -- & 5. & 4. & - & - \\
\hline $\mathrm{Cr}$ & 17. & 24. & 50. & 90. & 84. & 64. & 20. & 4. & 3. & 2. & 47. & 40. & 40. & 32. \\
\hline $\mathrm{Cu}$ & 60. & 100. & 100. & 60. & 29. & 50. & 48. & 23. & 24. & 24. & 76. & 62. & 47. & 76. \\
\hline $\mathrm{Ga}$ & 9. & 12. & 15. & 34. & 23. & 26. & 7. & 12. & 21. & 19. & 18. & 14. & 13. & 11. \\
\hline La & - & - & 51. & 72. & -- & 38. & - & - & -- & - & - & - & - & - \\
\hline $\mathrm{Mn}$ & 30. & 30. & 130. & 330. & 420. & 330. & 38. & 30. & 34. & 38. & 240. & 180. & 62. & 52. \\
\hline Mo & - & 10. & 14. & 14. & - & 160. & 700. & 220. & 130. & 62. & - & 8. & 23. & 39. \\
\hline $\mathbf{N i}$ & - & -- & 4. & 9. & 10. & 7. & -- & - & - & - & 13. & 13. & 6. & 9. \\
\hline $\mathrm{Pb}$ & - & - & - & -- & 36. & - & - & 41. & 600. & 1000 & -- & - & - & - \\
\hline Sc & 4. & 6. & 10. & 19. & 23. & 18. & 3. & 4. & 2. & 3. & 7. & 5. & 5. & \\
\hline $\mathrm{Sr}$ & 100 & 130. & 170. & 90. & 710 . & 170 & 65. & 210. & 150. & 150. & 120. & 130. & 160. & 120. \\
\hline Ti & 1100. & 2200 & $>5000$ & $>5000$ & $>5000$ & $>5000$ & 3000 & 2200 & 2800 & 2600 & $>5000$ & 4800 & $>5000$ & 4000 \\
\hline v & 18. & 28 , & 68. & 81. & 65. & 57. & 24. & 23. & 32. & 28. & 46. & 38. & 29. & 34. \\
\hline $\mathbf{Y}$ & - & - & 24. & 28. & 24. & 20. & 14. & - & - & - & 18. & 18. & 28. & 26. \\
\hline $\mathrm{Yb}$ & -- & - & 2. & 3. & 2. & 3. & - & - & - & - & 2. & -- & 2. & - \\
\hline $\mathrm{Zr}$ & 50. & 120. & 220. & 150. & 200 & 94. & 150. & 32. & 52. & 64. & 110. & 130. & 140. & 180. \\
\hline \multicolumn{15}{|c|}{ Chemical analyses (parts per million) } \\
\hline $\mathrm{Au}$ & $<0.05$ & $<0.05$ & $<0.05$ & $<0.05$ & $<0.05$ & $<0.05$ & $<0.05$ & $<0.05$ & $<0.05$ & $<0.05$ & $<0.05$ & $<0.05$ & $<0.05$ & $<0.05$ \\
\hline $\mathbf{F}$ & 100. & 200. & 500. & 900. & 600. & 700 . & 200. & 300. & 500. & 700. & 600. & 500. & 400. & 500. \\
\hline $\mathrm{Hg}$ & .13 & .098 & .072 & .089 & .1 & .075 & .098 & .12 & .13 & .13 & .13 & .15 & .71 & .13 \\
\hline Th & 3.86 & 8.48 & 18.2 & 23. & 8.8 & 20.4 & 5.02 & 9.85 & 11.8 & 35.4 & 20.6 & 20. & 19.6 & 19. \\
\hline $\mathrm{u}$ & 1.1 & 1.98 & 3.96 & 5.94 & 2.85 & 4.69 & 2.46 & 2.62 & 2.03 & 3.28 & 4.58 & 4.1 & 5.24 & 3.37 \\
\hline W & 4.1 & 90. & 6. & 8.3 & 1.4 & 5.9 & 6.3 & 5.7 & 5.9 & 5.4 & 6.2 & 13. & 7.8 & 5.6 \\
\hline $\mathrm{Zn}$ & 23. & 62. & 14. & 33. & 81. & 43. & 15. & 12. & 9.8 & 7.4 & 98. & 30. & 28. & 41. \\
\hline
\end{tabular}

TABLE 28.-Analytical data obtained along traverse B-B' (fig. 77)—Continued

\begin{tabular}{|c|c|c|c|c|c|c|c|c|c|c|c|c|c|c|}
\hline Analysis & 15 & 16 & 17 & 18 & 19 & 20 & 21 & 22 & 23 & 24 & 25 & 26 & 27 & 28 \\
\hline Fie1d No. & $79 \mathrm{C} 61$ & $79 \mathrm{C} 60$ & $79 \mathrm{C59}$ & $79 \mathrm{C58}$ & $79 C 57$ & $79 C 56$ & $79 \mathrm{C} 70$ & $79 \mathrm{C} 69$ & $79 \mathrm{C} 68$ & $79 C 67$ & $79 \mathrm{C} 66$ & $79 \mathrm{C71}$ & $79 \overline{C 72}$ & $79 \mathrm{C73}$ \\
\hline \multicolumn{15}{|c|}{ Quantitative emission spectrographic analyses (parts per million) } \\
\hline $\mathrm{Ag}$ & 3.0 & - & - & -- & - & -- & - & 2.0 & 3.0 & - & - & - & 3.0 & - \\
\hline B & 160. & 170.0 & 46.0 & 140.0 & 110.0 & 40.0 & 34.0 & 64. & 50. & 82.0 & 80.0 & 40.0 & 52. & 100.0 \\
\hline $\mathrm{Ba}$ & $>2000$ & 1940. & 1210 & 1630. & 460 & $>2000$ & $>2000$ & $>2000$. & 22000 . & $>2000$ & $>2000$ & 1000 & 1160. & 260 \\
\hline Co & -- & - & - & - & - & - & - & - & -- & - & - & 6. & - & - \\
\hline $\mathrm{Cr}$ & 3. & 2. & 38. & 5. & 32. & 6. & 6. & 2. & - & 4. & 5. & 32. & 22. & 13. \\
\hline $\mathrm{Cu}$ & 40. & 54. & 66. & 53. & 64. & 49. & 59. & 68. & 50. & 59. & 70. & 170. & 140. & 62. \\
\hline $\mathrm{Ga}$ & 17. & 13. & 10. & 14. & 10. & 12. & 15. & 24. & 26. & 20. & 15. & 15. & 11. & 10. \\
\hline La & - & - & - & - & - & - & 26. & 54. & 40. & - & - & 34. & 31. & 31. \\
\hline $\begin{array}{l}\text { Mn } \\
\text { Mo }\end{array}$ & $\begin{array}{r}26 . \\
360 \text {. }\end{array}$ & $\begin{array}{r}120 . \\
11 .\end{array}$ & $\begin{array}{l}90 . \\
80 .\end{array}$ & $\begin{array}{r}70 . \\
130 .\end{array}$ & $\begin{array}{r}70 . \\
200\end{array}$ & $\begin{array}{r}34 . \\
800\end{array}$ & 20. & $\begin{array}{r}54 . \\
110 .\end{array}$ & $\begin{array}{l}30 . \\
90 .\end{array}$ & $\begin{array}{l}740 . \\
100 .\end{array}$ & $\begin{array}{l}52 . \\
36 .\end{array}$ & $\begin{array}{r}160 . \\
20 .\end{array}$ & $\begin{array}{l}30 . \\
36\end{array}$ & $\begin{array}{l}40 . \\
50 .\end{array}$ \\
\hline $\mathrm{Ni}$ & - & 9. & 12 & - & 39 & & 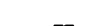 & 4. & - & 4 & 5 & 60 & 5. & 2 \\
\hline $\mathrm{Pb}$ & -- & - & - & 49. & - & 47. & -- & 180. & 900. & 39. & 3. & - & $=$ & 140. \\
\hline $\mathrm{Sc}$ & 3. & 3. & 3. & 2. & 4. & 3. & -- & 3. & 3. & 3. & 3. & 5. & 4. & - \\
\hline $\mathrm{Sr}$ & 150. & 300. & 150. & 180. & 94. & 180 . & 150. & 220. & 210. & 190. & 190. & 160. & 82. & 49. \\
\hline $\mathbf{T i}$ & 3400 . & 2800 . & 3000 . & 2600 . & 2800 . & 2600 . & 2200 . & 2600 . & 2200 . & 2000. & 3000 . & 3400 . & 2600 & 1800. \\
\hline $\mathrm{v}$ & 34. & 29. & 30. & 28. & 37. & 33. & 30 . & 48. & 40 . & 50. & 57. & 38. & 30 . & 23. \\
\hline $\mathbf{Y}$ & - & - & -- & - & - & - & -- & - & - & 14. & 14. & 24. & 16. & -- \\
\hline $\mathrm{Yb}$ & - & - & - & - & - & -- & - & - & - & - & - & - & - & -- \\
\hline $\mathrm{Zr}$ & 58. & 58. & 58. & 46. & 52. & 24. & 76. & 130. & 160. & 100. & 54. & 190. & 160. & 200. \\
\hline \multicolumn{15}{|c|}{ Chemical analyses (parts per million) } \\
\hline $\mathrm{Au}$ & $<0.05$ & $<0.05$ & $<0.05$ & $<0.05$ & $<0.05$ & $<0.05$ & $<0.05$ & 0.06 & $<0.05$ & $<0.05$ & $<0.05$ & $<0.05$ & $<0.05$ & $<0.05$ \\
\hline F & 900. & 400 & 300. & 800. & 600. & 400. & 400 & 800 . & 600. & 1000. & 800 . & 1000 & 900. & 500. \\
\hline $\mathrm{Hg}$ & .11 & .12 & .072 & .2 & .21 & .13 & .14 & .25 & .23 & .16 & .14 & .13 & .14 & .13 \\
\hline Th & 9.06 & 13.9 & 12. & 9.29 & 7.1 & 6.36 & 8.8 & 11.2 & 9.31 & 10.1 & 11. & 18.4 & 11.4 & 10.2 \\
\hline $\mathrm{U}$ & 2.13 & 3.06 & 3.21 & 2.67 & 1.96 & 1.69 & 3.58 & 2.92 & 2.98 & 2.69 & 3.24 & 3.53 & 2.61 & 3.22 \\
\hline $\begin{array}{l}\mathrm{W} \\
\mathrm{Zn}\end{array}$ & $\begin{array}{l}13 . \\
12 .\end{array}$ & $\begin{array}{r}14 . \\
110 .\end{array}$ & $\begin{array}{r}24 . \\
50\end{array}$ & 12. & $\begin{array}{l}26 . \\
76\end{array}$ & $\begin{array}{r}76 . \\
7.9\end{array}$ & $\begin{array}{l}88 . \\
32 .\end{array}$ & $\begin{array}{l}61 . \\
40 .\end{array}$ & $\begin{array}{l}26 . \\
16 .\end{array}$ & $\begin{array}{r}110 . \\
91 .\end{array}$ & $\begin{array}{l}80 . \\
41 .\end{array}$ & $\begin{array}{r}30 . \\
380\end{array}$ & $\begin{array}{r}110 . \\
35 .\end{array}$ & $\begin{array}{l}17 . \\
54 .\end{array}$ \\
\hline
\end{tabular}


TABLE 29.-Analytical data obtained along traverse C-C' (fig. 77)

[Emission-spectrographic analyses in parts per million; analysts, J. Harris and B. Spillare. Relative standard deviation of any single reported concentration should be taken as plus 50 percent and minus 33 percent. Looked for, but not found, at parts-per-million detection levels in parentheses: $\mathrm{Cd}(32), \mathrm{Dy}(22), \operatorname{Er}(10), \operatorname{Eu}(2.2), \mathrm{Gd}(15), \operatorname{Hf}(15), \operatorname{Ho~(6.8),~} \operatorname{Ir}(15), \operatorname{Li}(68), \operatorname{Lu}(15), \mathrm{Os}(22), \operatorname{Pd}(1), \operatorname{Pr}(68), \operatorname{Pt}(4.6), \operatorname{Re}(10), \operatorname{Rh}(2.2), \operatorname{Ru}(2.2)$, $\mathrm{Sm}$ (10), Ta (460), Tb (32), Th (22), Tl (4.6), U (320). F determined by specific-ion-electrode methods, and $\mathrm{W}$ determined colorimetrically; analysts, D. Kobilis and J. Gillison. Au determined by fire assay supplemented by atomic-absorption spectroscopy, and As, Sb, and Hg determined by cold-vapor atomic-absorption spectroscopy; analysts, R. Moore and W. D'Angelo. -, not detected]

\begin{tabular}{|c|c|c|c|c|c|c|c|c|c|c|c|c|c|c|c|c|}
\hline Field No. & 82 TT41 & $82 \mathrm{TT} 42$ & $82 \mathrm{TT} 43$ & $82 \mathrm{TT} 44$ & 82 TT45 & $82 \mathrm{TT} 46$ & 82 TT47 & $82 \mathrm{TT} 48$ & $82 \mathrm{TT} 49$ & 82 TT50 & $82 \mathrm{TT} 51$ & 82 TT52 & 82 TT53 & $82 \mathrm{TT} 54$ & 82 TT55 & $82 \mathrm{TT} 56$ \\
\hline \multicolumn{17}{|c|}{ Emission spectrographic analyses (parts per million) } \\
\hline $\mathrm{Ag}$ & 14.0 & 6.4 & 2.3 & 0.6 & -- & 3.3 & 3.9 & 0.88 & 0.16 & 8.1 & 6.0 & 0.5 & 0.39 & 2.1 & 1.1 & 0.22 \\
\hline B & iu. & -- & 20 & 18. & -- & 25. & 160. & 43. & 9.3 & 17. & 75. & 47. & 16. & 34. & 74. & 11. \\
\hline $\mathrm{Ba}$ & 250 . & 2500 & 740. & 370. & 1200.0 & 600. & 770. & 760. & 360. & 650. & 950. & 1400 & 970. & 320. & 390. & 540. \\
\hline $\mathrm{Be}$ & 1.3 & -- & 1.4 & -- & 2.4 & 1.3 & 3.1 & -- & -- & 1.1 & 1.4 & 1.2 & 1.1 & -- & 1.8 & 1.3 \\
\hline $\mathrm{Bi}$ & 17. & 47. & 26. & -- & -- & - & -- & -- & -- & - & 82. & -- & -- & -- & -- & -- \\
\hline $\mathrm{Ce}$ & -- & -- & -- & -- & 100. & -- & -- & 89. & 55. & -- & -- & 51. & -- & -- & -- & -- \\
\hline Co & -- & 1.2 & -- & -- & 4.2 & -- & -- & -- & 1.7 & 1.7 & -- & - & 1.3 & -- & 3.7 & 5.8 \\
\hline $\mathrm{Cr}$ & 20. & 61 . & 38. & 20. & 150. & 48. & 7.2 & 24. & 45. & 24 . & 2. & 10. & 42. & 25. & 42. & 36. \\
\hline $\mathrm{Cu}$ & 75. & 150. & 32. & 34. & 32. & 33. & 100 & 30. & 51. & 52. & 32. & 32. & 71. & 32. & 400 & 99. \\
\hline $\mathrm{Ga}$ & 8.4 & 19. & 7.8 & 5.5 & 34. & 11. & 21. & 6.3 & 6.1 & 6.7 & 13. & 16. & 9.2 & 7.7 & 8.4 & 10. \\
\hline Ge & -- & 2.4 & -- & -- & -- & 1.9 & -- & -- & -- & -- & -- & -- & - & 1.7 & - & - \\
\hline Ir & -- & -- & -- & -- & 8.4 & -- & -- & -- & -- & -- & -- & -- & -- & - & -- & -- \\
\hline $\mathrm{La}$ & 26. & 11. & 19. & 25. & 68. & 26. & 16. & 36. & 19. & 24. & 29. & 30. & 26. & 25. & 33. & 37. \\
\hline Mn & 27 . & 46. & 35. & 18. & 150. & 24. & 37. & 39. & 39. & 37. & 40. & 34. & 61. & 22 . & 30. & 24. \\
\hline Mo & 3. & 11. & 2.5 & 24. & 48. & 37. & 28. & 140. & 45. & 74. & 75. & 85. & 120. & 12. & 12. & - \\
\hline $\mathrm{Nb}$ & 7. & 4.8 & 9.3 & 6.3 & 7.6 & 14. & 15. & 5.3 & 9. & 6.5 & 4.6 & 9.3 & 9.5 & 9. & 8.1 & 9.2 \\
\hline Nd & - & -- & -- & -- & 36. & - & - & -- & -- & -- & -- & -- & - & - & -- & 30. \\
\hline $\mathrm{Ni}$ & 2. & 3.1 & 3.5 & 2.3 & 22. & 5.1 & 3.3 & 3. & 6.6 & 2.1 & 2.7 & 3.9 & 5. & 3.3 & 11. & 18. \\
\hline $\mathrm{Pb}$ & 37. & 33. & 20. & 13. & 22 . & 180 & 12. & - & 8.4 & 49. & 160. & 16. & 14. & 9.6 & 99. & 9.6 \\
\hline Sc & 5.3 & 8.3 & 7. & 4. & 20 & 8.7 & 11. & 4.6 & 7.4 & 4.8 & 4.9 & 6.2 & 9.3 & 5.3 & 8. & 9. \\
\hline Sn & 3.5 & 7. & 9.2 & 3. & 4.8 & 2. & 8.3 & 3.1 & 2.6 & 4.5 & 3.4 & 2.6 & 2.8 & 2.3 & 4.9 & 4.1 \\
\hline Sr & 41 & 370. & 150. & 72. & 420 & 160. & 29. & 150. & 150. & 78. & 160. & 230. & 220 . & 99. & 100 & 160. \\
\hline $\mathrm{Ti}$ & 1500 & 1900 & 1900. & 850 & 3800 & 2400 & 2300 & 1500 & 1700 & 1500 & 1600 & 2200 & 2100 & 1700 & 2200 & 2200 \\
\hline $\mathrm{v}$ & 38 . & 59. & 52. & 35. & 120 & 64. & 90. & 40. & 52. & 45. & 60. & 75. & 75. & 59. & 68. & 40. \\
\hline $\mathbf{Y}$ & 3.7 & 4.3 & 7.8 & 5.2 & 20. & 10. & 6.1 & 6.4 & 9.8 & 9.6 & 7.4 & 5.7 & 7. & 13. & 21. & 12. \\
\hline $\mathrm{Yb}$ & .47 & .35 & 1.2 & .74 & 2.8 & 1.2 & 1.1 & .83 & 1.1 & 1.3 & .84 & .68 & 1.2 & 1.2 & 2. & 1.7 \\
\hline $\mathrm{Zn}$ & -- & - & - & - & 43. & - & - & -- & -- & -- & -- & -- & - & -- & -- & -- \\
\hline $\mathrm{Zr}$ & 180. & 76. & 180. & 170 & 94. & 130. & 190. & 180. & 93. & 120. & 75. & 92. & 130. & 150. & 190. & 220 \\
\hline \multicolumn{17}{|c|}{ Chemical analyses (parts per million) } \\
\hline As & 53.0 & 420.0 & 36.0 & 98.0 & 2.7 & 80.0 & 23.0 & 78.0 & 4.7 & 12.0 & 63.0 & 12.0 & 39.0 & 24.3 & 51.0 & 14.0 \\
\hline $\mathrm{Au}$ & .18 & $<.05$ & $<.05$ & $<.05$ & $<.05$ & $<.05$ & $<.05$ & $<.05$ & $<.05$ & $<.05$ & $<.16$ & $<.05$ & $<.05$ & $<.05$ & $<.05$ & $<.05$ \\
\hline $\boldsymbol{F}$ & 400 & 1000 & 1300 & 600 & 1400 & 1000 & 1200. & 600 & 1000 & 700. & 1100 & 1000 & & 1000 & 1000 & 600. \\
\hline $\mathrm{Hg}$ & .23 & .05 & .03 & .02 & .05 & .03 & 1.1 & .05 & .02 & .04 & .09 & .03 & .02 & .37 & .03 & .02 \\
\hline $\mathrm{Sb}$ & 21. & 2.6 & 1.2 & 41. & 34. & 12. & 19. & 12. & 3.2 & 4.6 & 15. & 14. & 7.6 & 6. & 6. & 13. \\
\hline W & 16. & 21 . & 30. & 10. & 6.1 & 41. & 26 . & 22 . & 11. & 27. & 34. & 26. & 15. & 24. & 53. & 28. \\
\hline
\end{tabular}


TABLE 30.-Analytical data on biotite hornfels and altered biotite hornfels of the Upper Cambrian Harmony Formation near the West stock, and on one sample of monzogranite porphyry of the West stock obtained along traverse D-D' (fig. 77)

[Emission-spectrographic analyses in parts per million; analysts, J. Harris and B. Spillare. Relative standard deviation of any single reported concentration should be taken as plus 50 percent and minus 33 percent. Looked for, but not found, at parts-per-million detection levels in parentheses: Bi (10), Cd (32), Dy (22), Er (10), Eu (2.2), Gd (15), Hf (15), Ho (6.8), In (6.8), Ir (15), Li (68), Lu (15), Os (22), Pd (1), Pr (68), Pt (4.6), Re (10), Rh (2.2), Ru (2.2), Ta (460), Tb (32), Th (22), Tl (4.6), Tm (4.6), U (320). As and $\mathrm{Sb}$ determined by flameless atomic-absorption spectroscopy, Au determined by fire assay followed by atomic-absorption spectroscopy, and $\mathrm{Hg}$ determined by coldvapor instrumental atomic-absorption methods; analysts, R. Moore and W. D'Angelo. F determined by specific-ion-electrode methods, and W determined colorimetrically; analyst, J. Gillison. —, not detected]

\begin{tabular}{|c|c|c|c|c|c|c|c|c|c|c|c|c|c|}
\hline Ana1ysis & 1 & 2 & 3 & 4 & 5 & 6 & 7 & 8 & 9 & 10 & 11 & 12 & 13 \\
\hline Field No. & $82 \mathrm{TT} 25$ & $82 \mathrm{TT} 26$ & $82 \mathrm{TT} 27$ & $82 \mathrm{TT} 28$ & $82 \mathrm{TT} 29$ & $82 \mathrm{TT} 30$ & $82 \mathrm{TT} 31$ & 82TT32 & 82TT33 & 82 TT34 & $82 \mathrm{TT} 35$ & 82 TT36 & 82 TT37 \\
\hline
\end{tabular}

Emission spectrographic analyses (parts per million)

Biotite hornfels

Wel1-developed quartz stockworks

Intensely bleached rocks

\begin{tabular}{|c|c|c|c|c|c|c|c|c|c|c|c|c|c|}
\hline $\mathrm{Ag}$ & - & 0.14 & 0.35 & -- & - & 0.17 & 0.11 & 0.67 & -- & 1.5 & -- & - & 0.13 \\
\hline B & - & -- & 5.4 & -- & - & -- & -- & -- & 5.3 & 12. & 6.9 & -- & 64. \\
\hline $\mathrm{Ba}$ & 380.0 & 430 & 160 & 330.0 & 430.0 & 760 & 1400 & 310. & 150. & 330. & 210 & 350.0 & 1400 \\
\hline $\mathrm{Be}$ & 3.2 & 1.4 & 1.2 & 1.6 & 1.3 & 2.9 & $\cdot 3.1$ & - & - & 1.2 & -- & -- & 1.9 \\
\hline $\mathrm{Ce}$ & - & 54. & -- & 61. & - & 81. & 160. & -- & -- & -- & -- & - & - \\
\hline Co & 19. & 6.7 & 1.9 & 17. & 8.2 & 9.8 & 16. & 1.1 & -- & -- & - & 1.1 & - \\
\hline $\mathrm{Cr}$ & 140 & 61. & 15. & 93. & 47. & 140 & 250 . & 11. & 6.6 & 20 . & 8.9 & 16. & 1.5 \\
\hline $\mathrm{Cu}$ & 67. & 30. & 53. & 73. & 52. & 46. & 88. & 250 . & 79. & 33. & 26. & 50 & 12. \\
\hline $\mathrm{Ga}$ & 23. & 13. & 2.9 & 21. & 12. & 21 . & 25 . & 2.6 & -- & 3.2 & 1.9 & 3.1 & 18. \\
\hline $\mathrm{Ge}$ & -- & -- & -- & -- & -- & -- & -- & -- & - & -- & 2.2 & -- & -- \\
\hline $\mathrm{La}$ & 39. & 33. & 24. & 38 & 33. & 49. & 77. & 17. & 22. & 16. & 13. & 19. & 32. \\
\hline $\mathrm{Mn}$ & 430. & 360. & 110 & 550. & 320 . & 370. & 640. & 79. & 84. & 42. & 29. & 85. & 85. \\
\hline Mo & 18 & 18. & 130. & 110. & 88. & 170. & 74. & 180. & 51. & 180 & 770 & 48. & 96. \\
\hline $\mathrm{Nb}$ & 18. & 8.9 & 7.9 & 11. & 6.3 & 17 & 54. & 5.4 & 4.1 & 11. & 7.5 & 3.8 & 6.3 \\
\hline $\mathrm{Nd}$ & -- & 33. & -- & - & -- & -- & 62. & - & -- & -- & -- & - & -- \\
\hline $\mathrm{Ni}$ & 41. & 13. & 13. & 26. & 19. & 45. & 68. & 14. & 7.7 & 6.1 & - & 18. & 2.5 \\
\hline $\mathrm{Pb}$ & 15. & 14. & 12. & 10. & 15. & 19. & 24. & -- & -- & 11. & 11. & 10. & 11. \\
\hline Sc & 22 . & 12. & 3.7 & 16. & 12. & 22 . & 23. & 2.6 & 1.9 & 4.1 & 1.6 & 3.9 & 4. \\
\hline $\mathrm{Sn}$ & - & -- & 2.9 & - & -- & 2.1 & - & 3.1 & 2.2 & -- & 5. & 2.3 & 5. \\
\hline $\mathrm{Sr}$ & 290 & 170 & 67 & 76 . & 180 & 330. & 480 . & 40 & 15. & 22 . & 11. & 90. & 170 \\
\hline $\mathrm{Ti}$ & 4100 & 2300 & 880 & 2700 & 2100 & 3800 & 7700 & 630. & 330. & 1200 & 1100 & 950. & 1100 \\
\hline V & 110 & 64 & 33. & 75 & 68 & 110 & 120 & 19. & 13. & 39. & 15 & 29. & 44 \\
\hline$Y$ & 22 . & 12. & 7.2 & 16. & 12. & 20 & 29. & 5.2 & 2.9 & 7.9 & 4.4 & 8.1 & 5.2 \\
\hline $\mathrm{Yb}$ & 2.8 & 1.6 & 0.87 & 1.7 & 1.2 & 2.2 & 2.6 & .62 & .22 & .83 & .35 & .71 & .49 \\
\hline $\mathrm{Zn}$ & 54. & 21 & 28 & 71. & 29. & 52. & 96. & 73. & 53. & 84. & -- & 46. & 50. \\
\hline $\mathrm{Zr}$ & 150. & 140. & 150 & 95. & 110 & 160. & 230 & 170 & 96. & 180 & 190. & 110 & 84. \\
\hline \multicolumn{14}{|c|}{ Chemical analyses (parts per million) } \\
\hline As & 3.4 & 1.8 & 2.9 & 5.3 & 12. & 3.4 & 2.9 & 60. & 16. & 23. & 11. & 26. & 12. \\
\hline $\mathrm{Au}$ & $<.05$ & $<.05$ & $<.05$ & $<.05$ & $<.05$ & $<.05$ & $<.05$ & $<.05$ & $<.05$ & $<.05$ & $<.05$ & $<.05$ & $<.05$ \\
\hline $\mathbf{F}$ & 1000 & 400 & 300 & 700 & 700 & 1000 & 1400 & 200 & 300 & 400 & 200 & 200 & 900. \\
\hline $\mathrm{Hg}$ & .04 & .02 & .03 & .04 & .03 & .04 & .02 & .03 & .04 & .03 & .04 & .03 & .04 \\
\hline $\mathrm{Sb}$ & .7 & 1.6 & .3 & .7 & 1.2 & $<.3$ & .3 & .8 & 3.1 & 2.7 & .5 & 1.3 & 6.6 \\
\hline W & 2. & 1.5 & 2.2 & 1.3 & 2.1 & 1.9 & 8. & 3.7 & 2.3 & 5.9 & 4.6 & 2.4 & 4.8 \\
\hline
\end{tabular}

1-12. Upper Cambrian Harmony Formation.

13. Late Cretaceous monzogranite porphyry of West stock. 
TABLE 31.-Analytical data obtained along traverse E-E' (fig. 77)

[Optical-spectroscopic analyses in parts per million by inductively coupled plasma methods of Scott and Kokot (1975) and F.E. Lichte (unpub. data, 1983); analyst, G. Riddle. Chemical analyse in parts per million by single-solution method of Shapiro (1975); analyst, F. Brown. Au determined by optical-spectroscopic methods, using $\mathrm{HBr} / \mathrm{Br}_{2}$ extraction procedures rather than fireassay preconcentration; analyst, J. Crock. —, not detected]

\begin{tabular}{|c|c|c|c|c|c|c|c|c|c|c|c|c|}
\hline Field No. & $81 \mathrm{TT} 176$ & 81 TT177 & 81 TT178 & 81 TT179 & 81 TT180 & 81 TT181 & 81TT182 & 81 TT183 & $81 \mathrm{TT} 184$ & $81 \mathrm{TT} 185$ & $81 \mathrm{TT} 186$ & 81TT187 \\
\hline & & & & tical spe & troscopic & analyses & parts per & million) & & & & \\
\hline $\mathrm{Ag}$ & -- & -- & -- & - & -- & -- & -- & -- & -- & -- & -- & -- \\
\hline As & -- & -- & -- & -- & -- & -- & -- & -- & 20.0 & -- & 10.0 & -- \\
\hline $\mathrm{Ba}$ & 860.0 & 330.0 & 380.0 & 450.0 & 900.0 & 170.0 & 380.0 & 660.0 & 410.0 & 660.0 & 140 & 1800.0 \\
\hline $\mathrm{Be}$ & 2. & -- & 1. & -- & 2. & 2. & 1. & -- & -- & -- & -- & 2. \\
\hline $\mathrm{Cd}$ & 2. & -- & -- & - & 3. & 2. & -- & -- & -- & - & -- & 3. \\
\hline $\mathrm{Ce}$ & 130. & 42. & 65. & 60. & 96. & 16. & 8. & 13. & 6. & 21. & 8. & 82. \\
\hline Co & 8. & 5. & 10 . & 3. & 8. & 5. & 3. & 4. & 4. & 4. & -- & 11. \\
\hline $\mathrm{Cr}$ & 78. & 28. & 46. & 34. & 62. & 54. & 45. & 34. & 23. & 54. & 16. & 49. \\
\hline $\mathrm{Cu}$ & 53. & 82. & 50. & 88. & 140. & 210 . & 99. & 380. & 120. & 85. & 28. & 280 . \\
\hline $\mathrm{Ga}$ & 24. & 8. & 11. & 11. & 18. & 11. & 7. & 9. & 4. & 8. & 5. & 18. \\
\hline La & 73. & 24. & 40. & 31. & 55. & 12. & 8. & 9. & 5. & 12. & 4. & 48. \\
\hline $\mathrm{Li}$ & 22. & 15. & 13. & 16. & 29. & 8. & 7. & 8. & 10. & 8 . & 7. & 22 . \\
\hline Mn & 130. & 45. & 430. & 110. & 140. & 170. & 310. & 160. & 96 . & 120. & 120. & 210. \\
\hline Mo & - & 14. & 2. & 8. & 8. & 6. & 3. & 12. & 2. & -- & 3. & 12. \\
\hline $\mathrm{Nb}$ & 10. & - & 9. & 8. & 11. & 9. & 9. & 5. & - & 5. & - & 11. \\
\hline $\mathrm{Ni}$ & 23. & 18. & 24. & 19. & 31. & 14. & 7. & 7. & 4. & 12. & 7. & 28. \\
\hline $\mathrm{Pb}$ & -- & -- & 8. & 8. & 14. & 11. & 7. & 6. & -- & 9. & 22. & 18. \\
\hline Sc & 18. & 6. & 12. & 7. & 16. & 7. & 6. & 4. & -- & 6. & 2. & 13. \\
\hline Sn & - & -- & -- & -- & -- & 5. & -- & - & -- & -- & -- & -- \\
\hline $\mathrm{Sr}$ & 40. & 95. & 230 . & 200 . & 140. & 400. & 400. & 240 . & 120. & 270 . & 80 . & 280 . \\
\hline $\mathrm{Ta}$ & -- & - & -- & - & -- & - & -- & - & -- & -- & -- & -- \\
\hline Th & 21. & 10. & 8. & 10. & 11. & - & -- & -- & -- & -- & -- & 17. \\
\hline v & 76. & 32 . & 47. & 36. & 68. & 51. & 48. & 42. & 31. & 36. & 32. & 62 . \\
\hline $\mathbf{Y}$ & 15. & 5. & 16. & 11. & 11. & 10. & 7. & 6. & 2. & 7. & 2. & 14. \\
\hline $\mathrm{Zn}$ & 22 . & 8. & 25. & 7. & 23. & 20. & 15. & 17. & 9. & 18. & 140. & 29. \\
\hline $\operatorname{Pr}$ & 20. & -- & -- & -- & -- & -- & -- & -- & -- & -- & - & 10. \\
\hline Nd & 74. & 22. & 33. & 30. & 46. & 9. & -- & 6. & -- & 10. & -- & 49. \\
\hline Sm & 10. & -- & - & -- & -- & -- & - & -- & -- & -- & -- & -- \\
\hline Gd & 20. & -- & -- & -- & -- & - & -- & -- & - & -- & - & 10. \\
\hline Dy & 5. & -- & - & -- & -- & -- & -- & -- & -- & - & - & 5. \\
\hline $\mathrm{Yb}$ & 2. & -- & 2. & -- & - & 1. & -- & -- & -- & -- & -- & 1. \\
\hline \multicolumn{13}{|c|}{ Chemical analyses (parts per million) } \\
\hline $\mathrm{Au}$ & $<0.1$ & $<0.1$ & $<0.1$ & $<0.1$ & $<0.1$ & $<0.1$ & $<0.1$ & $<0.1$ & $<0.1$ & $<0.1$ & $<0.1$ & $<0.1$ \\
\hline $\mathrm{Cl}$ & 320 & 670. & 480 . & 290. & 220. & 180. & 150. & 170. & 72 . & 140 & 130. & 140 \\
\hline $\mathbf{F}$ & 700 & 300. & 700. & 500 . & 500. & 300 . & 100 & 200. & 200 & 300. & 100. & 600 . \\
\hline W & 2.5 & 1.2 & 2.2 & 2.1 & 2.1 & 3.7 & 13. & 8. & 2.9 & 1.2 & 1.6 & 4.5 \\
\hline
\end{tabular}


TABLE 31.-Analytical data obtained along traverse E-E' (fig. 77)—Continued

\begin{tabular}{|c|c|c|c|c|c|c|c|c|c|c|c|c|c|c|}
\hline Field No. & $81 \mathrm{TT} 188$ & 81 TT189 & $81 \mathrm{TT} 190$ & 81 TT1 91 & $81 \mathrm{TT1}$ & 81 TT193 & $81 \mathrm{TT194}$ & $81 \mathrm{TT195}$ & 81TT201 & $81 \mathrm{TT} 200$ & 81 TT196 & 81TT197 & 81TT198 & 81TT199 \\
\hline & & & & & Optical & spectroscopic & analyses & (parts per & $r$ million) & & & & & \\
\hline $\mathrm{Ag}$ & -- & -- & -- & 4.0 & -- & -- & -- & -- & -- & -- & -- & -- & - & - \\
\hline As & 30.0 & -- & - & 410 & -- & -- & -- & -- & -- & -- & -- & -- & -- & -- \\
\hline $\mathrm{Ba}$ & 490. & 810.0 & 360.0 & 370. & 250.0 & 180.0 & 180.0 & 160.0 & 85.0 & 46.0 & 210.0 & 650.0 & 410.0 & 230.0 \\
\hline $\mathrm{Be}$ & -- & -- & - & - & 1. & 1. & 2. & 1. & -- & - & - & - & - & - \\
\hline Cd & -- & -- & -- & 8. & 2. & 2. & 3. & 2. & -- & -- & - & -- & - & - \\
\hline $\mathrm{Ce}$ & -- & 65. & 30. & 13. & 12. & 12. & 8. & 4. & 41. & 10. & 7. & 26. & 43. & 9. \\
\hline Co & 32. & 8. & 3. & - & 2. & 1. & - & 2. & 4. & 2. & 2. & 4. & 1. & - \\
\hline $\mathrm{Cr}$ & 15. & 46. & 17. & 39. & 48. & 50. & 65. & 48. & 27. & 9. & 32. & 36. & 26. & 12. \\
\hline $\mathrm{Cu}$ & 220. & 150. & 180. & 530. & 62. & 79. & 190. & 160. & 35. & 65. & 140. & 85. & 150. & 27. \\
\hline $\mathrm{Ga}$ & 4. & 13. & 5. & 10 . & 10 . & 11. & 10. & 11. & 11. & 5. & 5. & 10. & 5. & - \\
\hline $\mathrm{La}$ & 15. & 36. & 16. & 8. & 8. & 8. & 6. & 6. & 16. & 7. & 7. & 17. & 28. & 5. \\
\hline $\mathrm{Li}$ & 9. & 19. & 9. & 6. & 7. & 4. & 5. & 8. & & 3. & 6. & 6. & 7. & 4. \\
\hline $\mathrm{Mn}$ & 69. & 160. & 48. & 48. & 190. & 140. & 150. & 200 & 2000 . & 1800. & 300. & 380. & 220. & 71. \\
\hline Mo & 8. & 9. & 23. & 42. & 7. & 8. & 2. & 2. & - & -- & -- & - & -- & 2. \\
\hline $\mathrm{Nb}$ & - & 11. & -- & 7. & 10. & 7. & 6. & 4. & 5. & - & -- & 4. & 4. & -- \\
\hline $\mathrm{Ni}$ & 6. & 24. & 9. & 2. & 8. & 8. & 9. & 9. & 15. & 14. & 11. & 10. & 7. & 3. \\
\hline $\mathrm{Pb}$ & 10. & 21. & -- & 930. & 10. & -- & -- & - & 4. & 10. & 6. & 9. & 9. & 8. \\
\hline Sc & 3. & 10. & 3. & 4. & 5. & 6. & 7. & 6. & 4. & - & 4. & 5. & 3. & -- \\
\hline $\mathrm{Sn}$ & -- & -- & - & 9. & -- & -- & -- & -- & 24. & 18. & -- & - & - & - \\
\hline $\mathrm{Sr}$ & 84. & 130. & 73. & 100 & 430. & 470. & 500 & 370. & 140. & 13. & 230 & 270 . & 150. & 71 . \\
\hline $\mathrm{Ta}$ & -- & -- & - & -- & -- & -- & 190. & -- & -- & -- & -- & - & -- & -- \\
\hline Th & 4. & 14. & 6. & -- & -- & -- & -- & -- & 11. & -- & -- & -- & -- & -- \\
\hline $\mathrm{v}$ & 23. & 53. & 32. & 43. & 43. & 40. & 48. & 53. & 67. & 25. & 29. & 36. & 34. & 17. \\
\hline $\mathbf{Y}$ & 6. & 11. & 6. & 2. & 8. & 8. & 10. & 8. & 11. & 3. & 5. & 7. & 4. & 2. \\
\hline $\mathrm{Zn}$ & 15. & 45. & 9. & 220 . & 14. & 10. & 12. & 16. & 32. & 41. & 21. & 21. & 22 . & 12 . \\
\hline $\mathrm{Pr}$ & -- & -- & -- & -- & -- & - & -- & -- & -- & - & - & - & - & - \\
\hline $\mathrm{Nd}$ & 10. & 35. & 15. & -- & -- & 7. & 5. & 6. & 27. & 6. & -- & 9. & 14. & -- \\
\hline Sm & -- & -- & -- & -- & - & -- & - & -- & -- & - & -- & - & - & -- \\
\hline Gd & -- & -- & -- & -- & -- & -- & -- & -- & -- & -- & -- & -- & -- & -- \\
\hline Dy & -- & -- & - & -- & -- & - & -- & -- & 7. & 4. & -- & - & -- & -- \\
\hline $\mathrm{Yb}$ & -- & -- & -- & -- & -- & -- & -- & -- & 1. & -- & -- & -- & - & -- \\
\hline \multicolumn{15}{|c|}{ Chemical analyses (parts per million) } \\
\hline $\mathrm{Au}$. & $<0.1$ & $<0.1$ & $<0.1$ & $<0.1$ & $<0.1$ & $<0.1$ & $<0.1$ & $<0.1$ & $<0.1$ & $<0.1$ & $<0.1$ & $<0.1$ & $<0.1$ & $<0.1$ \\
\hline $\mathrm{C} 1$ & 73. & 210. & 100 & 73. & 190. & 150. & 150. & 270 . & 320. & 380. & 540 & 400 & 100 & 73. \\
\hline F & 300 & 500 & 300 . & 400. & 200 & 200. & 200. & 200. & 100 & 100 & 100. & 200. & 300. & 400. \\
\hline W & 7.2 & 3.3 & 140. & 18. & 6.9 & 24. & 14. & 6.8 & 9.9 & 7.8 & 2. & 2. & 140. & 18. \\
\hline
\end{tabular}


TABLE 32.-Supplementary analytical data for thorium and uranium obtained along traverse B-B' (fig. 77; table 28)

[Chemical analyses by delayed-neutron counting, using methods of Millard and Keaten (1982); analysts, H.T. Millard, Jr., B.A. Keaten, and F.M. Luman. Coefficient of variation is equal to one standard deviation, based on counting statistics, and expressed as a percentage of reported concentration]

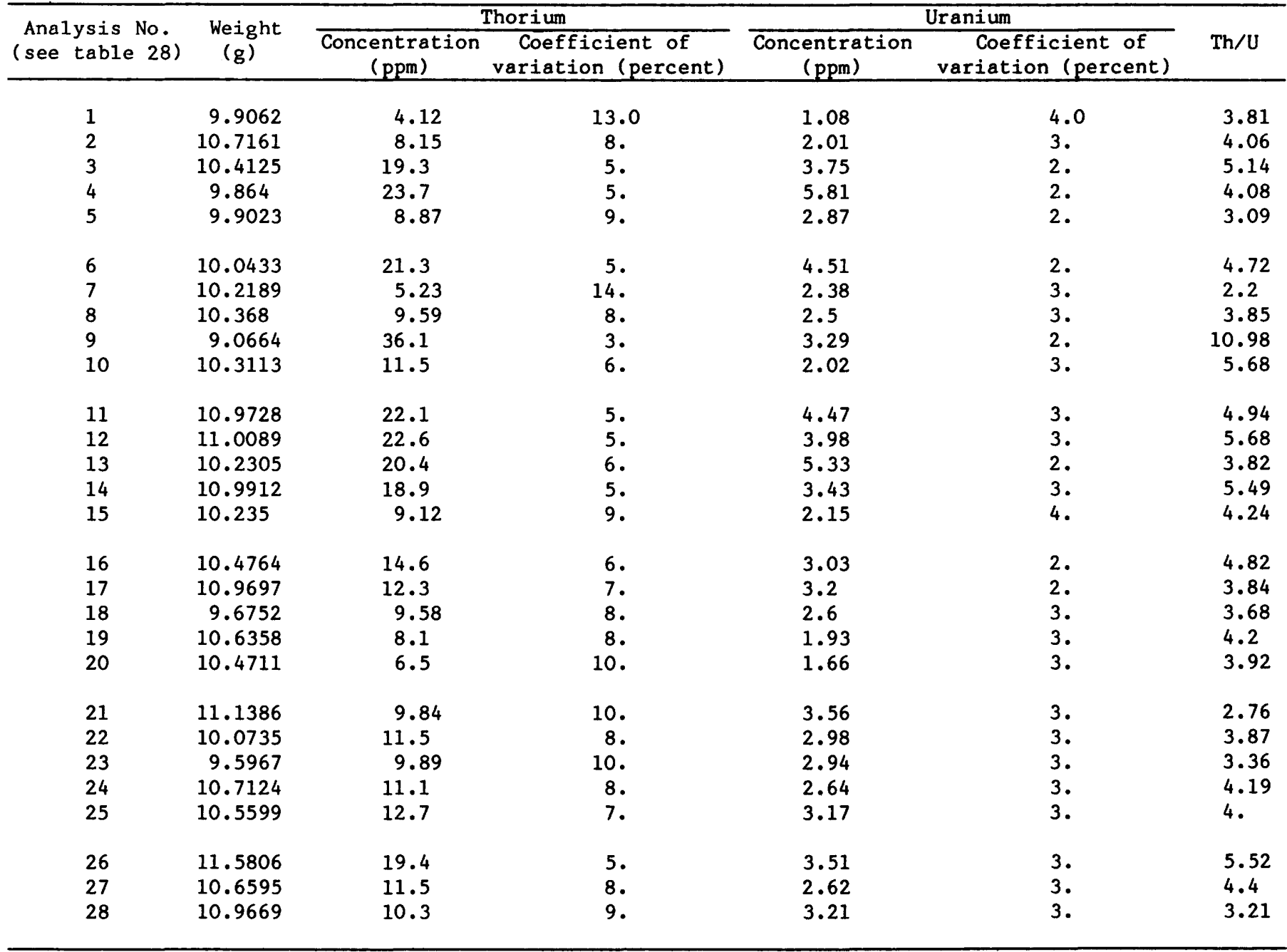

in the samples is in scorodite. Primary ores from the Little Giant Mine include pyrite, arsenopyrite, galena, sphalerite, and tetrahedrite (Roberts and Arnold, 1965). Some samples from the mine also include boulangerite and polybasite, secondary lead sulphosalts that replace some of the primary minerals there. The specific mineral that gives rise to the tin anomaly at the Little Giant Mine is not known. Tin also is present in detectable concentrations in one other sample along geochemical profile $A-A^{\prime}$ (260 ppm; sample 22, table 27). This sample is well within the outer limit of the quartz stockworks, but the elemental associations within the sample (130 ppm Ag; more than 20,000 ppm As; more than $10,000 \mathrm{ppm} \mathrm{Pb}$; more than $10,000 \mathrm{ppm}$ $\mathrm{Sb})$ all suggest that the mineralization is Tertiary in age and temporally related to the same event as that at the Little Giant Mine.

Variations in molybdenum, fluorine, tungsten, boron, copper, zinc, barium, manganese, uranium, and thorium contents along geochemical profile $B$ $B^{\prime}$ (fig. 77) are shown in figure 80 . The east part of this profile is largely through the East stock and provides, thereby, a geochemical section through a level of the Buckingham system that originally was at an elevation higher than that now exposed in the West stock. Restoration of offsets along the postmineral Buckingham and Second faults results in the currently exposed parts of the East stock attaining an elevation higher than the West stock (see subsection above entitled "Economic Geology"). Combined dip-slip components of the offsets along 
TABLE 33.-Replicate analytical data for thorium and uranium in samples of mineralized rocks of the Upper Cambrian Harmony Formation and in samples of Late

Cretaceous granitic rocks and late Eocene or early Oligocene granodiorite porphyry analyzed in tables 11, 20, and 22

[Chemical analyses by high-precision delayed-neutron counting, using methods of Millard and Keaten (1982); analyst, R.B. Vaughn. Coefficient of variation is equal to standard deviation, based on six individual determinations, and expressed as a percentage of reported mean concentration]

\begin{tabular}{|c|c|c|c|c|c|c|c|c|c|c|}
\hline \multirow{2}{*}{$\begin{array}{c}\begin{array}{c}\text { Analysis } \\
\text { No. }\end{array} \\
1\end{array}$} & \multirow{2}{*}{$\frac{\text { Tab1e }}{22}$} & \multicolumn{6}{|c|}{$\begin{array}{c}\text { Delayed neutron determinations of thorium } \\
\text { (parts per million) }\end{array}$} & \multirow{2}{*}{$\begin{array}{l}\begin{array}{l}\text { Mean } \\
(\mathrm{ppm})\end{array} \\
10.63\end{array}$} & $\begin{array}{l}\text { Coefficient of variation } \\
\text { (percent) }\end{array}$ & $\begin{array}{l}\text { Rock-type } \\
\text { or unit }\end{array}$ \\
\hline & & 11.1 & 10.5 & 11.1 & 11.3 & 10.1 & 10.7 & & 2.0 & Harmony Formation \\
\hline 2 & 22 & 6.4 & 9.4 & 7.96 & 8.6 & 7.22 & 7.06 & 7.77 & 6. & Do. \\
\hline 1 & 20 & 13.1 & 14.3 & 12.8 & 15.5 & 15.4 & 16.9 & 14.67 & 5. & Monzogranite porphyry \\
\hline 2 & 20 & 11.6 & 11.9 & 8.76 & 10.3 & 11.4 & 11.7 & 10.94 & 5 . & Do. \\
\hline 3 & 20 & 9.38 & 9.44 & 9.04 & 8.55 & 10.4 & 10.8 & 9.6 & 4. & Do. \\
\hline 4 & 20 & 10.5 & 10.7 & 8.86 & 11. & 12.2 & 11.2 & 10.74 & 5. & Do. \\
\hline 5 & 20 & 12.7 & 10.1 & 12.4 & 12.1 & 11.2 & 14.3 & 12.13 & 5. & Do. \\
\hline 6 & 20 & 11.4 & 10.5 & 11 & 10.8 & 9.12 & 10.7 & 10.59 & 3. & Do. \\
\hline 7 & 20 & 13.9 & 11.9 & 11.4 & 11.5 & 11.3 & 13.4 & 12.23 & 4. & Do. \\
\hline 8 & 20 & 7.1 & 13.6 & 8.9 & 12.6 & 5.9 & 10.5 & 9.77 & 14. & Do. \\
\hline 9 & 20 & 8.3 & 9.9 & 10.6 & 13. & 9.57 & 8.1 & 9.91 & 8. & Do. \\
\hline 1 & 11 & 8.5 & 10.1 & 5.9 & 9.1 & 8.7 & 6.3 & 8.1 & 9 . & Granodiorite porphyry \\
\hline 2 & 11 & 6. & 8.6 & 5.9 & 7.9 & 8.3 & 9.6 & 7.72 & 9. & Do. \\
\hline 3 & 11 & 6.5 & 4.8 & 9.71 & 8.1 & 3.79 & 9.23 & 7.02 & 15 . & Do. \\
\hline 4 & 11 & 10. & 7.3 & 7.9 & 7.9 & 9.3 & 5.9 & 8.05 & 8. & Do. \\
\hline 5 & 11 & 6.8 & 11.2 & 9.8 & 9.4 & 6.7 & 6.7 & 8.43 & 10. & Do. \\
\hline 6 & 11 & 9.8 & 8. & 9.6 & 9.2 & 7.9 & 7.9 & 8.73 & 5. & Do. \\
\hline $\begin{array}{l}\text { Analysis } \\
\text { No. } \\
\end{array}$ & Table & \multicolumn{6}{|c|}{$\begin{array}{c}\text { Delayed neutron determination of uranium } \\
\text { (parts per million) }\end{array}$} & $\begin{array}{l}\text { Mean } \\
(\mathrm{ppm}) \\
\end{array}$ & $\begin{array}{l}\text { Coefficient of variation } \\
\text { (percent) }\end{array}$ & $\begin{array}{l}\text { Rock-type } \\
\text { or unit }\end{array}$ \\
\hline 1 & 22 & 2.45 & 2.61 & 2.63 & 2.33 & 2.57 & 2.57 & 2.53 & 2.0 & Harmony Formation \\
\hline 2 & 22 & 2.06 & 2.01 & 1.97 & 1.67 & 1.83 & 1.87 & 1.9 & 3. & Do. \\
\hline 1 & 20 & 5.76 & 6.01 & 6.13 & 5.96 & 6.05 & 5.61 & 5.92 & 1. & Ionzogranite porphyry \\
\hline 2 & 20 & 3.9 & 3.89 & 3.76 & 3.84 & 3.88 & 3.89 & 3.86 & 1. & Do. \\
\hline 3 & 20 & 3.83 & 3.9 & 3.89 & 3.8 & 3.93 & 3.69 & 3.84 & 1. & Do. \\
\hline 4 & 20 & 4.08 & 4.03 & 4.32 & 4.03 & 3.96 & 4.07 & 4.08 & 1. & Do. \\
\hline 5 & 20 & 3.63 & 4.17 & 3.96 & 3.89 & 4.25 & 3.75 & 3.94 & 3. & Do. \\
\hline 6 & 20 & 3.67 & 3.84 & 3.76 & 3.86 & 3.88 & 3.82 & 3.8 & 1. & Do. \\
\hline 7 & 20 & 3.77 & 3.94 & 4.06 & 3.89 & 4.06 & 3.65 & 3.89 & 2 . & Do. \\
\hline 8 & 20 & 5.43 & 5.08 & 5.35 & 5.11 & 5.41 & 5.23 & 5.27 & 1. & Do. \\
\hline 9 & 20 & 4.35 & 4.08 & 4.14 & 3.98 & 4.16 & 4.17 & 4.15 & 1. & Do. \\
\hline 1 & 11 & 4.8 & 5.02 & 5.21 & 4.95 & 5.16 & 5.23 & 5.06 & 1. & ranodiorite porphyry \\
\hline 2 & 11 & 5.95 & 5.9 & 6.24 & 5.63 & 6.14 & 5.69 & 5.92 & 2. & Do. \\
\hline 3 & 11 & 4.41 & 4.38 & 4.16 & 4.18 & 4.6 & 4.28 & 4.33 & 2. & Do. \\
\hline 4 & 11 & 6.02 & 6.17 & 6.18 & 6.01 & 6.06 & 6.15 & 6.1 & 1. & Do. \\
\hline 5 & 11 & 6.1 & 5.9 & 5.96 & 5.93 & 6.23 & 6.16 & 6.05 & 1 . & Do. \\
\hline 6 & 11 & 6.78 & 6.89 & 7.06 & 6.82 & 6.92 & 6.96 & 6.90 & 1. & Do. \\
\hline
\end{tabular}


TABLE 34.-Unqualified minimum and maximum values for each of 30 selected elements in samples analyzed in tables 27 through 31, and the number and type of qualified determinations for rocks analyzed along traverses A-A', B-B', C-C', DD', and E-E' (fig. 77) in the Buckingham area

$[-$, not determined $]$

\begin{tabular}{|c|c|c|c|c|c|c|c|}
\hline & \multicolumn{3}{|c|}{ Unqualified determinations } & \multicolumn{4}{|c|}{ Qualified determinations } \\
\hline & Number & $\frac{\text { Minimum }}{\text { (Parts per }}$ & $\frac{\text { Maximum }}{\text { mil1ion) }}$ & Not & $\begin{array}{l}\text { analyzed } \\
\text { for }\end{array}$ & $\begin{array}{l}\text { Less than } \\
\text { determir }\end{array}$ & $\begin{array}{l}\text { Greater than } \\
\text { tion limit }\end{array}$ \\
\hline Ag & 45.0 & 0.11 & 1300.0 & & -- & ${ }^{1} 83.0$ & -- \\
\hline B & 75. & 5.3 & 170. & & 26.0 & ${ }^{2} 27$. & -- \\
\hline Ba & 116. & 40. & 2800 . & & -- & -- & 12.0 \\
\hline co & 70. & 1. & 32. & & -- & ${ }^{1} 58$. & -- \\
\hline Cr & 127. & 1.5 & 250. & & - & 1. & -- \\
\hline $\mathrm{Cu}$ & 127. & 4. & 530. & & -- & 1. & -- \\
\hline $\mathrm{Ga}$ & 126. & 1.9 & 34. & & -- & ${ }^{1} 2$. & -- \\
\hline La & 81. & 4. & 77. & & -- & 47. & -- \\
\hline $\mathrm{Mn}$ & 128. & 18. & 200. & & -- & -- & -- \\
\hline Mo & 87. & 2. & 800. & & -- & ${ }^{1} 41$. & -- \\
\hline $\mathrm{Ni}$ & 102. & 2. & 68. & & -- & 26. & -- \\
\hline $\mathrm{Sb}$ & 32. & .3 & 2600 . & & 26. & ${ }^{1} 69$. & 1. \\
\hline Sc & 121. & 1.6 & 26. & & - & 7. & -- \\
\hline $\mathrm{Sn}$ & 30. & 2. & 260 . & & -- & ${ }^{1} 98$. & -- \\
\hline St & 126. & 8. & 710 . & & -- & ${ }^{1} 2$. & - \\
\hline $\mathrm{Ti}$ & 88. & 300. & 7700. & & 26. & 1. & ${ }^{2} 13$. \\
\hline $\mathrm{v}$ & 125. & 13. & 190. & & - & 3. & - \\
\hline$Y$ & 102. & 2. & 46. & & -- & 26. & -- \\
\hline Yb & 78. & .22 & 9. & & - & 50. & -- \\
\hline $\mathrm{Zr}$ & 101. & 24. & 560. & & 26. & 1. & - \\
\hline As & 34. & 1.8 & 2800 & & -- & ${ }^{2} 90$. & 4. \\
\hline $\mathrm{Au}$ & 6. & .06 & 12. & & -- & ${ }^{1} 122$. & -- \\
\hline $\mathrm{F}$ & 127. & 100. & 1400. & & 1. & -- & -- \\
\hline $\mathrm{Hg}$ & 102. & .02 & 1.1 & & 26. & -- & -- \\
\hline Th & 84. & .29 & 43. & & 30. & 14. & -- \\
\hline U & 71. & .09 & 12.82 & & 56. & 1. & -- \\
\hline W & 128. & .79 & 140. & & - & $\ldots$ & -- \\
\hline $2 n$ & 113. & 7. & 5800 . & & - & ${ }^{1} 15$. & -- \\
\hline $\mathrm{Pb}$ & 64. & 4. & 1000 & & - & 60. & 4. \\
\hline $\mathrm{Nb}$ & 48. & 3.8 & 54. & & -- & ${ }^{1} 80$. & -- \\
\hline
\end{tabular}

1 Variable lower 1 imits of determination.

2 Variable upper limits of determination.

these faults are approximately $800 \mathrm{~m}$. However, geochemical profile $B-B^{\prime}$ also includes a part of the West stock. Therefore, comparison of the variations of plotted elements between the West stock and East stock parts of the profile might provide some hint of vertical changes in elemental concentrations throughout the Buckingham system. Apparent increased abundances of fluorine and tungsten in the East stock part of the profile may indicate the preferential concentration there of these elements toward the uppermost parts of the system (fig. 80). Both tungsten and fluorine have been shown by Hildreth (1979) to be among the elements compositionally zoned preferentially in the direction of the top of rhyolite magma belonging to the Pleistocene Bishop Tuff associated with the Long Valley caldera in east-central California. However, such conclusions concerning metal zonation at Buckingham must be considered cautiously because of the multiplicity of the magmatic pulses that accompanied the emplacement of the system. In addition, tungsten in the Buckingham system appears to be preferentially concentrated on the periphery of the highest molybdenum concentrations (see subsection above entitled "Economic Geology")-a relation that seems to hold true along geochemical profile $A-A^{\prime}$ (fig. 78). Such concentrations of tungsten probably result from an overlapping of hydrothermal pulses that accompanied each succeeding magmatic phase of the system. An attempt will be made below to assess further by means of factor-analysis methods, some of the metal associations in the system.

Variations in molybdenum, fluorine, tungsten, boron, copper, barium, manganese, tin, antimony, and arsenic contents along the geochemical profile of Vail Ridge $\left(C-C^{\prime}\right.$, fig. 77$)$ are shown in figure 81. As in the two preceding geochemical profiles discussed above, molybdenum contents are elevated sharply in the rocks veined heavily by quartz. In addition, the $\mathrm{Mo} / \mathrm{Cu}$ ratio is greater than 1 . The local background for molybdenum in the altered rocks surrounding quartz stockworks here is probably 2 to $12 \mathrm{ppm}$, whereas eight heavily veined rocks analyzed show molybdenum contents of 38 to $140 \mathrm{ppm}$ (fig. 81). Overall tungsten contents along geochemical profile $C-C^{\prime}$ are conspicuously elevated with respect to the rest of the sampled parts of the Buckingham system (compare figs. 78, 80 , and 81 ). However, tungsten contents along profile $C-C^{\prime}$ show erratic fluctuations between sample localities, and the concentrations do not relate closely to rocks veined by quartz. Tungsten abundances on Vail Ridge also seem to show a fairly positive correlation with boron contents (fig. 81). None of the other plotted elements (copper, barium, manganese, tin, antimony, and arsenic; fig. 81) show a correspondence to the distribution of veined rocks in this part of the Buckingham system. Tin, antimony, and arsenic contents are shown primarily to provide estimates of these elements in exposed parts of presumably different levels of the system. In addition, the concentrations of these elements in the Buckingham molybdenum system contrast significantly with elemental signatures along the fault-controlled, Tertiary base- and precious-metal deposits in the area. Veined rocks on Vail Ridge contain tin in the range $2-8 \mathrm{ppm}$, antimony in the range $6-18 \mathrm{ppm}$, and arsenic in the range 4-80 ppm (fig. 81).

Concentrations of tin and arsenic in veined rocks very close to the West stock (table 31 ) seem to show elemental abundances comparable to similarly veined rocks on Vail Ridge. Veined rocks adjacent to the West stock contain tin in the range $<2-5 \mathrm{ppm}$ and arsenic in the range $3.4-60 \mathrm{ppm}$. 


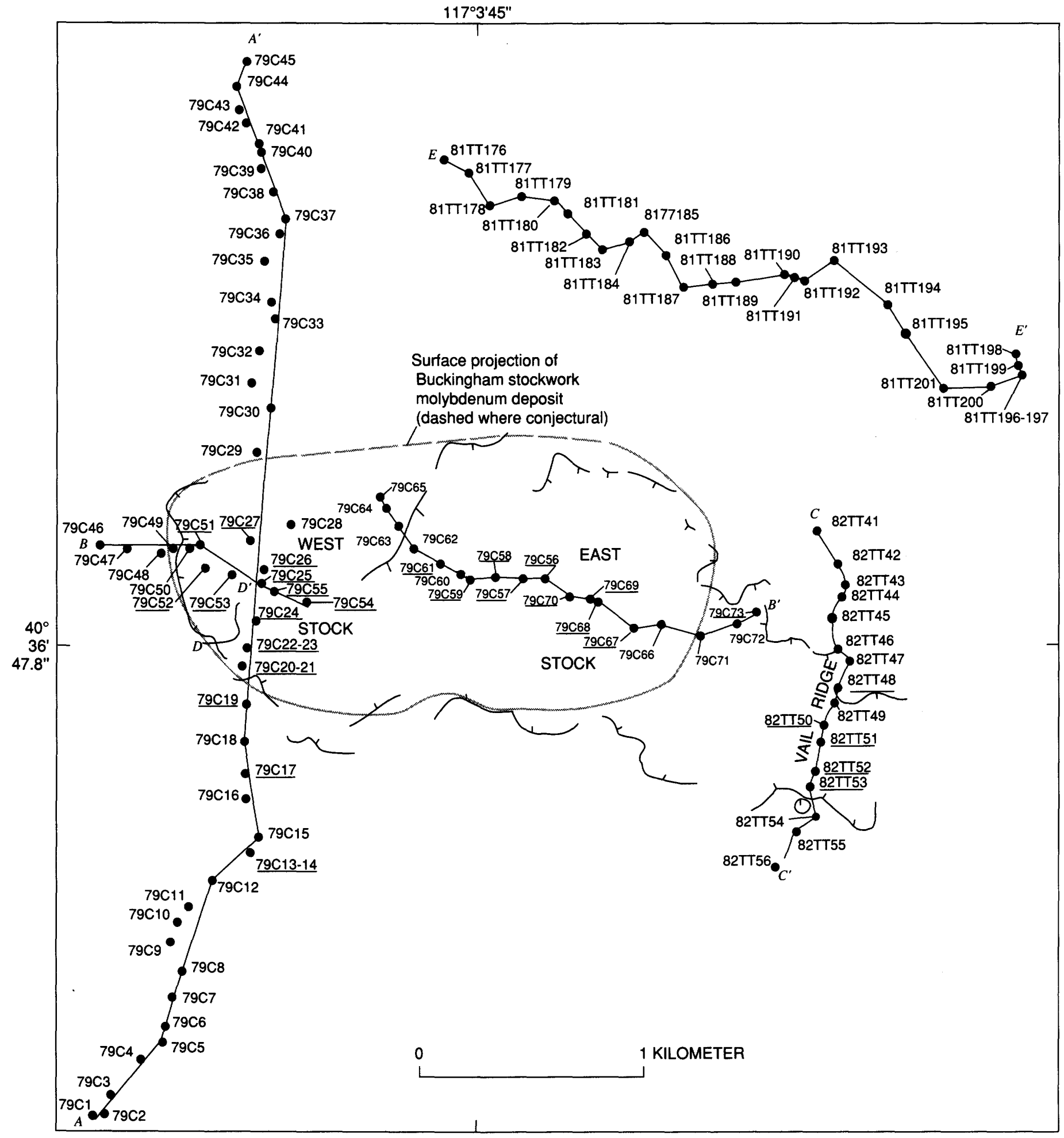

FIGURE 77.-Sample-locality map of rocks analyzed in tables 27 through 31 , showing traces of geochemical traverses $A-A^{\prime}, B-B^{\prime}, C-C^{\prime}$, $D-D^{\prime}$, and $E-E^{\prime}$. Underlined sample numbers indicate molybdenum contents greater than 50 ppm. Hachured line approximately encompasses outer limit of intensely developed quartz stockworks. 

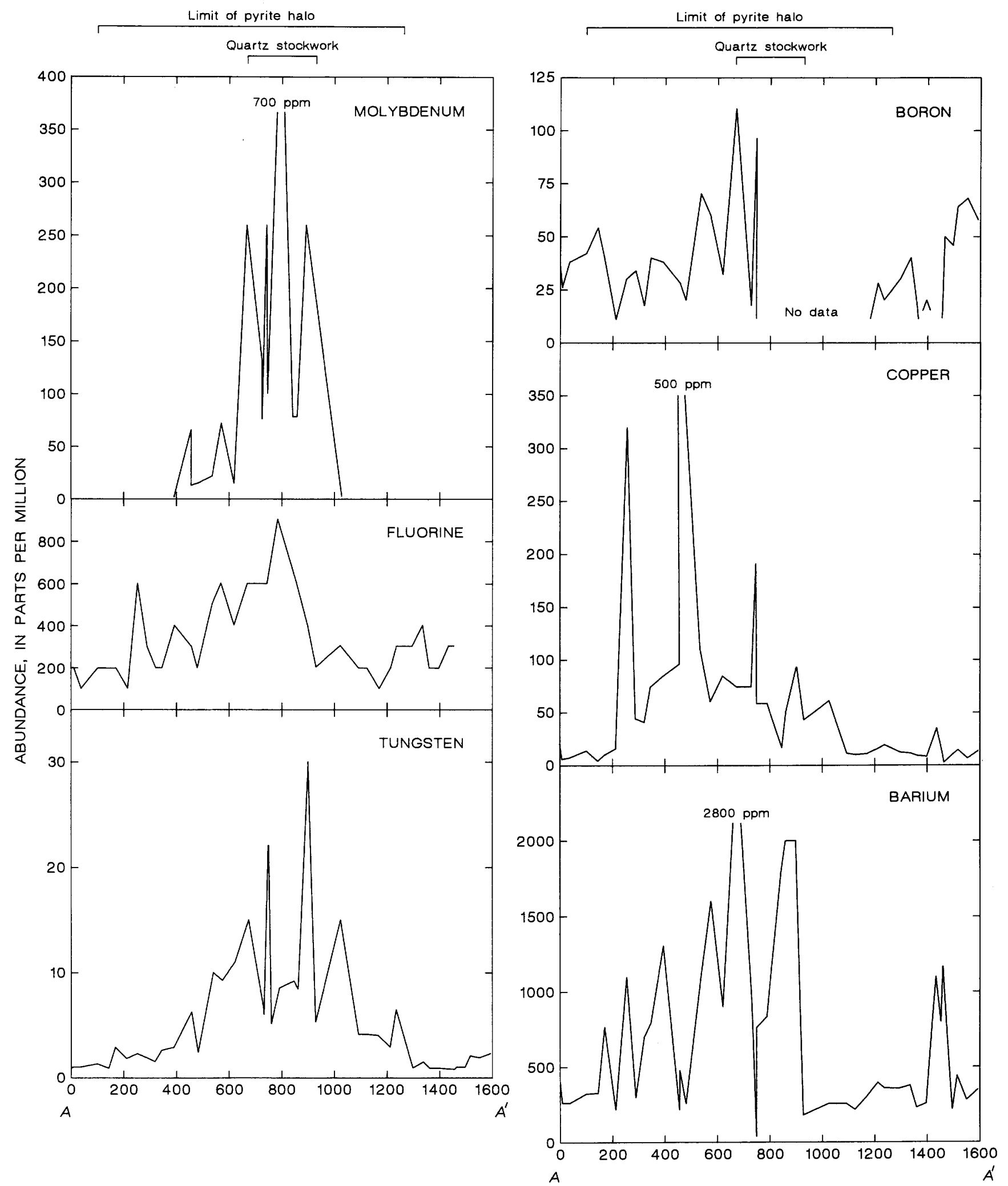

DISTANCE ALONG TRAVERSE $A-A^{\prime}$, IN METERS

FIGURE 78.-Abundances of molybdenum, fluorine, tungsten, boron, copper, and barium versus distance along traverse $A-A^{\prime}$. See figure 77 for location of traverse. 
Thus, there does not appear to be a widespread and progressive buildup in arsenic concentrations through successively shallower quartz-veined parts of the Buckingham system. However, arsenic is present in relatively high concentrations at the Empire Mine (T.G. Theodore and G.M. Jones, unpub. data, 1989), which is a silver-gold, silicapyrite ore body associated with the Buckingham stockwork molybdenum system (Schmidt and others, 1988). At this deposit, arsenic was detected, at a $100-p p m$ lower detection level, in 10 of 22 samples of jasperoid. The mean arsenic content in those 10 samples is about $400 \mathrm{ppm}$; there is a range of 180 to $1,100 \mathrm{ppm}$ in the values of detected arsenic.

\section{VARIATION OF MINOR ELEMENTS IN THE GENERAL AREA OF BLUFF}

Frequency distributions for 12 elements (molybdenum, fluorine, tungsten, barium, copper, zinc, lead, niobium, manganese, vanadium, nickel, and lithium) along geochemical profile $E-E^{\prime}$ (fig. 77)
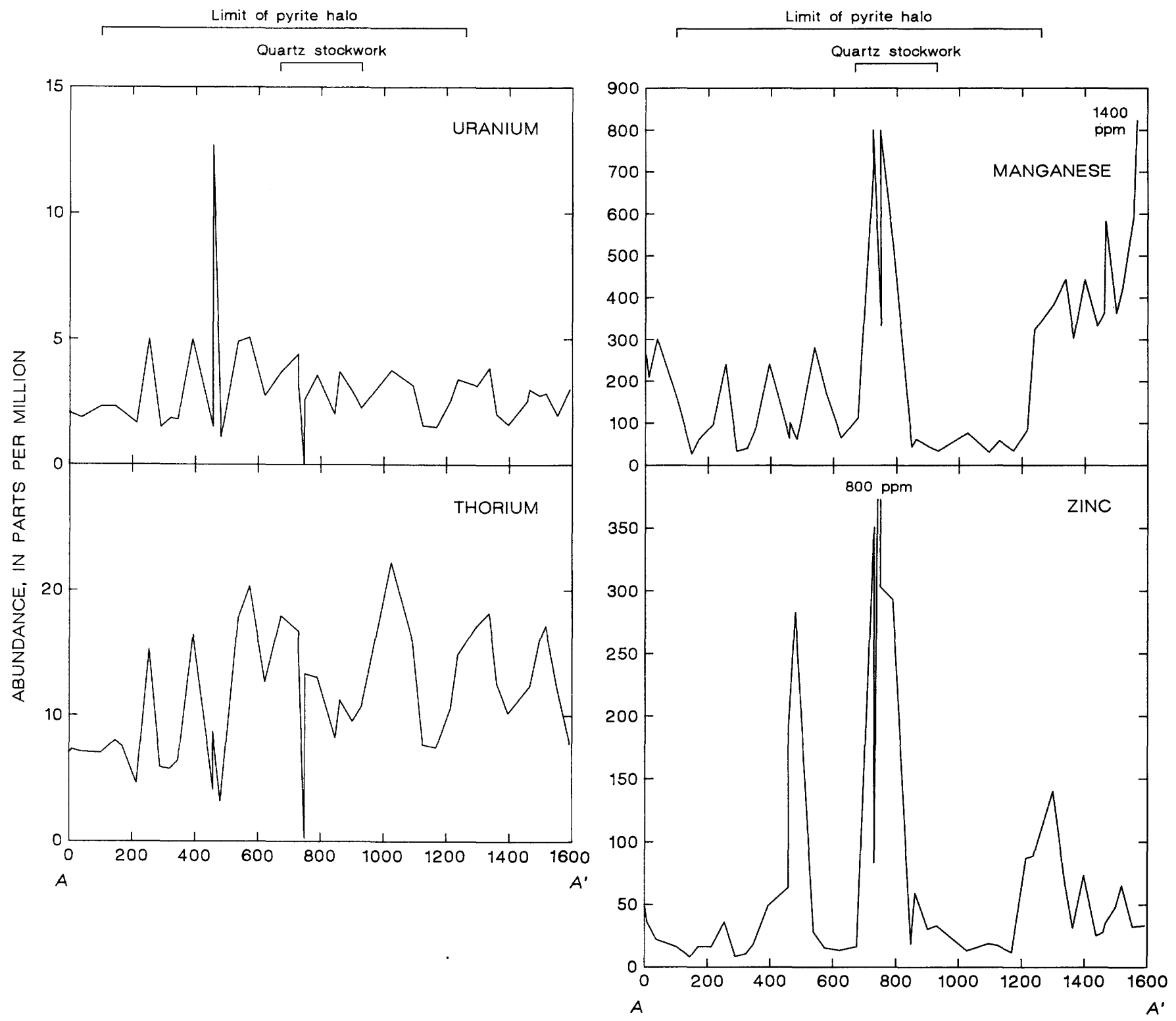

DISTANCE ALONG TRAVERSE A-A: IN METERS

FIGURE 79.-Abundances of uranium, thorium, manganese, and zinc versus distance along part of traverse $A-A^{\prime}$. See figure 77 for location of traverse. 


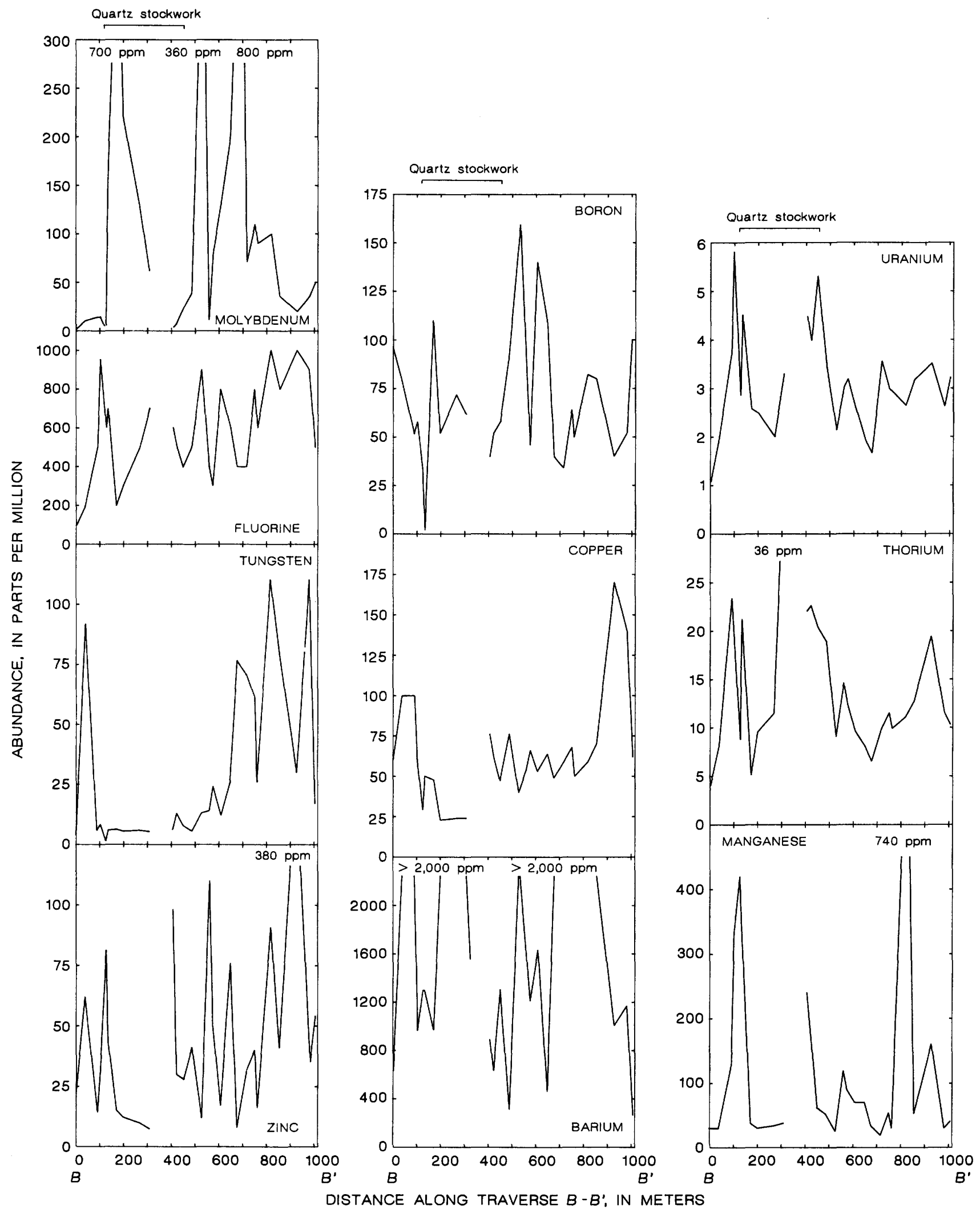

FIGURE 80.-Abundances of molybdenum, fluorine, tungsten, boron, copper, zinc, barium, manganese, uranium, and thorium versus distance along traverse $B-B$. See figure 77 for location of traverse. 
near Bluff are shown in figure 82. Some of these distributions and the remaining data along the profile (table 31 ) provide a local geochemical contrast between altered rocks that surround the Buckingham system and intensely mineralized rocks related closely to the system itself. Although frequency distributions for many elements commonly extend beyond their lower limits of determination, median values from many of these elemental distributions provide a significant contrast with similar determinations on quartz-veined rocks that surround the Buckingham deposit. For example, molybdenum along geochemical profile $E$ $E^{\prime}$ shows a median value of about $2.5 \mathrm{ppm}$; fluorine about $200 \mathrm{ppm}$; tungsten about $2.5 \mathrm{ppm}$; and barium about $300 \mathrm{ppm}$-values all significantly less than in the quartz-veined rocks along geochemical profiles $A-A^{\prime}, B-B^{\prime}, C-C^{\prime}$, and $D-D^{\prime}$ (compare figs.

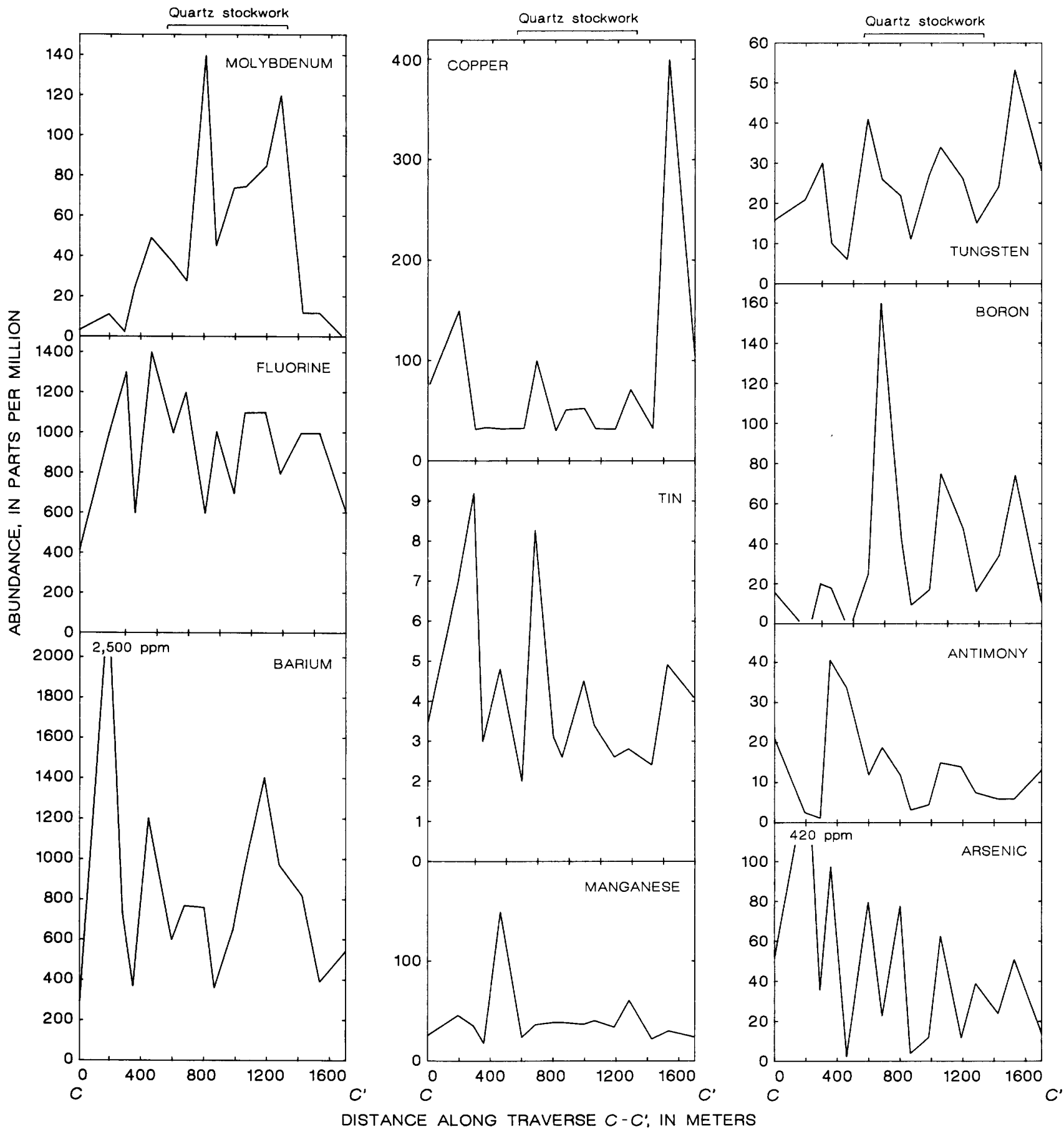

Figure 81.-Abundances of molybdenum, fluorine, tungsten, boron, copper, barium, manganese, tin, antimony, and arsenic versus distance along traverse $C-C^{\prime}$. See figure 77 for location of traverse. 
78-81; table 31). Copper content, however, shows a median value of about $110 \mathrm{ppm}$ along profile $E-E^{\prime}$ (fig. 82)-a value that is apparently intermediate between the approximately 50 -ppm concentrations in the quartz-veined rocks in the general area of the West stock (fig. 78), and the approximately 200-ppm concentrations of copper in the quartzveined rocks of the Vail Ridge part of the Buckingham system (fig. 81). Median values for zinc, lead, niobium, manganese, vanadium, nickel, and lithium contents are, respectively, about 15, 7.5, 5, $150,35,7.5$, and $7.5 \mathrm{ppm}$ along geochemical profile $E-E^{\prime}$ (fig. 82). All these frequency distributions, with the possible exception of that for vanadium, show either strongly skewed or strongly censored distributions.

Plots of fluorine versus molybdenum, barium, copper, and lithium contents in the rocks analyzed along geochemical profile $E-E^{\prime}$ show these data to be grouped by rock type into broad, only partly overlapping domains (figs. $83 A-83 D$ ). The fluorine contents of Tertiary granitic rocks in this general area are generally less than those of nearby biotite hornfels of the Harmony Formation, in contrast to the fluorine contents in and adjacent to the Buckingham molybdenum system, as described in the next subsection. However, along geochemical profile $E-E^{\prime}$, the fluorine content of the granitic rocks seems to show a very weak positive correlation with molybdenum content, whereas fluorine and molybdenum contents seem to vary inversely in rocks of the Harmony Formation (fig. 83A). Two samples of garnet-pyroxene skarn related to Tertiary granitic rocks also were sampled along geochemical profile $E-E^{\prime}$. These Tertiary skarns show a fluorine content of $100 \mathrm{ppm}-$ considerably below the range in fluorine content of $1,900-2,700 \mathrm{ppm}$ found in garnet skarn D apparently associated with the Buckingham stockwork molybdenum system (table 24; see section below entitled "Mineral Chemistry of Late Cretaceous and Tertiary Skarns"). As such, these low flourine contents in the skarn along geochemical profile $E-E^{\prime}$ further provide a characteristic grouping of their data points into a domain distinct from that of other rock types in the plots of fluorine versus barium and lithium contents (figs. 83B, 83D).

\section{COMPARISON OF THE DISTRIBUTIONS OF FLUORINE, MOLYBDENUM, AND COPPER IN THE BLUFF AREA WITH THE BUCKINGHAM MOLYBDENUM SYSTEM}

Plots of fluorine versus molybdenum and copper contents by rock type in the Bluff area and in the West stock and Vail Ridge parts of the Buckingham molybdenum system further emphasize the minor element contrast among these suites of rocks (figs. $84 A-84 D$ ). Tertiary granitic rocks of the Bluff area show overall much lower fluorine and molybdenum contents than exposed granitic rocks of the Buckingham system (fig. 84A). This plot also accentuates the contrast between the fluorine content of granitic rocks at a deep level of the system (West stock) compared with presumably shallower parts (Vail Ridge). Although no significant copper mineralization is known to be associated with Tertiary granitic rocks in the Bluff area, the plot of fluorine versus copper contents (fig. 84B) for these rocks suggests that more copper may be associated with rocks of the Bluff area than with those of the Buckingham system. However, such a judgement would entail a misinterpretation of these data. It must be recalled from above that copper abundances in the Buckingham system are zoned to increased concentrations outward from the steeply plunging shells of molybdenite mineralization that make up the deposit. Thus, the data points for the Buckingham system shown (fig. $84 B$ ) should not be used alone as a suggestion of its relative potential for copper. As we discussed above, evolution of the Buckingham system includes very significant copper mineralization in the areas of the Copper Basin Mine and the Copper Queen Mine.

The plots of fluorine versus molybdenum and copper contents for rocks of the Harmony Formation in these three areas (Bluff, West stock, and Vail Ridge) show significantly greater scatter (figs. $84 C, 84 D$ ) than similar plots for granitic rocks there. Furthermore, these data from the Harmony Formation do not show a clustering of plotted values into approximately three spatially separate domains, as do data from the granitic rocks. Nonetheless, the rocks of the Harmony Formation from geochemical profile $C-C^{\prime}$ include fluorine contents that cluster near the high end of the range $200-1,400 \mathrm{ppm}$.

\section{MULTIVARIATE STATISTICS}

Multivariate statistics were prepared initally on a data set consisting of 128 samples from the Buckingham area (tables 27-31) and 30 selected elements (silver, boron, barium, cobalt, chromium, copper, gallium, lanthanum, manganese, molybdenum, nickel, antimony, scandium, tin, strontium, titanium, vanadium, yttrium, ytterbium, zirconium, arsenic, gold, fluorine, mercury, thorium, uranium, tungsten, zinc, lead, and niobium) after first substituting all qualified determinations by usage of programs GXFIXX and REPLACE (see Kork and Miesch, 1984; U.S. Geological Survey, 1984). Strengths of association between variables 
are usually determined by Pearson, or productmoment correlation, or Spearman or Kendall rankcorrelation, and analysis of variance techniques. The product-moment technique requires bivariate normal distributions between variables being compared (Dixon and Massey, 1951; Lovering and others, 1968), whereas the rank-correlation technique makes no assumption about sample distribution
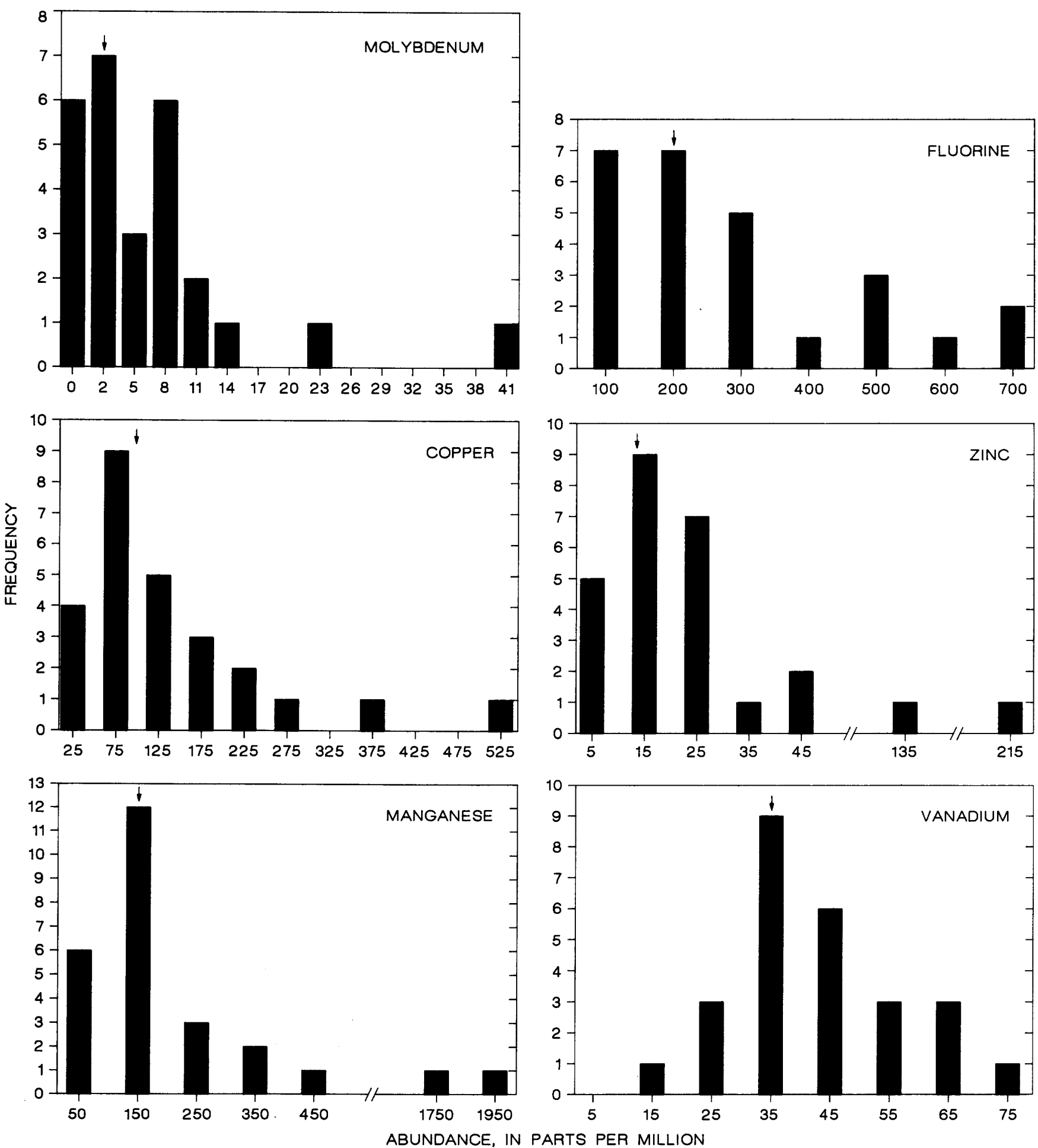

Figure 82.-Frequency distributions of 12 elements in 26 rock samples from geochemical 
(Siegel, 1956; Flanagan, 1957). Visual inspection of histograms prepared for elemental distributions of the data set from the Buckingham area indicates that most of the elements here do not approximate either a normal or a lognormal distribution. These characteristics of the data set would weaken the strength of association between elements determined by a product-moment correlation analysis.
However, comparative tests on somewhat similarly distributed geochemical data (Theodore and Blake, 1975) have shown that a product-moment correlation analysis may be useful in at least a qualitative manner as mathematical indices of association only within the data set (D.A. Singer, written commun., 1986). All coefficients of correlation absolutely greater than 0.44 indicate the strongest
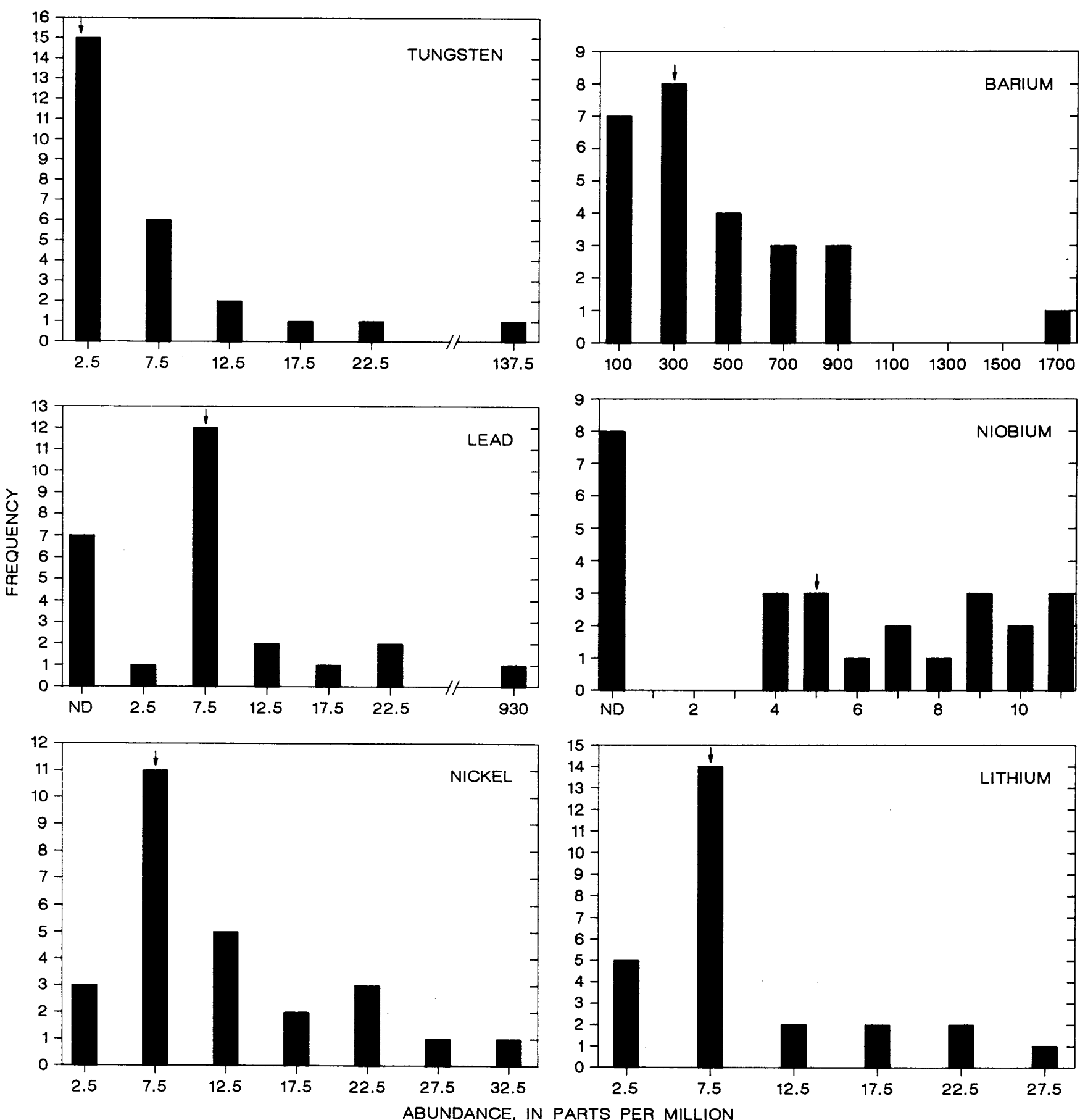

traverse E-E' (fig. 77; table 31). ND, below limits of determination. Arrow indicates median. 
positive and negative associations in a furtherculled geochemical data set of 19 elements that includes a high percentage of unqualified determinations (table 35). The 11 remaining elements (silver, boron, cobalt, antimony, tin, ytterbium, arsenic, gold, uranium, lead, and niobium) each have more than 50 qualified determinations (less than or greater than the limits of determination, or not analyzed for; see table 34). Nonetheless, in light of all of the aforementioned perplexities with the data set, some geologically reasonable associations can be made.

Molybdenum is strongly correlated positively $(r \geq+0.44)$ only with fluorine, and negatively $(r \leq-0.44)$ with zircon (table 35$)$. Fluorine, however, shows a strong positive correlation with barium, lanthanum, molybdenum, vanadium, and thorium; vanadium shows a strong positive association with chromium, lanthanum, scandium, strontium, titanium, and yttrium. As we discussed above, the plots of the elemental concentrations along the geochemical profiles seem also to show sympathetic positive variations among molybdenum, barium, and fluorine contents in the immediate area of the Buckingham deposit.

Several other multivariate statistical approaches, $\mathrm{R}$ - and Q-mode types of factor analysis (see Davis, 1973), were used in an attempt to detect additional,
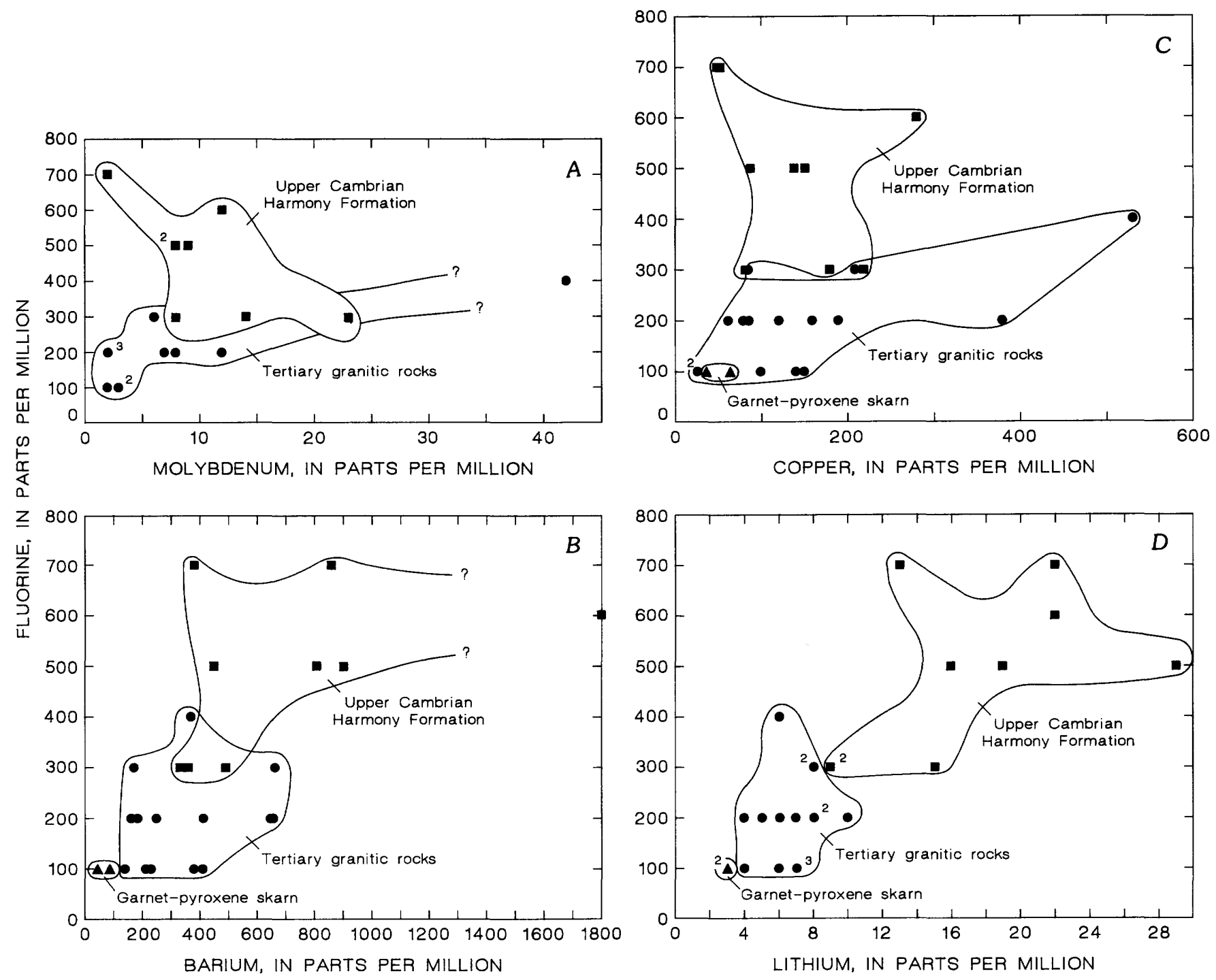

Figure 83.-Fluorine versus molybdenum $(A)$, barium $(B)$, copper $(C)$, and lithium $(D)$ contents in 26 rocks analyzed along geochemical traverse $E-E^{\prime \prime}$ (fig. 77). Numbers indicate more than one sample. Fields queried where extent uncertain. 
geologically significant elemental associations that may not have been resolved by means of the correlation coefficients alone. Our preliminary tests involved the utilization of various standard options (U.S. Geological Survey, 1984; see Miesch, 1976a, b, 1981) associated with both R- and Q-mode factor analyses of the 30-element- by 128 -sample data set. These data presumably include fairly reasonable substitutions of all qualified determinations as required in the statistical manipulation of data sets by the various factoranalysis programs (Davis, 1973; U.S. Geological Survey, 1984). Of the options attempted, a moderately complex Q-mode factor analysis using six factors apparently provides here a very geologically reasonable discrimination of the variances among the geochemical data. Such a six-factor model accounts, on average, for 69 percent of the variances of all 30 elements. However, the proportions of the variances thus accounted for in the suitably transformed data set include low values of 8,41 , and 42 percent for niobium, zinc, and uranium, respectively. If we disregard these low values, then the average proportion of the variances accounted for by the six-factor model is 73 percent. By comparison, a relatively simple threefactor model accounts for an average of 43 percent of the proportion of the variances, and a 10-factor model accounts for 80 percent. The Q-mode analysis reveals the following associations among the elements in the six-factor model, all considered by us to be moderate at best because the correlation between the highest varimax factor loadings and the elements (see Klovan, 1968; Davis, 1973) is about 0.5:
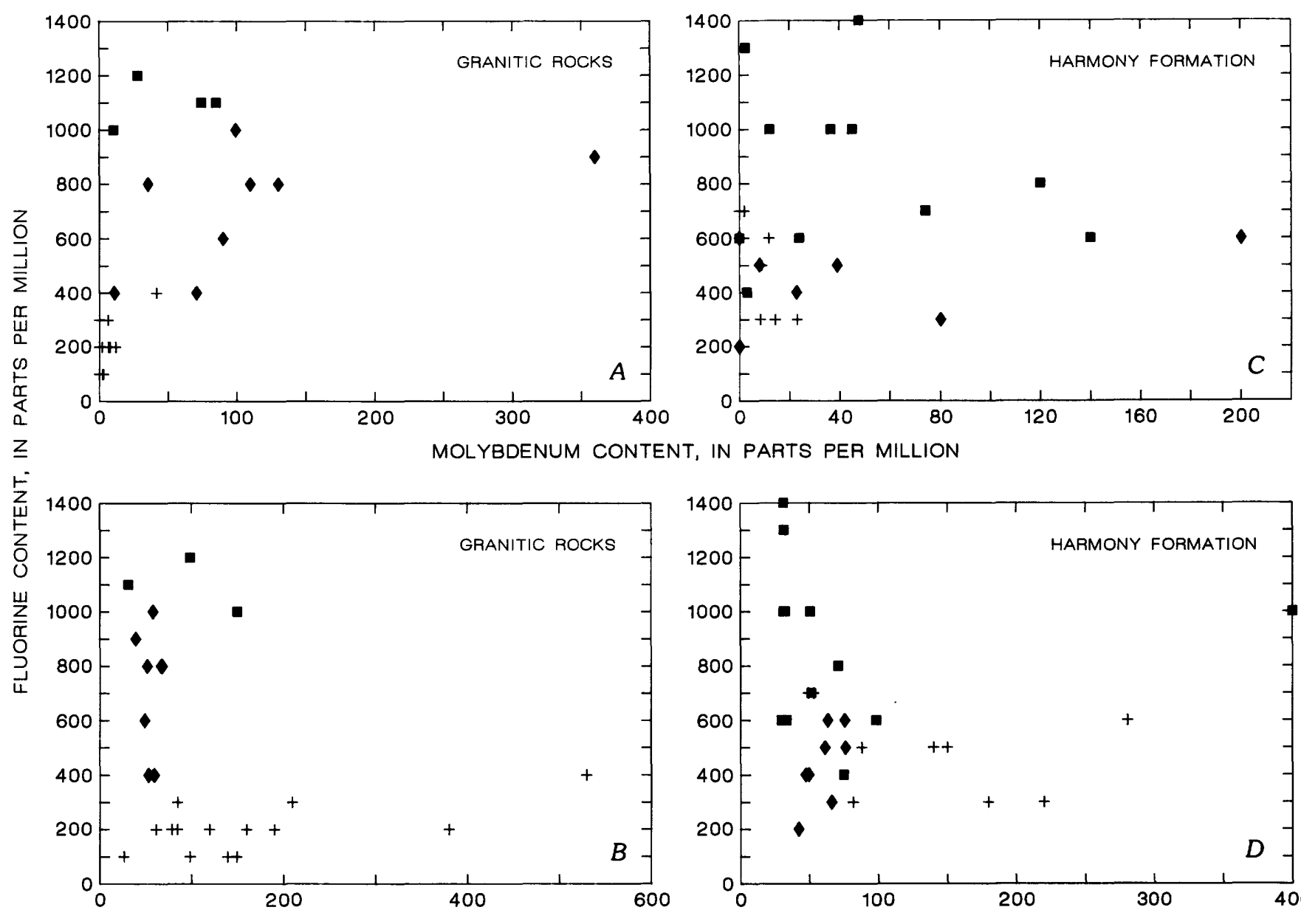

COPPER CONTENT, IN PARTS PER MILLION

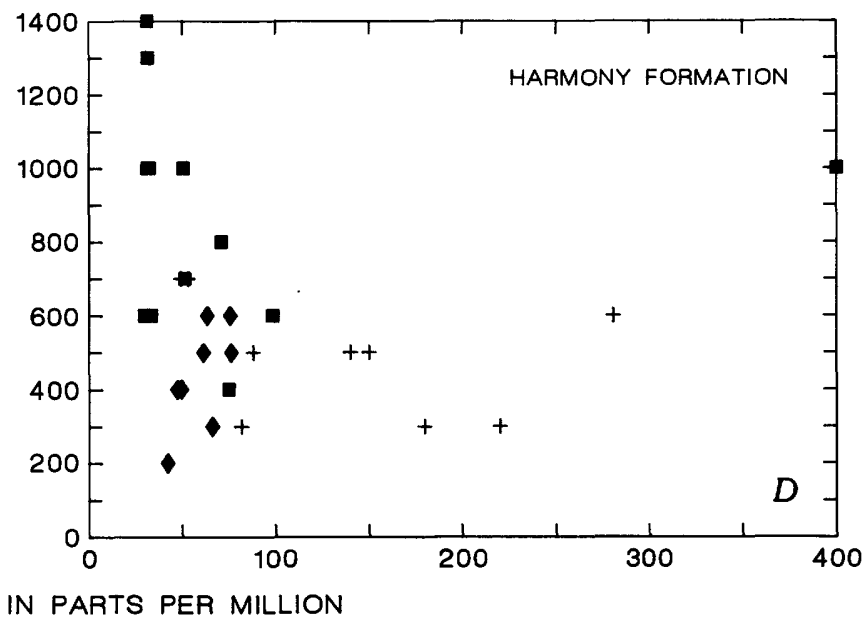

FiguRE 84.-Fluorine versus molybdenum and copper contents in Tertiary granitic rocks along geochemical traverse $E-E^{\prime}$ in Bluff area, in Late Cretaceous granitic rocks along traverses $A-A^{\prime}$ and $C-C^{\prime}$ of Buckingham molybdenum system $(A, B)$, and in rocks of the Upper Cambrian Harmony Formation $(C$, $D$ ). Squares, from profile $C-C^{\prime \prime}$, Vail Ridge area; diamonds, from profile $A-A^{\prime}$, West stock; plusses, from profile $E-E^{\prime}$, Bluff area. 
TABLE 35.-Array of correlation coefficients for 128 rocks (tables 27-31) from the Buckingham area

[Dots, correlation coefficients equal to or greater than +0.44 ; circles, correlation coefficients equal to or less than -0.44 ; dashes, correlation coefficients between -0.44 and +0.44$]$

\begin{tabular}{|c|c|c|c|c|c|c|c|c|c|c|c|c|c|c|c|c|c|c|c|}
\hline & $\mathrm{Ba}$ & $\mathrm{Cr}$ & $\mathrm{Cu}$ & $\mathrm{Ga}$ & $\mathrm{La}$ & $\mathrm{Mn}$ & Mo & $\mathrm{Ni}$ & Sc & $\mathrm{Sr}$ & Ti & $\mathrm{V}$ & $\mathrm{Y}$ & $\mathrm{Zr}$ & $F$ & $\mathrm{Hg}$ & Th & W & $\mathrm{Zn}$ \\
\hline $\mathrm{Ba}$ & -- & -- & -- & - & -- & -- & -- & - & -- & 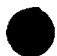 & - & -- & -- & - & 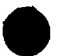 & -- & -- & -- & -- \\
\hline $\mathrm{Cr}$ & & -- & - & -- & -- & -- & -- & $C$ & -- & $=$ & - & & & - & - & -- & - & -- & - \\
\hline $\mathrm{Cu}$ & & & & -- & -- & -- & -- & -- & -- & -- & -- & -- & 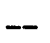 & -- & -- & -- & -- & -- & -- \\
\hline $\mathrm{Ga}$ & & & & - & 0 & -- & -- & - & -- & -- & - & - & -- & - & -- & -- & -- & -- & -- \\
\hline $\mathrm{La}$ & & & & & - & -- & -- & -- & - & -- & -- & & & -- & 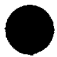 & -- & -- & -- & - \\
\hline $\mathrm{Mn}$ & & & & & & -- & - & 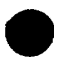 & -- & -- & - & 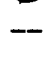 & & -- & -- & -- & -- & -- & -- \\
\hline Mo & & & & & & & -- & -- & -- & -- & -- & -- & & ( & 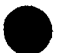 & -- & -- & -- & -- \\
\hline $\mathrm{Ni}$ & & & & & & & & -- & -- & -- & -- & -- & - & $=$ & - & -- & -- & - & -- \\
\hline $\mathrm{Sc}$ & & & & & & & & & -- & -- & 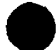 & & & -- & -- & -- & - & -- & -- \\
\hline $\mathrm{Sr}$ & & & & & & & & & & -- & - & & & - & -- & -- & -- & -- & - \\
\hline $\mathrm{Ti}$ & & & & & & & & & & & -- & & & -- & - & -- & -- & -- & - \\
\hline $\mathrm{V}$ & & & & & & & & & & & & - & & -- & & --- & -- & - & - \\
\hline$Y$ & & & & & & & & & & & & & & & & -- & & - & -- \\
\hline $\mathrm{Zr}$ & & & & & & & & & & & & & & -- & -- & -- & - & -- & - \\
\hline F & & & & & & & & & & & & & & & -- & -- & & -- & - \\
\hline $\mathrm{Hg}$ & & & & & & & & & & & & & & & & - & -- & - & -- \\
\hline Th & & & & & & & & & & & & & & & & & -- & - & -- \\
\hline W & & & & & & & & & & & & & & & & & & -- & -- \\
\hline $\mathrm{Zn}$ & & & & & & & & & & & & & & & & & & & - \\
\hline
\end{tabular}

Factor 1: positive for $\mathrm{Co}, \mathrm{Cr}, \mathrm{Mn}, \mathrm{Mi}, \mathrm{Sc}, \mathrm{Y}$, and $\mathrm{Yb}$; negative for $\mathrm{W}$;

Factor 2: positive for $\mathrm{Ba}, \mathrm{Mo}, \mathrm{F}$, and $\mathrm{W}$; negative for $\mathrm{Mn}, \mathrm{Ni}$, and $\mathrm{Yb}$;

Factor 3: positive for $\mathrm{B}$ and $\mathrm{Sb}$; negative for $\mathrm{Th}$;

Factor 4: positive for $\mathrm{Ag}, \mathrm{Sb}, \mathrm{Sn}, \mathrm{As}, \mathrm{Au}$, and $\mathrm{Pb}$;

Factor 5: negative for $\mathrm{La}$ and $\mathrm{Ni}$;

Factor 6: negative for $B$.

All the elements listed above show correlations with their respective factors higher than 0.5 (positive) or lower than -0.5 (negative). As tabulated, the elements are listed in their order in the data set and their order in the listing does not imply a relative strength. If the correlations considered to be geologically significant between the highest varimax factor loadings and the elements are increased to higher than 0.57 or lower than -0.57 , then the Q-mode analysis reveals the following associations in the six factor model:
Factor 1: positive for $\mathrm{Co}, \mathrm{Sc}, \mathrm{Y}$, and $\mathrm{Yb}$;

Factor 2: positive for $\mathrm{Ba}, \mathrm{Mo}$, and $\mathrm{W}$; negative for $\mathrm{Cr}$ and $\mathrm{Mn}$;

Factor 3: positive for $\mathrm{Sb}$; negative for $\mathrm{Th}$;

Factor 4: positive for $\mathrm{Ag}, \mathrm{Sn}, \mathrm{As}, \mathrm{Au}$, and $\mathrm{Pb}$;

Factor 5: none;

Factor 6: negative for B.

The resulting groupings of the elements in the sixfactor model seem to reflect a dominance largely by three major geologic environments and by their associated geologic processes. These environments consist of first the unaltered rocks of the Harmony Formation and (or) the weakly sulfidized rocks of the Harmony Formation near the outer margins of the pyritic halo that surrounds the Buckingham system. Factors one and five seem to show a dominance by this environment. Somewhat more specifically, factor five also seems to include loadings that result from the effects of alteration of diabase. The second major 
geologic environment consists of the effects of fairly intense alteration and mineralization associated with the Buckingham system (factors 2 and 6). Factor 2 includes a moderate, positive loading for barium, molybdenum, fluorine, and tungsten, statistically confirming thereby associations of these elements depicted graphically by the plots above showing their concentrations along the geochemical profiles across the Buckingham system. Factor 6, dominated by a strong negative loading for boron, results primarily from the apparent strong depletion of boron in the immediate area of the West stock of the Buckingham system. Third, elements either introduced or depleted significantly during the Tertiary, mostly fracture controlled base- and precious-metal mineralization, exemplified by that at the Little Giant Mine, largely make up factors 3 and 4 . Various plots of the Q-mode factor loadings for the 128 samples analyzed depict graphically a selective grouping of the samples into several fairly discrete domains (fig. 85). From such plots, the superposition of the effects of progressively large loadings on factor 2 , or samples associated closely with molybdenum mineralization, onto the variances associated mostly with largely unmineralized or weakly sulfidized rocks of the Harmony Formation are readily apparent (fig. 85A). Furthermore, those few samples in the data set that show a dominance by the effects of Tertiary base- and precious-metal mineralization (factor 4) plot significantly away from the loadings on the other samples (fig. 85B).

\section{MINERAL CHEMISTRY OF LATE CRETACEOUS AND TERTIARY SKARNS}

By Jane M. Hammarstrom

\section{INTRODUCTION}

An electron microprobe was used to study the mineral chemistry of a number of mapped bodies of skarn in the northeastern part of the study area (stippled patterns, pl. 1). These skarns are exposed at the surface east of the main part of the Buckingham porphyry molybdenum stockwork system and extend northward from the center of Copper Basin copper mining activity in the Contention pit. Skarn formed in three metasedimentary rock units: the Upper Cambrian Harmony Formation, the
Middle Pennsylvanian Battle Formation, and the Upper Pennsylvanian and Lower Permian Antler Peak Limestone. Previous discussions in this report describe the geology of these skarn bodies and show that some skarns may be related to Cretaceous magmatism associated with the Buckingham system, whereas others are more closely linked with Tertiary intrusive events. Recent summary studies (for example, Einaudi and others, 1981; Meinert and others, 1981; Einaudi and Burt, 1982; Meinert, 1983; Kwak, 1986) show that calcic

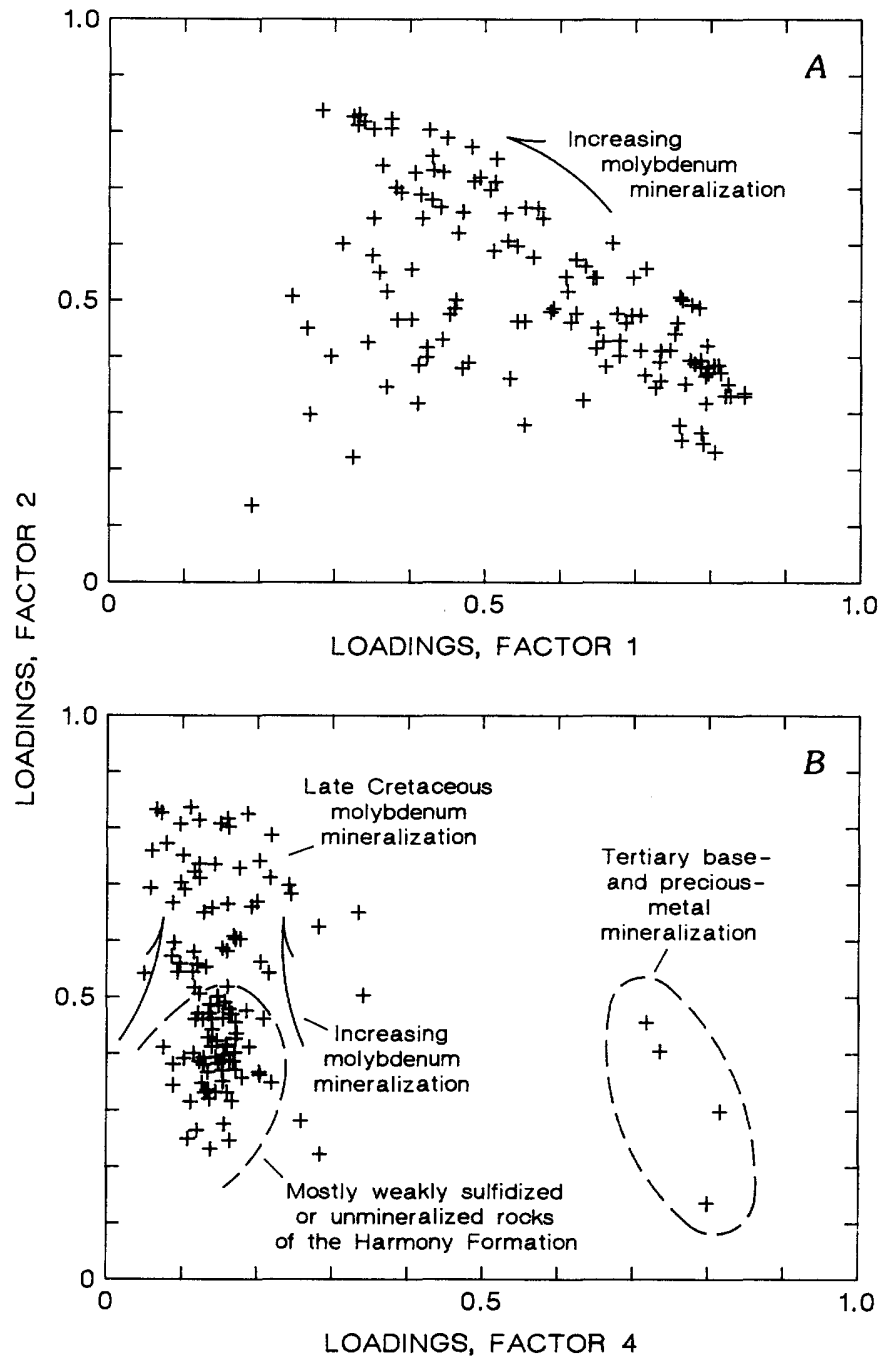

FIGURE 85.-Loading on Q-mode factor most closely associated with molybdenum mineralization (factor 2) compared with factor (factor 1) most closely related to weakly sulfidized or unmineralized rocks of the Upper Cambrian Harmony Formation $(A)$ and Q-mode factor compared with factor (factor 4) most closely related to Tertiary base- and precious-metal mineralization $(B)$. A value of zero loading on a factor indicates an average contribution of that factor in a particular sample; a value of +1.0 indicates 1 standard deviation above average (see text). 
skarns evolve through multiple stages. In the early stages of calcic skarn evolution, a prograde anhydrous mineral assemblage dominated by pyroxene and garnet forms as a result of contact metamorphism and metasomatism. Sulfide deposition in calcic skarns accompanies hydrous alteration of earlier stage anhydrous garnet and pyroxene to form amphibole, epidote, and chlorite. Different classes of skarns, as defined by the principal economic metal exploited, represent differences in tectonic settings and types of associated magmatism. Garnet and pyroxene compositions provide a characteristic fingerprint of associated metallization and provide clues about the oxidation-sulfidation environment of skarn formation. The complex zoning patterns in skarns arise from the overprint of stages as the skarn front advances through space and time. Meinert (1983) emphasized the fact that aspects of local geologic environment such as depth, structure, and host-rock composition affect the extent of development of various stages in any given skarn.

This chapter describes the mineral chemistry of the Copper Basin skarns. Mineral compositions are compared with published results for other skarns, and constraints on conditions of formation imposed by observed mineral assemblages are discussed. The observations and conclusions reached in this report are based almost entirely on surface samples representing the oxide zone. Current (1989) active exploration and development may reveal additional sulfide zones and will undoubtedly reveal exposures critical to the understanding of the paragenesis of these skarns.

\section{ACKNOWLEDGMENTS}

Most samples included in this study were collected during the summer of 1985 by T.G. Theodore and J.M. Hammarstrom, with the help and guidance of Rob Benson, Kirk Schmidt, and Pat Wotruba of the Battle Mountain Gold Co. Theodore provided additional samples, including the well-studied 76CB suite of samples (fig. 86). Pat Wotruba provided a drill-core sample from the Surprise gold deposit. Robert Hershiser, U.S. Geological Survey, prepared excellent polished sections for microprobe work. Lisa Perry of Santa Fe Mining, Inc. kindly sent samples for some of the skarns at the Overlook property at the north edge of the map area. John White, U.S. National Museum, furnished an andradite sample for use as a microprobe standard. Karen Gray, U.S. Geological Survey, assisted with sample preparation, mineral separations, and X-ray work. Phil Bethke and Mike Foose, U.S. Geological Survey, and Larry Meinert, Washington State University, offered advice on interpretation of microscopic textures. Barney Berger, U.S. Geological Survey, kindly arranged for analytical work on nontronite samples. Bruce Lipin, U.S. Geological Survey, offered advice on chromite.

\section{DESCRIPTION OF SAMPLES}

Individual mapped skarn bodies, or groups of closely spaced mapped skarn bodies are given letter designations, A through $\mathrm{F}$, assigned from west to east; thus, their overall relation is proximal to distal relative to the main part of the Buckingham system (fig. 86). All samples represent surface samples typical of the skarn in the outcrop area. In addition to skarn, a few samples of hornfels, diabase, and yellow-green clay layers associated with skarn were examined. The mineralogy of all samples in the microprobe study is summarized in tables 36 and 37 .

Additional major- and trace-element data (see table 24) are given for samples from the Harmony Formation (skarn D), massive garnetite skarn formed in the middle member of the Battle Formation (skarn E), and associated clays (table 38).

Most of the samples included in this study represent barren skarn. In the Copper Basin area, mineralized skarn deposits are confined to the Harmony Formation in the eastern part of the district near the unconformity that separates the Harmony Formation from the lower member of the Battle Formation. Intersecting faults are an important control on localization of mineralized skarn deposits (fig. 86) which include the Battle Mountain Gold Co.'s Labrador gold skarn deposit, Surprise gold-copper skarn, and Carissa copper-gold skarn deposit (pl. 1). Roberts and Arnold (1965) described the geology of the Carissa underground mine and D.W. Blake described skarn mineralization in the Carissa and Contention open-pit mines in this report (see subsection above entitled "Supergene Copper Deposits at Copper Basin"). Schmidt and others (1988) described the geologic setting of the Surprise and Labrador skarn deposits at Copper Basin. Santa Fe Mining, Inc. explored the gold potential for skarn in area B (fig. 86). No mineralization is known to be associated with the other two areas of skarn in the Harmony Formation (A and C), or with skarn formed in the Battle Formation (E) or in the Antler Peak Limestone (F) at Copper Basin. The Battle Formation and Antler 
Peak Limestone host copper and gold-bearing skarn deposits associated with a middle Tertiary granodiorite pluton at the West ore body (Theodore and Blake, 1978) and Fortitude Mine (Wotruba and others, 1986) at Copper Canyon.

\section{SKARN IN THE HARMONY FORMATION}

The letters A, B, C, and D (fig. 86) refer to four areas of skarn within the Harmony Formation. Skarns A, B, and C appear to be spatially and genetically associated with Tertiary porphyritic leucogranite. Skarn D, which parallels the unconformity between the Harmony and Battle Formations, is displaced by the Surprise fault and cut by a number of smaller faults (pl. 1). Blake and others (1979) showed that before open-pit mining, skarn D could be traced more or less continuously southward into Late Cretaceous porphyritic monzogranite (see subsection above entitled "Associated Skarn Alteration"). The change in mineralization from copper-gold at the Carissa deposit to gold at the Labrador deposit may represent a proximal to distal metal zoning relative to the Late Cretaceous system similar to the metal zoning described by Myers and Meinert (1988) for the proximal, copperrich West ore body and distal, gold-rich Fortitude deposit associated with the middle Tertiary, altered granodiorite of Copper Canyon stock. However, localization of mineralization along fault zones and the presence of porphyritic leucogranite of probable Tertiary age at the Labrador deposit (Schmidt and others, 1988) suggest that gold mineralization there is a local Tertiary event, possibly overprinting the more extensive Late Cretaceous skarn.

Samples of skarn A exhibit varying degrees of calc-silicate encroachment on hornfels to form bedded skarn (see fig. 35). Samples 84JH041 through 84JH044 represent a traverse across strike from west to east in skarn A. These four samples show a transition from biotite hornfels cut by quartz and $\mathrm{K}$ feldspar veins, through pyroxene-rich hornfels with successive replacement of pyroxene by poikilitic garnet, to a rock consisting of alternating veins of red garnet and quartz. Small grains of opaque iron oxide minerals, chromite, pyrite, apatite, and sphene are noted. This particular skarn body represents the metamorphic and (or) initial metasomatic stages of skarn evolution; retrograde hydrous silicate assemblages are not developed.

Skarn B consists of a group of mostly fault segmented, massive skarn bodies and includes the
Overlook property explored by Santa Fe Mining, Inc., and the Battle Mountain Gold Co. Rocks from skarn $B$ are red or green spongy garnetites, containing pyroxene and coarse-grained epidote; the garnet is mostly colorless to pale yellow and anisotropic, but many crystals have distinct yellow, isotropic cores. Epidote fills interstices among garnet grains and selectively replaces zones within individual garnet crystals. Brown chlorite occurs within garnets and as $0.02-\mathrm{mm}$-wide bands separating individual garnet crystals. Two samples from skarn B are garnet free: sample 85JH097, from an earthy, pale-green epidosite layer that is separated from a chilled porphyritic leucotonalite dike by garnet-bearing sample 85JH096; and sample $85 \mathrm{JH} 102$, a pyroxene-rich rock collected at a prospect pit in skarn formed along a fault marked by a conspicuous gouge zone. Pyrite replaces rosettes of green chlorite in sample 85JH102. This pyrite has a distinctive colloform texture that suggests gellike growth at low temperatures. In the samples from skarn $B$, the retrograde stage of skarn formation, represented by the hydrous silicate assemblages, was not accompanied by extensive sulfide mineralization. However, gold mineralization has been reported in skarn associated with diabase in this general area (E.I. Bloomstein, Santa Fe Mining, Inc., oral commun., 1987).

Skarn $\mathrm{C}$ is a bedded skarn made up of finely laminated and veined, red and green calc-silicate rocks and hornfels cut by a diabase dike. In some thin sections, as many as nine or more discrete subparallel layers of varying texture and modal mineralogy are present within $2 \mathrm{~cm}$. Garnet forms patches or discontinuous veinlets with partly developed euhedral rims; subhedral to anhedral pyroxene and epidote form clots with K-feldspar. Some garnets are colorless and anisotropic, whereas others are red and isotropic or have isotropic cores with zoned rims. Veinlets of K-feldspar or combtextured quartz are common. Small grains of apatite, sphene, and zircon are present throughout these rocks, and coarse-grained scapolite is observed in one sample from the contact between a garnet-rich layer and a pyroxene-feldspar layer. Samples 85JH078 through 85JH086 represent skarn formed in hornfels. Samples $85 \mathrm{JH} 087$ and 85JH088 represent endoskarn formed in the chilled margin of a 5-m-wide, dark-gray diabase dike that cuts across bedding in the laminated hornfels. The endoskarn samples are fine-grained, green rocks cut by calc-silicate veins. Igneous textures are preserved in two coarser grained samples, 85JH089 


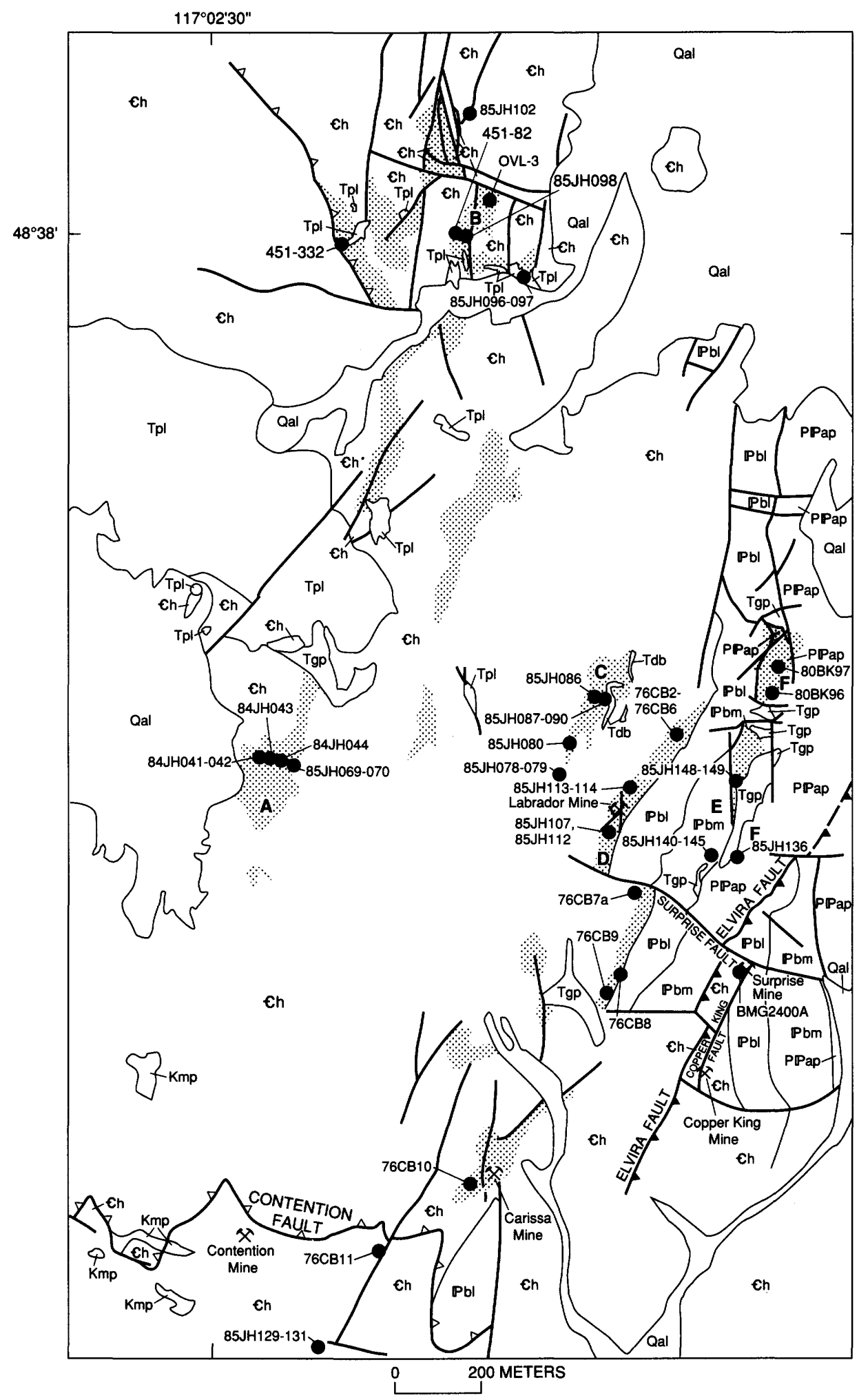

FIGURE 86.-Geologic sketch map of northeastern part of Buckingham study area (modified from pl. 1), showing skarns (A-F) and sample locations for mineral chemistry studies. 
and 85JH090, which are from the central parts of the dike. These rocks are essentially composed of pyroxene and plagioclase; they show effects of hydrothermal alteration but lack garnet veins. Plagioclase in endoskarn is more calcic than the plagioclase in bedded skarn from skarn $\mathrm{C}$ (table 39).

Skarn $\mathrm{D}$ is an elongate, north-south-trending, massive skarn body along the unconformity between the Harmony and Battle Formations. Samples were collected from a traverse along the length of this skarn from north (sample 76CB2) to south (sample 76CB11). Rocks from this skarn are mainly garnetites, with little or no pyroxene. The garnet-rich nature of the skarn is demonstrated by the bulkrock chemistry (table 24), which approaches the composition of a garnet. The degree of retrograde alteration of the anhydrous, prograde assemblage increases markedly from north to south, and the southernmost samples contain sulfide minerals, mostly pyrite, in veins and filling polygonal interstices between coalesced garnets. In some samples,

\section{EXPLANATION}

Qal

Tgp/ $/$ Td $\mathrm{Tdb}$

$\mathrm{Tpl}$

$\mathrm{Kmp}$

PPap

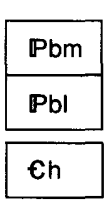

Ch

Harmony Formation

Contact

Faults-Dashed where approximately located

Normal fault

Thrust fault-Sawteeth on upper plate Low-angle gravity glide fault-Sawteeth on upper
plate

76CB11 Sample locality

Skarn

Figure 86.-Continued. two generations of garnet can be seen in hand specimen. Fine-grained mats of early-stage, mostly anisotropic, millimeter-size garnet that is amber in hand specimen and colorless in thin section are cut by veins and pods of later stage, coarse-grained garnet that is dark reddish brown in hand specimen. In thin section, this later stage garnet has distinct yellow, isotropic cores rimmed by alternating growth bands (to $0.02 \mathrm{~mm}$ wide) of colorless, anisotropic garnet and yellow, isotropic garnet. Some of the early garnets are zoned in alternating bands similar to the rim areas of the coarser grained garnets and also exhibit sector twinning. Cores of early garnets tend to be poikilitic, whereas the late-stage garnets are free of inclusions. Smaller garnets form tightly packed mats; coarser grained garnets commonly protrude into open pore space or are separated from each other by quartz or calcite. Samples 76CB3, 76CB4, and 85JH107 are mineralogically distinct and contain shaly layers, similar to those in the laminated calcsilicate rocks of skarn C. Garnets in these samples appear much "dirtier" than other garnets because of clay and brown chlorite within cores and between grains. The opaque mineral in these samples is chromite; in one sample, chromite has reacted with garnet to produce a local zone of bright-green, chromium-rich garnet. Although the chromite grains are broken, they are surprisingly unaltered. Anomalously high levels of chromium, nickel, and vanadium detected in these samples (tables 24,38 ) reflect the presence of chromite. These samples represent a lens or layer within the Harmony Formation that was mineralogically distinct from surrounding sediments. Chromite is also observed in pyroxene-rich hornfels from skarn A. The chromite in the Harmony Formation may represent a detrital mineral deposited in sediments via turbidity currents or alternatively, may be derived from intercalated mafic or ultramafic igneous rocks. An occurrence of greenstone in the Harmony Formation west of the study area is described in the subsection above entitled "Harmony Formation." To our knowledge, chromite has not previously been reported as a detrital mineral in the Harmony Formation.

Schmidt and others (1988) described gold mineralization along gossaniferous faults in garnet skarn at the Labrador deposit within skarn D (fig. 86). None of the samples from the northern segment of skarn D included in this study were collected from mineralized zones associated with the Labrador deposit. However, neutron-activation analysis of a garnet separate (analysis 2, table 38 ) from massive 
TABLE 36.-Mineralogy of skarn, hornfels, and associated diabase from the Upper Cambrian Harmony Formation

[X, present; tr, present in trace amounts; ?, questionably present; -, not found]

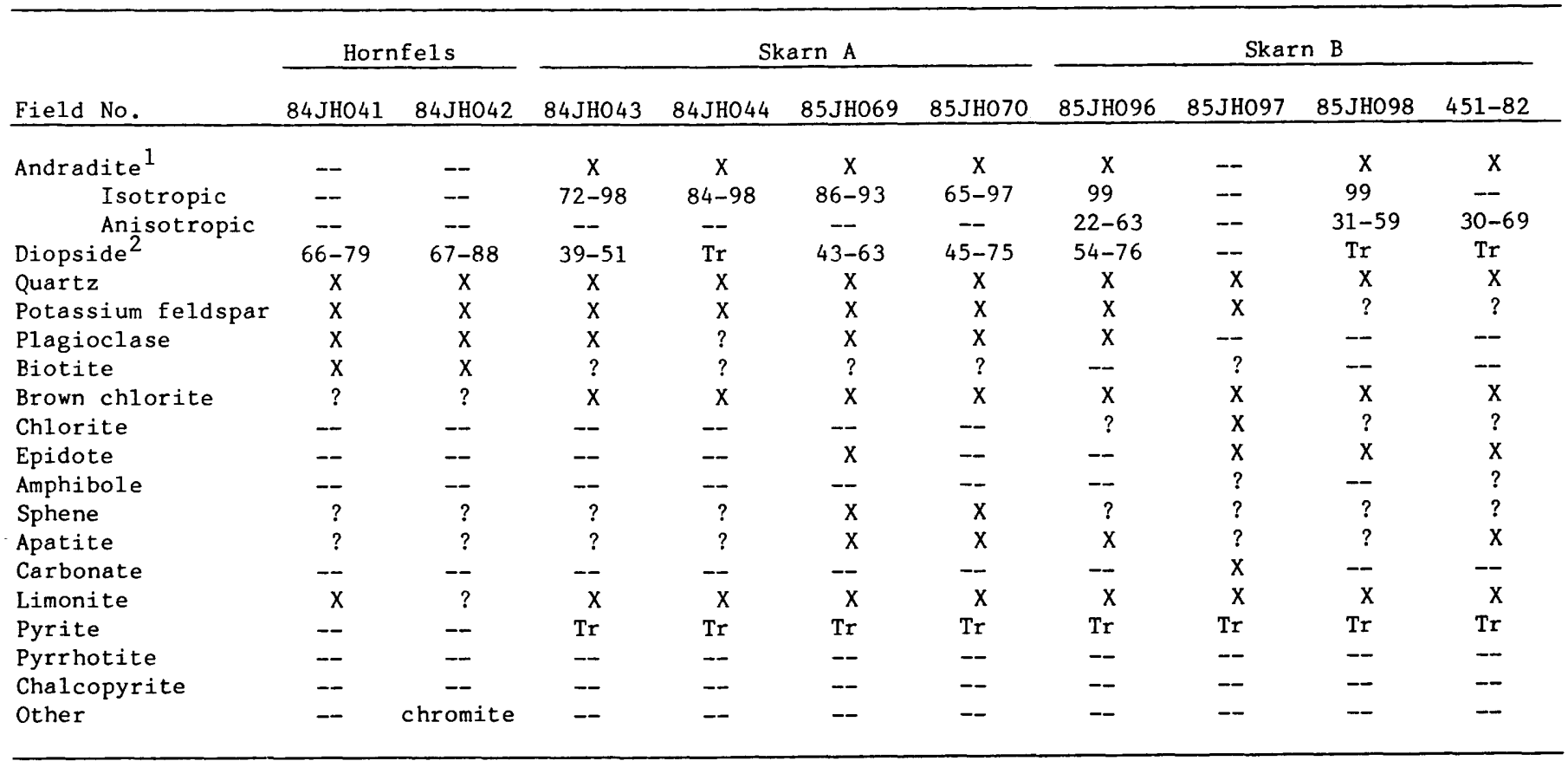

TABLE 36.-Mineralogy of skarn, hornfels, and associated diabase from the Upper Cambrian Harmony Formation-Continued

\begin{tabular}{|c|c|c|c|c|c|c|c|c|c|c|}
\hline \multirow[b]{2}{*}{ Field No. } & \multicolumn{3}{|c|}{ Skarn B } & \multicolumn{4}{|c|}{ Skarn C } & \multicolumn{2}{|c|}{ Endoskarn } & \multirow{2}{*}{$\frac{\text { Diabase }}{85 \mathrm{JH} 089}$} \\
\hline & OVL-3 & $451-332$ & $85 \mathrm{JH} 102$ & $85 \mathrm{JHO} 78$ & $85 \mathrm{JHO} 9$ & $85 \mathrm{JH} 080$ & $85 \mathrm{JHO} 86$ & $85 \mathrm{JHO} 87$ & $85 \mathrm{JHO} 88$ & \\
\hline Andradite ${ }^{1}$ & $\mathrm{X}$ & $28-63$ & - & $45-99$ & $\mathrm{X}$ & $\mathrm{x}$ & $\mathrm{X}$ & $\mathrm{x}$ & $\mathrm{x}$ & -- \\
\hline Isotropic & 99 & $\mathrm{X}$ & - & $\mathrm{X}$ & $73-99$ & 99 & $51-97$ & $67-97$ & $83-97$ & -- \\
\hline Anisotropic & $28-63$ & $\mathrm{x}$ & -- & $\mathrm{x}$ & $43-76$ & $16-71$ & - & -- & - & -- \\
\hline Diopside ${ }^{2}$ & $51-67$ & $67-89$ & $67-75$ & $54-78$ & $39-58$ & $49-69$ & $54-72$ & $67-78$ & $59-88$ & $79-88$ \\
\hline Quartz & ? & $\mathrm{X}$ & $\mathrm{x}$ & $\mathrm{x}$ & $\mathrm{x}$ & $\mathrm{x}$ & $\mathrm{x}$ & $\mathrm{x}$ & $\mathrm{x}$ & - \\
\hline Potassium feldspar & ? & $\mathrm{x}$ & ? & $\mathrm{x}$ & $x$ & $\mathrm{x}$ & $\mathrm{x}$ & $\mathrm{x}$ & $\mathrm{x}$ & -- \\
\hline Plagioclase & ? & ? & -- & $\mathrm{x}$ & ? & $\mathrm{x}$ & ? & $\mathrm{x}$ & $\mathrm{x}$ & $\mathrm{x}$ \\
\hline Biotite & -- & - & - & - & - & - & $\mathrm{x}$ & - & - & -- \\
\hline Brown chlorite & $\mathrm{x}$ & $\mathrm{x}$ & $\mathrm{x}$ & $\mathrm{x}$ & $\mathrm{x}$ & $\mathrm{x}$ & $\mathrm{x}$ & $\mathrm{x}$ & $\mathrm{x}$ & $\mathrm{x}$ \\
\hline Ch1orite & $?$ & - & $\mathrm{x}$ & - & - & -- & $?$ & - & - & $?$ \\
\hline Epidote & $\mathrm{x}$ & $x$ & $\mathrm{x}$ & $x$ & $\mathrm{x}$ & $\mathrm{x}$ & $?$ & $\mathrm{x}$ & $\mathrm{X}$ & $\mathrm{x}$ \\
\hline Amphibole & ? & -- & $\mathrm{x}$ & -- & -- & -- & ? & ? & ? & $\mathrm{x}$ \\
\hline Sphene & $?$ & ? & $\mathrm{x}$ & $?$ & $\mathrm{x}$ & $?$ & $?$ & $\mathrm{X}$ & $\mathrm{x}$ & $\mathrm{x}$ \\
\hline Apatite & $?$ & $?$ & $?$ & $\mathrm{X}$ & $\mathrm{x}$ & $?$ & $?$ & $\mathrm{x}$ & $?$ & -- \\
\hline Carbonate & $\mathrm{x}$ & $?$ & $\mathrm{x}$ & $?$ & $?$ & $\mathrm{x}$ & $?$ & -- & - & -- \\
\hline Limonite & $\mathrm{X}$ & $\mathrm{x}$ & $\mathrm{x}$ & $\dot{x}$ & $\mathrm{x}$ & $\mathrm{x}$ & $x$ & -- & -- & $\mathrm{x}$ \\
\hline Pyrite & $\operatorname{Tr}$ & - & $\mathrm{X}$ & $\operatorname{Tr}$ & - & $\operatorname{Tr}$ & $\operatorname{Tr}$ & -- & $\mathrm{x}$ & $\mathrm{x}$ \\
\hline Pyrrhotite & -- & -- & -- & -- & -- & -- & -- & -- & -- & .- \\
\hline Chalcopyrite & -- & - & -- & -- & -- & -- & -- & -- & -- & $\operatorname{Tr}$ \\
\hline Other & - & zeolite & - & zircon & zircon & scapolite & rutile & - & -- & -- \\
\hline
\end{tabular}

garnetite skarn along D near the Labrador deposit showed it to contain $118 \mathrm{ppb}$ Au.

Samples from the offset segment of skarn D south of the Surprise fault (fig. 86) are massive garnetites or garnet-rich quartzose rocks. The shaly layers and chromite noted in samples from the northern segment are not present. Multiple garnet generations are present in most samples. For example, completely altered, euhedral garnet cores in sample $76 \mathrm{CB} 8$ are surrounded by clean, 
TABLE 36.-Mineralogy of skarn, hornfels, and associated diabase from the Upper Cambrian Harmony Formation-Continued

\begin{tabular}{|c|c|c|c|c|c|c|c|c|c|c|}
\hline \multirow[b]{2}{*}{ Field No. } & \multirow{2}{*}{$\begin{array}{l}\text { Diabase } \\
85 \text { JH090 }\end{array}$} & \multicolumn{9}{|c|}{ Skarn D (north of the Surprise fault) } \\
\hline & & $76 \mathrm{CB} 2$ & $76 \mathrm{CB} 3$ & $76 \mathrm{CB} 4$ & $76 \mathrm{CB} 5$ & $85 \mathrm{JH} 113$ & $85 \mathrm{JH} 114$ & $76 \mathrm{CB} 6$ & $85 \mathrm{JH} 107$ & $85 \mathrm{JH} 112$ \\
\hline Andradite ${ }^{1}$ & -- & $\mathrm{x}$ & $\mathrm{X}$ & $\mathrm{x}$ & $\mathrm{x}$ & $69-94$ & $\mathrm{x}$ & $47-97$ & $55-99$ & $51-99$ \\
\hline Isotropic & -- & $88-99$ & $93-98$ & 99 & $86-96$ & $\mathrm{x}$ & 92 & $\mathrm{X}$ & $\mathrm{X}$ & $\mathrm{x}$ \\
\hline Ani sotropic & -- & $57-82$ & $17-67$ & $20-72$ & $75-90$ & $\mathrm{x}$ & $50-82$ & $\mathrm{x}$ & $\mathrm{x}$ & $\mathrm{x}$ \\
\hline Diopside 2 & $\mathrm{x}$ & $\operatorname{Tr}$ & $\operatorname{Tr}$ & $\mathrm{x}$ & $\operatorname{Tr}$ & $\operatorname{Tr}$ & $\operatorname{Tr}$ & $\operatorname{Tr}$ & 99 & $\operatorname{Tr}$ \\
\hline Quartz & -- & $\mathrm{x}$ & $\mathrm{X}$ & $x$ & $\mathrm{X}$ & $\mathrm{X}$ & $\mathrm{X}$ & $\mathrm{X}$ & $\mathrm{x}$ & $\mathrm{x}$ \\
\hline Potassium feldspar & -- & $x$ & $\mathrm{x}$ & $\mathrm{x}$ & $?$ & $\mathrm{X}$ & $?$ & $?$ & $?$ & $\mathrm{x}$ \\
\hline P1agioclase & $\mathrm{x}$ & -- & - & -- & - & - & - & -- & - & -- \\
\hline Biotite & -- & -- & -- & -- & -- & -- & -- & -- & -- & -- \\
\hline Brown chlorite & $\mathrm{x}$ & $\mathrm{x}$ & $\mathrm{x}$ & $\mathrm{x}$ & $\mathrm{x}$ & $\mathrm{x}$ & $\mathrm{x}$ & $\mathrm{x}$ & $\mathrm{x}$ & $\mathrm{x}$ \\
\hline Chlorite & $\mathrm{x}$ & -- & -- & -- & - & -- & -- & - & -- & -- \\
\hline Epidote & $\mathrm{x}$ & $x$ & $\mathrm{X}$ & $\mathrm{x}$ & - & -- & -- & -- & $\mathrm{x}$ & -- \\
\hline Amphibole & $\mathrm{x}$ & -- & -- & -- & - & -- & -- & -- & $\mathrm{X}$ & $?$ \\
\hline Sphene & $\mathrm{x}$ & -- & -- & - & -- & -- & -- & -- & -- & - \\
\hline Apatite & $?$ & $?$ & $\mathrm{X}$ & $?$ & $?$ & $\mathrm{X}$ & $?$ & $?$ & $?$ & $\mathrm{X}$ \\
\hline Carbonate & -- & $?$ & $\mathrm{x}$ & ? & $?$ & $?$ & $?$ & $?$ & $\operatorname{Tr}$ & $?$ \\
\hline Limonite & -- & $\operatorname{Tr}$ & -- & -- & $\operatorname{Tr}$ & $\mathrm{x}$ & $\mathrm{x}$ & $\mathrm{x}$ & $\mathrm{X}$ & $\mathrm{x}$ \\
\hline Pyrite & -- & -- & $\mathrm{x}$ & -- & -- & $\operatorname{Tr}$ & $\mathrm{x}$ & -- & -- & -- \\
\hline Pyrrhotite & -- & -- & -- & -- & -- & -- & -- & -- & -- & -- \\
\hline Chalcopyrite & -- & -- & -- & -- & -- & -- & -- & -- & -- & -- \\
\hline Other & ilmenite & -- & chromite & chromite & -- & chrysocolla & - & -- & chromite & -- \\
\hline
\end{tabular}

TABLE 36.-Mineralogy of skarn, hornfels, and associated diabase from the Upper Cambrian Harmony Formation-Continued

\begin{tabular}{|c|c|c|c|c|c|c|c|c|c|c|}
\hline \multirow[b]{2}{*}{ Field No. } & \multirow{2}{*}{$\frac{\text { C1ay }}{85 \mathrm{JH} 115}$} & \multirow{2}{*}{$\frac{\text { Diabase }}{85 \mathrm{JH} 124}$} & \multicolumn{2}{|r|}{ Skarn D } & \multirow{2}{*}{$\begin{array}{c}\text { ( south of } \\
85 \mathrm{JH} 126\end{array}$} & \multicolumn{3}{|c|}{ the Surprise fault) } & \multirow{2}{*}{$\begin{array}{c}\text { Carissa } \\
\text { Mine }\end{array}$} & \multirow{2}{*}{$\begin{array}{c}\begin{array}{c}\text { Contention } \\
\text { pit }\end{array} \\
76 \mathrm{CB} 11 \\
\end{array}$} \\
\hline & & & $76 \mathrm{CB} 7$ & $85 \mathrm{JH} 125$ & & $85 \mathrm{JH} 127$ & $76 \mathrm{CB} 8$ & 76 CB9 & & \\
\hline Isotropic & -- & -- & $x$ & 99 & 99 & $\mathrm{X}$ & $95-99$ & 99 & $92-98$ & -- \\
\hline Anisotropic & -- & -- & $\mathrm{x}$ & $36-63$ & $46-85$ & -- & $15-67$ & $61-91$ & $60-84$ & $47-78$ \\
\hline Diopside ${ }^{2}$ & -- & -- & $\operatorname{Tr}$ & -- & -- & -- & $\operatorname{Tr}$ & 21 & 80 & $\operatorname{Tr}$ \\
\hline Plagioclase & -- & $\mathrm{X}$ & -- & $?$ & ? & $\mathrm{x}$ & - & -- & -- & -- \\
\hline Biotite & -- & -- & -- & -- & -- & -- & -- & -- & -- & -- \\
\hline Brown chlorite & $\mathrm{X}$ & $?$ & $\mathrm{X}$ & $x$ & $\mathrm{X}$ & $x$ & $\mathrm{x}$ & $\mathrm{X}$ & $\mathrm{X}$ & $\mathrm{x}$ \\
\hline Chlorite & -- & $\mathrm{x}$ & -- & -- & $?$ & -- & $\mathrm{X}$ & -- & $\mathrm{x}$ & $\mathrm{x}$ \\
\hline Epidote & -- & -- & $\mathrm{x}$ & $\mathrm{x}$ & $\mathrm{x}$ & $\mathrm{x}$ & $\mathrm{x}$ & $\mathrm{x}$ & $\mathrm{x}$ & $\mathrm{X}$ \\
\hline Amphibole & -- & $\mathrm{X}$ & $\mathrm{X}$ & $?$ & $\mathrm{x}$ & ? & -- & $\mathrm{x}$ & $\mathrm{X}$ & $?$ \\
\hline Sphene & -- & $\mathrm{x}$ & -- & -- & -- & -- & - & -- & -- & -- \\
\hline Pyrrhotite & -- & -- & -- & -- & -- & -- & -- & - & $\operatorname{Tr}$ & $\mathrm{X}$ \\
\hline Chalcopyrite & -- & -- & -- & -- & -- & -- & -- & $\operatorname{Tr}$ & $\mathrm{X}$ & $\mathrm{x}$ \\
\hline Other & clay & -- & - & -- & -- & -- & - & -- & anhydrite & -- \\
\hline
\end{tabular}

yellow andradite, which, in turn, is rimmed by colorless, anisotropic grossular-andradite garnet. In sample 76CB9, all the garnet appears yellow in thin section (plane-polarized light) but is complexly zoned and anisotropic. Green chlorite content increases from north to south along this segment of skarn $\mathrm{D}$, and limonite pods as large as $2 \mathrm{~mm}$ wide are present in interstices between garnets. Coarse, 
TABLE 36.-Mineralogy of skarn, hornfels, and associated diabase from the Upper Cambrian Harmony Formation-Continued

\begin{tabular}{|c|c|c|c|c|c|}
\hline \multirow[b]{2}{*}{ Field No. } & \multicolumn{3}{|c|}{ Contention pit } & \multirow{2}{*}{$\begin{array}{l}\text { Surprise } \\
\text { BMG2400A }\end{array}$} & \multirow{2}{*}{$\begin{array}{l}\text { Mine } \\
\text { Ore } \\
\end{array}$} \\
\hline & $85 J H 129$ & $85 \mathrm{JH} 130$ & $85 \mathrm{JH} 131$ & & \\
\hline Andradite ${ }^{1}$ & $\mathrm{X}$ & -- & $\mathrm{X}$ & $\mathrm{x}$ & $\mathrm{x}$ \\
\hline Isotropic & $33-70$ & - & $\mathrm{x}$ & $95-98$ & - \\
\hline Anisotropic & $\operatorname{Tr}$ & -- & -- & $27-75$ & -- \\
\hline Diopside ${ }^{2}$ & -- & $\mathrm{x}$ & $\operatorname{Tr}$ & -- & $\mathrm{X}$ \\
\hline Quartz & $\mathrm{X}$ & $\mathrm{x}$ & $\mathrm{X}$ & - & $\mathrm{X}$ \\
\hline Potassium feldspar & $?$ & $?$ & $?$ & -- & $\mathrm{x}$ \\
\hline Plagioclase & -- & - & -- & -- & $?$ \\
\hline Biotite & - & - & - & -- & $?$ \\
\hline Brown chlorite & $\mathrm{x}$ & $\mathrm{X}$ & $\mathrm{x}$ & $\mathrm{X}$ & $\mathrm{x}$ \\
\hline Chlorite & $\mathrm{x}$ & $\mathrm{x}$ & $\mathrm{x}$ & $?$ & $\mathrm{x}$ \\
\hline Epidote & -- & $\mathrm{x}$ & -- & -- & $x$ \\
\hline Amphibole & -- & $\mathrm{x}$ & -- & $?$ & $\mathrm{x}$ \\
\hline Sphene & -- & - & - & -- & -- \\
\hline Apatite & $?$ & $?$ & $x$ & -- & $\mathrm{x}$ \\
\hline Carbonate & $?$ &.$?$ & $?$ & -- & $\mathrm{x}$ \\
\hline Limonite & -- & -- & -- & $\mathrm{x}$ & $\mathrm{x}$ \\
\hline Pyrite & $\mathrm{x}$ & $\mathrm{X}$ & $\mathrm{X}$ & -- & $\mathrm{x}$ \\
\hline Pyrrhotite & $\mathrm{x}$ & $\mathrm{x}$ & $\mathrm{Tr}$ & -- & $\operatorname{Tr}$ \\
\hline Chalcopyrite & $\mathrm{x}$ & $\mathrm{x}$ & $\mathrm{x}$ & -- & $\mathrm{x}$ \\
\hline Other & -- & - & $--\quad c$ & hrysocolla & $\mathrm{X}$ \\
\hline
\end{tabular}

\footnotetext{
${ }^{1}$ Compositions given a mole percent andradite. In some cases, fine-scale zoning obscures precise determination of isotropism for individual points (for example, sample 451332).

${ }^{2}$ Compositions given as mole percent diopside.

${ }^{3}$ Composite mineralogy for 15 samples of gold skarn ore from the 5670-ft and 5595-ft benches of Battle Mountain Gold Company's surprise openpit mine. Other minerals present include electrum, hematite, magnetite, chrysocolla, zircon, and chalcedony.
}

twinned calcite is present in some samples. Limonite represents the oxidation product of paragenetically earlier sulfides; rare blebs of pyrite or chalcopyrite are preserved within some of the limonite.

Samples of mineralized skarn from the Harmony Formation include samples $76 \mathrm{CB} 10$ from the Carissa deposit, and samples 76CB11 and 85JH129 through 85JH131 from the Contention pit area. Various stages of oxidation of sulfides are preserved in these samples (fig. 87). Veins and pods of fresh pyrite are the most abundant sulfide mineral, but chalcopyrite and pyrrhotite are also present. Some pyrite grains have mottled cores and cracks suggestive of a replacement texture. This mottling resembles the "bird's-eye" texture described by Ramdohr (1969) for the weathering of pyrrhotite to secondary pyrite and marcasite, although no marcasite is observed. Theodore and Blake (1975) described similar textures in pyrrhotite in the east ore body of the Copper Canyon porphyry copper deposit. Digenite rims on chalcopyrite are common. A pod of anhydrite crystals associated with limonite in one sample from the Carissa Mine area is the only example of preservation of sulfate derived from alteration of sulfide.

Gold-copper skarn ore at the Surprise Mine is extremely oxidized (fig. 88). In addition to drill-core sample $2400 \mathrm{~A}$ described in table 36,15 samples of low- and high-grade ore from the 5670- and 5595-ft benches of the Surprise open pit were examined. A sample of typical low-grade, garnet skarn ore (table 38 , analysis 1) was analyzed by a variety of techniques. These analyses show that the Surprise ore is enriched in potassium, magnesium, volatiles, and silver relative to other garnet-rich samples of skarn from the Harmony Formation (tables 24, 38); neither gold contents $(29 \mathrm{ppb})$ nor base-metal contents are particularly anomalous for this sample relative to values reported for barren skarn formed in the Har- 
TABLE 37.-Mineralogy of skarn from the Middle Pennsylvanian Battle Formation and the Upper Pennsylvanian and Lower Permian Antler Peak Limestone

$[\mathrm{X}$, present; tr, present in trace amounts; ?, questionably present; - , not found]

\begin{tabular}{|c|c|c|c|c|c|c|c|c|c|}
\hline \multirow[b]{2}{*}{ Field No. } & \multicolumn{5}{|c|}{ Skarn E } & \multicolumn{3}{|c|}{ Skarn F } & \multirow{2}{*}{$\frac{\text { Clay }}{85 \mathrm{JH} 142}$} \\
\hline & 85JH140 & $85 \mathrm{JH} 143$ & $85 \mathrm{JH} 145$ & $85 \mathrm{JH} 148$ & 85JH1 49 & $85 \mathrm{JH} 136$ & $80 \mathrm{BK} 96$ & 80 BK97 & \\
\hline Andradite ${ }^{1}$ & $\mathbf{X}$ & $\mathrm{X}$ & $\mathrm{X}$ & $\mathrm{x}$ & $\mathrm{X}$ & $\mathrm{X}$ & $\mathrm{X}$ & $52-99$ & --- \\
\hline Isotropic & ---- & $--\infty$ & 94 & $90-97$ & $95-97$ & --- & $93-96$ & $\mathrm{X}$ & --- \\
\hline Anisotropic & $87-98$ & $31-46$ & $60-94$ & $60-93$ & $65-84$ & $32-39$ & $53-76$ & $\mathrm{X}$ & ---- \\
\hline Diopside & $\mathrm{X}$ & $12-58$ & --- & ---- & --- & $-\infty$ & $55-79$ & ---- & $\mathrm{X}$ \\
\hline Quartz & $\mathrm{X}$ & $\mathrm{X}$ & $\mathrm{X}$ & $\mathrm{x}$ & $x$ & $\mathrm{X}$ & $\mathrm{X}$ & $\mathbf{x}$ & $\mathrm{X}$ \\
\hline Potassium feldspar & $?$ & $?$ & $?$ & $?$ & ? & $?$ & $\mathrm{X}$ & $\mathrm{X}$ & ? \\
\hline Plagioclase & --- & --- & --- & $-\infty-$ & ---- & --- & $-\infty$ & $-\cdots$ & ---- \\
\hline Biotite & --- & --- & ---- & --- & ---- & ---- & ---- & ---- & $--\infty$ \\
\hline Brown chlorite & $\mathrm{x}$ & $\mathrm{x}$ & $\mathrm{X}$ & $x$ & $\mathrm{X}$ & $\mathrm{X}$ & $\mathrm{X}$ & $\mathrm{X}$ & $\mathrm{X}$ \\
\hline Chlorite & $?$ & $?$ & $\mathrm{X}$ & $x$ & $\mathrm{X}$ & $?$ & ? & $x$ & ---- \\
\hline Epidote & --- & --- & --- & ---- & --- & $\mathrm{X}$ & $-\infty$ & ---- & $\mathrm{X}$ \\
\hline Amphibole & $\mathrm{x}$ & $x$ & $?$ & $\mathrm{x}$ & $x$ & $?$ & $\mathrm{X}$ & $\mathrm{X}$ & $-\infty-$ \\
\hline Sphene & --- & --- & --- & ---- & --- & $\mathrm{X}$ & --- & $--\infty$ & --- \\
\hline Apatite & $?$ & $\mathrm{x}$ & $\mathrm{X}$ & $\mathrm{X}$ & $?$ & $?$ & $\mathrm{x}$ & $\mathrm{x}$ & ---- \\
\hline Carbonate & $\mathrm{X}$ & $\mathrm{X}$ & $\mathrm{X}$ & $\operatorname{Tr}$ & $\operatorname{Tr}$ & $x$ & $\mathrm{X}$ & $\mathrm{X}$ & $\mathrm{X}$ \\
\hline Limonite & $\mathrm{X}$ & $\mathrm{X}$ & $\mathrm{X}$ & $\mathrm{X}$ & $\mathrm{X}$ & $-\infty$ & $\mathrm{X}$ & $\mathrm{X}$ & --- \\
\hline Pyrite & $\operatorname{Tr}$ & $\mathrm{Tr}$ & ---- & $\operatorname{Tr}$ & ---- & --- & $\mathrm{X}$ & ---- & --- \\
\hline Pyrrhotite & ---- & $\mathrm{Tr}$ & --- & $\operatorname{Tr}$ & ---- & ---- & --- & ---- & ---- \\
\hline Chalcopyrite & $\operatorname{Tr}$ & $\operatorname{Tr}$ & --- & $\operatorname{Tr}$ & ---- & $-\infty$ & --- & ---- & $-\cdots$ \\
\hline Other & fossils & ---- & --- & --- & ---- & --- & ---- & ---- & clay \\
\hline
\end{tabular}

1 Compositions given as mole percent andradite.

2 Compositions given as mole percent diopside.

mony Formation or in the Battle Formation. Colorless, twinned, anisotropic grossular-andradite garnets are ubiquitous at the Surprise deposit. These garnets are typically about $0.5 \mathrm{~mm}$ in diameter; large $(2 \mathrm{~mm}$ wide) garnets with yellow andradite cores form pods within a matrix of smaller garnets in some samples. Various degrees of replacement of garnet are present ranging from green and brown chlorite in garnet cores to mixtures of chlorite, calcite, and quartz completely replacing garnet. Potassium feldspar veins are locally abundant. Sprays of hematite, hematite rims and lamellae in magnetite, and disseminated pyrite are present in some chlorite-rich samples. Clinopyroxene and amphibole are minor. High-grade ore near fault zones is vuggy, limonitic and veined by chrysocolla and chalcedony. Gold is present as electrum in anhedral grains as much as $100 \mu \mathrm{m}$ long in limonite and in chlorite. Limonite encloses perfectly euhedral quartz crystals that commonly contain sulfide minerals and are almost totally devoid of fluid inclusions. These sulfides range from less than $1 \mu \mathrm{m}$ to as much as about 10 $\mu \mathrm{m}$ in diameter; bismuth- and tellurium-bearing phases, as well as iron-bearing sphalerite, have been qualitatively identified by scanning electron microscopy. However, pyrite and chalcopyrite are the most abundant sulfides in euhedral quartz; no electrum has been identified in quartz.

\section{SKARN IN THE BATTLE FORMATION}

Two outcrops of skarn in the Battle Formation were sampled at a contact with Tertiary granodiorite porphyry. Skarn E is an outcrop at the southwest contact of the granodiorite porphyry. Samples 85JH145 and 85JH143 are spongy and massive calcite-bearing garnetites from the intrusive contact. A layer of yellow-green, earthy clay (sample 85JH142) and coarse-grained, massive calcite separate these samples from sample $85 \mathrm{JH} 140$, which is from a contact between garnet skarn and silicified fossiliferous limestone. Samples 85JH148 and 85JH149 are from an outcrop along the same contact to the north on the east side of a fault that strikes north (fig. 86). Garnets in skarn $\mathrm{E}$ are mostly colorless and perfectly euhedral, individual grains in calcite. All garnets show growth zones; most are anisotropic, but a few cores are isotropic. Rosettes of green to brown chlorite fill interstices among garnet crystals and replace pyroxene inclusions in garnet. Some garnet cores are completely 
TABLE 38.-Analytical data on skarn and garnet formed in the Upper Cambrian Harmony Formation, skarn formed in the middle member of the Middle Pennsylvanian Battle Formation, and associated clay layers at Copper Basin

[Chemical analyses by X-ray-fluorescence spectroscopy; analysts, J. Taggart, A. Bartel, D. Siems, and E. Robb. $\mathrm{FeO}, \mathrm{H}_{2} \mathrm{O}$, and $\mathrm{CO}_{2}$ determined by titration methods of Baedaecker (1988), and $\mathrm{Cl}$ determined by specific-ion-electrode methods; analyst, E. Brandt. $\mathrm{Hg}$ determined by cold-vapor atomic-absorption spectroscopy, Au determined by flame atomic-absorption spectroscopy, and $\mathrm{Pt}, \mathrm{Pd}$, and $\mathrm{Rh}$ determined by inductively coupled plasma (ICP) mass spectrometry; analysts, B. Libby, C. Gent, S. Wilson, R. Moore, R. O'Leary, and S. Wilson. Emission-spectroscopic method a: 44-element quantitative ICP direct-reader analysis; analysts, M. Malcolm, P.H. Briggs. Emission-spectroscopic method b: six-step d-c-arc semiquantitative analysis; analysts; B. Adrian, and $O$. Ehrlich. Instrumental neutron-activation analyses by G. Wandless.

,- not detected; n.d., not determined]

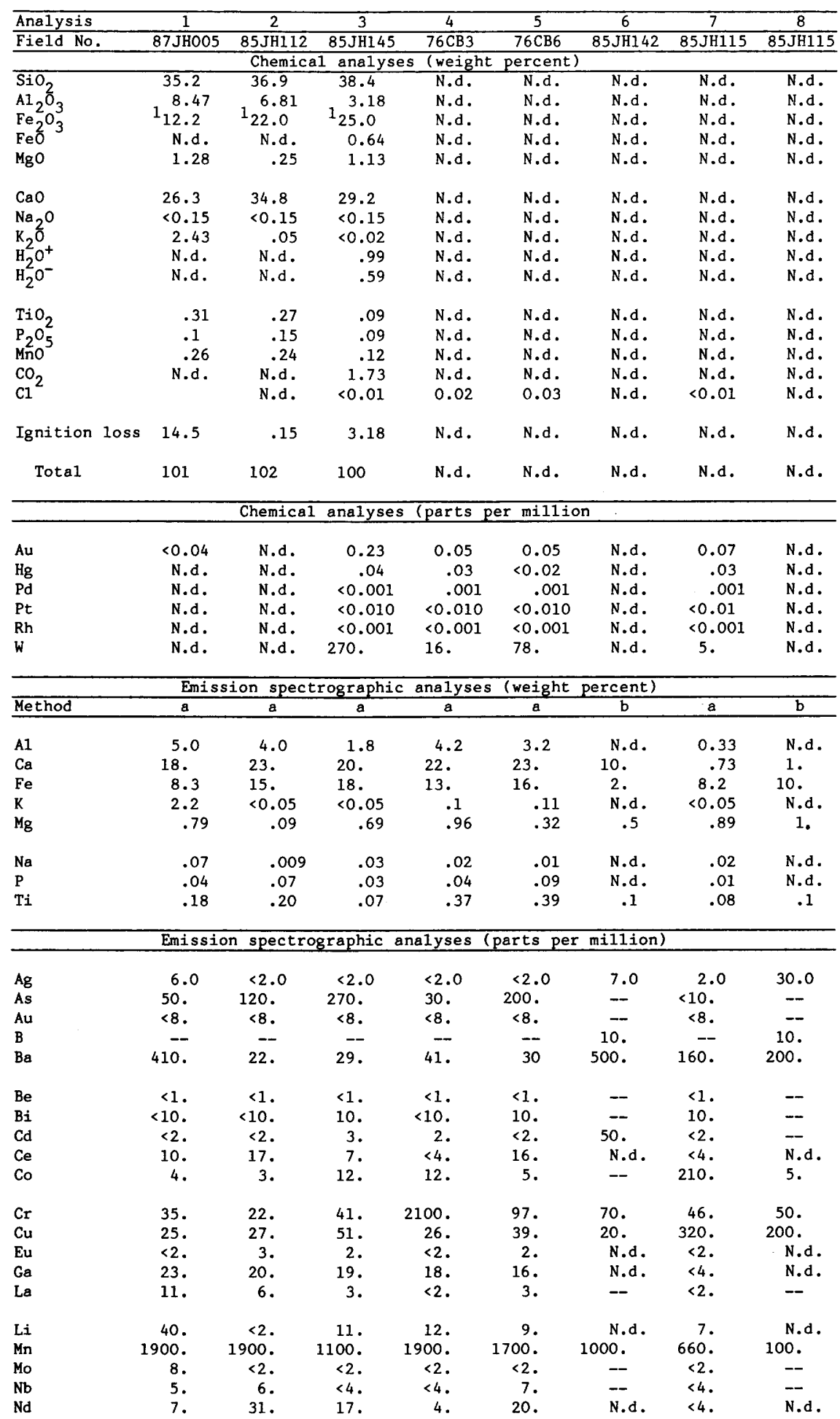


TABLE 38.-Analytical data on skarn and garnet formed in the Upper Cambrian Harmony Formation, skarn formed in the middle member of the Middle Pennsylvanian Battle Formation, and associated clay layers at Copper Basin-Continued

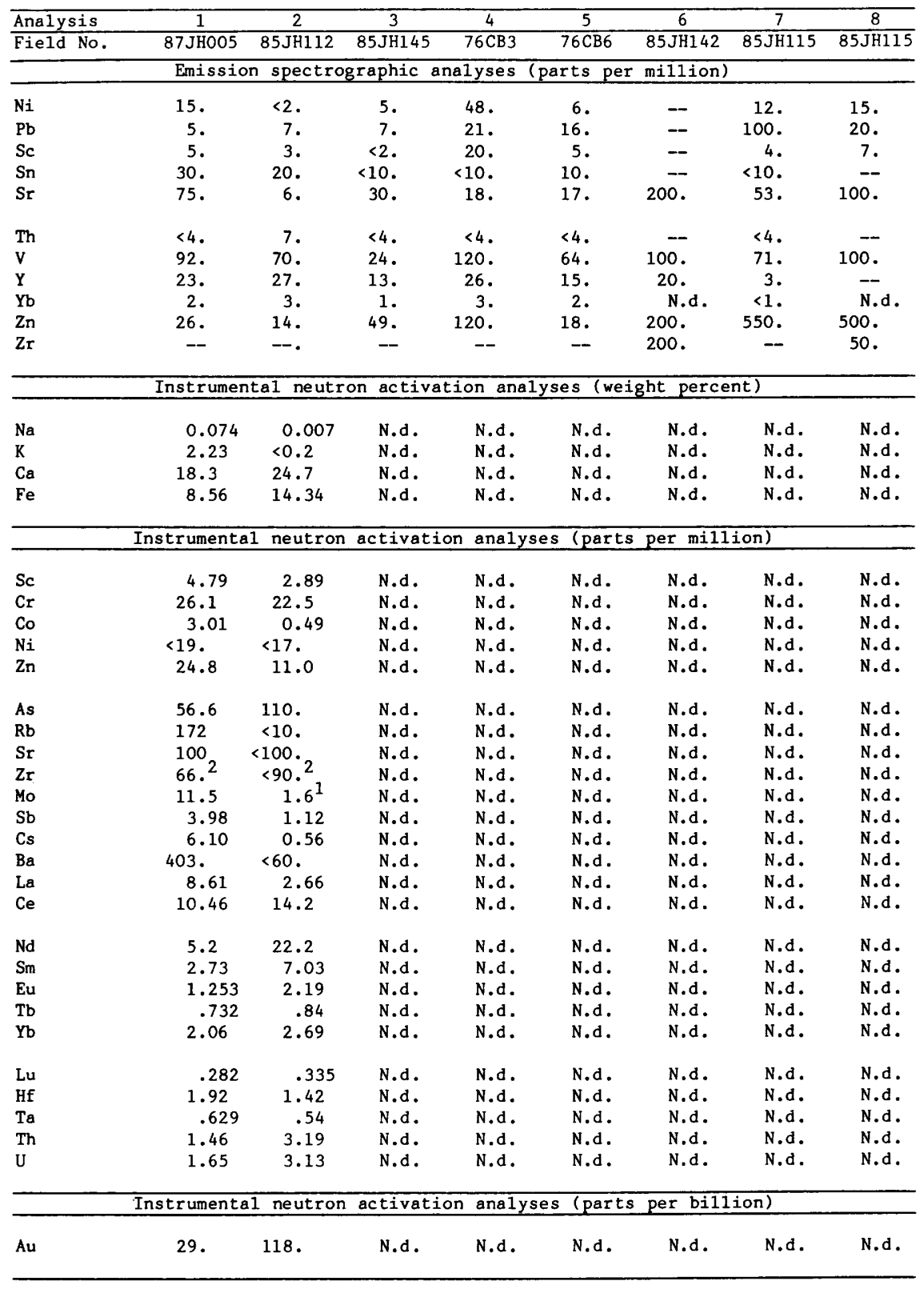

1. Low-grade, garnet-rich skarn ore from the $5670^{\prime}$ bench of the Surprise mine, Harmony Formation.

2. Garnet separate from massive garnetite, skarn D, Harmony Formation, near the Labrador gold skarn deposit.

3. Unmineralized garnetite, skarn E, Battle Formation.

4. Chromite-bearing shaley garnet skarn, skarn D, Harmony Formation.

5. Garnet skarn, skarn D, Harmony Formation.

6. Yellow-green clay layer interbedded with garnet skarn in Battle Formation; mixture of nontronite, calcite, and quartz.

7. Yellow-green clay layer interbedded with garnet skarn, skarn D, Harmony Formation; mixture of nontronite and quartz.

8. Do.

1 Total iron reported as $\mathrm{Fe}_{2} \mathrm{O}_{3}$.

2 Fission product interference exceeds $20 \%$ of the reported value. 
TABLE 39.-Representative analyses of feldspar in hornfels and skarn from the Upper Cambrian Harmony Formation

[KF, K-feldspar; PG, plagioclase. FeO(T), total iron reported as $\mathrm{FeO}$. (n), average of $n$ points]

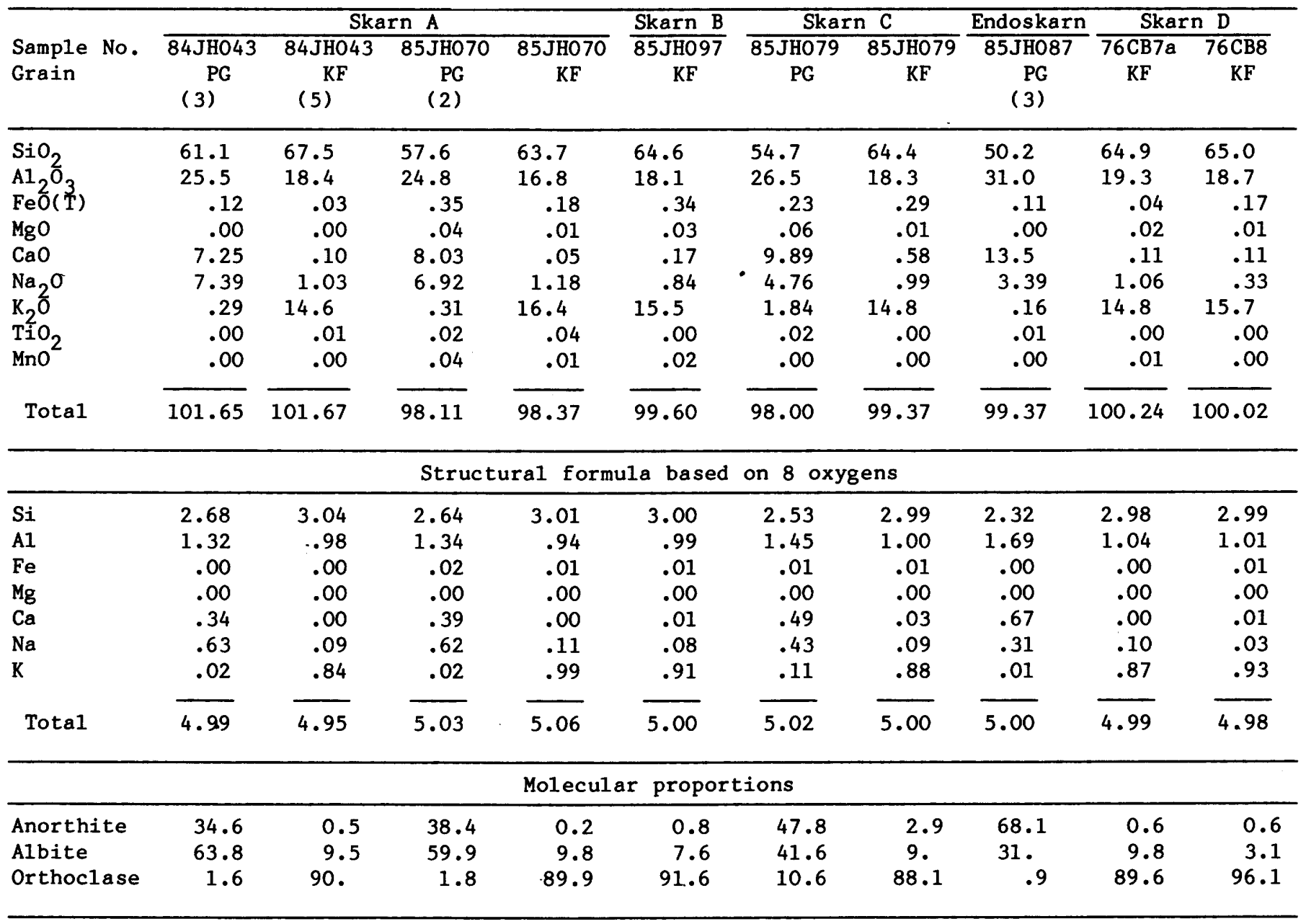

replaced by mixtures of chlorite and calcite. Majorand trace-element chemistry (tables 24, 38) show that although the massive garnetite skarn in the Battle Formation has a bulk composition similar to that of the skarns in the Harmony Formation (table 24), the skarn of the Battle Formation contains less aluminum and titanium.

\section{SKARN IN THE ANTLER PEAK LIMESTONE}

Skarn F formed in the Antler Peak Limestone along the eastern margin of the Tertiary granodiorite porphyry. Early-stage, colorless, anisotropic garnet is found in mats of amphibole, mixtures of green and brown chlorite, or coarse-grained calcite containing pale-green amphibole needles. Sample 85JH136 represents incipient calc-silicate growth in the silica-dominant, carbonate-rich siltite facies of the Antler Peak Limestone, whereas the other samples represent the main and late metasomatic stages of skarn growth formed in the more reactive micrite facies to the north. Abundance of coarsegrained, clean calcite crystals distinguishes skarns of the Battle Formation and Antler Peak Limestone from those in the Harmony Formation; absence of pyroxene and abundance of amphibole distinguishes skarn in the Antler Peak Limestone from skarn in the Battle Formation.

\section{ANALYTICAL TECHNIQUE}

The mineral chemistry of 50 polished thin sections was studied using an ARL-SEMQ electron micro- 
probe operated at $15 \mathrm{kV}$ and a beam current of 0.10 $\mu \mathrm{A}$. Count time for each element was a minimum of 20 s. Standards used for garnet, pyroxene, epidote, chlorite, and feldspar include the following natural and synthetic minerals: $\mathrm{Si}$ and $\mathrm{Al}$, pyrope or labradorite; Fe, hedenbergite; $\mathrm{Mg}$, pyrope or diopside; $\mathrm{Ti}$, sphene; $\mathrm{Mn}$, rhodonite; $\mathrm{Na}$, fluor-richterite; $\mathrm{K}$, orthoclase; Ca, wollastonite, pyrope, or hedenbergite; $\mathrm{S}$, anhydrite; Cr, chromite; F, fluor-phlogopite; and $\mathrm{Cl}$, biotite or scapolite. Natural and synthetic apatites and rare-earth glasses were used as standards for apatite analyses. Natural hornblende, andradite, and several pyroxenes were analyzed as working stand- ards to monitor accuracy. Metallic gold and silver were used as standards for electrum analyses. Detection limits for the major silicate constituents are typically 0.10 oxide weight per cent or less under these operating conditions with backgrounds determined by an automatic interpolation method (McGee, 1985) based on the average atomic number of the analyzed point. Data reduction was accomplished automatically using the $\$$ ANBA computer program (McGee, 1983); this program uses a Bence and Albee (1968) correction scheme with alpha factors tabulated by Albee and Ray (1970). To preserve compositional information recorded by the fine-scale

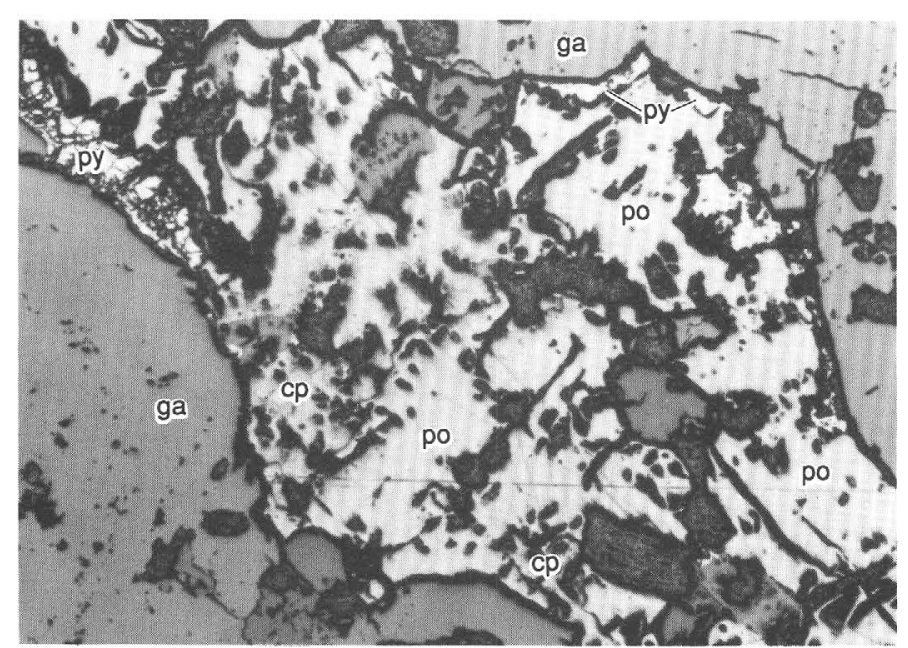

$\boldsymbol{A}$

0

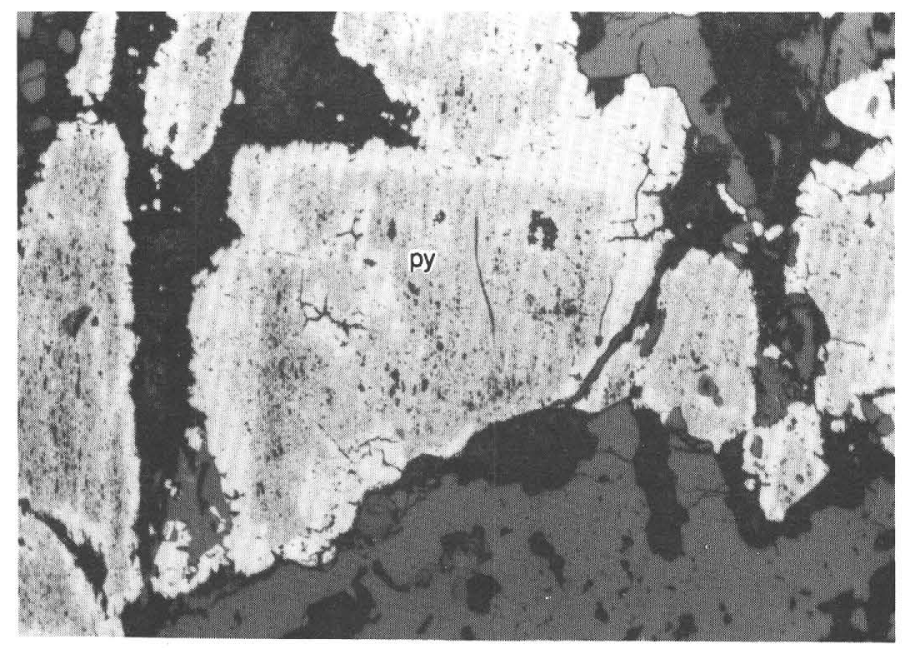

$\boldsymbol{B}$

0

0.5 MILLIMETER

FIGURE 87.-Photomicrographs showing alteration textures in sulfide minerals in skarn D in the Upper Cambrian Harmony Formation. Reflected light. A, Coexisting pyrrhotite (po), chalcopyrite (cp), and pyrite (py) interstitial to garnet (ga)

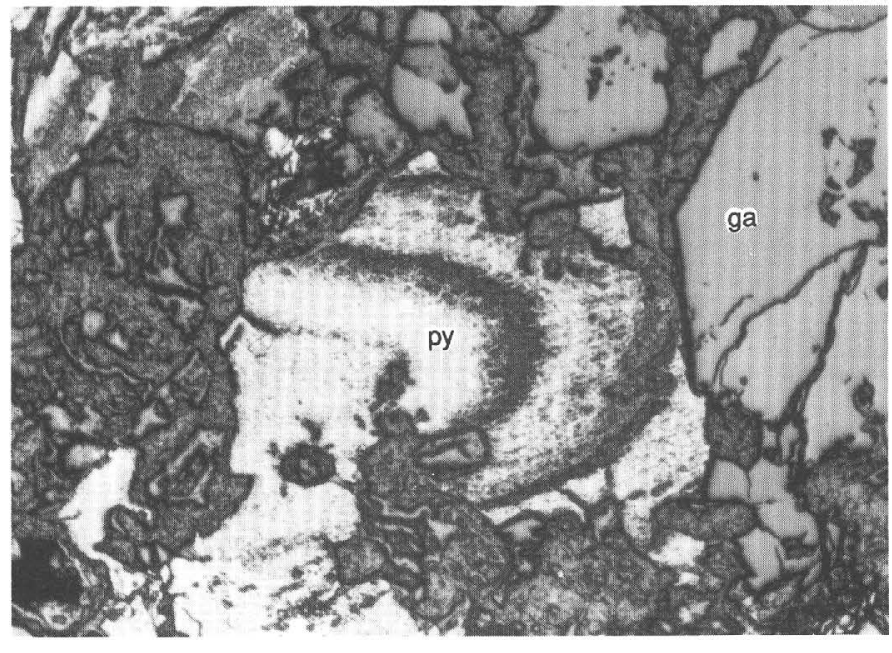

C 0 0.5 MILLIMETER

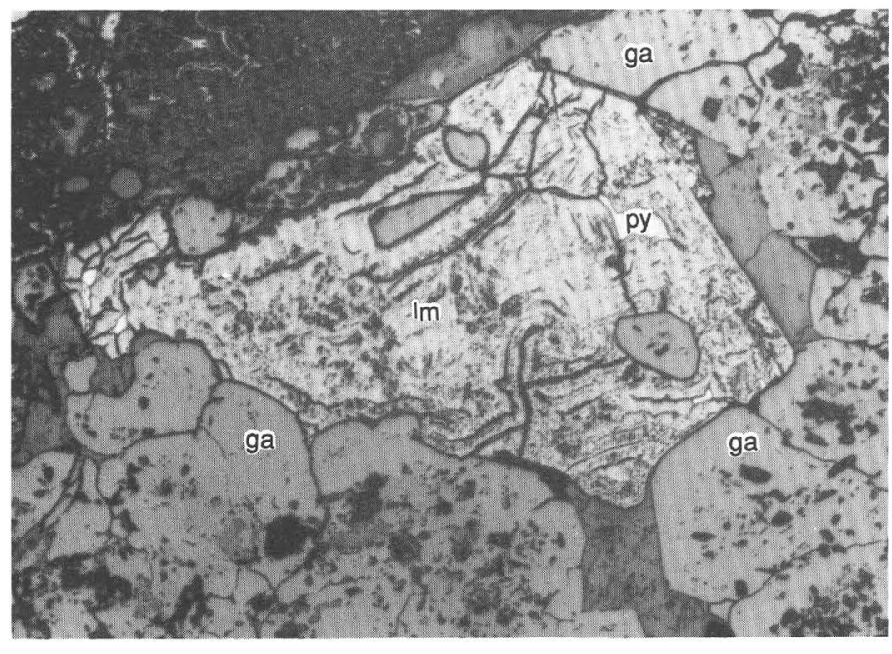

D

0

0.5 MILLIMETER

Sample 76CB11. B, Mottled core in pyrite. Sample 85JH129. C, "Bird's-eye" texture in pyrite. Sample 76CB11. D, Limonite (lm) after sulfides. Sample 76CB9. 
zoning typical of the skarn minerals, most analyses represent single points rather than averages. Averages are presented for grains or samples indicated to be homogeneous by comparison of standard deviations for averages of multiple points with expected standard deviations based on counting statistics alone.

Typically, three to five grains of each major mineral in a thin section were analyzed, with several points chosen to examine compositional variations across individual crystals or veins. For some sam-

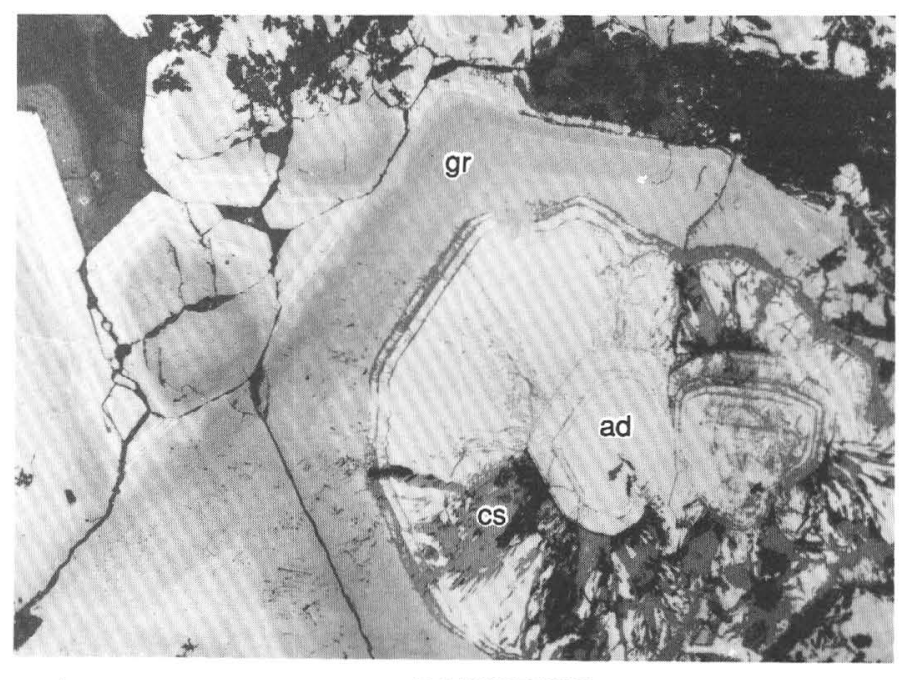

$\boldsymbol{A}$

0100 MICRONS

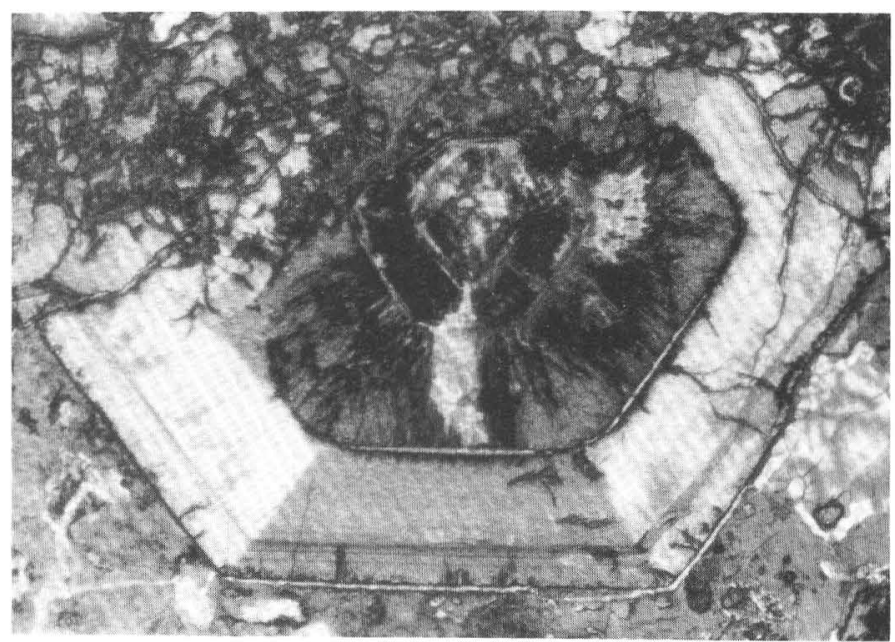

$\boldsymbol{B}$

1 MILLIMETER

FIGURE 88.-Photomicrographs showing varieties of gold-copper skarn ore at Surprise deposit. A, Backscatter scanning electron micrograph showing a cluster of complexly zoned garnets. Brighter areas indicate more iron-rich compositions. Note sharp boundary between andradite (ad) core and more grossularitic rim (gr) on largest garnet. Alteration in core is ples, as many as 10 or 12 grains were analyzed per thin section to examine textural variants of a given mineral. Data are presented in tables grouped by mineral, and data for individual skarns are summarized in ternary plots. Assumptions are required for conversion of the microprobe analyses reported as oxide weight percentages, with total iron reported as $\mathrm{FeO}$ and no water analyses, to mineral formulas based on a fixed number of oxygens per formula unit. Data-reduction techniques for individual mineral groups are discussed below.
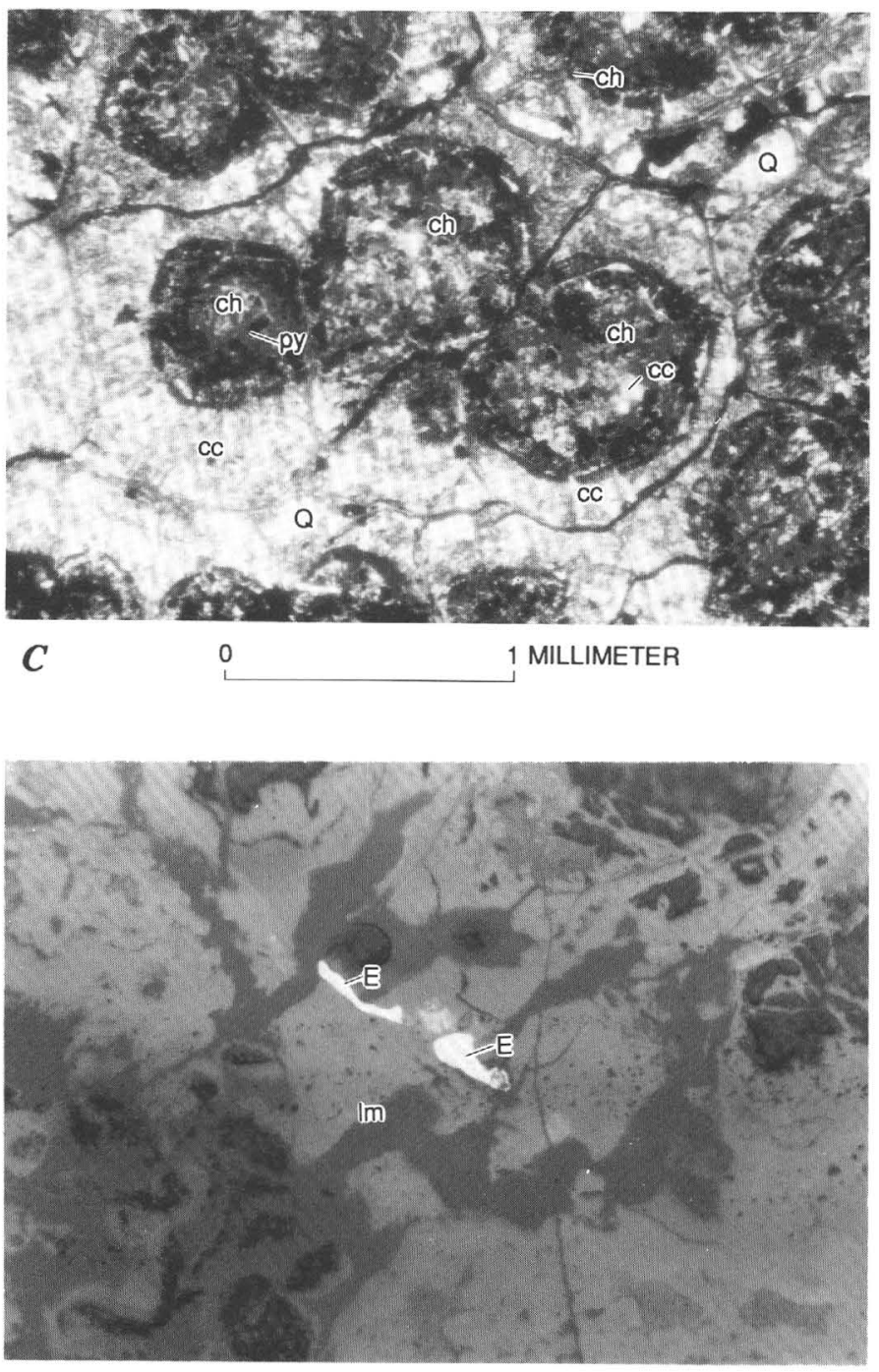

D

O 20 MICRONS

mostly chrysocolla (cs). Sample BMG2400A. B, Sector twinned, zoned garnet. Crossed nicols. Sample BMG2400A. C, Garnets completely replaced by chlorite (ch), calcite (cc), and quartz (Q). Note pyrite (py) in cores. Plane-polarized light. Sample KS513. $D$, Electrum (E) in limonite $(\mathrm{lm})$ in high-grade gold ore along Copper King shear zone. Reflected light. Sample 89JH009. 


\section{MINERAL CHEMISTRY}

\section{GARNET}

Garnet is the major modal constituent of Copper Basin skarns. Many rocks are massive garnetites having bulk-rock compositions approaching a garnet composition (tables 24, 38). Although optical properties vary considerably, almost all compositions can be described in terms of solid solution between the ideal garnet end members andradite, $\mathrm{Ca}_{3}\left(\mathrm{Fe}^{3+}\right)_{2} \mathrm{Si}_{3} \mathrm{O}_{12}$, and grossular, $\mathrm{Ca}_{3} \mathrm{Al}_{2} \mathrm{Si}_{3} \mathrm{O}_{12}$ (tables $36,37)$. Other garnet components (pyrope, spessartine, and almandine) account for less than $10 \mathrm{~mol}$ percent of the garnets (table 40). Hammarstrom (1987) tabulated all garnet analyses and gave examples of formula calculations. Ferric iron contents are estimated by assuming garnet stoichiometry on the basis of an ideal formula unit having 8 cations and 12 oxygen anions. This assumption is not valid if a hydrogarnet component is present. If enough iron is available for partitioning between $\mathrm{Fe}^{3+}$ and $\mathrm{Fe}^{2+}$, then amounts of $\mathrm{Fe}_{2} \mathrm{O}_{3}$ and $\mathrm{FeO}$ are computed; otherwise, total iron is converted to $\mathrm{Fe}_{2} \mathrm{O}_{3}$; oxide sums are adjusted to represent calculated iron values, generally bringing totals to between 98 and 102 percent. Normalized cations are partitioned into sites according to the ideal garnet formula $\mathrm{X}_{3} \mathrm{Y}_{2} \mathrm{Z}_{3} \mathrm{O}_{12}$, where $\mathrm{X}=\mathrm{Ca}, \mathrm{Mg}, \mathrm{Mn}, \mathrm{Na}, \mathrm{Fe}^{2+} ; \mathrm{Y}=\mathrm{Al}$, $\mathrm{Fe}^{3+}, \mathrm{Ti}, \mathrm{Cr}$; and $\mathrm{Z}=\mathrm{Si}, \mathrm{Al}$. Deviations from ideal stoichiometry in the resulting mineral formulas indicate analytical error, which is probably most severe for $\mathrm{Si}$, as well as errors in ferric iron estimates and failure to include water or other elements. Molecular percentages for end members are computed from normalized cations by Rickwood's (1968) method.

All Copper Basin garnets are zoned, commonly over a range of 30 or more mol percent andradite within a single crystal. Although there is considerable overlap among garnet compositions for different skarns (fig. 89), some trends in the data are apparent.

Skarn A garnets are all andradite rich $\left(\mathrm{Ad}_{65}-\mathrm{Ad}_{98}\right)$. Titanium content tends to increase with decreasing andradite content. Garnet in sample 84JH044, which contains only traces of pyroxene, is slightly enriched in andradite and pyralspite relative to garnet in the pyroxene-bearing samples. In skarn A, garnet is found as veins or anhedral clots, rather than discrete euhedral crystals. Traverses across veins show that the central parts tend to be slightly enriched in andradite relative to vein walls against quartz- or pyroxene-rich layers, indicating that garnet-forming solutions became enriched in iron as growth proceeded from the vein walls inward.

Skarn B garnets exhibit a much wider range in composition $\left(\mathrm{Ad}_{22}-\mathrm{Ad}_{99}\right)$, color, and anisotropy than skarn A garnets; however, most are euhedral, colorless, anisotropic, zoned crystals, with compositions in the range ${A d_{30}}_{30}-\mathrm{Ad}_{60}$. Rims are iron rich relative to cores, except for a few crystals with distinctly yellow, andraditic cores. Garnets from the westernmost samples included in skarn B lack yellow cores. A gap of about $20 \mathrm{~mol}$ percent andradite separates compositions of homogeneous yellow cores from compositions of colorless rims. Ti contents, though variable, are highest for the most grossular rich compositions.

Skarn C garnets range from $\mathrm{Ad}_{43}$ to $\mathrm{Ad}_{99}$ in composition and include colorless, red, and yellow varieties. One garnet grain in a fine-grained pyroxene-K-feldspar layer in sample $85 \mathrm{JH} 080$ has a distinct, grossular-rich composition. Fine-scale zoning obscures precise color and optical determinations in many grains. Microprobe traverses (fig. 90) across complexly zoned grains, perpendicular to growth planes, show early-stage, grossular-rich, colorless, anisotropic garnet surrounded by later stage zones of alternating grossular- and andradite-rich compositions. In skarn $\mathrm{C}$, garnets form veins and pods, similar in texture to garnets in skarn A, but having more grossular rich compositions. Endoskarn garnets form red, isotropic veins that are more iron rich than most of the garnet compositions in the laminated calc-silicate rocks.

Early-stage garnets in skarn D have intermediate compositions and are typically zoned from grossularrich cores to andradite-rich rims, for example, from $\operatorname{Ad}_{70}$ to $\mathrm{Ad}_{92}$. In contrast, the late garnets have conspicuous yellow, isotropic andradite cores surrounded by oscillatory zones of more grossular rich compositions. Yellow isotropic cores in late-stage garnets (fig. 91) are homogeneous andradite; in oscillatorily zoned areas, compositions are constant for distances of several tens of micrometers and change abruptly by 15 to $20 \mathrm{~mol}$ percent andradite. Changes in the mole percentage of andradite are exactly offset by changes in grossular content. Field evidence suggests that most of skarn $D$ is paragenetically related to Cretaceous intrusives that cut skarn in the Contention pit of the Copper Basin Mine. Data for selected samples of massive skarn from a north-south traverse along skarn D are plotted (fig. 92) to examine garnet compositions as a function of distance from the intrusive. Garnet composition in sample 85JH129, the skarn sample nearest to known 


\begin{tabular}{|c|c|c|c|c|c|c|c|c|c|c|}
\hline \multirow[b]{2}{*}{$\begin{array}{l}\text { Sample No. } \\
\text { Grain }\end{array}$} & \multicolumn{4}{|c|}{ Skarn A } & \multicolumn{6}{|c|}{ Skarn B } \\
\hline & $\begin{array}{c}84 \mathrm{JH} 043 \\
\text { GA2-3 } \\
\text { vc } \\
\text { I }\end{array}$ & $\begin{array}{c}84 \mathrm{JHO} 03 \\
\mathrm{GA} 2-2 \\
\mathrm{vr} / \mathrm{PX} \\
\mathrm{I}\end{array}$ & $\begin{array}{c}\text { 85JH070 } \\
\text { GAl-3 } \\
\text { vc } \\
\text { I }\end{array}$ & $\begin{array}{c}85 \mathrm{JHO} 070 \\
\mathrm{GA} 1-1 \\
\mathrm{vr} / \mathrm{Q} \\
\mathrm{I}\end{array}$ & $\begin{array}{c}85 \mathrm{JHO} 08 \\
\mathrm{GAl}-1 \\
\mathrm{c} \\
\mathrm{A}\end{array}$ & $\begin{array}{c}\text { 85JH098 } \\
\text { GAl-4 } \\
\mathrm{r} \\
\mathrm{A}\end{array}$ & $\begin{array}{c}\text { 85JH098 } \\
\text { GA5-1 } \\
\text { c } \\
\text { I }\end{array}$ & $\begin{array}{c}\text { 85JH098 } \\
\text { GA5-2 } \\
\text { r } \\
\text { A }\end{array}$ & $\begin{array}{cc}8 & 451-332 \\
\text { GA1-1 } \\
\text { c } \\
\text { A }\end{array}$ & $\begin{array}{c}\overline{451-332} \\
\cdot \text { GA1-2 } \\
\text { r/EP } \\
\text { A }\end{array}$ \\
\hline \multicolumn{11}{|c|}{ Microprobe analyses (weight percent) } \\
\hline $\begin{array}{l}\mathrm{SiO}_{2} \\
\mathrm{Al}_{2} \mathrm{O}_{3} \\
\left.\mathrm{FeO}^{(\mathrm{T}}\right) \\
\mathrm{MgO} \\
\mathrm{CaO} \\
\mathrm{Na}_{2} \mathrm{O} \\
\mathrm{TiO}_{2} \\
\mathrm{MnO} \\
\mathrm{Cr}_{2} \mathrm{O}_{3}\end{array}$ & $\begin{array}{c}37.0 \\
3.5 \\
24.2 \\
-- \\
33.2 \\
.01 \\
.82 \\
.35 \\
\text { N.d. }\end{array}$ & $\begin{array}{c}37.1 \\
4.38 \\
22.9 \\
-- \\
33.2 \\
-- \\
.57 \\
.52 \\
\text { N.d. }\end{array}$ & $\begin{array}{c}35.5 \\
1.13 \\
28 . \\
.17 \\
32.8 \\
.02 \\
.03 \\
.32 \\
.02\end{array}$ & $\begin{array}{c}35.7 \\
2.65 \\
25.7 \\
.18 \\
33 . \\
.01 \\
.07 \\
.29 \\
--\end{array}$ & $\begin{array}{l}37.6 \\
11.7 \\
13 . \\
.19 \\
34.6 \\
.02 \\
.09 \\
.32 \\
.03\end{array}$ & $\begin{array}{c}37.3 \\
8.51 \\
17.4 \\
.19 \\
34.4 \\
.01 \\
.06 \\
.28 \\
.01\end{array}$ & $\begin{array}{c}35.3 \\
.43 \\
28.3 \\
.2 \\
32.9 \\
.02 \\
-. \\
.2 \\
--\end{array}$ & $\begin{array}{r}37.2 \\
12.6 \\
11.6 \\
.2 \\
34.9 \\
.01 \\
.59 \\
.37 \\
-\end{array}$ & $\begin{array}{c}37.5 \\
14.6 \\
9.75 \\
.46 \\
36 . \\
.01 \\
1.38 \\
.27 \\
\text { N.d. }\end{array}$ & $\begin{array}{c}37.6 \\
9.82 \\
17.3 \\
.23 \\
34.9 \\
.01 \\
.18 \\
.28 \\
\text { N.d. }\end{array}$ \\
\hline Total & $\overline{99.0}$ & $\overline{98.6}$ & $\overline{98.0}$ & $\overline{97.7}$ & $\overline{97.4}$ & $\overline{98.1}$ & $\overline{97.3}$ & $\overline{97.5}$ & $\overline{100 .}$ & $\overline{100}$ \\
\hline $\begin{array}{l}\mathrm{Fe}_{2} \mathrm{O}_{3} \\
\mathrm{FeO}\end{array}$ & $\begin{array}{c}24.6 \\
2.01\end{array}$ & $\begin{array}{c}23.4 \\
1.85\end{array}$ & $\begin{array}{c}31.1 \\
--\end{array}$ & $\begin{array}{c}28.5 \\
--\end{array}$ & $\begin{array}{r}14.3 \\
.05\end{array}$ & $\begin{array}{c}19.3 \\
--\end{array}$ & $\begin{array}{c}31.4 \\
--\end{array}$ & $\begin{array}{c}12.9 \\
-\end{array}$ & $\begin{array}{c}10.8 \\
--\end{array}$ & $\begin{array}{c}19.2 \\
--\end{array}$ \\
\hline Tota1 & $\overline{101 .}$ & $\overline{101 .}$ & $\overline{101 .}$ & $\overline{101 .}$ & $\overline{98.8}$ & $\overline{100}$ & 100 & $\overline{98.8}$ & $\overline{101 .}$ & $\overline{102 .}$ \\
\hline \multicolumn{11}{|c|}{ Structural formula (normalized to 8 cations) } \\
\hline $\begin{array}{l}\text { Si } \\
\text { Al }\end{array}$ & $\begin{array}{l}3.02 \\
--\end{array}$ & $\begin{array}{l}3.03 \\
--\end{array}$ & $\begin{array}{r}2.96 \\
.04\end{array}$ & $\begin{array}{r}2.97 \\
.03\end{array}$ & $\begin{array}{l}3.01 \\
--\end{array}$ & $\begin{array}{l}3.00 \\
--\end{array}$ & $\begin{array}{r}2.97 \\
.03\end{array}$ & $\begin{array}{r}2.96 \\
.04\end{array}$ & $\begin{array}{c}2.90 \\
.1\end{array}$ & $\begin{array}{r}2.96 \\
.04\end{array}$ \\
\hline $\mathrm{z}$ & $\overline{3.02}$ & $\overline{3.03}$ & $\overline{3.00}$ & $\overline{3.00}$ & $\overline{3.01}$ & $\overline{3.00}$ & $\overline{3.00}$ & $\overline{3.00}$ & $\overline{3.00}$ & $\overline{3.00}$ \\
\hline $\begin{array}{l}\mathrm{Al} \\
\mathrm{Fe}^{+3} \\
\mathrm{Ti} \\
\mathrm{Cr}\end{array}$ & $\begin{array}{r}0.36 \\
1.51 \\
.05 \\
\text { N.d. }\end{array}$ & $\begin{array}{r}0.46 \\
1.44 \\
.04 \\
\text { N.d. }\end{array}$ & $\begin{array}{l}0.07 \\
1.95 \\
-- \\
--\end{array}$ & $\begin{array}{l}0.23 \\
1.78 \\
-- \\
--\end{array}$ & $\begin{array}{r}1.10 \\
.86 \\
.01 \\
--\end{array}$ & $\begin{array}{l}0.81 \\
1.17 \\
-- \\
--\end{array}$ & $\begin{array}{l}0.01 \\
1.99 \\
-- \\
--\end{array}$ & $\begin{array}{r}1.15 \\
.78 \\
.04 \\
--\end{array}$ & $\begin{array}{r}1.23 \\
.63 \\
.08 \\
\text { N.d. }\end{array}$ & $\begin{array}{r}.87 \\
1.14 \\
.01 \\
--\end{array}$ \\
\hline $\mathbf{Y}$ & $\overline{1.92}$ & $\overline{1.94}$ & $\overline{2.00}$ & $\overline{2.01}$ & $\overline{1.98}$ & $\overline{1.98}$ & $\overline{2.00}$ & $\overline{1.96}$ & $\overline{1.94}$ & $\overline{2.01}$ \\
\hline $\begin{array}{l}\mathrm{Fe}^{+2} \\
\mathrm{Mg} \\
\mathrm{Ca} \\
\mathrm{Mn} \\
\mathrm{Na}\end{array}$ & $\begin{array}{l}0.14 \\
-- \\
2.91 \\
.02 \\
--\end{array}$ & $\begin{array}{l}0.13 \\
-- \\
2.91 \\
.04 \\
--\end{array}$ & $\begin{array}{l}-- \\
0.02 \\
2.93 \\
.02 \\
--\end{array}$ & $\begin{array}{l}-- \\
0.02 \\
2.94 \\
.02 \\
--\end{array}$ & $\begin{array}{l}-- \\
0.02 \\
2.97 \\
.02 \\
--\end{array}$ & $\begin{array}{l}-- \\
0.02 \\
2.97 \\
.02 \\
--\end{array}$ & $\begin{array}{l}-\overline{0.03} \\
2.96 \\
.01 \\
--\end{array}$ & $\begin{array}{l}-- \\
0.02 \\
2.99 \\
.03 \\
--\end{array}$ & $\begin{array}{l}-- \\
0.05 \\
2.99 \\
.02 \\
--\end{array}$ & $\begin{array}{r}-- \\
.03 \\
2.94 \\
.02 \\
--\end{array}$ \\
\hline $\mathrm{x}$ & $\overline{3.07}$ & $\overline{3.08}$ & $\overline{2.98}$ & $\overline{2.99}$ & $\overline{3.01}$ & $\overline{3.01}$ & $\overline{3.00}$ & $\overline{3.04}$ & $\overline{3.06}$ & $\overline{2.99}$ \\
\hline \multicolumn{11}{|c|}{ Mo1ecular proportions of end-member garnet } \\
\hline $\begin{array}{l}\text { Andradite } \\
\text { Uvarovite } \\
\text { Pyrope } \\
\text { Almandine } \\
\text { Spessartine } \\
\text { Grossular } \\
\text { Schorlomite }\end{array}$ & $\begin{array}{c}76.5 \\
\text { N.d. } \\
-- \\
4.7 \\
.8 \\
16.3 \\
1.7\end{array}$ & $\begin{array}{l}73.1 \\
\text { N.d. } \\
-- \\
4.3 \\
1.2 \\
20.2 \\
1.2\end{array}$ & $\begin{array}{c}98.9 \\
.1 \\
.7 \\
-- \\
.3 \\
-- \\
--\end{array}$ & $\begin{array}{c}90.0 \\
-- \\
.7 \\
-- \\
.7 \\
8.4 \\
.1\end{array}$ & $\begin{array}{r}43.7 \\
.1 \\
.8 \\
.1 \\
.7 \\
54.4 \\
.2\end{array}$ & $\begin{array}{c}59.1 \\
-- \\
.8 \\
-- \\
.6 \\
39.4 \\
.1\end{array}$ & $\begin{array}{c}99.3 \\
- \\
.2 \\
-- \\
.5 \\
--\end{array}$ & $\begin{array}{c}39.1 \\
-- \\
.8 \\
-- \\
.8 \\
58.1 \\
1.2\end{array}$ & $\begin{array}{c}31.7 \\
\text { N.d. } \\
1.8 \\
-- \\
.6 \\
63.2 \\
2.7\end{array}$ & $\begin{array}{r}57.4 \\
\text { N.d } \\
.9 \\
-. \\
.6 \\
40.7 \\
.4\end{array}$ \\
\hline
\end{tabular}


TABLE 40.-Representative analyses of garnet from Copper Basin skarns-Continued

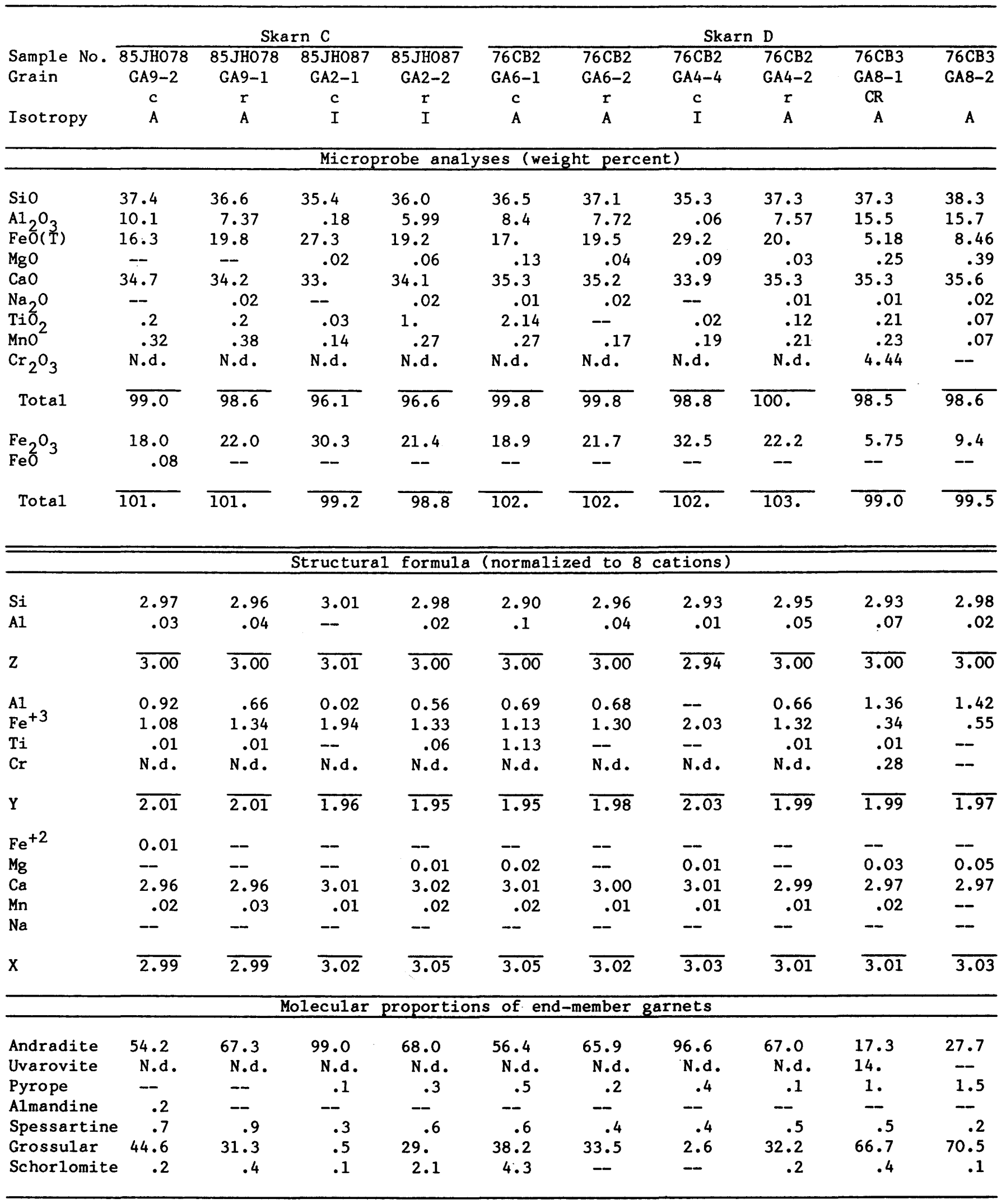


TABLE 40.-Representative analyses of garnet from Copper Basin skarns-Continued

\begin{tabular}{|c|c|c|c|c|c|c|c|c|c|c|}
\hline \multirow{3}{*}{$\begin{array}{l}\text { Sample No. } \\
\text { Grain }\end{array}$} & \multicolumn{2}{|c|}{ Contention Pit } & \multicolumn{8}{|c|}{ Skarn E } \\
\hline & $\begin{array}{l}76 \mathrm{CB} 11 \\
\mathrm{GA} 1-1\end{array}$ & $\begin{array}{l}76 \mathrm{CB} 11 \\
\mathrm{GA} 1-2\end{array}$ & $\begin{array}{l}85 \mathrm{JH} 140 \\
\mathrm{GA} 2-2\end{array}$ & $\begin{array}{l}85 \mathrm{JH} 140 \\
\mathrm{GA} 2-1\end{array}$ & $\begin{array}{l}85 \mathrm{JH} 143 \\
\text { GA2-1 }\end{array}$ & $\begin{array}{l}85 \mathrm{JH} 143 \\
\text { GA2-2 }\end{array}$ & $\begin{array}{l}85 \mathrm{JH} 148 \\
\text { GA9-1 }\end{array}$ & $\begin{array}{l}85 \mathrm{JH} 148 \\
\text { GA9-2 }\end{array}$ & $\begin{array}{l}85 \mathrm{JH} 149 \\
\text { GA3-1 }\end{array}$ & $\begin{array}{l}85 \mathrm{JH} 149 \\
\text { GA3-4 }\end{array}$ \\
\hline & /PY & c & c & $\mathrm{r} / \mathrm{CC}$ & c & $r$ & c & $\mathrm{r} / \mathrm{AM}$ & c & $r$ \\
\hline Isotropy & A & A & A & A & A & A & A & I & A & A \\
\hline \multicolumn{11}{|c|}{ Microprobe analyses (weight percent) } \\
\hline $\mathrm{SiO}_{2}$ & 36.0 & 36.0 & 35.0 & 35.0 & 37.2 & 37.2 & 36.8 & 35.5 & 36.6 & 36.2 \\
\hline $\mathrm{Al}_{2} \mathrm{O}_{3}$ & 7.17 & 4.41 & -- & 2.16 & 14.6 & 10.9 & 6.66 & .17 & 6.94 & 4.89 \\
\hline $\mathrm{FeO}\left(\mathrm{T}^{\mathrm{T}}\right)$ & 19.7 & 22.9 & 28.1 & 25.7 & 9.78 & 14.2 & 20.9 & 28.3 & 19.8 & 22.2 \\
\hline $\mathrm{MgO}$ & .22 & .21 & .05 & .01 & .23 & .09 & .03 & .04 & .01 & .01 \\
\hline $\mathrm{CaO}$ & 34.1 & 33.8 & 34. & 34.9 & 37.2 & 36.6 & 35.5 & 34.4 & 36. & 35.3 \\
\hline $\mathrm{Na}_{2} \mathrm{O}$ & .02 & -- & -- & -- & -- & - & -- & - & -- & -- \\
\hline $\mathrm{TiO}_{2}$ & .36 & .06 & -- & -- & .88 & .76 & .03 & -- & .08 & .06 \\
\hline $\mathrm{MnO}^{2}$ & .52 & .3 & .11 & .09 & .25 & .15 & .19 & .11 & .18 & .09 \\
\hline $\mathrm{Cr}_{2} \mathrm{O}_{3}$ & .01 & .01 & N.d. & N.d. & N.d. & N.d: & N.d. & N.d. & N.d. & N.d. \\
\hline Total & $\overline{98.1}$ & $\overline{97.7}$ & $\overline{97.3}$ & $\overline{97.8}$ & $\overline{100}$ & 99.9 & $\overline{100}$ & $\overline{98.5}$ & $\overline{99.7}$ & $\overline{98.8}$ \\
\hline $\mathrm{Fe}_{2} \mathrm{O}_{3}$ & 21.9 & 25.5 & 31.2 & 28.5 & 10.9 & 15.8 & 23.2 & 31.4 & 22.0 & 24.6 \\
\hline $\mathrm{FeO}^{3}$ & -- & -- & - & - & - & - & - & - & - & - \\
\hline Total & $\overline{100}$ & $\overline{100}$ & $\overline{100}$ & $\overline{101 .}$ & $\overline{101 .}$ & $\overline{102 .}$ & $\overline{102}$. & $\overline{102 .}$ & $\overline{102}$. & $\overline{101.24}$ \\
\hline \multicolumn{11}{|c|}{ Structural formula (normalized to 8 cations) } \\
\hline $\mathrm{Si}$ & 2.93 & 2.96 & 2.95 & 2.91 & 2.87 & 2.92 & 2.95 & 2.96 & 2.93 & 2.96 \\
\hline A1 & .07 & .04 & -- & .09 & .13 & .08 & .05 & .02 & .05 & .04 \\
\hline$z$ & $\overline{3.00}$ & $\overline{3.00}$ & $\overline{2.95}$ & $\overline{3.00}$ & $\overline{3.00}$ & $\overline{3.00}$ & $\overline{3.00}$ & $\overline{2.98}$ & $\overline{3.00}$ & $\overline{3.00}$ \\
\hline AI & 0.62 & 0.39 & - & 0.12 & 1.20 & 0.93 & 0.58 & - & 0.61 & 0.43 \\
\hline $\mathrm{Fe}^{+3}$ & 1.34 & 1.58 & 1.98 & 1.78 & 0.63 & .93 & 1.4 & 1.97 & 1.33 & 1.51 \\
\hline $\mathrm{Ti}$ & .02 & - & - & - & .05 & .04 & -- & -- & -- & -- \\
\hline $\mathrm{Cr}$ & -- & -- & N.d. & N.d. & N.d. & N.d. & N.d. & N.d. & N.d. & N.d. \\
\hline $\mathbf{Y}$ & $\overline{1.98}$ & $\overline{1.97}$ & $\overline{1.98}$ & $\overline{1.90}$ & $\overline{1.88}$ & $\overline{1.91}$ & $\overline{1.98}$ & $\overline{1.97}$ & $\overline{1.94}$ & $\overline{1.94}$ \\
\hline $\mathrm{Fe}^{+2}$ & -- & -- & -- & -- & -- & -- & -- & -- & -- & -- \\
\hline $\mathrm{Mg}$. & 0.03 & 0.03 & 0.01 & -- & 0.03 & 0.01 & -- & -- & -- & -- \\
\hline $\mathrm{Ca}$ & 2.98 & 2.98 & 3.06 & 3.10 & 3.08 & 3.07 & 3.05 & 3.08 & 3.11 & 3.09 \\
\hline Mn & .04 & .02 & .01 & .01 & .02 & .01 & .01 & .01 & .01 & .01 \\
\hline $\mathrm{Na}$ & -- & -- & -- & - & - & -- & -- & -- & -- & -- \\
\hline $\mathrm{x}$ & $\overline{3.05}$ & $\overline{3.03}$ & $\overline{3.08}$ & $\overline{3.10}$ & $\overline{3.12}$ & $\overline{3.09}$ & $\overline{3.06}$ & $\overline{3.09}$ & $\overline{3.12}$ & $\overline{3.10}$ \\
\hline \multicolumn{11}{|c|}{ Molecular proportions of end-member garnets } \\
\hline Andradite & 68.1 & 79.8 & 100.7 & 91.8 & 32.4 & 47.2 & 71.1 & 95.9 & 67.6 & 76.7 \\
\hline Uvarovite & - & -- & N.d. & N.d. & N.d. & N.d. & N.d. & N.d. & N.d. & N.d. \\
\hline Pyrope & .9 & .9 & -- & -- & .9 & .4 & .1 & 0.1 & -- & -- \\
\hline Almandine & -- & -- & -- & -- & -- & -- & -- & -- & -- & -- \\
\hline Spessartine & 1.2 & .7 & -- & .2 & .6 & .3 & .4 & .3 & .4 & .2 \\
\hline Grossular & 29. & 18.5 & -- & 7.9 & 64.4 & 50.6 & 28.2 & 3.7 & 31.8 & 22.9 \\
\hline Schorlomite & .7 & .1 & - & -- & 1.7 & 1.5 & .1 & -- & .2 & .1 \\
\hline
\end{tabular}


TABLE 40.-Representative analyses of garnet from Copper Basin skarns-Continued

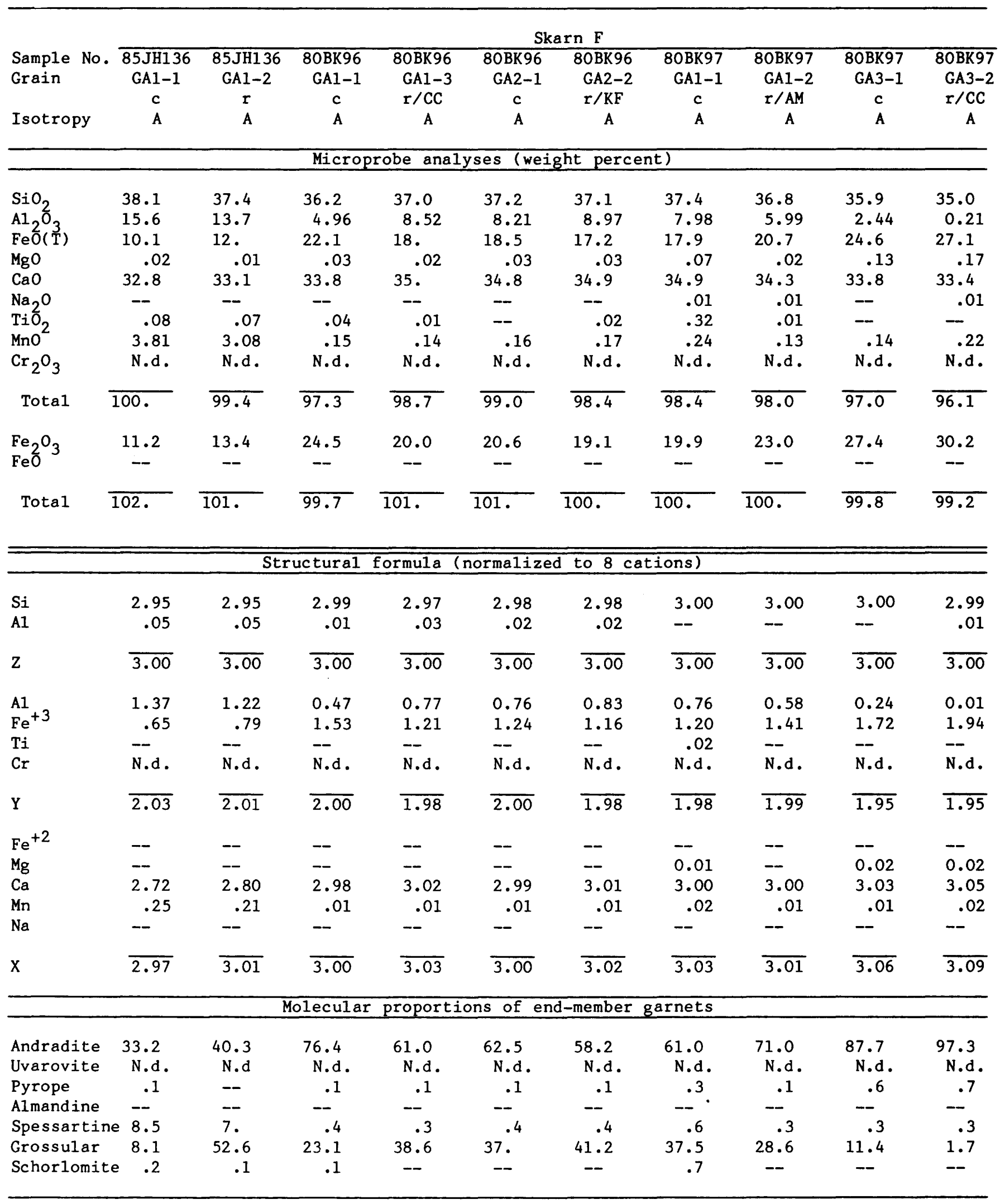




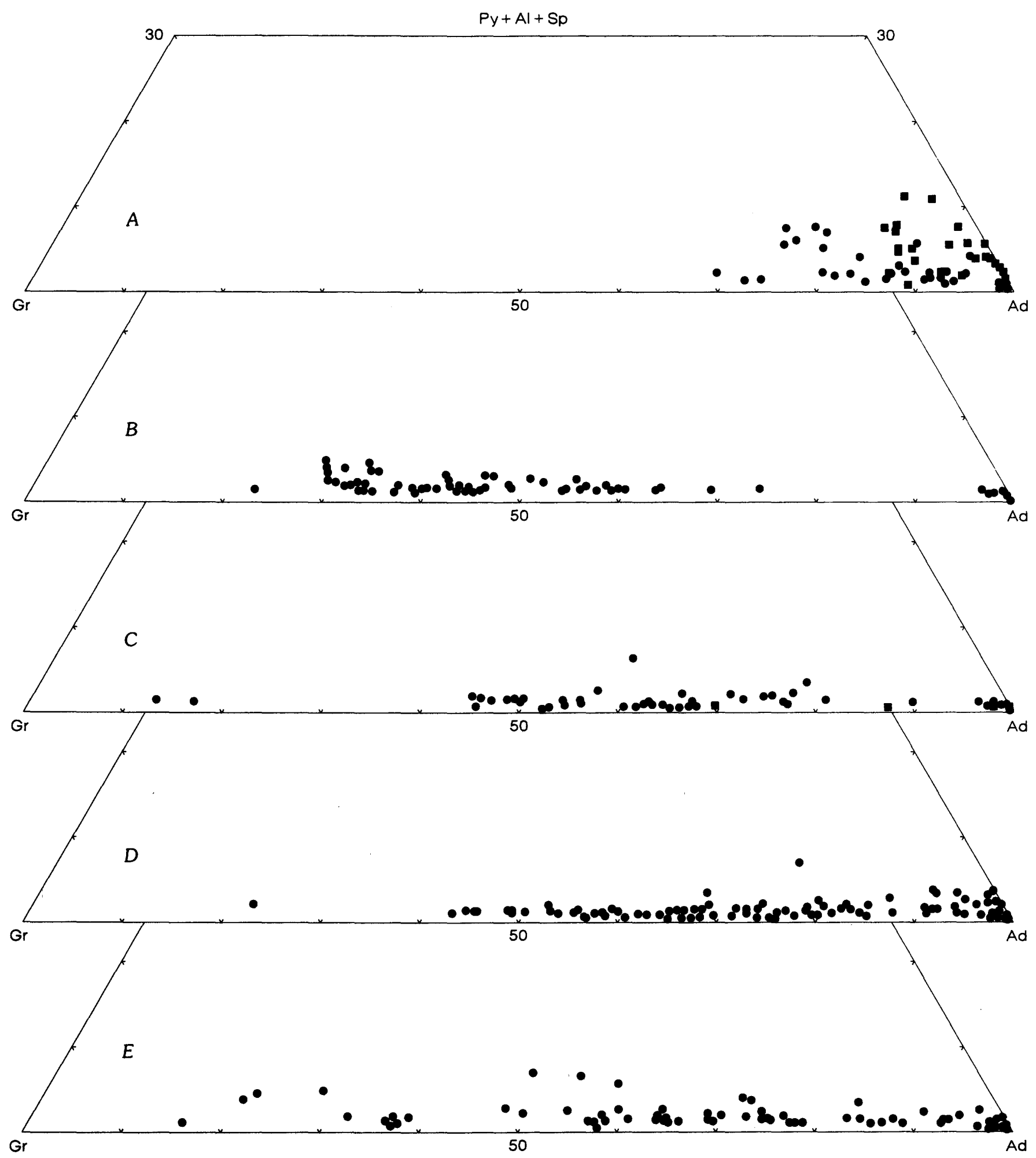

Figure 89.-Ternary plots showing Copper Basin garnet compositions in terms of molecular proportions of pyrope+almandine+spessartine $(\mathrm{Py}+\mathrm{Al}+\mathrm{Sp})$, grossular $(\mathrm{Gr})$, and andradite (Ad). A, skarn A in the Upper Cambrian Harmony Formation; dots, pyroxene-bearing samples; squares, pyroxene-free sample 84JH044. B, dots, skarn B in the Harmony Formation. $C$, dots, skarn $\mathrm{C}$ in the Harmony Formation; squares, Tertiary diabase endoskarn. $D$, dots, skarn $\mathrm{D}$ in the Harmony Formation along unconformable contact between the Harmony and the Middle Pennsylvanian Battle Formations, north of Surprise fault. $E$, dots, skarn D in the Harmony Formation south of Surprise fault. $F$, skarn $\mathrm{E}$ in middle member of the Battle Formation; dots, samples adjacent to Tertiary porphyritic leucogranite; triangles, skarn in contact with fossiliferous silicified limestone in sample 85JH140; squares, samples 85JH148 and 85JH149. 


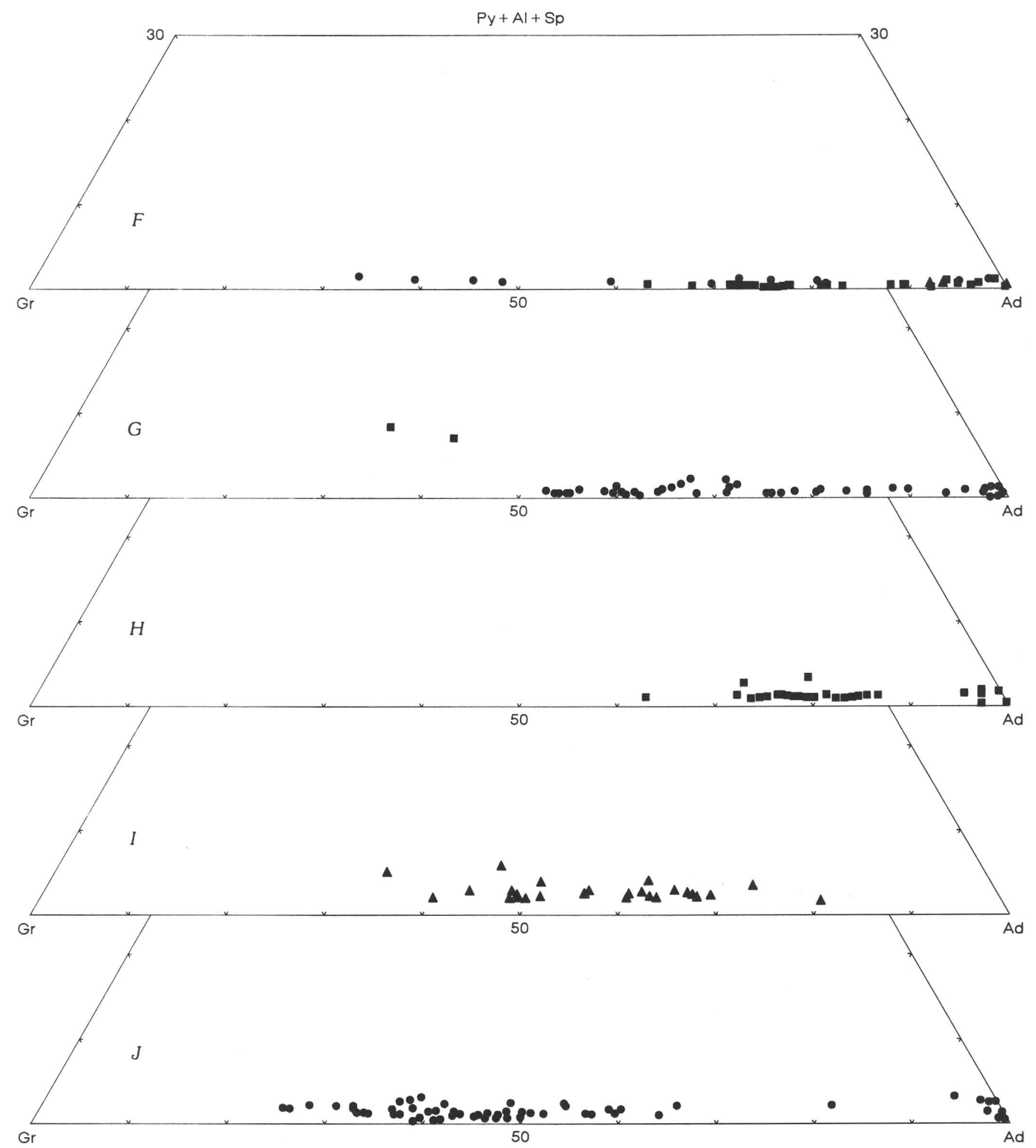

FIGURE 89.-Continued. G, skarn F in the Upper Pennsylvanian and Lower Permian Antler Peak Limestone; dots, samples $80 \mathrm{BK} 96$ and 80BK97; squares, clastic carbonate sample 85JH136. $H$, Squares, mineralized skarn at Carissa deposit. $I$, triangles, mineralized skarn samples 76CB11 and 85JH129 from Contention pit. $J$, dots, mineralized skarn at Surprise deposit. 
exposures of Cretaceous monzogranite, ranges from $\operatorname{Ad}_{30}$ to $\mathrm{Ad}_{75}$. Garnet in the two southernmost samples of the traverse, 85JH129 and 76CB11, is colorless and anisotropic; both of these samples are mineralized. Samples at the Carissa deposit contain colorless to pink garnets, some of which have isotropic cores of nearly pure andradite. Although garnets in sample 76CB9 all have the yellow color typical of iron-rich compositions, isotropic areas are pure andradite, whereas anisotropic areas display oscillatory zoning in the range $\mathrm{Ad}_{58}$ to $\mathrm{Ad}_{91}$. Sulfide minerals are absent in sample 76CB9 and all samples farther
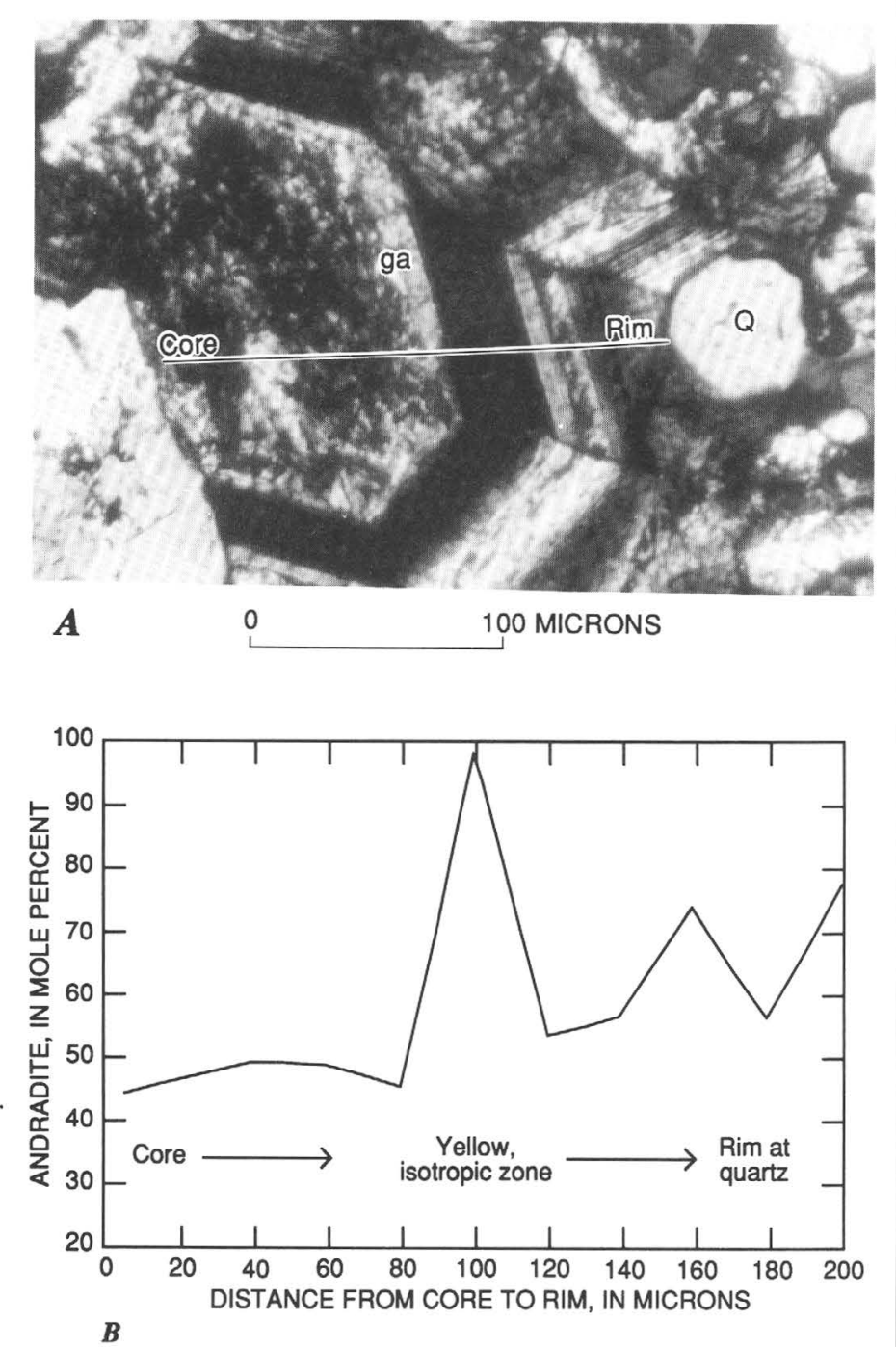

Figure 90.-Zoned garnet from finely laminated bedded skarn sample 85JH079 from skarn C in the Upper Cambrian Harmony Formation. $A$, Photomicrograph showing trace of $200-\mu \mathrm{m}-$ long microprobe traverse garnet (ga) core to rim at quartz (Q). Crossed nicols. $B$, Variation in mole percentage of andradite as a function of distance across zoned garnet shown in figure $90 \mathrm{~A}$. north along skarn D. Samples from the northern segment of skarn $\mathrm{D}$, which contains shaly layers, locally contain some unusually grossular and uvarovite rich garnets (analyses 19, 20, table 40) resulting from re-

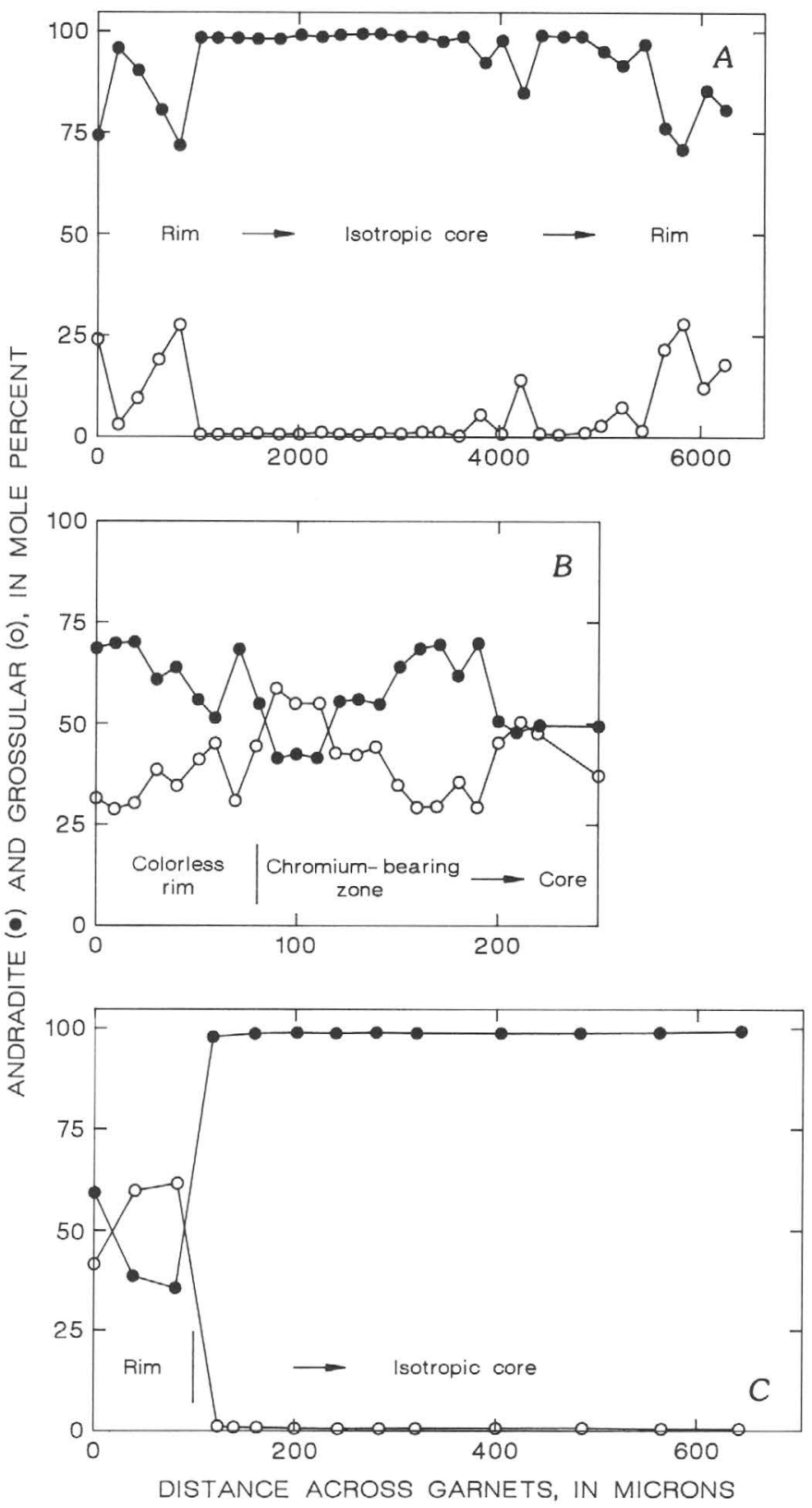

FiguRE 91.-Microprobe traverses across zoned garnets from skarn D. A, Traverse perpendicular to growth-zone boundaries from colorless anisotropic rim through yellow isotropic core to opposite rim across a second-generation, coarsegrained garnet from sample 76CB2. Sample subsequently used for fluid-inclusion studies, this report. $B$, Traverse from colorless rim through yellow-green, chromium-bearing zone to colorless core for anisotropic garnet. Sample 76CB4. $C$, Traverse from colorless anisotropic rim at calcite, across yellow isotropic middle zone of crystal. Sample 76CB8. Euhedral core of this garnet is completely altered to chlorite. 


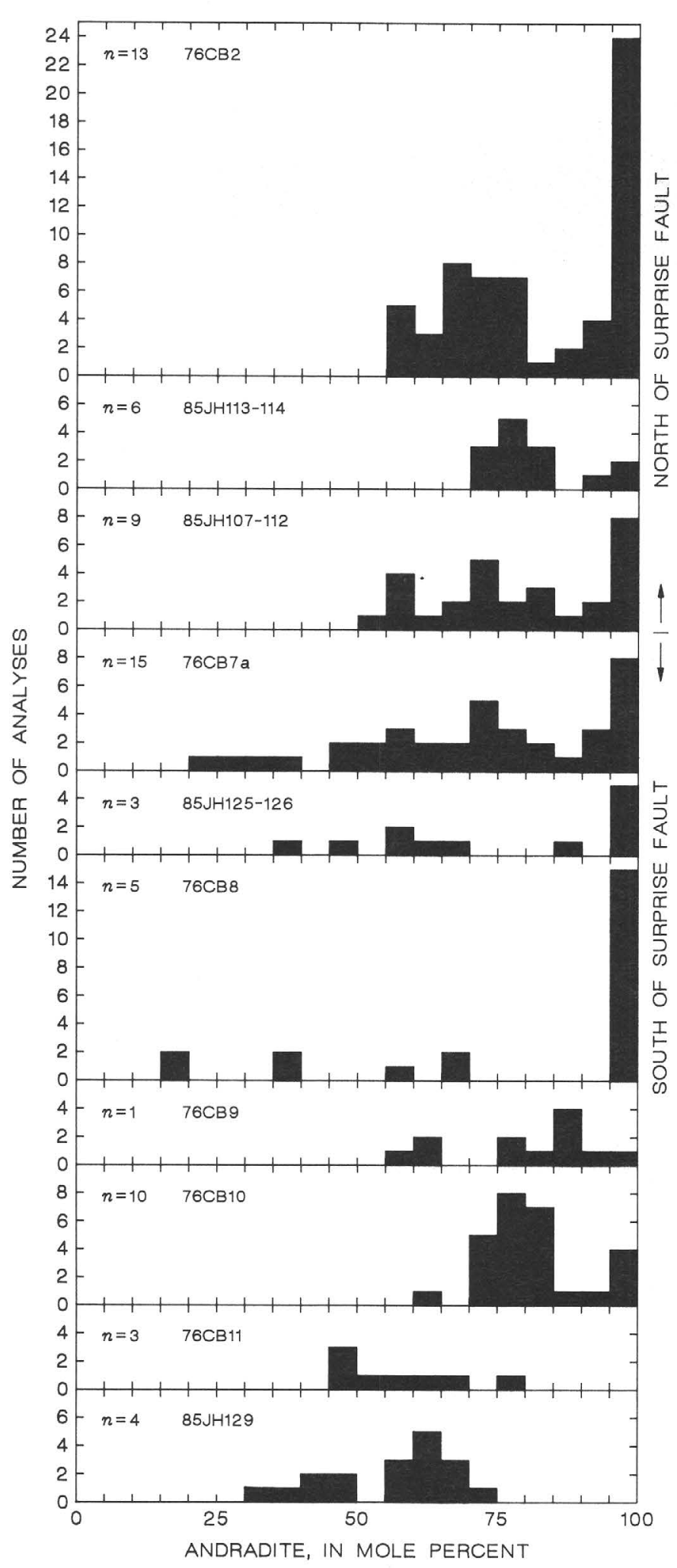

FIgURE 92.-Variation in garnet compositions in terms of mole percentage of andradite along a traverse for skarn $\mathrm{D}$ in the Upper Cambrian Harmony Formation. Data presented from north (sample 76CB2) to south (sample 85JH129); $n$, number of grains analyzed. See figure 86 for sample locations. action of chromite in the protolith with metasomatic fluids. Most skarn D garnets fall within the range $\mathrm{Ad}_{50}-\mathrm{Ad}_{100}$; some samples show a gap along the andradite-grossular join similar to that observed in skarn B garnets, whereas garnets in other samples span the entire range of compositions.

Garnets in a mineralized sample from skarn in the Harmony Formation at the Surprise Mine have compositions in the range $\mathrm{Ad}_{27}$ to $\mathrm{Ad}_{75}$ for anisotropic, colorless garnets; all compositions of $\mathrm{Ad}_{95}$ or higher represent yellow, isotropic cores or zones, and manganese contents are low (less than 0.5 weight percent $\mathrm{MnO}$ ). Narrow bands of brown chlorite separate altered cores from unaltered rims in some grains. The complex zoning patterns (fig. 88 ) suggest that some of the garnets from the Surprise Mine record at least three major events: (1) growth of homogeneous andradite cores, (2) alteration of cores, and (3) growth of rims under fluctuating conditions resulting in alternating zones of aluminum- and iron-rich garnet.

Garnets in skarn E are mostly colorless, contain almost no pyralspite component, and span a range in composition from $\mathrm{Ad}_{60}$ to $\mathrm{Ad}_{98}$ comparable to that for garnets in Harmony skarns. Sample 85JH144 is a siltite in skarn $\mathrm{E}$ that contains anomalously aluminum rich garnets $\left(\mathrm{Ad}_{31}-\mathrm{Ad}_{46}\right)$ and hedenbergitic pyroxenes (table 37 ) growing in calcite-rich pockets and veins. The iron content of these grossular-rich garnets increases from core to rim, and calcite cores are present in many grains. In other samples that are all massive garnetites, isotropic zones are andradite rich $\left(\mathrm{Ad}_{90}-\mathrm{Ad}_{98}\right)$ and commonly have a yellow tinge, but the reverse is not true-some andradite-rich compositions are anisotropic. Garnets in the northernmost samples (85JH148, 85JH149) are clean and are enclosed by fibrous actinolite, whereas garnets in samples farther south have calcite cores containing brown chlorite. Many garnets in skarn $\mathrm{E}$ have textures that suggest growth in open spaces that are now filled by quartz and calcite. Zoning trends are highly variable.

Garnets in siltite from skarn F are distinctly manganiferous ( 3 weight percent $\mathrm{MnO}$ ) and grossular rich relative to other garnet compositions. Garnet compositions for samples from limestone, north of the siltite outcrop (fig. 86), overlap compositions for most garnets in the Battle and Harmony Formations. Sharp optical breaks in garnets formed in limestone, commonly marked by a zone of alteration, correspond to sharp breaks in composition. In detail, zoning patterns are complex. Two garnets from sample $80 \mathrm{BK} 97$ illustrate typical patterns (fig. 93). Small, euhedral, sector-twinned 
garnet is completely enclosed in calcite that is riddled with amphibole needles (figs. 93A, 93B). Andradite content decreases outward from the core, then increases sharply at the rim; $\mathrm{TiO}_{2}$ content is negligible across the entire crystal. Other garnet in the rock is zoned in a similar manner with respect to andradite content (figs. 93C, 93D), but as much as 1 weight percent $\mathrm{TiO}_{2}$ is present in the outermost, least iron rich parts of the crystal

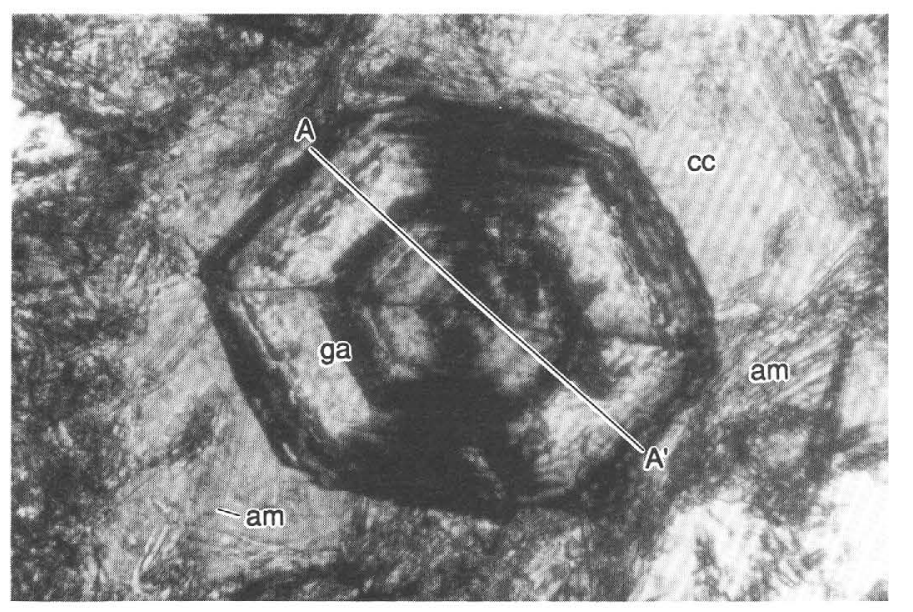

$\boldsymbol{A}$

0 100 MICRONS

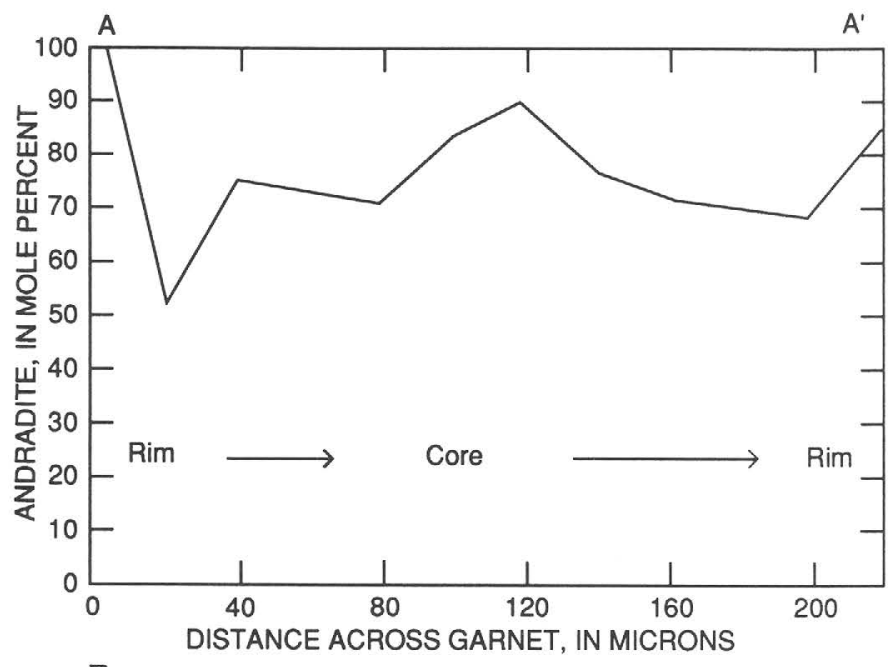

B

Figure 93.-Examples of garnets from skarn formed in the Upper Pennsylvanian and Lower Permian Antler Peak Limestone. Sample 80BK97, skarn F. A, Sector-twinned euhedral garnet (ga) in calcite (cc). Note amphibole (am) laths in calcite. Crossed nicols. $B$, Mole percentage of andradite along microprobe traverse from $\operatorname{rim} \mathrm{A}$ to $\operatorname{rim} \mathrm{A}^{\prime}$ across garnet shown in figure $93 A$. that is in contact with late-stage, void-filling calcite and quartz.

Complex zoning, anisotropism, and multiple generations of garnet are common features of skarns elsewhere, and all these features are strikingly evident at Copper Basin. Vlasova and others (1985), who identified several different types of zoning associated with calcic skarn garnets, found that the type of zoning most common in magnetite, copper,
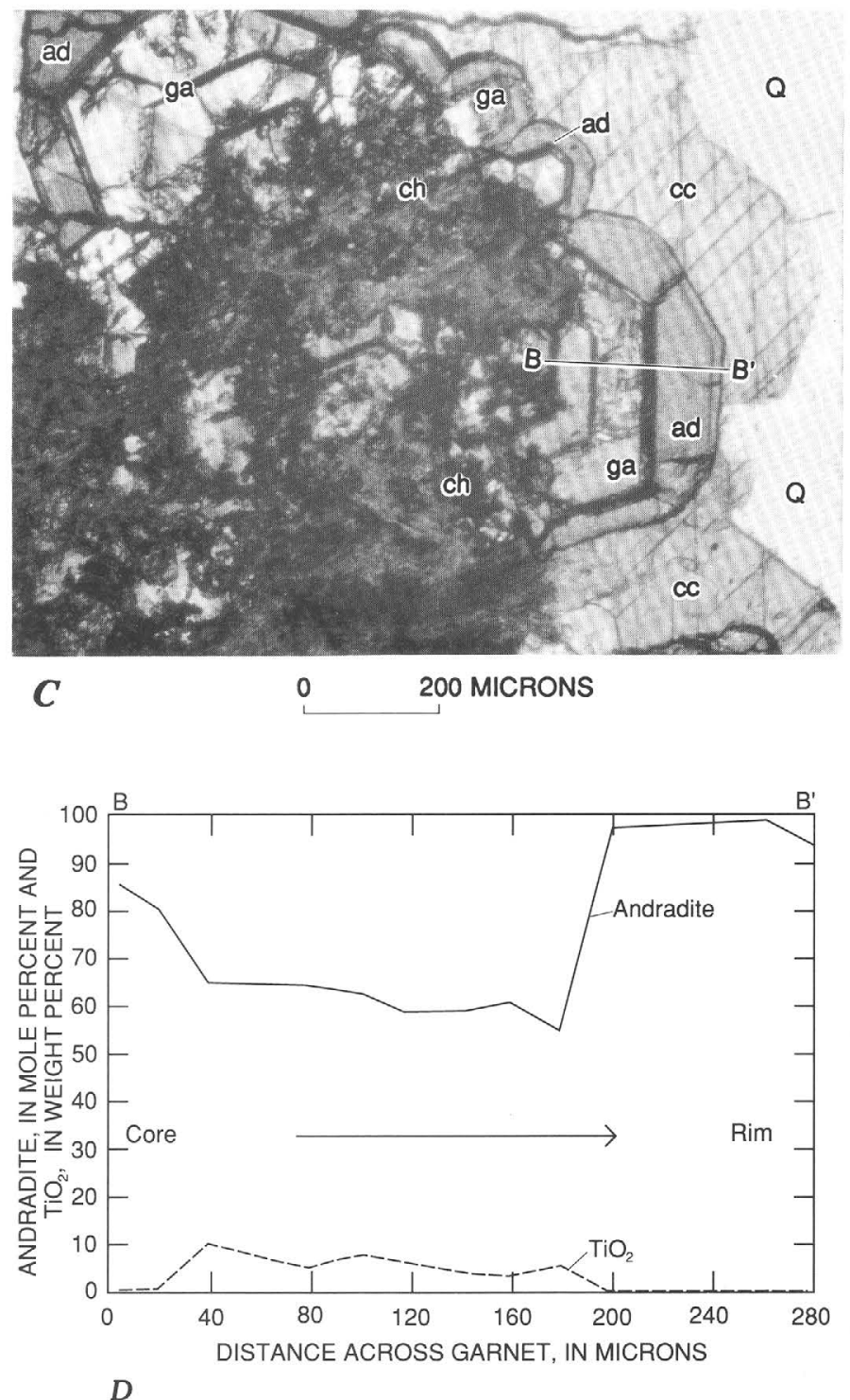

Figure 93.-Continued. C, Cluster of zoned garnets (ga), showing chlorite (ch) alteration in cores and late-stage andradite (ad) overgrowths against coarse-grained twinned calcite (cc) and quartz (Q). Plane-polarized light. $D$, Mole percentage of andradite and $\mathrm{TiO}_{2}$ content along microprobe traverse from core $\mathrm{B}$ to rim $B^{\prime}$ at calcite across garnet shown in figure 93C. Abrupt changes in composition correspond to sharp optical boundaries along traverse. 
and base-metal deposits involves core-to-rim increases (normal zoning) or decreases (inverse zoning) in ferric iron, whereas calcium and pyralspite components remain constant; the dominant substitution is the exchange of $\mathrm{Fe}^{3+}$ for $\mathrm{Al}$. The normal zoning trend is typical of garnets from porphyry copper skarns (Einaudi, 1982b) and follows trends predicted by Johnson and Norton (1985) for compositional variation with decreasing temperature during main-stage metasomatism, assuming constant pressure at oxidation states comparable to the range defined by pyrite-magnetite-pyrrhotite to pyritemagnetite-hematite. For porphyry copper skarn at Cananea, Mexico, Meinert (1982) described mainstage green garnets that have dominantly normal zoning patterns and paragenetically later, darkbrown (yellow in thin section) isotropic andradite and complexly zoned, "two-banded birefringent" garnet veins and segments. His banded garnets, which consisted of alternating zones of isotropic, pure andradite and zoned $\left(\mathrm{Ad}_{30}-\mathrm{Ad}_{85}\right)$, birefringent garnet, spanned the compositional range of early-generation garnet; banded garnets tend to be free of alteration. Veinlets and late-stage overgrowths of pure andradite on earlier formed garnet, which are frequently described in the literature (Einaudi, 1982a), probably formed at temperatures below about $300{ }^{\circ} \mathrm{C}$, assuming pressures on the order of 500 bars (Johnson and Norton, 1985). Zoning trends for Copper Basin garnets are examined in figure 94 by plotting the percentage of the total number of grains from each skarn that exhibit normal zoning (core-to-rim increase in andradite content). For example, 62 percent of $\mathbf{2 1}$ garnet cores and rims examined by microprobe from skarn B are zoned normally, whereas 48 percent are zoned inversely. Both normal and inverse core-to-rim zoning patterns are present in all the Copper Basin skarns. Although normal zoning predominates for skarn A garnet and inverse zoning predominates for garnet at the Carissa Mine, no clear-cut pattern distinguishes skarn by protolith, or by intensity of mineralization. Some variation in the zoning patterns will be a function of the particular plane of the garnet crystal along which the polished section was cut. However, much of the variation indicates presence of multiple generations of garnet that are present in almost all samples. Titanium content generally decreases from core to rim as andradite content increases in normally zoned garnets. For example, microprobe data for a typical zoned garnet from skarn $\mathrm{B}$ show that $\mathrm{TiO}_{2}$ content decreases from 2.08 weight percent at the core $\left(\mathrm{Ad}_{31.7} \mathrm{Gr}_{59.6} \mathrm{Py}_{0.9} \mathrm{Sp}_{0.8} \mathrm{Al}_{2.6} \mathrm{Uv}_{0.2} \mathrm{Sch}_{4.3}\right)$ to 0.01 weight percent at the rim $\left(\mathrm{Ad}_{45.1} \mathrm{Gr}_{53.1} \mathrm{Py}_{0.7} \mathrm{Sp}_{0.9} \mathrm{Al}_{0} \mathrm{Sch}_{0}\right)$.
A number of recent skarn studies have addressed the effects of protolith on garnet composition. In a study of calcic iron skarns formed in volcanic, intrusive, and carbonate rocks in British Columbia, Meinert (1984) found such elements as titanium, aluminum, and vanadium, that are generally regarded as relatively immobile in metasomatic processes, to be present in significant concentrations in early garnet of skarn developed in igneous protolith. For five of the six deposits he studied, Meinert (1984) reported that garnet and pyroxene in skarn replacing a carbonate protolith were enriched in iron relative to those in skarn replacing igneous rock. Moreover, garnet in carbonate protolith was characterized by low to moderate titanium content (0-3 mol percent schorlomite). At one deposit, however, he found grossularand titanium-rich garnet in skarn in a carbonate protolith and suggested that these elements had been transported from nearby volcanic rocks because there was no evidence for a nearby source in the carbonate sequence. Beddoe-Stephens and others (1987) made

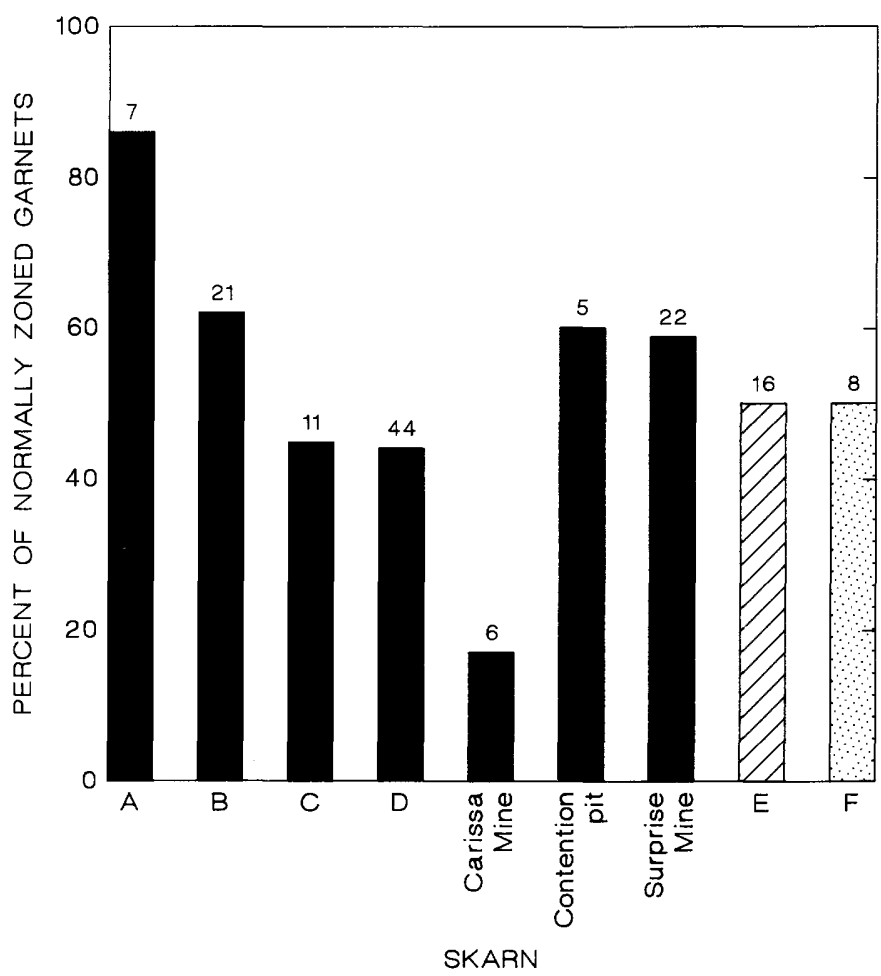

Figure 94.-Frequency of normal zoning in garnet for skarns at Copper Basin. Normal zoning is defined as a core-to-rim increase in ferric iron content. Number of core-rim pairs analyzed for each skarn is given above each column. Shaded pattern, skarn hosted by Upper Cambrian Harmony Formation; hachured pattern, skarn hosted by middle member of the Middle Pennsylvanian Battle Formation; stippled pattern, skarn hosted by Upper Pennsylvanian and Lower Permian Antler Peak Limestone. Skarns A-F shown on figure 86 . 
similar observations about garnet chemistry in their study of gold-mineralized skarns formed in limestone and in volcanic protoliths near Muara Sipongi in West Sumatra. They found that enhanced chromium, as well as titanium and vanadium, characterized grossular-rich garnet formed in skarn developed from a volcanic protolith. Garnets in skarn formed in limestone were inversely zoned, and $\mathrm{TiO}_{2}$ contents ranged from 0 to 1.5 weight percent.

The data base for garnet in skarn at Copper Basin allows us to examine variations in garnet chemistry for barren and mineralized skarns formed within the Harmony Formation and to compare garnets in skarn formed in the Harmony protolith with garnets in skarns that developed in the middle member of the Battle Formation and in the Antler Peak Limestone. In a preliminary overview of gold in skarn deposits, Meinert (1988) noted that host rocks for gold skarns are clastic or volcaniclastic, rather than pure carbonate sequences. Most gold mineralization at Copper Basin seems to be localized in skarn formed in the Harmony Formation. However, the Battle Formation and Antler Peak Limestone both host gold skarn deposits elsewhere in the Battle Mountain Mining District. Descriptions of the mineralogy and chemical analyses for the protoliths of skarn in this report (see tables 1,3 ) show that all three stratigraphic units are heterogeneous. In the area north of the Copper Basin Mine, shale and calcareous shale layers are common in the Harmony Formation. Some mafic flows have elevated contents of $\mathrm{TiO}_{2}$ (as much as 2.3 weight percent; table 1) and $\mathrm{Cr}_{2} \mathrm{O}_{3}$ and are intercalated with metasandstone and metasiltstone of the Harmony Formation. In the Copper Basin area, the middle member of the Battle Formation is a calcareous silty shale. Roberts (1964) reported a chemical analysis of a representative sample of calcareous shale containing 0.46 weight percent $\mathrm{TiO}_{2}$. The Antler Peak Limestone in the general area of Copper Basin includes a micrite facies that contains less than 0.1 weight percent $\mathrm{TiO}_{2}$, as well as a silica-rich carbonate siltite facies containing as much as 0.4 weight percent $\mathrm{TiO}_{2}$ (table 3 ). These differences in protolith composition are shown to some extent by garnet compositions of skarn (fig. 95). The decrease in $\mathrm{TiO}_{2}$ content from core to rim noted above in normally zoned garnets in skarn in all three protoliths suggests that titania in the protolith is incorporated into garnet during metamorphism and initial stages of metasomatism. In skarn $\mathrm{A}$, garnet in early-stage K-feldspar+diopside+garnet assemblages is enriched in $\mathrm{TiO}_{2}$ relative to garnet in the late-stage garnet+quartz assemblage that replaces it. For the other skarn bodies formed in the Harmony Formation, the $\mathrm{TiO}_{2}$ content of garnet ranges from 0 to 5 weight percent. Highly andraditic compositions (greater than $\mathrm{Ad}_{95}$ ) are free of titanium. The most titaniferous and chromitiferous compositions present are in grossular-rich garnets in shaly skarn in the northern part of skarn $D$, where local pods of bright-green, uvarovite-rich garnet adjacent to chromite provide clear evidence of reaction between chromite and metasomatic fluids. Garnet composition in sulfide-bearing skarn at the Carissa deposit ranges from $\mathrm{Ad}_{60}$ to $\mathrm{Ad}_{85}$ (less than 0.5 weight percent $\mathrm{TiO}_{2}$ ); garnet from sulfide-bearing skarn in the Contention pit is more aluminous $\left(\mathrm{Ad}_{30}-\mathrm{Ad}_{80}\right)$ and a few garnet cores contain as much as 2 weight percent $\mathrm{TiO}_{2}$. Despite the extensive retrograde alteration of calc-silicates and oxidation of sulfides at the Surprise Mine, early titaniferous, grossular-rich garnets are preserved. Garnet in skarn formed in Battle Formation and in Antler Peak Limestone is somewhat more andraditic and less titaniferous (less than 1 weight percent $\mathrm{TiO}_{2}$ ) than garnet in most of the skarn formed in Harmony Formation. Titanium appears to be somewhat mobile in the metasomatic environment because some garnets incorporated titanium as they grew (for example, fig. 93D) and $\mathrm{TiO}_{2}$ contents as high as about 1 weight percent or so are common regardless of protolith. Titanian andradites are not uncommon in alkaline igneous rocks (Deer and others, 1982), and so there is no crystalchemical basis for the observed decreases in titanium content with increasing andradite content.

FIGURE 95.- $\mathrm{TiO}_{2}$ versus andradite contents in garnets from skarns at Copper Basin. Samples shown in figures $A-J$, and symbols included therein, are same as in figure 89. A, skarn A in the Upper Cambrian Harmony Formation; dots, pyroxenebearing samples; squares, pyroxene-free sample 84JH044. B, skarn $\mathrm{B}$ in the Harmony Formation. $C$, dots, skarn $\mathrm{C}$ in the Harmony Formation; squares, Tertiary diabase endoskarn. $D$, skarn $\mathrm{D}$ in the Harmony Formation along unconformable contact between the Harmony and the Middle Pennsylvanian Battle Formations, north of Surprise fault. $E$, skarn D in the Harmony Formation south of Surprise fault. $F$, skarn $\mathrm{E}$ in middle member of the Battle Formation; dots, samples adjacent to Tertiary porphyritic leucogranite; squares, samples 85JH148 and 85JH149. $G$, skarn F in the Upper Pennsylvanian and Lower Permian Antler Peak Limestone; dots, samples $80 \mathrm{BK} 96$ and $80 \mathrm{BK} 97$; squares, clastic carbonate sample 85JH136. $H$, mineralized skarn at Carissa deposit. $I$, mineralized skarn samples 76CB11 and 85JH129 from Contention pit. $J$, mineralized skarn at Surprise deposit. 


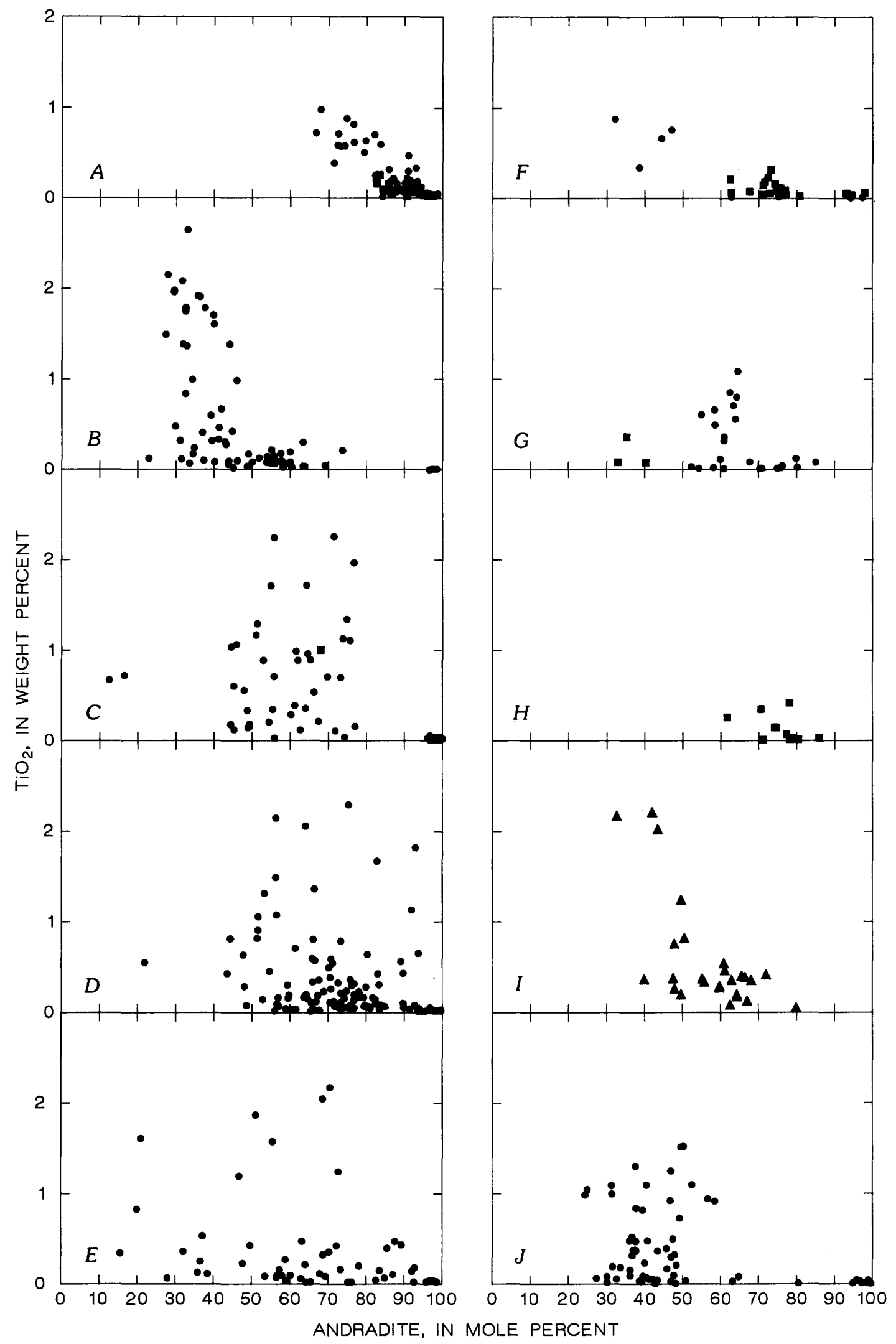


Einaudi (1982b) used the term "skarnoid" for garnet-rich rocks formed in impure carbonate and shale beds where the distinction between metamorphic and metasomatic processes is obscured. He showed that garnets in skarnoids that represent largely metamorphic or local metasomatic (reaction skarn) processes are grossular rich relative to the more andradite rich $\left(\mathrm{Ad}_{80}-\mathrm{Ad}_{100}\right)$ garnets formed during metasomatism. Although skarn A has some of the characteristics of skarnoid, garnet compositions are iron rich, rather than the grossular-rich compositions described elsewhere (for example, for skarnoid in andesite tuff at Yerington, Nev.; Harris and Einaudi, 1982) or for skarnoid in argillaceous limestone at Cananea, Mexico (Meinert, 1982). Theodore and Hammarstrom (1991) documented trends of local iron depletion and enrichment in hornfels and skarn, respectively, at skarn A and suggested that iron was carried by high temperature, highly saline fluids emanating from the nearby Tertiary porphyritic leucogranite stock. The more grossularitic and titaniferous compositions observed in cores of garnet in some of the other skarns may represent relict metamorphic and (or) early metasomatic compositions that retain a chemical signature from the protolith and that failed to equilibrate completely with subsequent fluids that eventually produced well-developed metasomatic zones and overgrowths of nearly pure andradite. Fine-scale oscillations between andraditic and grossularitic compositions in garnet rims are typical of skarn garnets and represent fluctuating conditions (such as temperature changes, changes in fluid composition due to boiling or influx of newly arrived metasomatic or meteoric fluids, and so on) during the prograde stages of skarn growth.

The compositional boundary between isotropic and anisotropic garnet is not clear cut. In general, andradites $\left(\mathrm{Ad}_{95}-\mathrm{Ad}_{100}\right)$ are isotropic, and compositions between $\mathrm{Ad}_{50}$ and $\mathrm{Ad}_{90}$ are anisotropic; few analyses fall in the compositional range $\mathrm{Ad}_{85}-\mathrm{Ad}_{95}$. Except for the red garnets in skarn A, most andradite-rich compositions represent yellow cores or zones surrounded by colorless anisotropic garnet. Andradite in skarn A is distinct because it is uniformly red in hand specimen, is pink to red in thin section, and has higher pyralspite component than other garnets.

Comparison of Copper Basin skarn garnets with compilations for garnets classified by dominant associated metal shows that the garnets fall entirely within the field for calcic skarns associated with copper deposits. Garnets in skarns related to porphyry copper deposits are commonly reddish brown closest to the intrusive and green farther out, and show an overall trend of increasing iron content over time. Tracking the evolution of Copper Basin skarns by mineralogic signatures is difficult because map patterns of surface rocks show that the distribution of skarns is not necessarily constrained by intrusive contacts and Tertiary faulting segments most skarn bodies.

\section{PYROXENE}

The skarn pyroxenes (tables $36,37,41$ ) are essentially solid solutions between diopside and hedenbergite; johannsenite components are low, but tend to increase slightly with increasing hedenbergite content. Although there is considerable scatter in the data (fig. 96), both manganese and sodium tend to increase with increasing iron content. Representative pyroxene analyses were recalculated using MINCLC (Freeborn and others, 1985), a FORTRAN program for recalculating mineral analyses. MINCLC computes formal pyroxene site occupancies and normative pyroxene components based on a scheme that assumes no vacancies and formulates 64 different pyroxene components by using the smallest amounts of a given element to fill sites in the order M2 sites, M1 sites, then tetrahedral sites. Such calculations show that: (1) silicon, aluminum, and sometimes a small amount of ferric iron (approx 0.01 cations) fill the tetrahedral site; (2) calcium is the dominant cation in the eightfold coordinated M2 site, with minor amounts of potassium, sodium, manganese, and ferrous iron; (3) magnesium, ferrous iron, and titanium are the principal cations in the octahedral M1 site; (4) excess ions (commonly calcium) remaining after completely filling available sites are generally less than or equal to 0.02 ; (5) measured amounts of potassium and chromium can be accommodated in terms of ideal end-member components; and (6) sodium is assigned to minor amounts of an acmite or jadeite end-member component by the default normalization scheme. Robinson (1980) cautioned against the use of ideal end members to describe pyroxenes because the choice of end members and the sequence by which they are computed is arbitrary. End members (fig. 97) are defined in terms of cation ratios, as follows: johannsenite $(\mathrm{Jo})=\mathrm{Mn} /\left(\mathrm{Mn}+\mathrm{Mg}+\mathrm{Fe}^{2+}\right)$, diopside $(\mathrm{Di})=\mathrm{Mg} /\left(\mathrm{Mn}+\mathrm{Mg}+\mathrm{Fe}^{2+}\right)$, and hedenbergite $(\mathrm{Hd})=$ $\mathrm{Fe}^{2+} /\left(\mathrm{Mn}+\mathrm{Mg}+\mathrm{Fe}^{2+}\right)$.

Pyroxene in garnet-free hornfels from skarn $\mathrm{A}$ is magnesium rich and manganese poor relative to 
TABLE 41.-Representative analyses of pyroxene from Copper Basin skarns

[c, core; r, rim; /X, at contact with mineral X; [X], enclosed in mineral X. GA, garnet; KF, K-feldspar. ( $n$ ), average of $n$ analyses; n.d., not determined; -, not detected]

\begin{tabular}{|c|c|c|c|c|c|c|c|c|c|c|}
\hline \multirow[b]{2}{*}{$\begin{array}{l}\text { Sample } \\
\text { Grain }\end{array}$} & \multicolumn{6}{|c|}{ Skarn A } & \multicolumn{4}{|c|}{ Skarn B } \\
\hline & $\begin{array}{c}84 \mathrm{JHO} 42 \\
\mathrm{PXI}-1 \\
\mathrm{c}\end{array}$ & $\begin{array}{c}84 \mathrm{JHO} 42 \\
\mathrm{PX1} 1-2 \\
\mathrm{~m}\end{array}$ & $\begin{array}{c}84 \mathrm{JHO} 42 \\
\mathrm{PX} 1-3 \\
\mathrm{r} / \mathrm{KF}\end{array}$ & $\begin{array}{c}\text { 84JH043 } \\
\text { PX6 } \\
\text { (2) }\end{array}$ & $\begin{array}{c}85 \mathrm{JHO} 0 \mathrm{Ob} \\
\mathrm{PX} 4-1 \\
\mathrm{c}\end{array}$ & $\begin{array}{c}85 \mathrm{JH} 070 \mathrm{~b} \\
\mathrm{PX} 4-2 \\
\mathrm{r}\end{array}$ & $\begin{array}{l}\text { OVL-3 } \\
\text { PX3 } \\
\text { (3) }\end{array}$ & $\begin{array}{c}451-332 \\
\text { PX1-1 } \\
c\end{array}$ & $\begin{array}{c}451-332 \\
\text { PX1-3 } \\
r\end{array}$ & $\begin{array}{c}\text { 85JH102 } \\
\text { PX1 } \\
(4)\end{array}$ \\
\hline \multicolumn{11}{|c|}{ Microprobe analyses (weight percent) } \\
\hline $\mathrm{SiO}_{2}$ & 52.6 & 52.4 & 52.2 & 51.5 & 51.1 & 50.4 & 51.2 & 53.3 & 53.4 & 52.1 \\
\hline $\mathrm{Al}_{2} \mathrm{O}_{3}$ & .71 & .74 & .84 & .27 & .16 & .3 & .57 & .12 & .15 & .22 \\
\hline $\mathrm{FeO}^{3}$ & 11.3 & 10.4 & 7.44 & 18.2 & 13.3 & 16.4 & 13.9 & 7.71 & 5.84 & 9.9 \\
\hline $\mathrm{MgO}$ & 12.4 & 12.8 & 14. & 6.77 & 9.88 & 7.91 & 9.65 & 13.4 & 14.4 & 12.2 \\
\hline $\mathrm{CaO}$ & 22.7 & 22.9 & 24.2 & 23.3 & 24.3 & 23.4 & 23.9 & 25.5 & 25.5 & 24.7 \\
\hline $\mathrm{Na}_{2} \mathrm{O}$ & .17 & .23 & .28 & .15 & .21 & .15 & .16 & .04 & .04 & .12 \\
\hline $\mathrm{K}_{2} \mathrm{O}$ & .02 & -- & .07 & -- & -- & -- & N.d. & N.d. & N.d. & .02 \\
\hline $\mathrm{TiO}_{2}$ & .03 & .03 & .09 & .02 & .01 & .02 & .01 & -- & - & .02 \\
\hline $\mathrm{MnO}^{2}$ & .41 & .37 & .22 & .51 & .32 & .81 & .46 & .43 & .35 & .39 \\
\hline Total & 100.34 & $\overline{99.87}$ & $\overline{99.34}$ & $\overline{100.72}$ & $\overline{99.28}$ & $\overline{99.39}$ & $\overline{99.86}$ & $\overline{100.50}$ & $\overline{99.68}$ & $\overline{99.67}$ \\
\hline
\end{tabular}

\begin{tabular}{|c|c|c|c|c|c|c|c|c|c|c|}
\hline \multicolumn{11}{|c|}{ Cations (norma1ized to 4 ) } \\
\hline $\mathrm{Si}$ & 1.98 & 1.97 & 1.95 & 2.00 & 1.97 & 1.97 & 1.97 & 1.98 & 1.98 & 1.97 \\
\hline A1 & .03 & .03 & .04 & .01 & .01 & .01 & .03 & .01 & .01 & .01 \\
\hline $\mathrm{Fe}^{+3}$ & .03 & .04 & .07 & -- & .07 & .06 & .05 & .03 & .03 & .06 \\
\hline $\mathrm{Fe}^{+2}$ & .33 & .29 & .16 & .59 & .36 & .48 & .39 & .21 & .15 & .25 \\
\hline Mg & .7 & .71 & .78 & .39 & .57 & .46 & .55 & .74 & .80 & .69 \\
\hline $\mathrm{Ti}$ & -- & -- & - & -- & -- & - & -- & -- & -- & -- \\
\hline $\mathrm{Mn}$ & .01 & .01 & .01 & .02 & .01 & .03 & .01 & .01 & .01 & .01 \\
\hline $\mathrm{Ca}$ & .91 & .92 & .97 & .97 & 1.00 & .98 & .98 & 1.01 & 1.02 & 1.00 \\
\hline $\mathrm{Na}$ & .01 & .02 & .02 & .01 & .02 & .01 & .01 & -- & - & .01 \\
\hline K & -- & -- & -- & -- & -- & -- & N.d. & N.d. & N.d. & -- \\
\hline \multicolumn{11}{|c|}{ Molecular proportions of end-member pyroxene } \\
\hline Jo & 1.3 & 1.2 & 0.7 & 2.0 & 1.1 & 2.8 & 1.6 & 1.4 & 1.1 & 1.8 \\
\hline $\mathrm{Di}$ & 67.2 & 70.4 & 82 . & 39. & 60.6 & 47.7 & 57.5 & 77.1 & 83. & 72.2 \\
\hline $\mathrm{Hd}$ & 31.5 & 28.4 & 17.3 & 59. & 38.3 & 49.5 & 40.9 & 21.5 & 15.8 & 26.5 \\
\hline
\end{tabular}

pyroxene in garnetiferous samples from the same area. Minimum iron contents of pyroxene and garnet tend to increase from the margins to the center of an outcrop of bedded skarn, as shown by mineral compositions for the west to east traverse from hornfels sample 84JH041 to garnet-quartz skarn 84JH044 (cols. 1-4, table 36). Pyroxene enclosed in garnet is generally too small and anhedral for resolution of core-to-rim compositional differences; core and rim analyses on coarser grains (table 41) show zoning, though not nearly so dramatic as for garnet. Compositional variations within single grains are typically less than $10 \mathrm{~mol}$ percent Di. Rims tend to be iron rich relative to cores, but there are numerous exceptions to this trend. Pyroxene com- positions for skarn B overlap those for skarn A, except for the westernmost sample, 451-332, which contains distinctly more diopsidic pyroxene. Skarn $\mathrm{C}$ includes rocks that contain metasomatic, as well as relict igneous pyroxene. Pyroxene in the diabase is quadrilateral pyroxene, as indicated by lower calcium content. This igneous pyroxene is distinctly enriched in aluminum and titanium relative to the metasomatic pyroxene that occurs bordering garnet-filled veinlets in diabase endoskarn. All the pyroxene in endoskarn sample $85 \mathrm{JH} 088$ appears to be metasomatic. Pyroxenes from veins in endoskarn sample 85JH087 have compositions similar to pyroxenes with relict igneous textures. These latter pyroxenes, though more aluminous than the 
TABLE 41.-Representative analyses of pyroxene from Copper Basin skarns-Continued

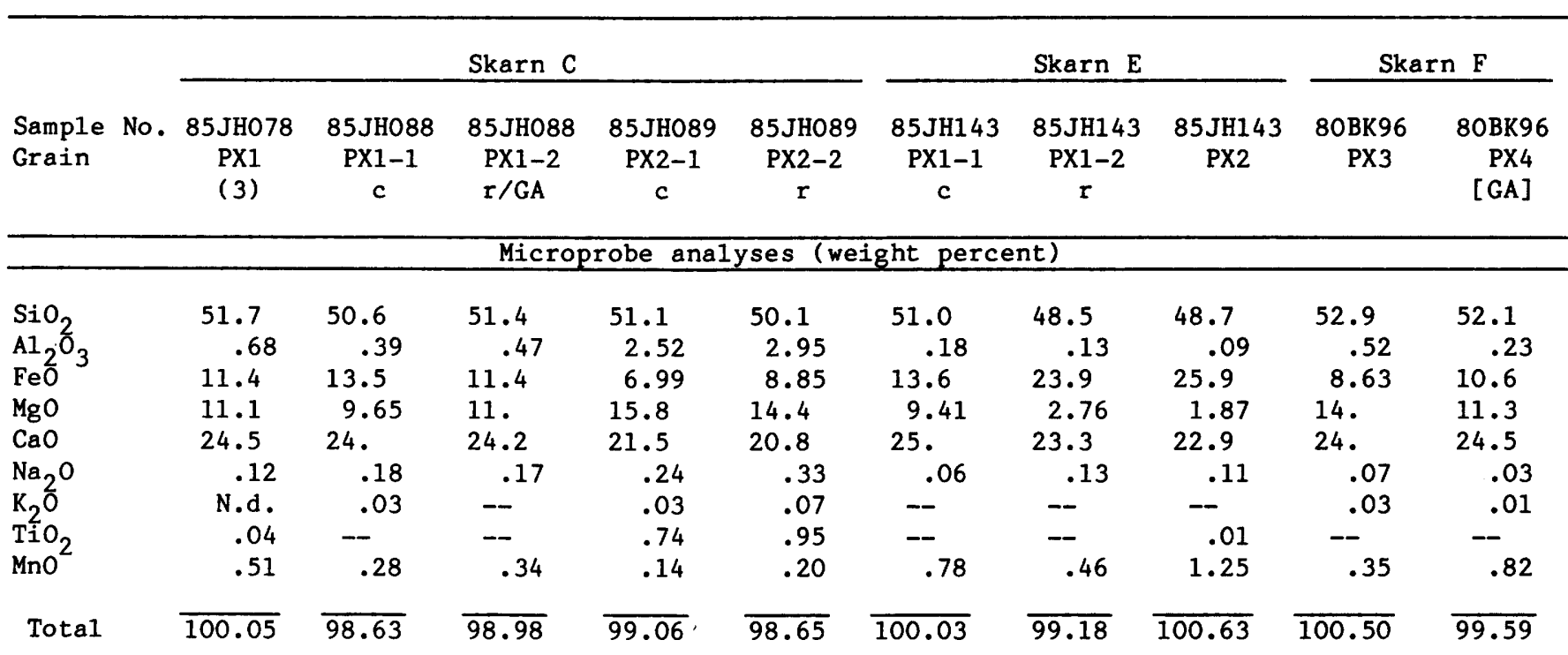

\begin{tabular}{|c|c|c|c|c|c|c|c|c|c|c|}
\hline \multicolumn{11}{|c|}{ Cations (normalized to 4) } \\
\hline $\mathrm{Si}$ & 1.96 & 1.97 & 1.97 & 1.90 & 1.88 & 1.96 & 1.97 & 1.97 & 1.96 & 1.98 \\
\hline $\mathrm{A} 1$ & .03 & .02 & .02 & .11 & .13 & .01 & .01 & -- & .02 & .01 \\
\hline $\mathrm{Fe}^{+3}$ & .06 & .07 & .05 & .08 & .08 & .08 & .06 & .07 & .06 & .03 \\
\hline $\mathrm{Fe}^{+2}$ & .31 & .37 & .31 & .14 & .2 & .36 & .76 & .81 & .21 & .31 \\
\hline $\mathrm{Mg}$ & .63 & .56 & .63 & .88 & .81 & .54 & .17 & .11 & .77 & .64 \\
\hline $\mathrm{Ti}$ & -- & -- & -- & .02 & .03 & -- & -- & -- & -- & -- \\
\hline$M n$ & .02 & .01 & .01 & -- & .01 & .03 & .02 & .04 & .01 & .03 \\
\hline $\mathrm{Ca}$ & 1. & 1. & .99 & .86 & .84 & 1.03 & 1.01 & .99 & .95 & 1. \\
\hline $\mathrm{Na}$ & .01 & .01 & .01 & .02 & .02 & -- & .01 & .01 & .01 & - \\
\hline $\mathrm{K}$ & N.d. & -- & -- & -- & -- & -- & -- & - & -- & - \\
\hline \multicolumn{11}{|c|}{ Molecular proportions of end-member pyroxene } \\
\hline Jo & 1.7 & 1. & 1.2 & .4 & .4 & 2.7 & 1.7 & 4.4 & 1. & 3.1 \\
\hline $\mathrm{Di}$ & 66. & 59.5 & 65.9 & 85.7 & 85.7 & 58.3 & 17.7 & 11.7 & 55.2 & 65.3 \\
\hline $\mathrm{Hd}$ & 32.3 & 39.6 & 32.9 & 13.9 & 19.9 & 39. & 80.6 & 83.9 & 50. & 31.6 \\
\hline
\end{tabular}

vein pyroxenes, do not have compositions that fall within the pyroxene quadrilateral. Pervasive alteration of the rocks and presence of clean, late-stage K-feldspar grains suggest that pyroxenes having relict igneous textures in endoskarn represent incompletely reequilibrated compositions, whereas pyroxenes in the vein-free core of the diabase dike have retained their magmatic signature. Pyroxene is scarce in the massive garnetites of skarn $D$, is always enclosed in another mineral, commonly garnet, and has highly variable compositions. Traces of chromium are detected in pyroxenes in garnet rims from sample 76CB4; the high aluminum and titanium contents in these pyroxenes suggest that they may represent relict igneous compositions. Pyroxene in one sample from skarn formed in the
Battle Formation has the most iron rich compositions observed, whereas pyroxene composition in skarn formed in the Antler Peak Limestone is similar to that of skarns of the Harmony Formation. Relict pyroxene in a clay layer in skarn from the Battle Formation is nearly pure diopside.

\section{EPIDOTE}

Epidote is common in most skarns in the Harmony Formation but is rare in skarn A or in skarn developed in the Battle Formation and Antler Peak Limestone (table 42). Ferric iron is normally restricted to the asymmetric octahedral $M(3)$ site in the epidote-group minerals, resulting in maximum 
observed pistacite contents of $33 \mathrm{~mol}$ percent-that is, one $\mathrm{Fe}^{3+}$ ion substitutes for $\mathrm{Al}$ in the ideal formula $\mathrm{Ca}_{2} \mathrm{Al}_{3} \mathrm{Si}_{3} \mathrm{O}_{12}(\mathrm{OH})$. All but two of the skarn epidote analyses have a mole percentage of pistacite $(\mathrm{Ps})$, defined as $100 *\left[\mathrm{Fe}^{3+} /\left(\mathrm{Fe}^{3+}+\mathrm{Al}\right)\right]$, less than 33. The two anomalous analyses, with $\mathrm{Ps}_{35}$ and $\mathrm{Ps}_{34}$, both represent epidote cores or zones in garnet, rather than discrete epidote crystals. Both analyses have nearly stoichiometric amounts of silicon and calcium, $<2.00 \mathrm{Al}$ cations, $>1.00 \mathrm{Fe}^{3+}$ cations, and reasonable oxide sums, suggesting that the compositions are correct. Tulloch (1979) found epidote with anomalously high pistacite contents $\left(\mathrm{Ps}_{36}-\mathrm{Ps}_{48}\right)$ associated with andradite-grossular garnet and other calcium-aluminum silicates as low-grade alteration products of granitoid biotite, and Meinert (1984) reported exceptionally iron rich epidote compositions $\left(\mathrm{Ps}_{50}-\mathrm{Ps}_{60}\right)$ in veins in calcic iron skarns in British Columbia. Magnesium and titanium are present in minor concentrations and sodium is negligible. Manganese contents are generally low (less than 0.10 weight percent $\mathrm{MnO}$ ), but a few analyses show as much as 0.4 weight percent $\mathrm{MnO}$. All epidotes are zoned, with rims always more alumi-

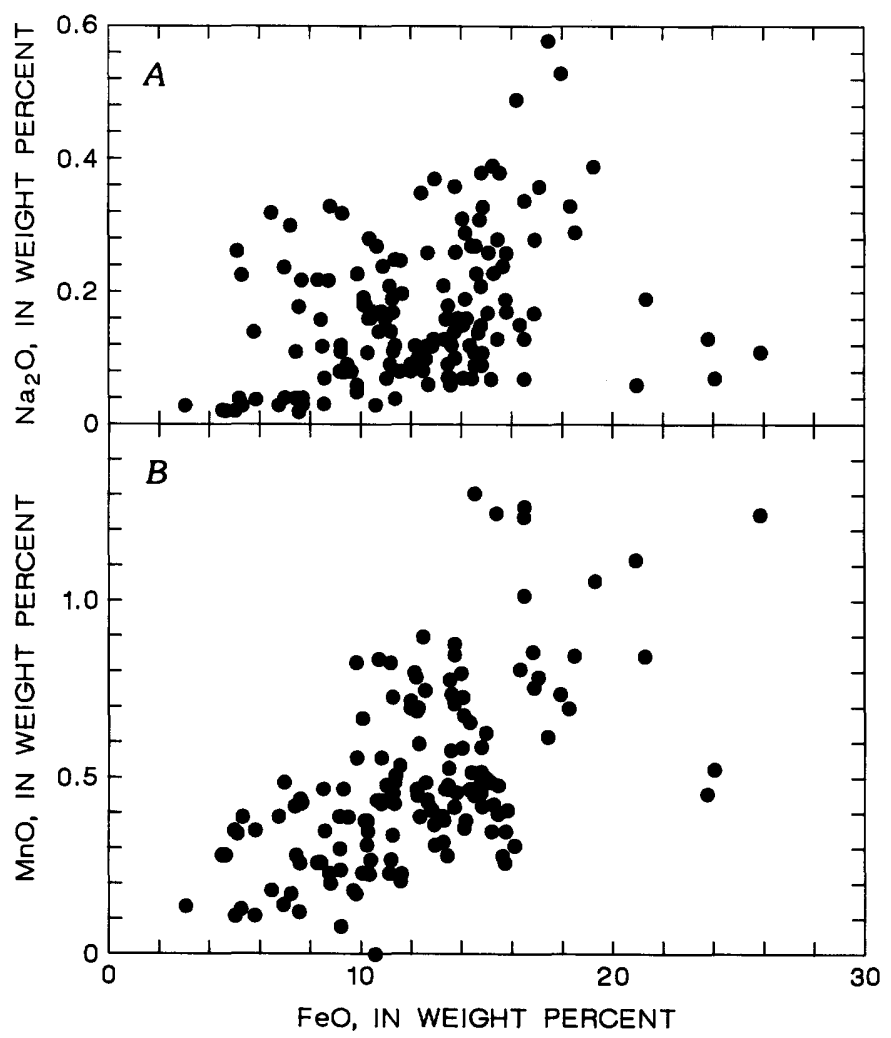

Figure 96.-Total iron as $\mathrm{FeO}$ versus sodium oxide $(A)$ and manganese oxide $(B)$ contents in Copper Basin pyroxenes. nous than cores; this zoning is opposite to the normal zoning trend observed for early-generation skarn garnets. Ranges of epidote composition overlap among the different skarns, but epidote in skarn $\mathrm{C}$ tends to be more aluminous (fig. 98).

Kitamura (1975) examined aluminum-iron partitioning in coexisting garnet-epidote pairs from copper skarns of the Chichibu Mine in Japan. He defined a partition coefficient based on the

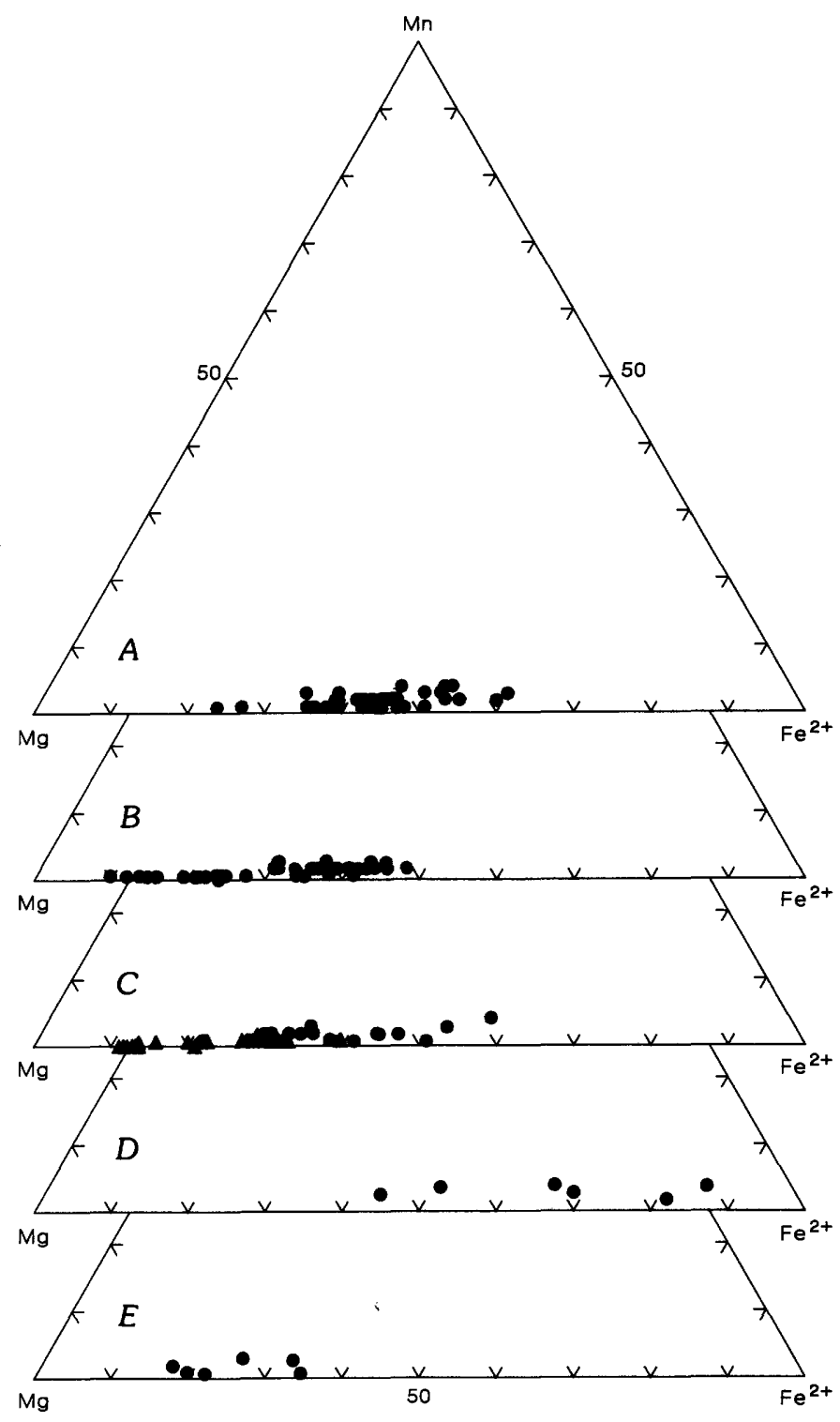

FIgURE 97.-Compositions of Copper Basin pyroxenes in terms of molecular proportions of Mn (johannsenite), $\mathrm{Mg}$ (diopside), and $\mathrm{Fe}^{2+}$ (hedenbergite). A, skarn A, Upper Cambrian Harmony Formation. $B$, skarn $\mathrm{B}$, Harmony Formation. $C$, skarn $\mathrm{C}$, Harmony Formation; triangles, diabase endoskarn; dots, exoskarn. $D$, skarn E, sample 85JH143, Middle Pennsylvanian Battle Formation. $E$, skarn G, sample 80BK96 Upper Pennsylvanian and Lower Permian Antler Peak Limestone. 
TABLE 42.-Representative analyses of epidote from Copper Basin skarns

[c, core; r, rim; /X, at contact with mineral X; [X], enclosed in mineral X. GA, garnet; KF, K-feldspar; OP, opaque minerals. Total iron reported as Fe $\mathrm{O}_{3}$; Ps, mole percentage of pistacite, defined as $100 *\left(\mathrm{Fe}^{3+} /\left(\mathrm{Fe}^{3+}+\mathrm{Al}\right)\right)$. $(n)$, average of $n$ spot analyses; n.d., not determined; - , not detected]

\begin{tabular}{|c|c|c|c|c|c|c|c|c|c|c|c|c|}
\hline $\begin{array}{l}\text { Sample } \\
\text { Grain }\end{array}$ & $\begin{array}{c}\text { Skarn A } \\
\text { 85JH069 } \\
\text { EP1 } \\
\text { (4) }\end{array}$ & $\begin{array}{c}\text { 85JH097 } \\
\text { EP3-1 } \\
\text { r/KF }\end{array}$ & $\begin{array}{c}85 \mathrm{JH097} \\
\text { EP3-2 } \\
\text { c }\end{array}$ & $\begin{array}{c}\text { Sks } \\
\text { 85JH097 } \\
\text { EP5-1 } \\
\text { c }\end{array}$ & $\begin{array}{c}\text { rn B } \\
\text { 85JH097 } \\
\text { EP5-2 } \\
\text { r }\end{array}$ & $\begin{array}{c}451-332 \\
\text { EP1 } \\
\text { (5) }\end{array}$ & $\begin{array}{c}451-332 \\
\text { EP3 } \\
{[\mathrm{GA}](2)}\end{array}$ & $\begin{array}{c}85 \mathrm{JHO} 78 \\
\text { EP1 } \\
\text { /OP (2) }\end{array}$ & $\begin{array}{c}\text { Skarn C } \\
\text { 85JH079 } \\
\text { EP2-2 } \\
\text { C }\end{array}$ & $\begin{array}{c}85 \mathrm{JHO} 079 \\
\text { EP2-1 } \\
\text { r/KF }\end{array}$ & $\begin{array}{c}\text { Skarn D } \\
76 \text { CB3 } \\
\text { EP1-1 } \\
\text { (3) }\end{array}$ & $\begin{array}{c}\text { Skarn E } \\
\text { 85JH142 } \\
\text { EP1-2 }\end{array}$ \\
\hline \multicolumn{13}{|c|}{ Microprobe analyses (weight percent) } \\
\hline $\begin{array}{l}\mathrm{SiO}_{2} \\
\mathrm{Al}_{2} \mathrm{O}_{3} \\
\mathrm{Fe}_{2} \mathrm{O}_{3} \\
\mathrm{MgO}_{3} \\
\mathrm{CaO} \\
\mathrm{Na}_{2} \mathrm{O} \\
\mathrm{K}_{2} \mathrm{O} \\
\mathrm{TiO}_{2} \\
\mathrm{MnO}\end{array}$ & $\begin{array}{r}38.2 \\
23.4 \\
14.3 \\
.14 \\
23.6 \\
.02 \\
\text { N.d. } \\
.02 \\
.01\end{array}$ & $\begin{array}{c}37.7 \\
24.9 \\
11 . \\
.12 \\
23.6 \\
.01 \\
.09 \\
.06 \\
.05\end{array}$ & $\begin{array}{c}36.9 \\
23.4 \\
12.8 \\
.12 \\
23.3 \\
-- \\
.01 \\
.06 \\
.1\end{array}$ & $\begin{array}{c}37.7 \\
21.7 \\
14.3 \\
.13 \\
23.4 \\
.01 \\
-- \\
.06 \\
.02\end{array}$ & $\begin{array}{c}37.1 \\
24.1 \\
11 . \\
.14 \\
23.7 \\
.01 \\
.01 \\
.02 \\
.11\end{array}$ & $\begin{array}{c}37.6 \\
22.6 \\
15.3 \\
.18 \\
23.1 \\
.01 \\
\text { N.d. } \\
.04 \\
.13\end{array}$ & $\begin{array}{c}37.6 \\
20.9 \\
17.7 \\
.18 \\
23.2 \\
-- \\
\text { N.d. } \\
.02 \\
.01\end{array}$ & $\begin{array}{r}37.6 \\
22.7 \\
14.7 \\
-- \\
23.4 \\
.01 \\
\text { N.d. } \\
.06 \\
.06\end{array}$ & $\begin{array}{c}37.3 \\
23.6 \\
15 . \\
.14 \\
22.9 \\
.01 \\
-- \\
.07 \\
.17\end{array}$ & $\begin{array}{r}38.1 \\
26.5 \\
8.7 \\
.1 \\
23.6 \\
.01 \\
.04 \\
.09 \\
.04\end{array}$ & $\begin{array}{r}36.9 \\
23.4 \\
13.3 \\
.17 \\
23.5 \\
.- \\
\text { N.d. } \\
.21 \\
.07\end{array}$ & $\begin{array}{c}37.1 \\
20.9 \\
18.1 \\
-- \\
23.8 \\
-- \\
-- \\
.01 \\
.02\end{array}$ \\
\hline $\begin{array}{l}\mathbf{F} \\
\mathrm{C} 1\end{array}$ & $\begin{array}{l}\text { N.d. } \\
\text { N.d. }\end{array}$ & -- & $\begin{array}{l}.1 \\
.02\end{array}$ & -05 & $\begin{array}{l}.1 \\
.03\end{array}$ & $\begin{array}{l}\text { N.d. } \\
\text { N.d. }\end{array}$ & $\begin{array}{l}\text { N.d. } \\
\text { N.d. }\end{array}$ & $\begin{array}{l}\text { N.d. } \\
\text { N.d. }\end{array}$ & -.03 & - & $\begin{array}{l}\text { N.d. } \\
\text { N.d. }\end{array}$ & -- \\
\hline Tota1 ${ }^{1}$ & $\overline{99.69}$ & 97.6 & 96.7 & $\overline{97.3}$ & 96.3 & $\overline{99.1}$ & $\overline{99.61}$ & $\overline{98.53}$ & 99.2 & $\overline{97.18}$ & $\overline{97.55}$ & $\overline{99.93}$ \\
\hline
\end{tabular}

\begin{tabular}{|c|c|c|c|c|c|c|c|c|c|c|c|c|}
\hline & & & & & ons ba & 1 on 12 . & oxygens & & & & & \\
\hline Si & 2.99 & 2.99 & 2.97 & 3.03 & 2.99 & 2.98 & 2.99 & 2.99 & 2.95 & 3.01 & 2.96 & 2.95 \\
\hline A1 & 2.17 & 2.33 & 2.23 & 2.06 & 2.3 & 2.11 & 1.96 & 2.13 & 2.2 & 2.46 & 2.21 & 1.96 \\
\hline $\mathrm{Fe}^{+3}$ & .84 & .66 & .78 & .86 & .66 & .91 & 1.06 & .88 & .89 & .52 & .80 & 1.08 \\
\hline $\mathrm{Mg}$ & .02 & .01 & .01 & .02 & .02 & .02 & .02 & - & .02 & .01 & .02 & -- \\
\hline $\mathrm{Ti}$ & - & - & -- & -- & - & -- & -- & -- & -- & - & -- & -- \\
\hline \multirow[t]{2}{*}{ Mn } & -- & -- & .01 & -- & .01 & .01 & -- & -- & .01 & - & - & -- \\
\hline & $\overline{3.03}$ & $\overline{3.01}$ & $\overline{3.03}$ & $\overline{2.95}$ & $\overline{2.99}$ & $\overline{3.06}$ & $\overline{3.04}$ & $\overline{3.01}$ & $\overline{3.12}$ & $\overline{3.00}$ & $\overline{3.05}$ & $\overline{3.04}$ \\
\hline $\mathrm{Ca}$ & 1.98 & 2.01 & 2.02 & 2.02 & 2.04 & 1.96 & 1.98 & 1.99 & 1.94 & 1.99 & 2.01 & 2.03 \\
\hline $\mathrm{Na}$ & - & -- & -- & - & -- & -- & - & -- & -- & -- & -- & -- \\
\hline \multirow[t]{2}{*}{$\mathbf{K}$} & N.d. & .01 & - & -- & -- & N.d. & N.d. & N.d. & -- & - & N.d. & -- \\
\hline & $\overline{1.98}$ & $\overline{2.02}$ & $\overline{2.02}$ & $\overline{2.02}$ & $\overline{2.04}$ & $\overline{1.96}$ & $\overline{1.98}$ & $\overline{1.99}$ & $\overline{1.94}$ & $\overline{1.99}$ & $\overline{2.01}$ & $\overline{2.03}$ \\
\hline Ps & 28.0 & 22.0 & 25.9 & 29.5 & 22.5 & 30.2 & 35.1 & 29.3 & 28.8 & 17.3 & 26.6 & 35.5 \\
\hline
\end{tabular}

1 Totals adjusted for oxygen equivalent of $\mathrm{F}$ and $\mathrm{C} 1$.

aluminum-iron exchange reaction andradite+ clinozoisite $=$ grossular + pistacite as $\mathrm{K}^{\prime}=\mathrm{Al} / \mathrm{Fe}$ in garnet $/(\mathrm{Al} / \mathrm{Fe})$ in the epidote $\mathrm{M}(3)$ site. Kitamura found that garnet-epidote pairs formed at temperatures greater than $400{ }^{\circ} \mathrm{C}$ (in vesuvianite+ diopside+anorthite assemblages) had smaller $\mathrm{K}^{\prime}$ values than pairs formed at lower temperatures (in chlorite+calcite+actinolite+magnetite assemblages). For coexisting minerals in several Japanese mines, he found that values for $\mathrm{K}^{\prime}$ typically ranged from 1.7 to 10 and suggested that $\mathrm{K}^{\prime}$ decreases with increasing temperature. $\mathrm{K}^{\prime}$ values computed for 13 mineral pairs from Copper Basin skarns, using only points analyzed at garnet-epidote contacts, range from 1 to 10 (fig. 99). Bird and Helgeson
(1980) considered the effects of substitutional order/disorder for epidote and confirmed the temperature dependence of the equilibrium constant for the exchange reaction by calculating theoretical compositions of coexisting epidote and garnet solid solutions from thermodynamic data. They also demonstrated that the equilibrium constant for the reaction is essentially independent of pressure and that compositions for natural pairs of coexisting garnets and epidotes from skarns, metamorphic rocks, and geothermal systems lie within the range of the calculated curves. Garnet-epidote pairs from skarns at Copper Basin (fig. 100) overlap the ironrich end of the calculated curves. Mineral pairs from skarn B and D mostly lie within the field for 


\begin{tabular}{|cc|cccc|}
\hline SKARN & $\begin{array}{c}\text { SAMPIE } \\
\text { NO. } \\
\text { (fig. 86) }\end{array}$ & \multicolumn{5}{c|}{ PISTACITE CONTENT, } \\
IN MOLE PERCENT
\end{tabular}

FIGURE 98.-Range of epidote compositions for Copper Basin skarns in terms of mole percentage of pistacite. Each point represents a single analysis.

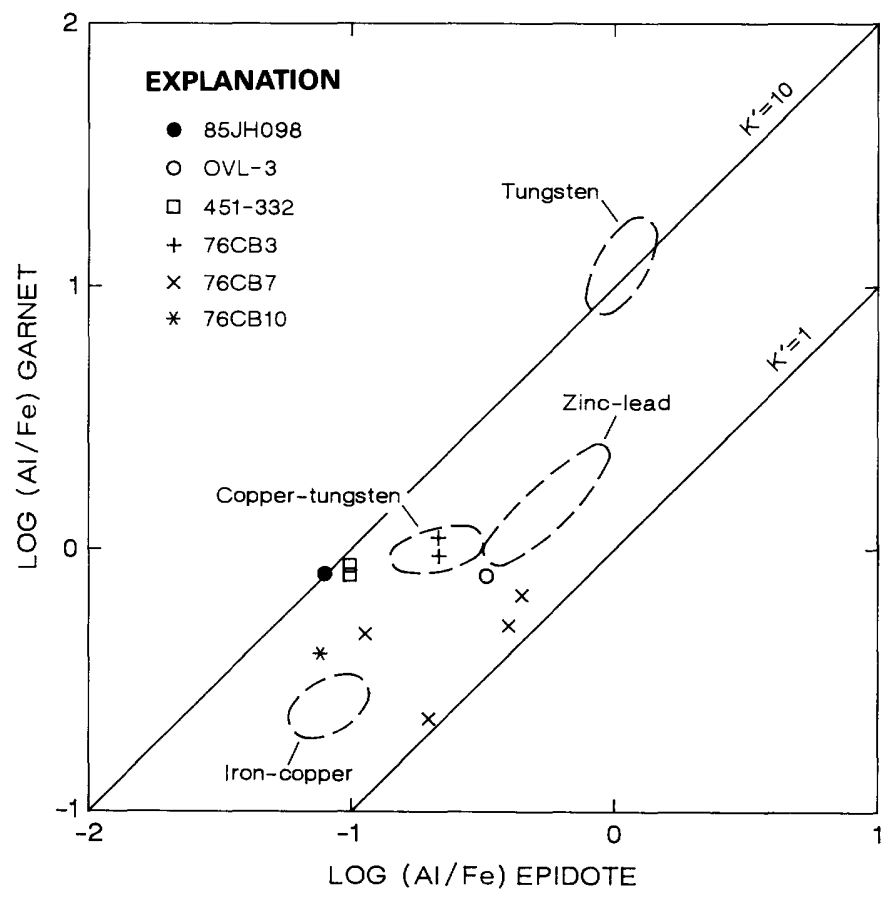

FIgURE 99.-Compositions of coexisting epidote-garnet pairs from skarns in the Upper Cambrian Harmony Formation at Copper Basin. Compositions are plotted in terms of a partition coefficient $\mathrm{K}^{\prime}$, defined by Kitamura (1975) as $(\mathrm{Al} / \mathrm{Fe})$ in garnet $/(\mathrm{Al} / \mathrm{Fe})$ in the $\mathrm{M}(3)$ site of epidote, based on the $\mathrm{Al}-\mathrm{Fe}$ exchange reaction andradite+clinozoisite $=$ grossular + pistacite. Dashed fields outline Kitamura's fields for garnet-epidote pairs from several types of Japanese contact-metasomatic ore deposits. Skarn B, samples 85JH098, OVL-3, and 451-332; Skarn $\mathrm{D}$, samples $76 \mathrm{CB} 3$ and $76 \mathrm{CB} 7$; Carissa Mine area, sample 76CB10. Multiple epidote-garnet pairs are plotted for some samples. epidote and garnet compositions reported by Kitamura (1975) for Japanese skarn deposits. Multiple garnet-epidote pairs from the same sample tend to cluster; however, the assumption of even local equilibrium may be invalid for complex metasomatic processes and, in many samples, textures indicate that epidote selectively replaces zones in garnet. Garnet in direct contact with epidote was not analyzed for skarn $\mathrm{C}$ samples. The range of garnet and epidote compositions observed for skarn $\mathrm{C}$, however, partly overlaps the mineral pairs from skarn $B$ and $D$ and extends to more iron rich garnet compositions. In addition, the data base is too

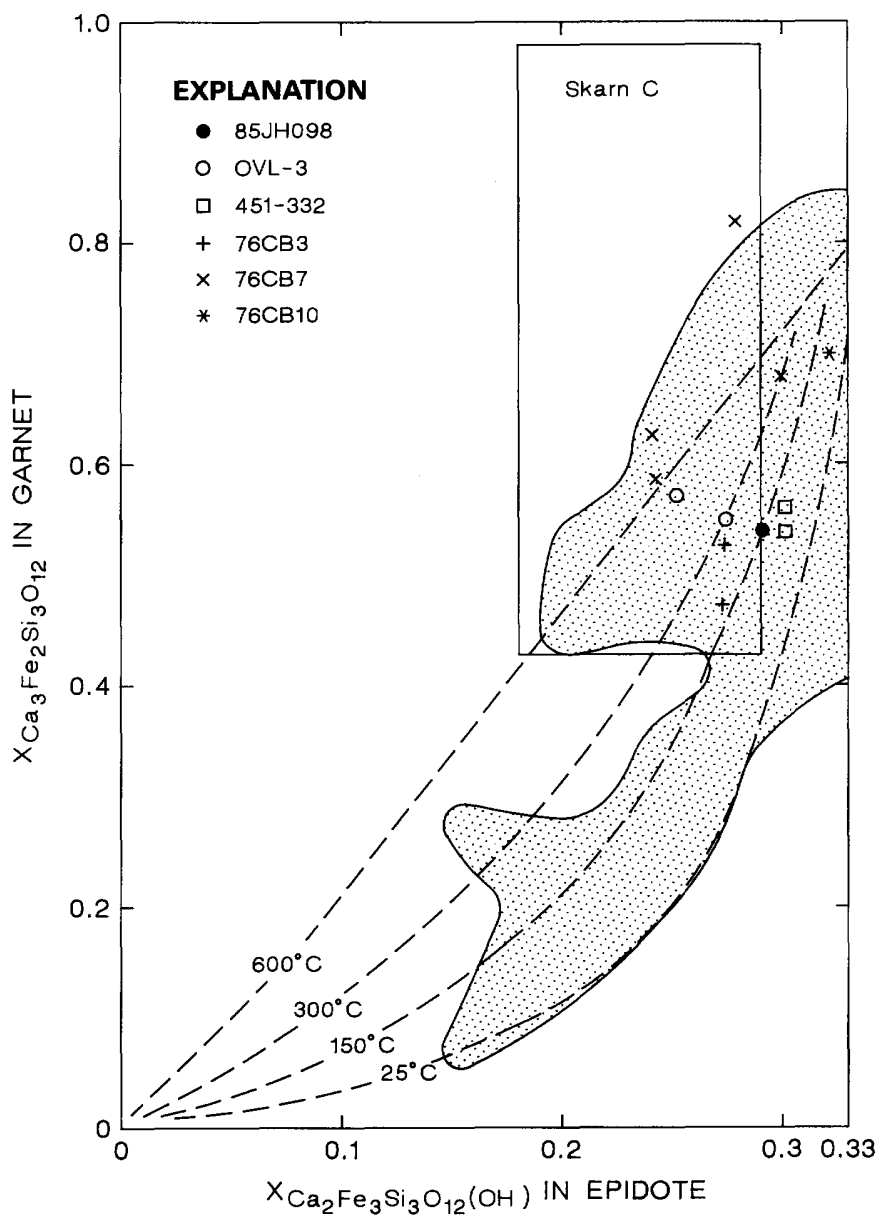

FIGURE 100.-Compositions of natural pairs of coexisting garnets and epidotes from skarns at Copper Basin versus mole fractions of andradite and pistacite in garnet and epidote, respectively. For skarn C, field encompasses all garnet and epidote compositions. Shaded area, field of coexisting natural garnet and epidote compositions reported by Kitamura (1975) for Japanese skarn deposits. Dashed curves, Bird and Helgeson's (1980, fig. 15) curves calculated from thermodynamic data for coexisting garnet and epidote for temperatures from 25 to $600{ }^{\circ} \mathrm{C}$ at $1 \mathrm{kbar}$. Skarn samples same as in figure 99 . 
TABLE 43.-Representative analyses of amphibole from Copper Basin skarns

[/X, at contact with mineral X; [X], enclosed in mineral X. CHL, chlorite; CC, calcite; GA, garnet; PX, pyroxene; PY, pyrite. FeO(T), total iron reported as $\mathrm{FeO}$; $\mathrm{Fe}_{2} \mathrm{O}_{3}$ and $\mathrm{FeO}$ computed from ideal amphibole formula (see text). ( $n$ ), average of $n$ analyses; n.d. not determined; - , not detected]

\begin{tabular}{|c|c|c|c|c|c|c|c|c|c|c|}
\hline Analysis & 1 & 2 & 3 & 4 & 5 & 6 & 7 & 8 & 9 & 10 \\
\hline & \multicolumn{4}{|c|}{ Skarn D } & \multirow{2}{*}{$\begin{array}{c}\text { Skarn E } \\
\begin{array}{c}\text { AM1 } \\
\text { SH140 }\end{array}\end{array}$} & \multicolumn{5}{|c|}{ Skarn F } \\
\hline $\begin{array}{l}\text { Sample No. } \\
\text { Grain }\end{array}$ & $\begin{array}{l}76 \text { CB7 } \\
\text { AM1-1 }\end{array}$ & $\begin{array}{c}76 \text { CB9 } \\
\text { AM1 } \\
{[\mathrm{GA}]}\end{array}$ & $\begin{array}{c}76 \mathrm{CB} 9 \\
\text { AM2 } \\
{[\mathrm{GA}]}\end{array}$ & $\begin{array}{c}76 \mathrm{CB} 10 \\
\mathrm{AM} 1 \\
{[\mathrm{PY}]}\end{array}$ & & $\begin{array}{c}85 \text { JH1 } 48 \\
\text { AM2-2 }\end{array}$ & $\begin{array}{c}\text { 85JH148 } \\
\text { AM3-3 }\end{array}$ & $\begin{array}{c}\text { 85JH149 } \\
\text { AM1 } \\
\text { (2) }\end{array}$ & $\begin{array}{c}80 \text { BK97 } \\
\text { AM1 } \\
{[\mathrm{GA}]}\end{array}$ & $\begin{array}{c}80 \mathrm{BK} 97 \\
\text { AM3 } \\
/ \mathrm{CHL}, \mathrm{CC}\end{array}$ \\
\hline \multicolumn{11}{|c|}{ Microprobe analyses (weight percent) } \\
\hline $\mathrm{SiO}_{2}$ & 49.7 & 53.2 & 49.9 & 53.0 & 50.0 & 51.9 & 53.9 & 49.9 & 51.7 & 53.0 \\
\hline $\mathrm{Al}_{2} \mathrm{O}_{3}$ & 4.11 & 1.9 & 3.31 & .94 & 4.42 & 1.5 & 1.8 & 2.96 & 2.48 & 2.33 \\
\hline $\mathrm{FeO}(\overrightarrow{\mathrm{T}})$ & 24.5 & 23.3 & 20.8 & 17.9 & 15.3 & 21.2 & 13.9 & 18. & 18.5 & 15.4 \\
\hline $\mathrm{MgO}$ & 7.38 & 8.89 & 10.5 & 13.5 & 13.4 & 11.1 & 15.3 & 12.1 & 11.9 & 14. \\
\hline $\mathrm{CaO}$ & 9.74 & 11.3 & 12.1 & 12.3 & 12.7 & 10.5 & 12.3 & 11.1 & 12.1 & 12.6 \\
\hline $\mathrm{Na}_{2} \mathrm{O}$ & .3 & .3 & .26 & .05 & .38 & .26 & .21 & .27 & .3 & .23 \\
\hline $\mathrm{K}_{2} \mathrm{O}$ & .33 & .2 & .26 & .02 & .23 & .14 & .17 & .18 & .19 & .14 \\
\hline $\mathrm{TiO}_{2}$ & .02 & .06 & -- & -- & .04 & .07 & .05 & .05 & .08 & .01 \\
\hline $\mathrm{MnO}^{2}$ & .26 & .11 & .18 & .51 & .29 & .32 & .27 & .23 & .23 & .21 \\
\hline $\mathrm{Cr}_{2} \mathrm{O}_{3}$ & -- & - & -- & - & N.d. & N.d. & N.d. & N.d. & N.d. & N.d. \\
\hline $\mathrm{Cl}^{23}$ & N.d. & N.d. & N.d. & N.d. & .02 & .01 & .01 & .02 & .02 & .01 \\
\hline $\mathbf{F}$ & N.d. & N.d. & N.d. & N.d. & .3 & .1 & .3 & .4 & .4 & .2 \\
\hline $\operatorname{Tota}^{1}$ & $\overline{96.34}$ & $\overline{99.26}$ & $\overline{97.31}$ & $\overline{98.22}$ & $\overline{97.0}$ & 97.1 & $\overline{98.1}$ & 95.0 & 97.8 & $\overline{98.1}$ \\
\hline
\end{tabular}

small to generalize on the utility of such diagrams for estimating temperatures for garnet-epidote equilibrium assemblages. The data are useful in showing that compositions of coexisting epidotegarnet pairs from Copper Basin skarns: (1) overlap the compositional ranges for many other skarn deposits; (2) overlap the entire temperature range $25-600{ }^{\circ} \mathrm{C}$ for calculated curves for theoretical garnet-epidote equilibrium at $1 \mathrm{kbar}$; and (3) are apparently somewhat iron rich compared with epidote-garnet pairs from some other skarn deposits.

\section{AMPHIBOLE}

Amphiboles in Copper Basin skarns (table 43) are all calcic. The program of Rock and Leake $(1984 a, b)$ was used to estimate ferric iron on the basis of amphibole stoichiometric constraints, recalculate the microprobe data on a 23-oxygen formula basis, and assign formal names recommended by the International Mineralogical Association. Results show that the names actinolite, ferroactinolite, ferriactinolite, or actinolitic hornblende apply. Estimates of ferric iron content range from 10 to 40 weight percent total $\mathrm{Fe}$. Alkali contents are low $\left(\mathrm{Na}+\mathrm{K}\right.$, approx 0.1 cation). $\mathrm{Al}_{2} \mathrm{O}_{3}$ content ranges from 0.9 to 5.4 weight percent, and minor amounts of octahedral aluminum are present in most analyses. Minor amounts (approx 0.2 weight percent) of $\mathrm{MnO}$ are detected in all analyses; titanium and chlorine contents are negligible. Fluorine was detected in all analyses, ranging from 0.1 to 0.5 weight percent. Amphiboles from skarn $D$ tend to be more iron rich than amphiboles from other skarns (fig. 101). As a group, the Copper Basin amphiboles overlap the iron-rich end of the range of amphibole compositions reported for porphyryrelated skarns at Cananea (Mexico), Yerington, Ely, and Bingham and extend to more iron rich compositions.

\section{PHYLLOSILICATE MINERALS}

Biotite is present only in hornfels associated with bedded skarn (table 44). Biotite from two closely spaced samples has quite different compositions. In both samples, biotite is evenly distributed throughout the hornfels, which consists of biotite, plagioclase, K-feldspar, and pyroxene. Sample 84JH041 contains red, anhedral biotite that is enriched in iron, titanium, and manganese relative to the brown, phlogopitic biotite in sample 84JH042. Sample 84JH042 contains detrital chromite grains, 
TABLE 43.-Representative analyses of amphibole from Copper Basin skarns-Continued

\begin{tabular}{|c|c|c|c|c|c|c|c|c|c|c|}
\hline Analysis & 1 & 2 & 3 & 4 & 5 & 6 & 7 & 8 & 9 & 10 \\
\hline $\begin{array}{l}\text { Sample No. } \\
\text { Grain }\end{array}$ & $\begin{array}{l}76 \text { CB7 } \\
\text { AMI-1 }\end{array}$ & $\begin{array}{c}\text { Ska } \\
76 \mathrm{CB} 9 \\
\mathrm{AM} 1 \\
{[\mathrm{GA}]}\end{array}$ & $\begin{array}{c}\text { D } \\
76 \text { CB9 } \\
\text { AM2 } \\
{[\mathrm{GA}]}\end{array}$ & $\begin{array}{c}76 \mathrm{CB} 10 \\
\mathrm{AM} 1 \\
{[\mathrm{PY}]}\end{array}$ & $\frac{\text { Skarn E }}{85 \mathrm{JH1} 40}$ & $\begin{array}{l}85 \text { JH1 } 48 \\
\text { AM2-2 }\end{array}$ & $\begin{array}{c}85 \mathrm{JH} 148 \\
\text { AM3-3 }\end{array}$ & $\begin{array}{c}\text { Skarn F } \\
\text { 85JH149 } \\
\text { AM1 } \\
\text { (2) }\end{array}$ & $\begin{array}{c}80 \mathrm{BK} 97 \\
\mathrm{AMI} \\
{[\mathrm{GA}]}\end{array}$ & $\begin{array}{c}\text { 80BK97 } \\
\text { AM3 } \\
/ \mathrm{CHL}, \mathrm{CC}\end{array}$ \\
\hline \multicolumn{11}{|c|}{ Cations based on 230} \\
\hline $\begin{array}{l}\mathrm{Si} \\
\mathrm{A} 1^{i v}\end{array}$ & $\begin{array}{r}7.49 \\
.51\end{array}$ & $\begin{array}{r}7.83 \\
.17\end{array}$ & $\begin{array}{r}7.46 \\
.54\end{array}$ & $\begin{array}{r}7.69 \\
.16\end{array}$ & $\begin{array}{r}7.36 \\
.64\end{array}$ & $\begin{array}{r}7.64 \\
.26\end{array}$ & $\begin{array}{r}7.73 \\
.27\end{array}$ & $\begin{array}{r}7.48 \\
.52\end{array}$ & $\begin{array}{r}7.62 \\
.38\end{array}$ & $\begin{array}{r}7.68 \\
.32\end{array}$ \\
\hline $\mathrm{T}$ & $\overline{8.00}$ & $\overline{8.00}$ & $\overline{8.00}$ & $\overline{7.85}$ & $\overline{8.00}$ & $\overline{7.90}$ & $\overline{8.00}$ & $\overline{8.00}$ & $\overline{8.00}$ & $\overline{8.00}$ \\
\hline $\begin{array}{l}\mathrm{Al}^{\mathrm{vi}} \\
\mathrm{Fe}^{3+} \\
\mathrm{Fe}^{2+} \\
\mathrm{Mg}\end{array}$ & $\begin{array}{r}0.22 \\
.99 \\
2.1 \\
1.66\end{array}$ & $\begin{array}{r}0.16 \\
.31 \\
2.56 \\
1.95\end{array}$ & $\begin{array}{r}0.04 \\
.49 \\
2.11 \\
2.34\end{array}$ & $\begin{array}{l}-- \\
0.64 \\
1.54 \\
2.92\end{array}$ & $\begin{array}{r}0.13 \\
.21 \\
1.68 \\
2.95\end{array}$ & $\begin{array}{l}-- \\
0.97 \\
1.64 \\
2.44\end{array}$ & $\begin{array}{r}0.03 \\
.22 \\
1.45 \\
3.26\end{array}$ & $\begin{array}{r}0.01 \\
.63 \\
1.63 \\
2.71\end{array}$ & $\begin{array}{l}0.05 \\
.18 \\
2.1 \\
2.63\end{array}$ & $\begin{array}{r}0.08 \\
.12 \\
1.74 \\
3.03\end{array}$ \\
\hline Mn & .03 & .01 & .02 & .06 & .04 & .04 & .03 & .03 & .03 & .03 \\
\hline $\mathrm{Ti}$ & -- & .01 & -- & -- & -- & .01 & .01 & .01 & .01 & -- \\
\hline $\mathrm{Cr}$ & - & -- & - & -- & N.D. & N.d. & N.d. & N.d. & N.d. & N.d. \\
\hline M1-M3 & $\overline{5.00}$ & $\overline{5.00}$ & $\overline{4.99}$ & $\overline{5.15}$ & $\overline{5.00}$ & $\overline{5.10}$ & $\overline{5.00}$ & $\overline{5.01}$ & $\overline{5.00}$ & $\overline{5.00}$ \\
\hline $\mathrm{Ca}$ & 1.57 & 1.78 & 1.94 & 1.90 & 2.00 & 1.66 & 1.89 & 1.79 & 1.92 & 1.95 \\
\hline $\mathrm{Na}$ & .09 & .09 & .06 & .01 & -- & .07 & .06 & .08 & .08 & .05 \\
\hline M4 & $\overline{1.66}$ & $\overline{1.87}$ & $\overline{2.00}$ & $\overline{1.91}$ & $\overline{2.00}$ & $\overline{1.73}$ & $\overline{1.95}$ & $\overline{1.87}$ & $\overline{2.00}$ & $\overline{2.00}$ \\
\hline $\mathrm{Ca}$ & -- & -- & - & -- & -- & - & - & - & -- & -- \\
\hline $\mathrm{Na}$ & -- & - & 0.02 & - & 0.11 & -- & -- & -- & 0.01 & 0.02 \\
\hline K & 0.06 & 0.04 & .05 & -- & .04 & 0.03 & 0.03 & 0.03 & .04 & .03 \\
\hline A & $\overline{0.06}$ & $\overline{0.04}$ & $\overline{0.07}$ & $\overline{--}$ & $\overline{0.15}$ & $\overline{0.03}$ & $\overline{0.03}$ & $\overline{0.03}$ & $\overline{0.05}$ & $\overline{0.05}$ \\
\hline $\mathrm{Cl}$ & N.d. & N.d. & N.d. & N.d. & 0.01 & -- & - & 0.01 & 0.01 & -- \\
\hline$F$ & N.d. & N.d. & N.d. & N.d. & .15 & 0.04 & 0.15 & .18 & .16 & 0.11 \\
\hline $\mathrm{Mg} /(\mathrm{Mg}+\mathrm{Fe})$ & 0.44 & 0.43 & 0.53 & 0.66 & 0.64 & 0.60 & 0.69 & 0.63 & 0.56 & 0.64 \\
\hline
\end{tabular}

\footnotetext{
1. ferro-actinolitic hornblende

2. ferro-actinolite

3. actinolitic hornblende

4. actinolite

5. actinolitic hornblende

6. ferrian actinolite

7. actinolite

8. actinolitic hornblende

9. actinolite

10. actinolite
}

1 Total adjusted for oxygen equivalent of $\mathrm{F}$ and $\mathrm{C} 1$.

2 Total iron redistributed between ferric and ferrous iron by normalization of tetrahedra1 and M1-, M2-, M3site cations to 13 using a computer program by Rock and Leake (1984a, b) that partitions iron and assigns the IMA-recommended names listed at bottom of table.

whereas none were observed in 84JH041. A chromite-bearing sample from massive garnetite in skarn D contains 2.7 weight percent $\mathrm{MgO}$ (analysis 2 , table 24), whereas the other samples from skarn
$\mathrm{D}$ contain less than 0.8 weight percent $\mathrm{MgO}$. The more magnesian biotite in sample $84 \mathrm{JH} 042$ may reflect a local difference in the bulk composition of the protolith, such as the presence of more magne- 
sian layers (possibly intercalated mafic rocks) in the Harmony Formation. Brown micaceous grains that resemble biotite but have nonstoichiometric compositions are common in many samples. Biotite has been reported in other skarns; for example, Newberry (1980) described biotite-magnetite veins cutting garnet skarn in the Pine Creek, Calif., district, but at Copper Basin all the biotite appears to belong to the metamorphic stage of skarn evolution.

Green chlorite is most abundant in sulfide-bearing samples; brown chlorite or oxychlorite is ubiquitous. The limited data obtained for chlorite (table 44) shows that it is uniformly iron rich and that both brown and green chlorites overlap in composition and vary considerably in iron and magnesium contents. Copper Basin chlorites are similar to chlorites. reported from skarns associated with tungsten mineralization at Pine Creek (Newberry, 1980) and are more iron rich than the range of compositions reported by Meinert (1980) for chlorites in copper skarns at Capote Basin (fig. 102).

Brown chlorite ranges in color from reddish brown through pale brown to greenish brown, commonly within a single grain. Brown chlorite is present in several textures: replacing garnet cores; replacing pyroxene or amphibole inclusions in poikilitic garnets; rimming or partly replacing patches of interstitial limonite; and as narrow veinlets within and between garnet grains. Brown chlorites may be oxidized or may represent mixtures of green chlorite and oxychlorite, or may owe their color to finely dispersed limonite. Brown chlorite probably differs from green chlorite in ferric iron content, but because of our inability to distinguish between ferric and ferrous iron by microprobe, we report total iron as ferrous iron. Dark-colored, nonmagnetic grains were handpicked from low specific gravity fractions (less

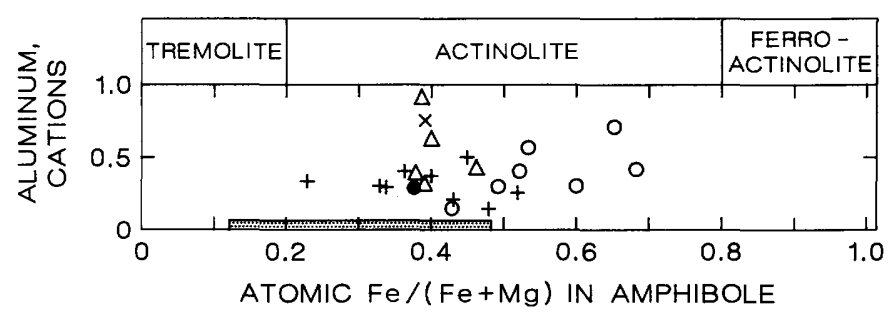

Figure 101.-Range of compositions for amphiboles from Copper Basin skarns in terms of $\mathrm{Fe} /(\mathrm{Fe}+\mathrm{Mg})$ ratio and aluminum cations, based on a 23-oxygen formula unit. Dots, skarn B; circles, skarn $\mathrm{D}$; X, skarn $\mathrm{E}$; crosses, skarn $\mathrm{F}$; triangles, skarn G; shaded box represents amphibole compositions from porphyry copper-related skarns at Cananea (Mexico), Yerington, Ely, and Bingham (Nevada), as outlined by Einaudi (1982b). than 3.3) of two samples from skarn in the Harmony Formation. Both samples (76CB9 and 85JH145) contain abundant brown chlorite. Resulting separates are not pure; they contain intimately associated limonite. X-ray-diffraction patterns for both samples show the characteristic $14-\AA$ chlorite 001 peak. The separate from sample 76CB9 consists of chlorite, goethite, hematite, and traces of amphibole whereas the separate from sample 85JH145 consists mostly of chlorite and quartz. No mica peaks were observed. The relative X-ray-diffraction intensities of the 001 $(14 \AA)$ and $002(7 \AA)$ basal spacings of chlorites are a function of composition: for the iron-rich chlorites, the intensity of the 002 peak is much stronger than that of the 001 peak (Brindley and Brown, 1980). Predicted compositions based on relative intensities of basal peaks for chlorites in these two samples agree with microprobe data. Brown chlorite analyzed in thin section for samples 76CB9 and 85JH145 had $\mathrm{Fe} /(\mathrm{Fe}+\mathrm{Mg})=0.81$ and 0.50 , respectively.

\section{CLAY MINERALS}

Yellow-green clay layers are present in massive garnetite skarns in the Harmony Formation and in the middle member of the Battle Formation. X-raydiffraction patterns using randomly oriented slides show that clay samples contain $14-\AA$ peaks that expand to $17 \AA$ upon glycolation; this is the characteristic behavior of a montmorillonite clay. The 060 peak position, which distinguishes dioctahedral smectite (nontronite) from trioctahedral smectite (montmorillonite or ferrosaponite), is not diagnostic because several weak peaks are present in the range 1.49-1.53 $\AA$. These clays are probably mixtures of nontronite and other smectite clays. Abundant quartz is present in the clay layer associated with skarn in the Harmony Formation, whereas quartz, calcite, epidote, and relict pyroxene are identified in clay from the middle member of the Battle Formation. Microprobe data (table 45) obtained for clays in polished thin sections show that they are quite iron rich and extremely low in aluminum. Total iron is reported as $\mathrm{FeO}$, but most or all of the iron probably is present in the ferric state. Mössbauer data for sample 85JH115 (Robert Johnson, U.S. Geological Survey, written commun., 1987) show a typical nontronite pattern having nearly all the iron present in the ferric state. Montmorillonite clays commonly contain about 15 weight percent $\mathrm{H}_{2} \mathrm{O}$ (Deer and others, 1962b). High oxide sums for microprobe data may indicate volatilization of water from the electron beam and dehydration resulting from evacuation of the mi- 
TABLE 44.--Representative analyses of biotite and chlorite from Copper Basin skarns

[Cations and $\mathrm{H}_{2} \mathrm{O}$ computed on the basis of 24 and $18(\mathrm{O}+\mathrm{OH}+\mathrm{F}+\mathrm{Cl})$ for biotite and chlorite, respectively. FeO(T), total iron reported as FeO. ( $\left.n\right)$, average of $n$ analyses; n.d., not determined; - , not detected]

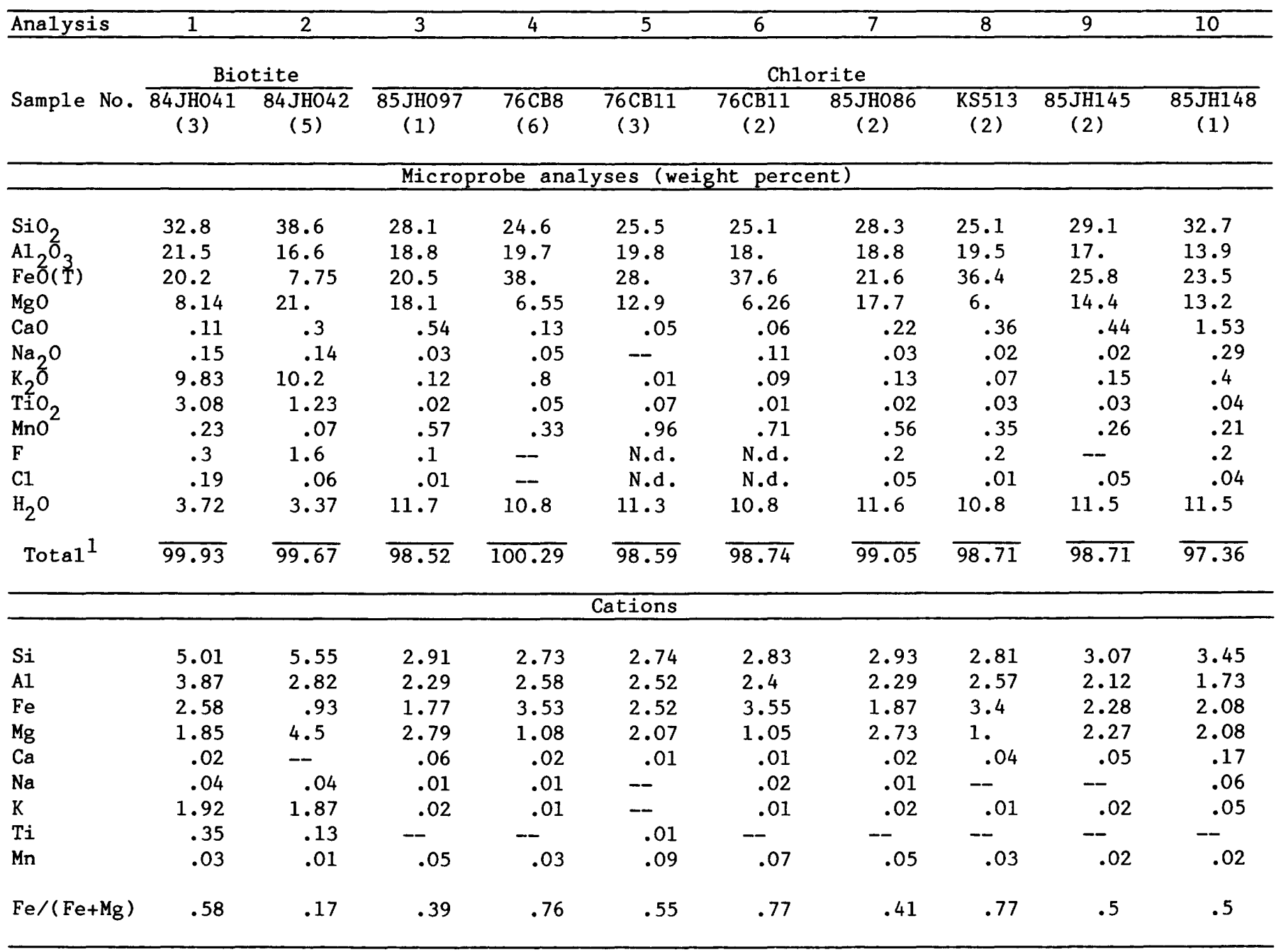

1. Biotite in hornfels.

2. Biotite in hornfels adjacent to skarn $A$.

3. Green chlorite in calcite; skarn B.

4. Green chlorite; skarn D.

5-6. Green chlorite.

7. Brown chlorite rimming limonite; skarn $\mathrm{C}$.

8. Green chlorite; Surprise Mine.

9. Brown chlorite in garnet; skarn $\mathrm{E}$.

10. Brown chorite; skarn F.

1 Total adjusted for oxygen equivalent of $\mathrm{F}$ and $\mathrm{C} 1$.

croprobe sample chamber to operating conditions. The fine-grained nature of the clay material precludes expansion of the microprobe beam to minimize water loss during analysis. A standard nontronite clay was analyzed along with the skarn samples (table 45) to test the effects of the vacuum and beam impingement on resulting microprobe analyses. Shimizu and Iiyama (1982) reported microprobe data for nontronites formed by alteration of clinopyroxene in skarn near ore bodies for the zinc-lead skarn deposits at the Nakatatsu Mine in Japan. Their data show high totals (90 weight percent), high iron, 
calcium as the principal interlayer cation, and significant manganese contents. Data for several clay grains in sample 85JH115 are consistent, and this consistency suggests that the dominant clay material is a nontronite like mineral having calcium as the interlayer cation. Data for several grains in sample 85JH142 are highly variable. This heterogeneity may indicate the presence of fine-grained mixtures of clay and quartz; one dark grain is an extremely heterogeneous, manganese-rich phase. Nontronites from the Nakatatsu Mine replace iron-rich pyroxenes. Nontronites in the Copper Basin rocks replace andradite or epidote after andradite; relict pyroxenes in the clay layers are diopsidic.

The extensive interaction between rock and latestage metasomatic fluids needed to produce massive clay layers prompted us to investigate the chemical signature of the clays as possible sinks for elements associated with mineralization. Although the two clay samples we analyzed are not pure clays, no sulfide minerals or sulfates were observed in thin section. The two clay samples (analyses $4-5$, table 38 ) have different chemical signatures; however, both samples contain small amounts of silver, several hundred parts per million zinc, and no detectable molybdenum.

\section{APATITE}

Apatite is present as tiny, probably detrital grains in bedded skarns and as inclusions in garnet or in quartz in most of the massive skarns. Late-stage, coarse, euhedral apatite grains are extremely abun-

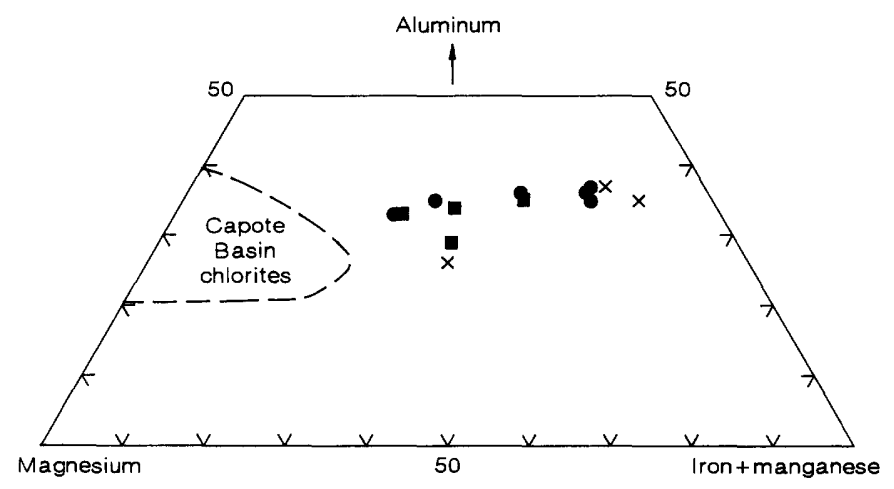

FIGURE 102.-Ternary diagram showing Copper Basin chlorite compositions in terms of cations aluminum, magnesium, and iron+manganese. Dots, green chlorites; squares, brown chlorites. Also shown are fields for chlorite compositions in copper skarn at Capote Basin (Meinert, 1980) and chlorites in tungsten skarns at Pine Creek ( $\times$; Newberry, 1980). dant in sample 85JH112, a massive garnetite from skarn $\mathrm{D}$. These late-stage apatites cut across $\mathrm{K}$ feldspar veinlets and are also inclusions in patches of brown chlorite interstitial to massive garnet. All apatite (table 46) is fluorine rich and contains minor, but variable amounts of chlorine. $\mathrm{CO}_{2}$ (carbon substitutes for phosphorus in carbonate-apatites) and water cannot be detected by microprobe analysis. However, formula proportions calculated on an ideal anionic basis $(\mathrm{O}+\mathrm{OH}+\mathrm{F}+\mathrm{Cl}=26)$ suggest that these apatites are nearly fully fluorinated. Manganese contents are low, and chlorine content is low but variable. The paragenesis of most of the apatite is unclear-metamorphic, metasomatic, or relict igneous origins are all possible. The coarse-grained apatite in skarn D however, is clearly a late-stage metasomatic phase. Cerium, lanthanum, and strontium were sought in all the apatites. Strontium contents are generally low (less than 0.1 weight percent $\mathrm{SrO}$ ). Apatite in skarn A contains 0.3 to 1.8 weight percent $\mathrm{Ce}_{2} \mathrm{O}_{3}+\mathrm{La}_{2} \mathrm{O}_{3}$, whereas concentrations for these elements in metasomatic apatites from skarn $\mathrm{D}$ are at or below detection limits. Harris and Einaudi (1982) observed apatite associated with latestage magnetite in rocks from the Douglas Hill Mine at Yerington, and they attributed the apatite formation to the phosphatization of andradite at temperatures below $200{ }^{\circ} \mathrm{C}$, on the basis of homogenization temperatures of fluid inclusions within the apatites.

\section{SCAPOLITE}

Scapolite forms a complex silicate solid solution between the end-member compositions marialite, $\mathrm{Na}_{4} \mathrm{Al}_{3} \mathrm{Si}_{9} \mathrm{O}_{24} \mathrm{Cl}$, and meionite, $\mathrm{Ca}_{4} \mathrm{Al}_{6} \mathrm{Si}_{6} \mathrm{O}_{24} \mathrm{CO}_{3}$. Although scapolite is not an uncommon skarn mineral, it was observed in only one of the samples from Copper Basin, a finely laminated, red and green, garnet-rich calc-silicate rock from skarn C. Scapolite has not previously been reported from skarn in the Battle Mountain area. The scapolite is chlorine rich and marialitic. Mineral formulas (table 47) are calculated using the scheme adopted by Vanko and Bishop (1982). Silicon+aluminum are normalized to 12 based on the general scapolite formula $\mathrm{W}_{4} \mathrm{Z}_{12} \mathrm{O}_{24} \cdot \mathrm{R}$. Calcium, sodium, and potassium are assigned to the $\mathrm{W}$ sites, aluminum and silica are allocated to $\mathrm{Z}$, and enough carbonate is calculated to achieve charge balance, assuming $\mathrm{R}=\mathrm{Cl}+$ $\mathrm{CO}_{3}+\mathrm{SO}_{4}=1.00$. Calculated carbonate contents are low. The occurrence of chlorine-rich scapolite confirms fluid-inclusion data indicating that skarn for- 
TABLE 45.-Analytical data for clays associated with skarns at Copper Basin

$[\mathrm{FeO}(\mathrm{T})$, total iron reported as $\mathrm{FeO}$ for analyses 1 through $13 . \mathrm{tr}$, trace; n.d., not determined; - , not detected]

\begin{tabular}{|c|c|c|c|c|c|c|c|c|}
\hline Analysis & 1 & 2 & 3 & 4 & 5 & 6 & 7 & 8 \\
\hline \multirow[b]{2}{*}{$\begin{array}{l}\text { Sample No. } \\
\text { Grain }\end{array}$} & \multicolumn{6}{|c|}{ Skarn D } & \multicolumn{2}{|c|}{ Skarn E } \\
\hline & $\begin{array}{c}85 \mathrm{JH} 115 \\
\text { CL1-1 }\end{array}$ & $\begin{array}{c}85.5 H 115 \\
\text { CLI-2 }\end{array}$ & $\begin{array}{c}85 \mathrm{JH} 115 \\
\mathrm{CL} 2-1\end{array}$ & $\begin{array}{l}\text { 85JH115 } \\
\text { CL2-2 }\end{array}$ & $\begin{array}{c}\text { 85JH115 } \\
\text { CL3 }\end{array}$ & $\begin{array}{c}\text { 85.JH115 } \\
\text { CL5 }\end{array}$ & $\begin{array}{l}85 \mathrm{JH142} \\
\text { CL1 }\end{array}$ & $\begin{array}{c}85 \mathrm{JH}_{14} 42 \\
\text { CL2-1 }\end{array}$ \\
\hline SiO & .15 & .10 & 1.63 & 40.08 & 45.28 & 59.52 & 47.45 & 61.82 \\
\hline & 1. & 1.47 & 1.23 & & 1.59 & 1. & .42 & .48 \\
\hline & & N.d & N.d. & & N.d. & & N.d. & N.d. \\
\hline $\mathrm{FeO}(\mathrm{T})$ & 39.23 & 32.81 & 40.53 & 41.42 & 32.67 & 21.35 & 32.58 & 19.21 \\
\hline $\mathrm{MgO}$ & 1.86 & 1.51 & 49 & 1. & 1.7 & 2.32 & 2.79 & 1.97 \\
\hline & & & & & 1.92 & 1.51 & 2.37 & 1.69 \\
\hline $\mathrm{Na}_{2} \mathrm{O}$ & .0 & .0 & .05 & .0 & .01 & .02 & .08 & .06 \\
\hline $\mathrm{K}_{2} \mathrm{O}$ & .13 & .08 & .03 & . & .01 & .07 & .04 & .07 \\
\hline $\mathrm{TiO}_{2}$ & .06 & .03 & .01 & .0 & .05 & .04 & .02 & .01 \\
\hline Mnc & -- & -- & .0 & & .02 & .01 & .03 & .03 \\
\hline $\mathrm{Cr}_{2} \mathrm{O}_{3}$ & .0 & .0 & .06 & .0 & .04 & 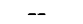 & N.d. & N.d. \\
\hline 23 & N.d. & N.d & N.d. & N.d. & N.d. & N.d & .01 & \\
\hline $\mathrm{C} 1$ & $\mathrm{~N}, \mathrm{~d}$ & N.C & N.d. & & N.d. & N. & .05 & .05 \\
\hline $\mathrm{SO}_{3}$ & N.d. & N.d. & N.d. & N.d. & N.d. & N.d. & .04 & .03 \\
\hline Totale & 1.36 & 82.48 & 7.34 & 5.62 & .28 & 5.32 & $\overline{5.88}$ & $\overline{5.42}$ \\
\hline
\end{tabular}

TABLE 45.-Analytical data for clays associated with skarns at Copper Basin-Continued

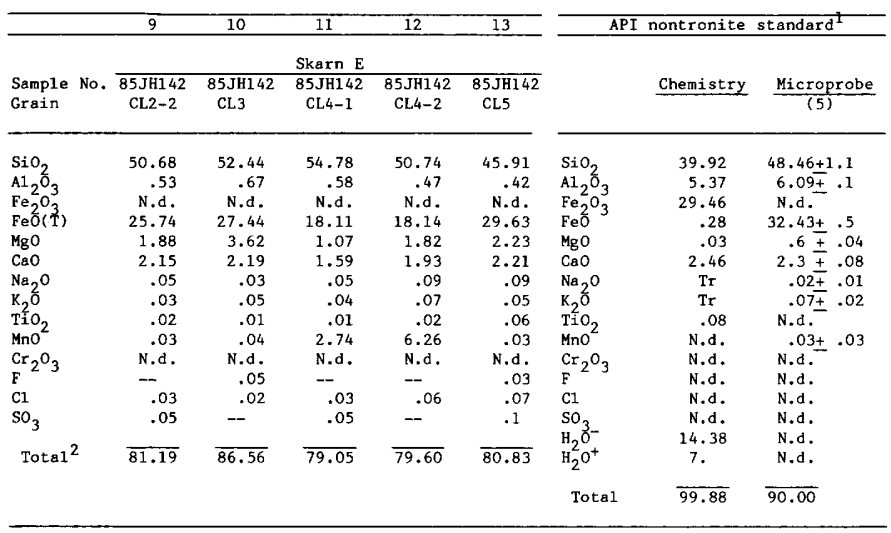

1 API reference clay H33a, nontronite from Garfield, Washington. Chemistry reported by Kerr and others, 1950, p.55. Microprobe analysis represents an average of 5 points taken from a polished mount of the standard clay rock.

2 Total adjusted for oxygen equivalent of $\mathrm{F}$ and $\mathrm{Cl}$.

mation involved circulation of highly saline fluids in the Harmony Formation.

\section{OPAQUE MINERALS}

Opaque minerals in the Copper Basin skarns include iron oxide minerals, hydrous iron oxide minerals, chromite, and sulfides (pyrite, chalcopyrite, and pyrrhotite). Electrum is the gold-bearing mineral in mineralized skarn at the Surprise Mine. A distinctive feature of the Copper Basin skarns is the pervasive replacement of sulfides by limonite. Limonite, a fine-grained to cryptocrystalline mixture of goethite, lepidocrocite, silica, other minerals, and ad- sorbed water, appears as discrete black grains with red fringes in transmitted light and occupies polygonal interstices among garnet crystals in most of the Copper Basin skarns. Some limonite grains contain traces of pyrite or chalcopyrite, and rarely, hematite. Brown chlorite forms patches in limonite or partially rims it. Limonite is isotropic and has low reflectivity relative to sulfides or hematite. Most grains appear extremely heterogeneous in reflected light and exhibit textures that vary from mottled to colloform banded. Secondary electron images on limonite from sample 76CB9 from skarn D show a mixture of less-than-0.05- $\mu \mathrm{m}$ iron-silicon- and ironsilicon-copper-bearing phases. Quartz was not identified as a discrete phase. No magnetite was observed in any polished sections. A few grains of magnetic material removed from sample 85JH145 (skarn E) with a hand magnet produced an X-ray pattern showing a mixture of magnetite, hematite, quartz, and calcite. Nonmagnetic opaque grains handpicked from a heavy fraction of the same sample proved to be a mixture of hematite, goethite, and lepidocrocite. X-ray-diffraction patterns for nonmagnetic opaque fractions separated from skarn $D$ (Harmony Formation) and skarn G (Antler Peak Limestone) gave patterns showing assemblages of chlorite+goethite+hematite+amphibole+quartz, and goethite+lepidocrocite+amphibole, respectively. Microprobe analyses for limonite (table 48) show variable compositions, as expected for such mixtures. All limonite analyses have low sums, high iron contents, and silica contents of several tenths of a weight percent to several weight percent. These data are consistent with analyses reported by Deer and others (1962c), which show limonites having 74 to 84 weight percent $\mathrm{Fe}_{2} \mathrm{O}_{3}, 13$ to 14 weight percent $\mathrm{H}_{2} \mathrm{O}, 3$ to 5 weight percent $\mathrm{SiO}_{2}$, and variable amounts of other oxides. Limonite commonly forms as an oxidation product of pyrite or iron oxide minerals. Inclusions of sulfides in limonite and qualitative identification of copper in some of the iron silicate phases present in limonite suggest that much of the limonite replaces preexisting sulfide minerals. However, some of the limonite may replace magnetite or hematite that was deposited with garnet during the main stages of skarn growth. Magnetite and hematite are both observed in mineralized skarn at the Surprise deposit. Magnetite is commonly reported as a prograde stage mineral in calcic copper- and iron-bearing skarns. Samples from the southern extension of the skarn $D$ traverse in the Contention pit contain sulfides (pyrite, pyrrhotite, minor chalcopyrite) in veins and in the same 
TABLE 46.-Representative analyses of apatite from Copper basin skarns

[[X], enclosed in mineral X. CHL, chlorite; GA, garnet; Q, quartz. FeO(T), total iron reported as FeO. (n), average of n points; --, not detected]

\begin{tabular}{|c|c|c|c|c|c|c|c|c|c|c|}
\hline \multirow[b]{2}{*}{$\begin{array}{l}\text { Sample No. } \\
\text { Texture }\end{array}$} & \multicolumn{2}{|c|}{ Skarn A } & \multicolumn{2}{|c|}{ Skarn B } & \multirow{2}{*}{$\begin{array}{c}\text { Skarn C } \\
85 \mathrm{JHO} 8 \\
{[\mathrm{GA}]} \\
(2)\end{array}$} & \multicolumn{4}{|c|}{ Skarn D } & \multirow{2}{*}{$\begin{array}{c}\frac{\text { Skarn E }}{\text { 85JH149 }} \\
{[\mathrm{GA}]}\end{array}$} \\
\hline & $\begin{array}{c}85 \mathrm{JHO} 070 \\
{[\mathrm{GA}]} \\
(3)\end{array}$ & $\begin{array}{c}85 \mathrm{JHO} 070 \\
{[\mathrm{GA}]} \\
(2)\end{array}$ & $\begin{array}{c}85 \mathrm{JH096} \\
{[\mathrm{GA}]}\end{array}$ & $\begin{array}{c}85 \mathrm{JHO} 96 \\
{[\mathrm{GA}]}\end{array}$ & & $\begin{array}{c}\text { 85JH107 } \\
{[\mathrm{Q}]}\end{array}$ & $\begin{array}{c}85 \mathrm{JH} 107 \\
{[\mathrm{GA}]}\end{array}$ & $\begin{array}{c}\text { 85JH112 } \\
{[\mathrm{GA}]} \\
(3)\end{array}$ & $\begin{array}{c}85 \mathrm{JH} 112 \\
{[\mathrm{CHL}]} \\
(3)\end{array}$ & \\
\hline \multicolumn{11}{|c|}{ Microprobe analyses (weight percent) } \\
\hline $\mathrm{CaO}$ & 54.5 & 53.5 & 55.8 & 56.3 & 53.9 & 55.3 & 55.7 & 54.8 & 55.8 & 55.8 \\
\hline $\mathrm{Al}_{2} \mathrm{O}_{3}$ & .09 & .07 & .05 & .08 & .29 & .08 & .09 & .08 & .05 & .1 \\
\hline $\mathrm{FeO}(\stackrel{3}{\mathrm{~T}})$ & .47 & .46 & .29 & .24 & .62 & .28 & .49 & .14 & .24 & .82 \\
\hline $\mathrm{MgO}$ & -- & -- & .03 & -- & -- & -- & -- & -- & -- & -- \\
\hline Mno & .03 & .04 & .07 & .03 & .08 & .02 & .05 & .02 & .05 & -- \\
\hline $\mathrm{Na}_{2} \mathrm{O}$ & .03 & .02 & .04 & .03 & .04 & .03 & .01 & .02 & .02 & .11 \\
\hline Sro & .06 & .06 & .3 & .02 & .06 & .06 & .03 & .01 & .05 & .08 \\
\hline $\mathrm{La}_{2} \mathrm{O}_{3}$ & .12 & .62 & .12 & - & .08 & .02 & .08 & -- & - & .02 \\
\hline $\mathrm{Ce}_{2}^{2} \mathrm{O}_{3}^{3}$ & .21 & .91 & .29 & .06 & .15 & .03 & .06 & .01 & .02 & - \\
\hline $\mathrm{P}_{2} \mathrm{O}_{5}$ & 41.2 & 40.8 & 41.8 & 41.4 & 41.4 & 40. & 40.5 & 41.8 & 41.6 & 40.5 \\
\hline $\mathrm{SiO}_{2}^{3}$ & .4 & .88 & .31 & .23 & 1.66 & .25 & .21 & .16 & .16 & .26 \\
\hline $\mathrm{Cl}$ & .3 & .44 & .11 & .19 & .08 & .29 & .33 & .47 & .27 & .09 \\
\hline $\mathbf{F}$ & 3.3 & 3. & 3.8 & 3.4 & 3.1 & 3.12 & 3.04 & 3.12 & 3.66 & 3.79 \\
\hline Tota ${ }^{1}$ & 99.3 & 99.4 & 101. & $\overline{100.56}$ & 100 & $\overline{98.2}$ & 99.2 & 99.2 & 100 . & 100 . \\
\hline
\end{tabular}

\begin{tabular}{|c|c|c|c|c|c|c|c|c|c|c|}
\hline & & & & tions $b$ & on 26 & oxygens & & & & \\
\hline $\mathrm{Ca}$ & 9.92 & 9.78 & 9.97 & 10.15 & 9.68 & 10.24 & 10.21 & 9.95 & 10.03 & 10.16 \\
\hline AI & .02 & .01 & .01 & .02 & .06 & .02 & .02 & .02 & .01 & .02 \\
\hline $\mathrm{Mg}$ & -- & -- & .01 & -- & -- & -- & -- & -- & -- & -- \\
\hline Mn & - & -- & .01 & -- & .02 & -- & .01 & - & .01 & -- \\
\hline $\mathrm{Na}$ & .01 & .01 & .01 & .01 & .01 & .01 & -- & .01 & .01 & .04 \\
\hline \multirow[t]{2}{*}{$\mathrm{Ce}$} & .02 & .06 & .02 & -- & .01 & - & -- & -- & - & -- \\
\hline & 10.0 & $\overline{9.98}$ & 10.1 & $\overline{10.2}$ & $\overline{9.87}$ & $\overline{10.32}$ & $\overline{10.32}$ & $\overline{9.99}$ & $\overline{10.10}$ & $\overline{10.34}$ \\
\hline$P$ & 5.93 & 5.90 & 5.90 & 5.89 & 5.88 & 5.86 & 5.87 & 5.99 & 5.92 & 5.82 \\
\hline $\mathrm{Si}$ & .07 & .15 & .05 & .04 & .28 & .04 & .04 & .03 & .03 & .04 \\
\hline \multirow[t]{2}{*}{ F } & 1.79 & 1.64 & 2. & 1.81 & 1.64 & 1.71 & 1.65 & 1.67 & 1.94 & 2.03 \\
\hline & $\overline{1.87}$ & $\overline{1.77}$ & $\overline{2.03}$ & $\overline{1.87}$ & $\overline{1.67}$ & $\overline{1.79}$ & $\overline{1.74}$ & $\overline{1.81}$ & $\overline{2.02}$ & $\overline{2.06}$ \\
\hline \%REE ${ }^{2}$ & .26 & 1.02 & .54 & .06 & .20 & .09 & .11 & .02 & .06 & .09 \\
\hline
\end{tabular}

1 Total adjusted for oxygen equivalent of $\mathrm{Cl}$ and $\mathrm{F}$.

2 \%REE $=100 *((\mathrm{Ce}+\mathrm{La}+\mathrm{Sr}) /($ Sum of Ca-site cations $))$. 
TABLE 47.-Representative analyses of scapolite in sample 85JH080, skarn C, Upper Cambrian Harmony Formation

$[\mathrm{FeO}(\mathrm{T})$, total iron reported as $\mathrm{FeO}$. Each analysis represents an average of three points. $\mathrm{CO}_{2}$ content computed from theoretical amount of $\mathrm{CO}_{3}$ calculated by assuming ideal charge balance ( 48 oxygens) based on general scapolite formula $\mathrm{W} \mathrm{Z}_{2} \mathrm{O} \cdot \mathrm{R}$, where $\mathrm{W}=\mathrm{Ca}+\mathrm{Na}+\mathrm{K}, \mathrm{Z}=\mathrm{Si}+\mathrm{Al}$, and $\mathrm{R}=\mathrm{Cl}+\mathrm{CO}_{3}+\mathrm{SO}_{4} ; \mathrm{Me}=100 *(\mathrm{Ca} /(\mathrm{Ca}+\mathrm{Na}+\mathrm{K})) .$, , not detected $]$

\begin{tabular}{|c|c|c|c|}
\hline Grain & $\mathrm{SC1}$ & $\mathrm{SC2}$ & $\mathrm{SC} 3$ \\
\hline Microprobe & analyses & (weight & $\overline{\text { percent) }}$ \\
\hline $\mathrm{SiO}_{2}$ & 56.71 & 56.52 & 56.83 \\
\hline $\mathrm{Al}_{2} \mathrm{O}_{3}$ & 22.82 & 23.22 & 22.96 \\
\hline $\mathrm{FeO}(\mathrm{T})$ & .07 & .1 & .09 \\
\hline $\mathrm{MgO}$ & -- & -- & - \\
\hline $\mathrm{CaO}$ & 6.62 & 7.26 & 6.65 \\
\hline $\mathrm{Na}_{2} \mathrm{O}$ & 9.66 & 9.4 & 9.7 \\
\hline $\mathrm{K}_{2} \mathrm{O}$ & 1.32 & 1.08 & 1.15 \\
\hline $\mathrm{TiO}_{2}$ & -- & - & -- \\
\hline $\mathrm{MnO}^{2}$ & -- & -- & .01 \\
\hline F & .03 & -- & .02 \\
\hline $\mathrm{Cl}$ & 3.09 & 2.94 & 3.12 \\
\hline $\mathrm{SO}_{3}$ & .21 & -- & .07 \\
\hline Total & $\overline{100.53}$ & $\overline{100.52}$ & $\overline{100.60}$ \\
\hline$F=0$ & .01 & - & .01 \\
\hline $\mathrm{C} 1=\mathrm{O}$ & .71 & .68 & .72 \\
\hline $\mathrm{CO}_{2}{ }^{2}$ & .85 & 1.06 & .8 \\
\hline New total & $\overline{99.96}$ & $\overline{100.23}$ & $\overline{99.96}$ \\
\hline \multicolumn{4}{|c|}{ Structural formula } \\
\hline $\mathrm{Si}$ & 8.14 & 8.08 & 8.13 \\
\hline \multirow[t]{2}{*}{$\mathrm{A} 1$} & 3.86 & 3.92 & 3.87 \\
\hline & $\overline{12.00}$ & $\overline{12.00}$ & $\overline{12.00}$ \\
\hline $\mathrm{Fe}^{2+}$ & .01 & .01 & .01 \\
\hline $\mathrm{Mg}$ & -- & - & -- \\
\hline $\mathrm{Ca}$ & 1.02 & 1.11 & 1.02 \\
\hline $\mathrm{Na}$ & 2.69 & 2.61 & 2.69 \\
\hline K & .24 & .2 & .21 \\
\hline $\mathrm{Ti}$ & -- & -- & -- \\
\hline \multirow[t]{2}{*}{ Mn } & -- & -- & -- \\
\hline & $\overline{3.96}$ & $\overline{3.93}$ & $\overline{3.93}$ \\
\hline $\mathrm{F}$ & .01 & -- & .01 \\
\hline $\mathrm{C} 1$ & .75 & .71 & .76 \\
\hline \multirow[t]{2}{*}{$S$} & .02 & -- & .01 \\
\hline & .79 & .71 & .77 \\
\hline $\mathrm{CO}_{3}$ & .17 & .21 & .16 \\
\hline$\% \mathrm{Me}$ & 25.8 & 28.4 & 26.0 \\
\hline
\end{tabular}

1 Structural formula calculated by assuming $\mathrm{Si}+\mathrm{Al}=12$. interstitial textures occupied by limonite in samples farther north (see fig. 87). The transition from sulfide to limonite, which occurs between samples 76CB10 and 76CB9, is accompanied by a change in garnet color and composition and may indicate differences between subsurface sulfide-zone skarn sampled in the pit and surface samples of oxide-zone skarn collected north of the pit along the same skarn body. The presence of detrital chromite in hornfels associated with skarn A and in garnetite from skarn D (table 48) implies that mafic or ultramafic igneous rocks contributed to the source material for the Harmony Formation. The aforementioned greenstone layers in the Harmony Formation are possible chromite sources, however, the greenstone analysis reported in table 1 is low in $\mathrm{Cr}_{2} \mathrm{O}_{3}$ content. Chromite grains are zoned and have been brecciated. Though partly reacted with the surrounding garnet, the chromite remains remarkably fresh, considering the exposure to metasomatic fluids. No pervasive oxidation to ferritchromite occurs, although narrow ferritchromite rims and lamellae are observed in most grains. Ferritchromite is a highly reflecting, magnesium- and aluminum-depleted alteration product of chromite commonly found rimming chromite grains in serpentinites. Ferritchromite is not formally recognized as a mineral, but it is the term used for chromite alteration with the aforementioned physical and chemical properties (Lipin, 1984). Though most commonly attributed to serpentinization processes, ferritchromite paragenesis has also been linked to magmatic alteration (Bliss and MacLean, 1975). Chromite compositions are unusually aluminous, but they fall mostly within the field for metamorphic chromites outlined by other workers (fig. 103). The relatively coarse grain size (approx $0.5 \mathrm{~mm}$ diam) argues against a volcanic origin as Evans and Wright (1972) found that chromite in lavas is typically very fine grained (less than 40 $\mu \mathrm{m})$. Zoning trends show iron enrichment from core to rim, consistent with typical zoning patterns for metamorphic chromites. Lower temperatures favor more iron rich chromite; chromite loses magnesium, chromium, and aluminum to silicates and gains iron as chromite compositions move toward magnetite. Garnets surrounding chromite (see table 40) are locally enriched in aluminum, chromium, and magnesium; in some places chromium enrichment is sufficient to impart a bright-green color to the garnet.

Electrum grains in limonite in two samples from the Surprise deposit were analyzed by microprobe, including the grain shown in figure $88 D$. The compositions observed, in terms of atomic percent, are 
TABLE 48.--Representative analyses of opaque minerals in Copper Basin skarns

[c, core; $\mathrm{m}$, between core and rim; $\mathrm{r}$, rim; /EP, in contact with epidote. $\mathrm{FeO}(\mathrm{T}$ ), total iron measured as $\mathrm{FeO} . \mathrm{Fe} 2 \mathrm{O}$ (calc) and $\mathrm{FeO}$ (calc) determined assuming two cation sites for hematite or total iron as Fe2O3 for limonite. (n), average of $n$ analyses; n.d, not determined; - , not detected]

\begin{tabular}{|c|c|c|c|c|c|c|c|c|c|c|}
\hline \multirow[b]{3}{*}{ Sample No. } & \multirow{3}{*}{$\frac{\text { Skarn A }}{85 \text { JH069 }}$} & \multicolumn{8}{|c|}{ Limonite (LM) and hematite(HM) } & \\
\hline & & \multicolumn{2}{|c|}{ Skarn B } & \multirow{2}{*}{$\frac{\text { Skarn C }}{85 \mathrm{JHO} 79}$} & \multicolumn{5}{|c|}{$\frac{\text { Skarn D }}{76 \mathrm{CB} 6 \quad 76 \mathrm{CB} 7 \mathrm{a}}$} & \\
\hline & & $\begin{array}{l}\text { 85JH097 } 4 \\
\end{array}$ & $\overline{51-332}$ & & $\overline{76 \mathrm{CB} 4}$ & $76 \mathrm{CB} 6$ & 76CB6 & $76 \mathrm{CB} 7 \mathrm{a}$ & $76 \mathrm{CB9}$ & \\
\hline Description & LM & $\begin{array}{l}\text { LM } \\
\text { colloform }\end{array}$ & LM & $\begin{array}{l}\mathrm{LM} \\
\mathrm{r} / \mathrm{EP}\end{array}$ & LM & $\begin{array}{l}\mathrm{HM} \\
(4)\end{array}$ & LM & LM & LM & LM \\
\hline \multicolumn{11}{|c|}{ Microprobe analyses (weight percent) } \\
\hline $\mathrm{SiO}_{2}$ & 4.88 & 8.49 & 5.20 & 4.76 & 3.98 & 0.70 & 6.54 & 1.93 & 4.79 & 0.68 \\
\hline $\mathrm{A}_{2} \mathrm{O}_{3}$ & -- & .04 & .17 & - & .17 & .32 & -- & .03 & .28 & 2.69 \\
\hline $\mathrm{FeO}\left(\frac{3}{T}\right)$ & 73.9 & 70.1 & 76.5 & 74.2 & 79.5 & 86.5 & 75.8 & 74.4 & 70.5 & 85.8 \\
\hline $\mathrm{MgO}$ & .04 & .28 & .16 & .48 & .25 & .04 & .08 & .51 & -- & -- \\
\hline $\mathrm{CaO}$ & .51 & .49 & .43 & .83 & .68 & .12 & .39 & .25 & .16 & .3 \\
\hline $\mathrm{Na}_{2} \mathrm{O}$ & .04 & .07 & .04 & -- & .13 & N.d. & .03 & -- & -- & .05 \\
\hline $\mathrm{K}_{2} \mathrm{O}$ & N.d. & .07 & N.d. & .05 & N.d. & N.d. & N.d. & .04 & .02 & .05 \\
\hline $\mathrm{TiO}_{2}$ & .05 & -- & .01 & .03 & .01 & 1.05 & .01 & .01 & .01 & 1.22 \\
\hline $\mathrm{MnO}^{2}$ & .04 & .01 & .01 & 2.6 & .06 & .11 & .02 & .15 & .02 & .1 \\
\hline $\mathrm{Cr}_{2} \mathrm{O}_{3}$ & N.d. & .02 & N.d. & .03 & N.d. & .02 & .01 & .02 & .01 & N.d. \\
\hline Tota1 & $\overline{79.46}$ & $\overline{79.57}$ & $\overline{82.52}$ & $\overline{82.98}$ & $\overline{84.78}$ & $\overline{88.86}$ & $\overline{82.88}$ & $\overline{77.34}$ & $\overline{75.79}$ & $\overline{90.89}$ \\
\hline $\mathrm{Fe}_{2} \mathrm{O}_{3} \mathrm{calc}$ & 82.1 & 77.9 & 85.0 & 82.5 & 88.4 & 94.6 & 84.3 & 82.6 & 78.3 & 95.3 \\
\hline $\mathrm{FeO}$ calc. & -- & -- & -- & -- & -- & 1.39 & -- & -- & -- & -- \\
\hline New total & 87.6 & $\overline{87.4}$ & $\overline{91.0}$ & $\overline{91.3}$ & 93.7 & 98.5 & 91.4 & $\overline{85.5}$ & $\overline{83.6}$ & $\overline{100.41}$ \\
\hline Other ${ }^{1}$ & $\mathrm{~S}$ & - & - & -- & -- & $\mathrm{v}$ & - & -- & -- & $\mathrm{Cu}$ \\
\hline
\end{tabular}

$\mathrm{Au}_{51} \mathrm{Ag}_{49}$ and $\mathrm{Au}_{68} \mathrm{Ag}_{38} ;$ no other elements were detected.

\section{DISCUSSION}

All the Copper Basin skarns are calcic skarns; no magnesian skarn formed because significant dolomite does not occur in the protolith. Garnet is the dominant prograde skarn mineral. Textures in many of the skarn samples indicate that garnet replaces earlier stage pyroxene-rich assemblages. Although the preservation of sedimentary textures (layering) and the occurrence of poikilitic garnets in some of the skarns support a metamorphic origin, metasomatic fluids must have been associated with all the skarns to some extent to account for the pervasive veining and extreme iron enrichment relative to the bulk composition of the sedimentary protoliths. Mineral assemblages (iron-rich garnet, diopsidic pyroxene, epidote, actinolitic amphibole, hematite/magnetite) are similar to the assemblages associated with copper, gold, and silver mineralization in the Copper Canyon area to the south. There base- and precious-metal deposits in the
Antler Peak Limestone, as well as in calcareous siltstone and conglomerate of the Battle Formation and the Pumpernickel Formation, such as the Fortitude and West ore-body deposits, are present in association with a $38.5-\mathrm{Ma}$ altered granodiorite porphyry (Wotruba and others, 1986). Mineral compositions of garnets and pyroxenes largely overlap among the three rock formations in which skarn formed in the Copper Basin area. Garnet and pyroxene compositions are similar to those described by N.G. Banks (in Theodore and Blake, 1978) for copper-gold-silver skarn at the West ore body in the Antler Peak Limestone at Copper Canyon. Garnet in the West ore body is similar to that in the Copper Basin skarns in that the isotropic garnet is andradite and the anisotropic garnet is more grossular rich. In the West ore body, isotropic garnets are present as cores and late-stage overgrowths, and diopside remains stable in sulfidized samples. One significant difference between the sulfidized garnetites of the West ore body and those from Copper Basin is that garnet in the few sulfidized samples from skarn $D$ in the Contention pit is relatively grossular rich; most garnets are $\mathrm{Ad}_{33}$ to $\mathrm{Ad}_{84}$, and only two cores have compositions greater than $\operatorname{Ad}_{90}$. The absence of late-stage, andradite-rich com- 
TABLE 48.-Representative analyses of opaque minerals in Copper Basin skarns-Continued

\begin{tabular}{|c|c|c|c|c|c|c|c|c|c|c|}
\hline \multicolumn{11}{|c|}{ Chromite, skarn D } \\
\hline $\begin{array}{l}\text { Sample No. } \\
\text { Grain }\end{array}$ & $\begin{array}{c}76 \mathrm{CB} 3 \\
\mathrm{CR} 1-1 \\
\mathrm{c}\end{array}$ & $\begin{array}{c}76 \mathrm{CB} 3 \\
\mathrm{CR} 1-2 \\
\mathrm{~m}\end{array}$ & $\begin{array}{c}76 \mathrm{CB} 3 \\
\mathrm{CR} 1-3 \\
\mathrm{r}\end{array}$ & $\begin{array}{l}76 \mathrm{CB} 3 \\
\mathrm{CR} 2\end{array}$ & $\begin{array}{c}76 \mathrm{CB} 3 \\
\text { CR3 }\end{array}$ & $\begin{array}{c}76 \mathrm{CB} 3 \\
\mathrm{CR} 4\end{array}$ & $\begin{array}{c}76 \mathrm{CB} 4 \\
\mathrm{CR} 1-1 \\
\mathrm{c}\end{array}$ & $\begin{array}{c}76 \mathrm{CB} 4 \\
\mathrm{CR} 1-2 \\
\mathrm{~m}\end{array}$ & $\begin{array}{c}76 \mathrm{CB} 4 \\
\mathrm{CR} 1-3 \\
\mathrm{r}\end{array}$ & $\begin{array}{c}76 \mathrm{CB} 4 \\
\mathrm{CR} 1-4 \\
\mathbf{r}\end{array}$ \\
\hline \multicolumn{11}{|c|}{ Microprobe analyses (weight percent) } \\
\hline $\begin{array}{l}\mathrm{SiO}_{2} \\
\mathrm{Al}_{2} \mathrm{O}_{3} \\
\mathrm{TiO}_{2} \\
\mathrm{Cr}_{2} \mathrm{O}_{3} \\
\mathrm{MnO} \\
\mathrm{MgO} \\
\mathrm{CaO} \\
\mathrm{Na}_{2} \mathrm{O} \\
\mathrm{FeO}(\mathrm{T})\end{array}$ & $\begin{array}{c}0.04 \\
24.7 \\
1.19 \\
33.35 \\
.51 \\
7.65 \\
.04 \\
.12 \\
31.64\end{array}$ & $\begin{array}{r}0.09 \\
24.38 \\
1.21 \\
33.39 \\
.54 \\
6.53 \\
.08 \\
.17 \\
32.88\end{array}$ & $\begin{array}{c}0.04 \\
24.5 \\
1.11 \\
32.69 \\
.78 \\
4.22 \\
.16 \\
.24 \\
34.59\end{array}$ & $\begin{array}{c}0.03 \\
23.61 \\
1.17 \\
36.63 \\
.32 \\
9.3 \\
.05 \\
.08 \\
28.19\end{array}$ & $\begin{array}{c}0.05 \\
24.1 \\
1.06 \\
36.78 \\
.54 \\
7.96 \\
.34 \\
.07 \\
28.37\end{array}$ & $\begin{array}{r}0.06 \\
23.37 \\
.89 \\
37.47 \\
.46 \\
7.89 \\
.12 \\
.12 \\
29.89\end{array}$ & $\begin{array}{r}0.04 \\
24.86 \\
1.11 \\
34.25 \\
.23 \\
9.33 \\
.03 \\
.08 \\
29.75\end{array}$ & $\begin{array}{c}0.05 \\
24.41 \\
1.3 \\
34.34 \\
.22 \\
9.39 \\
.02 \\
.09 \\
30.39\end{array}$ & $\begin{array}{c}0.02 \\
21.6 \\
1.91 \\
32.8 \\
.44 \\
7.39 \\
.07 \\
.10 \\
35.35\end{array}$ & $\begin{array}{c}0.02 \\
20.65 \\
1.83 \\
31.5 \\
.88 \\
3.8 \\
.51 \\
.22 \\
37.6\end{array}$ \\
\hline Total & $\overline{99.24}$ & $\overline{99.27}$ & $\overline{98.33}$ & $\overline{99.38}$ & $\overline{99.27}$ & $\overline{100.27}$ & $\overline{99.68}$ & $\overline{100.21}$ & $\overline{99.68}$ & $\overline{97.01}$ \\
\hline $\begin{array}{l}\mathrm{Fe}_{2} \mathrm{O}_{3} \text { calc. } \\
\mathrm{FeO} \text { calc. }\end{array}$ & $\begin{array}{r}8.33 \\
24.14\end{array}$ & $\begin{array}{r}7.99 \\
25.68\end{array}$ & $\begin{array}{r}7.17 \\
28.13\end{array}$ & $\begin{array}{r}7.02 \\
21.87\end{array}$ & $\begin{array}{r}5.60 \\
23.33\end{array}$ & $\begin{array}{r}6.92 \\
23.66\end{array}$ & $\begin{array}{r}8.36 \\
22.22\end{array}$ & $\begin{array}{r}8.88 \\
22.39\end{array}$ & $\begin{array}{l}10.65 \\
25.76\end{array}$ & $\begin{array}{l}10.67 \\
29.52\end{array}$ \\
\hline New total & $\overline{100.07}$ & $\overline{100.06}$ & $\overline{99.04}$ & $\overline{100.08}$ & $\overline{99.84}$ & $\overline{100.96}$ & $\overline{100.51}$ & $\overline{101.09}$ & $\overline{100.74}$ & $\overline{99.60}$ \\
\hline \multicolumn{11}{|c|}{ Cations (normalized to 3 ) } \\
\hline Si & -- & -- & -- & -- & -- & - & -- & -- & -- & -- \\
\hline A1 & 0.92 & 0.91 & 0.94 & 0.87 & 0.90 & 0.87 & 0.91 & 0.89 & 0.81 & 0.82 \\
\hline $\mathrm{Ti}$ & .03 & .03 & .03 & .03 & .02 & .02 & .03 & .03 & .05 & .05 \\
\hline $\mathrm{Cr}$ & .83 & .84 & .84 & .91 & .92 & .93 & .84 & .84 & .83 & .84 \\
\hline Mn & .01 & .01 & .02 & .01 & .01 & .01 & .01 & .01 & .01 & .02 \\
\hline $\mathrm{Mg}$ & .36 & .31 & .2 & .43 & .38 & .37 & .43 & .43 & .35 & .19 \\
\hline $\mathrm{Ca}$ & -- & -- & -- & -- & .01 & -- & -- & -- & -- & .02 \\
\hline $\mathrm{Na}$ & .01 & .01 & .02 & -- & -- & .01 & -- & .01 & .01 & .01 \\
\hline $\mathrm{Fe}_{2}^{3}$ & .2 & .19 & .18 & .16 & .13 & .16 & .2 & .21 & .26 & .27 \\
\hline $\mathrm{Fe}^{2}$ & .64 & .68 & .77 & .57 & .62 & .62 & .58 & .58 & .69 & .78 \\
\hline $\mathrm{Cr} /(\mathrm{Cr}+\mathrm{A} 1)$ & 0.47 & 0.48 & 0.47 & 0.51 & 0.51 & 0.52 & 0.48 & 0.49 & 0.51 & 0.51 \\
\hline $\mathrm{Mg} /\left(\mathrm{Mg}+\mathrm{Fe}^{2+}\right)$ & .36 & .31 & .21 & .43 & .38 & .37 & .43 & .43 & .34 & .2 \\
\hline
\end{tabular}

1 Peaks noted on qualitative spectra acquired with an energy dispersive spectrometer during quantitative analysis; $S$, sulfur; $V$, vanadium; $\mathrm{Cu}$, copper.

positions in these samples may indicate limited sampling or, more likely, that these particular samples were closest to the assumed source of the skarn-forming fluids, the Late Cretaceous monzogranite porphyry associated with the Buckingham system. Andradite-rich compositions characterize all samples from the more distal (northern) regions of skarn D. Trends of iron enrichment in skarn minerals outward from an intrusive source have been reported for other calcic skarns (Harris and Einaudi, 1982). The complex zoning and multiple garnet generations recognized in most of the skarns point to a complex, fluctuating fluid history. None of the skarns formed in the Harmony Formation appear to be constrained to intrusive contacts. Skarns A, C, and D have the geometry of subparallel, north-south-trending veinlike beds in hornfels that were selectively altered to skarn. The contact between the Harmony and Battle Formations provided a favorable pathway for fluids allowing the extensive development of skarn D and skarn at the Surprise deposit. All three skarns represent the prograde stages of metamorphism and (or) metasomatism: retrograde minerals are rare, bedding is preserved, and massive sulfides are lacking. Mineral compositions across skarn A show that silicates become more iron rich toward the center of the mapped skarn body. Massive skarn is observed where skarn is restricted to intrusive contacts, such as for skarn $\mathrm{E}$ and $\mathrm{F}$, and where extensive faulting is present, such as for skarn B. Although prograde skarn silicate minerals are abundant, hydrous silicate minerals such as epidote and amphibole, which indicate late-stage 
metasomatism and retrograde alteration, are more common in massive skarn. Skarn $\mathrm{D}$, which has aspects of both bedded and massive skarn, is present along an unconformable contact and varies in extent of retrograde skarn development along its length. Although some of the skarns appear to be genetically related to intrusive rocks of the Buckingham stockwork molybdenum system, the skarns are not molybdenum-bearing and do not re-

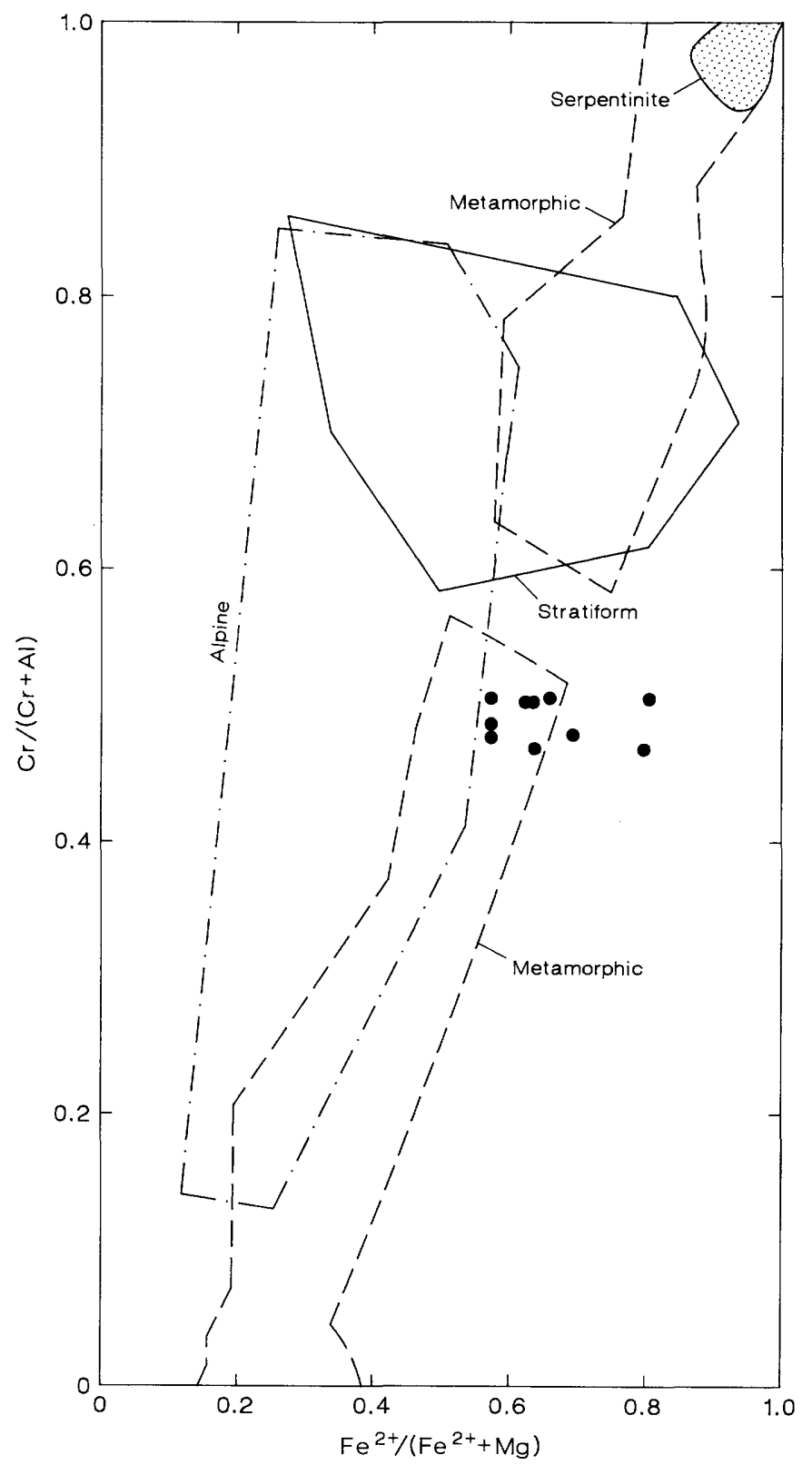

FiguRE 103.-Range of chromite compositions (dots) from samples $76 \mathrm{CB} 3$ and $76 \mathrm{CB} 4$, skarn $\mathrm{D}$, in terms of cation ratios. Fields for metamorphic, stratiform, and alpine chromites and for chromites from serpentinites are based on data of Evans and Frost (1975) and Irvine (1967). semble molybdenum-bearing skarns in mineralogy, mineral chemistry, or associated igneous rocks (Einaudi and others, 1981). Although most of the samples described in this chapter represent barren skarn, significant concentrations of sulfides (more than 50 volume percent) are reported for skarn and for calc-silicate hornfels associated with hypogene copper mineralization (mostly chalcopyrite) in the Contention pit (see subsection above entitled "Supergene Copper Deposits at Copper Basin"). The mineralogy and mineral chemistry of the Copper Basin skarns resemble those of the skarns associated with porphyry copper stocks at Copper Canyon and elsewhere (fig. 104). Myers and Meinert (1988) showed that the West ore body and Fortitude deposits are part of a large, zoned hydrothermal system centered around the $38-\mathrm{Ma}$ granodiorite stock of Copper Canyon. They demonstrated that mineral assemblages and mineral compositions change continuously from the proximal, copper-rich garnet $\left(\mathrm{Ad}_{70}-\mathrm{Ad}_{100}\right)$-pyroxene $\left(\mathrm{Hd}_{20}-\right.$ $\mathrm{Hd}_{45}$ ) skarn at the West ore body to the distal, gold-rich pyroxene $\left(\mathrm{Hd}_{20}-\mathrm{Hd}_{100}\right)$-garnet $\left(\mathrm{Ad}_{90}-\mathrm{Ad}_{100}\right.$ cores, $\operatorname{Ad}_{30}-\mathrm{Ad}_{60}$ rims) skarn at the Fortitude deposit. Proximity of skarns A through F to the Surprise and Labrador gold deposits, reports of wire gold associated with skarn at the Overlook property (skarn B area), and nearby gold placers warrant comparison of the silicate mineral chemistry of the Copper Basin skarns with the emerging characteristics of the gold skarn deposit type (Vakrushev, 1972; Meinert, 1988; Orris and others, 1987; Theodore and others, 1991), many of which occur with, or have previously been classified as copper or iron skarns. Aspects of the mineralogy of the Copper Basin skarns fit the characteristic assemblage of the copper class of calcic skarn deposits as defined by Einaudi and Burt (1982): andradite $\left(\mathrm{Ad}_{60}-\mathrm{Ad}_{100}\right)$, diopside $\left(\mathrm{Hd}_{5}-\mathrm{Hd}_{50}\right)$, actinolite, chlorite, montmorillonite clays, chalcopyrite, pyrite, hematite, and magnetite. However, the

FIGURE 104.-Ternary plots showing range of garnet and pyroxene compositions in barren and mineralized skarn at Copper Basin (this study), in skarn at other deposits in north-central Nevada, and in other skarns grouped by associated metal (from Meinert, 1983, figs. 2, 3). A, B, Garnets, in terms of molecular proportions of pyrope (Py)+almandine (Al)+spessartine (Sp), grossular (Gr), and andradite (Ad). $C, D$, Pyroxenes, in terms of molecular proportions of johannsenite (Jo), diopside ( $\mathrm{Di}$ ), and hedenbergite ( $\mathrm{Hd})$. Data for West ore body at Copper Canyon from N.G. Banks (in Theodore and Blake, 1978); data for Fortitude and McCoy deposits from unpublished data of J.M. Hammarstrom. 

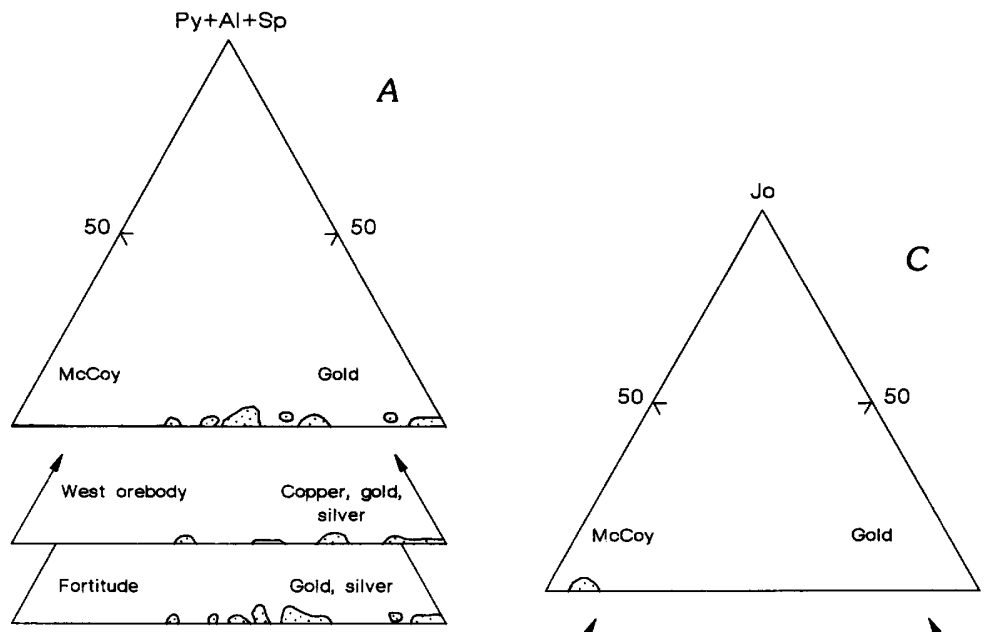

Copper Canyon
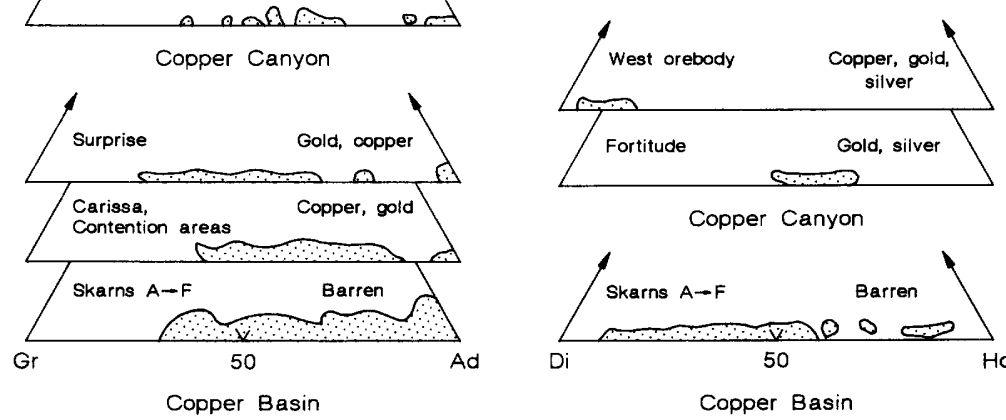

Copper Canyon
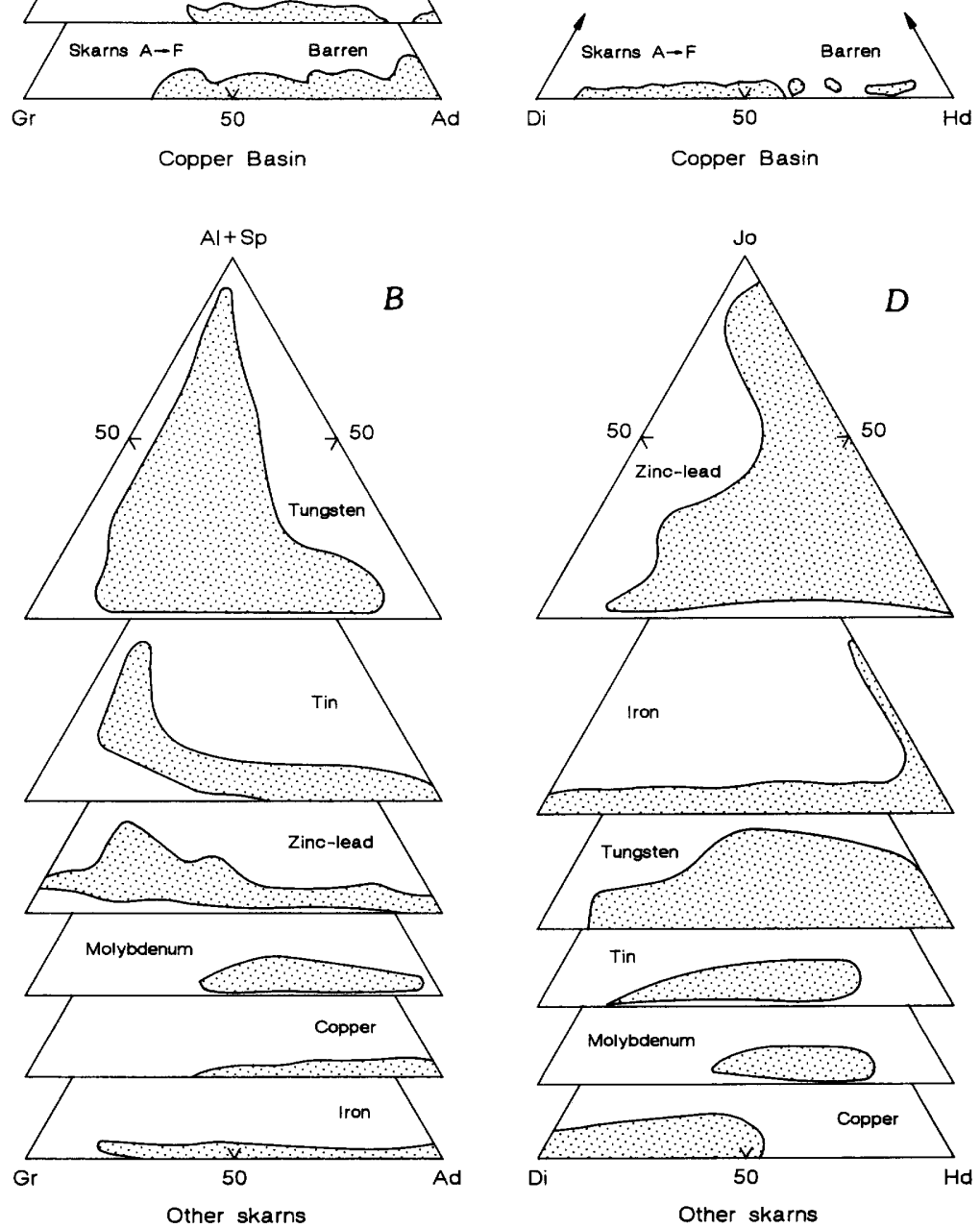
paucity of pyroxene, presence of garnet compositions more grossular rich than $\mathrm{Ad}_{60}$, extensive oxidation of sulfides, abundance of epidote and brown chlorite, absence of wollastonite, and presence of pyrrhotite as the dominant sulfide in mineralized skarn (see subsection above entitled "Supergene Copper Deposits at Copper Basin") are distinctive features of the Copper Basin skarns. Meinert (1988) outlined fields for garnet and pyroxene compositions from gold skarns that fall within the established fields for mineral compositions for copper skarns and noted that garnets and amphiboles associated with gold skarns appear to be more aluminous and pyroxenes tend to be more hedenbergitic than those found in other types of skarns. He also pointed out that pyrrhotite and arsenopyrite are characteristic sulfides of gold skarns, although there are some notable exceptions, such as the McCoy, Nev., gold skarn deposit (see Theodore and others, 1991). Meinert's fields for silicate mineral chemistry, however, represent data for the Whitehorse Mining District, Yukon Territory, Canada, which does not reach the cutoff grade of $1 \mathrm{~g} \mathrm{Au} / \mathrm{t}$ used by Theodore and others (1991) to define gold skarn and byproduct gold skarn. No data base yet exists for gold skarn mineral chemistry comparable to the extensive data base that exists for other types of skarn, although several studies are currently underway.

\section{ENVIRONMENT OF SKARN DEVELOPMENT}

The superposition of retrograde assemblages on main-stage skarn-forming metasomatic assemblages, which, in turn, replace early-stage, contactmetamorphic assemblages in skarn environments, makes it very difficult to identify equilibrated mineral assemblages that can be used in conjunction with experimentally determined or calculated phase equilibria to outline a particular skarn-forming environment. Observed mineral assemblages and mineral compositions described in this chapter can be combined with other data (for example, fluid-inclusion data) to place some broad constraints on the intensive parameters during formation of Copper Basin skarns. Observed mineral assemblages are a function of temperature, pressure, oxygen fugacity, sulfur fugacity, and fluid composition, as well as bulk composition of the protolith. General similarities to skarns associated with porphyry copper environments, association with porphyritic rocks, and geobarometric estimates from stratigraphic thicknesses and fluid-inclusion studies (see subsection below entitled "Fluid-Inclusion Studies") suggest that the Copper Basin skarns formed under total pressures of no more than 200 to 1,000 bars. Pervasive supergene alteration of most sulfides and iron oxide minerals that may have been deposited during late-stage metasomatism precludes precise definition of oxygen and sulfur fugacity regime. However, the following observations point to a relatively oxidizing environment of skarn formation near or above conditions defined by the magnetite-hematite buffer: absence of graphite, the presence of hematite in some samples, apparent oxidation of earlier stage sulfide minerals to goethite and other hydrous iron oxide minerals, the iron content of epidote, the diopsidic composition of pyroxene, and the preponderance of garnet replacing pyroxene. Einaudi (1982b) showed that $X_{\mathrm{CO}_{2}}$ in skarn-forming environments is commonly less than 0.1 . Assumption of an $\mathrm{H}_{2} \mathrm{O}$-rich metasomatic fluid for some stages of Copper Basin skarn formation is supported by the absence of $\mathrm{CO}_{2}$ in fluid inclusions in second-generation andradites from skarn D (see subsection below entitled "FluidInclusion Studies") and the absence of carbonate in skarn A. However, the presence of multiple generations of garnet, the likelihood of multiple fluids permeating these rocks over time, and the variable carbonate contents of the protolith sedimentary rocks suggest that fluid compositions may have fluctuated significantly.

Meinert (1982) outlined fields for stable assemblages of garnet+pyroxene+quartz, actinolite, and actinolite+quartz+calcite to depict the $T-f_{\mathrm{O}_{2}}$ environment of skarn formation at Cananea, Mexico, for the conditions $P_{\text {fluid }}=500$ bars, $X_{\mathrm{CO}_{2}}=0.1$; figure $105 A$ is based on Meinert's plot. The diagram is constructed from reactions studied experimentally by a number of workers, and corrections were made for effects of compositional variation. As pointed out by Einaudi and others (1981), lowering $X_{\mathrm{CO}_{2}}$ from 0.1 to 0.01 at constant pressure lowers the thermal stability of many reactions by 50-100 ${ }^{\circ} \mathrm{C}$. For example, the minimum thermal stability of andradite, based on the reaction $3 \mathrm{Q}+3 \mathrm{CC}+1 / 4 \mathrm{Hm}+1 / 2 \mathrm{Mt}+1 / 8 \mathrm{O}_{2}=\mathrm{Ad}+3 \mathrm{CO}_{2}$ studied by Taylor and Liou (1978) at 2,000 bars, occurs at $640{ }^{\circ} \mathrm{C}$ for $X_{\mathrm{CO}_{2}}=1.0$ but drops to $550{ }^{\circ} \mathrm{C}$ for $X_{\mathrm{CO}_{2}}=0.22$. However, at very low $X_{\mathrm{CO}_{2}}$ values (less than 0.1), andradite is stable to much lower temperatures. Much of the late-stage, clean, yellow, isotropic andradite in the Copper Basin skarns may have formed under such conditions of low $T$ and low $X_{\mathrm{CO}_{2}}$. Taylor and Liou (1978) noted that 

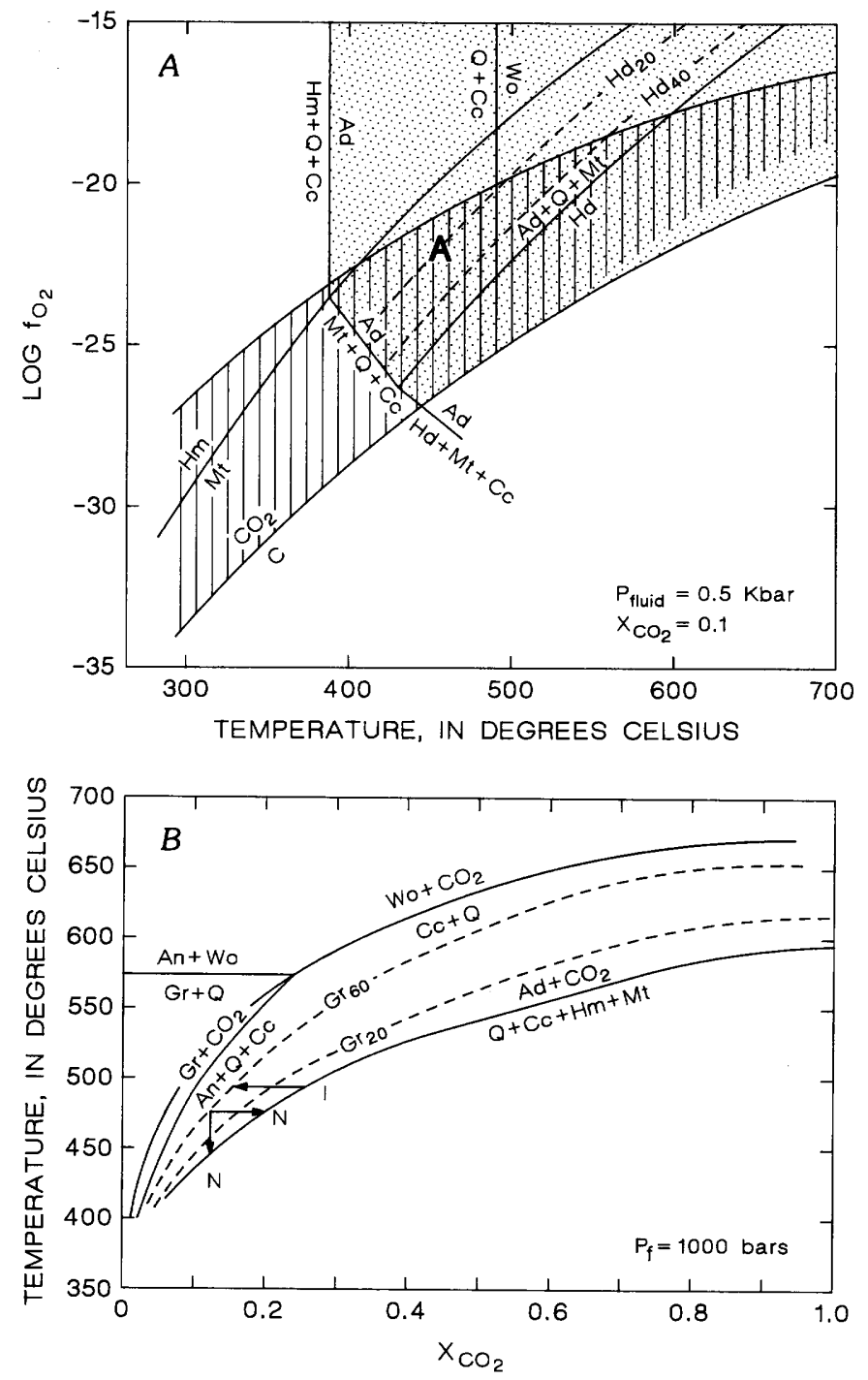

FIgURE 105.-Phase diagrams showing equilibria that can be used to approximate conditions of skarn formation. $A$, Temperature (T)-oxygen fugacity $\left(f_{\mathrm{O}_{2}}\right)$ diagram showing estimated conditions of formation for skarn $\mathrm{A}$, based on observed mineral assemblages and fluid-inclusion studies, for assumed conditions of pressure and fluid composition. Garnet is stable within shaded field; pyroxene $\left(\mathrm{Hd}_{2} \mathrm{O}-\mathrm{Hd}_{4} \mathrm{O}\right)$ coexists with garnet in dotted field. Oxygen buffers for hematite $(\mathrm{Hm})$-magnetite $(\mathrm{Mt})$ and graphite $(\mathrm{C})$-carbon dioxide $\left(\mathrm{CO}_{2}\right)$ are shown for reference, as well as wollastone $\left(\mathrm{Wo}_{2}\right)=$ quartz $(\mathrm{Q})+$ calcite $(\mathrm{Cc})$ reaction. Amphibole is stable over much of garnet+pyroxene region of diagram, as well as at lower temperatures as indicated on diagram. Estimates of region for skarn formation at Fortitude and West ore-body deposits are from Myers and Meinert (1988). Ad, andradite; An, anorthite $B$, Temperature (T)- $\mathrm{X}_{\mathrm{CO}_{2}}$ diagram showing stability field for garnet solid solutions relative to assemblage quartz $(\mathrm{Q})+$ calcite $(\mathrm{Cc})+$ hematite $(\mathrm{Hm})+$ magnetite $(\mathrm{Mt})$ as a function of grossular (Gr) content. Modified from Lee and Atkinson (1985, fig. 7). Arrows indicate possible idealized trends for normal (N) and inverse (I) zoning in skarn garnets under assumed conditions of pressure and temperature of fluid composition. andradite will be replaced by epidote via retrograde reactions involving $\mathrm{H}_{2} \mathrm{O}$-rich fluids at higher temperatures than grossular-rich garnets will be replaced. Thus, andradite-rich bands in zoned garnet may be selectively replaced as temperatures decline during retrograde skarn stages where $\mathrm{H}_{2} \mathrm{O}$ rich fluids are present; such textures are observed in many of the samples from skarn in the Harmony Formation and have been described elsewhere. In skarn formed in the Battle Formation and in the Antler Peak Limestone, epidote is observed only in clay and siltite samples and calcite is ubiquitous; for carbonate-rich protoliths, $X_{\mathrm{CO}_{2}}$ may have been higher in fluids associated with skarn formation than in those associated with skarn formed in the Harmony Formation. The reaction $9 \mathrm{Hd}+2 \mathrm{O}_{2}=$ $3 \mathrm{Ad}+\mathrm{Mt}+9 \mathrm{Q}$ represents the upper oxygen fugacity limit for pure hedenbergite at constant $P$ and $X_{\mathrm{CO}_{2}}$. Meinert (1982) showed that the effect of increasing the diopside component of the pyroxene involved in this reaction is to raise the $f_{\mathrm{O}_{2}}$ for the reaction at any given temperature. Pure ferrotremolite is only stable at very low oxygen fugacities (Ernst, 1966), but as in the case for hedenbergite, the incorporation of magnesium raises the oxygen fugacity at which the amphibole is stable for any given temperature. Occurrence of pyroxene of compositions $\mathrm{Hd}_{20}$ to $\mathrm{Hd}_{40}$ undergoing replacement by andraditerich garnet with no evidence for retrograde replacement by amphibole suggests that oxygen fugacities for skarn A may have been at or above the $\mathrm{Hd}_{20}$ and $\mathrm{Hd}_{40}$ reactions shown in figure $105 \mathrm{~A}$. The absence of calcite in the skarns formed in the Harmony Formation and the abundance of epidote replacing iron-rich garnet suggest that $X_{\mathrm{CO}_{2}}$ may have been significantly lower that the value of 0.1 for which figure $105 \mathrm{~A}$ was constructed in which case the minimum thermal stabilities for these reactions would be lowered. Lack of pyroxene in most samples from skarns $C$ and $D$ suggests conditions above the hedenbergite breakdown reaction, but no values for $T$ or $f_{\mathrm{O}_{2}}$ can be assigned. Skarn $\mathrm{F}$, formed in the Antler Peak Limestone, shows good textural evidence (fig. 93C) for a stable assemblage involving calcite, quartz, and late-stage andradite. The presence of quartz and calcite instead of wollastonite suggests that $500{ }^{\circ} \mathrm{C}$ is an upper temperature limit for the late stages of skarn growth under the assumed pressure and fluid composition. No wollastonite was observed in any of the samples studied, and calcite and quartz commonly are present as inclusions in garnet cores; however, textural evidence for contiguous calcite and quartz is only demonstrated for skarn G. Theodore and Blake 
(1978) noted the absence of wollastonite in skarn at Copper Canyon and suggested that once-stable wollastonite assemblages may have been consumed by subsequent reactions. Theodore and Hammarstrom (1991) estimated that prograde skarn genesis in skarn A involved highly saline (as much as 70 weight percent $\mathrm{NaCl}$ equivalent) sodium-calcium-iron brines at temperatures of about $475{ }^{\circ} \mathrm{C}$. Myers and Meinert (1988) estimated conditions of formation for skarn at Copper Canyon. They concluded that much of mineralization at the proximal, garnet-rich West ore body formed at temperatures in the range $450-550{ }^{\circ} \mathrm{C}$ in association with relatively saline (more than 26 weight percent $\mathrm{NaCl}$ equivalent) fluids. For the Fortitude skarn, they estimated lower temperatures $\left(300-450{ }^{\circ} \mathrm{C}\right)$ and salinities, and relatively low oxygen ( $\log f_{\mathrm{O}_{2}}=$ $-30)$ and sulfur $\left(\log f_{\mathrm{S}_{2}}=-10\right)$ fugacities. Hedenbergite is stable with massive pyrrhotite, which hosts the gold at the Fortitude deposit. Although the Surprise deposit has undergone extensive supergene alteration and, probably, remobilization of gold, the occurrence of garnet-dominated assemblages including minor diopside with magnetite and hematite suggests that the environment of skarn formation at the Surprise deposit was probably more oxidizing than at the Fortitude deposit. However, only the supergene-oxidized, upper parts of the Surprise deposit have been exposed to date (1989).

The effects of fluctuating conditions of temperature and fluid compositions on garnet equilibria were examined by Lee and Atkinson (1985). Figure $105 B$ is modified from their study, which was based partly on work by Sweeney (1980). These studies show that zoning trends and sudden shifts between relatively andradite and grossular rich compositions can be accomplished by increasing or decreasing $X_{\mathrm{CO}}$ at constant temperature and pressure, as well as by raising or lowering temperature at constant $X_{\mathrm{CO}_{2}}$ and pressure. Possible mechanisms for these changes, all or some of which could have prevailed at various stages of skarn evolution at Copper Basin include (1) lowering $X_{\mathrm{CO}_{2}}$ by boiling, (2) a change in the pressure regime because of fracturing, (3) influx of hightemperature fluids, or (4) mixing of fluids with meteoric water. The arrows in figure $105 B$ indicate idealized paths that would result in normal $(\mathrm{N})$ and inverse (I) zoning.

The extent of development of different skarn stages varies over the study area. Prograde garnet+pyroxene assemblages are present in the westernmost skarns in the Harmony Formation. Late-stage metasomatic and retrograde assemblages characterized by replacement of garnet and pyroxene by hydrous phases are best developed in skarns in the Battle Formation, in the Antler Peak Limestone, and where the Harmony Formation is extensively fractured. Except for traces of pyrite and chalcopyrite in limonite, sulfide-bearing assemblages are observed only in samples from the Contention pit and Surprise deposit.

\section{FLUID-INGLUSION STUDIES}

Fairly comprehensive standard heating and freezing studies of fluid inclusions (see Hollister and Crawford, 1981; Roedder, 1984) were performed on many samples from several different lithometallogenic environments in the Buckingham area. Some of these studies built upon the preliminary fluidinclusion investigations by Blake and others (1979) of 24 samples of molybdenum-mineralized rocks from the Harmony Formation and Late Cretaceous monzogranite from the Buckingham system. In this report, we have supplemented those earlier fluidinclusion investigations by performing additional heating and freezing tests on 43 samples from the quartz stockwork part of the Buckingham system. A scanning electron microscope (SEM) was used extensively throughout the entire investigation to identify daughter minerals and trapped minerals in fluid inclusions (see Roedder, 1984). In addition, the SEM was also used to identify the predominant cation species in the fluids of those two-phase fluid inclusions (liquid and vapor at room temperature) that do not contain daughter or trapped minerals. By means of the energy-dispersive X-ray elemental microanalyzer of the SEM, we were able to identify desiccation products on walls of fluid inclusions after some samples were broken at room temperature, and after other samples had been frozen in liquid nitrogen, then broken while still frozen, and subsequently freeze-dried slowly. In addition, a cryogenic stage attached to the SEM was used to determine qualitatively the cation make up of fluid-inclusion ice in a few selected fluid inclusions. Data describing the pressure-temperature-chemical environment of presumably some of the earliest fluid(s) associated with the Buckingham system that we will infer from fluid-inclusion relations in the Buckinghamassociated andradite-pyroxene skarns is presented below. Finally, the implications of fluid-inclusion studies on the inferred genesis of some of the Tertiary base and precious-metal mineralized and potentially mineralized systems (including the mostly 
silver producing Little Giant Mine, the gold-bearing quartz stockworks at the head of Paiute Gulch and Poorman's Gulch, and skarn associated with porphyritic leucogranite) are also described.

Fluid inclusions are classified for descriptive purposes according to a scheme modified somewhat from one devised by Nash and Theodore (1971) for the Tertiary copper-gold-silver deposits at Copper Canyon (fig. 106). Type I fluid inclusions generally show only two phases at room temperature, mostly liquid $\mathrm{H}_{2} \mathrm{O}$ and vapor. Some of these phases may

Type I

Liquid $\mathrm{H}_{2} \mathrm{O}$

( \pm Liquid $\mathrm{CO}_{2}$ at temperature $<20^{\circ} \mathrm{C}$ )

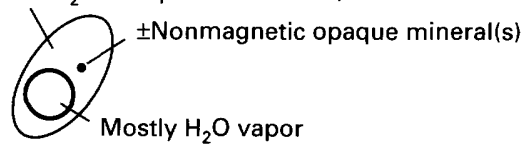

Type II

Liquid $\mathrm{H}_{2} \mathrm{O}$

( \pm Liquid $\mathrm{CO}_{2}$ at temperature $<20^{\circ} \mathrm{C}$ )

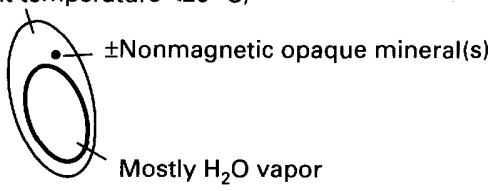

Type IV
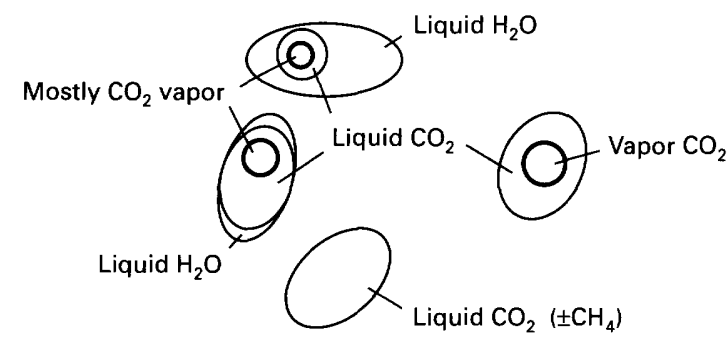

Type III
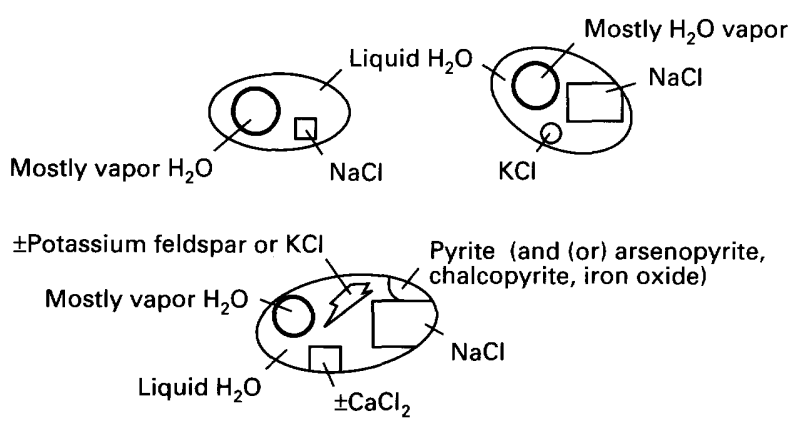

Figure 106.-Sketches of four types of fluid inclusions found in Cretaceous and Tertiary deposits in Buckingham area. Modified from Nash and Theodore (1971). include a very small, nonmagnetic opaque mineral. Type II fluid inclusions (fig. 106) are similar to type I fluid inclusions, except that the liquid-vapor proportion has switched: Generally more than 50 volume percent of these fluid inclusions is vapor at room temperature. Again, they may also include a very small, nonmagnetic opaque mineral. Type III fluid inclusions (fig. 106) are composite, and they may contain approximately 10 to 20 volume percent vapor, and at least one nonopaque daughter mineral. Some of the type III fluid inclusions are crystal rich, inasmuch as they contain more than one nonopaque daughter mineral; other crystal-rich varieties of type III fluid inclusions contain small, equant to irregular, relatively large opaque minerals. Type III fluid inclusions are relatively rare throughout the quartz stockwork part of the Buckingham molybdenum system. Type IV fluid inclusions show at room temperature $\left(21 \pm 2{ }^{\circ} \mathrm{C}\right)$ the presence of three phases, mostly liquid $\mathrm{H}_{2} \mathrm{O}$, some liquid $\mathrm{CO}_{2}$, and $\mathrm{CO}_{2}$ vapor (fig. 106). Type IV fluid inclusions at room temperature contain highly variable proportions of $\mathrm{CO}_{2}$ vapor, from about 5 to more than 50 volume percent. In addition, there are some extremely $\mathrm{CO}_{2}$ rich fluid inclusions, containing as much as 100 weight percent $\mathrm{CO}_{2}$, concentrated locally in some parts of the system. In addition, the percentage of type IV fluid inclusions relative to the entire fluid-inclusion population trapped in a sample is extremely irregular. Some samples of vein quartz examined from deep within the West stock of the Buckingham system show a fluid-inclusion population that seems to be made up entirely of type IV fluid inclusions.

An attempt was made first to establish the relevant system of the aqueous brine trapped by all type I fluid inclusions investigated according to the procedures outlined in Roedder (1984) after first determining, if possible, paragenesis of the fluid inclusions relative to their host mineral. Assignment to a chemical system was accomplished by observing, whenever possible, the eutectic melting temperature of the frozen aqueous brine as it warmed slowly and then referring to phase data for pertinent chloride-bearing aqueous solutions (Crawford, 1981). Freezing temperatures of the liquid-andvapor fluid inclusions (types I and II) were measured using the depression-of-freezing-point method of Roedder (1962; see Bodnar and others, 1985a). Salinities of fluid inclusions whose eutectic temperatures could not be determined and of those with eutectic temperatures in the range -20 to -24 ${ }^{\circ} \mathrm{C}$ (and thus close to the $\mathrm{H}_{2} \mathrm{O}-\mathrm{NaCl}$ eutectic of $-20.8{ }^{\circ} \mathrm{C}$ ) were calculated from the freezing point 
depressions using the equations of Potter and others (1978), and are expressed as weight percent $\mathrm{NaCl}$ equivalent. Some of the liquid-and-vapor fluid inclusions are hosted by second-generation andradite of skarn $\mathbf{D}$ and have eutectic temperatures ranging from -38 to $-49{ }^{\circ} \mathrm{C}$; they probably contain abundant $\mathrm{CaCl}_{2}$ as a dissolved species. The salinities of such fluid inclusions were determined from the freezing point depressions using the data of Linke (1965). The methods of Collins (1979) and Bozzo and others (1975) were used to determine the salinities of those fluid inclusions, mostly type $\mathrm{IV}$, found to form clathrates $\left(\mathrm{CO}_{2} \cdot 5 \frac{3}{4} \mathrm{H}_{2} \mathrm{O}\right)$ during cooling tests. The salinities of fluid inclusions containing $\mathrm{NaCl}$ and (or) $\mathrm{KCl}$ daughter minerals (type III) were estimated by establishing the temperature of solution of $\mathrm{NaCl}$ and (or) $\mathrm{KCl}$ and referring to the phase data of Linke (1965) and to the relevant part of the system NaCl-KCl- $\mathrm{H}_{2} \mathrm{O}$ in Roedder (1984).

Carbon dioxide is an important component of the fluids associated with the molybdenum-mineralized Buckingham system, probably amounting to somewhere from 5 to $10 \mathrm{~mol}$ percent dissolved $\mathrm{CO}_{2}$ in the system west of the Long Canyon fault, and much more than these amounts locally in small domains of the uppermost quartz-stockwork-rich parts of the system that crop out east of the Long Canyon fault and in small domains of quartz veins studied deep within the West block. One important aspect of the classification scheme that we have adopted for the Buckingham study is the apparent continuum that exists among fluid-inclusion types I, II, and IV. Such a continuum indicates that the variable proportions of $\mathrm{CO}_{2}$ in the fluid inclusions are due primarily to boiling of the fluids during the early stages of mineralization and following effervescence. A critical aspect of the overall classification scheme is the paragenesis of fluid inclusions relative to the enclosing host mineral: primary, pseudosecondary, or secondary (Roedder, 1984). Nonetheless, we recognize the difficulties inherent in the accurate determination of primary fluid inclusions in a dynamic environment such as an evolving porphyry system. Thus, type I fluid inclusions (fig. 106), mostly liquid $\mathrm{H}_{2} \mathrm{O}+$ vapor at room temperature, may or may not contain $\mathrm{CO}_{2}$; some of these type I fluid inclusions exsolve liquid $\mathrm{CO}_{2}$ when cooled to temperatures less than room temperature. The presence of $\mathrm{CO}_{2}$ in these fluid inclusions was confirmed by crushing tests that showed the presence of a noncondensable gas at a vapor pressure higher than 1 bar, instantaneous dissolution of such released gases in a solution of acidified $\mathrm{BaCl}_{2}$ (Roedder, 1984, p. 218-219), and the observed transition from solid to liquid at -56.6 ${ }^{\circ} \mathrm{C}$. Many of the type I fluid inclusions in vein quartz associated with the Buckingham system contain a mostly liquid $\mathrm{H}_{2} \mathrm{O}$ phase and a vapor bubble at temperatures above 5-10 ${ }^{\circ} \mathrm{C}$. However, at temperatures generally below these, liquid $\mathrm{CO}_{2}$ condenses from the vapor and, in many fluid inclusions, forms an interface of various thicknesses between the vapor and the moderately saline liquid $\mathrm{H}_{2} \mathrm{O}$ (0-13.0 weight percent $\mathrm{NaCl}$ equivalent). In addition, some two-phase fluid inclusions in the uppermost parts of the system, east of the Long Canyon fault, appear to be typical type I fluid inclusions when observed at room temperature. However, heating and cooling tests show them to consist almost entirely of $\mathrm{CO}_{2}$ liquid and $\mathrm{CO}_{2}$ vapor. The highly variable proportions of vapor, liquid $\mathrm{CO}_{2}$, and mostly liquid $\mathrm{H}_{2} \mathrm{O}$ in type IV fluid inclusions throughout the system may indicate (1) local exsolution of $\mathrm{CO}_{2}$ from the fluid during mineralization (especially in light of the experimental studies of Takenouchi and Kennedy (1965) that showed significant decreases in the solubility of $\mathrm{CO}_{2}$ in even moderately saline solutions); (2) nonuniform fixation of $\mathrm{CO}_{2}$ as carbonate in late-stage gangue minerals; or (3) boiling or effervescence. Freezing tests showed repeated development of solid $\mathrm{CO}_{2} \cdot 5 \% / 4 \mathrm{H}_{2} \mathrm{O}$ (Roedder, 1963), mostly at the site of the former liquid $\mathrm{CO}_{2}$ in the fluid inclusions, and these tests yielded final melting points in the range -0.5 to $+11.0{ }^{\circ} \mathrm{C}$ for the hydrates. Moreover, the unrecognized presence of $\mathrm{CO}_{2}$ in some type I and type II fluid inclusions at Buckingham may contribute to reported determinations of salinity slightly higher than actual. Dissolved $\mathrm{CO}_{2}$ in pure $\mathrm{H}_{2} \mathrm{O}$ can lower the temperature of final melting of ice in the system $\mathrm{H}_{2} \mathrm{O}-\mathrm{CO}_{2}$ to as much as $-1.48^{\circ} \mathrm{C}$ (Bodnar and others, $1985 \mathrm{~b})$. Such a depression-of-freezing-point value would correspond to a salinity determination apparently 2 weight percent $\mathrm{NaCl}$ equivalent higher than the real value. Salinities in types I and II fluid inclusions reported below are in the range 0-20 weight percent $\mathrm{NaCl}$ equivalent.

\section{BUCKINGHAM MOLYBDENUM SYSTEM}

\section{SKARN}

Second-generation, red-brown andradite in andradite-clinopyroxene skarn $D$, apparently associated temporally and genetically with the Late Cretaceous Buckingham system, commonly contains some spectacularly developed type I fluid inclusions 
Tests using a crushing stage (see Roedder, 1984, p. 212-217) show no detectable $\mathrm{CO}_{2}$ as a noncondensable gas in the fluid inclusions hosted by the second-generation andradite in skarn $\mathrm{D}$. This rela-

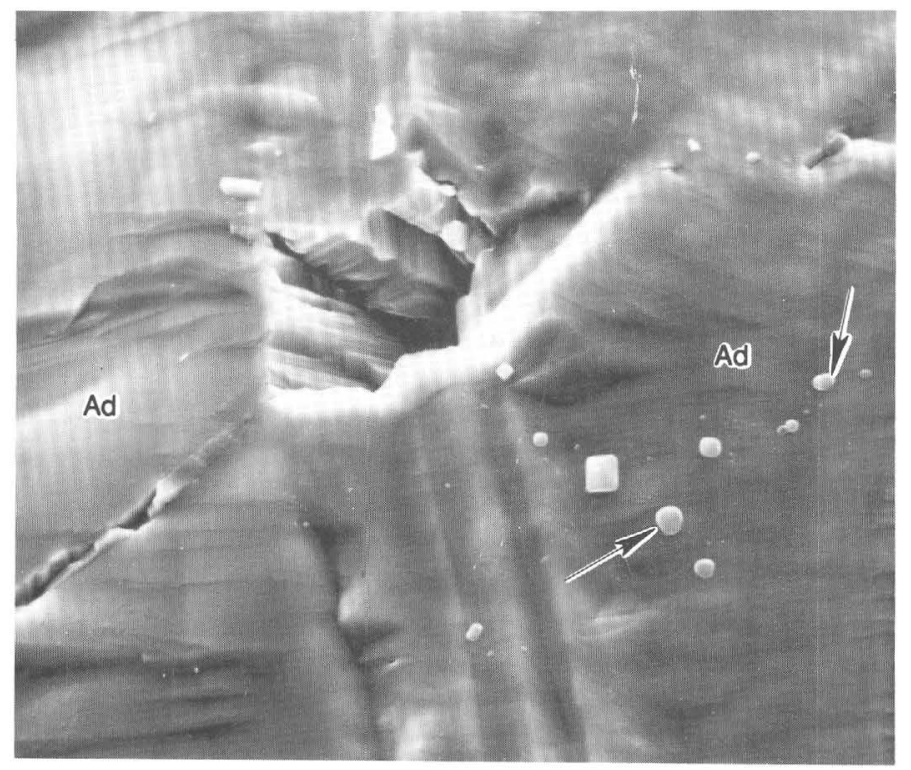

$\boldsymbol{A}$ 0 

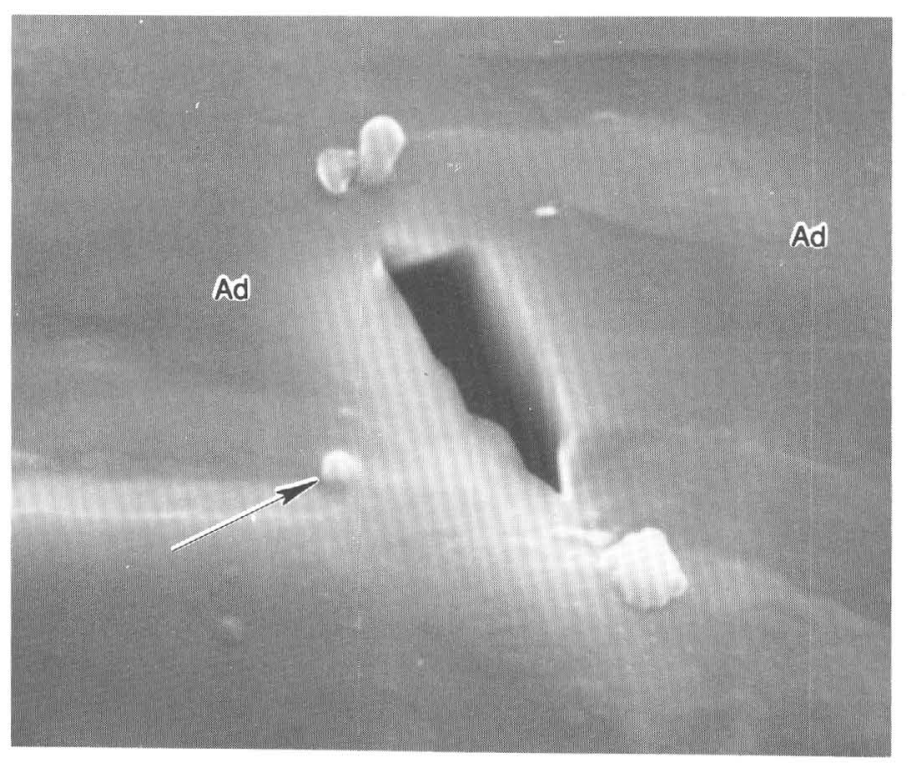
$\boldsymbol{B}$ 0 6 MICRONS

FIGURE 108.-Scanning electron micrographs of fluid-inclusion cavities and desiccation products from fluid-inclusion waters on artificially broken surfaces of andradite. Sample 76CB2A. Ad, andradite. A, Approximately $20-\mu \mathrm{m}$-long fluid-inclusion cavity that lies astride several growth zones in andradite. Analyzed desiccation products (calcium, chlorine, and traces of sodium) at heads of arrows (see spectrum, fig. 109A). B, Approximately tion is in striking contrast to the widespread distribution and relative abundance of $\mathrm{CO}_{2}$ in selected samples of vein quartz in stockworks from the Buckingham system. Individual andradite crystals were handpicked, then crushed in immersion oil between glass plates on the stage of a microscope. As pointed out by Roedder (1984, p. 213) and Bodnar and others (1985b), this is an extraordinarily sensitive method that can be used to detect minute amounts of noncondensable gases, such as $\mathrm{CO}_{2}$, in fluid inclusions. Painstaking crushing tests repeatedly show instantaneous inward collapse of the immersion oil into fluid inclusions and microcracks that developed throughout the crystals of andradite as the pressure was applied slowly on the crushing stage. The microcracks fail to lead to the expansion of visible gas bubbles from the fluid inclusions into the surrounding immersion oil. Because the vapor pressure of $\mathrm{CO}_{2}$ at room temperature is almost always higher than 1 bar (see Hollister, 1981; Bodnar and others, 1985b), the content of $\mathrm{CO}_{2}$ as a noncondensable gas in these fluid inclusions in andradite must be extremely low if there is any such gas there at all. Nonetheless, some $\mathrm{CO}_{2}$ may be dissolved in

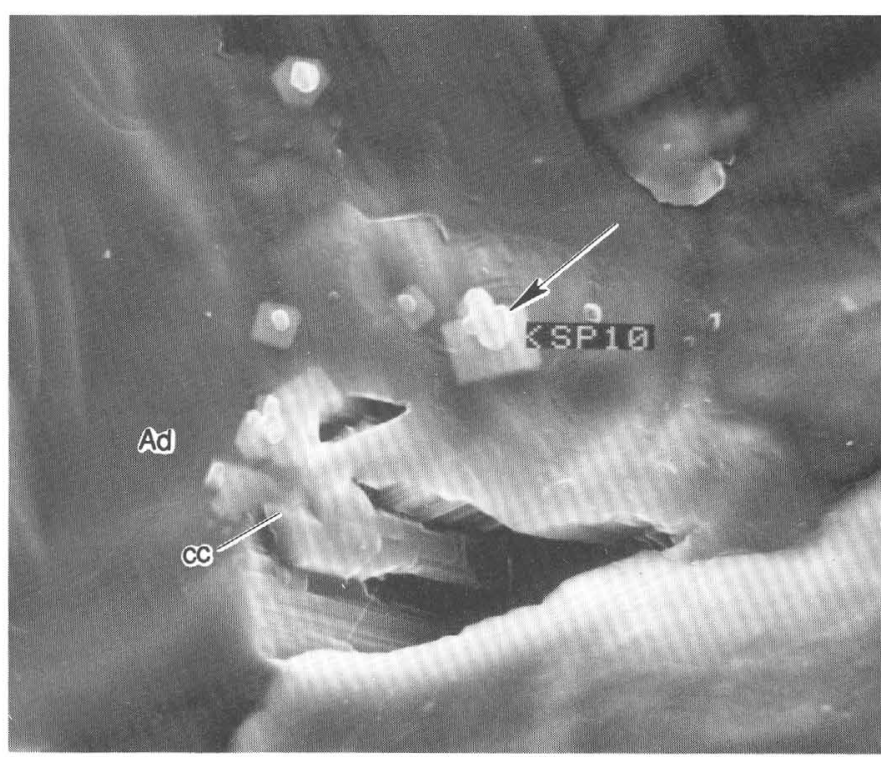

C 0 16 MICRONS

$6-\mu \mathrm{m}$-long fluid-inclusion cavity in andradite. Desiccation products (at head of arrow) show presence of calcium, chlorine, and sodium (trace); $C$, An approximately $10-\mu \mathrm{m}$-long fluid-inclusion cavity in andradite, showing blebby desiccation products that include chlorine, calcium, sodium, and potassium on surface of andradite. Fluid-inclusion cavity also contains some calcite (cc). Spot analysis at head of arrow (see fig. 109). 
that were trapped apparently before the cessation of andradite growth (fig. 107A). We can only infer that these second-generation andradite crystals are associated with the Buckingham system. Some iron metasomatism in the form of narrow veins of andradite is superposed onto Buckingham systemrelated skarn D at the Labrador Mine (pl. 1; fig. 86), which is located south of the sample site of the andradite of figure 107 (loc. 76CB2, fig. 86). Gold mineralization at the Labrador Mine is most likely associated genetically with late Eocene or early

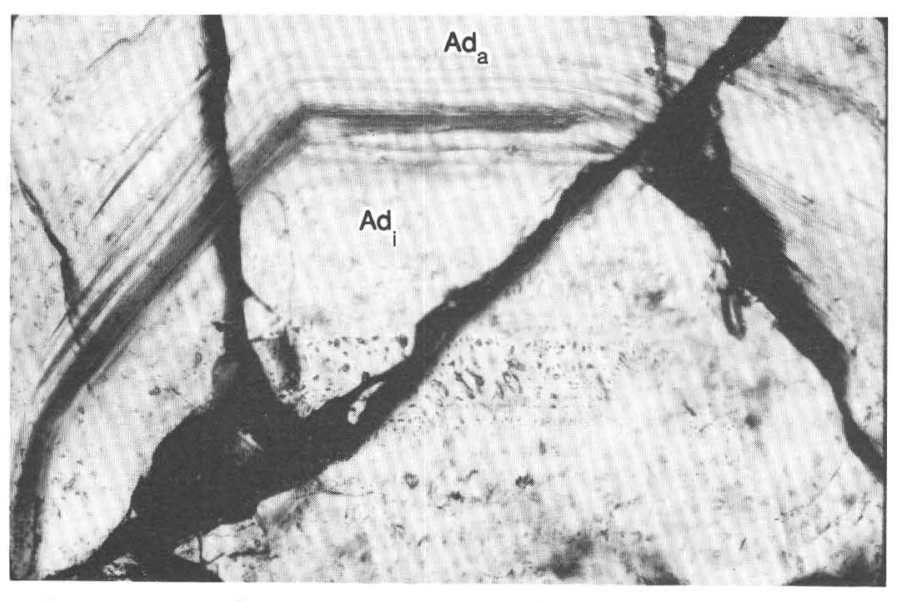

$\boldsymbol{A}$ 0 0.8 MILLIMETER

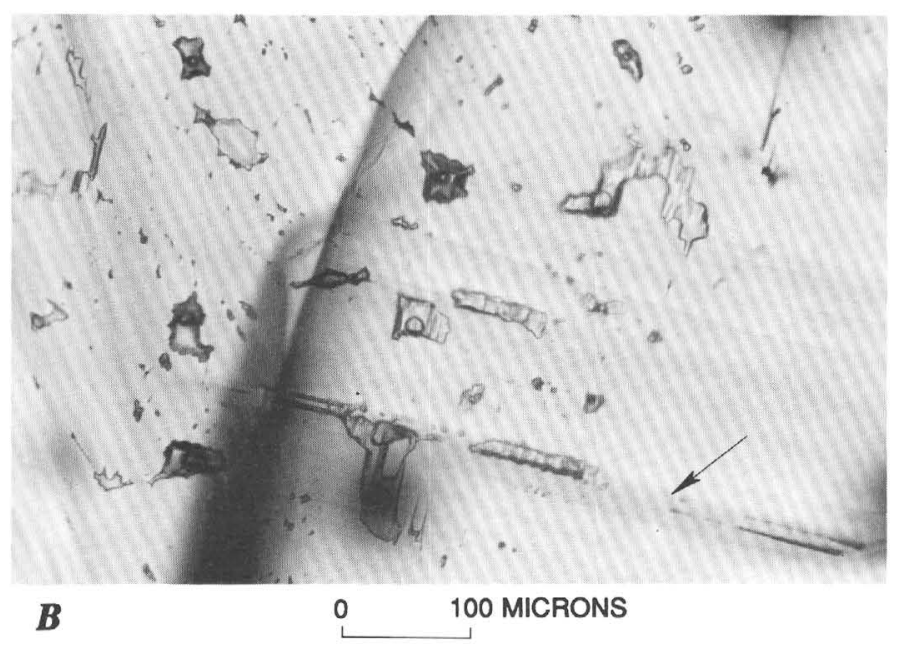

FIGURE 107.-Photomicrographs of primary and pseudosecondary type I fluid inclusions in andradite (Ad). Plane-polarized light. Samples collected from skarn D approximately $150 \mathrm{~m}$ south of north end (see fig. 86). A, Large crystal of andradite, showing a preferred concentration of fluid inclusions in its isotropic core $\left(\mathrm{Ad}_{\mathrm{i}}\right)$ and an anisotropic $\operatorname{rim}\left(\mathrm{Ad}_{\mathrm{a}}\right)$ of andradite free of fluid inclusions. Sample 76CB2C. B, Primary and (or) pseudosecondary fluid inclusions that follow traces of octahedral crystal growth surfaces (at head of arrow) in isotropic andradite.
Oligocene porphyritic leucogranite (see above; Schmidt and others, 1988) that, to the northwest, has been demonstrably shown to be associated with fluids saturated highly by $\mathrm{NaCl}$ during andraditeforming stages (Theodore and Hammarstrom, 1991). In marked contrast, fluids trapped in the second-generation andradite crystals might be associated with the generally moderately saline fluid environment of the Buckingham stockwork molybdenum system (see below). The final homogenization temperatures and salinities of such fluid inclusions presumably provide significant insight as to the $P-T-X$ conditions of some of the fluids associated with these second-generation andradites in this part of the system. These type I fluid inclusions are concentrated especially in isotropic cores of andradite, and they are present in several paragenetic associations relative to the host andradite crystals: (1) extremely small (generally less than 1 $\mu \mathrm{m})$ primary fluid inclusions that are restricted narrowly to crystal growth surfaces (fig. 107B); (2) relatively large, irregular, questionably primary but definitely pseudosecondary fluid inclusions whose largest dimension, typically about $100 \mu \mathrm{m}$, either parallels an individual crystal growth surface or lies astride several crystal growth surfaces; or (3) variable-size, pseudosecondary type I fluid inclusions that are arrayed along discontinuous, curviplanar surfaces that are confined mostly to the isotropic cores of the andradite but rarely also extend partly through the enveloping rims of anisotropic andradite. The curviplanar surfaces follow traces of annealed microcracks that intersect the andradite's crystal-growth surfaces at variable angles. Generally, the exceptionally thin, lamellar growth zones in the rims merge into the somewhat wider growth zones of the core without an apparent lapse in crystallization of andradite. Or, the incomplete anisotropic rim of one crystal may feather with flamelike intergrowths into the isotropic part of a somewhat later crystallized, adjoining crystal of andradite. Nonetheless, all of these relations attest to a repeated, microscopic opening and rehealing of skarn in a nonboiling environment while andradite of varying compositions (see section above entitled "Mineral Chemistry of Late Cretaceous and Tertiary Skarns") continued to grow. Furthermore, it is impossible to correlate with any certainty whatsoever the fluid inclusions trapped along one crystal face with those trapped along or across nearby crystals of andradite; this relation is in marked contrast with fluid-inclusion correlations among samples at other skarns elsewhere (Kwak, 1986). 
the liquid phase of these type I fluid inclusions in abundances of about 2 or 3 mol percent (Ypma, 1963; Bodnar and others, 1985b). Extremely small crystals of carbonate are present rarely in a few of the fluid inclusions in the andradites (see below).

Fluids containing appreciable amounts of $\mathrm{CaCl}_{2}$ apparently are the predominant type of fluid associated with the second-generation andradite in skarn D. Repeated determinations of the eutectic temperatures of such fluid-inclusion waters by means of the freezing stage showed that initial melting temperatures are in the range -49 to $-38{ }^{\circ} \mathrm{C}$ and their mean is about $-45^{\circ} \mathrm{C}$. By comparison, the eutectic temperature reported by Crawford (1981) for dissolved $\mathrm{CaCl}_{2}$ in $\mathrm{H}_{2} \mathrm{O}$ is -49.8

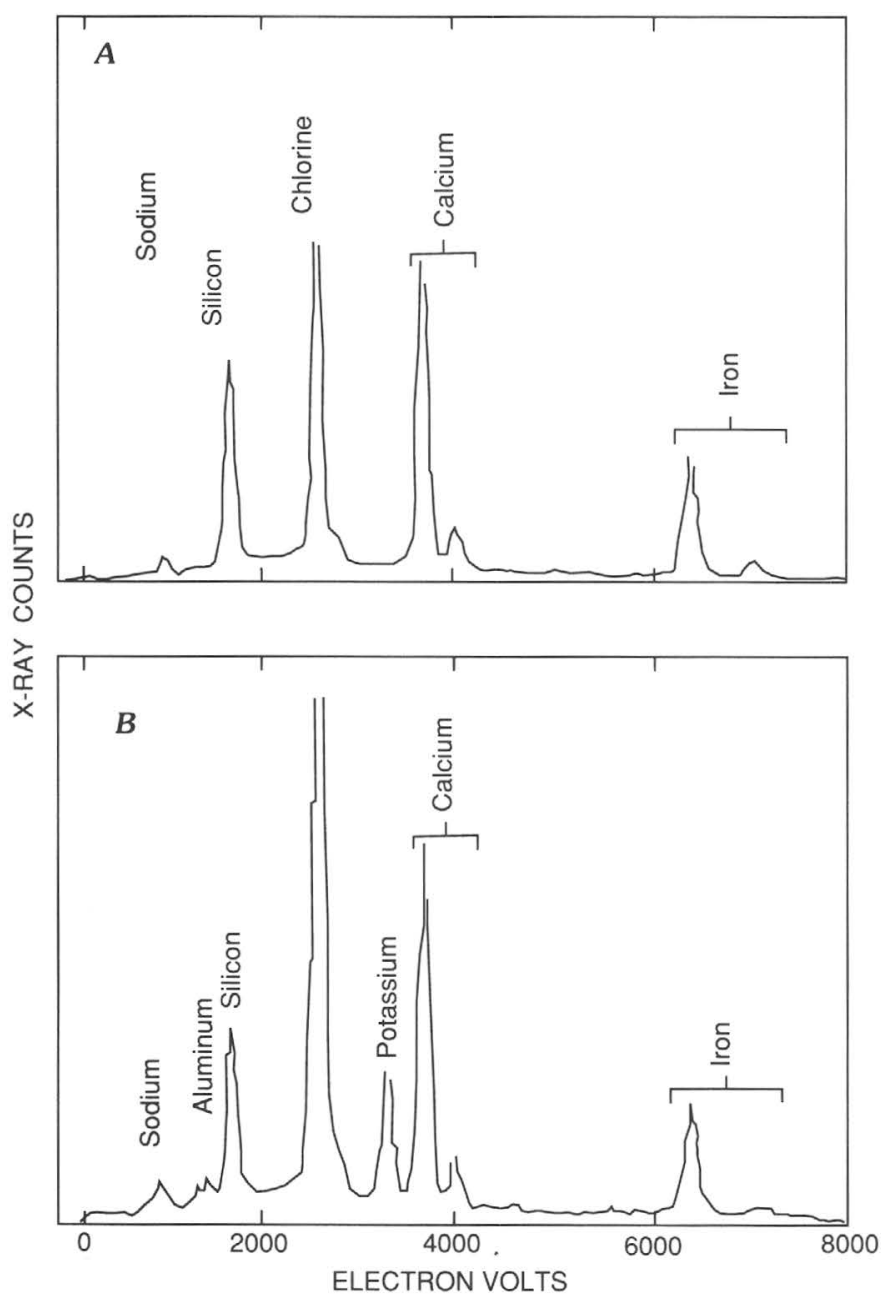

FiguRE 109.-Energy-dispersive X-ray spectra of minute minerals that formed as desiccation products from fluid-inclusion waters on artificially broken surfaces of andradite (see fig. 108). A, Xray spectra of elements detected in spot analysis at head of arrow in figure $108 A$. $B$, X-ray spectra of elements detected in spot analysis at head of arrow in figure $108 C$.
${ }^{\circ} \mathrm{C}$. In addition, minute crystals interpreted to be desiccation products from fluid-inclusion waters released on to artificially broken surfaces of andradite consistantly yield high peaks for calcium and chlorine in their X-ray spectra when examined by an X-ray microanalyzer attached to the SEM (figs. 108, 109). A few spectra obtained from some of these minute crystals (fig. 109B) also yield peaks of wide-ranging intensities for sodium and potassium. Thus, some of these fluid-inclusion waters probably contain minor amounts of dissolved sodium and potassium in addition to the major amount of calcium there. Furthermore, frozen fluid-inclusion waters examined using the methods of Metzger and others (1977) with the X-ray microanalyzer of the SEM in its cryogenic mode at temperatures of about -174 ${ }^{\circ} \mathrm{C}$ yield significant concentrations of calcium, chlorine, iron, and silicon. Some of the calcium and all of the iron and silicon probably indicates excitation by the electron beam of a volume of sample that includes some andradite that makes up the surrounding substrate of the fluid-inclusion ice. Examination of many frozen fluid-inclusion waters by the methods outlined above yield a much more widely prevalent presence of potassium in the ice than sodium. Therefore, the increase in eutectic temperatures from $-49.8^{\circ} \mathrm{C}$ to as high as $-38^{\circ} \mathrm{C}$ probably indicates primarily the presence of potassium in these fluid-inclusion waters. The reported eutectic for the system $\mathrm{KCl}-\mathrm{H}_{2} \mathrm{O}$ is $-10.6{ }^{\circ} \mathrm{C}$ (Crawford, 1981). "Before and after" electron micrographs of frozen fluid-inclusion waters and their resulting energy-dispersive $\mathrm{X}$-ray spectra are shown in figure 110. Some of the calcium from probable retrograde fluids continuing to circulate in the general area of skarn D at locality 76CB2 (fig. 86) is fixed now as carbonate trapped in highly irregular fluid inclusions (fig. 108C).

Heating and freezing studies were performed first on four selected samples of andradite from locality 76CB2-4, about $150 \mathrm{~m}$ from the north end of skarn D. All of these apparently pseudosecondary and possibly primary fluid inclusions in andradite homogenize to liquid by vapor disappearance somewhere in the temperature range $150-383{ }^{\circ} \mathrm{C}$. This relatively broad range in homogenization temperatures must indicate posttrapping necking of fluid inclusions, such that the liquid-vapor proportions in them were altered (Roedder, 1984). Nonetheless, the homogenization-temperature data are strongly unimodal; median and mode coincide at approximately $275{ }^{\circ} \mathrm{C}$ (fig. 111). These homogenization temperatures would require a pressure correction of about $+10{ }^{\circ} \mathrm{C}$ to give the actual trapping 


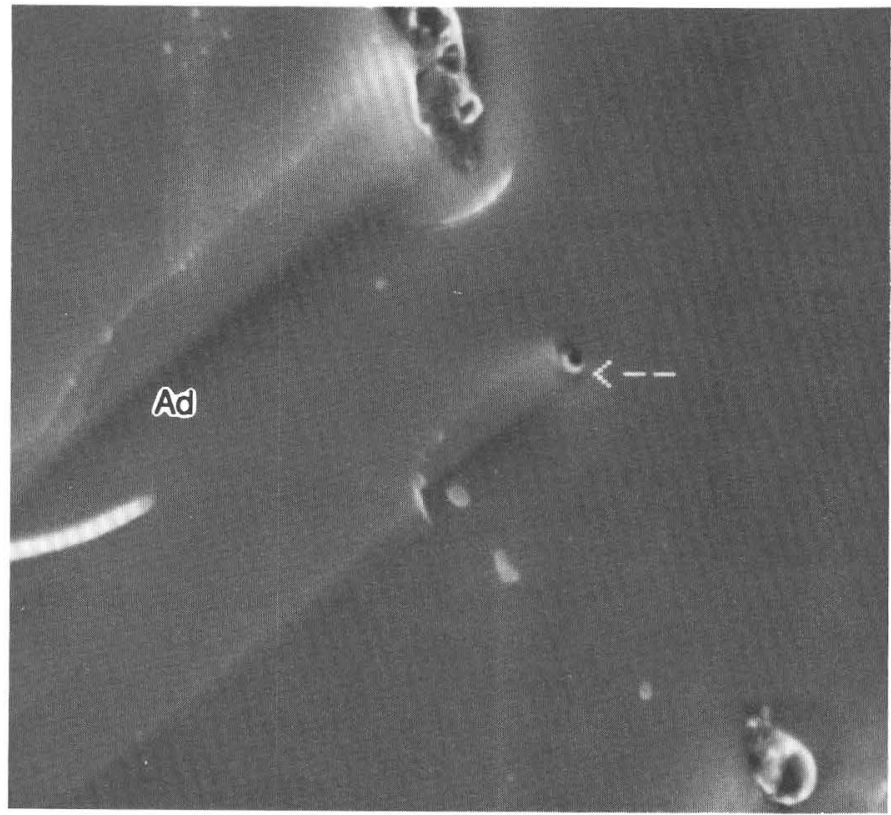

$A$ 0 4 MICRONS

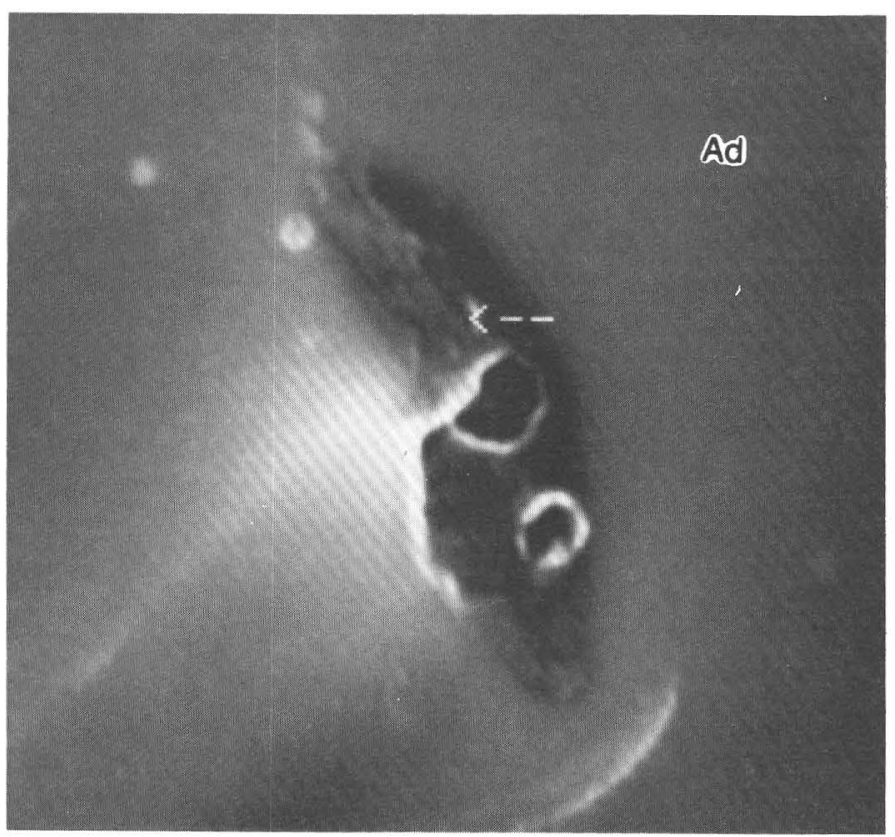

$B$ 0 2 MICRONS

FiguRE 110.-Scanning electron micrographs of frozen fluidinclusion waters in second-generation andradite (Ad) from skarn D, and energy-dispersive X-ray spectra. Examined at temperatures of about -172 to $-174{ }^{\circ} \mathrm{C}$ using a cryogenic stage. Sample 76CB2A. A, Train of fluid-inclusion cavities containing various amounts of ice in andradite. Small fluidinclusion cavity at head of arrow. $B$, Closeup of one fluid-
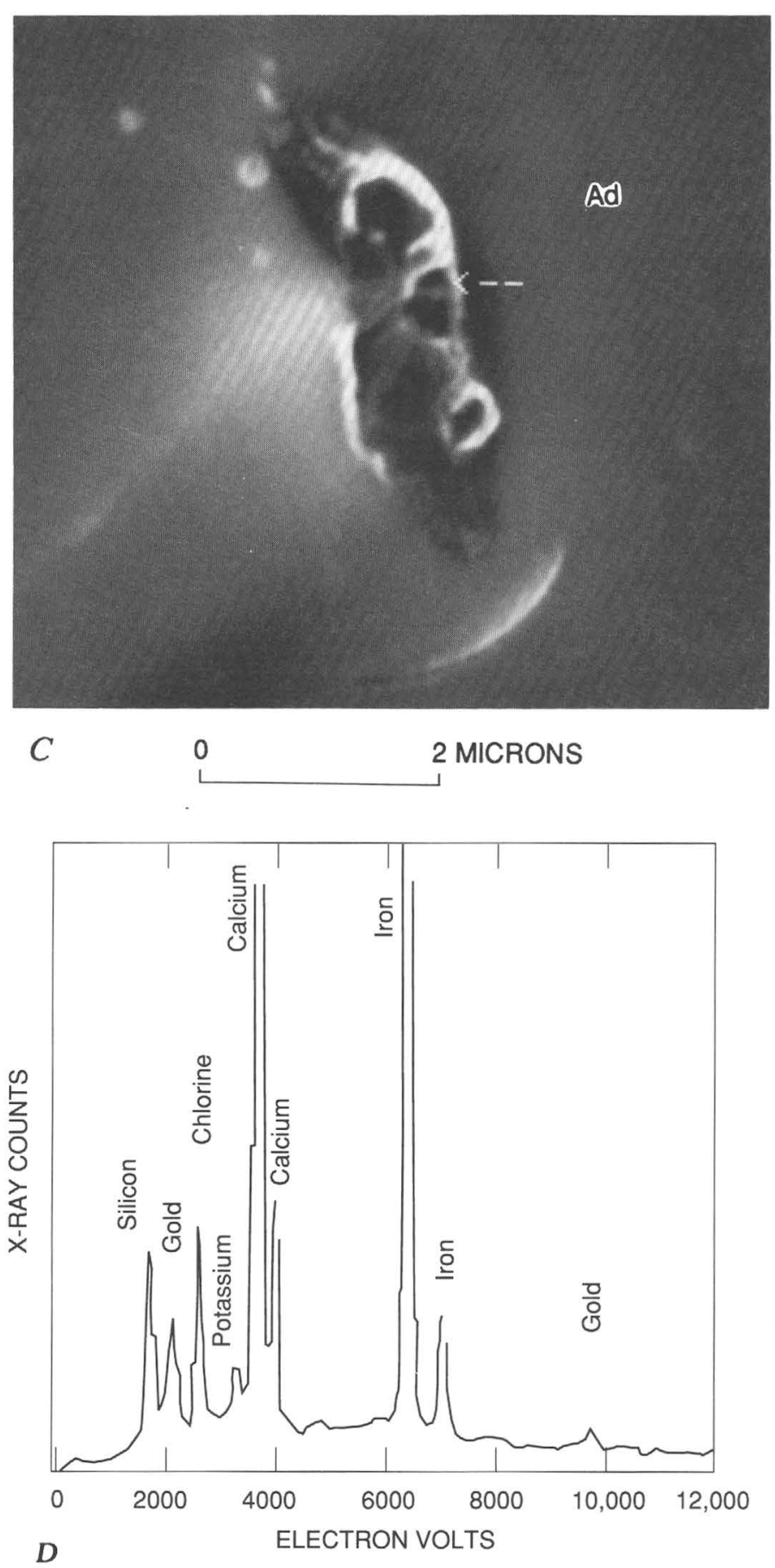

inclusion cavity in figure $110 \mathrm{~A}$ before ice at head of arrow was analyzed using electron beam; $C$, Same fluid inclusion as in figure $110 B$ after ice was analyzed. Area at head of arrow is a hole in fluid-inclusion ice. $D$, Energy-dispersive X-ray spectra resulting from spot analysis of ice at head of arrow in figure $110 B$. Gold in spectra is from coating medium. 
temperature if the fluids were trapped at a pressure of about 200 bars (see below) and if the $\mathrm{CaCl}_{2}$ fluids behaved similarly to 15 weight percent $\mathrm{NaCl}$ brines. One of the four selected samples of andradite includes exceptionally well displayed pseudosecondary fluid inclusions aligned in trains parallel to the growth lines of an andradite crystal (fig. 112). Determination of homogenization temperatures and final melting temperatures of many fluid inclusions in a transect across this andradite crystal reveal no apparent relation of such data to crystal growth (fig. 113). However, other andradite crystals appear to show slight decreases in the final melting temperatures of their apparently pri-

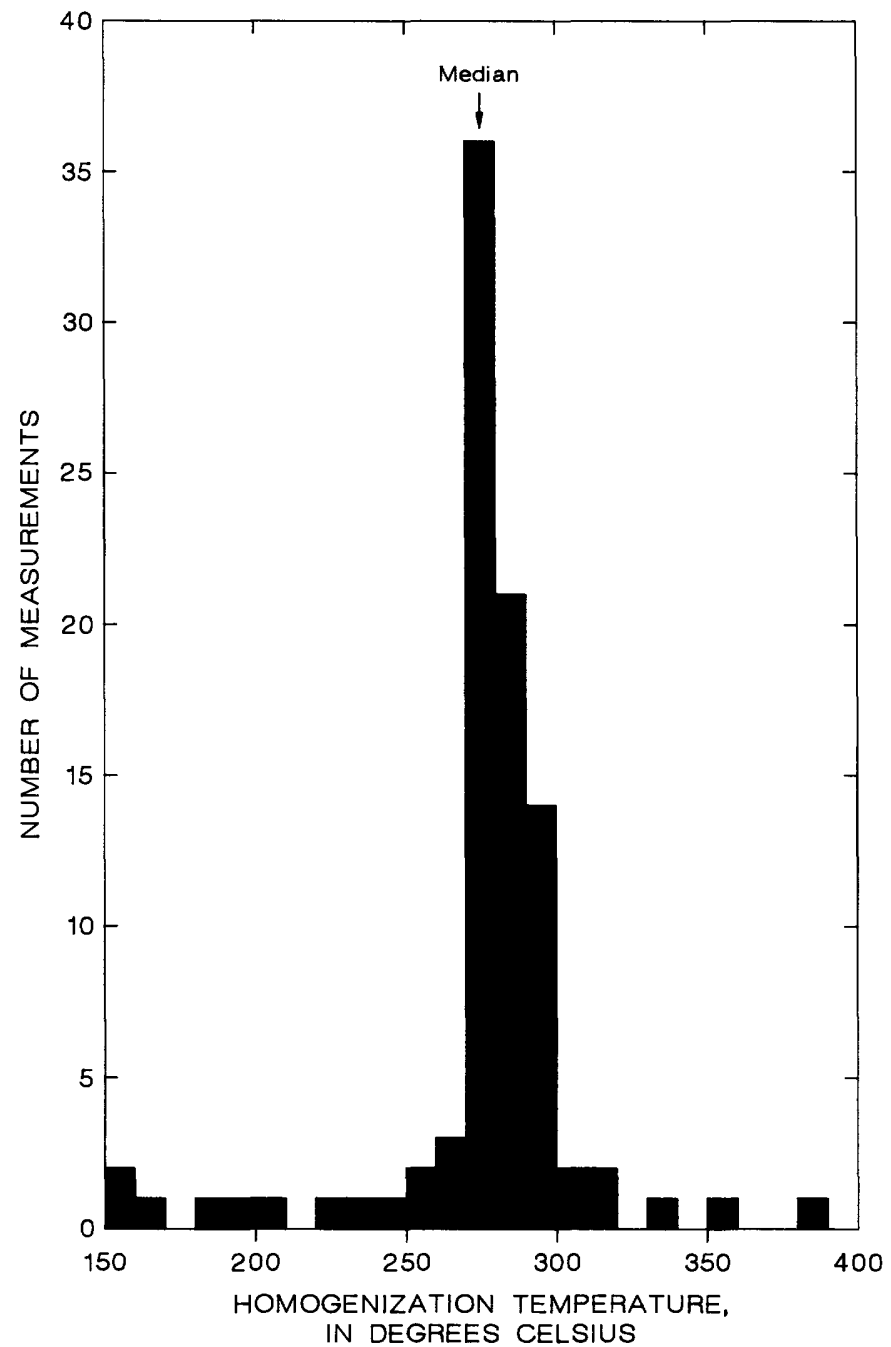

FIGURE 111.-Filling temperatures in second-generation andradite in four hand samples of skarn D apparently related to Buckingham molybdenum system. Samples collected approximately $150 \mathrm{~m}$ south of north end of skarn D. mary fluid inclusions toward the outer parts of the crystals and thus, over time, across some very narrow intervals of andradite (fig. 114).

In all, 89 salinities were determined for mostly pseudosecondary, but probably some primary, type I fluid inclusions hosted by second-generation andradite in skarn D at locality 76CB2-4 (fig. 115). As described above, waters in these fluid inclusions belong mostly in the system $\mathrm{CaCl}_{2}-\mathrm{H}_{2} \mathrm{O}$. Final melting temperatures of ice for these fluid inclusions are in the range -1.6 to $-14.3{ }^{\circ} \mathrm{C}$. Inasmuch as the freezingpoint depression of water for $\mathrm{NaCl}$ and $\mathrm{CaCl}_{2}$ solutions is largely coincident from $0^{\circ}$ to about $-15{ }^{\circ} \mathrm{C}$ (Crawford, 1981), salinities were determined in terms of weight percent $\mathrm{CaCl}_{2}$ equivalent by means of (1) the depression-of-freezing-point equation for $\mathrm{NaCl}$ solutions (Potter and others, 1978) or (2) a plot of depression-of-freezing-point data versus $\mathrm{CaCl}_{2}$ content of Linke (1965). This procedure-that is, the reporting of salinities in terms of weight percent $\mathrm{CaCl}_{2}$ equivalent-differs from common practice in most fluid-inclusion investigations (Roedder, 1984). However, in this case, referral to the system $\mathrm{CaCl}_{2}-\mathrm{H}_{2} \mathrm{O}$ is preferable because of our determination of the chemistry of the fluid-inclusion waters. The freezing tests yield salinities in the range 3.0-19.4 weight percent $\mathrm{CaCl}_{2}$ equivalent (fig. 115); the median for these data is in the class interval 13.0-13.9 weight percent, and this median coincides with the mode. As depicted on figure 115, the range in salinities determined for fluid inclusions in each of the four samples of andradite studied from skarn $D$ is much less than the overall range in salinities. Furthermore, the possibly primary fluid inclusions (sample 76CB2a, fig. 115) have salinities that cluster close to the high end of the histogram: from 12.4 to 19.4 weight percent $\mathrm{CaCl}_{2}$ equivalent.

Figure 116 plots salinity versus homogenization temperature for 52 fluid inclusions associated with the second-generation andradite in skarn D. Most of these data points are from fluid inclusions judged to be pseudosecondary. Although a direct variation between salinity and homogenization temperature is common in many deposits (for example, Scher-kenbach and others, 1985), the plot of salinity versus homogenization temperature for fluid inclusions in andradite at Buckingham shows that the overwhelming bulk of these pseudosecondary fluid inclusions homogenize by vapor disappearance within a very narrow temperature interval, $260-290{ }^{\circ} \mathrm{C}$. The clustering of four data points at filling temperatures below $200{ }^{\circ} \mathrm{C}$ may 
suggest necking (fig. 116). However, from the fact that these four fluid inclusions have salinities less than the other fluid inclusions plotted, we infer that the four fluid inclusions may indeed indicate late-stage fluids trapped in the cores of some of the andradite crystals. Relatively low homogenization temperatures and low salinities in garnet skarn associated with a porphyry environment have also been reported elsewhere. Abramson and others (1982) found that garnet skarn in the Central Mining District, N. Mex., hosts fluid inclusions that have an average homogenization temperature of about 280 to $310{ }^{\circ} \mathrm{C}$ and have salinities that range from 4.5 to 19.0 weight percent $\mathrm{NaCl}$ equivalent.
They ascribed development of garnet skarn there to essentially nonmetasomatic contact metamorphism. Furthermore, garnet has been observed to temperatures as low as $325{ }^{\circ} \mathrm{C}$ in active geothermal systems (Henley and Ellis, 1983), although most garnets from six studied active geothermal systems are considered to have formed at temperatures generally above $300{ }^{\circ} \mathrm{C}$ (Bird and others, 1984). Andradite apparently becomes stable in the Salton Sea, Calif., geothermal field in the highest temperature $\left(360{ }^{\circ} \mathrm{C}\right)$ parts of the biotite zone; andradite is present in a biotite+quartz+epidote+ andradite+albite+actinolite+pyrite + sphene assemblage (McDowell and Elders, 1983).

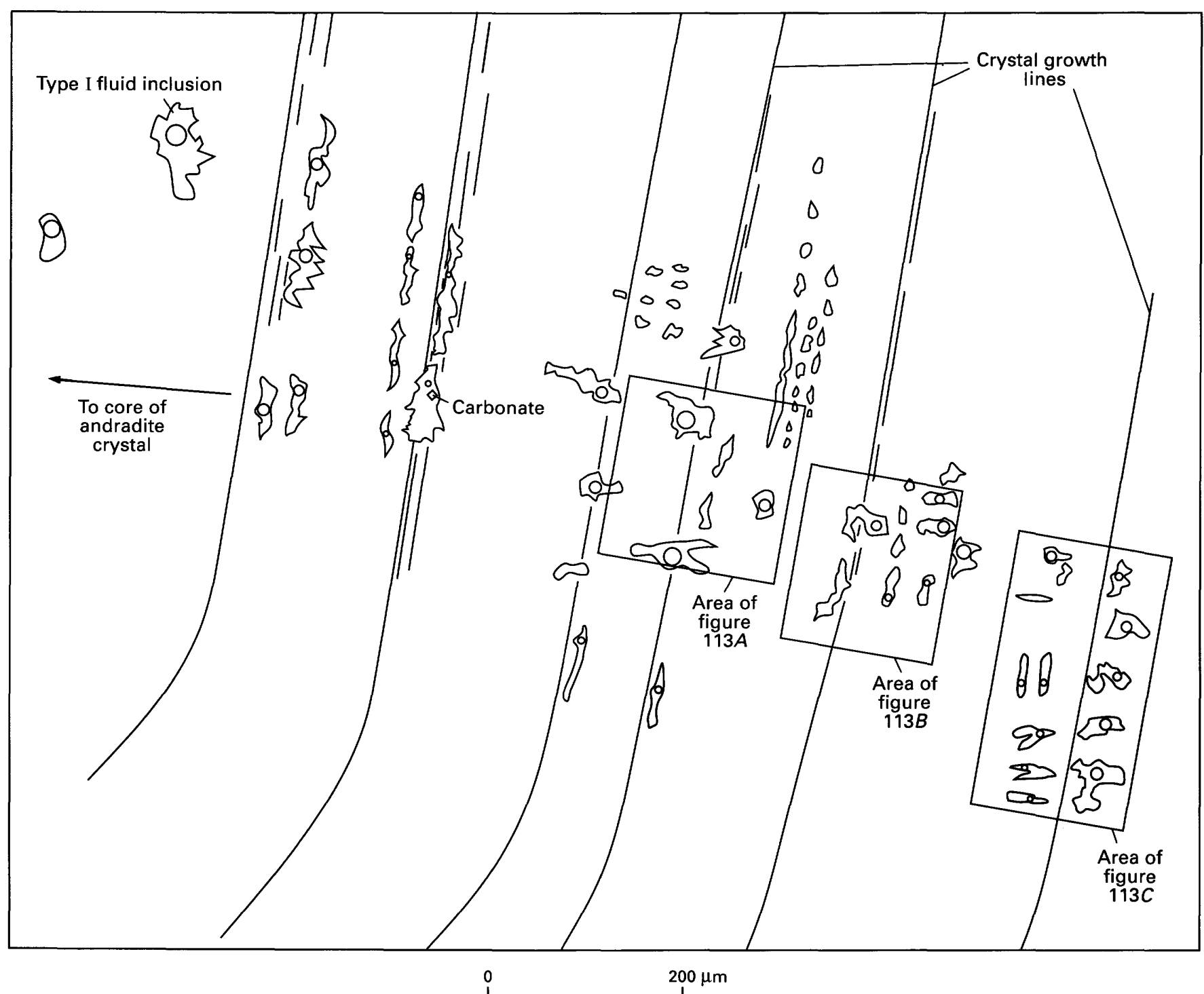

FIGURE 112.-Relations of fluid inclusions to growth bands in second-generation andradite from skarn D and locations of photomicrographs shown in figure 113 . Sample 76CB2b. 
Attempts, by heating and freezing tests on latestage hydrothermal quartz from skarn $\mathrm{D}$, to follow paragenetically and areally the evolution of subsequent fluids circulating in the environment of the skarn were unsuccessful because of the unavailability of optically suitable samples. This extremely sparse quartz is present as an open-space filling, together with K-feldspar and chalcopyrite and pyrrhotite, in andradite-diopside skarn beginning about $1 \mathrm{~km}$ south of the north end of the skarn. Sulfides become more or less generally dispersed in skarn at this distance from monzogranite porphyry. A specific post-andradite assemblage here is quartz, secondary biotite and tremolite-actinolite (mostly replacing diopside), and much lesser amounts of chalcopyrite and pyrrhotite (see section above entitled "Mineral Chemistry of Late Cretaceous and Tertiary Skarns"). Overall, the rocks at this distance from the monzogranite porphyry are weakly mineralized; copper content is about 500 ppm (analysis 5, table 24). The hydrothermal quartz in this assemblage contains relatively abundant, secondary type I fluid inclusions that are present along annealed microcracks. The fluid inclusions are typically in the range 5-20 $\mu \mathrm{m}$, and at room temperature, they show vapor proportions of about 10 to 15 volume percent-generally about the same proportions as the fluid inclusions described above in andradite. Crushing tests indicate the presence of some minor amounts of carbon dioxide in fluid inclusions from the skarn here. However, we cannot assemble convincing proof that the carbon dioxide is restricted entirely to hydrothermal quartz; some sparse amounts of carbon dioxide seem to be distributed nonuniformly in the fluid inclusions trapped in andradite.

\section{QUARTZ-MOLYBDENITE STOCKWORKS}

Heating and freezing tests were performed on 64 samples of quartz-stockwork veins from the Buckingham molybdenum system; these include 17 samples from surface exposures, and 44 samples of core obtained from various depths in 13 drill holes (fig. 117). Most of the samples of drill core were obtained from the East and the Vail Ridge tectonic blocks of the Buckingham system. In this part of the report, we have assembled our fluid-inclusion data from the Vail Ridge block, geologically the highest part of the system; then, the East block; and finally the West block, wherein the geologically lowest levels of the Buckingham system crop out.

\section{VAIL RIDGE BLOCK}

Our fluid-inclusion studies in the Vail Ridge part of the Buckingham system reveal that fluids of highly diverse chemistries and apparently wideranging temperatures circulated in the environment of the quartz stockworks as the system evolved (table 49). The fluids identified to date from non-crystal-bearing fluid inclusions consist of type I fluid inclusions that contain mostly $\mathrm{NaCl}-$ $\mathrm{H}_{2} \mathrm{O}$ with or without minor $\mathrm{KCl}$ and mostly NaCl$\mathrm{CO}_{2}-\mathrm{H}_{2} \mathrm{O}-\mathrm{CH}_{4}$, and type IV fluid inclusions that are mostly $\mathrm{CO}_{2}-\mathrm{CH}_{4}$ (?) (see below). Most of the veins studied show K-feldspar-stable selvages, and many of the veins also contain some K-feldspar as an apparently stable phase among their composite vein assemblages that commonly include minor amounts of carbonate. By far the predominant fluid inclusion here is a type $\mathrm{I}$, mostly liquid $\mathrm{H}_{2} \mathrm{O}$ and vapor at room temperature, that ranges broadly in salinity from 0.2 to 15.7 weight percent $\mathrm{NaCl}$ equivalent. Some samples show that most of these type I fluid inclusions are unequivocally cogenetic with type II fluid inclusions, and this indicates that boiling occurred sometime during the emplacement of the veins. For example, temperatures of total homogenization for types I and II fluid inclusions determined for a molybdenite-bearing quartz vein (sample 1469-425) collected from a drill hole about $150 \mathrm{~m}$ beyond the north limit of the quartz stockworks in the Vail Ridge block show. closely coincident distributions for fluid inclusions that fill to liquid and those that simultaneously fill to vapor (fig. 118A). Fluid inclusions that fill to liquid and fluid inclusions that fill to vapor are present along the same annealed microfracture. The range in temperature of the overlap between fluid inclusions that fill to vapor $\left(320-440{ }^{\circ} \mathrm{C}\right)$ is somewhat more restricted than that for those that fill to liquid $\left(290-470{ }^{\circ} \mathrm{C}\right)$. Although boiling may have occurred at any temperature within the determined overlap, from the distribution plot (fig. 118A), we suggest that $380-400{ }^{\circ} \mathrm{C}$ is a reasonable estimate for the temperature at which most of the fluids associated with this vein boiled. The measured range in temperatures of homogenization may result in part from the heterogeneous trapping of variable mixtures of two fluids rather than trapping of a homogeneous single phase, together with repeated opening and closing of microcracks along which fluids circulated as the system evolved (see Roedder, 1984). Indeed, as Sourirajan and Kennedy (1962) have shown, pressure release of a moderately 


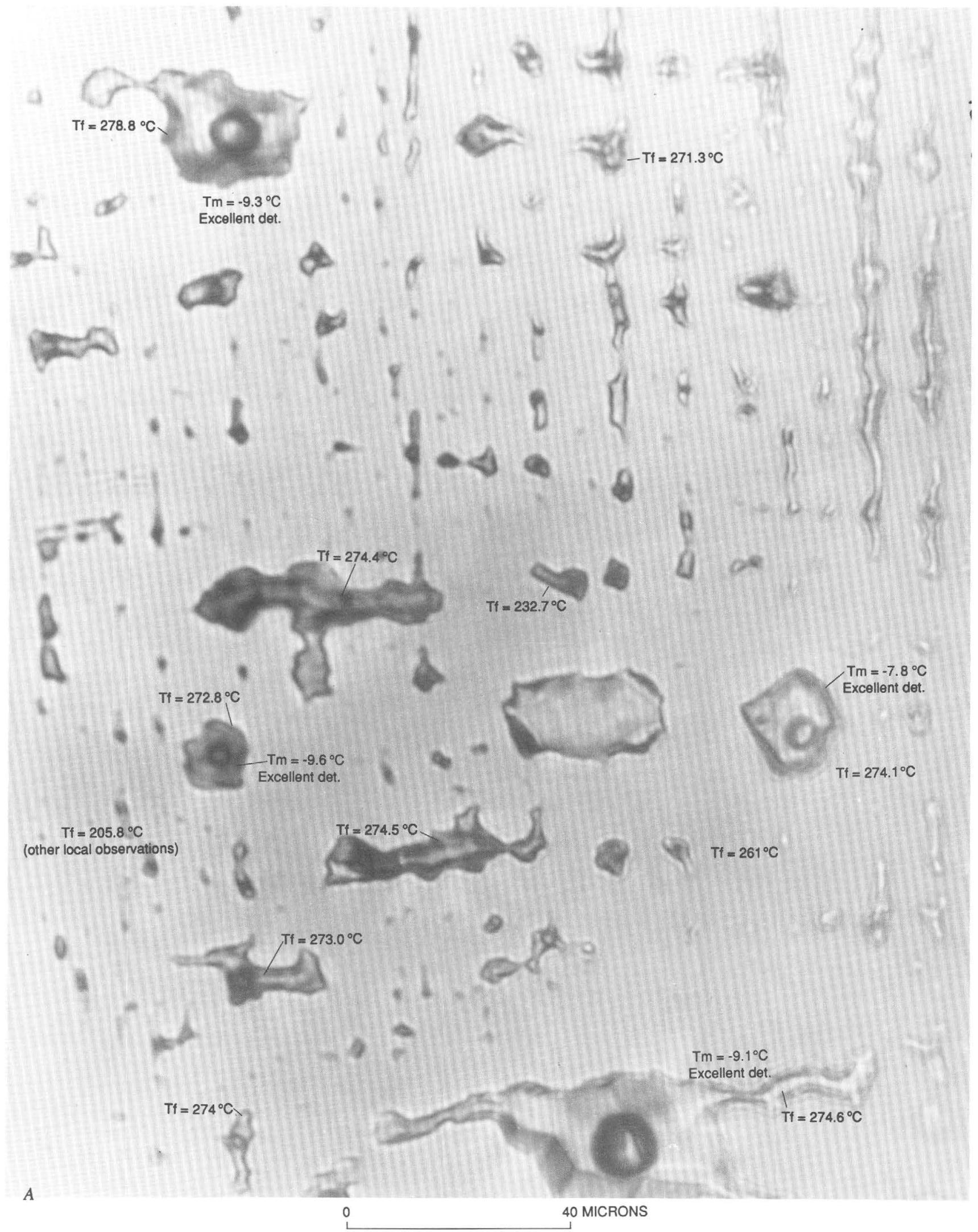

FIGURE 113.-Photomicrographs $(A-C)$ of fluid inclusions in a selected crystal of second-generation andradite from skarn D, sample $76 \mathrm{CB} 2 \mathrm{~b}$. See figure 112 for location. Homogenization temperatures and final melting temperatures of selected pseudosecondary fluid inclusions also shown. Tm, final melting temperature; Tf, filling temperature; det., determination. 


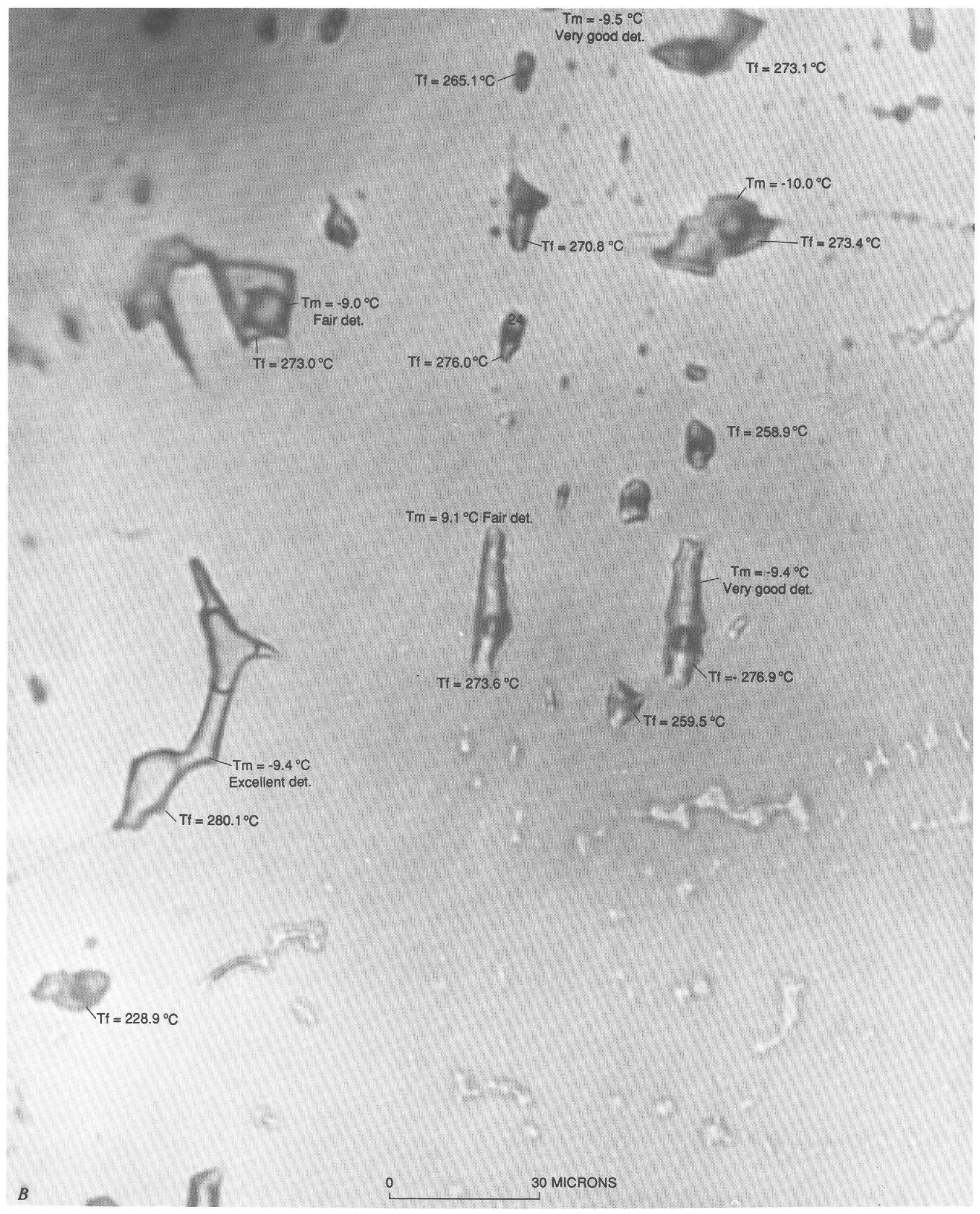

Figure 113.-Continued. 


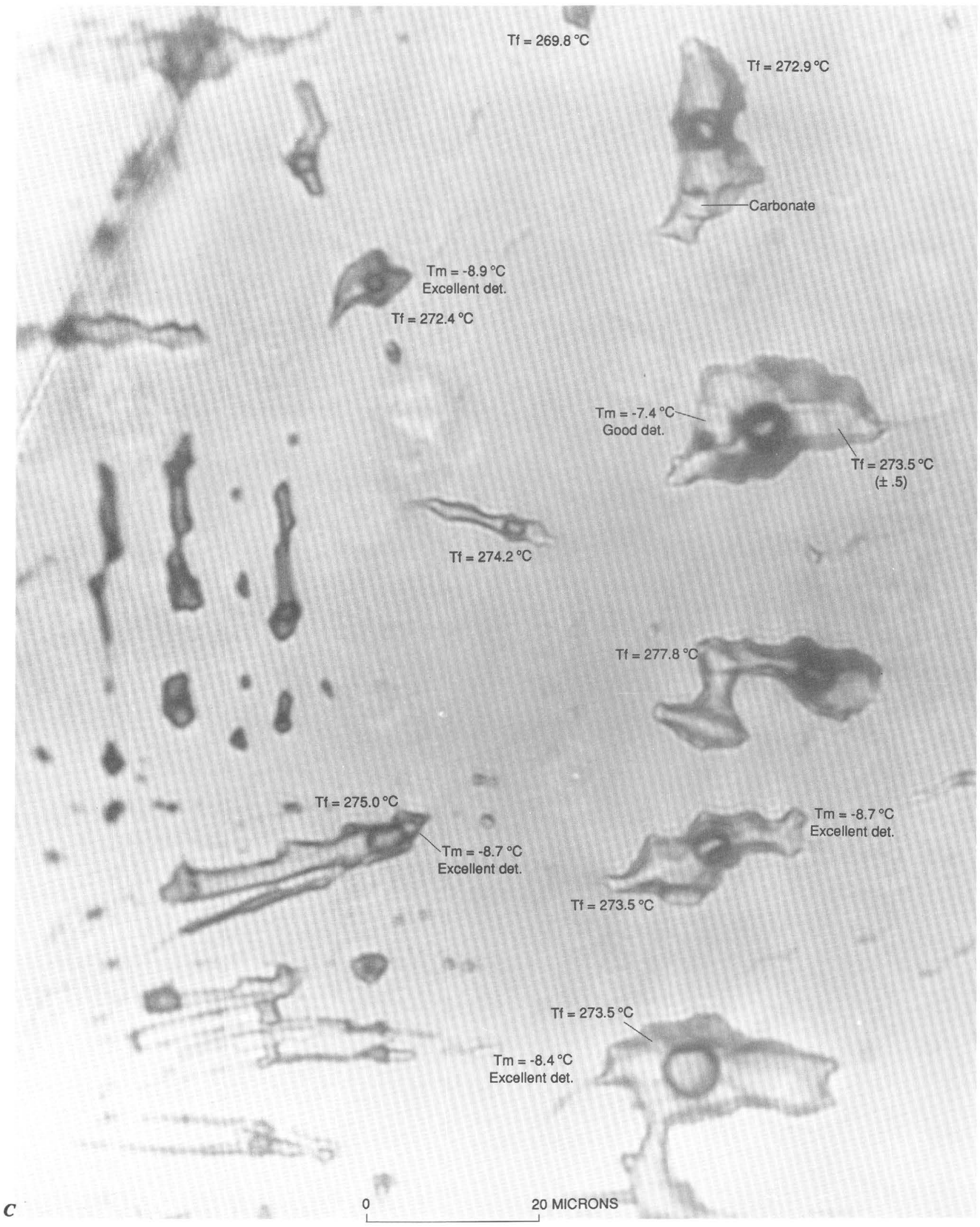

Figure 113.-Continued. 


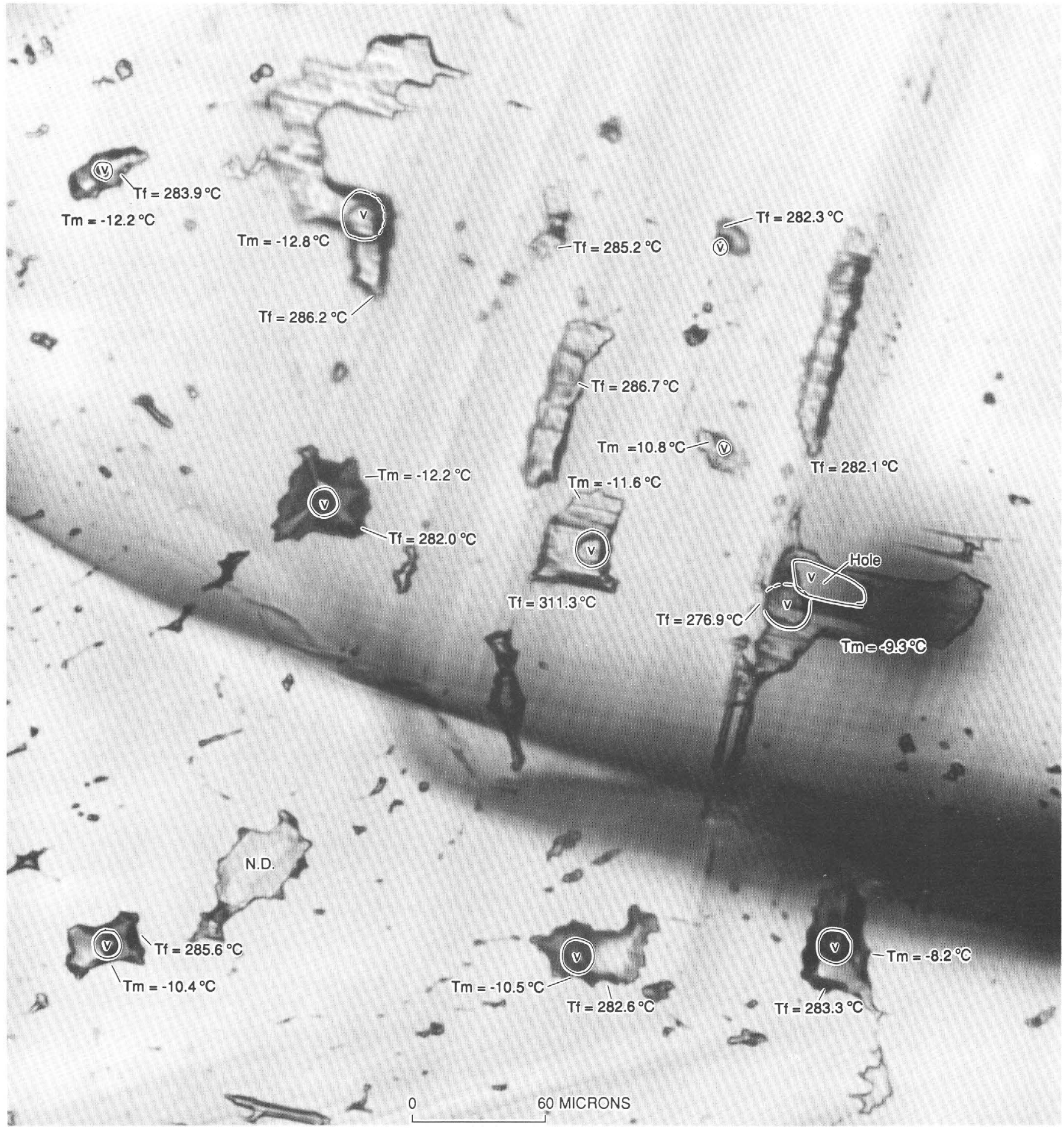

FIGURE 114.-Photomicrograph showing apparently primary fluid inclusions in second-generation andradite from skarn D and homogenization temperatures and melting temperatures of selected fluid inclusions. Sample 76CB2a. Tm, melting temperature; Tf, filling temperature; v, vapor; N.D., not determined. 
saline fluid will result in the separation of two phases: a low-salinity vapor phase (exemplified by the type II fluid inclusions that fill to vapor) and a cogenetic higher salinity liquid phase (type I or III fluid inclusions). That some of the type II fluid inclusions have somewhat higher salinities here than predicted by the experimental studies of Sourirajan and Kennedy (1962) probably indicates inhomogeneous trapping in the type II fluid inclusions of small amounts of the liquid phase during the boiling event. Furthermore, the generally preferred concentration of the type II fluid inclusions near the high-temperature end of the homogenization plots (fig. 118A) also suggests that small amounts of liquid may have been trapped during their development (see Scherkenbach and others, 1985), although this would be compensated by problems arising from the accurate temperature determination of final disappearance of liquid in such fluid inclusions when heated. In fact, the strong correspondence between the overall ranges in temperatures of total homogenization for types I and II fluid inclusions is somewhat surprising in light of

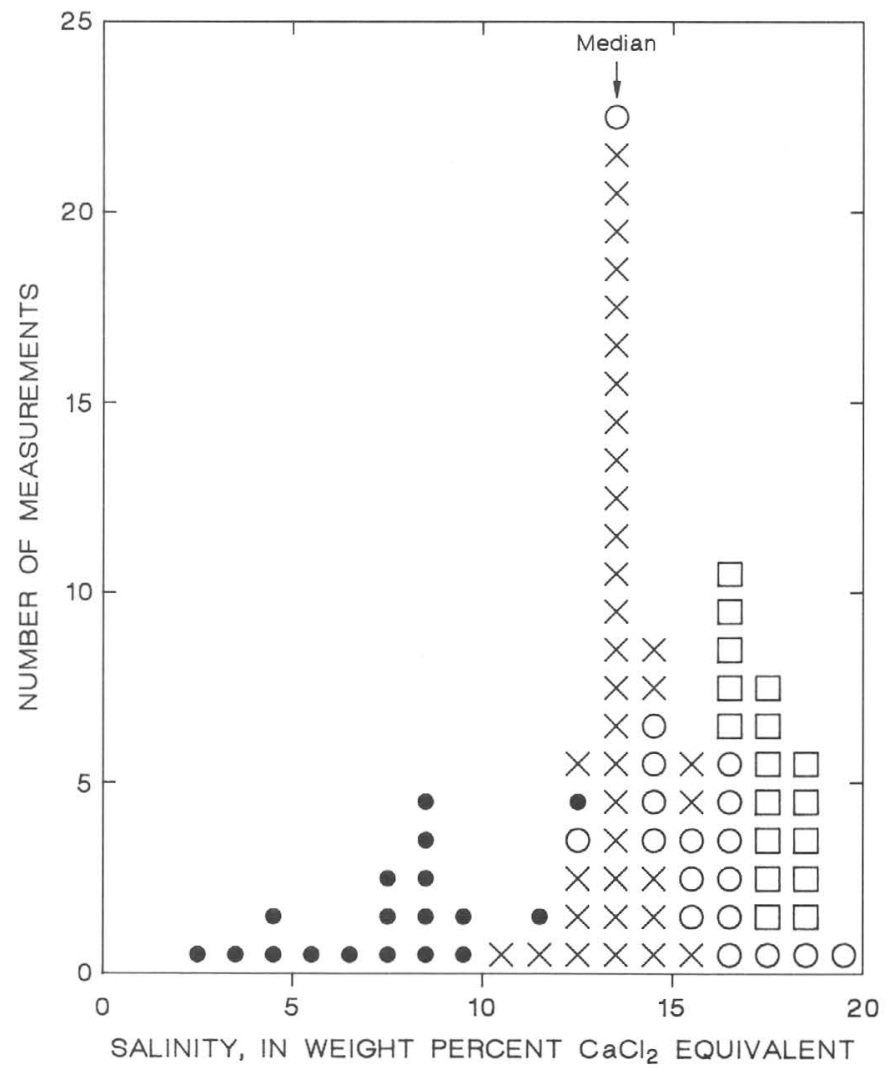

Figure 115.-Salinities (in weight percent $\mathrm{CaCl}_{2}$ equivalent) of pseudosecondary, and some possibly primary, type I fluid inclusions in second-generation andradite from skarn D. Dot, sample $76 \mathrm{CB} 2 ; \mathrm{X}$, sample $76 \mathrm{CB} 2 \mathrm{~b}$; circle, $76 \mathrm{CB} 2 \mathrm{a}$; square, 76CB2c. the experimental results obtained by Bodnar and others (1985a). These workers have shown that under ideal experimental conditions, vapor-rich fluid inclusions consistently yield apparent homogenization temperatures from 300 to $150{ }^{\circ} \mathrm{C}$ below known trapping temperatures, primarily because of difficulties in their resolving optically the temperature at which the last remaining liquid finally disappears. The fluid inclusions in sample 1469-425 are distributed more or less randomly, yet abundantly, throughout a mosaic-textured fabric of vein quartz, and they are moderately saline (5.6-12 weight percent $\mathrm{NaCl}$ equivalent, type I) and presumably highly dilute (type II), even though we do not have any salinity determinations from type II fluid inclusions in this particular sample.

Three additional samples, collected at various depths from another locality (3, fig. 117; table 49) just within the outer limit of the quartz stockworks that surround the molybdenum system, also show modes for their total homogenization data similar to that of sample 1469-425 (fig. 118B). Two of these samples show K-feldspar selvages, whereas the third (sample 2050-443) shows a chloritecarbonate selvage probably indicative of prograde propylitic alteration near the fringes of the system. In addition, most of the fluid inclusions contain highly variable amounts of $\mathrm{CO}_{2}$, some of which become optically resolvable only at temperatures below $20^{\circ} \mathrm{C}$. Optical limitations prevented application of the techniques of Sasada and others (1986)

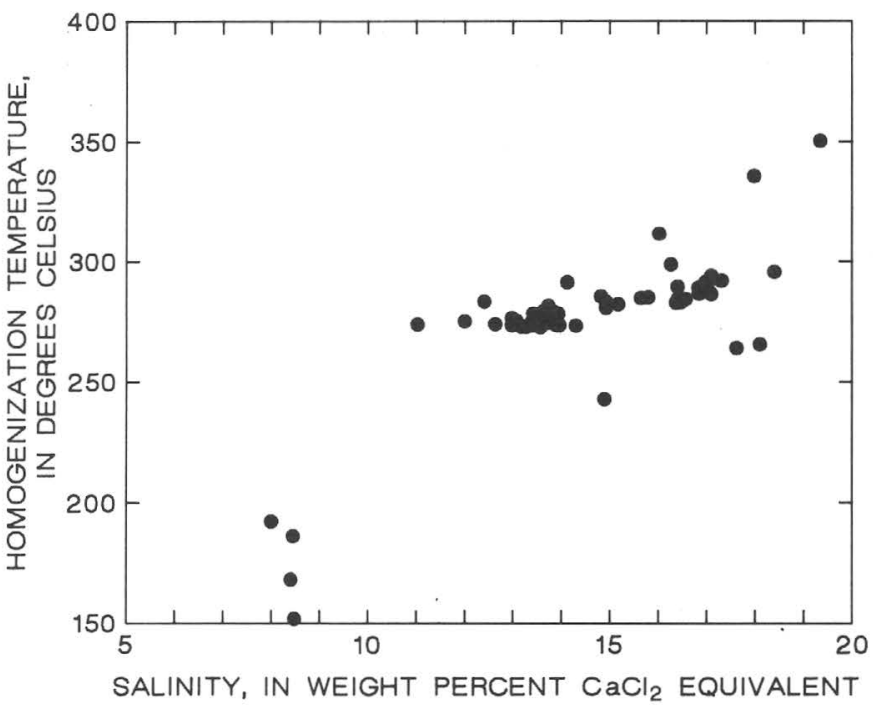

FIGURE 116.-Salinity (in weight percent $\mathrm{CaCl}_{2}$ equivalent) versus homogenization temperature for $\mathbf{5 7}$ mostly pseudosecondary fluid inclusions in second-generation andradite from skarn D, apparently associated with Buckingham molybdenum system. 


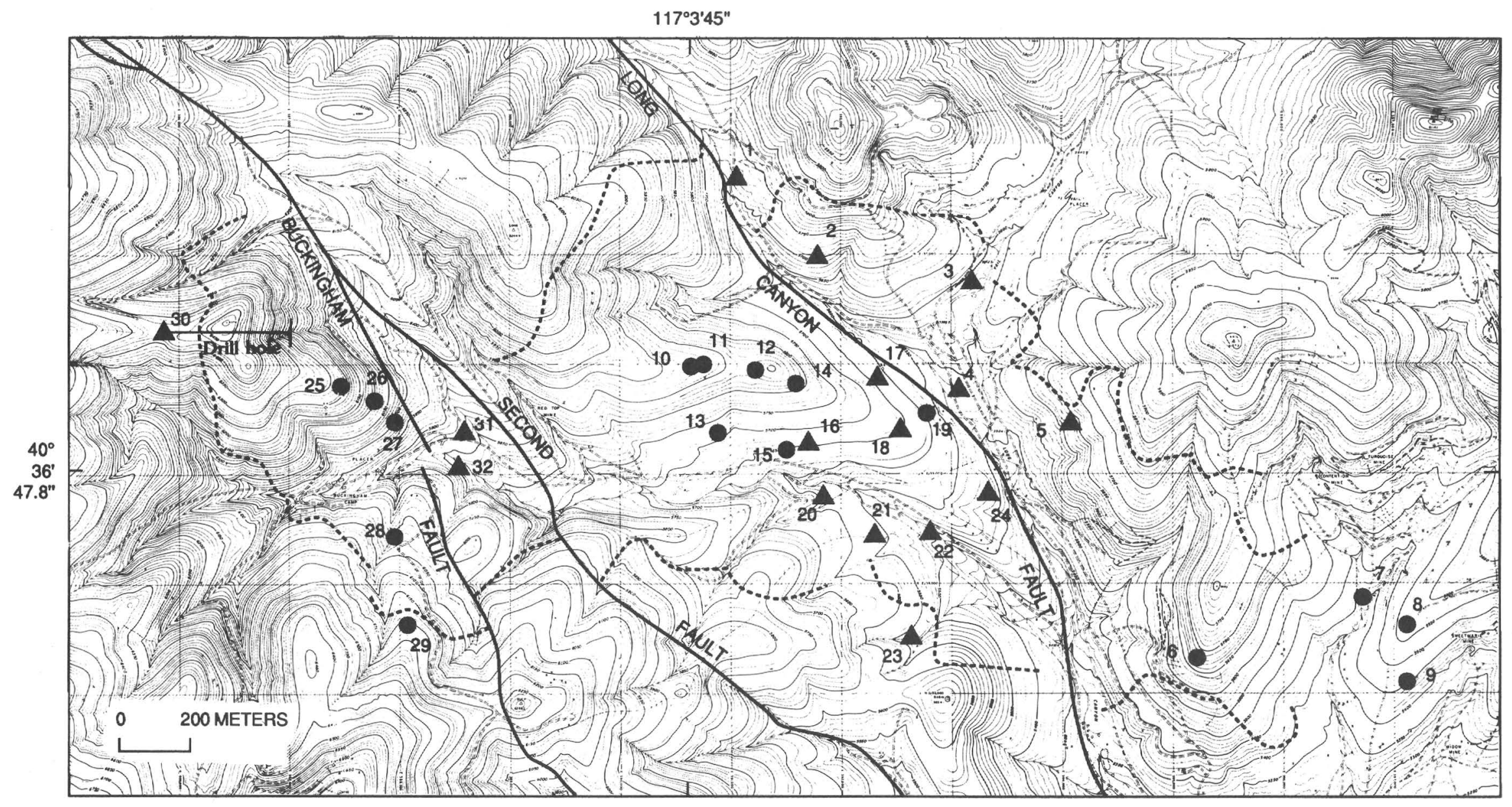

FIGURE 117.-Locality map showing sample sites of quartz veins from Buckingham system. Surface and core samples were studied by heating and freezing tests. Dots, surface samples; triangles, diamond-drill-core samples. Location numbers same as in tables 49 and 51 . Solid lines, trace of major postmineral faults; dotted lines, trace of outer limit of quartz stockworks (from pl. 1). Topographic base from aerial mapping company for Duval Corporation, 1962. Contour interval $10 \mathrm{ft}$. 
TABLE 49.-Temperature and salinity data from fluid inclusions hosted by vein quartz in the Vail Ridge block of the Buckingham stockwork molybdenum system

$$
[\operatorname{tr}, \text { trace; }- \text {, not determined] }
$$

\begin{tabular}{|c|c|c|c|c|c|c|c|c|c|}
\hline \multirow{2}{*}{$\begin{array}{l}\text { Loc. no. } \\
\text { (fig. 117) }\end{array}$} & \multirow[b]{2}{*}{ Sample no. } & \multirow[b]{2}{*}{$\begin{array}{l}\text { Rock } \\
\text { type }^{1}\end{array}$} & \multirow[b]{2}{*}{$\begin{array}{l}\text { Composite vein } \\
\text { assemb1age }{ }^{2}\end{array}$} & \multirow[b]{2}{*}{ Selvage ${ }^{2}$} & \multirow[b]{2}{*}{$\begin{array}{l}\text { Assemb1age(s) } \\
\text { in rock }\end{array}$} & \multirow[b]{2}{*}{$\begin{array}{l}\text { Type of } \\
\text { inclusion }\end{array}$} & \multirow[b]{2}{*}{$\begin{array}{l}\text { Homogenization } \\
\text { temp. Iange }\left({ }^{\circ} \mathrm{C}\right)\end{array}$} & \multicolumn{2}{|c|}{ Salinity } \\
\hline & & & & & & & & $\begin{array}{l}\text { Wt\% } \mathrm{NaCl} \\
\text { equivalent }\end{array}$ & $\begin{array}{l}\text { Number } \\
\text { measured }\end{array}$ \\
\hline 1 & $1469-425$ & $\mathrm{H}$ & $Q-K f(t r)-M o(t r)-P y(t r)--C c$ & $\mathrm{Kf}$ & $P, \operatorname{Prp}(t r)$ & $\begin{array}{c}\text { I } \\
\text { II }\end{array}$ & $\begin{array}{l}295-475(24)^{5} \\
320-440(27)\end{array}$ & $\begin{array}{c}5.6-12.0 \\
--\end{array}$ & $\begin{array}{r}5 \\
--\end{array}$ \\
\hline 2 & $1467-453$ & $\mathrm{H}$ & $Q-P y-K f(t r)-C h 1(t r)-C c(t r)$ & Kf & $\mathrm{P}$ & I & $337-398(8)$ & -- & -- \\
\hline 3 & $2050-99$ & $\mathrm{H}$ & $Q-M_{o}(t r)-C c(t r)$ & $\mathrm{Kf}$ & P, Phy & $\begin{array}{l}\text { I } \\
\text { II } \\
\text { IV }\end{array}$ & $\begin{array}{ll}269-371 & (47) \\
250-365 & (4) \\
245-250 & (2)\end{array}$ & $\begin{array}{c}.2-7.8 \\
. \\
.5\end{array}$ & $\begin{array}{r}8 \\
-1\end{array}$ \\
\hline 3 & $2050-443$ & $\mathrm{H}$ & Q-Py-Po-Bio-Wm-Cc-Ch1 & Prp & Prp & $\begin{array}{l}\text { I } \\
\text { II } \\
\text { IV }\end{array}$ & $\begin{array}{ll}241-398 & (62) \\
342-375 & (4) \\
347-361 & (6)\end{array}$ & $\begin{array}{l}3 .-15.6 \\
0-19.8 \\
0-7.5\end{array}$ & $\begin{array}{r}17 \\
4 \\
12\end{array}$ \\
\hline 3 & $2050-938$ & H & Q-Mo(tr) & $\mathrm{Kf}$ & $P, \operatorname{Prp}$ & I & $\begin{array}{l}281-381(22) \\
299-303(2)\end{array}$ & $\begin{array}{c}5 .-9.4 \\
--\end{array}$ & $\begin{array}{c}8 \\
-\end{array}$ \\
\hline 4 & $1471-760$ & $\mathrm{H}$ & Q-Mo-Wm-Kf (tr) -Py (tr) & KE & P, Phy & $\begin{array}{c}\text { I } \\
\text { II }\end{array}$ & $\begin{array}{r}292-345 \text { (8) } \\
335(1)\end{array}$ & -- & -- \\
\hline 4 & $1471-1120$ & H & Q-Kf-Mo-Py-Ep & $\mathrm{Kf}$ & P, Phy & I & $282-335(10)$ & $8.3-10.9$ & 5 \\
\hline 5 & $1472-604$ & M & Q-Mo-Py (tr) & $K^{R} \bar{c}$ & $P, I A$ & I & $293-324(24)$ & $9 .-15.7$ & 5 \\
\hline 5 & $1472-801$ & $\mathrm{H}$ & Q-Mo-Py (tr) & Kf & $\mathrm{P}$ & I & $250-342(17)$ & $.7-13.8$ & 6 \\
\hline 6 & $81 \mathrm{TT} 104$ & M & Q-Kf-Mo(tr)-Wm-Rut & $\mathrm{Kf}$ & $\mathrm{P}, \mathrm{IA}$ & $\begin{array}{l}\text { I } \\
\text { II } \\
\text { IV }\end{array}$ & $\begin{array}{ll}214-362 & (15) \\
285-358 & (2) \\
279-320 & (4)\end{array}$ & $\begin{array}{l}4 .-8.1 \\
-- \\
5 .-11.3\end{array}$ & $\begin{array}{r}2 \\
-\frac{6}{6}\end{array}$ \\
\hline 7 . & $81 \mathrm{TT} 121$ & M & $\mathrm{Q}-\mathrm{Kf}-\mathrm{Py}(\mathrm{tr})$ & $\mathrm{Kf}$ & $\mathrm{P}, \mathrm{IA}$ & $\begin{array}{l}\text { I } \\
\text { IV }\end{array}$ & $\begin{array}{ll}229-324 & (29) \\
285-316 & (2)\end{array}$ & $\begin{array}{l}5 .-11.6 \\
0-2 .\end{array}$ & $\begin{array}{l}5 \\
5\end{array}$ \\
\hline 8 & $81 \mathrm{TT} 118$ & M & $Q-K f-F x($ after $P y)-W m(t r)$ & $\mathrm{Kf}$ & $\mathrm{P}, \mathrm{IA}$ & $\begin{array}{l}\text { I } \\
\text { II } \\
\text { III } \\
\text { IV }\end{array}$ & $\begin{array}{ll}214-325 & (43) \\
360-364 & (2) \\
255-267 & (2) \\
267-370 & (5)\end{array}$ & $\begin{array}{c}.8-6.2 \\
-- \\
34 .-40 . \\
1 .-13 .\end{array}$ & $\begin{array}{r}6 \\
-- \\
2 \\
7\end{array}$ \\
\hline 8 & $81 \mathrm{TT} 119$ & M & $Q-K f-F x($ after $P y)-W m(t r)$ & KE & $P, I A$ & $\begin{array}{l}\text { I } \\
\text { II } \\
\text { III } \\
\text { IV }\end{array}$ & $\begin{aligned} 246-352 & (37) \\
350-365 & (3) \\
256 & (1) \\
360 & (1)\end{aligned}$ & $\begin{array}{l}5.6-10.3 \\
- \\
36 . \\
.8-\end{array}$ & $\begin{array}{r}6 \\
-- \\
1 \\
3\end{array}$ \\
\hline 8 & 81 TT120 & M & $Q-W m(t r)$ & $\mathrm{Kf}$ & $\mathrm{P}, \mathrm{IA}$ & $\begin{array}{l}\text { I } \\
\text { IV }\end{array}$ & $\begin{aligned} 219-306 & (26) \\
309 & (1)\end{aligned}$ & $\begin{array}{l}7 .-14 . \\
.5-4.5\end{array}$ & $\begin{array}{l}6 \\
2\end{array}$ \\
\hline 9 & 81 TT116 & M & $\mathrm{Q}-\mathrm{Kf}(\mathrm{tr})-\mathrm{Mo}(\mathrm{tr})-\mathrm{Wm}(\mathrm{tr})$ & Kf & $\mathrm{P}, \mathrm{IA}$ & I & $261-318(22)$ & $4 \cdot 6-10 \cdot 3$ & 11 \\
\hline
\end{tabular}

1 H, Upper Cambrian Harmony Formation; M, Late Cretaceous monzogranite porphyry.

2 Q, quartz, Kf, potassium feldspar; Mo, molybdenite; Cc, carbonate; Py; pyrite, Chl, chlorite;

Po, pyrrhotite; Bio, biotite; Wm, white mica; Ep, epidote; Rut, rutile; Fx, iron oxide(s).

3 P, potassic; Phy, phyllic; Prp, propylitic; IA, intermediate-argillic (see text).

4 At $22 \pm 2{ }^{\circ} \mathrm{C}: \mathrm{I}$, low vapor volume+most1y liquid $\mathrm{H}_{2} \mathrm{O}$; II, high vapor volume+mostly 1 iquid $\mathrm{H}_{2} \mathrm{O}$; III, halite bearing; IV, mostly $\mathrm{CO}_{2}$ vapor + liquid $\mathrm{CO}_{2}+$ mostly liquid $\mathrm{H}_{2} \mathrm{O}$ (see text).

5 In parenthesis, number of determinations of total homogenization temperature of fluid inclusions.

to estimate thereby the $\mathrm{CO}_{2}$ content in those fluid inclusions that do not show visible $\mathrm{CO}_{2}$ at room temperature. Again, there is an almost full-range overlap between the fluid inclusions that homogenize totally to vapor and those that homogenize totally to liquid during heating tests. Many vaporrich fluid inclusions are extremely dilute (salinities of $0-0.5$ weight percent $\mathrm{NaCl}$ equivalent are quite common), and many also include some liquid $\mathrm{CO}_{2}$ at room temperature. In addition, many of these fluid inclusions and the more common, liquid-rich type IV fluid inclusions show a shift of their $\mathrm{CO}_{2}$ solid-liquid-vapor phase transitions to temperatures slightly below $-56.6{ }^{\circ} \mathrm{C}$. Such phase transitions are commonly in the range -56.8 to $-57.2{ }^{\circ} \mathrm{C}$ here, and indicate thereby that $\mathrm{CH}_{4}$ is probably present in the trapped fluids (Barruss, 1981), although some other volatile component, such as $\mathrm{CO}$ or $\mathrm{N}_{2}$, that has a triple point below that of $\mathrm{CO}_{2}$ may cause a similar shift. In addition, some of these very dilute fluid inclusions also show a corresponding increase of their final melting of clathrate 
to temperatures of +10.1 to $+10.2{ }^{\circ} \mathrm{C}$; this seems to confirm the probable presence of $\mathrm{CH}_{4}$. Thus, the system of many individual fluid inclusions is apparently at least quaternary, $\mathrm{H}_{2} \mathrm{O}-\mathrm{NaCl}-\mathrm{CO}_{2}-\mathrm{CH}_{4}$,

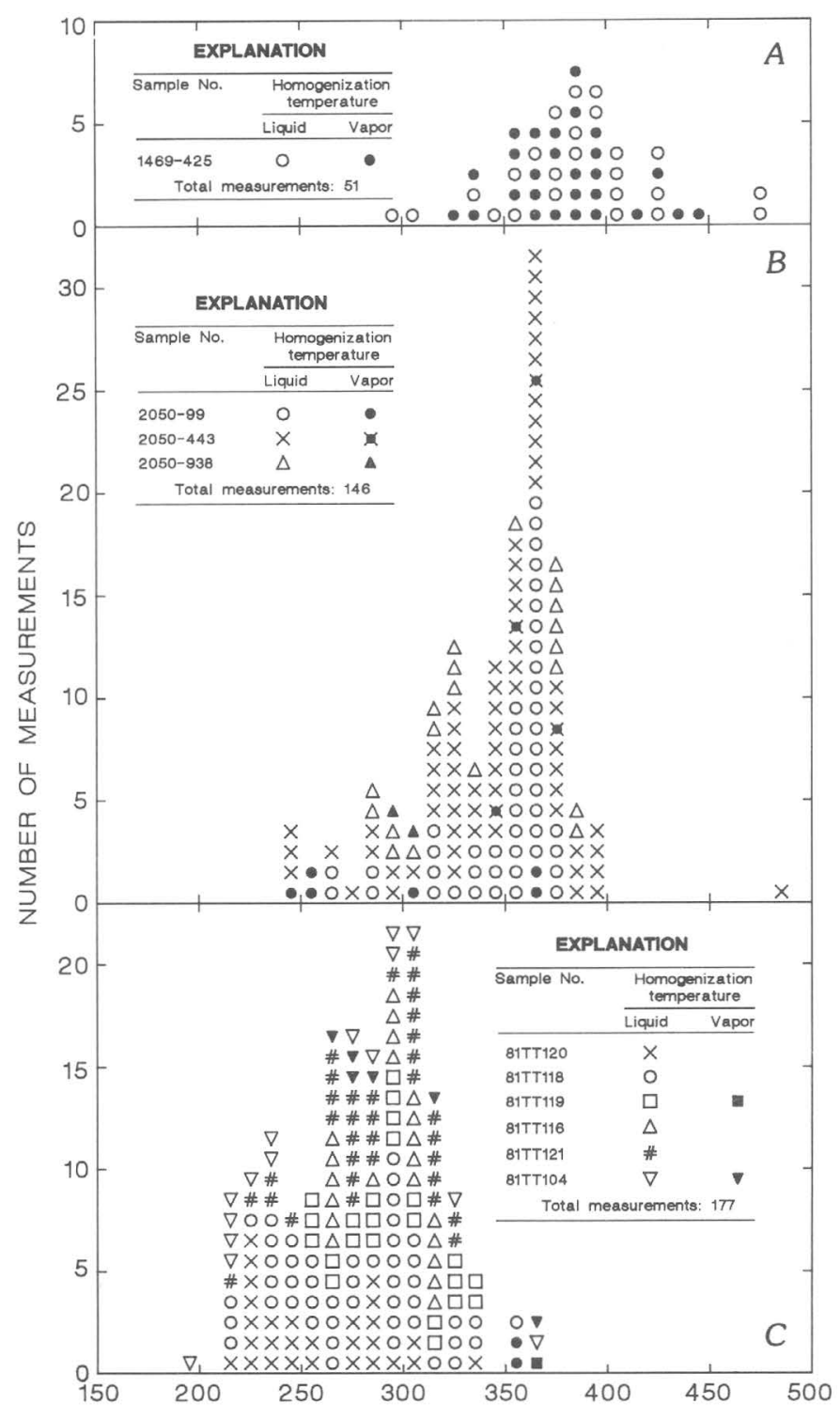

HOMOGENIZATION TEMPERATURE, IN DEGREES CELSIUS

FIgURE 118.-Variations in types I and II fluid-inclusion homogenization temperatures with distance away from locus of magmatism and quartz-stockwork development in Vail Ridge block. $A$, Veined sample of the Upper Cambrian Harmony Formation collected about $150 \mathrm{~m}$ beyond outer limit of quartz stockworks, showing well-developed potassic-alteration assemblage and minimal propylitic overprint (loc. 1, fig. 117). $B$, Three veined monzogranite porphyry samples, collected about $50 \mathrm{~m}$ within mapped outer limit of quartz stockwork that show welldeveloped potassic-alteration assemblage and substantial effects of intermediate argillic overprint (loc. 2, fig. 117). C, Six veined monzogranite porphyry samples collected near east-west core of system (locs. 6-9, fig. 117; see text). and it probably also includes minimal amounts of some additional components. For example, radiogenic argon, far in excess of that which could be supported by the ages of the rocks involved in the Buckingham system, has been measured by E.H. McKee and others of the U.S. Geological Survey (unpub. data, 1989; Turrin and others, 1989) to be present in fluid inclusions hosted by vein quartz in the Buckingham system.

There is also some variation with depth in the total homogenization temperatures obtained at locality 3 (fig. $118 B$ ). The mode $\left(370-379{ }^{\circ} \mathrm{C}\right)$ for the homogenization data from the sample obtained at a depth of $385 \mathrm{~m}$ is slightly greater than that for a sample at a depth of $30 \mathrm{~m}\left(360-369{ }^{\circ} \mathrm{C}\right)$. However, the significance of such a relation, if any, is difficult to evaluate. Nonetheless, the important relation determined at this locality is that very hot, boiling, $\mathrm{CO}_{2}$-bearing fluids circulated near the fringes of the quartz stockworks penecontemporaneous with the development of prograde potassic and (or) propylitic stages. For the most part, the fluids were moderately saline and probably contained minor amounts of $\mathrm{CH}_{4}$.

The fluid-inclusion population hosted by quartz veins that cut monzogranite porphyry near the east-west axial core of the Buckingham system differs in many aspects from that near the fringes of the system. First of all, the overwhelming bulk of the fluid inclusions, mostly type $\mathrm{I}$, in the veined samples of monzogranite porphyry (locs. 6-9, fig. 117; table 49) are secondary relative to vein quartz, and they are concentrated in dense swarms along annealed microcracks oriented at high angles to the walls of the veins (fig. 119). These fluid inclusions must have been repeatedly trapped mostly during circulation of fluids associated with the widespread and locally intense, late-stage, intermediate argillic overprint that has affected these rocks. Nonetheless, almost all these veins here still show relict potassic-alteration assemblages along their selvages that suggest initial emplacement of veins occurred during potassic stages of the system. Although the overwhelming bulk of the fluid inclusions in the veined monzogranite porphyry are the type I variety, these veins also seem to show a slightly increased abundance of halite-bearing, type III variety of fluid inclusion relative to veins studied at the fringes of the system in the Vail block. Furthermore, liquid-vapor homogenization tests of fluid inclusions from these quartz veins in the monzogranite porphyry yield a plot (fig. 118C) significantly different from that which derives from quartz veins minimally affected by postpotassic 
alteration. This difference results in a $100{ }^{\circ} \mathrm{C}$ difference between medians for these two temperature-of-homogenization plots $\left(380{ }^{\circ} \mathrm{C}\right.$ for the potassic-alteration assemblage, compared with $280{ }^{\circ} \mathrm{C}$ for veins showing intense development of the intermediate argillic overprint). Thus, the apparent preferred concentration of fluid inclusions that homogenize to vapor at the high-temperature end of the distribution plot for samples of veined monzogranite porphyry suggest that these hightemperature fluid inclusions may be largely relict from early potassic stages (compare figs. $118 \mathrm{~A}$ and
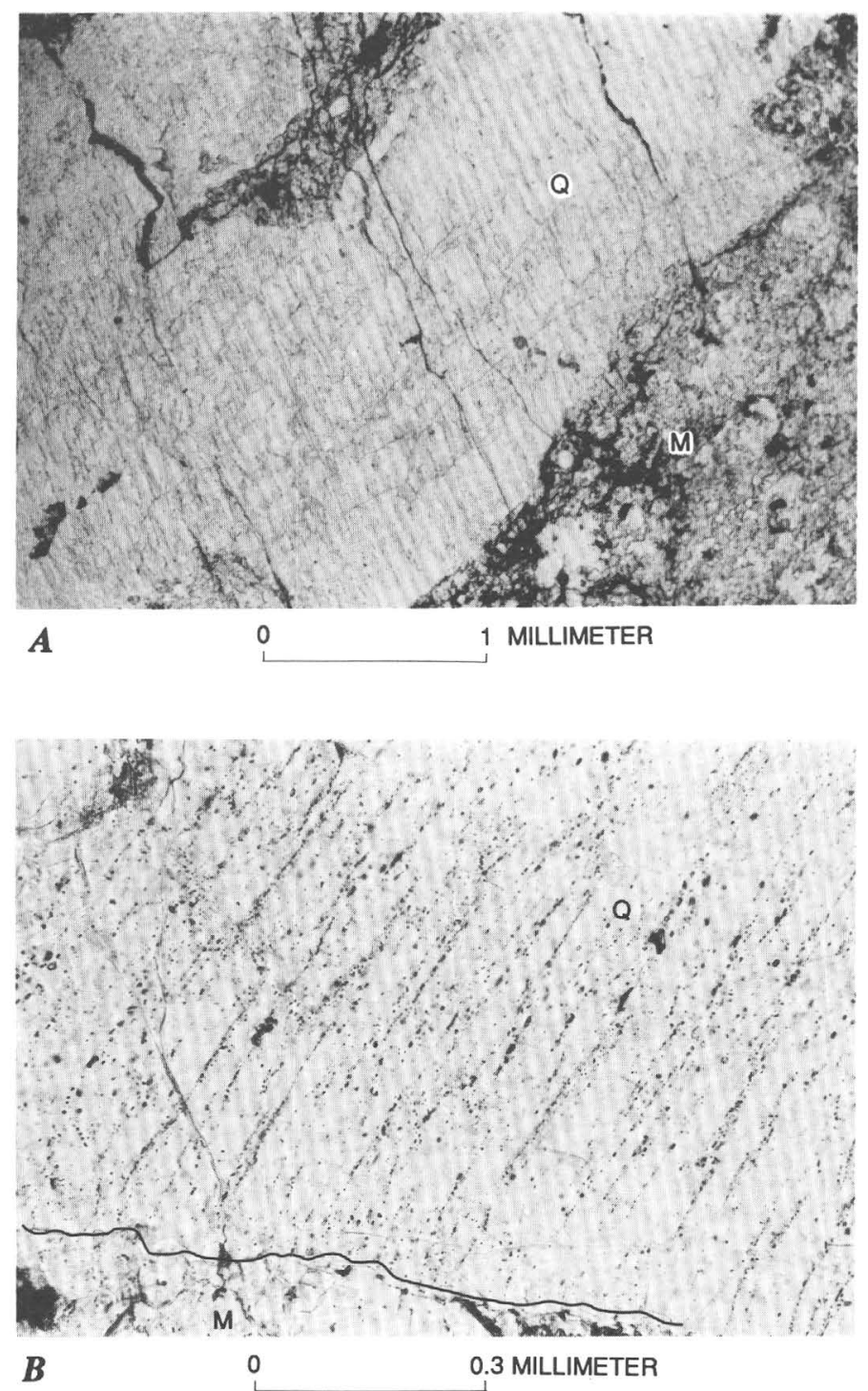

FIGURE 119.-Photomicrographs showing concentrations $(A)$ and closeup $(B)$ of secondary fluid inclusions in vein quartz (Q) from axial core of Buckingham system in Vail Ridge block. M, matrix of monzogranite porphyry. Sample 81TT120.
$118 B$ with fig. $118 C$; see Bodnar and Beane, 1980). Elsewhere, Alderton and Rankin (1983) found at the St. Austell granite in southwest England a strong spatial association of kaolinized granite with abundant, dilute, low-temperature fluid inclusions that homogenize mostly at temperatures below $170{ }^{\circ} \mathrm{C}$.

Type III fluid inclusions are extremely rare throughout the Buckingham stockwork molybdenum system, as well as in many other similar molybdenum systems elsewhere (Theodore, 1982a; Hall and others, 1984; Theodore and Menzie, 1984). This relation provides a significant contrast in the fluidinclusion signature of most low-fluorine- or quartz monzonite-type stockwork molybdenum deposits and the porphyry copper deposits (Roedder, 1971; Nash, 1976; Roedder, 1984). Nonetheless, type III fluid inclusions seem to be somewhat more abundant in the axial core of the Vail Ridge tectonic block of the Buckingham system than in the East block to be described below. Some samples deep within the West block, however, contain the most abundant concentrations of type III fluid inclusions in the Buckingham system. Determination of dissolution temperatures of $\mathrm{NaCl}$ daughter minerals in limited numbers of type III fluid inclusions from Vail Ridge suggests that some hypersaline fluids, probably containing more than 40 weight percent $\mathrm{NaCl}$ equivalent (table 49), also circulated in the stockwork environment here during its development. Some of these type III fluid inclusions are crystal rich and contain halite and sylvite, as well as some birefringent crystals (most likely $\mathrm{K}$-feldspar, carbonate, rutile, or iron chloride), with or without an opaque mineral (pyrite, chalcopyrite, magnetite, or, much less commonly, galena and sphalerite) (fig. 120). As pointed out by Bodnar and Beane (1980), such salinity estimates based on the dissolution temperature of $\mathrm{NaCl}$ actually yield minimum values because fluidinclusion waters trapped must also contain other cations and anions, as discussed below. These rare type III fluid inclusions homogenize by vapor disappearance at relatively low temperatures (255-267 ${ }^{\circ} \mathrm{C}$ ), and, most importantly, they do not appear to be cogenetic with any extremely high temperature, type II fluid inclusions (fig. 121). A plot of liquid-vapor homogenization temperature versus salinity for 44 fluid inclusions from the Vail block for which both are available shows a grouping of data into two domains (fig. 121). Fluid inclusions containing less than about 15 weight percent $\mathrm{NaCl}$ equivalent (types I, II, and IV) show filling temperatures from about 260 to $385{ }^{\circ} \mathrm{C}$. However, the limited number of data points available for the type III fluid inclusions show 
that their liquid-vapor homogenization occurs near the low-temperature end of the range for types I, II, and IV. The genesis of such apparently low temperature, hypersaline fluids, relatively high in the system, as condensation products during the "second

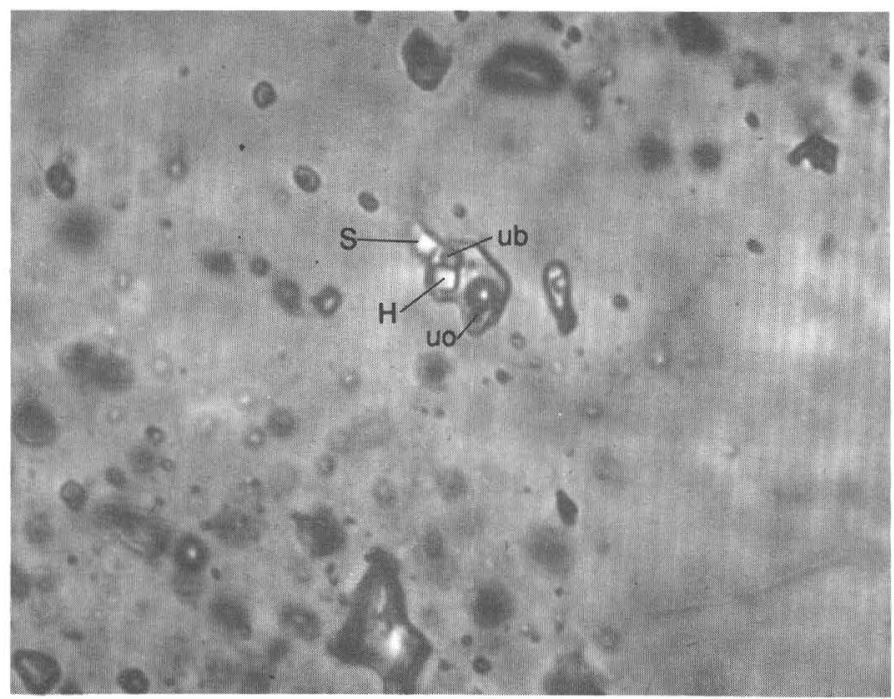

$\boldsymbol{A}$ 0 15 MICRONS

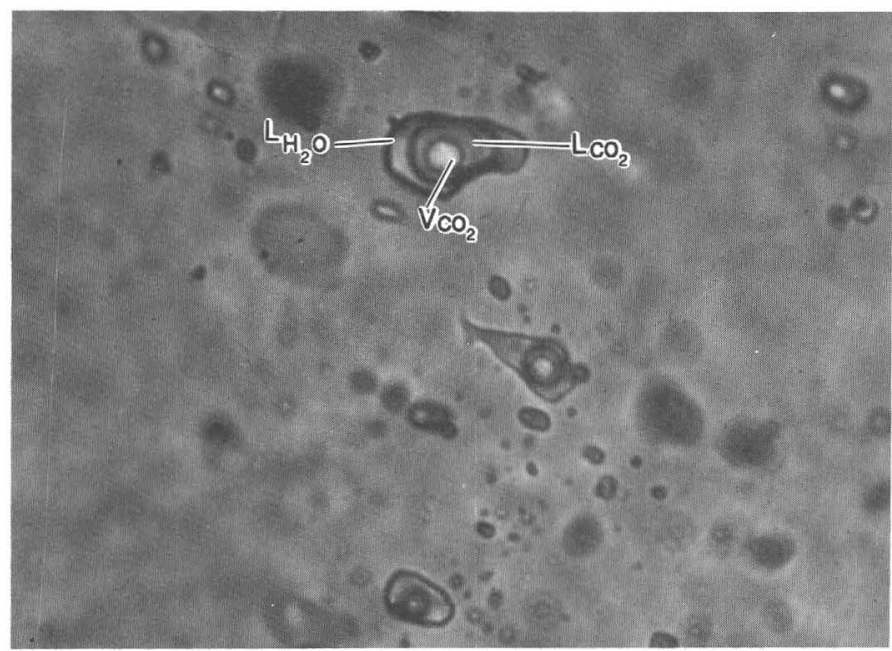

$\boldsymbol{B}$ 0 20 MICRONS

Figure 120.-Photomicrographs of fluid inclusions in quartz stockworks from Vail Ridge block of Buckingham system. Sample 81 TT118 (loc. 8, fig. 117). Plane-polarized light. $A$, Type III fluid inclusion that contains halite $(\mathrm{H})$, sylvite $(\mathrm{S})$, an unknown birefringent crystal (ub), and an unknown opaque mineral (uo). $B$, Type IV fluid inclusion showing, at room temperature, a relatively large proportion of liquid carbon dioxide $\left(\mathrm{L}_{\mathrm{CO}_{2}}\right)$ and minor amounts of mostly water $\left(\mathrm{L}_{\mathrm{H}_{2} \mathrm{O}}\right)$ and carbon dioxide vapor $\left(\mathrm{V}_{\mathrm{CO}_{2}}\right)$. boiling" (Burnham, 1979) of a moderately saline fluid will be discussed below. Extensive examination by SEM of artificially opened fluid-inclusion cavities resulted in the identification of many different minerals as trapped crystals or daughter crystals; these include several varieties of carbonate (calcite and manganese-bearing ferroan calcite), halite, sylvite, pyrite, chalcopyrite, galena, sphalerite, K-feldspar, rutile, and manganiferous iron chloride (fig. 122). One aspect of this part of the study that needs further comment is the relatively common occurrence of chalcopyrite rather than molybdenite in these fluid inclusions studied by the X-ray microanalyzer. However, when such occurrences are considered in light of the hypogene copper halo that surrounds the molybdenite-enriched parts of the Buckingham system, the relative abundance of chalcopyrite as trapped minerals and (or) daughter minerals in the samples is not surprising. The quartz stockworks exposed in the Vail Ridge part of the system now reside near the upper part of the system that is copper enriched. In addition, some of the crystals of chalcopyrite contain relatively minor concentrations of silver as determined by qualitative analysis using the $\mathrm{X}$-ray microanalyzer. The silver probably is present in the chalcopyrite either as a partial substitution for iron, or as a partial substitution for copper (Deer and others, 1962c). Scherkenbach and Sawkins (1982) and Scherkenbach and others (1985) also report widespread occurrences of chalcopyrite-bearing fluid inclusions in the Comobabi, northern Sonora, Mexico, molybdenum-mineralized breccia pipes.

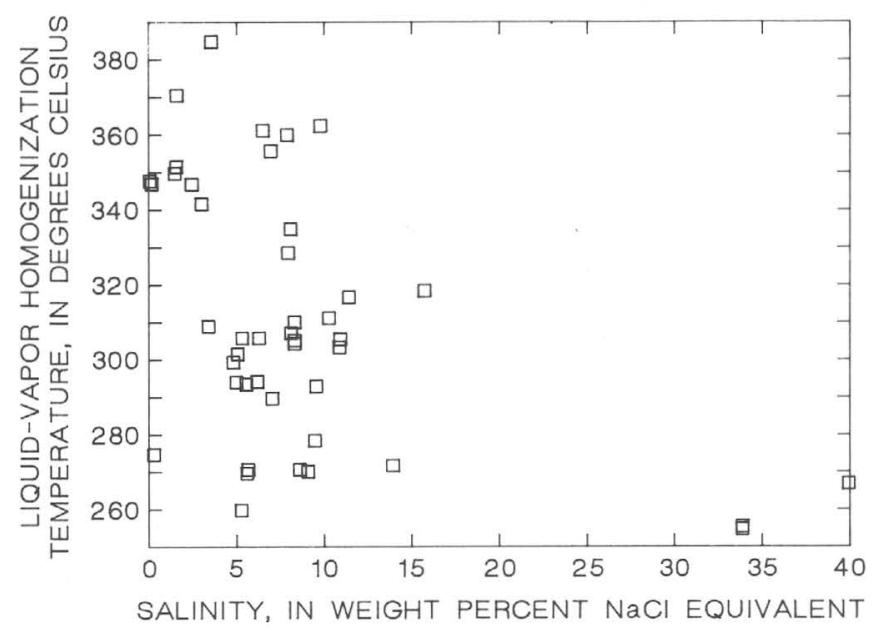

FIgURE 121.-Salinity versus homogenization temperature for 44 fluid inclusions in vein quartz associated with molybdenum mineralization in Vail Ridge part of Buckingham system. 
Some samples of veined monzogranite porphyry, particularly at locality 8 (fig. 117), also show enigmatic clusters of extremely $\mathrm{CO}_{2}$ rich fluid inclusions. Some evidence suggests they may be related to miscibility during the circulation of the early-stage fluids associated with potassic alteration. Individually, at room temperature these fluid inclusions compose

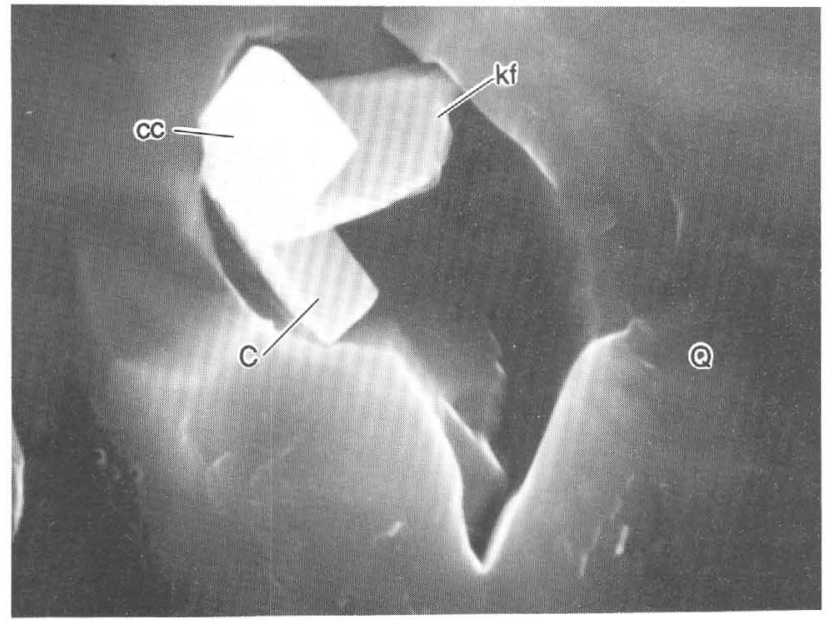

$\boldsymbol{A}$

0

4 MICRONS

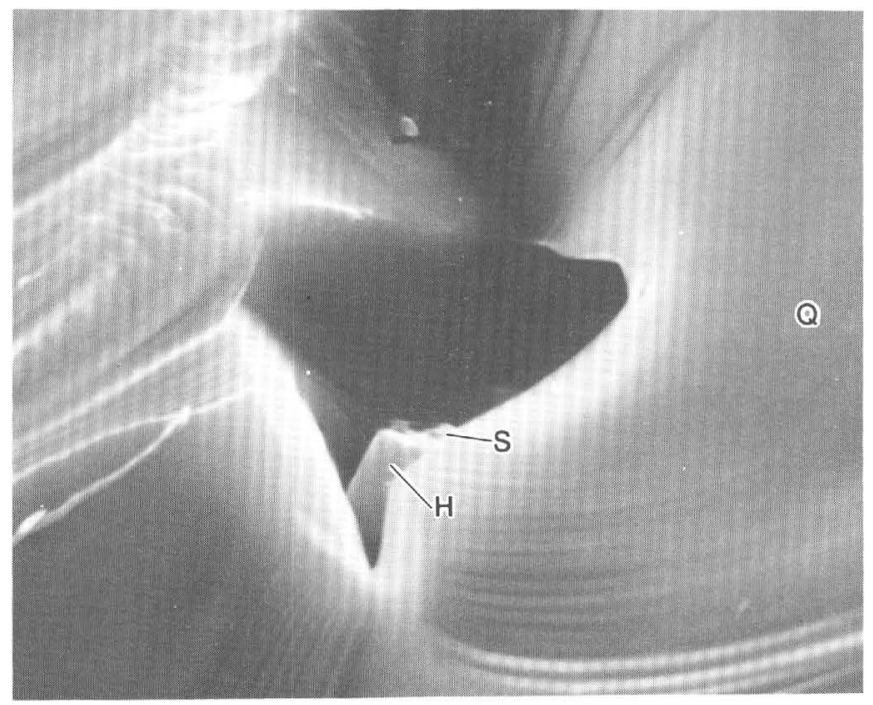

$\boldsymbol{B}$

0

4 MICRONS

Figure 122.-Scanning electron micrographs of artificially opened fluid-inclusion cavities in quartz veins from Buckingham stockwork system in Vail Ridge area. C, calcite; cp, chalcopyrite; $\mathrm{H}$, halite; $\mathrm{kf}, \mathrm{K}$-feldspar; py, pyrite; $\mathrm{Q}$, quartz; S, sylvite. $A-F$, Sample 81TT119. $G$, Sample 81TT118. $H$, Sample 120. $I-L$, Sample 81TT119; all at locality 8 (fig. 117). $A$, cc, manganiferous, iron-bearing calcite. $D$, fc, manganiferous iron chloride. $F$, cc, manganiferous, iron-bearing calcite; either two phases (liquid $\mathrm{CO}_{2}$ and mostly $\mathrm{CO}_{2}$ vapor) or three phases, mostly $\mathrm{H}_{2} \mathrm{O}$ and liquid $\mathrm{CO}_{2}$ and mostly $\mathrm{CO}_{2}$ vapor (fig. $120 \mathrm{~B}$ ). Many of the latter type IV fluid inclusions show relative proportions of about 70 to 95 volume percent mostly $\mathrm{CO}_{2}$. All but one of 66 measurements on the two-phase $\mathrm{CO}_{2}$-rich fluid inclusions show homogenization to liquid $\mathrm{CO}_{2}$ at

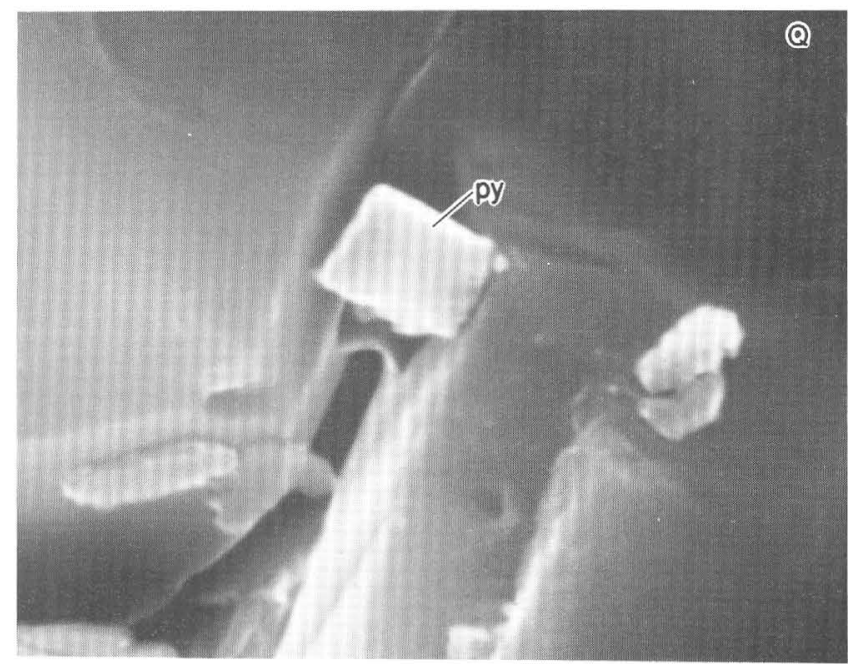

C 0 2 MICRONS

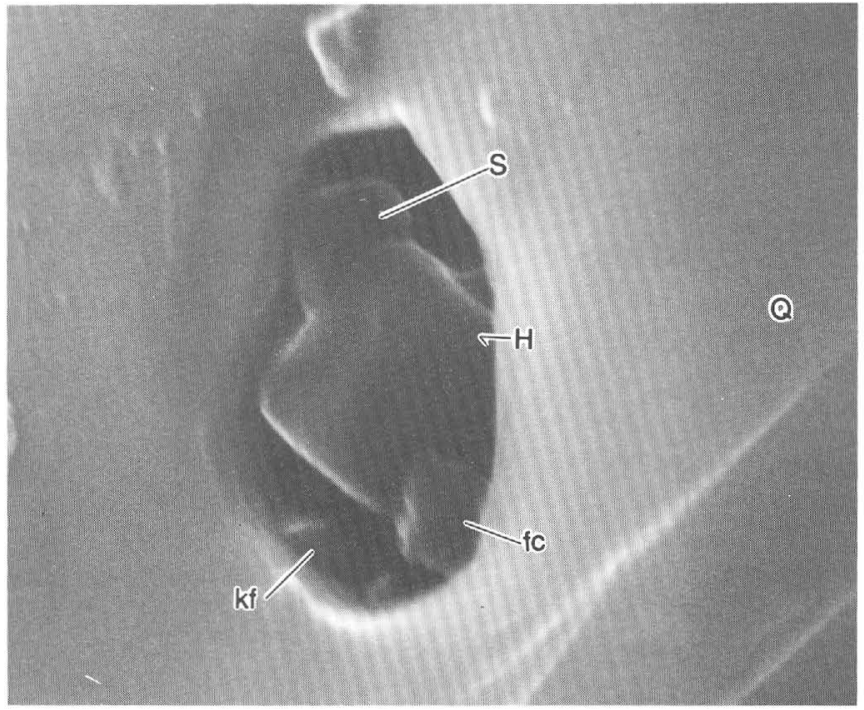

D 0 2 MICRONS

gn, galena; sid, siderite; sl, sphalerite. $G, \mathrm{M}$, magnetite; minute crystals of sylvite on surface of quartz near opened fluidinclusion cavity are probably residual products of desiccation of fluid-inclusion waters that spilled onto surface of quartz when fluid inclusion was broken open. $I$, fc, manganiferous iron chloride; $R$, rutile. $J$, cpa, silver-bearing chalcopyrite showing some trace amounts of zinc (sphalerite?). $K, \mathrm{M}$, magnetite; sl, sphalerite. $L$, wm, white mica. 

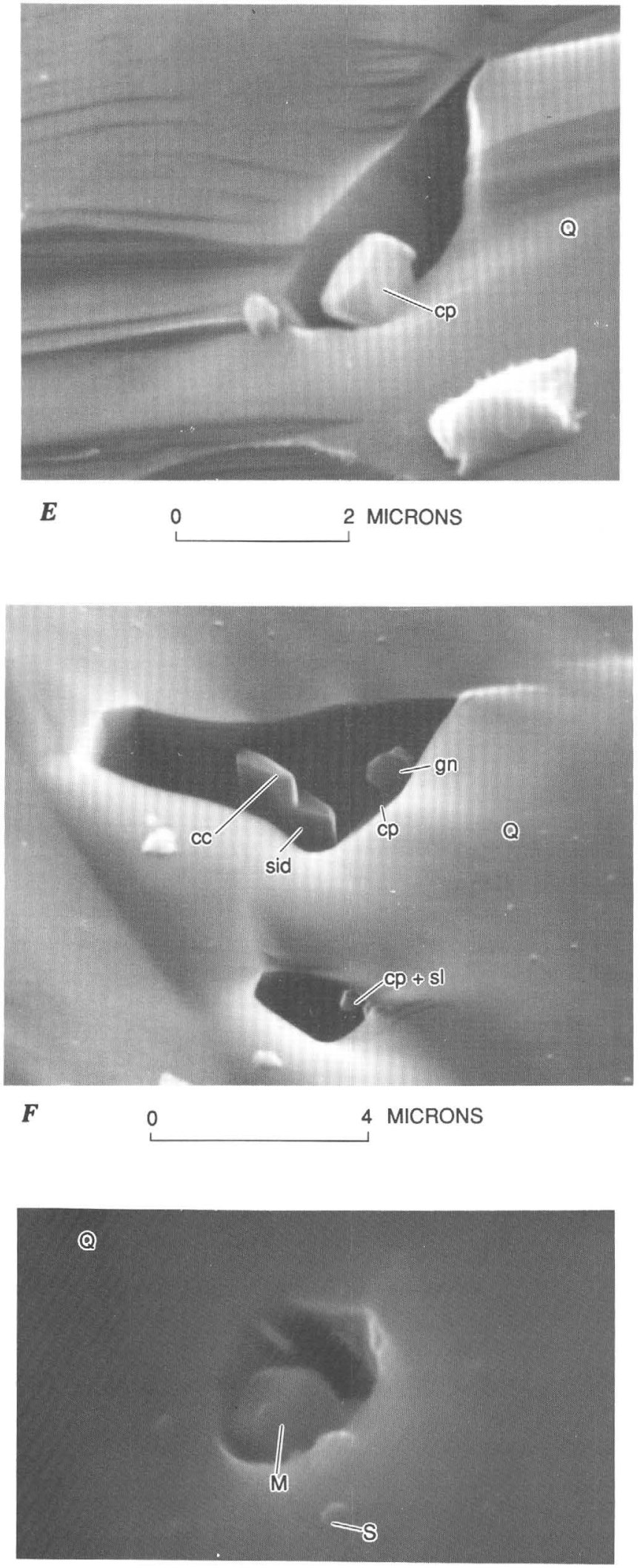

G 2 MICRONS
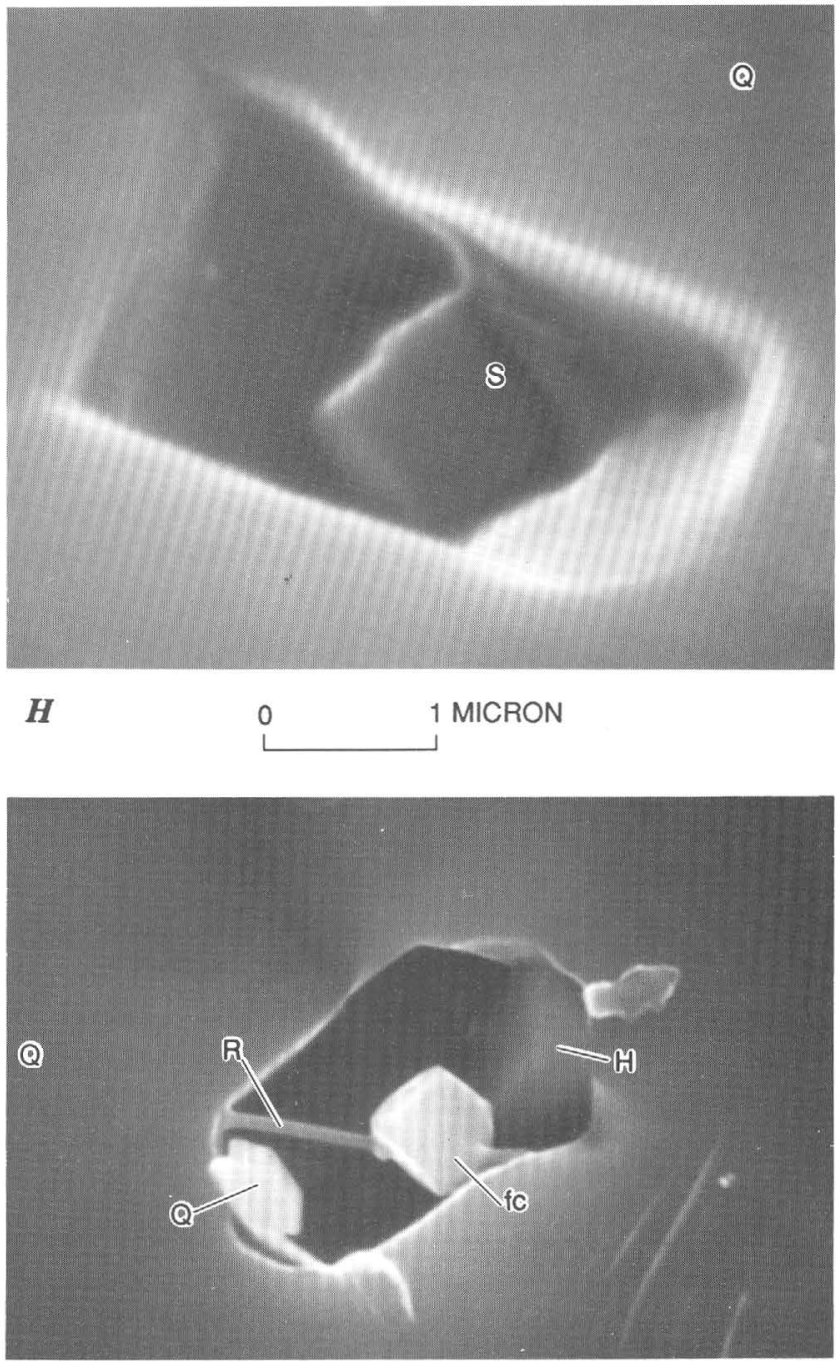

I

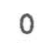

2 MICRONS

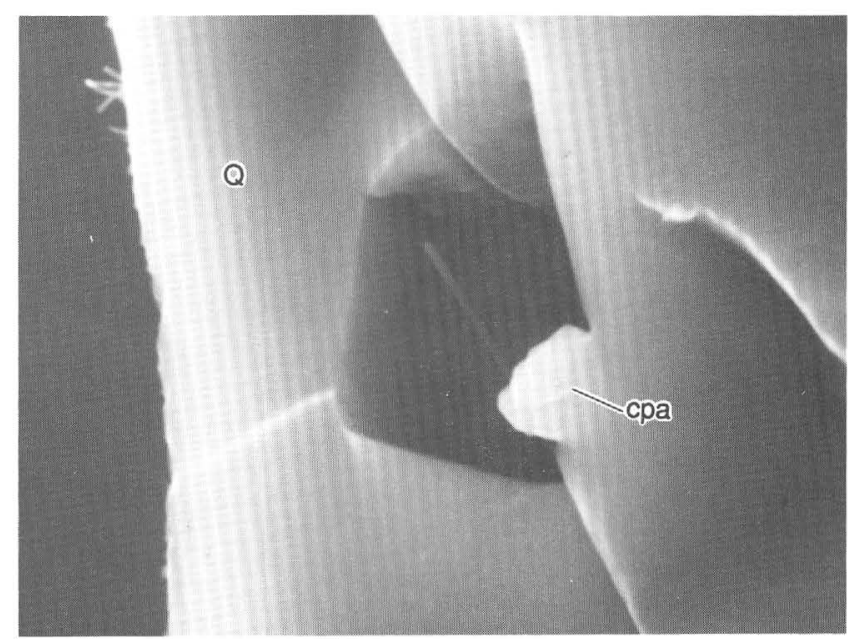

$\boldsymbol{J}$ 2 MICRONS

FIGURE 122.-Continued. 
temperatures less than the $31{ }^{\circ} \mathrm{C}$ critical point of $\mathrm{CO}_{2}$ (fig. 123). The overall range is from 7.7 to 27.3 ${ }^{\circ} \mathrm{C}$, which would correspond to densities of about 0.89 to $0.77 \mathrm{~g} / \mathrm{cm}^{3}$, respectively, in the system $\mathrm{CO}_{2}$ (Angus and others, 1973, in Hollister, 1981). However, the presence of $\mathrm{CH}_{4}$ in these fluid inclusions is suggested by a melting of solid $\mathrm{CO}_{2}$ at temperatures slightly but consistently below $-56.6{ }^{\circ} \mathrm{C}$ : from -56.7
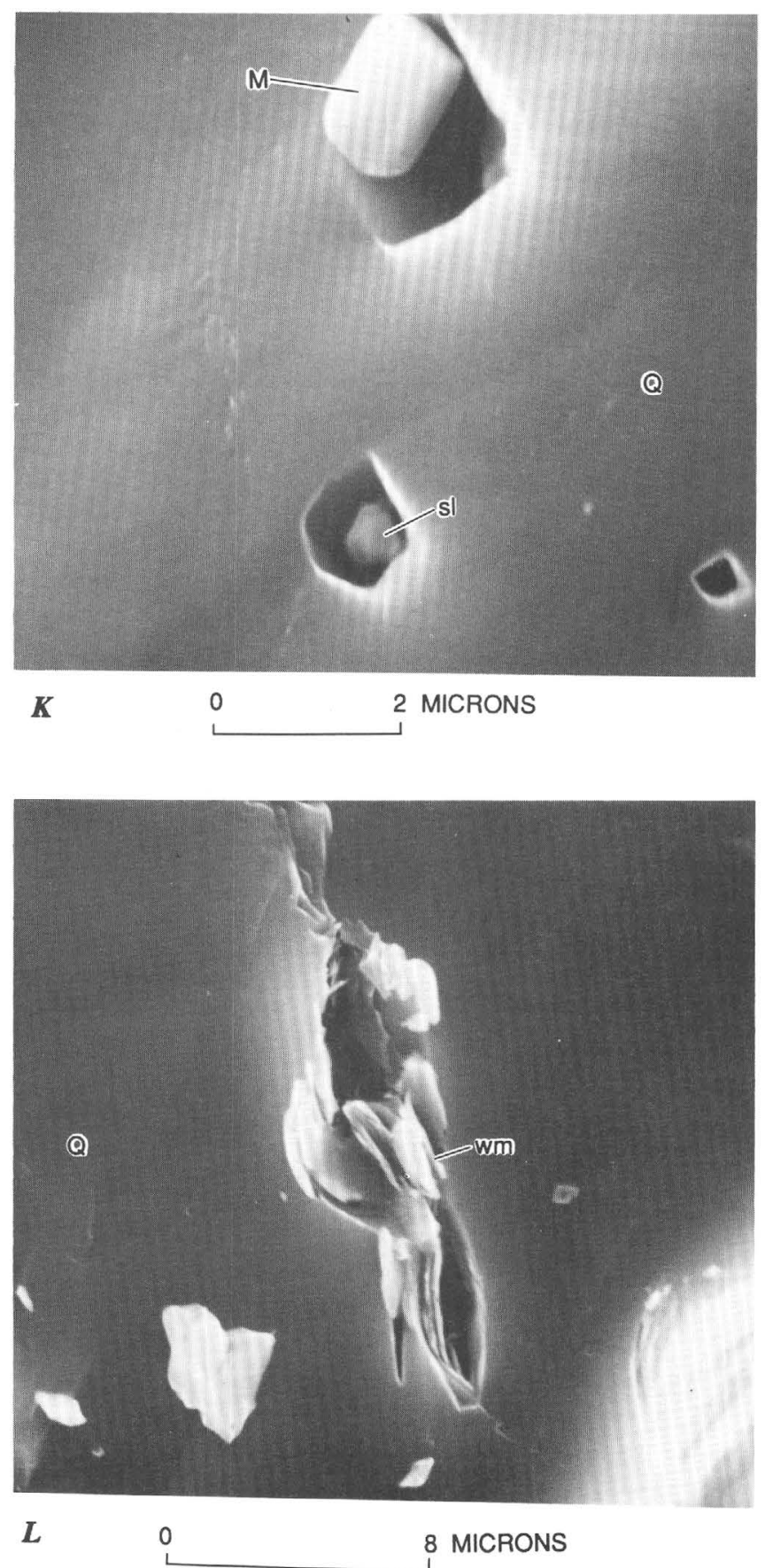

Figure 122.-Continued. to $-57.6{ }^{\circ} \mathrm{C}$. Norman and Sawkins (1987) found that porphyry-type systems typically have $\mathrm{CO}_{2}$ as the dominant gaseous species; the absence of organic compounds $\left(\mathrm{C}_{n} \mathrm{H}_{n}\right)$ and nitrogen may indicate a preponderance of magmatically derived fluids, as opposed to fluids that interacted significantly with sedimentary rocks. Pasteris and others (1983) have found that $\mathrm{CH}_{4}$ partitions strongly into the vapor phase in two-phase fluid inclusions belonging to the system $\mathrm{CO}_{2}-\mathrm{CH}_{4}$. A liquid-vapor tieline of $57{ }^{\circ} \mathrm{C}$ for the melting of $\mathrm{CO}_{2}$ in the system $\mathrm{CO}_{2}-\mathrm{CH}_{4}$ suggests that the $\mathrm{CO}_{2}$-rich fluid inclusions here may contain about 2 mol percent $\mathrm{CH}_{4}$ (Arai and others, 1971, in Barruss, 1981). Some three-phase type IV fluid inclusions are interspersed closely with these twophase, mostly liquid $\mathrm{CO}_{2}$ fluid inclusions, and appear texturally to belong to the same paragenetic stage as the two-phase, mostly liquid- $\mathrm{CO}_{2}$ fluid inclusions. Some of these type IV fluid inclusions homogenize totally to liquid at temperatures in the range 360 $370{ }^{\circ} \mathrm{C}$, suggesting thereby that the two phase, mostly liquid- $\mathrm{CO}_{2}$ fluid inclusions may also indicate trapping during the early potassic stages rather than the subsequent intermediate argillic overprint. Furthermore, $\delta^{13} \mathrm{C}$ values of $\mathrm{CO}_{2}$ in fluid inclusions from a nearby vein (sample 81TT121) suggest mixed origins, presumably magmatic and organic, for the $\mathrm{CO}_{2}$.

Four determinations of the $\delta^{13} \mathrm{C}$ and $\delta^{18} \mathrm{O}$ values of $\mathrm{CO}_{2}$ in fluid inclusions of vein quartz from the Vail Ridge tectonic block of the molybdenum system are available (table 50). Two of the samples (2050-512, 2050-633) are from quartz veins hosted

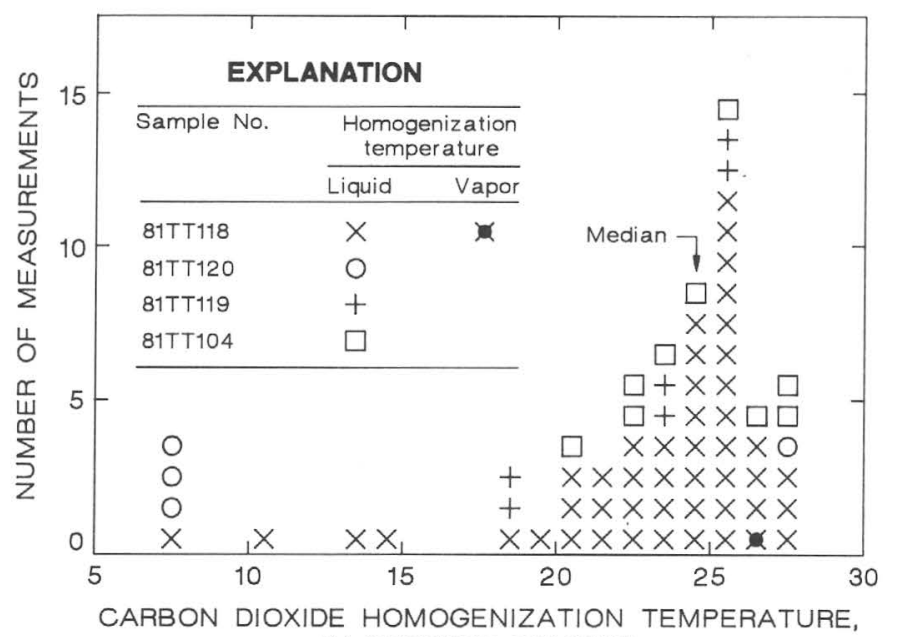

IN DEGREES CELSIUS

FIGURE 123.-Distribution of $\mathrm{CO}_{2}$ homogenization temperatures for 66 fluid inclusions in four samples from Vail Ridge block of Buckingham molybdenum system. 
TABLE 50.-Isotopic composition of carbon dioxide in fluid inclusions hosted by vein quartz from the Buckingham system

$\left[\delta^{13} \mathrm{C}\right.$ values in permil relative to Peedee belemnite (PDB); analyst, S.S. Howe. $\delta^{18} \mathrm{O}$ values in permil relative to standard mean ocean water (SMOW); analyst, L.D. White, in the laboratory of J.R. O'Neill, U.S. Geological Survey, Menlo Park, Calif.]

\begin{tabular}{|c|c|c|c|}
\hline $\begin{array}{c}\text { Sample } \\
\text { No. }\end{array}$ & $\begin{array}{c}\mathrm{CO}_{2} \\
(\mu \mathrm{mol})\end{array}$ & ${ }^{13} \mathrm{C}_{\mathrm{PDB}}$ & $\delta^{18} O_{\text {SMOW }}$ \\
\hline & Ridge $t$ & tectonic b1o & \\
\hline $2050-512$ & 10.0 & -4.76 & +17.1 \\
\hline $2050-633$ & 6.0 & -6.32 & +24.09 \\
\hline $81 \mathrm{TT} 121$ & 7.0 & -12.04 & -.92 \\
\hline $79 C 77$ & 8.0 & -4.67 & +21.78 \\
\hline
\end{tabular}

\begin{tabular}{lccc}
$78 \mathrm{C} 49$ & 24.0 & -5.69 & +35.97 \\
$78 \mathrm{C} 162$ & 4.0 & -9.16 & +12.25 \\
$78 \mathrm{C} 164$ & 9.0 & -5.08 & +36.8 \\
$80 \mathrm{BK} 20$ & 17.0 & -11.03 & -15.71 \\
\hline $78 \mathrm{C} 169$ & West stock tectonic b1ock \\
\hline
\end{tabular}

by altered rocks of the Harmony Formation near the outer fringe of the quartz stockworks that surround the system (loc. 3 , fig. 117). The samples are dominated by potassic-alteration assemblages with a minimum of late-stage overprint. The remaining two samples analyzed from the Vail Ridge tectonic block are from vein quartz in monzogranite porphyry near the projected core of the system (locs. $7-8$, fig. 117). They are dominated by mixed potassic and superposed intermediate argillic assemblages. The $\delta^{13} \mathrm{C}$ values near -5 permil (table 50 ) are close to those that have been inferred by others elsewhere to indicate deep-seated or presumed. magmatic origins for the $\mathrm{CO}_{2}$ in the fluid inclusions hosted by quartz (Conway and Taylor, 1969; Deines, 1970; Faure, 1977; Geldron and Le Bel, 1983; Hall and others, 1984; Bowman and others, $1985)$. The isotopically lightest value $(-12.04)$ in the Vail Ridge block (table 50) suggests that the $\mathrm{CO}_{2}$ in the fluid inclusions there includes both presumably magmatic $\mathrm{CO}_{2}$ and some $\mathrm{CO}_{2}$ from an organic crustal source-possibly nearby carbonaterich rocks of the Antler Peak Limestone (pl. 1). In addition, from the fact that this quartz vein sample contains significant concentrations of secondary fluid inclusions related to the intermediate argillic overprint and two of the others do not, we conclude that the major incorporation of organic crustal $\mathrm{CO}_{2}$ may have occurred during the intermediate argillic event, and that the bulk of the organic crustal $\mathrm{CO}_{2}$ may reside in the secondary fluid inclusions.

\section{EAST BLOCK}

Study of fluid-inclusion relations in the East block, which is bounded by the Long Canyon and Second faults, by heating and freezing techniques reveals that the fluids associated with mineralization there were generally similar in overall chemistry to those in the Vail Ridge block. Carbon dioxide also is common in fluid inclusions through much of this part of the system, and the fluids here for the most part are moderately saline (table 51). The highest salinity recorded for type I fluid inclusions is 21.5 weight percent $\mathrm{NaCl}$ equivalent, and the halite-bearing type III fluid inclusions are exceptionally rare. In addition, all these fluids seemingly were trapped at pressures and temperatures approximately similar to conditions apparently prevailing in the Vail Ridge part of the system (table 51). In all, these studies in the East block were of 35 samples: 7 from exposures at the surface and 28 from sampling sites at various depths in core obtained from eight drill holes into the system. All but one of the samples is hydrothermal vein quartz associated with the molybdenum mineralization. The one exception (sample 1463-563, table 51) is phenocrystic. quartz in Oligocene granodiorite porphyry that cuts the molybdenum system. Furthermore, ten of the studied samples are core samples obtained from depths between 43.6 and $503.5 \mathrm{~m}$ in one deep hole put down into the system (loc. 18, table 51).

There are, nonetheless, some very subtle apparent differences between the fluid-inclusion populations of the East and Vail Ridge blocks that are difficult to quantify. First of all, although many of the same trapped minerals and daughter minerals, together with similar desiccation products, have been found in samples from the East block (fig. 124), the overall abundance of type III fluid inclusions in the East block is much less than that in the Vail Ridge block. This conclusion is based on visual estimates of the relative abundance and proportion of the various fluid-inclusion types. In addition, careful determination of the $\mathrm{CO}_{2}$ triple point in numerous liquid $\mathrm{CO}_{2}-$ bearing fluid inclusions from the East block reveals 

system

\begin{tabular}{|c|c|c|c|c|c|c|c|c|c|}
\hline $\begin{array}{l}\text { Loc. No. } \\
\text { (fig. 117) }\end{array}$ & Sample No. & $\begin{array}{l}\text { Rock } \\
\text { type }\end{array}$ & $\begin{array}{l}\text { Composite vein } \\
\text { assemblage }^{2}\end{array}$ & Selvage 2 & $\begin{array}{l}\text { Assemblage }(s) \\
\text { in rock }\end{array}$ & $\begin{array}{l}\text { Type of } \\
\text { inclusion }^{4}\end{array}$ & $\begin{array}{l}\text { Homogenization } \\
\text { temp. range }\left({ }^{\circ} \mathrm{C}\right)^{5}\end{array}$ & $\begin{array}{l}\text { Salinity } \\
\text { Weight } \% \mathrm{NaCl} \\
\text { equivalent }\end{array}$ & $\frac{y}{\begin{array}{c}\text { Number } \\
\text { measured }\end{array}}$ \\
\hline 10 & $78 \mathrm{C} 162$ & м & Q-Kf-Rut-Wm(tr) & Kf & P, Phy(?) & $\begin{array}{l}\text { I } \\
\text { II } \\
\text { IV }\end{array}$ & $\begin{array}{l}266-331(41)^{5} \\
342-355(2) \\
284-323(3)\end{array}$ & $\begin{array}{c}2.3-6.6 \\
-- \\
0-8 .\end{array}$ & $\begin{array}{c}5 \\
-6\end{array}$ \\
\hline 11 & $78 \mathrm{C} 161$ & н & Q-KE & Kf & $\mathbf{P}$ & $\begin{array}{l}\text { I } \\
\text { II } \\
\text { IV }\end{array}$ & $\begin{array}{c}265-359(10) \\
365(1) \\
335-365(2)\end{array}$ & $\begin{array}{c}1.6-13.1 \\
.6 \\
--\end{array}$ & $\begin{array}{c}7 \\
1 \\
--\end{array}$ \\
\hline 12 & $78 \mathrm{C} 160$ & H & Q-Kf-Fx (after Py)-Wm(tr) & r) $\mathrm{Kf}$ & P, Phy(?) & $\begin{array}{l}\text { I } \\
\text { II } \\
\text { IV }\end{array}$ & $\begin{array}{c}227-372(17) \\
275-370(2) \\
371(1)\end{array}$ & $\begin{array}{c}4.7-10.5 \\
5.5 \\
-\end{array}$ & $\begin{array}{c}7 \\
1 \\
--\end{array}$ \\
\hline 13 & $78 \mathrm{C} 163$ & н & $\begin{array}{l}\text { Q-Kf-Ch1(tr)-Wm- } \\
\text { Fx(after Py) }\end{array}$ & Kf & $P, I A$ & I & -- & $8.8-10.2$ & 5 \\
\hline 14 & $78 \mathrm{C} 165$ & M & Q-Kf-Wm(tr) & Ke & $P, I A$ & I & $272-358(30)$ & $5 .-12.7$ & 10 \\
\hline 15 & $78 \mathrm{C} 164$ & M & Q-KE & Kf & $P, I A$ & $\begin{array}{l}\text { I } \\
\text { II } \\
\text { IV }\end{array}$ & $\begin{array}{c}258-359(35) \\
323(1) \\
338-360(3)\end{array}$ & $\begin{array}{c}4.6-7.8 \\
-- \\
1 .-5.5\end{array}$ & $\frac{7}{7}$ \\
\hline 16 & $1453-259$ & M & Q-Kf-Mo-Py & Kf & $P, I A$ & $\begin{array}{l}\text { I } \\
\text { II }\end{array}$ & $\begin{array}{l}261-328(37) \\
332-335(2)\end{array}$ & $\begin{array}{c}7.8-10.8 \\
--\end{array}$ & $\begin{array}{c}5 \\
--\end{array}$ \\
\hline 16 & $145,3-1057$ & M & Q-Kf-Wm-Cc-Mo-Py & Kf & P, Phy & I & $293-363(23)$ & -- & - \\
\hline 17 & $1466-170$ & H & Q-Kf-Py & Kf & P, Phy & I & $270-362(23)$ & $6.6-21.5$ & 10 \\
\hline 17 & $1466-530$ & M & $\mathrm{Q}-\mathrm{Wm}-\mathrm{Py}-\mathrm{Mo}-\mathrm{Cc}(\mathrm{tr})$ & Wm & Phy & I & $259-321(19)$ & $.5-3.2$ & 9 \\
\hline 18 & $1463-143$ & M & Q-Kf-Wm-Cc-Mo-Py & Kf & P, Phy & $\begin{array}{l}\text { I } \\
\text { II }\end{array}$ & $\begin{array}{l}269-370(45) \\
335-365(10)\end{array}$ & $\begin{array}{c}4.7-8.6 \\
--\end{array}$ & $\begin{array}{l}11 \\
--\end{array}$ \\
\hline 18 & $1463-307$ & H & Q-Kf-Cc-Py-Rut (tr) & Kf & $P, \operatorname{Prp}$ & I & $304-346(10)$ & -- & -- \\
\hline 18 & $1463-491$ & M & Q-Kf-Mo-Py & Kf & $\mathrm{P}$, & $\begin{array}{l}\text { I } \\
\text { II } \\
\text { IV }\end{array}$ & $\begin{array}{l}262-395(28) \\
371-385(4) \\
351-365(5)\end{array}$ & $\begin{array}{l}0-10.8 \\
-- \\
0-2.8\end{array}$ & $\begin{array}{l}19 \\
\overline{11}\end{array}$ \\
\hline 18 & $1463-563$ & Gp & Q(primary phenochrystic) & $\Rightarrow-$ & $\operatorname{Prp}$ & I & $237-346(22)$ & $3.8-10.7$ & 5 \\
\hline 18 & $1463-1110$ & M & Q-Mo-Kf & Kf & $P, I A$ & $\begin{array}{l}\text { I } \\
\text { IV }\end{array}$ & $\begin{array}{l}305-334(21) \\
299-346(6)\end{array}$ & $\begin{array}{c}4.8-13.8 \\
0-8 .\end{array}$ & $\begin{array}{l}12 \\
10\end{array}$ \\
\hline 18 & $1463-1134$ & M & Q-Mo-Py-Kf-Cc(tr)-Wm(tr) & ) $\mathrm{Kf}$ & $P, I A$ & I & $301-364(25)$ & $6.9-9.7$ & 9 \\
\hline 18 & $1463-1139$ & н & Q-Mo & Kf & $\mathrm{P}$ & $\begin{array}{l}\text { I } \\
\text { II }\end{array}$ & $\begin{array}{l}304-363(10) \\
340-372(2)\end{array}$ & $\begin{array}{c}5 .-10 \\
--\end{array}$ & $\begin{array}{c}6 \\
--\end{array}$ \\
\hline 18 & $1463-1466$ & H & $\begin{array}{l}\text { Q-Py-Cp-Po-Mo-Kf- } \\
\text { Ch1-Cc }\end{array}$ & $\begin{array}{l}\text { Kf, Act, } \\
\mathrm{Cc}\end{array}$ & P, Prp & $\begin{array}{l}\text { I } \\
\text { II } \\
\text { IV }\end{array}$ & $\begin{array}{l}258-348(46) \\
440 \quad(1) \\
312-430(6)\end{array}$ & $\begin{array}{c}5.1-10.1 \\
-\overline{.5-9.5}\end{array}$ & $\frac{12}{10}$ \\
\hline 18 & $1463-1599$ & н & Q-Po-Kf & $\begin{array}{l}\text { Kf, Act, } \\
\text { Cpx, Sph }\end{array}$ & $P$ & $\begin{array}{l}\text { I } \\
\text { II } \\
\text { IV }\end{array}$ & $\begin{array}{c}282-362(19) \\
330(1) \\
285-318(4)\end{array}$ & $\begin{array}{c}7.8 \\
-- \\
7 .-19 .\end{array}$ & $\frac{1}{10}$ \\
\hline
\end{tabular}




\begin{tabular}{|c|c|c|c|c|c|c|c|c|c|}
\hline 18 & $1463-1652$ & H & $\begin{array}{c}\mathrm{Py}-\mathrm{Po}-\mathrm{Q}-\mathrm{Kf}-\mathrm{Act}-\mathrm{Ep}-\mathrm{Ap} \\
\mathrm{Cpx}-\mathrm{Mo}(\mathrm{tr})-\mathrm{Cp}(\mathrm{tr})\end{array}$ & $\begin{array}{l}\text { Act, } S p h, \\
\mathrm{Kf}\end{array}$ & $\mathrm{P}$ & I & $284-380(53)$ & $.8-8.3$ & 41 \\
\hline 19 & $81 \mathrm{TT} 87$ & M & $\begin{array}{l}\text { Q-Kf-Wm }(t r)-R u t(t r)- \\
\text { Fx (after Py) }\end{array}$ & $\mathrm{Kf}$ & $P, I A$ & $\begin{array}{l}\text { I } \\
\text { II }\end{array}$ & $\begin{array}{l}257-329(26) \\
315-360(10)\end{array}$ & $\begin{array}{l}-- \\
--\end{array}$ & $\begin{array}{l}-- \\
--\end{array}$ \\
\hline 20 & $1468-613$ & M & Q-Kf(tr)-Wm(tr)-Py-Mo & $\mathrm{Kf}$ & $P, I A$ & $\begin{array}{l}\text { I } \\
\text { II }\end{array}$ & $\begin{array}{l}273-381(16) \\
349-386(4)\end{array}$ & $\begin{array}{c}5.9-8.2 \\
--\end{array}$ & $\begin{array}{c}9 \\
--\end{array}$ \\
\hline 20 & $1468-905$ & M & Q-Kf-Py-Cc(tr) & $\mathrm{Kf}$ & $P, I A$ & $\begin{array}{l}\text { I } \\
\text { II }\end{array}$ & $\begin{array}{l}277-365(20) \\
366-376(2)\end{array}$ & $\begin{array}{c}8.8-11.3 \\
--\end{array}$ & $\begin{array}{c}9 \\
--\end{array}$ \\
\hline 20 & $1468-1298$ & M & $\mathrm{Q}-\mathrm{Kf}(\mathrm{tr})-\mathrm{Py}-\mathrm{Mo}-\mathrm{Wm}(\mathrm{tr})$ & $\mathrm{Kf}$ & $P, I A$ & $\begin{array}{l}\text { I } \\
\text { II }\end{array}$ & $\begin{array}{l}227-353(20) \\
395(1)\end{array}$ & $\begin{array}{c}2.7-9.5 \\
--\end{array}$ & $\begin{array}{c}7 \\
--\end{array}$ \\
\hline 21 & $1470-238$ & M & $\begin{array}{l}\text { Q-Kf-Mo-Ce(tr)-Cp- } \\
\quad \text { Po }\end{array}$ & $\mathrm{Kf}$ & $\mathrm{P}$ & I & $253-346(19)$ & $6.7-11.8$ & 11 \\
\hline 21 & $1470-970$ & M & $\begin{array}{l}\text { Q-Kf-Mo-Po-Wm(tr) } \\
-\mathrm{Cc}(\mathrm{tr})\end{array}$ & $\mathrm{Kf}$ & P & I & $289-365(18)$ & $8 .-9.4$ & 5 \\
\hline 22 & $1465-208$ & M & Q-Mo-Kf $(t r)-A p(t r)$ & -- & $P, \operatorname{Pr} p$ & $\begin{array}{l}\text { I } \\
\text { II }\end{array}$ & $\begin{array}{l}268-347(14) \\
310-365(4)\end{array}$ & $\begin{array}{c}4.4-12 . \\
--\end{array}$ & $\begin{array}{l}7 \\
--\end{array}$ \\
\hline 22 & $1465-1123$ & $\mathrm{H}$ & $\mathrm{Q}-\mathrm{Wm}-\mathrm{Kf}(\mathrm{tr})-\mathrm{Mo}-\mathrm{Po}$ & $\mathrm{Kf}$ & P, Prp & $\begin{array}{l}\text { I } \\
\text { II }\end{array}$ & $\begin{array}{l}278-335(21) \\
330-335(3)\end{array}$ & $\begin{array}{c}6.6-9.4 \\
--\end{array}$ & $\begin{array}{c}6 \\
--\end{array}$ \\
\hline 23 & $1475-522$ & $\mathrm{H}$ & Q-Kf-Py(tr)-Mo & Kf & $\mathrm{P}$ & I & $272-321(8)$ & $8.1-12$ & 4 \\
\hline 23 & $1475-754$ & DB & Q-Ch1-Mo-Kf-Py-Cp(tr) & Act & $P(?)$ & I & $282-350(18)$ & $9.6-13.1$ & 4 \\
\hline 23 & $1475-1008$ & M & Q-Kf-Bi-Ap-Cc-Po & $B i$ & $\mathrm{P}, \operatorname{Prp}$ & $\begin{array}{l}\text { I } \\
\text { II }\end{array}$ & $\begin{array}{l}252-353(10) \\
315-360(3)\end{array}$ & $\begin{array}{c}6.2-11.1 \\
--\end{array}$ & $\begin{array}{c}6 \\
--\end{array}$ \\
\hline 23 & $1475-1044$ & M & $\mathrm{Q}-\mathrm{Py}-\mathrm{Mo}(\mathrm{tr})-\mathrm{Wm}$ & Ch1, Wm & P, Prp & I & $275-309(17)$ & $5.7-6.5$ & 3 \\
\hline 24 & $1464-145$ & M & $Q-K f-P y-W m(t r)$ & $\mathrm{Kf}$ & $\mathrm{P}$ & I & $267-322(26)$ & $4.0-12.0$ & 3 \\
\hline 24 & $1464-185$ & $\mathrm{H}$ & Q-Kf-Mo-Py (tr)-Wm(tr) & Kf, Rut & $\mathrm{P}$ & I & $251-310(26)$ & $.7-10$ & 13 \\
\hline 24 & 1464-1195 & $\mathrm{H}$ & $\begin{array}{r}Q-K f-M o(t r)-C c- \\
W m-P y(t r)-C h 1\end{array}$ & $\mathrm{Kf}$ & P, $\operatorname{Prp}(?)$ & I & $268-339(13)$ & $5.8-9.2$ & 5 \\
\hline
\end{tabular}

$1 \mathrm{H}$, Upper Cambrian Harmony Formation; DB, Ordovician and (or) Devonian diabase; M, Late Cretaceous monzogranite porphyry; GP, Oligocene granodiorite porphyry.

2 Q, quartz; Kf, potassium feldspar; Rut, rutile; Wm, white mica; Fx, iron oxide(s); Py, pyrite; Mo, molybdenite; Cc, carbonate; Cp, chalcopyrite; Po, pyrrhotite; Ch1, chlorite; Act, actinolite; Ep, epidote; Ap, apatite; Cpx, clinopyroxene; Bi, biotite; Sph, sphene; tr, trace.

3 P, potassic; Phy, phyllic; Prp, propylitic; IA, intermediate-argillic.

4 At $22 \pm 2{ }^{\circ} \mathrm{C}$ : I, low vapor volume+mostly 1 iquid $\mathrm{H}_{2} \mathrm{O}$; II, high vapor volume+mostly 1 iquid $\mathrm{H}_{2} \mathrm{O}$; IV, most $1 \mathrm{y} \mathrm{CO}_{2}$ vapor+liquid $\mathrm{CO}_{2}+$ mostly $\mathrm{H}_{2} \mathrm{O}$ liquid (see text).

5 In parentheses, number of determinations of total homogenization temperature of fluid inclusions. 
that the $\mathrm{CO}_{2}$ solid-liquid-vapor phase transition occurs at temperatures in the range -56.6 to $-57.2{ }^{\circ} \mathrm{C}$, somewhat similar to that found in samples from the Vail Ridge block. However, the overwhelming bulk of

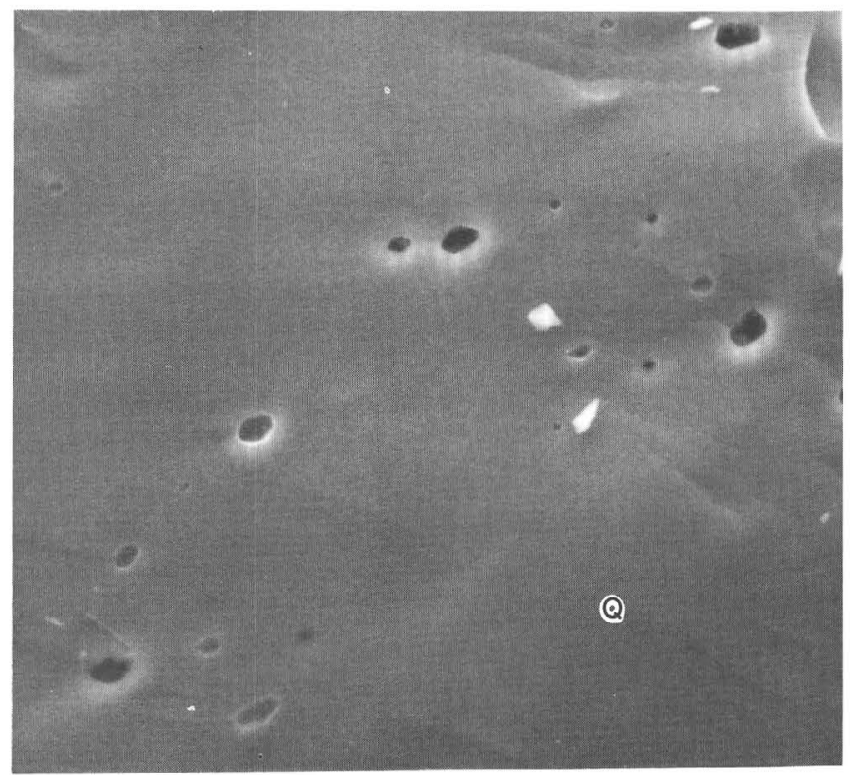

$$
\boldsymbol{A}
$$

0 30 MICRONS

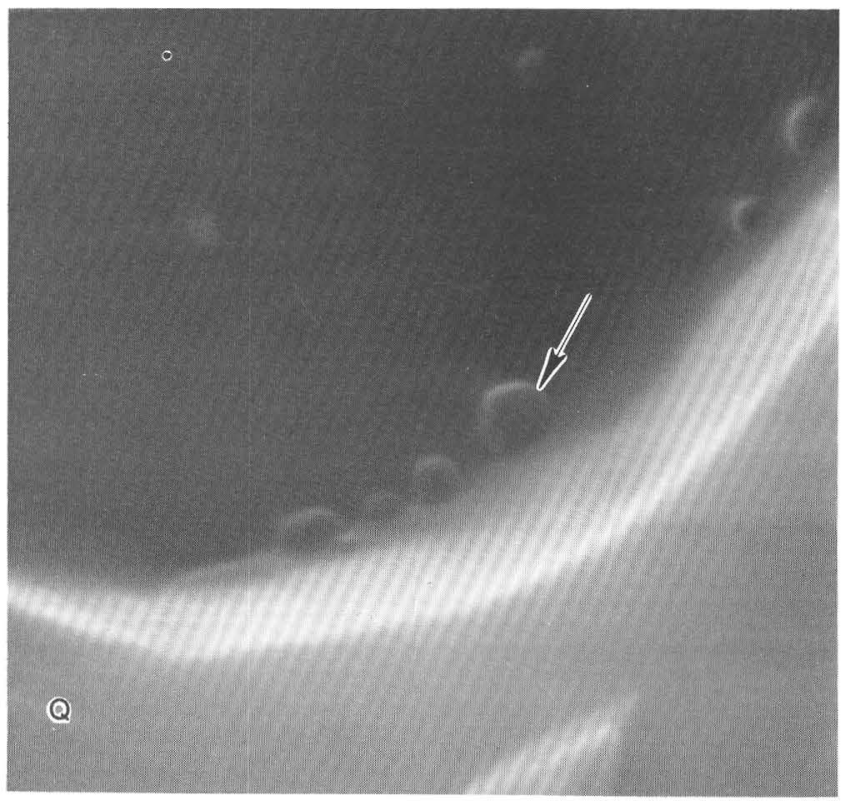

$\boldsymbol{B}$ 0 1 MICRON

Figure 124.-Scanning electron micrographs of fluid-inclusion cavities in vein quartz from East block of Buckingham molybdenum system, broken artificially. Q, quartz. Sample 78C161. $A$, Relatively small-scale view of artificially broken surface of vein quartz, showing a generally "pock-marked" appearance, owing to large numbers of fluid-inclusion cavities in field of these fluid inclusions from the East block show the transition to occur in the range -56.6 to $-56.9{ }^{\circ} \mathrm{C}$, from which we infer that the overall amounts of $\mathrm{CH}_{4}$ may have been depleted in the deep parts and relatively enriched in upper parts of the system as it evolved.

Relations determined from fluid inclusions in three pyrrhotite-bearing quartz veins that contain a diopside- and (or) actinolite-bearing, potassicalteration assemblage show that fluids of highly di-

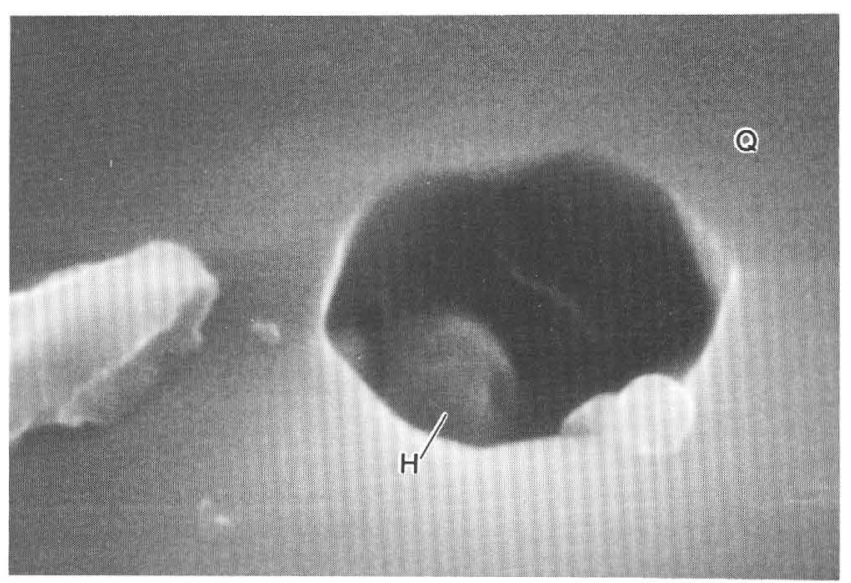

C 0 2 MICRONS

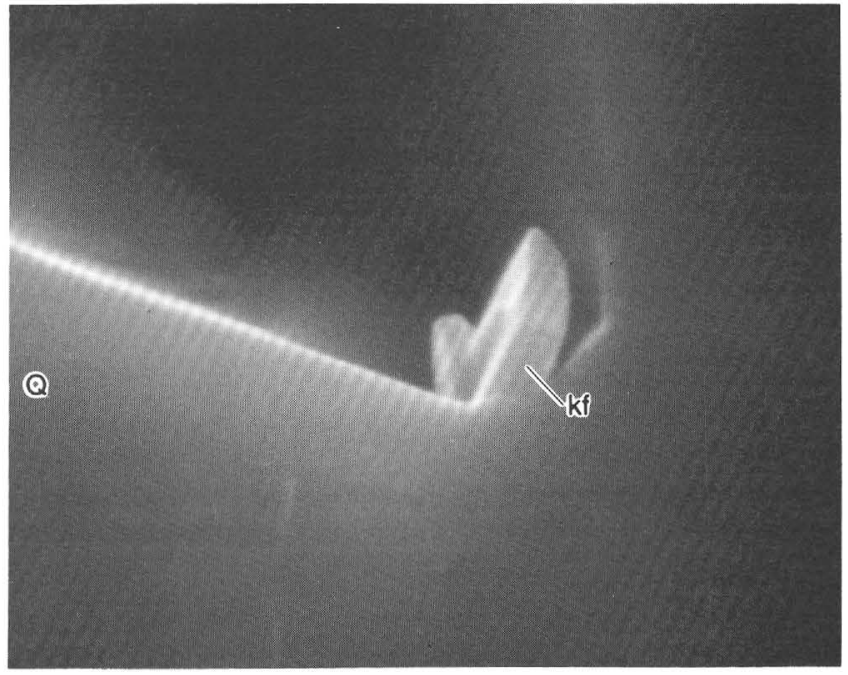

$\boldsymbol{D}$

0 2 MICRONS

view. $B$, Closeup of fluid-inclusion cavity, showing large numbers of extremely minute halite crystals (at head of arrow) resulting from desiccation of fluid-inclusion waters along walls of fluid-inclusion cavity. $C$, Daughter crystal of halite $(\mathrm{H})$ in an opened type-III fluid inclusion. $D$, Trapped crystal of K-feldspar (kf). 
verse chemistries were trapped in the Harmony Formation near the contact of the East stock (samples 1463-1466, 1463-1599, 1463-1652, table 51). These three samples are from the hanging wall of the Second fault, and they are from below the limit of the deposit as defined in the subsection above entitled "Economic Geology." In addition, the samples are from the copper-enriched halo that surrounds the gently dipping, lobate, molybdenumenriched shell associated with the East stock (fig. 51). The copper-enriched halo here, about $150 \mathrm{~m}$ wide, generally includes more than 0.1 weight percent $\mathrm{Cu}$ (fig. 64). Two of the studied samples show minor amounts of molybdenite in their vein assemblages (table 51). The two pyrrhotite-bearing quartz veins (samples 1463-1466, 1463-1599) close to the defined limits of the deposit along the drill hole show both elevated $\mathrm{CO}_{2}$ contents and, to a somewhat lesser degree, salinities of their fluid inclusions relative to the sample most distal from the deposit studied along the drill hole (sample 14631652, fig. 125). Most of the samples studied show salinities generally less than 10 weight percent $\mathrm{NaCl}$ equivalent. Eutectic temperatures in the range -21 to $-24{ }^{\circ} \mathrm{C}$ suggest that $\mathrm{Na}^{+}$is the dominant cation in these fluids. Some liquid- $\mathrm{CO}_{2}$ bearing fluid inclusions in sample 1463-1599 have salinities that are more than 18 weight percent $\mathrm{NaCl}$ equivalent. However, overall variability in salinities of the fluid-inclusion population throughout this part of the deposit obscures the hypothesis that less saline fluids may have circulated near the fringes of the deposit as it evolved.

Distribution plots of homogenization temperatures of fluid inclusions in quartz from the pyrrhotite-bearing quartz veins provide a significant contrast with the plots of similar data from the deposit at higher elevations along the drill hole (fig. 126). Sample 1463-563, Oligocene granodiorite porphyry, is not considered in the discussion to follow because its emplacement postdates molybdenum mineralization. The three pyrrhotite-bearing vein samples show weakly bimodal distribution plots for their homogenization data that are nonnormal and skewed toward high values of homogenization. On the one hand, modes for all three samples are very close to $300{ }^{\circ} \mathrm{C}$ (fig. 126). On the other hand, most samples studied from within the limits of the deposit show a nonnormal clustering of type I and type IV fluid-inclusion homogenization temperatures, including some that fill to liquid and others that fill to vapor, at approximately 350 ${ }^{\circ} \mathrm{C}$; several samples show distribution plots for their homogenization data skewed toward low val- ues; and there is a marked absence of fluidinclusion homogenizations at $300{ }^{\circ} \mathrm{C}$. Thus, moderately saline fluids that boiled at temperatures of about $350{ }^{\circ} \mathrm{C}$ seem to be associated with the

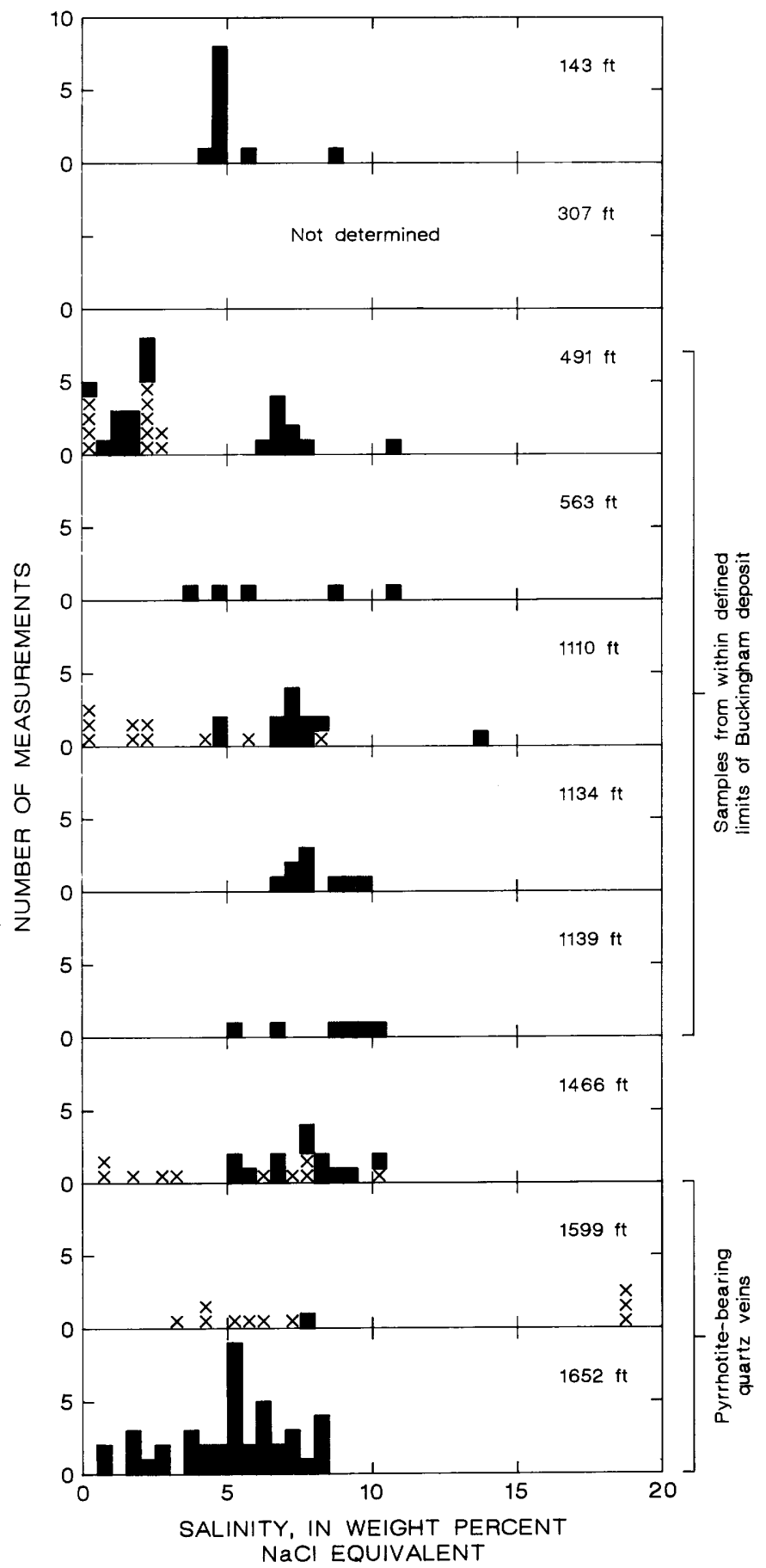

FIGURE 125.-Distribution of fluid-inclusion salinities in vein quartz from 10 samples studied from various depths (in feet) in drill hole 1463 that was collared in East block of Buckingham molybdenum system. Bar, type IV; $x$, type I. 


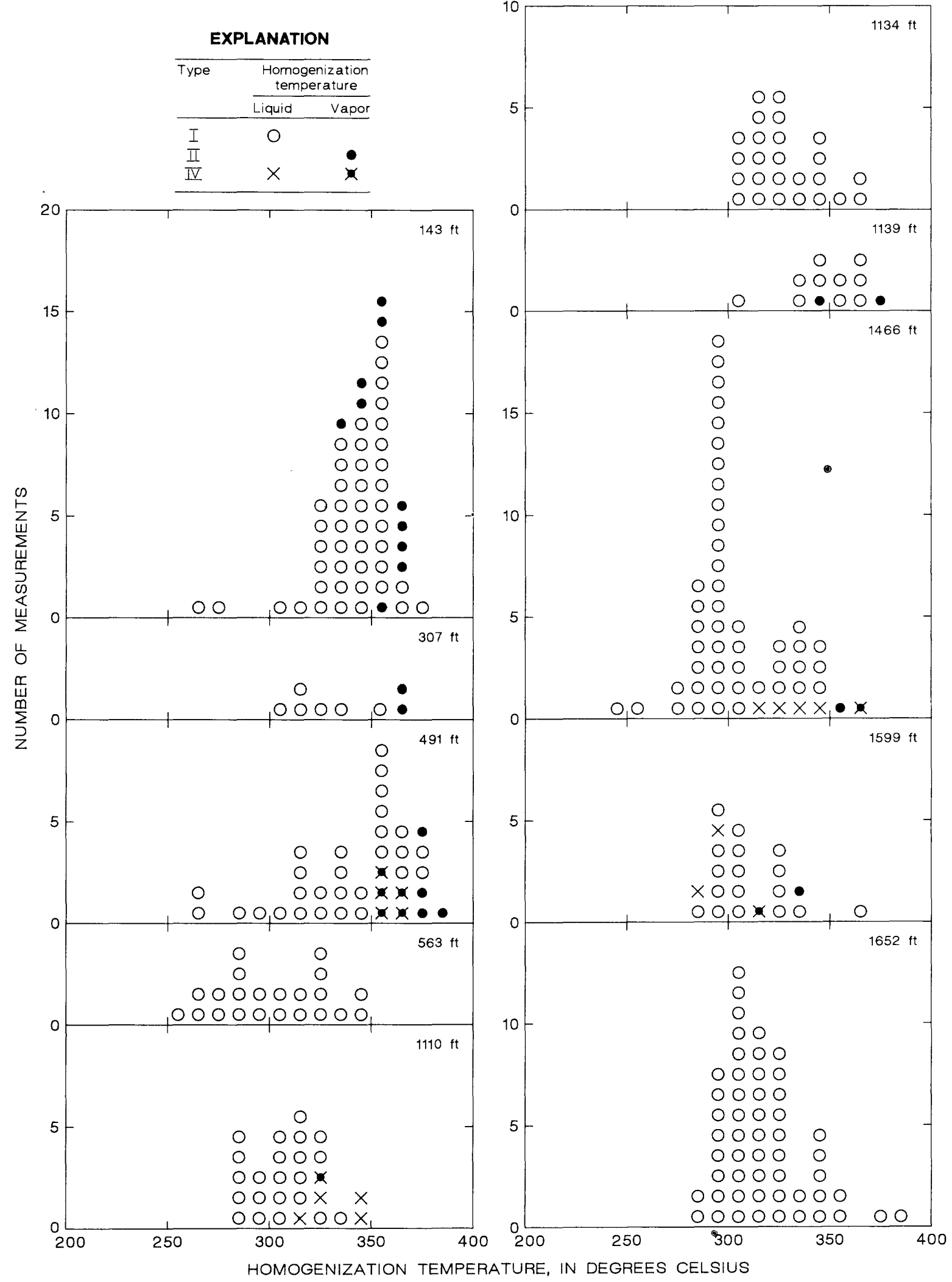

FiguRE 126.-Distribution of fluid-inclusion homogenization temperatures in vein quartz from ten samples from various depths (in feet) in drill hole 1463 collared near east contact of East stock of Buckingham molybdenum system. 
deposit in this tectonic block of the molybdenum system. In addition, two samples (1463-1466, 1463-1599) studied from below the deposit, also contain some type-I and type-IV fluid inclusions that homogenize to vapor during heating tests in the range $315-440{ }^{\circ} \mathrm{C}$, whereas most of the type I fluid inclusions homogenize to liquid close to 300 ${ }^{\circ} \mathrm{C}$. Some type IV fluid inclusions that homogenize to vapor at temperatures above $400{ }^{\circ} \mathrm{C}$ are also quite saline (approx 10 weight percent $\mathrm{NaCl}$ equivalent; table 51). Inasmuch as $\mathrm{NaCl}$ partitions very strongly to the liquid phase in a boiling environment (Roedder, 1984), these high-temperature fluid inclusions must indicate inhomogeneous trapping of two phases, and these phases also probably contributed to the abnormally high homogenization temperatures for the fluid inclusions (see Bodnar, 1982). These data, when further combined with the observation that high-temperature fluid inclusions that fill to vapor obviously are paragenetically early (probably pseudosecondary), attest to the probable circulation at some time through these rocks of minimal amounts of some relatively high temperature, boiling fluids that were followed by somewhat lower temperature, nonboiling fluids. Miscibility of the $\mathrm{CO}_{2}$-bearing fluids associated with sample 1463-1599 must have occurred during boiling because of the extremely wide range of phase proportions for type IV fluid inclusions at room temperature. Some type IV fluid inclusions in this sample include approximately 85 to 95 volume percent $\mathrm{CO}_{2}$ and 5 to 15 volume percent mostly $\mathrm{H}_{2} \mathrm{O}$.

The lowermost sample (1463-1652) examined using the heating-freezing stage from the East stock, however, shows no evidence for the presence of $\mathrm{CO}_{2}$ in its fluid inclusions nor does it include any evidence for boiling, including both fluid-inclusion phase proportions and homogenization data (fig. 125). Therefore, a diffuse interface between boiling fluids above and nonboiling below probably was present at times during the evolution of the system here near the east contact of the East stock. Location of the interface at this depth places it just above the Second fault (fig. 51).

A plot of salinity versus homogenization temperature for 120 fluid inclusions associated with molybdenum mineralization in the East stock shows a relatively broad range (fig. 127). There is no readily apparent sympathetic variation in these data between salinity and homogenization temperatures as has been reported by many others for non-porphyrytype ore deposits. Nonetheless, the overall variability in distribution of these data is similar to the moderate-salinity and low-density types of fluid inclusions reported in some porphyry copper systems (see Ahmad and Rose, 1980; Reynolds and Beane, 1985). However, such variability is also similar to fluid inclusions associated with unmineralized, late Eocene or early Oligocene porphyritic leucogranite and skarn (Theodore and Hammarstrom, 1991). The variability in the East stock presumably results from a wide range in the time of actual trapping of the individual fluid inclusions in a highly dynamic pressure and temperature environment wherein temperature and salinity fluctuated as the system evolved (see Roedder, 1984).

\section{WEST BLOCK}

Study of fluid-inclusion relations in quartz veins from the West block, geologically the deepest part of the system, revealed some striking contrasts with fluid-inclusion relations determined in vein quartz elsewhere in the system. Five samples from surface sites (locs. 26-30, table 52; fig. 117) and 12 samples obtained from drill core collected from three holes put down west of the Buckingham fault were studied using heating and freezing techniques (table 52). The K-feldspar-quartz monzonite border phase (see subsection above entitled "Economic Geology") of the undivided monzogranite porphyry of the Buckingham system composes the host rock for the quartz veins in 15 of the 17 samples. Furthermore, 6 of the 13 core samples studied are monzogranite porphyry

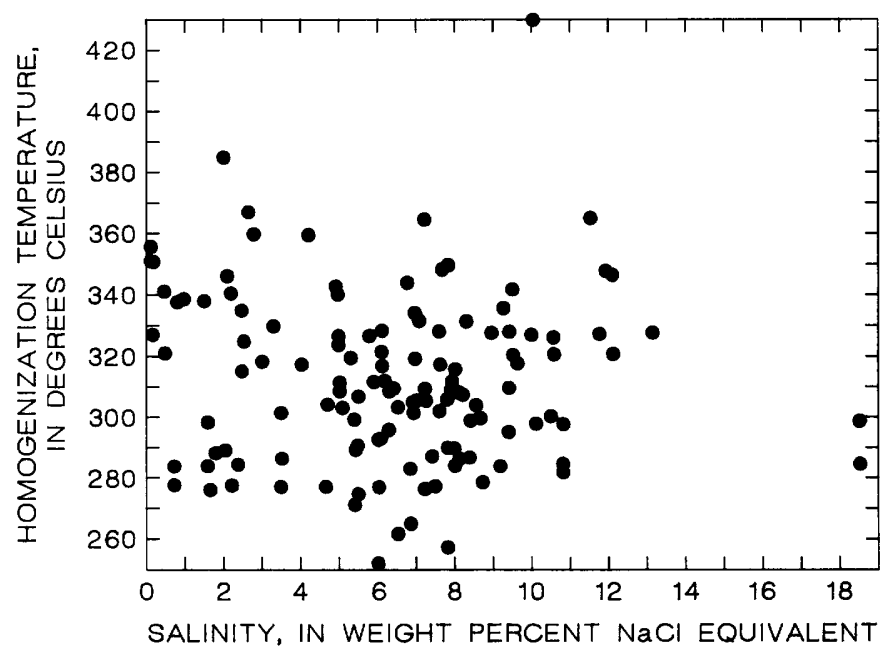

FIGURE 127.-Salinity versus homogenization temperature for 120 fluid inclusions in vein quartz associated with molybdenum mineralization near East stock of Buckingham molybdenum system. 
TABLE 52.-Temperature and salinity data from fluid inclusions hosted by vein quartz in the West block of the Buckingham stockwork molybdenum system

$[\because$, not determined $]$

\begin{tabular}{|c|c|c|c|c|c|c|c|c|c|}
\hline $\begin{array}{l}\text { Loc. No. } \\
\text { (fig. 117) }\end{array}$ & Sample No. & $\begin{array}{l}\text { Rock } \\
\text { type } 1 \\
\end{array}$ & $\begin{array}{c}\text { Composition vein } \\
\text { assemblage }^{2}\end{array}$ & Selvage ${ }^{2}$ & $\begin{array}{c}\text { Assemblage(s) } \\
\text { in rock }{ }^{3} \\
\end{array}$ & $\begin{array}{c}\text { Type of } \\
\text { inclusion } 4 \\
\end{array}$ & $\begin{array}{c}\text { Homogenization } \\
\text { temperature } \\
\text { range }\left({ }^{\circ} \mathrm{C}\right)^{5}\end{array}$ & $\begin{array}{l}\text { Salinit } \\
\text { Weight } \% \mathrm{NaCl} \\
\text { equivalent }\end{array}$ & $\begin{array}{c}\text { Number } \\
\text { measured }\end{array}$ \\
\hline 25 & $78 \mathrm{C} 169$ & M & $Q-K f-W m(t r)$ & $\mathrm{Kf}$ & $\mathrm{P}, \mathrm{IA}$ & $\begin{array}{l}\text { I } \\
\text { II } \\
\text { IV }\end{array}$ & $\begin{array}{c}334-346(7) \\
345-349(2) \\
332-347(10)\end{array}$ & $\begin{array}{c}7.0 \\
-\overline{.1-6.1}\end{array}$ & $\frac{1}{10}$ \\
\hline 26 & $78 \mathrm{C} 167$ & $M$ & Q-Kf-Wm (tr) & Kf & $P, I A, \operatorname{Phy}(t r)$ & IV & $\begin{array}{c}169-383(22) \\
380\end{array}$ & $\begin{array}{l}5 .-18 \cdot 3 \\
.5-10\end{array}$ & $\begin{array}{l}4 \\
5\end{array}$ \\
\hline 27 & $78 C 166$ & M & $Q-K f-W m(t r)$ & $\mathrm{Kf}$ & P, IA & I & $266-363(15)$ & $1 .-15.1$ & 3 \\
\hline 28 & $78 C 55$ & $\mathrm{H}$ & Q-Kf-Bio & $\mathrm{Kf}$ & $P$ & $\begin{array}{c}\text { I } \\
\text { II }\end{array}$ & $\begin{array}{c}188-394(11) \\
415-440(4)\end{array}$ & $\begin{array}{c}11.9-16.5 \\
-\end{array}$ & $\begin{array}{c}8 \\
--\end{array}$ \\
\hline 29 & $78 \mathrm{C} 35$ & $\mathrm{H}$ & Q-Kf-Bio-Rut & Bio, Kf & $\mathrm{P}$ & I & $295-420(3)$ & 9.2 & 1 \\
\hline 30 & B40-1615 & M & Q-Kf-Mo-Py-Wm(tr) & Kf & $\mathrm{P}, \mathrm{IA}$ & $\begin{array}{c}\text { I } \\
\text { II } \\
\text { III } \\
\text { IV }\end{array}$ & $\begin{array}{c}360-431(8) \\
365-480(5) \\
254-500(39) \\
450(1)\end{array}$ & $\begin{array}{c}- \\
-- \\
29 .-65 . \\
3.8-8.9\end{array}$ & $\begin{array}{c}-- \\
-- \\
36 \\
4\end{array}$ \\
\hline 30 & B40-1821 & M & $Q-K f-P y(t r)-W m(t r)$ & $\mathrm{Kf}$ & P, IA & $\begin{array}{c}\text { I } \\
\text { IV }\end{array}$ & $\begin{array}{c}338-349(2) \\
316-387(20)\end{array}$ & $\begin{array}{c}3.5-7 \\
0-7\end{array}$ & $\begin{array}{c}2 \\
20\end{array}$ \\
\hline 30 & B40-1822 & M & Q-Py-Mo-Wm $(t r)-C c(t r)$ & Wm & Phy & $\begin{array}{l}\text { I } \\
\text { III } \\
\text { IV }\end{array}$ & $\begin{array}{c}-- \\
321(1) \\
318-500(32)\end{array}$ & $\begin{array}{c}6.4 \\
31 . \\
2.3-9\end{array}$ & $\begin{array}{l}1 \\
1 \\
7\end{array}$ \\
\hline 30 & B $40-1823$ & M & Q-Kf $-\mathrm{Py}-\mathrm{Mo}(\mathrm{t} r)-W m(t r)$ & $\mathrm{Kf}$ & P, Phy & $\begin{array}{l}\text { I } \\
\text { II } \\
\text { III } \\
\text { IV }\end{array}$ & $\begin{array}{c}246-391(20) \\
440-445(4) \\
185-325(9) \\
450(2)\end{array}$ & $\begin{array}{c}1.2-2.1 \\
-- \\
29 .-33 . \\
1.8-2.5\end{array}$ & $\begin{array}{c}4 \\
-- \\
11 \\
3\end{array}$ \\
\hline 30 & B $40-1888$ & M & $Q-K f-M o-W m(t r)-P y(t r)$ & Kf & P, Phy & $\begin{array}{c}\text { I } \\
\text { IV }\end{array}$ & $\begin{array}{l}263-291(4) \\
360-392(8)\end{array}$ & $.7-14$ & $\overline{13}$ \\
\hline 30 & B40-1913 & M & $\mathrm{Q}-\mathrm{Kf}-\mathrm{Py}-\mathrm{Mo}(\mathrm{tr})$ & Ke & P,IA & IV & $335-395(21)$ & $.5-10$ & 10 \\
\hline 31 & $\mathrm{~B} 6-1650$ & $M$ & $Q-W m-P y(t r)-M o$ & $W m$ & Phy & IV & $299-365(33)$ & $.1-6$. & 16 \\
\hline 31 & B6-1990 & M & $Q-K f(t r)-P y(t r)-M o(t r)$ & $\mathrm{Kf}$ & P,IA & IV & $282-368(34)$ & $.9-9.8$ & 15 \\
\hline 31 & $B 6-2640$ & M & $Q-K f-P y(t r)-M o(t r)$ & Kf & $P, \operatorname{Prp}(?)$ & $\begin{array}{c}\text { I } \\
\text { IV }\end{array}$ & $\begin{array}{c}160-372(30) \\
355\end{array}$ & $\begin{array}{c}.8-12.4 \\
--\end{array}$ & $\begin{array}{l}14 \\
--\end{array}$ \\
\hline 32 & B16-1705 & M & $\begin{array}{c}\mathrm{Q}-\mathrm{Kf}-\mathrm{Py}(\mathrm{tr})-\mathrm{Mo}(\mathrm{tr})- \\
\mathrm{Cc}(\mathrm{tr})-\mathrm{ch} 1(\mathrm{tr})\end{array}$ & $\mathrm{Kf}$ & P, Prp & I & $325-364(30)$ & $1.9-11.7$ & 22 \\
\hline 32 & B16-194C & M & $\mathrm{Q}-\mathrm{Kf}-\mathrm{Mo}-\mathrm{Cc}(\mathrm{tr})$ & $\mathrm{Kf}$ & P,Prp(?) & $\stackrel{\text { I }}{\text { IV }}$ & $\begin{array}{c}201-212(2) \\
348-374(11)\end{array}$ & $\begin{array}{l}5.8 \\
4.7-8.1\end{array}$ & $\begin{array}{l}1 \\
9\end{array}$ \\
\hline 32 & B16-1965 & M & Q-Mo-Py-(tr)-Cc(tr) & $\mathrm{Kf}$ & P, Prp & $\begin{array}{c}\text { I } \\
\text { IV }\end{array}$ & $\begin{array}{l}174-221(6) \\
342-372(25)\end{array}$ & $.3-10.8$ & -- \\
\hline
\end{tabular}

${ }^{1} \mathrm{H}$, Upper Cambrian Harmony Formation; M, Late Cretaceous monzogranite porphyry.

${ }^{2} Q$, quartz; Kf, potassium feldspar; Wm, white mica; Bio, biotite; Rut, rutile; Mo, molybdenite;

Py, pyrite; CC, carbonate; Chl, chlorite; tr, trace.

${ }^{3} \mathrm{P}$, potassic; IA, intermediate argillic; Phy, phyllic; Prp, propylitic.

${ }^{4}$ At $22^{\circ} \pm 2^{\circ} \mathrm{C}$ : I, low vapor volume+mostly liquid $\mathrm{H}_{2} \mathrm{O}$; II, high vapor volume+liquid $\mathrm{H}_{2} \mathrm{O}$;

III, halite bearing; IV, mostly $\mathrm{CO}_{2}$ vaportliquid $\mathrm{CO}_{2}$ tmostly $\mathrm{H}_{2} \mathrm{O}$ liquid (see text).

${ }^{5}$ In parentheses, number of determinations of total homogenization temperature of fluid inclusions.

from depths between 492 and $583 \mathrm{~m}$ in one angle hole (B-40) collared in the Harmony Formation west of the West stock but bottomed in monzogranite porphyry to the east. All six of these samples from drill hole B-40 are from K-feldspar-quartz monzonite that forms an outer marginal shell of rock to a subsequently emplaced core of igneous rock termed a
"quartz-K-feldspar porphyry," the main mineralizing phase of the Buckingham system (see subsection above entitled "Economic Geology"). In addition, three samples of the border phase were also examined by heating and freezing methods from a narrow (approx. $79 \mathrm{~m}$ wide) interval of core from well within the deep potassic zone mapped in the West stock 
(see fig. 52). However, all but two of the vein samples studied show well-developed potassic-alteration assemblages in their selvages (table 52). Those two samples have phyllic assemblages along their margins. In addition, most of the samples include superposed alteration assemblages typical of more than one of the classic porphyry types of alteration: generally potassic+intermediate-argillic, potassic+phyllic, or potassic+propylitic (table 52). As in the other blocks of the system, the mostly pseudosecondary and secondary fluid inclusions of the vein quartz show a highly diverse chemical composition and wide-ranging filling temperatures (table 52). Of these 17 veins, 11 include variable amounts of molybdenite. A few of them show walls almost completely lined by molybdenite tightly intergrown with quartz and K-feldspar, whereas many of the other veins show their molybdenite to be intergrown with a variety of minerals, including in places sparse amounts of very late stage carbonate and white mica. These relations suggest a protracted paragenetic history for molybdenite here. As indicated on table 52, some vein quartz hosts all types of fluid inclusions, whereas other veins elsewhere in the block, from an identical paragenetic setting and identical specific vein assemblage, seem to host only a single type of fluid inclusion. For example, sample B16-1705 apparently contains only type I fluid inclusions, and thus shows a much lower overall abundance of carbon dioxide in its trapped fluids than samples B6-1650 or B6-1990, which apparently contain only type IV fluid inclusions.

A composite plot of homogenization temperatures for all the 421 fluid inclusions (table 52) tested from the West block of the system shows a multimodal distribution approximately in the range $160-500{ }^{\circ} \mathrm{C}$ (fig. 128). The major mode is in the class interval $360-370{ }^{\circ} \mathrm{C}$. The major mode and median thus correspond somewhat closely to similarly gathered data from some samples showing only potassic-alteration assemblages in the Vail block (fig. 118) and data from potassically altered samples from the East block (fig. 126). The distribution plot for homogenization temperatures of fluid inclusions in the quartz veins from the West stock shows the absence, however, of a welldeveloped mode centered at about $300{ }^{\circ} \mathrm{C}$ that is common to similar data plots for the East and Vail Ridge blocks. As described above, these homogenization temperatures near $300{ }^{\circ} \mathrm{C}$ may indicate the circulation of fluids associated with intermediate argillic alteration in the East and Vail Ridge blocks of the Buckingham system. Many of the rocks in the West block studied by heating and freezing techniques also show superposition, at highly variable intensities, of phyllic, propylitic, and intermediate-argillic assemblages onto the earlier stage potassic-alteration assemblages that are widespread here in the core of the system. The slightly nonnormal, negative skewness at 320-340 ${ }^{\circ} \mathrm{C}$ in the plot of homogenization temperatures (fig. 128) may in part indicate fluids associated with post-potassic-alteration assemblages. Accordingly, the highest homogenization temperatures found in the Buckingham system are from vein samples from deep within the West stock. Specifically, highsalinity type III fluid inclusions that fill to liquid and moderate-salinity type IV fluid inclusions that fill to vapor, both at $500{ }^{\circ} \mathrm{C}$, were determined. However, it is important to note that these two 500 ${ }^{\circ} \mathrm{C}$ temperatures were not measured in the same sample (table 52). Nonetheless, the maximum temperature $\left(500{ }^{\circ} \mathrm{C}\right)$ determined in this study

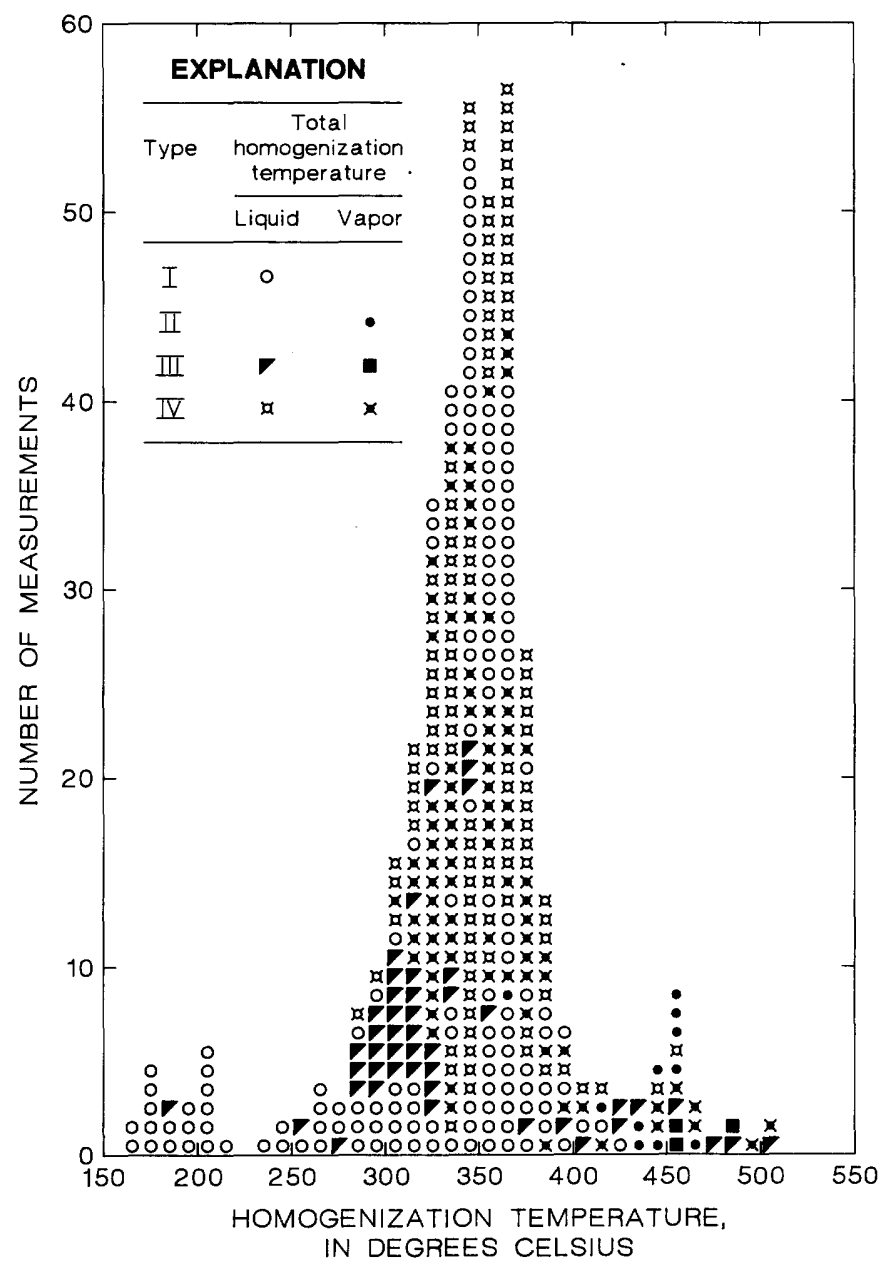

FIGURE 128.-Distribution of total homogenization temperatures in 421 fluid inclusions from 17 vein quartz samples from West block of Buckingham molybdenum system. 
corresponds closely to the highest temperatures recorded in many other porphyry molybdenum and porphyry copper systems (Roedder, 1984, table 155).

The fluid-inclusion population trapped in the veins of the West block seems to contain a much more widespread presence of moderately saline, as much as 14 weight percent $\mathrm{NaCl}$ equivalent, type IV fluid inclusions than the veins in either the East or Vail Ridge block. In fact, type IV fluid inclusions may be the most common type of fluid inclusion in the West block, although some veins show no type IV fluid inclusions as we described above (table 52). In addition, the type IV fluid inclusions in West block may be further classified into two subtypes based on the amount of $\mathrm{CO}_{2}$ they contain. The most widespread variety of type IV fluid inclusion contains generally less than 50 volume percent $\mathrm{CO}_{2}$, and more than a corresponding amount of mostly $\mathrm{H}_{2} \mathrm{O}$. Such fluid inclusions show homogenization of their $\mathrm{CO}_{2}$ to vapor at temperatures generally $2-3{ }^{\circ} \mathrm{C}$ less than the $31{ }^{\circ} \mathrm{C}$ critical point of $\mathrm{CO}_{2}$. Determination of the $\mathrm{CO}_{2}$ triple point in many liquid $\mathrm{CO}_{2}$-bearing fluid inclusions from the West block shows that the $\mathrm{CO}_{2}$ solid-liquidvapor phase transition consequently is very tightly constrained to the range -56.6 to $-56.7^{\circ} \mathrm{C}$, coinciding almost exactly with the $-56.6{ }^{\circ} \mathrm{C}$ solid-liquidvapor phase transition for pure $\mathrm{CO}_{2}$. Thus, the type IV fluid inclusions show a progressive east-to-west change across the Buckingham system (and thus with increasing depth into the system) in their $\mathrm{CO}_{2}$ solid-liquid-vapor phase transition: -56.8 to -57.2 ${ }^{\circ} \mathrm{C}$ in the Vail block, -56.6 to $-56.9{ }^{\circ} \mathrm{C}$ in the East block, and -56.6 to $-56.7{ }^{\circ} \mathrm{C}$ in the West block. These relations probably indicate a progressive decrease with depth in the $\mathrm{CH}_{4}$ content of the fluids trapped in the fluid inclusions.

At elevated temperatures, this subtype of the type IV fluid inclusions shows total homogenization to either liquid or vapor in the range $280-500{ }^{\circ} \mathrm{C}$ (fig. 128). This variety of type IV fluid inclusions may be pseudosecondary or secondary. Many samples from deep within the West stock and near its outer contact show relatively large type IV fluid inclusions, generally in the 10 to $40 \mu \mathrm{m}$ range, that at room temperatures are $\mathrm{CO}_{2}$ vapor rich and contain only a thin meniscus of liquid $\mathrm{CO}_{2}$. These type IV fluid inclusions are concentrated along broad bands that follow annealed microcracks through adjoining quartz crystals in the veins. In some samples, the secondary, type IV fluid inclusions show total homogenization in the range $330-380$ ${ }^{\circ} \mathrm{C}$. Furthermore, some paragenetically very late stage, possibly open-cavity-filling quartz also shows similar type IV relations, except that the type IV fluid inclusions seem to be pseudosecondary relative to the very late stage quartz. All these observed relations and assembled data attest to the circulation of high-temperature, low-density, $\mathrm{CO}_{2}$ bearing fluids near the margins of the West stock, presumably during the final stages of the Buckingham system. These paragenetic relations of fluid-inclusion populations suggest that at least locally there may have been an increase in the $\mathrm{CO}_{2}$ content of the fluids as the system evolved. With the available data, it is difficult to determine how widespread such a phenomenon may have been in the system. Nonetheless, this relation has been observed apparently in some other stockwork molybdenite deposits. Linnen and Williams-Jones (1984) found that type IV fluid inclusions at the Trout Lake, British Columbia deposit commonly contain as much as 50 volume percent $\mathrm{CO}_{2}$ and these fluid inclusions are typically associated with late-stage molybdenite-bearing stockworks of quartz, muscovite, calcite with or without K-feldspar. This assemblage was superposed on an earlier stage margarite-corundum-biotite-calcite-quartzoligoclase assemblage that showed fluid inclusions that contain 0.15 to $0.3 \mathrm{~mol}$ percent $\mathrm{CO}_{2}$.

The second subtype of the liquid- $\mathrm{CO}_{2}$-bearing fluid inclusions consists typically of $5-$ to $10-\mu \mathrm{m}$ wide, ovoid fluid inclusions that contain generally more than 90 volume percent $\mathrm{CO}_{2}$, as estimated optically at a temperature of about $40^{\circ} \mathrm{C}$. A very few of these fluid inclusions contain approximately 75 volume percent $\mathrm{CO}_{2}$; the remaining component of these fluid inclusions is mostly $\mathrm{H}_{2} \mathrm{O}$. Overall in the West block, such fluid inclusions that are highly $\mathrm{CO}_{2}$ enriched are quite rare. However, a few small domains wherein numerous such fluid inclusions are clustered are present in veined monzogranite porphyry near the bottom of diamond-drill hole $\mathrm{B}-6$; that is, near the western contact of the West stock. A selected cluster of 17 such fluid inclusions in sample B62640 shows a range of 29.0 to $30.8{ }^{\circ} \mathrm{C}$ for the $\mathrm{CO}_{2}$ liquid-vapor phase transition; all 17 homogenize to liquid $\mathrm{CO}_{2}$. The mean temperature for the $\mathrm{CO}_{2}$ liquid-vapor phase transition is $29.4{ }^{\circ} \mathrm{C}$, and the mean temperature of the $\mathrm{CO}_{2}$ solid-liquid-vapor triple point in ten of the fluid inclusions is $-56.6^{\circ} \mathrm{C}$. For the $\mathrm{CO}_{2}$ phase in the fluid inclusions, a temperature of $29.4{ }^{\circ} \mathrm{C}$ for the liquid-vapor phase transition corresponds to a density of about $0.76 \mathrm{~g} / \mathrm{cm}^{3}$ (Angus and others, 1973, in Hollister, 1981). Because of the limited amounts of $\mathrm{H}_{2} \mathrm{O}$ in most of these fluid inclusions that are highly $\mathrm{CO}_{2}$ enriched, the temperature 
of total homogenization is extremely difficult to resolve. However, one of the fluid inclusions that contains approximately 75 volume percent $\mathrm{CO}_{2}$, as opposed to the approximately 90 volume percent $\mathrm{CO}_{2}$ for the rest, was determined to have a minimum $355 \pm 5{ }^{\circ} \mathrm{C}$ temperature of total homogenization to vapor. This temperature suggests that the surrounding fluid inclusions that are highly $\mathrm{CO}_{2}$ enriched may also have been trapped under similar thermal conditions.

Determination of the $\delta^{13} \mathrm{C}$ and $\delta^{18} \mathrm{O}$ values of $\mathrm{CO}_{2}$ in fluid inclusions of vein quartz from the West block is available for a single sample, -7.07 and +26.78 permil, respectively ( $78 \mathrm{C} 169$, table 50$)$. This particular vein sample is from an outcrop near the center of the West stock, and the vein has a potassicalteration assemblage in its selvage. Homogenization temperatures from all fluid-inclusion types measured (types I, II, and IV) are confined to a relatively narrow range, $332-349{ }^{\circ} \mathrm{C}$ (table 52 ). The $\delta^{13} \mathrm{C}$ value near -7 permil suggests that the $\mathrm{CO}_{2}$ in the fluid inclusions hosts a major component of presumably magmatic $\mathrm{CO}_{2}$ and a minor component of $\mathrm{CO}_{2}$ from an organic crustal source (see above).

Only a very limited number of veins, some very molybdenite rich, contain abundant type III fluid inclusions in the West block (table 52). These veins were found deep within the West stock close to its contact with the metamorphosed rocks of the Harmony Formation. Specifically, the type III-bearing veins are present in the border phase of monzogranite porphyry whose phenocrystic quartz apparently does not host any type III fluid inclusions. Therefore, hypersaline fluids probably related to type III fluid inclusions must be associated with a pulse of magma much deeper in the system. Initially, it was believed that there may be some positive correlation between the presence of type III fluid inclusions in a particular vein and increased abundance of molybdenite because many of the type III-bearing quartz veins show well-developed concentrations of fine-grained molybdenite along their walls. However, careful thin-section examination of large numbers of veins that show similar concentrations of molybdenite along their walls revealed no correspondence between abundance of molybdenite and fluid-inclusion signature in the veins. Many more veins that contain only type I or IV fluid inclusions show well-developed concentrations of molybdenite along their walls than ones that contain type III fluid inclusions.

Type III fluid inclusions homogenize mostly by vapor disappearance at temperatures in the range 254-500 ${ }^{\circ} \mathrm{C}$ (fig. 128; table 52). A few type III fluid inclusions homogenize by liquid disappearance near the high end of the range, about $450-480{ }^{\circ} \mathrm{C}$. All of these investigated fluid inclusions show dissolution of their $\mathrm{NaCl}$ and (or) $\mathrm{KCl}$ daughter minerals at temperatures less than the temperature of total homogenization. Measured salinities of the type III fluid inclusions are 29 to 65 weight percent $\mathrm{NaCl}$ equivalent (table 52). However, these salinity determinations necessarily focused on those type III fluid inclusions in the system that show only $\mathrm{NaCl}$ and (or) $\mathrm{KCl}$ daughter minerals and are thus representative of rather simple chemical systems (fig. 129). The relatively restricted extent of type III fluid inclusions in the Buckingham system is emphasized by the fact that 39 of 49 salinity determinations listed in table 52 are from one vein. Although the proportion of $\mathrm{NaCl}$ in some type III fluid inclusions (fig. 129D) suggests $\mathrm{NaCl}$ contents in the fluid-inclusion waters comparable with the highest measured $\mathrm{NaCl}$ contents determined from the dissolution temperature $(65$ weight percent $\mathrm{NaCl}$ equivalent; table 52), such high values of salinity are not representative of the overwhelming bulk of the studied type III fluid inclusions. A value somewhere in the range 30-35 weight percent $\mathrm{NaCl}$ equivalent is probably most representative of type III fluid inclusions in the Buckingham system. Extensive study by SEM methods of artificially opened, type III fluid inclusions succeeded in the identification of many other minerals as apparent daughter minerals or trapped minerals (fig. 130). During these SEM studies, it was determined that a $\mathrm{CaCl}_{2}$-bearing mineral is present in many of the polyphase type III fluid inclusions from a few selected veins deep in the Buckingham system. Studies elsewhere have suggested that the $\mathrm{CaCl}_{2}-$ bearing phase identified by SEM methods in several deposits may be $\mathrm{CaCl}_{2} \cdot 6 \mathrm{H}_{2} \mathrm{O}$. However, $\mathrm{CaCl}_{2} \cdot 6 \mathrm{H}_{2} \mathrm{O}$ has a melting point of $29.92{ }^{\circ} \mathrm{C}$ (Roedder, 1984, p. 147-148; Vanko and others, 1988), and the $\mathrm{CaCl}_{2}$-bearing phase in the Buckingham system persists to temperatures above 300 ${ }^{\circ} \mathrm{C}$. Although the actual $\mathrm{CaCl}_{2}$-bearing mineral has not been identified at Buckingham, the presence of $\mathrm{CaCl}_{2}$ in the fluids associated with these type III fluid-inclusion-bearing veins is important from the standpoint of compositional trends during the evolution of the system (Kwak and Tan, 1981; Kwak, 1986). The textural mode of occurrence of the $\mathrm{CaCl}_{2}$-bearing phase in the fluid inclusions (fig. 130) suggests strongly that this phase is not there as a result of desiccation or evaporation of type III fluid-inclusion waters at the time the fluid inclusions were opened artificially at room temperature. 
Rather, the $\mathrm{CaCl}_{2}$-bearing phase appears to be an integral member of the daughter or trapped mineral assemblages. Subsequent studies should attempt to quantify the amount of $\mathrm{CaCl}_{2}$ in these fluid inclusions by means of the repeated heating and freezing procedures of Vanko and others (1988). Furthermore, the fact that many polyphase type III fluid inclusions show calcite among their included assemblages also attests to the widespread presence of significant amounts of calcium in these fluid inclusions. Other minerals in the type III fluid inclusions, in addition to those shown on figure 130, identified by SEM methods include iron (manganese) carbonate (a variety of siderite?), quartz, barite, jarosite, sphene, and rutile.

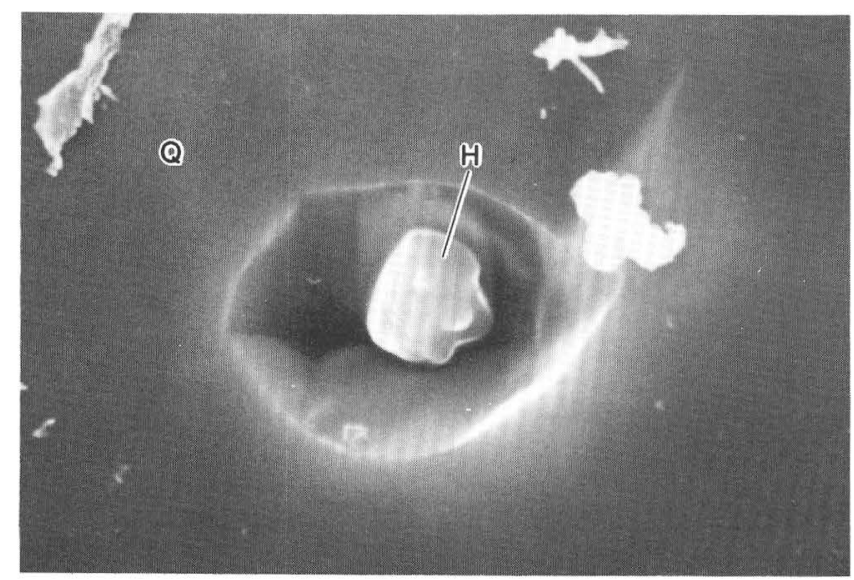

$\boldsymbol{A}$ $\stackrel{2}{0} \quad 2$ MICRONS

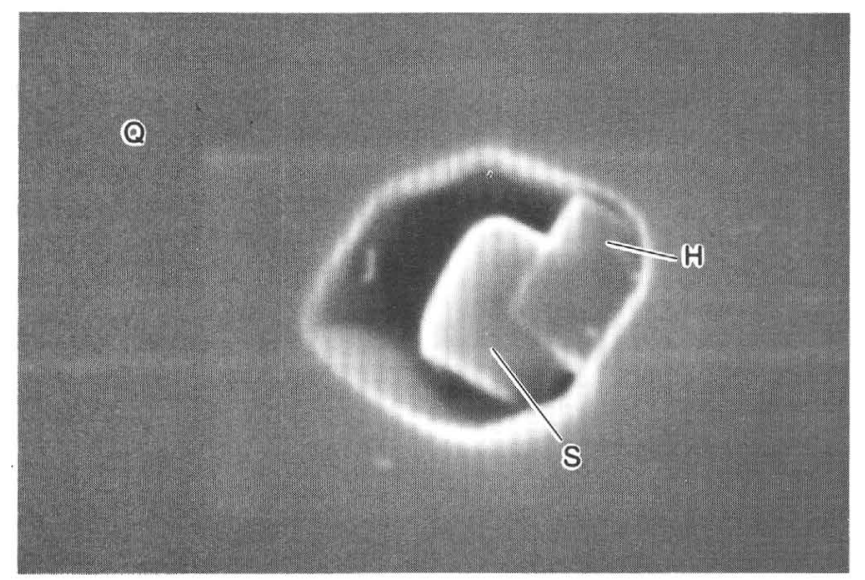

$\boldsymbol{B}$

2 MICRONS
All the apparent daughter minerals in such complex, polyphase type III fluid inclusions do not dissolve upon heating to temperatures as high as 500 ${ }^{\circ} \mathrm{C}$ for extended periods of time. Roedder (1984) suggested that this dilemma might be due to posttrapping leakage of $\mathrm{H}_{2}$ from the fluid inclusions, which, in turn, changes the oxidation state to a more oxidizing environment within the fluid inclusions. Certainly, such leakage of $\mathrm{H}_{2}$ may explain the exceptionally rare occurrence of sulfatebearing minerals in a few fluid inclusions. However, sulfides seem to occur rather commonly in type III fluid inclusions. Energy-dispersive X-ray spectra of spot analyses of the pyrite or chalcopyrite(?) in figure $130 B$ and the chalcopyrite and ar-

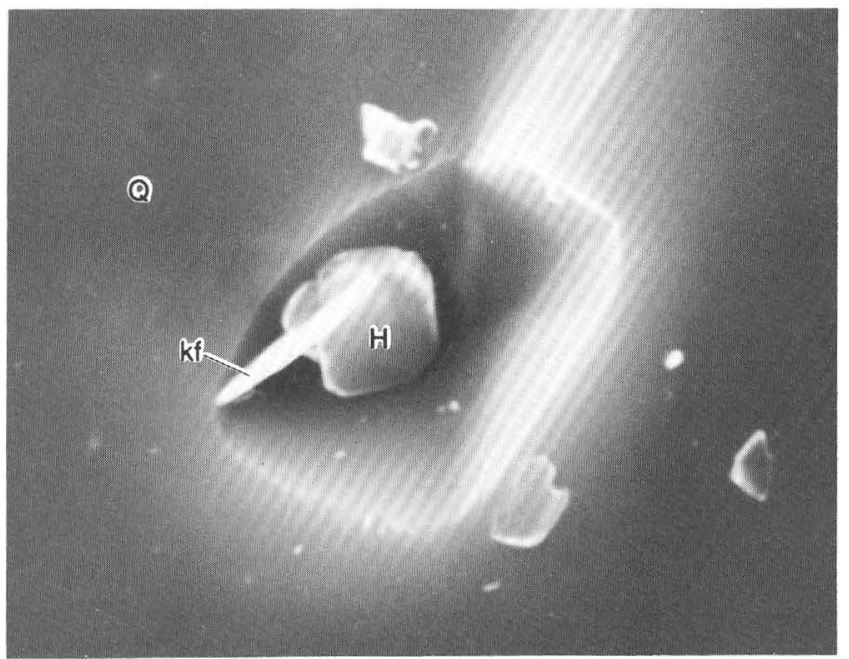

C 0 2 MICRONS

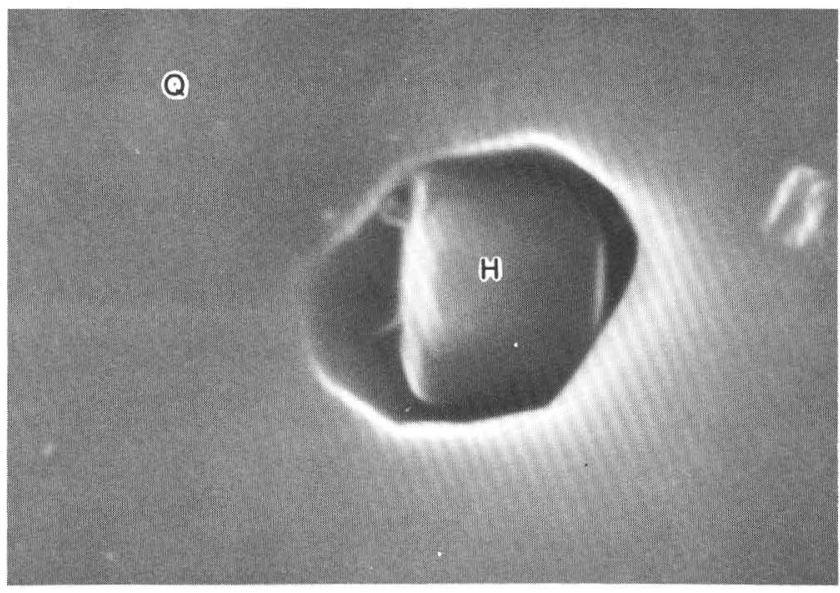

D 0 1 MICRON

FIGURE 129.-Scanning electron micrographs $(A-D)$ of artificially opened type III fluid inclusions from West block of Buckingham molybdenum system. H, halite; kf, K-feldspar; Q, quartz; S, sylvite. Sample B40-1615a. 
senopyrite(?) in figure $130 \mathrm{D}$ are shown in figure 131. The peaks for silica, calcium, and chlorine are from the quartz that hosts the fluid inclusion and from the $\mathrm{CaCl}_{2}$-bearing phase that also is present in the fluid-inclusion cavity. Roedder (1984) further suggested that dissolution of true daughter minerals in such polyphase fluid inclusions may not occur because of the sluggish kinetics involved.

Dissolution temperatures of both $\mathrm{NaCl}$ and $\mathrm{KCl}$ are available for six type III fluid inclusions contain-
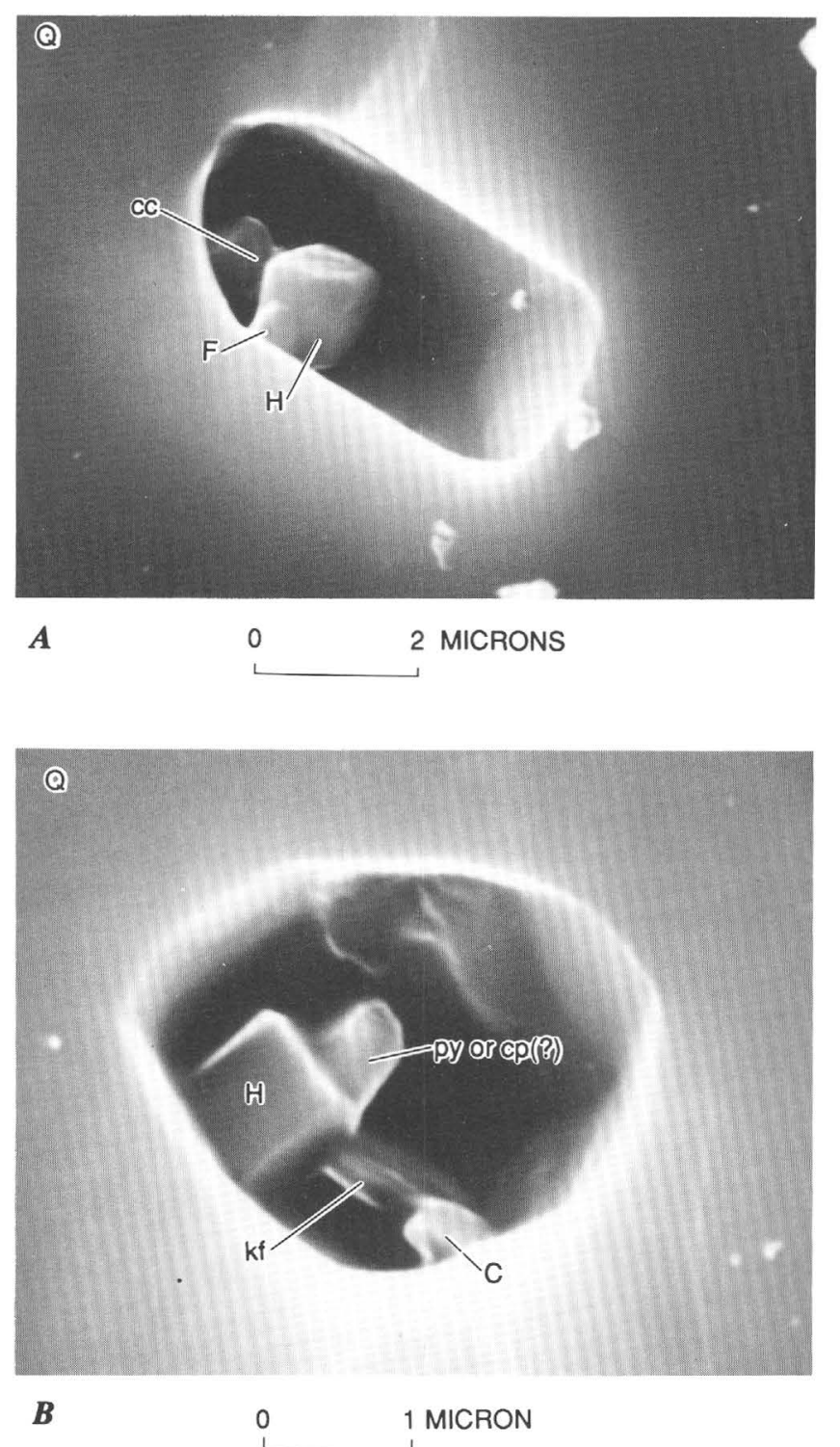

Figure 130.-Scanning electron micrographs of artificially opened type III fluid inclusions that are notably crystal rich or polyphase in West block of Buckingham molybdenum system. asp, arsenopyrite; $\mathrm{C}, \mathrm{CaCl}_{2}$; cc, calcite; cp, chalcopyrite; $\mathrm{F}$, iron chloride; fm, iron-manganese oxide; $\mathrm{H}$, halite; kf, $\mathrm{K}$-feldspar; py, pyrite; Q, quartz; S, sylvite. Mineral identification queried where uncertain. Sample B40-1615a. A, Halite, iron chloride, ing only these two phases as daughter minerals, and they provide thereby an estimate of the $\mathrm{NaCl} / \mathrm{KCl}$ ratios for the fluids in these fluid inclusions from the phase diagram of the vapor-saturated system $\mathrm{NaCl}$ $\mathrm{KCl}-\mathrm{H}_{2} \mathrm{O}$ (fig. 132). However, the presence of at least some $\mathrm{CaCl}_{2}$ in the fluid inclusions is probable because of the widespread occurrence of a $\mathrm{CaCl}_{2}$ bearing mineral in many of the polyphase type III fluid inclusions from the same vein. Repeated attempts to verify such presence of $\mathrm{CaCl}_{2}$ in the six
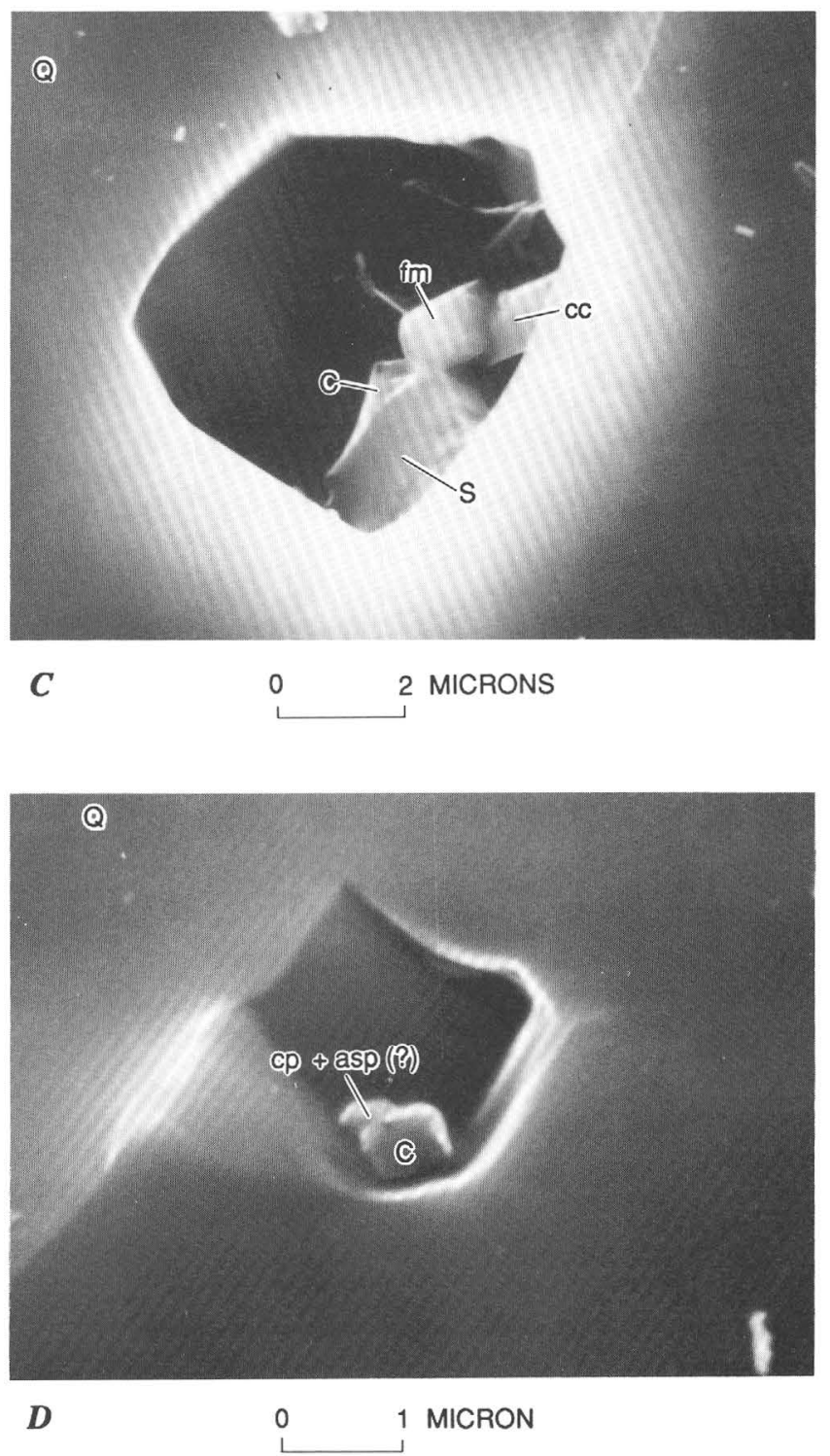

and calcite daughter minerals in quartz. $B$, Halite, K-feldspar, $\mathrm{CaCl}_{2}$, and pyrite or chalcopyrite(?) daughter minerals and (or) trapped minerals in quartz. $C$, Sylvite, $\mathrm{CaCl}_{2}$, iron-manganese oxide, and calcite daughter minerals and (or) trapped minerals in quartz. $D$, Chalcopyrite and arsenopyrite(?), and $\mathrm{CaCl}_{2}$ daughter minerals and (or) trapped minerals. 
fluid inclusions through a significant lowering of the eutectic (see Kwak and Tan, 1981) failed because of optical problems. The plot of the six fluid compositions inferred from the dissolution shows a tight cluster of five of the six data points (fig. 132). The cluster is centered at $\mathrm{NaCl} / \mathrm{KCl}$ weight ratios of approximately 1 and $\mathrm{H}_{2} \mathrm{O}$ contents of approximately 57 weight percent. Combined $\mathrm{NaCl}$ and $\mathrm{KCl}$ salt contents are about 43 weight percent. These data points,

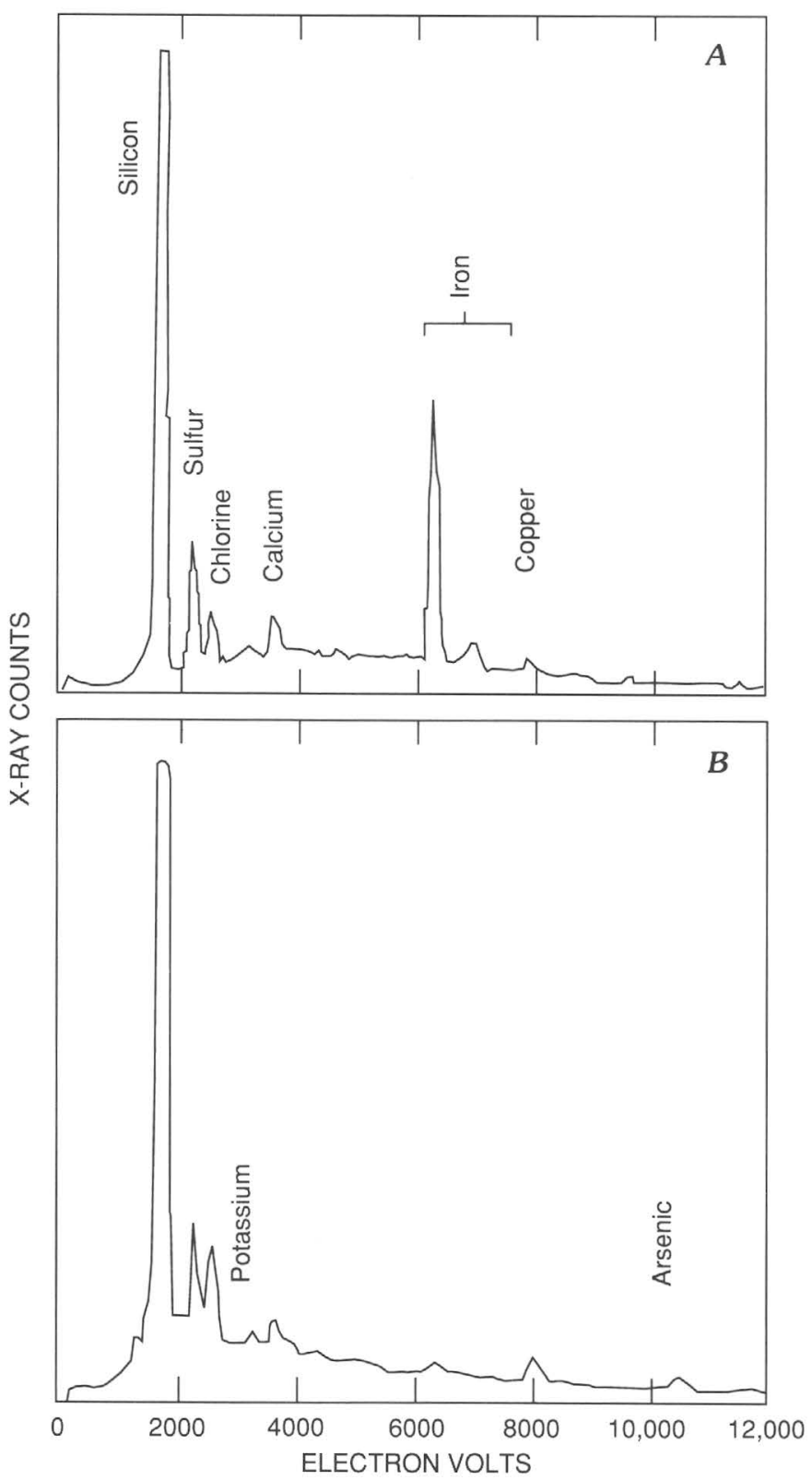

FIgURE 131.-Energy-dispersive X-ray spectra resulting from spot analysis of pyrite or chalcopyrite(?) in fluid inclusion shown in figure $130 B(A)$ and of chalcopyrite and arsenopyrite(?) in fluid inclusion shown in figure $130 D(B)$. Sample B40-1615a. when combined with the one remaining data point, seem to form a halite trend (see Cloke and Kesler, 1979) of fluid compositions elongated toward a locus at 75 weight percent $\mathrm{NaCl}$ on the $\mathrm{NaCl}-\mathrm{KCl}$ tieline. However, the overall significance of this trend is debatable, especially when one considers the trend being based on only six data points and the effect that the presence of $\mathrm{CaCl}_{2}$ might have (see Kwak and Tan, 1981). The occurrence of $\mathrm{CaCl}_{2}$ as a major component dissolved in the fluid-inclusion waters of these type III fluid inclusions would have a tendency of shifting the plotted data points (fig. 132) much closer to the $\mathrm{H}_{2} \mathrm{O}$ apex of the $\mathrm{H}_{2} \mathrm{O}-\mathrm{NaCl}-\mathrm{KCl}$ ternary diagram.

A plot of salinity versus homogenization temperature for 165 fluid inclusions for which both are available from the West block emphasizes many of the fluid-inclusion characteristics common to most porphyry systems (fig. 133). These characteristics include high maximum temperatures, high salinities, and evidence of boiling (Roedder, 1984). As further pointed out by Roedder, porphyry systems show generally an extreme variability in paragenetic sequence, the proportion of vapor in the fluid inclusion, salinity, the presence or absence of daughter minerals, and the number, size, and type of daughter minerals and possibly trapped miner-

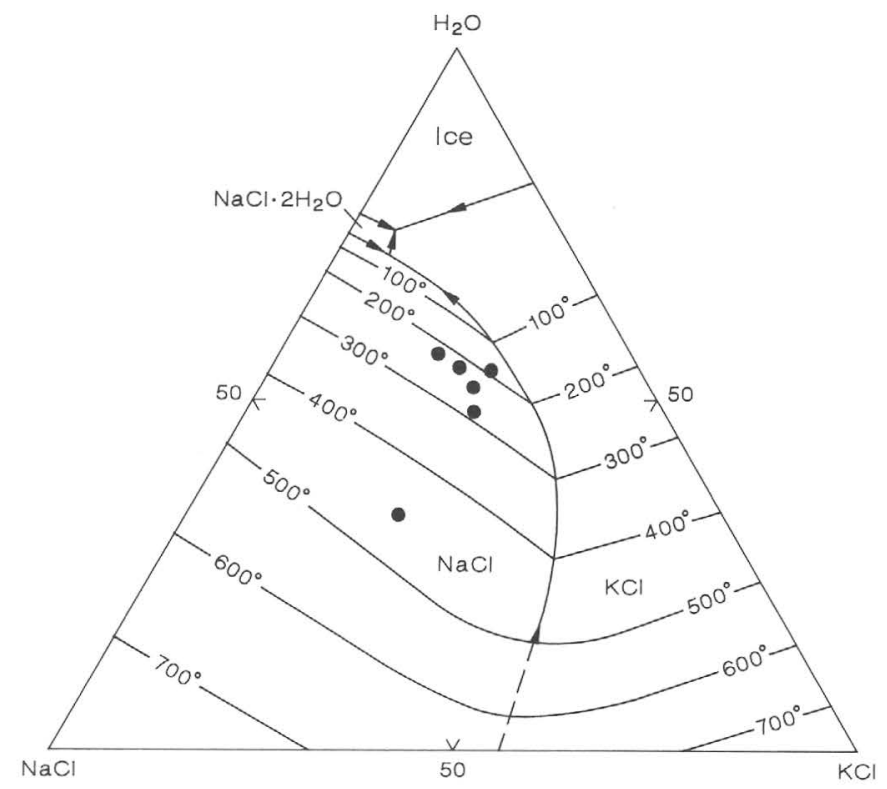

FIGURE 132.-Phase diagram for vapor-saturated system NaCl$\mathrm{KCl}-\mathrm{H}_{2} \mathrm{O}$, showing isotherms in degrees Celsius (from Roedder, 1984, fig. 8-25). Arrows point in direction of declining temperature; phase boundary between $\mathrm{NaCl}$ and $\mathrm{KCl}$ dashed where approximately located. Dots, point of final dissolution of $\mathrm{NaCl}$ in $\mathrm{NaCl}-\mathrm{KCl}$ type III fluid inclusions. Sample B40-1615a. 
als. It is important to note that such fluid-inclusion relations do not form diagnostic parts only of economic porphyry molybdenum or porphyry copper systems. Extensive fluid-inclusion study of unmineralized skarn genetically associated with the large body of porphyritic leucogranite north of the Buckingham stockwork molybdenum system revealed fluid-inclusion signature precisely analogous to that reported by Ahmad and Rose (1980) for porphyry copper mineralization at Santa Rita, N. Mex. (Theodore and Hammarstrom, 1991). As we described above, the bodies of skarn near the large body of porphyritic leucogranite are unmineralized. Moreover, the only mineralization known to be associated genetically with this igneous event is gold skarn at the Labrador Mine and at the Overlook group of prospects (pl. 1). Both of these occurrences of mineralized rock are some distance from the large body of porphyritic leucogranite. Although the locus of critical points in the $\mathrm{NaCl}-\mathrm{H}_{2} \mathrm{O}$ system and the boundary showing the position of $\mathrm{NaCl}$ saturation are shown on figure 133, it must be pointed out that these apply to the pure system $\mathrm{NaCl}-\mathrm{H}_{2} \mathrm{O}$. From our SEM studies above, some cations other than $\mathrm{Na}^{+}$probably are present in each of the plotted fluid inclusions. Nonetheless, the most likely explanations for the scattering of the data points are that the fluid inclusions plotted are mostly secondary relative to their vein-quartz host and that the small parts of each vein sampled were deposited in association with fluids showing an extremely wide range of temperature and salinity (Ahmad and Rose, 1980; Roedder, 1984). From the fact that all the type III fluid inclusions show melting of their

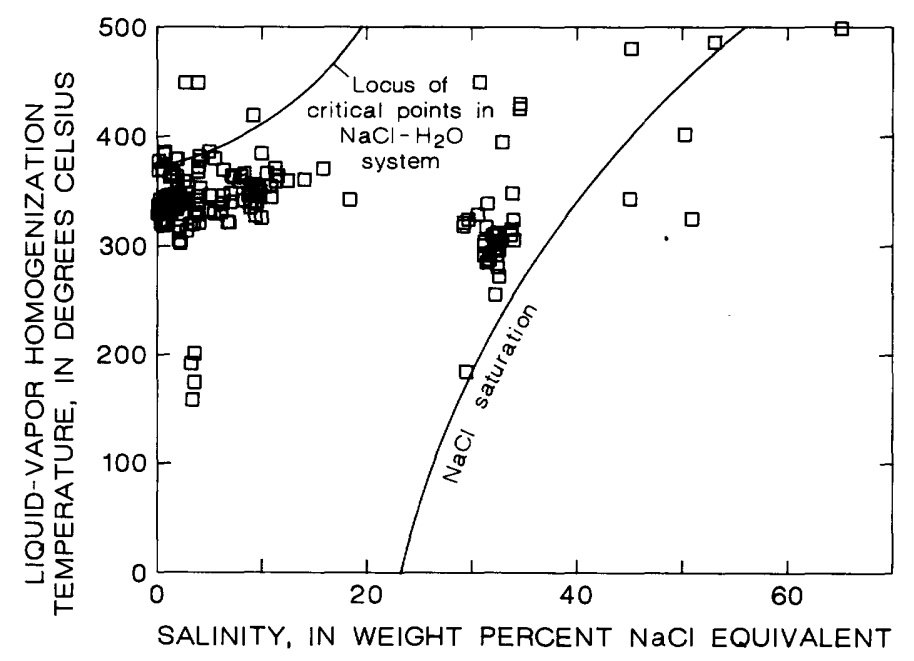

FIGURE 133.-Salinity versus liquid-vapor homogenization temperature for 165 fluid inclusions from West block of Buckingham molybdenum system.
$\mathrm{NaCl}$ or $\mathrm{KCl}$ daughter minerals before homogenization by either vapor or liquid disappearance, we may reasonably infer that the fluids were not saturated with respect to $\mathrm{NaCl}$ or $\mathrm{KCl}$ at the time of trapping and significant corrections need not be made to the measured homogenization temperatures (see Roedder, 1984). Although the type III fluid inclusions are quite restricted in the Buckingham system, their minor presence in the West block nonetheless results in a rather tight clustering of most of their salinities in the range 30-35 weight percent $\mathrm{NaCl}$ equivalent (fig. 133). However, these data indicate salinity determinations only for chemically simple type III fluid inclusions that show only $\mathrm{NaCl}$ with or without $\mathrm{KCl}$ as daughter minerals. The complex polyphase varieties of type III fluid inclusions may, in fact, have been saturated at the time of trapping with respect to one of their other chemical components. In the West block, salinity compared with the liquid-vapor homogenization temperature shows a grouping of data mostly into three loci. Two result from the types I, II, and IV fluid inclusions; they show an apparent bimodal clustering at approximately 2 to 3 weight percent $\mathrm{NaCl}$ equivalent and $340{ }^{\circ} \mathrm{C}$ and at approximately 10 weight percent $\mathrm{NaCl}$ equivalent and $350{ }^{\circ} \mathrm{C}$, and the other resulting from type III fluid inclusions and centered at approximately 33 weight percent $\mathrm{NaCl}$ equivalent and $300{ }^{\circ} \mathrm{C}$. When compared with fluid-inclusion relations in one of the well-studied porphyry copper systems, Santa Rita, N. Mex., the type III fluid inclusions at Buckingham certainly do not show as wide-ranging a distribution, nor do they extend as broadly into the NaCl-saturation field (see Ahmad and Rose, 1980). These relations emphasize that the overall amount of sodium and chlorine in the fluids associated with the Buckingham system, and presumably many of the other low-fluorine types of stockwork molybdenum systems as well, is much less than that in the typical porphyry copper system of the Southwestern United States and that in the late Eocene or early Oligocene skarn-forming environment north of the Buckingham stockwork molybdenum system.

A comparison of the domain of liquid-vapor homogenization temperature related to salinity for types I, II, and IV fluid inclusions for the West block with domains of similar data from the Vail Ridge and East blocks and the Late Cretaceous skarn shows that liquid-vapor homogenization temperatures tend to be somewhat higher in the West block and data cluster into ovoid domains (fig. 134). Furthermore, there does not appear to be a marked difference in the plot of homogenization temperature 
versus salinity between the Vail Ridge and East blocks data. The domain for fluid-inclusion data from the presumably Late Cretaceous andradite skarn, however, shows that the fluids there near the fringe of the Buckingham system tend to be somewhat more saline and to have generally lower homogenization temperatures than those associated with vein quartz. As described above, the fluid-inclusion waters in the andradite skarn are in the $\mathrm{CaCl}_{2}-\mathrm{H}_{2} \mathrm{O}$ system, whereas most of the fluid-inclusion waters in the quartz veins belong to the system $\mathrm{NaCl}-\mathrm{H}_{2} \mathrm{O}-$ $\left(\mathrm{CO}_{2}\right)$ with or without other minor components. Moreover, the fluid-inclusion data in the skarn were obtained from second-generation andradite in veins that cut massive skarn; second-generation andradite can only be inferred to be related to the Late Cretaceous Buckingham system. The relatively low temperatures in the environment of skarn near the fringes of the molybdenum system implied by these data, approximately $300{ }^{\circ} \mathrm{C}$, agree with the minimum thermal stability of andradite at 500 bars determined experimentally by Taylor and Liou (1978) for the reaction 3 quartz +3 calcite $+\mathrm{FeO}_{\mathrm{x}}=$ andradite + $3 \mathrm{CO}_{2}$ (see fig. 104B). As discussed above in the section entitled "Mineral Chemistry of Late Cretaceous and Tertiary Skarns," this andradite could be stable under $P-T-X$ conditions that included $\mathrm{X}_{\mathrm{CO}_{2}}$ values of approximately $\leq 0.01$. In addition, the outlined domains for fluid-inclusion types I, II, and IV (fig. 134) do not show elongations that extend toward the

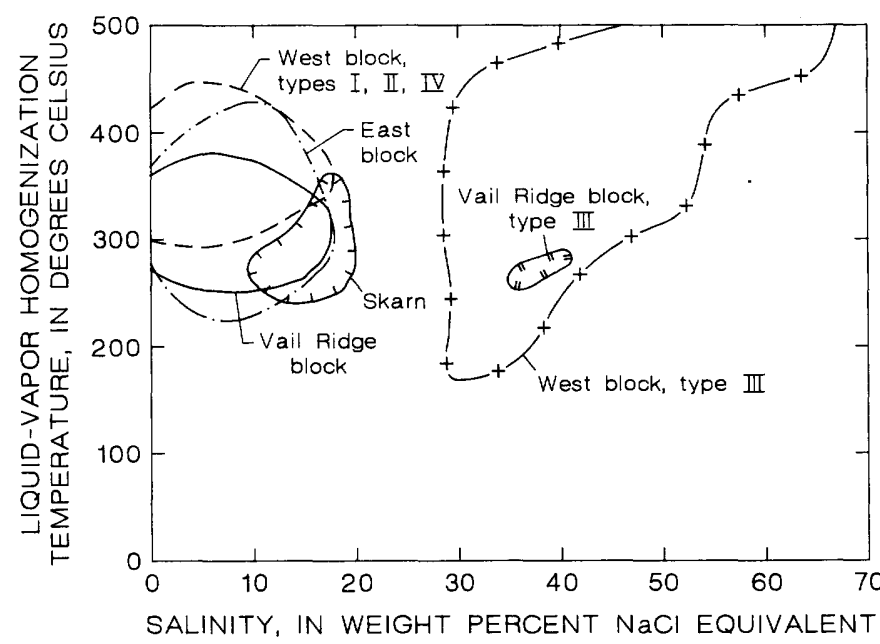

FIGURE 134.-Summary plot of liquid-vapor homogenization temperature versus salinity, comparing domains of types I, II, III, and IV fluid inclusions from West block of Buckingham molybdenum system with similar data from apparently Late Cretaceous skarn (fig. 116), Vail Ridge block (fig. 121), and East block (fig. 127). A few very low temperature data points, presumably very late, were excluded from domains. broad domain of the type-III fluid inclusions. There apparently is a "salinity gap" (see Roedder, 1984), but its significance is questionable, especially in light of the additional chemical components that must also be present in the fluid-inclusion waters (see below). Nonetheless, the generally cohesive nature of the plots for the types I, II, and IV fluidinclusion data suggests that significant fluid immiscibility may not have occurred within the pressure-temperature-chemical environment(s) depicted (see Charef and Ramboz, 1983).

\section{GEOBAROMETRY}

Highly variable pressures at the site(s) of molybdenum mineralization below the paleosurface of the Buckingham system may be inferred from the geobarometric implications of the fluid-inclusion data gathered above. Unfortunately, this variability may indicate in part an absence of suitable, wellcontrolled pressure-volume-temperature-chemical data for such chemically complex fluids (see Roedder and Bodnar, 1980; Roedder, 1984; Bodnar and others, 1985b) as those involved in the generation of the Buckingham system. Moreover, the unrecognized presence of even very small amounts of $\mathrm{CO}_{2}$ in a fluid inclusion may cause a significant rise in its vapor pressure, and, concomitantly, an increase in the paleodepth at which boiling or phase separation would commence (Bodnar and others, 1985b). Nonetheless, one sample in the Vail Ridge block (sample 1469-425, fig. 118; table 49) shows excellent textural and homogenization evidence for boiling, in which cogenetic vapor or low-density fluid and liquid belonging to the same chemical system as the vapor have been trapped simultaneously. This sample is a particularly good example of this phenomenon because it apparently does not contain any $\mathrm{CO}_{2}$, which could, during unmixing, effervesce preferably into low-density fluid and thereby yield a $\mathrm{CO}_{2}$-rich, lowdensity fluid chemically different from $\mathrm{CO}_{2}$-poor liquid (see Roedder, 1984). Salinity determinations on five type I fluid inclusions in sample 1469-425 range from 5.6 to 12.0 weight percent $\mathrm{NaCl}$ equivalent, and liquid-vapor homogenization temperatures range from 295 to $475{ }^{\circ} \mathrm{C}$, with the major mode in the class interval $380-390{ }^{\circ} \mathrm{C}$ (fig. 118). In addition, there is almost a full-range overlap between those fluid inclusions that fill to liquid and those low-density fluid inclusions that fill to vapor during heating tests. The spread in these temperature-of-homogenization data may result from the inhomogeneous trapping of small amounts of liquid in the low-density fluid inclusions that fill to vapor, and vice versa. In addi- 
tion, many of the measured fluid inclusions may not be exactly coeval. Thus, the homogenization temperatures of types I and II fluid inclusions and the textural criteria cited above all attest to circulation of boiling, moderately saline fluids near the fringe of the Buckingham stockwork system during the system's potassic stages. The vapor pressure in these fluids must have been the same as the pressure in the environment of the vein at the time the fluid inclusions were trapped, and the liquid-vapor homogenization temperature is the true temperature at the time of trapping. The maximum pressure corresponding to the trapping of a 10 weight percent $\mathrm{NaCl}$ equivalent fluid that is boiling at $380-390{ }^{\circ} \mathrm{C}$ is about 200 bars (see Roedder, 1984, fig. 9-6). As will be pointed out shortly below, this pressure estimate is the lowest pressure estimate from among several available geobarometers examined.

Pressure estimates significantly higher than 200 bars would result from the $\mathrm{CO}_{2}-\mathrm{H}_{2} \mathrm{O} \pm \mathrm{NaCl} \pm \mathrm{CH}_{4}$ type IV fluid inclusions that are common locally in some quartz veins in the Vail Ridge and West blocks, if one were to apply some of the equations of state proposed for such a chemical system (Holloway, 1981; Bowers and Helgeson, 1983; Parry, 1986). Visual volumetric estimate of phase proportions, temperatures of clathrate melting, and $\mathrm{CO}_{2}$ triple-point determinations suggest that, in at least several localities within the Buckingham system, some type IV fluid inclusions typically contain more than 90 volume percent $\mathrm{CO}_{2}$, no more than 2 mol percent $\mathrm{CH}_{4}$, and an indeterminate, but probably negligible, amount of $\mathrm{NaCl}$ (tables $49,51-52$ ). However, even as much as 10-20 mol percent $\mathrm{CH}_{4}$ would apparently cause a negligible change in bulk molar volumes at wide-ranging elevated temperatures and pressures because $\mathrm{CH}_{4}$ has a molar volume nearly identical to that of $\mathrm{CO}_{2}$ (Jacobs and Kerrick, 1981). Therefore, the small amounts of $\mathrm{CH}_{4}$ inferred to be present in these fluid inclusions should have no effect on pressure estimates based on the pure system $\mathrm{CO}_{2}-\mathrm{H}_{2} \mathrm{O}$ in light of the much larger sources of error inherent in the visual estimates of phase proportions. However, even these sources of error in the phase proportions may be circumvented by application of the iterative technique of Parry (1986). Using a volume relation originally derived by Bodnar (1983), Parry (1986) showed how the volume proportion of $\mathrm{CO}_{2}$ in a given type IV fluid inclusion could be calculated from (1) the density of $\mathrm{CO}_{2}$ (defined by the $\mathrm{CO}_{2}$ homogenization temperature), (2) the density of the $\mathrm{H}_{2} \mathrm{O}-\mathrm{NaCl}-\mathrm{CO}_{2}$ liquid (defined by the clathrate melting temperature), and (3) repeated assumed estimates of volume proportions until a calculated bulk homogenization temperature corresponded to the actual bulk homogenization temperature measured on the heating-freezing stage. Nevertheless, Parry's (1986) calculations are based on modified Redlich-Kwong coefficients from Bowers and Helgeson (1983), who, in turn, had used the equation of state of Holloway (1981). This equation of state does not reproduce accurately the available experimental data for water at high density (Brown and Lamb, 1986). Furthermore, Brown and Lamb (1986) prepared a series of pressuretemperature diagrams of bulk-fluid isochores, for differing densities of $\mathrm{CO}_{2}$, that apparently are applicable to the clusters of extremely $\mathrm{CO}_{2}$ rich fluid inclusions in the Vail Ridge and the West blocks.

In the Vail Ridge block near the core of the Buckingham system, sample $81 \mathrm{TT} 118$ contains abundant, very $\mathrm{CO}_{2}$ rich type IV fluid inclusions (fig. 123; table 49). Many of these fluid inclusions contain more than 90 volume percent $\mathrm{CO}_{2}$ as estimated at $40{ }^{\circ} \mathrm{C}$. The major mode of the homogenization-to-liquid temperature for the $\mathrm{CO}_{2}$ in this sample is in the class interval $25-26^{\circ} \mathrm{C}$ (fig. 123), which corresponds to a $\mathrm{CO}_{2}$ density of approximately $0.77 \mathrm{~g} / \mathrm{cm}^{3}$ (Angus and others, 1973). Ap-plication of a 90 -volume-percent- $\mathrm{CO}_{2}$ bulk-fluid isochore for a $\mathrm{CO}_{2}$ density of $0.8 \mathrm{~g} / \mathrm{cm}^{3}$ from Brown and Lamb (1986) to our data yields a pressure of 1.5 to $1.75 \mathrm{kbars}$ at temperatures in the range $300-350{ }^{\circ} \mathrm{C}$. These pressures are almost 10 times higher than the 200-bar pressure estimated above from boiling, moderately saline fluids in the same tectonic block as sample 81TT118, but close to the outer fringe of the quartz stockworks. Such high pressures are reduced only marginally if we instead were to assume a 100 -volume-percent- $\mathrm{CO}_{2}$ bulk-fluid isochore, as suggested by the phase proportions in some of the fluid inclusions in sample 81TT118. For a $\mathrm{CO}_{2}$ density of $0.8 \mathrm{~g} / \mathrm{cm}^{3}$, the 100 volume-percent- $\mathrm{CO}_{2}$ bulk-fluid isochore has a pressure of 1.2 to $1.4 \mathrm{kbars}$ at 300 to $350{ }^{\circ} \mathrm{C}$, respectively. At a $\mathrm{CO}_{2}$ density of $0.7 \mathrm{~g} / \mathrm{cm}^{3}$, this isochore shows a trajectory through $1 \mathrm{kbar}$ and 1.2 kbars at 300 and $350{ }^{\circ} \mathrm{C}$, respectively (P.E. Brown, written commun., 1986).

Inasmuch as sample 81TT118 from the core of the system in the Vail Ridge block shows an abundance of secondary fluid inclusions (see above), some very $\mathrm{CO}_{2}$ rich fluid inclusions deep within the West block, which do not show such a lowtemperature overprint $\left(300{ }^{\circ} \mathrm{C}\right.$, fig. $\left.118 \mathrm{C}\right)$, also were evaluated using the bulk-fluid isochores calculated by Brown and Lamb (1986). Sample B62640 hosts abundant type IV fluid inclusions, most of which are estimated to contain 90 to 95 volume 
percent $\mathrm{CO}_{2}$. These fluid inclusions show a mean homogenization-to-liquid temperature of $29.4^{\circ} \mathrm{C}$ for their $\mathrm{CO}_{2}$, which corresponds to a $\mathrm{CO}_{2}$ density of about $0.7 \mathrm{~g} / \mathrm{cm}^{3}$ (Angus and others, 1973). At 350 ${ }^{\circ} \mathrm{C}$, the measured homogenization temperature determined above for some of the somewhat more $\mathrm{H}_{2} \mathrm{O}$ enriched fluid inclusions coeval with those that contain 90 to 95 volume percent $\mathrm{CO}_{2}$, the bulk-fluid isochore for 90 volume percent $\mathrm{CO}_{2}$ is at 1.2 kbars (P.E. Brown, written commun., 1986)-a pressure that is not much different from that found in the Vail Ridge block. Thus, there seems to be a pressure difference of about 1.1 to $1.2 \mathrm{kbars}$ between the well-documented boiling-curve determination (200 bars) near the edge of the system and the pressure estimates near the core of the system based on bulk-fluid isochores for the system $\mathrm{CO}_{2}-\mathrm{H}_{2} \mathrm{O}$.

A 200-bar estimate for pressure near the outer edge of the uppermost exposed parts of the Buckingham system seems compatible with other pressure estimates for fluid-inclusion studies in the district (Nash and Theodore, 1971) and with geologic reconstruction of the placement of the Late Cretaceous paleosurface above the system. If one were to assume that the bulk of the fluids associated with early-stage molybdenum mineralization could be represented by a hydrostatic column of boiling, 10-weight-percent- $\mathrm{NaCl}$-equivalent fluid, then the maximum depth below the Late Cretaceous paleosurface (actually the depth below the water table associated with this surface) would be about $2.5 \mathrm{~km}$ (Haas, 1971, 1976). However, if one were to assume lithostatic conditions rather than hydrostaic conditions prevailed during mineralization, then the depth would reduce to about $0.6 \mathrm{~km}$. In addition, the Buckingham system may have periodically selfsealed during its evolution as a result of the massive deposition of quartz such that pressure at any point in the system indicated in part some combination of both hydrostatic and lithostatic controls (Roedder and Bodnar, 1980).

If the extremely high pressures suggested by the isochores of the $\mathrm{CO}_{2}$-rich type IV fluid inclusions are valid indicators of even a very local ambient pressure, then such pressures may have been generated by phenomena related to emplacement and subsequent crystallization of the monzogranite porphyry magma. Knapp and Knight (1977) pointed out that at relatively low confining pressures, such as the 200 bars suggested to be prevailing near the border of the quartz stockworks, the system $\mathrm{H}_{2} \mathrm{O}$ has a value of approximately 5 for its pressure coefficient near the critical point. That is, a $1{ }^{\circ} \mathrm{C}$ rise in temperature results in a 5-bar increase in the pressure of any confined $\mathrm{H}_{2} \mathrm{O}$. If we assume that the rocks in the general area of the top of the Buckingham system were at depths of about $2.5 \mathrm{~km}$, then they may have been at a temperature as high as $50{ }^{\circ} \mathrm{C}$, owing to the geothermal gradient alone. A thermal perturbation to $390-400{ }^{\circ} \mathrm{C}$ resulting from the emplacement of magma(s) in the Late Cretaceous could overpressurize isolated pockets of fluid to as much as $1.75 \mathrm{kbars}$. Furthermore, within the solid-liquid-vapor parts of the crystallizing magma associated with the monzogranite porphyry, each $10{ }^{\circ} \mathrm{C}$ cooling interval results in a potential pressure increase of about $1 \mathrm{kbar}$ (Knapp and Norton, 1981). Finally, Burnham (1979) calculated that the maximum internal overpressure that may be generated by a cooling column of magma theoretically could approach a value of infinity. However, such extremely high pressures could not be reached in the carapace above the magma column because the rocks there will fracture because of their relatively low tensile strength (Burnham, 1979). This state, in turn, enables outward dissipation of heat through the convection of heated fluids in the opened channelways. Halite dissolution temperatures approximately $100{ }^{\circ} \mathrm{C}$ higher than the liquid-vapor homogenization temperatures suggested to Kamilli (1978) that pressures in the Henderson, Colo., stockwork molybdenite deposit reached values much higher than lithostatic load. Such pressures resulted primarily from fluids evolving from the associated magma and, in turn, caused the dense concentration of fractures associated with the system. Naumov and others (1979) suggested that overpressures amounted to several hundred bars in the aqueous $\mathrm{CO}_{2}$-fluids associated with some wellstudied molybdenum- and tungsten-bearing quartz veins. Thus, the extremely high pressures suggested by the $\mathrm{CO}_{2}$-rich fluid inclusions in the Buckingham system may be authentic, a relation that adds further credence to the cautionary notes by Roedder (1984, p. 274) concerning geobarometric implications of fluid inclusions:

$* * *$ one may find inclusion evidence of boiling at a given pres-
sure, along with other inclusions, in the same deposit, indicating
possibly higher pressures. In this situation, the low-pressure limit
established by the boiling inclusions is most informative, because
it places an upper (hydrostatic) depth limit on the crystal in a
vein open to the surface $* * *$ the higher pressures are not as
meaningful because of [various] mechanisms for generating litho-
static or greater pressures at shallow depths $* * *$.

\section{STABLE ISOTOPES}

A total of 12 samples of diamond-drill core from quartz stockworks of the Buckingham system were 
analyzed by Blake and others (1979) for their $\delta^{18} \mathrm{O}$ values of the water calculated to be in equilibrium with vein quartz and for their $\delta \mathrm{D}$ values of the water liberated from fluid inclusions within the vein quartz. In these calculations, the fractionation equations of Bottinga and Javoy (1973) were used. These analyses were made to determine the origin of the water associated with the ore-forming fluids in the Buckingham system. In addition, since that report two other samples were analyzed in a similar manner for their $\delta \mathrm{D}$ values: samples $81 \mathrm{TT} 88$ and $78 \mathrm{C} 169$, from surface exposures of quartz stockworks in the East and West blocks of the system, respectively. Modified standard techniques were used to prepare samples and to liberate the fluid-inclusion water (for further details, see Roedder and others, 1963; Rye and Haffty, 1969; Batchelder, 1977). Generally 15 to $25 \mathrm{~g}$ of quartz was crushed in vacuo to liberate 2 to $5 \mathrm{mg}$ of fluid-inclusion water necessary for isotopic analysis. All the isotopic data (both hydrogen and oxygen) were reported by Blake and others (1979) in permil deviation from the SMOW (standard mean ocean water) standard using standard $\delta$-notation,

where

$$
\delta=\left(\frac{\mathrm{R}_{\text {sample }}}{\mathrm{R}_{\text {standard }}}\right)-1 \times 1,000
$$

The bromine pentafluoride technique (Clayton and Mayeda, 1963) was used to extract oxygen from the quartz for isotope analysis. The $\delta^{18} \mathrm{O}$ values of water in equilibrium with quartz were then calculated from the $\delta^{18} \mathrm{O}$ values of quartz, using fluid-inclusionhomogenization temperatures and the following calibration curve (Matsuhisa and others, 1979):

$$
10^{3} \ln \alpha_{\mathrm{Q}-\mathrm{H}_{2} \mathrm{O}} \cong 3.34\left(10^{6} \mathrm{~T}^{-2}\right)-3.31
$$

where

$$
10^{3} \ln \alpha_{\mathrm{Q}-\mathrm{H}_{2} \mathrm{O}} \cong \delta \mathrm{D}-\delta \mathrm{H}_{2} \mathrm{O}
$$

and

$$
\alpha=\left({ }^{18} \mathrm{O} /{ }^{16} \mathrm{O}\right) \mathrm{Q} /\left({ }^{18} \mathrm{O} /{ }^{16} \mathrm{O}\right) \mathrm{H}_{2} \mathrm{O}
$$

and $\mathrm{T}$ is the absolute temperature.

Homogenization temperatures of fluid inclusions were corrected for pressure by Blake and others (1979) from the curves of Potter (1977), assuming that fluids were nonboiling and at a pressure of 300 bars. However, the much more indepth fluid- inclusion study of this report has shown that the fluids were mostly boiling throughout the Buckingham system during its evolution. Therefore, homogenization temperatures determined using the heating stage need no further correction (see Roedder, 1984). Thus, values of quartz-water fractionation $\left(\Delta \mathrm{Q}-\mathrm{H}_{2} \mathrm{O}\right)$ of Blake and others (1979) were recalculated using, instead, the maximum homogenization temperature determined for fluid inclusions hosted by respective samples of vein quartz. These maximum homogenization temperatures for the 12 samples are in the range 316-400 ${ }^{\circ} \mathrm{C}$; the mean is $359{ }^{\circ} \mathrm{C}$, a value that compares quite favorably with temperatures thought to be prevailing in the system during its prograde potassic stages (see above). Resulting calculated $\delta^{18} \mathrm{O}_{\mathrm{H}_{2} \mathrm{O}}$ values average 0.6 permil isotopically heavier than those reported by Blake and others (1979). However, a plot of these data shows only a slight shift in the overall field for the calculated $\delta^{18} \mathrm{O}_{\mathrm{H}_{2} \mathrm{O}}$ versus $\delta \mathrm{D}$ values of vein quartz in the Buckingham system (compare fig. 135 with Blake and others, 1979, fig. 5).

The 12 fluid-inclusion waters in quartz in the Buckingham molybdenum system analyzed by Blake and others (1979) have $\delta D$ values ranging from -118 to -77 permil (fig. 135). The two samples analyzed subsequently, 81TT88 and 78C169, have $\delta \mathrm{D}$ values of -98 and -102 permil, respectively. $\delta^{18} \mathrm{O}$ values of water calculated to be in equilibrium with quartz range from +6.5 to +9.0 permil. Samples used for the isotope analyses are from quartz veins in either the Harmony Formation or monzogranite porphyry. Samples with the lowest $\delta \mathrm{D}$ values generally are from drill core rather close to post-Buckingham granodiorite porphyry dikes. Wall-rock hosting the veins does not appear to have affected values of either calculated $\delta^{18} \mathrm{O}_{\mathrm{H}_{2} \mathrm{O}}$ or $\delta \mathrm{D}$. The quartz veins containing fluid inclusions most deuterium enriched, however, are present in the Harmony Formation near monzogranite porphyry dikes where no granodiorite porphyry is found close by. The $\delta^{18} \mathrm{O}$ data do not provide any clear-cut patterns, but samples containing higher modal concentrations of molybdenite have generally depleted $\delta^{18} \mathrm{O}$ values.

In figure 135, waters from the Buckingham samples were plotted along with present-day meteoric water and the magmatic-water field of Taylor (1974). Two samples plot within, and one very close to, the magmatic-water field. This is good evidence for the presence of magmatic water in the fluids. The waters that plot farthest from the magmaticwater field have depleted deuterium values, probably resulting from a significant component of 
meteoric water in the fluid-inclusion waters. Present-day meteoric water has $\delta \mathrm{D}$ and $\delta^{18} \mathrm{O}$ values of -126 and -16.3 permil, respectively (Batchelder, 1977). In late Eocene or early Oligocene time, during emplacement of granodiorite porphyry dikes into the Late Cretaceous Buckingham system, isotopic values were probably slightly heavier $(\delta \mathrm{D}$ approx $10-15$ permil heavier and $\delta^{18} \mathrm{O}$ approx $1-2$ permil heavier; Taylor, 1974; O'Neil and Silberman, 1974; Batchelder, 1977). In fact, the meteoric-water trendline shown in figure 135 probably has not changed significantly during the past 150 m.y. (Taylor, 1974). Nonetheless, the actual value for isotopic composition of Late Cretaceous meteoric water in the district is not known, although it might be inferred from the lightest $\delta \mathrm{D}$ value (-118 permil) determined in samples from the Buckingham system and graphic examination of the magmatic-water field and meteoric-water trendline in the plot of $\delta \mathrm{D}$ versus calculated $\delta^{18} \mathrm{O}_{\mathrm{H}_{2} \mathrm{O}}$ values. The ${ }^{18} \mathrm{O}$ in these samples most likely has reequilibrated with ${ }^{18} \mathrm{O}$ in the country rock into which the Buckingham system was emplaced, causing an oxygen shift from A to B (see fig. 135).

The relative amounts of meteoric and magmatic water were estimated by comparing the relative distances from $\mathrm{A}$ to $\mathrm{F}$ and from $\mathrm{F}$ to $\mathrm{E}$, considering $\mathrm{AE}$ to correspond to the total fluid budget, with ACD being all possible values for mixed magmatic and meteoric water at Battle Mountain (Blake and others, 1979). The data may be interpreted to indicate that some fluid inclusions contain 100 percent magmatic water $(\mathbf{E})$ and other fluid inclusions 100 percent meteoric water (B). Alternatively, Taylor (1979) suggested, on the basis of the data of Batchelder (1977), that the magmatic-hydrothermal system as-

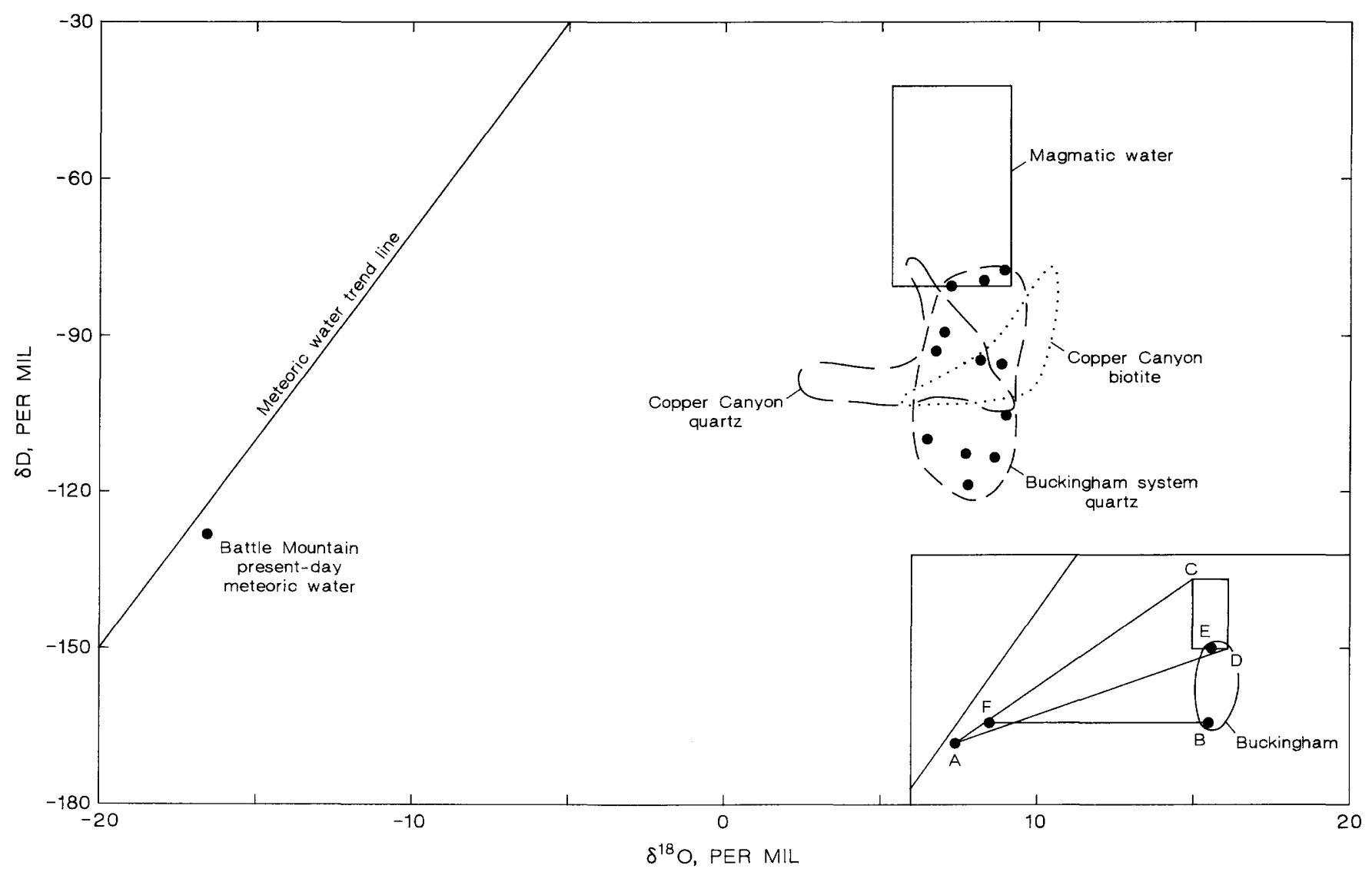

FiguRe 135.- $\delta \mathrm{D}$ versus $\delta 180$ values for water calculated to be in equilibrium with quartz (dots) (modified from Batchelder, 1977). In addition, isotopic fields from Copper Canyon quartz and biotite (Batchelder, 1977) and magmatic-water field are plotted for comparison. Inset in lower right corner shows $\delta \mathrm{D}$ and $\delta^{18} \mathrm{O}$ values possible for mixed meteoric and magmatic waters at Battle Mountain (ACD), approximate field of sam- ples from Buckingham molydenum system containing mostly magmatic water $(E)$, approximate location of specimens containing mostly meteoric water (B), and inferred isotopic composition of water at point $\mathrm{E}$ that would result if water were not affected by exchange with isotopically heavier $\left(\delta^{18} \mathrm{O}\right)$ wallrocks $(\mathrm{F})$. 
sociated with the copper and gold deposits at Copper Canyon may indicate that low- $\delta \mathrm{D}$ magmatic water was produced by interaction of magma at Copper Canyon with meteoric $\mathrm{H}_{2} \mathrm{O}$ before the emplacement of magma to its present levels in the crust. A similar hypothesis could be inferred from the plot of calculated $\delta^{18} \mathrm{O}_{\mathrm{H}_{2} \mathrm{O}}$ versus $\delta \mathrm{D}$ values for the Buckingham data. The Copper Canyon and the Buckingham data tightly overlap one another in a relatively restricted domain (fig. 135). In fact, the calculated $\delta^{18} \mathrm{O}_{\mathrm{H}_{2} \mathrm{O}}$ versus $\delta \mathrm{D}$ domains for both of these mineralized systems show slightly depleted overall $\delta \mathrm{D}$ values relative to similar plots for biotites from the porphyry copper systems at Bingham, Utah, Santa Rita, N. Mex., and Ely, Nev. (Taylor, 1979). The restriction of the domains for these data plots contrasts sharply with those found by Hall and others (1974) at the Climax, Colo., molybdenum system. At Climax, some sericites were shown by Hall and others (1974) to have extremely low $\delta \mathrm{D}$ values, some less than -160 permil. In addition, preliminary isotopic studies at the Thompson Creek, Idaho, low-fluorine stockwork molybdenite deposit found a $\delta \mathrm{D}$ value of -58 permil for white mica, and $\delta \mathrm{D}$ values in the range -108 to -155 permil for fluid-inclusion waters in vein quartz there (Hall and others, 1984).

Preliminary studies of the $\delta^{34} \mathrm{~S}$ values of molybdenite in the Buckingham system yield a rather restricted range, +4.3 to +5.2 permil relative to Cañon Diablo troilite (T.G. Theodore, unpub. data, 1989). These data, as well as the fact that the deposit is genetically related to monzogranite porphyry, suggest a source for the sulfur that involved isotopic homogenization before its transport and deposition by the fluids associated with the system. However, compositions of orthomagmatic total sulfur in igneous rocks are typically in the range -3 to +3 permil and close to meteoritic sulfide sulfur, which has a value of about 0 permil (Field and Fifarek, 1985). If the magma of monzogranite porphyry at Buckingham initially formed somewhere in the lower crust (see Farmer and DePaolo, 1984), then some crustal sulfur may have been incorporated into the system at that time because of the slightly heavy $\delta^{34} \mathrm{~S}$ values found in the molybdenite here (see Ohmoto and Rye, 1979). Farmer and DePaolo (1984), on the basis of the Sr and Nd isotopic composition of an analyzed sample of aplite from the system, suggested that intrusive rocks associated with the Buckingham system formed by mixing between mantle-derived magma and deepseated eugeoclinal sedimentary rocks. Hall and others (1984) also found that molybdenite in the Thompson Creek, Idaho, low-fluorine molybdenite deposit has $\delta^{34} \mathrm{~S}$ values heavier than Cañon Diablo troilite, +10.3 to $+\mathbf{1 1 . 4}$ permil. The Climax, Henderson, and Mount Emmons-Redwell Climax-type stockwork molybdenite deposits in Colorado have $\delta^{34} \mathrm{~S}$ values for their molybdenite between +2.5 and +5.3 permil (Stein and Hannah, 1985). In addition, these authors also noted that molybdenite from the Questa, N. Mex., stockwork molybdenite deposit has $\delta^{34} \mathrm{~S}$ values near +1.5 permil. As pointed out by Stein and Huebner (1984), the maximum possible ${ }^{34} \mathrm{~S}$-isotopic enrichment is +3.0 permil under equilibrium fractionation, oxidizing conditions, and a $\delta^{34} \mathrm{~S}$ value of 0 permil in the magma. Therefore, the somewhat heavy $\delta^{34} \mathrm{~S}$ values in part may indicate the effects of a high oxygen fugacity on the partitioning between $\mathrm{MoS}_{2}$ and aqueous fluid (see Candela, 1986). However, the entire enrichment in $\delta^{34} \mathrm{~S}$ to values as high as +5.2 in molybdenite from Buckingham apparently cannot all be the result of such an oxidizing effect if one assumes the above listed conditions were operative in the system as it evolved.

\section{DISCUSSION}

Hydrothermal fluids in the Buckingham system show complex histories that largely indicate their immediate chemical and physical environment as that environment, possibly less than $2.5 \mathrm{~km}$ depth, responded to successive influxes of fluids mostly from newly injected magma into loci of earlier emplaced igneous phases. In the distal parts of the system, where some of the andradite-diopside skarn presumably formed in carbonate beds of the Harmony Formation, the associated fluids were moderately saline $\mathrm{CaCl}_{2}$ brines apparently circulating at relatively low temperatures of about $300{ }^{\circ} \mathrm{C}$. Such temperatures, on the one hand, seem somewhat low as discussed above. For example, Einaudi (1982b) showed that andradite is stable with pyrite or pyrrhotite only above about $400{ }^{\circ} \mathrm{C}$ at low to intermediate sulfidation and oxidation states and at a $\mathrm{CO}_{2}$ mol fraction in the coexisting fluid of 0.1 . On the other hand, at mol fractions of $\mathrm{CO}_{2}$ much less than this value, that is under extremely $\mathrm{H}_{2} \mathrm{O}$ rich conditions, the assemblage andradite-pyritehematite becomes stable at temperatures below $300-350{ }^{\circ} \mathrm{C}$ (Einaudi, 1982b), and Taylor and Liou (1978) have shown andradite to be stable to approximately $300{ }^{\circ} \mathrm{C}$ at pressures of 500 bars and $X_{\mathrm{CO}_{2}}$ of approximately $\leq 0.01$. The fluid inclusions examined by heating and freezing techniques in the second-generation, vein-type andradite at 
skarn D show no evidence at all for the presence of $\mathrm{CO}_{2}$. However, in the proximal parts of the system, where most of the quartz stockworks and molybdenite were deposited, the fluids were relatively low density, boiling, low- to moderate-salinity $\mathrm{NaCl}$ brines that included highly variable amounts of $\mathrm{CO}_{2}$. Thus, these early-stage fluids in the system seem to have established an ascending "plume" of fluid considerably less saline than fluids associated with most porphyry copper systems in the Southwestern United States (see Roedder, 1984; Nash, 1976) and with Climax-type systems (Roedder, 1971). The magmas at Buckingham did not evolve large volumes of very dense, NaCl-rich fluids. High in the system, as exemplified by samples in the Vail Ridge block, the very sparse type III fluid inclusions there seem to have formed largely through condensation from an earlier, higher temperature and moderately saline fluid. In the West block, the high-temperature and high-saline type III fluid inclusions, having salinities as much as 65 weight percent $\mathrm{NaCl}$ equivalent and homogenization temperatures as high as $500{ }^{\circ} \mathrm{C}$, probably do indicate ponded magmatic fluids from a deep source. But, as we pointed out above, the overall distribution of veins associated with such fluids appears to be quite restricted.

Many of these fluid relations at Buckingham are common to other molybdenum systems elsewhere, especially the low-fluorine or quartz monzonite type of stockwork molybdenum system. Early-stage veins at the Hall, Nev., porphyry molybdenum system show moderate salinities (9-19 weight percent $\mathrm{NaCl}$ equivalent) similar to those at Buckingham, but prevailing temperatures $\left(470-595{ }^{\circ} \mathrm{C}\right)$ during this stage of the mineralization seem to have been somewhat higher than those at Buckingham (Shaver, 1984a). The Thompson Creek, Idaho, stockwork molybdenum deposit (Hall and others, 1984), the Mink Lake, Ontario, stockwork molybdenum system (Burrows and Spooner, 1984), and the Boy Scout-Jones molybdenum prospect in North Carolina (Shrader and Feiss, 1980) are all marked by fluid inclusions barren of daughter minerals in the associated quartz veins. In addition, although the Quartz Hill, Alaska, stockwork molybdenum deposit has a fluid-inclusion signature devoid of type III fluid inclusions, it has an abundance of type IV fluid inclusions in molybdenite-quartz stockworks at the discovery outcrop (T.G. Theodore, unpub. data, 1989). The Endako, British Columbia, stockwork molybdenite deposit shows abundant concentrations of types I and II fluid inclusions (Bloom, 1981), as does the Ambalavayal,
India, molybdenite prospect (Santosh, 1984). In the Transbaikalia region, U.S.S.R., the Shakhtama molybdenum deposit is considered to be an essentially molybdenum-only end member of coppermolybdenum porphyry systems that formed from boiling, moderate-salinity fluids (Sotnikov and others, 1979). Finally, the Medet, Bulgaria, porphyry copper deposit, a low-grade $(0.36$ weight percent $\mathrm{Cu}, 0.008$ weight percent $\mathrm{Mo}$ ) porphyry copper deposit of approximately 200 million tons (Sutulov, 1970, 1978), also has moderate salinities (4-12 weight percent $\mathrm{NaCl}$ equivalent) and includes $\mathrm{CO}_{2}$ in its fluid inclusions (Strashimirov, 1981). The low grades of this deposit were attributed by him directly to salinities lower than most other porphyry copper systems. In addition, the Hall, Nev., porphyry molybdenum system also includes some $\mathrm{CO}_{2}-$ bearing fluid inclusions, but most of them are .secondary (Shaver, 1984a). Stockwork-related molybdenum mineralization at the Silver Creek, Colo., deposit seems to be associated with boiling, moderately and highly saline fluids that contain some $\mathrm{CO}_{2}$ (Larson, 1987). The Boss Mountain, British Columbia, Canada, porphyry molybdenum system (MacDonald and Spooner, 1984), and the Thompson Creek, Idaho, porphyry molybdenum system (Hall and others, 1984) seem, however, to show overall concentrations of $\mathrm{CO}_{2}$ in their fluid inclusions comparable to those at Buckingham. Indeed, the relatively low homogenization temperatures, $300-350{ }^{\circ} \mathrm{C}$, at Boss Mountain, for fluid inclusions whose isotopic signatures are dominantly magmatic, were thought by MacDonald and Spooner (1984) to indicate cooling from solidus temperatures by irreversible adiabatic expansion of the fluid with an attendant significant drop in temperature. At the Central City, Colo., alkaline porphyry molybdenum system, Rice and others (1985) also attempted to resolve the presence of mostly moderately saline, $\mathrm{CO}_{2}$-bearing fluids and sparse amounts of hypersaline fluids by evoking rapid decompression and adiabatic cooling of an initially moderately saline, less than 20-weight-percent- $\mathrm{NaCl}$-equivalent $\mathrm{H}_{2} \mathrm{O}-\mathrm{CO}_{2}$ fluid (see Bloom, 1981). From the data of Bowers and Helgeson (1983), such a fluid should unmix to a $\mathrm{H}_{2} \mathrm{O}-\mathrm{CO}_{2}$-rich fluid and a NaCl-rich fluid when decompressed rapidly. Thus, Rice and others (1985) envisioned a model wherein the upper parts of the Central City system would have predominantly $\mathrm{H}_{2} \mathrm{O}-\mathrm{CO}_{2}$ fluids and the deep parts of the system might contain hypersaline fluids and, possibly, have increased molybdenum contents. Although such a fluid-immiscibility model is probably applicable to the Central City porphyry molybdenum 
system, where the exposed parts of the system are well above a buried inferred concentration of molybdenum, the geometry of the molybdeniteenriched shells and their proximity to the igneous source at Buckingham seem to argue against the prevalence of such a model here. These shells are tightly constrained to the flanks and apical parts of the East and West stocks, and the shells seem to show a genetic relation to the quartz-K-feldspar porphyry phase in the core of the stocks (see subsection above entitled "Economic Geology"). Furthermore, an approximately 1-km-long, composite vertical section through the Buckingham system is available for study in the three tectonically offset blocks, and nowhere do we find a really widespread occurrence of hypersaline fluids.

Therefore, it seems more likely that most of the moderately saline $\mathrm{H}_{2} \mathrm{O}-\mathrm{NaCl}-\mathrm{CO}_{2}$ mineralizing fluids associated with this deposit is related to the quartz-K-feldspar porphyry and slightly deeper equivalent igneous phases. Recent studies at several other stockwork molybdenite systems also have shown that fractional crystallization may result in a low-saline to moderately saline $\mathrm{H}_{2} \mathrm{O}-\mathrm{CO}_{2}$ fluid (Hall and others, 1984; Burrows and Spooner, 1985; John, 1986).

In pressure-temperature space, the aqueous fluid(s) that became immiscible with $\mathrm{H}_{2} \mathrm{O}$-saturated magma near its solidus must have followed a pathway at Buckingham along which temperatures were generally in excess of the muscovite+quartz breakdown curve during the early stages of mineralization, and pressures throughout the system maintained values in excess of the halite+ liquid+vapor curve (fig. 136). As such, the pathway that was followed, admittedly generalized because of the highly dynamic environment of the porphyry system together with periodic self-sealing in the system, may have coincided closely with the critical curve. Nonetheless, it must be kept in mind that the actual pressure-temperature coordinates for the granodiorite solidus and the muscovite+quartz breakdown curve are for $P_{\mathrm{H}_{2} \mathrm{O}}=P_{\text {total }}$. Because of the presence of $\mathrm{CO}_{2}$ in the system, these curves will shift to higher and lower temperatures, respectively. We suggest further that the magmatic fluids associated with the Buckingham system originated in a one-phase field near the solidus at some unknown value of $P_{\mathrm{H}_{2} \mathrm{O}}$ less than $P_{\text {total }}$ for an $\mathrm{H}_{2} \mathrm{O}$ content higher than 1 weight percent and, probably, lower than 5 weight percent. These $\mathrm{H}_{2} \mathrm{O}$ contents are inferred from the "biotite out" curves that would pass through the maximumbiotite-stability points in equilibrium with syntheticgranodiorite melt determined by Naney (1983) at 2 kbars. Although Naney (1983) did not determine the chemical composition of the biotite in his experimental charges, the biotites may have been quite magnesian because the univariant curve

$$
\begin{gathered}
\text { phlogopite }+3 \text { quartz } \rightarrow \\
\text { enstatite }+\mathrm{K} \text {-feldspar }+\mathrm{H}_{2} \mathrm{O}
\end{gathered}
$$

of Helgeson and others (1978) projects through the maximum biotite stability point for 1 weight percent $\mathrm{H}_{2} \mathrm{O}$. Again, we emphasize that the accurate position of the above reactions or stability fields must await the relevant experimental studies. Nonetheless, periodic decompression without significant conductive or convective heat exchange also could contribute to cooling of fluids from solidus temperatures to the $360-390{ }^{\circ} \mathrm{C}$ temperatures of homogenization (Barton and Toulmin, 1961). However, as $\mathrm{CO}_{2}$ increases in the system $\mathrm{H}_{2} \mathrm{O}-\mathrm{NaCl}-\mathrm{CO}_{2}$, boundaries between two phases and one phase show dramatic changes in pressuretemperature space (fig. 136), and the critical point also rises to higher temperature for a given $\mathrm{NaCl}$ content (Gehrig and others, 1979). In addition, the presence of iron in the fluids at Buckingham, documented above by identification of numerous ironbearing daughter or trapped minerals in fluid inclusions, may be relatively high (see Kwak and others, 1986). Kwak and others (1986) suggested that as much as 9 weight percent $\mathrm{Fe}$ may be soluble in fluids whose total anion content is about 20 to 30 weight percent. The addition of such chemical components has an unknown effect on stability relations in pressure-temperature space. Such high iron contents were subsequently verified by the experimental studies of Whitney and others (1985). These authors showed that in natural magmatic systems at $600{ }^{\circ} \mathrm{C}$, the iron content of chloride fluids coexisting with biotite or magnetite is very high, 0.2 to 0.25 molal.

The evolution of fluids associated with mineralization at Buckingham thus seems to show a history similar to that of the Hall (Nevada Moly), Nev., system. The early fluids of both these systems predominantly are moderately saline, and both systems seem to show some late-stage saline and hypersaline fluid inclusions. These latter fluid inclusions probably indicate late-stage condensation. In addition, at Buckingham, some hypersaline prograde fluids circulated deep within the lowermost block only very locally. Shaver (1984c) previously noted that such a trend in fluid chemistry for the low fluorine or quartz monzonite type of stockwork molybdenite deposit (early-stage moderate 
salinities followed by hypersaline fluids) contrasts with the fluid pathways with time in the Climaxtype of stockwork molybdenite deposit (early-stage hypersaline fluids followed by low- to moderatesalinity fluids; see Roedder (1971) and Kamilli (1978) also). Shaver (1984c) further ascribed these differences primarily to differences in emplacement depths: 0.6 to $2.2 \mathrm{~km}$ for the Climax-type deposits and 2.2 to $3.5 \mathrm{~km}$ for the low-fluorine or quartz monzonite-type deposits. However, some lowfluorine stockwork molybdenite systems have been emplaced at much greater depths (Chesley, 1986), and an extremely shallow seated, low-fluorine stockwork molybdenum system seems to be repre- sented by the Ledyanoe deposit in the Stanovoi region, U.S.S.R. This deposit is marked by subvolcanic textures in extensively quartz-cerussitealtered hornblende-biotite diorite and granodiorite of Mesozoic age (Kastrykin, 1980). In addition, there is a strong molybdenum anomaly at the surface that results from fine-grained molybdenite that is finely dispersed in quartz stockworks. Although emplacement depth undoubtedly may be a significant factor contributing toward the overall chemistry of the aqueous fluids evolved from a magma (Taylor, 1979), the experimental results of Kilinic and Burnham (1972) indicate that an $\mathrm{H}_{2} \mathrm{O}$ saturated silicate melt containing 2.7 weight per-

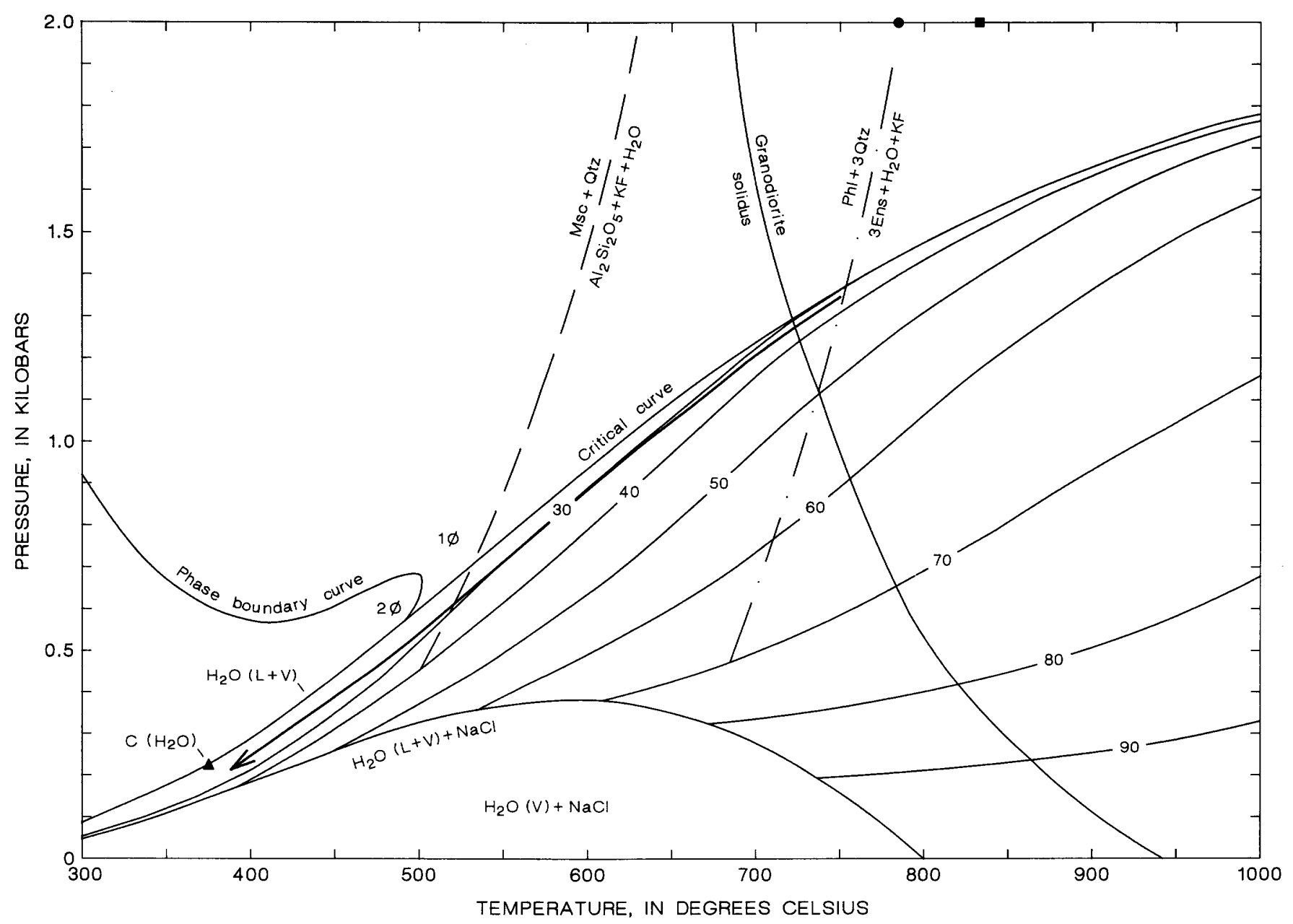

FIGURE 136.-Pressure-temperature projection of granodiorite solidus $\left(\mathrm{P}_{\mathrm{H}_{2} \mathrm{O}}=\mathrm{P}_{\text {total }}\right.$; modified from Burnham, 1979; Naney, 1983); $\mathrm{NaCl}-\mathrm{H}_{2} \mathrm{O}$ phase relations (modified from Bodnar and others, 1985); univariant equilibrium curves for muscovite+quartz and phlogopite and quartz $\left(\mathrm{P}_{\mathrm{H}_{2} \mathrm{O}}=\mathrm{P}_{\text {total }}\right.$, modified from Helgeson and others, 1978), and temperatures of maximum biotite stability at 2 kbars in synthetic granodiorite containing 1 and 5 weight percent $\mathrm{H}_{2} \mathrm{O}$ (dot and square, respectively) (Naney, 1983). Phase boundary curve of $\mathrm{H} 2$-rich side of ternary system $\mathrm{NaCl}-\mathrm{H}_{2} \mathrm{O}-\mathrm{CO}_{2}$ also shown for a system containing $9.69 \mathrm{~mol}$ percent $\mathrm{CO}_{2}$ and 6 weight percent $\mathrm{H}_{2} \mathrm{O}$ (modified from Gehrig and others, 1979). Numbered curves, critical curves at indicated weight percent $\mathrm{NaCl}$. Ens, enstatite; KF, K-feldspar; Msc, muscovite; Phl, phlogopite; Qtz, quartz. L, liquid; V, vapor; C, critical point of $\mathrm{H}_{2} \mathrm{O}$. 
cent $\mathrm{H}_{2} \mathrm{O}$ at $1 \mathrm{kbar}$ in an open system will have in its coexisting aqueous phase a higher weight fraction of $\mathrm{Cl}^{-}$than a comparable melt at 500 barsboth for greater than about 0.8 mass fraction of melt. However, at mass fractions of melt less than about 0.8 , or stated in another way, under conditions such that more than two-tenths of the melt has crystallized, the remaining $\mathrm{H}_{2} \mathrm{O}$-saturated melt at $1 \mathrm{kbar}$ will have a lower weight fraction $\mathrm{Cl}^{-}$in its coexisting aqueous phase than the melt at 500 bars. Therefore, if the fluid-salinity contrast between low-fluorine-type and Climax-type stockwork molybdenum deposits indicates primarily depth of emplacement, then most aqueous-fluid immiscibility of an aqueous phase from the magmas of the low-fluorine systems must have occurred after more than approximately two-tenths of their magmas had already crystallized. Thus, the timing of when immiscibility takes place relative to the crystallization history of the magma, as well as the chemistry of the magma (Burnham and Ohmoto, 1980), may be equally as important a constraint as the level of emplacement. In fact, the precise stage in the crystallization history of a magma when aqueous fluid becomes immiscible with silicate melt is very ambiguous (Roedder, 1984). Some very deep seated stockwork molybdenum systems, nonetheless, show fluid-inclusion relations that seem to corroborate the above salinity-versus-depth relations. For example, the Pear Lake, Mont., system contains mostly moderately saline fluids, 6 to 7 weight percent $\mathrm{NaCl}$ equivalent, that were trapped apparently at pressures of about $2 \mathrm{kbars}$ and temperatures of about $390-430{ }^{\circ} \mathrm{C}$ (Chesley, 1986).

The generalizations above regarding salinities and inferred depth of molybdenum mineralization locally may be complicated by variable rates of dilution by meteoric fluids along a column of ascending magmatic fluids. Near-surface molybdenite mineralization in the presently active geothermal system at Valles caldera, N. Mex., is associated seemingly with very dilute fluids that probably were circulating at temperatures of about $200{ }^{\circ} \mathrm{C}$; these fluids are interpreted as the surface expression of a very deep Climax-type molybdenum system (Hulen and others, 1987).

The widespread occurrence of low to moderate salinities in the low-fluorine or quartz monzonite type of molybdenum system seems to corroborate the low-salinity, magmatic aqueous-plume model of Henley and McNabb (1978). In fact, the moderate salinities associated with a large number of the low-fluorine stockwork molybdenum systems may in part indicate that most of the available sodium in such systems already was fixed in plagioclase before the exsolution of a relatively late stage aqueous fluid.

Transport of molybdenum in silicate melts and in aqueous fluids has been addressed by wide ranging experimental and theoretical studies that resulted in part from renewed economic interests because of the surge in the price of molybdenum to unprecedented heights during 1979-80. Glemser and Wendlandt (1963) suggested that aqueous phase transport of molybdenum probably occurs as $\mathrm{Mo}_{7} \mathrm{O}_{18}(\mathrm{OH})_{6}$. Westra and Keith (1981) suggested that molybdenum was transported mainly as $\mathrm{HMoO}_{4}^{-}$in the low-fluorine or quartz monzonite type of molybdenum stockwork deposit on the basis of preceding solubility studies of Smith and others (1980). Smith and others (1980) used thermodynamic properties of oxidized aqueous species of molybdenum at $25{ }^{\circ} \mathrm{C}$ to calculate the solubility of molybdenite at high temperatures. They further showed that ore-forming fluids at $350{ }^{\circ} \mathrm{C}$ show molybdenite solubilities of several thousand parts per million and that the solubility of molybdenite decreases about $10^{6}$ times for a temperature change from 350 to $300{ }^{\circ} \mathrm{C}$. However, before these studies, Krauskopf (1967) calculated that molybdenum should have a relatively high vapor pressure at 827 ${ }^{\circ} \mathrm{C}$ and a significantly lower vapor pressure at 627 ${ }^{\circ} \mathrm{C}$, from which he concluded that transport of molybdenum at magmatic conditions should pose no problem. Therefore, cooling of fluids apparently provides a highly efficient mechanism to deposit molybdenite. Arnorsson and Ivarsson (1985) showed that boiling and isochemical conductive cooling both lead to saturation by molybdenite in the geothermal waters of Iceland. Isuk and Carman (1981) suggested, furthermore, that molybdenum was carried in magma as silicate and (or) hydroxylated silicate complexes. Kudrin and others (1984) inferred that molybdenum was transported in solutions as hydroxoalkalichloride complexes of both hexavalent and tetravalent molybdenum. Kudrin (1989) apparently confirmed subsequently that the solubility of artificial crystals of $\mathrm{MoO}_{2}$ in aqueous solutions of $\mathrm{NaCl}$ and $\mathrm{KCl}$ increases with an increase of salinity, $\mathrm{pH}$, and oxygen fugacity; and seems to be controlled by $\mathrm{KHMoO}_{4}$ and $\mathrm{NaHMoO}_{4}$ complexes. Tingle and Fenn (1984) speculated that silicate liquids provide the major mechanism of molybdenum transfer in the aqueous fluid, and they also reaffirmed the earlier conclusions of Westra and Keith (1981) that fluorine is not important for the transport and concentration of molybdenum. Candela and Holland (1984), who 
did an elegant experimental study of the partitioning of molybdenum and copper between silicate melts and aqueous fluids at $750{ }^{\circ} \mathrm{C}$ and $1.4 \mathrm{kbars}$, concluded that the simplest equation to explain the distribution of molybdenum between melt $(\mathrm{m})$ and fluid (f) is

$$
\mathrm{MoO}_{3}^{m}+\mathrm{H}_{2} \mathrm{O}^{f}=\mathrm{MoO}_{2}\left(\mathrm{OH}_{2}\right)^{f}
$$

They also concluded that molybdenum probably is more commonly present in the hexavalent than the tetravalent state in aqueous fluid and that in fluorine-free systems, the partition coefficient of molybdenum seems to be essentially independent of the chloride content of the aqueous fluid. Drábek (1982) pointed out that only rarely in nature are conditions likely to be found such that very low sulfur and oxygen partial pressures would enhance tetravalent molybdenum to combine with iron in a spinel solid solution, $\mathrm{Fe}_{3} \mathrm{O}_{4}-\mathrm{Fe}_{2} \mathrm{MoO}_{4}$. Tacker and Candela (1987) experimentally extended the studies of Drábek (1982) and concluded that if, during the early crystallization stages of a magma before its exsolution of an aqueous phase, most molybdenum were fixed in ferromagnesian and (or) titanium-bearing minerals, then the overall amount of molybdenum available for development of a deposit would be reduced significantly. Nonetheless, there are some experimental studies that indicate that molybdenum complexing with chloride may become especially critical at high chloride concentrations. Ryabchikov and others (1981) conducted some element-distribution studies between melt and aqueous fluid wherein an initial solution containing $0.5 \mathrm{~mol} / \mathrm{kg} \mathrm{NaCl}$ and $0.5 \mathrm{~mol} / \mathrm{kg} \mathrm{KCl}$ showed a twofold to threefold increase in the amount of molybdenum partitioned into an aqueous fluid coexisting with granite melt at $750{ }^{\circ} \mathrm{C}$ compared with solutions that were devoid of chlorine. They also concluded that the typical granite magma containing an "average" concentration of heavy metals and sulfur is very close to being saturated in mclybdenite. Furthermore, Arnorsson and Ivarsson (1985) showed also that the molybdenum contents of some geothermal waters in Iceland tend to decrease concomitantly with a decrease in the chloride contents of the waters there. However, at the Boss Mountain, British Columbia, stockwork molybdenite deposit, MacDonald and Spooner (1982) found an apparent direct association between effervescence of $\mathrm{CO}_{2}$ and the presence of molybdenite; they ascribe this association to the destabilization of a mo- lybdenum carbonate complex. At this deposit, molybdenum grade declines rapidly below a certain depth that marks the interface where effervescence of $\mathrm{CO}_{2}$ from the ore-forming fluids first appears. At Mink Lake, northwest Ontario, Burrows and Spooner (1987) also described Precambrian, goldand tungsten-enriched molybdenite mineralization that is associated with $\mathrm{CO}_{2}$-bearing fluids. At Buckingham, however, the deepest samples examined all show the presence of $\mathrm{CO}_{2}$-rich fluid inclusions that homogenize to vapor. If molybdenum were carried as a molybdenum carbonate complex in fluids here, then the interface above which the breakdown of the complexes occurs must be at a depth greater than our deepest sampling sites.

Although each of the foregoing studies pertains to some aspect of the Buckingham stockwork system, the most critical factors in the genesis and evolution of this system apparently include an interrelation among the geologic environment, particularly the depth of emplacement; the timing of the immiscibility of the aqueous fluid relative to the crystallization history of the magma(s); the chlorine content of the magma(s) and the associated aqueous fluids; the presence of $\mathrm{CO}_{2}$ in the system; and a relatively high $\mathrm{Mo} / \mathrm{Cu}$ ratio (see subsection above entitled "Economic Geology"). As we described above, although most of the low-fluorine molydenum stockwork systems show wide-ranging emplacement depths, as a class of deposit, they seem to have been emplaced at depths somewhat greater than the Climax-type systems and possibly greater than many of the porphyry copper systems of the Southwestern United States. When we consider only the low-fluorine molybdenum stockwork systems in the Western United States, however, the Buckingham system with its probable emplacement depth of about $2.5 \mathrm{~km}$ (see above) is among the most near-surface known. Irrespective of the fact that magmas apparently contain $\mathrm{Cl}^{-} / \mathrm{H}_{2} \mathrm{O}$ overall ratios fairly fixed somewhere between $1 / 35$ and 1/10 (Gill, 1981), the first aqueous phase to form from a melt crystallizing in an open system at $0.5 \mathrm{kbar}$ and containing 2.7 weight percent $\mathrm{H}_{2} \mathrm{O}$ will show a chloride content of about 32 times that of the melt (Kilinic and Burnham, 1972). As crystallization proceeds, these authors further demonstrated a gradual increase of $\mathrm{Cl}^{-}$in the aqueous phase until the fluid in equilibrium with the last remaining melt showed $\mathrm{Cl}^{-}$contents 50 times higher in the last melt. Thus, if the magmas at Buckingham had abnormally high chloride contents, the apparent efficiency of the fractionation of $\mathrm{Cl}^{-}$into the aqueous phase throughout the crystal- 
lization of the magmas would have yielded widespread hypersaline brines in the fluid inclusions of the quartz stockworks. From the fact that significant dilution of such aqueous fluids by meteoric fluids does not appear to be a viable alternative (see above), we conclude that the chlorine content of the magma may have been relatively low. The relatively low overall salinities of the aqueous fluids may have inhibited their metal-transport capabilities. Moreover, the presence of significant amounts of $\mathrm{CO}_{2}$ in the Buckingham system effectively increased the depth below the paleosurface where boiling and (or) effervescence would be initiated. As a result, the volume of rock between the paleosurface and the boiling-nonboiling interface must increase, thereby also contributing to molybdenum concentrations in this class of deposit much less than those in the Climax type. Drummond and Ohmoto (1985) noted that fluids with the highest initial $\mathrm{CO}_{2}$ contents have a tendency to deposit minerals over the greatest vertical distance, aided in part by a corresponding increase in the $\mathrm{pH}$ of the fluids. Fluids with a comparatively high $\mathrm{Mo} / \mathrm{Cu}$ ratio may have been produced in the Buckingham system by a combination of immiscibility of the fluids from the magma at a relatively deep level, possibly late in the crystallization history of the magma, and relatively low overall initial chlorine contents (see Candela and Holland, 1986). Furthermore, the experimental results of Hemley and others (1986) indicated that some metals (iron, zinc, and lead) could be carried for relatively long distances on a decreasing pressure gradient as long as the corresponding decreases in temperature did not significantly offset the pressure effect. Such a phenomenon may also apply to molybdenum in the Buckingham system.

\section{LITTLE GIANT MINE}

Four samples of quartz-arsenopyrite veins associated with silver mineralization at the Little Giant Mine were studied for comparative purposes using the heating and freezing stage (table 53). These veins all cut late Eocene or early Oligocene rhyolite associated with mineralization. The overall fabric of individual veins is markedly different from the fabric of veins associated with the Buckingham molybdenum system. At the Little Giant Mine, many of the veins, generally 0.5 to $1.0 \mathrm{~cm}$ wide, show notable concentrations of terminated quartz crystals that indicate crystallization in an open-space environment. In addition, there are extremely wide ranging variations of fluid-inclusion concentrations along individual veins. Some adjoining quartz crystals show swarms of secondary 1.0to $5.0-\mu \mathrm{m}$ fluid inclusions concentrated in very small domains, whereas most of the nearby quartz crystals are almost barren of fluid inclusions. Elsewhere, some probable pseudosecondary fluid inclusions may be present close to some of the arsenopyrite crystals in vein quartz. The Little Giant Mine has types I, II, and IV fluid inclusions; all types are moderately saline $(0.2-14.7$ weight percent $\mathrm{NaCl}$ equivalent) and homogenize in the range $162-382{ }^{\circ} \mathrm{C}$ (table 53). Type II fluid inclusions fill to vapor in the range $310-350{ }^{\circ} \mathrm{C}$ and coexist in one sample with type I fluid inclusions that fill to liquid in an almost identical temperature interval $\left(305-345^{\circ} \mathrm{C}\right)$. Therefore, the fluids associated with early-stage silver mineralization at the Little Giant Mine appear to have been boiling at times in the temperature interval $305-350{ }^{\circ} \mathrm{C}$. In some of the samples examined, there appears to be a preferred concentration of $\mathrm{CO}_{2}$-bearing, type IV fluid inclusions in quartz phenocrysts. The quartz-veins in these samples do not seem to show increased abundance of type IV fluid inclusions. These relations may indicate circulation of $\mathrm{CO}_{2}$-bearing fluids in the mineralized parts of the Little Giant vein system before shattering by postrhyolite displacement(s) along the Little Giant fault and emplacement of fluids associated with most of the mineralization there. Thus, the fluids associated with silver mineralization appear not to be markedly different from most of those associated with the Buckingham molybdenum system with respect to homogenization temperature, salinity, presence of carbon dioxide, and occurrence of boiling.

\section{QUARTZ STOCKWORKS AT BLUFF}

Reconnaissance heating and freezing studies were made on four samples of vein quartz from the quartz stockworks at Bluff (pl. 1) primarily to quantify thereby the highly saline fluids associated with these rocks (table 53). As described above, the quartz stockworks at Bluff may have been the locus for the lode source(s) of placer gold in the Vail placer and in the placer of Paiute Gulch near the north boundary of the area. These four samples include local stockwork-veined fabrics in the biotite-hornblende monzogranite of Bluff area that shows mostly argillic assemblages, the biotite-hornblende monzogranite of 
TABLE 53.-Temperature and salinity data from fluid inclusions hosted by vein quartz in the Little Giant Mine and in the quartz stockworks centered at Bluff

\begin{tabular}{|c|c|c|c|c|c|c|c|c|}
\hline Sample No. & $\begin{array}{l}\text { Rock } \\
\text { type }^{1}\end{array}$ & $\begin{array}{l}\text { Composite vein } \\
\text { assemblage }\end{array}$ & Selvage 3 & $\begin{array}{l}\text { Assemblage(s) } \\
\text { in rock }{ }^{3}\end{array}$ & $\begin{array}{l}\text { Type of } \\
\text { inclusion }\end{array}$ & $\begin{array}{l}\text { Homogenization } \\
\text { temperature } \\
\text { range }\left({ }^{\circ} \mathrm{C}\right) 5\end{array}$ & $\begin{array}{c}\text { Salinit } \\
\text { Weight } \% \mathrm{NaC} 1 \\
\text { equivalent }\end{array}$ & $\begin{array}{l}\text { Number } \\
\text { measured }\end{array}$ \\
\hline \multicolumn{9}{|c|}{ Little Giant Mine } \\
\hline 83 TT50 & $\mathrm{R}$ & Q-asp-Wm(tr) & -- & Arg & I & $162-324$ (19) & - & -- \\
\hline $83 T T 46$ & $\mathrm{R}$ & Q-asp & -- & IA, Phy & I & $177-324(24)$ & $0.2-1.7$ & 10 \\
\hline 83TT51 & $\mathrm{R}$ & Q-asp-Mo-Wm(tr) & -- & Arg & $\begin{array}{l}\text { I } \\
\text { II }\end{array}$ & $\begin{array}{l}305-345(22) \\
310-350(15)\end{array}$ & $\begin{array}{c}4.9-6.6 \\
--\end{array}$ & $\begin{array}{l}7 \\
--\end{array}$ \\
\hline $83 \mathrm{TT}_{47}$ & $\mathrm{R}$ & Q-asp & -- & Arg & I, IV & $\begin{array}{c}340-382(31) \\
-\end{array}$ & $\begin{array}{c}1.1 \\
.4-14.7\end{array}$ & $\begin{array}{l}1 \\
4\end{array}$ \\
\hline \multicolumn{9}{|c|}{ Quartz stockworks at B1uff } \\
\hline $83 \mathrm{TT} 54$ & M & $\mathrm{Q}-\mathrm{ch} 1(\mathrm{tr})$-fx(after py?) & - & Arg & $\begin{array}{c}\text { I } \\
\text { II } \\
\text { III }\end{array}$ & $\begin{array}{ll}216-237 & (9) \\
385-420 & (3) \\
185-500 & (14)\end{array}$ & $\begin{array}{c}1.7-21.9 \\
-- \\
35 .-55 .\end{array}$ & $\begin{array}{l}18 \\
-- \\
8\end{array}$ \\
\hline 83TT52 & $\mathrm{H}$ & $Q-W m(t r)-p y$ & Phy $(t r)$ & Phy & I & $334-354(9)$ & $5.5-7.6$ & 4 \\
\hline 83 TT55 & M & Q-rut-Wm(tr)-bio(tr) & -- & $P, \operatorname{Arg}$ & III & $185-285(9)$ & $37 .-60$. & 9 \\
\hline 83TT53 & M & Q-bio(tr)-fx(after py?) & - & P, Arg & III & $181-472(17)$ & $46 .-68$. & 14 \\
\hline
\end{tabular}

1 R, late Eocene or early O1igocene rhyolite; M, biotite hornblende monzogranite of Bluff area; H, Upper Cambrian Harmony Formation.

2 Q, quartz; asp, arsenopyrite; Wm, white mica; Mo, molybdenite; chl, chlorite; fx, iron oxide; py, pyrite; rut, rutile; bio, biotite; tr, trace.

3 Phy, phyllic; P, potassic; Arg, argillic; IA, intermediate argillic.

4 At $22+2{ }^{\circ} \mathrm{C}$ : I, low vapor volume+mostly $\mathrm{H}_{2} \mathrm{O}$; II, high vapor volume+mostly liquid $\mathrm{H}_{2} \mathrm{O}$; III, halite bearing; IV, mostly $\mathrm{CO}_{2}$ vapor+1iquid $\mathrm{CO}_{2}+$ most1y $\mathrm{H}_{2} \mathrm{O}$ liquid (see text).

5 In parenthesis, number of determinations of total homogenization temperature of fluid inclusions.

Bluff area that includes mixed potassic-argillic assemblages, and a quartz-veined sample of the Harmony Formation that shows a phyllic assemblage. The veined sample of the Harmony Formation also shows a marked difference from the other samples in the fabric of its fluid inclusions. Vein quartz in this sample of the Harmony Formation (83TT52, table 53) shows abundant secondary fluid inclusions entrapped along swarms of annealed microcracks that parallel approximately the veins' walls and cut across quartz-quartz crystal boundaries. In contrast, the fluid inclusions in the remaining three samples are distributed quite randomly throughout individual quartz crystals of veins; there are no preferred concentrations of fluid inclusions along annealed microcracks that cut across quartz-quartz crystal boundaries. Although only type I fluid inclusions were measured during the heating and freezing tests because of optical limitations, vein quartz from this sample of the Harmony Formation also includes abundant type II fluid inclusions and sparse type IV fluid inclusions. Therefore, low-density, boiling fluids seem to have been associated with late- stage phyllic assemblages in this general area. However, extremely saline (as much as 68 weight percent $\mathrm{NaCl}$ equivalent) and high-temperature (as high as $500{ }^{\circ} \mathrm{C}$ ) boiling fluids appear to be associated genetically with the emplacement of early-stage quartz stockworks in the general area of Bluff. These relations attest to a fluid-inclusion signature characteristic of many porphyry copper systems elsewhere (Nash, 1976), but also quite similar to fluids associated with unmineralized porphyritic leucogranite and skarn southeast of the quartz stockworks at Bluff (see subsection below entitled "Porphyritic Leucogranite and Associated Skarn"). However, a porphyry copper system is not associated with these quartz stockworks.

\section{PORPHYRITIC LEUCOGRANITE AND ASSOCIATED SKARN}

After completion of the fluid-inclusion studies described above, a comprehensive investigation of 
fluid-inclusion relations in late Eocene or early Oligocene porphyritic leucogranite and its associated skarn A (see fig. 86) was undertaken by Theodore and Hammarstrom (1991). The rest of this section is a summary of the major conclusions of the fluidinclusion parts of that study. Fluid-inclusion relations suggest that high-temperature, boiling sodium-calcium brines circulated in the environment of skarn A as it evolved. A synoptic histogram plot of liquid-vapor homogenization temperature versus frequency for fluid inclusions of various types and paragenetic stages in quartz and andradite from skarn A and phenocrystic quartz from porphyritic leucogranite shows a multimodal distribution. The mode is $290-300{ }^{\circ} \mathrm{C}$ and is dominated by type III fluid inclusions that probably indicate condensation of relatively dense fluids during the later evolutionary stages of the skarn. Though difficult to quantify, the proportion of the type II fluid inclusions in phenocrystic quartz in the porphyritic leucogranite seems to be much higher than in vein quartz associated genetically with skarn A. Type III halite-bearing fluid inclusions show homogenization to liquid and show total overlap with filling temperatures determined for type II fluid inclusions, from $365{ }^{\circ} \mathrm{C}$ to higher than $600{ }^{\circ} \mathrm{C}$. Boiling may have occurred anywhere in this range of temperatures. The median homogenization temperature for all type II fluid inclusions is about $450{ }^{\circ} \mathrm{C}$; the median homogenization temperature for type II fluid inclusions from skarn $\mathrm{A}$ is about $475{ }^{\circ} \mathrm{C}$. The latter temperature probably is a good estimate of temperatures prevailing in skarn A during much of its prograde genesis. Although Roedder (1984) pointed out that the minimum temperature of homogenization for fluid inclusions that fill to vapor most likely approximates the pure endmember vapor in an unmixing fluid environment, one must also consider the protracted passage of fluid(s) past any point in such a system and the potential effects of necking on lowering the temperature of homogenization during such passage. Theodore and Hammarstrom (1991) used median temperatures because of necking and the possible offsetting effects of inhomogenous trapping of liquid and vapor. Five of the quartz veins they studied from skarn A show selvages of andradite. In addition, limited heating tests on type I pseudosecondary fluid inclusions hosted by andradite in skarn A yield filling temperatures in the range $475-575{ }^{\circ} \mathrm{C}$.

The dynamic nature of the boiling or unmixing event that accompanied development of skarn A is reflected by the wide-ranging values of salinity determined for vapor-rich type II fluid inclusions. Depression-of-freezing-point tests indicate that sa- linities of type II fluid inclusions are in the range 026.1 weight percent $\mathrm{NaCl}$ equivalent, unusually broad for this type of fluid inclusion (Roedder, 1984). The chemically complex nature of many type II fluid inclusions is indicated further by their unsaturated state with respect to $\mathrm{NaCl}$ at room temperature and above, although a significant number of them show minimum salinities higher than 23.3 weight percent $\mathrm{NaCl}$ equivalent, the value at the $\mathrm{NaCl}-\mathrm{H}_{2} \mathrm{O}$ eutectic (Roedder, 1984). Initial melting temperatures in the range -18 to $-40{ }^{\circ} \mathrm{C}$ for ice in type II fluid inclusions further suggest that there may be significant concentrations of calcium in these fluid inclusions. Thus, phase proportions in many type II inclusions at room temperature must result from the trapping of liquid and vapor in an unmixing or boiling environment. In addition, condensation of some highly saline fluid, type III fluid inclusions, may have occurred from the vapor-enriched fluid fraction in the boiling environment.

Salinities measured for type III fluid inclusions in skarn $\mathrm{A}$ and porphyritic leucogranite by Theodore and Hammarstrom (1991) are in the range 28.1-63.3 weight percent $\mathrm{NaCl}$ equivalent; the median salinity for these type II fluid inclusions is about 43 weight percent $\mathrm{NaCl}$ equivalent. The maximum error in reported $\mathrm{NaCl}$ contents is no more than 2 weight percent $\mathrm{NaCl}$ equivalent (Chou, 1987), when the volume of vapor remaining at the temperature of homogenization is not considered, as in the study by Theodore and Hammarstrom (1991). These salinities and widespread indication of dissolved $\mathrm{CaCl}_{2}$ are comparable with salinities and chemical signatures associated with skarn-forming fluids that elsewhere formed significant deposits of copper, gold, silver and tungsten (Kwak, 1986). However, the presence of significant amounts of $\mathrm{CaCl}_{2}$ in high-salinity fluid inclusions will have a tendency to reduce markedly the solubility of $\mathrm{NaCl}$ in the brine and will indicate erroneously high $\mathrm{NaCl}$ and $\mathrm{KCl}$ contents if melting temperatures are referred to the system $\mathrm{NaCl}-\mathrm{KCl}-\mathrm{H}_{2} \mathrm{O}$ (Sterner and others, 1988).

The absence of significant gold mineralization in skarn $\mathrm{A}$ at the present levels of exposure may reflect a local structural setting and extent of skarn development different from that present in skarns mineralized farther to the east at the Labrador Mine and at the Surprise Mine (pl. 1). Certainly solubility of gold as a gold-chloride complex in the highly saline brines associated with development of skarn $\mathrm{A}$ is adequate for transport at the pressure and temp-erature that we infer prevailed during skarn development (Seward, 1984). A pH increase accompanied by a corresponding decrease in 
chloride activity and (or) temperature would be effective in precipitating gold through destabilization of gold-chloride complexes, if the fluid were reduced by reaction with wallrock (Einaudi, 1982b; Henley, 1985). However, the Harmony Formation in the general area of skarns A, B, and C does not include significant concentrations of minerals that could act as reductants. Furthermore, the absence of any significant concentration of sulfides in skarn A suggests that activity of sulfur species in solution during prograde genesis of the skarn was low. Elsewhere, some gold-bearing skarns apparently are associated with high-temperature fluids and highly saline fluids (Cocker and Pride, 1986; Theodore and others, 1986). Bodnar (1986), however, notes that gold deposition in a skarn environment typically is associated with circulation of late-stage, low-salinity (less than 15 weight percent $\mathrm{NaCl}$ equivalent), moderate-temperature fluids $\left(250-350{ }^{\circ} \mathrm{C}\right)$ of probable meteoric origin. At the Red Dome, Australia, gold skarn deposit, Ewers and Sun (1988) suggest that nonboiling, 260-400 ${ }^{\circ} \mathrm{C}, 2$ to 24 weight percent $\mathrm{NaCl}$ equivalent fluids were diluted over time to cause precipitation of gold. At the Fortitude gold skarn deposit, sulfide deposition with accompanying free gold formed at temperatures of $300-450{ }^{\circ} \mathrm{C}$ from relatively low salinity fluids (much less than 26 weight percent $\mathrm{NaCl}$ ) (Myers and Meinert, 1988). Myers and Meinert (1988) further suggested that bisulfide complexes were dominant in the distal Fortitude gold skarn, whereas chloride complexes may have been dominant in the proximal West ore body, a copper-gold-silver skarn. Nonetheless, all of the above discussion presupposes that gold was present in the environment of skarn A as it evolved. Trudu and Bloom (1988) pointed out that to generate an ore deposit, hypersaline fluids emanating from a magma must be relatively long lived and abundant and must contain gold. In the environment of skarn A, none of the three conditions may have been prevailing.

\section{PLACER NUGGET FROM PAIUTE GULCH}

Several gold nuggets were collected from placer operations during 1985 at Paiute Gulch near the north boundary of the area (pl. 1). The gold in one of these nuggets has been molded against abundant euhedral terminated quartz crystals (fig. 137A). Examination of a doubly polished plate of this nugget reveals that fluid inclusions in the quartz are mostly type I, but sparse concentrations of type II are present also. The fluid inclusions are extremely small, generally in the range 1-10 $\mu \mathrm{m}$. Although the optics made the sample extremely difficult to work with, 28

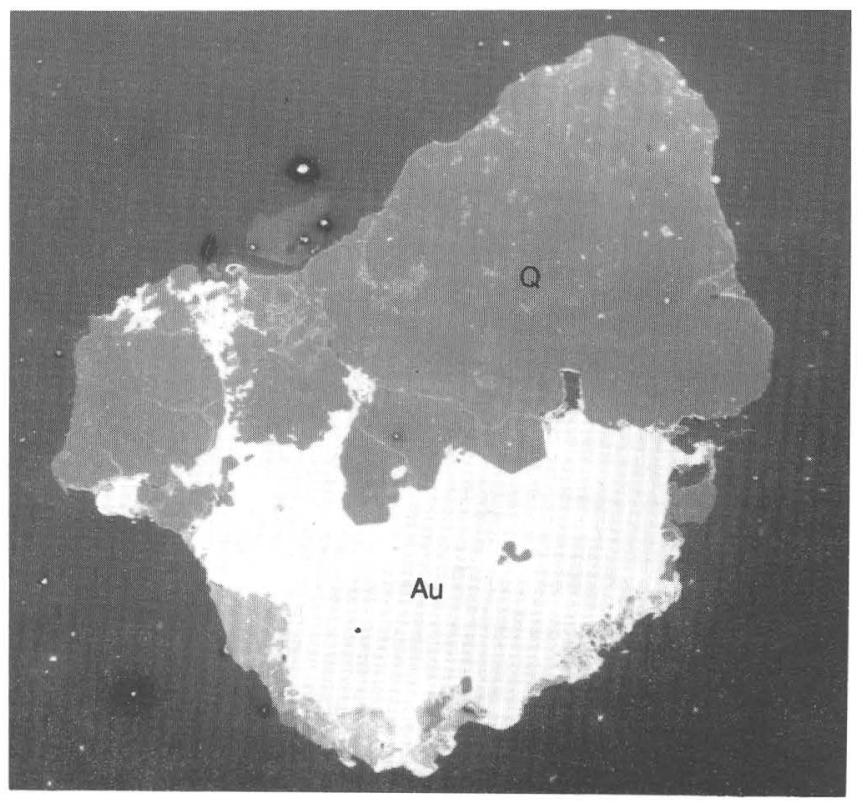

$\boldsymbol{A}$
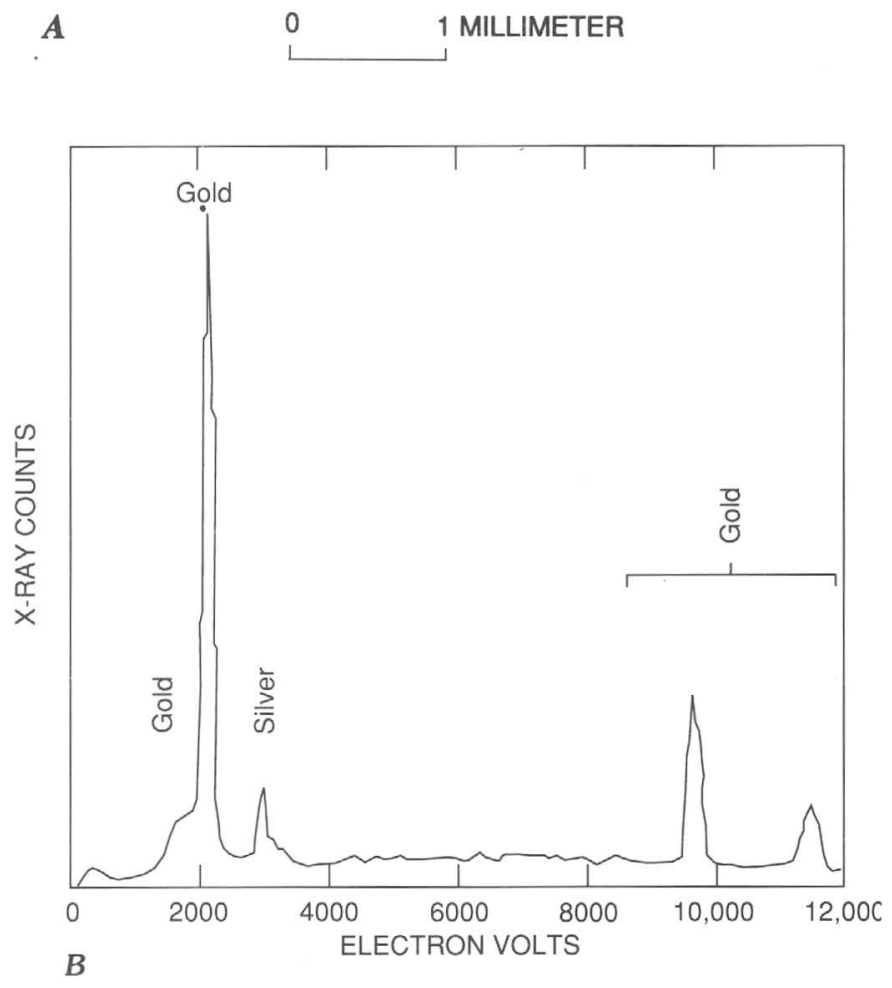

FIguRE 137.-Secondary-electron micrograph (A) and energydispersive X-ray spectra $(B)$ of placer gold with attached vein quartz from Paiute Gulch placer. Au, gold; Q, quartz. Sample 87TT1a. 
homogenization temperatures were obtained from type I fluid inclusions that were approximately 5 to $10 \mu \mathrm{m}$ wide. The range of homogenization temperatures is $150-353{ }^{\circ} \mathrm{C}$; the mean is about $265{ }^{\circ} \mathrm{C}$. No type III fluid inclusions are present in the quartz, and the optics precluded determination of any homogenization temperatures of the sparse numbers of type II fluid inclusions in the sample, and determination of any salinities for the type I fluid inclusions. The absence of type III fluid inclusions in the vein quartz attached to the gold nugget seems to suggest that most of such gold in the placer may not have been associated genetically with some of the hightemperature and high-saline stages of vein emplacement in the lode source. Nonetheless, the presence of types I and II fluid inclusions together in the vein quartz suggests that the fluids genetically associated with the gold may have been boiling. The phyllicaltered, quartz-veined sample of the Harmony Formation examined above from quartz stockworks of the Bluff area may be representative of an inplace lode vein of a paragenetic stage equivalent to vein quartz attached to the gold nugget. Qualitative analysis of energy-dispersive X-ray spectra of the placer nugget suggests that there may be about 6 atomicweight percent $\mathrm{Ag}$ in the gold (fig. 137B).

Initial examination of other placer gold nuggets from Paiute Gulch by SEM revealed that gold is also intergrown with several bismuth-bearing minerals including bismutite $\left(\mathrm{Bi}_{2}\left(\mathrm{CO}_{3}\right) \mathrm{O}_{2}\right)$, tellurobismuthite $\left(\mathrm{Bi}_{2} \mathrm{Te}_{3}\right)$, and sillenite $\left(\gamma-\mathrm{Bi}_{2} \mathrm{O}_{3}\right)$ (Theodore and others, 1988). One of the nuggets shows a highly irregular, wormy intergrowth of gold with sillenite (fig. 138).

Examination by X-ray powder-camera techniques of a part of the nugget (fig. 138), showing gold intergrown with a previously unknown bismuthbearing mineral, established that the mineral intergrown with gold is sillenite (ideally, $\gamma-\mathrm{Bi}_{2} \mathrm{O}_{3}$; Frondel, 1943; Strunz, 1957), an unusual polymorph of the $\mathrm{Bi}_{2} \mathrm{O}_{3}$ family of minerals that is bodycentered cubic (Theodore and others, 1988). The infrequency in nature of this mineral, and, in fact, of all $\mathrm{Bi}_{2} \mathrm{O}_{3}$ polymorphs, is evidenced by their absence from a treatise on the geochemistry of bismuth (see Angino and Long, 1979). However, sillenite in the nugget probably does not include sparse amounts of silicon and does not have a formula that approaches $\mathrm{Bi}_{12} \mathrm{SiO}_{20}$ as reported by Fleischer and others (1984). No silicon was detected by X-ray microanalysis of polished surfaces of sillenite using the SEM, and electron microprobe examination shows the sillenite to be quite homogeneous, free of silicon, calcium, and iron, and to contain less than 0.04 weight percent $\mathrm{S}$ (Theodore and others, 1988). The common variety of $\mathrm{Bi}_{2} \mathrm{O}_{3}(\alpha-$ $\mathrm{Bi}_{2} \mathrm{O}_{3}$ ) was considered to be a low-temperature form, which elsewhere is present locally in association with bismutite (ideally, $\mathrm{Bi}_{2}\left(\mathrm{CO}_{3}\right) \mathrm{O}_{2}$; Frondel, 1943). Some bismutite is, indeed, also present in the nugget from Paiute Gulch. The domain with low reflectivity near the left part of figure $138 \mathrm{~A}$ probably has both of these bismuth-bearing minerals. Bismutite, the darker phase of the two when examined by scanning secondary electrons, appears to be present in diffuse veins, and thereby it probably postdates sillenite. Therefore, the overall fabric in the nugget seems to suggest myrmekitic or eutectoid exsolution of gold and bismuth from some unknown precursor mineral(s), and subsequent alteration of the bismuth to sillenite, the latter mineral possibly forming in the supergene environment. Elsewhere, the $\gamma-\mathrm{Bi}_{2} \mathrm{O}_{3}$ polymorph, sillenite, has been found to be present near Durango, N. Mex. (Frondel, 1943), and in the Monapo, Mozambique, granite pegmatite (Correia Neves and others, 1974). However, the specific geologic mode of the occurrence near Durango is not given. Furthermore, nor is the stability field of $\gamma-\mathrm{Bi}_{2} \mathrm{O}_{3}$ known with confidence from the few experimental studies carried out on this mineral to date. Fusion for 5 minutes and rapid cooling of $\mathrm{Bi}_{2} \mathrm{O}_{3}$ or heating of $\mathrm{Bi}_{2} \mathrm{O}_{3}$ at $700{ }^{\circ} \mathrm{C}$ in an evacuated tube results in neocrystallization of $\gamma-\mathrm{Bi}_{2} \mathrm{O}_{3}$, sillenite (Sillen, 1938; Palache and others, 1958). Subsequently, Aurivillius and Sillen (1945) inferred from density measurements and powder photographs that the unit cell of body-centered-cubic sillenite contains $\mathrm{Bi}_{26} \mathrm{O}_{39}$. Lastly, Surnina and Litvin (1970) synthesized prismatic, 1- to 2-mm-long crystals of $\mathrm{Bi}_{2} \mathrm{O}_{3}$ at $450{ }^{\circ} \mathrm{C}$ and 400 to 2,000 bars in aqueous $\mathrm{NaOH}$ solutions wherein the ratio of $\mathrm{Bi}_{2} \mathrm{O}_{3}$ to metal oxide (aluminum, gallium, or indium) is greater than 2 .

Using an image-processing system, Theodore and others (1989) determined the areal percentages of the component minerals in the eutectoid-type intergrowth of sillenite and gold at Paiute Gulch. The overall range for the eight areas examined is 34.5 to 46.3 areal percent Au. However, seven of the eight determinations fall in the narrow range 42.0-46.3 areal percent $\mathrm{Au}$, corresponding well to the gold content of maldonite, $\mathrm{Au}_{2} \mathrm{Bi}$ (65.7 weight percent $\mathrm{Au}$ ). The $\mathrm{Au}-\mathrm{Bi}$ system shows a peritectic at $373{ }^{\circ} \mathrm{C}$, the upper stability limit for $\mathrm{Au}_{2} \mathrm{Bi}$ (Hansen, 1958). Thus, the nugget texture is unlikely to have developed from deposition above 373 ${ }^{\circ} \mathrm{C}$. This gold-sillenite intergrowth, of maldonite bulk composition, is considered to have resulted 
from initial crystallization of maldonite at or below $373{ }^{\circ} \mathrm{C}$, perhaps even from a melt at temperatures between 373 and $341{ }^{\circ} \mathrm{C}$. More probably, however, the maldonite crystallized within the lower part of

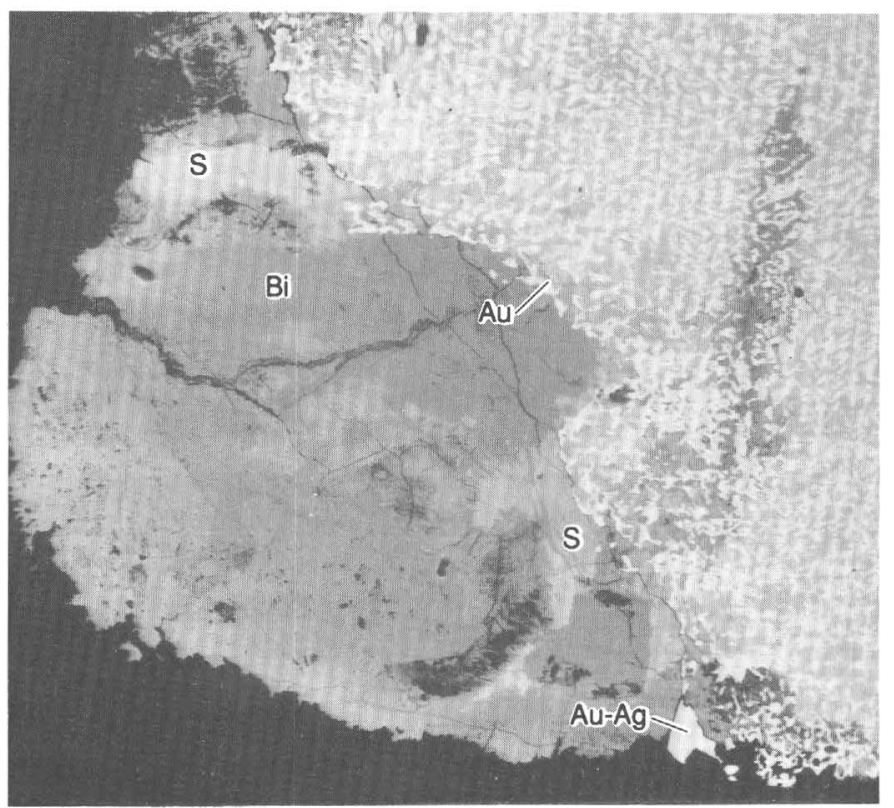

$\boldsymbol{A}$ 0 400 MICRONS

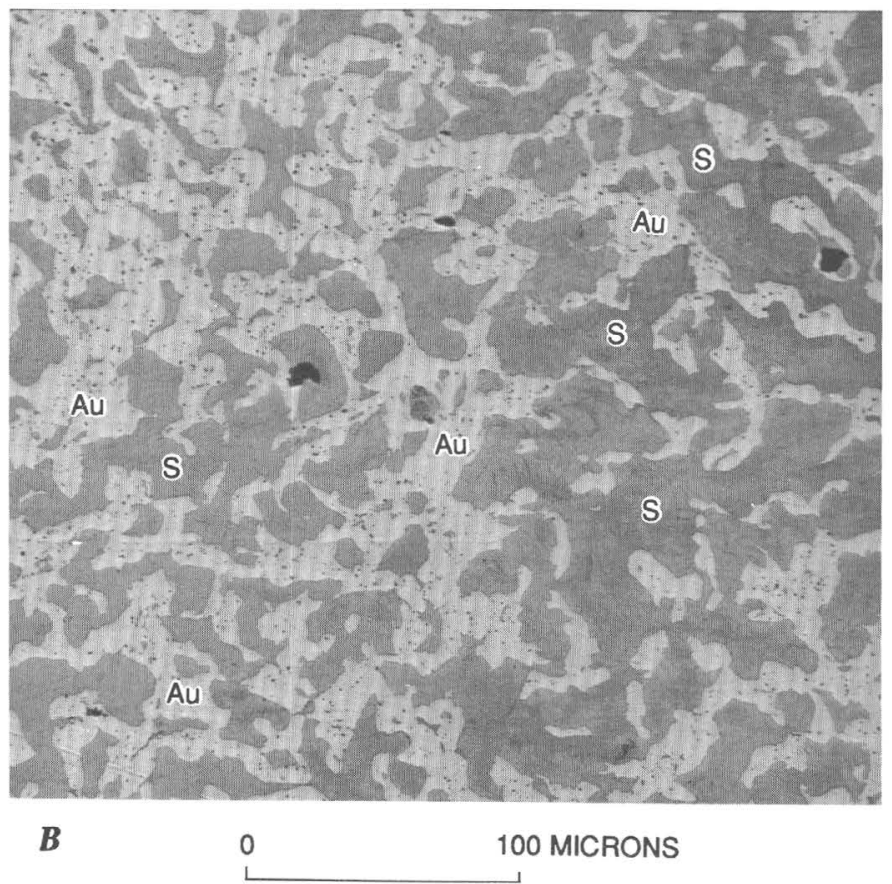

FIGURE 138.-Scanning secondary-electron micrographs $(A-C)$ of placer gold from Paiute Gulch intergrown with sillenite (S), $\mathrm{Bi}_{2} \mathrm{O}_{3}$, and probable bismutite, $\mathrm{Bi}_{2}\left(\mathrm{CO}_{3}\right) \mathrm{O}_{2}$ (Bi) (see text). Most gold $(\mathrm{Au})$ shows no detectable silver in its energy-dispersive $\mathrm{X}$-ray spectra. Field with a generally low reflectivity in figure this range of temperatures by deposition from hydrothermal fluids. Subsequently, the maldonite is presumed to have broken down to yield the eutectoid-type texture. Barton and Skinner (1979) note that maldonite becomes unstable with respect to gold and bismuth at a temperature of approximately $113{ }^{\circ} \mathrm{C}$. Ramdohr (1969) noted that he had never seen maldonite; he suspected that myrmekitically intergrown gold and bismuth in an approximate $1: 1$ ratio represents decomposed maldonite.

Another gold nugget consists of silver-bearing gold and an interbladed bismuth-telluride mineral (fig. 139). The bismuth-telluride may be tellurobismuthite, ideally $\mathrm{Bi}_{2} \mathrm{Te}_{3}$. The association of gold with bismuth in these placers suggests that some gold there may also be derived from skarn (Orris and others, 1987).

\section{SUGGESTIONS FOR EXPLORATORY PROGRAMS}

The data gathered during our study of the Buckingham system, combined with other resource data, provide regional and local implications for ex-

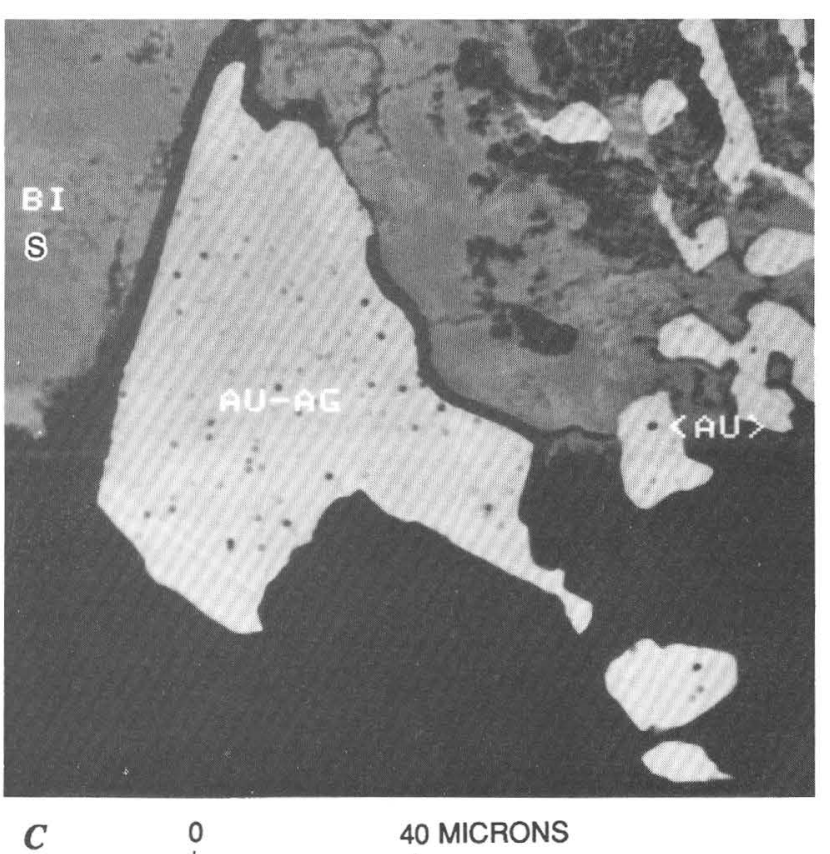

$138 \mathrm{~A}$ probably includes some bismutite, indicated by those dark domains with extremely low reflectivity that in places cut the sillenite. Some silver was detected in one fragment (Au-Ag, fig. $138 A, C$ ) intergrown with sillenite. 
ploratory programs for molybdenum. On the regional scale, the presence of an extremely large, Late Cretaceous stockwork molybdenum system at Buckingham, together with notable occurrences of molydenite in the Late Cretaceous granodiorite at Trenton Canyon in the western part of the district, suggests that all shallow-seated, Late Cretaceous
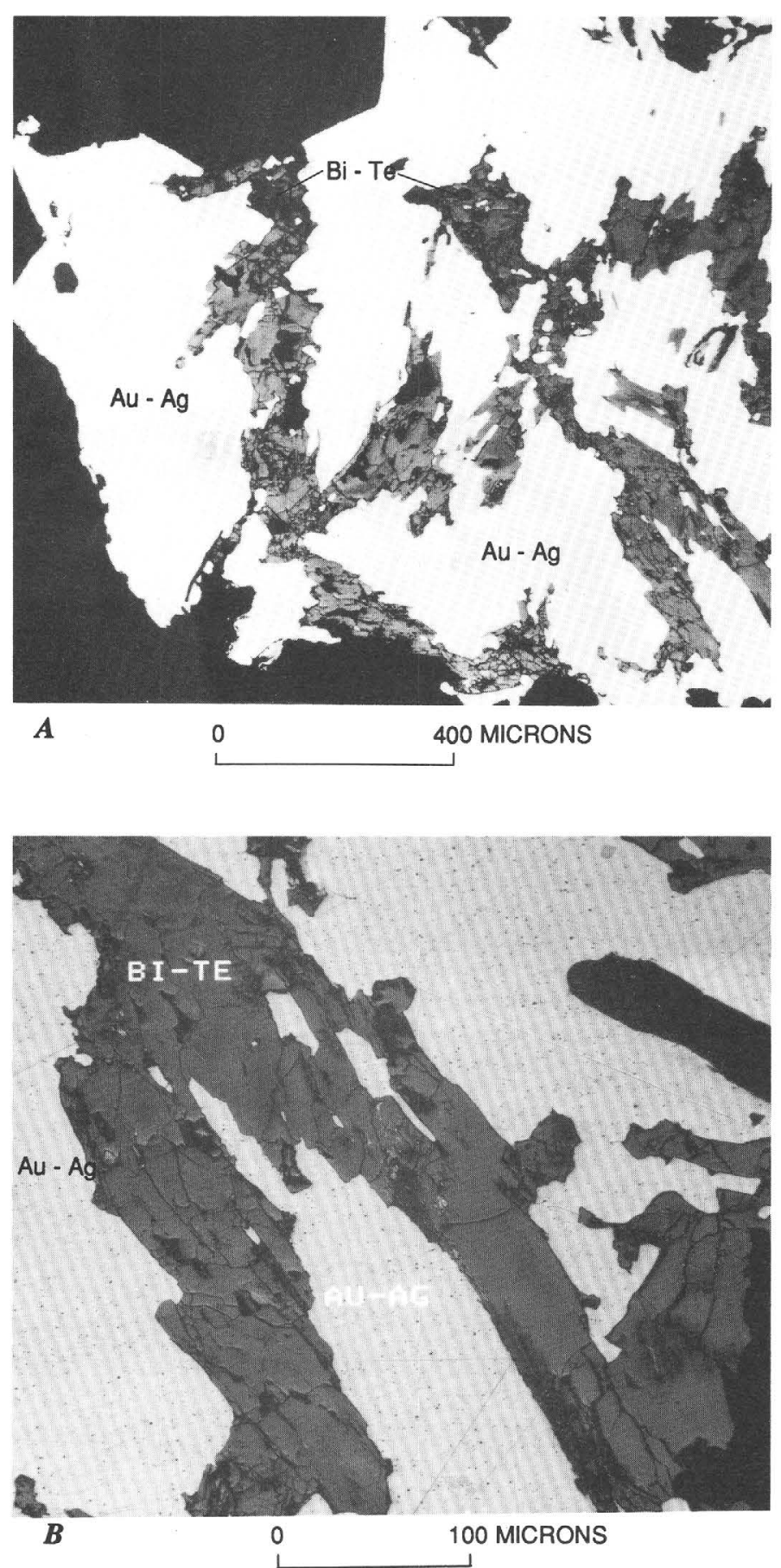

Figure 139.-Scanning secondary-electron micrographs $(A, B)$ of a placer gold nugget from Paiute Gulch that contains some interbladed bismuth-telluride, possibly tellurobismuthite. Au$\mathrm{Ag}$, silver-bearing gold; Bi-Te, tellurobismuthite(?). composite granitoids exhibiting base- and ferrousmetal geochemical anomalies, including widespread occurrences of polymetallic veins, should be considered at least permissive for the presence of associated molybdenum mineralization of the low-fluorine or quartz monzonite type. The Late Cretaceous granitoids in the Battle Mountain Mining District and variably mineralized other intrusive rocks of approximately the same age at Gold Acres, at the north end of the Fish Creek Range, at Gregg Canyon, at the north end of Buffalo Mountain, and northeast of Gold Run Creek seem to define a loosely constrained cluster of both stockwork molybdenum systems of the low-fluorine type and porphyry copper-molybdenum systems in this part of the Great Basin (see fig. 1). The potential presence there of molybdenum or copper-molybdenum mineralization would be further enhanced by indications in outcrop of widespread quartz stockworks together with widespread potassic-alteration assemblages and (or) intermediate-argillic assemblages. Molybdenum-enriched ore shells may be draped umbrella shaped over genetically associated stocks and may not be exposed widely if the current erosional level is well below the paleosurface of the system. Furthermore, superposition of successively emplaced pulses of molybdenum, with associated tungsten and silver as potential byproducts, may lead to relatively large tonnages of enriched grades as exemplified by overlapping of mineralized shells belonging to the West and East stocks at Buckingham. Within the Buckingham system itself, the extent of molybdenum mineralization in the Vail Ridge block of the system, including that part immediately below the Contention pit, has not been fully defined at depth. Lowangle tectonic disruption during the Tertiary of the east-west alignment of stocks that make up the Buckingham system resulted in successively shallower parts of the system to be exposed on the east. The uppermost parts are exposed in the Vail Ridge block; on the surface of this block are increased abundances of molybdenum in its quartz stockworks. On the basis of the geometries in the West and East blocks, however, the molybdenumenriched shells in this block of the system could extend to considerable depths below the surface. In addition, precious-metal deposits zoned peripheral to the Buckingham system, particularly in the Vail Ridge block, should be considered carefully. Such potential increased abundances of precious metals could be structurally or lithologically controlled as exemplified by silica-pyrite associated gold mineralization at the Star Pointer Mine at Ely, Nev. (Smith and others, 1987), and known at Buck- 
ingham at the Empire and Northern Lights Mines (Schmidt and others, 1988).

Some relatively small tonnages of silver or goldsilver ore may be associated with Tertiary structures and intrusive rocks within the overall limits of the Buckingham system. The viability of such targets, however, is diminished by the general absence of rock types most favorable as hosts for replacement deposits.

The potential for additional gold-skarn deposits, or gold-bearing skarn deposits, following the terminology of Orris and others (1987) and restricted by them to skarns containing more than $1 \mathrm{~g} \mathrm{Au} / \mathrm{t}$, appears to be confined to the northern part of the area. Oxidized gold-copper skarn as described above at the Surprise Mine, just to the north of the pits at Copper Basin (pl. 1), appears to be related to Late Cretaceous magmatism associated with emplacement of the Buckingham molybdenum stockwork system (Schmidt and others, 1988). The oxidized ores at the Carissa Mine also may be considered as gold skarn. Thus, any porphyry-type systems recognized in the region, in fact, become systems that are at least potential hosts of gold skarn deposits. One of the significant results of our investigations is the genetic linkage between gold skarn, as described above, and Late Cretaceous stockwork molybdenum mineralization, although Late Cretaceous gold skarn is known elsewhere in Nevada (Dennis and others, 1989). All stockwork molybdenum systems known regionally should be considered carefully as possible hosts of gold skarn ore bodies. Gold in placers near these systems may indicate that the systems carry gold. In addition, widespread occurrence of late Eocene or early Oligocene garnet-diopside skarn associated with porphyritic leucogranite (pl. 1), provides another geologic environment for occurrence of gold skarn at Buckingham. However, as described above, much of the garnet-diopside skarn that is present relatively close to the large body of porphyritic leucogranite is apparently unmineralized and not affected significantly by hydrosilicate-alteration assemblages. Nonetheless, this igneous event has generated economically viable, copper-poor gold skarn at the Labrador Mine (Schmidt and others, 1989) and somewhat smaller overall concentrations of gold in skarn at the Overlook group of prospects. Much of the gold at both of these occurrences apparently is structurally controlled (K.W. Schmidt, oral commun., 1989). A broad, annulus-shaped area around the southeast end of the large body of porphyritic leucogranite may contain additional occurrences of genetically related gold skarn. Finally, minor gold is present in goethite-rich fault zones that cut skarn associated with Oligocene granodiorite porphyry north of the Surprise Mine.

\section{REFERENGES}

Abramson, B.S., Palin, J.M., Noll, M.R., Eggleston, Ted, NovoGradac, K.J., and Norman, D.L., 1982, Skarn formation and mineralization at the Continental mine, Central mining district, southwest New Mexico [abs.]: Geological Society of America Abstracts with Programs, v. 14, p. 429.

Ahmad, S.N., and Rose, A.W., 1980, Fluid inclusions in porphyry and skarn ore at Santa Rita, New Mexico: Economic Geology, v. 75 , no. 2 , p. 229-250.

Albee, A.L., and Ray, L., 1970, Correction factors for electron probe microanalysis of silicates, oxides, carbonates, phosphates, and sulfates: Analytical Chemistry, v. 42, p. 14081414.

Alderton, D.H.M., and Rankin, A.H., 1983, The character and evolution of hydrothermal fluids associated with the kaolinized St. Austell granite, SW England: Geological Society of London Journal, v. 140, p. 297-309.

Angino, E.E., and Long, D.T., eds., 1979, Geochemistry of bismuth: Benchmark Papers in Geology/49, Stroudsburg, Pa., Dowden, Hutchinson and Ross, 423 p.

Angus, S., Armstrong, B., de Reuk, K.M., Altunin, V.V., Gadetskii, O.G., Chapala, G.A., and Rowlinson, J.S., 1973, International thermodynamic tables of the fluid state: Carbon dioxide: New York, Pergamon, $67 \mathrm{p}$.

Anonymous, 1981, Major discoveries promise big surge in U.S. gold production: Arizona Paydirt, November 1981, no. 509, p. 12.

1986, New development highlights: Nevada: Engineering and Mining Journal International Directory, Mining Activity Digest, v. 13, no. 5, October 24, 1986, p. 12.

-1987a, Battle Mt. Gold reports on projects: California Mining Journal, January, 1987, v. 56, no. 5, p. 29-30.

$-1987 b$, Here it grows again: Battle Mt. profit up: Northern Miner, February 23, 1987, v. 72, no. 50, p. 24.

Arai, Y., Kaminishi, G., and Saito, S., 1971, The experimental determination of the P-V-T-X relations for the carbon dioxide-nitrogen and the carbon dioxide-methane systems: Journal of Chemical Engineering, Japan, v. 4, p. 113-122.

Argall, G.O., Jr., 1986, The golden glow at Battle Mountain: Engineering and Mining Journal, v. 187, no. 2, p. 32-37.

Armstrong, R.L., 1975, Precambrian (1500 m.y. old) rocks of central Idaho-The Salmon River Arch and its role in Cordilleran sedimentation and tectonics: American Journal of Science, v. 275-A, p. 437-467.

Arnorsson, Stefan, and Ivarsson, Gretar, 1985, Molybdenum in Icelandic geothermal waters: Contributions to Mineralogy and Petrology, v. 90, p. 179-189.

Atkinson, W.W., Jr., Kaczmarowski, J.H., and Erickson, A.J., Jr., 1982, Geology of a skarn-breccia orebody at the Victoria Mine, Elko County, Nevada: Economic Geology, v. 77, no. 4, p. 899-918.

Aurivillius, Bengt, and Sillen, L.G., 1945, Polymorphy of bismuth trioxide: Nature, v. 155 , no. 3932, p. 305-306.

Ayuso, R.A., and Shank, S.G., 1983, Quartz-molybdenite veins in the Priestly Lake granodiorite, north-central Maine: U.S. Geological Survey Open-File Report 83-800, 10 p.

Babaie, H.A., 1987, Paleogeographic and tectonic implications of the Golconda allochthon, southern Toiyabe Range, Nevada: Geological Society of America Bulletin, v. 99, p. 231-243. 
Bagby, W.C., and Berger, B.R., 1985, Geologic characteristics of sediment-hosted, disseminated precious-metal deposits in the western United States, in Berger, B.R., and Bethke, P.M., eds., Geology and geochemistry of epithermal systems: Society of Economic Geologists Reviews in Economic Geology, v. 2, p. 169-202.

Barruss, R.C., 1981, Analysis of phase equilibria in C-O-H-S fluid inclusions, in Hollister, L.S., and Crawford, M.L., eds., Fluid inclusions: Applications to petrology: Mineralogical Association of Canada, Short Course Handbook, v. 6, May, 1981, p. 39-74.

Barth, T.F.W., 1948, Oxygen in rocks, a basis for petrographic calculations: Journal of Geology, v. 56, no. 1, p. 50-60.

1962, Theoretical petrology (2d ed.): New York, John Wiley, $416 \mathrm{p}$.

Barton, M.D., Battles, D.A., Bebout, G.E., Capo, R.C., Christensen, J.N., Davis, S.R., Hanson, R.B., Michelson, C.J., and Trim, H.E., 1988, Mesozoic contact metamorphism in the western United States, in Ernst, W.G., ed., Metamorphism and crustal evolution of the western United States: Englewood Cliffs, N.J., Prentice-Hall, p. 110-178.

Barton, P.B., and Toulmin, Priestly, III, 1961, Some mechanisms for cooling hydrothermal fluids: U.S. Geological Survey Professional Paper 424-D, p. D348-D352.

Barton, P.B., Jr., and Skinner, B.J., 1979, Sulfide mineral stabilities, in Barnes, H.L., ed., Geochemistry of hydrothermal ore deposits: New York, John Wiley, p. 278-403.

Batchelder, J.N., 1973, A study of stable isotopes and fluid inclusions at Copper Canyon, Lander County, Nevada: San Jose, California State University, M.S. thesis, 92 p.

1977, Light-stable-isotope and fluid-inclusion study of the porphyry copper deposit at Copper Canyon, Nevada: Economic Geology, v. 72 , no. 1 , p. $60-70$.

Batchelder, J.N., Theodore, T.G., and Blake, D.W., 1976, Stable isotopes and geology of the Copper Canyon porphyry copper deposits, Lander County, Nevada: Society of Mining Engineers Transactions, v. 260, no. 3, p. 232-236.

Bateman, P.C., 1961, Granitic formations in the east-central Sierra Nevada near Bishop, California: Geological Society of America Bulletin, v. 72, no. 10, p. 1521-1538.

Bateman, P.C., Clark, L.D., Huber, N.K., Moore, J.G., Rinehart, C.D., 1963, The Sierra Nevada batholith-a synthesis of recent work across the central part: U.S. Geological Survey Professional Paper 414-D, p. D1-D46.

Beane, R.E., 1982, Hydrothermal alteration in silicate rocks: Southwestern North America, in Titley, S.R., ed., Advances in geology of the porphyry copper deposits, southwestern North America: Tucson, Ariz., University of Arizona Press, p. 117-137.

Beddoe-Stephens, B., Shepherd, T.J., Bowles, J.F.W., and Brook, M., 1987, Gold mineralization and skarn development near Muara Sipongi, West Sumatra, Indonesia: Economic Geology, v. 82 , no. 7 , p. $1732-1749$.

Bence, A.E., and Albee, A.L., 1968, Empirical correction factors for the electron microanalysis of silicates and oxides: Journal of Geology, v. 76, no. 4, p. 382-403.

Bird, D.K., and Helgeson, H.C., 1980, Chemical interaction of aqueous solutions with epidote-feldspar mineral assemblages in geologic systems. 1. Thermodynamic analysis of phase relations in the system $\mathrm{CaO}-\mathrm{FeO}-\mathrm{Fe}_{2} \mathrm{O}_{3}-\mathrm{Al}_{2} \mathrm{O}_{3}-\mathrm{SiO}_{2}-\mathrm{H}_{2} \mathrm{O}-\mathrm{CO}_{2}$ : American Journal of Science, v. 280, no. 9, p. 907-941.

Bird, D.K., Schiffman, Peter, Elders, W.A., Williams, A.E., and McDowell, S.D., 1984, Calc-silicate mineralization in active geothermal systems: Economic Geology, v. 79, no. 4, p. 671695.
Blake, D.W., and Kretschmer, E.L., 1983, Gold deposits at Copper Canyon, Lander County, Nevada: Nevada Bureau of Mines and Geology Report 36, p. 3-10.

Blake, D.W., Theodore, T.G., Batchelder, J.N., and Kretschmer, E.L., 1979, Structural relations of igneous rocks and mineralization in the Battle Mountain Mining District, Lander County, Nevada, in Ridge, J.D., ed., Papers on mineral deposits of western North America: International Association on the Genesis of Ore Deposits Symposium, 5th, SnowbirdAlta, Utah, 1978, Proceedings: Nevada Bureau of Mines and Geology Report 33, p. 87-99.

Blake, D.W., Theodore, T.G., and Kretschmer, E.L., 1978, Alteration and distribution of sulfide mineralization at Copper Canyon, Lander County, Nevada: Arizona Geological Society Digest, v. 11, p. 67-78.

Blake, D.W., Wotruba, P.R., and Theodore, T.G., 1984, Zonation in the skarn environment at the Tomboy-Minnie gold deposits, Lander County, Nevada, in Wilkins, Joe, Jr., ed., Gold and silver deposits of the Basin and Range province, western U.S.A.: Arizona Geological Society Digest, v. 15, p. 6772.

Bliss, N.W., and MacLean, W.H., 1975, The paragenesis of zoned chromite from central Manitoba: Geochimica et Cosmochimica Acta, v. 39, no. 6-7, p. 973-990.

Bloom, M.S., 1981, Chemistry of inclusion fluids: Stockwork molybdenum deposits from Questa, New Mexico, and Hudson Bay Mountain and Endako, British Columbia: Economic Geology, v. 76, no. 7, p. 1906-1920.

Bloomstein, E.I., 1986, Ammonia alteration is a geochemical link in gold deposits of the Carlin-Midas belt [abs.]: Journal of Geochemical Exploration, v. 25, no. 1-2, p. 239.

Bodnar, R.J., 1982, Fluid inclusions in porphyry-type deposits: Course notes, Mineral Deposits Research Review for Industry, Pennsylvania State University, April 6-9, 1982, p. RB1RB25.

1983, A method of calculating fluid inclusion volumes based on vapor bubble diameters and P-V-T-X properties of inclusion fluids: Economic Geology, v. 78, no. 3, p. 535-542.

1986, Fluid inclusion characteristics of skarns and limestone-hosted precious metals deposits associated with intrusions [abs.]: Geological Society of America Abstracts with Programs, v. 18, no. 6, p. 545.

Bodnar, R.J., and Beane, R.E., 1980, Temporal and spatial variations in hydrothermal fluid characteristics during vein filling in preore cover overlying deeply buried porphyry copper-type mineralization at Red Mountain, Arizona: Economic Geology, v. 75, no. 6, p. 876-893.

Bodnar, R.J., Burnham, C.W., and Sterner, S.M., 1985a, Synthetic fluid inclusions in natural quartz, III. Determination of phase equilibrium properties in the system $\mathrm{H}_{2} \mathrm{O}-\mathrm{NaCl}$ to $1000{ }^{\circ} \mathrm{C}$ and 1500 bars: Geochimica et Cosmochimica Acta, v. 49 , p. $1861-1873$.

Bodnar, R.J., Reynolds, T.J., and Kuehn, C.A., 1985b, Fluid-inclusion systematics in epithermal systems, in Berger, B.R., and Bethke, P.M., eds., Geology and geochemistry of epithermal systems, Reviews in Economic Geology, v. 2: El Paso, Texas, Society of Economic Geology, p. 73-97.

Bookstrom, A.A., 1977, The magnetite deposits of El Romeral, Chile: Economic Geology, v. 72, no. 6, p. 1101-1130.

1981, Tectonic setting and generation of Rocky Mountain porphyry molybdenum deposits: Arizona Geological Society Digest, v. 14, p. 215-226.

Botinelly, Theodore, 1979, Mineralogy as a guide for exploration in the Montezuma district, central Colorado: U.S. Geological Survey Open-file Report 79-1177, 16 p. 
Bottinga, Y., and Javoy, J., 1973, Comments on oxygen isotope geothermometry: Earth and Planetary Science Letters, v. 20, p. 250-265.

Bowers, T.S., and Helgeson, H.C., 1983, Calculation of the thermodynamic and geochemical consequences of nonideal mixing in the system $\mathrm{H}_{2} \mathrm{O}-\mathrm{CO}_{2}-\mathrm{NaCl}$ on phase relations in geologic systems: Equation of state for $\mathrm{H}_{2} \mathrm{O}-\mathrm{CO}_{2}-\mathrm{NaCl}$ fluids at high pressures and temperatures: Geochimica et Cosmochimica Acta, v. 47, p. 1247-1275.

Bowman, J.R., Covert, J.J., Clark, A.H., and Mathieson, G.A., 1985, The Can Tung E zone scheelite skarn orebody, Tungsten, Northwest Territories: Oxygen, hydrogen, and carbon isotope studies: Economic Geology, v. 80, no. 7, p. 1872-1895.

Bozzo, A.T., Chen, H.-S., Kass, J.R., and Barduhn, A.J., 1975, The properties of the hydrates of chlorine and carbon dioxide: Desalination, v. 16, p. 303-320.

Brew, D.A., and Ford, A.B., 1984, The northern Coast plutonicmetamorphic complex, southeastern Alaska and northwestern British Columbia, in Coonrad, W.C, and Elliot, R.C. eds. The U.S. Geological Survey in Alaska: Accomplishments during 1981: U.S. Geological Survey Circular 868, p. 120-124.

Brindley, G.W., and Brown, G., eds., 1980, Crystal structure of clay minerals and their X-ray identification: Mineralogical Society Monograph No. 5, London, 495p.

Brown, P.E., and Lamb, W.M., 1986, Mixing of $\mathrm{H}_{2} \mathrm{O}-\mathrm{CO}_{2}$ in fluid inclusions; Geobarometry and Archean gold deposits: Geochimica et Cosmochimica Acta, v. 50, no. 5, p. 847-852.

Brueckner, H.K., and Snyder, W.S., 1985, Structure of the Havallah sequence, Golconda allochthon, Nevada: Evidence for prolonged evolution in an accretionary prism: Geological Society of American Bulletin, v. 96, p. 1113-1130.

Bryant, D.G., 1968, Intrusive breccias associated with ore, Warren (Bisbee) Mining District, Arizona: Economic Geology, v. 63, no. 1, p. 1-12.

Bryner, Leonid, 1961, Breccia and pebble columns associated with epigenetic ore deposits: Economic Geology, v. 56, no. 3, p. 488508.

-1968, Proposed terminology for hydrothermal breccias and conglomerates: Economic Geology, v. 63, no. 6, p. 692.

Burnham, C.W., 1967, Hydrothermal fluids at the magmatic stage, in Barnes, H.L., ed., Geochemistry of hydrothermal ore deposits: New York, Holt Rinehart and Winston, p. 34-76.

1979, Magmas and hydrothermal fluids, in Barnes, H.L., ed., Geochemistry of hydrothermal ore deposits ( $2 \mathrm{~d}$ ed.): New York, John Wiley, p. 71-136.

Burnham, C.W., and Ohmoto, Hiroshi, 1980, Late-stage processes of felsic magmatism, in Ishihara, Shunso, and Takenouchi, Sukune, eds., Granitic magmatism and related mineralization: Mining Geology (Japan), special issue 8, p. 1-11.

Burrows, D.R., and Spooner, E.T.C., 1984, Fluid inclusion evidence for $\mathrm{H}_{2} \mathrm{O}-\mathrm{CO}_{2}$ phase separation associated with magmatically derived $\mathrm{MoS}_{2}$ mineralization within a posttectonic Archean granodiorite/trondhjemite intrusion, Mink Lake, N.W., Ontario [abs.]: Geological Association of CanadaMineralogical Association of Canada, Program with Abstracts, v. 9 , p. 49 .

-1985, Generation of an Archean $\mathrm{H}_{2} \mathrm{O}-\mathrm{CO}_{2}$ fluid enriched in $\mathrm{Au}, \mathrm{W}, \& \mathrm{Mo}$ by fractional crystallization in the Mink Lake intrusion, NW Ontario [abs.]: Geological Society of America Abstracts with Programs, 1985, v. 17, p. 536.

Burruss, R.C., 1981, Analysis of phase equilibria in C-O-H-S fluid inclusion, in Hollister, L.S., and Crawford, M.L., eds., Fluid inclusions: applications to petrology: Mineralogical Association of Canada Short Course Handbook, v. 6, p. 39-74.
Camus, Francisco, 1975, Geology of the El Teniente orebody with emphasis on wall-rock alteration: Economic Geology, v. 70, no. 8, p. 1341-1372.

Candela, P.A., 1986, The evolution of aqueous vapor from silicate melts: Effect on oxygen fugacity: Geochimica et Cosmochimica Acta, v. 50, p. 1205-1211.

Candela, P.A., and Holland, H.D., 1984, The partitioning of copper and molybdenum between silicate melts and aqueous fluids: Geochimica et Cosmochimica Acta, v. 48, p. 373-380. -1986, A mass transfer model for copper and molybdenum in magmatic hydrothermal systems: The origin of porphyrytype ore deposits: Economic Geology, v. 81, no. 1, p. 1-19.

Carmichael, I.S.E., Turner, F.J., and Verhoogen, John, 1974, Igneous petrology: New York, McGraw-Hill, 739 p.

Charef, A., and Ramboz, C., 1983, Evidence from fluid inclusions of fluid immiscibility during the deposition of late drusy barite in the $\mathrm{Pb}-\mathrm{Zn}$ district of Les Malines [abs.]: Symposium, European Current Research on Fluid Inclusions, Orleans, France, 1983, Program, p. 17.

Chesley, J.T., 1986, A combined ${ }^{18} \mathrm{O} /{ }^{16} \mathrm{O}$ and $\mathrm{D} / \mathrm{H}$ isotopic study of molybdenite mineralization at Pear Lake and related areas in the Pioneer Mountains, southwest Montana: Corvallis, Oregon State University, M.S. thesis, 91 p.

Chivas, A.R., 1978, Porphyry copper mineralization at the Koloula igneous complex, Guadalcanal, Solomon Islands: Economic Geology, v. 73, no. 5, p. 645-677.

Chou, I-M., 1987, Phase relations in the system $\mathrm{NaCl}-\mathrm{KCl}-\mathrm{H}_{2} \mathrm{O}$. Part III: Solubilities of halite in vapor-saturated liquids above $445{ }^{\circ} \mathrm{C}$ and redetermination of phase equilibrium properties in the system $\mathrm{NaCl}-\mathrm{H}_{2} \mathrm{O}$ to $1000{ }^{\circ} \mathrm{C}$ and 1500 bars: Geochimica et Cosmochimica Acta, v. 51, p. 1965-1975.

Christiansen, E.H., and Lee, D.E., 1986, Fluorine and chlorine in granitoids from the Basin and Range province, western United States: Economic Geology, v. 81, no. 6, p. 14841494.

Clayton, R.N., and Mayeda, T.K., 1963, The use of bromine pentafluoride in the extraction of oxygen from oxides and silicates from isotopic analysis: Geochimica et Cosmochimica Acta, v. 27, p. 43-52.

Cloke, P.L., and Kesler, S.E., 1979, The halite trend in hydrothermal solutions: Economic Geology, v. 74, no. 8, p. 18231831.

Coats, R.R., and Riva, J.F., 1983, Overlapping overthrust belts of late Paleozoic and Mesozoic ages, northern Elko County, Nevada, in Miller, D.M., and others, eds., Tectonic and stratigraphic studies in the eastern Great Basin: Geological Society of America Memoir 157, p. 305-327.

Cocker, M.D., and Pride, D.E., 1986, Evolution of Au-Ag-Pb-Zn$\mathrm{Cu}-\mathrm{Mo}$ mineralization in the Breckenridge mining district, Colorado [abs.]: Geological Society of America Abstracts with Programs, v. 18, no. 6, p. 567.

Collins, P.L.F., 1979, Gas hydrates in $\mathrm{CO}_{2}$-bearing fluid inclusions and the use of freezing data for estimation of salinity: Economic Geology, v. 74, no. 6, p. 1435-1444.

Conway, C.M., and Taylor, H.P., Jr., $1969, \mathrm{O}^{18} / \mathrm{O}^{16}$ and $\mathrm{C}^{13} / \mathrm{C}^{12}$ ratios of coexisting minerals in the Oka and Magnet Cove carbonatite bodies: Journal of Geology, v. 77, p. 618-626.

Correia Neves, J.M., Lopes Nunes, J.E., Sahama, T.G., Lehtinen, Martii, and von Knorring, O., 1974, Bismuth and antimony minerals in the granite pegmatites of northern Mozambique: Universidade de Lourenco Marques Revista de Ciencias Geologicas, v. 7, ser. A, p. 1-37.

Cox, D.P., and Singer, D.A., eds., 1986, Mineral deposit models: U.S. Geological Survey Bulletin 1693, 379 p. 
Crawford, M.L., 1981, Phase equilibria in aqueous fluid inclusions, in Hollister, L.S., and Crawford, M.L., eds., Fluid inclusions: Applications to petrology: Mineralogical Association of Canada Short Course Handbook, v. 6, p. 75100.

Creasey, S.C., 1966, Hydrothermal alteration, in Titley, S.R., and Hicks, C.L., eds., Geology of the porphyry copper deposits; southwestern North America: Tucson, University of Arizona Press, p. 51-74.

1984, The Schultze Granite, the Tea Cup Granodiorite, and the Granite Basin Porphyry: A geochemical comparison of mineralized and unmineralized stocks in southern Arizona: U.S. Geological Survey Professional Paper 1303, 41 p.

Crittenden, M.D., Jr., Coney, P.J., and Davis, G.H., eds., 1980, Cordilleran metamorphic core complexes: Geological Society of America Memoir 153, $490 \mathrm{p}$.

Czehura, S.J., 1983, Vein paragenesis at Nevada Moly Hall deposit [abs.]: Geological Society of America Abstracts with Programs, v. 15, no. 5, p. 276.

Dalrymple, G.B., and Lanphere, M.A., 1969, Potassium-argon dating-principles, techniques, and applications to geochronology: San Francisco, W.H. Freeman Co., 258 p.

Dana, E.S., and Ford, W.E., 1949, A textbook of mineralogy (4th ed.): New York, John Wiley, 851 p.

Davis, J.C., 1973, Statistics and data analysis in geology, with a section on FORTRAN programs, by R.J. Sampson: New York, John Wiley, $550 \mathrm{p}$.

Deer, W.A., Howie, R.A., and Zussman, J., 1962a, Rock-forming minerals. Volume 1. Ortho- and ring silicates: London, Longmans, Green and Co., $333 \mathrm{p}$.

1962b, Rock-forming minerals. Volume 3. Sheet silicates: London, Longmans, Green and Co., 270 p.

1962c, Rock-forming minerals. Volume 5. Non-silicates: London, Longmans, Green and Co., 371 p.

1978, Rock-forming minerals. Volume 2A. Single chain silicates (2d ed.): New York, John Wiley, 668 p.

1982, Rock-forming minerals. Volume 1A. Orthosilicates: New York, John Wiley, 919 p.

Deines, P., 1970, The carbon and oxygen isotopic composition of carbonates from the Oka carbonatite complex, Quebec, Canada: Geochimica et Cosmochimica Acta, v. 34, p. 11991225.

Dennis, M.D., Myers, Greg, Wilkinson, W.H., and Wendt, C.J., 1989, Precious metal mineralization at Mt. Hamilton, White Pine County, Nevada: Littleton, Colo., Society of Mining Engineers Preprint 89-180, 3 p.

Desrochers, G.J., 1984, Geology of part of the Hilltop District, Lander County, Nevada: Reno, University of Nevada, M.S. thesis, $96 \mathrm{p}$.

Dickinson, W.R., 1970, Interpreting detrital modes of graywacke and arkose: Journal of Sedimentary Petrology, v. 40, p. 695-707.

-1979, Cenozoic plate tectonic setting of the Cordilleran region in the United States, in Armentrout, J.M., Cole, M.R., and TerBest, H., Jr., eds., Cenozoic paleogeography of the western United States: Pacific Coast Paleogeography Symposium 3: Los Angeles, Society of Economic Paleontologists and Mineralogists, Pacific Section, p. 1-13.

1981, Plate tectonic evolution of the southern Cordillera, in Dickinson, W.R., and Payne, W.D., eds., Relations of tectonics to ore deposits in the southern Cordillera: Arizona Geological Society Digest, v. 14, p. 113-135.

Dickinson, W.R., and Rich, E.I., 1972, Petrologic intervals and petrofacies in the Great Valley sequence, Sacramento Val- ley, California: Geological Society of America Bulletin, v. 83, p. 3007-3024.

Dickinson, W.R., and Suczek, C.A., 1979, Plate tectonics and sandstone compositions: American Association of Petroleum Geologists Bulletin, v. 63, no. 12, p. 2164-2182.

Dilles, J.H., and Wright, J.E., 1988, The chronology of early Mesozoic arc magmatism in the Yerington district of western Nevada and its regional implications: Geological Society of America Bulletin, v. 100, no. 5, p. 644-652.

Dixon, W.J., and Massey, F.J., 1951, Introduction to statistical analysis: New York, McGraw-Hill, 370 p.

Dolmage, Victor, and Brown, C.E.G., 1945, Contact metamorphism at Nickel Plate Mountain, Hedley, B.C.: Canadian Institute of Mining and Metallurgy and Mining Society of Nova Scotia Transactions, v. 48, p. 27-68.

Drábek, Milan, 1982, The system Fe-Mo-S-O and its geologic application: Economic Geology, v. 77, no. 4, p. 1053-1056.

Drummond, S.E., and Ohmoto, Hiroshi, 1985, Chemical evolution and mineral deposition in boiling hydrothermal systems: Economic Geology, v. 80, no. 1, p. 126-147.

Dunn, P.G., 1982, Geology of the Copper Flat porphyry copper deposit: Hillsboro, Sierra County, New Mexico, in Titley, S.R., ed., Advances in geology of the porphyry copper deposits, southwestern North America: Tucson, Ariz., University of Arizona Press, p. 313-325.

Einaudi, M.T., 1982a, Garnet and pyroxene compositions in skarn deposits: Carnegie Institute Washington Year Book 81, p. $320-324$.

1982b, Skarns associated with porphyry copper plutons, I. Descriptions of deposits, southwestern U.S., II. General features and origin, in Titley, S.R., ed., Advances in the geology of the porphyry copper deposits, southwestern North America: Tucson, Ariz., University of Arizona Press, p. 139-209.

Einaudi, M.T., and Burt, D.M., 1982, Introduction-terminology, classification, and composition of skarn deposits: Economic Geology, v. 77 , no. 4 , p. $745-754$.

Einaudi, M.T., Meinert, L.D., and Newberry, R.J., 1981, Skarn deposits, in Skinner, B.J., ed., Economic Geology, Seventyfifth anniversary volume, 1905-1980: New Haven, Conn., Economic Geology Publishing Co., p. 317-391.

Epler, Bill, 1985, Battle Mountain Gold gains listing on Toronto stock exchange: Southwestern Paydirt, no. 558, p. 10B-11B.

Erickson, R.L., and Marsh, S.P., 1974, Paleozoic tectonics in the Edna Mountain quadrangle, Nevada: U.S. Geological Survey Journal of Research, v. 2, p. 331-337.

Ernst, W.G., 1966, Synthesis and stability relations of ferrotremolite: American Journal of Science, v. 264, no. 1, p. 37-65.

Evans, B.E., and Frost, B.R., 1975, Chrome-spinel in progressive metamorphism-a preliminary analysis: Geochimica et Cosmochimica Acta, v. 39, no. 6-7, p. 959-972.

Evans, J.G., and Peterson, J.A., 1986, Distribution of minor elements in the Rodeo Creek NE and Welches Canyon quadrangles, Eureka County, Nevada: U.S. Geological Survey Bulletin 1657, $65 \mathrm{p}$.

Evans, J.G., and Theodore, T.G., 1978, Deformation of the Roberts Mountains allochthon in north-central Nevada: U.S. Geological Survey Professional Paper 1060, 18 p.

Evans, W.W., and Wright, T.L., 1972, Composition of liquidus chromite from the 1959 (Kilauea Iki) and 1965 (Makaopuhi) eruptions of Kilauea volcano, Hawaii: American Mineralogist, v. 57, no. 1-2, p. 217-230.

Evoy, E.F., 1961, Geology of the Gunnar uranium deposit, Beaverlodge area, Saskatchewan: Madison, University of Wisconsin, Ph.D thesis, 80 p. 
Ewers, G.R., and Sun, S.-S., 1988, Genesis of the Red Dome deposit, northeast Queensland: Bicentennial Gold 88, Melbourne, 1988, v. 2: Geological Society of Australia Abstracts Series, no. 23, p. 110-115.

Farmer, G.L., and DePaolo, D.J., 1983, Origin of Mesozoic and Tertiary granite in the western United States and implications for pre-Mesozoic crustal structure: 1 . Nd and $\mathrm{Sr}$ isotopic studies in the geocline of the northern Great Basin: Journal of Geophysical Research, v. 88, no. B4, p. 3379-3401.

1984, Origin of Mesozoic and Tertiary granite in the western United States and implications for pre-Mesozoic crustal structure: 2. Nd and $\mathrm{Sr}$ isotopic studies of unmineralized and $\mathrm{Cu}$ - and Mo-mineralized granite in the Precambrian craton: Journal of Geophysical Research, v. 89, no. B12, p. 1014110160.

Faure, Gunter, 1977, Carbon, chap. 20 of Principles of isotope geology: New York, John Wiley, p. 379-401.

Ferguson, H.G., Muller, S.W., and Cathcart, S.H., 1953, Geological map of the Coaldale quadrangle: U.S. Geological Survey Geologic Quadrangle Map GQ-23, scale 1:125,000.

Field, C.W., and Fifarek, R.H., 1985, Light stable-isotope systematics in the epithermal environment, in Berger, B.R., and Bethke, P.M., eds., Geology and geochemistry of epithermal systems, Reviews in Economic Geology, v. 2, p. 99-128.

Flanagan, F.J., 1957, Semi-quantitative spectrographic analysis and rank correlation in geochemistry: Geochimica et Cosmochimica Acta, v. 12 , no. 4, p. 315-322.

Fleischer, Michael, Wilcox, R.E., and Matzko, J.J., 1984, Microscopic determination of the nonopaque minerals: U.S. Geological Survey Bulletin 1627, $453 \mathrm{p}$.

Folk, R.L., 1974, Petrology of sedimentary rocks: Austin, Tex., Hemphill's Book Store, 182 p.

Fournier, R.O., 1967, The porphyry copper deposit exposed in the Liberty open-pit Mine near Ely, Nevada-part I. Syngenetic formation: Economic Geology, v. 62, no. 1, p. 57-81.

Freeborn, W.P., McGee, E.S., and Huebner, J.S., 1985, MINCLC: A FORTRAN program for recalculating mineral analyses: U.S. Geological Survey Open-File Report 85-257, 45 p.

Frondel, Clifford, 1943, Mineralogy of the oxides and carbonates of bismuth: American Mineralogist, v. 28, p. 521-535.

Gans, P.B., 1981, Geometry of pre-Basin and Range extension, east-central Nevada [abs.]: Eos (American Geophysical Union Transactions), v. 62, no. 17, p. 399.

Gans, P.B., and Miller, E.L., 1983, Style of mid-Tertiary extension in east-central Nevada, in Gurgel, K.D., ed., Geologic excursions in the overthrust belt and metamorphic core complexes of the intermountain region: Utah Geological and Mineral Survey Special Studies 59, p. 107-160.

Gans, P.B., Miller, E.L., McCarthy, J., and Ouldcott, M.L., 1985, Tertiary extensional faulting and evolving ductile-brittle transition zones in the northern Snake Range and vicinity: New insights from seismic data: Geology, v. 13, no. 3, p. 189-193.

Gates, Olcott, 1959, Breccia pipes in the Shoshone Range, Nevada: Economic Geology, v. 54, no. 5, p. 790-815.

Gehrig, M., Lentz, H., and Franck, E.V., 1979, Thermodynamic properties of water-carbon dioxide-sodium chloride mixtures at high temperatures and pressures, in Trimmerhaus, K.D., and Barber, M.S., eds., International Conference on Highpressure Science and Technology, 6th, Boulder, Colo., 1977, v. 1, Physical properties and material synthesis: New York, Plenum Press, p. 539-542.

Geldron, A., and Le Bel, L., 1983, Fluid characteristics of the stockwork molybdenum mineralization of Breittenbach (Vosge) [abs.]: Symposium, European Current Research on Fluid Inclusions, Orleans, France, 1983, Program, p. 28 [in French].
Gill, J.B., 1981, Orogenic andesites and plate tectonics: New York, Springer Verlag, 390 p.

Gilluly, James, and Gates, O., 1965, Tectonic and igneous geology of the northern Shoshone Range, Nevada: U.S. Geological Survey Professional Paper 465, $153 \mathrm{p}$.

Gilluly, James, and Masursky, Harold, 1965, Geology of the Cortez quadrangle, Nevada, with a section on Gravity and aeromagnetic surveys, by D.R. Mabey: U.S. Geological Survey Bulletin 1175, $117 \mathrm{p}$.

Glemser, O., and Wendlandt, H.G., 1963, Gaseous hydroxides: Advances in Inorganic Chemistry and Radiochemistry, v. 5, p. $215-258$.

Guilbert, J.M., and Park, C.F., Jr., 1986, The geology of ore deposits: New York, W.H. Freeman, 985 p.

Gustafson, L.B., and Hunt, J.P., 1975, The porphyry copper deposit at El Salvador, Chile: Economic Geology, v. 70, no. 5, p. 857-912.

Haas, J.L., Jr., 1971, The effect of salinity on the maximum geothermal gradient of a hydrothermal system at hydrostatic pressure: Economic Geology, v. 66, no. 6, p. 940-946. 1976, Physical properties of the coexisting phases and the thermochemical properties of the $\mathrm{H}_{2} \mathrm{O}$ component in boiling $\mathrm{NaCl}$ solutions: U.S. Geological Survey Bulletin 1421-A, p. A1A73.

Hague, Arnold, and Emmons, S.F., 1877, Descriptive geology: U.S. Geological Exploration of the 40th Parallel (King), v. 2, 890 p.

Hall, W.E., Friedman, Irving, and Nash, J.T., 1974, Fluid inclusion and light stable isotope study of the Climax molybdenum deposits, Colorado: Economic Geology, v. 69, no. 6, p. 884-901.

Hall, W.E., Schmidt, E.A., Howe, S.S., and Broch, M.J., 1984, The Thompson Creek, Idaho, porphyry molybdenum deposit-an example of a fluorine-deficient molybdenum granodiorite system, in Janelidze, T.V., and Tvalchredlidze, A.G., eds., International Association on the Genesis of Ore Deposits Quadrennial Symposium, 6th, Tbilisi, U.S.S.R., 1982, Proceedings: Stuttgart, E. Schweizerbart'sche Verlagsbuchhandlung, Stuttgart, v. 1, p. 349-357.

Hammarstrom, J.M., 1987, Data tables for microprobe analyses of garnets from skarns at Copper Basin in the Battle Mountain Mining District, Lander County, Nevada: U.S. Geological Survey Open-File Report 87-149, 103 p.

Hansen, Max, 1958, Constitution of binary alloys: New York, McGraw-Hill, 1,305 p.

Harris, N.B., and Einaudi, M.T., 1982, Skarn deposits in the Yerington District, Nevada: Metasomatic skarn evolution near Ludwig: Economic Geology, v. 77, no. 4, p. 877-898.

Hastings, N.A.J., and Peacock, J.B., 1974, Statistical distributions, a handbook for students and practitioners: London, Butterworths, $129 \mathrm{p}$.

Helgeson, H.C., Delany, J.M., Nesbitt, H.W., and Bird, D.K., 1978, Summary and critique of the thermodynamic properties of rock-forming minerals: American Journal of Science, v. $278-\mathrm{A}, 229 \mathrm{p}$.

Hemley, J.J., Cygan, G.L., and d'Angelo, W.M., 1986, Effect of pressure on ore mineral solubilities under hydrothermal conditions: Geology, v. 14, no. 5, p. 377-379.

Henley, R.W., 1985, The geothermal framework for epithermal deposits, in Berger, B.R., and Bethke, P.M., eds., Geology and geochemistry of epithermal systems: El Paso, Texas, Society of Economic Geologists, Reviews in Economic Geology, v. 2, p. 1-24.

Henley, R.W., and Ellis, A.J., 1983, Geothermal systems ancient and modern, a geochemical review: Earth-Science Reviews, v. 19 , no. 1 , p. $1-50$. 
Henley, R.W., and McNabb, Alex, 1978, Magmatic vapor plumes and ground-water interaction in porphyry copper emplacement: Economic Geology, v. 73, no. 1, p. 1-20.

Hietanen, Anna, 1963, Idaho batholith near Pierce and Bungalow, Clearwater County, Idaho: U.S. Geological Survey Professional Paper 344-D, p. D1-D42.

Hildreth, E.W., 1979, The Bishop Tuff: evidence for the origin of compositional zonation in silicic magma chambers: Geological Society of America Special Paper 180, p. 43-74.

-1981, Gradients in silicic magma chambers: implications for lithospheric magmatism: Journal of Geophysical Research, v. 86, no. B11, p. 10153-10192.

Hollister, L.S., 1981, Information intrinsically available from fluid inclusions, in Hollister, L.S., and Crawford, M.L., eds., Fluid inclusions: applications to petrology: Mineralogical Association of Canada Short Course Handbook, v. 6, p. 1-12.

Hollister, L.S., and Crawford, M.L., eds., 1981, Fluid inclusions: applicatons to petrology: Mineralogical Association of Canada, Short course handbook, v. 6, $304 \mathrm{p}$.

Holloway, J.R., 1981, Compositions and volumes of supercritical fluids in the Earth's crust, in Hollister, L.S., and Crawford, M.L., eds., Fluid inclusions: applications to petrology: Mineralogical Association of Canada, Short course handbook, v. 6, May 1981, p. 13-35.

Hotz, P.E., and Willden, Ronald, 1964, Geology and mineral deposits of the Osgood Mountains quadrangle, Humboldt County, Nevada: U.S. Geological Survey Professional Paper $431,128 \mathrm{p}$.

Hudson, Travis, Arth, J.G., and Muth, K.G., 1981, Geochemistry of intrusive rocks associated with molybdenite deposits, Ketchikan quadrangle, southeastern Alaska: Economic Geology, v. 76, no. 5, p. 1225-1232.

Hulen, J.B., Nielson, D.L., Goff, Fraser, Gardner, J.N., and Charles, R.W., 1987, Molybdenum mineralization in an active geothermal system, Valles caldera, New Mexico: Geology, v. 15 , no. 8 , p. $748-752$.

Ignatovich, V.I., 1969, Geologic features and prospects for exploration of stockwork molybdenum mineralization in the Buryat ASSR, in Geology and metallogeny of Transbaikal: Akademiia Nauk SSSR Sibirskoye Otdelenie, Ulan-Ude, 1969 (Materialy konferentsii, posviachchennoi 10-letiiu Buriatskogo geologiches-kogo upravliniia), p. 127-137.

Ingamells, C.O., 1970, Lithium metaborate flux in silicate analysis: Analytica Chimica Acta, v. 52, no. 2, p. 323-334.

Irvine, T.N., 1967, Chromian spinel as a petrogenetic indicator, part 2. Petrologic applications: Canadian Journal of Earth Sciences, v. 4, p. 71-103.

Isuk, E.E., and Carman, J.H., 1981, The system $\mathrm{Na}_{2} \mathrm{Si}_{2} \mathrm{O}_{5}-\mathrm{K}_{2} \mathrm{Si}_{2} \mathrm{O}_{5}$ $\mathrm{MoS}_{2}-\mathrm{H}_{2} \mathrm{O}$ with implications for molybdenum transport in silicate melts: Economic Geology, v. 76, no. 8, p. 2222-2235.

Jachens, R.C., Blakely, R.J., and Moring, B.C., 1989, Analysis of concealed mineral resources in Nevada: Constraints from gravity and magnetic studies [abs.], in Schindler, K.S., ed., USGS Research on mineral resources-1989: Program and Abstracts: U.S. Geological Survey Circular 1035, p. 35-37.

Jacobs, D.C., and Parry, W.T., 1979, Geochemistry of biotite in the Santa Rita porphyry copper deposit, New Mexico: Economic Geology, v. 74, no. 4, p. 860-887.

Jacobs, G.K., and Kerrick, D.M., 1981, Methane: An equation of state with application to the ternary system $\mathrm{H}_{2} \mathrm{O}-\mathrm{CO}_{2}-\mathrm{CH}_{4}$ : Geochimica et Cosmochimica Acta, v. 45, p. 607-614.

James, R.S., and Hamilton, D.L., 1969, Phase relations in the system $\mathrm{NaAlSi}_{3} \mathrm{O}_{8}-\mathrm{KAlSi}_{3} \mathrm{O}_{8}-\mathrm{CaAl}_{2} \mathrm{SiO}_{8}-\mathrm{SiO}_{2}$ at 1 kilobar water vapour pressure: Contributions to Mineralogy and Petrology, v. 21, p. 111-141.
John, D.A., 1986, Evolution of hydrothermal fluids in intrusions of the central Wasatch Mountains, Utah: Stanford, Calif., Stanford University, Ph.D. thesis, $236 \mathrm{p}$.

Johnson, J.G., 1983, Comment on Mid-Paleozoic age of the Roberts thrust unsettled by new data from northern Nevada [by K.B. Ketner]: Geology, v. 11, no. 1, p. 60-61.

Johnson, J.W., and Norton, Denis, 1985, Theoretical prediction of hydrothermal conditions and chemical equilibria during skarn formation in porphyry copper systems: Economic Geology, v. 80 , no. 7 , p. $1797-1823$.

Johnston, W.P., and Lowell, J.D., 1961, Geology and origin of mineralized breccia pipes in Copper Basin, Arizona: Economic Geology, v. 56, no. 5, p. 916-940.

Jones, D.L., and Murchey, Benita, 1986, Geologic significance of Paleozoic and Mesozoic radiolarian chert: Annual Review of Earth and Planetary Sciences, v. 14, 1986, p. 455-492.

Jones, D.L., Wrucke, C.T., Holdsworth, B., Suczek, C.A., 1978, Revised ages of chert in the Roberts Mountains allochthon, northern Nevada [abs.]: Geological Society of America Abstracts with Programs, v. 10, no. 3, p. 111.

Jones, R.S., 1969, Gold in igneous, sedimentary, and metamorphic rocks: U.S. Geological Survey Circular 610, 28 p.

Jones, W.R., Hernon, R.M., and Moore, S.L., 1967, General geology of the Santa Rita quadrangle, Grant County, New Mexico: U.S. Geological Survey Professional Paper 555, $144 \mathrm{p}$.

Joralemon, Peter, 1951, The occurrence of gold at the Getchell mine, Nevada: Economic Geology, v. 46, no. 3, p. 267-310.

Kamilli, R.J., 1978, The genesis of stockwork molybdenite deposits: Implications from fluid inclusion studies at the Henderson Mine [abs.]: Geological Society of America Abstracts with Programs, v. 10, no. 7, p. 431.

Kastrykin, Y.P., 1980, Molybdenum porphyry mineralization in the western Stanovoi Range: Geologiya i Geofizika, v. 21, no. 9, p. 59-67 [in Russian; translated in Soviet Geology and Geophysics, Allerton Press, v. 21, no. 9, p. 46-53].

Kay, Marshall, and Crawford, J.P., 1964, Paleozoic facies from the miogeosynclinal to the eugeosynclinal belt in thrust slices, central Nevada: Geological Society of America Bulletin, v. 75 , p. $424-454$.

Keith, S.B., and Swan, M.M., 1987, Oxidation state of magma series in the southwestern U.S.: Implications for geographic distribution of base, precious, and lithophile metal metallogeny [abs.]: Geological Society of America Abstracts with Programs, v. 19, no. 7, p. 723-724.

Kerr, P.F., Kulp, J.L., Patterson, C.M., and Wright, R.J., 1950, Hydrothermal alteration at Santa Rita, New Mexico: Geological Society of America Bulletin, v. 61, p. 275-347.

Ketner, K.B., 1977, Deposition and deformation of lower Paleozoic western facies rocks, northern Nevada, in Stewart, J.H., Stevens, C.H., and Fritsche, A.E., eds., Paleozoic paleogeography of the western United States: Pacific Coast Paleogeography Symposium 1: Los Angeles, Society of Economic Paleontologists and Mineralogists, Pacific Section, p. 251258.

-1984, Recent studies indicate that major structures in northeastern Nevada and the Golconda thrust in northcentral Nevada are of Jurassic or Cretaceous age: Geology, v. 12 , p. $483-486$.

Ketner, K.B., and Smith, J.F., Jr., 1982, Mid-Paleozoic age of the Roberts thrust unsettled by new data from northern $\mathrm{Ne}-$ vada: Geology, v. 10, p. 298-303.

Kilinic, I.A., and Burnham, C.W., 1972, Partitioning of chloride between a silicate melt and coexisting aqueous phase from 2 to 8 kilobars: Economic Geology, v. 67, no. 2, p. 231-235. 
Kistler, R.W., 1974, Phanerozoic batholiths in western North America, in Donath, F.A., ed., Annual Review of Earth and Planetary Sciences, v. 2, p. 403-418.

1983 , Isotope geochemistry of plutons in the northern Great Basin, in The role of heat in the development of energy and mineral resources in the northern Basin and Range Province, Special Report, Geothermal Resources Council, v. 13, p. 3-8.

Kistler, R.W., and Peterman, Z.E., 1973, Variations in Sr, Rb, K, $\mathrm{Na}$, and initial $\mathrm{Sr}^{87} / \mathrm{Sr}^{86}$ in Mesozoic granitic rocks and intruded wall rocks in central California: Geological Society of America Bulletin, v. 84, p. 3489-3512.

Kitamura, Kenji, 1975, Al-Fe partitioning between garnet and epidote from the contact metasomatic copper deposits of the Chichibu Mine, Japan: Economic Geology, v. 70, no. 4, p. 725738.

Klovan, J.E., 1968, Selection of target areas by factor analysis: Symposium on Decision-Making in Exploration, Vancouver, British Columbia, Canada, 1968, Proceedings, 9 p.

Knapp, R.B., and Knight, J.E., 1977, Differential thermal expansion of pore fluids: Fracture propagation and microearthquake production in hot pluton environments: Journal of Geophysical Research, v. 82, no. A17, p. 2515-2522.

Knapp, R.B., and Norton, D.L., 1981, Preliminary numerical analysis of processes related to magma crystallization and stress evolution in cooling pluton environments: American Journal of Science, v. 281 , no. 1 , p. $35-68$.

Kork, J.O., and Miesch, A.T., 1984, USGS STATPAC, spatial statistics, graphics, and digitizing programs for an IBM personal computer, in Peters, D.C., Urban, S.B., Dahm, J.N., Krajewski, S.A., and Stewart, C.R., eds., Geotech '84, "Personal Computers in Geology," Denver, Colo., 1984, Proceedings: American Institute of Professional Geologists, Colorado Section, p. 25-28.

Krauskopf, K.B., 1967, Introduction to geochemistry: New York, McGraw-Hill, 721 p.

Krohn, M.D., Abrams, M.J., and Rowan, L.C., 1978, Discrimination of hydrothermally altered rocks along the Battle Mountain-Eureka, Nevada mineral belt using Landsat images: U.S. Geological Survey Open-File Report 78-585, 66 p.

Kudrin, A.V., 1989, Behavior of molybdenum in aqueous solutions of sodium and potassium chlorides at 300 to $450{ }^{\circ} \mathrm{C}$ : Akademia Nauk CCCP, Geochimia, no. 1, p. 99-112 [in Russian].

Kudrin, A.V., Varyash, L.N., Pashkov, Y.N., and Rekharsky, V.I., 1984, Copper and molybdenum behavior during the formation of copper-molybdenum deposits [abs.]: International Geological Congress, 27th, Moscow, 1984, Abstracts of Papers, v. 6, p. 176-177.

Kuhn, T.H., 1941, Pipe deposits of the Copper Creek area, Arizona: Economic Geology, v. 36, no. 5, p. 512-538.

Kwak, T.A.P., 1986, Fluid inclusions in skarns (carbonate replacement deposits): Journal of Metamorphic Geology, v. 4, no. 4 , p. $363-384$.

Kwak, T.A.P., Brown, W.M., Abeysinghe, P.B., and Tan, T.H., 1986, Fe solubilities in very saline hydrothermal fluids: their relation to zoning in some ore deposits: Economic Geology, v. 81 , no. 2 , p. $447-465$.

Kwak, T.A.P., and Tan, T.H., 1981, The importance of $\mathrm{CaCl}_{2}$ in fluid composition trends-evidence from the King Island (Dolphin) skarn deposit: Economic Geology, v. 76, no. 4, p. 955960.

Lanphere, M.H., and Dalrymple, G.B., 1971, A test of the ${ }^{40} \mathrm{Ar} /{ }^{39} \mathrm{Ar}$ age spectrum technique on some terrestrial materials: Earth and Planetary Science Letters, v. 12, no. 4, p. 360-372.
Larson, P.B., 1987, Stable isotope and fluid inclusion investigations of epithermal vein and porphyry molybdenum mineralization in the Rico Mining District, Colorado: Economic Geology, v. 82, no. 8, p. 2141-2157.

Lawson, A.C., 1913, The petrographic designation of alluvial-fan formations: Berkeley, University of California, Department of Geology Bulletin, v. 7, no. 15, p. 325-334.

Lee, C.G., and Atkinson, W.W., Jr., 1985, Geochemistry of zoned garnet from the San Pedro Mine, Santa Fe County, New Mexico: New Mexico Geology, v. 7, no. 4, p. 69-74.

Lee, J.W., 1951, The geology of Nickel Plate Mountain, British Columbia: Stanford, Calif., Stanford University, Ph.D. thesis, $89 \mathrm{p}$.

LeMaitre, R.W., 1976, The chemical variability of some common igneous rocks: Journal of Petrology, v. 17, no. 4, p. 589-637.

Leroy, Jacques, 1978, The Margnac and Fanay uranium deposits of the La Crouzille district (western Massif Central, France): Geologic and fluid-inclusion studies: Economic Geology, v. 73 , no. 8 , p. $1611-1634$.

Lewis, R.S., Kilsgaard, T.H., Bennett, E.H., and Hall, W.E., 1987, Lithologic and chemical characteristics of the central and southeastern part of the southern lobe of the Idaho Batholith, in Vallier, T.L., and Brooks, H.C., eds., Geology of the Blue Mountains region of Oregon, Idaho, and Washington: The Idaho batholith and its border zone: U.S. Geological Survey Professional Paper 1436, p. 171-196.

Lindsey, D.A., and Fisher, F.S., 1985, Mineralized breccias in intrusive complexes of Late Cretaceous and Paleocene age, north-central Montana: U.S. Geological Survey Professional Paper 1301-A, p. 1-37.

Linke, W.F., 1965, Solubilities of inorganic and metal-organic compounds: K-Z (4th ed.): Washington, American Chemical Society, v. 2, 1,914 p.

Linnen, R.L., and Williams-Jones, A.E., 1984, The Trout Lake molybdenum deposit, S.E. British Columbia: A study of contact metamorphism, wallrock alteration, and ore deposition [abs.]: Geological Association of Canada-Mineralogical Association of Canada, Program with Abstracts, v. 9, p. 84.

Lipin, B.R., 1984, Chromite from the Blue Ridge Province of North Carolina: American Journal of Science, v. 284, no. 45, p. 507-529.

Livingston, D.E., Mauger, R.L., and Damon, P.E., 1968, Geochronology of the emplacement, enrichment, and preservation of Arizona porphyry copper deposits: Economic Geology, v. 63, no. 1, p. $30-36$.

Lockard, D.W., and Schilling, J.H., 1983, The mineral industry of Nevada, in Area reports: Domestic, v. 2 of U.S. Bureau of Mines, Minerals yearbook, centennial edition, 1981: p. 319330.

Locke, Augustus, 1926, The formation of certain ore bodies by mineralization stoping: Economic Geology, v. 21, no. 5, p. 431-453.

Lovering, T.G., Lakin, H.W., and Hubert, A.E., 1968, Concentration and minor element association of gold in ore-related jasperoid samples, in Geological Survey research, 1968: U.S. Geological Survey Professional Paper 600-B, p. B112-B114.

Lowell, J.D., and Guilbert, J.M., 1970, Lateral and vertical alteration-mineralization zoning in porphyry ore deposits: Economic Geology, v. 65 , no. 4 , p. 373-408.

Ludington, S.D., 1981, Granite molydenite systems, in Erickson, R.L., ed., Characteristics of mineral deposit occurrences: U.S. Geological Survey Open-File Report 82-795, p. 43-46.

MacDonald, A.J., and Spooner, E.T.C., 1982, Carbonate complexing of molybdenum in hydrothermal solutions: Evidence from Boss Mountain, British Columbia [abs.]: Geologi- 
cal Society of America Abstracts with Programs, v. 14, p. 552.

1984, Hydrodynamics of a magmatically derived hydrothermal fluid, Boss Mountain, British Columbia [abs.]: Geological Association of Canada-Mineralogical Association of Canada Program with Abstracts, v. 9, p. 86.

Madrid, R.J., 1987, Stratigraphy of the Roberts Mountains allochthon in north-central Nevada: Stanford, Calif., Stanford University, Ph.D. thesis, 341 p.

Mandl, G., and Crans, W., 1981, Gravitatirnal gliding in deltas, in McClay, K.R., ed., Thrust and nappe tectonics: Geological Society of London Special Publication 9, p. 41-54.

Mason, D.R., 1978, Evolution of porphyry copper mineralization in an oceanic island arc: Panama-a discussion: Economic Geology, v. 73, no. 5, p. 982-984.

Matsuhisa, Yukihiro, Goldsmith, J.R., and Clayton, R.N., 1979, Oxygen isotopic fractionation in the system quartz-albiteanorthite water: Geochimica et Cosmochimica Acta, v. 43, no. 7 , p. $1131-1140$.

Maybey, D.R., 1966, Regional gravity and magnetic anomalies in part of Eureka County, Nevada: Society of Exploration Geophysicists Mining Geophysics Case Histories, v. 1, p. 77-83.

Maybey, D.R., Zietz, Isadore, Eaton, G.P., and Kleinkopf, M.D., 1978, Regional magnetic patterns in part of the Cordillera in the Western United States, in Smith, R.B., and Eaton, G.P., eds., Cenozoic tectonics and regional geophysics of the western Cordillera: Geological Society of America Memoir 152, p. 93-107.

McBride, E.F., 1963, A classification of common sandstones: Journal of Sedimentary Petrology, v. 33, no. 3, p. 664-669.

McCollum, L.B., McCollom, M.B., Jones, D.L., and Repetski, J.E., 1987, The Scott Canyon Formation, Battle Mountain, Nevada: structural amalgamation of the Ordovician Valmy Formation and Devonian Slaven Chert [abs.]: Geological Society of America Abstracts with Programs, v. 19, no. 17, p. 764.

McDowell, F.W., and Kulp, J.L., 1967, Age of intrusion and ore deposition in the Robinson Mining District of Nevada: Economic Geology, v. 62, no. 7, p. 905-909.

McDowell, S.D., and Elders, W.A., 1983, Allogenic layer silicate minerals in borehold Elmore \#1, Salton Sea Geothermal Field, California: American Mineralogist, v. 68, no. 11-12, p. 1146-1159.

McGee, J.J., 1983, \$ANBA-a rapid, combined data acquisition and correction program for the SEMQ electron microprobe: U.S. Geological Survey Open-File Report 83-817, 47 p.

1985, ARL-SEMQ electron microprobe operating manual: U.S. Geological Survey Open-File Report 85-837, 62 p.

McKee, E.H., 1976, Geology of the northern part of the Toquima Range, Lander, Eureka, and Nye Counties, Nevada: U.S. Geological Survey Professional Paper 931, 49 p.

McKee, E.H., and Noble, D.C., 1986, Tectonic and magmatic development of the Great Basin of western United States during late Cenozoic time: Modern Geology, v. 10, no. 1, p. $39-49$.

McKee, E.H., and Silberman, M.L., 1970, Geochronology of Tertiary igneous rocks in central Nevada: Geological Society of America Bulletin, v. 81, no. 8, p. 2317-2328.

Meinert, L.D., 1980, Skarn, manto, and breccia pipe formation in sedimentary rocks in the Cananea District, Sonora, Mexico: Stanford, Calif., Stanford University, Ph.D. thesis, 232 p.

1982, Skarn, manto, and breccia pipe formation in sedimentary rocks of the Cananea Mining District, Sonora, Mexico: Economic Geology, v. 77, no. 4, p. 919-949.

-1983, Variability of skarn deposits: Guides to exploration, in Boardman, S.J., ed., Revolution in the earth sciences- advances in the past half-century: Iowa, Kendall/Hunt, p. 301-316.

1984, Mineralogy and petrology of iron skarns in western British Columbia, Canada: Economic Geology, v. 79, no. 5, p. $869-882$.

1988, Gold in skarn deposits-a preliminary overview, in Zachrisson, E. ed., International Association on the Genesis of Ore Deposits Quadrennial Symposium, 7th, Proceedings: Stuttgart, E. Schweizerbart'sche Verlagsbuchhandlung, p. 363-374.

Meinert, L.D., Newberry, Ranier, and Einaudi, M.T., 1981, An overview of tungsten, copper and zinc-bearing skarns in western North America, in Silberman, M.L., Field, C.W., and Berry, A.L., eds., Geological Society of America Symposium on Mineral Deposits of the Pacific Northwest, Corvallis, Oreg., 1980, Proceedings: U.S. Geological Survey Open-File Report 81-355, p. 303-327.

Metzger, F.W., Kelly, W.C., Nesbitt, B.E., and Essene, E.J., 1977, Scanning electron microscopy of daughter minerals in fluid inclusions: Economic Geology, v. 72, no. 1, p. 141-152.

Meyer, Charles, and Hemley, J.J., 1967, Wall rock alteration, in Barnes, H.L., ed., Geochemistry of hydrothermal ore deposits: New York, Holt, Rinehart, and Winston, p. 166-235.

Miesch, A.T., 1976a, Q-mode factor analysis of geochemical and petrologic data matrices with constant row-sums: U.S. Geological Survey Professional Paper 574-G, p. G1-G47.

$1976 \mathrm{~b}$, Interactive computer programs for petrologic modeling with extended Q-mode factor analysis: Computers \& Geosciences, v. 2, no. 4, p. 439-492.

1981, Computer methods for geochemical and petrologic mixing problems, in Merriam, D.F., ed., Computer applications in the earth sciences: New York, Plenum, p. 243-265.

Millard, H.T., Jr., and Keaten, B.A., 1982, Precision of uranium and thorium determinations by delayed neutron counting: Journal of Radioanalytical Chemistry, v. 72, p. 489-500.

Miller, B.W., and Silberman, M.L., 1977, Cretaceous K-Ar age of hydrothermal alteration at the North Fish Creek porphyry copper prospect, Fish Creek Mountains, Lander County, Nevada: Isochron/West, no. 18 , p. 7 .

Miller, E.L., Gans, P.B., Wright, J.E., and Sutter, J.F., 1986, Metamorphic history of the east-central Basin and Range province: Tectonic setting and relationship to magmatism [abs.]: Geological Society of America Abstracts with Programs, v. 18 , no. 2 , p. 158.

Miller, E.L., Kanter, L.R., Larue, D.K., Turner, R.J., Murchey, B.L., and Jones, D.L., 1982, Structural fabric of the Paleozoic Golconda allochthon, Antler Peak quadrangle, Nevada: Progressive deformation of an oceanic sedimentary assemblage: Journal of Geophysical Research, v. 87, p. 3795-3804.

Mitcham, T.W., 1974, Origin of breccia pipes: Economic Geology, v. 69 , no. 3 , p. $412-413$.

Monger, J.W.H., and Berg, H.C., 1984, Lithotectonic terrane map of western Canada and southeastern Alaska (part B), in Silberling, N.J., and Jones, D.L., eds., Lithotectonic terrane maps of the North American Cordillera: U.S. Geological Survey Open-File Report 84-523, p. B1-B31.

Monger, J.W.H., Southern, J.G., and Gabrielse, H., 1972, Evolution of the Canadian Cordillera: A plate-tectonic model: American Journal of Science, v. 272, p. 577-602.

Moorhouse, W.W., 1959, The study of rocks in thin section: New York, Harper and Brothers, 514 p.

Moreau, Marcel, and Ranchin, Guy, 1973, Altérations hydrothermales et controles tectoniques dans les gites filoniens d'uranium intragranitiques du massif Central Francais, in Morin, Phillippe, ed., Les roches plutoniques dans leurs rap- 
ports avec les gites minéraux: Paris, Masson and Co., p. 77100.

Morrissey, F.R., 1968, Turquoise deposits of Nevada: Nevada Bureau of Mines Report 17, $30 \mathrm{p}$.

Murphy, M.A., Power, J.D., and Johnson, J.G., 1984, Evidence for Late Devonian movement within the Roberts Mountains allochthon, Roberts Mountains, Nevada: Geology, v. 12, no. 1 , p. 20-23.

Mutschler, F.E., Wright, E.G., Ludington, Steve, and Abbott, J.T., 1981, Granite molybdenite systems: Economic Geology, v. 76 , no. 4 , p. $874-897$.

Myers, G.L., and Meinert, L.D., 1988, Zonation of the Copper Canyon-Fortitude gold skarn system [abs.]: Geological Society of America Abstracts with Programs, v. 20, no. 7, p. A93.

Naney, M.T., 1983, Phase equilibria of rock-forming ferromagnesian silicates in granitic systems: American Journal of Science, v. 283, no. 10, p. 993-1033.

Nash, J.T., 1976, Fluid-inclusion petrology—data from porphyry copper deposits and applications to exploration: U.S. Geological Survey Professional Paper 907-D, p. D1-D16.

Nash, J.T., and Theodore, T.G., 1971, Ore fluids in the porphyry copper deposit at Copper Canyon, Nevada: Economic Geology, v. 66 , no. 3 , p. 385-399.

Naumov, V.B., Ivanova, G.F., and Motorina, Z.M., 1979, Formational conditions for tungsten, tin-tungsten, and molybdenum-tungsten deposits: Novosibirsk, U.S.S.R., Osnovnye Parametry Prirodnykh Protsessov Endogennogo Rudoobrazovaniia Nauka, v. 2, p. 53-62.

Newberry, R.J., 1980, The geology and chemistry of skarn formation and tungsten deposition in the Central Sierra Nevada, California: Stanford, Calif., Stanford University, Ph.D. thesis, $325 \mathrm{p}$.

Nielsen, R.L., 1968, Hypogene texture and mineral zoning in a copper-bearing granodiorite porphyry stock, Santa Rita, New Mexico: Economic Geology, v. 68, no. 1, p. 37-50.

Nilsen, T.H., and Stewart, J.H., 1980, Penrose Conference Report; The Antler orogeny, mid-Paleozoic tectonism in western North America: Geology, v. 8, no. 6, p. 298-302.

Noble, J.A., 1970, Metal provinces of the western United States: Geological Society of America Bulletin, v. 71, no. 6, p. 16071624.

Nockolds, S.R., 1954, Average chemical compositions of some igneous rocks: Geological Society of America Bulletin, v. 65, p. 1007-1032.

Norman, D.I., and Sawkins, F.J., 1987, Analysis of volatiles in fluid inclusions by mass spectrometry, in Horn, E.E., and Behr, H.-J., eds., Current research on fluid inclusions: Chemical Geology, v. 61, p. 1-10.

Norton, D.L., 1982, The thermal history of magma-hydrothermal systems: Lithocaps and cupola regions in fossil systems, southeastern Arizona: Tucson, University of Arizona, Department of Geosciences Field Manual, 83 p.

Norton, D.L., and Cathles, L.M., 1973, Breccia pipes-products of exsolved vapor from magmas: Economic Geology, v. 68, no. 4 , p. $540-546$.

O’Connor, J.T., 1965, A classification for quartz-rich igneous rocks based on feldspar ratios, in Geological Survey research, 1965: U.S. Geological Survey Professional Paper 525-B, p. B79-B84.

Ohmoto, Hiroshi, and Rye, R.O., 1979, Isotopes of sulfur and carbon, in Barnes, H.L., ed., Geochemistry of hydrothermal ore deposits (2d ed.): New York, John Wiley, p. 509-567.

Oldow, J.S., 1983, Tectonic implications of a late Mesozoic fold and thrust belt in northwestern Nevada: Geology, v. 11, no. 9 , p. 542-546.
O'Neil, J.R., and Silberman, M.L., 1974, Stable isotope relations in epithermal Au-Ag deposits: Economic Geology, v. 69, no. 4, p. 902-909.

Orris, G.J., Bliss, J.D., Hammarstrom, J.M., and Theodore, T.G., 1987, Descriptions and grades and tonnages for gold-bearing skarns: U.S. Geological Survey Open-File Report 87-273, 50 p.

Ortoleva, Peter, Chadam, John, Merino, Enrique, and Sen, A., 1987, Geochemical self-organization II: The reactive-infiltration instability: American Journal of Science, v. 287, no. 12, p. 1008-1040.

Palache, Charles, Berman, Harry, and Frondel, Clifford, 1958, The system of mineralogy of James Dwight Dana and Edward Salisbury Dana (7th ed.): New York, John Wiley, 834 p.

Palmer, A.R., 1971, The Cambrian of the Great Basin and adjoining areas, western United States, in Holland, C.H., ed., Cambrian of the New World: New York, Wiley-Interscience, p. 1-78.

Papke, K.G., 1984, Barite in Nevada: Nevada Bureau of Mines and Geology Bulletin 98, $125 \mathrm{p}$.

Parker, R.L., 1967, Composition of the Earth's crust: U.S. Geological Survey Professional Paper 440-D, p. D1-D17.

Parry, W.T., 1986, Estimation of $\mathrm{X}_{\mathrm{CO}_{2}}, \mathrm{P}$, and fluid inclusion volume from fluid inclusion temperature measurements in the system $\mathrm{NaCl}-\mathrm{CO}_{2}-\mathrm{H}_{2} \mathrm{O}$ : Economic Geology, v. 81, no. 4, p. 10091013.

Pasteris, J.D., Patel, R., Bergman, S.C., and Adar, F., 1983, Comparative spectroscopy and microthermometry on fluid inclusions in a mantle xenolith [abs.]: Eos (American Geophysical Union Transactions), v. 64, p. 340.

Peacock, M.A., 1931, Classification of igneous rock series: Journal of Geology, v. 39, no. 1, p. 54-67.

Pearce, J.A., and Gale, G.H., 1977, Identification of ore deposition environment from trace-element geochemistry of associated igneous host rocks: Geological Society of London Special Publication 7, p. 14-24.

Perry, V.D., 1961, The significance of mineralized breccia pipes: Mining Engineering, v. 13, p. 367-376.

Pettijohn, F.J., 1949, Sedimentary rocks: New York, Harper and Brothers, $718 \mathrm{p}$.

Phillips, W.J., 1973, Mechanical effects of retrograde boiling and its probable importance in the formation of some porphyry ore deposits: Institute of Mining and Metallurgy Transactions (London), sec. B, v. 82, p. B90-B98.

Pokalov, V.T., 1977, Deposits of molybdenum, in Smirnov, V.I., ed., Ore deposits of the U.S.S.R.: London, Pitman, v. 3, p. 125179.

Poldervaart, Arie, 1955, Chemistry of the Earth's crust, in Poldervaart, Arie, ed., Crust of the Earth-a symposium: Geological Society of America Special Paper 62, p. 119-144.

Potter, R.W., II, 1977, Pressure corrections for fluid-inclusion homogenization temperatures based on the volumetric properties of the system NaCl- $\mathrm{H}_{2} \mathrm{O}$ : U.S. Geological Survey Journal of Research, v. 5, no. 5, p. 603-607.

Potter, R.W., II, Clynne, M.A., and Brown, D.L., 1978, Freezing point depression of aqueous sodium chloride solutions: Economic Geology, v. 73, no. 2, p. 284-285.

Powers, M.C., 1953, A new roundness scale for sedimentary particles: Journal of Sedimentary Petrology, v. 23, no. 2, p. 117119.

Price, N.J., 1977, Aspects of gravity tectonics and the development of listric faults: Geological Society of London Journal, v. 133 , pt. 4, p. 311-327.

Ramberg, Hans, 1981, The role of gravity in orogenic belts, in McClay, K.R., ed., Thrust and nappe tectonics: Geological Society of London Special Publication 9, p. 125-140. 
Ramdohr, Paul, 1969, The ore minerals and their intergrowths: Oxford, Pergamon, 1,174 p.

Reynolds, T.J., and Beane, Richard, 1985, Evolution of hydrothermal fluid characteristics at the Santa Rita, New Mexico, porphyry copper deposit: Economic Geology, v. 80, no. 5, p. 1328-1347.

Rice, C.M., Harmon, R.S., and Shepherd, T.J., 1985, Central City, Colorado: The upper part of an alkaline porphyry molybdenum system: Economic Geology, v. 80, no. 7, p. 1769-1796.

Rickwood, P.C., 1968, On recasting analyses of garnet into endmember molecules: Contributions to Mineralogy and Petrology, v. 18, p. 175-198.

Roberts, R.J., 1964, Stratigraphy and structure of the Antler Peak quadrangle, Humboldt and Lander Counties, Nevada: U.S. Geological Survey Professional Paper 459-A, 93 p.

1966, Metallogenic provinces and mineral belts in Nevada: Nevada Bureau of Mines Report 13, pt. A, p. 47-72.

Roberts, R.J., and Arnold, D.C., 1965, Ore deposits of the Antler Peak quadrangle, Humboldt and Lander Counties, Nevada: U.S. Geological Survey Professional Paper 459-B, 94 p.

Roberts, R.J., Hotz, P.E., Gilluly, James, and Ferguson, H.G., 1958, Paleozoic rocks in north-central Nevada: American Association Petroleum Geologists Bulletin, v. 42, no. 12, p. 28132857.

Roberts, R.J., and Thomasson, M.R., 1964, Comparison of late Paleozoic depositional history of northern Nevada and central Idaho: U.S. Geological Survey Professional Paper 475-D, p. D1-D6.

Robinson, Peter, 1980, The composition space of terrestrial pyroxenes-internal and external limits, in Prewitt, C.T., ed., Pyroxenes: Reviews in Mineralogy, v. 7, p. 419-494.

Rock, N.M.S., and Leake, B.E., 1984a, The International Mineralogical Association amphibole nomenclature scheme: Computerization and its consequences: Mineralogical Magazine, v. 48 , no. 347 , p. $211-217$.

1984b, A FORTRAN program for the classification of amphiboles according to the International Mineralogical Association (IMA 1978) scheme: British Geological Survey, Petrology Group Petrological and Mineralogical Report 5028, 9 p.

Roedder, Edwin, 1962, Studies of fluid inclusions, I: Low temperature application of a dual-purpose freezing and heating stage: Economic Geology, v. 57, no. 7, p. 1045-1061.

-1963, Studies of fluid inclusions II: Freezing data and their interpretation: Economic Geology, v. 58, no. 2, p. 167-211.

1971, Fluid-inclusion studies on the porphyry-type ore deposits at Bingham, Utah; Butte, Montana; and Climax, Colorado: Economic Geology, v. 66, no. 1, p. 98-120.

1984, Fluid inclusions: Mineralogical Society of America Reviews in Mineralogy, v. 12, 644 p.

Roedder, Edwin, and Bodnar, R.J., 1980, Geologic pressure determinations from fluid inclusion studies: Annual Review of Earth and Planetary Sciences, v. 8, p. 263-301.

Roedder, Edwin, Ingram, Blanche, and Hall, W.E., 1963, Studies of fluid inclusions, III: Extraction and quantitative analysis of inclusions in the milligram range: Economic Geology, v. 58, no. 3, p. 353-374.

Rose, A.W., and Baltosser, W.W., 1966, The porphyry copper deposit at Santa Rita, New Mexico, in Titley, S.R., and Hicks, C.L., eds., Geology of the porphyry copper deposits, southwestern North America: Tucson, Ariz., University of Arizona Press, p. 205-220.

Rose, A.W., and Burt, D.M., 1979, Hydrothermal alteration, in Barnes, H.L., ed., Geochemistry of hydrothermal ore deposits (2d ed.): New York, John Wiley, p. 173-227.
Rowell, A.J., Rees, M.N., and Suzcek, C.A., 1979, Margin of the North American continent in Nevada during Late Cambrian time: American Journal of Science, v. 279, p. 1-18.

Russell, B.J., 1984, Mesozoic geology of the Jackson Mountains, northwestern Nevada: Geological Society of America Bulletin, v. 95 , no. 3 , p. 313-323.

Ryabchikov, I.D., Rekarskiy, V.I., and Kudrin, A.V., 1981, Mobilization of molybdenum by fluids during the crystallization of granite melts: Geokhimiya, no. 8, p. 1243-1246 [in Russian].

Rye, R.O., and Haffty, Joseph, 1969, Chemical composition of the hydrothermal fluids responsible for the lead-zinc deposits at Providencia, Zacatecas, Mexico: Economic Geology, v. 64, no. 6 , p. $629-643$.

Rytuba, J.J., 1985, Development of disseminated gold deposits of Cortez, Horse Canyon, and Gold Acres, Nevada, at the end stage of the caldera-related volcanism [abs.], in Krafft, Kathleen, ed., USGS Research on Mineral Resources-1985, Program and Abstracts: U.S. Geological Survey Circular 949, p. 47.

Saller, A.H., 1980, Petrology of post-Antler sedimentary rocks in north-central Nevada [abs.]: Geological Society of America Abstracts with Programs, v. 12, no. 3, p. 151.

1982, Depositional environments and tectonic significance of the type Antler Peak Limestone, Upper Pennsylvanian, north-central Nevada [abs.]: Geological Society of America Abstracts with Programs, v. 14, no. 4, p. 230.

Santosh, M., 1984, Precipitation of molybdenum in the Ambalavayal molybdenite prospect, Kerala: Fluid inclusion evidences [abs.]: National Seminar on Sciences and Industrial Applications of Fluid Inclusions in Minerals, Dehra Dun, India, 1984, Abstracts, p. 9.

Sasada, Masakatsu, Roedder, Edwin, and Belkin, H.E., 1986, Fluid inclusions from drill hole DW-5, Hohi geothermal area, Japan: Evidence for boiling and procedure for estimating $\mathrm{CO}_{2}$ content: Journal of Volcanology and Geothermal Research, v. 30, p. 231-251.

Sawkins, F.J., 1969, Chemical brecciation, an unrecognized mechanism for breccia formation?: Economic Geology, v. 64, no. 6 , p. $613-617$.

Sayers, R.W., Tippett, M.C., and Fields, E.D., 1968, Duval's new copper mines show complex geologic history: Mining Engineering, v. 20 , no. 3 , p. 55-62.

Scherkenbach, D.A., and Sawkins, F.J., 1982, The molybdenum deposit of Cumobabi, northern Sonora, Mexico [abs.]: Geological Society of America Abstracts with Programs, v. 14, p. 609 .

Scherkenbach, D.A., Sawkins, F.J., and Seyfried, W.E., Jr., 1985, Geologic, fluid inclusion, and geochemical studies of the mineralized breccias at Cumobabi, Sonora, Mexico: Economic Geology, v. 80, no. 6, p. 1566-1592.

Schmidt, R.G., 1978, The potential for porphyry coppermolybdenum deposits in the Eastern United States: U.S. Geological Survey Professional Paper 907-E, p. E1-E31.

Schmidt, K.W., Wotruba, P.R., and Johnson, S.D., 1988, Goldcopper skarn and related mineralization at Copper Basin, Nevada: Geological Society of Nevada Field-Trip Guidebook, 1988, 6 p.

Scott, R.H., and Kokot, M.L., 1975, Application of inductively coupled plasmas to the analysis of geochemical samples: Analytica Chimica Acta, v. 75, p. 257-270.

Seal, R.H., II, Clark, A.H., and Morrissy, C.J., 1987, Stockwork tungsten (scheelite)-molybdenum mineralization, Lake George, southwestern New Brunswick: Economic Geology, v. 82 , no. 5 , p. $1259-1282$. 
Seward, T.M., 1984, The transport and deposition of gold in hydrothermal systems, in Foster, R.P., ed., Gold '82: The geology, geochemistry and genesis of gold deposits: Rotterdam, A.A. Balkema, p. 165-181.

Shannon, J.R., Walker, B.M., Carten, R.B., and Geraghty, E.P., 1982, Unidirectional solidification textures and their significance in determining relative ages of intrusions at the Henderson Mine, Colorado: Geology, v. 10, no. 6, p. 293-297.

Shapiro, Leonard, 1975, Rapid analysis of silicate, carbonate, and phosphate rocks (revised ed.): U.S. Geological Survey Bulletin 1401, 76 p.

Sharp, J.E., 1978, A molybdenum mineralized breccia pipe complex, Redwell Basin, Colorado: Economic Geology, v. 73, no. 3, p. 369-382.

Shaver, S.A., 1984a, Fluid inclusion study of alteration and mineralization at the Hall (Nevada Moly) deposit, Nye Co., Nevada [abs.]: Geological Society of America Abstracts with Programs, v. 16, p. 652-653.

-1984b, The Hall (Nevada Moly) molybdenum deposit, Nye County, Nevada: Geology, alteration, mineralization, and geochemical dispersion: Stanford, Calif., Stanford University, Ph.D. thesis, 560 p.

- 1984c, Origin of differences between Climax-type and quartz monzonite-type porphyry moly deposits [abs.]: Geological Society of America Abstracts with Programs, v. 16, p. 254.

-1986, Elemental dispersion associated with alteration and mineralization at the Hall (Nevada Moly) quartz monzonitetype porphyry molybdenum deposit, with a section on Comparison of dispersion patterns with those from Climax-type deposits, in Nichols, C.E., ed., Exploration for ore deposits of the North American cordillera: Journal of Geochemical Exploration, v. 24, no. 1-2, p. 81-98.

Shaver, S.A., and McWilliams, Michael, 1987, Cenozoic extension and tilting recorded in Upper Cretaceous and Tertiary rocks at the Hall molybdenum deposit, northern San Antonio Mountains, Nevada: Geological Society of America Bulletin, v. 99, p. 341-353.

Shawe, D.R., 1986, Complex history of precious metal deposits, southern Toquima Range, Nevada: U.S. Geological Survey Open-File Report 86-459, 41 p.

Shawe, D.R., Marvin, R.F., Andriessen, P.A.M., Mehnert, H.H., and Merritt, V.M., 1986, Ages of igneous and hydrothermal events in the Round Mountain and Manhattan gold districts, Nye County, Nevada: Economic Geology, v. 81, no. 2, p. 388407.

Shawe, D.R., and Stewart, J.H., 1976, Ore deposits as related to tectonics and magmatism, Nevada and Utah: Society of Mining Engineers of AIME Transactions, v. 260, p. 225-231.

Shimizu, Masaaki, and Iiyama, J.T., 1982, Zinc-lead skarn deposits of the Nakatatsu Mine, Central Japan: Economic Geology, v. 77, no. 4, p. 1000-1012.

Shrader, Nancy, and Feiss, P.G., 1980, Fluid inclusion filling temperatures in quartz veins at the Boy Scout-Jones molybdenum prospect, Halifax County, North Carolina [abs.]: Geological Society of America Abstracts with Programs, v. 12, p. 208.

Siegel, Sidney, 1956, Nonparametric statistics-for the behavioral sciences: New York, McGraw-Hill, $312 \mathrm{p}$.

Silberling, N.J., 1986, Pre-Tertiary stratified rocks of the Tonopah $1^{\circ} \times 2^{\circ}$ quadrangle [abs.], in Whitebread, D.H., compiler, Abstracts of the symposium on the geology and mineral deposits of the Tonopah $1^{\circ} \times 2^{\circ}$ quadrangle, Nevada: U.S. Geological Survey Open-File Report 86-467, p. 2-3.

Silberling, N.J., Jones, D.L., Blake, M.C., Jr., and Howell, D.G., 1984, Lithotectonic terrane map of the western conterminous
United States (part C), in Silberling, N.J., and Jones, D.L., eds., Lithotectonic terrane maps of the North American Cordillera: U.S. Geological Survey Open-File Report 84-523, p. C1-C43.

Silberling, N.J., and Roberts, R.J., 1962, Pre-Tertiary stratigraphy and structure of northwestern Nevada: Geological Society of America Special Paper 72, $58 \mathrm{p}$.

Silberman, M.L., and McKee, E.H., 1971, K-Ar ages of granitic plutons in north-central Nevada: Isochron/West, no. 71-1, p. 15-32.

Sillen, L.G., 1938, X-ray studies on bismuth trioxide: Arkiv for Kemi, Mineralogi och Geologi (Stockholm), v. 12A, no. 18, p. 1-15.

Sillitoe, R.H., 1980, Types of porphyry molybdenum deposits: Mining Magazine, v. 142 , p. 550-551, 553.

Sillitoe, R.H., and Sawkins, F.J., 1971, Geologic, mineralogic, and fluid inclusion studies relating to the origin of copper-bearing tourmaline breccia pipes, Chile: Economic Geology, v. 66, no. 7, p. 1028-1041.

Simmons, S.F., and Sawkins, F.J., 1983, Mineralogic and fluid inclusion studies of the Washington $\mathrm{Cu}-\mathrm{Mo}-\mathrm{W}$-bearing breccia pipe, Sonora, Mexico: Economic Geology, v. 78, no. 3, p. 521526.

Simons, F.S., 1964, Geology of the Klondyke quadrangle, Graham and Pinal Counties, Arizona: U.S. Geological Survey Professional Paper 461, $173 \mathrm{p}$.

Singer, D.A., Theodore, T.G., and Mosier, D.L., 1986, Grade and tonnage model of Climax Mo deposits, in Cox, D.P., and Singer, D.A., eds., Mineral deposit models: U.S. Geological Survey Bulletin 1693, p. 73.

Smith, Mike, Wilson, Bill, Valenti, Paul, Benham, Julia, and Pescio, Carl, 1987, The Star Pointer gold deposit, Robinson Mining District, White Pine County, Nevada [abs.]: Bulk Mineable Precious Metal Deposits of the Western United States, Reno, Nev., 1987, Program with Abstracts, p. 40.

Smith, R.W., Norman, D.I., and Popp, C.J., 1980, Calculated solubility of molybdenite in hydrothermal solutions [abs.]: Geological Society of America, Abstracts with Programs, v. 12, p. 525 .

Sokolov, G.A., and Grigor'ev, V.M., 1977, Deposits of iron, in Smirnov, V.I., ed., Ore deposits of the U.S.S.R.: London, Pitman, v. 1, p. 7-113.

Sotnikov, V.I., Nikitina, E.I., and Usova, L.V., 1979, Specific features of the composition of the rutile from molydenum ore deposits of different associational types; Geologiya $i$ Geofizika, v. 20, no. 3, p. 55-64 [in Russian; translated in Soviet Geology and Geophysics, Allerton Press, v. 20, no. 3, p. 39-46].

Sourirajan, S., and Kennedy, G.C., 1962, The system $\mathrm{H}_{2} \mathrm{O}-\mathrm{NaCl}$ at elevated temperatures and pressures: American Journal of Science, v. 260, no. 2, p. 115-141.

Speed, R.C., 1977, Island arc and other paleogeographic terranes of late Paleozoic age in the western Great Basin, in Stewart, J.H., Stevens, C.H., and Fritsche, A.E., eds., Paleozoic paleogeography of the western United States: Pacific Coast Paleography Symposium 1: Los Angeles, Society of Economic Paleontologists and Mineralogists, Pacific Section, p. 349-362.

Speed, R.C., and Sleep, N.H., 1982, Antler orogeny and foreland basin: A model: Geologic Society of America Bulletin, v. 93, p. 815-828.

Stacey, J.S., Sherrill, N.D., Dalrymple, G.B., Lanphere, M.A., and Carpenter, N.V., 1981, A five collector system for the simultaneous measurement of argon isotopic ratios in a static mass spectrometer: International Journal of Mass Spectrometry and Ion Physics, v. 39, p. 167-180. 
Steiger, R.H., and Jäger, Emilie, 1977, Subcommission on Geochronology-convention on the use of decay constants in geo- and cosmochronology: Earth and Planetary Science Letters, v. 36, p. 359-362.

Steigerwald, C.H., Mutschler, F.E., and Ludington, Steve, 1983, A bibliography of stockwork molybdenite deposits and related topics (with emphasis on the North American literature): U.S. Geological Survey Open-File Report 83-382, $110 \mathrm{p}$.

Stein, H.J., and Hannah, J.L., 1985, Movement and origin of ore fluids in Climax-type systems: Geology, v. 13, p. 467-474.

Stein, H.J., and Huebner, M., 1984, A heavy isotope enriched sulfur source for Climax-type porphyry molybdenite deposits: Molybdenite compositions [abs.]: Geological Society of America Abstracts with Programs, v. 16, p. 667.

Sterner, S.M., Hall, D.L., and Bodnar, R.J., 1988, Synthetic fluid inclusions. V. Solubility relations in the system $\mathrm{NaCl}-$ $\mathrm{KCl}-\mathrm{H}_{2} \mathrm{O}$ under vapor-saturated conditions: Geochimica et Cosmochimica Acta, v. 52, p. 989-1005.

Stewart, J.H., 1980, Geology of Nevada-a discussion to accompany the Geologic Map of Nevada: Nevada Bureau of Mines and Geology Special Publication 4, 136 p.

Stewart, J.H., MacMillan, J.R., Nichols, K.M., and Stevens, C.H., 1977, Deep-water upper Paleozoic rocks in northcentral Nevada-a study of the type areas in the Havallah Formation, in Stewart, J.H., Stevens, C.H., and Fritsche, A.E., eds., Paleozoic paleogeography of the western United States: Pacific Coast Paleogeography Symposium 1: Los Angeles, Society of Economic Paleontologists and Mineralogists, Pacific Section, p. 337-347.

Stewart, J.H., and McKee, E.H., 1977, Geology, pt. 1 of Geology and mineral deposits of Lander County, Nevada: Nevada Bureau of Mines and Geology Bulletin 88, p. 1-59.

Stewart, J.H., Murchey, Benita, Jones, D.L., and Wardlaw, B.R., 1986, Paleontologic evidence for complex tectonic interlayering of Mississippian to Permian deep-water rocks of the Golconda allochthon in Tobin Range, north-central Nevada: Geological Society of America Bulletin, v. 97, no. 9, p. 1122-1132.

Stewart, J.H., and Poole, F.G., 1974, Lower Paleozoic and uppermost Precambrian Cordilleran miogeocline, Great Basin, Western United States, in Dickinson, W.R., ed., Tectonics and sedimentation: Society of Economic Paleontologists and Mineralogists Special Publication 22, p. 28-57.

Stewart, J.H., and Suczek, C.A., 1977, Cambrian and latest Precambrian paleogeography and tectonics in the western United States, in Stewart, J.H., Stevens, C.H., and Fritsche, A.E., eds., Paleozoic Paleogeography of the western United States: Pacific Coast Paleogeography Symposium 1: Los Angeles, Society of Economic Paleontologists and Mineralogists, Pacific Section, p. 1-17.

Strashimirov, S., 1981, Cryometric studies of inclusions in quartz from the Medet deposit: Sofia, Godishnik na Visshiya Minno-Geolozhiki Institut, v. 27, 1980-81, no. 2, p. 73-80 [in Bulgarian, with English summary].

Streckeisen, A.L., chairman, 1973, Plutonic rocks: Classification and nomenclature recommended by the IUGS Subcommission on the Systematics of Igneous Rocks: Geotimes, v. 18, no. 10 , p. $26-30$.

Strunz, Hugo, 1957, Mineralogische Tabellen: Leipzig, Akademische Verlagsgesellschaft, Geest \& Portig K.-G., 448 p. [in German].

Suczek, C.A., 1977, Tectonic relations of the Harmony Formation, northern Nevada: Stanford, Calif., Stanford University, Ph.D. thesis, 96 p.
Surnina, V.S., and Litvin, B.N., 1970, Phase formation in the $\mathrm{Na}_{2} \mathrm{O}-\mathrm{Me}_{2} \mathrm{O}_{3}-\mathrm{Bi}_{2} \mathrm{O}_{3}-\mathrm{H}_{2} \mathrm{O}$ system ( $\mathrm{Me}=\mathrm{Al}, \mathrm{Ga}$, or In) under hydrothermal conditions: Crystallography (Soviet Physics), v. 15 , no. 3 , p. $527-529$.

Sutulov, Alexander, 1970, Molybdenum and rhenium recovery from porphyry copper: Concepción, Chile, $259 \mathrm{p}$.

Sutulov, Alexander, ed., 1978, International molybdenum encyclopedia, 1778-1978, v. 1: Santiago, Chile, Intermet, 402 p.

Sweeney, M.J., 1980, Geochemistry of garnets from the North Ore shoot, Bingham Mining District, Utah, M.S. thesis: Salt Lake City, University of Utah, $154 \mathrm{p}$.

Tacker, R.C., and Candela, P.A., 1987, Partitioning of molybdenum between magnetite and melt: A preliminary experimental study of partitioning of ore metals between silicic magmas and crystalline phases: Economic Geology, v. 82, no. 7 , p. $1827-1838$.

Takenouchi, Sukune, and Kennedy, G.C., 1965, Dissociation pressures of the phase $\mathrm{CO}_{2} \cdot 5 \mathrm{LH}_{2} \mathrm{O}$ : Journal of Geology, v. 73 , no. 2 , p. $383-390$.

Taylor, B.E., and Liou, J.G., 1978, The low-temperature stability of andradite in $\mathrm{C}-\mathrm{O}-\mathrm{H}$ fluids: American Mineralogist, v. 63 , no. 3-4, p. 378-393.

Taylor, H.P., Jr., 1974, The application of oxygen and hydrogen isotope studies to problems of hydrothermal alteration and ore deposition: Economic Geology, v. 69, no. 4, p. 843-883.

-1979 , Oxygen and hydrogen isotope relationships, in Barnes, H.L., ed., Hydrothermal ore deposits (2d ed.): New York, John Wiley, p. 236-277.

Taylor, W.P., 1976, Intrusion and differentiation of granitic magma at a high level in the crust: The Puscao pluton, Lima Province, Peru: Journal of Petrology, v. 17, pt. 2, p. 194-218.

Theodore, T.G., 1982a, Preliminary model outline for fluorinedeficient porphyry molybdenum deposits, in Erickson, R.L., ed., Characteristics of mineral deposit occurrences: U.S. Geological Survey Open-File Report 82-795, p. 37-42.

$-1982 \mathrm{~b}$, Preliminary geologic map of the BuckinghamCopper Basin area, Lander County, Nevada: U.S. Geological Survey Open-File Report 82-54, scale 1:4,800.

Theodore, T.G., and Blake, D.W., 1975, Geology and geochemistry of the Copper Canyon porphyry copper deposit and surrounding area, Lander County, Nevada: U.S. Geological Survey Professional Paper 798-B, 86 p.

1978, Geology and geochemistry of the west ore body and associated skarns, Copper Canyon porphyry copper deposits, Lander County, Nevada, with a section on Electron microprobe analyses of andradite and diopside, by N.G. Banks: U.S. Geological Survey Professional Paper 798-C, p. C1-C85.

Theodore, T.G., Czamanske, G.K., and Keith, T.E.C., 1988, Sillenite and other bismuth minerals associated with placer gold, Battle Mountain Mining District, Nevada [abs.]: Geological Society of America Abstracts with Programs, v. 20, no. 3 , p. 237.

Theodore, T.G., Czamanske, G.K., Keith, T.E.C., and Oscarson, R.L., 1989, Bismuth minerals associated with placer gold, Battle Mountain Mining District, Nevada, in Schindler, K.S., ed., U.S.G.S. research on mineral resources-1989 [abs.]: U.S. Geological Survey Circular 1035, p. 72-74.

Theodore, T.G., and Hammarstrom, J.M., 1991, Petrochemistry and fluid-inclusion study of skarns from the northern Battle Mountain mining district, Nevada, in Akysuk, A.M., and others, eds., S.S., ed., Skarns-their genesis and metallogeny: Athens, Theophrastus, p. 497-554.

Theodore, T.G., Howe, S.S., Blake, D.W., and Wotruba, P.R., 1986, Geochemical and fluid zonation in the skarn environment at 
the Tomboy-Minnie gold deposits, Lander County, Nevada: Journal of Geochemical Exploration, v. 25, no. 1-2, p. 99128.

Theodore, T.G., and Menzie, W.D., 1984, Fluorine-deficient porphyry molybdenum deposits in the cordillera of western North America, in Janelidze, T.V., and Tvalchrelidze, A.G., eds., International Association on the Genesis of Ore Deposits Quadrennial Symposium, 6th, Tbilisi, U.S.S.R., 1982, Proceedings: Stuttgart, E. Schweizerbart'sche Verlagsbuchhandlung, v. 1, p. 463-470.

Theodore, T.G., and Nash, J.T., 1973, Geochemical and fluid zonation at Copper Canyon, Lander County, Nevada: Economic Geology, v. 68, no. 4, p. 565-570.

Theodore, T.G., Orris, G.J., Hammarstrom, J.M., and Bliss, J.D., 1991, Gold-bearing skarns: U.S. Geological Survey Bulletin $1930,61 \mathrm{p}$.

Theodore, T.G., and Roberts, R.J., 1971, Geochemistry and geology of deep drill holes at Iron Canyon, Lander County, Nevada, with a section on Geophysical logs of drill hole DDH-2 by C.J. Zablocki: U.S. Geological Survey Bulletin 1318,32 p.

Theodore, T.G., Silberman, M.L., and Blake, D.W., 1973, Geochemistry and K-Ar ages of plutonic rocks in the Battle Mountain Mining District, Lander County, Nevada: U.S. Geological Survey Professional Paper 798-A, 24 p.

Thompson, T.B., 1982, Classification and genesis of stockwork molybdenum deposits: Discussion: Economic Geology, v. 77, no. 3 , p. $709-710$

Thornton, C.P., and Tuttle, O.F., 1960, Chemistry of igneous rocks, I. Differentiation index: American Journal of Science, v. 258, no. 9, p. 664-684.

Thorman, C.H., and Ketner, K.B., 1979, West-northwest strikeslip faults and other structures in allochthonous rocks in central and eastern Nevada and western Utah, in Newman, G.W., and Goode, H.D., eds., Basin and Range Symposium and Great Basin Field Conference, 1979: Denver, Colo., Rocky Mountain Association of Geologists, p. 123-133.

Tingle, T.N., and Fenn, P.M., 1984, Transport and concentration of molybdenum in granite molybdenite systems: Effects of fluorine and sulfur: Geology, v. 12, no. 3, p. 156-158.

Tippett, M.C., 1967, The geology of the Copper Basin ore deposits, Lander County, Nevada: Reno, University of Nevada, M.S. thesis, $30 \mathrm{p}$.

Titley, S.R., 1982, Advances in geology of the porphyry copper deposits, southwestern North America: Tucson, University of Arizona Press, 560 p.

Titley, S.R., and Hicks, C.L., eds., 1966, Geology of the porphyry copper deposits, southwestern North America: Tucson, University of Arizona Press, $287 \mathrm{p}$.

Trudu, A.G., and Bloom, M.S., 1988, A genetic model for the origin of hypogene gold in porphyry copper systems: The Triad porphyry copper-gold deposit (Guinaoang, NW Luzon, Philippines): Bicentennial Gold 88, Melbourne, May 1988: Geological Society of Australia Abstracts Series, no. 23, p. 211-216.

Tulloch, A.J., 1979, Secondary Ca-Al silicates as low-grade alteration products of granitoid biotite: Contributions to Mineralogy and Petrology, v. 69, p. 105-117.

Turner, R.J., 1985, A late Devonian stratiform $\mathrm{Pb}-\mathrm{Zn}$ and stratiform barite metallogenic event in the North American Cordillera: Margin-long extension and implications for the Antler orogeny [abs.]: Geological Society of America Abstracts with Programs, v. 17, no. 6, p. 414.

Turrin, B.D., McKee, E.H., Theodore, T.G., and Conrad, J.E., 1989, ${ }^{40} \mathrm{Ar} /{ }^{39} \mathrm{Ar}$ studies of fluid inclusions in vein quartz from Battle
Mountain, Nevada [abs.], in Schindler, K.S., ed., U.S.G.S. Research on Mineral Resources-1989, Program and Abstracts: U.S. Geological Survey Circular 1035, p. 75-76.

Tuttle, O.F., and Bowen, N.L., 1958, Origin of granite in the light of experimental studies in the system $\mathrm{NaAlSi}_{3} \mathrm{O}_{8}-\mathrm{SiO}_{2}-\mathrm{H}_{2} \mathrm{O}$ : Geological Society of America Memoir 74, $153 \mathrm{p}$.

U.S. Geological Survey, 1984, Brief descriptions of STATPAC and related statistical programs for the IBM personal computer: Open-File Report 84-522, 21 p.

Vakrushev, V.A., 1972, Mineralogiya, geokhimiya i obrazovaniye mestorozhdeniy skarnovo-zolotorudnoy formatsii [Mineralogy, geochemistry, and genesis of gold-bearing skarn formations]: Akademiya Nauk SSSR Sibirskoye Otdeleniye, Institut Geologii i Geofiziki, 238 p. [in Russian].

Vanko, D.A., and Bishop, F.C., 1982, Occurrence and origin of marialitic scapolite in the Humboldt Lopolith, N.W. Nevada: Contributions to Mineralogy and Petrology, v. 81, p. 277-289.

Vanko, D.A., Bodnar, R.J., and Sterner, S.M., 1988, Synthetic fluid inclusions: VII. Vapor-saturated halite solubility in part of the system $\mathrm{NaCl}-\mathrm{CaCl}_{2}-\mathrm{H}_{2} \mathrm{O}$, with application to fluid inclusions from oceanic hydrothermal systems: Geochimica et Cosmochimica Acta, v. 52, no. 10, p. 2451-2456.

Vlasova, D.K., Podlesskiy, K.V., Kudrya, P.F., Boronikhin, V.A., and Muravitskaya, G.N., 1985, Zoning in garnets from skarn deposits: International Geology Review, v. 27, no. 4, p. 465482.

Wallace, S.R., Muncaster, N.K., Jonson, D.C., MacKenzie, B.W., Bookstrom, A.A., and Surface, V.E., 1968, Multiple intrusion and mineralization at Climax, Colorado, in Ridge, J.D., ed., Ore deposits of the United States, 1933-1967 (Graton Sales volume): New York, American Institute of Mining, Metallurgical and Petroleum Engineers, p. 606-640.

Westra, Gerhard, and Keith, S.B., 1981, Classification and genesis of stockwork molybdenum deposits: Economic Geology, v. 76 , no. 4 , p. $844-873$.

White, W.H., Bookstrom, A.A., Kamilli, R.J., Ganster, M.W., Smith, R.P., Ranta, D.E., and Steininger, R.C., 1981, Character and origin of Climax-type molybdenum deposits, in Skinner, B.J., ed., Economic Geology, Seventy-fifth anniversary volume, 1905-1980: New Haven, Conn., Economic Geology Publishing Co., p. 270-316.

Whiteford, W.B., Little, T.A., Miller, E.L., and Holdsworth, B.K., 1983, The nature of the Antler orogeny: View from northcentral Nevada [abs.]: Geological Society of America Abstracts with Programs, v. 15, no. 5, p. 382.

Whitney, J.A., 1975, Vapor generation in a quartz monzonite magma: A synthetic model with application to porphyry copper deposits: Economic Geology, v. 70, no. 2, p. 346-358.

Whitney, J.A., Hemley, J.J., and Simon, F.O., 1985, The concentration of iron in chloride solutions equilibrated with synthetic granitic compositions: The sulfur-free system: Economic Geology, v. 80, no. 2, p. 444-460.

Willden, Ronald, 1979, Ruby orogeny-a major early Paleozoic tectonic event, in Newman, G.W., and Goode, H.D., eds., Basin and Range Symposium and Great Basin Field Conference: Denver, Colo., Rocky Mountain Association of Geologists, p. 55-73.

Wong, George, 1983, Preliminary map of resource areas in the Basin and Range province of Nevada: U.S. Geological Survey Open-File Report 83-271, 37 p.

Woodcock, J.R., and Hollister, V.F., 1978, Porphyry molybdenite deposits of the North American Cordillera: Minerals, Science, and Engineering (Johannesburg), v. 10, p. 3-18.

Wotruba, P.R., Benson, R.G., and Schmidt, K.W., 1986, Battle Mountain describes the geology of its Fortitude gold-silver 
deposit at Copper Canyon: Mining Engineering, July 1986, v. 38 , no. 7 , p. $495-499$.

Wrucke, C.T., 1974, Geologic map of the Gold Acres-Tenabo area, Shoshone Range, Lander County, Nevada: U.S. Geological Survey Miscellaneous Field Studies Map MF-647, scale $1: 15,840,2$ sheets.

Wrucke, C.T., and Armbrustmacher, T.J., 1975, Geochemical and geologic relations of gold and other elements at the Gold Acres open-pit mine, Lander County, Nevada: U.S. Geological Survey Professional Paper 860, 27 p.

Yan, Mei-Zhong, Wu, Yong-Le, and Li, Chong-You, 1980, Metallogenetic systems of tungsten in southeast China and their mineralization characteristics: Tokyo, Mining Geology, special issue 8 , p. 215-221.

Yoder, H.S., Jr., and Tilley, C.E., 1962, Origin of basalt magmas-an experimental study of natural and synthetic rock systems: Journal of Petrology, v. 3, pt. 3, p. 342-532.

Ypma, P.J.M., 1963, Rejuvenation of ore deposits as exemplified by the Belledonne metalliferous province: Leiden, The Netherlands, University of Leiden, Ph.D. thesis, $212 \mathrm{p}$.

Zhang, Huifen, Lin, Chuanyi, Ma, Zhongwei, Yang, Zhenguo, and Zhang, Enlin, 1984, Magnetic properties, characteristic spectra and colors of turquoise: Beijing, Geochemistry, v. 3, no. 4 , p. $322-332$. 
